(1)

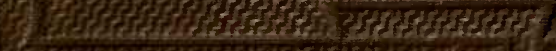

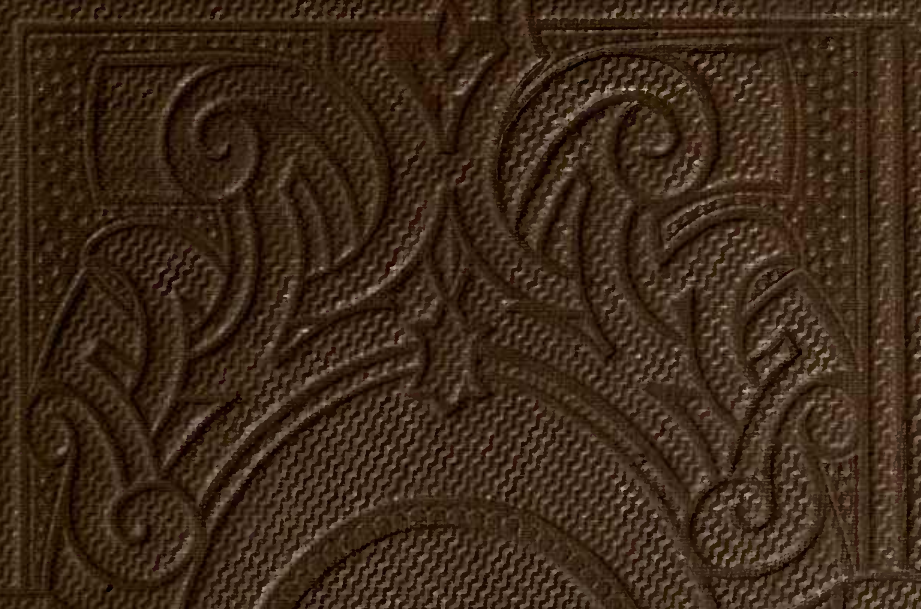

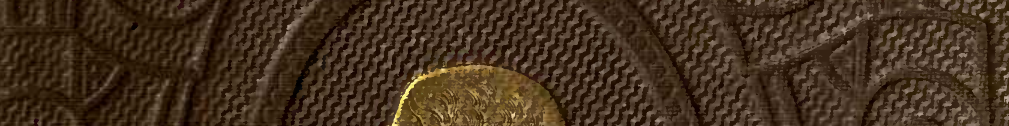

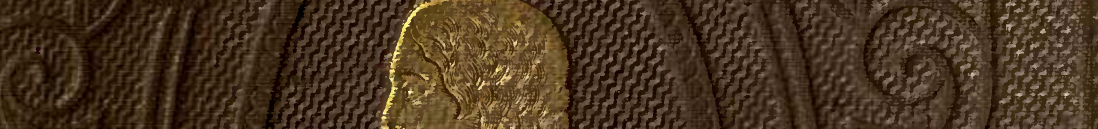

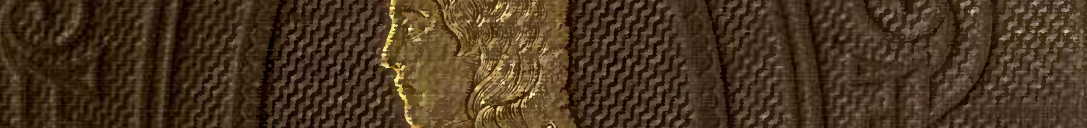

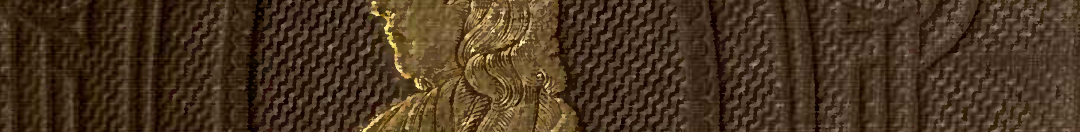

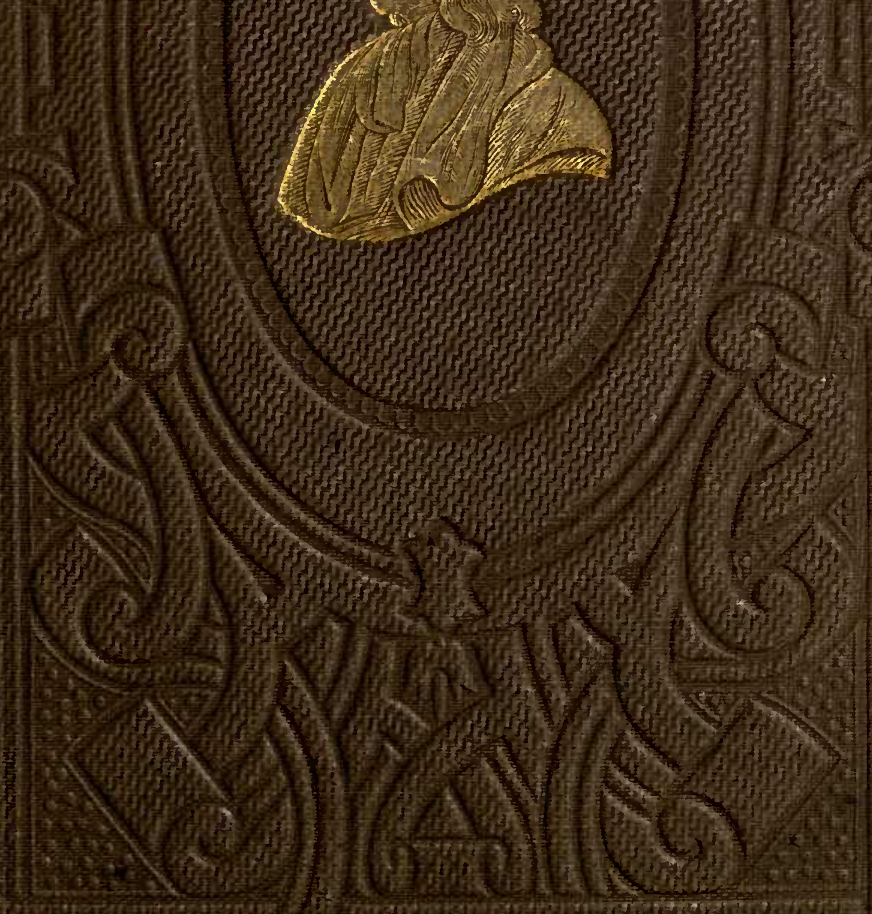

(10)

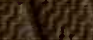




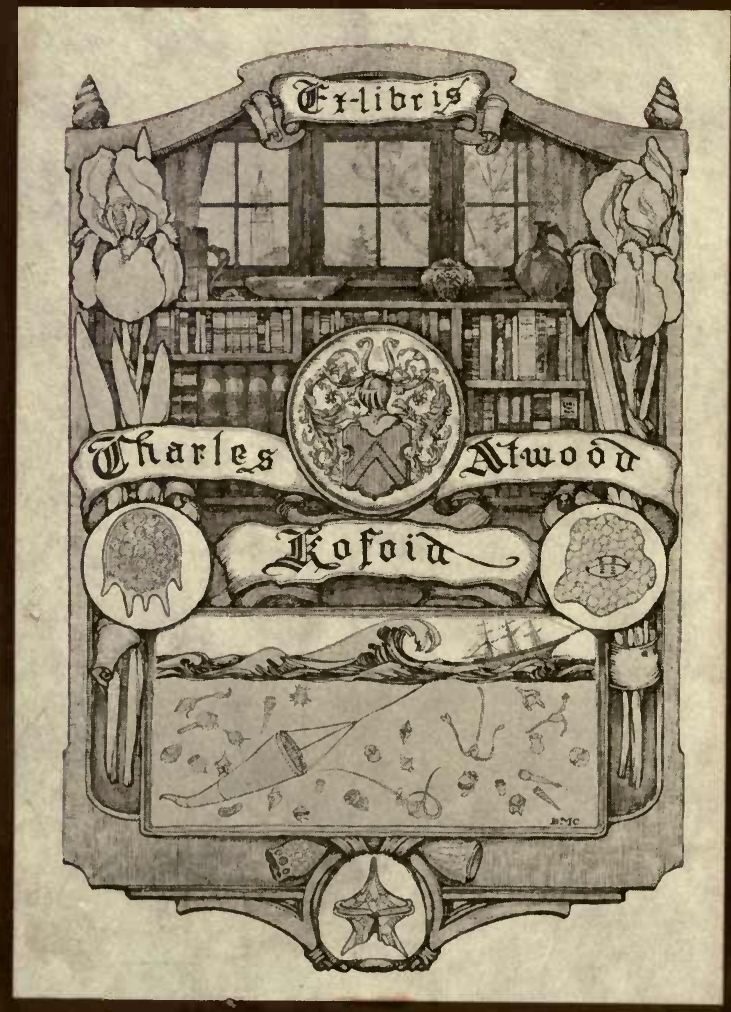




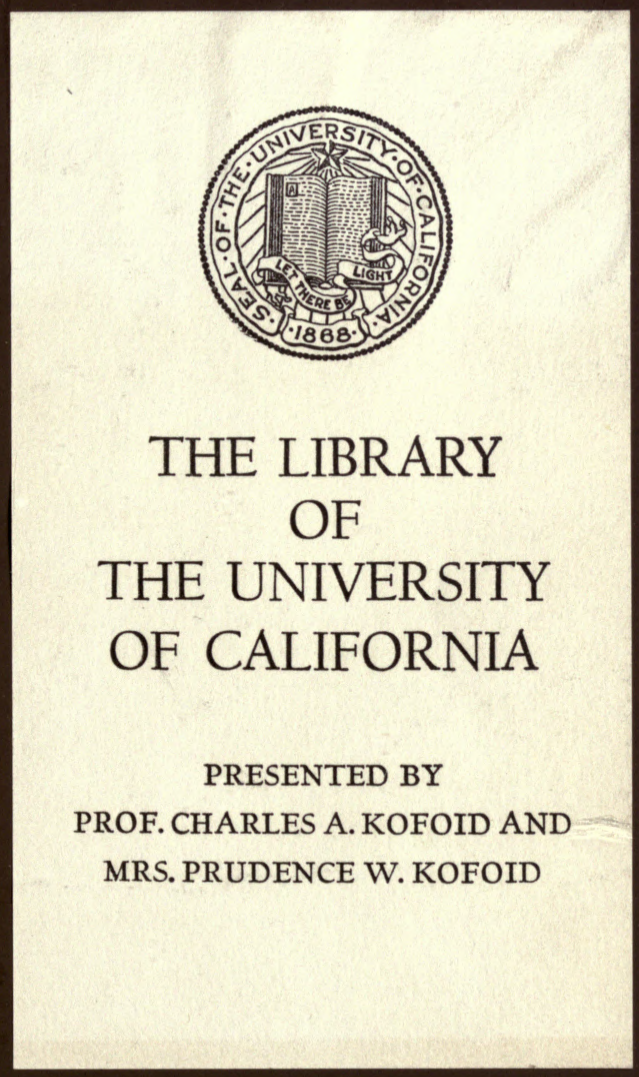




\section{THE NEW SYDENHAM SOCIETY.}

Instituted MDCCCLVIII.

VOLUME CXXXII. 


\section{MICR0-0RGANISMS}

WITH SPECIAL REFERENCE TO THE

\section{ETIOLOGY OF THE INFECTIVE DISEASES,}

BY

Dr. C. FLÜGGE,

O. O. Professor and Director of the Hygienic Institute at Göttingen.

\section{Translated from the}

SECOND AND THOROUGHLY REVISED EDITION OF "FERMENTE UND MIKROPARASITEN."

B Y

W. WATSON CHEYNE, M.B., SURGEON TO KING'S COLLEGE HOSPITAL.

WITH 144 DIA $W I N G S$.

QPondour:

c THE NEW SYDENHAM SOCIETY.

MDCCCXC. 

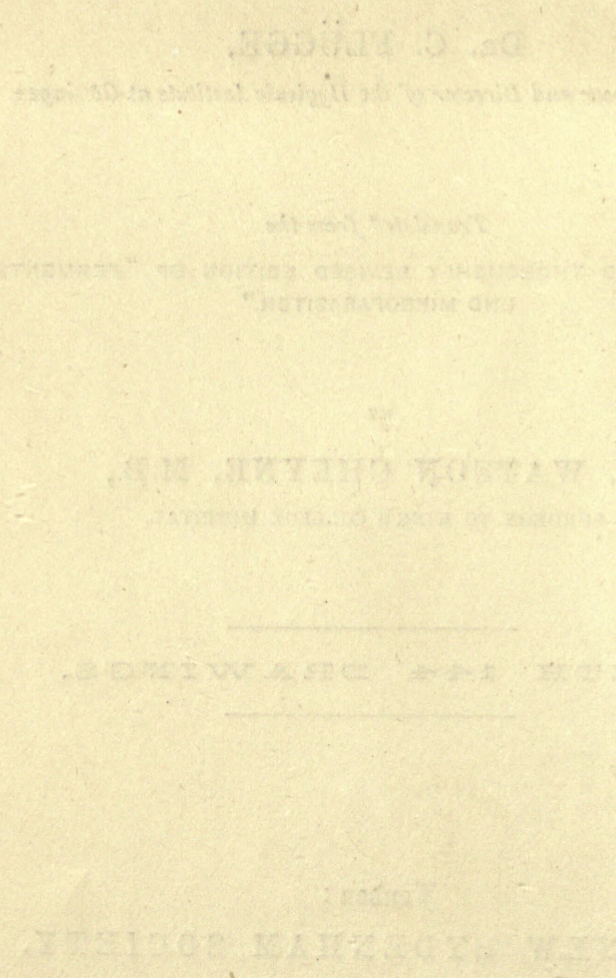


$$
\begin{aligned}
& \text { K-QR41 } \\
& \text { F62 } \\
& \text { Bul. } \\
& \text { Lile. }
\end{aligned}
$$

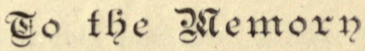

OF

J. HENIE. 


\section{PREFACE.}

THE first edition of the present work formed a part of the Handbuch der Hygiene, edited by von Ziemssen and von Pettenkofer; the description, however, there given was incomplete, because it was intended to supplement it by articles by other authors on "Air," "Soil," and "Common Diseases." As, howerer, the appearance of these supplementary articles has been greatly delayed, and as also, on account of the great dirergence of the views on the subject of micro-organisms, uniformity of description was scarcely possible, I have preferred to publish the second edition of "Micro-organisms" in a separate form, and to add chapters on the subjects which were not treated of in the first edition.

Apart from these additions, the chapters of the previous edition have been fully revised and in great part re-written.

There are two leading ideas which have guided me in the preparation of the present edition. In the first place, I desired to give a practically useful classification of bacteria. For this purpose I have described as fully as possible the culture characteristics of the individual forms, and have provided a key for the diagnostic separation of the different species of bacteria in each of the three chief groups.

I have not made any attempt to give a scientific classification of the bacteria, and the characteristics described are only of use practically in enabling the reader to obtain a general idea as regards the species already known, and to recognise new species should he meet with them, \&c. In this way material will be collected, which may, perhaps, at a future period be of use in leading us to a truly scientific classification. 
Our knowledge of micro-organisms is as yet so imperfect that for the present we absolutely require some such rough method of making ourselves mutually intelligible. The attempts to classify bacteria according to other principles, and with reference to their ontogenetic and phylogenetic development are doubtless justified, but in view of the small number of definite observations are premature, and at any rate for practical purposes are in the meantime completely useless.

Nor can we form a practical classification on the basis of spore formation, because in the case of most species it is very difficult to decide whether, under what conditions, and how they fructify.

On the other hand, by careful attention to the characteristics of growth on certain soils, it is comparatively easy, as the experience of several years has taught us, for the beginner to find his way in the labyrinth of the forms of bacteria, and we are certainly justified in the meantime in joyfully trusting ourselves to this Ariadne thread, always bearing in mind that the indications so obtained are provisional and only pave the way for more thorough linowledge.

For the diagnostic summary attempted here it was necessary to give names as far as possible to the individual species of bacteria. The culture characteristics have for the most part formed the bases for these names, and hence they have, like the classification itself, only a provisional importance, and are only justified in so far as they render mutual understanding easier for the present. Should some authors be dissatisfied with the names which have here been chosen for the bacteria first described by them, they may excuse my action when they remember the necessity for a terminology, the provisional character of the names, and the possibility of altering them at any time.

Some of the more common forms of saprophytes collected in this Hygienic Institute are only described incompletely, and with almost exclusive reference to the characters which are of use in differentiating them. A more complete study of these forms is proposed at a later time. I am deeply indebted to the workers at the Institute, Drs. Oberdiek, Henrijean, Guarneri, Kreibohm, 
\&ce, but in particular to my assistants, Dr. Deneke and Dr. Praussnitz, for the help which they hare given me in this arduous work.

The second idea which guided me in altering the former edition has reference to the etiology of the infective diseases.

As to the mode of spread of these diseases we have as yet received explanations almost entirely from the experiences of medical practice, and from statistical observations. The number of definite results obtained in this way has, however, been extremely small, and where a law such as the peculiar local and seasonal distribution of typhoid and cholera epidemics is recognised we are, with regard to the significance and explanation of the phenomena, thrown back on a series of more or less probable hypotheses.

The bacteriological investigations of the last few years have produced a complete change in this respect. By the discovery of numerous disease germs, and of the methods of their pure cultivation, it has become possible to study experimentally the conditions of life of the infective organisms, their mode of life, their relation to their surrounding, their transportability, and the mode of their entrance into man, and thus to obtain information as to the causes of the peculiar mode of spread of epidemic diseases, in a manner incomparably quicker and more trustworthy than by empirical and statistical methods.

I have as far as possible in the present work made use of these advances of the most recent scientific investigations, the bearing of which is decidedly underrated, and have attempted to explain the mode of spread of infective diseases, more especially of cholera, by reference to the facts ascertained by experiment as to the characteristics of the causal agents.

It must be erident that we have already gained in this way, in the case of a number of infective diseases, a deeper insight into their mode of spread and the prophylactic measures necessary in combating them. In the case of many diseases we do not as yet fully understand their mode of spread; nevertheless by the aid of the results of bacteriological investigations we can 
at least understand what are the points which will eventually lead to the elucidation of the peculiarities in this respect; and we can recognise most clearly that it is not correct to regard in a one-sided manner the soil or the water as the only important factor. In every case we may hope that a continued experimental investigation carried on with a definite aim will lead us most quickly to an increase of our knowledge, and to a rational method of prophylaxis against the epidemic diseases.

Many other duties have prevented me from finishing the publication of this book as quickly as I could have wished. I have not been able to utilise completely the literature of 1885 , and only the most important of the works which have appeared in the present year have been added while the book was passing through the press. The yearly report of micro-organisms lately published by Baumgarten, and written with as much care as knowledge, relieves me, however, of the necessity of giving in an appendix a notice of the more recent works.

\section{FL ̈̈GGE.}

\section{GöTTINGEx,}

August 24th, 1886. 


\section{LITERATURE。}

\section{TEXT-BOOKS, HAND-BOOKS, REVIEWS, \&c.}

Ehrenberg, die Infusionsthierchen als vollkommene Organismen. Leipzig, 1838.

Dejardin, Histoire naturelle dès zoophytes. Paris, 1841.

Hexte, Pathologische Untersuchungen, 1840. Handbuch der rationellen Pathologie, 2 Band. 2 Abth., 1853.

Bonorden, Handbuch der allgemeinen Mykologie, 1851.

BAIL, Die wichtigsten Sätze der neueren Mykologie. Jena, 1361. Hallier, Die pflanzlichen Parasiten. Leipzig, 1836. Parasitologische Untersuchungen, Leipzig, 1868. Phytopathologie, ib. 1868.

De Bary, Morphologie und Physiologie der Pilze \&c. 2 Bd. 1 Abth. von Hofmeister's Handbuch der physiologischen Botanik. Leipzig, 1866.

ErdaM, Der gegenwärtige Standpunkt der Mykologie, 2 Auft. Berlin, 1872.

SACHS, Lehrbuch der Botanik, 4 Aufl. Leipzig, 1874.

Pfeffer, Pflanzenphysiologie, ein Handbuch, \&c, 2 Bde. L sipzig. 1881.

Leuvis, Synopsis der Pflanzenkunde; 3 Abth., Kryptogamen, bearb. von Frank. Hannover, 1877. 3 Aufl, 1883 (in the press).

Rabenhorst's Kryptogamenflora, 1 Bd. Pilze, von Winter. Leipzig, 1881.

Robin, Histoires des végétaux parasites.

Van Tieghem, Traité de botanique, 1883.

Grove, A Synopsis of the bacteria and yeast-fungi and allied. species.

Maganin, Les bactéries. Paris, 1878.

References by Richter and Birch-Hirschfeld in Schmidt's Ja'rrbüchern der ges. Medicin especially, Bd. 159, S. 169; 1875, Bd. 166 , S. 169 ; Bd. 168 , S. 57.

Lex, in Roth und Lex, Militärgesundheitspflege, I., S. 167, and 480. Ziegler, Lehrk. der patholog. Anatomie, 3 Anfl. Jena, 1885. 
KLEBS, Beiträge zur Anatomie der Schusswunden. Leipzig, 1872 -1873.-Article "Ansteckende Krankheiten" in Eulenburg's Realencylopädic.

Declaux, Ferments et Maladies. Paris, 1882.

Perroncito, Parassiti dell' uomo e degli animali utili: delle qui comuni malatti da essi prodotte : profilasi é cura relativa. Milano, 1882.

Rochas, Les schizophytes parasites de l'homme. Bâle, Lyon, Génève, 1884.

Fol, Les microbes. Génève, 1885.

Woodhead and Hare, Pathological Mycology, 1 Section. Edin. burgh, 1885.

Cornil et Babés, Les Bactéries. Paris, 1885.

Zopf, Die Spalt-pilze, 3 Aufl. Breslau, 1885.

De Bary, Vergleichende Morphologie, u. Biologie der Pilze. Mycetozoen u. Bacterien. Leipzig, 1884.

Fisch, Die systematische Stellung der Bakterien. Biolog. Centralbl., Bd. 5, 1885.

Tommasi-Crupeli, Instituzioni di Anatomia patologica. Torino, 1884.

(See also under "Production of Disease.")

GENERAI, LITERATURE.

Сону, Untersuch. über d. Entwickelungsgesch, d. microscop. Algen u. Pilze, Nov. Act. Leop., Vol. 24, 1853.

-, Beiträge zur Biologie der Pflanzen, I. Band 1875; II. Band 1877; III. Band 1879-1880.

De Bary v. Woronin, Beiträge z. Morphol. u. Physiologie der Pilze. Frankfurt-a-M. 1864, 1866, 1870.

Hofmann, Mykologische Berichte. Giessen, 1870-1872.

NÄG ELI, Beiträge z. wissenschaftlichen Botanik, Heft. II. (1860).

- Die niederen Pilze in ihren Beziehangen zu den Infectionskrankheiten. München, 1877.

-, Untersuchungen über niedere Pilze. München, 1882.

Reinke u. Bertiold Die Zersetzung der Kartoffel durch Pilze. Berlin, 1879.

Cinnkowski, Zur Morphologie der Bakterien: Petersburg, 1876.

Zopf, Zur Morphologie der Spaltpflanzen. Leipzig, 1882.

—, Zur Kenı.tniss des Phykomyceten I. Halle, 1884.

- Zur Morphologie u. Biologie der niederen Pilzthiere (Monadinen). Jeipzig, 1885. 
Zopf, Die Pilzthiere oder Schleimpilze. Breslau, 1885.

Davaine, Recherches sur les Vibrioniens. Compt. rend., 1834, T. 59, p. 629 .

Pasteur, Animalcules irfusoires, \&c. Compt. rend., LII., 1861.

Jovbert et Chamberiand, La théorie des germes et ses applications ì la médicine et chirurgie. Compt. rend. 1878 , Vol. 86, p. 1037 -1043 .

KLEBS, Beiträge zur Anatomie der Schusswunden. Leipzig, 1872. Brelreth, Untersuchungen über die Vegetationsformen d. Coccobacteria septica. Berlin, 1874.

Lronex Beale, Disease germs, their nature and origin, 1872.

KuEIN, Experimental Contribution to the Etiology of Infections Diseases, with special reference to the Doctrine of Contagium vivum. Proceed. of the Roy. Soc. of London, Febr, 1878, Vol. 27. Aufrecht, Pathologische Mittheilungen., I. Heft. Magdeburg, 1881, bei Faber.

Baumatrtex, Ueber pathogene pfllanzliche Organismen, II. Die pathogenen Sehizomyceten. Berlin, 1884.

Mituhemungex des kaiserlichen Gesundheitsamts, Bd. I., 1881. Bd. II., 1884.

Arbeiten aus dem kaiserl. Gesundheitsamt., Bd. I., 1885.

\section{Spontaneots Generation. \\ (See also "Fermentation.")}

Schulze, Gilbert's Annalen der Physik u. Chemie, 1836, Bd. 33 , S. 487.

Ehrexbera, Abhdl. der Königl. Akad. d. Wissench. za Berlin, Jahrg. 1830, 1832, 1834-1835. Uebersicht der seit, 1847, fortgesetzten Untersuchungen über das von der Atmosphäre unsichtbar getragene reiche organische Leben. Aus den Abhdl. d. Kgl. Akad. d. Wissenseh. z. Berlin, 1871, C, Vogt.

Schwaxy, Gilbert's Annalen der Chemie u. Physik, 1837, Bd. 41, S. 184.

Schröper v. v. Dusich, Annalen der Chemie u. Pharm., 1854, Bd. 89 , S. $232-24: 3 ; 1859$, Bd. 109 , S. $35-52 ; 1861$, Bd. 117, S. $273-294$.

F. Schulze, Ann. d. Phys. u. Chem., 1836, Bd. 39.

Pouchet, Hétérogénie ou traité de la génération spontanée. Paris, 1859.

Pouchetet Houzead, Compt. rend. de l'Acad. des sc., 1858, Bd. 47. Pasteur, Compt. rend. de l'Acad. des se., 1860, Bd. 50 u. 51.

Huizixa, Arch. f. d. ges. Physiolngie, 1873, 1874, 1875. 
Bastian, Centralbl. f. d. med. Wissenschaften, 1876, S. 521.

$\rightarrow$ Compt. rend., Bd. 83, No. 8.

-, On Fermentation and the appearance of Bacilli, Micrococci, and Torulæ in Boiled Fluids. London, 1877.

Cherne, Antiseptic Surgery, 1882.

Gscheidlen u. Putzers, Pflüger's Arch., 1874, Bd. 9, S. 163-174.

Samuelson, Pflüger's Arch., Bd. 8, S. 277, 288

Burdon-Sanderson, Nature, Bd. 8, S. 478.

NüESCH, Die Nekrobiose in morphologischer Beziehung. Schafhausen, 1875.

Arvot, Untersuchungen über die Entstehung von Coccen u. Bacterien in organischen Substanzen. Virch. Arch., 1880, Bd. 82 , S. $119-146$.

TAschenberg, Lehre von der Urzengung sonst und jetzt. Halle, 1883.

Вєснамр, Les Microzymes dans leurs rapports avec l'hétérogenié, \&c. Paris, 1883.

Wigand, Entstehung und Fermentwirkung der Bacterien. Marburg, 1884.

On the Existence of Germs in Living Tissues.

VAN Dew Brock, Ann. f. Chemie u. Pharm., 1860, S. 115, 175.

Pasteur, Compt. rend., 56, S. 738, 1194, 1863, Bull. de l'acad. de méd., 1875. Etudes sur la bière, 1876, p. 46.

Gayon, Recherches sur les altérations spontanées des oufs. Paria, 1875, p. 45.

-, Compt. rend., 1873, Jan.

IÜDRrs, Arch. f. mikr. Anat., 8, S. 317, 1867.

SAmoel, Arch. f. exp. Pathol., 1873, Bd. 1.

Sternberg, John Hopkin's Univ. stud. biol. Baltimore, Vol. 2.

Lewis, Quart. Journ. of Microsp. sc., 1879, Vol. 19.

Hexsen, Ibid., p. 342.

Rindfleisch, Virch. Arch., 54, S. 39, 1872.

Chauveau, Compt. rend., 76, p. 1092, 1873.

Paschutin, Virch. Arch.; 59, S. 490, 1874.

Kolaczer, Centralbl.f. Chirurgie, 1875, S. 197.

T'regei, Virch. Arch., 60, S. 453, 1874.

Kovkol-YASNopolski, P'flüger's Arch., 12, S. 80, 1876.

Servel, Compt. rend., 79, p. 1270, 1874.

Burdon-Sanderson, Thirteenth report of the Medical Office of the

Priv. Counc., p. 63; Quarterly Journ. of Microscop. sc., 1871;

The British Medical Journ., 1878, p. 119.

Nexcki v. Giacosa, Joum. für pract. Chemie., N. F., Bd. 19 น. 20. 
Roserts, Philosophical Transactions, 1874, p. 457.

Cazeneuve et Livon, Compt. rend., 45, p. 571, 1877.

Brllroth, Arch. f. klin. Chir., 20, S. 432, 1877. Coccobacteria septica, p. $59 \mathrm{ff}$.

Weissgerber u. Perls, Arch. f. exp. Pathol., Bd. 6.

Lister, Journ. of Microsp. sc., 1878, p. 179.

Watson Cheyne, Path. Soc. Transactions, 1879, and Antiseptic Surgery, 1882.

Chiene and Cossar Ewart, Journ. of Anat. and Phys., 1878, April, p. 448.

Rosexbach, Ueber einige fundamentale Fragen in der Lehre yon den chirurgischen Infectionskrankeiten; Deutsche Zeitschr. f. Chirurgie, Bd. 13, S. 334, 1880. There also detailed reference to Meissner's experiments.

ZAHN, Virchow's Archiv, Bd. 95.

Leube, Zeitschr. f. klin. Med., 1881, Bd. 3.

Firket, Annal. de la soc. méd. chir. de Liège, 1879, Vol. 18. Horsicy and Motr, Journ. of Physiolog., 1880, Vol. 3.

Hauser, Arch. f. ges. Physiol., Bd. 33.

v. Hoffuans, Untersuchungen über Spaltpilze im menchslichen Blute. Berlin, 1884.

Marchand, Sitzungsber. d. Ges. zur Beförderung d. ges. Naturwissenchaften zu Marburg 1885, März.

\section{GENERAL LITERATURE ON MOULD FUNGI.}

Lecnis, Rabenhorst, de Bary, p. 1.

Brefeld, Botan. Untersuchungen über Schimmelpilze, I.-IV.

Siebenmann, Die Fadenpilze. Wiesbaden, 1883.

van Tieghem, Sur le développement de quelques Ascomycètes (Aspergillus). Bull. soc. bot. de France, 1877.

-, Recherches sur les Mucorinées. Ann. sc. nat., 1873, 1875, 1878. Zimmermann, Das Genus Mucor. Chemnitz, 1871.

BREFELD, Landw. Jahrb. V. 1876 (Mucor racemosus).

For further facts see Leunis und de Bary.

\section{Diseases of Plants due to Mould Fungi.}

Tulasse, Mémoire sur les Ustilagin. compar. aux Urédin. Annal. des sc. natur., 3 sér., T. 7, 1847; T. 2, 1854. Mém. sur l'Ergot. Ibid., T. 20.

DE BARr, Untersuchungen über die Brandpilze, 1853. Untersuchungen über Uredineen. Monatsber. d. Königl. Acad. d. Wiss. zu Berlin, $1864-66$.

-, Annal. de Landwirthschaft., 23 Jahrg., 1865. 
de BARy, Recherches sur le déreloppement de quelques champignons parasites. Ann. des. sc. nat. 4 sér. II., 1865.

ve Bary 0. Woronin, Beiträge zur Morph. u. Phys. der Pilze, III. Frankfurt, 1870.

Küнn, Die Krankheiten der Culturgewächse. Berlin, 1858.

WiLlкомм, Die mikroskopischen Feinde des Waldes. Dresden, 1866.

Hofrmann, Botanische Untersuchungen, herausgeg. von Karsten, 1866.

Fischer U. Waldheim, Jahrb. f. wiss. Botanik ron Pringsheim, Bd. 7, 1869.

REes, Die Rostpilzformen der deutschen Coniferen. Halle, 1869. Hartig, Wichtige Krankheiten der Waldäume.

-, Untersuchungen ans dem forstbotan. Inst. zu München, I.-III.

-, Ueber die durch Pilze bedingten Pflanzenkrankheiten.Vorträge im ärztlichen Verein zu München, 1881.

—, Die Zerstörung des Bauholzes durch Pilze, I. Berlin, 1885.

Sorauer, Landwirthsch. Versuchsstationen, Bd. 25, 1880. Botan.

Zeitung, 1882.

WoLfF, Thiel's Landw. Jahresber, 1872.

\section{Mould Fungi as Animal Parasites. \\ In Caterpillars.}

RoBin, Histoire naturelle des végétaux, qui croissent sur l'homme et les animaux vivans. Paris, 1848, 1853.

De BARY, Zur Kenntniss insectentödtender Pilze, Botan. Zeit., 1867, 1869.

BaIL, Ueber Pilzepizootien der forstrerhereenden Raupen. Danzig, 1869.

\section{In Flies.}

Görhe, Hefte zur Morphologie, I. 292.

Nees y. Esenbeck, Nov. Act. Acad. Caes. Iseop. Car. Nat. Cur., Bd. 15, 1831.

Coнn, Empusa muscae u. die Krankheit der Stubenfliege. Breslau, 1865.

Lebert, Abh. der naturforsch. Ges. in Zürich, 1856.

Fresenius, Abh. d. Senckendorff'schen. natnif. Ges., Bd. 2, S. 201. Brefeld, Unters. über die Entwickl. der Empusa muscae and Emp. radicans. Halle, 1871.

Peyritsch, Sitzungsber der k. k. Akad. der Wiss. in Wien., Bd.64, 1871. 
In Man and Higher Animals.

Roвis, 1. c.

Friedreich, Virch. Archiv, Bd. II.

CoHNheim, Ibid., Bd. 33.

Fürbẹinger, Ibid., Bd. 76.

Rosenstein, Berl. klin., Wochenschr., 1867.

WAGNer, Jahrb. f. Kinderheilkunde, 1868.

Zenker, Jahresb. der Ges. für Natnr- u. Heilk. in Dresden, 186162.

Groнe, Berl. klin. Woch., 1871.

Block, Ueber Pilzbildung in thierischen Geweben. Diss. Stettin, 1871.

LEBER, Aerztl. Intelligenzbl., 28 Jahrg., Nr. 7.

BszoLd, In den Vorträgen im ärztlichen Verein zu München, 1881. KITT, Deutsche Zeitschr. f. Thiermedicin., Bd. 7.

Grawitz, Virchow's Archiv, Bd. 70, 1877 ; Bd. 81, 1880.

-, Berl. klin. Woch., 1881, Nr. 45 u. 46.

Krannhals, St. Petersb. med. Woch., 1881.

Srebenmann, Die Fadenpilze. Wiesbaden, 1883 (See there the older literature).

GaFFKY, Mittheilungen des Kais. Ges.-Amts., 1 Bd., S. 80.

LÖFFLER, Ibid., S. 134.

KоcH, Berl. klin. Woch., 1881, Nr. 52.

L.EBER, Berl. klin. Woch., ]882, Nr. 2.

Lichtheim, Berl, klin. Woch., 1882, Nr. 9 u. 10.

- Ueber pathogene Mucarineen. Zeitschr. f. klin. Medicin., Bd. 7, H. 2.

Schürz, Ueber das Eindringen von Pilzsporen in die Athmungswege. Mitth. a. d. Kais. Ges.-Amt., Bd. II.

—, Ueber den Pilz des Hühnergrinds, Ibid., Bd. II.

Hëckel, Zur Kenntniss der Biologie von Mucor corymbifer.

Beitr. zur path. Anat. u. Phys. von Ziegler u. Nauwerck., Heft.

I. Jena, 1884.

Kleinhans, Die parasitären Hautaffectionen. Erlangen, 1864.

PICK, Unters. über die pflanzlichen Hautparasiten. Verhandl. d. zoolog. botan. Ges. in Wien., Bd. 15, 1865.

Pexritsch, Beitrag. zur Kenntniss des Favus. Wien. Inedicin. Jahrb., Bd. 17, 1869.

Bizzozero, Ueber die Mikrophyten der normalen Oberhaut des

Menschen. Virch. Arch., 98.

BABÈs (Ö̈dium subtile cutis) Biolog. Centralbl., Bd. 2.

Friedreich, Virchow's Arch., Bd. 30, 1864. 
ExGlisch, Centralbl. f. Chirurgie, Bd. 15, 1883 (Schimmelpilze an dem Praeputium von Diabetikern).

Behrend, Herpes tonsurans u. Favus. Viertelj. f. Dermatol u. Syphilis, 1884.

Kundrat, Ueber Gastro-enteritis favosa. Wien. medie., Bl., Nr. 49. Baumgarten, Die pathogenen Hyphomyceten. Deutsche MedicinalZeitung, 1874.-Berl. klin. Woch., 1882.

Balzer, Contribution à l'étude de l'érythème tricophytique (Herpes cireinnatus), Arch. de Phys., 1883, Bd. 1.

RoEcki, Ueber Pneumonomykosen. Deutsche Zeitschr. f. Thiermed. X., S. 122.

\section{ACTINOMYCES.}

Bollinger, Centralbl. f. d. Med. Wissensch., 1877.

Ponrick, Die Actinomykose. Berlin, 1881 (See there the older literature).

IsRa ËL, Virchow's Arch., Bd. 74.-Bd. 78.-Bd. 95 u. 96. Klinische Beiträge zur Kenntniss der Actinomykose des Menschen. Berlin, 1885.

Johne, Deutsehe Zeitsehr. f. Thiermed,, 1881.

Hink, Centralbl. f. d. med. Wiss., 1881, 1882.

Prlug, Centralbl. f. d. med. Wiss., 1882.

Ganner, Boston Med. and Surg. Journ., 1882.

Fleming, Actinomycosis, London, 1883.

'Treves, Lancet, 1884, p. 107.

Firket, Rev. de Méd., Paris, 1884.

Pusch, Arch. f. wiss. u. gr. Thierheilk, 1883.

BANG, Tidskrift far. Veterinaerer, 1883. Ref. in Fortschr. d. Medicin, II., Heft 6.

Zemann, Wien. Med. Jahrb., 1883, S. 477.

Virchow, Virchow's Archiv, Bd. 95.

Mrtteldorpf, Deutsche Medic. Woch., 1884.

Karsten, Ibid., 1884.

Cirnari, Prager med. Woch., 1834, Nr. 10.

Boströм, Verh. d. Congr. f. innere Med. Wiesbaden, 1885.

Magnussen, Beiträge zur Diagnostik u. Casuistik der Actinomykose.

Dissertation. Kiel, 1885.

\section{BUDDING FUNGI--YEAST.}

(For Fermentation, see p. 45.)

Cagniard-Latrour, Mémoire sur la fermentation vineuse. Ann. de. chim. et de phys., 2 sér., T. 68 , p. 206.

Schwann, Annal. d. Phys. u. Chemie., 1837, T. 41, p. 184. 
KüTzING, Journ. f. prakt. Chemie., Band 11, S. 385.

REES, Botan. Unters, üb. d. Alkoholgährungspilze. Leipzig, 1870. -, Ueber den Soorpilz. Sitz-ber. der phys. med. Ges. zu Erlangen, : Juli, 1877, u. Januar., 1878.

Boxorden, Abh. der naturf. Ges. zu Halle, 1864.

Cienkowski, Die Pilze der Kahmhaut. Mélang. biolog. Acad. Imp. de St. Petersbourg, T. 8.

Grawitz, Virchow's Arch., Bd. 70, 1877, and Bd. 73, 1878.

Pasteur, Mémoire sur la fermentation alcöolique. Ann. Chim. Phys., T. 58.

—, Etudes sur la bière. Paris, 1876.

Schützenberger, Unters. über die Bierhefe. Ber d. Chem. Ges., 27,

S. 192. Compt. rend., 1879, p. 383.

Fitz, Ber d. Chem. Ges., Bd. 6, 1873.

Brefeld, Mucor racemosus und Hefe. Flora, 1873.

-, Thiel's Landw. Jahrb., 1875-1878.

-, Botanische Unters. über Hefepilze (Leipzig, 1883).

Fischer, Die systematische Stellung der Hefepilze. Biolog, Centralb., Bd. 4, 1884.

HAlvsex, Meddedelser fra Carlsberg-Laboratoriet, Band I.

-, Botan. Centralb., Bd. 17.

-, Neue Untersuchungen - über Alkoholgährungspilze. Ber. d. deutsch. botan. Gesellsch., 1884, Bd. II.-Zeitschr. f. d. ges. Brauwesen, 1884.

Bонn, Article "Soor" in Gerhardt's Handb. d. Kinderkrankheiten. Tübingen, 1880.

Kehrer, Ueber den Soorpilz. Heidelberg, 1883 (See there the older literature).

Martin, Soor beim Truthahn. Jahrb. d. k. Theierarzneisch. zu München, 1882-1883.

Plaut, Beitrag zur systematischen Stellung des Soorpilzes. Leipzig, 188.5.

Prerffer, Ueber Sprosspilze in der Kälberlymphe. Weimar, 1885.

\section{GENERAL LITERATURE ON BACTERIA AND} INFECTIVE DISEASES OF WOUNDS.

KocII, Wundinfectionskrankheiten. Leipzig, 1878.-Mittheil. d. Kais. Ges.-Amts., Bd. I.

Wolfr, Virchow's Arch., Bd. 81, Bd. 92.

Perret, De la Septicémie. Paris, 1880.

Semmer, Virchow's Archiv, Bd. 83.

Rindfleisch, Lehrb. der pathol. Gewebelehre, 1 Auf. 1866., S. 204, 
vos Recklinghausen, Verh. der Würzb. phys.-med. Ges., 1871.

Birch-Hrrschfeld, Untersuchungen über Pyämie. Leipzig, 1873.

K I.eBs, Beitr. zur. pathol. Anat. der Schusswunden. Leipzig, 1872.

-, Arch. f. exper. Pathol. u. Pharmakol. Leipsig, Band I., 1873.

III. 1875, IV. 1875, V. 1876, X. 1879.

-, Centralb. f. d. med. Wissensch. Berlin, Bd. 6, 1868.

Birch-Hirschfeld, References in Schmidt's Jahrbüchern, Bd. 166,

S. 169 , as to the literature during the years 1872-1874.

Virchow, Embolie u. Infection. Gesamm. Abhdl. 1857, S. 656.

WALDEYER, Zur pathol. Anatomie der Wundinfectionskrankheiten,

Virchow's Arch., Bd. 40, 1867.

1-, Mikrokokkencolonien in den parenchymatischen Organen.

Vortrag. i. d. med. Ges. zu Breslan, 4 Ang., 1871.

Sтісн, Charité-Annal., 1852.

Wrér, Deutsche Klinik., 1864-65.

Billroth, Arch. f. klin. Chir., Bd. 6, 265.

Billroth und Ehrlich, Ibid., Band 20, 1876.

Brluroth, Coccobacteria sept. Berlin, 1874.

Fischer, Centralblatt f. d. med. Wissench., 1868.

T'IEGEL, Ueber den fiebererregenden Eigenschaften des Microsporon septicum. Bern. 1871, Diss.

-, Virchow's Archiv, Bd. 60, 1874.

ZАHN, Zur Lehre von den Entzündungen, \&c. Heidelberg, 1872.

Heiberg, Die puerpalen u. pyämischen Processe. Leipzig, 1873.

Овтн, Virchow's Arch., Bd. 59, 1874.

-, Areh. d. Heilk. Leipzig, Bd. 13, 1872.

-, Virchow's Arch., Bd. 58, 1873.

- Arch. f. wissensch. u. prakt. Thierheilk. Bd. 3, 1877.

-, Berliner klin. Wochenschr., Bd. 9, 1872.

Coze et Feutz, Recherches expérimentales. Strassburg, 1866.

Lacassagne, De la putridité morbide et de la septicémie. Paris, 1872.

Davaine, Bouley, Behier, Vulpian, Colin, Hayem, Bull. d. l'Acad. de méd., 1872-1873.-Ibid., 1862, 1879, 1881.

- Compt. rend. Soc. de biol. Paris, 1874.

Nassiloff, Virchow's Arch., Bd. 57, 1873.

Eererth, Zur Kenntniss der bakterischen Mykosen. Leipzig, 1872.

-, Med. centralblatt. 11, S. 8, 32. 1873.

-, Virchow's Arch., Bd. 57, 1873.

一, Ibid., Bd. 77, 1879.

一, Ibid., Bd. 80, 1880.

Lerer, Med. Centrlbl., Bd. 11, 1873.

Heiber(, Med. Centrlbl., Bd. 12, 1874. 
Clementr, Med. Centrlbl., 1873, 45.

Ilveter, Allgem. Chirurgie. Leipzig, 1873.

-, Deutsche Zeitschr. f. Chirg., 1872.

Huber, Deutsches Archiv f. klin. Med. Leipzig, Bd. 25.

LAxdaU, Arch. f. klin. Chir. Berlin, 27, 1874.

-, Verhandl. d. deutschen Gesell. f. Chirurgie, Band 2, 1878.

Scrüller, Deutsche Zeitschr. f. Chir. Leipzig, Bd. 6, 1875.

Nepvev, Ueber die Bedentung der niederen Organismen bei chirurgischen Affectionen. Gaz. de Paris, 1875.

Feltz, Compt. rend. Acad. d. sc. Paris, T. 76, 1873.-Ibid., T. $79,1874$.

Letzerich, Arch. f. exper. Path. u. Pharmakol. Leipzig, Band 7, 1877.

-, Virchow's Arch., Bd. 68, 1876.

Cinauveau, Compt. rend. Acad. d. sc. Paris, T. 76, 1873.-Ibid., T. $92,1881$.

-, Gaz. hebd. de méd. Paris, T. 12, 1875.

-, Gaz. d. hôp. Paris, 1881.

Colin, Bull. Acad. de Méd. Paris, T. II., 1873.-Ibid., T. 4, 1875.

-, Ibid., T. 7, 1878.-Ibid., T. 8, 1879.-Ibid., T. 10, 1881.

Bert, Compt. rend. Soc. de biol. Paris, T. 2, 1875.-Ibid., T. 5, 1878.-Ibid., T. 7, 1880.

Balfour, Edinburgh Med. Journ., Vol. 23, 1877.

Pasteur, Bull. Acad. de méd., Paris, T. 9, 1880.

-, Compt. rend. Acad. d. sc. Paris, T. 85, 1877.-Ibid., 'T. 87, 1878.

PuкY, Virchow's Arch., Bd. 69.

Beck, Rep. Med. Off. Local Gov. Board, 1879.

IsRäex, Virchow's Archiv, Bd. 74, 1878.

-, Berl. klin. Wochenschr., Bd. 15, 1878.

Litres, Berl. klin. Wochenschr., 1878.

—, Zeitschr. f. klin. Med., 1880.

Drysdale, Pyrexia. London, 1880.

Tinfmanss, Verhdl. d. dentschen Gesellsch. f. Chirurgie, Band 7, 1878.

Toussaint, Compt. rend. Acad. de sc. Paris, T. 91, 1880.

Trndali, Essays on the Floating Matter of the Air in relation to

Putrefaction and Infection. London, 1881.

Zweifel, Zeitschr. f. physiol. Chemie. Strassburg, Band 6, 1882.

Mıkvlicz, Arch. für klin. Chir. Berlin, Band 22, 1878.

Lister, Lancet, Vol. 2, 1867.

-, Med. Times and Gazette, Vol. 2, 1877. 
Lister, Quart. Journ. Micr. Sc. London, Vol. 13, 1873.-Ibid., Vol. 18, 1878.-Ibid., Vol. 21, 1881.

Kuein, Rep. Med. Off. Lucal Board (1881) London, 1882.

Braidwood and Vacher, Brit. Med. Journ., Vol. I., 1881.

Oertei, Zur Aetiologie der Infectionskrankheiten, 1881.

OGstos, Brit. Med, Journ., Vol. I., 1881.

-, Journ. of Anat. aud phys., Vol. 17, 1882.

Raynad, Bull. Acad. de méd. Paris, T. 10, 1881.

Rószahegy, Practitioner, London, Vol. 38, 1882.

Rósenberger, Verhdl. der phys. med. Ges. zu. Würtzburg, 1882.

Sternberg, Am. Journ. Med. sc. Philad., Vol. 84, 1882.

- John Hopkins Univ. stud. biol. lab. Baltimore, Vol. 2, 1882.

NaUny , Berl. klin. Wochenschr., Bd. 20, 1883.

Ewart, Proc. Roy. Soc. London, Vol. 32, 1881.

Gussenbauer, Sephthämie, Pyohämie, und Pyosephthämie. Deutsche

Chirurgie von Lücke und Billroth. Stuttgart, 1882.

Dowdesweli, Proc. Roy. Soc. London, Vol. 34, 1883.

—, Quart, Journ. Micr. Sc. London, Vol. 18, 1878.

Cornil et BABÈs, Arch. de physiol. norm. et path., T. 2, 1883.

BıвÈs, Compt. rend. Acad. de sc. Paris, T. 97, 1883.

Arloring, Compt. rend. Acad. de sc. Paris, T. 98, 1884.

Cheyne, Trans. path. Soc. London, Vol. 30, 1879.-Ibid., Vol. 35,

1884. Brit. Med. Journal, 1884, 1886, 1888, \&c.

Sutron, Trans. Path. Soc. London, Vol. 34, 1813.

Strange, Brit. Med. Journ., Vol. 2, 1883.

Stevens, Glasgow Med. Journ., Vol. 22, 1884.

Rosenbach, Mikroorganismen bei den Wundinfektionskrankheiten

des Menschen. Wiesbaden, 1884.

Passet, Fortschritte d. Medicin, Bd. 3, 1885.

Arlonvg, Recherches sur les septicémies, Lyons, 1884.

\section{SUPPURATIVE INFLAMMATION OF THE CELLULAR TISSUE.}

Pasteur, Le furoncle. Bull. de l'Acad. de Méd., Sér. 2, T. 9, 1880.

Löwenberg, Le furoncle de l'oreille. Paris, 1881.

Rosenbach, Mikroorganismen bei den Wundinfectionskrankheiten des Menschen. Wiesbaden, 1884.

PASsEt, Ueber Mikroorganismen der eitrigen Zellgewebsentzündung des Menschen. Fortschritte d. Med., 1885, No. 2.

Garré, Zur Aetologie acut eitriger Entzündungen. Fortschritte de Med., 1885, 165. 
Duclaux (Bouton d'Alep. et de Biskra), Bull. de l'Acad. de médecine, 1884, 10th June.

Cheyne, Brit. Med. Journal, 1884, 1886, 1888.

\section{OSTEOMYELITIS.}

Collyans, Bakterien im Organismus eines an einer Verletzung am

Oberschenkel verstorbenen Mädchens. Göttingen, 1873.

ËвеRт, Virchow's Arch., Bd. 65, 1875.

Frieduann, Fall von primärer infectiöser Osteomyelitis. Berl. klin. Wochenschr., XII. 4, 5, 6, 1876.

SCHÜLLER, Zur Kenntniss der Mikrokokken bei acuter infectiöser

Osteomyelitis. Mikrokokkenherde im Gelenkknorpel, Centralbl. f. Chir., 1881., No. 12.

BECkER, Vorl. Mitth. über den die acute infectiöse Osteonyelitis erzeugenden Mikroorganismus., D. Med. Wochenschr., Nov., 1883.

Kratse, Ueber einen bei der acuten infectiösen Osteomyelitis vorkommenden Mikrokokkus, Fortschr. d. Med, Bd. 2, 1884.

Rosenbach, Vorl. Mitth. über die acute Osteomyelitis beim Menschen erzeugenden Mikroorganismen. Centralbl.f. Chir., 1884, No. 5.

Peyroud, Compt. rend., 1884, October.

RoDet, Etude expérimentale sur l'osteomyélite infectieuse. Compt. rend., T. 99, p. 569.

\section{ERYSIPELAS.}

Recklinghausen u. Lankowski, Ueber Erysipelas. Virchow's Archir, B. 60, 1874.

Lukомsкт, Virchow's Archiv, Bd. 60, 1874.

Hëter, Med. Centralbl., No. 34, 1868.

Orth, Archiv f. exper. Pathol. u. Pharmacol., Bd. 1, 1873.

Raynadd, Union Méd., Paris, 1873.

Trosier, Bull. Soc. anat. de Paris, 1875.

BaAder, Zur Aetiologie des Erysipels. Schweiz, naturf. Gesellsch. Basel, 1875.

Klebs, Archiv f. exper. Pathol u. Pharmakol, Bd. 4, 1875.

Ehrlich, Langenbeck's Archiv, Bd. 20.

'Tillmanns, Verhandl. d. deutsch. Ges.f. Chirurgie, 1878.

-, Experimentelle u. anatomische Unters, \&c., Archiv f. klin.

Chirurgie. Band 23, 1879.

Wol,fF, Virchow's Archiv, Bd. 81. 
Dupexrar, Reserches cliniques et experimentales sur la pathogénie d. l'érysipèle. Paris, 1881.

Fenteisen, Die Aetiologie des Erysipels. Berlin, 1883.

-, Deutsche Zeitschr. f. Chirurgie. Band 16, 1882.

-, Ueber den Erysipelaspilz. Würzburger phys. med. Ges. Aug., 1881.

Jayicke. v. Neisser, Exitus lethalis nach Erysipelas. Centralbl. f. Chir., 1884, No. 25.

Rheiner, Beitr z. path. Anat. des Erysipels bei Gelegenheit der Typhusepid. in Zürich, 1884. Virchow's Arch., Bd. 100, Heft 2.

\section{EMBOLI AND METASTASES.}

Burkart, Ein Fall von Pilzembolie. Berl. klin. Wochenschr., XI., 1874.

Martini, Deutsche Ges. f. Chirurgie, 19 April, 1873.

ORTH, Mitth. ü. d. Mikrokokkenembolieen in den Capillarcn. Sitzung der Niederrh. Ges. f. Natur- u. Heilkunde. Bonn, März., 1879.

Peris v. Weissgerber, Archiv f. exper. Pathol. u. Pharmakol., Bd.6. Recklinghausen und Lankowsky, Verhandl, der physik. med. Ges. Würzburg, Bd. II., 1871.

Wassilieff, Beitr. zur Fräge über die Bedingungen zur Entwicklung von Mikrokokken in den Blutgefässen. Centralbl. f. d. med. Wissensch., Nr. 52, 1881.

Parenski, Ueber embolische Darmsgeschwüre. Med. Jahrbücher, 1II. Heft, 1876.

RIBbert, Eine mikroparasitäre Invasion der ganzen Gehirnrinde. Virchow's Arch., Bd. 80.

Letzerich, Encephalitis bacteritica. Virchow's Arch., Bd. 65. FoA, Mycose d. Pancreas. Giorn. Internat. della scient. medica, III., 1841.

Letzerich, Ueber Mycosis oesophagi. Arch. f. exper. Pathol., Bd. 7, 1877.

LitTten, Einige Fälle von mycotischer Nierenerkrankung. Zeitschr. f. klin. Med., 6.

Kradse, Ueber dic acute katarrhal. Gelenksentzündung bei klcinen Kindern und den dabei vorkoinmenden Kettenkokkus. Berl. klin. Wochenschr., 1884, Nr. 43.

Heubner v. Bahide, Zur Kenntniss der Gelenkeiterungen bei Scharlach. Berl. klin. Wochenschr., 1884, Nr. 44.

Fleischuauer, Acuter Gelenkrheumatismus mit. miliaren Absecssen. Virchow's Arch., Bd. 62, 1875. 


\section{PUERPERAL FEVER.}

Maynhoren, Vibrionen als Krankheitsursache des Puerperalfiebers. Monatsischr.f. Geburtsk. u. Frauenkrankheiten. Bd. 25, 1865. WALDEYER, Ueber Vorkommen von Bakterien bei der diphtheritischen Form des Puerperalfiebers. Arch. für Gynäkologie, 1872, III.

Heibera, Die puerperalen und pyämischen Processe. Leipzig, 1873.

- Om pyaemia og puerperalfieber. Norsk. Magaz. for Lägevelsk, Bd. 11.

Orth, Virchow's Arch., Bd. 58, 1873.

LAFFTER, Gehirnerweichungsherde durch Mikrokokkenembolieen bei puerpeialer Pyämie. Bresl. ärtztl. Ztg., 1879.

KAREwski, Exper. Unters. über die Einwirkung puerperaler Secrete auf den thierischen Organismus. Zeitschr. f. Geburtsh. u. Gynäkologie,'Bd. 7, 1881.

DoLERIs, La fièvre puerpérale et les organismes infect. Paris, 1880.

Pasteur, Bull. de l'Acad. de méd., 1880, T. 9.

Aurrecht, Die exper. Erzeugung der Endometritis diphtherica prerperalis. Naturforsch. Versamml., 1884.

\section{ENDOCARDITIS.}

Maier, Virchow's Arch., Bd. 62.

EBerth, Virchow's Arch., Bd. 57, 62, 65.

KoEster, Virchow's Arch., Bd. 72.

Birch-Hirschfeld u. Gerber, Archiv d. Heilkunde, 1876.

Li'Ttex, Zeitschr. für klin. Med., Bd. 2.

Weigert, Virchow's Arch., Bd. 84.

O. Rosenbacr, Ueber artificielle Herzklappenfehler. Archiv für exper. Pathol., Bd. 9, 1878.

Heiberg-HJalmar, Virchow's Arch., Bd. 56.

Wedel, Berl. klin. Wochenschr., 1877.

Klebs, Archiv f. exper. Pathol,, Bd. 9.

HAMBdra, Ueber acnte Endocarditis, Berlin, Inaug.-Diss., 1880.

Leyden, Zeitschr. f. klin. Medicin., 1881.

Bramweid, Diseases of the Heart. Edinburgh, 1884.

OBERBECK, Casuistische Beiträge zur Lehre von der Endocarditis ulcerosa. Inaug.-Diss. Göttingen, 1881.

Kundrat, Sitz.-Ber. d. Kais. Acał. d. Wissensch. zu Wien, 1883.

Wrsokowitsch, Centralbl. f. d. med. Wissensch., 1885, Nr. 33. 


\section{MALIGNANT CEDEMA AND TETANUS.}

Davaine, Bull. de l'Acad. de Méd., 1862, Sept.

Pasteur, Ueber d. Vibr. septique. Bull de l'Acad. de Méd., 1877, 1881.

Kocr, Mitth. aus dem Ges.-Amt., I., S. 54.

GAFFky, Ibid., S. 88.

Brieger, U. Ehrlich, Berl. klin. Wochenschr., Nr. 44, 1882.

LeBedefF, Versüche uber Desinfection bei malignen Oedembacillen.

Arch. de phys. norm. et path., 1882, 6 .

Trifaud, De la gangrène gazeuse foudroyante. Rev. de chir., III.

Cinauveau et Arloing, Bull. de l'Acad. de Méd., 1884, 6 May-19

August.

Lustia, Zur Kenntniss bakteriämischer Erkrankungen bei Pferden

(Malignes Oedem). Jahresber. d. K. Thierärzneischule zu Hannover, 1883-4.

Kıтr, Unters. über malignes Oedem und Rauschbrand bei Hausthieren Jahresber. der K. Thierärzneischule zu München, 1883-4. Hesse, W. and R., Ueber Züchtung der Bacillen des Malignen

Oedems. Deutsche med. Wochenschr., Nr. 14, 1885.

Carle \& Rattone, Studio sperimentale sull' etiologia del tetano.

Giorn. della R. Acad. di Medicina di Torino, März, 1884.

Nicolaier, Deutsche med. Wochenschr., 1884, Nr. 52.

Voges, Drei Fälle von infectiösem Tetanus. Deutsche med. Wochenschr., 1885, Nr. 31.

\section{PUTRID INTOXICATION, PTOMAINES.}

Hemmer, Exper: Studien. uber d. Wirkung faulender Stoffe. München, 1866.

Sichweringer, Ueber d. Wirkung faulender org. Substanzen, \&c. München, 1866 .

v. RaIson, Zur Kenntniss der putriden Intoxication, \&c. Diss. Dorpat, 1866.

Frese, Weidenbacm, Schmitz, Peterssex, Schmidt, v. Brfin,

Dissertationen über d. putride Gift, \&c. Dorpat, 1866 - 7:2,

Bergmann, Das putride Gift, \&c. Bd. I. Dorpat, 1866.

-, Deutsche Zeitschr. f. Chirurgie, Bd. I., 1872.

Bergmanx v. Schmiedeberg, Med. Centralbl., 1868, S. 397.

'Zülzzer U. Sonnenschein, Berl. klin. Wochenschr., 1869.

Panum, Virchow's Arch., Bd. 60, 1874.

Friscr, Exper. Studien, üb, d. Verbreitung d. Faulnissorganismen, dc. Erlangen, 1874. 
Ravitsch, Zar Lehre von der putriden Infection, \&c. Berlin, 1872. Hiller, Centralbl. f. Chirurgie, 1876.

-, Die Lehre von der Fäulniss. Berlin, 1879.

Nencri, Ueber die Zersetzung der Gelatine, \&c. Bern, 1876Journ.f. prakt. Chem., Bd. 26, 1882.

Clementi \& Thin, Unters. üb. d. putride Infection. Wien. med. Jahrb., 1873, S. 292.

Kehrer, Archiv f. exper. Pathol., Bd. I., 1874.

BltuBerg, Experimenteller Beitrag zur Kenntniss der putriden

Intoxication. Virch. Arch., Bd. 100, S. 377.

Selmi, Chemische Ber., Bd. 6, 7, 12.-Sulle ptomäine ad alcaloide cadaverici. Bologna, 1878 .

Bouchard, Compt. rend. de Biol., 1882, Aug.

Gautier, C. R. de l'Acad. d. sc., T. 94, 2.

- Journal de l'anat. et de la phys., T. 17.

Gautier et Etard, C. R. de l'Acad. de sc., T. 94.

Brouardel et Boutmy, C. R. de l'Acad. de sc., T. 92, p. 1056.

-, Annal. d'hyg. publ., 3 sér., T. I.

Tanret, Ibid., 92 T., publ. 1163.

Schrffer, Arch. f. Anat. u. Physiol. Abtheil., 1882.

Boccr, Ctrlbl., f. d. med. Wiss, 1882.

Groebner, Beiträge z. Kenntniss Der Ptomäine. Dorpat, 1882.

Guareschi et Mosso, Arch. ital. de Biolog., 1883.

Salkowsir E. \& A., Ber. d. Chem. Ges., Bd. 16.

Salomonson, Nordisk. Archiv, Bd. 13.

MaAs, Ueber Faülnissalkaloide des gekochten Fleisches und des Fischfleisches. Fortschr. d. Med., II. 729.

Vandevelde, Les ptomäines. Arch. d. Biol. par van Beneden. Gent, 1884.

Willgirodt, Ueber Ptomäine. Freiburg, 1834.

Husemann, Arch. d. Pharmac, 1880, 1882, 1883.

Kösig, Massenerkrankung von Menschen nach dem Genuss von Fleisch einer an putrider Metritis verendeten Kuh (Putride Intoxication). Ber. üb. d. Veterinär-Wesen im Königreich Sachsen, 1881.

Bergmann \& Angerer, Das Verhältniss der Fermentintoxication zur Septicämie. Wurtzbürger Jubil Festschr., 1882.

Schmiedeberg U. Harnack, Arch. f. exp. Pathol., Bd. 16.

Brieger, Zur Kenntniss der Faülnissalkaloide. Zeitschr. f. physiol. Chemie., Bd. 7, 1883.-Ber. d. Deutsch. Chem. Ges., 1884, Bd. 17.

-, Ueber Spaltungsproducte der Bakterien, Zeitschr. f. physiol. Chemie, 1884, Band 8, Heft 4.-Bd. 9, Heft 1. 
Brieger, Ueber giftige Producte der Fäulnissbakterien. Berl. klin. Wochenschr., 1884, No. 4.

-, Ueber Ptomäine. Berlin, 1885.

- Weitere Untersuchangen über Ptomäine. Berlin, 1885.

BaCkLisch, Ber. d. deutsch. chem. Gesellsch, Bd. 18, 1885.

CAPpola, Arch. ital. de biolog., Bd. 4. Foa \& Pellacani, Arch. ital. de biolog., Bd. 4.

Offinger, Die Ptomäine. Wiesbaden, 1885.

Oтто, Anleitung zur Ausmittelung der Gifte. Braunschweig, 1884.

\section{DIPHTHERIA.}

Oertel, Deutsch. Arch. f. klin. Med., Bd. 8, 1871.

-, von Ziemssen's Handb. der spec. Pathologie u. 'Therapie, Band II.

-, Zur Aetiologie der Infectionskrankheiten. München, 1881.

Hueter \& Tomassi, Centralbl. f. d. med. Wissensch., 1868.

Trendelenburg, Arch. f. klin. Chirurgie, Bd. 10.

Nassiloff, Virch. Arch., Bd. 50.

ZAнN, Beiträge zur Pathol. u. Histol. der Diphtherie. Leipzig, 1878.

Cornir, Arch. de physiol., 1881.

KLebs, Arch. f. exp. Pathol., Bd. 4, 1875.

LETZERICH, Virchow's Arch., Bd. 52, 55, 61, 68.

-, Mikrochemische Erscheinungen des Diphtheritispilzes. Berl. klin. Wochenschrift, XI., 1874.

Éвеrтu, Der diphtheritische Process. Med. Ctrlbl., XI., No. 8, 1873.

Everetr, Med. and Surg. Reporter. Philadelphia, 1881.

Wood and Formad, Nat. board of health Bull. Wash., 1882.

TAlamon, Bull. de la soc. anat. de Paris, T. 56, 1881.

SAlisbury, Gaillard's Med. Journ. New York, 1882.

Friedberger, Ueber Croup u. Diphthèritis beim Hausgeflügel.

Deutsche Zeitschr. für Thiermed. u. vergl. Pathol., 1879.

Nicati, Compt. rend., 1879, Bd. 88.

Nedmayer, Neue Thesen zur Diphtheritisfrage. Freising, 1880. Fürbringer, Virch. Arch., Bd. 91, 1883.

Heubner, Die experimentelle Diphtherie. Leipzig, 1883.

Gerhardt v. Klebs, Verhandl. d. Congresses f. inn. Med. Wiesbaden, 1883.

Loeffler, Mittheil. a. d. Kais. Ges.-Amt., Bd. II.

Francotte, La Diphthérie. Liège, 1883. 
Eмmarich, Ueber die Ursachen der Diphtherie des Menschen und der Tauben. Deutsche med. Woch., 1884, S. 614.

-, Compt. Rendus et Mémoires du V. Congrès internat. d'Hygèine. la Haye, 1884, p. 247.

Rivolta, Die Diphtherie der Hühner im Vergleich zu der des Menschen. Giornale de Anat. Fisiol. e Patol. delli anim., 1884.

\section{GONORRHEA, OPHTHALMOBLENNORRHCEA, AND SYPHILIS.}

\section{Blexworrha:}

Netsser, Centrlbl. f. d. medicin. Wiss., 1879, Nr. 28.

Bokal, Ueber das Contagium der acuten Blennerrhoe. Allgem. med. Centralzeitung, 1880, Nr. 74.

Boraf and Finkelstein, Prager med. chir., Presse, 1880.

Bücker, Ueber Polyarthritis gonorrhoica Diss. Berlin, 1880.

Avfrecht, Pathologische Mittheilungen, 1881.

Weiss, Le microbe du pus blennorrhagique. Thèse de Nancy, 1880. Ann. de Dermatol., I., 1881.

HaAB, Corresp. f. Schweizer Aerzte, 1881.

-, Der Mikrokokkus der Blennorrhoea neonator. Weisbaden, 1881. Hirschibrg v. Krause, zur Pathologie der ansteckenden Augenkrankheiten. Centralblatt f. pract. Augenheilk, 1881.

Kradse, Die Mikrokokken der Blenorrhoea neonator. Ibid., 1882. Leistikow, Ueber Baktere in bei den venerischen Krankheiten. Charité-annalen, 7 Jahrg., S. 750, 1882.

kikund, Sur les microbes de la blennorrhagie. Haarlem, 1882. Ref. in Schmidt's Jahrbüchern, Bd. 197, S. 139.

Bockinart, Beitrag z. Aetiologie und Pathol. des Harnröhrentrippers. Viertelj. f. Dermatol und Syph., 1883. Sitzungsbericht d. phys. med. Ges. zu. Würzburg. Sept., 1882.

Martin, Rech. sur les inflamm. métast. à la suite de la gonorrhée. Genève, 188:.

Arving, Gonokokken bei Bartolinitis. Vierteljschi. f. Dermatol. u. Syph. 1883, S. 371.

Eschbaum, Beitr. zur Aetiologie der gonorrh. Secrete. Deutsche med. Woch., 1883, S. 187.

Newberry, Maryland Med. Journ. Febr., 1883.

Cамpona, Italia Medica., 1883.

Aufrecht, Mikrokokken i. d. inneren Organen bei Nabelvenenentzündung Neugeborener. Centralbl. f. d. med. Wiss., 1883, Nr. 16. 
Petrone, Sulla natura dell artrite blennorragica Rivista clin. 1883, No. 2.

Zweifel, Zur aetiol. der Ophthalmoblennorrhoea neonator. Arch. f. Gyn. XXII., S. 318.

Bumm., Gonorrhoe d. weibl. Genitalien. Ibid. XXIII., S. 328.

Welander, Sur les microbes pathogènes de la blennorrhagie. Gaz. médicale, 1884, u. Nord. med. Arkiv. Bd. 16., Nr. 2.

Leopold v. Wessel, Beitr. z. Aetoil. u. Prophylaxe der Ophthalmoblennorhoea neonat. Arch. f. Gyn. XXIV., S. 92.

Chameron, Progrès médical., 1884, 43.

Sternberg, Med. news., Bd. 45, 1884, Nr. 16.

Kammerer, Ueber gonorrh. Gelenkentzündung. Centralbl. f. Chirurgie, 1884, Nr. 4.

KRONER, Zur Aetiol. der Ophthalmoblennorrhoea neonator. Naturfosschervers. in Magdeberg, 1884, Arch. f. Gyn. XXV., S. 109.

SÄNGER, Ueber gonorrh. Erkrankung der Uterusadnexe. Ibid., S. 126.

OpPenhemer, Ibid., XXV., S. 51,

EвäNKen, Deutsch. med. Wochenschr., 1885, S. 22.

Bumm, Der Mikroorganismus der gonorrhoischen Schleimhauterkrankungen. Weisbaden, 1885.

LundströM, Studien über Gonococcus. Dissert. Helsingfor's, 1885.

E. FränKel, Mikrokokken bei Colpitis. Deutsche med. Wochenschr., 1885, No. 2.

\section{Srphilis.}

Lostorfer, Arch. f. Dermat. u. Syph., 1872.

KLeBS, Arch.f. exp. Pathol., Bd. 10, 1879.

Aurrecht, Centralbl. f. d. med. Wissensch., Bd. 19, 1881.

Martinead et Hamonic, De la bactéridie syphilitique. Compt. rend., 1882 , p. 443.

Morison, Maryland Med. Journ. Baltimore, 1882.-Ibid., 1883.Weiner Med. Wochenschr., 1883.

Birch-Hirschfeld, Bakterien in syphilitischen Neubildungen. Centralbl. f. d. med. Wissensch., 1882, Nr. 33, u. 34.

Pescher, Centralbl. f. Augenheilk, 1882.

LÉTNIK, Wien. med. Wochenschr., 1883.

Petrone, Gaz. medica Ital. Lomb., 1884.

Tornery et Marcus, C. R. de l'Acad. d. sc., 1884, p. 472.

Lustgarten, Wein. med. Wochenschr., 1884, Nr. 47.

Köntaer, Deutsche med. Wochenschr., 1884, S. 816.

Lídstgarten, Die Syphilisbacillen. Wien, 1885.

Doutrelepont U. SchÜtz, Deutsche med. Wochenschr., 1885, No. 19. 
DE Giacomi, Nene Färbangsmethode der Syphilisbacillen. Correspondenzbl. f. Schweizer Aertze, Bd. 15.

Gö'Ttstein, Fortschr. d. med., Bd. 3, S. 543.

Alvarez et Taver, Bull. d, l'Acad. de méd., 1885, August.

\section{Tuberculosis.}

Vilienis, Etude sur la Tuberculose. Paris, 1868.

Сонлегі, Uebertragbarkeit der Tuberculose. Berlin, 1877.

Kuebs, Arch. f. exp. Pathol. u. Pharmakol., Bd. 1., 1873.-Ibid., Bd. 17, 1883.

-, Virchow's Arch., Bd. 44, 1868.

Toussaint, Compt. rend. Acad. de sc., Paris, T. 93, 1881.

Koch, Die Aetiologie der Tuberculose. Berl. klin. Wochenschr., 1882.

-, Mittheilungen aus dem Kais Ges.-Amt, Bd. II., 1884.

-, Kritische Besprechung der gegen die Bedeutung der Tuberkelbacillen gerichteten Publicationen. Deutsche med. Wochenschr., 1883, No. 10.

Baumgarten, Berl. Klin. Wochenschr., Bd. 17, 1879.

-, Centralbl. f. d. med. Wissensch. Berlin, Bd. 19, 1881.-Ibid., Bd. 20, 1882.-Ibid., Bd. 21, 1883.-Ibid., Bd. 22, 1884.

-, Deutsche med. Wochenschr, Bd. 8, 1882.

-, Zeitschr f. klin. Med., Bd. 6, 1883.

Aufrecht, Centralbl. f. d. med. Wissensch., Bd. 21, 1883.

Bollinger, Ibid., Bd. 21, S. 600, 1883.

Cheyne, Brit. Med. Journ., Vol. 1, 1883 and 1885.

-, Nature, Vol. 27, 1883.

-, Practitioner, London, Vol. 30, 1883.

Воск, Virchow's Archiv, Bd. 91, 1883.

BALOGH, Wien. med. Wochenschr., 1882.

Këssser, Beitr. z. Impftuberculose, Deutsche med. Wochenschr, $1883, \mathrm{Nr} .36$.

ANDREw, Lancet, Vol. 1, 1884.

Biedert, Virchow's Archiv, Bd. 98.

AlbRecht, Arch. f. Kinderheilk, Bd. 5, 1884.

Schotrelius, Zur Kritik d. Tuberculosefrage. Virchow's Archiv, Bd. $91,1883$.

Tscherning, Inoculationstuberculose beim Menschen. Fortschr d. Med., III., 65.

WAHL, Zur Tuberculosefrage, Deutsch. med. Wochenschr., 1882, $\mathrm{Nr} .46$.

Van Ermengem, Le microbe dela tuberculose. Ann. de la Soc. belge de Microscopie, 1882. 
Hiller, Deutsche med. Wochenschr., Bd. 8, 1882.

Raymond, Arch. gén. de méd. Paris, Bd. 11, 1883.

Bouley, La nature vivante de la contagion, contagiosité de la Tuberculose. Paris, 1884.

Babès et Cornil, Note sur les bacilles de la Tuberculose. Journ. de l'Anat. et de la Phyșiol. norm. et pathol., 1884.

Dettweller, Berl. klin. Wochenschr., Bd. 21, 1883.

Formad, The bacillus tuberculosis. The Philad. Medical Times, 1882, Nov.

Spina, Studien über Tuberculose. Wien, 1883.

Crämer, Sitzungsber. d. phys. med. Soc. zu Erlangen, 1883.

Marchand, Deutsche med. Wochenschr., 1883, Nr. 15.

Heron, Lancet, Vol. 1, 1883.

Green, Brit. Med. Journ., Vol. 1, 1883.

—, Lancet, Vol. 1, 1882.--Ibid., Vol. 2, 1882.

Kundrat, Wien. med. Presse, 1883.

Landouzy et Martin, Rev. de méd., T. 3, 1883.

Chiari, Wien. Med. Presse, 1883.

Cochet, Compt. Rend. Soc. de biol., Paris, T. 5, 1883.

Pfeiffer, Berlin klin. Wochenschr., Bd. 21, 1883.

Doutrelepont, Die Aetiologie des Lupus vulgaris. Vierteljahrschrff.

Dermatologie u. Syphilis, 1884.

Connil \& Lelorr, Recherches etc. sur la nature du lupus. Arch.

de physiol. norm. et pathol., 1884.

Leube, Sitzungsber. der phys.-med. Soc. zu Erlangen, 1883.

Creighton, Brit. Med. Journ., Vol. 1, 1885.

-, Lancet, Vol. 1, 1885.

-, Trans. Path. Soc. London, Vol. 33, 1882.

Désérine, Rev. de Méd. Paris, T. 4, 1884.

GaFrKx, Verhalten der Tuberkelbacillen im Sputum. Mitth. a. d.

Kaiserl. Gesund-heitsamt, Bd. 2.

NEGRI, Colorations des spores dans les bacilles de la tuberculose.

Journ. de Microsc., T. 8, 1884.

Rindrleisch, Phys. med. Ges. zu Würzburg, 1882, Nr. 8.

IAEYDEx, Klinisches über Tuberkelbacillen Zeitschr. f. klin. Med., 1884, VIII.

ZienL, Bedentung der'Tuberkelbacillen für Diagnose und Prognose.

Deutsche med. Wochenschr., 1883, Nr. 5.

Dieulafor ét Krishaber, Arch. de physiol. norm. et path., T. I., 1883.

Malassez et Vignal, Ibid., T. II., 1883.-Compt. rend., T, 97, 1883.-Sur le microorg. de la tuberculose zoogloeïque. Compt. rend., T. 99, p. 200. 
Vignal, Compt. rend. Soc. de biol. Paris, T. 5, 1883.

Gibbes, Lancet, Vol. 1, 1883.

Ewart, Brit. Med. Journ., Vol. 1, 1882.

—, Lancet, Vol. 1, 1882.

EHRlich, Deutschemed. Wochenschr., Bd.8, 1882.-Ibid., Bd.9, 1883. Lustig, Ueber Tuberkelbacillen im Blut bei an allg. acuter Miliartub. Erkrankten. Wien. Med. Wochenschr., 1884, Nr. 48. Levinsky, Deutsche med. Wochenschr., Bd. 9, 1883.

Lichтнеiм, Fortsehr. d. Med., Bd. 1, 1883.

WEST, Lancet, Vol. 1, 1883.

-, Trans. Path. Soc. London, Vol. 34, 1883.

DAMsch, Die Impfbarkeit der Tuberculose als diagnostisches Hülfsmittel bei Urogenitalerkrankungen. Deutsches Arch. f. klin. Med., Bd. 31.

-, Deutsche Med. Wochenschr., 1883, Nr. 17.

Babes, Der erste Nachweis des Tuberkelbacillus im Harn. Centralbl. f. d. med. Wissensch, 1883.

Rosenstein, Centralbl. f. d. med. Wissenseh, 1883.

Johne, Ein zweifelh. Fall von congenitaler Tubereulose. Fotschr.

d. Med. III., 198.

Weigert, Deutsche med. Wochenschr., 1883. Nr. 24, ff.

NAUWERCK, Ibid., 1883.

SCHÄFfer, Ibid., Nr. 21, ff.

Celli \& Guarneri, Arch. pour les sciences médic. 1883.

Fräntzel u. Palmers, Berl. klin. Wochenschr., 1882, 1883.

De Gracomi, Fortschr. d. Med. I., 1883, S. 14.5.

Schuchardt 0. Krause, Ibid., I., 277.

MüLLER, Ueber den Befund ron Tuberkelbacillen bei fungösen

Knochen n. Gelenk-affectionen. Centralbl. f. Chir., 1884, 3.

Broviluy, Note sur le présence des bacilles dans les lésions chirurgicales tuberculeuses. Rev. de chir., T. 3, 1883.

Schlegtexdal, Fortschr. d. Med., I., 1883.

Schilu v. Fischer, Mitth. a. d. Kaiserl. Ges.-Amt., Bd. I1.

Smith, Bristol Med. Chir. Journ., Vol. I., 1883.

Wilifiams, Lancet, Vol. 2, 1883.

Veraguth, Arch. f. exp. Path. u. Pharmakol. Leipzig, Bd. 16, 1883. Voltouni, Ueber Tuberkelbacillen im Ohr. Deutsche med. Wochenschr., 1884, Nr. 31. Strassmand, Virchow's Archiv, Bd. 96, 1884.

FütTERER, Ueber das Vorkommen u. die Vertheilung der Tuberkelbacillen in den Organen. Virch. Arch., Bd. 100, Heft 2. Püтz, Ueber die Beziehungen der Tuberculose des Menschen zu der der Thiere. Stuttgart, 1883. 
Esser v. Scuürz, Zur Casuistik der Tuberculose bei Thiere Arch. f. wiss. u. prakt. Thierheilk, XI.

Bollinger, Münch. ärztl. Intelligenzbl., 1883, Nr. 16.

Johne, Die Geschichte der Tuberculose. Leipzig, 1883.

-, Zur Aetiologie der Hühnertuberculose. Deutsche Zeitschr. f. Thiermed. u. vergl. Pathol., Bd. X., S. 155.

-, Ber. üb. d. Veterinärwesen im Königr. Sachsen, 1883.

Zippelius, Wochenschr. f. Thierheilk., Bd. 20.

Demme, 20 Jahresber d. Jenner'schen Kinderspitals. Bern. 1883.

Lydtin, Badische thierärztl. Mittheil, 1883.

RibBert, Ueber d. Verbreitungsweise der Tuberkelbacillen bei Hühnern.- Deutsche med. Wochenschr., 1883, nr. 28.

Bang, Ueber Eutertuberculose der Milchkühe. Deutsche Zeitschr.

f. Thiermed. u. vergl. Pathol., Bd. XI.

Sutron, Trans. Path. Soc. London, Vol. 35, 1884.

Weichselbaum, Wien. med. Jahrb. 1883 (Tuberkelbacillen im Blut.).

Meisels, Wien med. Wochenschr., 1884, Nr. 39 u. 40.

Dottrelepont, Fall von Meningitis tuberculosa nach Lupus, Tuberkelbacillen im Blut. Deutsche med. Wochenschr., 1885, Nr. 7. Spina, Casopis lekaru ceskych, 1885, Nr. 4.

Oвrzut, Prof. Spina's neue Färbungsmethode der Fäulnissmikroorganismen und ihre Beziehung zu den Tuberkelbacillen. Deutsche med. Woch., 1885, Nr. 12.

\section{LEPROSY.}

Neisser, Breslaner ärztl. Zeitschr., 1879.

-, Jahresber. d. schles. Ges. für vaterl. Cultur., 1879.

-, Virchow's Archiv, 1881, Bd. 84.

KöBNER, Virchow's Arch., 1882.

Hansen, Armauer, Virchow's Arch., Bd. 79.-Ibid., Bd. 90.

Cornil et Suchard, Ann. de dermat. et syph. Paris, 1881.

Gaucher et Hillairet, Progrès méd. Paris, 1880, 'T. 8. Société de biolog., 1881.

JoHs Hiuls, On leprosy in British Guiana. London, 1881.

Kaposi, Wiener med. Wochenschr., 1883.

Hiluis, Trans. Path. Soc. London, 1883, Vol. 34.

BABı̀s, Etude comparative des bactéries de la lèpre et de la tuber-: culose. Compt. rend., 1883, T. 96.

VIDAL, La lèpre et son traitement. Paris, 1884.

ARring, Ueber das Vorkommen der bacillus leprae bei Lepra anaesthetica s. nervorum. Virchow's Archiv, Bd. 97. 
MüLler, Deutsches Archiv f. klin. Med., Bd. 34, 1884.

DАмsch, Uebertragungsversuche von Lepra auf Thiere. Virch. Aich., Bd. 92, 1883.

-, Centralbl. f. d. med. Wissensch., Bd. 21, 1883.

KöBser, Uebertragungsversuche von Lepra auf Thiere. Vir chow's Arch., 1882.

Campana, Sur la transmissibilité de la lèpre aux animaux. Arch. ital. de biolog., T. 5. fasc. 2.

Vossrus, Uebertragungsversuche von Lepra auf Kaninchen. Ber. über d. Ophtalmologencongress in Heidelberg, 1881.

Virchow, Berl. klin. Wochenschr., 1885, Nr. 12.

UNNı, Ueber. Leprabacillen. Deutsche med. Wochenschr., 1885, Nr. 32.

\section{GIJANDERS.}

LüFricter U. Schürr, Ueber den Rotzpilz. Deutsche med. Wochenschr., 1882, Nr. 52.

Israel, Berl. klin. Wochenschr., 1883, Nr. 11.

Bodchard, Capitan et Charrin, Bull de l'Acad d. sc. 1882, Nr. 51 (27 Decbr.).

WassiliterF, Deutsche med. Wochenschr., 1883, Nr. 11 :

Molkextin, Zur Sicherstellung der Diagnose von Rotz. Inaug.Diss. Dorpat, 1883.

Grünwatd, Zur Differentialdiagnose des Rotzes. Oesterr. Monatsschr. für Thierheilk, 1884, Nr. 4.

Weichselbaum, Zur Aetiologie der Rotzkrankheit des Menschen.

Wiener med. Wochenschr., 1885, 21-24.

Fröhner, Rotzige Elephantiasis des Kopfes beim Pferde. Rep.d. Thierheilk, 188:-4.

KIrT, Versuche über d. Züchtung des Rotzpilzes. Jahresber d. München Thier-arzneisch., 1883-84.

\section{ANTHRAX.}

(Compare also p. 53, "Immunity and Protective Inoculation.")

Pollender, Vierteljahrschr. f. ger. Med., Bd. 8, 1855.

Brauell, Virchow's Arch., Bd. 11, 1857.-Ibid., Bd. 14, 1858.

Davalne, Compt. rend Acad. de sc. Paris, T. 57, 1863.-Ibid., T. 59,1863 ; T. 60,1865 ; T. 61,1866 ; T. $77,1873$.

-, Rec. de méd. vét., T. 4, 1877.

- Compt. rend. 1877 (Review of Davaine's Publications in

Cornil et Babès' Handbuch, p. 493). 
Pasteur, Bull. Acad. de méd. Paris, 1877, 1879, 1880 (Earth Worms).

-, Compt. rend. Aead. de sc. Paris, T. 84, 1877; T. 90, 1880 ;

Ibid., T. 91, 1880; T. 92, 1881; Ibid., T. 95, 1882.

Colin, Bull. Acad. de méd. Paris, T. 2, 1873; Ibid., T. 7, 1878. Ibid., T. 8, 1879 ; Ibid., T. 9, 1880 ; Ibid., T. 10, 1881.

Feltz, Sur la rôle des vers de terre dans la propagation du charbon. Compt. rend., 1882, T. 95.

Bert, Compt. rend. Soe. de biol., T. 4, 1877 ; Ibid., T. 5, 1878 ; Ibid., T. 6, 1879.

Bollinger, v. Ziemssen's Handbuch der spec. Pathol. u. Therapie. Bd. III.

-, Centralbl. f. d. med. Wissensch., 1872, Bd. 10.

Toussaint, Recherehes expérimentales sur la maladie charbonneuse.

Paris, 1879.

-, Compt. rend. Aead. de sc., T. 85, 1877, 1878, 1880.

Chauveau, Compt. rend. Acad. de sc., T. 90, 1880; 'T. 91, 1880 ; T. 92,1881 ; T. 94,1882 ; T. $96,1883$.

Bovley, Bull. Acad. de Méd. Paris, T. 9, 1880 ; Ibid., T. 10, 1881. -, Compt. rend. Aead. de sc., T. 92, 1881. Ibid., T. 93, 1881.

Косн, Beitrag zur Biologie der Pflanzen. Breslau, 1876, Bd. 2, Heft 2.

-, Wundinfeetionskranklheiten. Leipzig, 1878.

-, Mitth. aus d. Ges.-Amt., Bd. I., 1881.

Oemler, Archiv f. wissensch. u. pract. Thierheilk., Bd. 4, 1878. -Ibid., Bd. 5, 1879 ;-Bd. 6, 1880.

Sснмірт, Milzbrand bei Wildschweinen. Deutsche Zeitschr. f. Thiermed. u. vergl. Pathol., 1879.

Ewart, Quart. Journ. of Microsc. Sc., April, 1878.

Roder, Compt. rend., T. 94, 1882.

- Contribution à l'étude expérimentelle du Charbon Bacteridien. Lyon, 1881.

Wachenheim, Etude expérimentelle sur la septieité et la virulence du sang eharbonneux. Naney, 1880.

Sternaerg, Am. Monthly Micr. Journ., Vol. 2, 1881.

Huber, Deutsehe med. Wochenschr., Bd. 7, 1881.

Greenfield, Proc. Roy. Soc. London, Vol. 30, 1880.

-, Quart. Journ. Micr. Sc. London, Vol. 20, 1879.

KLEIN, On the relation of Pathogenic to Septic Bacteria, as illustrated by Anthrax Cultivations. Rep. of the Medical Officer of the Local Government Board for 1881, ff.

-, On a Morphological Variety of Bacillus Anthracis. Quart. Journ. Micr. Sc. n. s., Vol. 23, 1883. 
Fokner, Virchow's Archiv, Bd. 88, 1882.

-, Centralbl. f. d. med. Wissensch., Bd. 18, 1880.-Ibid., Bd. 19, 1881.

Semmer, Centralbl. f. d. med. Wissensch., Bd. 18, 1880.-Ibid., Bd. $22,1884$.

-, Der Milzbrand und das Milzbrandcontagium. Jena, 1882.

Rolofr, Ueber die Milzbrandimpfung und d. Entwicklung d. Milzbrandbakterien. Archiv f. wissensch. u. pract. Thierheilk., Bd. 9, 1883.

- Der Milzbrand. Berlin, 1883.

Archangelshi, Centralbl. f. d. med. Wissensch., 1882, 1883.

Dowdeswell, Rep. Med. Off. Local Gov. Board, 1883.

'Toepper, Die neueren Erfahrungen über d. Aetiologie d. Milzbrands. Jena, 1883.

Buchner, Ueber die exper. Erzeugung des Milzbrandcontagiums aus den Heupilzen, München, 1880.

-, Versuche ïber die Entstehung des Milzbrands durch Einathmung. Sitzungsber. d. K. bayer, Akad. d. Wissensch., 1880.

-, Vorträge im ärztl. Verein zu München, 1881.

-, Die Umwandlung der Milzbrandbakterien in unschädliche

Bakterien. Virchow's Arch., Bd. 91, 1883.

Prazmowski, Acad. d. wissensch. in Krakau, 1884 (polish).

-, Biol. Centralbl., Bd. 4, 1884.

Szpilman, Zeitschr. f. physiol. Chemie. Strassburg, Bd. 4, 1880.

Friedrich, Zur Aetiologie des Milzbrands. München. Inaug-Diss. Leipzig, 1885.

Esser \& Schürz, Zur Casuistik des Milzbrands. Mitth. a. d. K. preuss. amtl. Vet. Sanitätsbericht, 1882-1883.

Bollinger, Zur Aetiologie des Milzbrands. Sitzungsber. d. Ges. f.

Morphol u. Physiol. zu München, 1885, 10 Febr.

Kıтт, Ibid., 1885, Febr.

Bleuler, Milzbrand beim Menschen. Correspondenzbl. d. Schweiz. Aerzte, 1884.

Schrakamp, Zur. Aetiologie des Milzbrandes. Arehir. f. Hygiene, Bd. 2, 1884.

V. Chelchowsky, Zur Charakteristik des Milzbrandvirus. Der Thierarzt, 1884.

\section{TYPHOID FEVER.}

KLEBS, Arch. f. exper. Pathol. u Pharmakol., Bd. 12, 13, 15. 1880 81.

Brrch-Hirschfecd, Unters. zur Pathologie des Typhus abdominalis,

Zeitschr f. Epidemiologie, I., 1874. 
KLEIN, Med. Centralbl., XII., 1874.

SокоцоF, Virchow's Archiv, Bd. 66.

Feltz, Compt. rend., 1877, T. 85.

Eppinger, Beitr. zur pathol. Anatomie aus d. patholog. Institut. Prag., 1880.

LETZERICH, Virchow's Archiv, Bd. 68.

-, Archiv f. exper. Pathol., Bd. 9, 1878; Bd. 10, 1881.

-, Experimentelle Untersuchungen über die Aetiologie des

Typhus abdominalis. Leipzig, 1883.

Wernich, Zeitschr. f. klin. Med., Bd. 6, 1882.

Fischel, Ueber das Vorkommen von Mikrokokken in einigen

Organen bei Typhus abdominalis. Beitr. zur Pathol. Anat. aus

d. pathol-anat. Inst. Prag., 1880.

Trzzon, Studi. di pat. sperim. sulla gen. d. tifo. Milano, 1880.

Rappin, Contrib. á l'étude des bact., de la bouche, à l'état normal

et dans la fièvre typhoïde. Paris, 1881.

Maraghano, Centralbl. f. d. med. Wissensch., Bd. 15, 1882.

Brauthecht, Pathogene Bakterien im Trinkwasser bei Epidemieen.

Virchow's Arch., Bd. 84, 1881.

Acmquist, Typhoïdfeberus-Bakterie. Stockholm, 1882.

Crooke, Brit. Med. Journ., Juli, 1882.

Boens, Acad. roy. de Méd. de Belgique. Bull, 1883. 3. Ser., T. 17. Eвerth, Der Typhus-Bacillus und die intestinelle Infection.

Volkmann, klin. Vorträge, 1883.

-, Arch. f. pathol. Anat., Bd. 81, 1880. -Ibid., Bd. 83, 1881.

Meyer, Unters. über den Bacillus des Abdominaltyphus. Inaug.Diss. Berlin, 1881.

GafFKY, Zur Aetiologie des Abdominaltyphus. Mitth. a. d. Ges.Amt., Bd. 2, 1884.

CoAts, Eberth's 'Typhoïdbacillus. Brit. med. Journ., März, 1882.

TAYon, Le microbe de la fièvre typhoïde de l'homme. Compt. rend., T. 99 , p. 331 ; T. 101, No. 6.

Preiffer, Ueber den Nachweis der Typhusbacillen im Darminhalt и. Stuhlgang. Deutsche med. Wochenschr., 1885, Nr. 29.

\section{RELAPSING FEVER.}

Obermeier, Vorkommen feinster, eigene Bewegung zeigender Fäden im Blute von Recurrenskranken. Med. Centralbl., 1873.-Berl. med. Ges., März, 1873. Berl. klin. Wochenschr., 1873.

ExaEL, Ueber die Obermeier'schen Recurrensspirillen. Berl. klin.

- Woch., 1873.

WeIGERT, Deutsche med. Wochenschr., 1876. 
Moczutowsky, Deutsch. Archiv f. klin. Med., Bd. 24.

Birch-Hirschfeld, Ibid., Bd. 13, 1874.

LAptschinskx, Centralbl. f. d. med. Wissensch., Bd. 13, 1875.

Alвrecht, St. Petersb. med. Wochenschr., 1879, Nr. 1.

Cous, Deutsche med. Wochenschr., 1879.

Heydenreich, Der Parasit des Rückfalltyphus. Berlin, 1877.

-, St. Petersb. med. Wochenschr., 1876.

Косн, Deutsche med. Wochenschr., 1879.

Gutrmanx, Virchow's Arch., 1880.

MühlhäUser, Virchow's Arch., Bd. 97, 1884.

v. JAKSCH, Wien. med. Wochenschr., 1884, Juli.

\section{CHOLERA.}

Kocr, Ueber die Cholerabakterien. Deutsehe med. Wochenschr., 1884.

Verhandluxgex der Conferenz zur Erörterung der Cholerafrage. Berliner klin. Wochenschr., 1884, Nr. 31, ff. Deutsche med. Wochenschr., 1884, S. 504 ff.-2. serie: 4. May, 1885, and the following days. Deutsche med. Wochenschr., 1885, Nr. 19, 20 ; 37 a, 38, 39 .

Van Ermengem, Recherches sur le microbe du choléra asiatique. Paris-Bruxelles, 1885.

-, Conclusions prés à la Soc. Belge de Microsp. dans la séance du 26 Oct., 1884.

-, Note sur l'inoculation des produits de culture du bacillevirgule. Bull de l'Acad. roy. de méd. de Belgique. 3 Sér., XVIII.

Gibier et vax Ermexgem, Rech. expér. sur le Choléra. Compt. rend., T. 101, 1885.

Pfeiffer, Ueber die Cholera in Paris. Deutsche med. Wochenschr., 1885, Nr. 2.

Joнne, Einiges über die sogen. Choleracurse im K. Ges.-Amt. Deutsche Zeitschr. f. Thiermed., Bd. XI.--published separately by Vogel, Leipzig.

Bianchi, Lancet, Vol. 2, 1884.

Machamara, Brit. Med. Journ., Vol. 1, 1884.

Hunter, Ibid., Vol. 1, 1884.

CARTer, Lancet, Vol. 2, 1884.

Cameron, Brit. Med. Journ., Vol. 1, 1884.

Strauss, Roux, Thuililer et Nocard, Compt. rend. Soc. de biol. Paris, T. 4, 1883.

Doyen, Mikroorganismen in Leber und Niere von Choleraleichen. Soc. de Biol. de Paris, 13 Dec., 1884. 
Buchner, Ueber Cholerabacillen. Münchn. ärztl. Intelligenzb., 1884 , S. 549.

KLEBS, Ueber Cholera asiatica. Basel, 1885.

Schotтelius, Zum mikrosk. Nachw. v. Cholerabacillen in Dejectionen. Deutsche med. Wochenschr., 1885, Nr. 14

Bochefontaine, Expér. pour servir à l'étude des phénomènes déterminés chez l'homme par l'ingestion stomacale du liquide diarrhéïque du choléra, Compt. rend., T. 99, p. 845; and T. 100, p. 1148.

KIEIN, Brit. Med. Journ., Vol. 1, 1885.

-, Lancet, Vol. 2, 1884. Ibid., Vol. 1, 1885.

-, Proc. Roy. Soc. London, Vol. 38, 1885.

Finkler U. Prior, Unters. über Cholera nostras, Deut. med. Woch., 1884, Nr. 36.

- Ueber den Bacillus der Cholera nostras und seine Cultur. Naturforscherversammlung Magdeburg, 1881.

- Ueber die Kommabacillen. Kölnische Zeit. (!), 1884, 11 Novbr.

- Forschungen über Cholerabakterien. Ergünzungshefte zum Centrabl. f. allg. Gesundheitspflege, Bd. 1, Heft 5 u. 6.

Dехеке, Ueber eine neue den Choleraspirillen ähnliche Spaltpilzart. Deutsche med. Wochenschr., Nr. 3, 1885.

Muller, Kommaförmiger Bacillus aus der Mundhöhle. Dent. med. Woch., 1885, Nr. 9.

Emmerich, Die Cholera in Neapel. Deutsche med. Wochenschr., $\mathrm{Nr} .50,1884$.

F'üGGF, Kritik der Emmerich'schen Untersuchungen über Cholera.

Deutsche med. Wochenschr., Nr. 2, 1885.

Cheyne, Brit. Med. Jonrnal, 1885.

Drasche, Allg. Wien. med. Zeit., 1885.

Bruvetti, Fatti Considerazioni Conclusioni sul coléra Padua, 1885.

Nicati Et Rietsch, Arch. de physiol., 1885. Compt. rend., T. 99, p. 928 .

-, Revue d'hygiène, 1885.

-, Revue de médecin, T. 5, 1885.

Transact. of the Royal Medical and Chirurgical Society of London, March-April, 1885.

Vililikrs, Sur la formation des ptomaïnes dans le choléra. Compt. rend., T. 100 , p. 91.

Pfeiffer, Der bisherige Verlauf der Cholera in Thüringen etc. Corresp. Bl. des allgem. ärztl. Ver. in Thüringen, 1884, Nr. 9.

Ferran, Sur l'action pathogène et prophylactique du bacillusvirgule. Compt. rend., T. 100 , p. 959. 
Héricourt, Sur la nature indifférente des bacilles-virgules. Ibid., p. 1027.

Van Ermengem, Die Ferran'schen Impfungen. Deutsche med.

Wochenschr., 1885, Nr. 29. Compare. Bull. de l'Acad de méd. Séance du 13 Juillet, 1885.

\section{PNEUMONIA.}

Kӥнм, Die Uebertragbarkeit endemischer Pneumonieformen auf Kaninchen. Berl. klin. Wochenschr., 1881, Nr. 38.

-, Die contagiöse Pneumonie. Deutsch. Arch. f. klin. Med., 1878.

Friedländer, Virchow's Arch., Bd. 87, 1882.

-, Fortschr d. Med., Bd. 1, 1883, S. 715. Ibid., Bd. 2, 1884, S. 333 u. 652

—, Beste Färbung zur Darstellung der Kapseln der Pneumoniekokken. Fortschritt, III., 92.

Matray, Wien. med. Presse, 1883, Nr. 23.

Ziehl, Ueber das Vorkommen der Pneumoniekokken im pneumonischen Sputum. Centralbl. f. d. med. Wissensch., 1883, 1884. JÜrGENSEn, Berl. klin. Wochenschr., 1884, Bd. 22.

Mendelssohn, Zeitschr. f. klin. Med., 1884, Bd. 7.

Emmerich, Pneumoniekokken in der Zwischendeckenfüllung. Archiv f. Hygiene, Bd. 2, Heft 1.

Germain-Sée, Compt. rend. Acad. de se. Paris, 1884.

—, Des maladies specifiques du poumon. Paris, 1885.

Salvioli U. Zäslein, Ueber den Micrococcus und die Pathogenese der croupösen Pneumonie. Centralbl. f. d. med. Wissench., 1883.

-, Arch. pour les sc. méd., Bd. 8, 1884.

Platonow, Ueber die diagnostische Bedeutung d. Pneumoniekokken. Inaug.-Diss. Würzburg, 1884.

Maguire, Brit. Med. Journ., Vol. 2, 1884.

Giles, Ibid., Vol. 2, 1883.

Talamon, Progr. médic., 1883.

Afanassiew, Compt. rend. Soc. de biol. Paris, T. 5, 1884.

Korányi u. Babès, Pester med. chirurg. Presse, 1884.

A. Fränkel, Verhandl. d. Congr. f. innere. Med., 1884.-Fortschr. d. Med., 1884, Nov.

Brieger, Zeitschr. f. physiol. Chemie., Bd. 8.

KLEIN, Centralbl. f. d. med. Wissensch., 1884.

NAUwerck, Ueber morbus Brightii bei croupöser Pneumonie.

Beitr. zur pathol. Anat. von Ziegler. Jena, 1884. 
Ribbert, Zur Färbung d. Pneumoniekokken. Deut. med. Wochenschr., 1885, Nr. 9.

Dreschfeld, Ueber Wanderpneumonie a. ihre Beziehung zur epidemischen Pneumonie. Fortschr. d. Med., III., 389, 1885.

Schov, Untersuchungen über Vaguspneumonie. Fortschr. der Medicin., Bd. 3, Nr. 15, 1885.

\section{MALARIA.}

Klebs u. Tommasi-Crudeli, Arch. f. exp. Pathol., Bd. 2; 1879. Tommasi-Crudeli, Der Bacillus Malariae im Erdboden von Selinunte u. Campobello. Arch. f. exp. Pathol., Bd. 12.

- La production naturelle de la malaria. Conférence faite à la 8 sess. du congrés intern. méd. à Copenhague, 1884.

-, Die Malaria von Rom. Deutsch von Schuster. München, 1882.

Laveran, Les parasites du sang dans l'impaludisme. Compt. rend., No. 17, 1882.

- Traité des fièvres palustres. Paris, 1884 .

Ricinard, Compt. rend., No. 8, 1882.

Marchand, Zur Aetiologie der Maleria. Virchow's Archiv, Bd. 88, 1882.

ZienL, Deutsch. med Woch., Nr. 48, 1882.

Roszahegyi, Von der Ursache des Wechselfiebers. Biol. Ctrlbl., Bd. 2, 1882.

Kotelmann, Der Bacillus Malariae im Alterthum. Virchow's Arch., Bd. 97, 1884.

Sternberg, Nat. Board of Health. Bull. Suppl., Washington, 1881.

Cuboni und Marchiafava, Atti della, R. Acad. dei Lincei., 1881.

- Neue Studien ïb. d. Natur der Malaria. Arch. f. exp. Pathol., Bd. 13.

CEcr, Ueber die in den malarischen und gewöhnlichen Bodenarten enthaltenen Keime und niederen Organismen. Arch. f. exp. Pathol., Bd. 15 u. 16.

Marchiafava U. Celui, Neue Untersuchungen über die Malariainfection. Fortsch. d. Med., III., 339.

- Blutveränderung bei Malaria. Arch. ital. de biologie, Bd. 5, fasc. 2.

-, Atti della R. Academia dei Lincei, 1884.

v. SeHien, Fortschr. d. Med., Bd. II., 1884.

Leoni, Gazetta medica di Roma, 1884, Dec.

Gerhardt, Zeitschr. f. klin. Med., Bd. 7, 1884. 
Marriotmi \& Ciarrocchi, Lo sperimentale, Bd. 54, 1884.

ToRelLI, La malaria in Italia. Roma, 1883.

Madrex, L'étiologie et la nature du paludisme. Ann. d'hygièuc, 1883.

BARDELS, Gaz. des hôpit., 1882.

\section{EYE AFFECTIONS.}

EBERTH, Ueber Entzündung der Hornhaut nach TrigeminusDurchsneidung. Med. Centralbl., XI., 1873.

Friscr, Die Milzbrandbakterien und ihre Vegetationen in d. lebenden Hornhaut. Acad. d. Wiss., Bd. III., 1876.

Schмidт-RImpler, Ueber Hornhautimpfungen mit Berücksichtigung eiteriger Keratitis beim Menschen. Marburger Sitzungsber., 1876, III.

LEBER, Ueber Entzündung der Hornhaut durch septische Infection. Med. Centralblatt., XI., 1873.

BALOGH, Sphaerobakterien in der entzündeten Hornhaut. Med. Centralbl., XIV., 1879.

DoLschenkofF, Impfung faulender Substanzen auf die Kaninchenhornhaut. Med. Centralbl., 1873.

HoRNER, Keratitis mycotica. Monatsbl. f. d. Augenheilk, XIII.

Röтн, Retinitis septica. Virchow's Archiv, Bd. 55.

Kahler, Ueber septische Retinitis. Prager Zeitschr. f. prakt. Heilk., Bd. I., 1882.

Förster, Pilzmasse im unteren Thränenkanälchen. Arch. f. Ophthalm., XV., 1.

GRÄFE, Ibid., Bd. XV., 1.

Coнv, Ibid., Bd. 15.

v. Reuss, Pilzconcretionen i. d. Thränenröhrchen. Wien. med. Presse, 1884.

GoLDzieHER, Streptothrix Foersteri im unteren Thränenröhrchen. Centralblatt f. prakt. Augenheilk, 1884, Febr.

Herzog von Bayern, Zur Kenntniss der beim Menschen vorkommenden Bacillen. Ibid., 1880, October.

SATtLer, Unters. über das Trachom. Ber. üb. d. OphthalmologenCongress zu Heidelberg, 1882.

KRoner, Zur Aetiologie der Ophthalmoblennorrhoe. Verh. d. Naturforscher Vers. Magdeburg, 1884 (for the rest of the literature see under "Gonorrhoea").

Kuschbert u. Neisser, Zur Pathologie und Aetiologie der Xerosis conjunctivae. Bresl. ärztl. Zeitschr., 1883, Nr. 4.

Kuschbert, Deutsch. med. Woch., 1884, Nr. 21. 
LEBer, Ueber die Xerosis der Bindehaut. v. Graefe's Arch. f. Ophthalmologie 29, 3.

Schutich, Verh. des Ophthalmologen-Congr., zu Heidelberg, 1883.

Bock, Ueber die miliare Tuberkulose der Uvea. Virchow's Arch., 1883, Bd. 91.

Mrchel, Graefe's Archiv f. Augenheilkunde, Bd. 1, 1882.

Deutschmann, Zur Pathogenese der sympathischen Ophthalmie.

v. Graefe's Arch., 30, 2 Abthl.

A вRAнам, Dublin Journ., 73. Febr., 1882.

De WeCker, Die Jequirity'sche Ophthalmie. Klin. Monatsbl. f. Augenheilkunde Jahrg., 20 u. 21.

SatTler, Ueber d. Natur der Jequirity-Ophthalmie. Zehender's klin. Monatşblatt, Juni, 1883.

-, Wien. med. Woch., 1883. Nr. 17.

Sattler et de Wecker, L'Ophthalmie jequiritique. Paris, 1883.

Cornil et Berlioz, Sur l'empoisonnement par le Jéquirity.

Compt. rend. de l'Acad. d. sc., 1883, Sept.

Neisser, Fortschr. d: Med., Bd. II., S. 73.

Salomonson, Ibid., Bd. II., S. 78.

KLeIN, Centralbl. f. d. med. Wiss., 1884, Nr. 8.

Vennemann et Bruylants, Le jéquirity et son principe pathogène. Bruxelles, 1884.

Sattler, Ibid., II., S. 501.

Vossius, Berl. klin. Wochenschr., 1884, Nr. 17.

DE Wecker, v. Graefe's Arch., Bd. 30, Abth. 1.

-, Archiv. f. Augenheilkunde., Bd. 14.

KNAPP, Klinische Beob. über die Anwendung von Jequirity bei Trachom. Arch. f. Augenheilk., XIV.

\section{OTHER INFECTIVE DISEASES OF MAN.}

\section{Variola, Vaccinia.}

Keber, Virchow's Arch., Bd. 42.

Chauveau, Compt. rendus., 1868, Februar.

Cон,, Virchow's Archiv, Bd. 55, 1872.

Luginbuhl, Der Micrococcus der Variola. Verhdl. d. phys.-med.

Ges. in Würzburg, 1873.

Z̈̈LZER, Berl. klin. Wochenschr., 1872.

Weigert, Anat. Beitr. z. Lehre v. d. Pocken., 1874.

Pissin, Berl. klin. Wochenschr., 1874.

KLeBS, Arch. f. exp. Path. u. Pharmakol. Leipzig, Bd. 10, 1878.

Poul-Pincus, Vaccination. Berlin, 1882. 
TAPpe, Aetiologie u. Histologie der Schafpocken. Berlin, 1881.

Plaut, Das organis. Contagium der Schafpocken. Leipzig, 1883. Cornil et Babès, Soc. médicale des hôpitaux, 1883, 10 August. Quist, St. Petersburg medic. Woch., 1883, Nr. 46.

Fürst, Corresp.-Blatt. d. ärztl. Kreis- u. Bez.-Vereins. in Sachsen. Leipzig, Bd. 33.

Hanerink, Ueber die sog. Vaccination u. Variola. Prag., 1884. Pfeifrer, Ueber die Rückimpfung auf Kühe und Kälber. Jahrb.

f. Kinderheilk, 1882, Bd. 19.

-, Ueber Sprosspilze in der Kälberlymphe.

M. WoLf, Zur Impffrage. Berl. klin. Wochenschr., 1883, Nr. 4.

\section{Scarlatina.}

Coze et Feltz, Les Maladies infectieuses, 1872.

Porl-Pincus, Centralbl. f. d. med. Wiss., 1883.

Hevbner U. BahrdT, Zur Kenntniss der Gelenkeiterungen bei Scharlach. Berl. klin. Woch., 1884, Nr. 44.

Crooke, The Lancet, 1883, March.

Rотн, Münchener ärztl. Intelligenzbl., 1883.

BokaI, Orvosi hetilap. 1882 u. 1885. (Arthritis scarlatinosa; s. Cornil u. Babès' Handbuch, S. 537.)

\section{YelLow Fever.}

Domingos Freire, Recherches sur la cause, \&c., de la fièvre jaune. Rio de Janeiro, 1884.

Domingos Freire et Rebourgeon, Compt. rend., T. 99, p. 804. 1884.

BabEs, Sur les microbes trouvés dans le foie et dans le rein d'individus morts de la fièrre jaune. Compt. rend. 1883. 17 Sept.

Bouley, L'inoculation préventive de la fièvre jaune. Compt. rend., Bd. 100, p. 1276.

\section{Cerebrospinal-Meningitis.}

Leyden, Die Mikrokokken der Cerebrospinal-Meningitis. Centralbl. f. klin. Med., 1883, Nr. 10.

Leichtesstern, Deutsche Medic. Woch., 1885, Nr. 23 u. 31.

\section{INFLUENZA.}

SeIfert, Ueber Influenza. Volkmann's Sammlung klin. Vorträge, Nr. 210. 
Acute Yellow Atrophy of the Liver.

Eppinger, Prag. Viertelj., 1875.

Hlava, Prag. med. Wochenschr., 1882.

HEMOPHILIA NEONATORUM.

KLebS U. Eppinger, In Klebs' Beitr: zur pathologischen Anat., 1878.

\section{RABIES.}

Cours, Bull. Acad, de méd. Paris, T. 10, 1881.

Doléris, Gaz. méd. de Paris, T. 3, 1881.

-, Tribune méd. Paris, T. 14, 1881.

Pasteur, Compt. rend. Acad. de sc., 1881-83.

-, Nouvelle communication sur la rage. Ann. de méd. vétérin, 1884, Part 5.

Pasteur, Chamberland, Roux et Thulller, Nouveaux faits pour servir à la connaissance de la rage. Compt. rend., 1882, T. 95. Bert, Contribution à l'étude de la rage. Compt. rend., 1882. Gibier, Ibid., T. 96, 1883.

\section{RHiNosCleRoma.}

Cornil, B. de la soc. anatom., 1885, 15 Febr.

Cornir et Alvarez, Sur les micro-organismes du Rhinosclerome. Acad. de Méd., 1885, March.

\section{Ozaena.}

E. FrÄNKEL, Virchow's Arch., Bd. 90, 1882.

Löwenberg, Deutsche med. Woch., 1855, Nr. 1.

\section{Lung Affections (Pneumonia, see p. 31).}

JAFF氏 U. LEYDEN, Ueber Organismen bei Lungengangrän (Leptothrix). Med. Centralzeitung 1866. Deutsch. Arch. f. klin. Med., II.

Traube, Leptothrix im Sputum. Deutsche Klinik., 1853.

Heimer, Ueber Pneumonomycosis sarcinica. Deutches Arch. f. klin. Med., 1877 (vgl. Sarcina, S. 29).

Burger, Der Keuchhustenpilz. Berl. klin. Wochenschr., 1883, Nr. 1.

\section{Goltre.}

KLEBS, Studien über Kretinismus. Prag, 1877. Bircher, Der endemische Kropf. Basel, 1883. 
Skin Afrections.

Rindfleisch, Mycosis fungoides. Deutsche med. Woch., 1885. Auspitz, Granuloma fungoides. Viertlj. f. Dermat. u. Syph., 1885.

v. Sehlen, Mikrokokken bei Area Celsi. Fortschr. de Med., Bd. 1, 1883.-Virch. Arch., Bd. 99, S. 327.-Bd. 100, S. 361.

Michelson, Ibid., Bd. 99, S. 572.-Bd. 100, S. 576.

Thin, British Medic. Journ., 1882, S. 304.

\section{DISEASES OF THE MOUTH AND TEETH.}

(As to Leptothrix see also p. 24, Förster, ff., S. 26, Jaffé u. Leyden ff; as to Thrush, s., S. 9.)

Leber, Berl. klin. Wochenschr., 1867, Nr. 16.

Leber u. Rottenstein, Unters. über Caries der Zähne. Berlin, 1867. Satyerthwaite and Cur'sis, Rep. of the New York Board of Health, 1877.

Miller, Der Einfluss der Mikro-organismen auf die Caries der Zähne. Arch. f. exp. Path., XVI., 1882.

-, Deutsche med. Woch., 1884, Nr. 25 u. 36.

-, Correspdzbl. f. Zahnärzte., Bd. 13, 1884.

-, Ueber einen Zahnspaltpilz Leptothrix gigantea. Ber de deutsch. bot. Ges., 1883, Heft 5.

v. UBISCH, Leptothrixbildung im Munde. Berl. klin. Wochenschr., 1875, Nr. 52.

Arndt, Beob. an Spirochaeta denticola. Arch. f. pathol. Anat., Physiol. u. klin. Med., 1880, Bd. 79.

Pas'teur, Bull. de l'Ac. de méd., 1881, Januar.

Raynaud et Lannelongue, Bull. de l'Acad. de méd., 1881, Febr.

Vulpian, Ibid., 1881, März.

Küнs, Berl. klin. Woch., 1881.

A. Fränkel, Deutsche med. Wochenschr., 1884, Nr. 25.

RAPPIN, Des bactéries de bouche á l'état normale et dans la fièvre typhoïde. Paris, 1881.

Rasmussen, Om Drykning af Microorganismer fra spyt of sunde mennesker. Kopenhagen, 1883.

KLeIN, Centralbl. f. d. med. Wiss., 1884, Nr. 30.

Lörfler, Mittheilungen aus dem kais. Ges.-Amt., Bd. II., S. 449 u. 480.

Rosenbach, Microorganismen dei den Wundinfectionskrankheiten.

Wiesbaden, 1884, S. 77 (Zahncaries). 


\section{DISEASES OF ANIMALS.}

General Literature.

RöLL, Die Thierseuchen. Wien, 1881.

Zürn, Parasiten in und auf dem Körpey der Haussäugethiere, 1874. Pürz, Die Seuchen- und Herdekrankheiten der Hausthiere. Stuttgart, 1882.

Hydrophobia, see p. 36 .

RaUschbrand.

(Symptomatic Anthrax, Black leg, \&c.)

Boluinger v. Feser, Wochenschr. f. Thierheilkunde., 1878.

Arloing, Cornevin et Thomas, Compt. rend. de l'Acad de sc. $1880-83$.

—, Revue de méd., 1881, 1883, 1884.

-, Du charbon bactérien. Paris, 1883.

-, Bull. de l'Acad. de Méd., 1881.

BABÈs, Journ. de l'anatomie, 1884, Janvier.

Nergsen v. Ehleks, Ueber den Rausehbrand. Ber. d. Naturforsch. Ges. zu Rostock., Januar, 1884.

EhIıRs, Unters. üb. d. Rauschbrandpilz. Inaug.-Diss. Rostock, 1884.

KIтr, Unters. über malignes Oedem und. Rauschbrand bei Hausthieren. Jahresber der K. Thierarzneisch. in München, 1883-84.

\section{Rinderpest.}

Semmer U. Archangelski, Ueber das Rinderpestcontagium und dessen Mitigation. Centralbl. f. d. med. Wiss., 1883.

Sемmer, Rinderpestähnliche Erkrankungen und die Mikroorganismen bei denselben. Deutsche Zeitschr. f. Thiermed. XI., S. 77.

\section{Pleuro-Pneumonia.}

SussporfF, Ueber d. Lungenseuche des Rindes. Deutsche Zeitschr. f. Thiermed. u. vergl. Pathol., 1879.

Mayrwieser, Ueber infectiösen Bronchialcroup bei Rindern. Wochenschr. f. Thierheilk u. Viehzucht., 1884, 19.

Pastelr, Note sur la péripneumonie contagieuse des bêtes à cornes. Recueil de méd. vét., 1882.

Corvil et Babès, Arch. de physiol. norm. et path., 1883, T. 2. Püls u. Nolen, Centralbl. f. d. medic. Wissensch., 1884, Nr. 9. 


\section{Swine Erysipelas.}

Pasteur, Sur le rouget, on mal rouge des porcs. Compt. rend., T. 95, 1882.

Cornil et Babìs, Arch. de physiol., 1883, August.

KLEIN, Rep. of the Med. Offic. of the Privy Council, 1877-78.

-, Die Bakterien der Schweinesenche. Virchow's Archir, Bd. 95.

EgGeing, Reference in Fortschr. d. Med. I., 793.

Pasteur et Thulliter, Bull. de l'Acad. de méd. de Paris, 1883.

Compt. rend., Bd. 97, 1883.

LöFfLER, Experimentelle Untersuchungen über Schweinerothlauf.

Arbeiten aus dem kaiserl. Gesundheitsamt, Bd. 1, 1885.

Sснётz, Ueber den Rothlanf der Schweine und die Impfung desselben. Ibid., S. 56.

Lxdtin u. Schottei.ıus, Der Rothlauf der Schweine. Wiesbaden, 1885.

\section{Chicken Cholera.}

ZïrR, Die Krankheiten des Hausgeflügels. Weimar, 1882.

Mégnin, Maladies des oiseaux.

IoANnès ET M€́gnin, Journ. d'acclimatation, 1877.

Semmer, Hühnerpest. Deutsche Zeitschr. f. Thiermed. u. vergl. Path., 1878.

Pastedr, Sur la choléra des poules. Compt. rend., T. 90, 1880.

-, Hühnercholera. Uebersetzt von A. Schuster. Arch. f. exp. Pathol., Bd. 12.

Perroncrto, Ueber das epizootische Typhoïd der Hühner. Arch.

f. wiss. u. prakt. Thierheilk, 1879.

Convil, Arch. de physiol., 1882, Bd. 10.

BABÈs, Compt. rend. de l'Acad. d. sc., 1883, Sept.

- Arch. de physiol., 1883, Juli.

KIтT, Mittheilungen über die Typhoïdseuche des Geflügels. Allg. deutsche Geflügel-zeitung, 1885, 15 Febr.

Petri, Centralbl. f. d. med. Wissensch., 1884.

Barthélemy, De l'incubation des oeufs d'une poule atteinte du choléra des poules. Compt. rend., 1883, T. 96, No. 18.

\section{Disease of Parrots.}

Eberth, Virchow's Archiv, Bd. 80.

WolfF, Ibid., Bd. 92, 1883. 


\section{Disease of Sillkworms.-Pebrine.}

Cornalia, Rapp. della Comissione per le studio della mallattia dei briochi. Milano, 1877.

-, Ueber Pebrine. Monographia del Bombice del Gelso. Milano, 1856.

Lebert, Verein zur Beförderung d. Seidenbaues d. Prov. Brandenb., 1856-57.

Frey u. Lebert, Ueber Panhistophyton. Vierteljahrschr. d. naturwissensch. Ges.-Zürich, 1856.

Osimo \& Vittadini, Giorn. Instit. Lombard, Bd. 3.

-, Recherches sur les maladies des vers à soie. Padua, 1859.

NäGeLI, Ueber Nosema bombycis. Bot. Zeitg., 1857.

Pasteur, Etudes sur les maladies des vers à soie. Paris, 1870.

\section{Flacherie.}

Leydig, Ueber Gattine. Du Bois-Reymond's u. Reichert's Archiv, 1863.

Ве́снамт, Ueber Micrococcus bombycis. Compt. rend., 1867, Bd. 64.

- Pasteur, Ibid., Bd. 64.

Verson et Vlacovitsch, Recherches sur la gattine et la flacherie. Publ. de la station séricicole de Montpellier, 1874.

FerRy de la Billone, Compt. rend. du congrès internat. séricicole, 1878.

\section{SAPROPHYTES.}

\section{(See also References in the Text.)}

Bacteria which produce Pigment.

Ehrenberg. Micr. prodigiosus. Verhandl. d. Berl. Acad., 1839.

SснRöter, Ueber einige von Bakterien gebildete Pigmente. Cohn, Beitr. z. Biol. der Pflanzen, Bd. I., Heft 2.

ERduann, Bildung von Anilinfarben aus Proteïnkörpern. Journ. f. pract: Chemie., Bd. 99, 1866.

Lankester, On a Peach-coloured Bacteriûm. Quart. Journ. of micr. sc., Vol. 13, 1873 ; Ibid., Vol. 16, 1876.

- - An experiment on the destructive effect of heat upon life of Bacteria and their germs. Nature, 1874, IX.

KLEIN, Quart. Journ. of micr. sc., Vol. 15, 1875.

Wernich, Cohn's Beiträge zur Biol. d. Pflanzen, IlI., Heft 1.

Giard, Revue des sc., T. 5, 1877.

Frank (Bacillus ruber), Cohn's Beitr. z. Biol. d. Pflanzen, Bd. I., Heft 3. 
Cohn u. Miflet (Bact. erythrosporus), Ibid., Bd. III., Heft 1.

Van Tieghem, Bull. de la Soc. bot. de France, 1880.

LÜске, Arch. f. klin. Chir., 1862 (blue pus).

Girard, Unters. über blauen Eiter. Chirurg. Centralbl. II., 1875. Éberth, Centralbl. f. d. med. Wissensch., 1863 (Idem).

—, Virchow's Archiv, Bd. 72, 1875 (Idem).

Fordos, Compt. rend. de l'Acad. de sc., T. 51 (Idem).

Gessard, De la pyocyanine et de son microbe. Thèse de Paris, 1882.

Charrin, Communication faite à la Société anatomique, 1884, December (Blauer Eiter).

BABÈs, Vom rothen Schweiss. Biolog. Centralbl., Bd. 2, 1882.

\section{Phosphorescence.}

Bancel et Husson, Sur la phosphorescence de la viande dehomard. Compt. rend., 1879, T. 88.

Nüesch, Ueber das leuchtende Fleisch gestorbener Thiere.

Cosmos les Mondes, Revue hebdom. des sciences, 1878.

Lassar, Pflüger's Archiv, Bd. 21, 1880.

Ludwig, Micrococcus Pflügeri. Hedwigia, 1884, Nr. 3.

-, Ueber die spectroscopische Untersuchung pathog. Pilze.

Zeitschr. f. Mikrosk., Bd. 1, 1884.

\section{Sarcina.}

Goodsir, Edinb. Med. and Surg. Journ., 1842.

Oersted, Naturhist. Tidsskrift., Bd. III., 1840.

Welcker, Ueber Sarcina. Henle's Zeitschr. f. ration. Med., 3

Ser., Bd. 5 .

EвERTh, Virchow's Archiv, 1858, Bd. 13.

Corn, Beitr. z. Biol. d. Pflanzen, Bd. 1, Heft 2.

Itrigisohn, Virchow's Archiv, Bd. 13.

CaSpary, Schriften der physik. ökon. Ges. zu. Königsberg, Bd. 15, 1874.

Virchow u. Cohnheim, Virchow's Arch., Bd. 10 u. 33.

Suringar, Arch. Neerland, 1866.

—, Ueber den Zellenbau der Sarcina. Bot. Zeit., 1866.

Heller, Heller's Arch. f. Chemie., 1847 (Harnsarcine).

WELCKER, Zeitschr. f. ration Med., 1859 (Idem).

Munk, Virch. Arch., Bd. 22, 1861.-Med. Centralbl., 1864 (Idem).

Pástedr, Ann. de chim. et de phys., T. 6\$, 1862.

Losdorfer, Med. Jahrb, 1871, Heft 3. 
Friedreich, Beiträge zur Kenntniss der Sputa. Virch. Arch., Bd. 30.

Hrimer, Ueber Pneumonomycosis sarciniea. Deutsch Arch. f. klin. Med., 1877.

Falkfinheim, Arch. f. exp. Patholog. u. Pharmakol, Bd. 19.

\section{Other Saprophytes.}

LUDERs, Ueber Abstammung u. Entwicklung des Bacterium termo. Bonn, 1867.

Ewart, Proceedings of the Roy. Soc. of London, 1874.

DALLivger, Journ. of the Roy. Microscop. Soc., London, 1878.

Dallinger and Drysdale, The Monthly Microsc. Journ., 1875.

Eidam, Cohn's Beitr. zur Biol. d. Pflanzen, Bd. 1, Heft 3.

Vax Tieghem, Sur les prétendus cils des bactéries. Bull. de la Soc. bot. de France, 1879.

Engelmane, Bacterium photometricum. Unters. aus d. phys. Laborat. zu Utrecht, 1882.-Pflüger's Arch. f. d. ges. Physiol., Bd. 30, S. $95,1882$.

Kurth, Bacterium Zopfi. Ber. d. dentsch. bot. Ges. Botanische Zeitg., 1883.

ZOPF, Bacterium merismopedioïdes. Sitz.-Ber. d. Botan. ver. d. Prov. Brandenb., Juni., 1882.

Brefeld, Bacillus subtilis. Ges. nat. Freunde, Berlin, 1878, u. in Schimmelpilze, Heft 4.

Vaxdevelde, Studien zur Chemie des Bacillus subtilis. Zeitschr. f. phys. Chemie, Bd. 8, 1884.

As to Leptothrix s., pp. 24, 37, 53.

Geddes and Ewart, On the Life-History of Spirillnm. Proceed. of the Roy. Soc. of London, 1878.

Münıнӥuser, Ueber Spirillen. Virch. Arch., Bd. 97, 1884.

KüTZıNG, Sphaerotilus natans. Linnaea 8, 1883.

Eidam, Schles. Ges. f. vaterl. Cultur., 1876.

Wrisse, Monas Okenii. Bull. phys.-mathemat. de St. Pétersbourg, III., 184.5.

Coнs, Ueber d. Brunnenfaden. Beitr. z. Biol. d. Pflanzen, Bd. I., Heft 1.

Zopf, Ueber Crenothrix polyspora. Berlin, 1879.

Lankester, Quarterly Journal of Microscop. Sc., 1873 and 1876.

ExGI,ER, Pilzvegetat. des weissen oder todten Grundes in der Kieler Bucht. Ber. d. Comm. zur Erforschung deutscher Meere, 1881.

BitLet, Sur la formation des spores chez le Cladothrix dichotoma. Compt. rend., T. 100, p. 1251. 
Grard, Sur le Crenothrix Kühniana. Compt. rend., 1882. Zopr, Zur Morphologie der Spaltpflanzen. Leipzig, 1882. Coнs, Ueber zwei neue Beggiatoen. Hedwigia, 1865, p. 81-83. Cienkowski, Zur Morphologie der Bakterien. St. Petersburg, 1876. Richter, Ibid., 1884.

\section{BIOLOGY OF THE BACTERIA.}

General.

Conv, Beitr. z. Biol. d. Pflanzen. Breslau, 1875, and following years. Näsisli, Die niederen Pilze. München, 1877.

-, Unters. über niedere Pilze. München, 1882.

Nexcki, Beitr. z. Biologie d. Spaltpilze. Journ. f. prakt. Chemie., N. F., Bd. 19, 20, 23.

-, Virchow's Archiv, 1879.

Wiesner, Sitz.-Ber. d. Kaiserl. Akad. d. Wissensch. zu Wien. I. Abthlg., 1873, April.

ErndM, Cohn's Beitr. zur. Biol. d. Pflanzen, Bd. I., Heft 3.

\section{Analyses.}

Ravlin, Compt. rend., T. 56.

Gayon, Bull. de la Soc. Chim., T. 35.

Sieber, Journ. f. prakt. Chemie. (2) 23, p. 412.

NäGEl, Sitz.-Ber. d. K. bayer. Akad. d. Wissensch., 1878, Mai.

Martin v. Löw, Journ. f. prakt. Chemie., Bd. 17.

Nexcki, Beiträge zur Biol. der Spaltpilze. Leipzig, 1880.

- , Ueber das Eiweiss der Milzbrandbacillen. Ber d. deutschen chem. Gesellsch., 1884, p. 2605.

\section{Nutrient Materials.}

Raulin, Compt. rend., T. 56.

Buchnoltz, Arch. f. exp. Pathol., Bd. 7.

Mayer u. Knierim, Landwirthsch. Versuchsstat., Bd. 16.

Corn, 1. c.

NäGELI, Untersuchungen über niedere Pilze. München, 1882.

v. JAKSCH, Zeitschr. f. physiol. Chemie., Bd. 5, 1881.

See under Fermentation, page 45; Pasteur, Duclaux, Schützen-

berger, Mayer, Nägeli.

(Nutrient Materials of Yeast.)

\section{INFLUENCE OF OXYGEN.}

Pasteur, Compt. rend. 52, p. 340, 1260, T. 56.-T. 75.-T. 80.

Liebig, Annal. d. Chem. u. Pharm., 1870, T. 153. 
Schützenberger et Quinquaud, Compt. rend., T. 77.

A. Mayer, Landwirthsch. versuchsstat., 1873, Bd. 16.-Ibid., 1880, Bd. 25.

—, Poggendorf's Annalen., 1871.

-, Zeitschr. f. Biol., Bd. 5.

Müntz, Ann. de Chim. et de Phys., 1876, Bd. 8.

Brefeld, Landwirthsch. Jahrber., 1874, Bd. 3.-Ibid., 1876, Bd. 5.

_, Verhandl. d. Würzburger physik.-med. Ges., 1873.

HÜFNer, Journ. f. prakt. Chemie., 1876, Bd. 13.

Paschutin, Virchow's Arch., Bd. 59.

Grossmann u. Mayerhausen, Archiv f. phys., 1877, Bd. 15.

Gunning, Chem. Centralbl., 1878, P. 799.-1880, P. 9.-Ibid., 20, P. 418.

Traube, Ber d. chem. Ges. 1874, P. 875.

Nexcki, Beiträge z. Biologie d. Spaltpilze., 1880.

—, Journ. f. prakt. Chemie., 19, P. 337.

- Ueber die Zersetzung der Gelatine. Bern, 1876.

Lechartier et Bellamy, De la fermentation des fruits. Compt. rend., T. $69,75,79,81$.

Popofr, Pflüger's Arch. f. Physiol., 10, P. 135.

JeAnneret, Journ. f. prakt. Chemie., N.F. 15, P. 353.

Hoppe-Seyler, Ueber d. Einfluss des Sauerstoffs auf Gärungen. Strassburg, 1881.

- Die Einwirkung von Sauerstoff auf die Lebensthätigkeitniederer Organismen. Zeitschr. f. phys. Chemie., Bd. 8, 1884.

Grossmann u. Mayerhausen, Das Leben der Bakterien in Gasen. Pflüger's Arch., Bd. 15.

Spilmann, Verh.d. Milzbrandbacillen in Gasen. Zeitschr. f. physiol. Chemie., Bd. 4.

PaUmès, Rech. sur la respiration de la lecure. Ref. Fortschr. d. Med., Bd. 2, p. 53.

Influence of Light, Electricity and Atmospheric Pressure.

Evgelmann, Botan. Zeitg.,1882.-Arch. f. d. ges. Physiologie, Bd. 26. Jamieson, Transact. of the Roy. Soc. of Victoria, Vol. 20.

Strasburger, Wirkung des Lichts und der Wärme auf. Schwärmsporen, 1878.

Downes and Blunt, Ibid., Bd. 20.

Cohn u. Mendelsohn, Ueber Einwirkung des elektrischen Stromes auf die vermehrung d. Bakterien. Beitr. z. Biol. d. Pflanzen., Bd. III., Heft 1.

Duclaux, Influence de la lumière du soleil sur la vitalité des germes de microbes. Compt. rend., Nr. 2, 1885. 
Cortes, De l'action des hautes pressions sur les phénomènes de la putréfraction, etc. Compt. rend., T. 99, p. 385.

REGNARD, Rech. sur l'influence de très hautes pressions sur les org. vivants. Compt. rend., T. 98, p. 744.

Influence of Movement.

Horvath, Arch. f. d. ges. Physiol., Bd. 17.

ReINke, Ibid., Bd. 23.

Tumas, St. Petersb. med. Wochenschr., 1881.

\section{FERMENTATION.}

\section{(For Yeast, see p. 8.)}

Fermentation in General and the Alcoholic Fermentation.

Braconnot, Ann. de Chim. et Phys., T. 47, 59.

Schubert, Poggendorf's Annalen., Bd. 69 u. 77.

Berzelius, Lehrbuch der Chemie, Bd. 8, P. 84.

一, Jahresberichte, 1839, 1840.

Schönbein, Journ. f. prakt. Chemie, Bd. 63, P. 323.-Bd. 89, P. 323.

-, Verhandl. d. Baseler. naturf. Ges., [Bd. 4, P. 797.-Bd. 5, P. 1-5.

—, Zeitschr. f. Biol., Bd. 1, P. 273.-Bd. 3, P. 140.-Bd. 4, P. 367. Mitscherlich, Monatsber d. Berl. Akad. d. Wiss., Dec., 1841.

—, Poggendorf's Annalen., 1842, Bd. 55.-Ibid., 1843, Bd. 59.

Liebig, Verhandl. der Münchener. Akad. d. Wiss. 9 Mai, 1861 u. 5 Nov., 1869.

-, Annalen der Pharmacie, Bd. 30, P. 250.

-, Die Chemie in ihrer Anwendung auf Agricultur u. Physiologie. Braunschweig, 1846, P. 371-584.

-, Ueber Gährung, Quelle der Muskelkraft und Ernährung. Leipzig u. Heidelberg, 1870.

Pasteur, Etudes sur le vin., 1866.

- Etudes sur la bière, 1876.

-, Annal. de chim. et de phys., 1860, III. súr., T. 58, Ibid., T. 64, 1862.

-, Compt. rend., 1857, T. 45-Ibid., 1861, T. 52.-Ibid., 1863, T. 56.-Ibid., 1864, Jan.-Ibid., 1871, Dec.-'bid., 1872, T. $75 \mathrm{ff}$.

Traube, Chem. Ber., 8, P. 776.

-, Poggendorf's Annalen., 1858, Bd. 103, P. 331.

- Theorie der Fermentwirkungen. Berlin, 1858. 
Dumas, Compt. rend., 1872, T. 75, Nr. 6.

-, Ann. de chim. et de phys., 1874.

Heцmholтz, Müller's Archiv, 1843, P. 453.

-, Journal f. prakt Chemie, Bd. 31, P. 423.

Turpin, Compt. rend., T. 7, 1838.

-, Annal. d. Chemie u. Pharmacie, 1839, T. 23, P. 100.

Lüdersdokff, Poggendorf's Annalen, Bd. 67, P. 408.

C. Schmidt, Annal. d. Chemie und Pharm., T. 61, P. 168.

Blondeau, Journ. de Pharm., 1846, T. 12, Pp. 244 u. 336.

WAGNer, Journ. f. prakt. Chemie, Bd. 45, P. 241.

Berthelot, Compt.rend., 1857, T. 44.

Hofmanx, Aerztl. Verein. zu Wien., Mai, 1873.

—, Allgem. med. Centralbl., 1873, P. 605.

Duclaux, Thèses prèsentées à la faculté de Paris, 1865 .

Dubrunfaut, Compt. rend., 1871, T. 73.

Lex, Centralbl. f. d. med. Wiss., 1872, P. 291.

Panum, Nord. med. Ark., 10, P. 4.

Mosler, Mykologische Studien am Hühnerei. Virch. Arch.. Bd. 29, P. 510.

HÜFner, Journ. f. prakt Chemie, N. F. 10, P. 148.

Colin, Annal. d. Chim. et Phys., 28, p. 128 ; 30, p. 42.

Hoppe-Seyler, Arch. f. Phys., 12.

-, Medic. chem. Untersuchungen, 1871, H. 4.

-, Zeitschr. f. physiolog. Chemie, Bd. 2.

Baumann, Ibid., Bd. 5, P. 244.

Fleck, Ber. d. chem. Centralst. Dresden; 1876.

Karsten, Chemismus der Pflanzenzelle. Wien, 1869.

HaLlier, Gährungserscheinungen. Leipzig, 1867.

Schützenberger, Die Gährungserscheinungen, 1874.

A. Mayer, Lehrbuch der Gährungschemie, 2 Aufl., 1876.

$\mathrm{H}_{\mathrm{ARZ}}$, Grundzüge der alkoholischen Gährungslehre. Munchen, 1877.

NÄGELI, Theorie der Gährung. München, 1879.

Brefeld, Landwirthsch. Jahresber, 1874, Bd. 3.-Ibid., 1875, Bd. 4.-Ibid., 1876, Bd. 5.

Fitz, Berichte d. chem. Ges., 1873, Bd. 6, P. 48.-1878, Bd. 10,

P. 276. -1879, Bd. 11, P. 42 u. 498.; Bd. 12, P. 474.-1880,

Bd. 13, P. 1309.--1882, Bd. 15, P. 857.-1883, Bd. 16, P. 844.1884, Bd. 17, P. 1188.

Prazmowski, Untersuchungen über die Entwicklungsgeschichte und Fermentwirkung einiger Bakterien. Leipzig, 1880.

TyNDALL, Essays on the floating matter of the air in relation to putrefaction and infection. London, 1881.

EkIKsson, Unters. aus d. botan. Institut in Tübingen, 1881, Heft 1. 
Poporf, Botan. Jahresber, 1875.

KöNıG, Berichte d. deutsch. chem. Gesellsch., B. 14.

\section{Lactic Acid Fermentation.}

Boutron et Fremy, Ann. de chim. et de phys. (3), T. 2.

Pasteur, Ibid. (3), T. 52.

LeBolt, Journ. f. prakt. Chemie, Bd. 77.

Proust, Ann. de chim. et de phys. (2), T. 10.

Lister, The cause of the putrefaction and lactic fermentation. The Pharmac. Journ. and Transact., 1877.

Boutroux, Sur la fermentation lactique. Compt. rend., T. 86, 1878.

Richet, Compt. rend., T. 88, 1879.

Hueppe, Mitth. a. d. Ges. Amt., Bd. 2.-Deutsche med. Woch., 1884, Nr. 48.

\section{Butyric Fermentation, Fermentation of Cellulose.}

Pasteur, Compt. rend., T. 52, 1861.

'TRécur, Bacillus Amylobacter. Compt. rend., 1865, T. 61.-1867, T. 65.

一, Ann. des sc., sér. 5, T. 7, 1867.

Van Tieghem, Développement du Spirillum amyliférum. Bull. de la Sos. bot. de France, 1879.

-, Sur la fermentation de la cellulose. Ibid., 1879, p. 25-30.

-, Compt. rend., T. 89, 1879.

-, Sur le Bacillus Amylobacter. Compt. rend., 1879, T. 88.

- Identité du Bacillus Amylobacter et du Vibrion butyrique de Pasteur.-Ibid., Compt. rend., 1879, T. 89.

-, Sur le ferment butyrique à l'époque de la houille. Ibid., 1880.

-, Déreloppement de l'Amylobacter dans les plantes à l'état et vie normale. Compt. rend., 1884, No. 6.

TAPpeiner, Celluloseverdaung. Fortschr. d. Med., I., 151; II., $377,416$.

Prazmowski, Unters. üb. d. Entwicklungsgeschichte und Fermentwirkung einiger Bakterien. Leipzig, 1880.

\section{Ammoniacal Fermentation.}

Van Tieghem, Compt. rend., T. 58, 1864, p. 210.

Feltz et Ritter, Journ. de l'Anat. et Phys., 1874.

Pasteur, Compt. rend., T. 50, 1860. 
Pasteur, Ann. de chim. et de Phys., T. 64, 1862.

—, Bull. de l'Acad. de méd., 1876, No. 27.

Tyndall, Compt. rend., T. 58, 1864.

MÜLleR, Journ. f. prakt. Chemie, Bd. 81.

Colıs, Bull. de l' Acad. de méd., 1875.

Musculus, Ber. d. chem. Ges., 1874, P. 124.

-, Archiv. f. Phys. 12, P. 214.

Hiller, Centralbl. f. d. med. Wiss, 1874, P. 53.

Bеснамт, Compt. rend., 60, p. 445.

Dubelt, Arch. f. exp. Pathol. 5, P. 195.

Pasteur et Joubert, Compt. rend. de l'Acad. d. sc., T. 83, 1876.

-, Ber. d. chem. Ges. 9, P. 1130.

V. JACKsCH, Studien über den Harnstoffpilz. Zeitschr. f. physiol. Chemie, Bd. 5, 1881.

Guiard, Thèse de Paris, 1883.

Lépine et Roux, Compt. rend., T. 101, 1885.

LECBE, Ueber die ammoniakalische Harngährung. Virch. Arch., Bd. 100 , P. 540.

Ladtreat, Sur le ferment ammoniacal. Compt. rend., T. 99, p. 877.

BiLiet, Sur le bacterium urea. Ib., T. 100, p. 1252.

Mannite Fermentation.

Pasteur, Bull. de. la soc. chim., 1861.

Monoyer, Thèse de Strassburg, 1862.

Bєснамт, Compt. rend., T. 93.

\section{Dextran Fermentation.}

Van Tieghem, Leuconostoc mesenterioides. Ann. d. sc. nat., 6 sér., T. 7.

-, Sur la gomme de sucrerie. Ibid.

Scheibier, Ueber die Natur des Froschlaich. Zeits. f. Rübenzuckerindustrie, 1874.

Crenkowski, Die Gallertbildungen d. Zuckerrübensaftes. Charkow, 1778.

Putrefactive Fermentation.

(See "Putrid Intoxication, Ptomaines," p. 16).

Hoppe-Seyler, Zeitschr. f. phys. Chemie, Bd. 2.

—, Arch. f. d. ges. Physiol., Bd. 12.

Baumanx, Ibid., Bd. 5-7.

Nexcki, Uber den ehemischen Mechanismus der Fäulniss. Journ. f. praktische Chemie, Bd. 17. 
Nencki, Ueber die Zersetzung der Gelatine und des Eiweisses bei der Fäulniss mit Pancreas. Bern., 1876.

SıLкоwsккі, Zur Kenntniss der Eiweissfäulniss. Ber. d. deutsch. chem. Ges., XII., 107, 648; XIII., 189.

-, Zeitschr. f. physiol. Chemie, V., 424.; IX., 8, 491.

Brieger (see p. 17).

Salomonsen, Die Fäulniss des Blutes. Kopenhagen, 1877 (Danish), Just, Jahresbericht für 1877, P. 222.

Kaufmann, Zersetzung des Blutes durch Bacillus subtilis. Journ. f. prakt. Chemie, Bd., 17, 1878.

Rosenbach, Giebt. es verschiedene Arten von Fänlniss? Deutsche Zeitschrift für Chirurgie, XVI., P. 342, 1882.

Etard et Olivier, De la reduction des sulfates par les être vivants. Compt. rend., 1882, p. 846.

Brenstock, Ueber die Bakterien der Faeces. Zeitschr. f. klin. Med., Bd. 8.

Escherich, Die Darmbakterien des Neugeborenen und Säuglings.

Fortschritte der Med., Bd. 3, P. 515.

Hauser, Ueber Fäulnissbakterien. Leipzig, 1885.

TAPpeiner, Medic. Centralbl., 1884.

Decomposition of Milk (See p. 47).

HüPPE, Unters. üb. die Zersetzungen der Milch durch Mikroorganismen. Mitth. a. d. Ges. Amt., Bd. 2, 1884.

-, Deutsche med. Wochenschr., 1884, Nr. 48 ff.

Duclaux, Ann. de l'Institut agronomique, 1882.

Fuchs, Zur Kenntniss der gesunden und fehlerhaften Milch der Hausthiere. Gurlt's u. Hertwig's Mag. f. d. ges. Thierheilk., Bd. $7,2$.

Hermatët, Ueber die blane und rothe Milch. Iseipzig, 1833.

Sreinhoff, Ueber das Blauwerden der Milch. Neue Ann. d. meklenb. landw. Ges., 1838.

Chabert et Fromage, D'une altération du lait de vache, désignée sous le nom du lait bleu. Paris, 1850.

Gielen, Mag. f. ges. d. Thierheilkunde., Bd. 18, 1852.

Moster, Ueber blaue Milch und durch deren Genuss herbeigeführte Krankheiten. Virchow's Archiv, Bd. 43, 1868.

Neelsen, Cohn's Beitr. z. Biologie d. Pflanzen., Bd. III., Heft 2.

Hugues, Le lait bleu. Echo vétérinaire. Liège, 1884.

Sснмірт-Müнlнeiм, Unters. über fadenziehende Milch. Arch.f. die ges Physiol., T. 27, P. 490-510.

KERN, Ueber ein neues Milchferment aus dem Kaukasus. Bull. de. la Soc. Imp. des Naturalistes de Moskau, 1881, No. 3. 
Kern, Dispora cancasica, eine neue Bakterienform. Biolog. Centralbl., Bd. 2, P. 137.

Mandowsky, Deutsche med. Woch., 1884.

Krannhals, Ueber das kumysähnliche Getränk Kephir. Deutsches Arch. f. klin. Med., Bd. 35, 1884.

\section{Other Decompositions.}

GaYon, Sur les altérations des oeufs. Compt. rend., 1877, T. 85. Bє́champ et Eustache, Ibid., 1877, T. 85 , p. $854-857$; p. $1290-$ 1292.

Marcano, Fermentation de la fécule. Présence d'un vibrion dans la graine de maïs qui germe et dans la tige de cette plante. Compt. rend., 1882, p. 345 .

Prillieux, Corrosion de grains de blé colorés en rose par des Bacteries. Bull. de la Soc. Bot. de France, 1879, p. 31.

-, Ibid., p. 187-189.

JoLy, Etudes nouvelles tendant à établir la véritable nature de la glairine ou barégine. Compt. rend., 1882, T. 95, No. 24.

\section{Unorganised Ferments.}

MaYer, Die Lehre von den chemischen Fermenten. Heidelberg, 1882.

Baranetzky, Die stärkeumbildenden Fermente, 1878.

KraUCH, Landwirthsch. Versuchsstation, 1879, Bd. 23.

Schürzenberger, Die Gährungserscheinungen, 1876.

MAYER, Landwirthsch. Versuchsstation, 1871, Bd. 14.

Gayon, Compt. rend., 1878, T. 86, p. 52.

-, Bull. soc. chim., T. 35.

Duclaux, Compt. rend., T. 91.

Donath, Ber. d. chem. Ges., 1875, p. 286.

Barth, Ibid., 1878, p. 474.

NäGELI, Sitzber. d. Bayr. Akad. d. Wiss., 1878, H. 2, S. 177.

Berthelot, Compt. rend., 50, p. 890.

Hoppe-Seyler, Ber. d. chem. Ges., 4, p. 810.

-, Arch. f. Phys., Bd. 12.

v. Gorup-Besanez, Ber. d. chem. Ges., 1874, Bd. 7.-1875, Bd. 8.

A. Sснмірт, Ueber Emulsie., \&c. Diss. Tübingen, 1871.

v. D. Horst, Chem. Centralbl., 1878, P. 279.

Krukenberg, Unters. des physiologischen Instituts zu Heidelberg. 2, P. 273.

Wurtz et Bouchut, Compt. rend., 89, p. 425; 90, p. 1379.

Boucuut, Compt. rend., 91, p. 67. 
Duclaux, Compt. rend., T. 91, p. 731.

KüHnE, Unters. aus dem phys. Institut z. Heidelberg, Bd. 1.

-, Centralbl. f. d. med. Wiss., 1878, P. 357.

v. Nexcki, Ber. d. chem. Ges., 9, P. 295.

Scymanski, Zur Kenntniss des Malzpeptons. Chem. Ber., Bd. 18.

Wortmans, Ueber das diastatische Ferment der Bakterien. Ztschr.

f. physiol. Chemie, 1882, Bd. 6.

-, Biol. Centralbl., Bd. 3.

\section{PRODUCTION OF DISEASE.}

\section{General Literature.}

NäGeli, Die niederen Pilze. München, 1877.

Buchyer, Die Nägeli'schen Theorie der Infectionskrankheiten. Leipzig, 1877.

КосH, Untersuchungen über Wundinfectionskrankheiten. Leipzig, 1878.

Billroth, Coccobacteria septica. Berlin, 1874.

KI,EBs, Beiträge zur Anatomie der Schusswunden. Leipzig, 1872-73.-Arch. f. exp. Pathol. n. Pharm., Bd. 1-16.Artikle; "Ansteckende Krankheiten" in Eulenburg's RealEncyclopädie.

Wernicir, Die Entwicklung der organisirten Krankheitsgifte. Berlin, 1880.

Buchner, Boldivger, Soyka u. A., Vorträge a. d. ärztl. Verein in München, 1881.

VIRcirow, Krankheitswesen u. Krankheitsursachen. Virchow's Archiv, Bd. 79.

HILieR, Berl. klin. Wohnschr., 1877.

F'risch, Experimentelle Studien über Verbreitung der Fäulnissorganismen in den Geweben. Frlangen, 1874.

Bejfield, On the Relations of Micro-organisms to Disease. The Med. Rec., Vol. 23, 1883, No. 9-16.

$\mathrm{R}_{\mathrm{ALPH}}, \mathrm{On}$ the Occurrence of Bacteria in Living Plants. Transact. of Roy. Soc. of Victoria, T. 20, 1884.

Traube v. Gscheidlen, Ueber Füulniss u. den. Widerstand der lebenden Organismen gegen dieselbe. Schles. Ges. f. vaterländische Cultur, 1874.

RibBert, Die Schicksale der Osteomyelitiskokken im Organismus. Deutsche med. Woch., 1884, P. 682.

Colin, Rech. expér. sur la conservation temporaire des virus dans l'organisme des animaux où ils sont sans action. Compt. rend., T. 99 , p. 759. 
v. Bergmans, Ueber eine Blutveränderung bei den acuten Infectionskrankheiten. Verhandl. des Chirurgencongresses, 1882. Rossbach, Mikrokokken nach Papayotin-Finspritzungen. Centralbl. f. die med. Wiss., 1882.

SAlomonsen, Pseudoinfection bei Fröschen. Fortschr. d.Med., II., 617. Schov, Untersuchungen über Vaguspneumonie. Fortschr. d. Med., III., Nr. 15, 1885.

Rosenberger, Centralbl. f. d. med. Wissensch., 1882.

Metschnikoff, Ueber die Beziehung der Phagocyten zu den Milzbrandbacillen. Virchow's Arch., Bd. 97, P. 502-526.Ibid., Bd. 96, P. 177.

Virchow, Der Kampf der Zellen und der Bakterien. Virch. Arch., Bd. 101, Heft 1.

RrBberT, Ueber das Vorkommen von Spaltpilzen in der normalen

Darmwand des Kaninchens. Deutsche med. Wochenschr., 1885, Nr. 13.

-, Weitere Untersuchungen über das Schicksal pathogener Pilze im Organismus. Deutsche med. Wochenschr., 1885, Nr. 31. FaLK, Verhalten von Infectionsstoffen im Verdauungskanale. Arch.

f. pathol. Anat. u. Phys. u. f. klin. Med., 93, 1883, Nr. 2.

Nepvev, Uebergang von Bakterien durch die Darmwand bei Darmstrictur. Soc. de biol., 1883.

Fscherich, Bakteriolog. Unters. über Frauenmilch. Forts. d. Med:, III., 231, P. 93a.

\section{Transmission of Bacteria to the Fetus.}

Strrauss et Chamberland, Passage de la bactéridie charbonneuse de la mère åu foetus. Compt. rend., 1882, T. 95, Nr. 25.

Koubassoff, Compt. rend. de l'Acad. d. sc., 1885, Juli.

Коск, Mitth. a. d. k. Ges.-Amt., Bd. II. Berl., 1884, P. 86.

Iandodzy et Martin, Faits cliniques et expérimentaux pour servir. à l'histoire de l'hérédité de la tuberculose. Revue de méd., 1883, Dec.

Joнхe, Ein zweifelloser Fall von congenitaler Tuberkulose. Fortschr. d. Med., Bd. 3, P. 198.

Passage of Organisms into the Urine (Microc. Urex., See p. 47). Grawitz, Virchow's Arch., Bd. 70 (Schimmelpilzsporen).

Kannenberg, Zeitschr. f. klin. Med., Bd. 1, 1830.

BABł̀s, Wien. med. Wochenschr., 1884.

Pasteur, Compt. rend., Vol. 56, 1863.

Cazeneuve et Livò, Compt. rend., Vol. 85, 1877.

Meissner, Deutsche Zeitschr. f. Chir., Bd. 13, P. 344.

Cheyne, Brit. Med. Journal, 1883. 
Lister, Transactions of the Roy. Soc. of Edinb., 1875.

Nencki u. Giacosa, Journ. f. pract. Chem., N. F., Bd. 20.

Leube, Zeitschr. f. klin. Med., Bd. 3, 1881.

Strauss ex Chamberland, quoted in Centralbl. f. Gynäkol, 1883 (Anthrax bacilli).

Duclaux, Bull. de l'Acad. de Méd., 1884, Nr. 24 (Micrococci of clou de Biskra).

Walter, Bayer. Intelligenzbl., 1884 (Cocci in Diphtherie).

BaLOGH, Wien. med Wochenschr., 1882 (Cocci in Scharlach).

EkLund, Bayer. Intelligenzbl., 1884 (Cocci in Scharlach).

Marckwald, Inaug.-Diss. Königsberg, 1872 (Bacteria in Septicemia).

Senetz, Petersb. med. Wochenschr., 1883 (The same).

Welcker, Zeitschr. f. ration. Med., 1859 (Sarcina).

Munk, Virch. Arch., Bd. 22, 1861.-Med. Centralbl., 1864 (Sarcina).

Kuessner, Berl. klin. Wochenschr., 1876, P. 278 (Leptothrix).

Huber, Deutsch. Arch. f. klin. Med., 1879 (Leptothrix).

Wilson, Centralbl. f. klin. Med., 1885 (Bacilli in Chyluria).

Benda, Deutsche med. Wochenschr., 1884, P. 154 (Tubercle

bacilli in urine).

Ditrel, Centralbl. f. Chir., 1883 (The same).

Damsch, Deutsch. Arch. f. klin. Med., 1882 (The same).

Baumgarten, Centralbl. f. d. med. Wissensch., 1883, P. 753 (The same).

Rosenstern, Ibid., P. 65 (The same).

Babès, Ibid., P. 9 (The same).

Philipowicz, Ueber das Auftreten pathogener Mikroorganismen im Harn. Wien med. Bl., 1885, Nr. 22 u. 23.

\section{Immunity and Protective Inoculation.}

Toussaint, Bull. de l'Acad. de Méd., 1880, Juli-Sept.

-, Gazette Médicale de Paris, 1881, Nr. 32.

-, Compt. rend., 1880-81.

-, Pasteur, Schutzimpfung bei Hühnercholera, Bull. de l'Acad. de Méd., 1880.-Gaz. Méd. de Paris, 1880, Nr. 18.

-, Sur la Vaccination charbonneuse. Compt. rend., 1883.

-, La Vaccination charbonneuse. Paris, 1883.

-, Réponse au Doct. Koch. Revue Scientifique, 20 Jan., 1883.

Chauveau, De la prédisposition et de l'immunité pathologique. Compt. rend., T. 89, 1879.

-, Da rôle de l'oxygène de l'air dans l'attenuation quasi instantanée des cultures virulentes par l'action de la chaleur. Ibid., 1883, T. 96, Nr. 11. 
Chauveau, Ibid., 1883, T. 96, Nr. 10.

一, Ibid., 1883, T. 96, Nr. 9, p. 553-557.

- De l'attenuation des cultures virulentes par l'oxigène comprimé. Gaz. hebdom. de med. et de chir., 1884, 22.

Oluive, Sur la résistance des moutons de la race berberine à l'inoculation du charbon. Compt. rend., 1879, T. 89.

Perroncito, Sull'attenuazione del virus carbonchioso. Atti R. Acc. d. Lincei., Bd. 8, 1882-83.

Chamberland et Roux, Compt. rend., 1883, T. 96, Nr. 15, p. 1088-1091.

Chamberland, Le charbon et la vaccination charbonneuse d'après les travaux récents de M. Pasteur. Paris, 1883.

Massé, Des inoculations préventives dans les maladies virulentes. Paris, 1883.

Oemler, Arch. f. Wissensch. u. pract. Thierheilk, 1876-1881.

Loeffler, Zur Immunitätsfrage. Mitth. a. d. Ges.-Amt., Bd. 1.

Koch, Gaffky U. Loeffler, Exper. Studien über. d. künstl.

Abschwächung der Milzbrandbacillen. Mitth. a. d. Ges.-Amt., Bd. II.

Косн, Ueber die Milzbrandimpfung. Cassel u. Berlin, 1882.

Roloff, Ueber die Milzbrandimpfung, \&c. Arch. f. wissensch. u. pract. Thierheilkunde, Bd. 9.

Eggening, Die Resultate der nach der Pasteur'schen Methode auf der Domäne Packisch angestellten Milzbrand-Impfrersuche. Deutsche landwirthsch. Presse, Jahrg., 10.

Blazekovic, Zur Präventiv-Inoculation Pasteur's. Oesterr. Monatschr. f. Thierheilk, 1884.

Rószahegri, Ueber die mit Pasteur'scher Schutzimpfung gegen Milzbrand in Ungarn ausgeführten Versuche. Pester. med., chir. Presse, 1882.

Frank, Jahresber. d. K. Thierarzneischule in München, 1882-83.

Püтz, Vorträge f. Thierärzte, Ser. 7, Heft. 1, 1884.

Hess, Vorl. Mitth. ü. die Schutzimpfung gegen Milzbrand im Kanton Bern nach der Methode Chauveau. Schweiz. Arch. f. Thierheilk, Bd. 27.

Arloing, Cornevin ex Thomas, Du charbon bactérien ; Pathogénie et inoculations préventives. Paris, 1883.

Strebel, Zur. Rauschbrandimpfung. Schweiz. Arch. f. Thierheilk, $1885,1$.

Semmer, Virchow's Arch., Bd. 83.

Semmer u. Krajewsisi, Centralbl. f. d. med. Wissensch., 1880.

Pastedr, Vaccination des Schweinerothlaufs. Bull. de l'Acad. de méd., 1883. 
Grawitz, Die Theorie der Schutzimpfung. Virchow's Arch., Bd. $84,1881$.

Buchner, Eine neue Theorie über Erzielung v. Immunität gegen Infectionskrankheiten. München, 1883.

WolfFBerg, Unters. zur Theorie des Impfschutzes, sowie über die Regeneration der Pockenanlage. Ergänz. Hefte z. Centralbl. f. allgem. Gesundheïtspflege I., Heft 4; Ibid., I., Heft 1.

Feltz, De la durée de l'immunité vaccinale anticharbonneuse chez le lapin. Compt. rend., T. 99, p. 246, 1884.

Bouley, L'inoculation préventive de la fièvre jaune. Compt. rend., T. 100 , p. 1276.

\section{DISTRIBUTION OF THE MICRO-ORGANISMS.}

V. Fodor, Hygienische Unters. über Luft, Boden, u. Wasser. Braunschweig, 1882.

Syart, Germs, Dust, and Disease. Edinburgh, 1883.

Koch, Vortr. a. dem. 11 deutschen Aerztetag, Juni, 1883.

NäGELI, Unters. über niedere Pilze. München, 1882.

Buchner, Die Bedingungen des Uebergangs von Pilzen in die Luft. Zur Aetiologie der Infectionskrankheiten, Vorträge im ärztl. Verein zu München, 1881.

Wernich, Cohn's Beiträge z. Biol. d. Pflanzen, Bd. 3, 1879, p. 105. Sorka, Sitz.-Ber. der K. bayr. Akad. d. Wiss. Math. Physik. Classe, 1881.

—, D. Vierteljsch f. öff. Ges., Bd. 14, 1882.

-, Vorträge im ärztl. Verein in München. München, 1881.

PAsteur, Compt. rend. de l'Acad. d. sc., T. 50, 52, 56, 85.

-, Ann. de chim. et de phys., 3 sér., T. 64.

Tyndali, Med. Tim. and Gaz., 1870.

-, Brit. Med. Journ., 1877.

- Essays on the floating matter of the air. London, 1881.

Pouchet, Compt. rend., T. 47.

Lemaire, Ibid., T. 57.

Maddox, Monthly Microscop. Journ., Vol. 3.

Liechtenstein, Berl. klin. Wochenschr., Bd. 11.

Cunningham, Microscopical Examination of the air. Calcutta, 1874. Tissandier, Compt. rend., T. 78.

Miflet, Unters. über die in der Luft suspendirten Bakterien. Cohn's Beitr. z. Biol. d. Pflanzen, Bd. III.

Eмmerich, Ueber die Bestimmung der entwicklungsfähigen Luftpilze. Archiv f. Hygiene, Bd. 1, Heft 2.

Klebs U. Tommasi-Crudeli, Unters. der Luft auf die Mikroorganismen der Malaria. Archiv f. exper. Path., Bd. 11, 1879. 
V. Sвнцек, Fortschr. d. Med., Bd. 2, P. 585.

Hesse, Ueber quantitative Best. der in der Luft enthaltenen Mikroorganismen. Mitth. a. d. Ges.-Amt., Bd. II.

-, Ueber Abscheidung d. Mikroorganismen aus d. Luft. Deutsche med. Woohenschr., 1884, 2.

-, Weitere Mitth. über Luftfiltrution. Deutschemed. Wochenschr., 1884, Nr. 51.

Miquir, Compt. rend., 'T. 86.

- De la présence dans l'air du ferment de l'urée. Bull. de la Soc. chim., 1878.

-, Ann. d'hygiène, 1879.

-, Annuaire de l'Observat. de Montsouris, 1877-82.

- Les organismes vivants de l'atmosphère. Paris, 1883.

Gracosa, Les corpuse. organ. de l'air des hantes montagnes. Arch. ital. de Biol., 'T. 3.

Mrquer fr Frevdexreich, La semaine médicale, 1884.

Ourver, Les germes de l'air. 'Thèse. Rev. scientif., 1883.

Moreau ex Prantruausiox, La semaine Médicale, 1884.

Frevbrrich, Les microbes de l'air des montagnes. Rev. scientif., II., p. 384.

Kocr, Verhandl, der Choleraconferenz., 1884 u. 1885.

v. Petrenkorer, Verhandl. der Choleraconferenz., 1885.

Lemrinich, Exp. Unters. üb. die Aetiologie des Typhus mit bes. Berücksichtigung der 'Trink- u. Gebrauchswïsser, 1883.

Zasder, Centralbl. f. allg. Ges., 1883, 2.

Axaus Smrri, On the examination of waters. Soe. Rep. to the Loeal Government Board. London, 1884.

-, Sanit. Record, 1883, Febr.

Guxxixa, Beitr. z. hygienischen Untersuchung des Wassers. Arch. f. Hyg., 1883, 3.

Wiscacker, Ueber die in Rinnsteinen beobacht. nied. Organismen. Göttinger Inaug.-Diss. Frankfurt a. M., 1882.

Die Wasserversorausa rox Zürich, Zurich, 1885. (Herein a report by Cramer as to the presence of bacteria in various waters).

Becker, Reichsmedicinalknlender, 1885.

Fou rr Dusaxt, Arch. des sc. phys. et natur. Bibliothèque universello do Genère, T. 13, 1885, Febr.

Chamberland, Sur un filtre domnant de l'eau physiologiquement pure. Compt. rend., T. 99, p. 247.

Hesse, Ueber Wasserfiltration. Dentsche med. Woch., 1885, Nr. 5. WoLtsy, Ueber die Thätigkeit niederer Organismen im Boden.

Viert. f. öff. Ges., 1883, P. 705.

-, Doutsche landwirthschaftl. Presse, Bd. 9. 
HOPPE-SEyler, Ueber d. chem. Vorgänge im Boden $\mathfrak{u}$. Grundwasser $u$. ihre hygienische Bedentung. Arch. f. öff. Gesdhtspfl. in Iothringen, 1883.

SоYкA, Die Lebensthätigkeit niederer Organismen bei wechselnder Bodenfeuchtigkeit. Prager med. Woch., 1885, Nr. 4.

Kocir, Milzbrandbacillen im Boden. Mitth a. d. Ges.-Amt., Bd. 1, P. $65 \mathrm{ff}$.

Schrakamp, Archiv f. Hygiene, Bd. 2, 1884.

Cecr, Malariakeime im Boden. Arch. f. exp. Pathol., Bd. 15 u 16. Torelli, La malaria in Italia. Roma, 1883.

Eмmerich, Die Verunreinigung der Zwischendecken unsrer Wohuräume. Ztschr. f. Biol., Bd. 18.

- Pneumoniekokken in der 'Zwischendeckenfüllung. Arch. für Hyg., Bd. 2, Heft 1.

Grassi, I malefizi delle mosche (Distribution of bacteria by Flies). Ga\%. degli Ospitali, 1883.

Marpuax, Die Verbreitung von Spaltpilzen durch Fliegen. Areh. für Hygiene, Bd. 2, Heft 3.

HELLE:, Septische Infection durch Insekten. Inaug.-Diss. Tübingen, 1883.

Declaux, Pasteur, Stoffwechsel bei Ausschluss von Mikroorganismen. Compt. rend., 1885, Nr. 1.

\section{Disinfectios.}

\section{General.}

Lex, Roth u. Lex, Militärgesundheitspflege.

-, Vierteljahrschr. f. öffentl. Ges., Bd. 4.

Fischer, Article "Desinfection" in the Neuen Handwörterbuch der C'hemie.

Wernich, Grundriss der Desinfectionslehre. Wien u. Leipzig, 1837.

NäGeli, Die niederen Pilze. München, 1877.

Schröter, Cohn's Beitr. zur Biol. der Pflanzen, Bd. I., Heft 3.

Kосн, Ibid., Bd. II., Heft 2.

-, Ueber desinfection. Mitth. a. d. Ges.-Amt., Bd. 1, P. 234.

Isstrectioss for Disinfection, prepared for the National Board of Health, New York, 1879.

Plaut, Desinfection der Viehställe. Leipzig, 1884. Verl. v. H. Voigt.

Steinaeyer, Ueber Desinfectionslehre. Braunschweig, 1884.

W. Cheyxe, Antiseptic Surgery, its principles, practice, history, and results. London, 1882.

Forster, Wie soll der Arzt seine Hände reinigen? Centralbl. f. klin. Med., 1885, Nr. 18. 
Mrller, Die Anwendbarkeit einiger Antiseptica bei der Behandlung der Krankheiten der Mundhöhle n. d. Zähne. Deutsche med. Wochenschr., 1885, Nr. 32.

Mrquel, Antiseptiques et bactéries. Semaine médicale, 1883.

—, Annuaire de l'observatoire de Montsouris pro 1884.

Chauveau, Compt. rend., 1883, 1884.

Chamberland et Roux, Ibid., 1883.

Perroncito, Sur la tenacité de vie du virus charbonneux. Arch. ital. de biol., 1883.

VAllin, Traité des désinfectants et de la désinfection. Paris, 1883. Ratimoff, Revue Scientif. I., p. 797.

Bucholtz, Antiseptica u. Bakterien. Klebs' Archiv f. exp. Path., Bd. 2 u. 4.

-, Ueber das Verhalten von Bakterien zu einigen Antisepticis. Dorpat, 1876.

-, Arch. f. exp. Pathol., Bd. 7, 1877.

HABerkors, Das Verhalten von Harnbakterien gegen einige Antiseptica. Dissert. Dorpat, 1879.

DE LA Crorx, Das Verhalten der Bakterien d. Fleischwassers gegen einige Antiseptica. Arch. f. exp. Pathol., Bd. 13, 1881.

Schwartz, Sitzungsber. d. Dorpater Naturf.-Ges., 1879.

Wernicke, Diss. Dorpat, 1879.

Meyer, Ueb. d. Milchsäureferment u. sein Verhalten gegen Antiseptica. Dorpat, 1880.

Schotte U. Gärtner, Viertelj. f. öff. Ges., 12, 337.

SALKowski, Viertelj. f. ger. Med., 23, 375.

Soyka, Ber. d. Bayr. Akad. d. Wissensch, 1879, Mai.

Toussaint, Bull. de l'Acad., 1880.

Schill v. Fischer, Ueber die Desinfection des Auswurfs der Phthisiker. Mitth a. d. Kaiserl. Ges.-Amt., Bd. II.

Lebedefr, Desinfectionsversuche am malignen Oedem. Arch. de. physiol. norm. et pathol., 1882.

Cours, Desinf. versuche mit Blut v. Choléra des poules.-Thieren. Compt. rend., T. 99.

Charry, Action des agents chimiques sur les bactéries du genre Tyrothrix., ib., p. 980.

\section{MODES OF DISINFECTION IN DETAIL.}

\section{Heat and Cold.}

Frisch, Ueber den Einfluss nied. Temp. auf. d. Lebensfähigkeit der Bakterien. Sitzungsber. d. Wiener. Akad., Bd. 75 n. 80.

Picter et Young, De l'action du froid sur les microbes. Compt. rend., T. 98,1884 , p. 747. 
EidAM, Einwirkung versch. Temperaturen a. d. Entwicklung ron Bacterium termo. Cohn's Beitr. zur Biol., Bd. 1, Heft 3.

LebedefF, Arch. de phys. norm. et pathol., 1882, No. 6 .

Heydenreich, Sur la stérilisation des Liquides au moyen de la marmite de papin. Compt. rend., 1884, 'T. 98.

Merke, Virchow's Archiv, 1880, Bd. 81.

-, Viertelj. f. ger. Med., Bd. 37.

Tyndall, Philos. Transact. of the Roy. Soc., 1877.

Vallin, Ann. d'hyg., 1877.

Hornemann, Hygiejnske Mededelser, Ny. Raekke., III., 1.

Mörschell, Deutsche med. Wochenschr., 1880.

LASSAR, Ibid.

Pasteur, Ann. d'hyg., 1880.

Arloing, Cornevin et Thomas, Lyon médical., 1883.

Kосн U. Wolffhügel, Unters. üb. die Desinfection mit heisser

Luft. Mitth. a. d. Kaiserl. Ges.-Amt., Bd. I., P. 301.

Hueppe, Ueber das Verhalten ungeformter Fermente gegen hohe Temperatur. Mittheilg. a. d. Kaiserl. Ges.-Amt., Bd. I., P. 341

-, Ueber die Hitze als Desinfectionsmittel. Deutsche militärärztl. Zeitschr., 1882.

Koch, GAFfKy, U. Löfrler, Versuche über die Verwerthbarkeit heisser Wasserdämpfe zu Desinfectionszwecken. Mitth. a. d. Kaiserl. Ges.-Amt., Bd. I., P. 322.

Vallin, Les nouvelles étuves à desinfection. Revue d'hygiène, 1883.

- Ann. d'hygiène, 1877, 1884.

Rochefort, Herscher, Revue d'hygiène, 1884.

M. WolfF, Zur Desinfectionsfrage. Centralbl. f. d. med. Wissensch. 1885, Nr. 11.

\section{Sulphurous Acid.}

WolffiüGel, Ueber den Werth der schwefligen Säure als Desinfectionsmittel. Mittheilg a. d. Kais. Ges.-Amt., Bd. I., P. 188.

Laillier, Du gaz acide sulfureux. Ann. d'hygiène, 1883.

Dujardin-Beaumetz, Bull. de l'Acad. de méd. de Paris, 1884, September.

LegOUEST, Ibid.

Marié-Davy, Revue d'hygiène, 1884.

Chlorine and Bromine.

Frank, Bericht der 56 u. 57 Naturforscherversammlung.

-, Ueber Desinfection von Abtrittsgruben. Berlin, 1885, Verlag. der deutschen Medicinal-Zeitung.

Fischer t. Proskater, Mitth. a. d. Kaiserl. Ges.-Amt., Bd. II. 
WoLfFhÜGEL U. KNorRe, Zu der verschiedenen Wirksamkeit von Carbolöl u. Carbolwasser. Mitth. a. d. Kaiserl. Ges.-Amt., Bd. I., P. 352.

Wernich, Die aromatischen Fäulnissproducte in ihrer Einwirkung auf Spalt. und Sprosspilze. Virchow's Archiv, Bd. 78, 1879.

ReNaudot (Borphenyl acid), Rev. scient., II., p. 318.

Bremond (Vapour of Turpentine Oil), Ann. d. hygiène, 1884, p. 344. RossbaCh, Einfluss des innerl. Naphtalingebrauchs auf die Harnfäulniss. Berl. klin. Wochenschr., 1884.

- Fortscher. d. Med. Beilage, 215.

Fischer, Unters. üb. d. Wirkung des Naphtalins. Berl. klin. Wochenschr., 1883.

REPONd (Salicylresorcinketon, \&c.), Corr. f. Schweizer Aerzte., 1883, Nr. 8.

Reinl, Zur Theorie der Heilwirkung des Franzensbader Moores. Prager med. Wochenschr., 1885, Nr. 10 u. 11.

Rohat (Sulphate of Iron), Compt. rend., 1883.

Credé ( $2 \%$ Arg. nitr. against Blennorrhoea neonat.), Arch. f. Gynäkol., Bd. 21.

Lewiv, Die Borsäure. Inaug. Diss., Bonn, 1883.

Schede, Die antiseptische Wundbehandlung mit Sublimat.

Sammlung klin. Vorträge, Nr. 251, 1885.

Köxı

Larrivé, L'eau oxygènée. Thèse de Paris, 1883, Jan.

Maly v. Emich, Antisept. Wirkung der Gallensäuren. Sitzungsber. d. kais. Akad. d. Wiss. zu Wien., 1883, Jan.

Schultz, Die antiseptischen Eigenschaften der Citronensäure.

Deutsche med. Wochenschr., 1883, Nr. 17.

Hoffmann, Experimentelle Untersuchungen über die Wirkung der Ameisensäure. Dissertat. Greifswald, 1884.

Tноц, Ueber d. Einfluss nicht aromat. organ. Säuren auf Fäulniss u. Gährung. Dissertat. Greifswald, 1885.

Scholz, Die Ameisensäure als Antisepticum. Deutsche med. Woch., 1885, Nr. 24.

Schnetzler, Les propriétés antiseptiques de l'acide formique. Archiv de Génève, Jan., 1884.

\section{CONSTANCY AND VARIABILITY OF THE VARIOUS SPECIES OF BACTERIA.}

Billroth, Unters. üb. d. Vegetationsformen der Coccobacteria septica. Berlin, 1874. 
KLEBS, Article "Ansteckende Krankheiten" in Eulenburg's RealEncyclopädie, and numerous other articles in the Archir f. exp. Pathol.

NäGELI, Die niederen Pilze, 1877.

—, Unters. über niedere Pilze. München, 1882.

Buchner, Sitzungsber. d. Ges. f. Morphol. u. Physiol. zu München, 1855, Heft I.

-, Virchow's Arch., Bd. 91.

-, Vorträge im ärztl. Verein. zu München, 1881.

-, Die Nägeli'sche Theorie der Infectionskrankheiten. Leipzig, 1877.

Grawitz, Virchow's Archiv, Bd. 81.

ZopF, Ueber den genetischen Zusammenhang ron Spaltpilzformen.

Sitzungsber. d. Berl. Akad. d. Wissench., 1881.

—, Zur Morphologie der Spaltpflanzen. Iseipzig, 1882.

-, Deutsche med. Wochenschr., 1885, Nr. 4.

Zope v. Miller, Arch. f. exp. Pathol., 1882.

Miller, Archiv f. exp. Pathol., Bd. 14.

一, Deutsche med. Wochenschr., 1884, Nr. 36.

Nefelen, Cohn's Beitr. z. Biol. d. Pflanzen, Bd. 3.

-, Neuere Ansichten üb. d. Systematik d. Spaltpilze. Biolog.

Centralbl., III., Nr. 18.

Vandevelde, Zeitschr. f. physiol. Chemie, Bd. 8.

Roloff u. Archangelski, Centralbl. f. d. med. Wiss., 1882, 1883.

FоккеR, Ibid., Bd. 18, 19.

V. JАCKSCH, Zeitschr. f. phys. Chemie, Bd. 5.

Vax Tieghem, Compt. rend., 1879.

Hađser, Ueber Fäulnissbakterien. Leipzig, 1881.

Kосн, Mitth. a. d. Kaiserl. Ges.-Amt., Bd. I., P. 49.

GaffKr, Ibid., Bd. I., P. 80.

FlëGGe, Deutsche med. Wochenschr., 1884, Nr. 46.

Hueppe, Fortschr. d. Med., 1883, Nr. 6.

Bredert, Virch. Arch., Bd. 100, P. 439.

\section{METHODS.}

(For further Literature, see Hueppe's "Metholik.")

Microscopic Examination.

KocH, Untersuchungen über Wundinfectionskrankheiten. Leipzig, 1878.

-, Verfahren zur Untersuchung, zum Conserviren und Photographiren der Bakterien. Cohn's Beitr. z. Biol. d. Pflanz., Bd. II., 3. Heft, 1877. 
KocH, Zur Untersuchung von path. Organismen. Mitth. a. d. K. Ges.-Amt., Bd. I., 1881.

Weigert, Schnittpräparate. Virchow's Arch., Bd. 84, 1881.

--, Sitzungsber. d. Schles. Ges. f. vaterl. Cultur., 10 Dec., 1875.

Аввє́, Ueber Stephenson's System der homogenen Immersion.

Sitzungsber. d. Jenaischen Ges. f. Med. u. Naturw., 1879, 10 Jan. EhrLich, Zeitschr. f. klin. Med., Bd. I., 1880, P. 553.-Bd. II., Heft 3.

-, Deutsche med. Wochenschr., 1882, Nr. 19.

Schwarze, Ueber eosinophile Zellen. Dissert., Berlin, 1880.

Westphal, Ueber Mastzellen. Dissert., Berlin, 1880.

Gram, Ueber die isolirte Färbung der Schizomyceten. Forts. d. Med., II., 1884, Nr. 6.

Friedlânder, Mikroskopische Technik, 2 Aufl., 1884.

Buchner, Ueber das Verhalten der Spaltpilzsporen zu den Anilinfarben. Aerztl. Intelligenzbl., 1884, Nr. 33.

Baumgarten, Beitr. zur Darstellungsmethode der Tuberkelbacillen.

Zeitschr. f. wissensch. Mikrosk., I., 1884, p. 51.

-, Ueber Untersuchungsmethoden zur Unterscheidung von Lepra und Tuberkelbacillen. Zeitschr. f. wissensch. Mikrosk., Bd. I., Heft 3.

Fürterer, Ueber eine Modification der Ehrlich'schen Färbemethode für Tuberkelbacillen. Virch. Arch., Bd. 101, 1885.

Plaut, Färbungsmethoden zum Nachweis der Mikroorganismen. 2 Aufl. Leipzig, 1884.

Behrens, Hilfsbuch zur Ausführung mikroskopischer Untersuchungen, 1883.

Hueppe, Die Methoden der Bakterienforschung. Wiesbaden, 1885. Bizzozero et Firket, Manuel de Microscopie clinique. 2 éd., ParisBruxelles, 1885.

\section{Methods of Cultivation.}

KLEBS, Ueber fractionirte Cultur. Archiv f. exp. Pathol., Bd. I., 1873.

Kосн, Zur Untersuchung von pathogenen Organismen, Mitth. a. d. Kaiserl., Ges.-Amt., Bd. I., 1881.

-, (Blood serum) Berl. klin. Wochenschr., 1882, Nr. 15.

-, Mitth. a. d. Kaiserl. Ges.-Amt., Bd. 2, 1884.

Brefeld, Methoden z. Unters. der Pilze. Verhandl. d. physik med. Ges. in Würzburg. N. F., Bd. 8, 1874-75.

-, Kulturmethoden z. Untersuchung der Pilze. Bot. Unters. über Schimmelpilze, Bd. IV., 1881. 
Brefeld, Die künstl. Kultur parasitischer Pilze. Bot. Unters. über Hefepilze, Bd. 5, 1883.

Fehleisen, Ueber neue Methoden der Untersuchung a. Cultur pathogener Bakterien. Physik. med. Ges. zu. Würzburg, 1882, p. 113-121.

Pasteur, Etudes sur la bière, 1867.

Buchner, In Nägeli's Untersuchungen über niedere Pilze. München, 1882.

SAlomonsen, Zur Isolation differenter Bakterien. Bot. Zeitg., 1879, Nr. 39.

-, Eine einfache Methode z. Reincultur versch. Fäulnissbakterien. Ib., 1880, Nr. 28.

Johne, Ueber die Koch'schen Reinculturen und die Cholerabacillen. Leipzig, 1885.

As to Anäerobiosis see p. 43. For the investigation of air, water, and soil, see under "Distribution of the Micro-organisms," p. 55. 



\section{INTRODÚCTION.}

IN the outer world with which mankind is in daily con- Significance tact, and which forms the subject of hygienic research, of microthe attentive observer finds micro-organisms widely distributed and only just visible with the aid of the best optical means; these bodies, however, on account of their silent yet widespread and energetic activity, play an important part in the economy of nature and in the existence of mankind. They occasion the destruction of dead organic material, they cause the oxydation of substances otherwise very resistant, and constantly provide new nutriment for chlorophyllous plants; they set up the most varied fermentations, and are indispensable aids in the preparation of our ordinary nutritious and savoury food; on the other hand they attack our plants as parasites, bringing degeneration and death to their hosts; at times they cause the severest diseases in the lower and higher animals, and threaten even man with fatal epidemics. In no department of hygiene is their influence missed; in the air, in the water, in the soil, in our immediate surroundings, in our dwelling, and in our food, the same minute organisms are present as constant companions, and at times as dangerous foes.

The majority of these important yet minute bodies Synonyms. are plants of the most elementary structure and with the most simple mode of propagation, but yet with extraordinary powers of multiplication. They are grouped together under the headings "micro-organisms" or "microbes"; at times they are designated as "lower fungi" or as "bacteria." Further, various terms are applied to particular groups of these organisms according to the particular mode of action to which attention is directed. Thus, from the physio- 
logical chemical standpoint, they have been termed "organised ferments"; on the other hand, from the special pathological point of riew, "parasitic plants" or " micro-parasites."

The object of the present work is to describe the form and vital characteristics of these micro-organisms in so fur as they have a direct or indirect interest from a hygienic point of view.

The method

The plan of this work embraces in the first place a short historical sketch of the development of our knowledge with regard to the ferments and parasites during the last few years. Then follows a description of the form and mode of development of those micro-organisms which are important from a hygienic standpoint, and also a short morphology and classification, a knowledge of which is indispensable for the comprehension and the further successful study of these bodies, so difficult to recognise and to distinguish one from the other. Nor is the biology of the micro-organisms less instructive; hence the third part deals with the general conditions of life of the lower fungi; in the fourth are described the results of their life, their tissue change, and energy, as well as their action as exciting agents of fermentation and of parasitic diseases; and the fifth chapter deals with the conditions of decay of the microorganisms and with the means which cause their enfeeblement or death.

In the sixth and seventh divisions the points which are of special interest in hygiene are referred to ; in the sixth the distribution of the various micro-organisms in our surroundings, in air, soil, water, food, and dwelling; and in the seventh there is given a digest of the conclusions to which we must come with regard to the etiology and prophylaxis of the infective diseases. The contents of this chapter include the discussion of the external sources of infection, of the local and seasonal predisposition to infective diseases, of the mode of entrance of the infective agents into the organism and their fate in the body, of the means by which it is possible to obtain protection against the 
danger of infection and to overcome it, of immunity and protective inoculation, of the general prophylactic rules, and of the modes of disinfection suitable in practice.

Finally, in the last chapter there is added a sketch of those methods of investigation which are most useful in the study of this most difficult department of hygiene. 

THE PROGRESS OF KNOWLEDGE WITH REGARD TO THE FERMENTS AND MIICRO-PARASITES DURING RECENT YEARS.

Tre first undoubted observation as to the existence of The earliest small microscopical living beings in our surroundings was with regard made by Ehrenberg, who found numerous organisms $\begin{gathered}\text { to micro- } \\ \text { organisms. }\end{gathered}$ in water and in dust, and designated them "Infusion animals (Infusionsthierchen, 1828)." Eight years later the vegetable nature of yeast was discovered by CaignardLatour and Schwann, although the cell form had been seen much earlier (first by Leeuwenhoek, 1680), and their organised and regetable character had been suspected by several investigators (Thénard, Persoon). Schwann also, in the year 1837 , asserted as the result of experiments, that the atmospheric air was constantly laden with fermentative and putrefactive germs, and also that certain fermentative processes were dependent on the access of living organisms.

From that time dates the lasting and active interest in micro-organisms, and the development of the subject has chiefly taken two different directions: on the one hand, the problem investigated was the relation between the fermentative germs and the processes of fermentation and putrefaction; on the other hand, the attempt was made to demonstrate a causal connection between similar minute living bodies and infective diseases in man and animals, a connection which various hypotheses and analogies rendered probable. It is only possible to follow the numerous controversies with regard to the significance of the micro-organisms by tracing separately the gradual development of knowledge, on the one hand with regard to fermentation, and on the other with regard to parasitic growth. 


\section{Micro-organisms as the Exciting Agents of Fermentation and Putrefaction.}

Schwann's discovery of the organic nature of yeast.

\section{Gradual Development of the Vitalistic or Germ Theory.}

Before Schwann's discovery the essence of the fermentative process - and especially of the alcoholic or vinous fermentation in which sugar is broken up into alcohol and carbonic acid-was by some not at all associated with the yeast, which was looked on as only an accidental accompaniment; by others the rôle of the yeast was regarded as an etiological one, but only in the sense that the mass of these cells acted as a porous body which easily condensed the oxygen, passed it over to the other substances, and thus occasioned the decomposition of the sugar (Braconnot, 1831), or that the yeast possessed catalytic properties, and thus had the power of splitting up the fermentescible substances in the same way as peroxide of hydrogen is decomposed by finely divided platinum, \&c. (Berzelius, 1827). Up to this time no one had held the view that the process of fermentation was closely connected with the living multiplying yeast cells, and was in fact the result of their life, and no one could hold such a view previously, because the organised nature of yeast was not yet known. Schwann was the founder of the vitalistic or germ theory. As the result of new experiments he asserted that the cause of the fermentation was the vegetation and multiplication of the living yeast in the fermentescible fluid, that the yeast cells took from it the materials necessary for their growth, and that the elements which were not taken up by the yeast became grouped together principally in the form of alcohol. Schwann's experiments were repeated several times in the course of the next few years, and the results were confirmed and extended; among the more immediate advances it is only necessary to mention the proof furnished by Lüdersdorff that triturated yeast cells are inoperative, and that only intact cells can produce fermentation, and also the observation by Blondeau that 
different fermentations are caused by different kinds of micro-organisms.

The strict proof that living yeast cells or minute Evidence reorganisms similar to yeast are the only cause of every prove to defermentation, could however only be furnished by a pendence of series of experimental investigations, which must have on living for their aim the following questions :yeast.

1. In the first place it was necessary to show that 1. Living cells germs are present in all fermenting and putrefying in all fermentfluids. This was proved by all the investigators who ing fluids. busied themselves with the question of fermentation after Schwann, and in fact it was the constant presence of definite microscopical organisms which formed the starting point of the vitalistic theory. The fact itself was much less disputed by the adversaries of this theory, than its meaning. Not till later years were here and there observations published which asserted the existence of putrefying and fermenting media without microorganisms-observations which will be considered in detail later.

2. From the constant concurrence of putrefaction and 2. Fermenmicro-organisms the causal rôle of the latter did not tescible subof course directly follow; that must on the contrary ferment when be proved by special experiments. The behaviour of of living yeast fermentescible substances without micro-organisms was vented. therefore tested in the first instance; and for this purpose the attempt was made to kill any germs which might be present in the substances themselves, in the vessels, \&c., by a temperature of at least $100^{\circ} \mathrm{C}$., care being then taken to protect the materials against the entrance of fresh germs, either by suitable methods of closing the ressels, or by subjecting the entering air to the action of means which could kill the germs.

These experiments also date back to an early period. In $1836 \mathrm{~F}$. Schulze showed that no decomposition occurred in putrescible materials when he boiled them, thus killing any germs which might be present, and then prevented the access of air, as for example by interposing a layer of oil, or conducted the entering air through sulphuric acid, which detained and destroyed 
the germs. Schwann also in 1837 made similar experiments; he freed the entering air from the organisms by heating it strongly. At a later period Schröder and von Dusch attempted to remove the putrefactive germs from the air by simple mechanical means, for example by filtering the air through cotton wool; this was completely successful, and no putrefaction occurred in vessels containing boiled putrescible materials and plugged with cotton wool. Hoffmann, and later Cherreuil, and in 1862 Pasteur obtained the same result by drawing out the neck of the flask used for the experiment, and bending it several times acutely.

The weight of all these experiments was much enhanced by the fact that control experiments were made in which the same fermentescible fluids were employed, and treated in the same way (by prolonged. boiling, \&c.), only with this difference, that the air entered the vessels without being previously deprived of its gerims by filtration or by destructive agents. In these control-experiments fermentation or putrefaction always occurred; and the same result was obtained if the protective arrangements were subsequently removed from vessels which had been preserved free from germs for a long time, and the entrance of germ-laden air was permitted, or when germs were intentionally sown from other putrefying fluids.

These experiments were repeated later on a gigantic scale in the preservation of articles of food ; scarcely any biological experiment has been so extensively carried out, and has furnished such a uniform result. If fermentescible substances are treated by methods which are able to destroy existing organised germs, and if the entering air, and everything that will eventually come in contact with these substances, is treated in such a way that no organised living germs can enter, neither fermentation nor putrefaction occurs; if any of these precautions are omitted, and the entrance of germs is allowed, then fermentation takes place. It is true, as may be remarked here in passing, that at a later period contradiction of these experiments and their results was not wanting. 
Some investigators asserted that in spite of the most careful isolation of the fermentescible substances, and in spite of the most thorough destruction of existing germs, putrefaction and fermentation nevertheless occurred. These experiments will be discussed below, but I may here point out that a contradictory result must be obtained when even one of the many necessary precautions is omitted during the experiment, and that therefore a certain percentage of unsuccessful attempts at preservation is something quite intelligible.

The more experienced the experimenter, the more rarely do the experiments fail ; the more the methods of preserving food have been developed, so much the more successful are the results. The best experimenter must register a series of failures when he begins to busy him. self with these questions, in which the sources of error are so numerous, and in which unusual precautions are required. But for this very reason a few of these contradictory experiments, in which putrefaction and fermentation occurred, in spite of the apparently complete exclusion of all germs, cannot be used as a proof against the vitalistic theory.

If we assume, for the present, that the result of the most numerous and carefully conducted of these experiments is that by the exclusion of organisms putrefaction and fermentation are prevented in fermentescible substances, there at once arises another old matter of dispute, namely, that with regard to abiogenesis (generatio requivoca). Seeing that no development of organisms occurs in substances which under ordinary conditionș offer a most admirable soil for their development, when the access of living organisms is rendered impossible, and seeing that the most active life at once appears as soon as exen the smallest number of living organisms enters, the conclusion is justified that the living cells cannot be formed from unorganised material, but that they always originate from another organised cell.

The experiments referred to admitted, however, of two valid objections, and hence they required to be further modified if they were to prove absolutely the 
vitalistic theory of fermentation, or the improbability of abiogenesis. Thus a possible objection to some of the experiments was that the deficiency of oxygen in the boiled and hermetically sealed vessels hindered the development of organic life; but this objection was already met by the fact that the experiments with air filtered through cotton wool permitted an undiminished supply of oxygen, and that nevertheless the development of organisms was prevented. It was much more difficult to answer the other objection; it was said that the heating of the fermentescible substances which were employed for the experiments altered them in such a way that so-called chemical ferments which were previously present, and were able to cause their decomposition without the intervention of organisms, were destroyed by the heat, and that it was for this reason that decomposition did not occur. Had the heating not taken place these substances would have undergone fermentation under the influence of those ferments even without the entrance of organisms. The adrocates of spontaneous generation also put forward a similar plea, assuming that as the result of the action of the heat an alteration of the material occurred, and that it thus became unsuitable for the generation of cells. These objections gave rise to a large number of new experiments with unboiled and quite unaltered organic materials. Van der Broek, Pasteur, Rindfleisch, Lister, and many others, more recently Meissner, Leube, Hauser, Marchand, Cheyne, were able to preserve for years a great variety of fermentescible substances without the occurrence of any fermentation or putrefaction if only they were not previously exposed to the danger of contamination by organisms, and were protected from the entrance of new germs and kept in absolutely pure ressels. In this way success was obtained with grape juice, yolk of egg, blood, milk, the most various animal organs, \&c. These experiments, which we must discuss more fully at a later period, and as compared with which a few experiments in which the attempt to preserve materials by the same method failed have of 
course no value, are of the greatest importance for the questions of abiogenesis, and of the role of the organisms in fermentation and putrefaction. It was only as the result of these experiments that it could be absolutely maintained that spontaneous generation does not take place, and that fermentation and putrefaction do not occur without the aid of minute organisms.

3. If organisms are the constant cause of fermentation 3. Fermentaand putrefaction, one must, bearing in mind the fact tiveorganism that decomposition of putrescible materials occurs at all where, and that decomposition of putrescible materials occurs at all where, and places and at all times (provided that no special means escible subare employed to prevent it), come to the conclusion that always these lower putrefactive organisms are extremely widely undergo dedistributed, and that thus there is always and every- provided that where opportunity for the infection of putrescible organisms are materials. The further efforts of the advocates of the not intentionvitalistic theory were therefore directed to the demonstration of the presence of organised ferments in all our surroundings. Investigations which were begun by Ehrenberg, and then continued by Pouchet, Tyndall, Pasteur, Cohn, \&c., demonstrated with certainty that the air always contains the germs of ferrnentation and putrefaction, that dust consists in part of micro-organisms, and that water, soil, and in fact all our surroundings are always contaminated by these minute cells. In recent times the methods, more especially of aëroscopy, have been perfected on the view that the air is the most frequent carrier of the germs, and is the medium which leads most frequently to the infection of fermentescible substances. Later investigations (Sanderson, Rindfleisch, Cohn, Hiller, Brefeld) have, however, shown that the air in most places contains relatively few actire germs, and that the active agents of fermentation are conveyed by solid substances, water, \&c., which are contaminated with germs, more frequently than through the medium of the air; but by this alteration in the views as to the part played by the different media in setting up fermentation there is no change in the doctrine of Panspermism and of the universal distribution of germs in our surroundings. 
The causal connection between micro-organisms and fermentation and putrefaction is definitely demonstrated by the investigations to which we have referred. It was found that organisms were present in all putrefying and fermenting substances; the same organisms were shown to be widely distributed in our surroundings; it was demonstrated that without these organisms no fermentation or putrefaction occurred even when the fermentescible substances were left otherwise unaltered, the entrance of the organisms being alone prevented, and that these changes only occurred when living germs had been introduced by contact with the impure surroundings.

Mode of action of the yeast cells in the fermentative process.

But there remained the further question, viz., in what way the action of these organisms on the fermentescible substances was to be explained; and the further experiments and researches with reference to the etiology of the process of fermentation were made with the view of ascertaining whether fermentation and putrefaction were to be regarded as a vital process, as a manifestation of the life and activity of the causal organisms, and what were the intimate changes that took place.

Even shortly after Schwann's discovery definite views were formed as to the mode of action of the organisms. Schwann himself asserted that the fermentative process went on pari passu with the growth of the yeast, and that fermentation occurred by the yeast plant withdrawing from the nutritive substratum certain materials necessary for its growth, and at the same time inducing the formation of alcohol from the elements which were of no use for nutrition. The contemporaries of Schwann expressed views which were similar but on the whole more speculative, and not sufficiently based on experiment. The vitalistic theory was in reality first elaborated by Pasteur. It is true that Pasteur did not succeed in finding at first a suitable explanation of the process of fermentation, or one which was permanently adopted; on the contrary, his teaching has undergone most important modifications in the course of time, and as the result of further experiments and better know- 
ledge; but in such a complicated question, and one requiring the whole efforts of more than one investigator, a definite conclusion was not at first possible, and too. rigid a deduction would only have impeded the development of knowledge.

In 1857 Pasteur demonstrated that fermentation was Pasteur's most intimately bound up with the life and the growth of the yeast cells, and was thus a result of the action of these cells. The growth of the yeast takes place at the expense of the constituents of the fermentescible fluid, and therefore all the sugar cannot be broken up into alcohol and carbonic acid; on the contrary a portion (about 5 per cent.) is employed for building up the cell constituents and for the formation of bye-products. The fermentescible materials form the nutriment of the yeast, and these cells employ a portion for the formation of new cell substance, while the other and much larger portion is transformed in the yeast cell into alcohol and carbonic acid. As the yeast cells consist also of nitrogenous material and mineral substances Pasteur assumed that traces of both these materials must be present in the fermentescible fluids if the yeast was to develop and break up the sugar. Pasteur found at a later period that yeast could develop in pure sugar solutions free from nitrogenous materials, and could there excite fermentation; but the further development in this case takes place at the expense of a reserve stock of nitrogenous material which fresh yeast cells usually contain: In like manner old dead yeast cells seem to be able to furnish new nutritive material for young cells; and under certain circumstances, namely, when yeast is mixed with fluid free from sugar, the non-nitrogenous substance (cellulose?) of the old yeast cells can take the place of the sugar, produce alcohol and carbonic acid, and so give rise to a fermentation of the yeast itself.

In the year 1860 Pasteur showed that it was not essential that the nitrogenous nutriment of the yeast should consist of albuminous materials, but that salts of ammonia could take their place. Such salts along with mineral substances (which are most easily added in 
the form of ashes of yeast) and sugar form the only necessary ingredients for a cultivating fluid for yeast, and in solutions of this simple composition fermentation goes on well. These experiments were completely confirmed by Cohn, Duclaux, \&c., and they render it quite impossible to ascribe to the albuminous materials in the fermenting fluids such an important rôle in the fermentative process as Liebig, for example, has done. (See below.)

The following observations on its relation to oxygen were also very important for the knowledge of the tissue change of the yeast. Pasteur found that the fermentative organisms during their growth took up a large quantity of oxygen and gave off carbonic acid ; this fact was confirmed by Schützenberger, who further ascertained that the more oxygen was used the more active was the vegetation of the jeast cells. Sereral other investigations led to similar results (Traube, Brefeld), and thereby the biological behaviour of the fermentative organisms scemed to have been made clearer and the direct dependence of fermentation on the nutritive processes of yeast rendered more certain.

But further investigations by Pasteur led to very different results. He found that if the access of air were hindered alcohol was formed in large amount, while if oxygen was admitted but little sugar was broken up. Pasteur made the same observation in the case of other fermentative processes, for example in butyric fermentation and in putrefaction; active fermentation only occurred where the amount of oxygen was deficient; the admission of oxygen seemed in fact to be detrimental to the fermentative processes, although growth and multiplication of the yeast cells could take place. Certain exciting agents of fermentation and putrefaction did not however seem to be able to exist without free oxygen; Pasteur distinguished these organisms as aërobes from the anaërobes which are killed by free oxygen, or at any rate are active only in the absence of oxygen.

Deficiency of oxygen scemed to Pusteur to be the 
most necessary condition of fermentation; he looked on it as practically an indispensable condition for every fermentation, and formulated his views by saying that fermentation occurred as soon as any living cell was compelled to grow in the absence of oxygen, and that; wherever fermentation was found there also the oxygen was deficient. More especially in the case of the alcoholic fermentation Pasteur assumed that the yeast cells, owing to the deficiency of oxygen, took it from the sugar molecule, and thus caused the latter to break up.

Numerous later investigations have shown that Pasteur's results are only in part correct; the majority of fermentative organisms can, it is true, live and grow without free oxygen, and it is especially those organisms which can exist without oxygen which possess the property of exciting fermentation. But, and in this the more recent views differ somewhat from Pasteur's, these organisms are as a rule also able to thrive when oxygen is admitted, destruction or hampering of their development by oxygen only rarely happens, and the regetative life and the fermentative action of the most typical fermentative organisms occurs most actirely in the presence of oxygen.

Pasteur's view as to the more exact manner in which decomposition of the fermentescible materials by the micro-organisms takes place has not, therefore, held its ground, and other investigators have only as yet been able to suggest more or less probable hypotheses as to the nature of the physiological process of fermentation, and none of these views can be looked on as free from objection. (Compare the remarks in the fourth part.) But the numerous experiments which have been undertaken as proof of the one or the other hypothesis have always shown that the most intimate relations exist between the living micro-organisms and the fermentations, and that fermentation must undoubtedly be looked on as a physiological act of the micro-organisms. In farour of this view we have, besides the numerous is a physioexperiments of Schwann and his followers, the fact that logical action the intensity of the fermentation runs parallel with the yeast cells. 
development of the micro-organisms in the fermenting mixture, that the fermentations go on best at that temperature which corresponds with the optimum of temperature for the growth and the other vital functions of the micro-organisms, and that the typical physiological poisons, such as chloroform, ether, and hydrocyanic acid, are able even in small doses to prevent the fermentation. It has also been demonstrated by accurate chemical analysis of the products of fermentation, that the breaking up of the fermenting material during fermentation implies such a profound transformation of the molecules, and such an intense displacement of the atoms, that an approximately similar alteration could only be obtained by our strongest chemical agents. And as such chemical means do not come into play, we are thrown back on the physiological actions, the profound effects of which are everywhere evident.

Specific exciting agents of fermentation.
Of greater importance for the further development of the vitalistic theory of fermentation was the demonstration of the fact that different sorts of micro-organisms gave rise to diverse and specific actions. At the time when the germ theory was founded, one only spoke of organised ferments in general. The course and the products of fermentation and putrefaction were studied under varying conditions, without paying special attention to the species of fermentative agents present, and without ascertaining whether one definite species alone, or a mixture of different fungi, were concerned in the decomposition of the fermentescible materials. And yet rigid observation of this kind was absolutely necessary in order to learn accurately the conditions of the life of the organisms, and the relation between their life and nutritive processes and the phenomena of fermentation. In this direction also Pasteur's researches formed the real foundation. He distinguished with striking perspicuity a definite form of micro-organism which set up lactic acid fermentation, another which furnished butyric acid, \&c., and he laid stress on the necessity for further differentiation. It was thus that the advantages of 
experimenting with pure cultures of the fermentative organisms were understood, and by the help of the results so obtained a more accurate knowledge of the products of fermentation and of the equation according to which the material was broken up in the individual fermentations was gained. These questions even now form the subject of the most active discussion and work, and it seems as if, by the aid of the most recent and important improvements in the methods of pure cultivation of the micro-organisms, we may arrive at a precise knowledge of the different fermentative processes, such as Pasteur and numerous other supporters of the germ theory have striven for a long time to obtain.

\section{Objections to the Germ Theory.}

In what has gone before, the vitalistic theory has been represented as a completed whole, of which the development seemed to be steady, and with scarcely a trace of fundamental objections and attacks. This, objections to however, has by no means been the case; on the contrary, theory. from an early period adversaries of the new teaching have appeared, have laid: bare with much acuteness all its weak points, and have sought to upset the propositions of Pasteur and his followers by numerous experiments.

The following were the chief objections :

1. Various observers found that fermentation and 1. Fermentaputrefaction occurred in numerous experiments, even tion in spite of when the entrance of micro-organisms was completely $\begin{gathered}\text { clusion of } \\ \text { micro- }\end{gathered}$ prevented. In the interior of dead bodies, in the contents organisms. of hatched but uninjured hens' eggs, in dead embryos of man and animals, intense putrefaction was often present. Under similar conditions lactic, acetic, and butyric fermentations were also repeatedly observed (Colin, Billroth, Hiller, Schröder, Hoppe-Seyler, Kühne). Numerous experiments were also made by Hoppe-Seyler, Billroth, Tiegel, Servel, Paschutin, Sanderson, Nencki, and others, in which putrescible materials were kept for a long time with such precautions that entrance of organisms apparently could not occur; nevertheless, in many cases, 
putrefaction was observed. In the same way in urine, kept with certain precautions, an alkaline reaction and commencing putrefaction were observed after some time (Colin, Billroth, Hiller, \&c.). Attempts were also made to kill the organisms by the action of heat (Bastian, Huizinga, \&c.), or by the addition of a moderate amount of carbolic acid (e.g., urine 0.5 per cent.-Hoppe-Seyler). Nevertheless putrefaction sometimes occurred. Finally, attempts were made to remove the organisms from putrefying or fermenting fluids by filtration; but here, also, putrefaction or fermentation of the fluid thus filtered, and free from organisms, occurred in several cases (Helmboltz 1843, Fleck, and others).

In all these cases when the putrid fluids were ultimately examined the observers found either no trace of organisms, in which case the fermentation could only have occurred under the influence of chemical ferments, the existence and activity of which would lower the rôle of the micro-organisms to a subordinate position; or in spite of all the precautions against the entrance of organisms, they were found in the putrid substrata, and then the supporters of abiogenesis saw therein a new proof of the accuracy of their views. Even in quite recent times Béchamp and Wigand have supported with the greatest energy, and after many experiments, the theory of the spontaneous generation of minute organisms from the dying cell-protoplasm of higher organic beings. They observed the origin of moving and multiplying micro-organisms from the minutest constituents of dead animal and regetable cells, and when all external germs had apparently been completely excluded, putrefaction and fermentation occurred under the influence of these organisms.

Sources of In spite of the large number of observers and error in these experiments. experiments, the germ theory is however not in any way upset by these contradictory results. Sufficient weight cannot be laid on the fact stated above, that in these observations and experiments the results which are unfarourable to the vitalistic theory always coincide with possible errors of experimentation, or with want of 
accuracy in the observations. In view of the very wide distribution of the micro-organisms, and of their relatively great resisting power to noxious agents, it is not easy to devise faultless experiments in which the entrance of organisms into the fermentescible substances will be prevented with certainty. It is only recently that the degree of heat which will kill micro-organisms in all cases has been accurately determined; and we can now assert definitely that the earlier observers admitted sources of error in that the vessels and utensils employed were not freed from germs adhering to them by exposure to a sufficiently high temperature. Those experiments are of course especially difficult in which exposure to high temperatures, and in fact any alteration of the fermentescible material, must be avoided, in order not to interfere with any possible abiogenesis, or with the power of the chemical ferments. It is only after great practice and many failures that one is able to carry out such a series of experiments with uniform results. If one is contented with a small number of experiments, and is not completely master of the methods, all or the majority of his preparations will without doubt contain organisms, and show putrefaction or fermentation; and if the sources of error are overlooked, and if it is believed that in every case the precautions were sufficient to exclude micro-organisms, every erroneous experiment will furnish proof of abiogenesis, or of the occurrence of putrefaction without organisms. It is clear that it is only possible to attach weight to such results when they are uniform in all cases and when we are justified in assuming that the experimenter possesses the necessary skill in mycological work. On the contrary, it is known that several investigators-for example, Marchand, Meissner, and othershave obtained a large number of results which support the germ theory; substances of a putrescible nature have been preserved without alteration for years, simply by absolute exclusion of organisms, and indeed an increase in the percentage of successes is distinctly evident in these experiments in proportion to the increasing skill of the experimenter. 
As the result of more accurate knowledge of the conditions of the life and death of the lower fungi, it is at the present time easy to repeat at will the same experiments with similar results, and only he who continues to hold completely false ideas as to the biological peculiarities of the micro-organisms, and who is not intimately acquainted with the more recent experimental methods, can at the present day obtain results which may be used in proof of the doctrine of abiogenesis. The experiments recently published by Wigand have been made with complete disregard of our present knowledge. Wigand starts with the view that the distribution of the micro-organisms, and the danger of their entrance from without, is not particularly great, and he does not consider it necessary to test this assumption in the same precise manner as others have done.

The striking result also at which many of the abovementioned observers arrived as the result of their fermentation experiments, viz., that in spite of the existence of putrefaction or fermentation no organisms could be found in the fluids in question, rests, as we can now assert with certainty, on an error. Under certain circumstances it is a difficult task to recognise micro-organisms-perhaps degenerated and altered-in an albuminous fluid which has putrefied for a long time, and at all events it seems essential to employ in all cases the special methods which have been recently devised, such as drying, staining, \&c. ; in former times these methods were unknown, and as a matter of fact micro-organisms were not found. But that by no means justifies us in saying that in reality no organisms were present at any period of the experiment; for in more recent experiments on this point they have never been missed, if care was taken to examine the fluid at a sufficiently early stage of putrefaction.

2. Presence of microorganisms in fermentescible fluids without fer. mentation.
2. In contrast to the experiments in which putrefaction was found without micro-organisms, it was observed on the other hand that numerous micro-organisms could take up their abode in fermentescible substrata, without any resulting decomposition, fermentation, or putrefac- 
tion. Results of this kind were obtained by Hiller, for example, in his experiments with urine. Further, living micro-organisms were found by several observers in organs which had been taken from the freshly killed animal body, and their presence was therefore presumably unaccompanied by any alterative action.

These objections and experiments are, however, now only of historical interest. They dato from a period at which little or nothing was known of the various species of micro-organisms, and of their very different conditions of life and mode of action. It is now self-evident that it is not every organism which is able to grow actively in every nutritive substratum, and further that the development of certain organisms is not necessarily accompanied by the formation of stinking gases, in short, by the ordinary symptoms of putrefaction. To find organisms without accompanying putrefaction or fermentation is therefore not surprising, and proves nothing against the vitalistic theory.

3. In several series of experiments it was observed 3. Difficulty in that albuminous solutions were only slowly or not at all broken up by the micro-organisms sown in them, that the latter, in fact, like the higher plants, build up their protoplasm from the simplest organic compounds, and the assimilation of albuminous materials by micro: organisms. hence only grow and multiply with difficulty in the living animal tissue, and in cultivation experiments in eggs, for example. It was therefore concluded that it was impossible that they could take any important part in such intense decomposition of albuminous materials as is the characteristic of the putrefactive process. (Billroth, Hiller, Hoppe-Seyler, Paschutin, and others.)

These observations could only be puzzling at a time when the marked biological differences between the different species of fungi were as yet unknown or disregarded. Now we know with the most complete certainty that some micro-organisms occasion a profound decomposition of the albuminous molecules, and thus set up the putrefactive process, while on the other hand a large number of the lower fungi do not possess any such power, and therefore we cannot deduce from experi- 
4. Fermentation caused by so-called chemical ferments.

ments with any unknown kind of micro-organism that no species is able to cause the putrefactive decomposition of albumen.

4. More weighty objections, which have held their ground up to the most recent times, were brought forward by those investigators who sought a more directly chemical explanation of the processes of fermentation, and did not regard the vitalistic theory as clearing up, but on the contrary as obscuring what it was desired to unravel. Liebig, more especially, and at a later date Hoppe-Seyler took part in this opposition; Colin, Billroth, Hiller, Fleck, and others joined them.

Liebig's views. As early as the year 1839 Liebig had endeavoured to explain the phenomena of fermentation and putrefaction by assuming the existence in yeast of a soluble protëid substance, which in breaking up excited the decomposition of the sugar exactly in the same way as numerous well-known chemical bodies when uniting or breaking up are able to excite a similar movement of the atoms in other bodies. This breaking up of the soluble protëid substances is not an act of the living yeast cells, but on the contrary is a correlative phenomenon of their death. It is a peculiarity which may be noticed in many chemical actions, that relatively small quantitios of the body which is breaking up are able to set up the decomposition of large quantities of the other body; thus Liebig instanced the decomposition of oxalic acid, oxamid, and water in which a small quantity of oxalic acid is sufficient for a large amount of oxamid; he also pointed out the similar fact in the decomposition of cyanogen by aldehyde in the presence of water. The difference between the alcoholic fermentation and the putrefactive process can be easily explained on Liebig's view. In putrefaction the decomposition is transmitted by the decomposing albuminous material itself, so that the process once begun continues by its own movement even after the original cause which set it going has become inactive; in fermentation, on the other hand, the sugar (the substance here undergoing decomposition) is unable to transmit its own movement, and hence a 
foreign cause, a ferment, is necessary, not only for the commencement, but also for the continuance of the movement.

Liebig's view was, however, evidently a purely hypothetical one; the decomposing protëid substance which was supposed to be the cause of the fermentation was by no means demonstrated to be really present; the only experimental support of this supposition was the fact that in the so-called self-fermentation of yeast which takes place without the addition of sugar, and entirely at the cost of the yeast substance, much more alcohol is formed than could be derived from the amount of cellulose in the yeast cells, and that thus some other complex substance contained in the cells must furnish the materials for the formation of the alcohol. This analytical proof was, however, shown to be erroneous by Nägeli (Theorie der Gährung, p. 3), but at a much earlier period Liebig had been compelled to modify his theory considerably by the numerous experiments which absolutely proved the direct dependence of the fermentative process on the life of the yeast cells.

In 1870 he declared that the living yeast cells con- Later tained and produced the supposed ferment-like substance, modification and that therefore the formation of the ferment depends view. on the life of the cell ; the fermentative act, however, depends on an unorganised ferment, and the yeast cells in producing the ferment do nothing more than numerous other cells do. Just as man produces diastatic ferment, pepsin and trypsin, so all other animals and plants have their ferments; but the organisms are not identical with these ferments, and the fermentative action cannot be looked on as the direct work of the cells. If it were possible to separate the ferments from the cells the latter would then be no longer necessary for the commencement and continuance of the fermentative process. Similar views were taught by Traube in 1858; and in 1876 they were defended by Hoppe-Seyler. They rested in part on the analogy between the fermentative and putrefactive process, and the splitting up and decomposition caused by unorganised ferments. The micro-organisms 
according to this view are not the primary and immediate cause of the decompositions of organic substances occurring in fermentation and putrefaction; on the contrary, it was assumed that a transformation of the fermentescible materials usually occurs at first from causes present in the substances themselves - by soluble chemical ferments, and that it is only when the material has undergone a certain amount of alteration that multiplication of those organisms occurs, which on account of the wide distribution of their germs always of course gain access to these substances; the nature and constitution of the fermentescible substrata, and especially the first changes that occur in it, determine what particular species of organism chiefly develop and flourish. From that point these organisms aid as a rule in the decomposition of the substance; but they are not absolutely necessary even for its further splitting up, and the decomposition does not go on by any means parallel with their development.

On this view accordingly by far the most important rôle is ascribed to the unorganised soluble ferments. Lately we have become acquainted with a large number of such ferments, and in accordance with this knowledge the probability of their great activity in the ordinary processes of fermentation and putrefaction seems to increase. The action of diastase, of emulsine, of myrosine, of the inverting ferment of yeast, of ptyalin and pepsin, the energetic action of the pancreas, and of the trypsin isolated from it, offered the most important analogies, and the support of the "chemical" theory of

Differences between the action of chemical ferments and of the organised exciting agents of fermentation. fermentation. As a matter of fact the supporters of the germ theory have never disputed the influence and the action of chemical ferments, but an exact analysis of the decomposition caused by chemical ferments on the one hand, and of the marked alterations in fermentation and putrefaction on the other, lead us of necessity to the conviction that it is quite inadmissible to designate these two processes as sufficiently analogous and similar to warrant the inference that both are due to a similai cause. The chemical ferments only set up hydrolytic decompositions; their place can be taken by so-called 
contact-substances, and also by dilute sulphuric acid and various other agents; the amount of the chemical ferments remains the same or becomes diminished during the process; the best temperature for their action is about $60^{\circ} \mathrm{C}$., and they are not affected by powerful physiological poisons. In fermentation and putrefaction, on the other hand, there is always a complex alteration in the grouping of the atoms, a separation of carbonic acid, and often of other atomic groups; the number of the causal organisms increases in proportion to the intensity of the fermentation; they are most active at a temperature between $25^{\circ}$ and $40^{\circ} \mathrm{C}$., and their action ceases under the influence of physiological poisons. Thus the nature and action of the chemical ferments, and of the fermentative organisms, are sharply separated from one another, and a relation between them only exists in so far as in the more complex fermentative processes, and especially in putrefaction, both agents are often at work in such a manner that chemical ferments which are in part produced by the micro-organisms lead to the solution of the fermentescible substance, and so prepare the soil for its subsequent profound alteration under the influence of the specific organised ferments.

If, however, we assume with Liebig that in the latter instance the transposition of the atoms in fermentation and putrefaction occurs as the result of the action of a ferment-like group of atoms which can only be produced by living micro-organisms, and are practically bound up with the life of the cells, we cannot regard this view as an essential objection to the vitalistic theory; it is, on the contrary, a recognition of it. This view corresponds Recognitiono entirely with the vitalistic theory in the immediate de- the vitalistic pendence of the fermentative process on the life of the yeast cells; it only seeks to define more precisely the mode in which the living cells occasion the decomposition of the fermenting or putrefying substance. But the existence of such a ferment is a pure hypothesis, as is evident from the fact that it has as yet been found impossible to isolate the supposed ferment from the yeast cells; this failure being excused on the idea that the ferment is at 
once destroyed when the yeast cells die, or even when their life is interfered with.

As the result of the preceding historical sketch of the derelopment of the views on fermentation and putrefaction, we may take it as absolutely certain that minute living organisms are the direct cause of the processes commonly grouped together under these terms, and that these processes are intimately dependent on the life of the organisms.

\section{Mrcro-organisms as Parasitic Exciming Agents of Disease.}

Even at an early period of scientific obserration and research on the subject of the infective diseases, we meet with the belief that the immediate cause of these devastating affections is an entity endowed with vital

Earlier hypotheses as to the organised nature of contagia. properties, a contagium animatum. This view was clearly expressed by Hufeland; but at first all sorts of fantastic notions as to the more intimate nature and mode of action of this supposed entity, endowed with vital properties, were added to these leading ideas. Soon, however, there was evolved from this cloud of phantasies the definite view that the transmission of the infective diseases depended on the growth of independent minute organisms (Kircher, Linné, Wichmann, and others). In fact it was extremely tempting to refer the characteristic phencmena in the occurrence of the infective diseases to such organisms, and to draw a certain parallel between these diseases and the processes of fermentation and putrefaction, which are likewise caused by similar fungi. The sudden appearance of epidemics in various isolated places, their relatively slow spread, and the fact that they often remain localised to a particular locality, must exclude the idea of an evanescent, gaseous agent. The mode of their spread, the unlimited development of the infectire material through a large series of individuals, the transport of the infective material over considerable distances, its adherence to the most heterogeneous objects, the stage of incubation, the typical cyclical course 
of the disease, and the subsequent immunity, pointed more or less distinctly to the organised nature of the causal agents, and could be explained by the mode of development of these supposititious beings. The anxiety to find a relation between the phenomena of infective diseases and those of fermentation and putrefaction, is shown by the fact that by some pathologists the whole group of infective diseases was designated by the term "Zymotic diseases."

These views, which have continuously gained ground during the last forty years, did not, it is true, at first rest on clear knowledge, and were wanting in an experimental basis. They were only based on speculations; but these speculations were made with such acuteness, and with such logic, that they led to almost the same results as were arrived at forty years later by elaborate experimental investigations. It was more especially Henle who, in the year 1840, in his Pathologischen Untersuchungen, and later, in 1853, in his Handbuch der rationellen Pathologie, sketched with wonderful precision the relation of micro-organisms to the infective diseases, and defined the intimate nature, the vital properties, and the mode of action of the micro-organisms, as well as the dependence of the individual phases and symptoms of the diseases in question on the behaviour of the parasites, almost as accurately as has subsequently been done as the result of direct observations with optical aids, at that time unknown, and of numerous experiments. The great influence which Henle's views have exercised on the further development of knowledge on the subject of the parasitic exciting agents of disease renders it necessary for us to reproduce at this place some of the most important of these views in his own words :-

"If we trace the miasmatic contagia in their action on the animal organism, we find at once, although with many individual differences, a general and characteristic property which can only be ascribed to living matter, namely, that of multiplying at the cost and by the assimilation of foreign organic material. This conclusion is supported by the course of the great majority of miasmatic contagious diseases. They 
belong to the group of diseases which I have termed typical, whose sharply defined stages indicate a development of the cause in accordance with definite laws, such as we only find among living beings.

"What was stated above with regard to the properties of the cause of miasmatic diseases in general holds good as regards the multiplication of contagia by assimilation. It can, however, only be absolutely proved in the case of the inoculable diseases where we are able to define accurately both the point of entrance and the quantity of material taken up, and the proof becomes the more insufficient the more in any given epidemic the number of the cases produced by miasma exceeds those arising by contagion. That the cause of the disease has multiplied in the region affected by the epidemic is probable whenever the latter spreads gradually from small beginnings and attains large dimensions.

"It is only when its development and reproduction in the diseased body is demonstrated that we are justified in designating the material which occasions epidemic diseases as a contagium, and the analogy of these contagia with parasites, the analogy of the miasmatic contagious diseases with the results of the deposit of parasitic organisms in living bodies previously referred to becomes at once evident. This analogy, as I have indicated above, has led to the discovery of parasites as the cause of many affections formerly termed contagious diseases. There are, however, a number of diseases in the contagium of which nothing has been found which recalls the forms of known species of animals and plants. Nevertheless, this negative result is not so certain that we can, therefore, absolutely refuse to reckon the contagia among these microscopic parasites. It is not necessary to assume that the organisms which act as contagia are too small for our optical means. But the smallest animals can only be distinguished from the cells, nuclei, and granules which occur in so many tissues and excreta, especially in pus, by their movements, and the smallest plants only in certain stages of their development by the arrangement of their elementary constituents. The granules of which the Botrytis bassiana consists behave exactly like pigment granules or the molecules of pus. It is possible, therefore, that bodies of very various and of great significance may be concealed among the molecules which occur in every microscopical object. It is scarcely necessary to add that these speculations are as yet only hypothetical, but they are not superfluous even in the cases where animal or vegetable parasites have been, or will yet be discovered in the contagium. The question will, however, still remain, whether the parasite is an accidental inhabitant of the con- 
tagium and of the diseased body, or whether it is the important active constituent. Much has already been gained by these views which, though they may only represent a transitional period in our knowledge, will prove a lasting gain. In place of the unintelligible view that the diseased body, or the disease itself, forms the contagious material, we have the opinion that the formation of the contagium is a reproductive process, and that the disease is the result of the reproduction of this extraneous being in the organism and at its expense. From this point of view we must interpret the symptoms of the miasmatic contagious diseases.

"While we must hold that the cause of the miasmatic contagious diseases is a material endowed with independent life, which can reproduce itself after the manner of animals and plants, can increase by assimilation of organic materials, and, growing parasitically on the infected body, can give rise to the symptoms of the special disease, yet the question arises of what the as yet unseen body of this parasite is composed, the result of whose life is so evident and so devastating. It is one of the laws of human phantasy that we must ascribe to the contagium, as soon as we reckon it to be something living, one of the forms which the known organic world presents to our senses; hence in the earlier childish times of research one thought of insects, and when the microscopic animals were discovered, the infusoria could, with still better grounds, be accused of being contagium and miasma. At the present time, since the conclusions that have been arrived at with regard to the fungus of muscardine and similar diseases, it seems more likely that the contagium belongs to the regetable world, because the extensive distribution, the rapid multiplication, and the tenacity of life of the lower microscopical vegetable beings, as well as the mode of their action on the bodies which they have selected as the seat of their vegetation, present in fact the most remarkable analogies with the infective material of the miasmatic contagious diseases. Muscardine also arises in stagnant marshes, apparently independently, as if it were due to miasma; under the influence of heat and drought it becomes epidemic and contagious. 'Towards the cessation of the epidemic its contagiousness diminishes, and ultimately becomes lost. Currents of air carry the contagium over long distances, so that the disease appears again in another place, under the aspect of a miasmatic affection. The contagium is an aëriform, and at the same time a fixed, body It retains its power for years in a dry state. An imponderable and incommensurable quantity of it is sufficient to set up the disease, and even to produce devastating epidemics." 
The earliest discovery of parasitic exciting agents of disease.
Hallier's discoveries

Actual facts in support of the theory of the development of disease by micro-organisms were first obtained by the study of a number of diseases of plants and insects. As far back as 1835 Bassi demonstrated that a fungus was the cause of muscardine, a fatal disease of silkworms; other diseases of insects were shortly afterwards demonstrated with certainty to be due to similar fungi ; in like manner Tulasne, de Bary, and Kühn explained a number of devastating diseases of various kinds of grain, of potatoes, \&c., by the entrance and parasitic development of fungi. Also in the case of the higher animals and man positive proof was soon obtained that minute vegetable bodies were the cause of certain diseases. Apart from numerous discoveries of fungi which could not with certainty be demonstrated to be the cause of the accompanying diseases, favus, thrush, and various affections of the skin were shown to be dependent on parasitic microscopic fungi. Of especial importance was the discovery that anthrax was characterised by the appearance in the blood of minute rod-shaped organisms, and that these organisms could be shown experimentally to be the cause of the disease (Pollender, 1855 ; Davaine, 1863).

On the one hand the constantly increasing frequency of severe pestilences which led to the earnest desire to solve the etiological questions, on the other hand the convincing deductions of Henle, the numerous analogies with diseases of plants and animals, and the discovery of the contagium of anthrax, gave rise to a period of research which was characterised by an excess of zeal and by a large number of imperfectly proved discoveries which were of no real advantage to the parasitic theory.

It was Hallier more particularly who became a too enthusiastic apostle of the parasitic theory. As the result of numerous researches he asserted that the various micro-organisms only represented special vegetative forms of known mould fungi, arising in consequence of the external conditions of life; that these vegetative forms gave rise to all sorts of diseases, but that under suitable conditions one could always cultivate 
from them the corresponding mould, and could in this way demonstrate the true cause of the disease. By the investigation of and cultivation from a great variety of diseased organs and excreta Hallier obtained a series of different fungi which he proclaimed to be the causes of the diseases; and in a short time scarlet fever, measles, as well as cholera, typhoid fever, and all other diseases of this class, were referred to their supposed cause.

The reaction to this period of fantastical exaggeration Reaction was inevitable. Anthorities on fungi like de Bary against these showed that Hallier's investigations were quite valueless, because they were conducted with totally insufficient precautions against the entrance of extraneous organisms. De Bary's objections could not be upset, the structure of Hallier's teaching on parasitic diseases fell, and at the same time a serious blow was given to the whole parasitic theory; even up to the present day there are those who, as the result of the overthrow of these errors, look on the development of disease by micro-organisms as an erroneous and exploded view.

Further positive discoveries with regard to parasites which have been made by numerous investigators in recent years tended, however, to restore the lost faith. These discoveries had chiefly reference to the infective Microdiseases of wounds ; Rindfleisch, Waldeyer, and von irganisms in Recklinghausen $(1866,1870)$ were the first who directed diseases of attention to the micro-organisms which occurred in pyæmic processes; similar observations were made in erysipelas, in phlegmon, in diphtheria, and in puerperal fever (Hüter, Orth, Oerftel, and others). The pathogenic nature of the micro-organisms found was confirmed by numerous experiments on animals (Coze and Feltz, Davaine, Hüter, Eberth, Leber, Frisch, Klebs, and others).

The striking results of Lister's antiseptic treatment of Lister's wounds had a most important influence on the recogni- antiseptic tion of the parasitic theory ; carried out with the definite wounds. aim of preventing or hindering the action of the infective organisms, and followed by astonishing results, it spread widely the knowledge and importance of the micro- 
parasites, and the number of sceptics and opponents have diminished from year to year.-It is true that the difficulty of these investigations, which only permitted an extremely slow advance, and one but little satisfying to the earnest desire for rapid enlightenment, led some observers to overstep the limits of exact investigation, and to attach too far-reaching speculations to the results of the experiments : it was natural and pardonable that at times conclusions as to the origin of the diseases were drawn from the mere presence of micro-organisms in the dead bodies or in pathological secretions, and that these organisms were at times prematurely and erroneously proclaimed to be the exciting agents of the disease. On the other hand many investigators recognised that it was only by detailed study of the different forms of micro-organisms which came under observation, by the investigation of the conditions and results of their life, by improvement of the methods of microscopical observation, and by faultless experiments on animals that a basis could be obtained on which an accurate and sure insight into the rôle of the parasitic agents of disease could be founded. Based on the recognition of these facts the more recent methods of mycological investigations were built up. Before it was possible to obtain exact and unequivocal results it was necessary to have Pasteur's and Cohn's systematic cultivations, Koch's method of microscopical investigation and pure cultiration of the fungi, Weigert's and Ehrlich's raluable researches on the employment of dyes for demonstrating the micro-organisms, Brefeld's contributions to the methodical study of the lower fungi, and Nägeli's work as to the conditions of life and the tissue change of the lower fungi.

The objections which are raised against the parasitic theory are derived almost entirely from former times, and are now scarcely heard. Apart from the views of some stubborn adversaries, who only believe the contradictory results of their own experiments, the doubts raised against the recent work on tee parasitic theory have to do chiefly with individual cases and special diseases. 
Thus from time to time authors have denied that micro-organisms act as exciting agents of the infective diseases of wounds, their views being based more especially on the statements made by several observers, that after mechanical removal of the organisms from infective fluids the filtrate, which is devoid of organisms, exerts pathogenic action. More accurate experiments have however shown that this action depended solely on an intoxication, on a poison in solution, and that therefore it could not be at all compared with an infective process (Panum, Hiller, Koch, and others).-The Billroth's obresults of Billroth's investigations attracted special at- jections to the tention for a considerable time; he repeatedly found theory. micro-organisms in subcutaneous suppurations, where there was no external wound; he likewise found them in living organs; and he concluded, therefore, that living germs were always present in the body, but that they were not able to develop in the healthy body, and could not utilise the tissues of the living body as nutritive material. It was not till a "phlogogenous ferment" (Phlogistisches zymoid) had been formed as the result of decomposition, which ferment could of itself cause inflammation, that the conditions were suitable for the development and multiplication of the micro-organisms; and under favourable conditions these organisms can become carriers, and lead to the multiplication of this ferment. According to Billroth the micro-organisms originate from a single plant, the Coccobacteria septica, which is characterised by the multiplicity of its vegetative forms, and according to the external conditions appears now in one, now in another morphological form.

It is easy at the present time to refute Billroth's objections. In the first place, we know from numerous experiments that bacterial germs are not present in the normal living organism in recognisable numbers, and that the numerous organisms in the diseased living body can only be referred to entrance from without-to an infection. An objection might, howerer, be made that the facts made out, as to the absence of pre-existing germs 
in animal organs, do not of necessity apply to man, and it was therefore necessary, when possible, to bring forward experimental facts which would undoubtedly show that micro-organisms are the direct and only cause of certain diseases, and are not merely accidental companions of other noxious materials.

Definite proof Experiments were formerly performed with this aim of the parasitic in the following manner: inoculations were carried out
rofle of the microorganisms by isolating them same time to free the organisms from other materials and by infective ex. periments.

Isolation by filtration. adhering to them, which might possibly cause the disease. In some cases an attempt was made to isolate the organisms by the addition of distilled water, in which the organisms would sink to the bottom, or by filtration; but in these attempts it was always questionable whether the noxious materials by possibility present in solution were really removed, and on the other hand whether the organisms were not injured by the washing and by the great osmosis. Filtration in the living body, obtained by studying the relation of the fœtus to the infected maternal organism, did not lead to a definite result, as it was only in certain instances (anthrax) that the fœtus remained free from infection, while in other cases it also became attacked by the disease.

By dilution of Experiments were then made by dilution of the the infective infective material, on the assumption-undoubtedly
material. correct-that only a contagium dependent on a living organism capable of multiplication could be diluted to an extreme degree without losing its activity. Such a dilution was in reality obtained when one animal was successfully inoculated from an infected one, a third from the second, and so on through a whole series of animals; nevertheless there was always the possible objection in this case that the cells of the body might take part in the regeneration of the poison.

On the other hand all doubt as to the pathogenic properties of certain micro-organisms is removed in the face of the proof obtained during the last few years, that the infective material can be diluted outside the body to an extraordinary extent, without thereby losing its activity. Thus Koch was able to dilute infective blood 
to such a degree that one-millionth part of a cubic centimetre injected into the animal caused the same typical disease, fatal in eighteen hours, as was obtained by the injection of undiluted blood. The dilution can, however, be carried to a much greater extent by the aid of the methods of cultivation. Pasteur and Bycultivation Klebs were the first to show that micro-organisms, supposed to be pathogenic, could be cultivated outside the animal body in artificial nutritive material; that then after the growth of a cultivation a minimal quantity could be placed on a new nutrient material, that a trace of the colonies which then developed could be inoculated on a third soil, and that thus the micro-organism could be cultivated through a whole series of generations. Koch then gave us methods by which it is possible Koch's pure to prepare the cultivations of any given organism in such a way that no other organism grows along with it, and that on further transplantations on new soil only the same organism appears. Thus we could for the first time study witl certainty, and in an unaltered condition, the organism suspected as the cause of the parasitic disease, and that for a long time, and in spite of a large series of new transplantations. When an organism has in this way been cultivated through fifty or a hundred generations, it is self-evident that the last generation does not contain any of the materials which adhered to the original organisms ; it is easy to see that the dilution must be reckoned by trillions, and must ultimately be incalculable; any poisonous material originally mixed with it, however intense its action may be, cannot be present in the last cultivation in appreciable amount, and therefore when infection is obtained with the last cultivation it can only be because the micro-organisms themselves, which are constantly reproduced at the expense of the nutritive materials, are the real noxious agents.

As a matter of fact, inoculations with the minutest quantity of the hundredth pure cultivation succeed quite as well as with the original material. In the case of anthrax, of various forms of septicæmia, of glanders, of tuberculosis, \&c., Koch was able to carry on pure 
cultivations through a long series; if he introduced a trace of the last cultivation into an animal, the disease in question appeared with all its characteristic sjmptoms after the typical incubation period; death followed after a definite time. The results of the autopsy were always the same; organisms of the same form, and with the same characters as those introduced, were found in enormous numbers in the blood and tissues; and traces of the blood containing the organisms when inoculated into other animals, caused in them the same fatal disease.

In the case of these diseases the causal connection of the micro-organisms was therefore proved with complete certainty; and it was natural to draw similar conclusions with regard to the other numerous infective diseases which had the same characters. Nevertheless it is best, and will contribute more to the development of knowledge with regard to the micro-parasites, if we proceed with the greatest caution, avoid generalisations, and only proclaim a disease as parasitic when we succed in finding microorganisms with well-marked morphological characteristics, in demonstrating their presence in such numbers and with such a distribution that all the phenomena of the disease can thereby be explained, in transmitting them to other higher animals, or if possible in cultivating them for several generations on an artificial soil, and reproducing the characteristic disease by inoculation of animals with minute quantities of these cultivations.

That these minute organisms act as parasitic exciting agents of disease, is as much beyond question as is the function of similar minute beings in exciting fermentation and putrefaction. And it is to this fact that the great and many-sided importance of micro-organisms in relation to hygiene and public health is due. It was the processes of fermentation and putrefaction of organic substances in our surroundings which first awakened uneasiness and distrust, and called the efforts of modern hygiene into being, and the most important, and also the most difficult part of the hygienic investigation of soil, water, air, and dwellings, lies in ascertaining those conditions which favour the derelopment and spread of the exciting agents of disease. 


\section{PART II.}

\section{MORPHOLOGY AND CLASSIFICATION OF THE MICRO-} ORGANISMS.

The micro-organisms which have as yet been The microrecognised as exciting agents of fermentation and which interest putrefaction, or of disease, belong almost entirely usherebelong to the lower fungi. Certain preliminary observations fungi. render it probable that organisms which belong to other classes of plants or animals, for example the algæ, the flagellata, and the protozoa, may also occasionally act as larasites, and become of hygienic interest; but in the meantime the known facts are too few for a systematic review of this part of the subject, and it is therefore sufficient to include here only those micro-organisms which are of special importance for us, and which belongto the lower fungi.

In order to indicate the place of the lower fungi in the system of the plants the following short sketch is given, and the botanical handbooks, more especially the paper by Frank on the Cryptogams in Leunis's Botany, and de Bary's Comparative Morphology and Biology of the Fungi, will furnish further details.

The fungi, mycetes, belong to the cryptogams, that Place of the great division of the vegetable kingdom which is regetable characterised by propagation by means of spores, in kingdom. contrast to the other great division of the phanerogams. The phanerogams bear flowers and produce seeds, in which the various parts corresponding to the future structures of the plants are already distinguishable; the cryptogams are flowerless, and propagate by means of the spores just mentioned, that is to say, by small cells, which show no differentiation and, when present in large numbers, resemble one another. The cryptogams 
Former subdivision into fungi, alga, and lichens.

Untenability of this classifi. cation. are divided into the stem-forming cryptogams, and the thallophytes, or leafy plants, in which only a leaf or thallus is formed, which does not in any way follow the laws of growth of the higher stem-forming plants.

The thallophytes were formerly divided into three sub-classes-fungi, algæ, and lichens. The fungi were defined as cells devoid of chlorophyll, which can only obtain nutriment from previously formed organic compounds, and hence can only live as saprophytes on organic substances undergoing decomposition, or as parasites in living plants and animals. Algæ were described as cells always containing chlorophyll, which obtained nutriment from inorganic materials, and for the most part lived in water. Lichens were defined as a mixture of cells, some containing chlorophyll and others without it, which could obtain nutriment from inorganic materials, and for the most part lived in the air.

At the present time very little value is attached to these distinctions, which are based chiefly on the presence or absence of chlorophyll. Even among the phanerogams there are many plants which are devoid of chlorophyll (orchids, monotropaceæ), but which are not on that account struck out of the families or orders to which from their morphological characters they belong. If also in the case of the thallophytes the chief stress is laid on the mode of propagation, and on the morphological characters, the fungi and algæ show a great deal that is common to both. And with regard to the lichens the latest investigations have shown with considerable certainty that they consist of a fungus and an alga, the first of which preys upon the second, so that they cannot be looked upon as an independent class. Hence it is best to give up the former division into fungi, algæ, and lichens, and to choose for the whole of the thallophytes a principle of classification in conformity with that employed for the other plants.

Opinions vary greatly as to the most suitable and natural mode of classifying the thallophytes, but we need only refer here to de Bary's classification (Vergleichende Morphologie und Biologie der Pilze, page 
142), to Brefeld's subdivision (Untersuchungen über Schimmelpilze, Heft 4), and to Frank's classification in the third edition of Leunis's Botany, page 398. The present description will be based chiefly on Frank's classification, because Leunis's Synopsis is an indispensable book of reference for anyone who studies the thallophytes minutely.

Among the thallophytes only the fungi are at present of hygienic interest, hence the algæ and lichens are not at all referred to in the following pages, and with regard to the forms of algæ, morphologically similar to the fungi, reference must be made to Leunis's Synopsis and to Cohn's Beiträge zur Biologie der Pflanzen, Bd. 1, H. 2.

From the hygienic standpoint it seems most practical Subdivision of to depart from the botanical arrangement and divide a practical the fungi into four chief groups, of which the first hygienic comprises the true fungi, or mould fungi; the second the mycetozoa ; the third the yeast fungi, or blastomycetes; and the fourth the fission fungi, or schizomycetes.

\section{The Fungi Proper (Mould Funai).}

\section{General Morphology.}

The fungi consist of small microscopical cells, in Nature of the which we can distinguish a membrane and protoplasmic contents. The cell membrane is composed of a substance similar to cellulose but not identical with it, and does not show any violet colouration with iodine. In the protoplasm there are as a rule no nuclei, no starch granules, and no chlorophyll; on the other hand there are frequently vacuoles, oil globules, various colouring materials, and at times crystals of oxalate of lime which are however deposited especially on the outer surface of the cell wall in the form of small needles and prickles.

The growth of the fungi takes place by elongation of Нyphw. the cells. Thus a series of threads or hyphæ are formed. Usually the hyphæ are divided into segments 
Varieties of the mycelium.

by transverse divisions; and the threads are almost always branched, either by the formation of a branch at some part or other of a segment, or by the terminal cell becoming divided dichotomously during growth. The group of hyphr, whether they are present in small numbers or quite single, or whether they are united in masses, is termed the thallus of the fungus.

In the thallus we have to distinguish mycelium, and later fruit-bearing hyphæ. Before the development of the fruit-bearing hyphæ the mycelium is identical with the thallus, which signifies the more or less diffused and branched hyphæ which have grown on an organic substratum. As a rule by uniform spread of the threads in all directions and by continued branching a flocculent mycelium is produced. At times membranous parenchymatous layers or fibrous bands are formed by the close union of numerous hyphæ. Under certain circumstances the mycelium of many fungi assumes the form of the so-called sclerotia, tuberous fleshy bodies which develop secondarily from an ordinary mycelium. In the sclerotium we can distinguish a cortical and a medullary substance, the latter consisting of interwoven hyphæ, the former of the terminal cells of the hyphæ firmly bound together and surrounded by dark membranes. The sclerotium must be regarded as a resting form, from which a development of fluid-bearing hyphæ only occurs after a long time, and when the surroundings are constantly moist.

The hyphæ of the mycelium penetrate with great energy into the nutritive substratum. In the case of dead portions of plants the hyphr can bore through the cell membrane, the molecules of the membrane in contact with them being broken up. But even in the case of living plants the parasitic fungi not only spread on the surface, but the hyphr grow in between the cells of the plants and send short projections, so-called haustoria, into the interior of the cells; or they penetrate through the cell walls, as in the case of dead plants. In like manner animal membranes do not offer any marked resistance to the penetration of the growing 
hyphæ of many fungi, and even teeth and bones may become infiltrated with fungus threads.

The propagation of the fungi occurs usually by means Varieties of of spores, i.e., cells, which can give rise to one or several spore formagerminating tubes, and thus to a new regetative body similar to the original one. In rare cases some of the cells of the mycelium themselves form the spores; as a rule, however, certain hyphæ grow from the mycelium, take on another form and show other conditions of growth, and are termed fruit hyphæ, or fruit-bearers. If a large number of fruit hyphæ lie together, a so-called fruit body is formed, and this is more especially the case in the higher fungi. The modes in which the spores develop on the fruit-bearers, and the manner in which they are distributed after ripening, are very diverse, and these differences in fructification furnish in the main the principles on which the usual classification of the fungi is based.

With regard to the deve'opment and dissemination of the spores we distinguish-

a. Intercalary formation. Along the course of the growing hyphæ certain cells are marked off, assume a somewhat distinet form, and become spores or sporebearing cells. These formations are frequently termed semme.

b. Acrogenous segmentation. The terminal portions of the fruit hyphæ are separated by transverse division, and act as spores. The thin stalks or fruit-bearers are termed basidia. If from the ends of these hyphæ thin stalk-like branches proceed, on which the spores are formed by strangulation, these spore-bearing stalks are termed sterigmata. As to the mode in which the transverse division of the terminal cells occurs only one spore may be formed; or a number of buds may arise at the same time on the summit of the basidium; or several spores may be separated one after the other from one busidium. The freeing of the spores takes place either by disappearance of the stalk, or by strangulation, where a zone disappears, or softens in the transverse division between spore and fruit-carrier, or by being hurled away. 
The last mode of separation of the spore, which is rery peculiar, occurs in this way: the spore cell rests on the apex of a tube-like basidium, which, in consequence of continued absorption of water, becomes more and more turgescent, while it possesses at the same time a very clastic membrane; immediately beneath the transverse division the cohesion of this membrane is less than elsewhere, and here, therefore, as soon as the turgescence has reached a certain degree, a ringlike rupture occurs ; at once the elastic wall contracts, and a large part of the contained fluid is forcibly driven out of the rent, and carries the spore with it.

The spores formed by acrogenous segmentation are termed basidiospores, or acrospores, or simply conidia. At times this mode of spore formation occurs in fruit bodies, the so-called spermogonia and pycnida. These fruit bodies contain a cavity, on the inner wall of which is a thick layer of basidia which give off numerous spores.

c. Endogenous spore formation. The spores arise in the interior of mother cells, the walls of which persist as sporangia till ripening has occurred. The sporangia are for the most part acrogenous cells; spore formation occurs in them by division of the plasma without the formation of walls. The sporangia have often a clubshaped or tube-like form, and are then termed asci; in these eight ascospores are usually formed. The asci are often formed in small round or flask-like fruit bodies, the perithecia, which enclose a cavity, and the club-shaped tubes spring from the bottom of this cavity.

The ripe spores escape either through an opening in the sporangium which is formed by sudden and great swelling of a small circumscribed portion of the wall; or the largest and upper portion of the wall of the sporangium becomes converted into a deliquescent substance; or, in the case of the asci, the aborementioned ejaculation of the spores is not uncommonly obserred.

d. The spore formation is often preceded by a sort of sexual fructification. This may consist of the socalled copulation, in which two hyphæ, each with a club- 
shaped protrusion, grow towards one another, unite after absorption of the opposing walls, and form a zygospore. For the most part, however, well-marked male and female sexual organs are formed. The female is attached to a mycelium thread in the form of a globular swollen cell, and is termed oogonium; the male, antheridium, is a long or club-like swollen cell which attaches itself to the oogonium and becomes separated from its hypha; at times the antheridium sends a so-called fertilising tube into the interior of the oogonium. After fertilisation, the oospores, which are globular cells provided with a cellulose membrane, are formed in the oogonium. Such anastomoses between hyphr do not, however, in all cases indicate a sexual copulation.

The ripe spores are for the most part simple, often, Structure of howerer, composite, cells of very varying forms; usually they are spherical or oval; at times, however, they have the form of long thin rods. The wall consists of an external, and often coloured sheath, the episporium, and an inner, more delicate, colourless layer, the endosporium. The contents consist of protoplasm, and oil globules are frequently present. The general distinctive characteristic of the spores is that they either become converted into the mother cells of new spores, sporangia, or send out one or more germinating tubes from which the mycelium threads may again develop.

The swarming spores and the resting spores behave somewhat differently. The former are round, naked protoplasmic bodies without a firm cellulose envelope, provided with two cilia, and thus capable of movement; they arise endogenously from the spores by division of the spore contents, and become free by swelling of the sheath of the sporangium. They are only formed and liberated under water. After the mobile, naked stage has lasted for a short time, the swarming spores come to rest, surround themselves with a cell wall, and then, like other spores, send out a germinating tube. By resting spores we understand those spores which are not able to germinate immediately after their formation, but require first a period of rest, e.g., a whole winter. Zygospores and 
Different modes of spore formation in the same fungus.

oospores are the forms which usually behave as resting spores.

These different kinds of fructifying organs occur at times together or in succession on one and the same thallus; the same fungus can under certain conditions furnish basidiospores, and under other conditions ascospores; thus there is frequently a polymorphism of the fructifying organs. In addition an alternation of generation often occurs; the thallus of one fungus bears only one form of fructifying organ; the spores so developed grow to form a thallus whichis different from the original thallus and gives rise to another fructification, often indeed not growing on the same host, but requiring another species of plant for its development. From the spores formed on the second thallus, the original mycelium with its characteristic fructification is again developed.

\section{Classification of the True Fungi. \\ (After Frank in Leunis's Synopsis).}

Sketch of the classification of the fungi.
First order: Ascomycetes.-Highly developed form of fungus; at the height of vegetation ascospores are formed. A formation of protospores often precedes this fructification, these bodies appearing in the form of conidia-carriers and conidia or spermogonia. The protospore forms of the ascomycetes, such as Eurotium aspergillus, Erysiphe oïdium, \&c., which occur much oftener in nature than the higher forms of fructification, were formerly described as particular species of fungi, and have only recently been associated with the ascospore forms.

Families: Perisporiaceæ, Pyrenomycetes, Tuberaceæ, Discomycetes, Gymnoasci.

Second order: Basidiosporea.-In these the spore formation always occurs by acrogenous segmentation, even when the fungi have reached the acme of development. Almost all form fructifying bodies, which carry in their interior a hymenium layer of basidia. 
Families : Gasteromycetes, Hymenomycetes, Tremellini, Ecidiaceæ or Uredineæ, Entomophtoreæ, Ustilagineæ.

Third order: Zygomycetes.-These form zygospores, as the highest form of fructification ; these spores arising by copulation. A non-sexual formation of spores by sporangia, or by separation of conidia, usually precedes this fructification.

Families: Mucorineæ, Chrtocladiaceæ, Piptocephalideæ.

Fourth order: Phycomycetes.-These are unicellular thallophytes. The cell is tubular, and forms the spores at the end of some of its branches. In the non-sexual fructification these spores are swarming spores or conidia; oospores are also often formed.

Families: Saprolegniaceæ, Peronosporeæ, Chytridiaceæ.

Of the various orders and families mentioned, I Description of hove some specially have only selected for more detailed description those interesting which are of directly hygienic interest, in that they at fungi. times appear as parasitic exciting agents of disease in man and the higher animals; or those which demand attention on account of their wide distribution as ordinary mould fungi, and on account of their constant occurrence in all practical mycological work. In addition, some of the forms which attack lower animals and plants are described shortly where the mode of appearance and distribution of the diseases excited by them furnish analogies with human infective diseases. For all other details the botanical text-books mentioned above must be consulted.

A. The following forms, which are parasitic on plants or the lower animals, may be mentioned :-

1. Ustilagineæ. The fungi of various forms of blight Blight fungi. (order: Basidiosporeæ). These are parasitic on the organs of plants, especially on various kinds of grain. The fine mycelium threads grow between and transrersely through the cells of the plants. At certain spots the 
hyphæ multiply, become segmented, and break up into spores, which then occupy the place of the tissue destroyed, in the form of dark, dust-like masses. The short germinating tube (promycelium) branches in single segments (sporidia), which become detached from the promycelium, and can again grow in the form of germinating tubes. Different species of these fungi attack different

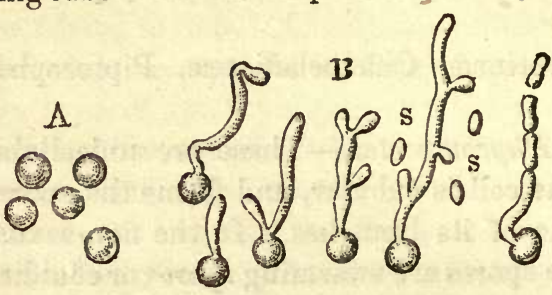

Fig. 1. - Ustilago carbo $\times 400$.

$A$, ripe spores.

$B$, germinating spores, forming promycelium and sporidia $(s)$. parts of the plant, now the flower, now the stalk and flower, and now the root. The detection of the disease depends chiefly on the presence of the dark masses of spores. Continued moisture is necessary for the germination of the spores, and for the penetration of the germinating tubes into the host. The disease is prevented by diminution of the moisture, or by disinfection of the grain, e.g., by means of sulphate of copper.

Ustilago carbo (brand, smut). - A black powder on the ears and panicles of wheat, barley, and oats. At the time of harvest the brand mass, which rapidly breaks up, is removed by wind and rain, and hence there is no contamination of the meal. Spores brown, spherical (fig. 1); episporium smooth; sporidia composed of longish cells (fig. 1, B). About 30 varieties.

Tilletia caries (smut). -A blackish brown powder in the grains of

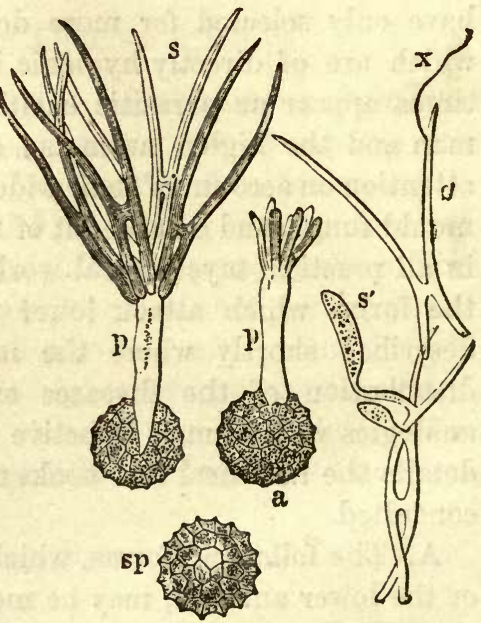

Fig. 2. - Tilletia caries $\times 400$.

$s p$, ripe spores.

$p p$, sprouting spores, at $a$ commencing development of the sporidia; at $s$ fully formed sporidia united in pairs.

$x$, germinating tube of a sporidium. $s^{1}$, secondary sporidia. 
wheat and spelt which smells of herring brine. The grains do not fall to pieces, but remain closed; hence the brand mass contaminates the meal, and imparts to it a disagreeable smell. Spores spherical, pale brown; episporium, with highly developed reticular thickenings. When the spores sprout there is formed at the end of the promycelium a whorl of threadlike sporidia, which at the lower half become united in pairs by a transverse branch, and drop off while thus united; these send out at some point or other a thread-like germinating tube, in which there is frequently a separation of secondary sporidia in the form of longish oval cells, which can again sprout (fig. 2).

When grown in saccharine solutions the Ustilaginea, according to Brefeld's recent investigations, form a continuous series of vegetative forms, the promycelium either continuing to develop in the form of buds, or the germinating tube of the resting spore growing to form a thread-like mycelium, which gives rise to spores by segmentation, either in the fluid or on branches rising into the air.

2. Entomophtoreæ (order: Basidiosporeæ). These Empusa organisms grow parasitically on insects, and cause the death of their hosts ; they are the cause of certain epidemic diseases of insects.

Empusa muscr.Parasitic on house flies. The flies which are killed by this fungus hang on the walls with their legs extended; three white belts (the basidia) project between the segments of the swollen posterior part of the body; the fly is surrounded by a broad white area of dust, which consists of spores which have been thrown off. The
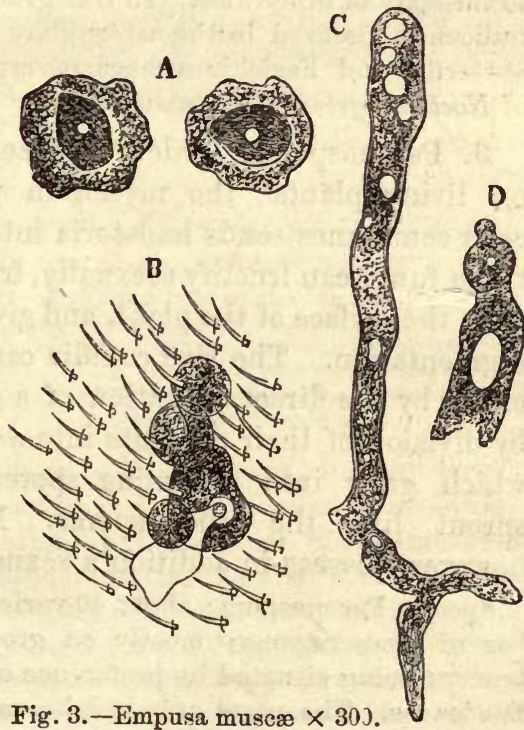

Fig. 3.-Empusa muscæ $\times 30$ J. (After Bref sld.)

$A$, ripe spores surrounded by protoplasm.

$B$, a portion of the skin of a fly with germinating spores.

$C$, a hypha formed in the interior of the body, the swollen end of which is doveloping into a basidium.

$D$, portion of a similar thread with the spore already evident 
Fungus of potato disease. spores $(0.011 \mathrm{~mm}$. in diameter) sprout readily on the skin of the abdomen of healthy flies, send out a germinating tube which penetrates under the skin and there forms, by budding, short round cells, which become detached and spread in the blood (the germinating tube possesses a very sensitive membrane which is at once dissolved in water, but not in salt solution). These cells ultimately develop into tube-like hyphæ, of which one end projects through the skin of the posterior part of the body, in the form of a club-like basidium. The upper end of the basidium then forms spores by the production of a pocket, into which plasma flows; this pocket, the future spore grows, and finally becomes cut off by. segmentation from the basidium. Large vacuoles are then formed in the latter, it takes up more and more moisture, and becomes swollen; finally it bursts, and the contents spouting out, hurl away the spore with considerable force. The empty tube shrinks, and in its place a new one appears, in which the same process is repeated. In this way the dusty layer of spores around the flies is formed; the round spores (fig. 3) are surrounded by a layer of plasma, which favours their adhesion to the body of other flies. To this group also belong Empusa radicans, observed in the caterpillars of the common white butterfly, and Farichium megaspermum in the caterpillars of Noctua segetum (Wintersaateule).

3. Peronosporeæ (order: Phycomycetes). Parasites on living plants; the mycelium present between the cells sometimes sends haustoria into their interior. All these fungi can fructify asexually, fruit hyphæ projecting from the surface of the plant, and giving rise to conidia by segmentation. The ripe conidia can at once germinate, either by the direct formation of a germinating tube, or by division of their contents into a number of portions, which grow into swarming spores; these ultimately sprout like the other spores. Many peronosporeæ, however, possess in addition a sexual fructification.

Species Peronospora; about 40 varieties, attacking a number of phanerogams; mostly on green parts, the conidia bearers being situated by preference on the under surface of the leaves. The parts attacked become prematurely yellow or brown, and die; the conidia bearers form a fine, grey, mould-like covering on the surface. Peronospora infestans : fungus of the potato disease; mycelial tubes $0.005 \mathrm{~mm}$. thick, without haustoria; conidia bearers with $1-5$ branches, thin towards the top, with ellipsoid or egg-shaped conidia (fig. 4).

This fungus has been known in Germany since 1830, and was rery destructive between 1845 and 1850 ; since then it 
has only been present when there was a large amount of moisture. From the end of June brown spots appear on the leares, the under surface of which shows the mould-like border of conidia bearers; this is soon followed by the death of the plant. 'Decomposition of the tubers then takes place; dirty brown patches indicate the development of the mycelium. On the dead tubers two forms of mould fungi frequently develop : Fusisporium solani and Acrostalagmus cinnabarinus, which however have nothing to do with the disease. The infective fungus lives through the winter in the tubers, reaches the field with the seed, and develops by preference during extreme moisture; it is only young parts with delicate membranes which permit the entrance of the germinating tubes. Disinfection experi-
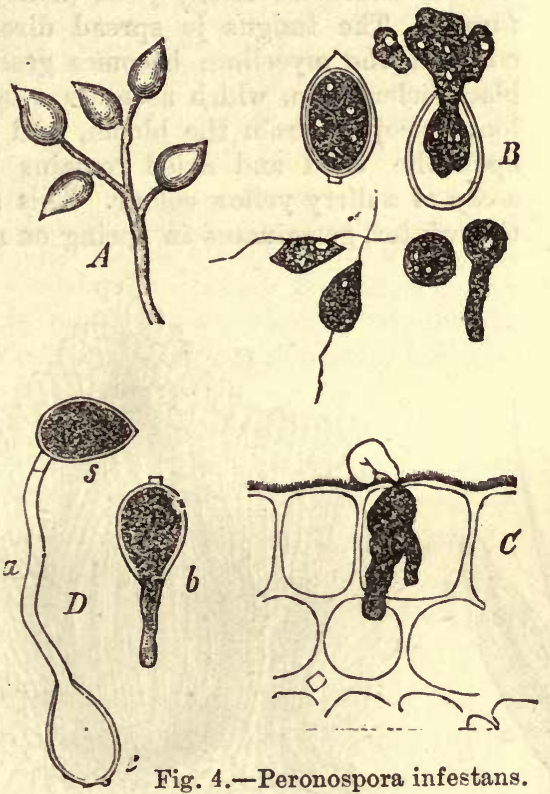

Fig. 4.-Peronospora infestans. (After de Bary.)

$A$, Young twig of the fungus.

$B$, Formation of swarming spores.

$C$, Swarming spores which have bored through the epidermis of a potato stalk.

$D, a$. The conidia $(c)$ forms a secondary one $(s)$. $b$. Sprouting of conidia.

ments have as yet been without result; but the local predisposition may be influenced by avoidance of moisture, the individual predisposition by the selection of resistant, toughwalled kinds of potatoes, and the seasonal predisposition by preserving the seed in a dry state and sowing late, a slow development of the fungus and a rapid growth of the potato being obtained in all these ways. Other kinds of peronospora occur on leguminous plants-clorer, vines, leares of beet-root, \&c.

4. Pyrenomycetes (order: Ascomycetes). They live partly as saprophytes and partly as parasites, on plants or insects. There are usually two modes of fructification: conidia and ascospores, the latter formed in perithecia.

Claviceps purpurea, the fungus of ergot, occurs in the fruit 


\section{CLASSIFICATION OF THE MICRO-ORGANISMS.}

Fungus of ergot. of grasses. The fungus develops in the first place on thebloom, in the form of a conidia-bearing stroma, which looks like a dirty white, cheese-like mass (sphacelia, see below). The numerous conidia project from the bloom, and are covered with a saccharine sticky juice (honey-dew) secreted by the fungus. The fungus is spread directly by means of the conidia; the mycelium becomes gradually converted into a black sclerotium, which assumes a horn-like form $(1-3 \mathrm{~cm}$. long), projects from the bloom, and carries at first on its apex the dead and dried remains of the mycelium, like a cap of a dirty yellow colour. This sclerotium lasts during the winter, germinates in spring on moist soil, and develops
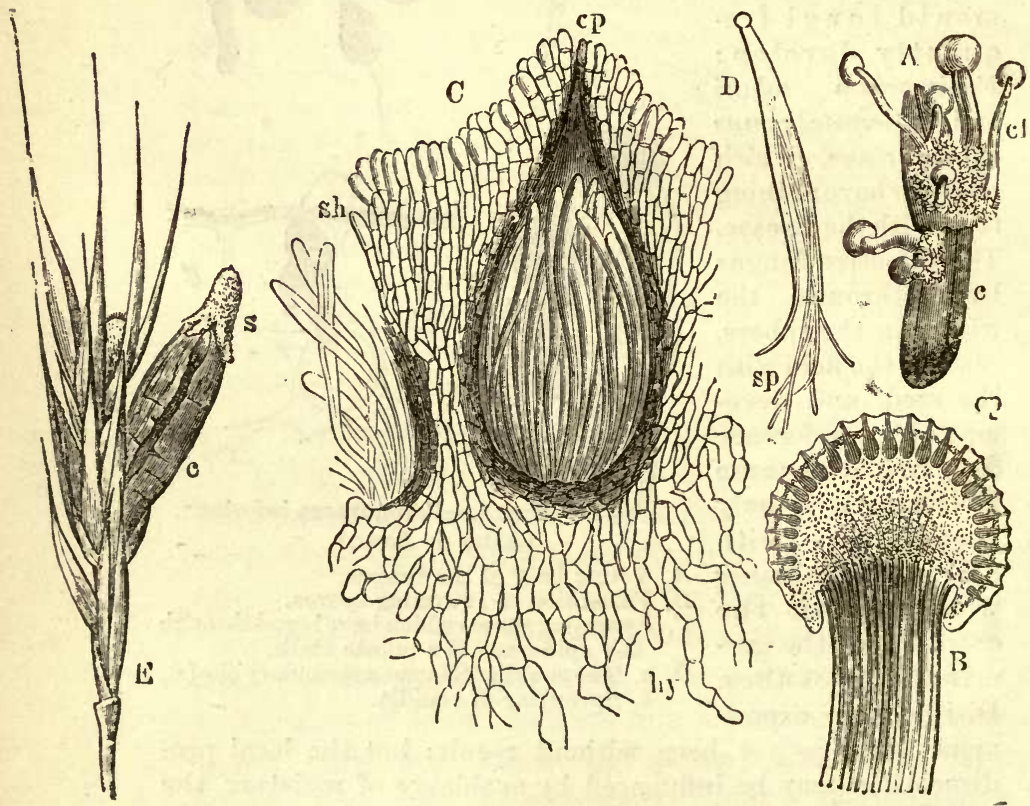

Fig. 5.-Claviceps purpurea.

$A$, sprouting sclerotium $(c)$ with fruit-bearers $(c l)$.

$B$, longitudinal section of the upper part of a fruit-bearing hypha;

$c p$, perithecia more highly magnified.

$C$, section through a perithecium; sh, external layer of tissue;

$h y$, network of hyphæ; $c p$; orifice of perithecium.

$D$, ascus torn and giving exit to the thread-like spores $s p$.

$E$, ear of rye with ergot $c$; $s$, remains of the sphacelia.

perithecial-bearing stromata in the form of small stalked reddish heads. The perithecia are embedded in the surface of the head; the spores are thread-like, unicellular. The sclerotium which has the form of a cylindrical, dark violet body with long sulci, and is in its interior white or reddish, and 
hard and wax-like, is known as ergot (Secale cornutum). It occurs most frequently in the bloom of rye, more rarely in barley and wheat. Damp situations favour its appearance.

To this group belong also Cordyceps isaria; fungi, whose conidia bearers (isaria) develop parasitically on living larvæ and caterpillars, while the perithecial fructification develops on the dead animals in the form of club-like stromata (cordyceps).-Also Fumago and pleospora, which are parasitic on ants, and laboulbenia on insects, but often without any serious disturbance of health.

Botrytis, grape mould.-Fruit hyphæ divided at the apex into little short closely aggregated branches, on which the unicellular spores are seated. The proper fructification by ascospores is unknown in most of the varieties. Mould-like fungi occurring on putrefying portions of plants, but also parasitic on insects.

Botrytis Bassiana, the muscardine fungus.-As was first Bassi's musrecognised by Bassi in the year 1835, this fungus is the cause cardine of the fatal disease of silkworms, called muscardine or calcino.
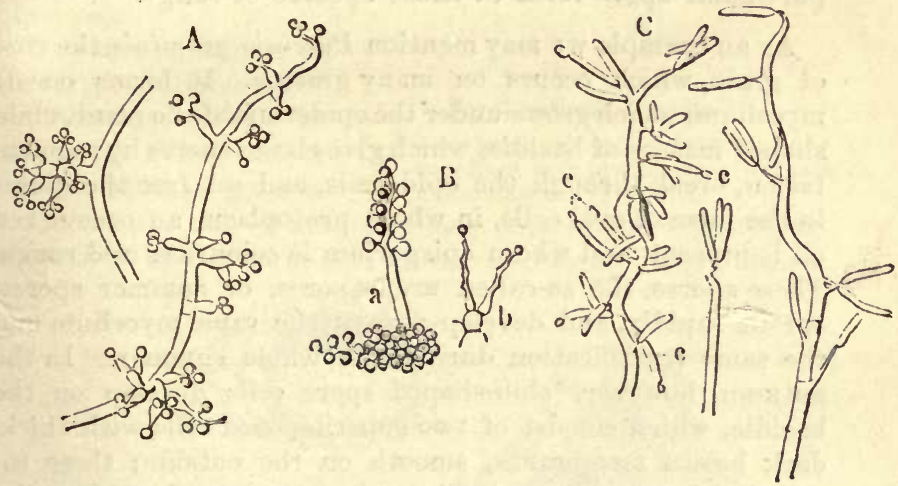

Fig. 6.-Botrytis Bassiana. (After de Bary.)

$A$, spore-bearing portions of the fruit hyphæ $\times 390$.

$B$, spore-bearing twigs, at $b$ most of the conidia have fallen off $\times 709$.

$C$, fungus threads from the inner part of the skin of a caterpillar, at $c$ numerous cylindriform conidia are being given off by strangulation $\times 300$.

This disease formerly caused great devastations, but for some years has almost entirely disappeared. This fungus also occurs on various indigenous butterfly caterpillars and insects. It penetrates through the skin into the body, the germinating tubes pass deeply anong the muscular bundles and fat lobules, where they give off cylindrical conidia from their sides and apices. These conidia multiply in the blood, and form a widely distributed mycelium by longitudinal growth and transverse segmentation. From this mycelium 
the numerous fruit hyphæ grow, clothe the stiff mummylike corpse with a snow-white mould, and bear on their sides several spore capsules, with colourless spherical spores. The latter germinate in various nutrient solutions, and are thus capable of artificial cultivation.

Rust fungi.

5. Uredineæ, or Ecidiaceæ (order: Basidiosporeæ). Parasites on plants. The thread-like mycelium grows between the cells of the plant which acts as host, and the organs of fructification which arise under the epidermis burst through it in the form of small, often reddish dust-like masses or patches, which consist of closely packed basidia. In most cases there is well-marked alternation of generation; formerly the different fructifying forms were described as distinct species of fungiuredo, puccinia, æcidium-while at the present time these former specific names are only used for the particular spore form of these species of fungi.

As an example we may mention Puccinia graminis, the rust of grain, which occurs on many grasses. It forms on its mycelium, which grows under the epidermis of the plant, clubshaped masses of basidia, which give rise to spores by segmentation, break through the epidermis, and set free the spores in the form of oval cells, in whose protoplasm an orange red oil is present, and whose episporium is colourless and rough. These spores, the so-called uredospores, or summer spores, sprout rapidly, and develop always the same mycelium and the same fructification during the whole summer. In the autumn, however, club-shaped spore cells develop on the basidia, which consist of two superimposed cells with thick, dark brown membranes, smooth on the outside; these so. called teleutospores, or winter spores, germinate in the following spring, but the germinating tube does not penetrate into a plant, but sends out only a few thin branches, at the end of which roundish, colourless cells are formed by segmentation. The sporidia so formed germinate quickly, not on grasses, but on the leaves of the barberry bush, through the epidermis of which the germinating tubes of the sporidia. penetrate. The thallus developed in the barberry is called Aicidium berberidis; from it short basidia are developed in flask-shaped organs (æcidium flasks, the covering of which is called peridia), and burst through the epidermis on the under surface of the leares. On the basidia long rows of simple roundish cells are formed, containing reddish-yellow oil drops. The rcidium spores germinate as soon as they are 
ripe, but the germinating tubes only continue to grow when they can penetrate into the stomata of the leaves of grasises. Here the original mycelium, with its uredospores, is then developed, and thus the peculiar cycle of derelopment of this fungus is completed. Along with the æcidia another fructifying apparatus, the spermogonia, always occurs; these are small jug-like capsules, which project by preference on the upper surface of the leaves, and shed their spores even before the xcidia are ripe; the germination of these spores has not yet been observed.

In some uredinea all three generations occur on the same host. In many rust fungi one or two of the chief genera-

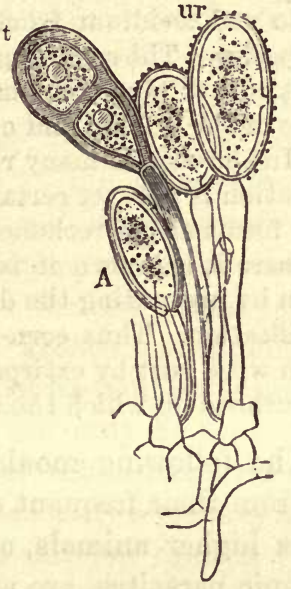

Fig. 7.-Rust of grain.

A, Puccinia graminis. A portion of the basidium with uredospores $(u r)$ and a teleutospore $(t) \times 390$.

tions are absent. When they only possess the teleutospore stage these spores germinate as soon as they are ripe, and com-

\section{B}
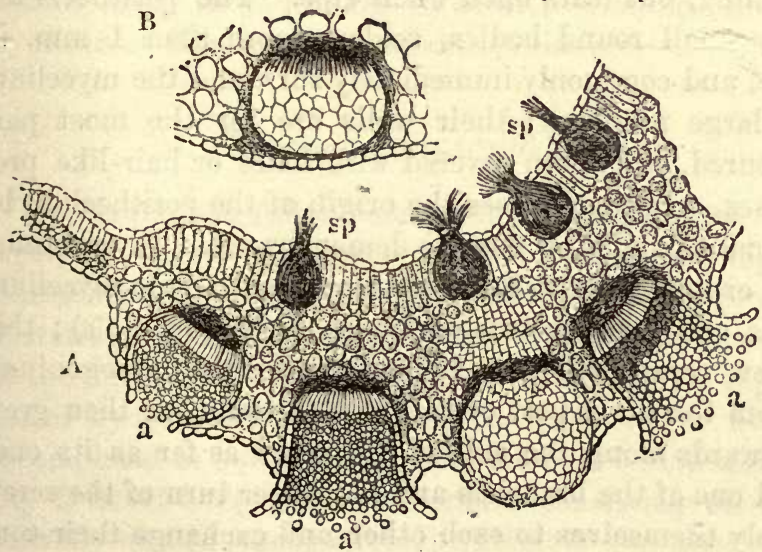

Fig. 8.

$A$, Acidium berberidis. Section through a thickened portion of the leaf containing æcidium flasks $(a)$ and spcrmogonia (sp.) At $a$ the under surface of the leaf.

$B$, section through an $x$ cidium in a young condition. 
mence the development again; if only the æcidia exist, the development begins likewise directly they are ripe, and the process of germination is similar to that of the teleutospores. The species of the uredineæ are described according to the teleutospores because these show distinct differences, while the uredo and æcidium fructification essentially coincide in all the species. The rust fungi occur extensively on the most various kinds of phanerogams, on grasses, shrubs, and trees. Moisture of the ground and of the air favours their development. In the case of many rust fungi the actual alternation of generation is not yet certain, and hence the independence of many forms as yet reckoned as particular species is doubtful. Where it is known it is often possible to prevent the infection by preventing the development of one of the stages of fructification. Thus corn-fields may be protected against infection with rust by extirpating the barberry bushes in the neighbourhood on which the æcidium generation occurs.

B. The following mould fungi, which are interesting either from their frequent occurrence, or from attacking at times higher animals, and even man, in the form of pathogenic parasites, are worthy of note :-

Perisporiacex. 1. Some forms of the Perisporiacex (order: Ascomycetes). In the fungi belonging to this family the spore tubes are formed in the interior of a capsule-like fruit body, the perithecium; the latter has no preformed opening, but tears open when ripe. The perithecia are very small round bodies, seldom more than $1 \mathrm{~mm}$. in size, and commonly immediately surround the mycelium in large numbers; their walls are for the most part coloured, and often covered with hairs or hair-like processes. In many cases the origin of the perithecium by sexual fecundation may be demonstrated. In eurotium, for example, short twigs develop from single mycelium cells and become twisted like a screw (fig. 9, c) ; this screw represents the female organ, the ascogonium. From the lower part of this thread branches then grow outwards along the side of the screw as far as its end, and one of the branches and the upper turn of the screw apply themselves to each other and exchange their contents; after this fecundation the male branches, the rollinodia, divide and branch frequently, and thus form a corering which becomes the wall of the perithecium. 
Some observers look on this supposed sexual copulation as only an unimportant anastomosis of hyphæ.

Besides the perithecia many perisporiacer present a second asexual fructification on the same mycelium; simple fruit hyphæ are formed which give rise to spores, or conidia, by fission. This asexual fructification is extremely widely spread, and very frequently it is the only form; it is only the presence of a large amount of nutriment which predisposes to the formation of perithecia. Thus the most common mould fungi usually form only the asexual fructification, and their connection with the perithecial forms is for the most part only recognised at a later period. Hence the conidia forms of these fungi were described as particular species, while from recent researches they can only be looked on as secondary fructifying forms of the ascomycetes. The conidia germinate readily immediately after they are ripe, form a mycelium, and again develop conidia bearers; on mycelium arising in this way from conidia, perithecia can also presumably develop under suitable conditions, but this has not as yet been directly observed. The ascospores are as a rule only able to germinate after a period of rest ; in the case of some of them it is certain that they develop to form a conidia-bearing mycelium. The most important species are-

\section{Eurotium-aspergillus.}

We distinguish (after Siebenmann) the so-called true Aspergillus. aspergilli (Asp. clavatus, flarus, fumigatus, niger, ochraceus, albus), and the two eurotium forms proper (Eurotium aspergillus glaucus and Eurotium repens). In the former the higher form of fructification is represented by a form of sclerotium, the formation of which is completed in two periods. In the first period a resting fruit (Dauerfrucht) is formed consisting of the centrally placed ascogonium, which is for the time being inactive, and the store material originating from the carpogonium. This condition persists so long as the sclerotium is in a dry surrounding. On a moist 
substratum the second period at once begins; after absorption of the store material the ascogonium enlarges and sends out branches which finally develop into asci containing spores. In the eurotium forms, on the other hand, very delicate perithecia form in the place of the tough sclerotia, and present the appearance of refracting clear yellow or sulphur yellow transparent bodies of the size of a grain of sand with an enveloping membrane which is very easily crushed.

The sclerotia of the true aspergilli are found in old

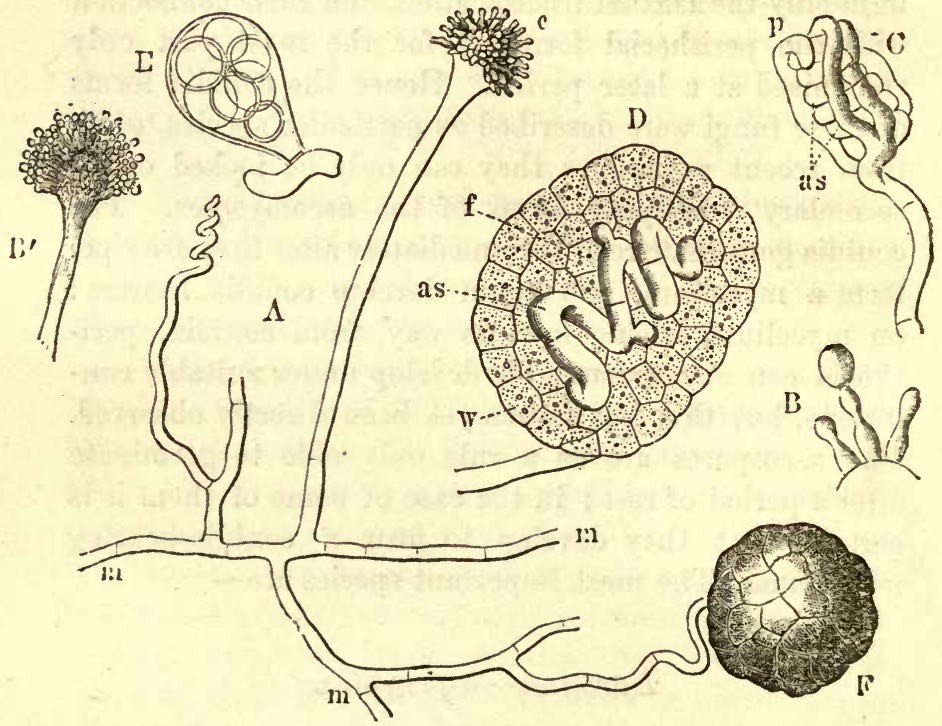

Fig. 9.-Aspergillus glaucus. (After de Bary.)

$A$, porticn of a mycelium thread $(m)$ with a conidia bearer $(c)$ and a young Eurotium perithecium $(F) \times 190$.

$B, B^{\prime}$, conidia bearer with basidia and conidia. $B$, some of the basidia more highly magnified.

$C$, ascogon surrounded by the pollinodia.

$D$, young perithecium cut longitudinally; $w$, the future wall; $f$, the store material $\times 250$.

$E$, an ascus with spores from a perithecium $\times 600$

cultivations (for example on brown bread) arranged in nests in those places where there is incomplete access of air, and where therefore conidia bearers do not grow ; they form granules $0.5-1.5 \mathrm{~mm}$. in diameter, and of irregular form. Usually, however, only the conidial 
fructification is met with. Fruit-bearing hyphæ, not branching and $0.3-10 \mathrm{~mm}$. in length, arise from a colourless mycelium consisting of delicate hyphæ. These fruit hyphr are globular at their upper end, or dilated in the form of club-shaped bladders, on which thin projections or sterigmata are arranged radially. It is only in the eurotium forms that the sterigmata are separated by septa from the bladders of the fruit-bearers. The sterigmata give off at their apices a succession of conidia, consisting of round or somewhat oval cells $1-6 \mu$ in diameter. Some aspergilli (A. clavatus, flavus, fumigatus) have unbranched sterigmata; in the other three on the contrary they are branched. The latter forms are also described as sterigmatocystis.

Asp. flavus or flavescens. - Yellow or greenish brown masses of fungi. Conidia yellow or brown with a fine warty surface; $5-7 \mu$ in diameter. Sclerotia very small, black. Grows best at about $+28^{\circ} \mathrm{C}$.

Asp. fumigatus.Greenish, often bluishgrey masses very like penicillium. Short conidia bearers, curred forwards to form a hemispherical bladder, $8-20 \mu$ in diameter. Closely packed awl-shaped sterigmata on

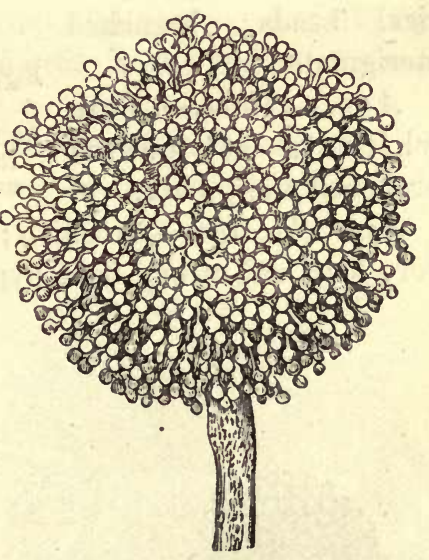

Fig. 10.-Aspergillus flavus $\times 300$. (After Siebenmann.) the hemispherical cup. Conidia round, smooth, with single contour, for the most part colourless, $2 \cdot 5-3 \mu$ in diameter. Sclerotia unknown. Thrives best at $37^{\circ}$ $-40^{\circ} \mathrm{C}$.

Asp. niger.-Dark brown masses. The knob of the fruit hypha completely spherical. Sterigmata 20-100 $\mu$ in length, branched like a hand. Conidia round, when ripe blackish-brown ; diameter $3 \cdot 5-5 \mu$ Sclerotia 
brownish red, of the size of a rape seed. Best temperature $34^{\circ}-35^{\circ} \mathrm{C}$.

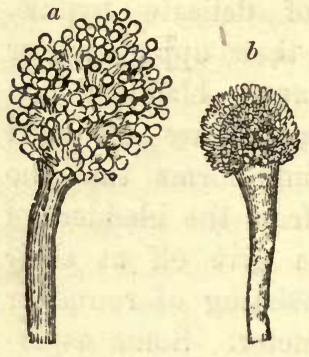

Fig. 11.-Aspergillus fumigatus $\times 300$.

(After Siebenmann.)

Asp. ochraceus.At first of a flesh colour, later ochre yellow; spherical heads; branched sterigmata.

$$
\text { Asp. albus. - Pure }
$$
white in all parts; branched sterigmata.

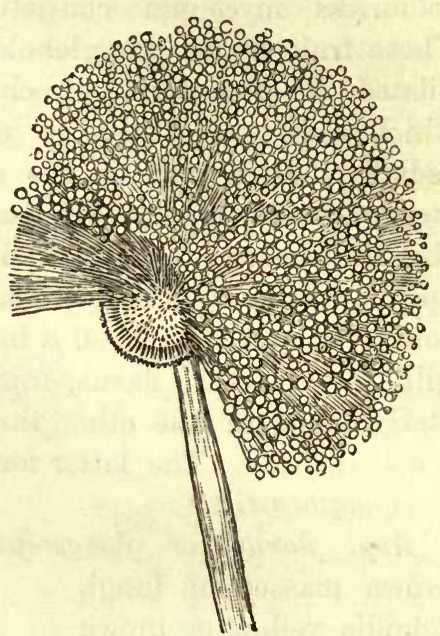

Fig. 12.-Aspergillus niger $\times 300$. (After Siebenmann.)

At the lower part on the left side the sterigmata have been removed astificially.

Asp. clavatus.-Greenish; club-shaped bladders on very long and strong fruit hyphæ; very smull conidia.

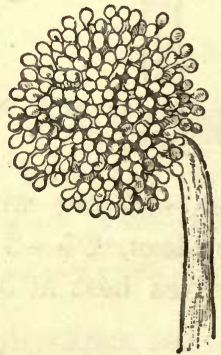

Fig. 13.--Eurotium aspergillus glaucus $\times 300$. (After Siebenmann.)

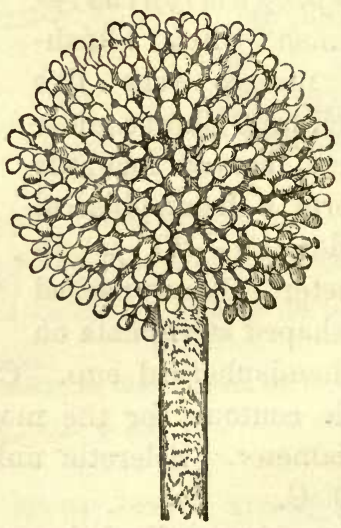

Fig. 14. - Eurotium repens $\times 300$. (After Siebenmann.)

The eurotium forms possess mycelium and conidia bearers like the true aspergilli. The perithecia, the 
formation of which corresponds with the general description given above, appear to the naked eye as brightly refracting, very small, round granules ${ }_{18}^{1}-\frac{1}{4} \mathrm{~mm}$. in diameter, arising from the aërial mycelium, which is of a sorrel colour in this stage of fructification.

Eurotium aspergillus glaucus. - Bluish-green or yellowish-green; heads regularly round. Conidia round, warty or knobby ; $9-15 \mu$ in diameter. It occurs in fruit juice, moist wood, frequently on damp walls, but only in very cool places-about $10^{\circ}-12^{\circ} \mathrm{C}$.

Eurotium repens. - At first white, ultimately dark green; heads often fringed; conidia oval, smooth, colourless or greyish-green, $5-8.5 \mu$ in largest diameter. Occurs on preserved fruits, bread, \&c.; the best temperature is $10^{\circ}-15^{\circ} \mathrm{C}$.

The aspergilli have of late excited special interest Pathogenic because some of them (Asp. fumigatus, Asp. flavus, properties of and Asp. niger) are able to grow in the bodies of warmblooded animals.

This pathogenic property was first ascertained by Action of studying the result of the injection of mixtures contain- injections of ing spores into the blood stream of animals, especially of rabbits. When the number of spores injected was very large the animals died in a few days, and numerous small deposits of fungus mycelium which had developed from the spores were found in the internal organs. If smaller quantities of spores were employed, the animals lived, but if they were killed after two or three days a small number of mycelial deposits were

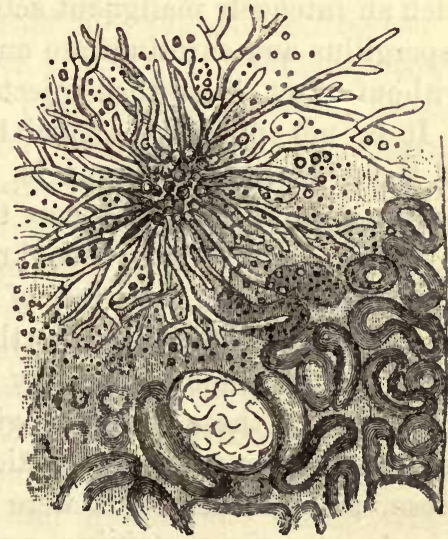

Fig. 15.-Microscopical section from the kidney of a rabbit killed 36 hours after the injection of spores. (After Grawitz.) found; at later periods these had disappeared, so that when 
in small numbers they were evidently quickly destroyed and were only able to occasion the death of the animal when in enormous quantity. The mycelia formed from the spores are not equally distributed in all the organs. The kidneys are attacked by preference; then the cardiac and other muscles; at times numerous masses are found in the liver. After the injection of the spores of Asp. fumigatus there are very peculiar disturbances of equilibrium, the animals lying on one side with the head placed obliquely, the one cheek looking upwards, the other downwards; the ejes are directed towards the same side. If one attempts to raise the animals from this position they resume it at once; if one places them on the opposite side they remain at first in this position, but soon assume the old posture with violent rotatory movements around the long axis. Lichtheim found that the explanation of these symptoms was the localisation of the fungi in the membranous labyrinth.

nfectivity of he different pecies of pergillus.

Vatural ocurrence of uspergillus nfection.

in birds.

The success of the infective experiments is most certain with Asp. fumigatus, and then with Asp. flavus. The spores of Asp. niger do not appear to have by any means such an intensely malignant action; the other species of aspergillus and eurotium are on the other hand entirely without effect, even when injected in large quantities.

It is not only by artificial infection that growth of these aspergillus forms is observed in the animal body, a natural infection seems to occur not uncommonly. Mycotic diseases have been known for a long time to occur in the ear passages of birds; in these cases we have to do with the growth of aspergilli. Schütz has recently demonstrated by exact experiments that the spores of these mould fungi can as a matter of fact set up severe pneumonic affections. If healthy pigeons, geese, and smaller birds were exposed for only a few minutes to air containing numerous spores of Asp. fumigatus the animals died of pneumonia as late as the fifth day afterwards. Numerous mycelial threads were then found in the bronchi, and in the cases where the disease had lasted longest extensive necrosis was present. 
An affection of the air passages also occurred when masses containing spores were swallowed. The pneumonomycosis aspergillina is caused most often by Asp. fumigatus, more rarely by Asp. niger; the spores of the latter do not form a luxuriant mycelium, but only germinate imperfectly, while Asp. fumigatus can even fructify in the larger bronchi when there is a plentiful supply of free oxygen to the mycelium. In zoological gardens extensive epidemics of these mycoses hare also been observed. In the case of mammals also, for example in cows, In mammals. similar conditions have been seen in the lungs, and aspergillus mycelium has been often observed in human sputum and in the bronchi of dead bodies. Hence it is not impossible that the inhalation of similar spores have also occasionally set up pneumonic affections in man.

Deposits of aspergilli have been found on two parts In man. of the surface of the buman body. Leber observed, after abrasion of the cornea by an ear of corn, that an abundant development of aspergillus mycelium took place in the cornea accompanied by severe suppurative lieratitis. On inoculation of the spores of the fungus cultirated pure in an artificial soil, on the cornea or into the anterior chamber of the eye of rabbits, growth of the fungus occurred. Further, the aspergilli develop not uncommonly in the external auditory meatus; nevertheless only when diseased conditions are already present, such as perforation of the tympanic membrane with degeneration of the wall of the tympanic cavity, and when there is a layer of serum which can act as a suitable nutritive substratum. In that situation suppurative and putrefactive processes interfere with the development of the aspergilli, while the use of astringent remedies as a rule favours it; the introduction of oil readily sets up eczema, and thus favours the growth of the fungus, or at any rate of the mycelium, while the formation of conidia is hindered.

It is noteworthy that it is only those aspergilli whose Temperature temperature optimum is high and approaches the body infective temperature, that can grow in the bodies of warm-blooded aspergilli. 
animals. Fränkel* was unable to diminish their pathogenic properties by the continued action of abnormally high temperatures. He cultivated Aspergillus fumigatus for half a year at $51^{\circ}$ C., numerous re-inoculations being made; under these circumstances the fungus formed only a sterile mycelium, and it was necessary to continue the cultivations from this mycelium. When however it was placed at a temperature of $37^{\circ} \mathrm{C}$., the fungus at once began again to fructify, and the spores formed proved to be as virulent as others cultivated

Distribution of the aspergilli. in the ordinary manner.-All these fungi appear to be very widely distributed in our climate. According to Siebenmann, it is only necessary to expose freshly baked brown bread to the air for a short time, to place it then in a moist chamber and to regulate the temperature at various heights; according to the temperature, it is found that either on the surface or in the interior of the piece of bread one or other form of aspergillus has developed.

\section{Erysiphe ö̈dium.}

Erysiphe forms the mould-like covering on living plants which is known as mildew. Summer and winter spores are developed; the former have the appearance of oval unicellular conidia which are formed by segmentation on single upright fruit hyphæ; the winter spores are formed in the perithecia which arise at a late period on the same mycelium, and they are only able to germinate after a period of repose. The fructification by conidia was formerly described as a separate species of fungus under the name oïdium. In the case of some forms of oïdium the corresponding perithecial fructification has not yet been found. Mildew attacks the most various kinds of plants, and the different species of plants have their particular forms of mildew. The plants which are attacked droop and die early. Damp weather in the latter part of summer and autumn and moist situations are favouring conditions.

Two important kinds of oidium whose perithecia are as yet unknown belong to this group.

\footnotetext{
* Deutsche med. Wochenschrift, 1885, No. 31.
} 
Oidium Tuckeri, the fungus of vine disease.-A whitish mildewy layer appears on brownish patches of the leaves and twigs of the vine, and also attacks the young berries, whose epidermis dies and bursts. The longish round conidia are placed singly on the fruit hyphæ.

Ö̈dium lactis.-Fruit hyphæ, single, upright, colourless; form a terminal chain of spores; at times apparent formation of branches, the fruit hyphæ growing upwards alongside the terminal chain of spores already formed. Spores short, cylindriform, $0.0077-0.0108 \mathrm{~mm}$. long (fig. 16). Very widely distributed, forming a whitish mouldy coating on milk, bread, dung, \&c. Flourishes best between $19^{\circ}$ and $33^{\circ} \mathrm{C}$. (Hausen).

In some parasitic skin affections of man development of fungi has been for a long time observed, and these fungi appear to have a certain resemblance to the mycelium and fructification of oïdium. Grawitz has in fact attempted to prove by cultivations that the favus fungus (Achorion Schönleinii), the fungus of Tinea tonsurans (Tricophyton tonsurans), and the fungus of Pityriasis versicolor (Microsporon furfur) are identical with $\mathrm{Oi-}$ dium lactis. According to Grawitz the conidia of this fungus, when cultivated artificially, form one or several germinating tubes; these soon become segmented and send out lateral branches which elongate by apical growth. The growth ceases often after a very short, often again after a longer time, and segmentation of the threads into conidia begins; these conidia are

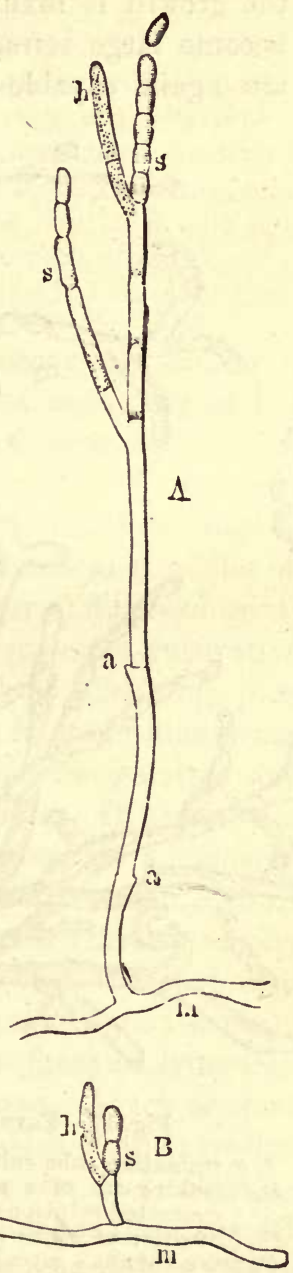

Fig. 16.-Oidium lactis.

$A$ older, $B$ younger, fruit hyphæ. m, mycelium ; $s$, chains of spores in the neighbourhood of which the fruit hyphæ $(h)$ continue to grow like a la. teral branch. $\times 200$. at first almost cubical cells, but later assume a longish oval

Oidium as the cause of Favus and Tinea tonsurans. 
form by rounding off of the borders. Certain threads give off lateral branches almost at right angles; where the growth is luxuriant, eertain of the lateral branches become large refracting globes, which are cut off, ard are again capable of growth. The mycelium of the

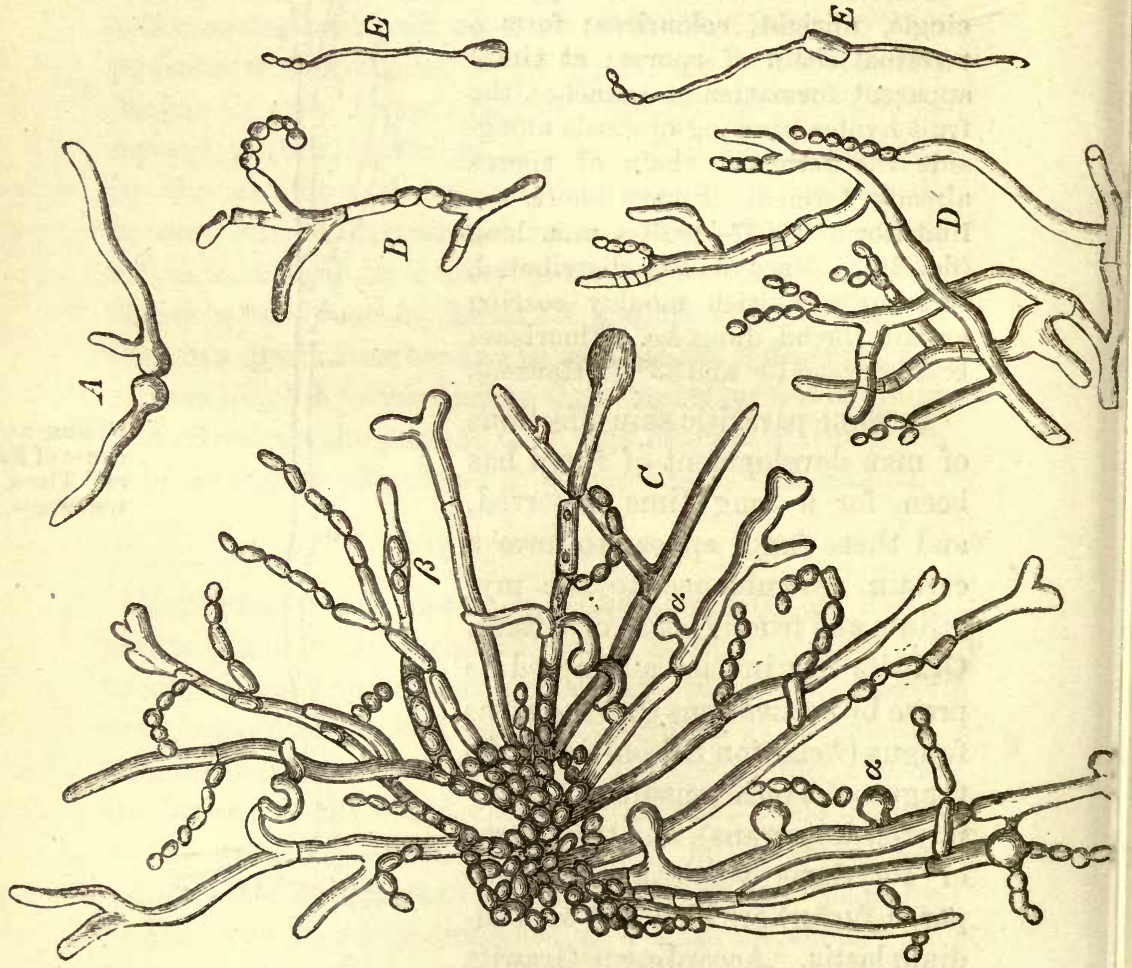

Fig. 17.-Favus and Tinea fungus. (After Grawitz.)

A. cerminating tube cultivated in gelatine solution.

$B$, kreaking up of a germinating tube into single conidia (in concentrated solution).

$C$, formation of fruit; $a$ formation of buds ; $b$, formation of gemmæ.

J), tinfa fungus ; mycelial threads with fructification.

$E$, conidia of Oidium lactis (in dilute acid nutrient solution, from which thin germinating tubes are growing out) $\times 350$.

tinca fungus, \&c., is very delicate in comparison with the much thicker conidia of the Oidium lactis growing on milk; but on alteration of the nutrient substratum Grawitz was able to obtain great varieties in this respect, so that, for example, a large conidia sent out a much 
more delicate thread, which then gave off a cell of onefourth of the diameter of the original one.

Grawitz's experiments were performed at a time when there were no trustworthy methods of isolating individual fungi from a mixture of organisms, such as are usually present on the affected skin, and hence they urgently require repetition with better methods, and the asserted identity is rendered very doubtful by the result of experiments made with other mould fungi. Oïdium lactis flourishes only comparatively imperfectly at the body temperature, and therefore its parasitic existence on the surface of the body is improbable.

In the lower animals affections occur very similar to Fungus of favus in man, and in these the causal agent has of late been cultivated pure. Such are the fungus of tinea galli fowl scal and that of the so-called favus of mice. The first has been studied by Schütz; it leads to the formation of whitish grey round patches on the comb and wattles of fowls, which gradually merge together and spread on to the neck, breast, and trunk. By continued cultivation on nutrient jelly Schütz succeeded in obtaining pure from the scales on diseased combs a fungus which forms a white mycelium, gradually liquefies the gelatine and causes it to assume a reddish colour. It grows also on potatoes, bread paste, \&c., and best at a temperature of about $30^{\circ}$ C. Microscopically the mycelium consists of segmented and often branched threads of very various dimensions; not uncommonly these threads show small warty or pedunculated projections; some of the segments are also globular, while others are lying free, and occasionally provided with processes. Again, in some cases fine shoots are seen on the sides of the mycelial threads, these shoots bearing one or two globular greyish coloured bodies. Whether these or the spherical bodies, or neither of them, are to be regarded as spores is as yet uncertain; the position of the fungus is therefore doubtful, and it is only the microscopical similarity of the mycelium and the simple separation of the cells supposed to be spores that has led to its provisional inclusion among the forms of oildium. Inoculation of pure cultivations of the fungus gave rise to the charac- 
Fungus of monse favus.

teristic morbid symptoms in fowls; mice, rabbits, and various other animals were not affected.

Mouse favus has been repeatedly studied, and quite recently in the author's laboratory. Nicolaier demonstrated that the disease could be transmitted by the application of scales to patches of the skin of healthy mice previously scraped with a knife and denuded of epidermis. After about eight days a crust is formed about the size of a lentil, whitish yellow, and pitted in the middle; this crust constantly enlarges till it finally comes to occupy the whole forehead and ears, spreads over the eyes and covers the head of the animal with a
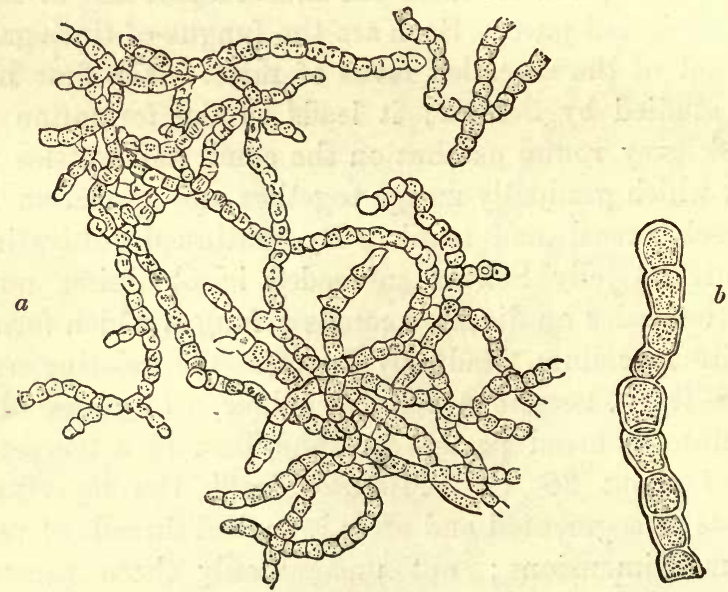

Fig. 18.-Cultivation of Mouse Favus.

$a$, mycelial threads $\times 300 ; b$, a thread more highly magnified $\times 700$.

whitish grey dry mass of a laminated character which forms a thick lajer on the skin. Small crusts planted on acid nutrient agar, or on potatoes impregnated with tartaric acid, and kept at $30^{\circ}-35^{\circ} \mathrm{C}$., give rise after repeated recultivations to a pure cultivation of a fungus which forms a thick low mycelium, at first of a pure white colour, with very closely packed, delicate hyphr, so that the whole mass (particularly on potatoes) looks like a crust of sugar. At a later period the surface of the mycelium assumes a red or reddish-brown colour. In microscopical preparations of the favus crusts, or of cul- 
tivations, we see a maze of jointed threads which are terminated by oval cells somewhat flask-shaped, or in some cases more spherical.

Special spore-bearing hyphæ or distinct spore formation have not as yet been observed. Inoculation of mice with small quantities of cultivations carried through a considerable number of tubes gave rise in all cases to the peculiar disease just described; inoculation of a cock was tried without result.

Cultivations made from human favus furnished appearances on the whole microscopically and macroscopically similar, but not identical; the investigations on this point are not yet concluded. All these three fungi probably belong to one species, and are in some respects closely allied to the oildium fungi, but they appear to differ among themselves as well as from the Oidium lactis, as shown, for example, by the differences in their temperature optima.

The fungus of thrush was formerly described under the name of Oidium albicans, and placed among these fungi. Recent investigations render it, however, probable that the thrush fungus belongs to the yeast fungi.

2. Mucorineæ (order: Zygomycetes). Very widely distributed; on putrefying substances they form white or brown patches of mould, which consist of delicate mycelium and fruit hyphæ given off at right angles. At the apex of the latter a globular sporangium is formed, the protoplasm of which breaks up into a large number of spores. The membrane of the sporangium is at first colourless, but later it usually becomes blackish, and when the sporangium is ripe it dissolves in water. Many mucorineæ form zygospores by the copulation of two mycelium branches; there is often also a formation of gemmæ.-Among these we may mention: Mucor Saprophytic mucedo. Fruit hyphæ colourless, simple or branched, forms of 1-13 cm. long; sporangia yellowish-brown to black; 

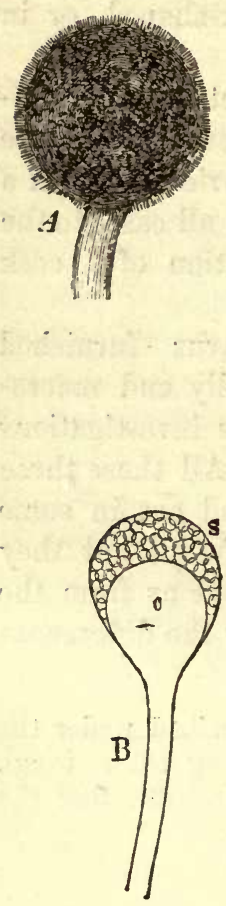
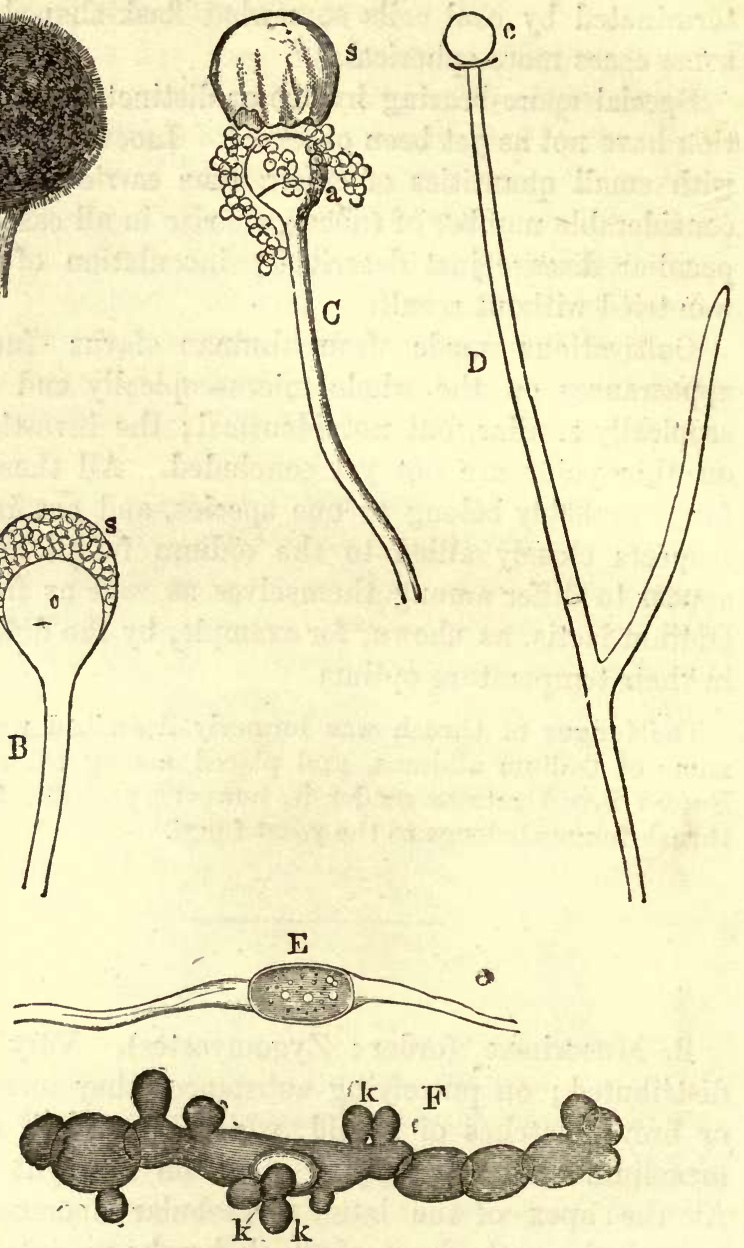

Fig. 19.-Mucor mucedo.

$A$, ripe sporangium.

$B$, the same, represented as transparent; $e$, columella; $s$, the space filled with spores.

$C$, almost ripe sporangium, the membrane having been removed by artificial pressure.

$\Pi$, fruit hypha with naked columella $(c) \times 70$.

$E$, an old mycelium thread which has formed an end cell which has become converted into a gemma $\times 350$.

$F$, spore of Mucor racemosus which has sprouted in a sugar solution to a germinating tube, and has formed spherical yeast-like cells (k) $\times 350$. 
membrane smooth, or closely covered with acicular cystals of oxalate of lime (fig. 19). Longish spores $(0.008 \mathrm{~mm}$. long, $0.0037 \mathrm{~mm}$. broad). Very widely distributed on all sorts of nitrogenous substances.Mucor racemosus, much more delicate fruit hyphæ, at most $1.5 \mathrm{~cm}$. long; sporangia yellowish to light brown; spores roundish. Grows extensively on substances rich in carbo-hydrates. When the mycelium is old, or when the spores germinate under water, so-called gemmæ or brood cells (that is to say, pear-shaped swollen spots, which develop thick membranes and a protoplasm rich in oil) are formed in the hyphæ.-On continued cultiration in saccharine fluids the germinating tubes become constantly shorter, and show yeast-like budding; the spherical segments are termed spherical or segmentation yeast (Kugel- or Gliederhefe). These spherical yeast cells readily lead to deficiency of oxygen in the nutritive medium, and can then break up any sugar which is present into alcohol and carbonic acid-in other words, set up fermentation. The rising bubbles of carbonic acid usually however carry the yeast cells to the surface, where they again form normal mycelium, so that the setting up of fermentation, and the production of $\mathrm{CO}_{2}$, seem to be the means by which the fungus returns to its normal conditions of life.

Mucor stolonifer.-Mycelium, with branches rising in arches and again sinking, and attached by root hairs; sporangia deep black and warty; spores brownish, almost spherical, 10-20 mikrom. in diameter; zygospores dark brown.

Further : M. macrocarpus; M. fusiger; M. aspergillus; M. phycomyces, rare.

M. Melittophtorus.-Found in the stomach of bees; colourless hyphæ, with egg or pear-shaped sporangia; colourless elliptical spores.

Lichtheim has recently discovered two new species of Pathogenic mucor which exert a pathogenic action : species of mucor.

M. rhizopodiformis. Mycelium at first snow-white, then mousy grey; mycelial threads colourless; brownish mycelial branches rise and sink in an arched manner on the surface of the substratum, giving rise at the point of contact to short-branched rhizoids, with 
straight pointed branches which run downwards, and to sporangia bearers which pass upwards, very like $M$

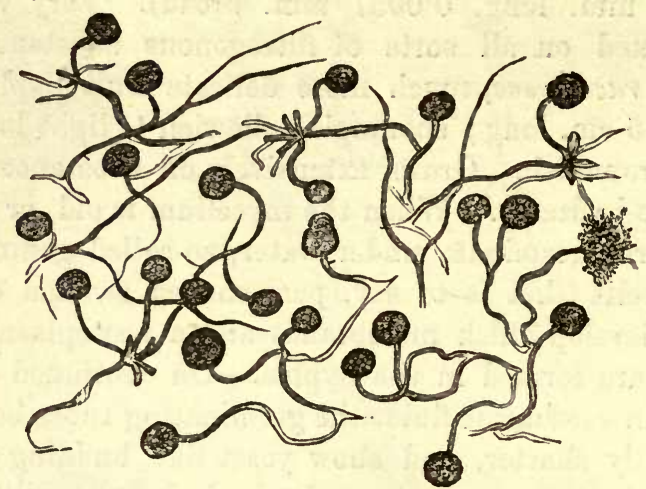

Fig. 20A. - Mucor rhizopodiformis. (After Lichtheim.)

Zeiss A, eye-piece 5 .

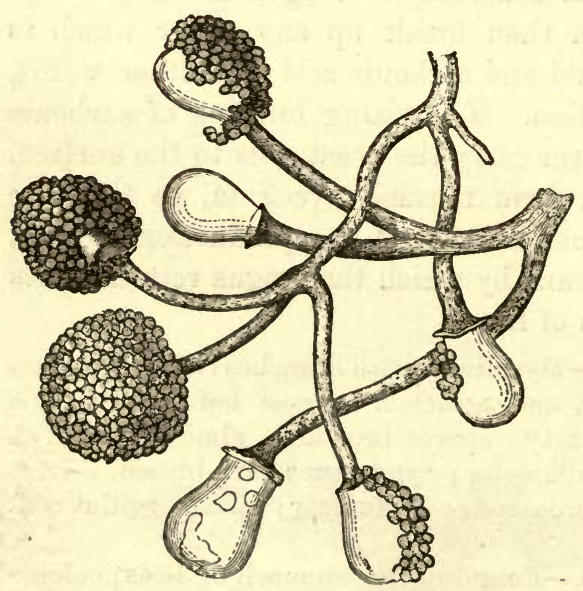

Fig. 20B.-Mucor rhizopodiformis after rupture of the membrane of the sporan. gium. (After Lichtheim.)

Zeiss E, eye-piece 2.

stolonifer, but with shorter sporangial stalks; the egg-shaped columella is arched forwards in a dome-like manner, and diminishes in size towards its base ; spores colourless, and only $5-6 \mu$ in diameter. M. corymbifer. Mycelium whitish grey ; sporangia bearers not passing upwards at right angles, but stretched lengthways, branched in an umbelliferous manner, and forming at the end of the branches a number of grape-like, umbelliferous, closely packed sporangia; the latter are also colourless when ripe, rounded off at their apex, jointed, top-shaped and gradually narrowing as they pass 


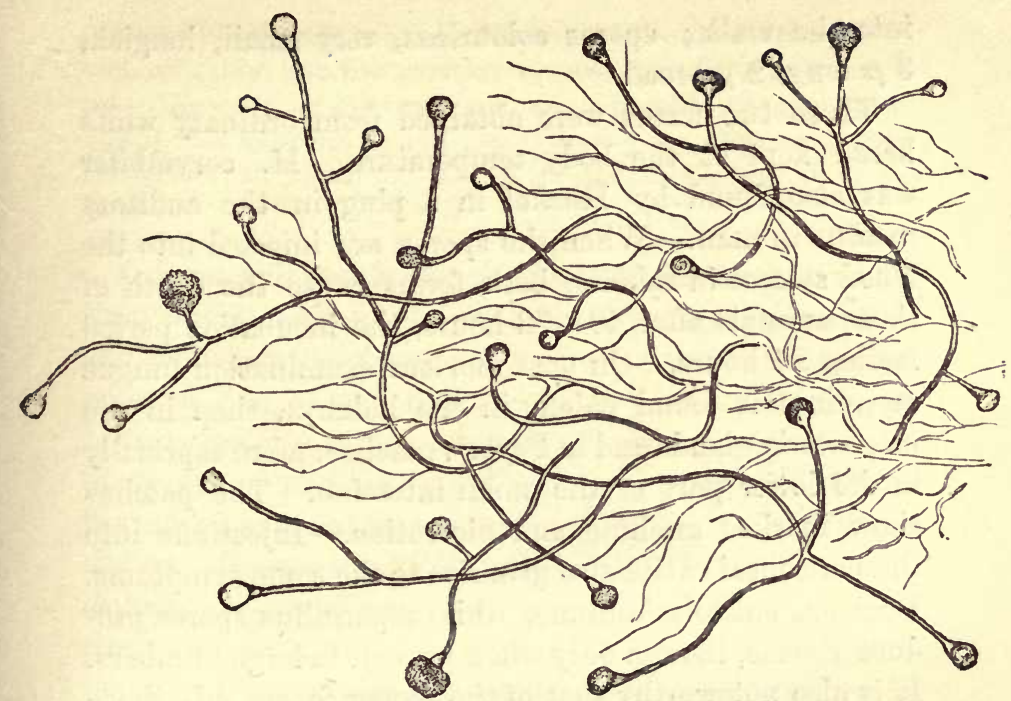

Fig. 21A.-Mucor corymbifer. (After Lichtheim.)

Zeiss C, eye-piece 4.

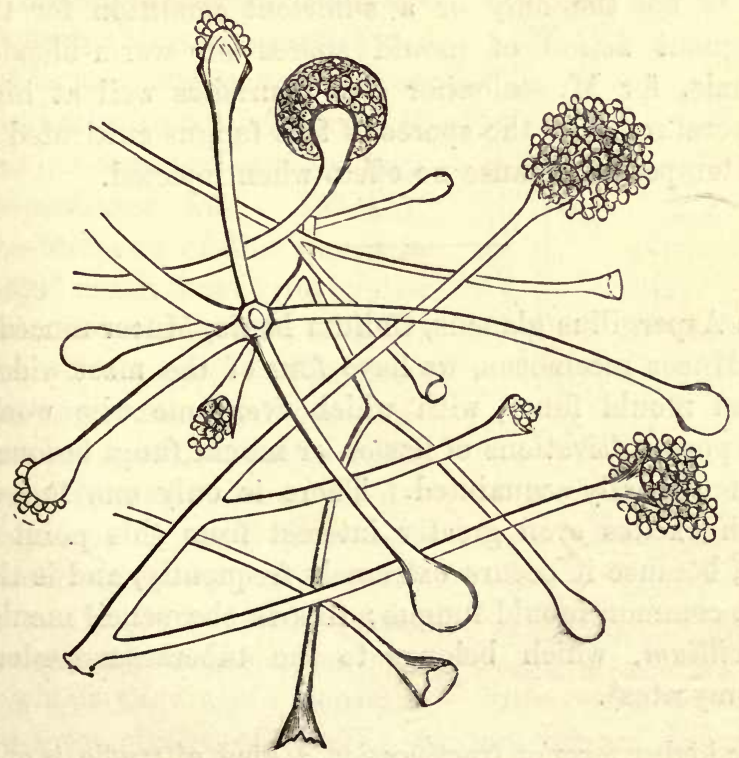

Fig. 21B.-Mucor corymbifer. After rupture of the wall of the sporangium. (After Lichtheim).

Zeiss E, eye-piece 5. 
into the stalk; spores colourless, very small, longish, $3 \mu$ long, $2 \mu$ broad.

These two forms were obtained from ordinary white bread kept at the body temperature. M. corymbifer was also found by Hückel in a plug in the auditory meatus in man.- When the spores are injected into the blood stream in rabbits, both forms cause the death of these animals after $48-72$ hours, the incubation period lasting 24 hours. On post-mortem examination fungus mycelium is found chiefly in the kidneys, then in the mesenteric glands and in Peyer's patches, more especially in the lower part of the small intestine. The patches show marked swelling and ulceration.-Injections into the peritoneal cavity also give rise to the same symptoms. Dogs are entirely immune, while aspergillus spores produce disease, though only when present in large numbers. It is also noteworthy that of the mucor forms only those can exert a pathogenic action which grow well at the body temperature. On the other hand it is evident that this is not the only or a sufficient condition for the malignant action of mould spores on warm-blooded animals, for M. stolonifer also flourishes well at high temperatures, but the spores of this fungus cultivated at that temperature cause no effect when injected.

The common pencil mould, Penicillium glaucum.

In Aspergillus glaucus, Ö̈dium lactis, Mucor mucedo, and Mucor racemosus, we have four of the most widely spread mould fungi, with which every one who works with pure cultivations of fission or mould fungi becomes unintentionally acquainted. There is only one fungus which excites even greater interest from this point of view, because it occurs extremely frequently, and is the most common mould fungus: this is the pencil mould, penicillium, which belongs to the tuberacex (order: Ascomycetes).

The higher form of fructification, a kind of truffle, is only observed very rarely, and under special conditions of cultivation. It presents the appearance of a small yellow, sand-like 
protuberance, and behaves like a thick-walled sclerotium, and probably, like the perithecia, owes its origin to a sexual act. On suitable cultivation an ascus-bearing fungus grows out of this sclerotium, and the ordinary mycelium and fructification can again be got from the ascospores thus obtained.

Otherwise it is only the conidia fructification of penicillium which is observed. The fruit hyphæ are segmented and branched like a tree, and a whorl of upright branches projects like a pencil from the uppermost cell, each branch bearing either a chain of spores or another whorl of branches, terminating in sporechains. Spores spherical, uni-。 cellular.-Penicillium glaucum, the most common mould fungus (fig. 22), gives rise to a flocculent mould growth, at first white, but later bluish-green. It grows on the most various nutritive substrata; it occurs everywhere, and hence its spores very often gain access to cultivations. It does not seem to flourish at high temperatures $\left(38^{\circ}-40^{\circ}\right.$ C. $)$. The diameter of the spores is $0.0035 \mathrm{~mm}$.; that of the hyphæ varies according to the food between 0.004 and $0.00071 \mathrm{~mm}$. The very stunted forms are unbranched, and bear only a single chain of conidia; when the development is most luxuriant several fruit hyphæ become united to form a thick stem (coremium), at the upper end of which they again separate

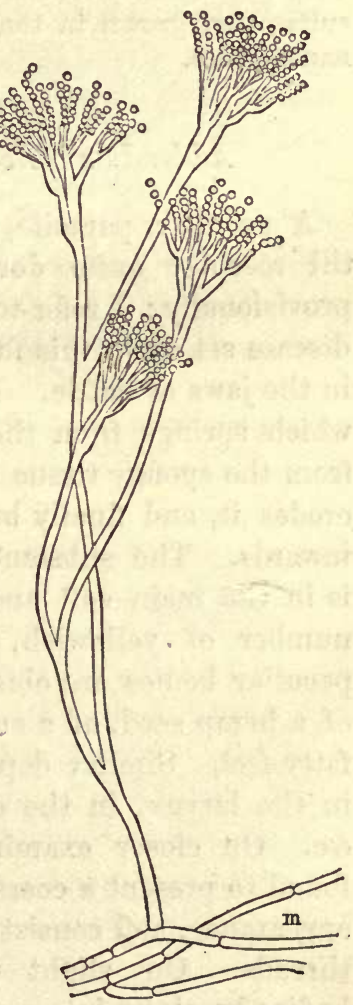

Fig. 22.-Penicillium glaucum. $m$, mycelial hypha with a fruit hypha passing upwards. and form chains of conidia, in the manner described above.

Penicillium spores may be injected into rabbits and other 
Development animals in large numbers without causing any bad effects. by cultivation According to Grawitz, however, malignancy can be produced properties in mould fungi. by gradual acclimatisation of the mould fungi on fluid alkaline substrata, and at the temperature of the animal body. This view rests on an error, for Grawitz evidently worked with a mixture of spores of Asp. flavescens and penicillium : when he cultive.ted this mixture at a low temperature $\left(15^{\circ} \mathrm{C}\right.$.) only the penicillium, which was quite harmless, grew; when, however, he employed temperatures of $35^{\circ}-37^{\circ} \mathrm{C}$., the luxuriantly growing aspergillus overpowered the penicillium, which grows only imperfectly at this temperature, and the aspergillus cultivation, which was quite similar in appearance to the penicillium cultivation grown in the cold, furnished spores of a malignant nature.

\section{Addendum: Actinomyces, Ray Fungus.}

A peculiar parasite, the relationship of which was till recently quite doubtful, may find a place here provisionally; I refer to the so-called ray fungus. The disease set up by this fungus is most frequently observed Morphological in the jaws of cattle. It forms there a whitish tumour, characters of the ray fungus.

which springs from the alveoli of the molar teeth, or from the spongy tissue of the bone, expands the latter, erodes it, and finally bursts outwards, or in rare cases inwards. The substance of this new formation, which is in the main soft and juicy, shows on section a large number of yellowish, abscess-like foci, from which peculiar bodies are obtained on scraping, about the size of a hemp seed, of a sulphur yellow colour, and with a fatty feel. Similar deposits are found in the pharynx, in the larynx, in the corresponding lymphatic glands, \&c. On closer examination these yellow bodies are found to present a coarsely granular, often mulberry-like appearance, and consist of numerous closely interwoven threads. On slight pressure the round gland-like bodies break up into a number of fungus masses; these are groups of bifurcated threads, like hyphæ, which, gradually spreading out from the centre, end in club or flask-like swellings (Bollinger). The threads are usually straight, more seldom slightly wavy, or even spiral, and they swell more and more towards the periphery. As 
they spread out in all directions from a central point, the resulting structure resembles that of a closely packed bunch of flowers, or of a druse of crystals.

Since more attention has been directed to this peculiar fungus it has been often found, chiefly in cattle and swine. In cattle it causes abscesses in the external soft parts of the head, in the tongue, and in the bones of the jaws. In swine it has been often found in the crypts of the tonsils, without any accompanying morbid appearances. Several cases of actinomycosis of the lung, and some of peritonitis, due to actinomyces, have also been observed in cows and swine. In some instances indeed actinomycotic diseases have appeared endemically; thus there was an endemic in Denmark, which attacked 30 cattle on

one farm. In this Fig. 24.-Actinomyces druse. Section from case the only thing

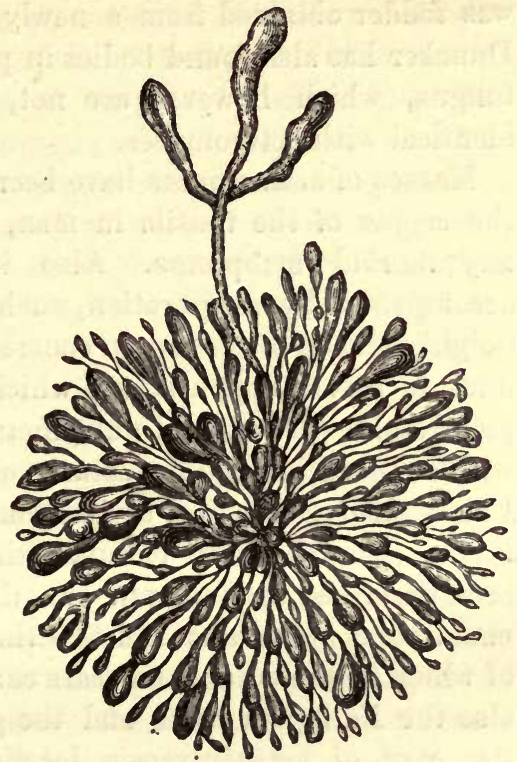

Occurrence of the ray fungus in animals.
Fig. 23. - Druse of actinomyces (ray fungus)
with an isolated branched thread passing upwards. (After Ponfick.)
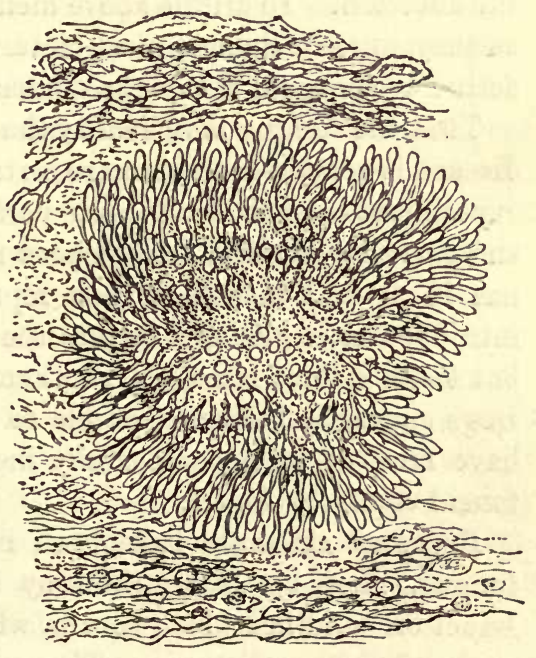
a tumour $\times 300$. 
that could be suspected as a common source of the disease was fodder obtained from a newly tilled field (Bang).Duncker has also found bodies in pork similar to the ray fungus, which however are not, according to Johne, identical with actinomyces.

Occurrence in Masses of actinomyces have been at times observed $n$ man.

the crypts of the tonsils in man, but here also without any morbid symptoms. Also in various affections accompanied by suppuration, such as abscesses in the neighbourhood of the jaw, in concretions in the lachrymal duct, in severe suppurations which present the clinical picture of a prevertebral phlegmon, or of a peripleuritis with suppuration and metastasis; or of a chronic pyæmia. Lately also five cases of peritonitis of actinomycotic origin (per. chronica, parametritis, perityphlitis) have been described by Zemann. In the latter affections the usual point of entrance must be the intestine, in the wall of which fresh nodules and scars can be found, or at times also the Fallopian tubes and the genital apparatus; in the case of actinomycosis localised on the face and neck, carious teeth, injuries to the jaw, inflammatory processes in the pharynx and tonsils, \&c., predispose to the affection. In all the above mentioned cases, different as they were in their clinical picture, the same masses of actinomyces could always be demonstrated in the pus.

Transmission to animals.

That the fungus is in reality the exciting agent of the disease is rendered much more certain by the inoculation experiments which have been performed with isolated and carefully purified actinomyces masses. The disease has in sereral instances been reproduced in calves, by introduction of the grains into the subcutaneous tissue, but feeding the animals with them has had no result. Dogs appear to be insusceptible to the disease; rabbits have recently been successfully inoculated in the peritoneal cavity by Israel.

Former cultivation experiments.
Repeated attempts have been made to cultivate the fungus, first by Harz, then by Johne, and then by Israel on solidified blood serum, which was intentionally made of soft consistence. The results of these cultivation experiments agree but little with each other, and 
these authors do not appear to have succeeded in cultivating the fungus on artificial substrata through a long series of generations. Hence we were up till recently entirely without any guide as to the place occupied by the ray fungus in the regetable kingdom. Lichtheim observed in his investigations on aspergillus and mucor that a stunted mycelium, closely resembling the ray fungus, was at times formed in the animal body; and this was the only fact, though in truth a rery feeble one, on which a relation of actinomyces with the mould fungi was provisionally based.

Lately Boström has made a preliminary communica- Boström's tion, from which we seem to be approaching an elucidation of the behaviour of the ray fungus in cultivations, and of its place in the vegetable world. Boström employed for his cultivation experiments not the refracting, club-like processes, which cannot be cultivated, but the central network. The grains were placed in gelatine, which was poured out on plates; the slow growth of the mass in the gelatine was not however awaited, but after a few days the grains which had remained free from contamination were taken out of the gelatine, crushed between glass plates, and then employed for stroke inoculations on ox blood serum and agar. These strokes soon acquire a finely granular, whitish appearance, having become in the first two days broader and thicker; then there appear in the centre small yellowish red nodular patches, the borders of which are occupied by extremely delicate, branched processes, growing from the line of inoculation at definite distances. These yellowish red masses become gradually confluent, and covered with a delicate downy white layer; at the periphery similar masses are subsequently formed. The cultures require seven to eight days for this stage. The temperature optimum is between $33^{\circ}$ and $37^{\circ} \mathrm{C}$. The gelatine is not liquefied by the actinomyces. The inoculation of such cultivations on various anima!s has been repeatedly carried out with positire results by Boström.

Microscopically the cultivations show in the first two days threads with true dichotomous branching. At 
first they are segmented at wide intervals, the segments afterwards become shorter, and when the yellowish red masses appear in the cultivations numerous very short rods and some more coccus-like structures are found lying free and mostly surrounded by a membrane. In the deeper layers, and on those places where the nutritive soil is exhausted, the well known club-shaped swellings appear in connection with the colonies.

According to these results the actinomyces does not belong to the mould fungi, but to the fission algæ, and must be looked on as a branched species of cladothrix. The place here assigned to the ray fungus is therefore a provisional one, and can only be maintained till the publication of more detailed and confirmatory communications.

\section{The MycetozoA.}

The mycetozoa, which are as yet but little known, include the myxomycetes, or slimy fungi, the acrasia, and the monadina. It is very difficult to define with certainty the place of the mycetozoa in the regetable kingdom on account of their morphological and biological peculiarities ; they are classified among the fungi because they form reproductive organs, which resemble fungus spores; on the other hand the division of the monadina, more especially, is placed by some botanists in the animal world, usually among the rhizopoda, with which they show many resemblances.

Morphology and development of the myxomycetes. of a slimy consistence and of variable form. At the period of fructification they become converted into sporangia, in which spores are developed by the formation of cells. When germination occurs, movable swarming bodies are developed from the spores, and by the fusion of large numbers of these bodies a plasmodium is again formed. The plasmodia form for the most part brightly coloured voluminous masses, which develop on putrefying regetable substrata, on trunks of trees, \&c.; they often 
flow upwards to higher levels, and send out and again withdiaw simple or branched processes. Under favourable conditions. of moisture groups of sporangia are formed from the plasmodia with considerable rapidity, presenting the appearance of large pedunculated or sessile bladders, only a few millimeters in size. The spores fill the interior of the ripe sporangium in the form of a dusty powder; they are simple roundish cells, with a coloured membrane; when they germimate nate they do not send out a cetes (trichia varia). a, not germinating tube, but the protoplasm passes out of the spore membrane in the form of

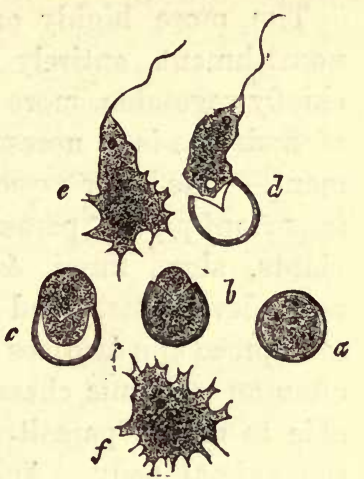
as yet germinated. $a$ to $f$, gradual extrusion of the amoboid swarming body. (After de Bary.) swarming spores, which are round or egg-shaped bodies, with a swinging cilium at their anterior end at this end of the swarming spore lies a cell nucleus, while the other part contains one or two vacuoles, which alternately contract and dilate, and contain watery fluid. The swarming spores sometimes swim freely, rotation round the axis and side to side movements being caused by the activity of the cilium; at other times they creep like amœbæ, protoplasmic processes being sent out and retracted. The swarming spores multiply by segmentation; they finally unite together in constantly increasing numbers, and thus form again a plasmodium.

The acrasia differ from the myxomycetes only in that Ths acrasiæ. the swarming spores do not fuse together to form plasmodia, but become closely aggregated and then each forms a spore.

The monadina, or the lower mycetozoa, form swarming The monadina. spores, amœbr, plasmodia, and spores in the same way as the higher mycetozoa; they are distinguished chiefly by the fact that the result of the differentiation of the plasma in the sporangia is the production of reproductive cells in the form of mobile swarming spores or amœbæ; 
Parasitic mycetozoa. the monadina thus form so-called zoocysts in contrast to the sporocysts in which resting spores develop (Zopf).

The more highly organised mycetozoa obtain their nourishment entirely from dead organic materials, chiefly vegetable, more rarely animal. A large amount of moisture is a necessary condition for their development.-The lower mycetozoa, on the other hand, play an important part as parasites. They chiefly attack aquatic 1lants, algæ, fungi, \&c., and in consequence of their rapid development and the ease with which their germs can spread the diseases of the algæ caused by them have often an epidemic character. But they seem also to be able to act as parasites on higher plants as well as in the animal body. Animals which seek their food in marsh water and in mud seem to be most readily affected. In the intestine of man also amœbæ have been found, but their characteristics are not accurately known. It is therefore very readily conceivable that the monadina, which it would be very difficult to recognise in the animal body, may deserve marked attention from a hygienic standpoint on account of their rôle as infective agents.

For the present only 2 monadinæ need be specially mentioned.

1. Plasmiodophora brassicæ.-This organism lives as a parasite in the roots of cruciferæ, especially in certain varieties of cabbage, and causes marked swelling at the part. Large cells with amoboid movements are found in the markedly enlarged cells of the roots, these ultimately become motionless and divide into a large number of spores, without previously forming a special membrane. A ciliated swarming spore escapes from the spore into the water, and eventually penetrates through the young epidermis of the root into a new host.

2. Haplococcus reticulatus.-This organism has been frequently found by Zopf in the muscles of swine. It forms zoocysts 16-22 $\mu$ in diameter, almost spherical, with smooth membranes. In these $6-15$ amœbæ are formed at the period of ripening, and these pass out of thin and ultimately completely gelatinous places in the membrane. The spores have the form of spheres, or tetrahedra, with markedly rounded surfaces and borders, and a diameter of $25-30 \mu$; on the surface there are often band-like elevations. In the contents of the ripe spore there is a large drop of reserve plasma. The mode of sprout- 
ing of the spores and the further behaviour of the amœbæ have yet to be ascertained.-Flesh, in which the parasites are present in large numbers, presents a perfectly healthy appearance; the muscular fibres seem only pressed together, or pushed out of their position here and there by the parasitic deposits. Nor is anything abnormal observed in the living swine. The distribution of the fungus, which is probably taken up with the food, seems to be very wide; Zopf found that 25-72 per cent. of the swine examined were affected. For further details as to mycetozoa see Zopf and de Bary.**

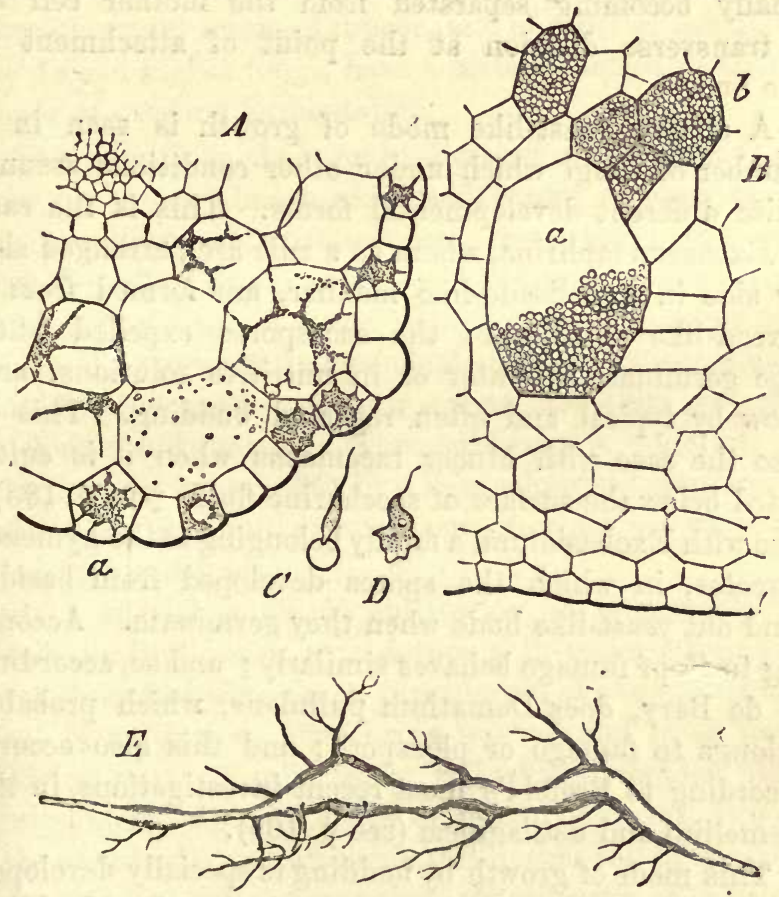

Fig. 26.-Plasmiodophora brassicæ. (After Zopf.)

$A, \times 90$. Transverse section through a young root of a cabbage seedling. In the epidermic cells $(a)$ amœboid or plasmodia-like condition of the parasite.

$B, \times 90$. Section through the lamina of a cabbage leaf; cells $(x, b)$ filled with the spores of the parasite.

$C$, a spore which is just emitting its swarming spore $\times 600$.

$I$, swarming spores becoming transformed in to amœ $b æ 600$.

$E$, portion of the root of a young cauliflower which shows swellings caused by the parasite. Natural size.

* Zopf, Die Pilzthiere oder Schleimpilze, Breslau, 1885. "Ueber Haplococcus reticulatus," Biolog. Centralblatt, 1884, No. 22. "Ueber Plasmiodophora": Woronin, Pringsheim's Jahrb., xi., p. 548. See also, de Bary, Morph. u. Biologie der Pilze; Mycetozoen u. Baklerien. Leipzig, 1884. 


\section{The Yeast or Budding Fungi.}

A common characteristic of all forms of budding fungi is that they consist of microscopical cells which multiply by budding, the cell membrane bulging out like a bladder at one or both ends of the cell, this projection becoming filled with a part of the contents of the mother cell, gradually assuming the same size and form, and finally becoming separated from the mother cell by a transverse division at the point of attachment of the bud.

Torulagrowth A similar yeast-like mode of growth is seen in a in mould fungi.

number of fungi which under other conditions assume quite different developmental forms. This is the case in Exoascus taphrina, where as a rule asci, arranged side by side in a palisade-like manner, are formed from a thread-like mycelium; the ascospores expelled when ripe germinate in water or in nutritive solutions, and grow by typical and often repeated budding. This is also the case with Mucor racemosus when it is cultivated below the surface of saccharine fluids (see p. 133); also with Exobasidium, a family belonging to the hymenomycetes, in which the spores developed from basidia send out yeast-like buds when they germinate. According to Zopf fumago behaves similarly; and so, according to de Bary, does Dematium pullulans, which probably belongs to fumago or pleospora; and this also occurs, according to Brefeld's most recent investigations, in the tremellini and ustilagineæ (see p. 109).

Budding fungi This mode of growth by budding is specially developed proper. in a class of fungi, which are termed, therefore, budding or yeast fungi. To this class belong the ordinary yeasts, the vinegar plant, and the fungus of thrush. It is probable that they must all be classed among the lower ascomycetes, and are most nearly allied to the species exoascus, mentioned above; at least in some typical yeast fungi a form of fructification has been found in which spores are formed within the cells corresponding exactly to the process known in connection with asci. In the cass of other yeast fungi this higher form of 
fructification has not yet been observed; nevertheless the position above indicated may be assigned to the whole class of the yeast fungi.*

Many of the yeast fungi excite fermentation, and are able to set up alcoholic fermentation in saccharine solutions. Nevertheless there are typical budding fungi, such as the pink torula, \&c., which are not able to set up fermentation; and on the other hand the yeast-like developmental forms of mucor, and of other of the above mentioned higher fungi, have a certain though restricted power of exciting fermentation.

The peculiar mode of multiplication of the yeast fungi Multiplicagoes on to an almost unlimited extent so long as all budding. the conditions of existence are farourable; the new formed cells which arise by budding develop fresh daughter cells which either soon become separated and continue to grow as independent individuals, or remain united to the mother cell for a time, and thus give rise to chains and masses. The cells have a spherical or oval form, are surrounded by a thin colourless membrane, and contain a granular protoplasm, in which are vacuoles filled with cell juice.

By a special mode of cultivation it is possible to By spore forobtain multiplication by ascospores in various forms of yeast (beer and wine yeast, mycoderma of wine). If the yeast is cultivated, after being washed and freed from adhering wort, on solid moist soil which provides little nourishment, e.g., on slices of potato or carrot, two or more round cells appear within the mother cell by free cell formation just as in spore tubes, these young cells being surrounded by a thick membrane and becoming free after some time by solution of the wall of the mother cell; in other cases the cell contents contract so as to form a single spherical body. The spores thus formed germinate in sugar solution, and develop in the form of ordinary yeast.

At times a tendency to form mycelial threads is Formation of observed. If the yeast is cultivated on the surface of mycelial

* De Bary l. c., p. 292. Compare the contrary views of Brefeld in Botan. Untersuchungen über Herepilze. Leipzig, 1382. 
solid substances with free entrance of air the yeast-lik buds lose their distinctness, the strangulations become less deep, and the whole chain takes on more the form of an elongated hypha-like cell with thicker and thinner places. The cellular chain then represents a mycelial hypha with the apical growth periodically interrupted, lut we never find the formation of a complete mycelium consisting of true hyphx, or of typical fruit-bearing hyphæ. A marked formation of threads was observed by Grawitz in the cells of mjcoderma vini, and the less the amount of sugar present in the nutritive fluid the longer were the threads that were formed ; but constriction of the apex or a subsequent segmentation were never noticed.

Pasteur's torulæ.
Pasteur and Hansen describe under the name of torula a group of yeast fungi which do not form ascospores or mycelial threads even on the most various solid substrata, but multiply only by budding as in saccharine fluids. They also occasion very slight or noalcoholic fermentation in these fluids, nor do they lead to the formation of a scum on the surface. These torulæ, of which Hansen describes five different kinds, are in some places very widely distributed, and can easily be confused with true yeast, because a morphological distinction between the two budding forms is not possible. With regard to these torulæ it is most probable that they are only development stages of other fungi.

It has not as yet been possible to distinguish in a satisfactory manner between the different kinds of yeast fungi by morphological and biological characters, because there was no method of cultivation by which we could isolate them, and thus obtain with certainty a pure cultivation of the individual forms. It is only lately that such a separation and classification has been attempted by Hansen and other investigators, but up to the present these attempts have not been sufficiently satisfactory to be of use for a handbook. Of the species formerly distinguished from one another, the following may be mentioned here :-

The most im. Saccharomyces cerevisice (Cryptococcus cer.), the portantikinds yeast of beer or brandy. Cells spherical or oval, 8-9
of yeast. 
$\mu^{*}$ in length, single or with branches composed of short chains. Three or four spores in the mother cell; $4-5 \mu$ in diameter. Employed in the brewing of beer; in the low fermentation which goes on slowly between $4^{\circ}$ and $10^{\circ} \mathrm{C}$., the yeast is deposited at the bottom of the vessel (unter-hefe), and the cells are for the most part single, or united in small numbers. In the high fermentation, which takes place between $14^{\circ}$ and $18^{\circ} \mathrm{C}$., the stream of carbonic acid carries up the yeast to the
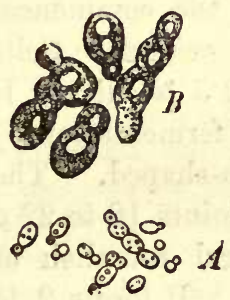

Fig. 27. - Saccharomyces cerevisia (yeast).

$A$, slightly enlarged.

B, low yeast highly magnified.

c', upper yeast highly magnified.
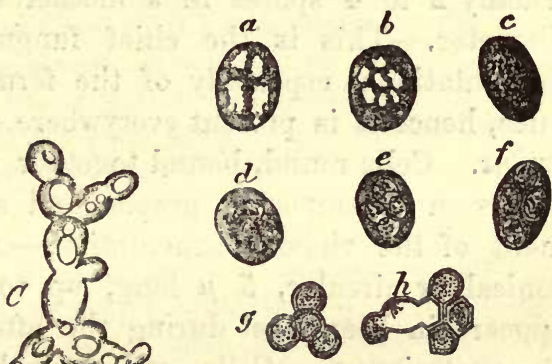

Fig. 28.--Spore formation in saccharomyces cerevisiæ.

(After Rees.)

$a, b$, cells with several vacuoles. $c$, cell with uniform granular: contents.

", four plasma portions.

$e$, young spores arising from these.

$f$, the same with double con: tours.

$g$, free spores after solution of the membrane.

$h$, commencing sprouting of the spores.

surface of the fluid, and this upper yeast (ober-hefe) contains branched bands composed of several buds. - The npper yeast is employed in baking to raise the dough; it further serves for the formation of the compressed yeast.-On plates of nutrient gelatine the colonies form after two days small white points, so long as they are beneath the surface; as soon as they reach the surface they form somewhat more extensive white drops, or dry masses. Under a low power the colonies appear yellowish-grey in colour, and with a rough contour, like

* The mark $\mu$, which is much used in the following pages, signifies a micromillimeter $=0.001$ of a millimeter. 
mulberries or bramble berries; here and there we see irregular processes which look like fine knotted strings. Under a somewhat higher power it is evident that these colonies are composed of a number of individual cells. In test tube cultivations they grow similarly and more luxuriantly on the surface than in the substance of the jelly, and send out relatively thick processes.

Sacch. ellipsoideus, wine yeast. Cells elliptical, as a rule $6 \mu$ in length, single or in short-branched chains ; usually 2 to 4 spores in a mother cell, 3 to $3 \frac{1}{2} \mu$ in diameter.-This is the chief fungus of spontaneous fermentations, especially of the fermentation of wine juice, hence it is present everywhere.-Sacch. conglomcratus. Cells round, bound together to form balls. It occurs on decomposing grapes, and at the commencement of the vinous fermentation.-S. exigurs. Cells conical or circular, $5 \mu$ long, up to $2.5 \mu$ thick. It appears in beer yeast during the after fermentation.$S$. pastorianus. Cells oval or club-shaped. The colonies consist of primary club-shaped joints 18 to $22 \mu$ in length, which form secondary lateral roundish or ovial daughter cells 5 to $6 \mu$ in length. It forms 2 to 4 spores. It occurs in the after fermentation of wine and cider, and in the fermentation of beer.-S. apiculatus. Cells citron-shaped, with short points at each end, 6 to $8 \mu$ in length, 2 to $3 \mu$ in breadth; its buds are only at the pointed ends. Seldom united in colonies. Spores unknown. Occurs along with other forms of yeast in various spontaneous fermentations. -S. spharicus. The basal cells of the colony are oblong or cylindrical, 10 to $15 \mu$ in length, $5 \mu$ in breadth; the other cells are spherical, 5 to $6 \mu$ in diameter, united in branched families. Spores unknown.

Sacch. mycoderma (Mycoderma cerevisiæ et vini, Kahmpilz). Cells oval, elliptical, or cylindrical, 6 to $7 \mu$ long, 2 to $3 \mu$ thick; form chains with numerous branches. The spore-forming cells may be as long as $20 \mu ; 1-4$ spores in every mother cell. Forms a scum on fermenting fluids, and grows on the surface without 
exciting fermentation; it is found especially on wine, then on beer, juice of fruits, sauerkraut, \&c.

Formerly it was supposed that this organism caused acetic fermentation in fermented fluids; but according to Nägeli the relation of the fungus to acetic fermentation is not a causal one. It is found especially on the surface of markedly acid fluids, e.g., wine poor in alcohol; in that case it occasions no formation of acetic acid, the latter is due rather to specific fission fungi, which, however, cannot regetate in markedly acid fluids. This fungus acts in the first place like a covering of mould, it leads to the combustion of the acid, and diminution of the amount of acid in the fluid. Thus it prepares the soil for the reception and multiplication of the fission fungus which produces acetic acid; the occurrence of this scum is therefore a necessary preparation for the acetic fermentation. Nägeli distinguishes the following scums on fermented fluids: 1. Acetic mother (Essigmutter), a very thick, tough, glue-like scum, with a smooth surface; oxidises the alcohol to acetic acid, consists of bacteria= Mycoderma aceti. 2. Acetic skin (Essighäutchen), thin, slimy, smooth, or finely wrinkled, oxidises the alcohol to acetic acid, consists of bacteria = Mycoderma cerevisiæ. 3 . Mesenteric skin (Kahmhaut; Gekrösehaut), comparatively Composition strong and firm, folded like the mesentery, consists of yeast fungi (Saccharomyces mesentericus), which destroy the fruit Kahmhaut. acids. At a later period the acetic fungus (bacterium) appears in the material, and oxidises the alcohol to acetic acid $=$ Mycoderma vini. 4. Smooth skin (Falsche Kalimhaut, Glatthaut), comparatively strong, but without folds, of a loosely granular composition, consists of yeast fungi, does not destroy the fruit acids to any marked extent, and does not permit the acetic fungus to settle in the fluid. 5. Acetic ether skin (Essigätherháutchen), thin, not folded. Composed of yeast fungi (Saccharomyces sphæricus) and of bacteria (acetic fungus), the combined action of which converts a part of the sugar into acetic ether.-The acetic mother and acetic skin are formed on alcoholic fluids, which contain few fruit acids, but on the other hand may contain a good deal of acetic acid; for example, on beer, on vinegar, to which wine or beer is added, seldom on slightly acid wine. The other skins, on the other hand, appear constantly on fluids which contain a certain quantity of fruit acids, the mesenteric skin on fermented wine juice and other fruit juices, the smooth skin at times on similar fluids which are altered by: the addition of sugar and other materials.-More recent investigations by Hansen on the membranes occurring on 
beer have given the following results: if the surface is grey and dull, Sacch. mycoderma is exclusively or chiefly present, and numerous air bubbles appear between the groups of cells; if the surface is glistening and slimy, the membrane consists of microbacteria, and the fluid is then muddy and discoloured. Under a membrane consisting exclusively of Mycoderma aceti, Mycoderma Pasteurianum (see description of both among the bacteria), or Sacch. mycoderma, the fluid is always clear and unaltered in colour. A temperature between $30^{\circ}$ and $34^{\circ} \mathrm{C}$. is particularly favourable for Myc. aceti and Pasteurianum. Sacch. mycoderma grows best at $15^{\circ} \mathrm{C}$., at higher temperatures it is difficult for it to hold its own against the bacteria; above $26^{\circ} \mathrm{C}$. this becomes practically impossible.

If this fungus is compelled to vegetate beneath the surface of fluids, a small quantity of alcohol is formed, but the fungus soon dies.

In watery, acid fluids, poor in sugar, the cells often form long tubes, which then send out further buds, become transversely divided, and finally break up into single cells. The latter again bud in a similar manner The fungus of (Cienkowsky). - This structure is most pronounced in
thrush. the case of Saccharomyces albicans, the fungus of thrush (formerly described as Oiddium albicans). Accord. ing to Rees and Grawitz this fungus resembles very closely the S. mycoderma, if, indeed, it is not identical with it. Cells partly spherical, partly oval or cylindrical, $3 \cdot 5-5 \mu$ in thickness; the cylindrical cells are 10-20 times as long as thick. The budding colonies consist for the most part of rows of cylindrical cells, from the ends of which rows of oval or spherical cells sprout out; spores single, formed in roundish cells. Occurs as thrush on the mucous membrane of the mouth, especially in suckling children, and forms greyish-white patches which contain also epithelium, schizomycetes, yeast cells, and mycelia of different mould fungi: The thrush fungus is easily cultivated on solid or in fluid nutritive substrata, which contain, besides sugar, tartrate of ammonia and inorganic salts; according to the amount of sugar present, the cells either sprout out to form long threads, or, in strong saccharine solutions, $4-8$ daughter cells project from 
one mother cell in various directions, these daughter

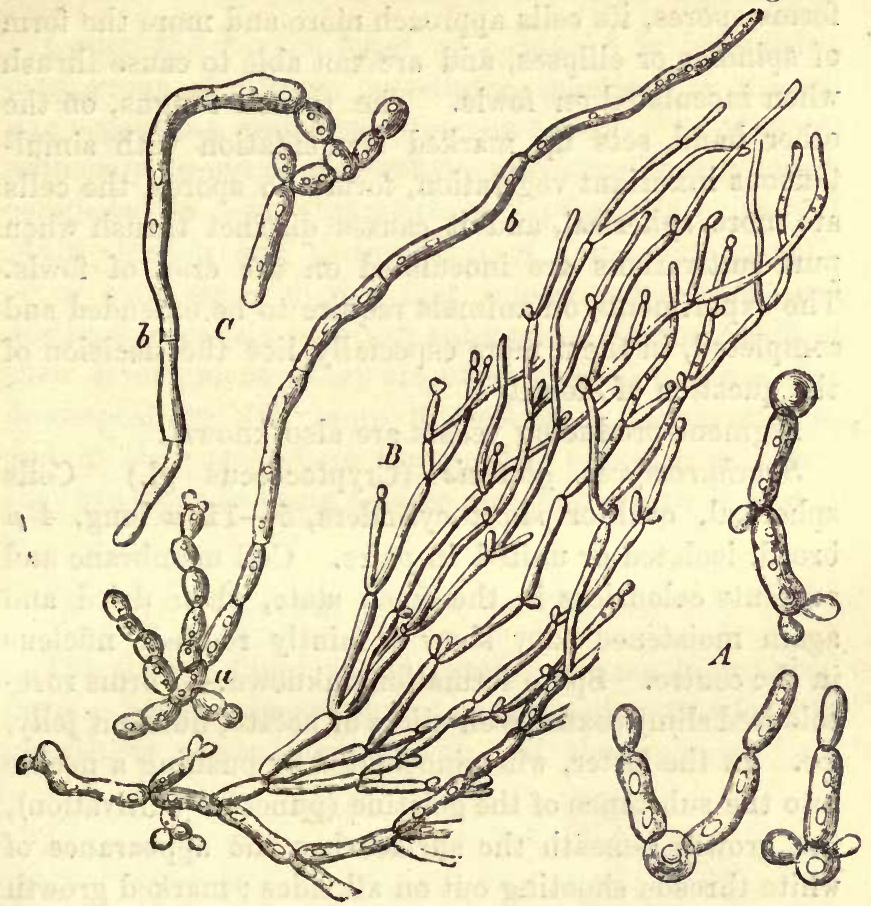

Fig. 29. - The thrush fungus, Saccharomyces mycoderma. (After Grawitz.)

$A$, sprouting spores highly magnified.

$B$, branched mycelium with a few, lateral buds, cultivated in dilute nutrient solutions.

$c$, at $a$ the yeast stage, at $b$ the mycelium stage of the thrush fungus.

cells being for the most part round and arranged in roll-like rows.-The fungus is able to set up a very mild alcoholic fermentation. Spore formation has not as yet been observed.

As the result of more recent investigations, Plaut does not regard S. mycoderma and the thrush fun-
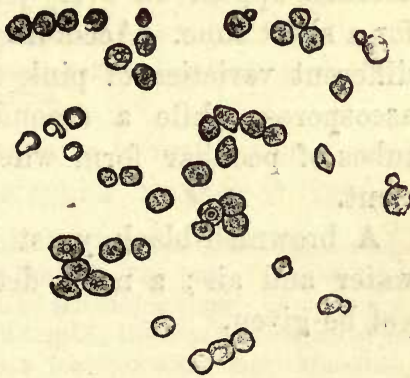

Fig. 30.-Pure cultivation of the thrush fungus on a nutrient soil containing sugar. (After Plaut). gus as identical; the first sets up only minimal fermentation 
with simultaneous death of the cells ; further, it readily forms spores, its cells approach more and more the form of spindles or ellipses, and are not able to cause thrush when inoculated on fowls. The thrush fungus, on the other hand, sets up marked fermentation with simultaneous luxuriant vegetation, forms no spores, the cells are more spherical, and it causes distinct thrush when pure cultivations are inoculated on the crop of fowls. The experiments on animals require to be extended and completed, in them more especially lies the decision of the question of identity.

Rose-coloured Pigment-producing yeasts are also known:

Saccharomyces glutinis (Cryptococcus gl.) Cells spherical, oval or short cylinders, 5-11 $\mu$ long, $4 \mu$ broad, isolated or united in pairs. Cell membrane and contents colourless in the fresh state, when dried and again moistened they show a faintly reddish nucleus in the centre. Spore formation unknown.-Forms rosecoloured slimy coatings on slices of potato, nutrient jelly, \&c. In the latter, when inoculated by pushing a needle into the substance of the gelatine (puncture cultivation), the growth beneath the surface has the appearance of white threads shooting out on all sides; marked growth and the production of colouring matter only take place on the surface. The colouring matter is not altered by acids and alkalies. The pink torula is apparently very widely distributed; in our neighbourhood one or more colonies appear on every jelly plate exposed to the air for a short time. According to Hansen there are three different varieties of pink torula, of which one forms ascospores, while a second gives rise to germinating tubes of peculiar form when the nutriment is insufficient.

A brownish-black yeast is also at times present in water and air; a more detailed description cannot as yet be given. 


\section{The Fission Fungr, Schizomycetes.}

Under the fission fungi or bacteria* is included a large group of minute, unicellular, spherical, or threadlike organisms, which multiply by fission. As they are ordinarily devoid of chlorophyll, they are, like the fungi, compelled to lead a parasitic or saprophytic existence. Multiplication and assimilation of nutriment usually occur with such energy that intense alteration and destruction of the nutritive substratum is the result of their development; they are often able to increase this decomposition still more by setting up fermentation, and in the cases where they lead a parasitic existence they are wont to bring disease and death to their host.

\section{General Morphological Characters.}

The fission fungi exhibit great varieties in external General form. Some grow as spheres or oval cells; this form of morrhology of growth is termed micrococcus; if the spheres form fungi.
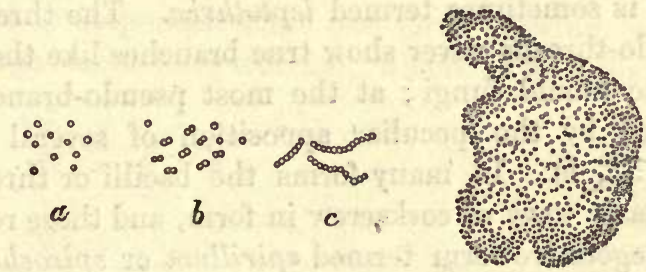

$d$

Fig. 31A. - Various vegetative forms $\times 700$.

$a$, micrococcus, isolated. $\quad b$, in the act of subdivision (diplococcus.) c, streptococcus, torula. d, zooglæa.

chaplet-like chains the organism is termed streptococcus or torula; if arranged in irregular masses it is dis-

* De Bary prefers the term Bacteria because some varieties contain chlorophyll, and are thus not true "fungi." The term "Bacterium" was formerly employed for a division of the fission fungi; as, however, this division can no longer be maintained, there is no objection to de Bary's suggestion. Other names for this class are: Microbes, Champignons, Torulacées, Bacteriés (Pasteur); Mikrozymas (Béchamp); Spalthefe (Nägeli) ; Mikrosporinen, and Monadinen (Klebs); Coccobacteria-with the subdivisions Mikro- Meso-Meg-acoccns, MikroMeso-Mega-bacteria-Gliacoccus, Petalococcts, \&ic. (Billroth). 
Various vegetative forms.

tinguished from the former as staphylococcus. Other fission fungi grow in the form of rods, the longitudinal diameter being markedly greater than the transverse; for this form the term bacillus is employed. (Formerly a distinction was made between the shorter rods, bacterium, and the longer rods, bacillus, in which the one diameter is more than two or three times greater
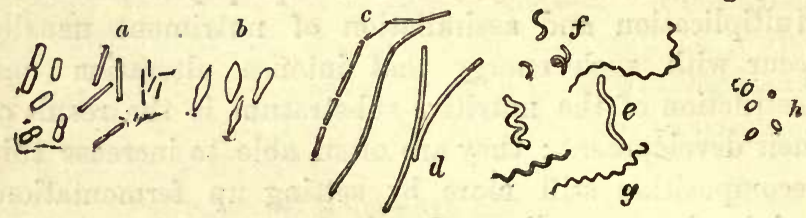

Fig. 318.-Various vegetative forms $\times 700$.

$a$, bacilli ; $b$, clostridium; $c$, threads, pseudo-threads ; $d$, apparent branching; $e$, vibrio; $f$, spirillum; $g$, spirochæte; $h$, spores.

than the other.) Bacilli which are swollen in the middle or spindle-shaped have the special name clostridium. Where the bacilli are much elongated we have true threads, or where several bacilli are arranged in a longitudinal direction so-called pseudo-threads; this thread form is sometimes termed leptothrix. The threads and pseudo-threads never show true branches like the hyphre of the mould fungi; at the most pseudo-branches are formed by the peculiar apposition of several threads (fig. $31, b$ ). In many forms the bacilli or threads are regularly wavy or corkscrew in form, and these represent the vegetative form termed spirillum or spirochate. If the turns of the corkscrew are not markedly developed, and if the spirilla appear more elongated, the organism is termed vibrio. Loops of threads, the ends of which are wound around each other like a plait of hair, are termed spirulina.

Spores. Another form which the fission fungi not uncommonly assume is that of spores. These are spherical or oval cells which serve only for the diffusion and the maintenance of the species, and always sprout and form again organisms similar to the mother forms from which they arose.

Involution forms.

Further, the fission fungi when grown in exhausted soil and under various other conditions present all sorts 
of aberrant forms which are due to their involution and lecay; flask-like swellings may be associated with stunted, shrunken, and broken up forms.

It is a characteristic of many fission fungi that they only occur under one form of growth, e.g., only in the form of micrococi. Other varieties of fission fungi present. various forms of growth through which each individual passes in a

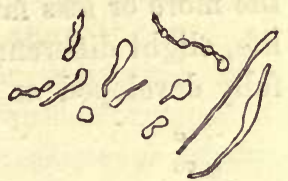

Fig. 32.-Involution forms. definite order during its development; thus many bacilli grow to threads; in the threads spores are formed, and from the spores bacilli are again developed. The bacillar thread and spore forms belong therefore to the cycle of development of this bacterium.

Besides the general characters of the vegetative forms which have been described, some slighter morphological differences characteristic of the one or other species can be made out in spite of the small dimensions of the fission fungi. Lither it is the size of the individuals Morphological which is of importance, the one form growing only as the same very ] arge cocci (megacoccus), which have a diameter fogetative

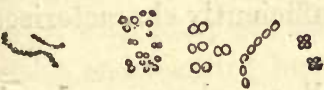

Fig. 33A.-Morphologically different cocci $\times 700$.

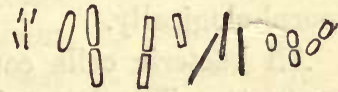

Fig. 33в.-Morphologically different bacilli $\times 700$.

of $1 \frac{1}{2}$ to $2 \mu$ or more; other kinds forming very small micrococci 0.1 to $0.2 \mu$ in diameter, \&c. Still more Morphologimanifold and typical differences are found among the cally difecies. bacilli; those of one species may be lank and thin, those of another short and thick; the one very large, the other extremely fine and delicate; or the one may have the ends rounded off or almost pointed, while the other are sharply truncated or even somewhat concave.

Individual differences in form may also occur in one Individual and the same species of bacterium. In this respect the differences in age of the individual is of the greatest influence; young species. bacilli appear shorter than older forms; cocci just formed by fission are often smaller than those which 
are about to undergo fission. The nutriment has also a certain influence; according to the medium in which the species in question is cultivated, and according to the more or less favourable state of all the conditions of life, slight differences in size and thickness appear, and fully developed or stunted individuals are formed. As
$\stackrel{a}{\infty}$
000
$00 \infty$
b

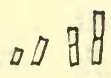
$c$
0080
$\begin{array}{ll}a & e \\ 0 & 0\end{array}$
$f \quad g$
a) 008

Fig. 34.-Individual morphological differences dependent on age and nutriment $\times 700$.

", cocci. Various conditions of age and nutrition of the same species. $b c$, varions conditions of age of two species of bacilli.

$d e$, modifications of one species of bacillus dependent on the nutritive conditions.

$f g$, modifications of another species of bacillus dependent on the nutritive conditions.

these factors, however, are of relatively slight intensity, none of them as a rule destroy the peculiar morphological character of the species; in spite of the modifications induced by age and food, certain characteristics, as for example the relations between longitudinal and transverse diameter, the form of the ends of the rod, \&c., are so completely preserved in the majority of the individuals that they are thereby sufficiently characterised morphologically.

Structure of the cells of the fission fungi.
All bacteric cells consist of cell membrane and cell contents. The latter have the appearance of ordinary protoplasm, are as a rule colourless, except in some forms recently discovered by van Tieghem, which contain chlorophyll, as well as some putrefactive organisms stained red by the so-called bacterio-purpurin. Small oil globules are often observed in the cells; at times also dark, highly refracting bodies, which consist of sulphur (beggiatoa and red putrefactive organisms). Some bacteria assume a blue colour on the addition of iodine, and thus show the presence of granulose; this reaction is especially marked in the stage preceding the formation of spores. Nuclei are not found. When the cells degenerate and die a marked turbidity and granular degeneration of the protoplasm occurs.

The cell membrane, which must be very extensile in 
the mobile forms, is in some species impregnated with colouring matter. On the outside a further gelatinous sheath may be recognised which is developed to a very variable degree in different species of bacteria. At times it is very distinct, especially after the use of staining materials, and surrounds the individual cells as a broad zone, the outer contour of which corresponds to the form of the cell; at times the existence of the sheath can only be suspected from the spaces left between the closely packed cells.

Some vegetative forms and species of bacteria are Independent always at rest; thus the spherical cells, and all those movement of species which only occur in the form of micrococci, exhibit only a trembling movement with very slight alteration of position which may be referred to unavoidable agitation and currents; they are never seen to travel over considerable distances. Other forms, bacteria, bacilli, and spirochæte are sometimes at rest, sometimes in active movement. This movement consists partly in rotation around their long axis and partly in bending and stretching; in many cases the action of flagella seems to be the cause of the commencement and maintenance of the movement. These flagella can be demonstrated with complete certainty in some spirilla and bacilli; but even in them they can only be seen with the best lenses, and after special treatment of the preparation (drying and staining with gentian violet, or better with con. centrated watery solution of hæmatoxysome forms bacteria.

lin). At times their presence is only betrayed by the peculiar whirling movement of the fluid surrounding the ends of the cells. The movement of the swarming bacteria takes place forwards and backwards in the direction of the long axis; at times it is slow, oscillating and rolling, at times active and darting, so that the field of the microscope is traversed in a moment. Various alterations of the external conditions, such as change of temperature, exclusion of oxygen, \&c., cause slowing and cessation of the movement. 
Different modes of arrangement.
The mon intimate pro cess of maulti. Mication by Ission.

In the quiesoent state the fission fungi either remain isolated or are muited in threads, or in extensive flat or massive colonies. In the latter eases the daughter cells which arise by fission do not become separated, but remain united by their gelatinous capsule; ultimately large conglomerations of cells are formed which are all united by gelatinous intereellular substance. This form is termed woogliea; it is most frequent in the micrococi and bacteria, but it is also observed in short bacilli and spirochetre. The exterual form of the zooglan masses is rery rarious; sometimes they are spherieal, sometimes tuberous, sometimes lobate; at times a very peculiar tree-like branching oecurs; in certain cases thick cartilaginous capsules aro formed. As a whole the zooglaea formation is closely similar to the formation of gelatinous capsules in some families of algre (phyeochromacese).

The multiplication of the bacteria by fission takes place as a rule continuously in the same direction, so that if the new formed cells remain attached to each other, a chain (streptococens) or a thread is formed. It is only in some mierococei (mikr. tetragonus, sarcina) that simultaneous or subsequent dirision in two or three different directions may be observed, leading to the formation of flat groups of four or packets of at least eight cells; the former are designated by Zopf by the special name merismopedia, the term sareina being reserred for the latter. In the spherieal bacteria the division may oecur in any diameter, in the rod-shaped cells on the other hand only in the transwerse diameter. Before dirision the cells increase in length; then as a rule a distinet constriction appears in the middle, and finally the two halres separate at this spot. These two independent indiridusls eau either undergo further segmentation apart from esch other, or they remain united by delicate gelatinous material and form chains and pseudo-threads, the transterse division always oceurring in the same direetion; or lastly, they take part in the formation of zooglaes masses, gelatinous materisl being produced in considerable quantities; in the interior of 
this zooglea mass the division of the individual cells can continue, leading to a denser accumulation in the zooglax.-The fission is as a rule completed very rapidly; at $35^{\circ} \mathrm{C}$. complete division was observed in the bacilli at the end of 20 minutes; external and individual influences may cause variations as regards the time, but it is evident that the the fission fungi can multiply to an enormous extent in one or a few days. If we start with a single bacterium and assume that each individual requires an hour to grow and divide, we find tha: in the course of a day about 16 million organisms have been formed, while by the end of the following day the number has reached sereral billions.

\section{Propagation by Spores.}

Besides multiplication by fission we find a true fructification, a spore formation, in many fission fungi under special circumstances, chiefly, but not exclusively, when the nutriment is becoming exhausted. Fructification by exdospores and by arthrospores may be observed; of Ponmation of rexting oporex. these the first is the most important and most definitely ascertained mode of spore formation. This occurs in various bacilli, and perhaps in some spirilla, but the process varies in different species. In many cases the bacilli grow to long threads before the formation of spores; under farourable conditions they may attain even

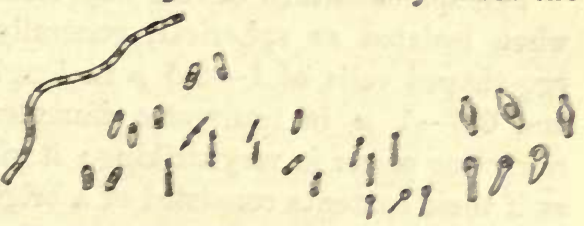
in 3-4 hours 20 times the length of the original bacillus. The threads may be much twisted, united in bundles or interworen to form a thick network, and they hare pale homogeneous contents. After some hours the segmentation of these pseudo-threads begins and becomes more distinct; at the same time the contents becone turbid and less in amount, and highly refracting granules appear in the threads at regular intervals. After about 
20 hours highly refracting spores with dark contours, and for the most part egg-shaped, are formed from these granules, and the threads present a moniliform appearance; the latter become gradually dissolred, and the spores are liberated and sink to the bottom of the fluid. In another mode of spore formation the bacilli do not grow out in the form of long pseudo-threads, but become broader; they thus assume spindle, elliptical, or tadpole forms, while at the same time the whole plasma becomes denser, and the membrane thickened. The contents then become turbid, and highly refracting largish drops are differentiated and transformed into the spores (spore formation in Clostridium butyricum according to Prazmowski). In other cases 2,3 , or more small spherical refracting points, which represent the spores, appear in the bacillus without the latter having undergone any marked alteration; or a spherical or oval spore which often markedly exceeds in diameter the parent bacillus develops at one end the rod. If a similar spore formation occurs at both ends of the bacillus, bodies are formed of a dumb-bell appearance. At times the spores bulge out the contour of the bacillus in a remarkable manner, so that the latter appears as if covered with small swellings.

The spores formed in this way within the cells appear when isolated as spherical, generally however longish egg-shaped cells of $1-2 \cdot 5 \mu$ in longitudinal diameter, and $0.5-1 \mu$ in transverse diameter. Their marked refracting power is very striking; it gives the impression as if their contents consisted of a bright oil globule. At the same time the refraction is not altered by boiling with ether, so that the contents cannot be regarded as fat, but rather as condensed protoplasm. The thickness of the wall is well-marked; at times two layers; an exosporium and an endosporium, can be differentiated, and there is often a peculiar clear area around it, which is sometimes regarded as a spherical clear mass in which the cells are embedded, sometimes however only as an optical appearance due to the high refracting power of the spore. 
The spores can germinate and form bacilli in suitable Germination nutrient solutions and at a proper temperature ; but this seldom occurs in the same solution in which the spores were formed, nor till after a considerable period of rest. According to Koch, when the process of germination begins the clear spherical mass in which the spores are embedded becomes egg-shaped, and then elongated, while the spore becomes pale and finally disappears. According to Prazmowski and Brefeld the spores swell in the first place, become pale and lose their dark contour and the clear area around; then half-moon shaped dark shadows either appear at each end, and the spore, which is in a state of trembling, dancing movement, sends out a projection on one side like a papilla which subsequently grows out to form a rod; or in other cases the germinating tube passes out in the direction of $-0.00 ? .00080 \mathrm{~d}$ the long axis of the spore, Fig 37.-Germination of spores the spore membrane having $\times 800$.

become uniformly thickened in its whole circumference. The endosporium then becomes the cell wall of the roung shoot, while the discarded exosporium usually remains for a considerable time near the newly formed rod.

In the case of the bacteria which form arthrospores so-called the fructification simply occurs by individual members arthrospores. of a chain or of a mass of bacteric cells showing greater vitality than the rest; there is often no morpholugical difference to be noted between them and the other bacteria in the same chain, while at other times the cells. destined for the maintenance of the species appear to become somewhat larger, thicker walled, and filled with denser and more highly refracting protoplasm. While the remaining cells of the group die; these segments form the commencement of new groups (de Bary).

Most spores, especially those formed endogenously, Resisting have the character of resting cells, which are more re-power of the sistant than the vegetative cells of the same species. Some are extraordinarily resistant, can even withstand boiling in fluids for several minutes, and are only slowly 
and incompletely destroyed by the most various chemical agents. It is clear that on account of these properties the spores possess a special hygienic interest; for example, the possibility of exterminating a pathogenic fungus from the surroundings of man by disinfecting means depends chiefly on whether or not the fungus in question forms resistant resting spores.-All resting spores do not show the same high degree of resisting power; different spores have apparently rery different powers of resistance, but a certain increased power of resistance, notably the capability of retaining their vitality for a long time in a dry state, must be held to be a necessary characteristic of spores. Bearing this in mind, we require better reasons than have as yet been brought forward for assuming the existence of the so.called arthrospores.-The micrococci and most of the spirilla are probably characterised by complete absence of resisting spores; at any rate if we examine strongly heated mixtures of bacteria to see what forms have retained their vitality after exposure to a temperature of $80^{\circ}-100 \mathrm{C}$., we find only the bacilli which form resting spores, and none of the other regetative forms.

\section{Characteristics of the Cultivations of the Fission Fungi.}

External characteristics of the cultivations of of zooglæa, the bacteria become visible eren to the naked the fission fungi.

eye. In fluids they cause either diffuse or cloudy muddiness, or they cover the surface in the form of thin or thick scums; or the zooglæa masses form swimming flakes; or a powdery deposit of bacteria forms at the bottom, especially when the nutritive materials in the fluid are exhausted and are no longer able to supply food for a further multiplication of the organisms. Some species of bacteria can also undergo extensire multiplication in fluids or on solids without anything becoming noticeable to the naked eje.-The appearance of the colonies of bacteria on solid substrata, 
containing much water, is especially characteristic. Solid substrata have of late been employed by preference Advantages of for the cultion solidsubstrata because they permit a completely independent develop- nition of the ment of each individual bacteric colony, while in fluids the individual species do not grow at a definite spot, but become mixed with any other species which may happen to be present. It is therefore only on solid substrata that the characteristic appearances of the colonies formed by any given species of bacteria can be observed, while it is just the external appearances of the isolated pure colonies which are of the greatest importance, because they differ in almost every species of bacteria, and because we can thus obtain much more important characters and better distinctive marks than we get with the help of the microscopical differences in form. For this reason the appearance of the isolated colonies is of special service in the diagnosis of the species of bacteria, a thing which is otherwise often very difficult.

As suitable solid substrata we employ either potatoes, bread-paste, \&c., on which the bacteric colonies appear, sometimes as slimy white, yellow, or reddish drops, sometimes as drier whitish films, sometimes as diffuse, gelatinous layers of various colours, and sometimes as delicate, scarcely noticeable skins; or we use the socalled nutrient jelly (see culture methods), which is prepared by adding so much gelatine to a good nutrient solution, that the mixture forms a transparent mass, which is solid below $25^{\circ} \mathrm{C}$. This nutrient jelly is employed for plate cultivations, in which a very small portion of the bacteric mixture to be investigated is added to a quantity of the nutrient jelly, which is liquefied by placing it at $30^{\circ} \mathrm{C}$.: after the admixture is complete it is then poured out on a horizontal gliss plate, so that the latter is covered by a layer a few millimetres deep. The jelly solidifies quickly; each Character of individual bacterium in the mixture is thus fixed at a the colonies definite spot, and grows there to form a colony. If the plates. experiment is successful, i.e., if too many bacteria have not been mixed with the quantity of jelly, and if 
they are not sown too closely on the plate, each colony develops apart from the others, and then shows distinctive characteristics, sometimes so marked that with some practice the species of bacteria present may be easily diagnosed in the development either of small gelatinous

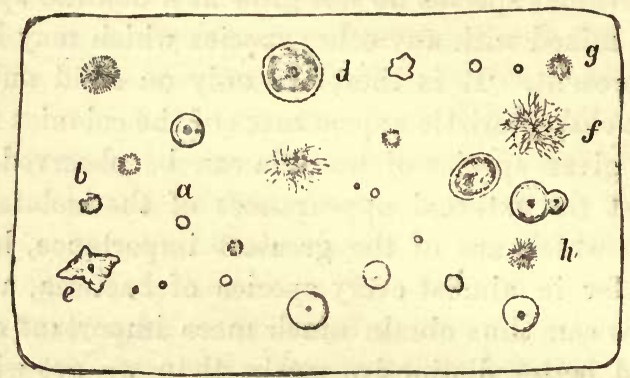

Fig. 38,-Various colonies on a gelatine plate.

coloured drops, white, yellow, rose-coloured, red, or violet (fig. 38, a) ; or of very small white or yellow circumscribed, almost point-like heaps; or of flat, mucous layers peculiarly bulged out at their borders (fig. 38, $b$, $e)$; or of branching and twisted threads of surprising fineness, which run out from a centre for a longer or shorter distance into the jelly (fig. $38, f, g, h$ ). Or the organisms in the colony in question have the power of gradually liquefying the gelatine, in which case a ditchlike depression is slowly formed around the colony, the periphery of which surrounds the colony in the form of a ring (fig. 38, d) ; or a funnel is quickly formed which is filled with fluid, at the bottom of which the original colony lies, and which often extends rapidly over large

Study of the colonies with low powers. areas of the plate. Thus the contour, colour, size, mode of liquefaction, \&c., furnish special characteristics for each bacteric colony; and the sum of these distinguish-
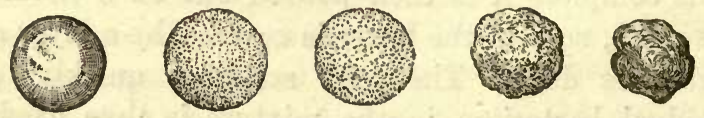

Fig. 39.-Youngest colonies of bacteria in gelatine $\times 80$.

ing features increases very considerably when the colonies are examined with a low power $(\times 80)$. It can then 
be seen that one colony presents a completely smooth, sharp outline, another is bulged out or dentate at its. margin, or is provided with small outgrowths, or shows wavy threads, which run out from the colony and lack to it again. The surface of the former colonies appears smooth, that of the latter granular; one is dark, almost black, another brown, a third light yellow ; some can scarcely be distinguished from the surrounding jelly by their colour.

If by this means of distinguishing and recognising the species of bacteria it nevertheless turns out that certain species do not differ in their growth on plates, the growth along strokes, or along a puncture, may show something characteristic. This is ascertained by Characterispouring the nutrient jelly into test tubes, and allowing puncture it to solidify in some of the tubes in an upright position, cultivations and in others in an oblique or almost horizontal layer. Then a small quantity of the colony which has grown on the plate is picked up on the point of a piece
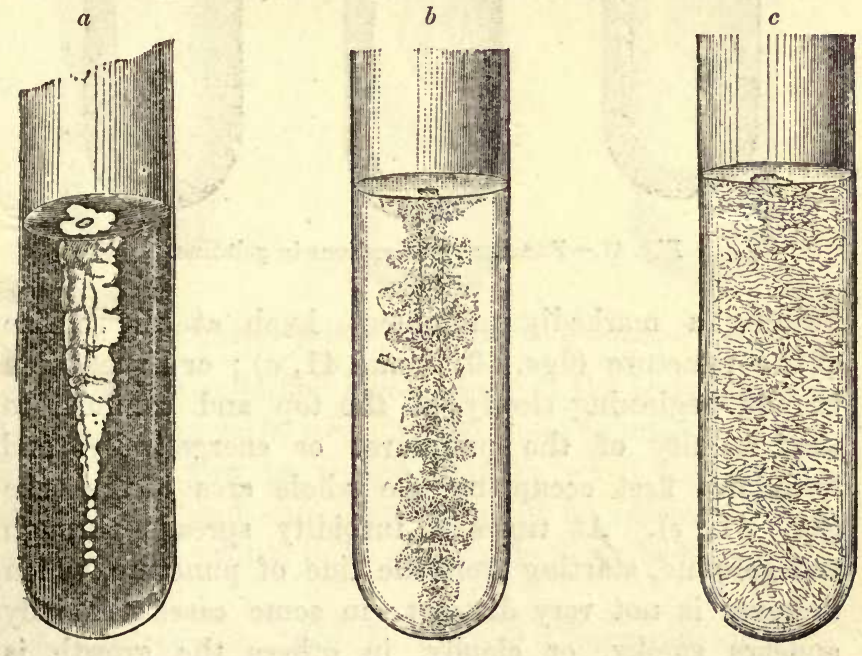

Fig. 40.-Pancture cultivations in gelatine.

of platinum wire, and long scratches are made on the surface of the oblique gelatine, while in the other tubes punctures are made with the wire to the depth of about $4 \mathrm{~cm}$. Along the punctures we either find only small 
isolated punctiform colonies (provided that the quantity inoculated was minimal); or a thin confluent layer is formed along the course of the puncture, so that the line of puncture appears as a thread, while a delicate layer spreads out at its upper end towards the periphery of the jelly (fig $41, b$ ); or a thick opaque mass is formed, filling the channel completely and
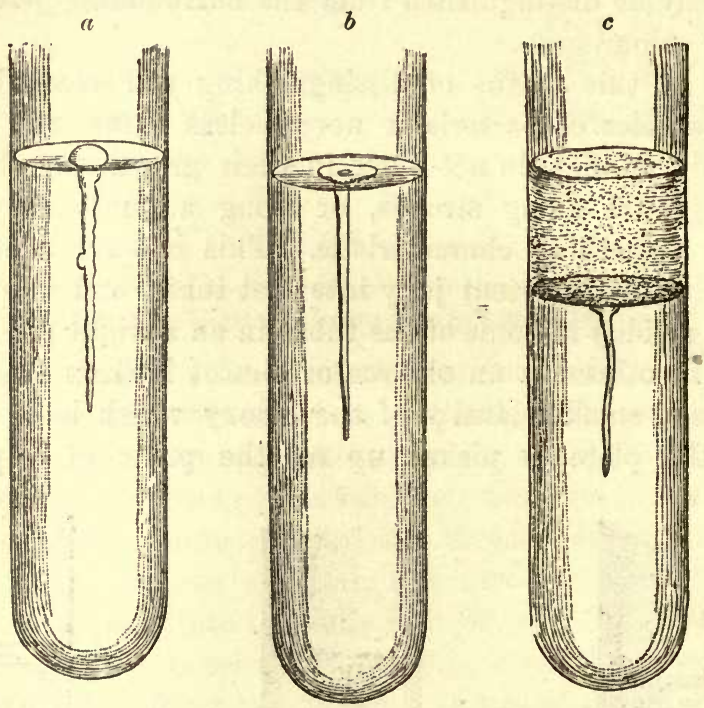

Fig. 41.-Puncture cultivations in gelatine.

forming a markedly prominent knob at the orifice of the puncture (figs. 40,a, and 41,a) ; or liquefaction occurs, beginning slowly at the top and confined to the vicinity of the puncture, or energetically and from the first occupying the whole area of the tube (fig. $41, c$ ). At times a turbidity spreads through the gelatine, starting from the line of puncture, which however is not very distinct; in some cases the jelly appears smoky, or cloudy, in others the growth is more in the form of rays, or of a network of threads

Characteris. tics of the stroke cultivations on gelatine. (fig. $40, b, c$ ). Where the stroke method is employed we see whether separate little drops form, whether these are glassy and transparent, or white and opaque; further, whether the growth remains limited to the 
line, or whether it spreads more or less rapidly from it towards the periphery; whether the spreading margin is straight or irregular, sinuous or jagged, \&c.

In the case of many organisms which liquefy gelatine energetically, we may now and then employ with advantage a mixture of the nutritive solution with agaragar, which remains solid at $37^{\circ} \mathrm{C}$.; nevertheless this cultivating medium does not on the whole show such characteristic differences in growth. Some bacteria

a

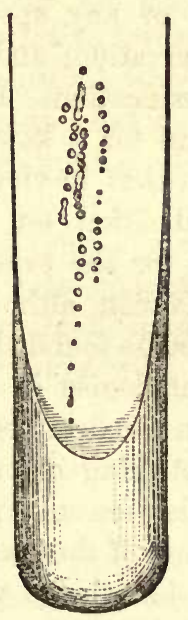

$b$

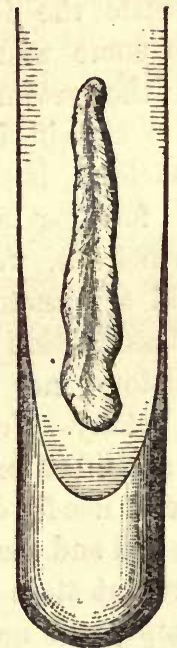

$c$

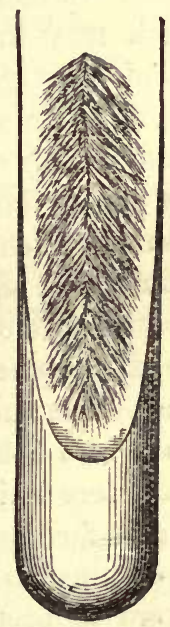

Fig. 42.-Stroke cultivations on gelatine.

grow only on solidified blood serum at the body temperature, and may form very characteristic colonies; finally, some only grow to visible colonies when free oxygen is excluded, and can therefore only be cultivated with special precautions, to be afterwards described.

\section{Classification and Distinctive Characters of the Bacteria.}

A systematic classification of the bacteria is a matter of very great difficulty, because they are so minute that even by the use of the highest powers of the microscope only the external form, and not the differ- 
ences in the structure of the individual cells, can be recognised; nor can any marked differences be made out in the process of fructification, and yet it is that process which furnishes the most important principle of classification in other plants and in the higher fungi. In view of the extremely numerous species of bacteria which are already known, and the number of which is rapidly increasing, an enumeration and classification of these organisms appears to be indispensable, in order that we may at least be able to obtain a general view of the known species, to settle the identity of any species which may in future come under observation, and to include new species in the system of classification. This

Necessity for a provisional classification of bacteria. necessity for a definite classification, and for a key for the diagnosis of the bacteria, is so great, that in view of the impossibility of forming a classification on the ordinary scientific principles, we must for the present put up with some kind of systematic division, althougl the principle of the classification may not be founded on the developmental history, nor have analogies in the other departments of botany. Just as in the first beginnings of a botanical classification any striking external characters which were of use for diagnosis were employed as aids for the distinction and classification of the plants, so we must in the present state of our lnowledge with regard to bacteria employ as means of distinction any properties of the bacteria, their morphological and biological characters, their external form, their mode of growth on certain nutrient substrata, their relation to oxygen, their behaviour with regard to stains, \&c., provided that these properties are constant and characteristic for the individual species, and enable us to distinguish them readily. We may hope that with the advances in our optical means, and with the further knowledge of the processes of fructification, we may gradually obtain for the bacteria a groundwork on which a true classification can be built, and we must therefore thoroughly realise the provisional character of our present attempts at classification. But to abstain entirely from these attempts would be in the lighest 
degree unpractical, and would retard for a long time; and practically prevent, the further progress of our knowledge with regard to the bacteria.

In the present state of our knowledge it is best to em- Morphological ploy both the morphological and the biological characters the four chief of the bacteria for their classification and distinction. groups.

Four great divisions are in the first place made by selecting a single vegetative form or a definite and limited cycle of vegetative forms which are common to a large number of species of bacteria. To the first belong all those bacteria which only occur in the vegetative form, micrococcus. In the second we include the bacilli which occur in the form of rods, at times also in that of threads or spores. The third division is composed of the spirilla, which are only met with in the form of spirals, or of fragments of spirals. The fourth includes those bacteria in whose cycle of development a variety of vegetative forms occur. The chief characteristics of these four divisions are the following :-

\section{Division I.-MicRococci.}

Spherical or egg-shaped cells multiplying by fission, Morphological and always forming spherical cells; they do not show the microspontaneous movement. (The micrococci often exhibit, ${ }^{\text {cocci. }}$ as above mentioned, a trembling molecular movement, and frequently also an alteration of situation due to imperceptible currents of fluid. On closer observation these can, however, be very easily distinguished from true spontaneous movement.) Further, in the micrococci endogenous spore formation does not occur; we either observe no spore formation at all (in most cases), or else so-called arthrospores are present and are distinguished from the other cells by their size and refracting character. In some micrococci the cells are not accurately isodiametric, but the one diameter exceeds the other to such an extent that an oval or egg form results. Further, the spherical form is often 
not distinctly marked when the act of fission has begun, and while the two cells still adhere to one another and the constriction is incomplete (diplococcus). The cells which are undergoing division are under these circumstances elongated with a sharp and more or less deep constriction in the centre, so that they resemble a short rod. A comparison with neighbouring individuals not yet undergoing division, or with those in which the division has proceeded further and led to distinct formation of two spheres, is as a rule sufficient in such a case to enable the diagnosis to be Distinction made as against bacilli. After the division is complete, between diplococci and short bacilli: the various arrangements mentioned on page 156 , staphylococcus, streptococcus, merismopedia, sarcina, zooglæa. If in the zooglæa formation the intercellular substance is very tough, so that cartilaginous masses are formed enclosed in the general mass, the group is termed ascococcus; if the gelatinous masses of such groups become dissolved in the interior, so that only a thin external layer surrounds a hollow cavity filled with fluid, the arrangement is termed clathrocystis.

\section{Division 2.-BaCILLI.} Morpholog:cal Rods in which the longitudinal diameter is 2, 3, or the bacilli. many times in excess of the transverse: The organisms belonging to the class of the bacilli for the most part pass through a definite cycle of forms, so that they do not appear exclusively in the vegetative form, bacillus; many can form threads, and in these spores; in others there is only well-marked thread formation; others produce spores in their middle, at the end, or at several places, according to the modes described on p. 161 ; most of them form at times all sorts of involution forms. We may also meet with these bacteria under many different forms ; but it is characteristic for all the thread forms, and round or oval cells, occurring in connection with the bacilli, that they have been developed from cells having the regetative form of bacillus, and that if 
they are at all capable of development they again grow into bacilli under favourable conditions, either directly or after an intermediate stage. The bacilli occur either in a quiescent stage, in which case they are often arranged in threads, heaps or zooglæa, or in a swarming stage. In many forms, however, the latter stage has not yet been observed. Now and then a mistake may be made between rods and micrococci when the rods are in an upright position and present their circular transverse section to the observer's eje; a correct conclusion may usually be arrived at by careful examination with repeated alteration of the fine adjustment of the microscope, and by comparison with neighbouring individuals. It is at times uncertain Distinction whether an elongated cell constricted in the middle is $\begin{gathered}\text { bstween } \\ \text { micrococci }\end{gathered}$ a diplococcus or a rod. The sharp, acute-angled con- and young striction which is noticeable after the division of a which are unstriction wherg dergoing coccus, and the round form of the two halves, may serve division, or as a means of distinction when contrasted with the those which less acute constriction of the rod, and the fact that the right angles single individuals are never isodiametric Even here to the field of however, it is only after comparison with other reighbouring cells, or after continued observation of the further development of the individual cell, that an absolute conclusion can be arrived at. Young bec.lli, which have just been formed by fission, or by the sprouting of a spore, often show a very slight excess of one diameter over the other, and thus approach the vegetative form, micrococcus, but are easily distinguished from it by their further development, and by the presence at the same time of older forms. Finally, in the spore form a confusion between bacilli Distinction and micrococci could also occur, if it were not sporeen and that the higher refracting power of the spores, and the cocci. feeble manner in which they take up aniline colouring matters, formed good points for their recognition; the diagnosis is rendered certain by the study of the furthcr behaviour of the two cells, the sprouting of the one to form a bacillus, and the multiplication of the other by division to form fresh spherical calls. 


\section{Division 3.-Spirillá.}

Morphological characters of the spirilla.

The iypical forms are spirally twisted threads, which produce new spirals by fission, and which are for the most part mobile and often united in swarms. As to the existence of a cycle of forms in the spirilla there is very little known, but they seem to have a special tendency to the formation of involution forms. In the case of some spirilla it can be distinctly seen that the spirals are composed of short, curved rods; under certain circumstances these rods form the prominent vegetative form, while under other conditions they become fused together, and spiral threads are developed. A precise differentiation of these rod-shaped spiral elements from true bacilli, which often show a slight curvature in microscopical preparations, is frequently very difficult; and it will probably be impossible, as our knowledge increases and transitional forms are discovered, to uphold the genus spirillum as an independent division. In the meantime, however, it appears desirable on practical grounds to group together in the genus spirillum those curved bacilli in which a development of spiral threads and a multiplication in that vegetative form is obserred.

\section{Division 4.-Fission Fungi with Variable Vegetative Forms.}

Characters of the bacteria which show variable vegetative forms.

The aquatic fungi studied by Zopf (formerly described as fission algæ)-cladothrix, beggiatoa, crenothrix-cannot be included in any of the foregoing divisions. In these fungi, according to Zopf, a manifold cycle of forms occurs, so that one and the same fungus may appear in micrococcal, bacillar, and spirillar vegetative forms. It is possible that in course of time other bacteria may become known in which an equally extensive series of forms occur. The species which can at the present time be included with certainty in this group are comparatively easily recognised and distinguished 
by their great tendency to the formation of various regetative forms, as well as by a number of other characteristics.

The external form of a bacteric cell does not of itself afford Necessity for information as to the species to which the vegetative form under observation belongs, but at times admits of various conceptions and interpretations. If, for example, we find a spherical cell, it may be a micrococcus, a spore, or an involution product. The cell can only be designated as a micrococcus when it can be proved that it arose by fission from a similar spherical cell, and that, under suitable circumstances, it may again give rise by fission to another spherical cell. For it is characteristic of the vegetative form, micrococcus, that the same spherical vegetative form repeats itself through a shorter or longer series of cells. If, on the other hand, the round cell has arisen not by fission but by spore formation from another bacteric cell, and if it is not capable of multiplying by direct fission, but must first sprout and form an individual similar to the mother cell, this spherical cell must be looked on as a spore. And, finally, if the spherical form of the cell has arisen from a cell of another shape only when it began to decay, if this spherical remnant is no longer able to multiply or propagate itself in any way, then we have a dead involution structure before us, to which the term micrococcus cannot be applied.

To take another example: if a twisted or spiral thread comes under observation, the question arises whether it has developed by fission from a cell of the same form, and whether it can again give rise to a cell of a similar shape. It is not till this is demonstrated that we are justified in saying that we have to do with the vegetative form spirillum or spirochæte. If this is not the case, it is possible that we have before us a portion of a thread accidentally twisted, or some phenomenon of decay which has arisen under abnormal conditions. It is very important to be clear from the first as to the meaning and the proper designation of these various vegetative forms, as otherwise confusion and mistakes readily occur.

The subdivision of the four chief groups cannot be made Employment exclusively according to the morphological characters; of the chathe various species of bacteria which occur in the micro- of growth for coccal form more expecially show the further differences of shape under the highest powers, and eren distinction of the arrangement of the cocci in chains or masses pre- 
sents so many transitional appearances that they cannot be employed as decisive distinctive characters. Here it is evidently of importance to make use of the manifold and valuable distinctions described above, those, namely, which the bacteria show when growing on certain substrata, especially on nutrient jelly. When sub-classes have been successfully formed by the help of these differences, the further subdivision of the relatively small number of bacteria in any small group may be made by the help of morphological characters, of behaviour with staining re-agents, of relation to oxygen, or of the power of exciting fermentation or disease, and thus we are ultimately able to recognise a given species by the study of its various characters as compared with other species. Of course the species thus formed cannot in the slightest degree be regarded as natural species or varieties; they have an entirely provisional character, and are only meant to serve as a means of rendering the further recognition of the bacteria easy, and of paving the way for a natural classification; they have only arisen from, and are only suitable for the

Practical method of diagnosing the bacteria. practical necessities. Hence the classification given here rests on that practical method which almost every one now employs who wishes to ascertain what bacteria are present in any unknown mixture of fungi. The first step is always an attempt at isolation by means of gelatine plates; the colonies which have developed on the plates can then be easily investigated by making a microscopical preparation with a small quantity, and ascertaining whether the colony consists of micrococci, bacilli, or spirilla. It is almost always easy to decide this point, because when we have a large number of similar individuals all at the same stage of development we have none of those uncertainties mentioned above which might render the diagnosis of an individual cell a matter of great diffculty. When the chief division to which the species in question belongs is thus ascertained, the appearance of the colonies, both macroscopically and under low powers of the microscope is investigated, and then with the help of a simple table (see p. 178) the relation of the species 
to a small group of similar species of bacteria is fixed. The distinction of these closely similar species is then easily made by the aid of some very characteristic reagent, or is a complicated study, and can only be done by observing the appearance of the growths in stroke or puncture cultivations, by studying the action of the cultivation on animals, \&c.

Formerly Cohn made the attempt to distinguish a large Cohn's former number of species of bacteria on the basis of their morpho- classification logical characters. But exactly similar morphological pecu- schizophytes. liarities occur in the lower algæ; and it lis essentially only the absence of chlorophyll which separates the fungi from the algæ; on this point however, as has been said above, no special weight is now laid. And thus when special attention is paid to the morphological characters, the resulting classification of the "schizophytes," must include fission fungi and fission algæ. Such a classification is certainly admirably adapted for placing in correct light certain similarities and differences between the lower algæ and fungi, but it is not sufficient for the number of species now discovered, and it no longer meets practical wants, more especially because a number of heterogeneous organisms of unequal value from a hygienic standpoint are mixed together. In the former edition of this handbook the author attempted by omitting the alga to transform Cohn's classification in the following manner so as to be useful for a circle of readers composed chiefly of medical men:- 

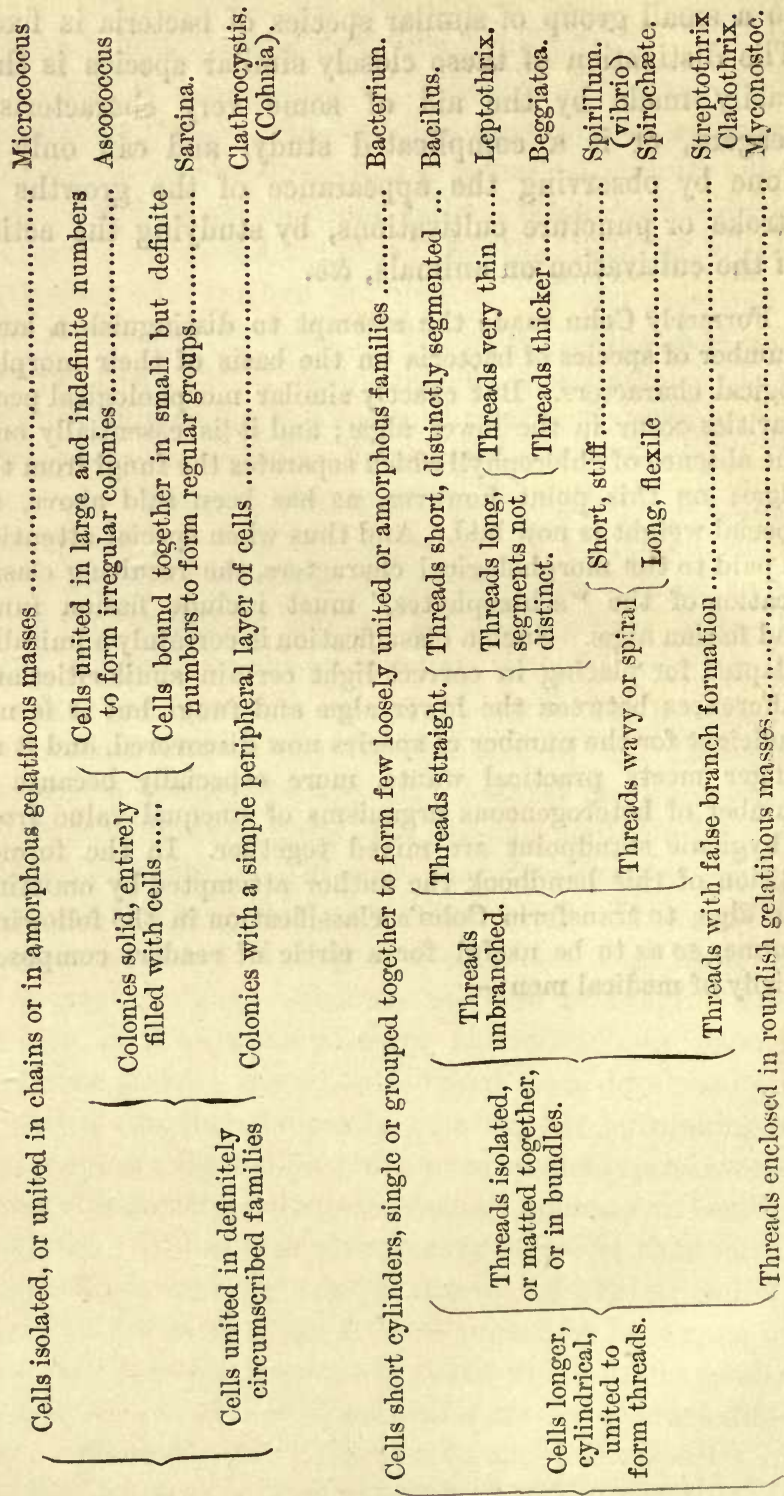

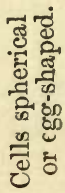

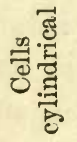


Bearing a doubtful relation to the fission fungi are: Crenothrix, sphærotilus, spiromonas, rabdomonas; monas Okenii, Warmingii, vinosa.

It was frequently stated in the previous edition that this Necessity for classification is in many points impracticable, that many of alteration of the genera cannot be upheld as independent forms, and that classification. it would have to give place to one more in accordance with practical requirements. In fact it has become more and more evident in the course of the last few years that certain of the genera up till recently reckoned as independent forms only represent vegetative and colony forms of various species belonging to other groups, and that the presence of gradual transitional forms greatly increases the difficulty of diagnosis. Thus a deposit within a tough gelatinous mass which was held to justify the classification under ascococcus occurs more frequently than was formerly supposed, and in bacteria of different vegetative forms (leuconostoc, clostridium, polymym, \&c.) Again, sarcina cells are spherical micrococci before the characteristic division into 8 occurs, and often exist for a very long time as isodiametric cells before the division into 4 or 8 is apparent; other micrococci usually occur as single cells or as diplococci, at times, however, in a merismopedia-like arrangement; hence this character can be employed at the most only in a small group of micrococci. As regards the method of arrangement, clathrocystis closely. resembles the genus ascococcus. Further, a distinction between bacterium and bacillus is impossible, because there are too many transition forms which may be placed with as much right in the one class as in the other. The genera leptothrix and streptothrix represent a vegetative form which is seen in many bacilli as an occasional stage of development. Similar difficulties attend the diagnosis between spirillum and spirochæte as between bacterium and bacillus. Finally, beggiatoa and cladothrix, on account of their great mutability of form as discovered by Zopf, must be entirely excluded from a classification based on the constancy of morphological characters.

Cohn, also, has always regarded his classification as a De Bary's provisional one, and one only intended as a general guide till classification. a suitable classification is obtained analogous to that of the higher plants, in which special regard is paid to the peculiarities of fructification, and to the natural process of development. Attempts have already been made from the botanical side to form such a classification. Thus Van Tieghem and de Bary make 2 great divisions-bacteria which form endospores, and those which form arthrospores; but this division is of little service for practical purposes, because it is just the mode of spore formation which is most difficult to 
ascertain in investigating a fungus, while on the other hand this subdivision only indicates the first beginnings of a scientifically correct classification.

Zopf 's classification of the bacteria.
Another classification of the bacteria has been made by Zopf. He extended the doctrine of pleomorphism which he had observed in the aquatic fungi mentioned above to the other bacteria, original observations, and some made by other observers, having demonstrated in several cases a change of form from cocci into bacilli, threads, and spirilla. Zopf is of opinion that variability of the vegetative forms occurs in all bacteria, and that though in the case of many bacteria the complete cycle of forms appertaining to them is not yet known, we may expect that even in the organisms as yet known only in a micrococcal form, thread-forming stages, \&c., will yet be discovered.

Zopf divides the bacteria according to these riews into 4 groups :-

1. Coccaceæ. These are as yet only known in the coccus form. To these the following genera belong: streptococcus (cocci arranged in threads like strings of beads); merismopedia, tablet cocci (division in two directions, leading to the formation of tablet-like flat layers of cells); sarcina, packet cocci (division in three directions, leading to the formation of bale-like colonies); micrococcus (division in one direction, the cocci becoming aggregated together in irregular heaps); and ascococcus (the heaps of cocci accompanied by marked formation of gelatinous material).

2. Bacteriaceæ. These possess chiefly coccus, rod, and thread forms; the former may also be absent; in the latter there is no contrast between base and apex. Threads straight or screw-like.

Genera: Bacterium, forms cocci and rods, or only rods which are arranged in rows to form ordinary threads; spore formation absent or unknown. Spirillum, threads screw-like, formed only of rods, or of rods and cocci; spore formation absent or unknown. Vibrio, threads screw-like, spore formation in the longer or shorter joints. Leuconostoc, forms cocci and rods, spore formation in cocci. Bacillus, cocci and rods, or only the latter in the form of simple or twisted threads; spore formation present, occurring in rods or in cocci. Clostridium, resembles bacillus, but the spore formation occurs in peculiar dilated rods.

3. Leptothrix. Coccal, rod, and thread forms; the latter show a contrast between base and apex; threads straight or screw-like; spore formation not demonstrated.

Genera: Crenothrix, threads enclosed in a sheath, cells without granules of sulphur; inhabitants of water. Beggiatoa, 


\section{DISTINCTIVE CHARACTERS OF THE BACTERIA. 181}

threads without a sheath, cells with sulphur granules; inhabitants of water. Phragmidiothrix, threads without sheaths, successive divisions very extensive; cells free from sulphur; inhabitants of water. Leptothrix, threads with or without sheaths, divisions not very extensite; cells devoid of sulphur.

4. Cladothrix. Show coccus, rod, thread, and spirillar forms. The thread form is provided with pseudo-branches. Spore formation not demonstrated. Genus: Cladothrix.

$A$ priori the possibility of the mutability of form of the bacteria asserted by Zopf, and to which expression is given in the foregoing classification, must at any rate be admitted; but before we accept it as a matter of fact, and as so general, we must demand complete proof, and we must insist the more strenuously on a satisfactory proof, as we would be deprived, by the admission of extensive changeability of form, of an important diagnostic aid which is of great value to us in medical and hygienic practice. We know now a number of exciting agents of disease which occur, for example, in the form of characteristic bacilli; we are able to make a diagnosis of tuberculosis by the discovery of the tubercle bacillus, and of cholera by the demonstration of the cholera bacilli. If the characteristic bacilli are absent on careful and repeated investigation, and if we find only bacilli or cocci of other form, we consider ourselves justified in denying the existence of tuberculosis or of cholera. Further, we frequently undertake the investigation of some object, which is suspicious from a hygienic point of view, for the presence of typhoid bacilli, of anthrax bacilli, \&c., and we can only hope for a result because we search in all cases for an organism of definite and characteristic form. If, however; Zopf's view is correct, and if these bacilli often occur in a coccal form, investigations of this kind must obviously be without result; it is impossible to recognise by the microscope organisms in the coccal form, and hence any extraneous innocent coccus might lead us to the diagnosis of tuberculosis or typhoid fever just as well as the supposed coccal form of these pathogenic bacilli. We should also meet with great difficulties in isolating organisms by cultivation if the colonies of, for example, the typhoid bacillus could occasionally contain only coccus forms. We should then find it very difficult to decide with regard to a group of cocci whether they should be included in the genus spirillum, or beggiatoa, or micrococcus, or bacterium, and also to what species of these genera they belonged.

Complete proof of the accuracy of Zopf's views has certainly Absence of not been furnished with regard to the great majority of the proof of the fission fungi. Our most skilled microscopists and bacteriolo- applicability gists have nerer as yet been able to demonstrate a trans- of Zopf's 
Sources of error in the proof.

formation of micrococci into bacilli or vice versâ. The positive observations which furnish support to Zopf's views proceed almost entirely from investigators who have not had a long and special instruction and experience in bacteriological research. These, however, are the investigators who are most liable to fall into errors which lead to a mistaken assumption of an alteration in form, and which are only avoidable by long practice and particularly careful observations. In the first place, it may easily happen that any roundish body which is like a coccus may be mistaken for a true coccus. Such a mistake is possible, for example, with spores and with involution forms (see p. 175); further, young bacilli just formed by fission show often only a very slight excess of the long diameter (see p. 173); bacilli standing upright and seen in transverse section resemble cocci; by the use of staining materials-a method to which we owe the most beautiful facts, but which in unskilled hands is a dangerous means and often leads to mistakes - a coccus form may be produced by staining very old bacilli which no longer take up the colouring matter in their whole extent, or by heating too strongly, or by employing differentiating materials for too long a time, so that again only a partial staining results. In investigating cultivations also, the possibility of contamination from without is never absolutely excluded, and abnormal forms must always in the first place be closely tested on the suspicion that they may be derived from contamination with other fungi; it is only when we repeatedly obtain similar results after employing all precautions for maintaining pure cultivations that we call conclude that all the forms observed have arisen from one and the same species.

Refutation of some statements made in support of Zopf's hypothesis.
These numerous sources of error certainly justify us in exercising a certain reserve with regard to the statements as to an extensive alteration in form of the bacteria. Many of these statements have already been shown to be undoubtedly erroneous; thus Kurth has, in the case of the bacterium Zopfii which is according to Zopf a striking example of the great mutability of form of the fission fungi, seen, according to his own description, spores, but not cocci, originating from the bacilli; for these "cocci" did not multiply by fission, but grew directly to rods in fresh nutritive solutions, and were less sensitive to external influences than the rods. In like manner the bodies which Hauser of late saw arising from bacilli, and which he erroneously termed cocci, do not produce new cocei by fission; while the spirulina of the same author represent simple bending and irregular intertwining of threads such as occurs in every long flexible thread. 'To mention another example, we may refer to de Bary's bacillus megaterium, 
which is said to occur in coccus forms; this form was observed "when the cultivations were rendered impure by the presence of other small bacteria, the species under discussion retaining, however, the upper hand; the torula-like chain form can then by purer cultivation be again transformed into that of the smooth rods." Undoubtedly such a transformation in very impure cultivations is not free from objection.-Thus a number of apparent proofs of the mutability of form of the fission fungi have been refuted or recognised as uncertain, while on the other hand we convince ourselves daily of the how extraordinarily constant the most various saprophytic bacteria. and pathogenic species of bacteria are when full attention is paid to all the sources of error. On the ground of these extensive and daily observations one may now with justice assert that variation in form does not occur to any large extent in the majority of the bacteria; that on the contrary most bacteria pass through only the limited cycle of forms which are easily observed and permit a diagnosis of the individual varieties. Should, however, new and unobjectionable investigations demonstrate an extensive mutability of form in one or other species, these species must then be classed with the fungi included in the last division of this provisional classification; we would, however, be compelled to regard such a state of matters rather as the exception than the rule, and would not be warranted in deducing a law applicable to all of exceptions. other bacteria from such exceptional cases, seeing that manifold investigations have always proved the contrary.

\section{MICROCOCCI.}

(For characteristics, see p. 171.)

\section{A. Micrococci Pathogenic in Man.}

Staphylococcus pyogenes aureus.

First observed by Ogston; cultivated by Rosenbach, later by Krause and Passet. Small isodiametric cells about $0.87 \mu$ in diameter (Passet). Often grouped as diplococci, at times in 4's, and also in short chains of 3 or 4 individuals, generally, however, in larger irregular masses. Retains the aniline stain after treatment with Gram's fluid (iodine and iodide of potassium solution and alcohol).-Grows on gelatine plates, $*$ and forms in

* Where we speak of nutrient jelly in the following pages we always 
Growth on gelatine plates.
In puncture eultivations.

Growth on other nutritive media. two days at the temperature of the room punctiform colonies, which under a low power of the microscope present the appearance of light brown circular balls, dark in the centre and with smooth borders. On the second or third day the colonies have generally increased to such an extent that they reach the surface of the gelatine; they then assume a characteristic appearance, presenting a yellow colour from this time forward, and also slowly liquefying the gelatine in their neighbourhood. The liquefaction becomes evident by the occurrence of a very shallow depression around the colony which is marked off from the rest of the gelatine by a sharp border. With suitable illumination a number of absolutely circular depressions, $5-10 \mathrm{~mm}$. in diameter, are seen on such a plate, and in the centre lie the yellow colonies of at the most $1 \mathrm{~mm}$. in diameter. At a later period the liquefaction extends further, the individual liquefying centres coalesce, and the colonies break up into fragments. - The puncture in nutrient jelly shows at first a white confluent layer along the track of the needle; liquefaction quickly occurs, beginning at the surface, and soon, as a rule, occupying the whole tube up to the glass; after a few days the yellow coloration appears, and increases somewhat in intensity up to the eighth day. The whole contents of the test-tube ultimately become liquid, and at the bottom lies the golden yellow mass of the deposited colonies.

If agar-agar is employed as the solidifying material instead of gelatine, no liquefaction occurs, and the growth of the colonies on the plates can be watched for a long time, but the very characteristic appearance due to the slow liquefaction of the gelatine is absent. In strokes and punctures the agar cultivations have the appearance of whitish masses, which after a few days present at the surface a golden yellow colour. The

refer to the mixture containing 5-8 per cent. of gelatine described in detail in the chapter on the methods; it is only in such a mixture that the characters of growth of the various bacteria present the appearances described here. Further, a temperature of $20^{\circ}-22^{\circ} \mathrm{C}$. is generally employed for gelatine cultivations. 
staphylococcus grows on potatoes in the form at first of a bright yellow, and later of a thick soft golden yellow layer.-When inoculated into milk, coagulation occurs after one to eight days in consequence of the production of one or several acids, among which lactic acid has the preponderance. A peculiar sour smell also becomes evident after some time in the cultivations on potatoes or agar.

The yellow colouring matter is only formed where Products of the colony is in contact with free air; under a layer of growth. oil the cultivations remain white. It is probable from the peculiar and energetic action of the fungus on the living tissue of warm-blooded animals that poisonous irritating materials are produced, and hence it would be very desirable to obtain a more accurate knowledge of the products of their growth. Brieger has recently (Weitere Untersuchungen über Ptomaine, p. 73) isolated an organic base from staphylococcus which had been grown in meat infusion. This base does not appear to be identical with any of the ptomaines as yet known, and thus seems to be a specific product of the growth of the staphylococcus; it did not however prove to be poisonous to the animals experimented on.

The staphylococcus is remarkable on account of its relatively great resisting power to external agents; the cultivations in gelatine or agar are active after more than a year.

The action of the staphylococcus on animals varies Action on greatly according to the mode of application. Subcutaneous inoculation is without result in mice, guineapigs, and rabbits; when inoculated on the cornea of rabbits a small greyish white infiltration occurs, accompanied by inflammation which subsides on the fourth day. After subcutaneous injection the pyogenic properties of the fungus become evident. It is only in mice, and after the injection of relatively large quantities, that death occurs early; in guinea-pigs and rabbits, on the other hand, an abscess forms in the first instance, and this can either heal and the animal recover, or a general infection may ultimately occur. Intraperitoneal and 
intravenous injections usually kill the animals after from two to nine days. On post-mortem examination the most characteristic alterations are found in the kidneys, which present the appearance of a septic embolic nephritis; whitish yellow masses from the size of pin points up to that of peas are present, and at times large wedges which infiltrate the kidney like pyramids. Many capillaries are completely blocked with thrombi consisting of cocci, as are also the smaller arteries in the cortex as well as a few straight tubules. Further, purulent metastases often occur in joints, in the muscles, and, where fractures have been recently made, in the medulla of the injured bones; frequently, however, the latter situation escapes, although recent fractures are present. Small quantities of the fungus are at times without effect, even when injected into the veins; nevertheless in these cases also deposits appear to form in the kidneys, but remain limited and heal.

Renal The deposits in the kidneys do not arise as the result deposits. of the excretion of the staphylococcus by the kidneys, nor does the localisation occur here in connection with any protective excretion; on the contrary, it has been demonstrated by the experiments of Wysokowitsch* that not a single coccus appears in the urine during the first six hours after the injection of large quantities of staphylococcus, and that when cocci can be cultivated from the urine deposits are always demonstrable in the

No physiological excretion through the urine.

Occurrence in man.

kidneys. The cocci introduced into the blood are deposited in various organs, especially in the spleen, in the medulla of bone, \&c., and they either soon die or remain for a long time capable of development.

Staphylococcus occurs very frequently in man; it is the most common pyogenic organism. The experiments of Rosenbach and Passet, repeated recently with great care, have shown that materials mechanically and chemically irritating (turpentine and mercury) can only excite suppuration in extremely exceptional cases, when microorganisms are not present at the same time. In almost all the cases of suppuration which come under observa-

\footnotetext{
* Gottinger hygien. Institut.
} 
tion in practice bacteria are the causal agents, and some forms of suppuration are more especially caused by staphylococcus aureus. This organism causes rapid suppurative destruction of the tissue, and it excites suppura- . tive phlegmons which spread more in the tissue than in the lymphatic vessels. Hence it is found more especially in acute abscesses, in empyema, and in boils ; further, in acute osteomyelitis, although the above mentioned experiments in animals have not demon-

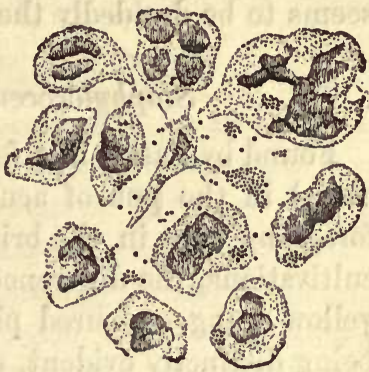

Fig. 43.-Pus containing staphylococcus $\times 800$. strated with absolute certainty the causal rôle of this fungus in that disease. Lastly, it occurs at times in some severe diseases, accompanied by metastases, in pyæmia, and in ulcerative endocarditis. According to the point of entrance of the fungus into the body, and according to the numbers which enter, affections of very different severity may follow. That in reality the staphylococcus cultivated from pus from osteomyelitis is also the exciting cause of furuncular inflammation has been proved recently by an experiment made by Garré on himself, where a culture of staphylococcus, originating from the pus from osteomyelitis, was rubbed into the completely intact skin of the arm, and where the organisms penetrating through canals of the cutaneous glands, set up furuncles over a large extent of the surface.

\section{Staphylococcus pyogenes albus.}

Found frequently by Rosenbach in pus along with staphyl. aureus. Corrcsponds in microscopical appearance, in the characters of its cultivations, and in its relation to animals, with staphyl. aureus, the only difference being that its colonies remain white even after a long time; in old gelatine cultivations a white deposit is seen at the bottom of the liquefied mass. According to Passet, staphyl. albus occurs more fre- 
quently in man than aureus ; according to Rosenbach, on the contrary, less frequently, and usually mixed with aureus. In many animals (rabbits) the staphyl. albus seems to be decidedly the most frequent.

\section{Staphylococcus pyogenes citreus.}

Found by Passet in a few cases (in 10 per cent. of the cases) in the pus of acute abscesses. Differs from the foregoing only in the bright citron yellow colour of its cultivations, the difference as contrasted with the dark yellow orange-coloured pigmentation of staphyl. aureus being distinctly evident, especially in old cultivations.

\section{Micrococcus of the "Clou de Biskra."}

By the term "Clou de Biskra, or Bouton d'Alep," is meant an endemic disease occurring in Aleppo, Bagdad, Biskra, and Tunis, characterised by tubercular swellings on the face and extremities, which develop in the course of a year, burst, and finally cicatrise. Duclaux has found micrococci in the blood of these patients, which were less than $1 \mu$ in diameter, occur in the form of diplococci or zooglæa (thus belonging to the staphylococci), and can be cultivated in neutralised veal infusion. Twenty drops of the cultivation injected subcutaneously into rabbits excite extensive gangrene, but the animals ultimately recover. Large doses injected into the blood of rabbits kill them within 16 hours, and on post-mortem examination pericarditis, pleuritis, hæmorrhagic infarcts in the lungs, \&c., are found. After the intravenous injection of small doses, a chronic disease, which gradually gets well, begins after an incubation period of 10 days; this disease is characterised by the occurrence of numerous small ulcerating nodules distributed over the skin of the whole body, and recalling exactly the disease in man. A confirmation of this observation by the investigation of other cases of Clou de Biskra must be awaited.

Duclaux has made a striking observation with regard to the cultivations of these micrococci. Old cultivations gradually lose their virulence, so that after standing for two months the cultivations were inactive, even in large doses. But if fresh infusion was inoculated from these old inactive cultivations, the new cultivation was as virulent in the first few days as the former young cultivations, and according to the dose employed it set up the whole series of morbid symp- 
toms described above. As, however, the experiments were made only with fluid media there is no absolute certainty that in these experiments impurities in the cultivations did not lead to mistakes.

\section{Micrococcus pyogenes tenuis.}

Found by Rosenbach in a few instances (in 10 per cent. of the cases examined) as the only micro-organism present in the pus of unopened abscesses. Irregular cocci, somewhat larger than staphylococci, showing in contrast to the latter, but little tendency to the formation of masses. Two dark poles with clear intermediate substance are frequently observed in the micrococci; the cultivations on agar have the appearance of thin deposits spreading out from the line of inoculation, almost as clear as glass; in puncture cultivations a somewhat thick and slightly opaque layer is formed. No experiments on animals have as yet been made.

\section{Streptococcus pyogenes.}

First recognised by Ogston from its microscopical Pyogenic appearance; cultivated from pus by Rosenbach, then by streptococcus. Krause and Passet.-Spherical cocci, about $1 \mu$ in diameter, larger than the staphylococci. Retain the stain in Gram's method. What is very characteristic, and the origin of the name of this species, is the tendency of the cocci to divide continuously in the same direction and to form chains of 4,5 , or even 10 , or more cocci; these chains are frequently united in delicate loops to form larger heaps. Besides the chain form, the fungus often appears as a diplococcus. At times one or other cell in a chain is larger than the rest; it is not certain whether this indicates the formation of arthrospores. The streptococcus grows on gelatine plates in the form of very small punc-

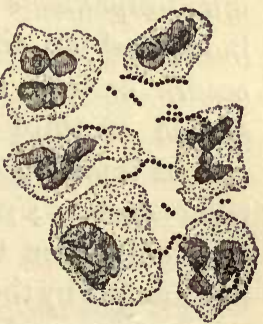

Fig. 44.-Pus contain. ing streptococcus $\times 800$. tiform colonies which spread out on the surface as very

Growth on gelatine plates. 
small, slightly prominent transparent drops, about $\frac{1}{2} \mathrm{~mm}$. in diameter. Even after several days there is no extension of these colonies and no liquefaction of the gelatine. Under a low power the youngest colonies present the appearance of round, seldom oval, yellow spots, with regular contours and finely granular surface. Later they become somewhat darker, almost brown, and the border is here and there interrupted by projecting chains of cocci, which either terminate in a free end, or form loops; the growth is somewhat more marked on agar plates, the colonies are rather broader

In puncture cultivations.

In stroke cultivations. and opaque.-Along the track of the puncture in gelatine a delicate layer appears, which consists, either entirely or in part, of isolated colonies; these are of a faintly whitish appearance, almosttransparent, very small; only a few attain the size of a pin's head. In stroke cultivations the streptococcus seldom forms continuous lines, it usually occurs in discrete centres; on agar the growth is thickest in the middle, and becomes gradually thinner in a terrace-like form towards the periphery; at the periphery punctiform masses of the organisms can be seen here and there. - On solidified blood serum the growth is similar to that on agar; it does not seem to grow on potatoes.

In mice in the majority of cases (about 80 per cent.) no effect follows the subcutaneous inoculation of small quantities; at times slight suppuration occurs at the point of inoculation, at times the animals die without the presence of any marked pathological change or of micro-organisms in any of the organs. If rabbits are inoculated on the ears marked redness and swelling occurs on the following day, but disappears on the second or third days; subcutaneous and even intravenous injection of considerable numbers of the streptococci cause as a rule no apparent effect in healthy rabbits. It is only when the animals are artificially weakened, as for example by the injection of toxic substances, that death occurs from marked growth of the micrococci; the animals also died after $2-5$ days from extensive endocarditis, with numerous deposits of streptococci, if the aortic valves had been injured before the injection (Wysokowitsch). 
Streptococcus pyogenes is frequently found in pus Occurrence in from man (in 40-60 per cent. of the kinds of pus examined). It occurs by preference in the inflammations which have their chief seat in the lymph tracks; it does not as a rule cause such rapid suppuration and destruction of the tissue as the staphylococcus, but it can penetrate further into the tissue and infiltrate it before suppuration and destruction occurs. Also in severe affections, in spreading gangrene, in several cases of pyæmia, cultivations from the pus have yielded only the strept. pyogenes (compare the following streptococci).

\section{Streptococcus erysipelatosus.}

Proved by Fehleisen by cultivation and re-inoculation Streptococcus on man to be the causal exciting agent of erysipelas; the streptococci had already been demonstrated microscopically by other observers. It can scarcely be distinguished from the preceding either microscopically (also by Gram's method) or by its behaviour in cultivations. It is only in the case of the stroke cultivations that Growth in a noticeable difference at times occurs in so far that cultivations. the colonies have a somewhat greater tendency to run together, appear more whitish and opaque, and show at the periphery numerous out-growths which consist of projecting chains, and give to the cultivation the appearance of a fern leaf. Nevertheless these characteristics are not sufficiently constant to furnish a trustworthy point of

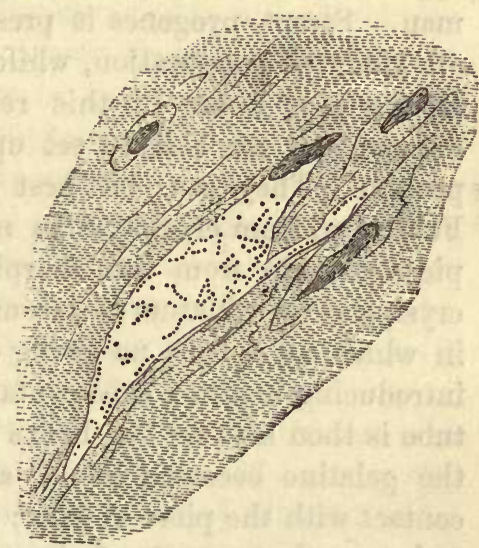

Fig. 45. - Erysipelas cocci $\times 700$. Section through a lymphatic vessel of the skin. distinction between the two cultivations.

Experiments on animals show a slight difference 
Action on animals.
Occurrence in man.

between the two forms of streptococci. Subcutaneous inoculations in mice are always without effect, the wounds almost always healing without suppuration. In rabbits inoculation on the cornea sets up keratitis, as in the case of streptococcus pyogenes; inoculations on the ear cause in the majority of cases an erysipelas which is recognised by redness and elevation of temperature of the ear; it appears later, and is not accompanied by such intense redness as is the case with the inflammation due to the streptococcus pyogenes. A sharply limited redness appears in the neighbourhood of the point of inoculation within 36 to 48 hours; and this extends in the direction of the veins as far as the root of the ear. In sections of the affected eur the lymphatic vessels are filled with micrococei in numerous places. The animals recover completely after a few days ; intravenous injections of large quantities of the organisms are also borne without bad effect.

While thus only very slight differences can be made out between these two streptococci as the result of cultivations and of experiments on animals, they apparently differ to a marked degree in their action on man. Strept. pyogenes is present in about the half of all kinds of suppuration, while the streptococci of erysipelas only occur in this relatively rare contagious disease, and are able to set up this disease in healthy Cultivation of people. They can be best obtained, according to the cocci from Fehleisen, from erysipelas in man, by excising a small
man. piece of skin from the sharply defined border of an erysipelas marginatum (not from the earlier affected parts, in which, as a rule, no living cocci can be found), and introducing it into a tube containing nutrient jelly; the tube is then kept for two hours at about $40^{\circ} \mathrm{C}$., so that the gelatine becomes liquid, and comes into intimate contact with the piece of skin; it is then kept at $20^{\circ} \mathrm{C}$., or better, the contents of the tube are poured out on a glass plate in the usual manner. After two or three days, numerous punctiform colonies can usually be found in the neighbourhood of the piece of skin.

Fehleisen has inoculated these cultivations on man after 
a number (17 and more) of successive cultivations on new Artificial nutrient jelly, and in these cases typical erysipelas has of the resulted. The experiments were carried out on patients cultivations who were suffering from malignant tumours, which could not be operated on (lupus, carcinoma, sarcoma), and this was done because former experience has shown that these tumours often improve in a remarkable manner, or entirely disappear after recovery from an accidental attack of erysipelas. Such an "erysipèle salutaire" has several times during the last few years been induced by inoculation of pure cultivations, and often with good therapeutical results. The incubation period in the cases observed by Fehleisen extended from 15 to 61 hours; the disease always commenced with an initial rigor, elevation of temperature, and disturbance of the general health. Individuals who had suffered from an attack of erysipelas a short time (up to some months) before the inoculation proved to be immune.

\section{Streptococcus pyogenes malignus.}

Cultivated by the author from necrotic masses in a leucæmic spleen. Not distinguishable microscopically from the streptococci previously described, the cultivations are also very similar in appearance; the colonies on gelatine plates and in puncture cultivations appear somewhat smaller and grow more slowly, so that they do not begin to be visible till after about 48 hours. The stroke cultivations resemble most closely those of Strept. pyog.-Experiments on animals yield results which differ in an important manner from those attained by the other streptococci; mice inoculated subcutaneously with small quantities of the cultivation die almost without exception after $3-5$ days; a large collection of pus is found at the place of inoculation, a moderate number of diplococci and short chains of cocci in the blood and especially in the spleen, at times also deposits of micrococci in the internal organs. The disease may be transmitted to other mice by small pieces of the tissue, or by the blood, if not in too small 
quantities. Rabbits, after inoculation on the ear, show at first almost the same appearances as after inoculation with Strept. pyog. and with Strept, erysip.; but after two or three days a general infection occurs, and death follows on the fourth day; the post-mortem appearances are similar to those found in mice; some of the joints are also frequently affected, and filled with pus containing numerous cocci. It is probable that the Strept. pyog. described by Krause, and which differed in its malignant effects on animals from the coccus isolated by Rosenbach and Passet, is identical with this organism.

\section{Streptococcus articulorum.}

Loeffler has observed chain-forming micrococci on and in the diseased mucous membrane in various forms of diphtheria ; these organisms probably do not bear any causal relation to the diphtheria itself, but appear to be accidental accompaniments which may give rise to secondary complications either local or general. If these cocci are cultivated on nutrient jelly, small light greyish drops, as clear as water, are noticed in about three days, their borders showing with a low power small curly lines composed of chains of cocci. The chains may contain up to 100 individuals, some of which attract attention by their size, and at times the whole of the chain consists only of these large cocci ; on closer examination indications of transverse division can be seen in these organisms.-On subcutaneous inoculation or injection of the cultivations into mice a considerable number, more than half, of the animals usually die; streptococci are found in the spleen and in other organs. After inoculation on the ear an erysipelatoid inflammation occurs in the case of rabbits; if, however, cultivations are injected into the veins, affections of the joints occur in 4-6 days, the joints becoming filled with pus containing streptococci, and the disease in most cases gradually ending in the death of the animals. Similar joint affections occur in connection with the streptococci already described, but here only as part of a general 
infection running a rapid course. Further, after injection of erysipelas cultivations Loefler obtained joint affections in two cases, but the author was unable to confirm this result in a larger number of experiments.

Heubner and Bahrdt have recently found similar streptococci in the pus in a fatal case of scarlatina, accompanied by suppuration of joints. They were able to show that the cocci entered the jugular vein through a purulent canal extending from the original diphtheritic affection of the tonsil, and then, just as in Loeffler's experiments, set up the suppurative inflammations of the joints.*

\section{Streptococcus septicus.}

Although this organism has not as yet been observed in man it may be mentioned here, because in its whole behaviour it shows a great resemblance with the other streptococci.-Strept. sept. was repeatedly found by Nicolaier, and afterwards by Guarneri, in impure earth. $\uparrow$ It cannot be distinguished microscopically from the other streptococci, but it has not such a morked tendency to form chains under all circumstances ; it occurs especially in the tissues, and usually in the form of diplococci. Where, however, masses are present, which are composed of larger balls of the organisms, the chain-like arrangement becomes distinctly marked, especially at the borders, and it is also well developed in cultivations in hanging drops, on plates, \&c.-The colonies on gelatine grow even more slowly than those of the other streptococci-not till after 3 or 4 days do they become evident as fine points; in puncture cultivations also distinct colonies are first seen on the 5 th or 6 th day. Mice die without exception in 48-72 hours after subcutaneous inoculation of minimal quantities of a cultivation. During the last 24 hours a distinct motor and sensory paralysis of the hinder extremities is present. On post-mortem examination large numbers of diplococci are found in the blood and organs, at times in large masses, which completely fill the vessels. Inoculations

* Berl. klin. Woch., 1884, No. 44.

+ Göttinger hygien. Institut. 
on other mice succeed with the minutest quantities of blood or splenic juice. In rabbits after inoculation on the ear there occurs in the first instance a local redness, then a general disease, and death after 2 or 3 days. In the internal organs a marked accumulation of micrococci is found everywhere, at times leading to plugging of the vessels and the formation of necrotic foci. This tendency to the formation of foci leads in the case of rabbits to transmission of the coccus to the fœtus, as shown by Oberdiek; * nevertheless in the latter there are always markedly fewer micrococci, because the lesion of the placental tissue evidently occurs only towards the termination of the life of the mother.

Comparison and distinction of the various streptococci.

In connection with the species of streptococci just described we meet with the striking fact that fire organisms, scarcely distinguishable from each other microscopically or by cultivation, are so markedly different in their action on man and the lower animals. The resemblances on the one hand, and the differences in pathogenic effect on the other, have been accurately ascertained by Guarneri in a special series of experiments in which particular attention was paid to any possible deception or confusion. More especially any possible immunity of the animals as the cause of the inefficiency of the pyogenic and erysipelas streptococci was excluded, because the same animals which had resisted one or several inoculations with the Strept. pyog. without effect, at once died from inoculation with Strept. pyog. malignus.

From this result we may assume that streptococci of very different virulence occur in the various infective diseases of wounds in man, and that the symptoms and the result of the disease caused by streptococci are due not only to the mode of invasion, or the functions of the organs attacked, but also to the specific characters of tlie organism. In order to recognise the latter it is

\footnotetext{
* Götting ar hygien. Institut.
} 
cvident from what has gone before that the characteristics observable by the microscope or by cultivation are not sufficient, but that experiments on animals must also be made, and in many cases even these are not sufficient for a diagnosis.

In a series of diseases in man streptococci have been found, but we have not been able to decide whether we have to do with specific organisms peculiar to the disease in question, or with one of the forms of streptococci previously mentioned. Thus in-

Endocarditis ulcerosa.--The masses of micrococci found in the vessels show for the most part a chain-like arrangement of the cocci; nevertheless staphylococci may present similar appearances in the tissues, and in one cultivation experiment with the micrococci of endocarditis only staphylococci grew (Wysokowitsch). Accord-

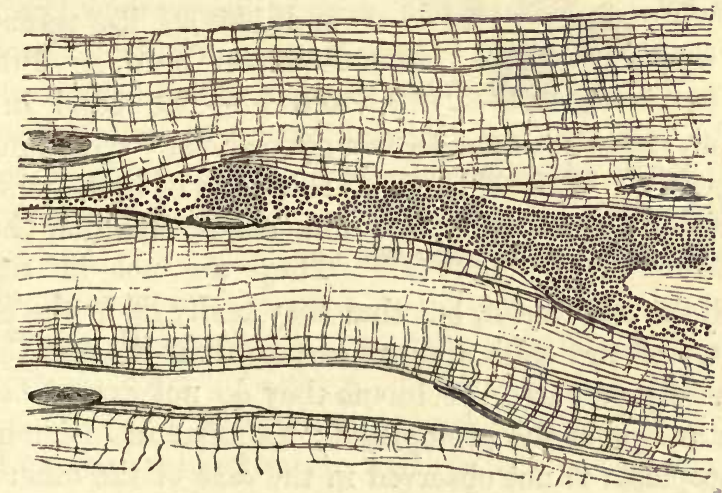

Fig. 46.-Endocarditis ulcerosa $\times 700$.

Section from the cardiac muscle. (After a photograph by Koch.)

ing to the author's experiments referred to above, it is at all events unnecessary to assume the existence of a specific organism in order to explain the origin of an endocarditis. Further, in many cases of pyæmia and pyæmic metastasis, also in puerperal metritis as well as in cerebrospinal meningitis, streptococci have been 
demonstrated microscopically, and have been assumed to be the causal agents of the disease (Lit., pp. 15 and 35).

\section{Micrococcus gonsrrhœa.}

Gonorrhœa coccus.

\section{Morphological
peculiarities.}

Observed by Neisser in 1879 in gonorrhcal secretions, and later termed gonococcus; cocci which almost always occur in the form of diplococci. The elongated body of the diplococcus in stained specimens shows in the middle a clear line (best seen in preparations stained with fuchsin), which with the highest powers appears as a distinct partition; this line divides the coccus into two halves, and gives it the roll (biscuit) form. As a rule the two halves are not true half circles; at times a slight concavity is present on the opposed and flattened surfaces of the hemispheres. Cocci not undergoing division are only exceptionally seen. The average

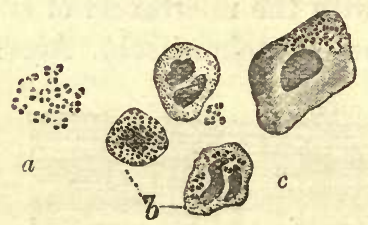

length of the diplococcus is about $1.25 \mu$; its long diameter varies between 0.8 and $1.6 \mu$., its transverse diameter between 0.6 and $0.8 \mu$. -The cocci in the Fig. 47.-Micrococcus of gonorrhœa gonorrhœal secretion lie $\times 800$. (After Bumm.)

$a$, free cocci.

$b$, cocci in pus cells.

$c$, epithelial cell containing cocci.

chiefly on or in the pus cells in small irregular heaps. They are not in contact with the cell nuclei, but that they really lie in the protoplasm of the cells appears certain from the fact that in carefully prepared specimens they do not extend beyond the margin of the protoplasm; a similar inclusion in the protoplasm is not observed in the case of the other nonspecific micrococci, which are also often present in considerable numbers in gonorrhœal secretion. The number of cells containing cocci is greatest not so much in the early period after infection, so long as the secretion still remains serous, as in the later suppurative stage of the gonorrhœa. - The cocci become decolourised in Gram's method.

In cultivation experiments with the gonorrhœal cocci, experiments. the saprophytic organisms present in the secretion have 
often led to mistakes. By the elaborate researches of Bumm it seems to be definitely ascertained that no growth of the specific cocci occurs on nutrient jelly or on the other ordinary nutritive substrata, or at the temperature of the room. Positive results under these circumstances have always been due to saprophytes morphologically very similar to the gonorrhœal cocci. According to Leistikow and Loeffler blood serum gelatine is a very suitable soil for the gonorrhœal cocci ; according to Krause and Bumm solidified blood serum is the best. Bumm obtained the best cultivations with moderately firm blood serum, the surface of which was protected from drying by placing the tubes in a moist chamber, and at about $32^{\circ} \mathrm{C}$. If he inoculated the secretion containing cocci on such blood serum, a fine layer spread over the surface from several spots along the inoculation stroke; this layer attained a breadth of 1-2 mm., ultimately presented the appearance of a very thin greyish yellow layer with moist smooth surface, and then ceased to grow, and was found to consist of closely packed masses of cocci. Further cultivations can be carried on through several generations when the reinoculations are made as early as possible. The growth is always very imperfect; the line of inoculation increases in breadth by scarcely $1 \mathrm{~mm}$. in the course of a day, and the organisms frequently die without any apparent reason.

Animals have proved completely immune to the Inoculation on gonorrhœal cocci. In dogs, rabbits, horses, monkeys, \&c., neither the fresh secretion, nor cultivations inoculated on the conjunctival or urethral mucous membrane have caused inflammation. On the other hand, the On man. attempt has been made in two cases by inoculation of cultivations on healthy human beings to demonstrate the etiological rôle of the cocci in gonorrhœa. In the first case Bockhart introduced a large quantity of a cultivation in peptonised nutrient jelly into the urethra of a lunatic who died some time afterwards from an accidentally acquired pneumonia; during life typical gonorrhœa had developed, the secretion being full of 
cocci, and in the sections through the urethral macous membrane numerous cells filled with cocci were found. This case is not quite free from objection, because later experiments have shown that no growth of the cocei occurs on nutrient gelatine; perhaps, therefore, the positive result was obtained by cocci which had not grown in the cultivation but had been carried over in the inoculations, and had remained alive; this is not at all improbable, because large quantities were employed in the inoculation from the pus, and in the subsequent reinoculations, and also because the fourth generation was employed for the infection experiment. A second inoculation experiment was made by Bumm on the healthy urethral mucous membrane of a woman, and in like manner with a positive result; the second generation of a cultivation on blood serum was employed. Here also, in spite of the fact that pus cells could not be found in the cultivation on microscopical examination, the objection is possible that perhaps cocci were carried over from the secretion, especially as the first inoculation on the artificial soil was always made with relatively large quantities.*

Occurrence of the gonorrhœa coccus.

The occurrence of the gonorrhœa coccus is, according to the opinion of all trustworthy observers who are acquainted with the saprophytic forms similar to the gonococcus, limited to gonorrhoal affections of the urethra or bladder, of the cervix uteri, \&c., and to the specific blennorrhœa of the conjunctiva. The characteristic cocci were also found in the purulent effusion into a knee joint in a case of gonorrhœal inflammation of the joint (Petrone and Kammerer).

\section{Micrococcus sulflavus.}

(Yellowish-white diplococcus of Bumm.)

Micrococcus similar to the gonorrhœa coccus.
Similar to the foregoing, frequently observed in the lochia and in vaginal secretions, and perhaps also

* Bumm has since obtained a successful result by inoculation of a twentieth cultivation. 
pathogenic for man. A diplococcus $0.5-1.5 \mu$. in diameter; it shows a central division, and is composed of two hemispheres like the gonococcus; in contrast to that organism M. subflavus retains the aniline dye after treatment with Gram's iodine solution. Twenty-four hours after inoculation on nutrient jelly whitish points develop and grow to whitish-grey, later yellowish, and finally ochre-coloured confluent masses; after a few days nutrient jelly and blood serum become liquid in the neighbourhood of the cultivation.-Inoculation experiments on various mucous membranes susceptible to the gonorrhœal contagium was without result. On the other hand, according to Bumm, an abscess, varying from the size of a pigeon's egg to that of a man's fist, and containing numerous diplococci, follows the injection of these bacteria into the subcutaneous cellular tissue in man.

Besides the lochia this organism was also found in the urine in some cases of catarrh of the bladder and also in the contents of the bullæ in pemphigus neonat., and in the pus of a mammary abscess. Further, Fränkel has found the same diplococcus, along with another coccus to be mentioned under the saprophytes, in the vaginal secretion in a large number of children suffering from colpitis, but not infected with gonorrhœa.

\section{Micrococci in Zoonotic Finger Erysipeloid.}

Cocci were found by Rosenbach* in a mild disease of the skin, not associated with general disturbance, which is characterised by a bluish brown red, sharply defined infiltration of the skin of some fingers and of the hand very similar to erysipelas. These organisms formed, when inoculated on agar, very delicate and elegant colonies which were scarcely visible without magnification. Inoculation of the cultivations on the upper arm of a healthy man reproduced the affection.

Corduat has studied 127 cases of the same disease.

* Mikroorganismen bei den Wundinfectionskrankheiten. Wiesbaden, 1S84, p. 117.

$\dagger$ Deutsche medicin. Wochenschrift, 1885, No. 33. 
The individuals chiefly affected were those who had to do with animals and animal tissues, such as tanners butchers, \&c. Cordua was able to cultivate cocci from the affected portions of slin, and they formed in $24-36$ hours on agar at $36^{\circ} \mathrm{C}$. luxuriant chalk-white colonies, with slightly facetted margins. Inoculations on animals were without result, but here, also, he was successful in setting up the affection on his own arm from a cultivation. Probably Rosenbach and Cordua have been dealing with cultivations of the same organism which presented different appearances only in consequence of differences in the nutritive substrata. Further investigations must be awaited.

Imperfectly known pathccocci.

Microcoçci have also been described as causal exciting agents in numerous other diseases in man, but they have been demonstrated either by microscopical investigation alone, or the infective and cultivation experiments are not free from objection, and therefore further confirmation appears to be necessary. To these belong *-

Variola.-Cohn, Weigert, Koch, and others, found micrococci in the pustules and in various internal organs in persons who died of smallpox. Cultivations have not yet been made.

Vaccinia.-In the lymph in the vesicles micrococci have been frequently observed; cultivations of cocci have also been repeatedly obtained from the lymph, but all the micro-organisms as yet cultivated are evidently only impurities for the most part of a saprophytic character, as a vaccine pustule has never been produced by inoculation of the cultivations. The recent cultivation experiments by Wolff do not seem to have given a better result.

Scarlatina, Measles.-Micrococci found, but of no importance (see Lit., p. 35).

Diphtheria.-In the former investigations by Klebs, Oertel, and others, these authors evidently did not work

* As to the Micrococcus pneumoniæ see under "bacilli." 
with specific organisms. As to Loeffler's streptococcus see above (p. 194); as to bacilli in diphtheria see below.

Cerebrospinal meningitis.-Leyden, and more recently Leichtenstern, have found cocci in the purulent exudation on the pia mater; these were sometimes enclosed in white blood cells, sometimes they lay outside them.

Influenza.-According to Seifert numerous micrococci $1.5-2 \mu$. in length and $1 \mu$. in breadth, are embedded in the tenacious mucus composing the greyish-white clumps present in the sputum and in the nasal secretion at the height of the ferer. They are mostly arranged in long chains; their numbers markedly diminish as the number of cells in the secretion increases. In control examinations of the secretion in bronchitis, \&c., the cocci were not found.

Ozcena.-Frënkel found various micrococci in the secretion, Loewenberg chiefly only one kind. The cultivation and infection experiments do not sufficiently establish their significance.

Cocci have been demonstrated in Hamoplitia neonatorium, and in acute yellow atrophy of the liver.

In yellow fever Domingos Freire has found a microorganism which he terms Cryptococcus xanthogenicus and which he regards as the cause of that disease; the observation, however, is evidently based on gross errors. Cornil and Babes recently found in one case that the capillaries of various organs contained long chains of diplococci, but they could not find these organisms in five cases investigated subsequently. As to bacilli in yellow fever see below.

In trachoma of the conjunctiva Sattler has found cocci in the secretion and in the trachoma nodules; he was able to cultivate these organisms on nutrient jelly, and when inoculated on the normal conjunctiva they set up vesicular-like granules without pathological secretion or subjective symptoms. We must await repetition of these experiments with more typical results before concluding that these cocci are the causal agents.

In area Celsi, Buchner, and later von Sehlen, have found micrococci somewhat less than $1 \mu$. in diameter, and 
have cultivated them in nutrient jelly. Michelson has however asserted that von Sehlen's case was not one of true area Celsi (see Lit., p. 37). :

Rindfleisch found numerous plugs of streptococci in the cutaneous capillaries in a case of mycosis fungoides or granuloma fungoides (spongy nodular out-growths of the skin consisting of granulation tissue); these organisms stain well with Gram's method. Auspitz has also seen cocci in a similar case.

\section{B. Micrococci Pathogenic in the Lower Animals.}

Micrococci have been stated to be the cause of some important infective diseases of domestic animals (mammalia), nevertheless the proofs as yet brought forward are insufficient.

Rinderpest.-In Russia, and in some parts of Austria, a widespread epidemic contagious disease exists among cattle; it is characterised by general prostration, increased secretions, fluid, slimy, or bloody stools, and quickly terminates in death. On post-mortem examination the appearances are those of an intense gastroenteritis with hypertrophy or ulceration of the solitary follicles, and of Peyer's patches. Semmer asserts that he has cultivated micrococci from the dead body, and that he has caused the disease by inoculation of these organisms. These investigations are however open to the same objections as the other bacteriological work of the same author.

Pleuropneumonia in cattle (péripneumonie contagieuse du gros létail). An epidemic pleuropneumonia of cattle which causes death in a fourth of the cases. Poels and Nolen have isolated cocci from the pulmonary exudation which resemble Friedlaender's pneumonia bacteria morphologically, and in their growth in cultivations. Cornil and Babes found a mixture of various bacteria in the exudation, as to the special etiological significance of which nothing has as yet been settled. The fluid flowing from 
the cut hepatised lung has been frequently employed for protective inoculations; it is injected subcutaneously into the tail, and causes at the most a local affection, and after this has passed off immunity is said to be attained.

Swine erysipelas (pig typhoid, \&c.). Pasteur and Thuillier have found micrococci in the blood and in the exudations, and have ascribed to them a causal significance. Loeffler and Schütz, Lydtin and Schottelius have, however, described bacilli as the true causal agents of this disease (see later).

A number of well characterised pathogenic micrococci have been observed in various of the animals ordinarily employed for experiment. To these belong, besides the above-mentioned staphylococcus, which can be inoculated on lower animals with success, streptococcus malignus and septicus.

\section{Micrococcus tetragenus.}

First described by Gaffky.* It is not uncommonly Micrococcus found in human sputum, and is especially observed in the sputum and in the walls of the cavities in cases of pulmonary tuberculosis. Micrococci about $1 \mu$. or Microscopic more in diameter, dividing into four individuals which appearanee. remain united by a gelatinous envelope. In cultivations we find some large spherical cells undergoing division, but the greatest number consist of cells in which the division has been completed. The round gelatinous envelope stains faintly, the microccoci strongly with aniline dyes; the colour is retained in Gram's method; the appearance recalls that of sarcina, but the division in the third plane and the formation of many-celled packets is absent.- On gelatine plates M. tetragenus Cultivations. forms in $24-48$ hours small white points which under a low power present the appearance of circular or citronshaped yellow masses, with a granular, mulberry-like surface, and regular, but somewhat rough, jagged

* "Klinische, experimentelle u. botanische Studien über die Bedeutung des Torfmulls als Verbandmittel." Von Dr. Neuber; Dr. Gaffky, u. Dr. Prahl, v. Langenbeck's Arch.f. Chir., vol. 28, Heft 3. 
borders. When they have reached the surface they form white raised thick drops on the gelatine $1-2 \mathrm{~mm}$. in diameter. In the inoculation puncture the colonies

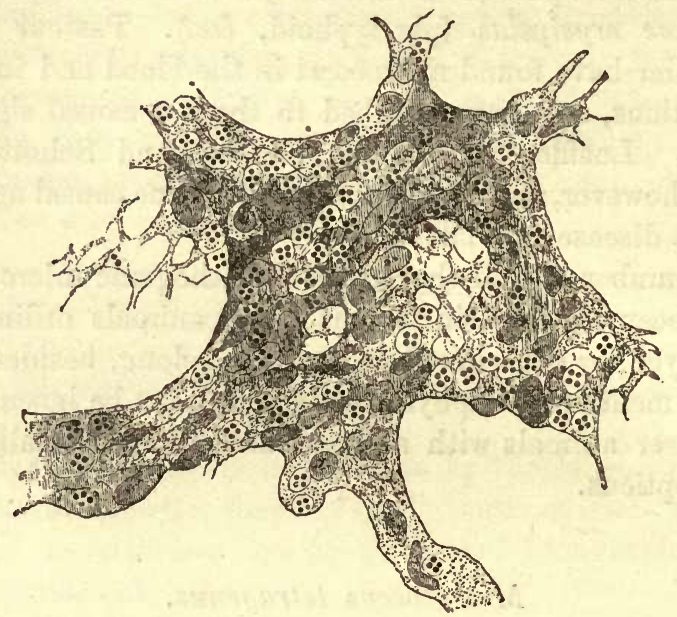

Fig. 48.-Micrococcus tetragenus. Section of lung $\times 800$.

become confluent, so that a thick white gelatinous mass is formed along the line of puncture, and fills any cracks or cavities in connection. with it; on the surface a thick layer $4-5 \mathrm{~mm}$. in breadth is formed.

Experiments on animals.

The minutest quantity of the cultivation inoculated subcutaneously into white mice causes in all cases a

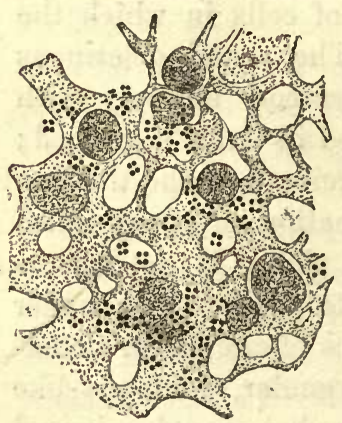

Fig. 49.-Micrococcus tetragenus. Section of spleen $\times 600$. fatal disease. The first 2 days pass by without noticeable symptoms; then the animals become still and somnolent, and after 3-6 days deathoccurs. Thecocci are only present in the interior of the blood vessels ; in the blood of the heart they are relatively few in number, they are present in larger numbers in the splenic juice and in sections of the lungs, in the glomeruli of the kidneys, in the liver, \&c. Grey house mice are almost without? exception immune against $\mathbf{M}$. 
tetragenus; guinea-pigs show either local abscesses or septicæmia; rabbits and dogs are unaffected by large quantities injected subcutaneously or into the veins. Whether in man the presence of $M$. tetragenus in the tuberculous lungs is accompanied by any secondary injurious results must be ascertained by further investigations. In the meantime $M$. tetragenus is of importance to us as it is a micro-organism admirably adapted for experiments on account of its morphological peculiarities and of the ease with which it can be cultivated.

The following are imperfectly known: Streptococcus perniciosus psittacorum. According to Eberth and parrots. Wolff parrots imported into Europe die in large numbers from a disease in which nodules are formed on the surface of the lungs, spleen, kidneys, \&c. Cocci of medium size with a tendency to the formation of chains are found in the vessels, in the nodules, and in the blood of the heart.

Streptococcus Charrin.-Found by Charrin* in the Charrin's bodies of rabbits which had died of anthrax. Oval micro- septicémie cocci 1 to $2 \mu$. in diameter, with a tendency to form au charbon. chains composed of as many as twenty cocci. They are present in large numbers in the vessels of all the organs. The micrococcus kills rabbits within eighteen to fortyeight hours after subcutaneous inoculation. On postmortem examination we find great swelling of the spleen and œdema at the seat of injection. Besides rabbits, sparrows and cats are also susceptible, the latter, however, not always; dogs and fowls are immune. This septicæmia is termed "septicémie consécutive au charbon." It is probably identical with Koch's coccal sepsis (p. 211).

Streptococcus bombycis (Mikrozyma bombycis, Bé- Silkworm champ.) Oval cells at most $1.5 \mu$. in diameter, single or united in pairs or chains of $4-8$, or even longer straight or curved chains; causes the lethargy (flacherie, flacci-Lethargy. dezza, maladie de morts-blancs) of the silkworms which appeared about 15 years ago, and since then has broken out with great violence from time to time.

\footnotetext{
* Société de biologie, Séance du 2 Août, 1884.
} 
The living animal shows diminished appetite, and becomes languid; soon after death the bodies become soft and almost fluid; after 24-48 hours they present a dark colour, and become filled with gases and blackish brown putrid fluid. The disease appears to develop "spontaneously" under unfavourable hygienic conditions-bad ventilation and food, $\& c$. ; it is also propagated by infection. The disease can be set up in healthy animals by feeding them with dust from affected localities. In the digestive tube of the diseased and dead animals, especially in the juice of the stomach, these

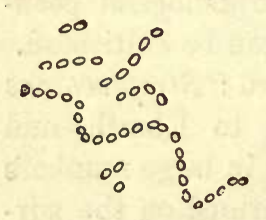

Fig. 50.-Micrococcus bombycis (afterCohn) $\times 600$. micrococci are constantly present in large numbers, and other bacteria also appear shortly before death. Nevertheless there is no proof that all the morbid symptoms can be explained by the distribution of the micrococci in the body, or that the minutest number of the isolated organisms can induce the disease; there is, therefore, a possibility that other bacteria more difficult to demonstrate are the true exciting agents of the disease.

Pebrine

Nosemabombycis (Micrococcus ovatus, Panhistophyton ovatum, corpuscules du ver à soie), the cause of the pebrine (Gattine, Fleckenkrankheit, maladie des corpuscules) of the silkworms

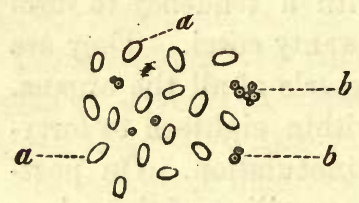

Fig. 51. -Nosema bombycis $\times 500$.

a, Nosema cells.

$b$, urates which are usually present in the preparations. (After Duclaux.) may be included here, although from the size and form of the organisms, as well as from the iniperfect knowledge of their developmental history, we are still doubtful as to their proper place. In the blood and in all the organs of the diseased worms we find highly refracting oval cells, $3-4 \mu$. long. $2 \mu$. broad; for the most part isolated, at timesunited in pairs or masses. They were first discovered by Cornalia, and subsequently described by Lebert, Nägeli, and Pasteur. Recently Metschnikoff has supported the supposition formerly entertained, that the exciting agents of pebrine belong to the psorospermex.

The disease is characterised by the appearance of blackish patches on the skin of the caterpillars. At the same time the appetite diminishes and the worms become more slender and watery; the silk organ swells up in a garland form, becomes opaque, and the diseased worms furnish no coccoons, or only very weak ones; finally, they die after a short time. The whole organs then appear to be infiltrated with the " micro- 
cocci"; the organisms are also found in the eggs of the butterflies, and by means of these infected eggs the hereditary transmission and the continuance of the disease is provided for ; for otherwise, on account of the slight resisting power of the micrococci, they would be in danger of disappearing. Pasteur has demonstrated experimentally that the disease may be transmitted by micrococci contained in the food, or by their penetration through injured parts of the skin, and that currents of air, handling by the breeder, \&c., may lead to the spread of the infective germs.-As prophylactic means the plan introduced by Pasteur is now generally adopted; the butterflies which are laying eggs are separated in pairs, and after copulation and the laying of the eggs, are examined as to the presence of the characteristic "micrococci." If the latter are found the oggs are destroyed, and not employed for breeding.

To this group also belong some infective wound dis-Koch's microeases in animals which were investigated as fully as infective possible by Koch by mieroscopical observation at a time wound when no trustworthy methods of cultivation were known. lower animals.

Micrococcus of Progressive Necrosis of tissue in Mice.Round cells, $0.5 \mu$. in diameter, usually arranged in beautiful and regular chains, at times massed together in thick groups (fig. 52), causes necrosis of the tissue; as far as the micrococci reach no blood or connective tissue cells remain intact, and even the cartilage cells are destroyed. The gangrene ex- Fig. 52.-Micrococci of progressive tends from the point of necrosis of tissue in mice. (After inoculation, and soon causes $a$, cells of the cartilage of the ear. death (in about 3 days);

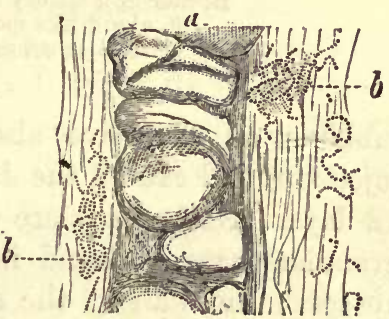

$a$, cells of the cartilage of the
$b$, chain forming micrococci. the blood and internal organs remain free from micrococci. From their behaviour we must assume that a soluble noxious material is produced by the vegetation of the cocci. - The disease was obtained by Koch by inoculation of putrid material on the ear of mice; at the same time, however, bacilli which caused septicæmia were always inoculated, and led to the death of the animal; it was not till field mice, which are immune against the 
bacillar septicæmia, were inoculated, that the course of the disease could be observed undisturbed by the presence of other bacteria.

Micrococcus of Progressive Abscess Formation in Rabbits.-Minute cells, only about $0.15 \mu$. in diameter, generally in thick cloud-like zooglæa masses (fig. 53). It was obtained by injection of putrefying blood into

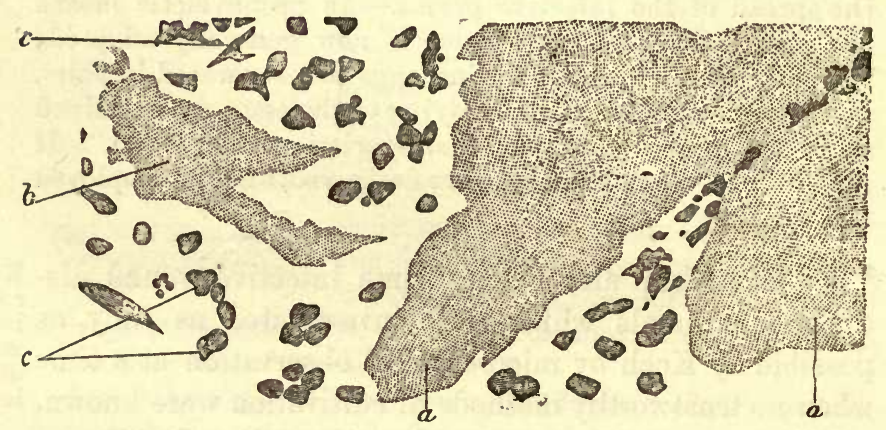

Fig. 53.-Micrococcus of progressive absoess formation in rabbits (after Koch) $\times 700$.

Border of a cheesy abscess :-

$a$, cloud-like masses of zooglæa.

$b$, smaller colonies of micrococci.

$c$, nuclei.

rabbits; an extensive abscess formed at the seat of injection, and caused the death of the animals in about 12 days. No bacteria are present in the blood; a finely granular mass is found in the cheesy contents of the abscess; the wall of the abscess is formed of a thin layer of micrococci united in dense zooglæa masses; towards the interior of the abscess the zooglæa appears to degenerate and die. Nevertheless the contents of the abscess are infective, and set up the same disease in healthy rabbits.

Micrococcus of Pyamia in Rabbits.--Round cells, $0.25 \mu$. in diameter, for the most part single or united in pairs; they tend to surround and enclose the blood corpuscles in a characteristic manner (fig. 54). The disease in question was obtained by injection of fluid used for maceration; on post-mortem examination there was great infiltration around the seat of injection, peri- 
tonitis, metastatic deposits in the lungs and liver-in short the appearances of pyæmia. In the capillaries of all the organs investigated dense micrococcal masses, with enclosed blood corpuscles, were found likewise in the metastatic deposits, where they had passed out of the vessels and attacked the neighbouring tissues. In the blood of the heart and of the larger vessels numerous micrococci were likewise present, but, in consequence of the numerous thrombi, they were not so numerous as in other septicæmic diseases. Healthy rabbits were infected successfully by inoculation of blood from the heart, \&c., but larger doses (1-3 drops) caused death more rapidly (40 hours) than

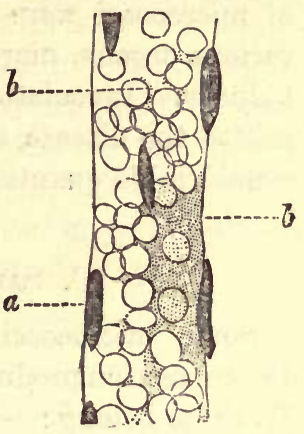

Fig. 54.--Micrococcus of pyæmia in rabbits (after Koch) $\times 700$

Vessel from the cortical part of the kidney :-

$u$, nuclei of the vascular wall.

$b$, micrococci. small quantities ( $\left.\frac{1}{10}\right)$ drop), on account of the relatively small numbers of cocci in the circulating blood.

Micrococcus of Septicamia in Rabbits (compare above Streptococcus Charrin).-Oval cells, $0.8-1 \cdot 0 \mu$. in greatest diameter. They do not cause coagulation in the blood, and never enclose the blood corpuscles, but

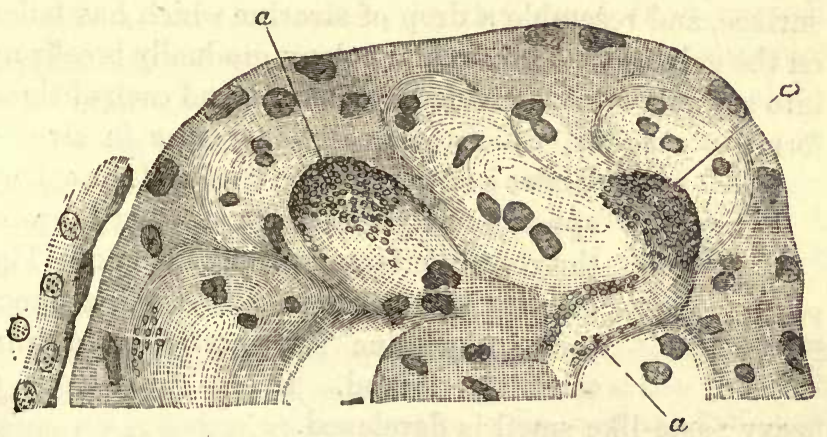

Fig. 55.-Micrococcus of septicæmia in rabbits (after Koch) $\times 700$.

Part of a glomerulus:-

At $a$ the capillary ressel with micrococci.

push them to one side (fig. 55). The disease was obtained by Koch by injection of meat infusion ; after 
death slight œdema was found at the seat of injection, small extravasations of blood, marked enlargement of the spleen; no embolic processes, no peritonitis. Masses of micrococci nere found obstructing the capillaries of various organs, more particularly in the glomeruli of the kidneys. Inoculation of the blood of the heart transmitted the disease to rabbits and mice, but only when considerable quantities $(2-10$ drops) were used.

\section{Saprophytic Micrococci.}

Some micrococci set up fermentations, or peculiar decomposition products, when growing in suitable media. To these belong:-

\section{Micrococcus Uree.}

Leube's micrococcus nreæ.
Micrococei $0.8-1.0 \mu$. in diameter, often grouped together in the form of diplococci and tetrads, frequently also in longer chains. In plate cultivations, according to Leube, white mother-of-pearl-like spots about the size of a hemp-seed, with smooth surfaces and sharply defined margins, are formed on the gelatine within 24 hours. In 10 days the colonies have attained the size of about a 20 pfennig piece (about the size of a sixpenny piece). They project somewhat above the surface, and resemble a drop of stearine which has fallen on the gelatine. The circular colony gradually breaks up into several portions divided by fissures, and each of these forms a zooglæa, which gradually increases in size.-

- $\infty$ Under a low power the border of the colony

of

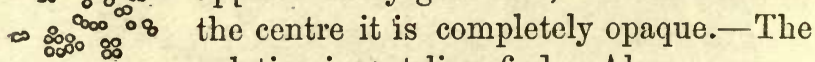
Fig. 56.-Micro- gelatine is not liquefied. Along a punccoccus urea $\times$ ture in gelatine the cocci form a thin
700.

tenacious thread. In old cultivations a heavy paste-like smell is developed.

If a small quantity of the cultivation is introduced into urine, or into a solution of urea, an energetic decomposition of urea into ammonium carbonate occur's. Pasteur and van Tieghem regarded micrococci as the 
active causes of this dehydration, and gave to this organism the name of M. urea; Leube has recently shown that a large number of bacteria (such as sarcinæ from the lungs, and several bacilli which are found in ammoniacal urine-see under "bacilli") can set up the same decomposition with, to some extent, the same energy. In the author's laboratory another coccus was isolated from decomposing urine, which, like the preceding, causes an energetic fermentation of urea, but shows certain differences in the characters of growth; more especially it liquefies the gelatine.

\section{Micrococcus uree liquefaciens.}

Spherical cells, 1.25-2 $\mu$. in diameter, single or A micrococcus forming chains of 3-10 individuals or irregular groups. urea which On gelatine plates they form in two days small white gelatine. points, which under a low power appear as darkgrey circular discs, with sharply defined borders. When they reach the surface the colonies become markedly larger; when magnified 80 times they have the appearance of dises of a yellowish-brown colour, which often contain in their middle a dark nucleusthe deeper portion of the colony; the surface of the dises is distinctly granular; the borders gradually assume a wavy character, at the same time gradual liquefaction of the gelatine occurs. In the puncture cultivation a white confluent layer is at first formed along the needle track, then liquefaction of the gelatine soon occurs, and extends to the wall of the glass; finally, the half or the greater portion of the tube becomes filled with a whitish turbid fluid, at the bottom of which a thick whitish-yellow deposit lies.

It might appear doubtful which of the two cocci described above was the one referred to in the observations published formerly at a time when a definite isolation of the individual species was not possible. Nevertheless, the circumstance that in Leube's elaborate experiments the organism first described was chiefly met with in the great majority of cases, Biological is in favour of the view that former observers were working properties of with it.-From the numerous contributions to the biology the micro- 
Musculus's ferment of urine.

of this organism which have been furnished by Pasteur van Tieghem, Musculus, v. Jaksch, and others, we learn that the alkaline reaction which occurs in no way interferes with the development of the organism. The fermentation continues till about 13 per cent. of carbonate of ammonia has been formed. Artificially prepared solutions of urea, to which the necessary salts have been added, are rapidly decomposed in the same manner. According to v. Jaksch the best artificial cultivating fluid consists of 3 grammes of urea, 5 grms. of tartrate of potash and soda, 0.12 grms. of monophosphate of potash, 0.06 grms. of magnesium sulphate, dissolved in $1,000 \mathrm{ccm}$. of water. The best temperature for development lies between $30^{\circ}$ and $33^{\circ}$ C.-Musculus has attempted to show that the ferment of the ammoniacal fermentation can be separated from the micrococei which produce it, just as the inverting ferment can be separated from the yeast. By precipitation of urine containing much mueus from cases of catarrh of the bladder by means of absolute alcohol, and subsequently drying and pulverising the precipitate, Musculus obtained a substance soluble in water which converts urea very energetically into carbonate of ammonia. Leube was able, nevertheless, to show that pure cultivations of Microc. ureæ filtered through plaster cells are inactive, that thus the ferment which was isolated is not produced by the organisms, but has perhaps some other source of origin.

According to $\mathrm{v}$. Jaksch and Billet the micrococcus shows a great variety of vegetative forms in that it can also give rise to rod-shaped forms, which again become changed into chains of cocci. These observations were made on cultivations in which there was no guarantee for their purity, and could not be confirmed either by Leube or in the author's laboratory.

\section{Leuconostoc mesenterioides.}

Recognised by Cienkowski and van Tieghem as the cause of the so-called frog-spawn fermentation (Froschlaichgährung) of the beet juice and molasses in sugar factories. Forms chains of cocci, which are surrounded by a thick tenacious gelatinous envelope; large compact gelatinous masses ultimately arise by union of numerous chains. When the nutritive materials are becoming exhausted, the majority of the cells die; some however, which appear to be larger, with thicker walls and more 
highly refracting, remain as arthrospores, and develop in fresh nutritive solutions to new coccus chains.

The organism grows on the surface of carrots or beetroot in the form of thick massive gelatinous cakes, of cartilaginous consistence. It also flourishes in solutions of grape and cane sugar, to which nitrates and phosphates have been added. Cane sugar is in the first place converted into glucose, by a ferment formed by the

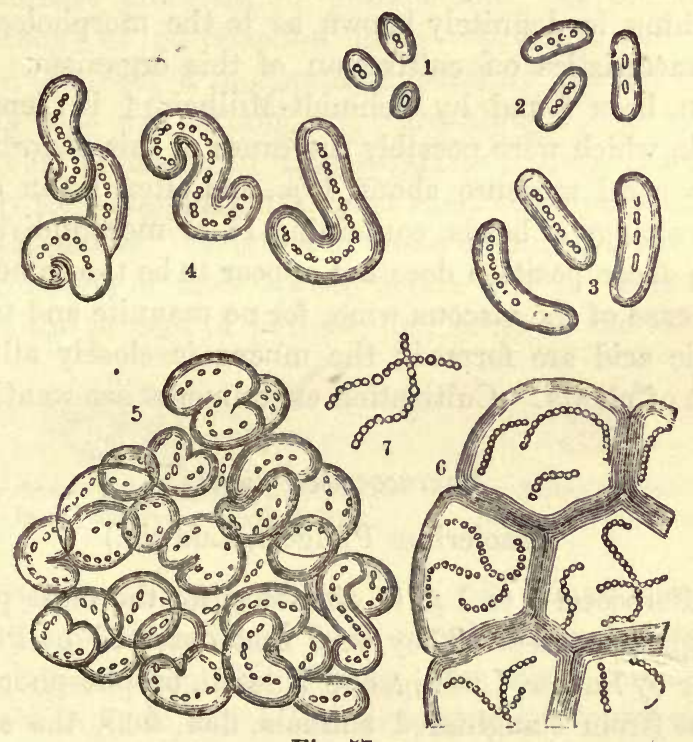

Fig. 57.

Leuconostoc mesenterioides. (After Zopf.)

$1,2,3,4$. Successive stages of division of the cocci and formation of the gelatinous material. 5. A collection of small zooglæa. 6. Section through an older zooglæa mass, containing fairly long torula-like threads. 7. Chain of cocci, showing spores here and there, the spores being larger than the cocci.

organisms. When the organisms develop luxuriantly, enormous quantities of sugar can be assimilated in a relatively short time and converted into the substance of the organisms, chiefly into the gelatinous material. This material is described by Scheibler as " dextran," and the whole process, which may be very hurtful to the manufacturers of sugar, is included under the term "dextran fermentation." Nothing is as yet known as to the growth of the organism on the ordinary solid nutritive media. 


\section{Micrococcus viscosus.}

Pasteur* has found a micrococcus which seems to be the cause of viscosity in wine (vin filant); the diameter of this organism is only $0.2 \mu$., and it is arranged chiefly in the form of chains. It grows in the most various saccharine fluids, and converts them into a viscoid and tenacious mass ; a form of gum is constantly developed, to which Béchampt has given the name of viscose. Nothing is definitely known as to the morphology and characteristics on cultivation of this organism. Cocci have been found by Schmidt-Mülheim $\ddagger$ in tenacious milk, which were possibly the cause of this abnormality. The cocci measure about $1 \mu$., and often lie in chains like strings of beads, containing 15 or more individuals. The decomposition does not appear to be the same as in the case of the viscous wine, for no mannite and no carbonic acid are formed; the mucus is closely allied to that of plants. Cultivation experiments are wanting.

\section{Micrococcus Pflïgeri.}

(Bacterium Pfiügeri, Ludwig.)

Micrococci $\frac{1}{2}$ to $1 \mu$. in diameter, for the most part in zooglæa masses. They were first observed by Pflüger, later by Lassar, Ludwig, and Nüesch, on phosphorescent meat (from slaughtered antmals, fish, \&c.), the surface of which was covered with a luminous slime. The cocci are also saitd to grow on boiled white of egg and potatoes, on which they also develop their peculiar luminosity. Further statements as to the conditions of cultivation, \&c., are wanting.

\section{Micrococcus foetidus.}

Found by Rosenbach in carious teeth. Very small oval somewhat irregular cocci which stain badly with aniline dyes. They could not be cultivated in stroke cultivations on agar jelly, but on the other hand grew

* Bull. de la Soc. Ch., 1861, 30.

† Compt.rend., T. 93.

‡ Pflüger's Archiv, 1882, vol. 27, p. 490. 
on exclusion of air at the bottom of nutrient agar, the growth being accompanied by the development of gas and foul smell.

\section{Micrococci of Putrefaction.}

Besides the forms already mentioned there are probably a number of micrococci which play some part in the ordinary processes of putrefaction. At the commencement of putrefaction more especially, and also when it occurs at a moderate temperature, micrococci of varying size and arrangement are always observed in enormous numbers in the substrata; they multiply actively for some time, and must exert some preparatory or direct action. Isolation of these organisms, and the determination of their special action and the part they play in the process of putrefaction, must be the subject

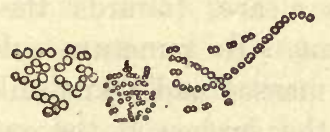

Fig. 58A.-Micrococci of various sizes from putrefying blood $\times 700$.

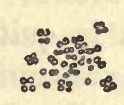

Fig. 58B.-Micrococci arranged in tetrads $\times 700$.

of subsequent investigations. Fig. 58A shows some of these micrococcus forms from blood which had stood for 4 days at about $10^{\circ} \mathrm{C}$; fig. 58B shows micrococci arranged in fours which had developed in wound secretions in man (both after Koch).

Some saprophytes are of interest to us because they are frequently found as accidental colonists on the jelly plates and on other nutritive substances; they are evidently very widely distributed in our surroundings, and can enter the cultivations from the air or by contact with a great variety of substances. Hence the forms described here represent only a small selection from the micrococci which have been met with in the Laboratory at Göttingen. A more complete description will shortly be published in another place. 


\section{Micrococcus candicans.}

Moderately large micrococci, completely round; unite together to form irregular masses. In gelatine plates the colonies lying in the substance of the jelly present after two days the appearance of white dises with a tendency to yellow $0.4-0.5 \mathrm{~mm}$. in diameter; those which lie on the surface form within the same time pure milk white flat colonies like drops of varnish, and with a diameter of $2 \mathrm{~mm}$. or more. Under a low power the deep colonies are quite circular, with smooth margins, and of a dark blackish brown colour with indications of a granular surface; the superficial colonies present irregular contours, often indented and sinuous; the surface is finely granular, and in correspondence with this shows under a somewhat higher power (100 diameters) a finely jagged border. In the middle the colonies are dark brown, but become clearer towards the border, which is quite transparent. In puncture cultivations there are confluent white masses and a knob-like elevation (nail cultivation) on the surface at the entrance of the canal.-An extremely frequent impurity on plates, \&c.*

\section{Micrococcus cinnabareus.}

Large spherical micrococci often in the form of diplococci, each half however being completely round; often arranged in threes and fours.-Grows extremely slowly; after 4 days the colonies lying in the depth are punctiform and just recognisable, while those placed superficially have attained a diameter of $0.5-1 \mathrm{~mm}$.; after about 8 days the latter are elevated above the gelatine in a knob-like form. The colonies appear at first of a light wax-red colour, later cinnabar red. Under a low power the youngest deep colonies are egg or lentilshaped, with sharp contour, and of a dark reddish-brown colour. The superficial colonies are light brown, transparent at the margins, round but with a somewhat irregular contour, due to projecting heaps of cocci.-In

* Göttinger hygienisches Institut. 
the puncture cultivation white colonies, which remain isolated, form in the deeper parts after 4 or 5 days; on the surface there is a moderately large knob, at first rose-coloured, and later of a cinnabar tint. The gelatine is not in the least liquefied. The growth is somewhat slower on potatoes.-It occurs frequently as an impurity on old cultivations.

\section{Micrococcus flavus liquefaciens.*}

Comparatively large cocci, arranged for the most part in twos or threes, or also in masses. They form small yellow colonies on gelatine plates after two days, around these a shallow depressed zone can be seen (similar to the Staphyloc. aureus). The youngest colonies are (as seen under a low power) circular or oval, or also at some parts irregular; their surface is finely granular; their contour sharp but finely toothed; their colour yellowish brown. The superficial colonies, which are already causing liquefaction, and are distinctly yellow, still show the remains of the deep colony in the centre; the border forms a ring with a sharp outline which is here and there interrupted by heaps of cocci, and ultimately several neighbouring colonies coalesce. The ring is separated from the centre by a broad clear zone, in which we see isolated, radially arranged lines of cocci. The whole colony has in this stage a diameter of 4-6 mm., and resembles microscopically the wheel of a waggon.-In test tubes spherical yellow colonies appear in two days along the puncture track; these become confluent, and soon liquefy the jelly, so that after 8 days the tube contains an upper zone filled with clear fluid with the yellow masses of organisms at the lower part.-It is comparatively common.

\section{Micrococcus flavus tardigradus. $\uparrow$}

Large spherical cocci, showing at times peculiar dark poles; for the most part arranged in masses. Grows extremely slowly. After 6 days the deep colonies in

* Göttinger hygienisches Institut.

$+1 b i d$. 
gelatine plates have attained the size of $0.4-0.6 \mathrm{~mm}$., are of a dark chrome yellow colour, round or oval; the superficial ones have a smooth wax-like surface, measure ultimately $\frac{1}{2}-1 \mathrm{~mm}$., and project at their middle somewhat above the gelatine. Under a low power the deep colonies present a sharp, smooth cantour, and a uniform dark olive green colour; in the superficial ones the colour becomes lighter and more of a greyish yellow tinge towards the margin.-In the puncture it is not till after $6-8$ days that a row of minute yellow colonies, which form balls and remain isolated, can be noticed. The gelatine is not at all liquefied.-Less common than the forms mentioned before; often occurs along with M. cinnabareus.

\section{Micrococcus coronatus.*}

Cocci somewhat more than $1 \mu$. in diameter, single or arranged in short chains or masses.-On gelatine plates the colonies appear on the second day as whitish yellow points ; those which lie superficially project somewhat above the gelatine, and are surrounded by a slightly depressed zone. The deep colonies appear, when magnified 80 times, as very dark opaque sharply dęfined plates. In the superficial ones the remains of the deep colonies are altered in a peculiar manner; at two or three places of the disc, which was formerly circular, short pointed processes project at equal intervals from the periphery ; the remains of the deep colonies which have become broadened out in this peculiar manner are of a dark colour, but are now surrounded by a broad yellowishbrown border, the superficial extension of the cocci. On the following day the gelatine is liquefied in the neighbourhood of this border; a ring has formed at a certain distance from the dark centre, and surrounds the original colony like a crown or halo. At times the colony lies somewhat excentrically in the ring, which is then more of an oval form. Between the ring and the

\footnotetext{
* Göttinger hygienisches Institut.
} 
original colony there is clear fluid. A low power shows at this stage that the contour of the original colony is no longer quite sharply defined, the ring having an irregular margin and granular surface.-In the puncture cultivation the growth and the liquefaction of the gelatine does not present much that is characteristic.-The organism was several times met with in examinations of air.

\section{Micrococcus radiatus.}

Micrococci under $1 \mu$. in diameter, at times arranged in short chains, more frequently in small masses.Even in 24 hours they form visible colonies; after tro days they are almost $1 \mathrm{~mm}$. in size. They have a white appearance with a yellowish green lustre; under a low power they are yellowish brown with sharply defined contours, granular, round, or with somewhat irregular borders; at times they form a series of out-growths, so that they appear like star-fish. In the middle a small remnant of the deeper part of the colony usually persists as a dark centre. At this stage the colonies sink a little into the gelatine, which has become gradually somewhat liquid, and after one or two days more a very delicate regularly arranged circle of rays has been formed from the out-growths; from the centre thickly packed delicate threads project with a radial arrangement, and these increase somewhat in breadth towards the periphery, and thas almost run together to form a ring; a true sharply defined ring is however not formed, but the irregular ends of the rays lie more regularly near one another. After two or three days more a secondary circle of rays has developed from the periphery of the first, and eventually a third is formed; the radial rays are then however shorter, and the arrangement more irregular. The whole colony occupies at this stage a circle 1 to $1.5 \mathrm{~cm}$. in diameter.

This organism also grows in a characteristic manner in test tubes, and here also the formation of rays becomes noticeable. Along the course of the line of inoculation isolated centres form from which projections 
extend in a horizontal direction, so that the line has a pinniform appearance. At the same time a funnelshaped area of liquefaction forms at the upper part, but this is very pointed and spreads relatively slowly.

\section{Micrococcus flavus desidens.}

Yellow

liquefying micrococcus.

Small cocci for the most part arranged as diplococci, but also in triangles and short chains.-After two days the colonies on nutrient jelly present the appearance of whitish yellow points, which, under a low power, appear as oval plates often projecting on one side, yellowish brown, finely granular; those which lie superficially have a lighter zone towards the margin. After four days the deeply lying colonies have undergone but little alteration, they have only become more distinct. The superficial ones are now $5-10 \mathrm{~mm}$. in size, but present a round form with various projections and a dull yellow colour passing into brown; they form a smooth mucous layer on the gelatine, and they neither project above it nor lie markedly below the surface. It is only on touching it that it becomes evident that the gelatine is softened and has become pulpy in the neighbourhood of the colony; after two days more this also becomes evident by a moderate sinking in of the colony, which is then surrounded by a very flat depressed ring $2-4 \mathrm{~mm}$. in breadth (hence the name desidens = slowly sinking in).In tubes a confluent mass of porcellanous white appearance is formed in the depth of the puncture canal; on the surface a yellowish brown slimy deposit, which does not however reach to the walls of the glass. After eight days the gelatine below the deposit is so far softened that a cylinder filled with thick fluid has been formed $3-4 \mathrm{~mm}$. in height, and of the diameter of the superficial deposit, to the bottom of which the latter then gradually sinks down.- Repeatedly observed as an accidental contamination on plates.

Micrococcus versicolor.

Versicoloured micrococeus.

Small cocci arranged in pairs or in masses. They 
form white points on gelatine plates after 24 hours; after two days, yellow colonies, spherical when lying deeply, up to $1 \mathrm{~mm}$. in size, circular under a low power, with sharp contours of yellowish green colour, opaque, finely granular. The colonies which lie superficially form flat deposits $2-6 \mathrm{~mm}$. in size, increasing even to $10 \mathrm{~mm}$. after four or five days, of irregular form, often almost quadrilateral, as a rule approaching this form very closely, and with an irregular outline. The deposit is gelatinous, glistening at the surface, and yellowish green, but according to the illumination there is a greenish and bluish shimmer like mother of pearl. In the middle of the deposit there is often a somewhat projecting knob, the remains of the deeper part of the colony. Along an inoculation puncture small spherical colonies of a yellow colour are formed; on the surface a deposit with irregular margins as if eaten out and changing colour like mother of pearl.-Common.

\section{Micrococcus viticulosus.*}

Micrococci with a very peculiar mode of growth Micrococcus. observed by Katz in the Hygienic Laboratory at Göttingen. They are somewhat oval, and measure about $1 \cdot 2 \mu$. in the largest and $1 \mu$. in the smallest diameters; they always form thick zooglæa masses, but without particularly marked development of gelatinous material. On gelatine plates their growth is quite different according as the colonies develop in the substance of the material or on the surface. In the first case fine hair-like tendrils develop from a centre, which soon however becomes scarcely noticeable, and these form an extremely fine and delicate meshwork and extend widely. Under the microscope we see that these processes do not have smooth contours, but are markedly bulged out; they consist of numerous spherical large or small zooglia masses arranged in rows like a string of beads.-If the threads reach the surface, or if from the first the colonies lie near the surface, a thin deposit is formed of a muddy white appearance and gelatinous consistence, and spreads

$$
* \text { cirrous. }
$$


very rapidly. This deposit often spreads along the threads which run in the deeper part of the gelatine, or sends here and there fine threads into the deeper layers of the gelatine.-In the puncture and stroke cultivations the same appearance is repeated; in the deeper part a delicate network of threads is formed, but this is soon obscured by the more quickly growing superficial layer; this network spreads out from the inoculation track in the form of rays like the plume of a feather.This organism has as yet only been met with once, and then as an accidental impurity.

Pigmentforming micrococci.
Some rarer cocci which attract attention by the production of colouring material may also be mentioned here, although they are for the most part as yet insufficiently known, and do not perhaps all belong to the miorococci. (M. cinnabareus, flavus, \&c., see above; Micrococcus prodigiosus, see Bacillus prodigiosus.)

Micrococcus luteus.*-Cells about $1 \mu$. in diameter, elliptical, highly refracting. Form yellow drops, $1-3 \mathrm{~mm}$. in diameter, on slices of cooked potato; on fluid substrata they form thick, yellow, wrinkled skins. The pigment is insoluble in water.

Micrococcus aurantiacus. - Oval bodies, $1-5 \mu$. in diameter, occurring singly or united in pairs, in fours or in zooglæa masses. Orange-yellow spots, which finally form an uninterrupted layer, especially on boiled white of egg; a thick, golden-yellow layer on nutrient solutions. Colouring matter soluble in water.

Micrococcus chlorinus.-Occurs in the form of a finely granular zooglæa ; forms yellow or greenish layers on nutrient solutions and boiled eggs. Colouring matter soluble in water, decolourised by acids.

Micrococcus cyaneus.-Elliptical spheres, giving to nutrient solutions and slices of potato an intense blue colour. The colouring matter is very similar to that of litmus; it is soluble in water, becomes red with acids, and again assumes the blue colour on neutralisation of the acid by ammonia.

Micrococcus violaceus.-Elliptical cells, larger than Mic. prodigiosus, often united in chains, form violet blue gela tinous clumps and patches on boiled potatoes.

* All described by Schröter, Cohn's Beiträge zur Biologie der Pfanzen. Bd. 1, Heft 2. 
Micrococcus fulvus.-Spherical cells $1.5 \mu$. in diameter, frequently united in pairs, with tough intercellular substance. Form rusty red drops of firm consistence and about $\frac{2}{2} \mathrm{~mm}$. in diameter on horse dung (Cohn, Beiträge, Bd. 1. Hft. 3).

To the pigment-producing micrococci belong also-

\section{Micrococcus hamatoides.}

Discovered by Babes as the cause of red sweat (sueur rouge). Micrococcus Micrococci $1 \mu$. in length and $0.6 \mu .-0.8 \mu$. in breadth, united of red sweat. by a gelatinous zooglæa mass of a uniform red colour. These zooglæa masses surround the hairs on those parts of the body where the red sweat is formed, e.g., the axilla. The cocci can be stained by Gram's method; they grow on white of egg at $37^{\circ} \mathrm{C}$., and here also produce the red colouring matter, which has similar reactions to that formed by Bacillus prodigiosus.

\section{Sarcina lutea.*}

Round cells more than $1 \mu$. in size, which divide in Yellow three axes; the daughter cells remain united together, and thus packet-like colonies are formed resembling corded bales of goods; these again may be united together in larger packets. When sown on gelatine

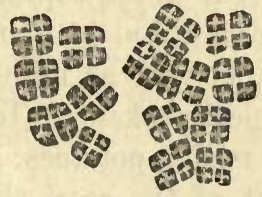

Fig. 59.-Sarcina $\times 600$. Drawn as if lying in one plane.

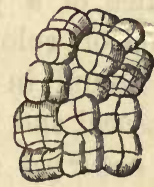

Fig. 60.-Sarcina $\times 650$. Diagrammatic picture.

plates the colonies form in two days yellow points which are just visible, and which under a low power present the form of irregular plates in part lobate and furnished with projections grey in colour but transparent towards the margin. In punctures and strokes on gelatine, agar, and slices of potato, a slowly growing, yellow confluent mass is formed. It is not uncommonly obtained from the air as an accidental impurity.

* Hygienic Laboratory at Göttingen. sarcina. 


\section{Sarcina aurantiaca.}

Orangecoloured sarcina.

Sarcina ventriculi.

Cultivation experiments.'

Observed in Koch's laboratory, and frequently employed in disinfection experiments. (Mitth: a. d. Kais. Ges. Amt, vol. 2). On nutrient jelly it forms slowly growing orange yellow colonies with gradual liquefaction of the gelatine. A more detailed description is wanting.

\section{Sarcina ventriculi.}

Discovered by Goodsir in 1842. Is found in the contents of the stomach in man and animals, and especially in the vomit; is most frequently observed in those cases where there are intense fermentative processes favoured by retention of the contents of the stomach; colourless or yellowish brown, round or slightly oval cells, with an average size of $2.5 \mu$., united in groups of eight forming small cubes rounded at the angles; these are bound together to form larger packets.

Falkenheim has recently obtained cultivations of this sarcina on gelatine plates; they formed after 36 to 48 hours roundish, for the most part prominent, colonies of a yellowish colour. On microscopical examination colourless spherical cocci $1.5 \mu$. in diameter were found in these cultirations, as well as numerous diplococci and tetrads, but no cubical packets. Growth also occurred on other nutritive media, potatoes, blood serum, \&c., but the arrangement of the cocci characteristic of sarcinæ was not present. On the other hand, this arrangement was well marked in cultivations in neutralised hay infusion, which showed after 24 hours brownish flocculi and a scum consisting of small brownish scales. In the scum as well as in the flocculent deposit were numerous sarcina packets with a distinctly cubical arrangement. On the addition to the hay infusion of 2 per cent. of cane or grape sugar growth was very luxuriant.

If the hay infusion was decolourised with animal charcoal, and then a solution of litmus added, it became 
evident that an acid reaction was produced by the vegetation of the sarcinæ. Falkenheim was also able Iodine to confirm the observation made by former writers, that reaction. the outer membrane of the sarcina cells gives a cellulose reaction with iodine and sulphuric acid, or with a solution of iodine and chloride of zinc. If a little fluid containing sarcinæ is placed on a slide, and a drop of Schultze's solution of iodine and chloride of zinc is added to and mixed with it, and if a cover glass is placed on the fluid, the outer membrane of the cells is seen after some time to present a distinctly reddish violet colour. Aniline dyes, which are as a rule very greedily taken up by the sarcinæ, and must therefore be employed in very dilute solutions, stain the contents of the cells. Nuclei cannot be demonstrated in the cells.

For the present it is doubtful whether this Sarcina ventriculi is identical with the Sarcina lutea described above, and which is everywhere present. Comparative cultivations and comparative measurements of the size of the individual cells are as yet wanting; the fact that in Sarcina lutea distinct cubical arrangement of the cells occurs in gelatine and potato cultivations, points for the present against any such identity.

There are many statements (varying somewhat with Occurrence of regard to the size of the cells and the composition of sarcina in the packets,) as to the occurrence of sarcinæ in other parts of the human and animal body, in the sputum and pulmonary tissue, in the urine, in the blood, \&c., as well as outside the body on the most various nutritive substrata. In the first mentioned cases it is probable that micrococci arranged in fours, especially micrococcus tetragenus, have been mistaken for sarcinæ. Whether in the other cases other species of sarcinæ than those described here have been present cannot in the meantime be decided.-Zopf has found in the cæcum of Zopf's Sarcina domestic fowls a species called by him Sarcina intestinalis, the colonies of which, however, do not form cubical packets, but plates composed of tetrads corresponding to the vegetative form merismopedia, but eventually arranged in several superimposed layers and 
Sarcina

then representing a true sarcina.-The Sarcina litolitoralis, \&c. ralis Reitenbachii hyalina, formerly reckoned here, has apparently only a merismopedia-like arrangement of the cells, and its other characters as well as its relationship to the algæ or to the bacteria are as yet doubtful.

In pus, secretions, \&c., of the human body, the following micrococci have also been occasionally observed as saprophytic parasites; their characteristics must however be more fully worked out.

\section{Micrococcus cereus albus.}

Cocci $1.16 \mu$. in diameter, single or in groups, at times also arranged in short chains. They form white points on gelatine plates during the first few days; these subsequently spread out on the surface and ultimately attain a size of $1-2 \mathrm{~mm}$. In stroke inoculations a white, dull stearin or waxy-like layer is formed with somew hat thickened, irregular margins. On blood serum a greyish white dull line appears along the line of inoculation; on potatoes a greyish white layer of medium thickness. Found by Passet on pus, but probably without pyogenic properties, as injections and inoculations of the cultivations into animals produced no results.

\section{Micrococcus cercus flavus.}

Microscopical characters and growth in cultivations like the foregoing, only the colour of the colonies soon passes from the original white to a dark citron yellow.Also isolated by Passet from pus; without pyogenic action.

\section{Micrococcus citreus conglomeratus.}

Observed by Bumm in pus from blennorrhœa, and also in dust from the air. Forms firmly agglomerated masses which resemble tuberculated lnobs; if these are crushed and diluted with much water we see diplococci, 
which have the tendency to unite in fours, and which very much resemble the micrococcus of gonorrhœa. The average size is $1.5 \mu .-$ Forms citron yellow colonies on gelatine, which extend over the gelatine like a tongue, and are raised like a wall at the margins; the surface is at first moist and slimy, later cracked and scaly.-Inoculation on animals produces no effect.

\section{Micrococcus lacteus faviformis.}

Frequently found by Bumm and Bockharc in the vaginal secretion, also in the secretion from the cervix, in sputum, \&c. In these materials it usually forms isolated diplococci ; preparations from cultivations, on the other hand, present a peculiar honeycomb appearance (hence the term faviformis), the individual diplococci lying side by side with their long diameter in the same direction. Each diplococcus measures on an average 1.25 $\mu$. and consists of two hemispheres which are separated by a fissure; the latter is narrower than in the gonococcus, but otherwise there is a great morphological similarity between the two cocci.-It grows readily on the most various soils at the ordinary temperature, and forms small points in the stroke inoculation, which gradually develop to milk white confluent colonies.-Not infective.

\section{Micrococcus albicans amplus.}

Found at times by Bumm in vaginal secretion. Diplococci, which are similar in form to the gonococcus, but are distinctly larger. Before division the hemispheres may attain the size of $2 \cdot 28 \mu$. Grows on nutrient jelly at the temperature of the room in the form of greyish-white lines.

\section{Micrococcus rosculs.}

Obtained accidentally on nutritive substrata from the dust of the air (Bumm). Diplococci like the gonococcus, bnt with a broader division between the hemispheres; size $=1-$ $1.5 \mu$. Grows luxuriantly on nutrient jelly at the ordinary 
temperature without causing liquefaction; forms in stroke cultivations broad raised stripes, with a moist, shiny, granular surface, and wall-like raised margins. The colour of the colonies is a distinct rosy red.

\section{Diplococcus albicans tardissimus.}

Cocci which are morphologically completely identical with the micrococci of gonorrhœa; the concave form of the division in the diplococci is also present. They stick together somewhat more readily than the gonococci, and form small masses. They grow extremely slowly on nutrient jelly, the inoculated track only attaining the breadth of $1 \mathrm{~mm}$. after some weeks. On blood serum at the body temperature whitish points develop after 2 or 3 days, which finally form thin greyishwhite, spots, with jagged contours and slightly moist surface. - Cultivated on several occasions by Bumm from pus from the urethra, but quite harmless.

A diplococcus has also been cultivated by E. Fränkel* from vaginal secretion which forms on nutrient agar a delicate layer consisting of bundles branching off at right angles from the line of inoculation; it never grows in the deeper parts. More detailed statements are as yet wanting.

Miller has isolated a coccus from carious teeth which occurs singly or in chains, and forms in nutrient jelly luxuriant spherical colonies, in the neighbourhood of which the gelatine becomes pulpy; also another which forms irregular masses, and very quickly liquefies the gelatine so that a funnel-shaped depression appears in the tubes $4-6$ hours after the inoculation, and after 36 hours a broad canal filled with fluid reaches to the bottom of the glass. See below.

\section{We may also mention-}

\section{Ascococcus Billrothii.}

The small spherical cells (micrococci) are united to form peculiar colonies. On the surface of nutrient solutions it forms a creamy skin in which numerous bodies of spherical or oval shape can be distinguished even macroscopically. Under the microscope it is evident that each of the bodies consists of an extremely resistant envelope $10-15 \mu$. in thickness, jelly-like and cartilaginous; one or several spherical

* Deutsche med. Woch., 1885, No. 2. 
or elliptical bodies are enclosed in it, $20-70$ and more $\mu$. in diameter, consisting of closely aggregated spherical bacteria, and an uncommonly firm scanty intercellular substance (fig. 61).

It was first observed by Billroth on putrid meat infusion, then by Cohn on ordinary nutritive solutions; in the latter it gives rise to a cheesy smell, converts the original acid reaction into a markedly alkaline one, and leads to the deve- Large tuberous cell families surrounded lopment of consi- by smaller ones, all of them being emderable quantities of

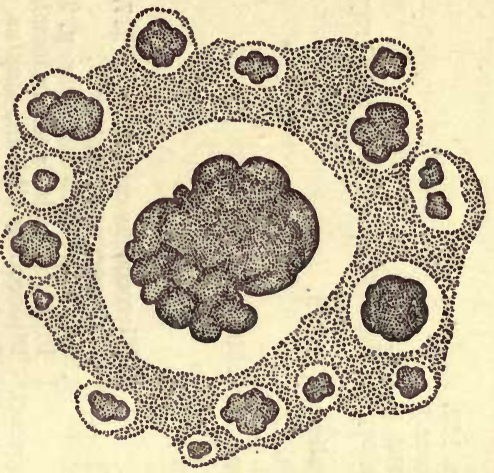

Fig. 61. -Ascococcus Billrothii $\times 65$. ammonia. It develops also on slices of turnip, in the form of a whitish-green slimy mass; in beetroot juice it sets up a viscous fermentation.

A development of the gelatinous enveloping substance to the degree as yet reckoned as characteristic of ascococcus has been also observed in various cocci and bacilli (as in Leuconostoc, in Mic. citreus conglom., Clostridium polymyxa, and in various other bacteria not yet isolated pure). It is doubtful whether the production of this marked gelatinous mass is constantly present in the species mentioned; at all events, on account of its extensive distribution, it does not appear sufficient of itself to serve as the distinguishing characteristic of an individual species or family. 


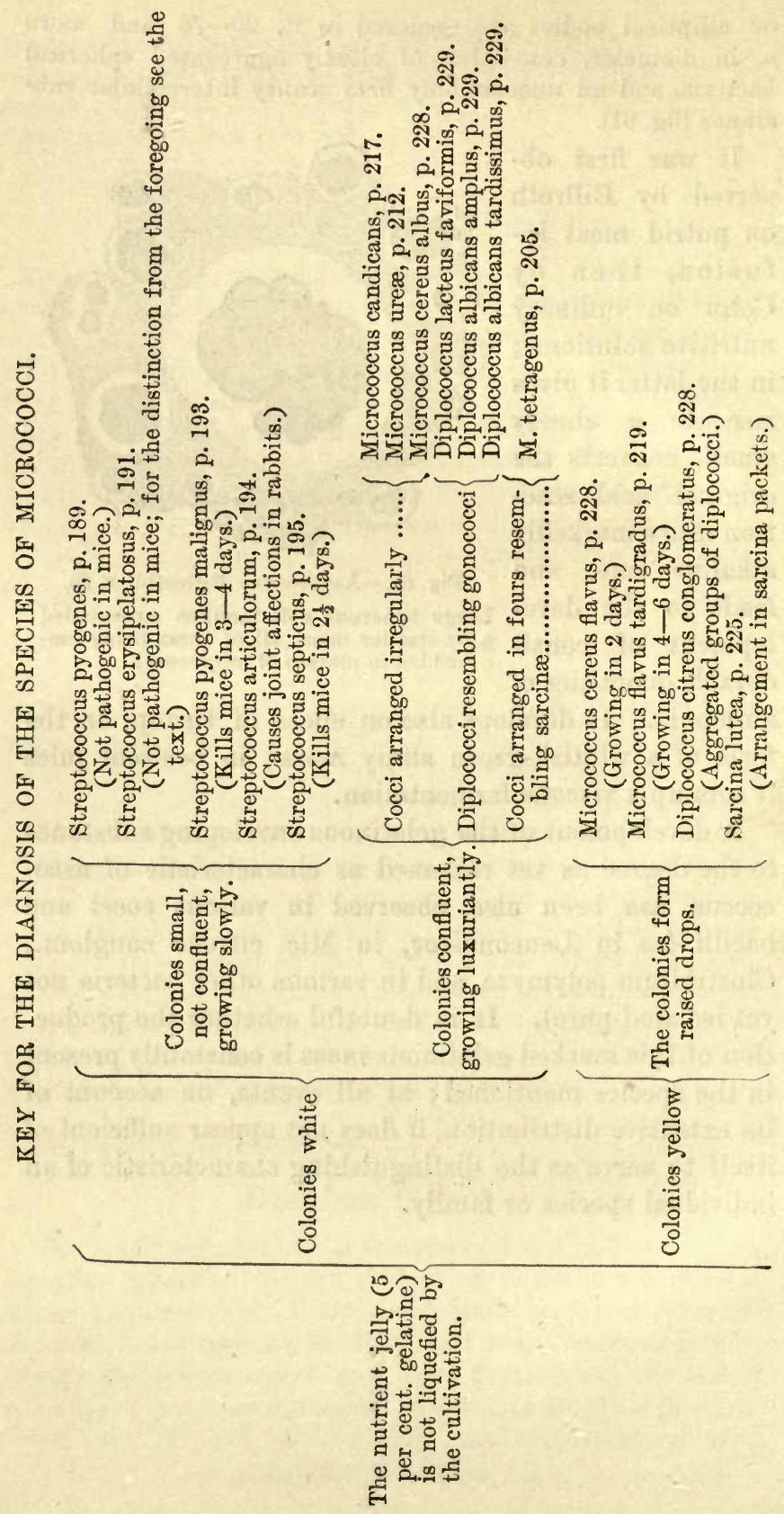




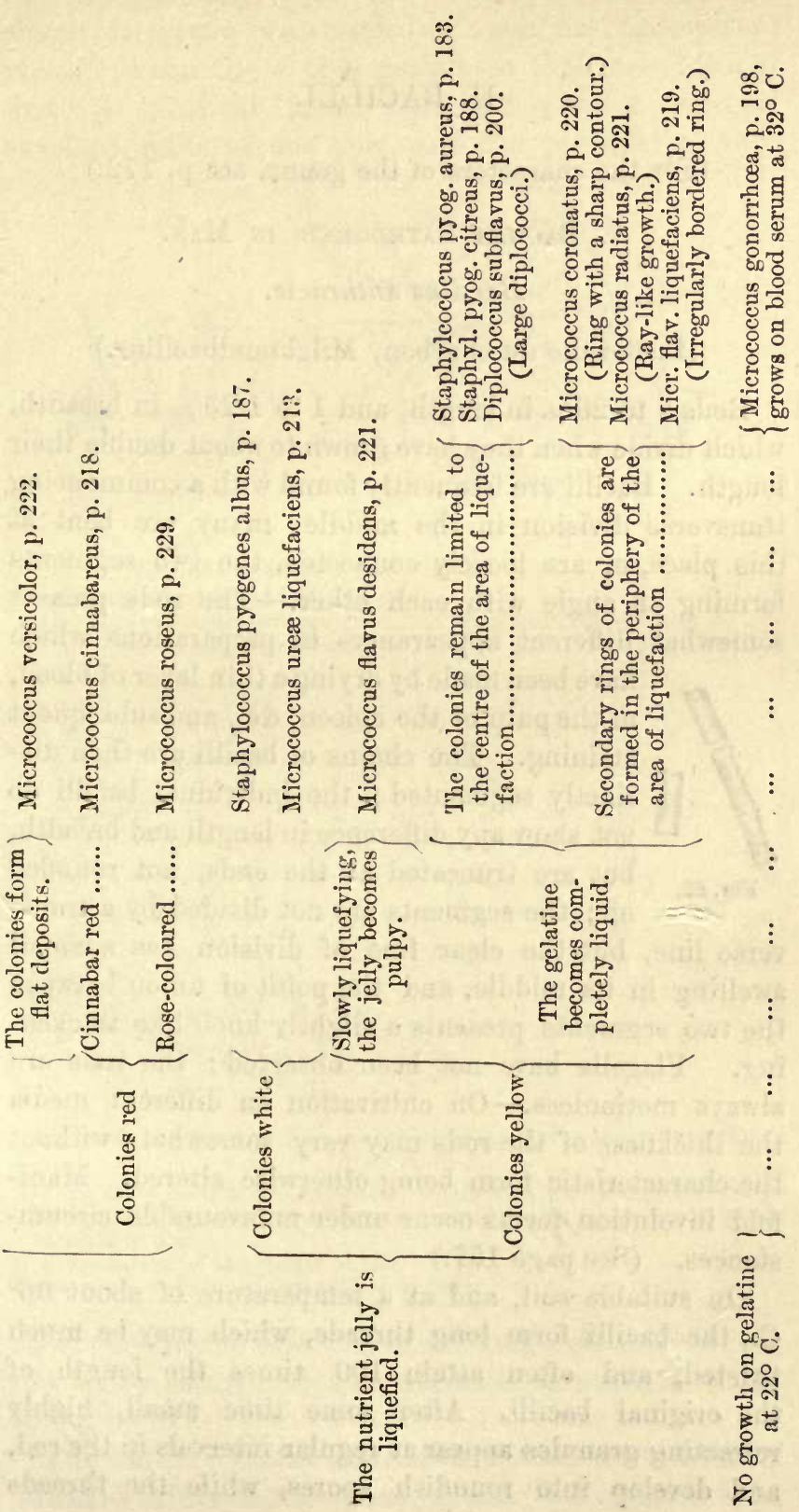




\section{BACILLI.}

(For the characters of the genus, see p. 172.)

\section{A. Bacillit Pathogenic in Man.}

Bacillus anthracis.

(Bactéridie du charbon, Milzbrandbacillus.)

Morphological characters of anthrax bacilli.

Rods 5 to $20 \mu$. in length, and 1 to $1 \cdot 25 \mu$. in breadth, which divide when they have grown to about double their length. Bacilli are frequently found with a commencing transverse division in the middle; many are bent at this place, or are loosely connected, the two segments forming an angle with each other.-The rods present somewhat different appearances in preparations which

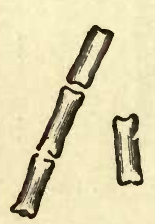

Fig. 62 . have been made by drying a thin layer of blood, of the pulp of the spleen, \&c., and subsequent staining. The chains of bacilli are then distinctly segmented; the individual bacilli do not show any difference in length and breadth, but are truncated at the ends, not rounded off; the segments are not divided by a transverse line, but the clear line of division has a small swelling in its middle, and the point of union between the two segments presents a slightly knob-like thickening. Flagella have not been observed; the rods are always motionless.-On cultivation on different media the thickness of the rods may vary somewhat, without the characteristic form being otherwise altered. Manifold involution forms occur under unfavourable circumstances. (See page 157.)

On suitable soil, and at a temperature of about $36^{\circ}$ C., the bacilli form long threads, which may be much twisted, and often attain 100 times the length of the original bacilli. After some time small, highly refracting granules appear at regular intervals in the rod, and develop into roundish spores, while the threads 
Growth on gelatine plates. seeds of plants containing starch, on juicy roots ; they may also be cultivated and form spores at a suitable temperature in alkaline urine, in neutralised hay infusion, in meat infusion. They belong to the aërobes, in so far that they only grow imperfectly when oxygen is excluded; attention must also be paid in cultivations to the great sensitiveness of the anthrax bacilli to an excess of acid in the nutrient substrata.-In plates of nutrient jelly they form after 24 to 36 hours small scarcely visible points; under a low power, however, a characteristic appearance can be seen at this stage; the round, dark, greenish-black colonies have an irregular wavy contour.
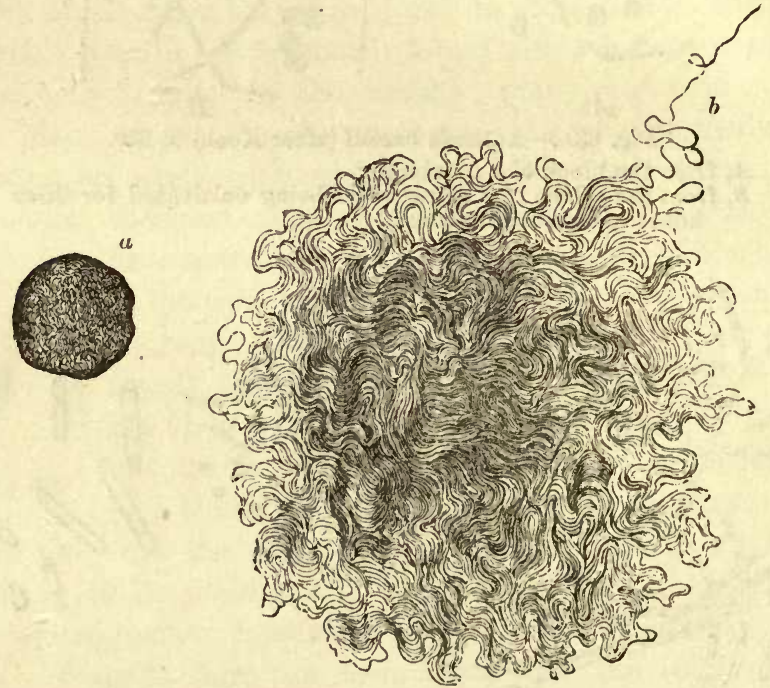

Fig. 64.-Anthrax colony in gelatine.

$a$, after 24 hours. $\quad b$, after 48 hours $\times 80$.

This wavy margin becomes more and more marked as the growth of the colony increases, and at once becomes much more distinct and spreads out more quickly on all sides when the colony has reached the surface of the gelatine. Under a low power the dark remnant of the deeply placed colony can only be seen in the middle; around this centre, however, there is a light-brown or light-grey shiny mass, which consists of numerous wavy, curly bundles, recalling the appearance of the locks of hair on 
the head of a medusa. Ultimately individual threads, or bundles of threads, branch off from the irregular periphery, and grow over the gelatine in various directions. At the same time the gelatine is liquefied over a small area; the colonies, which have now a diameter of 2 to $4 \mathrm{~mm}$, begin to float and break down at their margins under the action of the fluid formed.-In punc- Puncture ture cultivations in gelatine a delicate whitish line is cultivations. formed along the needle track, from which fine threads run off at right angles, and grow in a ray-like form into the jelly, extending furthest on and near the surface, to a less extent at the deeper parts of the puncture; here also slow liquefaction begins after two or three days, in such a way that the radiating branches at first remain, and it is only in the course of eight days that the colonies sink to the bottom of the liquefied area, which is now more extensive.- On the addition of a small quantity of agar to the nutrient jelly, no liquefaction occurs. On Growth on slices of boiled potatoes the anthrax bacilli form greyish- other nutrient white elevated gelatinous deposits with a rough surface; these deposits do not extend over the whole surface of the potatoes, but only spread for 3 to $5 \mathrm{~mm}$. from the line of inoculation. On blood serum they form whitish layers; in meat infusion they cause a cloudy turbidity, which develops by preference at the bottom of the ressel.

When introduced even in minimal quantities into the Action on blood of living animals or man by intravenous injection animals and or subcutaneously, the bacilli cause anthrax, which either takes the form of local symptoms, anthrax carbuncles, and then not uncommonly ends in recovery, or appears as a septicæmia, and then usually rapidly ends in death. Anthrax was the first case in which an infective disease occurring in man was proved with certainty to be due to a vegetable micro-parasite, the organism being at the same time inoculable on various animals, and being thus suitable for experimental study. The smallest trace of a cultivation of anthrax bacilli inoculated on mice, rabbits, guinea-pigs, hedgehogs, sparrows, sheep, and horses, causes the illness or death of the animals from 
anthrax, death occurring in the case of mice after about 20 hours, and in that of rabbits after 42 hours. After death the bacilli are found in largest numbers in the swollen spleen, and also in all the capillaries, especially in the lungs, liver, kidneys, and intestine; in the larger vessels, on the other hand, often only single bacilli are met with.-Certain races of sheep (Algerian), white rats, dogs (especially adults), and frogs, are entirely, or to a certain degree, immune against anthrax.

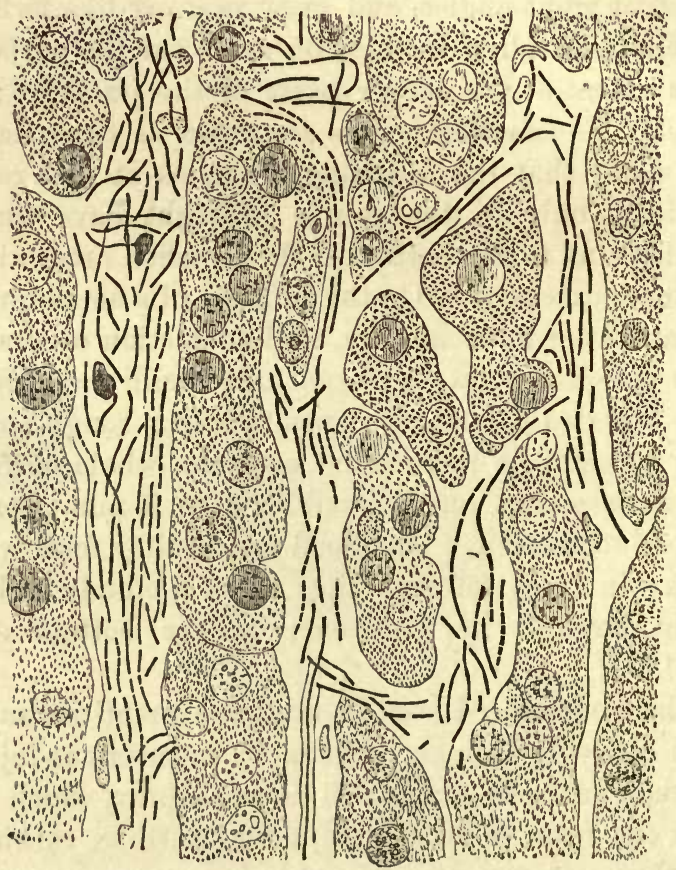

Fig. 65. - Anthrax, section from the liver $\times 700$.

Cattle are comparatively slightly susceptible to anthrax after inoculation, but on the other hand readily succumb to the natural infection, which generally spreads in the case of sheep and cattle from the intestine as the result of infection by the food. Non-spore-bearing bacilli do not appear to be able to retain their vitality in the intestine; on the other hand, it has been shown with regard to spores that they can sprout in the intestine of sheep, 
and penetrate through the uninjured mucous membrane.

In the body of living animals the bacilli multiply only Conditions of by fission, and never form spores. These arise on dead tion formanutritive substrata, but only under definite conditions, among which a suitable temperature is the most important. The highest limit of temperature is about $43^{\circ}$ C. ; the lowest from $12^{\circ}$ to $18^{\circ} \mathrm{C}$.; below $12^{\circ} \mathrm{C}$. neither growth of threads nor spore formation seem to occur. Hence if the bodies of animals which have died of anthrax are buried very deeply in the soil, where in our climate there is a constant temperature below $12^{\circ} \mathrm{C}$., spore formation does not occur, and the bacilli themselves speedily die without having passed into a resting form. Pasteur's assertion that the bacilli or their spores are preserved in the buried bodies, and that they are then brought up to the surface of the soil by means of worms, is thus wholly improbable. On the contrary, we have to explain the occurrence of an epidemic of anthrax, according to Koch, in the following manner: the germs Mode of which are distributed since ancient times in marshy anthrax regions, on banks of rivers, \&c., can again develop on bacilli. suitable vegetable substrata, and there form new spores; these are carried to pasture lands by floods, and thus become mixed with the fodder.-This mode of spread also explains the infection from the intestine, which is much the most frequent mode observed. Recently Schrakamp and Friedrich have mentioned the possibility that the growth and development of the anthrax bacilli may also occur in the upper layers of the soil ; while Kitt regards cattle dung as the chief nutritive substratum in which the development and spore formation of the bacilli occurs in the regions infected by this disease. (See the chapter on the exciting agents of disease.)

Of great scientific value is the discovery by Toussaint Artificial and Pasteur that the anthrax bacilli can lose their patho- attenuation of genic properties by the moderate action of abnormally bacilli. high temperatures, or of small doses of poisonous substances, while their morphological and biological characters remain otherwise unaltered. On the mode in 
which the means used for the attenuation are employed depends apparently the answer to the question whether and within what time the bacilli can regain their virulence on subsequent continued cultivation under favourable normal conditions. The degree of attenuation can be modified with precision to any desired extent by the method described by Koch.-The inoculation of sufficiently attenuated bacilli sets up in the case of sheep, cattle, \&c., a mild disease ending in recovery, after which the animals in question are immune for a considerable time against the virulent anthrax bacilli (Pasteur's protective vaccination).

Buchner's experiments.

According to Buchner the anthrax bacilli are extremely variable in morphological and biological characters, and by variations in the cultivations can be transformed, after passing through a series of intermediate stages, into the closely allied hay bacilli (Bacillus subtilis), and in like manner the latter can be converted by suitable cultivations into true anthrax bacilli. Buchner in the first place cultivated the anthrax bacilli for many generations in a nutritive solution containing extract of meat, peptone and sugar; after a short time these cultivations were only virulent in large doses, but the bacilli again regained their full virulence in the animal body; ultimately they entirely lost their pathogenic properties, but grew and behaved exactly like hay bacilli. Koch has shown in the most convincing manner that this supposed transformation can only have been due to contamination and the gradual displacement of the anthrax bacilli by the hay bacilli. Had it been a case of gradual loss of pathogenic properties, there must have been, in the first place, just as in the case of the anthrax bacilli cultivated at high temperatures, a less severe and no longer fatal disease; in Buchner's experiments there was no effect after small doses, while after large doses there was the complete fatal action; this circumstance, as well as the increase of virulence after passage through the animal experimented on, corresponds entirely with the behaviour of impure nutritive substrata containing only a few infective organisms from which by the cultivation in the body the pathogenic organism is again isolated and cultivated pure.-Buchner tried to carry out the transformation of the hay bacilli into anthrax bacilli by cultivating the former in the first place in white of egg with a little meat infusion, and then in fresh rabbit's blood which was constantly shaken up with air but not sterilised. From such blood cultivations further cnltures were made in meat in- 
fusion, and by the injection of large quantities of the spores formed in this medium a fatal disease was obtained in some cases which Buchner looked on as anthrax. Since it has, however, been demonstrated that among the so-called hay bacilli various pathogenic organisms are present which resemble the anthrax bacilli and give rise to similar diseases (see page 242), and that in meat infusion and putrefying blood spores of these pathogenic bacilli often occur, Buchner's experiments cannot be regarded as convincing; the disease which was finally obtained was possibly not anthrax, but malignant odema or some other affection. This possibility becomes a probability when we consider how extraordinarily constant anthrax bacilli and hay bacilli have proved to be under the most varied conditions of cultivation in the hands of those investigators who rightly estimate the magnitude of the sources of error in cultivations in fluid substrata. -Further, Buchner states that he has been able to obtain a transformation of anthrax bacilli in the first place into an intermediate form, and then into true hay bacilli within a very short time ( 24 hours) by cultivating them at $36^{\circ} \mathrm{C}$. in nutrient solutions composed of meat infusion, yolk of egg (from old eggs preserved in lime water), and a little alkali. The yolk of egg was not sterilised, and the inoculation was made from the spleen of an animal which had died of anthrax; thus there were two possible modes of entrance of extraneous germs, and that such an unintentional contamination had in all probability taken place is likely from the totally different results obtained in numerous other cultivation experiments with anthrax.-Recently Prazmowski has in so far supported Buchner's views that he has also in cultivations made by Buchner's method obtained a scumforming non-pathogenic motile bacillus which he looks on as the result of the transformation of the anthrax bacilli. On the other hand he ascertained that this organism was not identical with Bacillus subtilis, which is totally different from the anthrax bacillus in the mode of the sprouting of its spores, and in its other constant characters. Experiments which the author has set a-going with regard to Buchner's views have only led to the conviction that the development of extraneous organisms is a very frequent and scarcely avoidable occurrence in the method of experimentation described, and that there was in no case any guarantee that the bacilli ultimately obtained had been developed from the anthrax bacilli inoculated.- Kurth comes to a similar conclusion as the result of his own experiments in his work on "Bact. Zopfii."

A great variability in morphological form has also been wrongly attributed to the anthrax bacilli by various observers. 
Thus more especially Buchner, Zopf, Fokker, Archangelski, and Roloff have observed cocci as a vegetative form of the anthrax bacillus both in cultivations and in diseased animals. Numerous careful examinations by those observers who are thoroughly acquainted with microscopical technique, and who know how to aroid the sources of error mentioned above. (page 182), have demonstrated the inaccuracy of this assertion. -De Bary states that he has observed in certain cultivations (peptone solutions) a breaking up of the threads of the anthrax bacilli into round bodies which become aggregated in the form of grape-like or irregular groups, but which with doubtful exceptions proved to be dead. It is evident that these degenerative forms, which are very various, have not the slightest claim to be designated as cocci.

\section{Bacillus oedematis maligni.}

Discovered by Koch as the exciting agent of malignant œdema, a fatal disease of mice, guinea-pigs, and rabbits ; formerly termed by Pasteur vibrion septique. Malignant œdema has recently also been observed in domestic animals and in man.

Morphological character of the cedema bacillus.

The œdema bacilli, which are morphologically similar to the anthrax bacilli, are rods $3-3.5 \mu$. in length and $1-1 \cdot 1 \mu_{\text {. }}$ in breadth; usually two or three bacilli remain

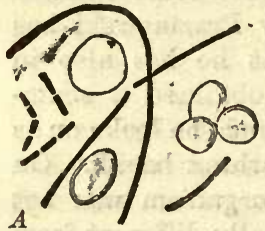

Fig. 66.-Bacillus of malignant odema (vibrion septique), after Koch, $\times 700$.

$A$, from the spleen of a guinea-pig. $B$, from the lung of a mouse. united together, and then the thread is two or thrce times longer; indeed one may frequently find long pseudo-threads 15 to 40 $B \quad \mu$. in length. The threads scem to bo comparatively stiff, and are often broken or bent; at times also they are looped and twisted around each other In stained preparations they frequently present a somewhat granular appearance, owing to irregular deposit of the colouring matter. Anthrax bacilli differ from the odema bacilli by their somewhat greater breadth, their truncated ends, and their peculiar segmentation in stained preparations. Further, one does not find in fresh anthracic blood the numerous 
long threads of the œdema bacilli, and the œdema bacilli are sometimes, though not always, motile, while the anthrax bacilli are always motionless. The most marked morphological difference between the two is, however, the mode of spore formation. In the cedema bacilli this does not occur in the threads in the same way as in the anthrax bacilli, but the individual bacilli show before the spore formation a slight swelling in the middle or at one end, so that a spindle or tadpolt form results, and in this swollen part the large oval spore, at first dull, but later highly refracting, is formed, and when its forma-

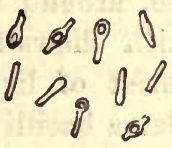

Fig. 67.-Spore formation in the bacilli of malignant œdema $x$ 700. tion is complete the colourable remains of the bacilli gradually disappear.

There is considerable difficulty in cultivating the Cultivation of œdema bacilli, because they are marked anaërobes, so the oded. much so that they only form visible colonies when oxygen is pretty completely excluded. They do not grow at all on gelatine plates, even in the deeper layers; nor do they grow along the inoculation track on gelatine, agar, or blood serum. On the other hand they can grow when they are inoculated at a certain depth in tubes containing nutrient agar or blood serum, in such a manner that the canal of inoculation becomes tightly closed over the material introduced. As Hesse first observed, a diffuse muddiness of the nutritive material consisting of bacilli appears in the nutrient agar, with here and there more markedly muddy lines or clouds. At the. same time gas bubbles are formed within the inoculation canal, which penetrate into the agar in various directions, often divide it transversely, and drive up the separated portion as high as the cotton wool plug, and at the same time so compress the agar that a muddy fluid is separated which collects at the bottom of the glass, and contains numerous bacilli. The escaping gas has a slight, somewhat heavy smell.-Blood serum is quickly liquefied by the bacilli, and there is at the same time marked development of gas; in a few days, when kept in an incubator at $37^{\circ} \mathrm{C}$, the whole mass 
of the blood serum is converted into a yellow fluid, at the bottom of which there still lie some pieces of the serum with eaten away, shreddy margins.- In nutrient gelatine a spherical layer, 5-10 $\mathrm{mm}$. in diameter, forms at the bottom of the inoculation puncture, around the material inoculated, the periphery of which shows fine radiating markings, and the contents consist of liquefied and somewhat turbid jelly. The œdema bacilli grow best in a nutrient jelly which contains 1-2 per cent. of grape sugar; and very characteristic cultivations are obtained in test tubes if the gelatine is fluid when inoculated, and the material well distributed through the whole jelly by shaking it before it is allowed to solidify. After two or three days a number of small spheres, $-1 \mathrm{~mm}$. in diameter, and filled with fluid, form in the lower part of the tube, and these show under a low power the radiating marking of the periphery. The colonies extend from the bottom of the vessel to about $2 \frac{1}{2} \mathrm{~cm}$. below the surface. The upper $2 \frac{1}{2} \mathrm{~cm}$. of the gelatine remain completely unal-

Fig. 68.-Cultivations of the bacilli of malignant œdema in gelatine.

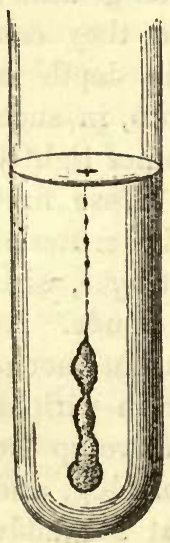

tered. By pouring on oil, introduction of carbonic acid, \&c., one can artificially raise the upper limit within which visible colonies are formed.*

The best temperature for growth is about that of the human body; but luxuriant growth also occurs at $18^{\circ}-20^{\circ} \mathrm{C}$., especially in jelly containing sugar. Spore formation has also been observed at this temperature, but it occurs more readily and plentifully at the higher temperature. In the animal body only bacilli and threads are found immediately after

* After observations by Dr. Liborius in the Hygienic Institute at Göttingen. 
death, but no spores; the latter are, however, observed when the body has lain for some time after death at a high temperature.

1. The œdema bacilli are apparently extremely widely Distribution distributed in our surroundings. They appear to be phytic life of present in almost all decomposing substances in greater the odema or less numbers, and they perhaps also take a definite though limited part in the putrefactive process. As is shown by the behaviour of the pure cultivations, the œdema bacilli have the power of energetically peptonising albumen, and possibly also of further breaking up the albuminous molecule. A more accurate analysis of the nature of the decomposition is as yet wanting, at all events the œdema bacilli can pass through their characteristic cycle of development as saprophytes. In accordance with this we find them in the most various putrid substances, in the bodies of nnimals which have died of suffocation and have then been kept at a high temperature, in the fæces, and in the intestinal contents; their spores are present in every specimen of earth which has been impregnated with putrid fluids, \&c.; they are also found in the dust of rooms, in the dust of rags, of hay, se.

At the same time, also, the œdema bacilli possess Pathogenic pathogenic properties, and by means of these their pre properties of sence can be most easily demonstrated, and they can be bacilli. most readily isolated from the mixture of other saprophytes. If not too small an amount of garden earth or hay dust is introduced under the skin of a guinea-pig (this is best done by making a small cut with scissors through a fold of skin over the abdomen, and then loosening the subcutaneous cellular tissue with the handle of the scalpel so that a small pocket is formed, which is then filled with earth and the wound closed with one or two stitches), the animal becomes ill very soon, and dies in 24 to 48 hours. On post-mortem examination the most striking appearance is an extensive subcutaneous œdema extending from the seat of inocution, the œdematous fluid being clear and red, and containing numerous bacilli and a few gas bubbles. The internal 
organs are but little altered, the spleen is for the most part enlarged and of a dark colour, and the lungs have a pale greyish-red appearance. Immediately after death few or no bacilli are found in the blood of the heart; on the other hand they are plentiful in the juice from the various organs, and also more especially in and on the serous coats of the organs. (In this point also this organism differs in an important manner from anthrax.) If some time has elapsed since the death of the animal the bacilli are found everywhere, even in the blood of the heart, in large numbers; thus they are apparently able to multiply actively in the dead body. In mice, however, the bacilli are not uncommonly found immediately after death in the blood of the heart and in the blood ressels of the organs; here therefore it is easily possible to mistake the disease for anthrax. As a rule, in mice the bacilli are only seen in the crushed spleen, on the pleural covering of the lungs, and most beautifully in preparations of the mesentery, obtained by spreading out a loop of intestine over a cover glass, loosening the mesentery at the margin of the cover glass, and subsequently treating it like the ordinary cover glass preparations (drying, heating, staining). In mice the œdema is for the most part not very marked; the animals die very quickly - on an average 16-20 hours after inoculation.-Horses, sheep, and swine are liable to malignant œdema; on the contrary, according to the researches of Arloing and Chauveau, cattle are not

Mode of inoculation. affected.-The animals cannot be infected with such small quantities of bacilli as in the case of anthrax; to transmit the disease from one animal to another it is best to employ small pieces of spleen, or one or two drops of œdematous fluid, or a portion of the subcutaneous tissue; from cultivations it is best to impregnate a silk thread with a little of the fluid containing bacilli, and then place this under the skin. The wound also must not be too trivial, it must really penetrate through the cutis ; it is only then that the conditions necessary for the existence of this anaërobic organism are obtained. Scarcely noticeable symptoms follow the intravenous 
injection of relatively large doses, 1, 5, 10 drops.- In How to obtain order to obtain cultivations from the dead body of an eultivations animal the skin is washed as soon as possible after animal body. death with sublimate solution, and then with sterilised water, or the hair is completely singed off at the part; then small portions of spleen, diaphragm, or of the œdematous dorsal muscles, are taken with heated instruments, and introduced into tubes of jelly containing sugar, and liept at the temperature of $30^{\circ} \mathrm{C}$.; these are then allowed to solidify.

Recently several cases of malignant œdema have Malignant been observed in man. This disease has commonly man. been designated by surgeons as progressive gangrenous emphysema (gangrine gazeuse); it seems to have been comparatively frequent before the introduction of antiseptic methods; it is now chiefly observed after compound fractures or deep wounds, into which earth or other material containing œdema bacilli has passed. A crepitating emphysema of the skin spreads in these cases from the wound, accompanied with the development of a very putrid smell; the muscles are at the same time converted into a peculiar reddish-brown, loose, frothy mass, full of gas bubbles; and death generally occurs in a few days with comatose appearances and gradual spread of the cdema. Lately the identity of this gangrene with malignant œdema has been repeatedly ascertained by inoculation of animals and by cultivations (Chaureau, Arloing, ${ }^{*}$ Brieger, and Ehrlich).

Chauveau and Arloing have observed that animals which Experiments recover from the disease are immune; injection into the on immunity. veins produces a similar immunity, which, however, cannot withstand repeated inoculations. Subcutaneous inoculations of small quantities produce, according to Loeffler's experiments, no noticeable disease, but also no immunity (Mitth. a. d. Kais. Ges. Amt., Bd. I.).

* Bull. de l'Acad. de Med., May, 1884, and August, 1884. 


\section{Bacillus typhi abdominalis.}

Eberth, Klebs, and Koch were able to demonstrate in the spleen, lymphatic glands, and Peyer's patches of patients suffering from typhoid fever, peculiar short, plump bacilli which were not met with in other diseases. According to Klebs, long threads develop from these bacilli, and in these rows of spores are formed; this statement was not confirmed by the other two authors, and probably rests on error owing to the accidental presence of putrefactive organisms. Meyer and Gaffky have subsequently confirmed Eberth and Koch's results. Occurrence of Gaffky found the characteristic bacilli 26 times in 28 the typhoid bacilli. cases of typhoid fever investigated; and recently similar

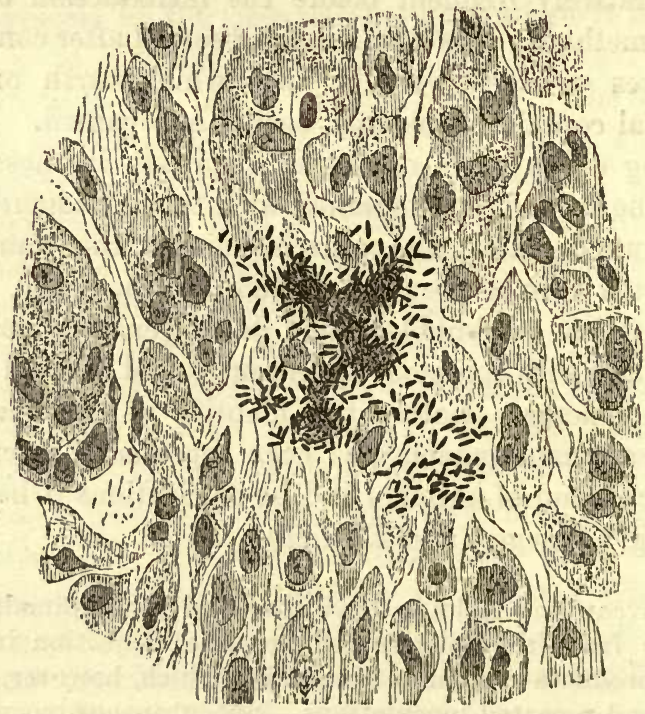

Fig. 69.-Typhoid bacilli; section from spleen $\times 800$.

observations have been made by a number of investigators. This constant occurrence of the bacilli, which are limited, as can be shown, only to typhoid affections, renders it highly probable that they are causally connected with the disease.

The bacilli are present in the diseased parts of the intestine, in the mesenteric glands, in the spleen and 
liver, but not so numerous in the kidneys. They are not diffusely distributed in these organs, but always occur in the form of small isolated deposits. This renders the microscopical investigation especially difficult; it is often only after the examination of a large number of sections that one or a few of these deposits are found. The masses occur in the form of groups with irregular outlines lying usually in the capillaries or smallest blood vessels, these groups being resolved at their margins into individual bacilli (see fig. 69).

The latter appear as rods $2-3 \mu$. in length, and Morphological about three times less in breadth. Their ends are distinctly rounded off. In many cases undoubted spores are found in the bacilli, presenting the appearance of round unstained portions occupying the whole breadth of the rod.-Aniline dyes are slowly taken up, but quite sufficiently when the staining process is continued for a considerable time; the best stains are gentian violet, Bismark brown, and especially alkaline methylene blue. With Gram's method the typhoid bacilli are very readily and completely decolourised.

Gaffky was the first to cultivate these bacilli on suitable soil from the organs of patients who had died from typhoid fever. Former attempts by other investigators did not lead to a pure culture of the typhoid bacilli. Gaffky succeeded in 13 cases in obtaining pure cultivations of the bacilli, by planting on nutrient jelly minute portions of tissue taken with all precautions from the interior of the spleen. These cultivation experiments showed that even in the cases where on microscopical examination it was only with difficulty and in a small proportion of the sections that bacilli could be demonstrated, every minutest portion of the juice of the organ gave rise to several colonies of bacilli, so that it was evident that the best idea of the number of bacilli present, and of their distribution, could be obtained by the cultivation method.-Cultivations of the typhoid bacilli have since been repeatedly made; they are invariably successful from the organs of fresh typhoid bodies. Pfeiffer has recently succeeded in isolating 
the characteristic bacilli by means of plate cultivations from typhoid stools, and from the intestinal contents of typhoid bodies.

Characters of the cultivations of typhoid bacilli.
Growth on potatoes.
When sown on gelatine plates the colonies of the typhoid bacilli form, after about 36 hours, minute white points; when magnified 80 times these appear as irregular, oval, and even whetstone or citron-shaped plates of a light yellow or yellowish-green colour, with sharp, smooth borders, and an indistinct granular character. In the course of 36 to 48 hours more the colonies have spread out to form a roundish greyish-white flat deposit 1 to $1 \frac{1}{2} \mathrm{~mm}$. in diameter; these do not form any knoblike elevation, and project very slightly above the gelatine. The contour of this layer is irregular, indented, and at times distinctly branched; under a low power the colony, with the exception of the central part, is colourless, and shows on the surface numerous lines and furrows. Liquefaction of the gelatine does not occur at any stage.-On agar plates at a higher temperature the characters are similar; after about 20 hours the young colonies have the appearance under a low power of pearor citron-shaped brownish plates with sharp borders.

In puncture cultirations in gelatine a thin whitish thread forms along the line of puncture; at the surface a greyish-white flat layer is constantly formed, at first small, but later reaching almost to the margin of the glass; the outline of the growth shows in the later stages numerous projections and irregularities. - In stroke cultivations a similar greyish-white layer forms on the surface of the gelatine.

The typhoid bacilli can also grow on blood serum, fluid and solid, in meat infusion, and on other nutrient substrata. In milk the bacilli grow actively but witkout causing any noticeable alteration of the milk.Their growth on boiled potatoes is extremely characteristic, and of special importance for the distinction of the typhoid bacilli from all other forms of bacteria as yet known. Slices of potato inoculated with small quantities of typhoid bacilli appear almost completely unaltered after two or three days; at the most 
the surface in the neighbourhood of the track of inoculation has acquired a somewhat moist, more shiny appearance. If this part of the potato is touched with a platinum wire it gives the impression as if the surface was corered with a resistant skin ; and if we examine microscopically a minute portion from the surface we can easily see that this skin consists of masses of bacilli which have taken possession of the soil over a great extent, often over the whole surface. If the inoculated potato is kept at $35^{\circ} \mathrm{C}$. the development of the layer of bacilli occurs more rapidly, while otherwise the appearance of the potato remains the same.

In all these cultivations the bacilli appear under the Morphological microscope as short, thin rods similar to those observed in the tissue. Nevertheless long pseudo-threads are characters of almost always formed in the cultivations, and there are also marked differences in length corresponding to the rarious stages of growth. It is also possible to stain culture preparations with aniline dyes, but it is more difficult than the staining of other bacilli (e.g., Bacillus anthracis).-Further, the bacilli taken from the cultivations show distinct and often fairly active movements. Spore formation can not be observed in cultivations kept at $15^{\circ}-$ $18^{\circ} \mathrm{C}$; ; at $20^{\circ} \mathrm{C}$. a few spores are formed, and betreen $30^{\circ}$ and $42^{\circ} \mathrm{C}$. the spore formation is plentiful. The spores are situated at the end of the rods, and only one spore is formed in each rod in the form of a highly refracting round body, occupying the

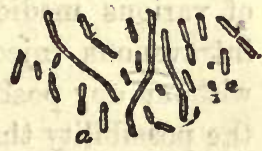

Fig. 70.-Typhoid bacilli from a cultivation $x$ 800.

Showing on the right hand sporebearing bacilli and free spores. whole breadth of the bacillus. Where two bacilli are joined together it is always the two ends not in contact which bear the spores.

Inoculation experiments on animals have as yet been Experiments without result, whether the material used was typhoid on animals. stools or the pure cultivated bacilli. Those few experiments in which a typhoid disease was said to follow inoculation or feeding have evidently been made with impure material containing other active bacteria. It is 
known that a group of fairly widespread organisms, which, however, differ totally from the typhoid bacilli, have this property in common, that when introduced either by intravenous or subcutaneous injection, they kill animals with the symptoms of a gastro-enteritis, often with marked swelling and ulceration of Peyer's patches. It is probably to these organisms that we must ascribe the apparent positive results which certain authors think they have obtained by inoculation of the typhoid bacilli; this remark applies more especially to the typhoid cultivations isolated by Tayon, and tested with apparent success on animals and man, for these in no respect correspond to the characters of pure cultivations of the characteristic bacilli which constantly occur in typhoid fever.-Recently numerous experiments have been made by Gaffky (and also in the laboratory at Göttingen) with the view of setting up a corresponding disease in animals with pure cultivations of the typhoid bacilli. Besides rabbits, guinea-pigs, and rats, calves and monkeys have also been employed in these experiments; infection has been attempted by continued feeding, in some cases along with simultaneous employment of various medicinal substances, by subcutaneous and intravenous injections, and by inhalations, but as yet without any positive result. However, there is always the possibility that some preliminary preparation of the animals may render them susceptible to an infection. The success of such experiments would be of great importance in completing the proof that the bacilli described are really the causal exciting agents of typhoid fever, although the constancy of their occurrence and their exclusive presence in this disease leaves scarcely any real doubt as to their significance.

Occurrence of typhoid bacilli in human surroundings.

Typhoid bacilli have never as yet been demonstrated with certainty outside the human body with the exception of Pfeiffer's demonstration of their presence in the dejecta of typhoid patients. It is true that there are statements by Brautlecht and Klebs as to the successful demonstration of typhoid bacilli in suspected drinking water; but according to the description which 
these authors give of the bacilli found by them it is certain that neither of them were dealing with typhoid bacilli. Brautlecht's bacilli were very thin, slender bacilli ; those isolated by Klebs from the water supply of Zürich were not decolourised by Gram's method, they showed another mode of spore formation, were infective for rabbits, and were therefore certainly not identical with the bacilli of Eberth and Gaffky.*

The most distinctive character of the typhoid bacilli is their peculiar mode of growth on potatoes; and when we have to diagnose these organisms the potato cultivations must be employed as the distinctive criterion. With the help of this aid to diagnosis it will now per-Modes of haps be possible to follow more closely the distribution of the typhoid bacilli in our surroundings and the modes bacilli. distribution in which it causes infection. What has as yet been done in this direction rests only on deductions and on practical experience and statistical facts which are in many respects open to question, and are in part contradictory. The following views may be deduced from the knowledge which we have gained during recent years as to the specific exciting agents of typhoid fever.

We may perhaps conjecture that the seat of entrance of the infective agents is by preference the digestive tract; in favour of this we have the observations as to the distribution of the typhoid bacilli in the body of the patient as well as the analogy with many other diseases which are chiefly localised in the intestine (swine erysipelas, cholera). Nevertheless, in spite of these observations and analogies, the possibility of some other seat of invasion is not excluded (see the chapter on the causation of disease).-Further, from the mode of spread of typhoid epidemics we may probably draw the conclusion that a certain preparation of the intestine for infection

* Kleb's article, "Bacillen," in Eulenburg's Realencyclopoedia.Lec'ure on the drinking water supply of the town of Zurich and its suburbs. Aussersihl, 1885.-Compare the refutation by Cramer in Die Wasserversorgung von Zürich, Zurich, 1885; and Die Wasserversorgung von Zürich und Ausgemeinder; Entgegnung der erweiterten Wasser-commission auf die Angriffe von Herrn Prof. Klebs. Zürich, 1885. 
must always take place, that a condition of irritation, a hyperæmia and detachment of epithelium, such as occurs, for example, in animals after the injection of putrid mixtures, prepares a spot for the entrance of the true infective agents.

If the view as to the important role played by the intestine in the production of infection is correct, it becomes probable that the transport of the typhoid bacilli to the seat of infection occurs most frequently through the food; and very various articles of food are not less suitable as rehicles than the drinking water which is commonly blamed in a somewhat one-sided manner.

Transport by articles of food.
Articles of food and drinking water can evidently be impreguated with large quantities of typhoid bacilli or spores in the most various ways; of great importance for the continued existence and development of the typhoid bacilli outside the body is, on the one hand, the fact that many typhoid bacilli leave the body of the patient in the form of resistent spores, and on the other hand that their development can occur on the most various nutrient materials at the ordinary temperature, and that without any alteration of the nutrient material noticeable to the naked eye. Thus the channels for the spread of the infective material from the dejecta of typhoid patients to articles of food are extremely numerous, and are in a marked manner subject to chance, which at one time follows no apparent rule, at another time may present a deceptive appearance of law. It is necessary to refer in illustration of this to the fact that the dejecta containing spores are ultimately deposited on garden earth, on fields, or on meadows, that the unaltered spores may be thence transported to the dwellings by fruit, man, \&c., and by unforeseen actions and accidents reach a suitable nutrient medium where they can multiply plentifully, and from whence further infection may eventually occur.

It is necessary to bear in mind these numerous and complex ways in which an infection may possibly occur in order to some extent to meet the prevailing tendency to treat these etiological questions in a schematic manner. 
In numerous typhoid epidemics a local and seasonal pre-disposition can be recognised, and Pettenkofer has, as is well-known, observed that the moisture of the soil plays an important part in this pre-disposition. How far this view can be brought into harmony with the biological characters of the typhoid bacilli will be discussed more in detail in the chapter on the causation of disease.

Bacillus pneumonice (Friedländer).

The infectious, and at times epidemic character of certain forms of pneumonia has been repeatedly pointed out by various observers,-for example by Kühn, Jurgensen, and others, - this character leading to the belief that micro-organisms may be the exciting agents of the disease. In 1883, Friedländer and Frobenius, as a matter of fact, found and isolated by cultivation bacteria in a large number of cases of pneumonia, the organisms presenting infective properties.

The bacteria were at first only found on post-mortem Occurrence of examination, especially in the alveolar exudation, in the pneumonia cover glass preparations of the juice, and in sections; they were also present in the pleuritic and pericardial exudation. The same bacteria have also been found by Ribbert, Ziehl, and others in the rust-coloured sputum, and by Friedländer, in one of six cases examined, in the blood obtained by cupping.

These micro-organisms present, under the microscope, Morphological the form of oval cells; it is difficult to say whether these characters. are to be regarded as oval micrococci, or as very short rods with rounded ends. Friedlünder has described them as micrococci, but in every preparation a relatively large proportion of the individuals shows such a preponderance of the longitudinal diameter that they cannot be reckoned among the cocci; further, isodiametric cells never occur, or only in so far as they are seen in preparations, where the cells stand at right angles to their long diameter; and as also under high powers of the microscope, even the shorter forms show distinctly parallel and longitudinal limiting lines, it seems more correct to designate the organisms as bacilli. 
In this species we not uncommonly find that the youthful stages only appear as oval, egg-shaped cells, and that under certain conditions, where the multiplication is very rapid, these young cells prepon-
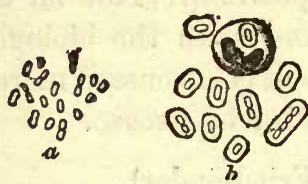

Fig. 71.-Pneumonia bacilli $\times 700$.

$a$, from cultivations.

$b$, from exudation showing capsules. derate; but the simultaneous presence of older individuals showing a distinct rod shape, enables us to determine that all the cells are bacilli, for if we had to do with the forms which we are accustomed to designate as cocci, we should only find round, or at most very slightly oval cells.

The short bacilli grow very frequently in chains of two to four members; these forms are apparently the more numerous, the more rapid is the multiplication, and hence in these preparations the short forms show a marked preponderance.

In preparations which are obtained from the animal body, but not in those taken from cultivations of the bacilli, the organisms are surrounded by a sort of

Staining of the capsule. capsule. Each bacillus lies embedded in a gelatinous sheath which is evidently composed of a substance similar to mucine, as shown by its solubility in dilute alkalies, and its insolubility in acetic acid; the sheath stains faintly when treated in a certain manner with gentian violet or fuchsine, and is thus rendered very distinct. In order to demonstrate the capsules distinctly in sections, Friedländer recommends the following method: place the sections for twenty-four hours in acid gentian violet solution (concentrated alcoholic solution of gentian violet 50 parts, distilled water 100 parts, acetic acid 10 parts), then decolourise in - 1 per cent. of acetic acid for one to two minutes; then treat with alcohol, oil of cloves, \&c. Ribbert employs for cover glass preparations a staining fluid composed of 100 parts of water, 50 parts of alcohol, $12 \frac{1}{2}$ of glacial acetic acid, saturated, when warm, with dahlia; the preparations are immersed in this solution only for a very short time, then washed in water and examined. 
The sheath has exactly the form of the bacillus which it surrounds, and hence it usually presents the appearance of an elongated ovoid; two to four bacilli in chains are often present in one capsule; in other cases the division is complete, and each of the new bacilli has its own capsule. The breadth of the sheath is at least as great as the transverse diameter of the bacilli ; at times, however, it is two to three times greater. This capsule formation is not at all peculiar to the pneumonia bacilli, in which, however, the enveloping substance which is present in a very large number of bacteria is particularly well formed; this material is also quite as great in some other species.

Cultivations of Friedländer's bacilli are readily obtained Cultivations. on rery various nutrient substrata. On gelatine plates white points appear after twenty-four hours, and under the microscope present the form of round, sharplydefined dises, with a dark granular centre, and a narrow olive-coloured border; at a later period a white porcellaneous deposit is formed on the surface of the gelatine, like a very prominent convex knob. In cultivations made by plunging the needle into the gelatine, a thick, white, confluent mass is formed along the track of the needle, and this mass extends into any fissures which may communicate with this track; here, also, we find a convex knob on the surface. In stroke cultivations a thick, white, creamy layer is formed.-The bacillus also grows well on agar, blood serum, and potatoes. On the latter whitish-yellow gelatinous masses are formed,which may extend over the whole surface of the potato, presenting a glistening surface and showing at times a development of gas and formation of bubbles. - The rod shape of the bacilli is particularly evident in microscopical preparations of cultures, especially when the frowth has occurred at a low temperature and the individual organisms have attained their full size before dividing. The formation of spores has not as yet been observed with certainty.

Friedländer and Frobenius have performed inoculation experiments on animals with pure cultivations of 
bacilli. If fluids containing the cultures were injected through the wall of the thorax into one lung of a rabbit by means of a Pravaz syringe, no disease occurred, rabbits being completely refractory to the organisms. On the other hand, 32 mice treated in the same way died; on post-mortem examination reddish, turbid fluid was found in both pleural cavities, both lungs were very markedly reddened, almost completely devoid of air, and showed scattered and ill-defined patches of red infiltration. Of 11 guinea-pigs, 6 showed similar appearances; of $5 \mathrm{dogs}, 1$. If the cultivation was exposed to a temperature of about $80^{\circ} \mathrm{C}$. for 15 to 20 minutes, and then injected into mice, the animals remained healthy, with the exception of a few, where the injury was unintentionally more serere. (This is a control experiment, which in view of the serious injury done by such injections into the lungs of mice was absolutely necessary, and still requires further repetition).-Five mice were also successfully infected by inhalation of cultivations, and these, in like manner, presented typical appearances of pneumonia. The same organisms could be cultivated from the affected lungs of the animals experimented on.

Significance of Friedländer's bacilli for the etiology of pneumonia.
In judging of the significance of Friedländer's pneumonia bacilli, more especially for the purpose of clinical diagnosis, it is very important to note that they cannot be distinguished with certainty from $\Omega$ number of other organisms, either by their microscopical characters, or by their cultivations. The same morphological characterseven the capsules-are present in a number of bacteria; the character of the cultivations is extremely common, and shared by many species of bacteria; both the morphological and cultural characteristics were combined in bacilli studied by Passet, Kreibohm, and others. Hence a definite diagnosis of these organisms is only possible by experiments on animals; and even in this respect. the distinction is difficult, because other organisms also. show similar pathogenic action to that of Friedländer's bacilli (for example, the bacillus isolated by Schou). The allied pathogenic bacteria which have been as yet isolated in a similar manner show, howerer, differences 
with regard to their growth in gelatine and with regard to the species of animals susceptible to their action, and these differences enable us to distinguish them from Friedländer's bacilli. But the diagnosis of the latter can only be made by the aid of elaborate comparative cultivations and experiments on animals. And hence the establishment of a causal connection of these bacilli with pneumonia, based on their distribution in pneumonic processes, is very difficult, because it is not possible in every case to employ all the methods which alone enable us to distinguish these organisms from others which are constantly present in the sputum and in the bronchi, and which are therefore frequently found in pneumonic exudation, although they are of no importance.

The answer to these questions is so much the more difficult because Friedlïnder's bacilli are, without doubt, not the only cause of the pneumonic process. We are already acquainted with pneumonias which are caused by aspergillus and actinomyces; it is a priori not improbable that also among bacteria there are several other species which can set up pneumonia ; and the probability of this view is increased by Schou's observations. Further careful observations, combined with cultivations and experiments on animals, will therefore possibly discover a greater variety of causes of pneumonia.*

Emmerich has demonstrated the presence of Friedländer's bacilli in the soil of a room in which there were many pneumonic patients; the diagnosis was rendered certain by inhalation experiments with cultirations on 18 mice, of which 8 died of pneumonia; hence the soil seems to be one of the places where the pneumonia bacilli can be preserved, and whence, in suitable cases, they may pass into human beings. Possibly also there are a number of other places in our surroundings which play a similar róle. But as the result of our present; knowledge as to their occurrence and their properties, we cannot make any more definite statement with regard to the mode of spread of these pneumonia bacilli.

* Fränkel has isolated a bacillus which is much more often associated with pneumonia than the above-mentioned organism. 


\section{Bacillus tuberculosis.}

Demonstration of tho inoculability of tuberculosis.
Method of demonstrating the tubercle bacilli microscopically.
Klencke, and at a later period Villemin, were the first to show that the affected organs from tuberculous human beings, and from animals suffering from perlsucht, set up tuberculosis when inoculated on animals; they thereby proved the infective nature of tuberculosis, and provided a justifiable basis for the supposition that in this disease also the exciting agent was an organised living body. The infective experiments were subsequently repeated in a convincing manner, more espeeially by Cohnheim and Salomonsen, and later by Damsch, who employed the eyes of rabbits as the seat of inoculation, and were able to set up tuberculosis of the iris by inoculation of tuberculous material into the eye, the discase spreading from thence to other organs. In spite of these experiments the nature and the ultimate cause of tuberculosis was for a long time obscure, as the attempts to find, even with the most careful microscopical examination, any organised bodies in tuberculous organs. which could be looked on as the cxciting agents of the disease were not successful, and as also experiments on the cultivation of the supposed organised virus did not lead to any definite result. It was not till a few years ago that by means of Koch's classical investigations we obtained a complete insight into the etiology of this disease; a result which so much the more deserres our most complete admiration, because entirely new and special methods were necessary as. well for the microscopical examination as also for the cultiration of the micro-organisms, and because the whole investigation was laid before us in such a complete form that in respect of this question the points as to the etiology of tuberculosis are scarcely capable of any further important expansion. The following description is consequently in the main based only on Koch's work on tuberculosis.

In the first place Koch succeeded in demonstrating the presence of peculiar bacilli in the most various tuberculous affections by means of a special method of staining. While no micro-org?nisms could be demon- 
strated by the aniline stains as ordinarily employed, nor by the other nuclear stains, organisms at once became quite evident when a small quantity of alkali was added to the solutions of the aniline colouring matters. As later investigations showed, the substitution of anilin, toluidin, turpentine, carbolic acid, or ammonia, for the alkali acts in a similar mannner in enabling the staining material to penetrate into the tubercle bacilli; even without any such addition to the staining fluids, the bacilli may be successfully stained if only the action of the staining material is sufficiently intense to show quantitative differences with respect to the taking up of the colouring matter. It is also of special advantage that the staining material once it has penetrated into the bacilli is held very tenaciously; Koch found that on treatment of sections stained in the alkaline colouring material with strong nitric acid or hydrochloric acid the colouring matter is extracted from cells, nuclei, and all other bacteria, while the tubercle bacilli alone remain stained. In the tissue, which is now colourless, the individual bacilli are remarkably easily recognised on account of their stain; and the picture may be further improved by treating the section, after the employment of the decolourising means, with an ordinary nuclear aniline stain, the tone of which presents a good contrast to the solution first employed for the staining of the tubercle bacilli. The cell nuclei and also the other bacteria (not tubercle bacilli) take on this second stain, so that, for example, the tubercle bacilli appear red, the cell nuclei and other bacteria blue, or the former violet, and the latter brown. (As to the modifications and the technique of the method of staining tubercle bacilli, as well as with regard to the exceptions to the exclusive staining of the tubercle bacilli, see the chapter on "Methods."

The bacilli found in tuberculous organs by the aid Morphological of this extremely sharp and sensitive method are rods $1.5-3.5 \mu$. in length; their breadth is constant when the same staining methods are employed, and corresponds to that of the bacilli of mouse septicæmia: For 
the most part the bacilli are slightly bent, or even more frequently curved. They are often spore-bearing, the number of the spores being usually $2-4$ or even 6 . By the ordinary method of treating the preparations the spores do not take up the colouring matter, and hence the spore-bearing bacillus when stained presents the appearance of a dark thread, interrupted by clear eggshaped spaces. At times it seems as if the spores pro-

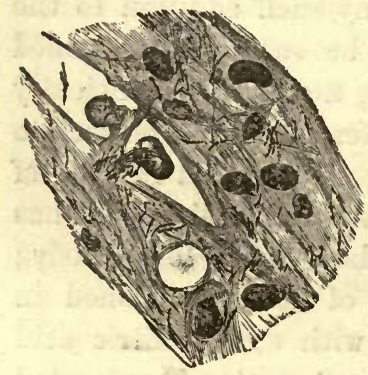

Fig. 72.-Sputum containing tubercle bacilli $\times 600$. jected laterally beyond the contour of the bacillus. If the specimen is examined with insufficient magnification one readily obtains the impression that such a spore-bearing thread is composed of a chain of cocci ; if the preparation is badly stained, too much heated, or too long treated with acid, this appearance is increased. Neverthe-

less it is always possible, in carefully prepared specimens and with the aid of good lenses (Zeiss $\frac{1}{18}$, Winkel $\frac{1}{24}$ ), to convince oneself that the supposed chain of cocci does not exist, but that the delicate contour of the bacillus can be for the most part traced through its whole length, and that it is only within this contour that the alternation of stained and unstained zones gives the deceptive appearance of stained cocci separated by narrow intermediate spaces. The assertion made by some observers that the tubercle bacilli also occur in the form of cocci can only be referred to this and other errors of observation. In all cases the tubercle bacilli appear to be non-motile.

Situation of the tubercle bacilli.

The bacilli are most readily found where the tubercular process is commencing or spreading. At first the bacilli are single, and then almost Fig 73.always lie in the immediate neighbourhood of a Tubercle nucleus and in the interior of the cell to which 1200 . this nucleus belongs; later they occur in closely packed small masses. The cheesy centre of the mass shows only broken down nuclear substance, which no longer 
takes on the nuclear stain, and in which there are very few or no tubercle bacilli; from the infectivity of the

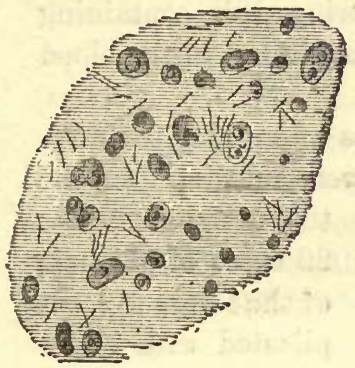

Fig 74.-Miliary tuberculosis of the lungs $\times 700$.

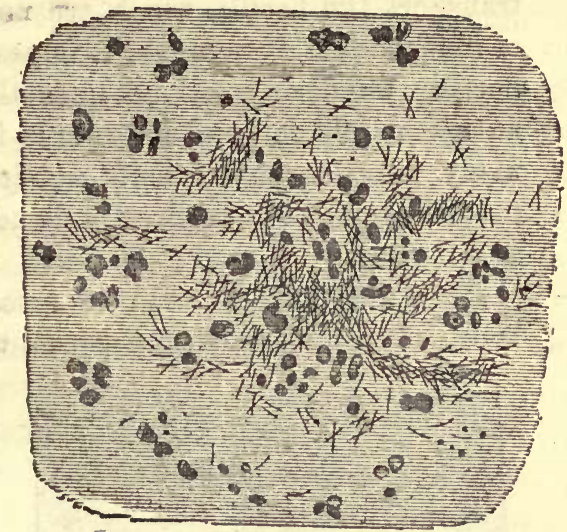

Fig. 75.-Tuberculosis of the intestine $\times 700$.

cheesy centre the conclusion may, however, be drawn that the bacilli have here passed into the spore stage, which cannot be demonstrated by staining.

As soon as giant cells appear in the tubercles, tubercle bacilliare almostalways found in them. They often contain only one bacillus, and then a peculiar antagonism is fre. quently evident between the nuclei of the giant cells and the enclosed bacillus. The latter takes up a position opposed to the nuclei, and lies as

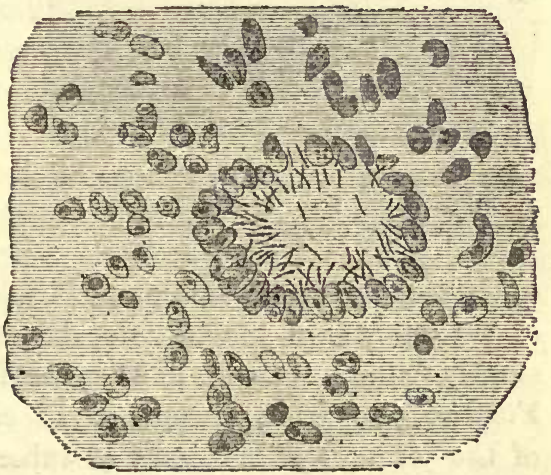

Fig. 76A. - Giant cell from a case of miliary tuberculosis $\times 700$. far as possible in the part of the cell which is free from nuclei (fig. $76 \mathrm{~B}$ ). If the number of tubercle bacilli which develop in the giant cells increases markedly, they finally break through the wall of nuclei, and the giant cell then apparently dies. 
The bacilli are probably first introduced into the diseased tissue by wandering cells which take up and transport the bacilli, which are not themselves capable of independent movement; it is possible that this transporting wandering cell becomes then transformed into an epithelioid cell and afterwards into a giant cell. In many infective experiments wandering cells containing tubercle bacilli can be directly demonstrated in the blood and tissues.

Distribution of the bacilli in the various tubercular affections.

Koch examined in man 13 cases of miliary tuberculosis, in none of which the bacilli were missing from the

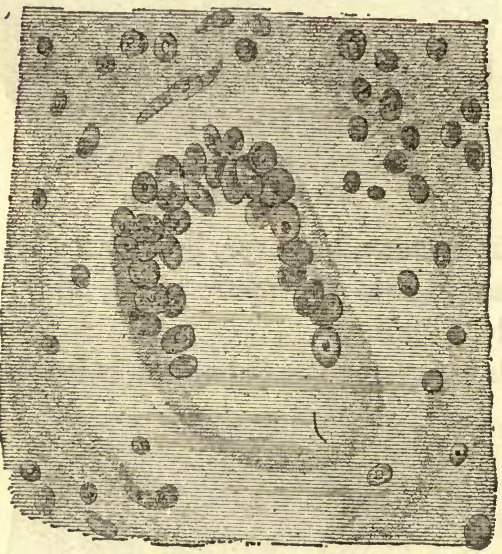

Fig. 76в.-Giant cell containing a tubercle bacillus; section from lupus of the skin $\times 700$. tubercular nodules : 29 cases of phthisis of the lungs $(8 \mathrm{com}$ plicated with intestinal tuberculosis); here also the bacilli were constantly found, and apart from the sputum they were most numerous in fresh cheesy infiltrations and in the interior of cavities where the walls were rapidly breaking down. In tuberculous ulcers of the tongue, in tuberculosis of the pelvis of the kidney, of the uterus, of the testicle, \&c., the bacilli were constantly found; likewise in 21 cases of tuberculous glands. Further, they were present in 13 cases of tuberculosis of the joints and 10 cases of tuberculous affections of bones; in 4 cases of lupus, where the bacilli were only found in giant cells, and only one organism in each; in 7 cases of bovine tuberculosis ; finally, in various animals inoculated with tubercular material (273 guinca-pigs, 105 rabbits, 44 field mice, 28 white mice, 19 rats, 13 cats, as well as dogs, marmots, fowls, pigeons, \&c.). Further, sputa and organs in a very large number of other non- 
tuberculous affections were examined; here, however, the characteristic bacilli were invariably absent.

From all these microscopical investigations it follows with certainty that the tubercle bacilli occur constantly and exclusively in tuberculosis, that they precede the pathological alterations which are peculiar to tuberculosis both in place and time, and that their number, their appearance, and their disappearance, stand in direct relation to the course of the disease. These results evidently imply an etiological relation between the tubercle bacilli and the tubercular process.

The cultivation of the tubercle bacilli was also ac-Cultivation of companied, like their microscopical demonstration, the tubercle by special difficulties, and required new and special methods. No growth occurred on the ordinary nutrient media. The tubercle bacilli evidently lead a parasitic existence, and saprophytic growth can only occur when the conditions under which they flourish in the animal body are copied as accurately as possible; as also the whole development of the tubercular process only goes on very slowly we can only expect a difficult and slow growth of the bacilli, even under conditions which to some extent correspond with those which are present in the animal body. As a matter of fact Koch only succecded in obtaining cultivations when he cmployed blood serum, gelatine, or solidified blood serum kept at the body temperature, and when also these nutritive media were so prepared that they could be kept for 14 days or longer at the body temperature without drying up, or becoming contaminated with other organisms. It was found that blood serum kept in test tubes, and sterilised, was the most suitable material, especially when the tubes were kept in an oblique position while the blood serum was solidifying, and thus a large surface was presented for the growth of the cultivation. (More accurate details as to the preparation of this nutrient medium will be given in the chapter on "Methods.") During solidification of the blood serum the condensed water collects in large drops at the lowest part of the oblique surface of the serum, and this reser- 
voir of water is in so far of importance for the cultivation, as by means of it the surface of the serum is kept sufficiently moist, and preserved from drying during the long time that it is kept in the incubator.

If tubercular masses are placed on such nutrient

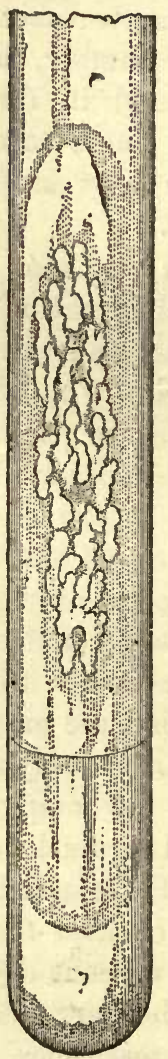
substrata (care being taken completely to exclude other bacteria), and kept permanently at $37^{\circ} \mathrm{C}$, distinct multiplication of the tubercle bacilli can be seen after about 14 days. The greatest care must of course be employed to exclude other bacteria, more especially because the saprophytes as a rule grow much more rapidly at the body temperature, and, starting from a very small number of individuals, may completely occupy the surface of the soil before the tubercle bacilli have even begun to multiply. According to Koch, it is best to commence the cultivations from the lymphatic glands of a guinea-pig which has been inoculated with tubercular sputum or tubercular organs, and has been killed after about three or four weeks. The skin is purified with corrosive sublimate, and one of the swollen lymphatic glands is exposed, a series of heated knives and scissors being employed for the purpose.

Finally, the gland is cut through and a portion of the interior is rubbed over

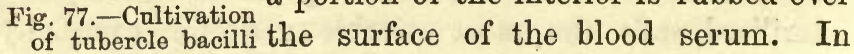
on blood serum.

spite of these precautions, it is always well to inoculate a considerable number of tubes, for some always become contaminated and useless. In the incubator the tubes remain unaltered for 7 to 10 days; after this time, sometimes not till the fourteenth day, dull white points and small flakes are formed on the surface of the serum, these flakes having the appearance of dry scales with a dull surface. At times they unite 
to form a thin, dull covering over the surface of the serum. On further inoculation of these cultivations on new blood serum the growth takes place more readily; later cultivations give more luxuriant growths, which also spread over the surface of the drop of fluid present at the lower part of the tube. When examined under a low power of the microscope (80 diameters) the appearance of the colonies is seen to be very peculiar and characteristic. After five to six days very peculiar and delicate figures are seen on the surface of the blood serum, forming finely curved and S-shaped lines; these gradually spread and form masses which ultimately become united with one another. These

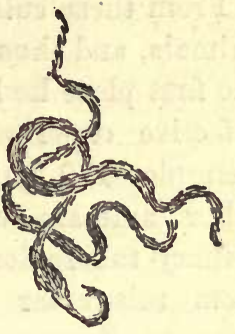

Fig. 78.-Colonies of tubercle bacilli from a cultivation, dried and stained on a cover glass $\times 700$. colonies can be obtained by pressing a cover glass on the surface of the serum, and they can then be stained and the individual bacilli recognised under high powers of the microscope.

Koch has made in all 43 cultivations from tubercular material; several of these being from bovine tuberculosis, scrofulous glands, fungous disease of joints, and lupus. Some of these cultivations have been now kept up through more than forty generations for over three years; but the bacilli have in no way lost their virulence.-Another soil on which they can grow is a mixture of infusion of meat with agar, but the growth on this material is by no means so good. Koch was only able to obtain a cultivation in neutralised meat infusion under special conditions, and in this material the bacteria formed, after four or five weeks, a white, granular deposit at the bottom of the clear fluid. No growth could be obtained on any vegetable substance. The development of the bacilli completely ceases below $28^{\circ}$ or $29^{\circ} \mathrm{C}$.; at $30^{\circ}$ C. it is very slow; it is best between $37^{\circ}$ and $38^{\circ}$, and completely ceases at $42^{\circ}$. The difficulty of cultivation and the narrow limits with-Cultivation in which growth occurs has been confirmed by other experiments 
Fxperiments on animals.

Inoculation with tubercular sputum.

Infection by pure cultivations of tube
cle bacilli. observers, and this fact shows that the supposed pure cultivations of tubercle bacilli carried out by earlier authors, and not under the conditions mentioned above, were not pure cultivations, but were cultivations of some accidental saprophyte.

From these cultivations Koch has infected numerous animals, and thus completed the necessary proof. In the first place he has in many cases repeated the former infective experiments with tubercular tissues. For example, 179 guinea-pigs, 35 rabbits, and numerous other animals were inoculated with nodules from miliary tuberculosis, with phthisical sputum, with pus from tubercular abscesses, with the material from fungous disease of joints, with scrofulous glands, with lupus, and with nodules from bovine tuberculosis, and in all the cases tuberculosis occurred.

The infection occurs most easily by introducing a little sputum into a pocket in the skin over the abdomen of guinea-pigs. The round is closed with a stitch, soon heals, and usually shows no reaction. After two to three weeks, however, swelling of the nearest lymphatic glands occurs; at the same time the seat of inoculation becomes hard, and a nodule is formed. This nodule subsequently ulcerates, and becomes covered with a dry crust, under which is a shallow ulcer with cheesy base. The animals become thin, they have difficulty of respiration, and generally die in from the fourth to the eighth week. - In rabbits the course of the disease after such an inoculation is not so definite; it is best here to inoculate into the anterior chamber of the eye.

Koch has further made numerous inoculations with pure cultivations. For this purpose animals freshly bought were employed; they were kept in a special cage, killed in the early stage of the disease, and in order to exclude, as far as possible, all suspicion of accidental tuberculosis, uninoculated control animals were always kept beside them. The pure cultivations were inoculated in a variety of ways; in the first place subcutaneously. As a result, all the guinea-pigs and 
field mice died, also one marmot. Fowls were in part By subcutanesusceptible; white mice were almost altogether insus- ous inoculaceptible. A second mode of infection was the invcula- By inoculation tion of the pure cultivations into the anterior chamber of into the the eye in rabbits. An incision several millimetres in ber of the eye. length was made at the upper border of the cornea, and, by means of a blunt hook, a minute fragment of a pure cultivation was pushed into the anterior chamber, or a mixture of the cultivation in water was injected by means of a syringe which possessed a fine, sharp canula. If by this mode of infection few bacilli were injected, tuberculosis of the iris occurred somewhat more quickly than after the introduction of tubercular tissue. This was followed by swelling and caseation of the nearest lymphatic glands, and subsequently by tubercular infection of other organs. Where large quantities of bacilli were injected, however, caseation of the bulb and general tuberculosis rapidly occurred, so that the lymphatic glands were, as it were, passed over by the infection.

In a third series of experiments, a mixture of the By injection cultivations was injected into the peritoneal cavity. By into tha this mode of infection, animals which were otherwise cavity. very insusceptible to the disease - such as dogs, rats, and white mice-died with extensive eruption of tubercles in the abdominal organs. Fourthly, mixtures of the By intracultivations, which had been filtered through fine injection. gauze, were injected into the veins (the jugular or aural vein). By this method the most rapid and most complete infection was obtained, an enormous number of tubercular nodules appearing in a much shorter time than is ever the case in spontaneous tuberculosis. In these experiments, therefore, the possibility of spontaneous tuberculosis can be excluded most readily, and with the greatest certainty.

Lastly, Koch attempted to introduce the cultivations By inhalation. of bacilli into the animals by inhalation. The mixture of the cultivations with water was sprayed by means of a hand spray into the interior of a box standing in the open air, and in this box 20 to 30 rabbits, guinea-pigs, 
rats, and white mice were placed. The animals were then kept in a special cage and well tended; after 28 days they were killed, and all showed extensive tuberculosis.

The inoculations were made on a total of 217 animals. The more susceptible animals-guinea-pigs, field mice, rabbits, and cats - died as the result of all the different modes of infection; and where large numbers of bacilli were employed, dogs, rats, and white mice were also unable to withstand their action.

Control experiments.

It must also be mentioned that numerous control experiments were made with a great variety of cultivations and mixtures of other bacteria, and that the inhalation experiments were also controlled by Koch in a similar manner. Nevertheless, in no case was tubercular disease observed in these animals.

The proof that we must look on the tubercle bacillus as the only and all-sufficient cause of all kinds of tubercular diseases has thus been brought by Koch with a completeness and certainty which has scarcely ever been attained as regards the etiology of any other disease. The results of Koch's experiments have been subsequently confirmed completely by several observers; thus the whole series of investigations has been repeated by Watson Cheyne, Rosenbach, the author, \&c. The constant and exclusive occurrence of the tubercle bacilli in tubercular diseases has been confirmed by numerous observers, more particularly their occurrence in phthisical sputum, and also in the surgical tubercular affections in lupus, bovine tuberculosis, \&c. The objections which have been raised by Formad, Spina, and others, against the etiological significance of the tubercle bacillus, or against certain parts of the proof furnished by Koch-for example, against the specific applicability of the methods of staining, against the experiments on animals, \&c.-have been shown to be badly founded in every respect, and have for the most part arisen only from imperfect employment of Koch's methods. 
From the knowledge which we have obtained, as the Deductions as result of experiments, with regard to the biological to the mode of relations of the tubercle bacilli, important conclusions may tubereulosis. be drawn as to the mode of spread of these bacilli, and of the disease caused by them. In our ordinary surroundings the conditions necessary for the multiplication of the tubercle bacilli are, without doubt, nerer present; in other words, they do not possess a saprophytic stage of existence, but they always behare as true parasites under the conditions which are present in nature. Hence the spread of tuberculosis could only occur by infection from individual to individual, were it not that the bacilli can retain their vitality and all their virulent characters for a considerable time outside the body. This preservation of the organisms is aided to a great degree by the presence of spores, which have proved, as the result of direct experiments, to be very resisting. Sputum, containing spore-bearing tubercle bacilli, was Length of life still virulent after six weeks, although it was kept moist, of the tubercle and although putrefaction occurred in it; such sputum when dried retained its virulence up to 186 days, as was proved by the inoculation of guinea-pigs. Hence we may assume that our ordinary surroundings must be frequently much contaminated with virulent bacillus spores, and that infection can occur not only directly from the patient, but also by means of the most various objects from his surroundings, often in a very indirect manner and after a relatively long time. The most Distribution important source of the contamination of our surround- of the bacilli ings with tubercle bacilli is undoubtedly phthisical phthisical sputum; as almost one-seventh of mankind die of phthisis of the lungs, and as a large portion of the sputum is constantly dried in the clothes and on other objects, and thus is able to pass into the dust, the distribution of the virulent material must be comparatively great.

Nevertheless numerous experimenters have failed to discover any tubercle bacilli in the air, eren of places such as wards in which phthisical patients were constantly present (Celli and Guarneri, Bollinger), and only 
Futile attempts to demonstrate tubercle bacilli in the air.

Reasons for the negative results.

Modes in which the tubercle bacillus enters the body. one observer (Williams) was able to demonstrate, by means of the microscope, tubercle bacilli in the air obtained from the ventilation shaft of a consumption hospital. These failures are, however, by no means sufficient to cause us to modify our convictions as to the wide distribution of virulent tubercle bacilli or spores; our methods are, on the contrary, much too imperfect to enable us to demonstrate with certainty bacilli in air, which, nevertheless, when inhaled, might introduce a number of these organisms into the body sufficient to produce infection. The examination of air with this view can be carried out by means of microscopical investigation, by cultivation, or by infection experiments. As regards the first method, we have already learued in the case of other fungi that by means of it we can only recognise a very small percentage of the bacteria which are really present, and that a negative result is obtained even in those cases where we are able to demonstrate the presence of numerous individuals by means of cultivation. With regard to the tubercle bacilli also, the investigation by means of cultivation, which is otherwise very useful and much more sensitive, cannot be employed for these experiments, because, as the result of the slow and difficult growth of the tubercle bacilli, the soil is always completely occupied at an earlier poriod by other unavoidable bacteria, and also because for infective experiments we require larger numbers of bacilli, and more especially a more concentrated material than is obtained by these investigations of the air, and hence it is not correct to conclude that because infection has not occurred the air investigated has been free from tubercle bacilli. Where a longer time is spent in rooms contaminated by phthisical sputum, \&c., and where the air of these rooms is breathed for some time, the entrance of the respiratory tract comes into contact with many more bacilli than can as yet be demonstrated by means of any mode of aeroscopic investigation.

The tubercular virus without doubt enters the body most frequently with the inspired air, and this is the mode in which healthy persons are most commonly 
infected with tuberculosis; in rare cases the tubercle bacilli may also penetrate into the body through wounds of the skin. At times tubercular animals are the source of the infection; but the disease seems only to be carried by the milk of tubercular cows when the mammary glands are themselves affected with the disease.

In apparent contrast to the influence of the local spread of the tubercle bacilli, we have the experience that as the result of living in the neighbourhood of tubercular individuals by no means all the healthy persons are infected; indeed, the percentage of infections is only slightly greater than where there is, as far as we can judge, much less opportunity for infection. The Important predisposition evidently plays a very important rôle in part played by the occurrence of tubercular infection; it practically predisposicontrols the mode of spread of the tuberculosis, and is more especially important because it has the greatest influence on the treatment of the disease. What this individual predisposition consists of is a question which has been as yet very little investigated as regards its relation to the infective agents which have as yet been recognised. We know that there are certain protective arrangements in the body which, along with the very limited conditions of life of the tubercle bacilli, render it difficult for the latter to obtain a foothold; in this respect we may point out the moist and sticky lining membrane at the entrance to the respiratory tract, the mode in which elements which have passed further are expelled by the ciliated epithelium and by coughing, and the resisting power of the normal cells, more especially of the epithelial cells (Veraguth), towards the individual parasites. It is only when, for example, as the result of chronic catarrh, there are lesions of the epithelial covering, or when there is stagnation of the secretion in certain parts of the lung, or when the nutrition and the energy of the epithelial cells is defective, that the bacilli which have entered can develop and multiply undisturbed; and these conditions again chiefly occur only in individuals in whom the thorax is abnormal or where the nutrition is bad, or in those who do not breathe sufficiently deeply, 
or again in those where, as the result of their employment, there is constantly irritation of the respiratory mucous membrane. In how far, however, these supposed predisposing causes can be experimentally proved, or can be brought into unison with clinical experience, must be for the present left in doubt.

\section{Bacillus lepre.}

In all forms of leprosy (Lepra tuberculosa, maculosa, and anæsthetica), and quite apart from the country in which the disease has been acquired, whether in the East, in Norway, or in other places where it is endemic, we find in the affected organs numerous characteristic bacilli, which were first described by Armauer, Hansen,

Occurrence of and Neisser. These bacilli have been demonstrated in the leprosy bacilli. the leprous tumours of the skin, in the mucous membrane of the mouth, palate, and larynx; further, in the peculiar interstitial affections of the peripheral nerves, of the cornea, cartilage, and testicle; in the lymphatic glands, spleen, and liver; in the anæsthetic form of leprosy, for example, in the thickened ulnar nerve; and lastly, on several occasions, in the blood of lepers. On making sections through the cutaneous nodules we see that the tissue is infiltrated with numerous small round or oval cells, which are more or less completely filled with bacilli; the latter often lie in a thick mass in various directions, they often appear arranged in a more or less ray-like form radiating from the centre of the cell; at times they form parallel bundles. In the older tumours the so-called true lepra cells are present in large numbers, these cells being large, multi-nucleated, and similar to giant cells, and also containing very numerous bacilli in their interior. In part, however, the bacilli also lie outside the cells in the lymphatic spaces. Recently Unna states that he has convinced himself, from the examination of dry sections, that the supposed cells containing bacilli are only masses of bacilli which are held together by gelatinous material, and that the greater number of the bacilli are free, and 
lie usually in globular masses in the lymphatic channels; but these statements require further proof in view of the unusual mode of investigation employed by Unna.-The epidermic layer of the skin is always free from bacilli; Babes alone has pointed out the presence of bacilli in the hair follicles, and in the sebaceous glands of the hair, and has thus shown that it is possible that the organisms may

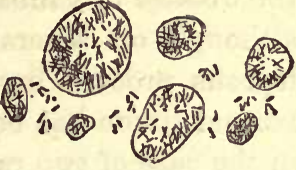

Fig. 79.-Lepra cells containing bacilli $\times 700$. in this way reach the surface of the skin.

The bacilli are 4 to $6 \mu$. in length, and less than Morphologica $1 \mu$. in breadth, resembling on the whole the tubercle characters. bacilli, but not so irregular as regards length as these, nor so often curved. Spores seem to be generally present, but they are not so distinct as in the case of the tubercle bacilli. The leprosy bacilli can be distinguished from the latter by the fact that they take up the ordinary aniline stains and the nuclear stains much more readily than the tubercle bacilli. They can, however, be stained in the same manner as the tubercle bacilli; like these, the leprosy bacilli alone among all the bacteria hold an alkaline aniline stain, or one containing aniline oil, so energetically that it is not removed on treatment with strong acids. Hence in the case of the leprosy bacilli we can employ the same method of double staining as. in the case of the tubercle bacilli. The bacilli can be stained red and the tissue blue, or violet and the tissue brown. This is the best method of staining sections of leprosy, and it shows most distinctly the individual organisms. If we wish to distinguish between leprosy bacilli and tubercle bacilli we place a dried cover glass. preparation for six to seven minutes in a dilute alcoholic solution of fuchsine, decolourise for a quarter of a minute in acid alcohol, wash in distilled water, and stain with methylene blue. When treated in this way the leprosy bacilli appear red on a blue ground, while the tubercle bacilli have not taken up the red stain in this short time (Baumgarten).

All attempts at cultivation of the leprosy bacilli have 
Cultivation experiments and experi. ments on animals.

been as yet in vain. Even after being kept for fourteen days on solidified blood serum at $37^{\circ} \mathrm{C}$. no, growth can be observed.-In like manner, attempts to communicate the disease to animals have met with great difficulties, although on several occasions a slight spread of the leprous process from the particles introduced to the normal tissue has been seen. Thus Damsch observed, in the case of two rabbits after inoculation of a piece of a tumour into the anterior chamber of the eye, that after five weeks in both animals the iris and the ciliary body were infiltrated with dense lines of large cells containing bacilli, and that deposits appeared on Descemet's membrane, and on the anterior capsule of the lens, which consisted of round cells containing bacilli. In like manner a successful attempt has been made to inoculate the leprous tumours into the peritoneal cavity, and under the skin of two cats. In the latter case the cats were killed after 120 days; on making an examination it was seen that the tumour had become flattened and shrunk in the subcutaneous tissue, and that it was surrounded and fixed to the skin by a brownish tissue of new formation, which contained numerous cells filled with leprosy bacilli. Vossius repeated the experiment of introducing pieces of tumour into the anterior chamber of the eye in rabbits, and likewise observed multiplication of the leprosy bacilli, and their penetration into the iris and cornea. But in none of the cases did the process spread further, nor was the clinical picture of leprosy produced; and in many other experiments even the infection of the neighbouring tissue has failed. Thus attempts which were made by Damsch to inoculate the disease subcutaneously in mice and rabbits, by Vidal in a pig, by Juöbner in frogs, eels, \&c., were entirely without result.In the case of man also, the spread of the disease by infection is extremely rare, and is evidently only possible under very special predisposing circumstances.

In spite of the great blanks in our knowledge with regard to the leprosy bacilli, we must look on these organisms as undoubtedly the cause of the disease, because they occur constantly and exclusively in this 
affection, and because also they are present in enormous numbers, and practically form the greater part of the affected tissue in the leprous organs.

\section{Bacillus mallei. (Glanders, Rotz, Morve.)}

Although several observers have described the occur- Historical rence of micro-organisms in cases of glanders, nothing facts as to the certain was ascertained as to their etiological significance the glanders
bacilli. till Loeffler and Schütz succeeded, three years ago, in completely clearing up the etiology of this disease by the demonstration of characteristic bacilli in the glanders nodules, by the cultivation of these bacilli on artificial substrata, and by the inoculation of the cultivations on various animals with the production of the typical disease. Almost at the same time Bouchard, Capitan and Charrin made cultivations in broth from an abscess in a man suffering from glanders, and from the ulcers of a horse, and, after several generations, inoculated these cultivations with success on asses, cats, and guinea-pigs; but these observers found in their cultivations only round organisms, at times occurring in chains, and they looked on these as the active exciting agents of the disease. About the same time also Israel made cultivations on blood serum from the glanders nodules of three horses, and was able to set up glanders in rabbits by means of these cultivations; Israel obtained bacilli in his cultivations corresponding with those isolated by Loeffler and Schütz. At a later period Kitt and Weichselbaum have made cultivations and inoculations of the glanders organisms, and both of these observers were able to confirm, in the main, the statements made by Loeffler and Schütz; Weichselbaum obtained the material for his cultivations from a man suffering from acute glanders.

The bacilli which have been described by all the Morphological observers-with the exception of the French investi- characters of gators before mentioned-are thin rods, similar to the bacilli. tubercle bacilli, but more uniform in size, and somewhat 
broader ; like these they are often slightly curved. One can almost always observe in stained preparations that the individual bacilli are composed of dark and clear zones, so that under a low power they may resemble a chain of cocci; but when higher powers are employed this impression is seen to be incorrect. The clear unstained spaces are probably spores. The bacilli lie in part singly, in part they are united in bundles of 4 to 8 parallel rods, in part they lie in confused masses. It is by no means easy to stain these organisms well in sections; the glanders bacilli take up the aniline stains
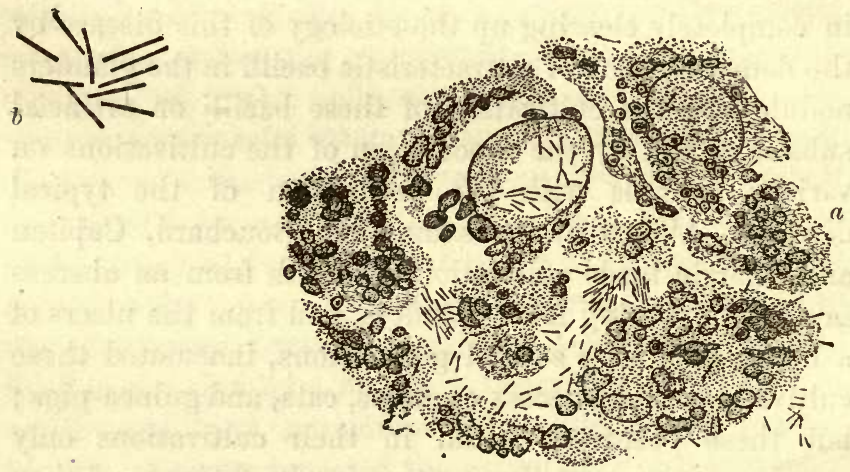

Fig. 80.-Glanders bacilli.

$a$, section from a glanders nodule $\times 700$.

$b$, bacilli of glanders stained with methylene blue $\times 1,500$.

with some difficulty, and further the dense accumulation of strongly staining nuclei in the glanders nodules renders the discovery of the bacilli difficult. The best plan is to stain with alkaline methylene blue for 12 to 24 hours, then to treat the specimen cautiously with very dilute acetic acid till the decolourisation has so far advanced that the bacilli can be distinctly seen. After such treatment we find, here and there, clearer parts in the tissue where the masses of glanders bacilli can be seen particularly sharply defined.

The best situation for finding the bacilli are fresh nodules which have not yet ulcerated; in old ulcers, in pus, in the secretions of the nose, \&c., it is often impossible to demonstrate bacilli, possibly because they have passed into the spore stage. Weichselbaum has suc- 
ceeded in demonstrating the bacilli microscopically in the blood of a patient suffering from glanders, and Philipowicz was able to set up the disease in healthy animals by injection of the urine of a guinea-pig suffering from glanders.

For the cultivation of the bacilli fresh nodules are most Cultivation. suitable; nevertheless, pure cultivation s have been obtained from abscesses. - On slices of boiled potato kept at $35^{\circ}$ C., they form within 2 or 3 days a brownish, slimy, but not very thick layer. The cultivations can be best preserved by inoculating mashed boiled potatoes, kept in Erlenmeyer's flasks, in the form of a layer on the bottom 1 to $2 \mathrm{~cm}$. in thickness; in these circumstances a chocolate-brown layer is formed on the surface, which, if protected from drying, contains for months living bacilli or spores. Potatoes are the best nutrient medium, and next to them comes solidified blood serum. On serum kept at $37^{\circ} \mathrm{C}$. we see, after three days, small transparent discrete drops, which scarcely differ in colour from the surface of the serum, but which distinctly project above it. According to Weichselbaum and Kitt the glanders bacilli also grow at about $25^{\circ} \mathrm{C}$., although much more slowly. On nutrient agar they form drop-like, soft, greyish-white colonies; in liquid nutrient jelly a tenacious whitish mass is developed.

Under the microscope the cultivations show the same bacilli which we find in the glanders nodules; as the result of differences in age and development there are greater differences in the length of the bacilli; as a rule spore formation can be distinctly seen.

If the cultivations were inoculated into house-mice, no Experiments result followed; rabbits were partially susceptible, but in some only local ulcers formed, anu these subsequently healed up. On the other hand the inoculation was always successful in the case of field-mice, guinea-pigs, horses, asses, and also in one sheep.-Field-mice die after subcutaneous inoculation with small quantities of the cultivation within 8 days, and show on post-mortem examination numerous small greyish-yellow nodules full of bacilli in the spleen and liver. In the case of 
guinea-pigs an ulcer develops 3 or 4 days after inoculation, and this is followed by swelling of the nearest lymphatic glands. If small quantities are inoculated the process may remain for weeks in this stage, in other cases acute nodular swellings form in the testicles, the ovaries, the vulva, or the feet, and ulcerative processes occur in the nasal cavities. In the case of horses and asses the typical picture of glanders was obtained.-The most susceptible animals, and hence the animals best suited for the diagnosis of glanders, are, according to Molkentin and Grünwald, young dogs.

From these results we can no longer doubt that the bacilli described above are the true cause of glanders. The observations made by Bouchard and Capitan, which differ as to the morphological characters of the causal micro-organisms, have evidently been due to their defective method of cultivation; for they made their inoculations into fluid nutrient media from open ulcers, containing of course other bacteria, and thus they must always have had a great excess of the more quickly growing saprophytes in their cultivations; the majority of these may, as Bouchard describes, have consisted of cocci, and the few glanders bacilli which were present, and to which the virulence of the cultures was due, may have been masked by them.

\section{Bacillus diphtheria.}

(Loeffler.)

Difficulties in the etiological investigation of diphtheria. the epidemic diphtheria of the throat, little that is trustworthy is as yet known, although recently Heubner has made out some important facts with regard to the more intimate process of the origin of the diphtheritic membrane, and with regard to the ultimate part played by the bacteria in the formation of the membrane. The difficulties which stand in the way of the knowledge of the ultimate causes of this disease are evidently particularly great and manifold. As the result of our recent investigations the possibility presents itself that in the case of diphtheria we have to do with organised infective agents which cannot be rendered visible by our 
present means, and perhaps require entirely new methods for their recognition. Expert microscopists, such as Eberth, Weigert, Heubner, Fürbringer, Loeffler, have been unable to find any micro-organisms, either in the deeper parts of the affected portion of the throat, in sections of the uvula and tonsils, in the internal organs in cases where there has been marked general infection of the body (especially in the kidneys), or in the blood. When we take into account the great number of negative Negative reresults, we must conclude that in the few cases in which bacteria have been demonstrated in the kidneys, or in other organs, we have to do with bacteria which have entered accidentally.-Unless we conclude from these negative results that we have not as yet been able to render the infective agents of diphtheria visible, there remains as a second explanation of the facts, the assumption that in the case of diphtheria, even in the cases where the morbid process is spread over parts of the body far removed from each other, we have only a local development of the infective micro-organisms in the diphtheritic membrane, that some soluble noxious materials are produced in that situation by certain micro-organisms, and that these products cause the other symptoms of disease. Even on this assumption, however, we meet with great difficulties in our attempts to discover the specific bacteria which furnish these noxious products. At the primary seat of disease, and in diphtheritic membranes, there is, it is true, no want of micro-organisms; but since we have begun not to see the cause of the disease in the presence of any sort of bacteria, but to require that for each wellcharacterised disease there must also be specific, wellcharacterised infective agents, we have the further task of discovering which of these various species of bacteria is of importance etiologically. We know now that a Mixture of number not only of saprophytic bacteria, but also of various kinds organisms which are very pathogenic in certain animals, the diphtherinhabit the cavity of the mouth of healthy individuals, and these find a good nutrient soil in the diphtheritic membrane ; without doubt, also, one of these kinds may 
grow better there than the others, and hence, in all probability, we shall see one or other species in largest numbers in the great majority of cases, thus leading us to the erroneous conclusion that they have a specific etiological meaning. It is evident that here we can only attempt to isolate the true infective agent with extreme caution, and with care that full weight is attached to all the sources of error. Insuscepti- Further difficulties arise from the behaviour of the
bility of the lower animals, animals ordinarily employed for experiments. These are much less sensitive than man to the infective agents of diphtheria; infective experiments with diphtheritic membrane have been carried out very extensively in various kinds of animals, but very often without any corresponding effect, although the membranes were placed directly on the mucous membrane of the open trachea (Trendelenburg, Francotte, and others). In some cases it is true that illness of the animals, formation of false membranes in the trachea, \&c., have been observed, but there has never been a development of typical diphtheria, with all its various symptoms, and those morbid phenomena which were observed could also be caused by inoculation with non-diphtheritic putrefying material (Hueter, Marcuse, and others), and also with rarious species of bacteria evidently not in etiological connection with human diphtheria, but nevertheless occurring at times in the normal secretions of the mouth. Such morbid conditions in animals resembling diphtheria cannot be of themselves utilised for the recognition of the infective agent of human diphtheria, and thus there is increased difficulty in experiments made for the purpose of clearing up the etiology of this devastating disease.

Various kinds Finally, many clinical and epidemiological facts indiof diphtheria. cate that there are various forms of diphtheria caused by different infective agents. If this idea is confirmed it is evident that a further complication of the investigations is unavoidable.

Former investigators have, without doubt, paid too little attention to these dangers and difficulties, and the 
repeated supposed discoveries of the diphtheritic bacteria rested on errors. - Of late Loeffler has attempted to clear Loeffler's up the etiology of diphtheria by the employment of better methods, and by bearing carefully in mind the sources of error. He found in sections of diphtheritic membranes that, in addition to what were evidently accessory organisms, two kinds were present which were of special interest; on the one hand, cocci which were Streptococci. arranged in the form of chains, and chiefly occurred in the diphtheritic throats in cases of scarlet fever. These had their starting point usually in a loss of substance of the diseased mucous membrane, and extended from that point into the tissue in the form of wedge-like or tonguelike masses, leaving necrosis of the tissue behind them ; they penetrate into the lymphatic vessels, and at times spread through the whole body. That these chains of cocci play a secondary rôle in diphtheria is probable from the fact that in other diseases accompanied by lesions of mucous membranes we can observe a similar growth of streptococci; and further, they were not so much characteristic of typical cases of diphtheria, with a definite membrane in the throat and with spread of the process to the air passages, as of cases of scarlet fever, in which the process remains limited to the throat. As to the characters of these cocci on cultivation, and in experiments on animals, see page 194.

The other bacteria found by Loeffler in the majority Loeffler's of the cases of typical diphtheria are rods with peculiar morphological and biological characteristics; they are probably identical with the form of bacillus which was also found by Klebs in diphtheria, and was looked on by him as the infective agent of the disease, although he did not succeed in obtaining pure cultivations of the organisms. Loeffler found these bacilli, which stain markedly with methylene blue, in the false membranes at a deeper level than the masses of other bacteria which covered the surface, namely, at the inner margin of the layer of exudation; they also occupied the oldest $\begin{aligned} & \text { Position of the } \\ & \text { bacilli in the }\end{aligned}$ portion of the membrane, and penetrated deeper than membrane. all the other bacteria. Cultivations could not be made 
on the ordinary gelatine plates, but Loeffler succeeded in growing them by diluting a small portion of the material taken from the diphtheritic membrane, and by inoculating drops of the diluted material on solidified blood serum; in this way pure cultivations of the bacilli Mode of com-were obtained. Wyssokowitsch recently succeeded in mencing the isolating the same rods from a piece of diphtheritic
cultivations. membrane which had been coughed up, employing agar plates for the purpose, and keeping the material at $35^{\circ} \mathrm{C}$. In order to render the isolation of the organisms certain one must always employ a large number of plates, as a large proportion of them are generally completely overgrown by the rapidly growing saprophytes.Loeffler found that the best medium was a solid material composed of three parts of calves' or sheep's blood serum, and one part of neutralised veal broth, to which one per cent. of peptone, one per cent. of grape sugar, and a half per cent. of common salt were added. On this soil the bacilli grew at $37^{\circ} \mathrm{C}$. in the form of whitish opaque drops, or of a thick white layer, which attained the acme of its development within two days. Agar jelly forms an almost equally favourable soil ; on nutrient jelly growth also occurs at about $22^{\circ} \mathrm{C}$., but it is slow and imperfect; no growth appears to take place on potatoes.

Growth on agar plates.

Morphological characters of the bacilli.

On agar plates the youngest colonies lying in the substance of the material appear, when magnified 80
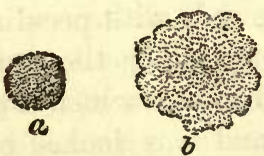

Fig. 81.-Colonies of diphtheritic bacilli on agar plates $x$ 80.

a, colonies lying in tho substance of the agar.

$b$, those situated on the surface. diameters, as round or oval, dark brown, coarsely granular, and not sharply outlined dises. Several colonies often run together, so that irregular figures are formed. The superficial colonies are greyishyellow, with granular, rough, almost net-like, surfaces, and with a delicate wavy border.

The rods are immobile, the majority of them are slightly bent. They vary much in length, being on an average of much the same length as the tubercle bacilli, but they are considerably thicker than 
the latter. It is not uncommon to find one end, and often even both, swollen; here and there there are distinct club-like forms. In an unstained condition the pole, and often also other portions of the bacilli, present a highly refracting appearance. When stained with methylene blue these portions of the rods take on the stain markedly, and thus there is not uncommonly an appearance as

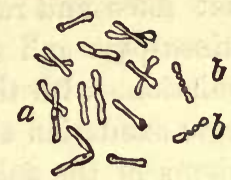

Fig. 82.-Diphtheritic bacilli $\times 1200$.

$a$, bacilli from a fresh cultivation. if the bacillus were composed of short pieces with irregular outlines. In the case of some bacilli, more especially when they are taken from cultivations on soil which was not very favourable for their growth, the ends appear very markedly enlarged, or the middle is distinctly thickened, or the rod is divided into large roundish or oval bodies. These deviations from the normal form of the bacilli, the club-like swellings, and the fragments which arise by fission, evidently imply the occurrence of involution. In favour of this view we have the fact that when they are grown on the best soil-in the living body-these abnormal swellings seldom appear, and are much less marked, so that there is only a slight thickening of individual portions, and more especially of the ends. On the other hand these appearances are the more numerous the worse the soil, and the more imperfect and slow the growth.-We might be inclined to look on the portions of the bacilli which are highly refracting as spores, or at least as the commencement of the formation of spores, but Loeffler was able to show that the rods, even when they showed large numbers of these bodies, died without exception after being exposed for half an hour to the temperature of $60^{\circ} \mathrm{C}$. Nor is there any better reason for looking on these bodies as the early stage of arthrospores at any rate not till we have some evidence that they possess a greater resisting power to noxious influences than bacilli in which this change has not occurred.-At the temperature of the room the cultivations retain their vitality for about three months. 
Lixperiments on animals.

Objections to the etiological significance of these bacilli.

As the result of experiments on animals which were made with cultivations of Loeffler's bacilli, it was found that mice and rats were immune against their action; guinea-pigs and small birds died after subcutaneous inoculation, with the occurrence of a whitish or hæmorrhagic exudation at the seat of inoculation, and extensive œdema of the subcutaneous cellular tissue. No microorganisms were found in the internal organs of these animals. If the cultivations were applied to the trachea of rabbits, fowls, and pigeons, characteristic and often very extensive false membranes appeared. These formed in like manner on the scarified conjunctiva of rabbits, and at the entrance of the ragina of guinea-pigs. Besides the false membranes, there also occurred a bloody œdema, hæmorrhages into the tissue of the lymphatic glands, and effusions into the pleural cavity. Young animals, as a rule, succumbed to the infection more readily and more quickly than older ones.

The symptoms caused by the bacilli are thus very similar to the morbid phenomena which are set up in man by the diphtheritic virus. Nevertheless, Loeffler has hesitated to assume as a matter of certainty that these bacilli are the sole specific exciting agents of diphtheria, because they were not found in the false membranes in a number of typical cases of diphtheria; because they were not present in the false membranes developed in animals in the same typical arrangement as was observed in man, but were, on the contrary, either entirely absent or only present in small numbers; and, thirdly, because they could not be inoculated on the healthy mucous membrane of susceptible animals, but required the presence of small injuries before they could cause infection. Nevertheless, it is quite possible that the bacilli, whose great tendency to involution was mentioned above, had already died in many of the membranes, or had been eliminated, and were hence no longer found; further, that even in the case of man trivial injuries of the mucous membrane may be necessary to enable them to enter, and that thus these objections do not exclude the possibility that these bacilli play a 
causal part in the disease. - Of greater weight is another objection which also arises from an observation made by Loeffler. On examining the secretion of the mouth in 20 children and 10 adults by the aid of cultivation, Loeffler obtained in one case colonies, which consisted, as shown by the microscope, by cultivation experiments, and by experiments on animals, of these diphtheria bacilli. Nevertheless, it is not impossible that the pathogenic bacilli may at times be present in the secretions of the mouth without setting up symptoms of disease, either because there are no points at which it can enter the body, or because, for some other reason, the patient is immune, and this assumption hardly seems to be too unlikely when we remember the characteristic distribution of these bacilli, and the striking result of the experiments on animals, which seem distinctly to imply that at least for a certain group of diphtheritic diseases these bacilli are the causal agents.

As regards the bacteria of diphtheria in pigeons and calves see below.

Emmerich has asserted in a preliminary communication Emmerich's published in the proceedings of the Hygienic Congress, at diphtheria Hagne, that the exciting agents of diphtheria are short, thick rods, which are twice as long as broad, and which grow luxuriantly on nutrient jelly in the form of round, whitish colonies, about the size of the head of a pin, and on potatoes in the form of a thick, whitish-yellow layer. The cultivations were successfully inoculated on pigeons, rabbits, and white mice; if a cultivation was applied to the mucous membrane of the trachea of a rabbit, it was found after death, which occurred about 60 hours later, that the mucous membrane was covered with a croupous; dirty greyish-yellow membrane; further, there was fibrinous inflammation of the pericardium and fibrinous deposits on the lungs. The bacilli were not only found in the false membrane and the mucous membrane, but were more or less numerous in the blood and internal organs, in the liver and spleen, and more especially in the kidney. Emmerich obtained the same result from 8 cases of human diphtheria, and 6 cases of pigeon diphtheria, and he looks on human and pigeon diphtheria as diseases caused by the same infective agent.

Emmerich's conclusions are, however, by no means suffciently satisfactory. According to the best observations, we 
cannot accept the identity of pigeon diphtheria with human diphtheria ; the almost constant presence of numerous bacilli in the internal organs, and more especially in the kidreys of the animals experimented on, when contrasted with the negative results obtained in man, seem to show that the disease caused by Emmerich's bacilli differs in an important manner from human diphtheria; as to the distribution of his bacilli in sections of human diphtheritic membrane, Emmerich makes no statements, although it must surprise the reader that Emmerich has obtained such markedly contradictory results to those obtained by Loeffler in his careful investigation, and that he has assigned to other bacteria which were not at all thought of importance by Loeffler, a greater rôle than Loeffler's streptococci and bacilli.-It is possible that the method employed by Emmerich, which is one by no means to be recommended, led to erroneous conclusions. Emmerich introduced pieces of mucous membrane and particles of the false membrane into nutrient substrata, allowed impure cultivations to grow, and then at once inoculated these on animals, with the view of separating the pathogenic from the non-pathogenic bacteria. By this mode of procedure it was almost unavoidable that septic bacteria which are almost always present in the secretions of the mouth, and in diphtheritic membranes, should infect the animals, and thus obscure the true diphtheritic bacteria.

The following bacilli, which are pathogenic on man, are only imperfectly known, and require further investigation:-

\section{Syphilis.}

Lustgarten's syphilis bacilli.
During the course of the last few years numerous authors (Hallier, Lostorfer, Klebs, Aufrecht, BirchHirschfeld, and others) have made statements which are evidently erroneous as to the discovery of the infective agents of syphilis, but lately Lustgarten has succeeded in demonstrating micro-organisms in the syphilitic new formations, by the aid of a special method of staining. These organisms may with considerable probability be looked on as the specific infective agents of syphilis, on account of their characteristic behaviour with regard to staining solutions, on account of their constant presence, and on 
account of the mode in which they are arranged in the diseased tissues.

The method of staining successfully employed by Lustgarten consists in staining the sections in aniline gentian violet solution, and subsequent decolourisation by means of a solution of permanganate of potash, the dioxyde of manganese-the product of the reduction process-being subsequently removed from the sections by sulphurous acid; after this treatment the sections appear quite colourless, with the sole exception of the syphilis bacilli.

Lustgarten's method may be shortly described as Method of follows :-

staining.

The sections remain in a mixture of 100 parts of aniline water, and 11 parts of concentrated alcoholic gentian violet solution for 12 to 24 hours at the ordinary temperature, or for 2 hours at the body temperature; they are then washed in alcohol, then for about 10 seconds in a $7 \frac{1}{2}$ per cent. watery solution of permanganate of potash ; in that fluid the preparations become covered with brownish flakes of dioxyde of manganese. By placing them for a short time in a watery solution of sulphurous acid, the dioxyde of manganese is reduced, dissolved, and washed away; the sections are then washed in distilled water, and if they have not been sufficiently decolourised, the process is repeated; as a rule it is only after repeating it three or four times that a good result is obtained. Finally the section is dehydrated in alcohol, and then placed in the usual manner in oil of cloves and Canada balsam. Cover glass preparations are treated in like manner, with the exception that, after the action of the violet, water, and not alcohol, is employed as the first decolourising agent. Not only is the tissue decolourised by this plan, but also all bacteria, with the exception of the syphilis bacilli, and the bacilli of leprosy and tubercle; the syphilis bacilli may, however, be distinguished from the latter by the fact that they are quickly decolourised by treatment with hydrochloric acid or nitric acid.

The bacilli found in syphilitic new formations are Morphological usually bent, slightly S-shaped, and on an average $4 \frac{1}{2}$ $\mu$. long; they often show a slight knob-like swelling at the ends; their contour is not quite uniform, but it is more or less wavy, or indented at parts. When highly magnified we can see, in the dark blue stained bacillus, clear oval refracting spots two to four in number and 
placed at equal distances; these spots are, in all probability, spores.

The bacilli do not occur free in the tissue, but are for

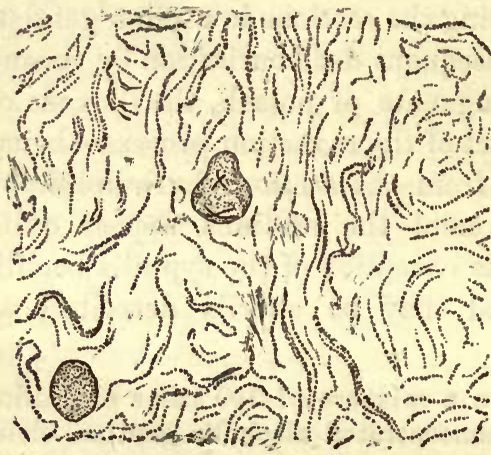

Fig. 83A.-Syphilis bacilli. Group from a chancre $\times 1050$. (After Lustgarten.) the most part present only in large oval or polygonal cells, in the interior of which they often lie in groups of two to eight, often crossed or twisted round one another. As a rule there are only relatively few bacilli in the affected parts, so that at times several sections must be examined before a cell containing bacilli is found.

Lustgarten has been able to demonstrate these bacilli in each of 16 cases of syphilis examined by him. They were also found in a periosteal gumma in a case of congenital syphilis; on the other hand, they were absent in two cases of soft chancre, and in numerous specimens of normal and pathological organs which were examined for purposes of control.

Othermethods De Giacomi, in demonstrating these bacilli, has of staining.

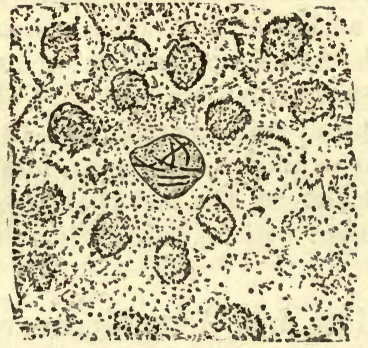

Fig. 83B.-Wandering cells containing syphilis bacilli $\times 1050$. (After Lustgarten.)

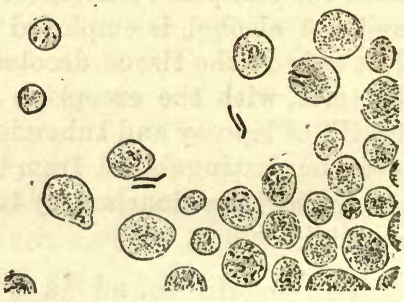

Fig. 83c.-Cover glass preparation from the pus from a chancre showing syphilis bacilli $\times 1050$. (After Lustgarten.)

employed a solution of chloride of iron to decolourise the sections and cover glass preparations; this method has been tested and recommended by Gottstein. In 
this method the sections are stained for 24 hours in fuchsine, washed in water, then placed for a few seconds in pure or diluted solution of chloride of iron, washed in alcohol, and then transferred to oil of cloves. The syphilis bacilli remain red or reddish-violet, the tissue and the other bacteria-with the exception of tubercle bacilli-remain unstained. Double staining can also be employed, both after this method and after Lustgarten's plan, but it does not add much to the distinctness of the picture.

Doutrelepont and Schütz were able to demonstrate Lustgarten's bacilli by placing thin sections for 24 to 48 hours in a 1 per cent. watery solution of gentian violet, then for a few seconds in dilute nitric acid (1 to 15), and then for about ten minutes in 60 per cent. alcohol; the tissues were afterwards stained in a dilute watery solution of safranin. After this treatment the tissues and nuclei had a bright-red appearance, while the syphilis bacilli were blue.

An investigation which has been recently made for similar bacilli purposes of control by Alvarez and Tavel in Cornil's in the smegma. laboratory, throws doubt on the exclusive applicability of Lustgarten's method of staining to the syphilis bacilli. These authors found bacilli in the smegma of the prepuce and of the vulva, which presented the same characters, as regards staining, reaction, and morphological appearance, as Lustgarten's bacilli. Hence further investigations are required to demonstrate the causal connection of these bacilli with syphilis, although their distribution in the tissues is decidedly against the idea that they are only accidental.

\section{Rhinoscleroma.}

In this disease, which has been observed in Austria, Bacilli of Italy, and Central America, and which is characterised rhinoby thickening of the skin and mucous membrane of the region of the nose and the formation of nodules, characteristic micro-organisms were first described by Frisch, 
and later by Pellizari, Chiari, Alvarez, and Cornil.* On examining sections of the affected skin we find a small celled infiltration of the cutis, sclerosis of the small vessels, and a considerable number of large spherical cells, most of them containing several small nuclei; the protoplasm of these cells contains very large numbers of bacilli, which are also present in the surrounding tissue and in the lymphatic vessels. The bacilli are short rods, 1.5 to $3 \mu$, in length, and $\cdot 5$ to $\cdot 8$ $\mu$. in breadth; their ends are rounded, and in their interior are three or more markedly stained granules. In order to render the bacilli visible, the sections are best stained in methyl violet for 24 or 48 hours, and then placed in iodine water. If we employ a strong violet solution, and leave the specimens in it for 48 hours, and then decolourise for 48 hours in absolute alcohol, we often see that each bacillus is surrounded by an oval resistant capsule of a light bluish violet colour. Cultivations, and attempts at inoculation with these bacilli, have been, as yet, without result. For further details, see Cornil and Babès "Les bacteries."

\section{Malaria.}

(Fièvre intermittente, Paludisme.)

For a long time it has been supposed that malaria is caused by an organised virus, and that it might be possible to obtain this virus by cultivation on artificial substrata. From the mode of spread of malaria it is evident that this disease is not contagious in the ordinary sense, and does not require the presence of a person suffering from the disease for direct or indirect transmission; on the contrary, it seems to be chiefly connected with a certain constitution of the local surroundings of man, and is not dangerous to man in other places. Hence we may assume that, in the case of malaria, we have not to do with a true parasite, which can only develop with difficulty, or not at all, outside the human body, but

- Frisch, Wien. medic. Wochenschr., 1882.-Pellizari, $1 l$ Rhinoscleroma, Florenz, 1883.-Chiari, Wien. medic. Juhrb., 1882, see f. 26. 
with an organism which can live, and probably also Influence of multiply under certain conditions, on the dead nutritive locality on th substrata in our ordinary surroundings, and which only of the virus of at times takes on a temporary parasitic existence.

As to the substratum which is necessary for the Insufficient levelopment of the pirus development of the virus of malaria, we have as yet the local prevery few facts which are trustworthy or of use in disposition. connection with artificial cultivation experiments. As a rule in former times it was thought that a warm, very moist, or marshy soil, containing a large amount of organic, and more especially vegetable materials, was a source of permanent danger in any particular region. As the result of the careful inrestigations of TommasiCrudeli, made within the last few years, which have shown that endemics of malaria may occur also in highlying and by no means marshy districts, and also in regions which have been rendered dryer by planting eucalyptus trees, it is evilent that the amount of moisture of the soil which is necessary for the development of malaria is very much less than was formerly supposed; the other factors of importance have been so difficult to define more precisely that we evidently require further elaborate investigations in this direction.

On the other hand, attempts at isolating and cultivating Inoculability the virus of malaria are the more encouraging because, as the result of recent experiments, the possibility of the existence of a true miasmatic virus has been distinctly disproved; because, therefore, we do not have to do with an unorganised something not capable of multiplication but produced by a particular soil. Cuboni, Marchiafara, Dochmann, and quite recently Gerhardt, have demonstrated that malaria is inoculable from man to man. Gerhardt was able to set up a distinct quotidian ague with temperatures up to $41 \cdot 1^{\circ} \mathrm{C}$. in two healthy men who had been under observation for a long time, and in a locality quite free from malaria, by inoculating them with blood taken during the attack from patients suffering from malaria.

As the result of the assumption, justified by these 
Attempts to recognise and isolate the virus of malaria.

Klebs' bacilli. much influenced by preconceived ideas. Thus Klebs and Tommasi-Crudeli found bacilli in the marshy ground in a malarial region, and described these organisms as "malaria bacilli"; "rods 2 to $7 \mu$. in length, which grow and form convoluted threads; these either become segmented by the appearance of clear intervals in their protoplasm, more seldom by distinct divisions, and then ultimately form, when exposed to the air, bundles of threads composed of short segments, or they develop resting spores in their interior either before or only after fission has commenced. In the rods these spores appear either at the centre, or at one end, or they may be both central and terminal." These bacilli were cultivated in isinglass jelly, in solutions of egg-albumen, in urine, \&c. ; they only grew in the presence of the air, and when they were inoculated on rabbits they set up a febrile affection which Klebs looked on as malaria. The statement with regard to their morphological characters, the results of the cultivations and the characters of the disease produced in animals do not, however, furnish any sort of guarantee that Klebs was dealing with pure cultivations of specific bacilli, and not with other infective organisms of the Bacilli in the soil. Shortly after this communication as to malaria blood of patients suffering from malaria. bacilli, Cuboni and Marchiafava announced that they had found in the blood of patients suffering from malaria, and at the period of commencement of the fever, mobile, short bacilli, usually containing spores at each end, and on the whole corresponding with the bacilli obtained by Klebs from the soil. Cuboni and Marchiafava, howerer, also demonstrated the same bacilli in the blood of persons not suffering from malaria, although in smaller numbers. Then followed observations by Ziehl, who found bacilli in the blood of three patients suffering from malaria, the organisms being hammer-shaped, $4 \mu$. in length, and $\cdot 7 \mu$. in breadth, and with spontaneous movement; the author looked on these as identical with the rods 
described by Klebs; he found them both during the paroxysms, and also in the afebrile period. Ziehl examined the blood of 25 patients suffering from other diseases without finding these bacilli ; they were, however, obtained in the case of a patient suffering from diabetes.

About the same time Laveran stated that he had Laveran's found in the blood of patients suffering from malaria, of the blood. micro-organisms of a totally different appearance. According to him these organisms belong to the class of protozoa, and in the fully developed state they form transparent spheres of the size of red blood corpuscles, and shoot out fine mobile filaments; dark red pigment granules, in active movement, are enclosed in the interior of the spheres. Richard has confirmed these observations, which, however, were made without the aid of the microscopical means now employed.

Finally, in the year 1883, Marchiafava and Celli Marchiafava's. observed in the blood of malarial patients, taken during and Celli's the period of fever, dried in a thin layer on the cover of blood. glass, and then stained with methylene blue, peculiar alterations of the red blood discs. Bluish stained bodies of various size and form were present in a greater or less number of the blood corpuscles; at first these bodies resemble micrococci stained of an interise blue colour, and in addition to these there are larger round or oval bodies, in the interior of which are granules, or masses of black pigment. At times the whole blood corpuscle is converted into a faintly blue stained round mass, which is filled with small clumps of pigment. On examining the fresh blood, without any addition to it, the larger bodies appear as colourless patches in the red blood dises; these patches usually contain pigment granules, and gradually increase in size, till ultimately the whole red blood corpuscle is composed of a colourless substance enclosing a large number of pigment granules.

Von Sehlen confirmed these observations, finding in blood taken from malarial patients during the febrile stage, and prepared with all ordinary precautions, 
round granules staining with methylene blue, 5 to $1 \mu$. in size, partly enclosed in the red blood corpuscles, partly lying free between them; in addition to these granules, there were ring-shaped bodies of almost double the size. When this blood was inoculated on nutrient agar, he obtained a pure cultivation of a species of micrococcus, growing in the form of a white gelatinous mass; in addition, in one case he obtained yellowish growths of micrococci. No positive results were obtained by experiments on animals with either of these species; these experiments have, however, only as yet been made on rats, and are not concluded. The method employed by Von Sehlen for making the cultivations affords no guarantee of the exclusion of accidental micro-organisms. Examinations of soil and air made by Von Sehlen in malarial regions and in regions free from malaria led, in both cases, chiefly to the isolation of two species of bacilli and cocci, the latter of which grew in a similar manner to those cultirated from blood, and were likewise without any marked action on the animals experimented on.

Criticism of the investigations which have been made up to the present time.

A consideration of these various facts leads us to t'se conclusion that the cultivation experiments have not as yet yielded any trustworthy results as to the organisms which take part in the malarial infection. The observations as to the presence of large bacilli in the blood of patients suffering from malaria are undoubtedly erroneous, as shown by the control investigations which liave been subsequently made. We cannot at once say the same as regards the results obtained by Laveran, by Marchiafava and Celli, and by Von Sehlen, which agree with regard to the constant occurrence of peculiar bodies in the interior of the red blood corpuscles; we can only say that Laveran evidently obtained a number of forms, as the result of errors in preparation, and mistook these forms, as well as the altered blood corpuscles, for stages of the development of a micro-organism. As the result of the investigations made by Marchiafava and Celli, the alteration of the red corpuscles seems to be, to some extent, a constant occurrence in malaria ; it is, 
however, as yet doubtful whether the granules and bodies observed are to be looked on as parasitic forms, or only as secondary products of the breaking up of blood corpuscles arising under the influence of microorganisms as yet unknown.

This last assumption, which is nevertheless equally justified, would open up the prospect that we must search for the true infective agents of malaria with other technical means than have as yet been tried; and it is probably advantageous to remember that these agents may not necessarily belong to the class of fission fungi, but to some other class of micro-organisms.

In the case of yellow fever Babès demonstrated in two cases short rods, similar to the typhoid bacilli, with large spores, usually at one end, and present in the mucous membrane of the small intestine. As regards the presence of cocci in this disease, see page 203 .

In the case of whooping cough, Letzerich (Virchow's Archiv, 1874) looks on the infective agents as cocci, and Burger (Berl. klin. Woch., 1883) as short rods often constricted in the middle, and present in the sputum of the patient; nevertheless there is no sufficient support for either of these views.

In some cases of lichen ruber, Lassar observed, on staining with fuchsine, the tissue at the same time being stained brown, distinct and extremely fine bacilli, which are aggregated in thick masses, and can only be recognised as individual rods under very high powers. They lie chiefly in the lymphatic channels of the affected parts in the form of tube-like masses.

In the case of xerosis conjunctive, Leber, Kuschbert and Neisser, and Schleich found micro-organisms. Leber describes them as short rods, often resembling cocci, which grow readily on nutrient gelatine, and when inoculated in large numbers on the conjunctiva of rabbits (the eyes of the animals being kept closed for forty-eight hours by means of superficial sutures) led to 
necrosis of the epithelium of the cornea, and to suppurative inflammation of the cornea. According to Kuschbert and Neisser, the bacilli are about as long as those of mouse septicæmia, and are of varying breadth, according as the sheath which surrounds the bacillus like a capsule is stained or unstained. If a small portion of the deposit on the surface of the conjunctiva is stroked orer the surface of blood serum jelly, dry, fatty whitish streaks grow, at the temperature of $37^{\circ} \mathrm{C}$., these streaks consisting of bacilli similar to those found on the conjunctiva. Neisser observed the production of spores, forming small spherical swellings at each end of the bacillus. At times the terminal joints break up into broad plates, or become swollen like a pear (formation of involution forms). Experiments on animals with the cultivations gave entirely negative results. As, however, the methods of cultivation employed were not devised with sufficient care to exclude accidental bacteria, which were so apt to be present on account of the exposed seat of the disease, the question as to the significance of the bacteria, which have as yet been found, for the etiology of xerosis cannot be regarded as completely settled.

In the case of caries of the teeth, which is probably due to the action of one or several species of specific bacteria, different bacilli have been isolated, which, however, seem chiefly to play a saprophytic part, and at the most to prepare the tooth for the occurrence of caries. As regards these organisms, see below.

As regards leptothrix and other bacteria of the mouth, see later. As regards jequirity, see the following chapter. 


\section{B. Bacilli Pathogenic in Animals.}

The following bacilli have been recognised as the exciting agents of infective diseases, partly in the case of domestic animals, and partly in animals used for experiments :-

\section{Bacillus of Rauschbrand.}

(Bactérie du Charbon symptomatique.)

In the case of Rauschbrand of cattle, Bollinger and Feser, and later Arloing, Cornevin, and Thomas, have found large rods, resembling anthrax bacilli, but nevertheless distinctly different, and have come to the conclusion that they are the exciting agents of the disease. This disease, which chiefly attacks young cattle, a half Symptoms of to four years old, and lambs, and which often runs through herds in the form of very fatal endemics, begins with loss of appetite, followed chiefly by the formation of an irregular swelling in the skin at some part or other of the body; this swelling rapidly increases in size, and distinct crepitation can be felt at its centre. Death occurs 36 to 48 hours after the commencement of the symptoms, the temperature rising at first and thên sinking to an abnormal degree. On making a Post-mortem post-mortem examination we find, at the seat of the appearances. swelling in the subcutaneous cellular tissue a collection of gas, which chiefly consists of a mixture of cabornic acid and methane; the muscles and cellular tissue are soaked with a large quantity of sero-sanguineous fluid, and the surface of the muscles are of a black colour; the lymphatic glands in the neighbourhood of the part affected are markedly hyperæmic. In the internal organs there are no characteristic or constant alterations. In the serous fluid between the fibrillæ of the muscle, and in the subcutaneous cellular tissue there are large numbers of bacilli; these may also be found in cover glass preparations made from the liver and spleen, and in the blood vessels and capillaries, though this is rare, and they are only found in these situations in 
considerable numbers when the post-mortem examination is not made immediately after death. Inoculation with the organs or the serous fluid from the tumours causes the same or similar phenomena and a fatal result, in calves, sheep, goats, rabbits, and guineapigs; horses, asses, and white rats are but little

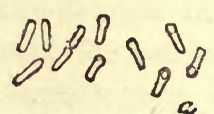

Fig. 84.- Rauschbrand bacilli, at $a$ spore bearing. susceptible; swine, dogs, cats, ordinary rats, and fowls are completely immune. In the case of guinea-pigs, the subcutaneous injection of the serous fluid causes an extensive œdema of the subcutaneous tissue; the animal dies after two or three days, and then it is found that the subcutaneous tissue is infiltrated with a large amount of sero-sanguineous fluid, and that the muscles are discoloured. If too small a quantity is injected, only a local tumour is formed in the animal inoculated, and this tumour heals and leaves the animal immune against larger doses.

Morphological characters of the bacilli.

Artificial the rausch. brand bacilli, and protective
inoculation. attenuation of

The bacilli are 3 to $5 \mu$. in length, $\cdot 5$ to $\cdot 6 \mu$. in breadth, with distinct spontaneous movement, and thus at once distinguished from the anthrax bacilli. They often show at one end a round swelling, so that their form resembles that of the clapper of a bell, and in this swelling an oval refracting spore, exceeding the rod in diameter, is gradually formed.

Cultivations. Arloing, Cornevin, and Thomas were able to cultirate the bacilli, but only by the exclusion of oxygen. The organisms grow best in fowl-broth, to which a little glycerine and sulphate of iron have been added, the vessels employed being exhausted of air, or filled with carbonic acid. In cultivations in other nutrient media the virulence of the organisms diminishes very rapidly.

The same observers were also able to obtain an artificial attenuation of the rauschbrand bacilli by another method, and on inoculation of these attenuated bacilli they were able to produce immunity of the animals against the virulent bacilli. They found in the first place that local affections, which left immunity behind, arose after subcutaneous inoculation of small quantities of the serous 
œdematous fluid containing the bacilli ; that immunity, however, was obtained with still greater certainty when small quantities of the ædematous fluid (in the case of cattle, 3 to 5 drops) were injected into the veins, with such precautions that none of the material passed into the subcutaneous tissue. At a later period another method proved to be more trustworthy and more practicable : the virulent cedematous fluid was dried quickly at $32^{\circ}$ to $35^{\circ} \mathrm{C}$. ; the dried mass was rubbed up with water and heated to $100^{\circ} \mathrm{C}$., and this formed the first vaccine material; another portion heated to $85^{\circ} \mathrm{C}$. formed the second vaccine. The dry vaccine, which can be sent where required, is rubbed up before use with 100 parts of water, filtered, and injected to the amount of 1 c.c. $\mathrm{m}$. into the animals; the second vaccine, which is less attenuated, is injected from 9 to 14 days later than the first. 'The inoculation is made in the case of cattle at the tail, and in the case of sheep on the inner surface of the thigh. The animals so inoculated ought to be completely immune against artificial and natural infection with virulent rauschbrand bacilli. The accuracy of these statements has been confirmed by numerous experiments, and it is probable that the protective inoculation against rauschbrand may be practically and advantageously employed. Thus Strebel states that in the course of 1884 , in 7 cantons in Switzerland 2,200 cattle were vaccinated, of which only a few developed a local tumour, from which they recovered, and of which a much smaller percentage died of rauschbrand acquired in the natural manner than was the case with uninoculated cattle kept under the same conditions. The experiments which have been made with other protective inoculations seem, however, to indicate that we must maintain a certain reserve with regard to the first favourable reports of the results of rauschbrand inoculations.

Rauschbrand and the bacilli which cause it show great Differences resemblance with malignant œdema and its cause between these cose balli and However, the œdema bacilli, as a rule, form longer those of threads, while the rauschbrand bacilli are always in the malignant form of isolated short rods; further, from the endemic 
and epidemic occurrence of rauschbrand we must assume that the distribution of the infective agents is different to that of the cedema bacilli, which occur everywhere in our surroundings. Kitt has also observed that while rauschbrand is always fatal after inoculation, a calf inoculated with malignant œdema became very ill, but recovered. It is probable that cultivations on solid nutrient substrata may show marked differences between the two organisms; but as yet we know nothing trustworthy with regard to the mode of growth of the colonies of the rauschbrand bacilli.

Neelsen and Ehlers found that the rauschbrand organisms formed in the animal body only bacilli and spores, but that, on the other hand, on cultivation on blood serum cocci developed. They stated also that on other nutrient substrata the cultivation of the bacilli taken from the affected animal did not in the first place succeed, but that after they had become accustomed to life outside the body by cultivation on blood serum they then grew on nutrient jelly, \&c. These statements, which are opposed to the results obtained by all other authors, and which are quite unlikely, are probably due to errors in the methods employed.

Bacilli of swine erysipelas.

(Rouget du porc, Mal rouge, Hog cholera, Pig typhoid.)

Within the last few years various investigators have - directed their attention to the erysipelas which occurs epidemically among swine, and which leads to great loss of life; and as the result of the investigations of Thuillier, Pasteur, Loeffler, Schütz, Lydtin, and Schottelius, the exciting agent of this disease has been discovered in the animals affected; it has been cultivated on artificial nutrient substrata, and the original disease has been again produced by inoculation of the cultivations on animals, and thus the chain of evidence necessary to demonstrate the etiological significance of the infective agents has been completed.

Symptoms of tiae disease.

The symptoms of swine erysipelas as a rule commence very suddenly. The swine attacked become suddenly dull, they creep about, and cease to eat; the voice 
becomes hoarse, and there is often evacuation of blood and slimy fæces. The temperature (which in normal young swine is between $39^{\circ}$ and $39.5^{\circ} \mathrm{C}$.) rises at times as high as $43^{\circ} \mathrm{C}$. Sometimes, even in the commencement, but usually not till the height of the disease, red patches appear at the lower surface of the belly, breast, and neck, which gradually extend and run together and ultimately assume a dark red or brown colour; swelling of the reddened portions of skin is not noticed, nor does there seem to be pain, nor is the temperature of the part apparently above that of the surrounding skin. Death occurs with increase of the listlessness, at times with paralytic symptoms of the hinder extremities, at times with convulsions. The duration of the disease, from its first appearance until death, varies from a few hours to four days. Where it ends in recovery, 6 to 20 days pass before the animal is quite well. Fifty-five to sixty-six per cent. of the animals attacked die; of those which survive the acute attack a considerable number ultimately die of chronic wasting. Older animals are never attacked, those which are affected are aged from three months up to at most three years. Different races show great differences in their susceptibility; the ordinary swine are almost without exception insusceptible, while the more noble races-more especially the English Suffolk swine-show a very great susceptibility to the disease.

According to the observations of veterinary surgeons Mode of the infection occurs almost entirely from the digestive track, the fres of the diseased animal getting into the fodder, or infected mice being eaten. At Lydtin's suggestion it was on several occasions shown experimentally, during the inquiry as to the causes and the mode of protection from swine erysipelas, in the Duchy of Baden in April, 1885, that swine can be infected by eating the intestines of other animals which hare died of swine erysipelas. In some of the experiments which gave negative results, the above mentioned insusceptibility of certain races seems to have come into play. In some cases also infection was caused by subcutaneous injection. According to the most trustworthy 
reterinary reports, the disease never recurs a second time.

Post-mortem appearances.

On making a post-mortem examination of the swine that die, the skin at the reddened parts is found to be infiltrated with œdematous and bloody fluid; the muscular tissue is soft, and of a greasy pale red appearance ; the lymphatic glands, especially the glands of the mesentery, are swollen, of a dark-red colour, and show on the cut surfuce punctiform hæmorrhages. The peritoneum is of a dirty-red colour, or covered with ecchymoses; the same is the case with the serous membrane of the small intestine. The mucous membrane of the small intestine is much reddened and swollen, and the summits of the folds are deprived of their epithelium and covered with blood; the solitary follicles and Peyer's patches are rery prominent, and here and there, especially in the neighbourhood of the ileo-cæcal valve, their place is taken by ulcers of considerable size. Liver and spleen are moderately enlarged. The lungs contain air and a large amount of blood. There are small hæmorrhages in the serous layers of the pericardium, and constantly in the epicardium of the auricles of the heart.

Morphological In cover glass preparations of fresh blood, and also in characters of the bacilli. the juice of various organs, in the lymphatic glands, and in the muscles, we find large numbers of delicate bacilli. These resemble most closely the bacilli of Koch's mouse septicæmia, but they are somewhat larger and

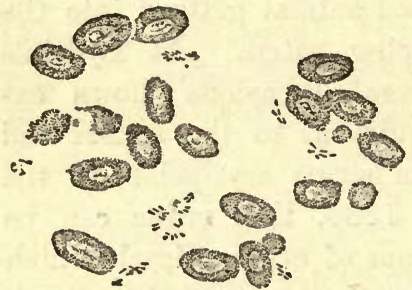

Fig. 85.-Pigeon blood containing the bacilli of swine erysipelas $\times 600$. (After Shütz.) thicker ( 6 to $1 \cdot 8 \mu$. in length), and they also resemble the latter in that they lie partly between the blood corpuscles, either singly or in pairs or groups of four, and partly in the swollen white corpuscles, leading evidently to degeneration of these cells. The bacilli stain well with the ordinary colouring materials; they also retain their colour on treatment by Gram's method. In sections the 
bacilli are found in largest numbers in the capillaries, especially of the spleen and lidneys; the walls of the capillaries are for the most part thickly covered with bacilli, while the lumen remains more or less free. The most beautiful preparations are obtained by means of Gram's method, or by double staining, in the first place with gentian violet, which colours the bacilli violet, and afterwards with picrocarmine, which gives the tissue a rosy-red hue.

These bacilli grow readily in alkaline meat juice, in Cultivations. blood serum, and in the ordinary nutrient jelly between $18^{\circ}$ and $40^{\circ} \mathrm{C}$. ; their growth is extremely like that of the bacilli of mouse septicæmia. On plate cultivations small round patches appear after two or three days, which have a cloud-like character, and are of a bluishgrey colour; these patches gradually increase in size, and under a low power of the microscope present the appearance of finely branching bundles of threads, not at all unlike the lacunæ and canaliculi of bone. The surface of the gelatine remains smooth, and the growth of the colonies only occurs in the deeper layers. A puncture cultivation in jelly shows, after three or four days, bluish-grey cloudy bundles, projecting into the gelatine on all sides at right angles to the line of inoculation, so that the cultivation resembles a glassbrush, such as is usually employed for cleaning test tubes. This cloudy appearance remains more or less limited to the neighbourhood of the line of inoculation, and is not so delicate as in the cultivations of the bacilli of mouse septicæmia. Growth does not occur on the surface. In meat infusion these organisms cause slight opacity of the fluid, and, at a later period, a whitish-grey deposit at the bottom of the vessel, which on very slight movement of the vessel rises in the form of very fine clouds. There is never any scum formed at the surface.

In the cultivations the bacilli occur singly or united Mobility of together in threads of various lengths. According to Schottelius the shorter bacilli show distinct, although not very active, spontaneous movement; other observers 

Spore forma- have, however, failed to observe any movement. In
tion. cultivations in meat infusion which bave stood for three days at the temperature of the room, or for 24 hours at

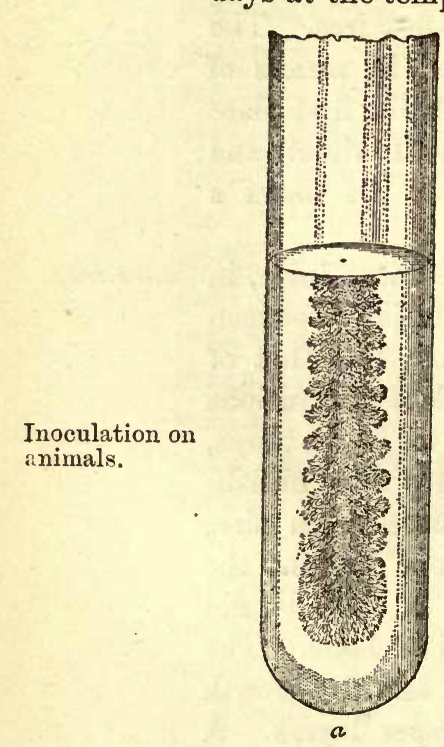

Fig. 86A.-Cultivation of the bacilli of swine erysipelas in gelatine.

$a$, puncture cultivation.

$b$, colony on a plate $\times 80$. forms, \&c., appear. $40^{\circ} \mathrm{C}$., we can observe the formation of small spheres which probably represent spores, although, on account of the minute size of the object, no accurate observations have as yet been made as to the formation and sprouting of these bodies. In old cultivations the ordinary involution forms, such as club-shaped swellings of the threads, drum-stick

These cultivations, after being carried for a series of generations through

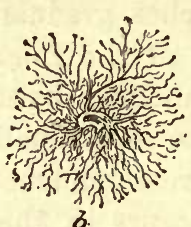
gelatine or meat infusion kill with great certainty the ordinary house mice in the course of two to four days, and on examination numerous fine bacilli are found in the blood and in the capil-

laries of all the organs. Pigeons are very susceptible, and die within three or four days. Rabbits are less susceptible; after inoculation on the ear of a rabbit an crysipelatous inflammation occurs in the first instance, just as after inoculation with the bacilli of mouse septicæmia. As a rule general infection follows and causes death in five to six days, nevertheless not uncommonly complete recovery takes place. Sheep, and perhaps also young cattle, are susceptible; on the other hand guineapigs and fowls are completely immune. The cultirations have also been repeatedly inoculated with success on swine belonging to susceptible races, and at a susceptible age.

Pasteur's protective inoculation.
Swine erysipelas has quite recently excited special interest because Pasteur has recommended a special mode of protective inoculation which has been experi- 
mentally tested in a large number of animals by Lydtin during April, 1885, in the Duchy of Baden.

Pasteur found that the virus of this disease was more virulent for swine when it had passed through the bodies of several pigeons in succession, and had attained the maximum of its virulence in the case of pigeons; that, on the other hand, the danger of the virus as reggards swine was markedly diminished when it was inoculated through a series of rabbits. If Pasteur inoculated the erysipelas bacilli into the thoracic muscle of a pigeon, the latter died in from six to eight days, having previously exhibited the exterual symptoms of chicken cholera. If, now, the blood of the first pigeon was inoculated into a second, the blood of the second into a third, and so on, the latter animals died much more quickly than the first, and the blood of the last pigeon was much more virulent for the swine than was the most poisonous product from a swine which had died of spontaneous erysipelas. On the other hand, by reinoculation from rabbit to rabbit, an increase of the rirulence of the virus in these animals was observed, and ultimately the animals died without exception, and more quickly than after the first inoculation. If now Pasteur inoculated the bacilli thus acclimatised in rabbits on swine the latter became ill, but did not die, and were protected, after recovery, against the most virulent erysipelas poison. (Pasteur always speaks in his papers of $\because$ round microbe, which, when taken from the blood of rabbits, was larger than in swine, and which had the form of the figure 8.)

Acting on these principles Pasteur has prepared two Control exvaccines with which young swine-the age is from periments 8 to 11 weeks-are inoculated by subcutaneous injection vaccine.

on the inner surface of the thigh at an interval of twelve days. By this means an immunity is obtained which lasts about a year-in other words, is sufficient to enable the animal to pass through the period of life when it is most liable to the erysipelas infection. These vaccines have been recently examined bacteriologically by Schütz and Schottelius, and their action on 
animals has also been tested. Besides some indifferent bacteria mixed with them, both authors found chiefly the characteristic erysipelas bacilli, and they were able to convince themselves by experiments that these organisms were as a matter of fact attenuated as regards the virulence of their action on swine; in like manner they were able to ascertain that the pigs inoculated with these vaccines, and which, after being ill, had again recovered, were immune against inoculation with virulent material. Thus the accuracy of Pasteur's experiments, and the possibility of attenuation and protective inceulation for swine erysipelas, is proved. This result was a priori not improbable, as Loeffler had formerly shown that the bacilli of mouse septicæmia, which so much resemble the erysipelas bacillus, cause a mild disease in rabbits, as the result of which these animals are rendered completely immune; and as also it was known that swine erysipelas belongs to the class of diseases which do not recur, one attack protecting against a later infection.

Practical ralue of the protective inoculation.
Nevertheless the result of the vaccination experiments carried out in large numbers in Baden cannot be regarded as being particularly favourable from a practical and economic standpoint. Of 119 animals inoculated, 6 , or 5 per cent., died of erysipelas as the result of the inoculation, while the average loss from the ordinary disease is at most only 2 per cent. ; however, the animals which died as the result of inoculation were, on account of their youth, of much less value than the animals which died of erysipelas. It was also ascertained that the animals which were rendered ill by the inoculation were able to infect other animals with the fatal disease; and, finally, we do not as yet linow whether the inoculated swine are protected against the natural infection. From these considerations it is evident that the final judgment as to the practical value of Pasteur's protective inoculation must be deferred till more accurate experimental evidence has been obtained.

Klein has claimed the discovery of the erysipelas bacillus, but from his statements that these bacilli may be confounded 
with bacterium termo, that the transverse diameter of the erysipelas bacilli is the same as that of the hay and anthrax bacilli, further that a superficial scum, as well as a deposit at the bottom is formed in the fluid cultivations, and, finally, that the bacilli taken from the cultivations move as actively as bacterium termo, we may with certainty assume that Klein has not recognised the true erysipelas bacilli, and, at most, has dealt with them in impure cultivations.

Pasteur also has at first probably not recognised the true infective agents, and has evidently worked with impure cultivations; and it is a matter of surprise that, nevertheless, he has obtained these interesting results with regard to protective inoculation, now confirmed on all sides. Baillet and Jolyet (Revue Veter, 1884) also describe the erysipelas organisms incorrectly as microbes of the form of the figure of 8 , at times arranged in chains, and-in opposition to all other observations-virulent in guinea-pigs.

Loeffler in a case of a pig, which had died of so-called swine erysipelas, but in which the disease was evidently different from the epidemic form, found other bacteria which cansed in guinea-pigs sero-sanguineous infiltration of the subcutaneous tissue and hæmorrhagic affections of the muscles. Further facts as to this discovery will be mentioned later.

Of special interest is the observation made by Schottelius, $A$ second that in almost all eultivations made from animals which had species of lied of this disease, the cultures being made in some cases bacilli in the a very short time after death (within 20 minutes), other larger cultivations. bacilli also grew which formed light yellow spherical colonies in the gelatine. This bacillus, which is described in detail below, breaks up the gelatine with the formation of a foul smell, and is thus evidently one of the exciting agents of putrefaction, and probably comes from the intestine, in the contents of which Schottelius was also able to demonstrate it. Hence it is probable that these bacilli are able to penetrate Entrance of into the body even before the death of the animal, entering these bacilli through those parts of the intestinal mucous membrane injough which are denuded of epithelium and ulcerated; this view is intestine. directly supported by the observation that these bacilli are present in largest numbers in the organs in the neighbourhood of the intestine (not only in the intestinal wall itself, but in the mesenteric glands, and in the spleen), while, on the other hand, they gradually diminish in numbers in the organs further away from the intestine, and thus only occur rarely in the lungs and the muscular tissue of the heart. This discovery enables us to draw important conclusions with regard to the entrance of fungi secondarily in other diseases accompanied with injury of the intestinal epithelium. 


\section{Bacilius murisepticus (Koch).}

\section{(Bacillus of Mouse Septicæmia.)}

Bacillus of mouse septicæmia.
These organisms, first discovered by Koch, and very closely resembling the bacilli of swine erysipelas, occur not uncommonly in all sorts of mixtures of bacteria. If small portions of putrefying fluids, which have been exposed to the entrance of all kinds of bacteria, are taken during the early stage of putrefaction and inoculated subcutaneously into, say, twenty mice, one or other of these animals generally dies of a septicæmia which is caused by the bacilli of which we are speaking.

The early symptoms of the disease are increased secretion from the conjunctiva and adhesion of the eyelids, lassitude, \&c.; the animal sits quietly with the back arched, and death occurs in this position 40 to 60 hours after the inoculation, coming on almost imperceptibiy and without any convulsive movement. Even after death the mouse generally remains in this position, while the mouse which has died of anthrax, for example, lies on its back or its side with its extremities stretched out. On making a post-mortem examination slight œdema is sometimes found at the seat of inoculation, and there is also considerable swelling of the spleen, but no further alterations. Delicate bacilli are present in the neighbourhood of the seat of inoculation, in all the blood vessels of the body, in the blood of the heart, and more especially in the capillaries of the kidneys and spleen.

Morphological These bacilli are 8 to $1 \cdot \mu$. in length, and about characters. $\cdot 2 \mu$. in thickness. They often occur in pairs or in fours, forming short threads ; they frequently form small groups; they have no spontaneous movement. They can be rendered distinctly visible by treatment with the aniline colours, which they readily take up ; corer-glass preparations of blood are best stained in alkaline methylene blue, and then decolourised by momentary immersion in very dilute acetic acid; Gram's method also gives very distinct pictures. For sections the method 
of double staining used for demonstrating the bacilli of sivine erysipelas can be employed.

In the preparations from the blood of the heart the bacilli show a very characteristic arrangement: they lie in part in the interior of the white blood corpuscles. When this is the case the latter are generally much swollen; in some of the cells the protoplasm takes on the stain ouly very feebly, and the outlines are indistinct; in other cases the whole body of the cell consists solely of thickly aggregated bacilli, which here and there project from the surface of the disintegrating cell mass. By examination of the various stages which can usually be recognised in the same specimen we obtain the impression that the cells are destroyed by the bacilli in their interior, and not that the bacilli undergo destruction in the cells.
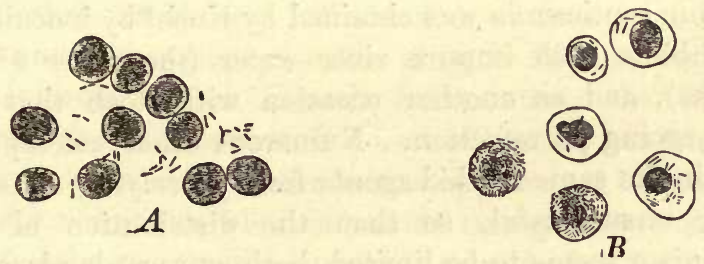

Fig. 87. -Bacilli of mouse septicæmia (after Koch) $\times 700$.

$A$, blood of a septicæmic mouse, red corpuscles with bacilli between them.

$R$, white corpuscles containing bacilli.

The bacilli can be readily cultivated, and grow on the cultivations. various nutrient substrata exactly in the same manner as the bacilli of swine erysipelas (except with the slight differences mentioned abore). On gelatine plates they form bluish-grey cloudy flakes lying underneath the surface, which are resolved, under a low power of the microscope, into a network of delicate threads; in jelly puncture cultivations a very delicate bluish-grey cloud forms around the track of the needle, and this cloud gradually extends outwards from the line of puncture till it almost reaches the wall of the vessel (fig. 86).

The minutest trace of blood containing bacilli or of a Inoculation on cultivation is sufficient to set up the disease in mice. animals. Field mice and guinea-pigs are completely immune; 
sparrows and pigeons are, on the other hand, susceptible. liabbits sometimes, but not always, die after inoculation; often they only show a local reaction, such as an erysipelatous formation on the ear, which can be traced over the ear to the parts beyond; after inoculation on the cornea an intense inflammatory process occurs in the eye. Loeffler has made out that rabbits which have once recovered from this inoculation on the ear, or on the cornea, are completely immune against any new attempt to introduce the bacilli, however large the dose employed.

Bacillus cuniculicida (Koch).

(Koch's Rabbit Septicæmia.)

I3actoria of rabbit scpticremia.

Microscopical characters.

Growth on plates.
This septicæmia was obtained by Koch* by inoculation of rabbits with impure river water (the water of the Panke), and on another occasion with flesh that was undergoing putrefaction. Numerous other attempts to obtain the same morbid agents from putrefying materials were unsuccessful, so that the distribution of this organism seems to be limited, both as regards place and time.

These organisms present the form of short rods somewhat pointed at their ends; when stained the ends take up the dye, while the central portion of the rod remains unstained; there is no constriction in the middle, but the peculiar distribution of the colouring matter readily leads to the erroneous idea that the organism consists of two micrococci lying side by side. They do not stain by Gram's method. Their length is $\mathbf{1 . 4} \mu$. and their breadth 6 to $\cdot 7 \mu$. Two and more bacteria often remain united after division, and thus form apparently longish rods; under these circumstances they frequently present the form of a figure of 8 , and are surrounded by a somewhat clear area. Spontaneous movement has not been observed.

The bacilli grow readily in broth, in blood serum, and on nutrient jelly. On gelatine plates small white points

* Mittheil. a. d. Kais. Ges. A., vol. i., p. 94, ff. 
appear on the third day, and these under a low power present the form of circular dises, with a sharp, dark outline not quite regular, and of a yellow colour, lighter towards the periphery. At a somewhat later stage the dark yellowish brown central zone and the clearer peripheral zone are often sharply marked off from each other, so that the colony appears to consist of concentric layers. When it spreads at the surface, which only occurs to a very slight extent, and does not extend further than a millimetre, the outline remains sharp, dark,

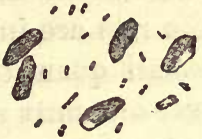

Fig. 88.-Baccillus of rabbit septicæmia (after Koch) $\times 700$.

Blood of a sparrow showing the nuclei of the red blood corpuseles with numerous bacteria between them. and for the most part fairly circular, though often somewhat irregular. The colony presents a finely granular appearance at this stage. In the puncture In puncture cultivations a thin deposit forms along the line of puncture, and this deposit does not become confluent in many places, but presents the appearance of discrete spherical colonies of a somewhat transparent yellowish white colour. On the surface it spreads in the form of a flat and limited layer; in stroke cultivations it forms a thin layer somewhat thickened at the borders, which are irregular and serrated; here and there the line is interrupted by isolated colonies. The cultivations only retain their vitality for 4 or 5 weeks.

If the minutest portion of a cultivation is inoculated Inoculation on into a rabbit (a prick in the cornea suffices) the body temperature becomes clevated after an incubation period of 10 to 12 hours, and the breathing becomes slow and laboured; ultimately the temperature falls below the normal, and after the occurrence of some convulsive attacks the animal dies 16 to 20 hours after the inoculation. On post-mortem examination, the spleen and lymphatic glands are found enlarged, and the lungs present a strikingly marbled appearance; there are no extravasations of blood, and no peritonitis. The characteristic rods are equally distributed everywhere throughout the blood; on sections of the various organs they 
are found in the blood ressels and capillaries; the best appearances are obtained from sections of lung, stained with gentian violet. Mice and birds (sparrows, pigeons, fowls) are as susceptible as rabbits; guinea-pigs and white rats are immune; dogs do not react on inoculation of small quantities, but after subcutaneous injection of larger amounts an extensive œelema of the subcutaneous cellular tissue occurs, and the animals die after two or three days. No experiments have as yet been made as to the attenuation of these bacilli ; in successive cultivations even continued for a long time they retain their fu!l rirulence.

\section{Bacillus cholere gallinarum.}

(Bacteria of Chicken Cholera, or Fowl Typhoid; Microbe du Cholera des Poules.)

Chicken cholera.

Clinical symptoms.

In the epidemic disease which occurs in poultry yards, and which has been known and dreaded for a long time in France under the title of chicken cholera (although the symptoms show very little resemblance to those of human cholera), bacilli were found in the first instance by Perroncito, then by Toussaint, and later by Pasteur, and these have proved to be the causal exciting agents of the disease. These observations bave been confirmed and extended by Rivolta, Marchiafava and Celli, and Kitt. Petri has also found bacteria in an epidemic in a poultry yard, which are probably identical with the bacilli of chicken cholera.

The disease begins by the fowls attacked becoming very hclpless and tumbling about, the wings hang, and ultimately the animal sits quietly rolled up in a ball, with erected feathers. The animals are very somnolent; if they are compelled to open their eyes they appear as if they had awaked from a deep sleep; they soon close the eyelids again, and usually after a slight convulsive attack, die without having moved from the spot. Very frequently at the height of the disease there is a slimy diarrbøa, the stools 
containing very numarous bacilli. The whole course of the disease is ofin $n$ very rapid, lasting only a few hours.

On post-mortem examination the spleen and liver are Post-mortem found to be enlarged, there is also intense inflammation of the intestinal mucous membrane, especially of the duodenum, with numerous hæmorrhages, and at times with ulcerations, hæmorrhagic infiltration in the peritoneum, hæmorrhagic pneumonia, and numerous ecchymoses in the pericardium, in the pleura, and in the brain.

Large numbers of short bacilli, very similar to those Microscopieal described before in rabbit septicæmia, but somewhat characters of shorter and thicker, are found in the blood of the heart, and of all the other organs. They have been described by Pasteur as cocci, but when highly magnified there is no doubt as to their rod character. The fully-grown individuals attain a length of about 1 to $1 \cdot 2 \mu$., and usually show, when stained, an aggregation of the colouring matter at the ends, as in the case of rabbit septicæmia, the dark poles being separated by an unstained central portion. The bacilli are usually in a state of active division, and thus many forms are found which are constricted in the middle, not unlike a diplococcus, and also numerous young individuals in which the length is only very slightly greater than the breadth. We can

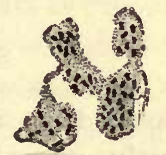

Fig. 89.-Bacilli of chicken cholera $x$ 800.

Cover glass preparation from a fresh cultivation.

always see, howerer, with good lenses that even the youngest individuals are not round, but more quadrilateral with parallel contours-in other words, that they are short bacilli. In sections of the organs the rod character is usually much more distinct; they are found there in varying numbers within the blood ressels, sometimes only a few examples, sometimes in dense masses.

The bacilli of chicken cholera can be readily cul-Growth in tivated. On plates of nutrient gelatine they appear on cultivations. the second day as whitish-yellow points, which are seen 
under a low power to be dises of a yellowish-brown colour with sharp outlines, finely granular, seldom circular, but as a rule with irregular boundaries. The centre is of a lightish-yellow colour, towards the periphery there is a narrow brownish ring, and then a light border. The superficial colonies form small moderately prominent, transparent drops of a yellowish-white

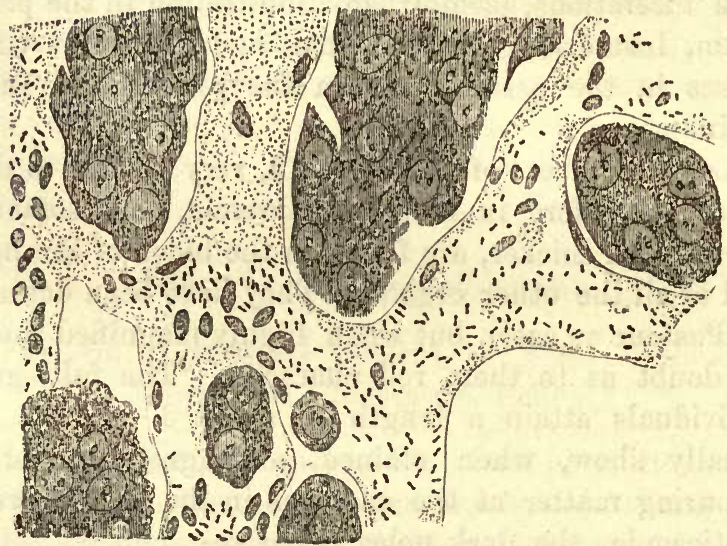

Fig. 90.-Chicken cholera.

Section from the liver of a hen $\times 700$.

colour, they show less of a circular form and are distinctly grauular; but the zones above mentioned can still be recognised, and have only become correspondingly broader. In puncture cultivations they form partly discrete and partly confluent colonies along the needle track; on the surface they spread out in a flat layer, which is somewhat more marked than in the case of the bacilli of rabbit septicæmia.-On blood serum the cultivations form a dull, white, thin layer. On potatoes a wax-like transparent greyish-white and only slightly prominent layer is formed, which grows slowly and only at a temperature of about $28^{\circ} \mathrm{C}$. Growth of the bacilli also occurs on hard-boiled white of egg. In neutralised broth they grow luxuriantly, and cause slight turbidity of the fluid.-According to Pasteur they soon lose their vitality in neutralised urine; they do not grow at all in yeast water. 
Subcutaneous inoculation of the smallest quantity of Inoeulation on a cultivation sets up in healthy fowls the symptoms described above, and death occurs in 24 to 36 hours. Pigeons, sparrows, pheasants, mice, and rabbits are likewise very susceptible to the disease; guinea-pigs, sheep, and horses do not as a rule die, but abscesses form at the seat of inoculation, the pus of which contains large numbers of bacilli. Mice, fowls, and rabbits can also be infected by feeding them with the cultivations; dogs remain healthy even when fed for a long time with the bacilli. It is probable that the natural mode of infection in the poultry yards is that the dejecta of the diseased animals which contain the bacilli contaminate the food, and are then swallowed by the healthy animals.

Pasteur failed to set up a fatal disease in fowls when Filtration of he filtered the cultivations in neutralised chicken-broth the cultivathrough plaster or porcelain, but after large doses of the filtrate there occurred in the first place a short period of excitement and then moderate somnolence, which after a few hours ended in recovery. This result is probably to be explained by the presence of toxic products of the bacilli in the filtered cultivations. Marchiafava and Celli have found that the bacilli of chicken cholera can pass from the mother to the fotus; such a transference is in many cases à priori probable, because in chicken cholera hæmorrhages and lesions of the vessels occur in all the organs, and in this way the organisms pass out of the blood vessels.

The bacilli of chicken cholera have excited special Attenuationo interest because Pasteur carried out with them his first and protective experiments on attenuation and protective inoculation. Pasteur observed that old cultivations which had stood for several months in ressels plugged with cotton wool had diminished in their virulence, as he concluded, as the result of the influence of oxygen; at any rate this attenuation did not occur when he preserved the cultivations in sealed ressels containing only very little air. The bacilli when attenuated retained the degree of virulence at which they had arrived, even when further 
cultivations were made in broth, and carried through several generations. If Pasteur inoculated fowls in the subcutaneous cellular tissue over the muscles of the breast with these attenuated bacilli, only an inflammatory swelling of the cellular tissue, especially of the muscle, occurred; the affected portions of the muscle soon became separated from the healthy by an abscess wall, so that a sequestrum of the muscular tissue was formed. This was absorbed with greater or less rapidity, and usually had completely disappeared some weeks after inoculation. The fowls which had thus recovered were then found to be immune against inoculation with the most virulent bacilli.

Discrepant results of other observers.

The results of Pasteur's experiments could not be confirmed by Kitt and others. Cultivations on potatoes and gelatine five or six months old, and always exposed to air, showed the same virulence as fresh cultivations. It is possible therefore that Pasteur's cultivations, which were always made in fluids, were gradually overgrown by other bacteria, and that thus the diminution in activity was produced.

\section{Bacillus septicus agrigenus.}

Septic earth bacilli.

These bacilli were first obtained by Nicolaier in the author's laboratory, and at a later period on several occasions from the earth of manured fields. These bacilli agree, as regards their size, for the most part with the two forms before mentioned, but they are usually Micrescopical somewhat longer; the same peculiar distribution of the
harceters. colouring matter is also at times seen, although not so frequently, nor so well marked. Rapid division occurs in cultivations, and hence, as a rule, there is only a trivial Cultivations. excess of the longitudinal diameter.-On gelatine plates the colonies present the appearance under a low power of circular discs, with sharp outlines and of a finely granular character; the centre is yellowish-brown, and the margin greyish-yellow, these two parts being separated from each other by a dark ring. These differences in colour gradually disappear at a later period, so that 
ultimately there are no distinct zones to be seen; on the other hand, the granular appearance becomes more marked; the circular outline for the most part remains. In puncture cultivations a thin and but slightly characteristic layer is formed.-Mice inoculated with small quantities of the cultivations die after 12 to 22 hours, as also do field mice; rabbits die after inoculation on the car in from 24 to 36 hours. On post-mortem examina-Action on tion no special abnormalities are found; the bacilli above described are present in the blood of the heart and in the capillaries of all the organs, but always in dccidedly smaller numbers than in the two diseases just described. Further, the bacilli show a special tendency to adhere to the blood corpuscles; the border of a blood corpuscle frequently has two, three, or four bacilli attached to it; but the bacteria do not seem to penetrate into the interior of the cells.

A number of short, fine bacteria, which are similar to Septic the three species of bacilli just described, have been sembling the observed by various authors in the deposit on the human former, pretongue, in the secretions of the mouth, and in the secretion of sputum. In the Hygienic Institute in Gottingen, Kreibohm found two bacteria which were chiefly distinguished from the above mentioned forms by the fact that they could not be cultivated on any of the ordinary artificial substrata.

The first species was obtained on two occasions from First species. the deposit on the tongue by the inoculation of some mice with this deposit; the animals died after a few lays, and large numbers of these bacilli were found in the blood. The rods resemble very closely those of rabbit septicæmia, but they are somewhat longer and more pointed at the ends; they do not show any constriction in the middle, but take up the colouring matter only at the poles, leaving a clear zone in the middle. In the blood they occur singly or in small groups, seldom in the form of threads composed of two 
Inoculation from animal to animal.

Failure of cultivation experiments.

Second species. or three members. - The blood containing the bacilli when inoculated on mice in the quantity of about one drop always produced the same disease in 30 inoculations continued in series : on the first day no alteration could be observed in the animals inoculated; on the second day they were lazy, they sat quietly with erected back, and the eyelids were stuck together; death occurred as a rule after two or three days, at times, however, not till after five days. On post-mortem examination nothing abnormal was found, except very marked enlargement of the spleen, and slight enlargement of the liver. In sections of the organs small groups of bacteria were found within the capillaries, but they were not particularly numerous; they were only present in very large numbers in the lungs. Rabbits are relatively but little susceptible; after inoculation with small quantities of blood only a transitory illness resulted; after subcutaneous injection of larger quantities of blood the animals died after two or three days, and the bacilli showed the same distribution as in the case of mice. Field mice were very susceptible; inoculation on a fowl was without result. Cultivations were frequently attempted with the most varied solid and fluid substrata, and at various temperatures; nevertheless they all failed, while control experiments with the bacteria of rabbit septicæmia were, without exception, successful.

The second species was isolated in a similar manner by the animal body (mice) from a deposit on the human tongue. These organisms consisted of short rods rounded at the ends, and slightly constricted in the middle; when stained they resemble a figure of 8 , the stain being more intense at the poles; they are also surrounded by a clear area, and on the whole they most closely resemble the bacilli of chicken cholera. The rods were present in large numbers in the blood of the heart of mice; in sections of the organs they were found inside the capillaries, but as a rule in isolated masses, and not more numerous in the lungs than in the other organs. The inoculation of the disease on mice was carried on successfully through 40 or 50 generations with minute quantities of blood; 
death occurred much more quickly than in the case of the first species, often even after 18 hours, at the latest after 40 hours. Rabbits were completely immune. Cultivation experiments showed at most a multiplication Cultivation of the bacteria in the blood inoculated on the first sub- experiments stratum; further attempts at inoculation were always unsuccessful. unsuccessful.

The following bacteria isolated from saliva by other authors are either identical with one or other of these species, or it may be different from them, but this cannot be decided on account of the absence of sufficient characteristic distinctive points.

Pasteur obtained a microbe from the saliva of a child Pasteur's which had died of hydrophobia. Raynaud and Lanne- microbe of longue had discovered that the inoculation of such saliva on rabbits caused the illness and death of the animals ; Pasteur confirmed these experiments, and cultivated a micro-organism from the blood of the rabbits in veal broth, this organism being rod-shaped and somewhat constricted in the middle in the form of a figure of " 8 "; the organism was only $1 \mu$. in diameter, and was surrounded by a gelatinous substance like an aureole. In the cultivations these rods were said to become converted into chains of cocci. Fowls and guineapigs were not susceptible to the action of the microbe.Although at first Pasteur supposed that he had obtained the infective agent of hydrophobia, he succeeded in setting up the same disease, and found the same organisms in rabbits inoculated with the saliva of healthy human beings. In like manner Vulpian was able to set other similar up, by inoculation of normal saliva on rabbits, a disease ${ }_{\text {(Fecies. }}^{\text {(Frenkel, }}$, which ended fatally in two days, and which could be Klein, transmitted from animal to animal by small quantities of blood.-Fraenkel also obtained a similar result by the inoculation of his own saliva. (See Literature, p. 37.)

Klein has set up infective diseases in rabbits and mice by the sputum of patients suffering from pneumonia, and he has described the infective agents of these diseases as belonging to various species of micro- 
cocci. It is possible that in these cases also the bacteria belonged to the group here described.-In like manner the septicæmia formerly described by Davaine, which is fatal to rabbits and guinea-pigs but not to pigeons, seems to have been due to similar bacteria.

Group of septic bacteria resembling the pneumonia bacilli.
Kreibohm's thick sputum bacilli. Microscopical characters.
Another smaller group of bacteria is formed by short, thick cells, egg-shaped when young, and resembling the pneumonia bacilli; like these they are often surrounded by a sheath which can be stained, and in puncture cultivations in gelatine they give rise to nail-shaped growths, and on potatoes to thick gelatinous deposits. It is at times impossible to distinguish the species belonging to this group from each other either by the microscope, or by the appearance of the cultivations, and this can only be done by experiments on animals.

\section{Bacillus crassus sputigenus (Kreibohm).}

These organisms were obtained by Kreibohm on two occasions from sputum, and on one occasion from the fur on the tongue. They present the form of short, thick bacilli, or oblongs with rounded corners; they are often bent like a sausage, or twisted. Immediately after division the longitudinal diameter is only about a half greater than the transverse, but later on the difference is more marked, so that before new division takes place the bacilli are three or four times as long as thick. The bacilli are often seen to be connected together, either while division is going on, or after division has occurred, but longer threads do not occur. The bacilli, both from blood and from cultivations, frequently present abnormal forms, often showing swollen ends or irregular contours, and here and there converted into shapeless masses. The bacilli stain readily, and retain the stain on treatment by Gram's method; at higher temperatures $\left(35^{\circ} \mathrm{C}\right.$.) they appear to

Cultivations. form spores. - The bacilli can be cultivated on a number of different substrata. In gelatine plates they form distinct greyish-white points after about 36 hours, 
these points soon rising above the surface and then spreading out in the form of greyish-white round gelatinous drops, which project considerably above the surface of the jelly. Under a low power the youngest colonies appear circular, of a greyish-brown dark colour with dark points, or with short dark lines over the whole surface. The superficial larger colonies appear distinctly lighter, irregular in outline, and the surfacemore especially at the border-is distinctly granular. In puncture cultivations the organisms grow very quickly, in about 24 hours, and show the typical nailshaped appearance. On potatoes they form a thick,

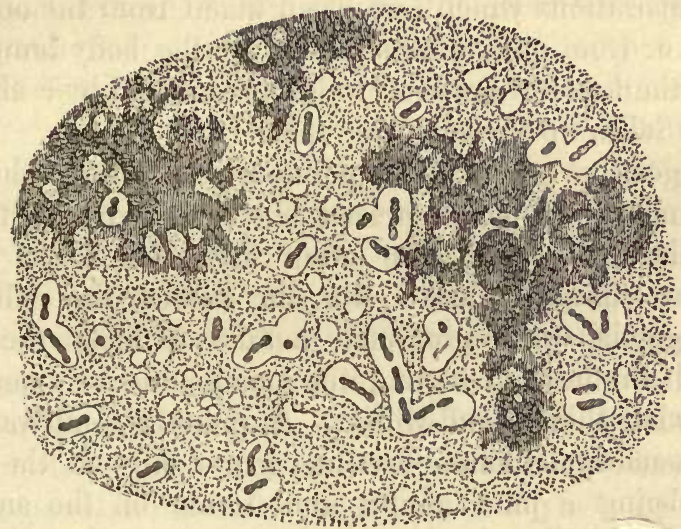

Fig. 91.-Bacillus crassus sputigenus (Kreibohm) $\times 700$.

Cover glass preparation from the blood of the heart of a mouse.

greyish-white moist and shining layer, similar to the cultivation of the pneumonia bacilli, but somewhat flatter and tougher, though as a rule scarcely distinguishable from the latter.-Mice die after inoculation with Experiment small quantities of the cultivation in about 48 hours; on animals. numerous bacilli are found in the blood of the heart, and in all the capillaries, in largest numbers in the liver. Rabbits are not markedly affected by small doses, if introduced by inoculation, but after intra-venous injection of small doses they die within 48 hours, large masses of bacilli being found in the blood. Large Action of quantities of the cultivation injected into the veins larger doses. cause in rabbits, and to a still more marked degree in 
dogs, diarrhœa, with at times bloody stools, and death within 3 to 10 hours; on post-mortem examination all the appearances of an acute gastro-enteritis are found.

\section{Bacillus pseudopneumonicus (Passet).}

Pseudopneumonic bacteria. Microscopical
characters.

Caltivations. In gelatine plates white points appear after 24 hours, and under a low power present the form of round, finely granular, grey, and later often very dark discs, with regular sharp outlines. On the surface the colonies form greyish-white prominent nodules of about the size of half the head of a pin; the pneumonia colonies are somewhat thicker and whiter. In puncture cultivations the pseudo-pneumonia bacillus grows only on the surface, being a pure aërobe, and forms on the surface greyish-white hemi-spherical glistening nodules; it does not grow at all along the track of the needle. On blood serum it forms a thin greyish-white layer; on potatoes kept at $37^{\circ} \mathrm{C}$. a thick white shiny moist layer appears in 24 hours, without any development of gas, Experiments or formation of bubbles.-In mice, rats, guinea-pigs, on animals. and rabbits the injection of Passet's bacteria into the pleura causes pleuritis, and into the abdomen, peritonitis; subcutaneous inoculation kills mice from septicæmia, but as a rule only causes the formation of abscesses in rats, guinea-pigs, and rabbits; 43 mice treated by inhalation of the cultivations remained well.

* They are described by the author as cocci, but on account of the analogy with the pneumonia bacteria, and for the reasons given with regard to the latter, these organisms have been included here under the bacilli. 


\section{Bacillus septicus sputigenus (Fraenkel).}

These organisms have been repeatedly observed by Fraenkel's A. Fraenkel* in the rust-coloured sputum of patients bacteria. suffering from pneumonia. These microbes have the appearance of cocci, resembling very much the pneumonia bacteria, and like these they are surrounded by a broad capsule. They do not grow on gelatine at the ordinary temperature, but they grow on agar and blood serum at the body temperature; in the latter they form a veil-like almost transparent layer, or a deposit like drops of dew. Rabbits die after subcutaneous inoculation in 24 to 48 hours, with the symptoms of acute septicæmia.-Fraenkel thinks it probable that these bacteria have a causal relation with human pneumonia and with the empyemata which develop after pneumonia. A more detailed description of these organisms has not as yet been furnished.

\section{Bacillus pneumonicus agilis (Schou).}

These organisms were cultivated by Schou on three Bacteria of occasions from the lungs of rabbits which had become monia. affected with pneumonia after section of the vagus nerve. They present the form of short thick rods, or more elliptical cells often occurring in pairs, or, seldom, in chains of three or four members. They do not stain by Gram's method. When examined in drop cultivations they show very active spontaneous movements; in gelatine plates the colonies of the bacilli appear under a low power as round, dark, granular dises, with a slightly rough surface and borders. After 20 to 24 hours liquefaction of the gelatine commences, and even under a low power we see very marked movements in the middle of the colony. At this stage the borders appear as if surrounded by a small crown of rays, but soon afterwards the gelatine becomes entirely liquefied. On solidified blood serum the bacillus grows very slowly, and leads to slight liquefaction of the serum; in broth it forms a plentiful yellowish deposit at the bottom of the

$$
\text { * Lit., p. } 37 \text {. }
$$


vessel; on potatoes it forms a reddish chamois-coloured flat layer, which extends very quickly.-Cultivations introduced into the lungs of rabbits through the wall of the chest, or by injection into the trachea, or by inhalation into the lungs, set up a violent pneumonia, which presents exactly the same appearance as the vagus pneumonia, in which the bacilli were originally found.

\section{Bacillus diphtheria columbarum (Loeffler).}

Bacilli of pigeon diphtheria. the disease.
Symptoms of

In fowls and pigeons we not uncommonly find epidemics of a disease resembling human diphtheria, which begins with hyperæmia of isolated spots of the mucous membrane; at a later period these spots become covered with a thick light yellow deposit. In the case of pigeons the base of the tongue, the mucous membrane of the throat, and the angle of the mouth, are more especially attacked; in fowls the usual seats are the tongue, the palate, the nasal cavities, the conjunctivæ, and the entrance of the larynx. The temperature of the affected animals is somewhat elevated. The disease runs its course as a rule within two or three weeks, and may at times last for some months with repeated exacerbations; 80 per cent. of the fowls affected die; of the pigeons, however, a smaller proportion. Young animals, and those belonging to pure breeds, are more especially predisposed to the disease.

Microscopical Loeffler* was able to isolate, from the exudation of a characters of the bacilli. pigeon which had died with these symptoms, bacilli which were only slightly longer and somewhat narrower than the bacilli of rabbit septicæmia, and were rounded at the ends, and usually occurred in groups. In sections of the lungs, and more especially of the liver, the rods were found in the interior of the blood vessels, forming Cultivations. masses similar to those of the typhoid bacilli.--On nutrient gelatine they form at the deeper parts whitish spheres, on the surface whitish layers; under a low power the colonies present a yellowish-brown appearance. On blood serum they form a grevish-white 
semi-transparent layer; on potatoes a deposit which is only distinguishable from the surface of the potato by having a somewhat greyer colour.-Pigeons inoculated Experiments subcutaneously with pure cultivations of these bacilli are attacked by inflammations ending in necrosis; after inoculation on the mucous membrane of the mouth a morbid process develops, which completely coincides with the natural infective disease. - Sparrows and rabbits are susceptible to the action of the bacilli; fowls, guineapigs, rats, and dogs are immune, or only show a transitory local affection. Mice show very characteristic effects; they die as a consequence of subcutaneous inoculation in about five days, and the short bacilli, described above, are found in the blood, and in all the organs, most numerous in the liver; they lie everywhere in the interior of the blood vessels, and often also in the interior of colourless blood cells. To the naked eye the peculiar character of the liver is most striking in the mice, as also the marked swelling of the spleen, and the patchy redness of the lungs; the liver has a marbled white appearance, due to the fact that in the pale red livertissue numerous white irregularly limited patches were present. Under the microscope no liver-tissue can be seen in the neighbourhood of these patches, and the nuclei do not stain at all; in the centre of the patches, however, there are dense masses of bacilli within the vessels, which have evidently led to the death of the surrounding tissue of the liver over a considerable area.As this post-mortem result is found in all the mice inoculated, we have in the inoculation of mice with these bacilli the best means of recognising them.

These bacilli must therefore be looked on as the exciting agents of pigeon diphtheria. As they were not found in human diphtheritic membranes, eren after the most careful microscopical examination, we must conclude that the two forms of diphtheria are not etiologically the same. The view that human beings can become affected with diphtheria from infection from diseased pigeons and fowls has been repeatedly expressed, but has been objected to by a number of 
Relation of pigeon diphtheria to human diphtheria.

authors (for example, Magnin*). Recently Gerhardt and Stumpf $\uparrow$ have published cases of infection of man from pigeon diphtheria; but in none of these cases has it been shown that the disease in man was true contagious diphtheria; on the other hand, it is probable that milder affections of the mucous membrane were present. It is possible that these affections might be caused by the diphtheritic bacteria of pigeons or fowls, especially as we know from the experiments on animals that many kinds of bacilli can set up diseases of the mucous membrane of the most various intensity, and even diseases. accompanied by the formation of membrane, and yet these affections cannot be included under the term contagious diphtheria; and further, severe diphtheritic attacks would be of much more frequent occurrence in man, in association with epidemics in poultry yards and among pigeons, if the infective agents in the two cases were identical. - Further, according to Loeffler's experiments, the diphtheria of fowls is apparently different from that of pigeons, and the etiology of the former is, as yet, not at all made out.

\section{Bacillus diphtheria vitulorum (Loeffler).}

Bacilli of the diphtheria of calves.
The diphtheria which occurs in calves in an epidemic form is characterised by great lassitude of the animals, flow of saliva, yellow exudation from the nose, imperfect Symptoms and attacks of coughing, and diarrhœa. On the mucous mempost-mortem brane of the cheeks, of the tongue, and of the hard palate, the diphtheria we find yellow deposits extending deeply into the tissue ;
of calves. often affected at the same time; and similar infiltrations have also been observed in the skin between the toes of the fore-feet. Death sometimes occurs on the fourth or fifth day, usually, however, the disease lasts for several weeks. On post-mortem examination we find besides these deposits similar alterations in the mucous membrane of the large intestine, and deposits in the lungs.

* Magnin, Gaz. des hôpit., 1879.

† Gerhardt, Lit., p. 18.-Stumpf, Deutsch., Arch.f. klin. Med., vol. 36. 
varying in size from a pea to a nut, of a greyish-yellow colour, and in part suppurating.-On microscopical examination of the deposits in the mucous membrane Loeffler* found, quite at the surface, numbers of all kinds of bacteria, more especially of micrococci; then follows a broad, unstained zone, the structure of which is unrecognisable, and in which there are no bacteria, and it is only close to the tissue itself that we find at first single, and then as we go deeper numerous long bacilli, ultimately arranged in long wavy bundles and dense masses, separated from the tissue by a narrow unstained zone on the further side of which we see a dense nuclear infiltration of the tissue. The majority of these Microscopical bacilli are united together to form longish threads; the characters of individual segments are about five or six times as long as broad; their thickness is about half that of the bacilli of malignant œdema. As Loeffler was able to demonstrate the presence of these bacilli with the same characteristic arrangement in seven cases of diphtheria in calves, we are justified in drawing a conclusion as to their causal connection with the disease from the constancy with which they occur.-Cultivation experi- Cultivation ments have as yet led to no result; nutrient jelly, without sheep's blood serum, \&c., have remained entirely sterile result. after inoculation; in calves' blood serum a whitish rim is formed around the pieces of organs which are planted on it, this ring consisting exclusively of the long bacilli, but attempts to inoculate fresh serum from this rim failed.-On the other hand, the fresh diphtheritic deposit was inoculated with success on mice, while guinea-pigs and rabbits did not show any characteristic disease. The mice died after 7 to 30 days; Inoculation on a greyish-yellow specliled infiltration extended from the seat of inoculation, involved the whole of the wall of the belly or back, reached often as far as the peritoneal cavity, and enveloped kidneys, liver, and intestine in yellow masses of exudation. Other mice could be successfully inoculated from this infiltration. In all the affected animals it could be shown by the microscope 
that, as in the case of the calves, the infiltration was occasioned by the long bacilli.-Further proof of the etiological rôle of these bacilli must be furnished by more extensive cultivation experiments.

Group of bacteria which set up gastroenteritis.
Later experiments with pure caltivations.

Another group of bacteria characterised by similarity in their pathogenic action is formed by those bacilli which set up a more or less severe gastro-enteritis in the animals ordinarily employed for experiments, such as dogs, rabbits, and guinea-pigs, the disease occurring when the bacteria are injected in relatively large numbers, either into the veins, or subcutaneously. Similar symptoms were formerly often obtained experimentally by the employment of mixtures of bacteria, and Virchow* observed, as long ago as 1847 , vomiting and diarrhœa with ultimate collapse, in animals after injection of a Earlierexperi- fluid obtained from putrid fibrin. Among more recent ments with mixtares of bacteria. writers we need only mention Popoff, $\uparrow$ who obtained similar results by the injection of a mixture of yeast, and also of putrid Pasteur's solution ; and Blumberg, $\ddagger$ who worked with putrefying dog's blood, and with the water employed for the maceration of dog's flesh, and set up violent vomiting and rapid death after intravenous injection, and milder and less constant symptoms after injection subcutaneously. On post-mortem examination of the animals, the severe cases showed the appearances of a hæmorrhagic gastro-enteritis with marked swelling, and often deep ulceration of Peyer's patches. In milder cases there was only hyperæmia of the stomach and intestines, and swelling of the follicles. After the elaboration of the methods for the pure cultivation of organisms, experiments have been made with different species of bacteria, and cultivations of these bacteria have set up the same morbid symptoms and the same anatomical appearances after intravenous, and sometimes after subcutaneous injection, as was done by the mixtures formerly employed.

* Handb. der spec. Pathol. u. Therapie, vol. i., p. 242.

† Berl. klin. Woch., 1872, Nr. 43.

$\ddagger$ Virch. Arch., vol. 100, p. 377. 
The effect obtained is, however, not, uniform, but varies according to the virulence of the individual species, as well as according to the number of bacteria introduced and the seat of their application. After symptoms in the injection of large quantities into the veins the the animals. animals become collapsed in a very short time and die in from one to three hours. Where smaller quantities are employed vomiting sometimes occurs, followed by profuse diarrhœa, the stools being often mixed with blood, and ultimately collapse, and death occurs after 12 to 24 hours. Some species of bacteria cause a passing diarrhœa, without any further bad result, after intravenous injection of very small doses or after the subcutaneous introduction of medium doses.-We cannot as yet properly explain this action of the bacteria. We do not usually find, either in the acute or in the protracted cases, any sufficient multiplication of the bacteria injected to explain the phenomena, and it has also been observed on some occasions that the same results follow the injection of sterilised cultivations. These two facts seem to indicate that we do not have here to do with the immediate action of the bacteria, but with the toxic effect of a substance which has been produced by the bacteria. More elaborate investigations will probably give us information as to this point.

The organisms which act in this way cannot be looked on in all cases as specific pathogenic organisms ; some of them are mainly saprophytes, or exciting agents of putrefaction, while many belong to the forms of bacteria previously described, which, when inoculated in small quantities, set up diseases, mostly forms of septicæmia, which run a slower course, but, on the other hand, when introduced into the blood stream in large doses, lead to the sudden illness just described. Thus, for example, we obtain these results with the Enumeration bacilli of rabbit septicæmia, in a very marked manner of the with the bacillus crassus sputigenus, the bacillus of longing to this pneumonia, and, among the bacteria which are chiefly saprophytic, with the bacillus ruber indicus. It must 
be mentioned that very many of the other kinds of bacteria, even the pathogenic kinds, when introduced even in very large quantities into the blood stream, do not produce this effect; thus the typhoid bacilli, bacillus tetragenus, the pyogenic cocci, the anthrax bacilli, and many others when introduced in enormous doses are either without effect, or set up specific diseases after they have gradually spread and multiplied in the body.

The following are some of the bacteria which set up these intestinal symptoms in the most marked manner :-

\section{Bacillus oxytocus perniciosus (Wyssokowitsch).}

Toxic lactic acid bacilli.

Experiments on animals.
These organisms were isolated by Wyssolkowitsch in the author's laboratory from milk, which had stood there for a considerable time. They present the form of short bacilli with rounded ends, somewhat thicker and shorter than the ordinary lactic acid bacteria. They form on gelatine plates at the deeper parts small yellow colonies, which under a low power have a circular appearance, are sharply outlined, finely granular, and brownish-yellow in colour. On the surface the colonies spread to the extent of about $1 \frac{1}{2} \mathrm{~mm}$., they are greyishwhite in colour, round, raised, and show under a low power a sharp outline, and light brown colour. In puncture cultivations a nail-shaped growth is formed at first, at a later period the cultivation extends superficially over the whole surface of the gelatine. In stroke cultivations a rapidly increasing deposit is formed of a yellowish-white, or greenish colour.-A small quantity of the cultivation added to sterilised milk causes coagulation and acid reaction within 24 hours. Neither the milk nor the cultivations have any odour.-Small doses inoculated on mice or rabbits have no effect at all. Mixtures prepared from one or two test tubes, and injected into the aural vein of rabbits, caused in each of six cases death within three to twenty-two hours. Violent diarrhœa set in about three-quarters of an hour after 
the injection. On post-mortem examination there was found in all cases intense and often hæmorrhagic inflammation of the intestinal mucous membrane.

\section{Bacillus cavicida (Brieger).}

These organisms present the form of very small rods Brieger's about twice as long as broad; they were isolated by bainea-pig Brieger* from human fæces. They form colonies on nutrient jelly composed of irregular concentric rings; the cultivations present an appearance resembling that of the scales on the back of a tortoise. On potatoes they form, pretty quickly, dirty yellow masses. Guineapigs are killed without exception within 72 hours by the subcutaneous inoculation of the most minute quantities of the cultivation; rabbits and mice are for the most part immune ; if guinea-pigs are fed with the cultivation no bad result follows. Koch $†$ has stated that the guineapigs killed by subcutaneous injection show alterations in the small intestine, marked injection of the mucous membrane, and a large quantity of thin fluid contents; in short, similar symptoms to those formerly obtained by the subcutaneous injection of mixtures of bacteria.

\section{Bacillus coprogenus parvus (Bienstock).}

This is an extremely small slowly-growing bacillus, Bienstock's obtained by Bienstock on several occasions from human small bacillus fæces. They are only slightly longer than broad, so that it is only under high powers that the rod form can be distinctly seen; they grow very slowly on nutrient jelly; in the course of weeks the cultivation extends from the line of inoculation to a distance of scarcely $1 \mathrm{~mm}$., and forms a scarcely visible layer on the nutrient soil.-If white mice are inoculated with a cultivation marked œdema occurs in the neighbourhood of the seat of inoculation within 10 hours; the animals die 24 hours later; after death the bacilli can be demon-

* Zeitschr.f. physiol. Chem., vol. viii., p. 308.

† Conferenz zur Erörterung der Cholerafrage, 2 Jahr. 
strated in small numbers in the blood of the heart. A rabbit showed after inoculation on the ear erysipelatous swelling, followed by profuse diarrhœa, and death occurred eight days after inoculation. On post-mortem examination catarrh of the intestinal mucous membrane was the only abnormal condition found.-Further experiments on animals with this bacillus are desirable.

\section{Bacterium coli commune (Escherich).}

Microscopical These bacilli were obtained by Escherich* from the characters. fæces of children nourished exclusively with their mothers' milk. They are short, slightly curved rods, their length varying from 1 to $5 \mu$., and their breadth from 3 to $4 \mu$. They stain intensely with aniline colours, but do not retain the stain when Gram's method is employed. When examined in drop cultivations they Cultivations. show slight mobility. On nutrient jelly the deeply seated colonies present the form of yellow granular discs; the superficial ones show a white lateral extension with a homogeneous granular appearance, or starshaped and wrinkled. On agar and blood serum they grow in the form of white deposits; on potatoes they form a soft layer of the colour of maize or yellow peas. The bacilli slowly coagulate milk with the formation of acid; in solutions of grape sugar they set up fermenta-

Experiments on animals. tion.-When a piece of a cultivation on potato about the size of a lentil is mixed with sterilised water, and injected into the veins of the neck of rabbits and guinea-pigs, the animals die after a few hours, or at latest after three days, with symptoms of elevation of temperature and violent diarrhœa. On post-mortem examination the duodenum and the upper coils of the small intestine show a rose-coloured hyperæmia, while the cæcum and colon have usually a normal appearance; Peyer's patches show alterations similar to those seen in the early stage of typhoid fever. In some cases we also find injection of the peritoneum and exudation into the peritoneal cavity. Subcutaneous injection of larger doses produce the same effect in guinea-pigs.

* Fortschritte der Medicin., vol. iii., 1885, Nr. 16. 


\section{Bacterium lactis aërogenes (Escherich).}

This organism was found, along with the previous A second one, in the frees of infants. It consists of short bacillns from generally constricted rods with rounded ends, on an infants. average $1 \cdot 4$ to $2 \mu$. in length, and $\cdot 5 \mu$. in breadth, as a rule occurring singly either as rods constricted in middle, or as pairs of rods; not motile. These organisms Cultivations. grow on nutrient jelly like the pneumonia bacteria; in plate cultivations they form round colonies, which spread on the surface and form raised points of a porcelain white colour. In puncture cultivations they grow luxuriantly along the track of the needle, the needle track being filled with a number of small white spheres arranged like a string of beads with, at the upper part, a knoblike swelling; at the surface the colonies show a limited growth, arched like the head of a pin, and of a soft consistence. On potatoes they form a whitish-yellow creamy layer full of gas bubbles. Milk coagulates with the for- Formation mation of lactic acid in the course of 36 to 48 hours, at lactic acid. the ordinary temperature; in solutions of milk sugar and grape sugar the organisms cause intense fermentative action. In sugar solutions they appear to form terminal spores. When sugar is present the bacteria are also able to grow when oxygen is excluded, and at the same time to cause fermentation, while without sugar they cannot live in the absence of oxygen.-Experiments Need for on animals gave the same result as with the species oxygen. previously mentioned, but the action was somewhat less intense.

\section{Bacillus Neapolitanus (Emmerich).}

A bacillus which appears to belong to this group of Bacillusfound bacteria was isolated by Emmerich* during the epidemic by Emmerich of cholera in Naples, in 1884, from the organs, and the bodies of later from the intestinal contents of patients who had patients who died of cholera. This organism presents the form of cholera. short rods, with rounded ends, about $9 \mu$. in breadth,

* Emmerich, Arch. f. Hygiene, vol. iii., $3 \& 4$ Heft.-Buchner, ibid. 
Microscopical and at times forming egg-shaped or even more elongated characters. cells, without or with very slight spontaneous movement. In certain nutrient solutions (cane sugar, extract of meat, and peptone) longer rods and threads are formed, according to Buchner; in glycerine jelly various involution forms appear, characterised by slight thickening of the rod, and by staining only at the ends.-On

Cultivations. gelatine plates the bacilli form colonies in the substance of the jelly, which present the appearance, under a low power, of round, and later irregular, alniost egg-shaped colonies with sharp outlines, of a brownish-yellow colour, highly refracting, and distinctly granular in the interior. On the surface of the gelatine the colonies spread to about ten times the diameter of the deeper ones, and lie on the surface like scales, of a cartilaginous or ground

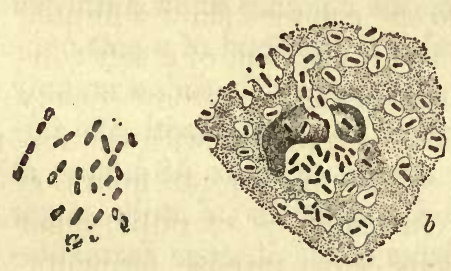

Fig 92.

a. Preparation from a piece of mucus from the rice water contents of the human intestine $\times 700$.

b. Preparation from the peritoneal exudation of a guinea-pig which had died after subcutaneous injection of the Naples bacteria (stained with aniline fuchsine) $\times$ 700. (Both after Emmerich.)

glass appearance, showing rainbow colours with transmitted light. Under a low power it can be seen that the limiting line is markedly irregular or lobular; the interior shows two zones, a peripheral one, clear, colourless, faintly granular; and a central one, yellowishbrown towards the middle, and equally granular. Where the colonies are more markedly developed, we can also notice radially arranged, though but slightly marked furrows (Buchner*). -On potatoes the bacilli grow at $37^{\circ} \mathrm{C}$., in the form of a brownish-yellow gelatinous layer.

Experiments on animals.
When Emmerich injected large quantities of the pure cultivations of this organism under the skin, into the lungs, or into the peritoneal cavity of guinea-pigs, death occurred in from 30 to 42 hours, and, on examination, hyperæmia of the intestinal and gastric mucous membrane, and even hæmorrhagic erosions and superficial

* Arch.f. Hygiene, vol. iii., 3 Heft. 
sloughs on Peyer's patches were found. Where the dose was smaller the course of the disease was more protracted, and in these cases the ulcerations in the intestine were more extensive and deeper. If the cultivations were injected into the peritoneal cavity death generally occurred in 8 to 10 hours.-Cats were less susceptible, relatively larger quantities of the cultivation being required in order to cause infection; and still larger quantities were necessary in the case of dogs and rabbits. Of the dogs infected only one died on the third day, while the others recovered after being ill for several days. A monkey died after 42 hours, and showed similar alterations in the intestine; Peyer's patches were of a dark brownish-red colour, and distinctly swollen. The guinea-pigs as a rule passed pulpy motions during life; the cats suffered from vomiting and diarrhœa; the monkeys had also vomiting, with repeated watery stools.-From the results of the experiments on animals, and of the proof furnished by cultivation that the bacilli were present in the blood and in all the organs of nine patients who had died of cholera, and that they were also present in the blood of patients in the last stage of the disease, Emmerich has come to the conclusion that these organisms are the exciting agents of cholera. Nevertheless, the results of the experiments on animals did not differ in any important particular from those obtained by the numerous forms of bacteria mentioned above and the method employed by Emmerich to demonstrate the presence of bacilli in the organs was by no means free from error. In more recent investigations made on Occurrenee of eight cholera bodies in Palermo, Emmerich and Buchner the bacilli in were unable to confirm the occurrence of these organ- of patients isms in the blood and in the internal orouns, but found suffering from them chiefly or only in the intestines and lungs.

It is evident that the presence of these organisms in the intestines of cholera patients can only be of significance if it is shown that the same bacillus is not present in the normal intestine, nor in intestines in which any other pathological process is going on. Such 
proof, however, does not appear to have been furnished; Occurrence of in Koch's laboratory, as well as in the author's, a bacilli in the bacillus has been repeatedly isolated from the intestinal normal in. testine.

contents of man and animals which is absolutely identical with that described by Emmerich both as regards microscopical characters, growth in cultivations, and pathogenic action. (The bacterium coli commune obtained by Escherich from the intestinal contents shows according to the description only very unimportant differences, due probably to differences in the nutrient substratum, and it is possibly identical with the bacillus of which we are speaking.) Hence there is no ground for the assumption that Emmerich's bacilli play any etiological rôle in the cholera process ; on the contrary, they represent a species of bacterium which occurs frequently in the intestine, and which corresponds in its pathogenic action on animals with other intestinal bacteria.

\section{Bacillus necrophorus (Lœfller).}

Loeffler's

bacteria which

This organism was obtained by Loeffler,* by the cause necrotic inoculation of small particles of broad condylomata into processes. the anterior chamber of the eye of rabbits. The bacilli are of varying length, but of uniform thickness, and they often form long thin threads, with a slightly wavy

Cultivation experiments. outline. They do not grow on the ordinary nutrient media, only slightly in horses' serum and in chicken broth, and best in neutralised rabbit broth. A whitish down is formed after about 3 days around the pieces of the organs which are placed in the rabbit broth, so that the particles of tissue appear as if they were enveloped in cotton wool; after a few days numerous white flakes are seen floating in the fluid consisting exclusively of a dense network of these bacilli, which have grown in the form of long threads. Here and there swellings are found in the threads which may be looked on as involution forms, and there are in addition light stained spots,* which, however, do not, on the whole, give the impres: Inoculation on sion of spores. - If rabbits are inoculated on the ear, or rabbits.

*. Mitth. a. d. Kaiserl. Ges. Amt., vol. ii., p. 493. 
into the anterior chamber of the eye, with a piece of the growth, or with a portion of an affected organ, they die on an average after about eight days ; at the seat of inoculation necrotic caseous processes are found, and in the lungs there are deposits surrounded by hæmorrhagic pneumonia, or accompanied by necrosis of the whole of the affected portion of the lung; there are also deposits in the heart. Where these deposits have reached the surface of the organs they cause exudation on the serous membranes. The alterations are chiefly limited to the lungs and heart, and it is only seldom that nodules are also found in the abdominal organs. In all these morbid products the same thin bacilli were constantly present.-White mice die after inoculation in six days; On mice. at the seat of inoculation there are greenish-yellow masses infiltrating the muscular tissue of the back over a large area, extending deeply into the muscles of the thigh, and ultimately reaching the peritoneum. In sections of the tissues which are altered in this way, long bundles of these bacilli are seen.

\section{Bacillus parvus ovatus (Loeffler).}

In a pig which had died of a disease resembling Bacilli of erysipelas, Loeffler * found on microscopical examination pseudoof the œdematous skin, and also of the liver and kidneys, swine. large numbers of small ovoid bacteria, sometimes recalling in form the bacilli of rabbit septicæmia, more especially in those forms which are undergoing division, Microscopical but distinguished from these organisms by the fact that characters. the latter are almost twice as large. In sections the organisms are best demonstrated by staining with alkaline methylene blue, and subsequent treatment with $1 \frac{1}{4}$ per cent. of acetic acid; in the skin they are arranged in rows following the bundles of the connective tissue. They grow readily in various nutrient Cultivation. media, in rabbit broth and blood serum; in nutrient jelly they develop somewhat better at the point of entrance of the puncture than along the needle track,

* Arbeiten a. d. Kaiserl. Ges. Amt., vol. i., 1885, p. 51. 
and around the point of entrance they form a greyishExperiments white wall, presenting a dry appearance.-After subon animals.

cutaneous inoculation, mice die in about 24 hours, and show on post-mortem examination œdema of the subcutaneous cellular tissue, swelling of the spleen, patchy redness in the lungs, and the same bacteria in all the organs. Rabbits also die quickly, and present the same post-mortem appearances as animals which have died of rabbit septicæmia. Guinea-pigs die after 1 to 3 days, and show extensive sero-sanguineous œdema of the subcutaneous tissue, and of the muscles. Fowls, pigeons, and rats proved insusceptible; on the other hand, in a pig the same disease, terminating fatally in 2 days, was produced as that which had formed the starting point of the investigation, the disease being characterised by enormous œdema of the skin, bluish-red colouration of the abdominal wall, and hyperæmia of the gastric mucous membrane, but without.alteration in the rest of the intestine or the mesenteric glands, and being thus distinguished from true swine erysipelas.

\section{Bacillus tetani (?).}

Tetanus bacilli.

Distribution in the soil.
In the Göttingen Hygienic Laboratory, Nicolaier made the observation that when garden earth was introduced under the skin of mice and rabbits, these animals frequently developed a series of symptoms which may be shortly designated as tetanic. For the peculiar bacilli found in the pus in these animals the name "tetanus bacilli" may for the present be retained, although it is doubtful whether these organisms are to be looked on as the specific exciting agents of that disease.-In all, over 30 different kinds of earth from fields, gardens, and streets were investigated; the animals frequently developed malignant œdema after inoculation, and died of this disease in from 24 to 36 hours; at times kinds of earth were found, the inoculation of which caused sometimes malignant œdema and sometimes tetanus; some kinds of earth, particularly earth taken from the deeper lajers, from the soil in forests, \&c., had no hurt- 
ful action; a larger proportion, more than half of the specimens investigated, caused always, or almost always, tetanus. In the case of mice about as much as lay on the point of a pen-knife, in the case of rabbits four or five times this quantity, was introduced into a small pocket in the skin, made on the back or thigh; in rabbits the wound was closed by one or two stitches.

After an incubation period of $1 \frac{1}{2}$ to $2 \frac{1}{2}$ days the Course of the earliest symptoms of the disease appear, consisting in slight abduction and stretching of the hinder extremity which is nearest the seat of inoculation, the limb soon becoming completely stiff. In the course of a few hours the hinder extremity on the other side is similarly affected, and then follow the anterior extremities. Ultimately the animals become quite helpless, and generally lie on their backs, while intermittent spontaneous contractions of the extensor muscles of the neck and back occur, in which the head is bent backwards, and the posterior part of the body is raised from the surface on which it is resting, the body thus describing a convex line. These attacks can, however, be set up artificially, and may even be caused by knocking the table, or by a slight touch. Breathing is difficult in this stage, the pauses become constantly longer, and finally respiration ceases, and death occurs. In the case of rabbits well developed trismus can be observed. Mice die on an average at the end of 3 days; rabbits, in whom the incubation period usually lasts from 3 to 5 days, die from the 5 th to the 7 th day after inoculation; guineapigs are also susceptible; dogs, on the other hand, are completely immune.

On post-mortem examination of animals which have Post-mortem died with these symptoms, a relatively small amount of appearances. pus of a peculiar musty disagreeable odour is found at the seat of inoculation. Besides this, however, no important or constant pathological alteration is noticeable in any organ, in the trunks of the nerves, or in the spinal cord. Microscopical examination of the blood and internal organs was also almost entirely without result; but in the pus at the seat of inoculation fine 
bacilli were constantly present which were somewhat Morphological longer, but scarcely thicker than the bacilli of mouse septi-
characters of the bacilli. cæmia, which form at times threads, and at times irregular groups, and which show a characteristic mode of spore formation. In the first place they become more or less equally thickened, then one end swells more markedly, finally an oval refracting spore with sharp outlines is formed at this end, while the rest of the bacillus remains as a thin thread, three or four times thinner than the spores. Numerous free spores are also usually present in the preparations. The same bacilli were found not only in the pus, where they were always mixed with other species, but also in the immediate neighbourhood of the seat of inoculation, and in the pyogenic membrane.

Experiments with sterilised earth.

Inoculation from animal to animal.
These bacilli could not be directly demonstrated in the earth. That, however, micro-organisms were the cause of the infective properties of the specimens of earth was evident from the fact that the same specimens when heated to $190^{\circ} \mathrm{C}$. were completely without effect, even when introduced in very large quantities. Further, the disease with all its characteristic symptoms could be transmitted from animal to animal. The pus proved to be the most virulent material; much smaller quantities of pus than of the original earth were required; a very minute loopful of pus introduced beneath the skin was sufficient to set up a more rapid and intense tetanus in mice after a shorter incubation period. Under these circumstances mice died in 24 to 36 hours, and rabbits in 3 to 4 days. - The disease could also be set up in healthy mice and rabbits by inoculation with the blood and organs (liver, spleen, spinal cord) of the animals which had died; but this was only successful when larger quantities of the material were employed, and even then the result was not constant, but only occurred in about a quarter of the cases. When it occurred, however, the whole group of symptoms were developed, and the case terminated fatally.

Cultivations. Nicolaier was able to cultivate the infective organisms in blood serum at the body temperature, without, however, obtaining a pure cultivation. The mixture of 
bacteria, which developed in the depth of the blood serum and not at the surface, proved, even when carried through nine cultivations, to be very virulent, and when introduced under the skin of mice and rabbits with a little wool or with a syringe, to the amount of $\frac{1}{2}$ to 1 drop, set up severe and fatal tetanus. He did not succeed in purifying these cultivations by the ordinary methods, but the growth obtained consisted chiefly of the fine bacilli above described with terminal spores; the virulent organisms were typical anaerobes, and could not be cultivated at all on gelatine or agar plates. In order to obtain a pure cultivation of these bacilli it was necessary to employ entirely new methods, in some ways more complicated, and with regard to which a report will be shortly published in the Zeitschrift fiir Hygiene.

Carle and Rattone have recently excised the seat of Transmission infection shortly after death from a patient who had of human died of tetanus, and they injected an emulsion made animals. from the tissue into the dorsal muscles or into the spinal canal of rabbits; 11 out of 12 animals became affected with typical tetanus after two or three days' incubation, and this disease corresponded absolutely in its symptoms and course to that produced by Nicolaier, and could be transmitted from animal to animal by inoculation of portions of the sciatic nerve. Thus the assumption becomes more probable that even in many cases of traumatic tetanus in man the infective agents discovered by Nicolaier are concerned in the disease. We must, however, await further investigations on this point.

\section{Bacillus alvei (Watson Cheyne).}

The etiology of the so-called foul brood of bees, a Bacilli of disease in which an organism has been repeatedly sus- foul brood of pected to be the causal agent, has been recently cleared up in the manner which was to be expected by Watson Cheyne and Cheshire.* The infective agents were iso-

* Frank R. Cheshire and W. Watso Cheyne Journ. of the Royal Microscop. Soc., 1885, 11, March. 
lated by first purifying the surface of a diseased comb containing in its interior affected larræ with sublimate solution, and then opening the cells with heated instruments; small portions of the dead and almost fluid larvæ were then employed for microscopical examination and for cultivation; by both methods a very characteristic bacillus was found alone and in large numbers.

Morphological The bacillus alvei is $3.63 \mu$. in length, and $83 \mu$. in characters.

breadth; the length of the organism in cultivations varied between 2.54 and $5 \cdot 08 \mu$. The ends of the bacilli are rounded or pointed. Slow spontaneous movement

Method of studying the formation of spores. can be noticed in many bacilli. They form very large spores, usually preceded by a swelling of the bacillus in a spindle-shaped form; these spores are $2 \cdot 12 \mu$. in length, and $1.07 \mu$. in breadth, and are thus broader than the bacillus and occupy more than half its length. The spores do not take up aniline colours, but the bacilli can be readily stained; when the spores are commencing to sprout, which occurs after they have become elongated at one pole, they again take up the colouring matter. Watson Cheyne has been able to study the formation of spores, and to follow accurately their mode of sprouting, by setting on foot numerous drop cultivations, some from material containing only bacilli, and some from material containing only spores, and after these cultivations have been kept at the body temperature for varying lengths of time $(10,20,40,60$ minutes, \&c.), taking off the cover glass, drying and staining it. The series of permanent preparations so obtained, replaced in a more complete manner the continued observation of one and the same cultivation. 
The bacilli grew well at $20^{\circ} \mathrm{C}$., on various nutrient Cultirations. media; in gelatine plates they form at first small round or oval dises, in which, with a low power, peculiar markings, occasioned by the bundles of bacilli, is noticable. The colonies become gradually pear-shaped, and from the pointed end of the pear prolongations begin to shoot out into the gelatine. These prolongations can be still better studied in stroke cultivations on gelatine plates. In that case growth in the first place occurs
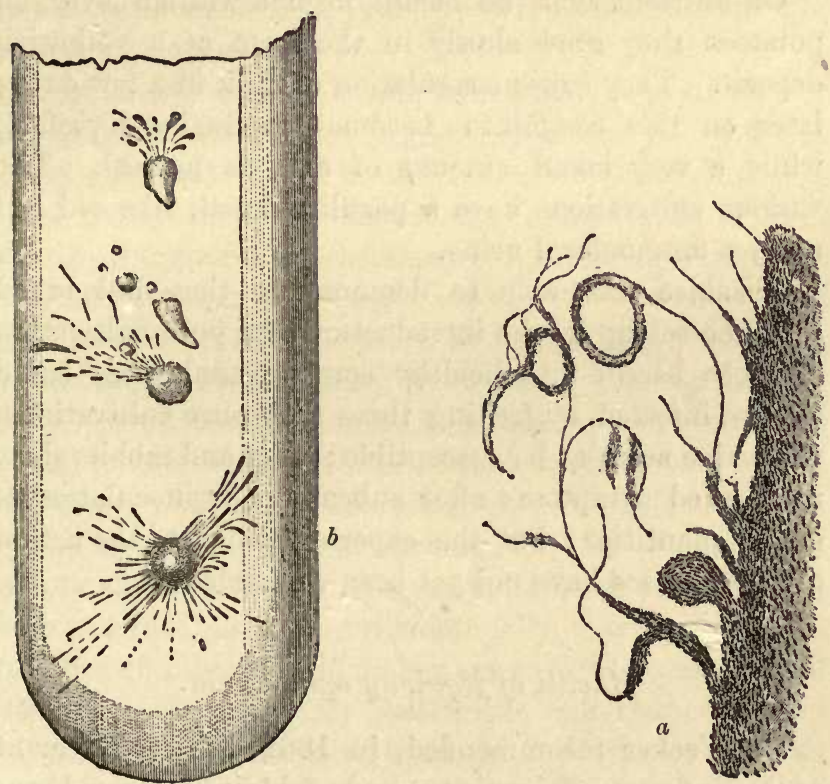

Fig. 94.-Cultivation of bacillus alvei.

n, growth on gelatine plates $\times 80$.

$b$, puncture cultivation in nutrient jelly $\times 4$.

along the track of the needle; but soon small lateral projections appear, and from these bands of bacilli grow out often in a single row, often two or three bacilli side by side; these projections gradually curve, and form well-marked circles; from these circles new projections proceed; the individual branches also anastomose with each other. In the immediate neighbourhood of the bacilli the gelatine becomes at the same time fluid, so that ultimately there is a network of fine canals in the 
gelatine. In puncture cultivations the same growth appears at the surface, but along the track of the needle white irregular clumps are formed, from which fairly coarse branches radiate, often thickened and club-shaped at the end, and varying much in direction and length. In the older cultivations the fine branches disappear, so that the connection between the primary and secondary centres is apparently lost; ultimately, the gelatine becomes gradually liquefied all around the colony.

On nutrient agar the bacilli form a whitish layer, on potatoes they grow slowly in the form of a yellowish deposit. They cause coagulation of milk in a few days ; later on this coagulum becomes gradually liquefied, while a very small amount of acid is formed. The various cultivations have a peculiar smell, like old but not yet ammoniacal urine.

Experiments on animals.

Cheshire was able to demonstrate that foul brood could be set up by the introduction of a pure cultivation of these bacilli into healthy combs; adult bees could also be infected by feeding them with pure cultivations. Flies also seem to be susceptible; mice and rabbits show no marked symptoms after subcutaneous inoculation of small quantities; but the experiments as to the action of larger doses have not yet been concluded.

\section{Bacilli of jequirity ophthalmia.}

Therapeutic employment of jequirity infusion.
De Wecker recommended, in 1882, the employment of an infusion of jequirity seeds (obtained from Abrus precatorius, a shrub which occurs in Southern Asia and in Africa, and which has been transplanted to America, and belongs to the family of the leguminosa) in order to set up inflammation and suppuration of the conjunctiva in cases of granulations and pannus, these troubles being, as we know, frequently cured by these means. The views of practitioners are at present divided as to the therapeutic value of this substance; it has chiefly attracted attention from the fact that some observers have referred the action of jequirity to specific bacilli.

The infusion employed is very dilute ( $\frac{1}{2}$ to 1 per 
cent.), and is prepared by maceration of the pounded Preparation of seeds with cold water for 24 hours, and subsequent the infusion. filtration (at the temperature of the body the infusion obtained is much weaker). If a few drops of this infusion are introduced into the eye of man or rabbits symptoms of irritation commence even after 3 hours; after 16 hours all the appearances of a severe ophthalmia are present, the conjunctiva becomes covered with a thick, greyish-yellow, firmly adherent membrane, and it is not till 5 or 6 days that the symptoms subside and recovery talies place.

Sattler has found bacilli constantly present in the Sattler's jequirity infusion, these organisms being 2.5 to $4.5 \mu$. jequirity in length, and $58 \mu$. in thickness; they are partly at rest, partly in active movement; they form distinct spores, the spores in the shorter rods being formed at the poles, and in the longer also in one or two parts of the middle of the bacillus; at times longer threads, containing rows of spores, are found. The bacilli at a later period become united together in the form of a scum on the surface of the infusion; they are typical aerobes. The spores are relatively resistant, and withstand in the dry state heating to $110^{\circ} \mathrm{C}$. for five minutes. The bacilli can be cultivated on solidified blood serum and on nutrient jelly, as well as in a number of other media; they cause liquefaction of the gelatine. According to Sattler the cultivations set up conjunctivitis when inoculated on the eyes of rabbits, though to a markedly less degree than the jequirity infusion and without the formation of membrane observed when the latter is employed.

Cornil and Berlioz believe that they were able to Infection of demonstrate infective properties in the jequirity bacilli, $\begin{aligned} & \text { frogs and } \\ & \text { warm-blooded }\end{aligned}$ these properties appearing after subcutaneous injection animals by of infusion containing the bacilli into warm-blooded infusion animals, and into frogs. In the case of frogs the injection of one drop of a 2 to 4 per cent. infusion into the dorsal lymph sac sets up a disease which ends fatally within a few days with symptoms of increasing muscular weakness; on post-mortem examination we find sub- 
Disproof of the reasons for assuming the existence of a parasitic action of the jequirity infusion.

cutaneous œdema, ecchymoses in the intestinal mucous membrane, and often large quantities of bloody fluid in the peritoneal cavity. The jequirity bacilli are present in the blood in large numbers. If such blood is injected into another frog, the latter animal dies with the same symptoms. In the case of mice, rabbits, guinea-pigs, and fowls, extensive œdema occurs after subcutaneous injection of the infusion, and severe pleuritis or peritonitis, as well as infarcts in the liver and lungs after injection into the pleural or peritoneal cavities. If the infusion is injected directly into the veins of rabbits, the animals die in a short time, often even after one hour. If the infusion containing the bacilli was filtered through a porcelain filter, the filtrate was found to be without effect.

In spite of these apparently convincing experiments, it has, nevertheless, been most definitely demonstrated by Neisser, Bordet, Widmark, Klein, Bruylants, and Vennemann, and especially by Salomonsen and DirckinckHolmfeld, * that no specific bacteria are concerned in the action of the jequirity, but that the effect is due to the presence of a soluble poisonous substance in the seeds. It was shown that infusions free from bacilli prepared with sterilised water and with the employment of the usual precautions exerted the same effect on the eye, and after subcutaneous injection on the body generally of frogs and warm-blooded animals; further, neither microscopically nor by cultivation could bacilli be demonstrated in the secretions of the affected eyes; and pure cultivations of the bacteria which occur in jequirity infusion either produced no effect on animals, or set up, when repeatedly applied to the eyes of rabbits, at most a mild inflammation which could also be produced by other bacteria not peculiar to the jequirity infusion. More accurate experiments also demonstrated that the

* Neisser, Fortschr. de Med., Bd. 2, Nr. 3.-Bordet, Le Jéquirity. Lyon, 1883. Thèse.-Widmark, Om Jequirity Oftalmien. Stockholm, 1843.-Klein, Centralbl. $f$. d. med. Wiss., 1884, Nr. 8.-Bruylants and Vennemann, Bull. de l'Acad. de Méd. de Belg., 3 sér., Bd. 18.-Salomonsen nnd Christmas Dirckinck-Holmfeld, Fortschr. d. Med., Bd. 2, Nr. 15 u. 19. 
jequirity ophthalmia could not be conveyed to liealthy eyes by pus or pieces of the membranous exudation, that further the blood of frogs containing bacilli or the œdematous fluid of warm-blooded animals infected with jequirity by no means always causes infection in other animals; on the contrary, it was only possible to transmit the disease in this way when the animals first infected were inoculated with such large doses of a concentrated infusion that in the second transmission a considerable portion of the original infusion was carried over. Cornil and Berlioz, who were the first to observe the transmission of the jequirity disease from one animal to another, have worked with these great concentrations, and hence have obtained an apparent reproduction of the virus, which, however, does not take place if the first infection is caused by smaller doses and less concentrated material.

All these observations imply that the actire agent of The action the jequirity seeds is not a virulent micro-organism, depends cn but a soluble poison, and, as a matter of fact, Salomonsen poison, and Dirckinck, and likewise Bruylants and Vennemann, succeeded in obtaining a poisonous material of this character in a concentrated form by extracting the pounded seeds with glycerine. The glycerine extract was precipitated with alcohol, the precipitate dried, extracted with water, again precipitated, and then dissolved in water or glycerine. These solutions of jequiritine had an extremely intense action, even the quantity contained in $\Gamma_{10}^{\frac{1}{0}}$ th millegramme of jequirity seeds being sufficient to set up marked conjunctivitis in rabbits, and the extract when injected subcutaneously rapidly causes the death of mice and frogs. Thus it is clear that the action of the jequirity seeds is only due to the presence in them of a poison soluble in water and glycerine, insoluble in alcohol, ether, benzine, and chloroform, and completely deprived of its power by keeping it for one hour at a temperature of $65^{\circ}$ to $70^{\circ} \mathrm{C}$.

Against the explanation of all the jequirity symptoms as the result of the action of an unorganised virus, we have only the observation made by Cornil and Berlioz 
Length of life that numerous bacilli are constantly present in the of various kinds of bacteria when injected into living frogs, at the same time that jequiritine is introduced.

blood of the infected frogs, as well as in the pathological secretions of warm-blooded animals. Salomonsen, however, was able to demonstrate that we had not here to do with the so-called jequirity bacilli, and that the species of bacteria found in the blood may be varied at will, according as one or other species is intentionally allowed to develop in the jequirity infusion. Salomonsen succeeded in obtaining multiplication of bacillus prodigiosus of the bacilli of blue milk, \&c., in the blood of frogs in the same manner as of the bacilli ordinarily present in jequirity infusion. The reason of this striking preservation and multiplication of bacteria in the interior of the body must be sought for in the action of the jequiritine, for it is only when this substance is at the same time introduced in sufficient amount into the animals that this multiplication of bacteria in the blood takes place.

Whether the so-called jequirity bacilli are a separate species of bacteria, or whether they are identical with some other well-known saprophyte, perhaps with one of the socalled hay bacilli, cannot as yet be determined from the statements which have been made with regard to their mode of growth and their morphological characters.

Bacilli causing erysipelas in the ear of rabbits. - In sections from an erysipelas of the ear which occurred in a rabbit after injection of softened fæces of mice, Koch found large numbers of thin bacilli, $3 \mu$. in length, and $3 \mu$. in thickness, they also formed threads up to $10 \mu$. in length. No experiments were made at that time (1878) as to the infective character and mode of growth of the bacilli.

Bacillar necrosis of the liver (Eberth).-This disease was only met with on one occasion accidentally in a guinea-pig. In the liver and spleen small greyish-yellow firm nodules were found; the lower portion of the liver was for the most part of a gelatinous appearance, and in a state of complete necrosis. In the necrotic tissue there were innumerable bacilli which stained by Gram's method, were rounded at the ends, and of an elongated egg-shape ; they often showed the presence of spores, either at their ends or in the middle, 
usually one, but at times two in number, and the bacilli containing the spores were swollen in the form of a spindle or whetstone. Experiments on rabbits were unsuccessful.

\section{Bacilli which have no known Specific Pathogenic Properties.}

In the course of the last few years a very large number of different kinds of saprophytic bacilli have been discovered, of which some have been shown to be without any pathogenic action on the higher animals, while with regard to others the absence of pathogenic properties has not yet been tested, or has not yet been demonstrated with certainty. Hence the possibility must be liept in mind that in future many of the bacteria grouped together under this heading will subsequently be included in one of the preceding groups when their characters have been subjected to more accurate study.

Among the saprophytic bacilli we know some which Classification attract attention at once by the fact that they produce of the sapropigment; others set up fermentation in mixtures containing carbo-hydrates; others are able to split up albumen, and thus take part in the process of putrefaction; with regard to others, again, no marked action on the substratum has as yet been observed. In the following description certain groups have been formed in accordance with the above facts, but these are only temporary, and are employed to simplify their study. A number of bacilli belong to several of these divisions, on account of the multiplicity of their functions-production of pigment, along with simultaneous decomposition of albumen or sugar-and in the case of others a similar multiplicity of properties will probably be found. Hence this classification is more or less arbitrary, and it must be left to the judgment of the individual in which group such bacteria should be placed. 
To the bacilli which produce colouring matter belong :-

\section{Bacillus prodigiosus.}

(Micrococcus prodigiosus, monas prodigiosa.)

M:crosecpical character. .

These are elliptical cells, about $1 \mu$. in their greatest diameter, distinctly rod-shaped before division, and at times forming pseudo-threads. When the multiplication is rapid the short egg-shaped cells predominate; but their contour is seen under a high power to present the form of an oblong with rounded ends, and not that of a circle or ellipse. This circumstance, taken in conjunction with the observation that when they grow slowly, distinct rods and threads appear, renders the previous designation of these organisms as micrococcus no longer tenable.

Cultiva'io

Bacillus prodigiosus grows very rapidly in nutrient jelly. In plates lept at $20^{\circ}$ to $22^{\circ} \mathrm{C}$., the deeply lying colonies are evident after 20 hours as light grey points, the superficial ones as light grey dises of about $1 \mathrm{~mm}$. in diameter, which are somewhat depressed and surrounded by an area of liquefied, but perfectly clear, gelatine, about $2 \mathrm{~mm}$. in diameter. Under a low power the deep colonies are seen to be round or oval with sharp outlines, of a light reddish-brown colour, clear and transparent at their margin. The superficial colonies present an irregular rough outline, a granular surface, and a light greyish-brown colour in their middle, darker towards the periphery.-The liquefaction of the gelatine goes on so rapidly that after a few hours the whole material on the plate is fluid; this fluid, as well as filter paper impregnated with it, gradually assumes a bright red colour; before the gelatine is completely liquefied, the colonies themselves show only very little of the red coloration. As the gelatine plates of the bacillus prodigiosus require great attention in order that they may be examined before they have become completely liquid, it is on the whole better to employ agar. The agar is not liquefied, and on this material 
the colonies, which are at first white, may be allowed to grow till their surface presents a distinct red colour. In puncture cultivations in gelatine there is rapid liquefaction and formation of a reddish deposit; in puncture cultivations in agar, colourless colonies develop sparingly along the track of the needle, while on the surface the growth extends towards the margin of the material, and gradually assumes a deep red colour.

Bacillus prodigiosus grows very well on potatoes; on this material an intensely blood-red, moist layer is formed, growing with a luxuriance and a production of a bright colour not found in the case of any other bacterium. When the cultivation has been kept for some time, the surface of the red deposit presents a greenish shimmer, similar to the appearance of crystals of fuchsine.-Growth also occurs on a great variety of other vegetable substrata, it also takes place in milk, and in the latter material the oil globules contain the red colouring matter in solution.

The bacilli themselves are colourless. The pigment Characters of is insoluble in water, but soluble in alcohol; its soluthe pigment. tion shows a characteristic absorption band both in the green and in the blue portions of the spectrum. By the addition of acid the colour changes to a carmine red, and then to violet; when an alkali is added it becomes yellow. The colouring matter is only formed when the colonies of fungi are in contact with free oxygen. Hence the more deeply seated colonies, and those which develop along the track of the needle in puncture cultivations, are colourless.-Not only do these bacilli produce pigment, but simultaneous they also set up marked decomposition of albuminous media, this change being characterised by the produc-stratum. tion of a smell resembling that of trimethylamine, as well as by the alkaline reaction of the gases which are formed; this change has not as yet, however, been accurately analysed.-Bacillus prodigiosus appears not Distribution. unconimonly as a spontaneous infection of articles of food; the phenomena which were formerly repeatedly observed of the so-called bleeding bread and the bleeding host were probably caused by it; in fact it occurs at 
times in an almost epidemic manner, as was the case in 1843 in Paris, where it grew more especially in the bread obtained from the military bakehouses. It does not set up any symptoms in the bodies of warm-blooded animals, even when it is injected into the blood in large quantities.

\section{Bacillus indicus ruber (Koch).}

This organism was isolated by Koch from the contents of the stomach of a monkey in India; it produces a colouring matter similar to that of bacillus prodigiosus. The organism has the form of fine very short bacilli, with rounded ends. In gelatine plates the deeply placed colonies show under a low power even after 20 hours a golden yellow colour and a wavy outline ; the superficial colonies liquefy the gelatine, and form a funnel-shaped depression, which very soon disappears on account of the rapidly spreading liquefaction. The liquefied gela-

Comparison with bacillus prodigiosus : higher optimum of temperature.

Colour more like that of red wax.

Toxic action on animals. tine has a distinctly red colour. The optimum of temperature is higher in the case of bacillus indicus than in the case of hacillus prodigiosus; while the latter grows best at about $25^{\circ} \mathrm{C}$, and as the temperature is increased gradually shows less growth, the bacillus indicus flourishes best at about $35^{\circ} \mathrm{C}$.; hence luxuriant cultivations can be obtained on agar, on which it forms deposits at first of a white colour, but soon assuming a red hue. On potatoes an intensely red layer is formed, the colour of which is more of a wax-red colour, while the colour of the bacillus prodigiosus is darker, with a slight tendency to violet.

Another important distinction between these two bacilli is that the bacillus indicus is not without effect on animals, but, on the contrary, rapidly kills them when it is injected directly into the blood in large quantities. Rabbits die within 3 to 20 hours, violent diarrhœa setting in a short time after the injection; on post-mortem examination we find the appearances of a severe gastro-enteritis, at times accompanied with extensire ulceration of the intestinal mucous membrane. 


\section{Bacillus ruber (Frank).}

These are actively moving rods, occurring singly or united in twos or fours; in some of these rods there are two to four highly refracting granules (spores). The organisms produce, when grown on boiled rice, a red colour resembling that of red lead or sealing-wax. Nothing further is as yet known regarding this organism.

\section{Bacillus pyocyaneus.}

(Bacterium aeruginosum, Organism of greenish-blue pus.)

It has been known for a long time that the greenishblue colour which sometimes appears in the dressings on suppurating wounds is occasioned by micro-organisms. More or less pure cultivations have also been made by numerous investigators, and most recently by Gessard and Charrin; but nevertheless the majority of observers do not seem to have obtained the organism quite pure, for they have described it usually as a round or oval micrococcus. The organism can be readily isolated by the aid of gelatine plates. It is a thin fine bacillus, of varying length, the average length being about the same as

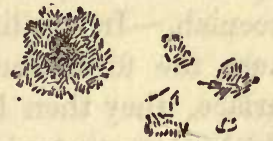

Fig. 95.-Basilli if Morphological greenish-blue pus characters. that of bacillus murisepticus, the thickness somewhat greater. Chains of two or three bacilli are observed, but usually they form irregular masses, united together by a tenacious zooglæa; spore-bearing bacilli are also not uncommon, and in that case they are usually somewhat thickened.-On gelatine plates the colonies form, Cultivations. after 24 hours, whitish opaque patches, which under a low power show a round, but not sharp outline, of a yellowish colour, and with radiating markings; the whole of the gelatine presents a greenish shiny appearance. Twenty-four hours later the deep colonies have a grey centre, with a dark brownish-yellow zone at the outermost border, from which delicate radially arranged threads 
pass out; the zones gradually spread, and the circle of fine ruys constantly becomes greater. In the superficial colonies the grey centre, and the surrounding narrow darker zone are enclosed in one which is much broader, finely granular, yellow, and highly refracting, and, towards the outer part, gradually more and more colourless, with indistinct outlines; and from the margin of this zone fine, radially arranged, and somewhat convoluted lines run into the gelatine. The gelatine is at the same time liquefied, so that the original colonies soon sink below the surface of the material.-In puncture cultivations the growth is less characteristic; complete liquefaction of the gelatine soon occurs with the production of a greenish colour, which becomes more yellow as the cultivations get older. On agar material a whitish deposit is formed at the surface, and the substratum assumes a bright green colour. On potatoes the organisms form a yellowish-brown moist layer; if this layer is completely removed, and the exposed portion is acted on for a long lime by the air, or for a short time by the vapour of ammonia, the surface of the potato becomes greenish.-In sterilised milk the bacilli in the first place cause the formation of greenish-yellow flakes on the surface, they then lead to precipitation of the casein, which they peptonise gradually, with the simultaneous appearance of ammonia.

The colouring matter produced by the bacilli has been investigated by Fordos and Gessard, and has been called pyocyanin. It is soluble in chloroform, and crystallises from the pure solution in the form of long blue needles; acids convert the blue into red, reducing substances into yellow. It is apparently closely related to the ptomaines because it is precipitated by chloride of platinum, phosphoric molybdic acid, \&c.This organism does not cause suppuration, and is apparently only a harmless inhabitant of wounds. 


\section{Bacillus fluorescens putidus.}

This organism occurs frequently in putrefying Fluoreseing materials ; it imparts to the latter a greenish hue, and bacillus. produces at the same time a smell resembling that of trimethylamine; it does not liquefy the gelatine.*-The organism presents the form of small, short, very actively moving bacilli, with rounded ends. They form in the deeper parts of the gelatine plates very small dark colonies (under a low power), which grow better at the surface, and then present the appearance of round dises, with sharp wavy outlines; in the centre the remains of the deep-seated colonies appear as a dark speck; the surrounding mass is yellow, light grey, and finely granular towards the margin. On the third day the colonies have extended markedly on the surface, they present an irregular outline and have a greenish shimmer, in fact the whole plate has a greenish shimmer; at the same time there is a strong smell resembling that of herring brine. In puncture cultivations a faint grey or milky muddiness develops along the track of the needle, this muddiness extending much more markedly on the surface; from the third day onwards there appears a greenish coloration of the gelatine gradually extending from above downwards. On potatoes the organisms grow rapidly in the form of a brownish, or at the surface more greyish, thin layer.

\section{Bacillus erythrosporus.}

This organism was formerly observed by Eidam, and Fluorescing afterwards by Cohn and Miflet, in meat infusion, in ${ }_{\text {reddish with }}$ putrefying albuminous fluids, \&c., and was obtained spores. from the air.t Since that time it has been often observed in a great variety of putrefying fluids as well as in drinking water. It presents the form of thin mobile bacilli with abruptly rounded ends, often forming short threads. At the ordinary temperature two to eight

* Göttinger hygienisches Institut.

† Cohn's Beiträge zur Biologie der Pfanzen, vol. iii., part 1, p. 128. 
oval spores, arranged like a string of beads, appear in each rod; these spores project in part beyond the contour of the bacillus, and, when brought into accurate focus, show a distinct dirty red colour. The spores also retain the red colour after staining the rods, for example, with methylene blue.-The bacilli form whitish colonies on gelatine which are circular under a low power, with irregular but sharp outlines. The opaque brownish centre is surrounded by a greenish-yellow lighter marginal zone; the surface shows faintly marked radiating lines. As the colonies spread on the surface of the gelatine their border becomes very irregular and dentate, and from the dark centre radiating lines, now much more distinct, run in a wavy manner towards the periphery, implying wrinkling of the layer. At the same time a greenish-yellow fluorescing colour appears around each colony.-In puncture cultivations a somewhat plentiful growth occurs along the whole canal, chiefly, however, at the surface; the whole of the gelatine gradually assumes a greenish colour by transmitted light, and yellowish by reflected light, this colour spreading from above.-On potatoes a slight deposit is formed, at first of a reddish hue, and later of a brownish nut colour.

\section{Bacillus fuorescens liquefaciens.}

Liquefying fluorescing bacillus.
This organism occurs extremely frequently in a great variety of putrefying substrata, in water, \&c.-It presents the form of short mobile bacilli arranged in pairs, and constricted in the middle; spore formation has not been seen.- On gelatine plates it forms whitish points which spread at the surface in the form of fairly large colonies, attaining even as much as $3 \mathrm{~mm}$. in diameter; at the same time a ring-shaped liquefied zone appears around each colony. Under a low power irregularly circular, and later sinuate colonies with sharp outlines are observed; the centre is dark brown, finely granular, and surrounded by a yellow finely granular zone, which becomes whitish-grey and transparent towards the 
margin. The whole gelatine gradually assumes a rreenish colour.--In puncture cultivations a whitish layer is formed along the track of the needle, and at the point of entrance of the needle a small funnel-shaped depression appears, containing at the lower part liquefied gelatine, and at the upper part air. The liquefaction gradually spreads until it reaches the wall of the glass, and slowly extends downwards; at the bottom of this liquefied material, a thick, whitish deposit is formed. Beneath the area of liquefaction the gelatine has a greenish-yellow fluorescing appearance; the liquefied mass does not show the play of colours so markedly.-On potatoes a brownish deposit is formed, which, however, is not characteristic.

Among the bacilli which produce greenish colouring matter Greenish should probably be placed the organism described by Engel- coloured mann as bacterium chlorinum, and by van Tieghem as bacbacteria. terium viride and bacillus virens, in which the substance of the cell itself presents a greenish colour. The species investigated by Engelmann was an oval, very mobile rod, 2 to 3 $\mu$. in length; the bacilli investigated by van Tieghem were non-motile. It is, however, not impossible that in all three cases these authors had to do with fission algæ; we must await a more accurate description.

\section{Bacillus luteus.*}

This is a short bacillus of medium thickness, and Yellow apparently non-motile. It forms in gelatine plates deeply placed colonies, of a lentil or whetstone form (as seen under a low power), at times with irregular outlines, at times with sharp smooth contour, and of a brown colour. The superficial colonies are 10 to 20 times larger, they measure 2 to $3 \mathrm{~mm}$. in diameter, and appear round, often irregular in outline, of a light brown colour, and with a whitish, clear, transparent margin. Macroscopically, the colonies are yellow and opaque; in puncture cultivations a yellow growth is formed both along the track of the needle and also on the surface,

* G̈̈ttinger hyg. Institut. 
but without liquefaction and without staining of the gelatine.-It occurs very frequently as an impurity on plate cultivations, \&c.

\section{Bacillus fuscus.*}

\section{(Bacterium brunneum.)}

Brown bacillus.

This organism was obtained by Schröter from a putrefying infusion of maize in the form of mobile rods, which produced a brown colouring matter, and which he described under the name of bacterium brunneum. These organisms are probably identical with a bacillus which also furnishes a brown colour, and which occurred in some rare cases as accidental impurities in Göttingen. - These organisms present the form of long narrow rods with abrupt ends, and irregular and in parts slightly projecting outlines. They form on gelatine plates fairly quickly growing knob-like colonies of a brownish colour; under a low power we see in the centre irregular brownish-black balls which are surrounded by a highly refracting border. In puncture cultivations their growth is not very characteristic ; on the surface they form a fairly thick, and at a later period a wrinkled brownish-red deposit around the point of entrance of the needle.

\section{Bacillus synxanthus.}

(Bacterium synxanthum, Ehrenberg.)

Bacillus of yellow milk.
These are actively moving rods which were observed by Schrötert in milk which had accidentally become yellow; by inoculating the organism on normal boiled milk, its colour became citron-yellow. The colouring matter was soluble in water, insoluble in alcohol and ether; acids decolourised it, alkalies again brought back the colour. Nothing further is known as regards the micro-organisms which produce these effects.

* Göttinger hyg. Institut.

† Cohn's Beitr. zur Biol. d. Pflanzen, vol. i., part 2, p. 120. 
Bacillus janthinus (Zopf).

(Bacterium janthinum, violet bacillus.)

Zopf observed on pieces of swine's bladder, which violet were floating on water containing fungi, violet patches consisting of longer and shorter mobile rods, ultimately breaking up into short segments.-These bacilli are perhaps the same as those found by Hueppe, and at a later period on several occasions in the laboratory at Göttingen, and which produce an intensely bluish-violet pigment. These bacilli when grown on gelatine form at first milk-white layers, which gradually assume a violet colour at the margins, and in the neighbourhood of which the gelatine acquires the same tint; it is not till after sereral days that the whole surface of the colonies acquires an intense violet hue. In puncture cultivations the violet growth only develops at the surface; on potatoes a deep violet layer is produced. In sterilised milk the bacilli produce patches on the cream, at first intense sky-blue in colour, but gradually becoming blackishblue; at the same time the casein is precipitated and then peptonised, the fluid acquiring an alkaline reaction, and ammonia being formed (Hueppe).

\section{Bacillus cyanogenus.}

(Bacterium syncyanum, Bacillus of blue milk.)

The occurrence of blue milk is frequently observed in Bacillas of many places; at times its occurrence varies, like that of blue milk. epidemics, in accordance with local and seasonal influences. Great moisture of the atmosphere has generally been regarded as a favouring factor, while temperature, light, \&c., do not apparently exercise any marked influence.

Fuchs in 1841 asserted that a vibrio was the agent Former which produces the blue colour, and he demonstrated investigathat this production of colour could be set up in good milk; these investigations were confirmed and extended by Haubner, Hermbstädt, Mosler, and others, and recently more especially by Neelsen and Hueppe. Neelsen has 
described bacilli which undergo an extensive change of form, and which always ultimately break up into cocci ; but these observations eridently depended on contamination of the cultirations with other forms of bacteria, such a contamination being almost unavoidable with the methods of cultivation employed at that time. It is now quite easy by the help of gelatine plates to isolate the characteristic bacteria from any specimen of blue milk. Morphological The bacilli move slowly, they have an average length
characters. of about $2 \mu_{\text {., }}$ but rary between 1.4 and $4 \mu$.; their thickness is about $\cdot 4 \mu$., and in stained preparations it also shows slight variations. In preparations from milk their size is more uniform. At the ordinary temperature spore formation occurs in gelatine, in milk, \&c.; the spores are formed at one end, so that the spore and the remains of the bacillus often present a club form. In unsuitable

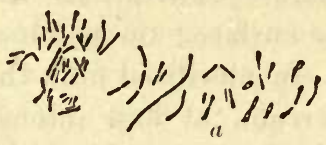

Fig. 96. - Bacilli of blue milk $\times 700$.

At $a$ we see spore-bearing bacilli, and others with unstained portions of plasma. nutrient solutions, for example in slightly acid solutions of tartrate of ammonia, or Cohn's nutrient solution to which nitrate of potash is added, involution forms often appear, the bacilli being club-shaped or spindleshaped, or presenting the form of long threads, with spherical dilatations at intervals.

Cultivations. In gelatine plates small greyish-white points appear after two days, and these spread out on the surface in the form of moist drops, 1 to $2 \mathrm{~mm}$. in breadth. The whole plate assumes a steel greyish-blue colour, so that the white colonies become gradually more distinct. Under low powers the smallest deeply-lying colonies present the form of circular dises with black centre and brownish granular margin, and with a sharp black outline. The superficial colonies show a blackishbrown centre, around this a greyish-brown area, and further outwards a narrow, yellowish, finely granular zone with sharp outline.-In puncture cultivations a whitish deposit is formed especially on the surface, and from this growth a dark steel blue staining of the gelatine spreads downwards.-On potatoes a yellowish moist 
deposit is formed, and in the neighbourhood the substance of the potato assumes a deep greyish-blue colour. At times the gelatine has a more greenish shade; distinct green colour is produced, for example, in solutions of tartrate of ammonia, of leucine, asparagine, \&c., but this green pigment only represents a lower stage of oxidation of theblue, and can be transformed into the blue by oxidising agents. - When inoculated in sterilised milk the bacilli cause no coagulation and no acidity, but gradually produce a slightly alkaline reaction; further, a slate-grey colour, which, however, on the addition of acid becomes an intense blue, appears in the first instance in the layer of cream, and then spreads downwards through the whole fluid. In milk which has not been sterilised, and Character of in which the lactic acid bacilli are growing at the same the pigment. time, the colour is sky-blue from the first. - In milk the colouring matter seems to be formed at the expense of the casein, while the milk sugar remains unaltered; the bacilli, however, are able to build up the colouring matter. synthetically in fluids which only contain lactate of ammonia, or tartrate of ammonia without any albumen. The optimum of temperature for the production of the pigment is from $15^{\circ}$ to $18^{\circ} \mathrm{C}$.; above $25^{\circ} \mathrm{C}$. the pigment production is delayed; at $37^{\circ}$ C. no colouration of the nutrient solution occurs. The pigment is not an aniline dye, but more accurate investigations as to its properties and its nature are still wanting.-The bacilli and the milk in which they are growing have proved to be quite harmless to animals, even when injected into the veins.

Among the bacilli which cause fermentation of carbohydrates, the following must be mentioned:-

\section{Bacillus acidi lactici.}

(Lactic acid bacteria.)

The phenomenon which has been for a long time well known, that when milk is kept for some time the milk sugar becomes transformed into lactic acid, and, as a 
result, the casein coagulates, was first ascribed by Pasteur to the action of definite micro-organisms. Nevertheless, Lister seems to have been the first to obtain a pure cultivation of lactic acid bacteria by the employment of

Formation of lactic acid by various kinds of bacteria.
Lactic acid bacillus.

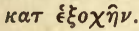

Morphological characters. the so-called dilution method.-As the result of the investigations of the last few years the views advocated by Pasteur and Lister have in so far undergone an important modification in that, according to more recent experience, the power of forming lactic acid from carbohydrates, and more especially from the milk sugar of the milk, evidently appertains to a large number of species of bacteria, and differences among these species exist mainly as regards the quantitative production by each kind. For example, this property is possessed by all the pyogenic organisms, more especially by the staphylococci, then by the bacillus oxytocus perniciosus; the bacterium coli commune, and bacterium lactis aerogenes; further, by a species of bacteria isolated by Miller from carious teeth ; lastly, according to Hueppe's experience, by bacillus prodigiosus, and by a species of coccus isolated from the secretion of the mouth, and growing in the form of flat white knobs. Undoubtedly the number of organisms which are capable of causing lactic acid fermentation is not exhausted by these 15 species.

Nevertheless, one definite organism seems to have the right to the designation " lactic acid bacterium," because it is evidently by far most frequently the cause of the spontaneous clotting of milk, and because also it is marked out from the other bacteria which have a similar action by its wide distribution, and by the intensity of its effect. This lactic acid bacillus has been accurately described by Hueppe, and is probably identical with that observed by Lister and Pasteur.

This bacillus forms short, thick cells, which are at least half as long again as broad, and are usually united in pairs, seldom in fours. Under too low a power the individual cells may present the appearance of oval cocci, but when more highly magnified we see distinctly that the outlines are parallel, and that the ends are slightly narrowed in the longitudinal direction. The average 
length of these rods is, according to Hueppe, 1 to $1 \cdot 7 \mu$., their breadth $\cdot 3$ to $\cdot 4 \mu$., but rods as long as $2 \cdot 8 \mu$. also occur. The bacilli have no spontaneous movement. In solutions of sugar they show distinet spores, which are also formed in milk, but are much more difficult to recognise in that medium. The spores appear as refracting globules at the ends of the bacilli ; if two bacilli are united together the spores often appear at the ends furthest removed from each other, but often also at the adjacent ends. Bacilli containing

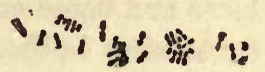

Fig. 97.-Lactic acid bacillus $\times 700$.

Cover glass preparation from a fresh cultiva. tion.

these spores are not killed when boiled for a short time.The bacilli grow readily on various soils. In gelatine Cultirations. plates they form on the second day whitish colonies, which under a low power, and so long as they are deeply situated, present the form of circular discs, uniformly dark, and with sharp black outlines; those which occur on the surface are surrounded by a somewhat clearer marginal zone. In puncture cultivations a deposit, which is at first delicate, and later somewhat denser, and which forms at parts discrete spheres, appears along the whole track of the needle. In stroke cultivations the individual colonies, which are at first circular, run together and form a narrow white stripe, with irregular borders.

Lactic acid fermentation can be set up with pure cul- Conditions of tirations of these bacilli in solutions of milk sugar, cane lactic acid sugar, mannite, and dextrose. In addition to lactic acid, carbonic acid is also always formed. When more than 8 per cent. of lactic acid is present in the fermenting mixture, the progress of the fermentation is interfered with, and hence when it is desired to carry the fermentation further it is necessary to add chalk in order to neutralise the acid.

According to Hueppe, free oxygen is necessary for the Necessity for occurrence of the fermentation; nevertheless, very small quantities are sufficient in order to permit the formation of the amount of lactic acid necessary to cause coagulation of the casein ; but larger quantities of acids appear to be formed only when there is a corre- 
spondingly larger amount of oxygen present. The optimum of temperature lies between $35^{\circ}$ and $42^{\circ} \mathrm{C}$.; Inoculation on at $45 \cdot 4^{\circ} \mathrm{C}$. fermentation ceases.-If a small portion of a
milk. pure cultivation is introduced into milk, previously sterilised at $100^{\circ}$ C., the latter becomes uniformly gelatinous in $\mathbf{1 5}$ to $\mathbf{2 4}$ hours at the body temperature. Here and there small spaces are visible in the coagulum, containing bubbles of carbonic acid. At a later period the coagulum contracts somewhat, and clear serum collects around it. The coagulum does not become peptonised subsequently.

Dehydrating properties of the bacilli.

Rennet-like precipitation of the easein by bacteria.

It appears that the lactic acid bacilli dehydrate the milk and cane sugar before they cause their fermentation. They are also able to convert starch into sugar in the same manner as a diastatic ferment. (See under "Ferments.")

It must be borne in mind that the casein of milk is not only coagulated by lastic acid, but also by rennetlike ferments, and that, as Duclaux first showed, a number of bacteria are able to furnish these ferments, and thus without the formation of lactic acid to coagulate the casein; the reaction of the material is amphoteric, that is to say, slightly acid, and slightly alkaline. This property occurs, for example, in the bacillus butyricus, in the so-called potato bacillus to be described below, in sarcina lutea, in a large coccus cultivated by Hueppe from water, and causing liquefaction of the gelatine, and probably also in many other bacteria. The same bacteria frequently exert a subsequent peptonising action on the coagulated casein.

\section{Bacillus butyricus.}

\section{(Clostridium butyricum, Bacillus amylnbacter.)}

Butyric acid bacillus.
In the case of the butyric acid fermentation we must probably also come to the same conclusion as in that of the lactic acid fermentation, viz., that several linds of bacteria can cause this fermentation of carbo-hydrates, and this without reckoning those bacteria which form butyric acid from other materials (for example, the 
bacilli of greenish-blue pus from glycerine, \&c.). Pasteur, Butyric acil Prazmowski, Fitz, and Hueppe have each described fermentation bailli which cause butyric fermentation, but which various according to the descriptions as yet given are not the same species in each case, although some of them have not been sufficiently accurately studied to enable us to come to a conclusion as to their identity. According to investigations in the author's laboratory the number of butyric acid bacilli is probably very considerable; but the majority of these, on account of the fact that they are anaerobes and cannot be isolated and cultivated pure by the ordinary methods of cultivation, present such great difficulties in their diagnosis that we must await further investigations in order to obtain an accurate knowledge of these forms. In the following description we shall take as our basis the description of the butyric acid bacillus given by Prazmowski, which corresponds fairly well with that of Pasteur and van Tieghem, but which has not been based on pure cultivations; secondly, we may describe for the present as a separate species an anaerobic bacterium, the characteristics of which have been studied by Liborius in the author's laboratory-with regard to its fermentative activity, accurate analyses are wanting, but it is possibly identical in its morphological and biological characters with Prazmowski's organism; and in the third place we must mention the bacillus isolated by Hueppe from milk, and which differs in an important manner from those previously mentioned on account of its aerobic properties.

\section{Bacillus butyricus (Prazmowskr).}

This organism presents the form of rods 3 to $10 \mu$. 1. Prazmowin length, and $1 \mu$., or somewhat less, in breadth. It acid bac.llus. frequently forms chains, or apparently threads, which have not undergone segmentation. It is usually actively mobile, but at times it is at rest and forms zoogloea. After some time the rods cease to grow in Morphological length and increase in thickness; the shorter rods increase in thickness chiefly in their middle, and 
Anaerobic properties.

assume a spindle form; the longer are often enlarged at one end like a tadpole. The swollen rods may attain a breadth of from 1.8 to $2 \cdot 6 \mu$. At the same time the plasma becomes more highly refracting, and the membrane markedly thickened. When this has taken place spore formation commences; the ovoid spores are 2 to $2.5 \mu$. in length, and $1 \mu$. in breadth, they become free by solution of the membrane of the mother cell. The spores sprout in the following manner:-At one of the pointed ends of the longish spore the double contour of the spore membrane disappears, and the germinating tube passes out; the longitudinal diameter of the latter is parallel to that of the spore. The dense spore membrane does not shrink, and often remains attached to the young rod for a long time.

This bacillus is a typical anaerobe; its whole vital
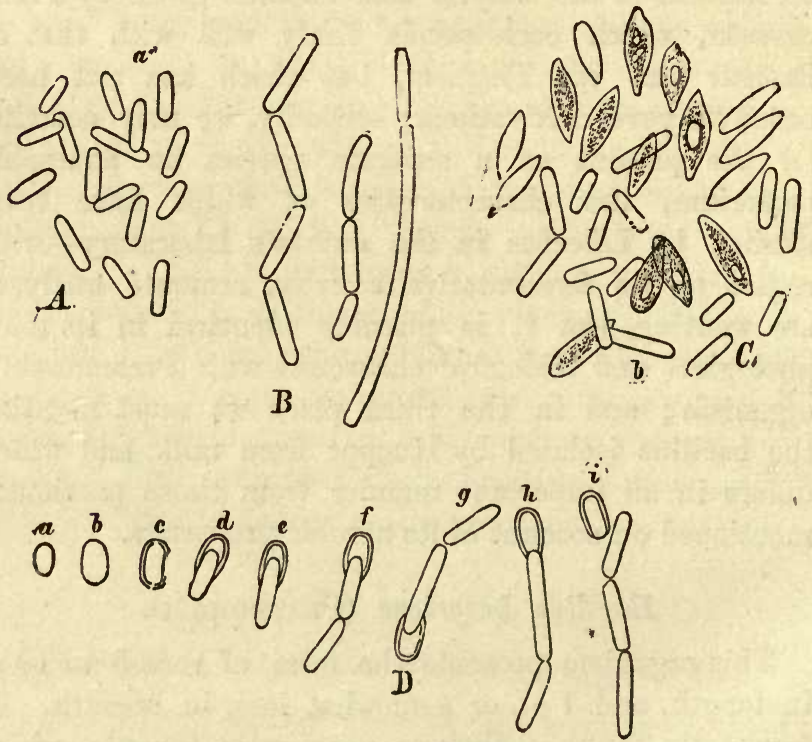

Fig. 98. - Bacillus butyricus (after Prazmowski) $\times 1020$.

$A$ and $B$, colonies and chains of bacilli.

$C$, colonies with swollen, spindle-shaped, and spore-forming bacilli.

$D$, germination of the spores; $a$ to $i$, successive stages.

functions seem to go on quite independently of the presence of free oxygen, and, in fact, they are inter- 
fered with when considerable quantities of that gas are present. The spore formation and the sprouting of the spores appears also to occur only when oxygen is absent. Hence it differs markedly in its physiological characters from the bacillus subtilis, which in other respects resembles it. Further, the spores of bacillus butyricus do not show the same resisting power as the spores of bacillus subtilis. The boiling temperature continued for five minutes is sufficient to kill them.

Intense fermentation can be readily set up by the Conditions of bacillus butyricus. In solutions containing starch, dextrine, sugar, or lactates, a considerable quantity of butyric acid is formed in the course of a few days as the result of the action of the bacillus butyricus, carbonic acid and hydrogen being at the same time given off. The vessels containing the nutrient solutions in which these fermentation experiments are made should be kept hermetically sealed, and freed as far as possible from air before the bacilli are introduced ; the high pressure which the accumulated gases exert after a short time does not at all interfere with the development of the bacillus and the progress of the fermentation. The same bacillus is the cause of the butyric acid fermentation which occurs in old milk, and in the ripening of cheese. In the case of milk this fermentation commences after the active growth of the lactic acid bacteria has converted a large portion of the milk sugar into lactic acid, either because the necessary removal of the oxygen is accomplished by the previous development of the aerobic lactic bacilli, or because the milk sugar is dehydrated by the lactic bacilli and thus converted into good fermentescible material. The best temperature for the fermentation is between $35^{\circ}$ and $40^{\circ} \mathrm{C}$. Just as in the lactic fermentation so here we must add chalk to the fermenting mixture in order to prevent the disturbing effect on the bacillus of the accumulation of acid.-According to Fitz the bacilli are also able to dissolve casein slowly, but not to cause the direct fermentation of sterilised milk, or its coagulation, because they are not able to break up millk sugar. 
Iodine reaction.

Other fermentative action.
A property which occurs under certain circumstances, and which is peculiar to the butyric acid bacillus, is the power of forming a material (granulose) in the plasma, which assumes a blue or blackish-violet colour with iodine. This property can be most readily observed when the bacillus is cultivated in media containing starch; but the coloration also occurs in the absence of starch when, instead of it, cellulose, or lactate of lime, or glycerine is present; it seems to occur seldom in nutrient solutions containing dextrine and sugar. Young rods stain of a pure blue colour, older rods of a dark violet; in some only a few transverse zones are blue, in others the rods are continuously stained (compare also Leptothrix, page 392 ; bacillus polymyxa, page 374 ; bacillus Pasteurianus, page 390 ).

It is possible also that the bacillus butyricus has another fermentative action, in that it is able to cause fermentation of cellulose; according to Tappeiner, methane, carbonic acid, and sulphuretted hydrogen, or only hydrogen and carbonic acid are formed according to variations in the composition of the nutrient substrata. (See the chapter on "Fermentation.") This decomposition of cellulose has probably a certain technical importance, for example in the preparation of flax, and is perhaps also of physiological significance in the digestion of cellulose by herbivora. (Van Tieghem ascribes the property of destroying cellulose to a special bacterium called bacterium amylobacter, an organism, however, which this author stated at a later period to be identical with the butyric acid bacillus described by Pasteur).

Distribution. Bacillus butyricus seems to be extremely widely distributed in nature; it can be obtained from hay-dust, from a great variety of putrefying vegetable infusions, from sauerkraut, from old cheese, from milk which has been kept for a long time; according to Déherain and Maquenne* it occurs also in the earth of fields. It has also been observed in the cells of plants which have a milky juice. Van Tieghem was able to recognise it

* Bull. soc. chim. (2), 39.-Compt. Rend., 97. 
from its morphological peculiarities in fossil conifers of the coal formation.

\section{Bacillus butyricus (Liborius).}

Liborius' butyric acid bacillus presents scarcely any 2. Liborius' noticeable difference from the former in its morphological bacillus. characters, more especially in its mode of spore formation. Cultivations in solid nutrient media (nutrient agar, or nutrient gelatine, best when grape sugar is added) only succeed when a fairly thick layer is employed, and in this case a superficial zone, about 3 $\mathrm{cm}$. in breadth, usually remains free from growth; the organism can also be cultivated in nutrient substrata from which the oxygen has previously been expelled by some other gas. Further, it is of importance not to inoculate the solid gelatine by the puncture method, and thus to form a canal for the air, but to mix the material with liquefied gelatine. In this case whitish, but not sharply defined colonies appear in the course of one or two days, and after 24 hours more become surrounded by a narrow line of liquefaction; the extent of the liquefaction gradually becomes greater, and the whitish mass of the colony sinks to the bottom; ultimately these globules coalesce, and at the same time gas bubbles usually penetrate into the upper part of the gelatine, drive out the oxygen from it, and thus the growth and the liquefaction gradually extend upwards. - In nutrient agar the form of the young colonies can be better recognised; and it is then seen that their outline is irregular, and even to the naked eye shows a finely branched appearance; under a low power the delicate ramifying threads around the margin of the colony form a very characteristic picture. In the test-tubes containing agar active development of gas also occurs, so that the upper portion appears as if it had been split. These gases have a disagreeable smell, often recalling that of pure butyric acid; other gases, which probably arise from the simultaneous decomposition of the albumen, are also often present. A more accurate analysis of the fermentative products is still wanting. 


\section{Bacillus butyricus (Hueppe).}

3. Hueppe's aerobic butyric acid bacillus.

Action on milk.

Organisms of kephyr.

The course of the kephyr fermentation.
Hueppe was able to isolate large bacilli from milk which was sterilised sufficiently to prevent the lactic fermentation, but in which the casein became precipitated later, the reaction of the medium being at first unaltered, and later slightly alkaline; these organisms resembled morphologically those described by Prazmowski, but were much less sensitive to oxygen. T'hey grew in nutrient jelly, and led to rapid liquefaction of it, and no precautions with regard to the removal of oxygen were necessary.These bacilli are unable to cause directly the fermentation of milk sugar, and only form butyric acid when the milk sugar has been either dehydrated by other bacteria or when lactates are present. They also cause coagulation of the casein like the rennet ferment, and then they split up the casein, and produce peptone, leucine, tyrosine, ammonia, and substances with a bitter taste. The coagulum of casein, which is at first precipitated from sterilised milk by the butyric acid bacilli, presents, after about 8 days, an appearance as if its edges were being eaten away, and it gradually disappears almost entirely.

\section{Bacillus caucasicus.}

\section{(Dispora caucasica, the ferment of kephyr.)}

An intoxicating drink has been repeatedly obtained from milk by alcoholic fermentation, as for example in the preparation of koumis from the milk of mares by the inhabitants of the Kirghiz steppes, and also in the preparation of kephyr from the milk of cows, as has been done from ancient times in the Caucasian higblands. In these cases the alcoholic fermentation appears to be always occasioned by a torula; as, however, the millsugar of milk cannot undergo the alcoholic fermentation directly, something must be added to it which is able to transform the milk sugar into fermentescible glucose. This transformation is carried out in an energetic manner by the ordinary lactic acid bacteria, and thus an alcoholic fermentation of milk may be set up by the combined use of lactic acid bacteria and yeast cells. But the lactic 
acid bacteria always transform at the same time a portion of the milk sugar into lactic acid, and this leads to the coagulation of the casein, and thus ultimately a drink results which contains alcohol, but which also has a very sour taste, and in which coagulated casein, usually in the form of finely divided flakes, is suspended. According to Hueppe, other bacteria are also present in the kephyr which are able to peptonise the casein, so that we have here a combined action of three micro-organisms.

The ferment of kephyr, which includes two or three Constituents active fermentative agents, can be dried, preserved for a of the kephyr long time, and sent from one place to another. In the milk the kephyr granules grow and form largish fungus masses which are composed of numerous microscopic globules. In these globules, according to Kern and Krannhals, three structures can be distinguished under a high power-yeast cells, fairly long rods, and smaller cells, which are looked on as free spores. The long rods have been accurately described by Kern, and called Dispora caucasica.

These bacilli are $3 \cdot 2$ to $8 \mu$. in length, and $8 \mu$. in Morphological breadth. At one end a flagellum can sometimes be seen, characters of and in fresh preparations the bacilli show spontaneous morement in the form of a slow, pendulous, and see-saw motion. The spore formation appears to be very characteristic; on each rod two terminal spherical cells are formed, and threads containing rows of spores occur, the spore being always so arranged that each of the cells contained in the thread has two spores. The spores which lie in the cells are about $\cdot 8 \mu$. in diameter, those which are free attain a size of $1 \mu$., and those which are sprouting may swell up to about 1.6 $\mu$. The usual mode of sprouting of the spores is that the thinner endosporium first projects out of the thicker exosporium like a small wart,

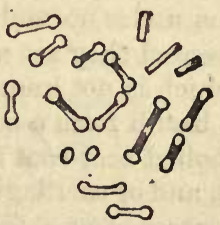

Fig. 99.-Dispora! caucasica $\times 1000$. (After Krannhals.) ? which gradually increases in size, and develops in the form of a cylindrical tube.-According Cultivation to Kern a suitable nutrient solution is formed by 5 experiments. 
parts of phosphate of potash, 5 parts of sulphate of magnesia, $\cdot 5$ parts of chloride of calcium, 9 parts of tartrate of ammonia, $44 \frac{1}{2}$ parts of milk sugar, and 1,000 parts of water; according to Krannhals they also grow in mixtures containing extract of meat, milk sugar, and gelatine. Investigators have, however, not as yet succeeded in making out any definite culture characteristics.

The yeast cells which are also present in the kephyr are round or egg-shaped, $3 \cdot 2$ to $6.4 \mu$. in diameter, and occur singly and in various stages of budding; spherical and ovoid spores are also seen.-We must await further investigations of these organisms, and more especially pure cultivations, in order to obtain a clear understanding of the peculiar fermentative process which takes place in the preparation of kephyr. (See under "Fermentation.")

The culture characteristics and the fermentative products of the following bacilli which act on media rich in sugar are imperfectly known.

Bacillus polymyxa (Clostridium polymyxa), Prazmowski.This organism exactly resembles bacillus butyricus in size, shape, and mode of development, and occurs along with it. The only difference between the two organisms is that in the case of the bacillus polymyxa we find here and there peculiar dilated and wavy threads without any distinct segmentation, and these break up at a later period into shorter segments; it is probable that these structures are involution forms. Further, these bacilli usually require free oxygen for their growth and spore formation, and do not exert any fermentative action under normal conditions; but if the access of oxygen is prevented they set up intense fermentation, the exact nature of which is not known, in infusions of potato, lupin-seeds, \&c. The bacilli form a scum on the surface of nutrient solutions; on boiled beet-root they form gelatinous masses of large extent, and of cartilaginous consistence like those of leuconostoc and ascococcus.-In nutrient solutions containing starch the bacilli show a faint blue colour when treated with iodine, but this reaction is not found when they are growing in solutions in which starch is not present.

Bacillus dysodes (Zopf).--These are rods forming threads which break up into short rods and cocci, and each of these rods produces an elliptical spore. They cause peculiar fermen- 
tative changes in bread, forming there fluid substances with a disagreeable smell (similar to that of a mixture of peppermint and turpentine oil), and the result of their growth is that the bread becomes greasy in its interior and unfit for use. If the yeast is washed with a half per cent. solution of hydrochloric acid, the hurtful action of the organism seems to be prevented.

As to the production of gluconic acid, acetic acid, propionic acid, \&c., from carbo-hydrates as the result of the growth of bacteria, see the chapter on "Fermentation."

Bacilli which are able to split up the albuminous Putrefactive molecule with the development of gaseous foul-smelling products, and thus set up putrefactive fermentation of a more or less intense character, are apparently very common. Among the bacteria already described, and which chiefly act in this manner, may be mentioned bacillus butyricus, bacillus prodigiosus, bacillus fluorescens putidus, bacillus fluorescens liquefaciens, and a bacillus isolated by Miller* from the intestines, but not as yet more accurately described, and which furnishes sulphuretted hydrogen and ammonia; also the bacillus ureæ, to be mentioned below; all these organisms are able to split up albumen or gelatine, with the formation of foul-smelling products. The following may also be mentioned as having considerable power in this respect.

\section{Bacillus pyogenes fotidus (Passet).}

This organism was obtained by Passet from the foul- Passet'sputresmeliing pus of an abscess. It consists of short rods, factive rounded at the ends, with slow movements, $1.45 \mu$. in pus. length, and $.58 \mu$. in breadth, and frequently arranged in pairs or in groups. One or two unstained spots can at times be seen in the interior of the rods; these are probably spores. In gelatine plates white points appear after 24 hours, which develop at the surface in the form of greyish-white patches, extending to about $1 \mathrm{~cm}$. in diameter, and becoming confluent, thicker, and whitish in the middle, thinner and greyish towards the margin. In puncture cultivations only fine points appear along the track of the needle, but on the surface a delicate

* Miller, Deutsche med. Woch., 1885, Nr. 49. 
greyish-white veil-like growth is formed, which is somewhat thicker, and irregular at the margin. On potatoes the bacillus forms luxuriant glistening, lightbrown cultivations; on blood serum, thick, whitish lines. In all these nutrient media a foul smell is de-

Fig. 100.-Bacillus pyogenes fœetidus (Passet) $\times 790$. veloped.-Animals are not affected by small doses administered subcutaneously, but when the quantity is larger a localised suppuration occurs.

\section{Bacillus putrificus coli (Bienstock).}

Bienstock's patrefactive bacillus from fæces.

Spore formation and germination.
These are thin, actively moving rods, about $3 \mu$. in length, though often shorter, and often arranged in the form of long threads. When spore formation takes place a thickening of the rod occurs at one, or, more rarely, at both ends, and this thickened part becomes gradually isolated from the rod, and assumes a spherical form. This spore remains for some time in connection with the rod, giving it thus the form of a drum-stick, and the rod continues to move about with the spore attached to it, that end of the bacillus being in front. As the result of the gradual disappearance of the rod the spherical and very highly refracting spore becomes free; if this spore is introduced into suitable nutrient material it becomes narrower and gradually elongates to form a rod. From these freshly formed rods chains of very short rods arise, these shorter bodies gradually growing to form longer rods and threads.The growth of the bacilli on nutrient gelatine has at first a mother-of-pearl aspect, but as it becomes older it acquires a yellowish colour, and presents a homogeneous appearance without any striped arrangement. More accurate statements as to the characters of growth are as yet wanting. Bienstock was able to demonstrate by careful analytical fermentative experiments that the bacilli can split up albumen energetically; when small quantities of a cultivation of 
these bacilli are introduced into Cohn's nutrient solu- Chemical tion containing fibrine in suspension, the following analysis of the substances are prołuced, namely, peptone, ammonia, fermentation. amine bases, fatty acids, amido fatty acids, tyrosin, phenol, paraoxyphenylpropionic acid, paraoxybenzoic acid,indol, scatol; further, when the bacilli act on these individual products the lower series of decomposition products

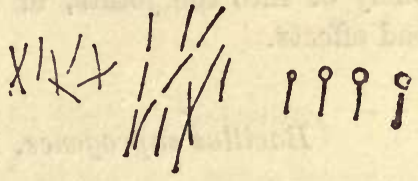

Fig. 101.-Bacillus putrificus coli (Bienstock) $\times$ about 1000 . are produced; for example, tyrosin gave rise to paraoxybenzoic acid, the latter to phenol, \&c. Albuminates of the alkalies are either not at all or only very gradually broken up. When air is excluded the whole process Necessity for runs its course somewhat more slowly, but otherwise ${ }^{\text {oxygen. }}$ in a similar manner. - The bacillus appears, according to Bienstock, to be constantly present in fæces, and is only absent in that obtained from infants fed exclusively on milk.

\section{Bacillus saprogenes, No. 1 (Rosenbach).}

These organisms have been repeatedly obtained by Rosenbach's Rosenbach from stinking secretions or as an accidental patrefactive contamination, \&c. They are fairly large bacilli, which produce a large spore at one end. Stroke cultivations on agar show a greyish-yellow, opaque line, which, however, is still transparent when viewed by strong transmitted light; it is about $1 \mathrm{~mm}$. in height, and of a tenacious, soupy consistence; at a later period a sort of wavy bloom is formed, so that the surface presents a shell-like appearance. The bacilli also grow on blood serum (nutrient jelly was not tried), and on both of these nutrient soils an intense putrefactive odour is produced.

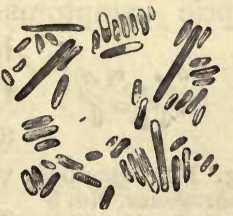

Fig. 102.-Bacillus saprogenes, No. 1

(Rosenbach) $\times 962$. Egg albumen and meat are rapidly decomposed by the 
bacilli when air is present, with the production of foul smell, while in the absence of air only a slight effect is produced.-Fluids containing these bacilli when injected into rabbits or dogs, either subcutaneously or into the joints, or into the pleura, caused no bad effects.

\section{Bacillus saprogenes, No. 2 (Rosenbach).}

This organism was isolated by Rosenbach from foul smelling sweaty feet. The organisms are bacilli, thinner and shorter than those just described. When inoculated on agar rapid superficial growth occurs; if a fine stroke has been made the whole surface appears on the next day as if sprinkled with minute drops, the growth gradually spreading over the surface in an equally thick layer, which at first has a watery appearance, but later is whitish-grey and of a tough, gelatinous

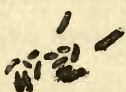

Fig. 103.-Bacillus saprogenes, No. 2 (Rosenbach) $\times 962$. consistence. The cultivations give off the foul smell of sweaty feet. Egg albumen and meat are rapidly decomposed in the presence of air with the formation of stinking gases; when oxygen is absent distinct, though delayed, putrefaction occurs.-When the cultivations were injected into the knee and pleural cavity of rabbits these animals died from suppurative inflammations.

Bacillus saprogenes, No. 3 (Rosenbach).

In two cases of suppuration of bone accompanied by septic symptoms Rosenbach obtained, among other bacteria, a short, thick bacillus, with rounded ends. When stroked over agar a layer about $3 \mathrm{~mm}$. in breadth is deFig. 104.-Bacillus veloped in about 8 days at the tempersaprogenes, No. 3 , ature of the room, this layer being of
(Rosenbach) $\times 962$. ature an ashy grey colour, and almost fluid; at the same time the material gives off' a foul putrefactive odour. Egg albumen is rapidly broken up and 
undergoes putrefaction after infection with cultivations of the bacilli in the presence of air ; when air is absent there is at first violent decomposition, which, however, soon ceases.-Suppuration occurred in rabbits after injection of the bacilli into the knee joint.

\section{Bacillus coprogenes fotidus (Schottelius).}

In the course of investigations on swine erysipelas Schottelius' Schottelius found that in all cases some of the puncture intestinal cultivations in nutrient jelly, where the infective material was taken from the organs, more especially from the mesenteric glands and the spleen, contained, besides the characteristic colonies of the erysipelas bacilli, also a few light yellow spherical colonies, composed of larger bacilli. These rods are about as thick as the hay bacilli Morphological but shorter; but the length of the individual bacilli characters. differs markedly, according to the nutritive conditions. They are non-motile. The ends of the rods are rounded. In cultivations spore formation occurs after 3 or 4 days at the temperature of the room; the spores are arranged in rows; when they germinate the long axis of the new rod is at right angles to the long axis of the spore, so that from a row of spores six or eight small rods may grow out, lying with the long diameter parallel to each other. The spores are only formed when air is present, and do not appear in the animal body. In the Cultivations. deeper parts of the nutrient jelly the bacilli form pale yellow closed colonies which do not liquefy the jelly; on the surface they produce a fine, transparent, greyish layer. The cultivations give off an intense putrefactive odour. On potatoes a light grey dry layer, about - $5 \mathrm{~mm}$. in thickness, is formed.-Sub-

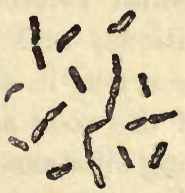

Fig. 105.-Bacillu coprogenesfoetidus (Schottelius) $\times$ about 600 . cutaneous injections of small quantities of the cultivation produced no effect on mice and rabbits; but very large quantities produced a toxic effect in rabbits, but none on swine.

The same organism could be demonstrated by Schot- 
Penetration of the bacilli from the intestine into the internal organs in swine affected with erysipelas.

telius in the intestinal contents of the swine; and as in the cases investigated these bacilli were always most numerous in the organs lying in the immediate neighbourhood of the intestinal canal, while they became fewer and fewer in the organs which were more remote from it, it is probable that they enter the body by the intestinal ulcerations which usually occur in this disease, and that they are purely secondary, and on the whole without any important significance.

\section{Proteus vulgaris (Hauser).}

Hauser's putrefactive bacilla.
Hauser has shown that in putrefying animal substances, in all putrefying meat infusions, in the contents of putrid ulcers, \&c., three species of bacteria almost always occur which show many characters in common, Morphological but also some constant differences.-The most common characters. of these varieties-Proteus vulgaris-forms rods on an average $6 \mu$. in thickness, and of very varying length; according to the conditions of their life they are sometimes very short, forming almost spherical bodies, sometimes they have the appearance of bacilli $1 \cdot 25$ to $3 \cdot 75 \mu$. in length, sometimes they appear as threads. These threads are sometimes twisted and convoluted, sometimes they present an appearance like plaited hair. Hauser designates these formations as spirilla and spirulina; they, however, give the impression of accidental twistings caused by a variety of external conditions, and not of a characteristic type of growth recurring in successive generations (see p. 175).-Many of the rods are in active movement; in some distinct Involution forms. long cilia can be seen. Involution forms are frequently observed, large, for the most part spherical bodies, on an average $1 \cdot 6 \mu$. in diameter.

Cultivations. The growth of these rods in 6 per cent. nutrient jelly is extremely characteristic. At the temperature of the room round depressions, containing liquefied gelatine and whitish-grey turbid masses of fungi, appear on gelatine plates, even after 6 to 8 hours. Under a low power we see that the gelatine around these depressions is covered by 
a narrow zone of bacteria two or three layers in thickness, Superficial this zone being at the outer part surrounded by a single ${ }^{\text {colonies. }}$ layer of bacteria. From the latter tongue-like branches and projections pass outwards, and these projections, which consist of groups of rods and threads, constantly vary their position, become separated, and pass with a slow gliding movement over the surface of the gelatine, forming isolated islands and anastomosing threads; after some time and at a favourable temperature $\left(20^{\circ}\right.$ to $22^{\circ} \mathrm{C}$.)

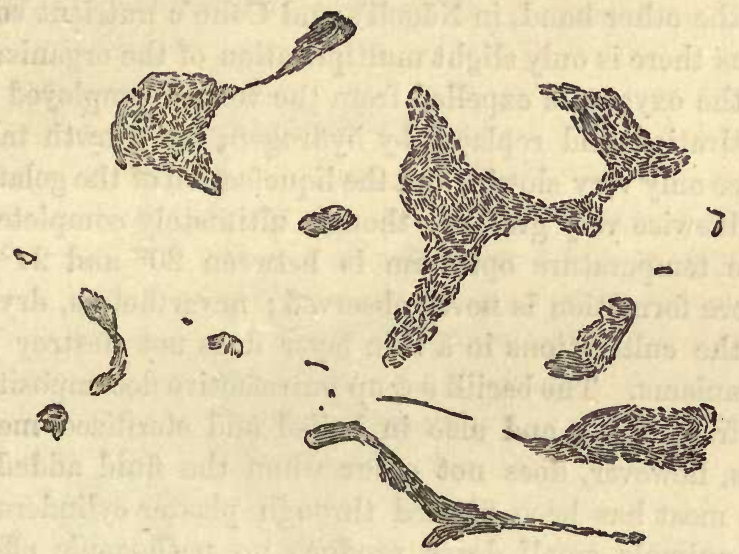

Fig. 106.-Swarming islands of proteus valgaris (Hauser) $\times 285$.

active changes of situation can be seen to be going on in all these islands and threads, and circular movements are more especially evident. Gradually the whole surface of the gelatine becomes covered with wandering colonies; from that point rapidly progressing liquefaction occurs, which, after 24 to 48 hours, affects the whole surface to a depth of about $1 \mathrm{~mm}$. At the same time there is a foul smell and a marked alkaline reaction.

While these phenomena are observed in the superficial Characters of colonies, a ray-like arrangement, composed of chains of the deeply rods, is formed around the deeper zooglæa masses; colonies. these chains as a rule run outwards in a radiating manner, and show a peculiar movement in that they often shoot out and then again retract. They gradually bore more deeply into the gelatine, the ray arrangement becomes more markedly developed, and the area of the 
liquefaction of the gelatine extends further; in the periphery of this area actively moving rods are found, and also some which show distinct cilia, as well as convoluted Zooglæa threads which are called spirilla and spirulina. Peculiar zooglæa formations often extend from the circle of rays in the form of clubs or screws, or of spirules twisted like corkscrews. - In 10 per cent. gelatine the migration of the colonies is no longer observed. In meat infusion there is active growth and the development of foul smell; on the other hand, in Nägeli's and Cohn's nutrient solutions there is only slight multiplication of the organisms. Necessity for If the oxygen is expelled from the vessels employed for oxygen.

cultivation and replaced by hydrogen, the growth takes place only very slowly, and the liquefaction of the gelatine is likewise very gradual, though ultimately complete.The temperature optimum is between $20^{\circ}$ and $24^{\circ} \mathrm{C}$. Spore formation is never observed; nevertheless, drying of the cultivations in a thin layer does not destroy the Production of organisms. The bacilli set up putrefactive decomposition putrefaction. in fresh meat, and also in boiled and sterilised meat; this, however, does not occur when the fluid added to the meat has been filtered through plaster cylinders.Experiments In animals small doses produce no pathogenic effect, on animals. somewhat larger doses often cause abscesses at the seat of injection, large doses injected into the veins or subcutaneously produce symptoms of poisoning in rabbits and guinea-pigs. As the same effect was brought about by cultivations which had been filtered through plaster of Paris, it was evident that liquid poisonous materials were the cause of the pathogenic action.*

\section{Proteus mirabilis (Hauser).}

Morphological These are rods $\cdot 6 \mu$. in breadth and of very various characters. length; they are sometimes almost round, sometimes in the form of rods 2 to $3 \cdot 75 \mu$. in length. This form is distinguished from the preceding variety more especially by the much more frequent occurrence of involution

* That this is not the whole truth is evident from Mr. Watson Cheyne's paper on "Some Conditions of Infection," Brit. Med. Journal, July, 1886. 
forms, large spherical or pear-shaped or spermatozoa- More frequent like structures $3 \cdot 75$ to $7 \mu$. in diameter. Further, the formolution liquefaction of the gelatine occurs much more slowly than in Proteus vulgaris. After 12 hours a roundish, Cultivations. whitish deposit 2 to $3 \mathrm{~mm}$. in diameter has formed on the jelly plates, and under a low power this presents a finely granular brownish appearance, diminishing in thickness towards the periphery in a stair-like manner, and showing an irregular or wavy outline. As in the case of Proteus vulgaris, projections pass out from the

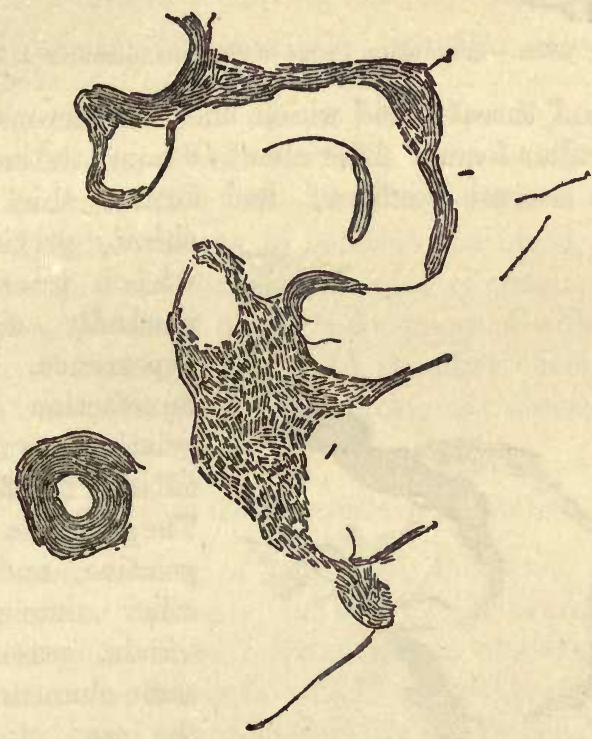

Fig. 107A.-Proteus mirabilis (Hauser), swarming islands, $\times 285$.

border, and these gradually become detached and move away; but in this case the movements are on the whole less active, and the network which is formed at the surface is characterised by the presence of threads of enormous length. In the moving islands we find the most marked involution forms. In the depth of the gelatine well-developed convoluted zooglæa masses appear; the appearances thus produced Irecall those found by Klebs in the organism which he looked on as the contagium of syphilis, and which he termed heli- 
Zooglæa formation.

comonas. At the outer margin of the puncture a ringlike.zone appears which is filled with a network of

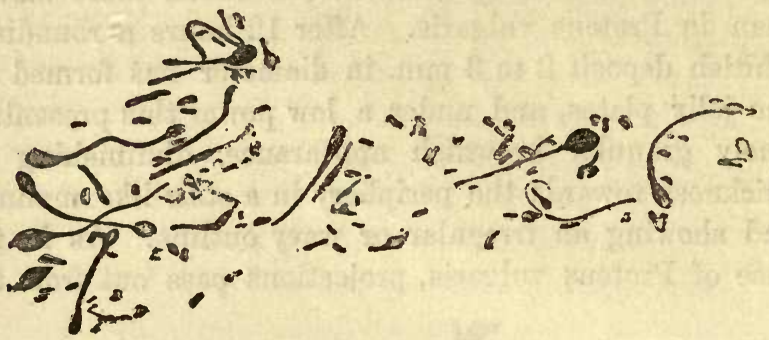

Fig. 107в.-Involution forms of Proteus mirabilis $\times 524$.

bacilli and threads, and which shows numerous spirilla and spirulina forms. After about 48 hours the superficial colonies become confluent, and form a thick, moist

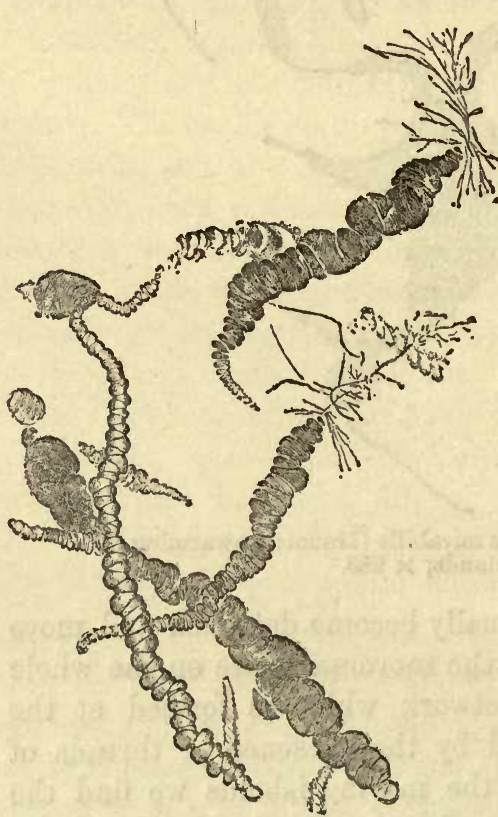

Fig. 108.-Zooglæa forms from a cultivation of Proteus mirabilis $\times 95$. fermentative action on egg albumen as well as in it pathogenic action.

shining greyish layer which presents : markedly sieve-like appearance. Tota liquefaction of the gelatine does not begir till after 2 to 3 days.The growth in stronge gelatine, and in the other nutrient ma terials, presents th same characters as in the case of Proteu: vulgaris; but in cul tivations in whicl oxygen is absent $\mathrm{n}$ liquefaction of th gelatine occurs ever after a long time Proteus mirabilis i also similar to the foregoing form in it 


\section{Proteus Zenkeri (Hauser).}

These are bacilli $\cdot 4 \mu$. in breadth, and of an average length of $1.65 \mu$.; sometimes the forms are rounder, at other times longer. After inoculation on gelatine $a^{\circ}$ layer, which towards the periphery becomes thinner like the steps of stairs, is formed around the point of inoculation, and from the margin of this layer numerous threads and rods begin to pass out; after 24 hours we find large numbers of moving islands, composed of rods and threads, presenting exactly the same appearance as in the case of Proteus mirabilis. The deposit becomes gradually thicker and opaque; but liquefaction of the gelatine does not occur (or only quite at the surface): The formation of spirilla and spirulina are seldom observed.-Cultivations in gelatine and blood serum do not show any marked development of smell; meat infusion, on the other hand, is decomposed with the production of a strong smell. In its other effects Proteus zenkeri resembles the species previously described.

\section{Anaerobes which excite putrefaction.}

In a great variety of putrefying mixtures, as also in the intestinal contents, in the buccal secretions, \&c., a peculiar want of correspondence is observed between the numerous bacteria which are evident under the microscope, and the species which can be isolated by the ordinary methods of cultivation. As a rule, by the latter methods only a few colonies are obtained, or the nutrient soil remains completely sterile, even after several days, and in spite of all sorts of variations in the composition and temperature. This absence of bacteria Part played by which can be cultivated appears to be due to a consider- - the anaerobes able extent to the fact that many of the species of factive bacteria which usually take part in the putrefactive process are anaerobes, and hence do not grow under the ordinary conditions of cultivation. The spores of these bacilli are probably very widely distributed, and almost always enter putrefying mixtures. As soon as the 
oxygen which is present has been used up by the preliminary development of the aerobes, and as soon as the nutrient medium has become loaded with the products of tissue change and of the fermentative action of these - bacteria, with carbonic acid, hydrogen, and other gases, the most favourable conditions conceivable for the growth of the anaerobes are produced, and from this point they multiply rapidly. If the access of air and the amount of oxygen in the nutrient substratum is from the first limifed, as is the case in the interior of dead animals, and more especially in those which have died of asphyxia, the anaerobes occupy the foremost place from the beginning.- $U p$ till recently only the bacilli of malignant œdema of symptomatic anthrax, of tetanus, and of the butyric acid fermentation, have been known as typical anaerobes. Some other anaerobic bacilli have been isolated in the course of the last few years in the author's laboratory, and among these are some which break up egg albumen energetically, and

Methods of cultivation. which produce intensely foul-smelling gases. These can be obtained pure by the aid of the ordinary gelatine or agar plates if kept permanently in an atmosphere of pure hydrogen. They also develop if a thick layer of a solid nutrient material is employed, in which case an upper portion, several centimetres in breadth, remains completely free from colonies.

The organisms which have been as yet isolated are for the most part large bacilli which form large, highly refracting spores in the threads, or after preliminary development of clostridium forms. At times they present the appearance of fine rods with large terminal spores. The majority do not produce dense and circumscribed colonies, but branched and knotted masses; gelatine and blood serum are liquefied, and the cultivations. give off a foul smell varying in degree and character in different cases. An accurate description of some of the bacilli which belong to this group will be shortly published. 
The bacterium termo was formerly looked on as the true Bacterium exciting agent of putrefaction, and it was defined in the following manner :-

Cells short, cylindrical, oblong; $1.5 \mu$. in length, $\cdot 5$ to $\cdot 7 \mu$. the exciting in breadth; the contents either light or dark, according to the agent of 'focussing; the membrane comparatively thick. It occurs in 1rregular dense masses, often arranged in rows, and forming clumps, or in dense grape-like spherical zooglæa. Flagella were observed in bacterium termo by Dallinger and Drysdale. Its mode of movement does not differ in any important particular from that of any other bacteria; "the cells twist around their long axis, and swim forwards, and then again, without turning round, they go backwards, or else move in a curved direction through the water, as a rule not very quickly, with a trembling or oscillating motion, but sometimes making sudden forward movements, sometimes rotating

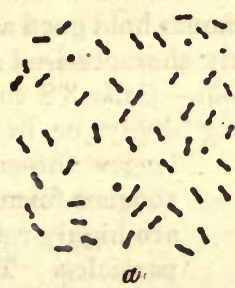

Fig. 109.-Bacterium termo $\times 650$.

$a$, isolated bacteria.

$b$, group of bacteria. around the transverse axis, and then again remaining quiet for a long time, and again suddenly moving backwards and forwards" (Cohn).

J. C. Ewart has made the following statement as to the mode of. development of bacterium termo in the moist chamber. The rods (their size is not stated) grew to form threads shorter than those of anthrax, and without any tendency to form a network or mycelium; in the threads small, refracting, round spores soon appear. Two or three days after their formation these spores escape from the threads, and lie either free in the middle of the cultivation, or form zooglæa masses at its edge. After some time they sprout and form small, narrow rods, which then multiply by transverse division. The accompanying drawings, however, show that Ewart was not studying the organism which Cohn had termed bacterium termo, but some sort of spore-bearing bacillus.In order to obtain bacterium termo, we should, according to Eidam, add a small quantity of an infusion of peas, which has stood for a long time, to Cohn's nutrient solution, and when this is done luxuriant development of bacterium termo very quickly occurs. The bacteria so cultivated, however, never caused, in Eidam's experiments, a putrid smell; at most a cheesy odour was produced.

The preceding description is evidently applicable to a large The term an imperfect one. 
number of bacteria which are now known, and the name at that time employed cannot be limited to any one of these species. Hence it is better to give up entirely the designation "bacterium termo," as it can only be regarded as a collective name for an inconstant mixture of different species. According to Eidam's experiments, the bacteria which were formerly grouped under the term "bacterium termo" have apparently no relation to the process of putrefaction; hence it is probably about time that we should cease to designate the species which are concerned in putrefaction as bacterium termo, although this term is still frequently employed in text-books and scientific papers.

The same statements hold good as regards bacterium lineola, which was formerly characterised as follows :-

Bacterium lineola.-Cells 3.8 to $5.2 \mu$. in length, $1.5 \mu$. in breadth; occurring singly, or in pairs, but never forming

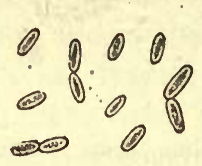

Fig. 110.-Bacterium lineola (after.Cohn) $\times 650$. longer threads; at times arranged in zooglæa form. The contents of the cells are highly refracting, and contain fatty particles. Their movements resemble those of bacterium termo. They occur in water from wells, \&c., in slimy masses on the surface of potatoes, \&c.

The following are some bacteria which occasion other fermentative processes, or which dehydrate certain chemical substances :-

\section{Bacillus Fitzianus.}

Fitz's glycerineaethyl bacteria.

Fitz bas been able to set up fermentation in férmentescible mixtures consisting chiefly of glycerine, the products of the fermentation being in the main aethylic alcohol; the organism present is a bacillus which he looks on as bacillus subtilis, and which he obtained from How to obtain the dust of hay. Buchner constantly obtained these this organism. bacilli when he allowed unboiled hay infusion to stand in a room for some days, and when he transferred a small portion of the scum which was then formed to a sterilised mixture containing 2 per cent. of meat extract with 5 per cent. of glycerine, and about 10 per cent. of carbonate of lime. According to the same author these bacilli have a breadth of $1 \mu$., but their length 
varies considerably from $1 \cdot 2 \mu$. upwards; where the Morphological rods are longer they are frequently bent at their ends. ${ }^{\text {characters. }}$ Spore formation takes place in a similar manner to that in bacillus subtilis.- On nutrient jelly they form brownish- Cultivation. yellow colonies, with sharp outlines and with dark, almost opaque, centres; the superficial colonies have the appearance of brownish-yellow, gelatinous drops lying on the surface of the gelatine.

\section{Bacillus aceticus.}

(Mycoderma aceti, Mycoderme du vinaigre, Essigpilz.)

According to Hansen's investigations the bacteria Bacteria of which have the specific property of transforming the the acetic alcohol of fermented liquors into acetic acid can be obtained with the greatest certainty by placing lager beer (for example the Copenhagen Carlsberg beer, containing 4 per cent. of alcohol and 5 per cent. of extract) in open vessels at a temperature between $30^{\circ}$ and $34^{\circ} \mathrm{C}$., best at $33^{\circ} \mathrm{C}$. ; after two or three days a scum is formed which consists almost entirely of acetic bacteria, while the fluid has become muddy and strongly acid. The bacilli are short rods, somewhat constricted in their middle, the ends of the rods being cut off at right angles to the long axis; their size is about the same as that of

$a$

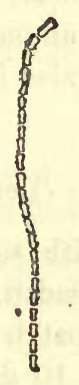

Fig. 111.-Mycoderma aceti.
Hansen.)

$a$, two normal chains $\times 1180$.

$b$, chain with involution forms $\times 1180$.

c, abnormal chain $X$ about 2000 .

the lactic acid bacteria. A characteristic appearance is their arrangement in long chains, which. often extend through several fields of the microscope. Some of the members of these chains show more or less distinct variations; they assume cylindrical, hour-glass, 
or spherical shapes, or form long thread-like and irregularly swollen cells. After treatment with iodine solution, all these forms take on the same yellow colour. It is not as yet possible to say with certainty whether some of the cells with thicker walls and of rounder shapes are to be looked on as arthrospores, and whether they are, as a matter of fact, much more resistant than the other growing cells, or whether all these variations from the ordinary form of the chains are in reality involution stages. Nothing trustworthy is as yet known as regards the mode of growth of this organism on solid nutrient substrata.

\section{Bacillus Pasteurianus (Hauser).}

\section{(Mycoderma Pasteurianum.)}

This organism does not differ morphologically from the foregoing one ; it forms similar chains and involution forms, but on treatiment with iodine all the cells take on a blue colour. It was first observed by Hansen in sweet Copenhagen double beer, and develops best in beer which contains a large amount of extract, and a small amount of alcohol, and also in beer wort.

\section{Bacillus uraa (Leube).}

Bacilli of the ammoniacal fermentation of urine.
These are plump rods with rounded ends, usually $2 \mu$. in length, and $1 \mu$. in breadth. On gelatine plates a small, almost transparent, patch appears after 2 days, and extends in the course of 10 days to about the size of a farthing; the colonies have the appearance of a ground glass plate which has been breathed upon; the growth extends from the point of inoculation in the form of circular irregular zones, so that at a later period a number of concentric rings are seen; the outermost zone shows a dentate outline. Growth occurs exclusively at the surface; the gelatine is not liquefied. In puncture cultivations the track of the needle appears after 10 days as a very thin grey prolongation, and it is only 
rarely that, at its uppermost part, the growth is somewhat broader. Older cultivations have a distinct smell of herring brine.-It was frequently found by Leube in old urine. The bacilli are able to convert urea into carbonate of ammonia, and they do this more energetically than the micrococcus ureæ.

Leube was able to demonstrate a similar energetic Other bacilli dehydrating action on urea in the case of two other which have a bacilli, and also of a species of sarcina. The first bacillus formed thick oval rods, 1.2 to $1.5 \mu$. in length, and $\cdot 7$ to $\cdot 8 \mu$. in thickness; on gelatine they form superficial dull grey colonies with sharp margins, which descend rapidly to the level of the nutrient soil, their marginal zone being narrow, transparent, and finely granular. The second bacillus was 1.2 to $1.4 \mu$. in length, $\cdot 6 \mu$. in breadth, had sharply truncated ends, and formed circular, highly refracting, fairly high colonies, of a pale greyish-yellow colour, and tough consistence.

\section{Bacteria in Dental Caries.}

The numerous organisms which are constantly present in the secretions of the mouth and in the deposit on the tongue and teeth, set up in part very various fermentative and putrefactive processes, and in part they play a rôle in the etiology of dental caries. According to Miller Etiology of the first stage of dental caries consists in a decalcificadental caries. tion of the dental tissue by acids, these being chiefly formed in the mouth by a process of fermentation; and the second stage must be regarded as a simple destruction of the softened tissue of the tooth by microorganisms.

Formerly the most important rôle in these processes Leptothrix was ascribed to a particular genus-the leptothrixbuccalis. which were defined as long thin threads, -7 to $1 \mu$. in breadth, apparently without any segmentation and often united in dense bundles or felt-like masses; the forms which occur in the buccal cavity mixed with micrococci and other fission fungi, were designated leptothrix buccalis. 
Morphological It was regarded as characteristic of the latter form that haracters.

the threads were mixed with dense masses of micrococci ; further, according to Leber, the threads of leptothrix buccalis show a special reaction: they assume a violet colour under the action of iodine and acids; Reaction with iodine alone does not cause this coloration, acids must.
iodine.

be added at the same time; but it is not necessary to employ sulphuric acid (if it were so the reaction would have a great resemblance to that of cellulose), very dilute hydrochloric acid, acetic acid, or lactic acid, act even better than sulphuric acid. If the medium is already acid the addition of iodine alone is sufficient to

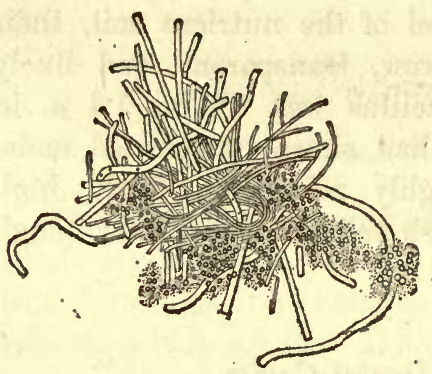

Other situations in which leptothrix is found.

Leptothrix gigantea.

Rasmussen's species of leptothrix.

Fig. 112.-Leptothrix buccalis cocci, and spirilla.

produce the colour. It is not the sheath which stains; on the contrary it remains colourless, and only the contents become violet; the septa of the threads remain unstained, and hence can be distinctly seen.

Leptothrix has also been found in the concretions in the tear-ducts, as well as in the sputum in cases of gangrene of the lungs (Traube, Leyden, and Jaffé); and Leber has recently demonstrated that Leptothrix buccalis, when inoculated on the cornea, causes severe suppuration, and that during the course of this process very fine, long, jointed threads and chains of rods are developed; which show the characteristic iodine reaction.*

Miller has described a form, under the name of Leptothrix gigantea, which occurs on the teeth of sheep, cattle, and other animals, and which forms very long and thick threads, and may also appear in the form of rods,

Rasmussen isolated from the human saliva by the aid of nutrient jelly and potato cultivations a number of bacteria, of which he reckons three as species of leptothrix, because they form in nutrient solutions (urine, meat

\footnotetext{
* Arch.f. Ophthalmol., vol. 15.
} 
infusion) long threads, which break up into short segments.

It is evident, however, that the designation "lepto- The existence thrix " cannot be employed as a generic term, for the of a genns most various kinds of bacilli may produce these thread- cannot be like formations, and the threads which occur in the buccal secretions and in the deposit on the teeth are probably nothing more than the thread form of various well known, or still unknown, and widely distributed bacilli. It is possible, for example, that bacillus butyricus not uncommonly takes part in the formation of leptathrix in the mouth; it is probable, however, that many other bacilli, more especially anaerobic bacilli, do the same. Since we have been able to work with better microscopes and with staining methods it is easy to convince ourselves, from the marked morphological differences, that the leptothrix threads of the mouth do not belong to one individual species; the threads show very great variations in thickness, at times they form spores (or the early stages of spore formation) arranged in a characteristic manner; some threads are stiff and readily broken, others are flexile, \&c. . The species of Fruitless bacteria which have as yet been isolated by cultivation $\begin{gathered}\text { attempts at } \\ \text { cultivation of }\end{gathered}$ from the buccal secretion do not appear to be identical bacilliforming with those bacilli which form the marked threads which forms. have led to the designation leptothrix; as a matter of fact we only obtain by cultivation a small fraction of the numerous species which we find by the microscope in the secretions of the mouth. Miller also states, in his most recent communication, that the leptothrix buccalis has not as yet been cultivated pure.

As regards the other organisms found in the mouth, Miller's Miller has isolated, during the last few years, 25 different bacteria from species, 12 coci and 13 rod forms. Some of these have teeth been already. mentioned; we may refer here to the organism described by Miller under the symbol $\epsilon$. This forms small curved bacilli, often S-shaped from the union of two individuals ; it grows on gelatine, and causes its liquefaction, and is probably identical with the spirillum of Finkler and Prior. The characteristics of the 
other species isolated by Miller have not as yet been published in detail.

With regard to the pathogenic bacteria present in the buccal secretions, see pages 319,322 and 325 ; as regards 'Spirochæte denticola, see below.

\section{Bacilli which are not known to produce Specific}

\section{- Fermentations.}

\section{Bacillus subtilis.}

\section{(Hay bacillus.)}

Hay bacillus. These are cylindrical rods, up to $6 \mu$. in length, and on an average about three times as long as they are thick. Morphological They grow and divide very rapidly; the length of time characters. between one fission and a second is, at $21^{\circ} \mathrm{C}$., about an hour and a quarter, and at $35^{\circ} \mathrm{C}$. about 20 minutes. Pseudo-threads frequently appear, which can be frequently seen to be made up of rods, by the fact that they soon become bent in a zig-zag manner; in other cases, however, they do not present this appearance. The individual-members of a thread are as a rule in different stages of growth and subdivision, and are therefore of different lengths. Under various conditions, which have not as yet been accurately ascertained, the rods begin to swarm; the movements are active and snake-like. At each end of the rod a fairly long and twisted flagellum can be seen, especially after treatment with hæmatoxylin (Koch).-When the substratum becomes poorer in nutrient material the continued multiplication of the rods by fission gradually ceases,

Spore forma- and then as a rule spore formation commences. At one tion.

part of the rod which has now ceased to move a dark, shaded part becomes evident, sometimes more in the middle, sometimes more towards one end, and ultimately this portion becomes converted into a highly refracting spore with dark outlines. The rods swell up at the same time in some cases in an almost unnoticeable manner. At the same time that the spores are formed the contour of the rods becomes dull and indistinct, and 
they soon disappear entirely, so that the spores become free, as a rule, during the course of one day. The spores are $1 \cdot 2 \mu$. in length, and $\cdot 6 \mu$. in breadth; when they are looked at from above they appear round. Around their dark centre there is a distinct light area, which is also seen when several spores are lying together. The sprouting of the spores often does not begin at the Sprouting of ordinary temperature of the room till after 12 hours; it occurs most quickly when the spores are boiled for five minutes in the nutrient solution, the material being then allowed to

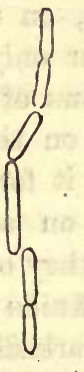

A

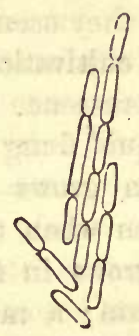

A 2. B

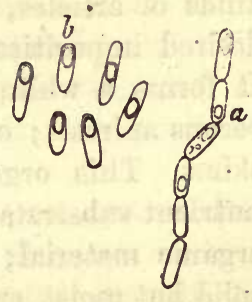
the spores.

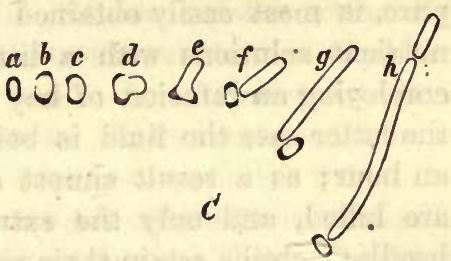

Fig. 113.-Bacillus subtilis (after Prazmowski) $\times 1020$.

$A$, colonies of bacillus subtilis.

$B$, spore formation$a$, in a pseudo-thread.

$b$, in individual rods.

$C$, germination of the spores. $a-h$, successive stages.

time, and a

lighter zone appears in the middle of the spore. This zone becomes larger, and then on one side a distinct projection is formed, at the apex of which the spore membrane is ultimately ruptured in order to permit the sprouting portion to pass out. The latter elongates and forms a rod, but for a time the end still remains sticking in the opening in the empty spore membrane as if a bladder were attached to it. The spore membrane can often be distinctly seen, even after repeated fission of the rods, and it accompanies the moving bacilli in their wanderings. 
The newly formed rod always stands at right angles to the long axis of the spore; but the long axis of the newly formed spore is the same as that of the rod in which it develops; hence, as the result of the spore formation, there is an alteration in the direction of growth of the bacilli.*

Distribution. Bacillus subtilis is tẹy widely distributed; its spores are present in the air, in dust, on the surface of all kinds of articles, and they occur only too often as un. desired impurities in cultivations of other organisms. It forms a white efflorescence on the dung of herbivorous animals; on liquid dung it forms thick wrinkled skins. This organism grows on a great variety of nutrient substrata, even when they only contain a little organic material; it grows in fluids just as well as on -solid but moist substrata; a markedly acid reaction of the media interferes, however, markedly with its development. A cultivation of this bacillus, to some extent pure, is most easily obtained by infecting the ordinary nutrient solutions with a little dust from hay, or by employing an infusion of hay as a nutrient solution; in the latter case the fluid is boiled for about'a quarter of an hour; as a result almost all the other fission fungi are killed, and only the extremely resistant spores of bacillus subtilis retain their vitality.

According to Buchner, in order to obtain bacillus subtilis with certainty, it is best to allow hay to stand at $36^{\circ} \mathrm{C}$. for four hours with extremely little water, then to pass it through a fine sieve, to dilute the water to a specific gravity of 1004, and then to raise about $500 \mathrm{~cm}$. of this mixture to the boiling point in a vessel closed with cotton-wool, the heat being continued for one hour, and only very little steam being developed; after it has been boiled the fluid, if kept at $36^{\circ} \mathrm{C}$., shows a scum on the surface after 48 hours, consisting of bacillus subtilis. It is only when the reaction is very markedly acid that it is nécessary to neutralise the material before boiling it.

On gelatine plates bacillus subtilis forms small whitish * After Brefeld, Botan. Unters., Part 4, and Prazmowski, Lit., p. 47. 
colonies, which, under a low power, have a yellowishbrown colour, and an irregular margin, with numerous hair-like processes projecting from it. At a later period a narrow clear zone appears around the dark centre, and beyond this there is a greyish layer consisting of a circle of rays. At the same time the gelatine is energetically liquefied.-On agar a thick wrinkled skin is formed. On potatoes thick yellowish-white deposits appear, which, on the second day, have a moist satinlike appearance, with dry, whitish spots at parts of the surface, soon extending over the whole extent of the layer; ultimately the cultivation appears as if powdered with a white granular mass.

These bacilli require plenty of oxygen, and growth, Necessity fo multiplication, and spore formation only go on in a oxygen. normal manner when there is no hindrance to the access of air; in vessels devoid of air no development visible to the naked eye takes place.-Under unfavourable conditions of life the bacillus subtilis forms the most various kinds of involution forms, flasklike swellings, \&c., which, under the microscope, show a peculiar fatty appearance. According to Buchner Involution these involution. forms appear especially when the amount of sugar in the nutrient solutions is markedly -greater than the amount of nitrogen. The same author found that even slight variations in the composition of the nutrient substratum occasion certain alterations in form, and more especially alterations in thickness of the bacilli.

Bacillus subtilis does not appear to exercise any Action on t] special fermentative action, more especially with reference nutrient to the carbo-hydrates; the reason why such properties were formerly ascribed to bacillus subtilis was evidently because it was confounded with bacillus butyricus and other bacteria. Vandervelde has recently asserted that bacillus subtilis can set up fermentation when it is compelled to exist without oxygen. Vandervelde tried to show this by careful analysis of the nutrient substratum in which a pure cultivation of bacillus subtilis had grown for a considerable time; he found that glycerine or grape 
sugar were used up, and that lactic acid, volatile fatty No fermenta- acids, carbonic acid, and hydrogen, were produced; but tion. these substances were formed in such small quantities, and after such a length of time ( 1 to 2 months) that we cannot speak of a true fermentation; on the contrary, these products only indicate the result of the assimilation and tissue change of the growing bacilli within ordinary limits. Further, in Vandervelde's experiments the absolute quantity of gases produced was not determined, and there was no certainty as to the purity of the cultivation, and for this reason the experiments, which are nevertheless interesting as regards the tissue change of bacteria, cannot be regarded as definite proof of the fermentative activity of bacillus subtilis.eptonising As the only energetic transformation of the substratum otion. caused by the bacillus.we have its peptonising power on albumen (also on blood serum) and on gelatine, as indicated by the mode of its growth in cultivations. As to the supposed transformation of hay bacilli into anthrax bacilli, see page 241 .

\section{Bacillus aerophilus.}

erobic acillus.

This organism was found by Liborius in the hygienic laboratory at Göttingen as an accidental impurity. It . Iorphological presents the appearance of thin rods, ${ }_{3}^{2}$ rds of the thickness haracters. of bacillus subtilis ; these vary in length and frequently hang together, forming straight or zig-zag pseudo-threads. In the unstained preparations we can at times see a delicate sheath around the bacillus. They form on agar ultivations. oval, highly refracting spores.-On gelatine plates fine punctiform colonies appear after 40 hours, which under a low power show sharply defined borders, are of an oval or pear shape, and have a yellowish green colour. Energetic liquefaction of the gelatine soon commences; while the colonies have only slightly increased in size, and have otherwise remained unaltered, the surface of the gelatine is liquefied over the whole plate.-In puncture cultivations a broad sac-like liquefied area is formed, the upper part of which is greyish-yellow and 
opaque, while the lower part is clearer, and is only rendered somewhat turbid by the presence of a few flakes.-On potatoes the bacilli form yellowish layers -with a flat surface and a dull paraffin-like appearance; later on the surface at the margin becomes drier, faintly granular, and assumes a striped appearance as the result of unevenness of the surface. - The bacillus requires the Necessity cr presence of oxygen to a greater degree than any of the other organisms as yet examined; it only grows on the surface, and ceases to form visible colonies, even when there is a relatively trivial interference with the supply of oxygen.

Among the so-called potato bacilli, which readily grow on the surface of potatoes, and which are often observed as accidental contaminations, we have-.

\section{Bacillus mesentericus fuscus.*}

This organism occurs in the dust of hay, in the air, Brown potato on the surface of potatoes, \&c. ; it is very widely distri- bacillus buted. The bacilli are small and short, often occurring in chains of two to four members, and actively mobile; they form irregularly arranged, small, refracting spores.-On gelatine plates roundish, whitish colonies appear with sharp contour under a low power, and later with delicate processes of a yellowish brown colour, and finely granular surface; liquefaction of the gelatine rapidly occurs. In puncture cultivations a whitish opacity is formed at first along the track of the needle, and at the same time there is a funnel-shaped area of liquefaction at the poirt of entrance of the needle, this area extending within 4 to 6 days till it reaches the wall of the glass; in this way an upper layer of fluid is formed, in which whitish. grey flakes are floating.-On potatoes smooth yellowish deposits appear on the first day, the surface of which, however, become very quickly wrinkled and brown; this

* Göttinger hyg. Institut. 
membrane is relatively thin, and does not extend deeply into the substance of the potato. The growth rapidly spreads over the whole surface of the potato.

\section{Bacillus mesentericus vulgatus.*}

Potato bacillus.

This organism is very widely distributed in nature; it is usually, though badly, described under the name "potato bacillus." The bacilli are thick and large, often forming pseudo-threads and spherical spores; they have an oscillating movement. On gelatine plates the colonies present a bluish-white appearance, they are almost transparent, but later the centre acquires an opaque white colour; the superficial colonies can attain the diameter of almost $1 \mathrm{~cm}$. These colonies sink to some extent into the liquefied gelatine; under a low power they present the appearance of dark, distinctly granular dises, with rough borders. The gelatine is energetically liquefied. In puncture cultivations a funnel-shaped area of liquefaction is formed at first, but later the whole of the upper part of the gelatine becomes flivid; in the fluid there are numerous grey flakes, and on it there is a delicate greyish-white wrinkled skin. At the bottom of the area of liquefaction a thicker floceulent mass is present; from that point downwards we still see, for the next few days, the remains of the line of puncture, clothed with a thick whitish deposit.-On potatoes a whitish thick growth is formed which is almost from the first markedly wrinkled, and which spreads rapidly over the whole. surface; if we attempt to pick up a portion of this skin it is seen that the colonies have grown deeply into the substance of the potato; the raised portions of the skin remain in connection with the substance of the potato by a tough mucous mass, so that long threads may be drawn out. According to Hueppe the bacilli are not able to form any ropy substances from sugar, but they have an energetic diastatic action; they also cause coagulation of casein

* Göttinger hyg. Institut. 
in milk in a similar manner to rennet, and cover the coagula, which are again gradually but almost entirely dissolved, with a thick tenacious envelope.

\section{Bacillus liodermos.*}

These are small, short bacilli, with rounded ends, and Potato with very active movement. They form on gelatine bacillus formplates colonies with irregular outlines which float on skin. the surface of the liquefied gelatine in the form of small white flakes. In puncture cultivations liquefaction occurs in the whole of the upper zone, and at the bottom of the fluid greyish-yellow flocks are deposited; in the lower part of the track of the needle there is a greyish growth.-On potatoes a smooth, shining layer is formed, which spreads rapidly over the whole surface, and gives to it an appearance as if it had been painted over with yellowish-white syrup. It is not till after several days that the smooth surface becomes opaque and slightly wrinkled, but in any case the wrinkles which are formed are never so marked as in the foregoing species.

\section{Bacillus multipediculus. $†$}

These are long thin non-motile bacilli. The colonies Bacillus with on gelatine plates present under a low power the appear- insect-like ance of round or oval, sharply outlined, dark discs, from the periphery of which small, relatively broad processes shoot out in various places; these processes are jointed, consisting of round balls arranged in rows, and gradually becoming smaller, and they have usually a radiating direction; at times, however, they curve, and present a concentric arrangement. After 2 or 3 days these processes are visible to the naked eye in the superficial oval white colonies; as these processes only occur here and there, and are usually only in considerable numbers at one of the pointed ends, the colony recalls the form of an insect with numerous feet and antennæ.-In puncture.

* Göttinger hyg. Institut. + Göttinger hyg. Institut. 
cultivations the growth is not so characteristic, but there also a row of short isolated processes is very gradually formed, these processes passing out from the whitish layer which appears along the track of the needle. On potatoes a dirty yellow layer of moderate extent, and with a smooth surface, is produced, and the portions of the potato around the borders of this layer show a dark colour.-It occurs not uncommonly as an accidental impurity on potatoes.

Branched funnelforming bacillus.

Of other bacilli not unfrequently met with in Göttingen the following may be mentioned :-

\section{Bacillus ramosus liquefaciens.}

These are fairly large, slowly moving bacilli with blunt ends. They form on gelatine plates very characteristic colonies; the youngest, when lying deeply in the material, present under a low power the appearance of roundish dark dises, the borders of which seem as if surrounded by hairs; the same appearance can also be seen in the superficial colonies, which are for the most part oval or pear-shaped. With the naked eye we also observe that a sharply defined funnel-shaped depression has been formed by a limited liquefaction of the gelatine. Even after several days this liquefaction has not extended any further, but the sharply defined, deep circular funnel, 2 to $3 \mathrm{~mm}$. in breadth, is surrounded by several concentric zones of varying breadth and distinguished from one another to some extent by their colour, these zones having on the whole a greyish-white ground glass appearance. On a black base these various zones can be particularly well seen.-In puncture cultivations a slight funnel-shaped depression, accompanied by liquefaction, forms at the entrance of the needle; beneath this funnel the track of the needle shows a number of branches which pass off at right angles, the uppermost extending furthest into the gelatine; as we pass deeper these branches become shorter. At a later period the lique- 
faction extends very gradually over the whole surface, and affects an upper zone of constantly increasing depth.This organism was found by Praussnitz as an accidental contamination; it is rare.

\section{Bacillus mycoides.}

\section{(Earth bacillus.)}

These are fairly thick mobile bacilli approaching in Earth bacillus size the anthrax bacilli, and often forming long pseudo- $\begin{gathered}\text { growing like } \\ \text { mycelium. }\end{gathered}$ threads. In the threads oval, highly refracting spores appear at regular intervals, and this is also the case in the individual bacilli; the spore lies about the middle of the bacillus.- In gelatine plates a whitish turbidity is formed in which fine whitish threads of irregular interwoven and branched appearance are seen. This network of threads attains, even after 12 to 20 hours, an extent of about $10 \mathrm{~mm}$., and resembles the mycelium of a fungus so much that one may be in doubt whether it is that, or whether it is a colony of bacteria. The threads remain delicate and fine so long as they lie in the depth of the gelatine, but they increase markedly in breadth and lose their sharp outlines when they reach the surface. The individual colonies soon run together as the result of the growth of this network of threads. Under a low power the threads are seen to be composed of bundles of bacilli, which usually lie loosely beside each other, but are at times densely matted together, and have on the whole a very curved and convoluted course. When the threads reach the surface liquefaction of the gelatine occurs in the uppermost layer, which has already become diffusely opaque as the result of the growth of the colonies. - In puncture cultivations minute hairs spread in the first place from the line of puncture into the gelatine in dense rows; later the accompanying liquefaction obscures the characteristic growth. On potatoes a whitish tenacious layer is formed which slowly extends over the surface. - These bacilli are almost always present in specimens of earth taken from the surface of 
fields or gardens, if these specimens are either directly dusted over gelatine plates, or if a watery extract of the earth is made and mixed with the gelatine.

The following bacilli have also been more or less accurately described :-

Bienstock's bacilli from faces.

Bienstock's fæces bacilli.

These organisms were constantly found in the fæces by Bienstock. They resemble bacillus subtilis in size and general appearance, but they do not possess spontaneous movement; they often form longish threads. The spores appear in these threads, or even in the individual rods, usually one in each rod, rarely two, the spore being generally somewhat nearer one end than the Morphological other. The size of the spore is about the same as that characters. of the spores of subtilis; the whole substance of the spore can be stained with warm aniline fuchsine, and is not decolourised by nitric acid; with methylene blue only a fuint staining of the periphery takes place. When the spore sprouts the ellipsoid form becomes gradually cylindrical, and the substance of the rod which commences to form at each end gradually extends towards the middle of the spore, and there becomes united Cultivation. together.-One of this species of bacilli grows out from the line of puncture in the nutrient gelatine like a mesentery; main branches of a whitish-yellow colour run out into the gelatine in all directions, these branches being united together by smaller anastomoses. - The second species grows in the form of white glistening colonies, at first smooth, but later somewhat uneven on the surface, the margins of these colonies showing projections like bunches of grapes; in the course of 10 or 12 hours it extends over the whole surface of the nutrient substratum. 


\section{Bacterium Zopfii.}

This organism was isolated by Kurth from the intestine Kurth's ballof fowls. It presents the form of bacilli $\frac{3}{4}$ to $1 \mu$. in forming breadth, and 2 to $5 \mu$. in length, usually in active movement. These bacilli form long threads, which, when growing in gelatine, show numerous bends; in fact regular spiral forms may occur, or in some cases felted structures or circular patches; all sorts of other bendings and twistings may also be seen. In fluids bacterium
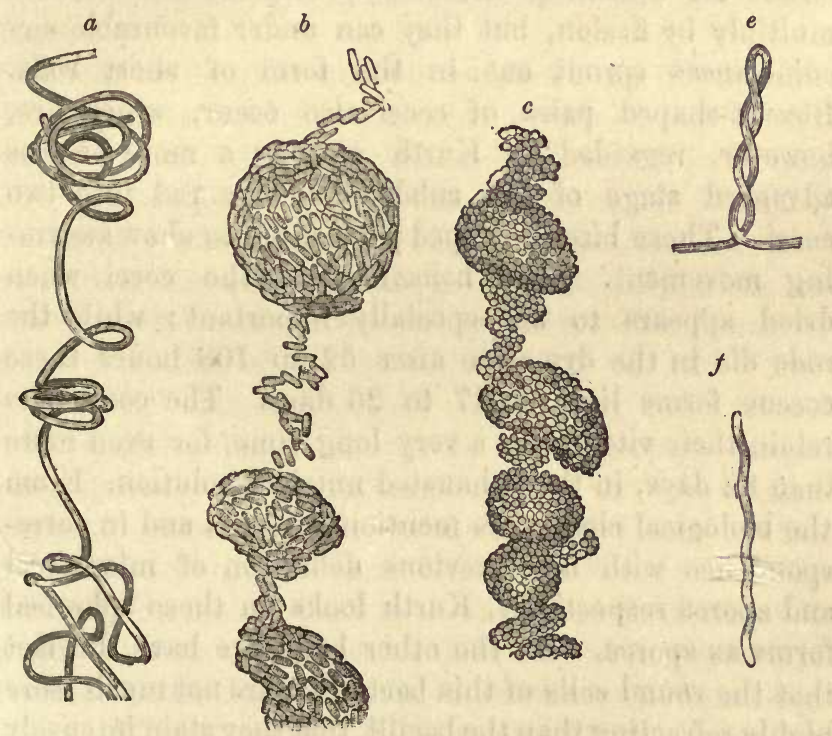

Fig. 114.-Bacterium Zopfii (after Kurth) $\times 740$.

$a$, threads with commencing formation of balls.

$b$, breaking up into rods.

$c$, breaking up into round segments.

$\boldsymbol{e}$ and $f$, spirilla and spirulina threads.

Zopfii always forms straight threads, and this has led Kurth to the conclusion that the origin of the bendings in the gelatine cultivations is a mechanical effect, and he supposes that, given a certain length of thread, and a corresponding rapidity of growth, the resistance which the gelatine offers to the penetration of the thread is greater than the rigidity of the rod. After some time Ball forma. 
dense balls are formed; in these balls the threads become broken up into short or long pieces, varying from 5 to $50 \mu$. in length; the short portions grow and bend almost always laterally from the original direction of the thread.

Formation of After some time growth ceases, and the organism bespherical bodies. comes broken up into spherical individuals, described by Kurth as cocci. The rows of cocci remain in the gelatine united in the form of balls; when sown on new gelatine, rods and threads are again formed within 16 hours. The round forms appear when the nutrient materials are becoming exhausted; they are not able to multiply by fission, but they can under favourable circumstances sprout out in the form of short rods. Biscuit-shaped pairs of cocci also occur, which are, however, regarded by Kurth only as a more or less advanced stage of the subdivision of a rod into two cocci. These biscuit-shaped pairs at times show swarming morement. The behaviour of the cocci when dried appears to be especially important; while the rods die in the dry state after 52 to 108 hours these

Are these spherical bodies spores? coccus forms live for 17 to 26 days. The cocci also retain their vitality for a very long time, for even more than 82 days, in the exhausted nutrient solution. From the biological characters mentioned above, and in correspondence with our previous definition of micrococci and spores respectively, Kurth looks on these spherical forms as spores. On the other hand, we have the fact that the round cells of this bacterium are not much more highly refracting than the bacilli, that they stain intensely with aniline brown, and that there is no difference between them and the bacilli in their resisting power to high temperatures. Nevertheless a higher refracting power, difficulty in staining, and resistance against heat have not as yet been looked on as indispensable for the assumption that any given cell is a spore, and as a matter of fact such an assumption cannot be made so long as the general characters have been studied on only a very small proportion of the existing spores. The only two important criteria which must be required on the part of a spore are a certain resistance against external 
influences which favours the maintenance of the species, and more especially a resistance against the effect of drying; and secondly, the fact that these cells do not multiply, but can give rise to an organism resembling the mother organism. These two requirements are completely fulfilled in the case of the round cells of bacterium Zopfii, and hence we have in this case undoubtedly a spore formation which only differs from the other spore forms as yet known in that the resistant properties depend less on a thickening of the cell contents than, probably, on an alteration of the cell membrane.

These bacilli grow well on nutrient jelly ( 2 per cent. Cultivations. meat extract and $2 \frac{1}{2}$ per cent. gelatine). After 24 hours a thick, whitish-yellow layer is formed along the line of inoculation, and in the course of the following 24 hours white anastomosing lines develop, and project from the original line in radiating directions, so that the appearance of the colony when looked at superficially is that of the mycelium of a fungus. The growth, however, only occurs on or under the surface, and never extends above it; on the other hand the organism requires a large amount of oxygen, and does not grow therefore in the deeper layers of the gelatine. No growth occurs on blood serum; a diffuse turbidity occurs at first in a 2 per cent. solution of meat extract, and later a thick, whitish deposit is formed at the bottom. The optimum of temperature seems to be about $20^{\circ} \mathrm{C}$.; the swarming movements of the rods cease at from $33^{\circ}$ to $37^{\circ}$ C.; from $37^{\circ}$ to $40^{\circ} \mathrm{C}$. involution forms appear, and when this temperature is continued for some time the bacilli lose their vitality.-Experiments on animals show that the bacilli are harmless saprophytes.

\section{Bacillus megaterium (de Bary).}

This organism was first observed by de Bary on Morphological boiled cabbage leaves. It presents the form of rods $2.5 \mu$. in thickness, and cylindrical in form, with rounded 
ends; it elongates till it is four to six times as long as broad, and then divides transversely into two halves; when acted on by alcohol or tincture of iodine the rods are seen to be composed of short segments. They are slightly bent; at times they form chains, which, however, rarely consist of many segments. The rods are in constant, though relatively slow, movement; flagella have

Spore formation. not been observed. At a later period it can be seen that each rod is composed of four to six isodiametric cells, separated from each other by delicate transverse divisions; a small, round, highly refracting body soon appears in the cell, this body increasing in size while the surrounding protoplasm gradually disappears;

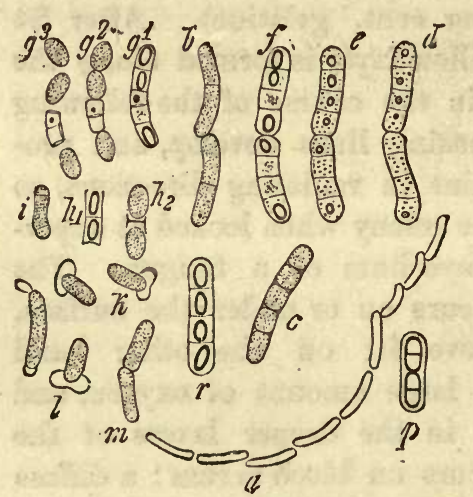
after a few hours it becomes converted into a longișh cylindrical spore. The latter is very highly refracting, of a bluish appearance; the membrane of the mother cell gradually disappears; and the spore becomes free. During the process of formation of the spores the movement of the Fig. 115.-Bacillus megaterium. (After rods becomes slower, but de Bary.)

Germination of the spores.

$a$, chain of rods $\times 250$.

$b$, short rods $\times 600$.

$p$, their appearance after the action of iodine solution.

$e-f$, spore formation.

$g-m$, germination of spores $\times 600$. does not entirely cease. When the spore germinates its dark outline and its highly refracting character disappear, and it gradually increases in size till it has attained the normal breadth of the rod. When this has occurred a delicate membrane, which is torn transversely or obliquely, is suddenly separated from the surface, and the rod Cultivation. passes out of this membrane.-The bacilli grow at $20^{\circ} \mathrm{C}$. in solutions of grape sugar and meat extract, or in meat extract alone with or without gelatine. The gelatine is liquefied as the result of the growth of the bacilli. 


\section{Bacillus tumescens (Zopf).}

This organism was observed by Zopf on boiled carrots kept fairly moist; it forms there a tough, wrinkled whitish skin, which consists of small disc-like gelatinous masses. The skin contains narrow rods arranged in zooglæa forms, these rods forming at a later period shorter joints, and in these shorter joints spores. Its other characters are not as yet known.

\section{Bacillus ulna (Cohn).}

This organism was first observed by Cohn, and then by Prazmowski, in decoctions of boiled egg albumen, and also under the shell of an egg. They are rods 1.5 to $2 \cdot 2 \mu$. in breadth and of varying length, attaining at least $3 \mu$.; they are mobile. As regards the formation of threads and spores, they resemble bacillus subtilis; the spores are 2.5 to $2.8 \mu$. in length, and over $1 \mu$. in breadth. This organism only grows on soil which is rich in albumen, for example, in decoctions of boiled egg albumen. These fluids become turbid on the day after inoculation, and cloudy masses are formed, which after some time collect on the surface of the fluid, and there run together to form a thick, but dry skin; the latter consists of very long matted bundles and balls of pseudo-threads. There is no formation of any gelatinous material. Fructification occurs in the skin on the third or fourth day. The pieces of albumen are not attacked to any marked degree by the growth of the bacilli; they retain their consistence and do not give rise to any putrefactive odour.

\section{Bacillus Hansenii (Rasmussen).}

Motile rods $2 \cdot 8$ to $6 \mu$. in length, and 6 to $8 \mu$. in breadth. They form spores $1.7 \mu$. in length and $1.1 \mu$. in breadth. They give rise to a whitish-yellow skin on meat infusion, malt decoction, \&c., at a temperature of $31^{\circ}$ to $33^{\circ} \mathrm{C}$. On potatoes the growth is of a chrome-yellow colour; at a later period it becomes drier and orange-yellow, or yellowish-brown in colour, and gives off a fruity odour. The pigment is insoluble in all the ordinary media (water, alcohol, chloroform, lyes, acids).

\section{Bacillus tremulus.}

Shorter and thinner than bacillus subtilis, with a flagellum at each end. It hasa peculiar tremulous or rotatory movement. The spore is thicker than the body of the bacillus, and it projects from the bacillus like a bladder; the completely formed spore usually appears on one side of the rod. When the growth 
is luxuriant, there are usually two or three completely formed spores and some imperfect ones.-This organism was found by Koch on putrefying regetable infusions, on which it forms a thick gelatinous skin.

\section{Bacterium merismopediö̈des (Zopf).}

This organism was found by Zopf in a decoction of stinking mud from the Panke river. "It forms threads which are not constant as regards thickness, but vary between 1 and 1.5 $\mu$. They divide in the first instance into long rods, then into short rods, and finally into cocci. It is clear that as the threads have varying diameters so the cocci must vary correspondingly in size. The latter become free, and then show active movement. When they come to rest they form on the surface of the water masses or superficial scums, as the result of continued division in one direction; and later, as the result of division in two directions, the very characteristic 'tafel' colonies are produced, which are morphologically quite similar to the little tablets of the merismopedic state of the phycochromaceæ. These colonies consist of $64 \times 64$ cells or more. Their walls become gelatinous as time goes on. When the colonies are numerous, and in close contact with each other, their gelatinous sheaths run together, and thus we have a continuous zooglæa which always forms a thin scum on the surface of the water.-The cocci swarm under suitable nutrient conditions (in fresh mud decoction) out of the tablet zooglæa, and again develop to rods and threads." The description given by Zopf, and the fact that the cultivations were exclusively carried on in fluid media, give rise to the suspicion that the observations depend on the presence of a mixture of various kinds of bacteria. 


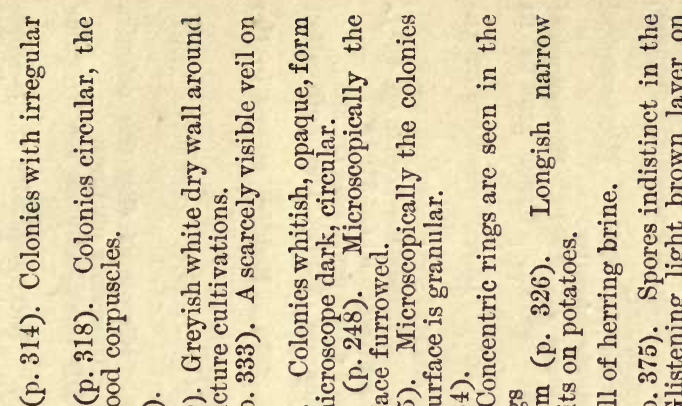

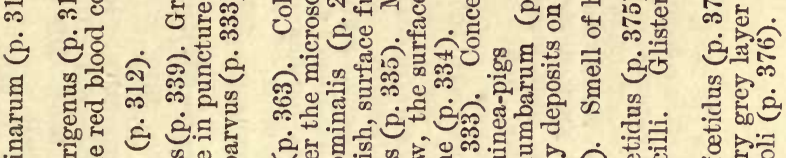

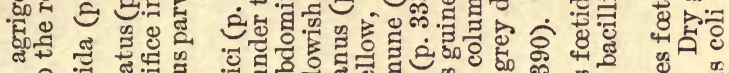

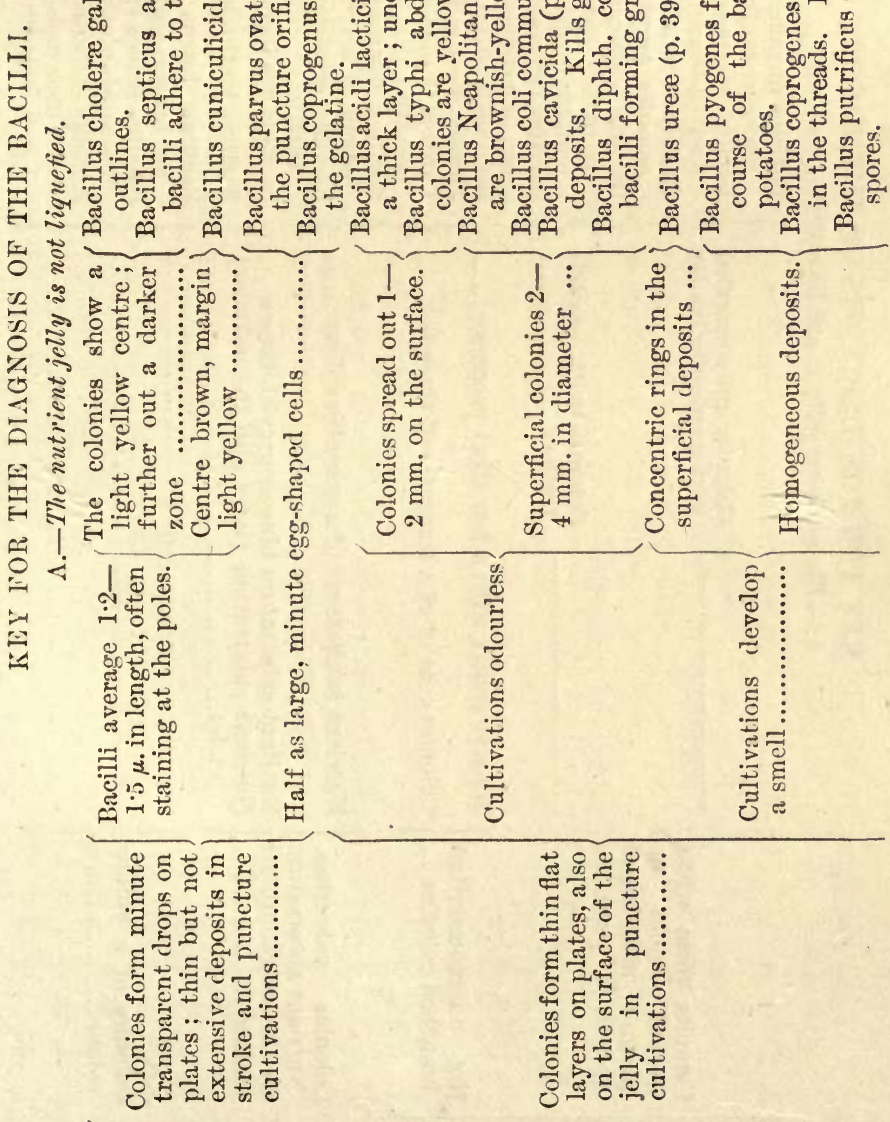

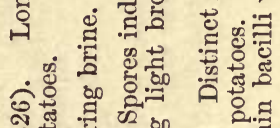
\% 


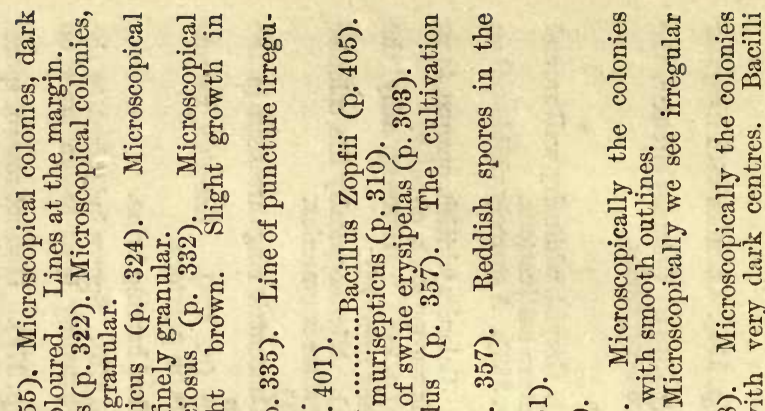

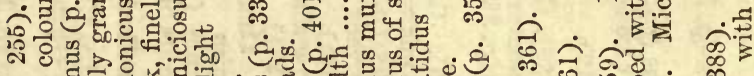
o : ق.

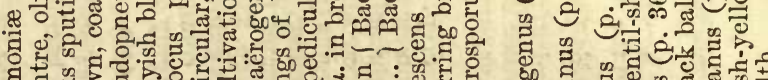

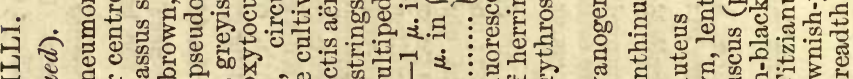

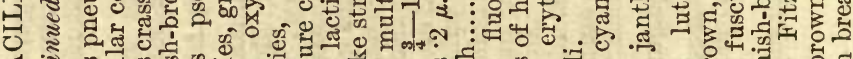

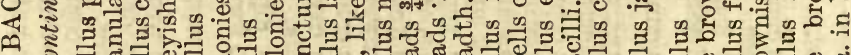

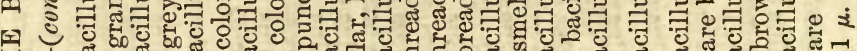

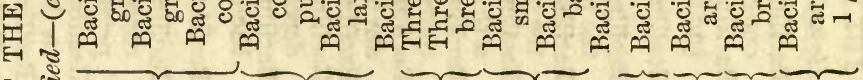

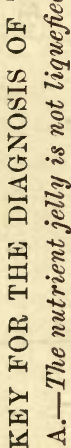
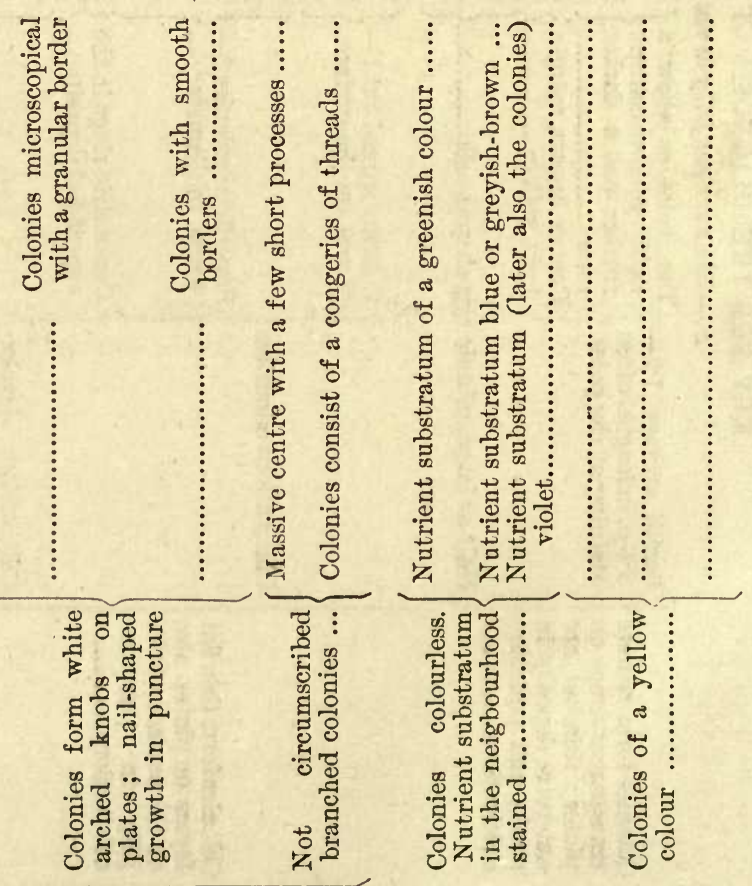


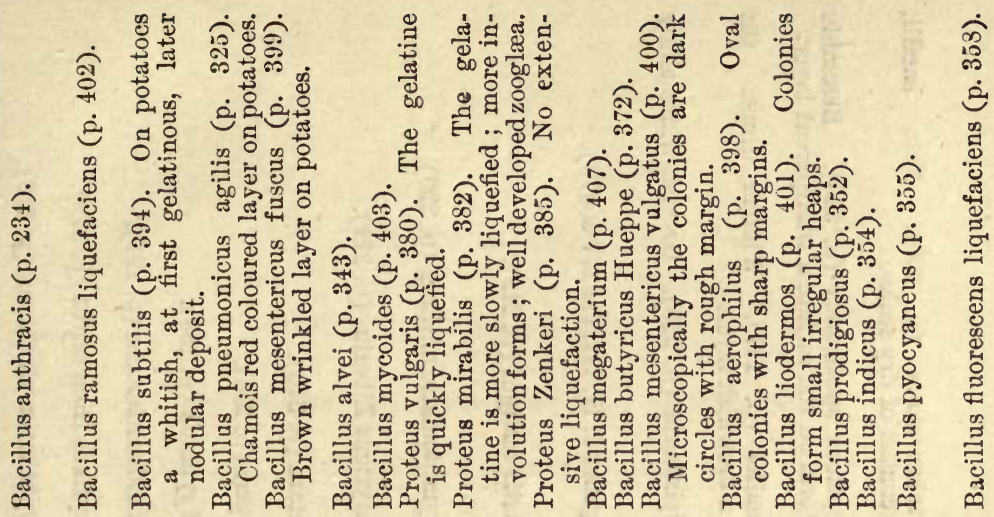

בٓ

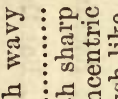

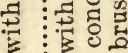

\%

ส

$8 \vdots \vdots$

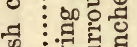

范

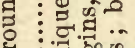

웅

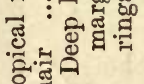

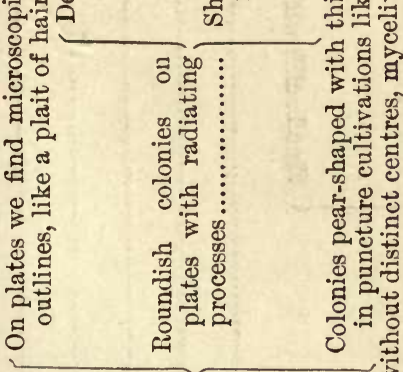

○

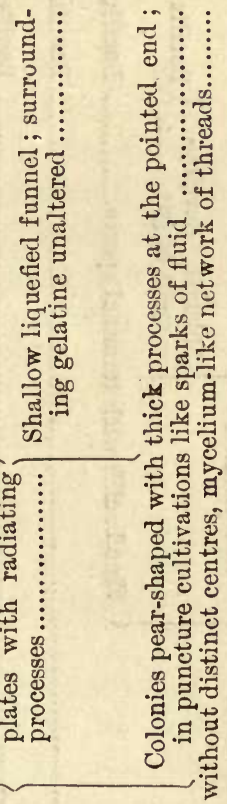

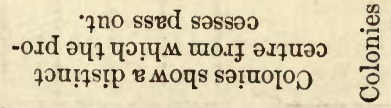

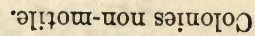

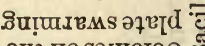

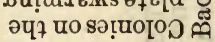

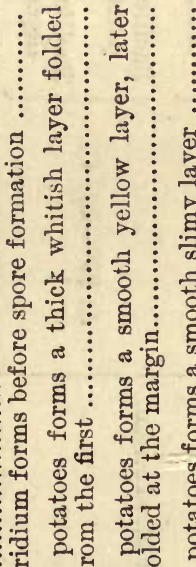

a

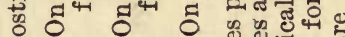
ชิ

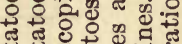

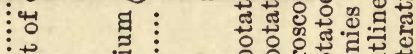

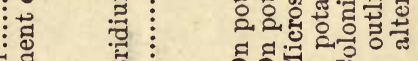
ธีธีำำ

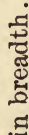

두 리

峦

है है क्षे 乙 ठृ: 4 节

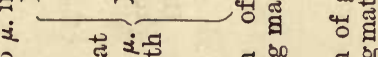
- $\rightarrow$ चु

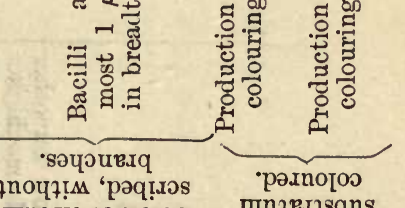

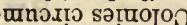




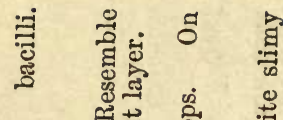

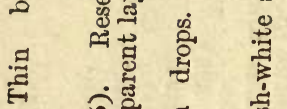

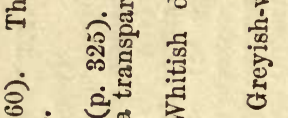

商高

งิ

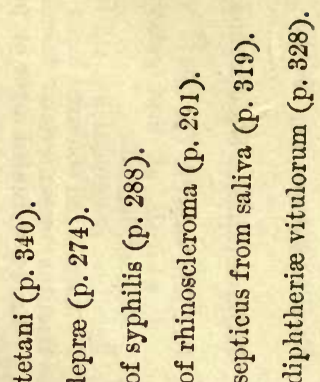

范

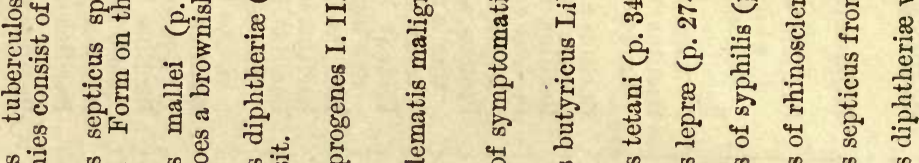

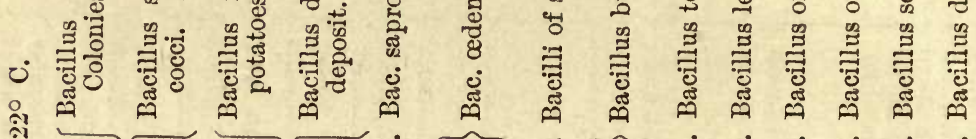

0

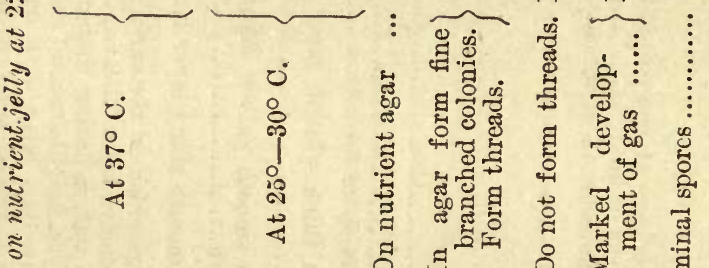

ป
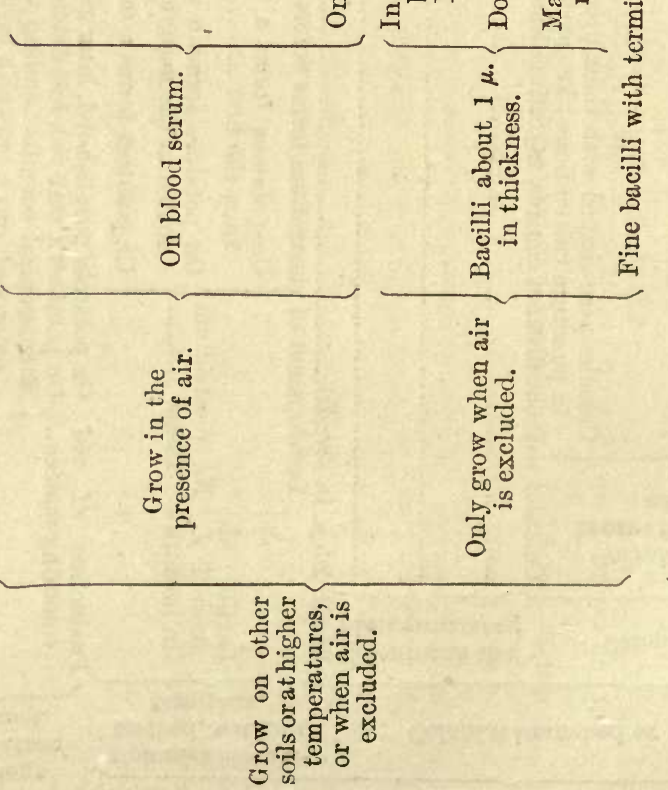

동용

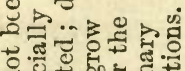

임

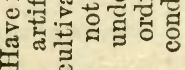




\section{SPIRILLA.}

\section{Spirillum Cholere Asiatica.}

\section{(Kommabacillus, Bacille-virgule cholérigìne.)}

Numerous investigations formerly made with the view of finding the causal organism of cholera, which was long suspected to exist, led to no certain results; the discovery of micro-organisms by Pacini in 1854, and by Klob in 1867, were of no value. It was not till 1884 Koch's disthat Koch succeeded in discovering as the causal agent ${ }^{\text {covery }}$ of the of Asiatic cholera a peculiar species of bacteria which bacilli. can be constantly demonstrated in the intestinal contents and in the dejecta of those suffering from cholera, and which is never found in the intestinal contents in healthy persons, nor in those suffering from other diseases ; it is exclusively limited to the cholera intestine, and is present there in largest numbers the more violent the disease. These bacteria are very small, generally bent like a "comma," but at times forming long screw-like threads, and they grow in nutrient gelatine, on plates and in puncture cultivations, in the form of characteristic colonies which slowly liquefy the gelatine.

On examination of numerous cases of cholera, Koch Condition of was unable to find, in the blood or organs, in in intestine spite of the most careful investigations, any bacteria which could be suspected as taking part in the infection; this result might have been expected, as the important pathological alterations only occur in the intestine, and not at all, or only to a subordinate degree, in the liver, spleen, kidneys, \&c. (Virchow*). In the intestine Koch found various alterations according to

* Verhandl. d. Chol.-Conferenz., 2 Jahr, 1885. 
In acute uncomplicated cases of cholera.

In more protracted cases.

the intensity and duration of the process. In some cases running a very acute course there was only slight swelling and rosy red coloration of the mucous membrane of the small intestine; and the contents of the intestine were colourless like rice-water, or better, like gruel. In these cases the comma bacilli were usually present in very large numbers in the intestinal contents, often almost in pure cultivation. If the morbid process had lasted longer the mucous membrane showed somewhat more marked alterations; more especially there was a patchy redness, which was particularly noticeable at the margins of the follicles and of Peyer's patches. At the same time it was found that the comma bacilli had penetrated into the mucous membrane; in sections the comma bacilli were found in the tube-like glands, and had to some extent penetrated between the epithelium and the basal membrane. Nearer the surface other bacteria were also frequently present, usually thicker or finer bacilli which had passed more or less deeply into the mucous membrane; but this had evidently occurred after the entrance of the comma bacilli, which always lay most deeply, and which had, as it were,

In typhoid cases. prepared the way for the other bacteria. - In a third category of the cases all sorts of secondary alterations had occurred in consequence of the longer duration of the disease ; the lower portion of the small intestine was of a dark brownish red colour, the mucous membrane showed superficial hæmorrhages, and at times it had undergone a superficial necrosis, and was corered with diphtheritic deposits. In correspondence with this, the intestinal contents were no longer colourless, but consisted of a bloody stinking fluid, and in it the comma bacilli were often difficult to recognise on account of the presence of numerous other kinds of bacteria.Methods em. In all these cases Koch found that the following was the demonstration best method for discovering the bacilli. For their of the cholera demonstration he employed either fresh dejecta, where
bacili. possible those of a soupy character; or the contents of the ileum obtained on post-mortem examination; or clothes which had been soiled with dejecta. Koch has 
observed that the comma bacilli usually multiply rapidly on moist linen or moist earth, and that it is not till after 2 or 3 days that other forms of bacteria have gained the upper hand. Hence shirts and bed-clothes, even when they have been kept for some time, are as a rule still suitable for the discovery of the comma bacilli.The microscopical investigation was made by spreading Microscopical out on cover glasses a drop of the dejecta, or, better, one investigation. of the small mucous flakes which are usually present in large numbers in the turbid fluid, and which contain the largest numbers of the comma bacilli; these cover glasses were then dried, heated, and stained for 1 to 5 minutes with warm methylene blue or fuchsine solutions. It is often difficult to recognise the comma bacilli with Modification certainty among the large number of other bacteria; of the method according to Schottelius it is of advantage in these cases, after mixing the dejecta with double the quantity of faintly alkaline meat infusion, to let it stand in an open vessel for 12 hours in a warm place $\left(30^{\circ}\right.$ to $40^{\circ} \mathrm{C}$.). Under these circumstances the comma bacilli multiply chiefly at the surface of the fluid, and by taking a specimen from the surface, preparations are obtained which contain almost exclusively comma bacilli in such numbers as are only otherwise found in the typical soupy dejecta.It is more difficult to demonstrate the comma bacilli in Demonstra. sections of the intestinal mucous membrane. In cases tion of comma which follow a very acute course the bacilli scarcely tions of the seem to penetrate into the mucous membrane at all; in mucous old cases the bacilli which have passed into the mem- membrane. brane have long since died, and only other bacteria which entered afterwards are found. The comma bacilli are best demonstrated in sections of intestinal mucous membrane which is in the state of patchy redness described above; under these circumstances they can be almost always found in sections through the red border of the follicles. They are best stained with alkaline methylene blue; a suitable method of double staining has not as yet been found, and this is so much the more to be regretted as it is by no means easy to see the comma bacilli in the midst of the cells and nuclei 
Difficulties of which are stained in a similar manner. An additional their demon- difficulty is caused by the fact that the bacilli only
stration in stration in rarely lie in the same plane, and seldom show the "comma" form distinctly; as a rule the curve is directed more or less upwards or downwards, or the comma may stand almost vertical; in all these cases a form results which differs markedly from that of the comma bacilli in cover glass preparations, where they are as a rule lying horizontally in one plane. Hence isolated comma bacilli cannot be recognised in the tissue with certainty; but where small groups are present there are usually some which show a distinct comma form, and which thus lead us to a correct conclusion as to the other individuals which are less favourably placed. If these difficulties are borne in mind, the comma bacilli can be demonstrated in the intestinal mucous membrane with complete certainty.

Demonstration by cultivation.

Much better than the microscopical examination for the demonstration of the comma bacilli is the method by cultivation, which, in fact, never fails for the discovery of other bacteria also, such as typhoid bacilli, even when a large number of microscopical specimens have failed to show any organisms. The cultiration is made in the usual manner by introducing a small mucous flake from the dejecta, or from the soiled linen, into a vessel containing liquefied gelatine (5 or 10 per cent.); from the original vessel two dilutions are usually made; the contents of all the three vessels are then poured out on glass plates, and after 24 , or at most 48 hours, characteristic colonies appear, which are so typical that the diagnosis of the presence or absence of the comma bacilli can be made with certainty.

Constant presence of comma bacilli in all cases of cholera.

By the aid of these methods it has been demonstrated that the comma bacilli are constantly present in every distinct case of Asiatic cholera, and also that they are only found in this disease, and never under normal conditions nor in the case of any other clisease. Koch has investigated the dejecta or the intestinal contents in about 100 cases of cholera in Egypt, India, and Toulon; Nicati and Rietsch have investigated 31 cases 
in Marseilles, Pfeiffer 12 cases in Paris; cholera patients have also been examined by Babès and Watson Cheyne in Paris, by van Ermengem in Marseilles, by Armanni and Fede in Naples, by Schottelius in Turin, by Ceci in Genoa, and also by Klein, Buchner, \&c. In all these cases comma bacilli have been demonstrated in the dejecta, or in the intestinal contents. In microscopical A few negative observations the comma bacilli were distinctly recognised $\begin{gathered}\text { results from } \\ \text { microscopical }\end{gathered}$ in by far the greatest majority of the cases. Some observations. observers never failed to find them by this method of investigation; the majority have, however, here and there obtained negative results. The number of these negative results will probably be still further reduced by the general use of Schottelius' method.-On the other Constant dishand plate cultivations have never failed in the hands of ${ }_{\text {means of }}^{\text {cover }}$ the observers mentioned above. It is true that the comma cultivation. bacilli were not found in every specimen of the dejecta, more especially in old or complicated cases; but the examination of several specimens of dejecta during the course of the disease, or of the intestinal contents after death, always yielded positive results. It is probable that greater difficulties will be experienced in demonstrating the bacilli in very mild cases, such as frequently appear to occur during cholera epidemics in individuals but slightly predisposed to the disease. It may be that in these cases the number of the bacilli is so small, and their presence in the dejecta so temporary, that a certain diagnosis will not be always possible. Hence in this direction the capabilities of the method have as yet to be determined.

Comma bacilli have only been found in the vomit in Occurrence of small numbers, on two occasions by Koch, and on three in the vomit, occasions by Nicati and Rietsch, but in these cases it is \&c. possible that the material romited was the intestinal contents which had passed into the stomach. Nicati and Rietsch also found comma bacilli in a few instances in the bile duct and in the gall bladder.-The blood and the other organs, even the mesenteric glands and liver, were always free from comma bacilli. 
Emmerich's denial of the constant presence of comma bacilli.
Exclusive limitation of the comma bacilli to the cholera process.
It is necessary for the demonstration of the comma bacilli that the observer must be thoroughly acquainted with the methods employed by Koch, and where the first experiments - of an observer give negative results, they by no means prove the absence of the comma bacilli. Thus Emmerich in his investigations failed at first in two cases to find the comma bacilli, while in eighteen further cases he was able to demonstrate their presence; as the result of this fact, which evidently quite harmonises with the above-mentioned positive results, Emmerich* raises one of his fundamental objections to Koch's views, by stating that the comma bacilli are not constantly found in cholera patients. In further confirmation of this assertion Emmerich brings forward erroneously the evidence of Schottelius, who, like all other authors, and like Koch himself, was not able to demonstrate the comma bacilli in all cases by microscopical examination, but who distinctly states, in the very paper cited by Emmerich, "that according to his experience the plate method always gives a positive result even in those cases in which, as the result of microscopical examination of numerous specimens, no comma bacilli could be found with certainty in the dejecta." $†$

In order to demonstrate that the comma bacilli were exclusively limited to the cholera process, Koch has made very numerous control investigations. He has, however, never been able to find these organisms in normal intestinal contents, in diarrhœic stools, or in patients who had recovered from cholera. In like manner the very numerous investigations made by other observers in this direction have given without exception a negative result; nowhere except in the dejecta of Asiatic cholera, or on objects which had been soiled with these dejecta (clothes, the water of a tank), have the characteristic comma bacilli described by Koch been found.

Similarbacilli. On several occasions similar comma-shaped bacilli have been seen, and at first these were erroneously identified with Koch's comma bacilli ; but on more accurate study, although morphological differences could not be made out, biological distinctions were nevertheless found between these various species and the true cholera bacilli, these distinctions being sufficient to allow of

† Deutsche med. Woch., Nr. 14, 1885. 
their differentiation from each other. This was the case, for example, with the spirilla observed by Finkler and Prior in dejecta, by Deneke in cheese, and by Lewis and Miller in the deposit on teeth. (See below.)

Even Koch's opponents have had to admit that their efforts to find Koch's comma bacilli elsewhere than in the dejecta of cholera patients have completely failed. Klein was compelled by Watson Cheyne's objections to make such an admission; and Buchner says in his most recent publication, "Koch's assertion that the vibrio found by him in the cholera process is exclusively limited to that process has as yet been unshaken." * In peculiar contrast to this statement of Buchner's is one Admission of made by his fellow-worker Emmerich in the same number of the limitation the Archiv für Hygiene, p. 358: "The markedly alkaline exu- to cholera. dation, rich in oxygen, washes out the intestine and removes the numerous micro-organisms which live there, while, on the other hand, it forms an admirable nutrient medium for Koch's vibrios, which also occur in limited numbers in the normal intestine, and which multiply enormously in cholera, and in many cases awake the suspicion that they are causally connected with the alterations." In support of this assertion, Unfounded which is of such extreme importance with regard to the objection by etiology of cholera, Emmerich has brought forward no proof, either from those portions of his experiments as yet published, or from those of any other investigator, and hence the statement is simply incorrect.

Hence we can no longer doubt that Koch's comma Deductions bacilli occur constantly and exclusively in Asiatic from the concholera; further, that they are found in the intestine in occurrence of numbers which are larger according as the cholera runs bacilli, and a purer and more typical course, and they are present their limitain the intestine in largest numbers at those parts where cholera the cholera process has set up the most marked alterations, namely, in the lower portion of the small intestine. This coincidence cannot be an accidental one; on the contrary, the two phenomena, the cholera process on the one hand, and the appearance of the comma bacilli on the other, must stand to each other in the relation of cause and effect. In explana- Necessity for tion of this constant concurrence we have only two assuming an possibilities. Either the cholera process is the cause connection of the presence of the large numbers of the comma comma bacilli

* Arch.f. Hygiene, vol. iii., 1885, p. 438. and cholera. 
bacilli, or the comma bacilli cause the cholera process. On the first assumption there are again two explanations of the appearance of the comma bacilli : either these organisms multiply to a great extent as the result of the cholera process from a few comma bacilli

Cholera cannot be the cause of the appearance of the comma bacilli. constantly present in the normal intestine ; against this, however, we have the constant negative results of numerous investigations of normal intestinal contents, along with the other necessary assumption that if this view is correct the comma bacilli must be distributed in a very remarkable manner, and must be constantly present in the normal intestine of Indians and Egyptians, as well as in that of Europeans ; and further, that as the result of any disease we have never as yet observed a similar constant and exclusive development of a definite form of bacteria under the favouring influence of the disease. It is evidently quite erroneous to bring forward as an analogous case the constant presence of oiddium lactis in sour milk, * in which from the constancy of its presence (though as a matter of fact it is not constantly present) one might come to an erroneous conclusion as to the etiological rôle of the oïdium, for in this example the second condition necessary to prove an etiological connection between the comma bacilli and the cholera process is absent, namely, the exclusive limitation of the occurrence of these organisms to cases of cholera ; on the contrary, in the case of oidium lactis we have to do with an organism which is extremely widely distributed everywhere, and which can be demonstrated in other places than in sour milk, and without any production of acid, and hence it is very easy to see that it does not stand in any etiological relation to the formation of acid. There is exactly the same objection to the other organisms, such as the aspergilli, which have likewise been brought forward by Buchner as evidence against the etiological significance of the comma bacilli. On the other hand, we do not know a single example in the whole range of mycology where the constant and exclusive occurrence of a definite species

* Buchner, Münchner ärztl. Int. Bl., 1885, Nr. 50. 
of bacterium in any process does not at the same time imply an etiological relation between the two.

The second hypothesis of the occurrence of comma bacilli in cholera is still more unlikely, namely, that Koch's comma bacilli have been developed as the result of the influence of the cholera disease from other species of vibrio which are normally present in the intestine. Such a transformation of one species of bacteria into another which is well characterised, and which has remained unaltered in its properties for years when cultivated under a great variety of conditions, has as yet never been observed, and certainly not in such a regularly recurring and exclusive manner, under the influence of a definite morbid process. Such an hypothesis is without any foundation, and directly contradicts all the facts which hare been obtained as the result of observation and experiment.

Hence in the present state of our knowledge we can As a consecome to no other logical conclusion than that Koch's quence we comma bacilli are the cause of cholera. With the same right with which we infer the etiological significance of bacilli as the the spirilla of relapsing fever, of the leprosy bacilli, of cholera. typhoid bacilli, \&c., from their constant and exclusive occurrence in these diseases; with the same right with which we must look on the syphilis bacilli as the cause of the disease as soon as their constant and exclusive occurrence in syphilitic new formations has been certainly proved, we must also recognise that the comma bacilli, on account of the proof of their constant and exclusive presence, are the only and sufficient cause of Asiatic cholera.

The following facts have up to the present time been Morphological ascertained with regard to the morphological and bio- characters of logical characters of Koch's comma bacilli :bacilli.

The comma bacilli usually present the appearance of short curved rods, which, under certain circumstances remain in connection with each other, and form long 
screw-like twisted threads, and therefore in their simplest form may be looked on as fragments of spirilla. The average length of the individual curved bacillus is about 1.5 $\mu_{\text {. }}$, varying between $8 \mu$. and $2 \mu_{\text {. }}$; the average thickness is from $\frac{1}{6}$ to $\frac{1}{3}$ of the length. The youngest individuals either show a very slight curve or no curve at all; the more fully formed ones generally show in fresh unstained specimens a distinct curve, sometimes only a slight bend, sometimes a full half circle; in the dried and stained specimens a larger number show a less curve or are even straight, the difference being due to the method of preparation. After division the two individuals often remain united together, and thus,

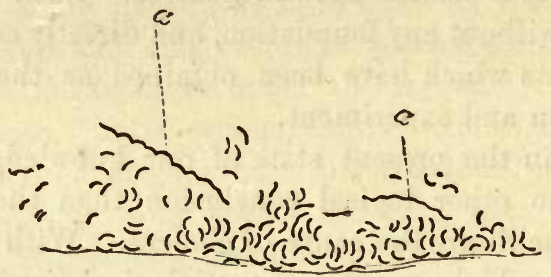

Fig. 116.-(After Koch.) Cover glass preparation from the border of a drop of meat infusion containing a pure cultivation of the comma bacilli.

Long screw-like threads $(a) \times 600$.

according to the age and degree of development, they form short and slight, or longer and more markedly bent and S-shaped figures; when examined in drop cultivations it may be seen that the two component parts of the " $\mathrm{S}$ " do not lie in one plane, but represent the commencement of a screw. As the result of the preparation we not uncommonly find in stained preparations $\epsilon$-shaped forms; it is probable that in this case the rods have become bent and displaced in the middle, so that the concavities, which were originally opposed to Spirilla. each other, now look in the same direction.-In drop cultivations there is almost always a formation of long screw-like threads or true spirilla, which may consist of 10,20 , or 30 narrow turns ; this continued adhesion of the newly developed individuals, to which the spirilla. 
owe their origin, is only observed in cultivations which are kept moderately warm. It is only relatively seldom that these spirilla can be well demonstrated in stained

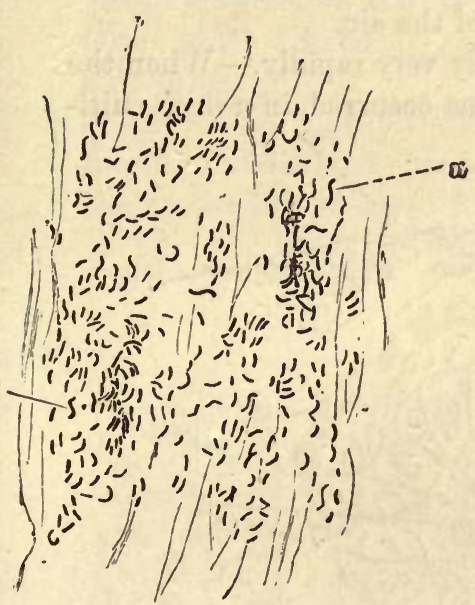

Fig. 117.-(After Koch.) Cover glass preparation.

Cholera dejecta on moist linen (two days old). Marked multiplication of the comma bacilli among which are S-shaped forms $(a) \times 600$.

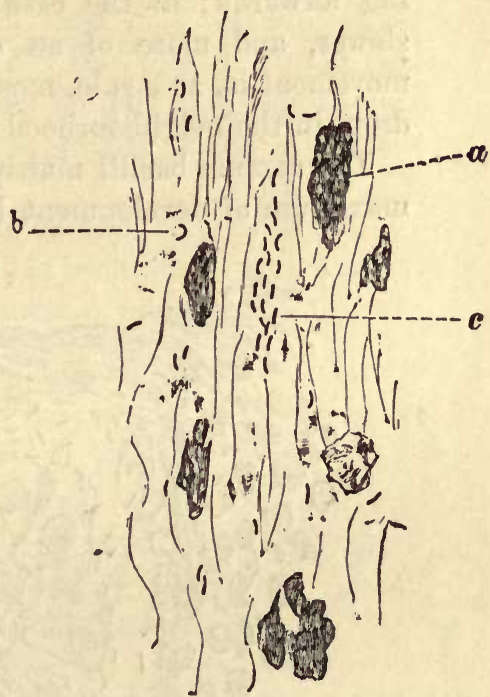

Fig. 118.-(After Koch.) Cover glass preparation from the contents of the intestine in a case of cholera.

Nuclei of the dead epithelial cells $(a)$. Semicircular comma bacillus $(b)$.

Very characteristic arrangement of the comma bacillus $(c) \times 600$.

cover glass preparations; as a rule the turns appear more or less opened out, so that we find almost straight threads; or the threads become torn, and we only obtain short fragments.-Hence the morphological characters of the comma bacilli are best studied in drop cultivations; in order to prepare these cultivations a drop of alkaline meat infusion (for the method, see the last chapter) is placed on a cover glass infected with a minute quantity of a cultivation of comma bacilli, and then so fixed on a hollow slide by the aid of vaseline that the drop hangs into the depression in the slide. The preparation is now kept at from $25^{\circ}$ to $30^{\circ} \mathrm{C}$., and the further development of the spirilla is watched from time to time by means of a high power (oil immersion). 
Movement of the comma bacilli.

By the employment of this method we also see that the comma bacilli are motile. The movement is as a rule very active, either turning round their axis or shooting forwards; in the case of the longer spirilla it is slower, and more of an oscillating character. The movement is, as a rule, most active at the margin of the drop, in the neighbourhood of the air.

The comma bacilli multiply very rapidly. - When the maximum of development has occurred in a drop culti-

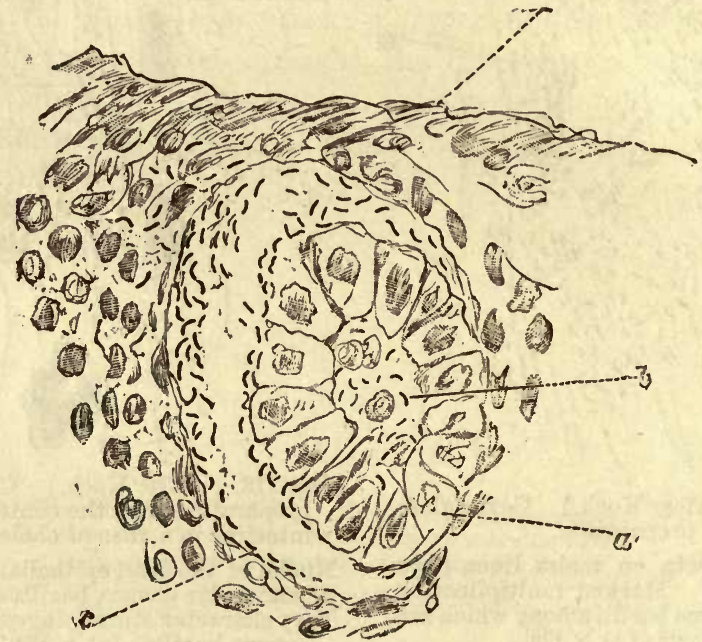

Fig. 119.-(After Koch.) Section of the intestinal mucous membrane from a case of cholera.

A Brunner's gland (a) cut transversely.

In the interior $(b)$ and between the epithelium and the basal membrane $(c)$ are numerous comma bacilli $X$ 600 .

vation involution appearances generally commence, at

Involution forms. first in a few, and later in numerous individuals. The dying bacilli lose their characteristic form, shrivel up or swell out, and in such a state take up the colouring matter only slightly or not at all. In the swollen plumper rod there is often such a subdivision of that portion of the plasma which takes on the stain that, on treatment with aniline colours, an unstained spot remains in the middle of the rod which recalls the appearance of the spores of other bacteria, and has in fact been erroneously looked on as spores. Further, according to 
Babés, longer and broader spirilla are formed in nutrient media containing alcohol, and at the end of these spirilla large round bladder-like dilatations appear; the latter then become detached, and may remain visible for a considerable time while the thread breaks up. These spheres, as well as the spindle and flask-shaped forms which also occur, are in reality sterile involution structures.

As yet no multiplication of the comma bacilli by means of undoubted spores has been observed. Against the probability of spore formation we have the observa-

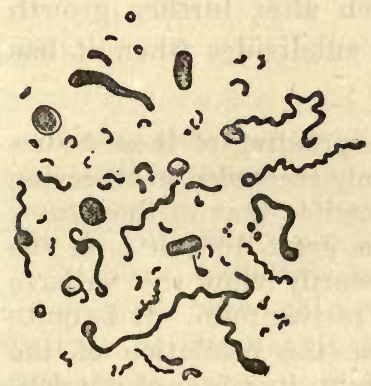

Fig. 120.-Involution forms of the cholera spirilla (after Ermengem) $\times 700$.

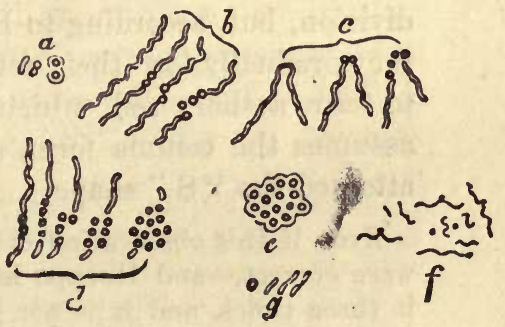

Fig. 121.-Resting forms of the cholera spirilla according to Hueppe.

$a$, breaking up of a comma bacillus into two spheres.

$b$ and $c$, formation of spheres in spirilla.

$d$ and $e$, groups of spheres.

$f$, spirilla with spheres from an old cultivation.

$g$, germination of the spheres.

tion made by Koch that in dejecta, linen, soil, \&c., impregnated with cultivations no living comma bacilli can be demonstrated if the objects have been thoroughly dried for a short time.

The involution forms just described, and the peculiar Apparent distribution of the colouring matter as the result of spore formadegeneration of the rods, have frequently led to the erroneous assumption that spores were formed. Thus Carillon* and Ferrant have described the spherical dilatations, and Cecif the formation of the unstained portions as processes of fructification; Ferran, in fact,

\footnotetext{
* Semaine médicale, 1884, Nor.

+ Gazeta medica Catalana, 1885, Jan.

¥ Semaine médicale, 1885, March.
} 
thinks that he has proved that the comma bacilli form part of the cycle of development of a mould fungus (Peronospora).-Recently Hueppe* has described a resting form of the comma bacilli. As the nutrient soil becomes exhausted long twisted threads are in the first place formed; then at one part of such a thread we have the production of two spheres which are only slightly larger than the diameter of the thread, and are more highly refracting. After a little two or four other spheres appear along the thread, and at times actual zonglæa heaps, composed of numbers of spheres, are observed. These spheres, which are immobile, do not multiply by subdivision, but, according to Hueppe's direct observations, they gradually lose their refracting power and elongate to form a short rod, which then after further growth assumes the comma form, and subdivides when it has attained the " $\mathrm{S}$ " shape.

Even if this observation of the sprouting of these bodies were correct,-and Hueppe has only succeeded in observing it three times, and it is not impossible that in these cases he was deceived on account of the great difficulties of the investigation,-it would not necessarily follow that we have here to do with a spore or with a resting form. It is quite conceivable that in the course of the involution of the spirilla a portion of the plasma retains its power of development, although this portion cannot be looked on as a spore; such an idea would only be justified when it was clearly shown that this body was distinctly more resistant, and hence of service for the maintenance of the species, and that it could resist drying and concurrence with saprophytes

Absence of any proof of greater resist. ing power. better than the comma bacilli. Such qualities have, however, not been demonstrated, either in the case of Hueppe's spheres, or in the case of the resting forms of the authors previously mentioned. Hueppe, it is true, says shortly that the spheres observed by him are more resistant against drying than the bacilli; but on account of the great importance of such a fact this assertion ought to have been accompanied by detailed proof, and this was so much the more required as Koch and his pupils have made very numerous experiments by drying a great variety of cholera cultivations, and among these, doubtless, some which contained Hueppe's spheres, without having met with any exception to the slight resisting power of the bacilli. 
The comma bacilli can be readily cultivated in very Behaviour of various nutrient media. On gelatine plates they form the comma after 24 hours at $22^{\circ} \mathrm{C}$. very minute white points which eultivations. under a low power present the appearance of small round whitish-yellow refracting discs, without any sharp outline, and with an irregular and wavy margin. These discs become gradually larger, they retain their faint yellow colour, which only becomes a little darker at the central part, but without any formation of zones, and the irregu-

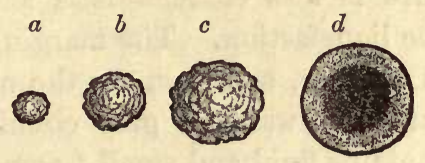

Fig. 122.-Colonies of cholera spirilla $\times 100$.

$a$, after 20 hou
$b, \quad, \quad 30$,
$c, \quad, \quad 36 \quad$,
$d, \quad, \quad 48$,

At $c$ there is commencing liquefaction of the gelatine; at $d$ the colony has sunk to the bottom of the funnelshaped liquefied area. lar outline becomes

more distinct; the same irregularity and roughness extends over the whole surface of the spherical colony, and as a consequence it presents a distinctly granular. or furrowed appearance. The highly refracting character of these colonies gives them a clear shiny appearance, and the surface of the plate looks as if it had been sprinkled over with small bits of glass. The gelatine now begins to undergo gradual liquefaction; even with the naked eye the gelatine on the plates appears somewhat depressed at the parts where the colonies lie; a small, sharply-defined funnel, containing fluid,
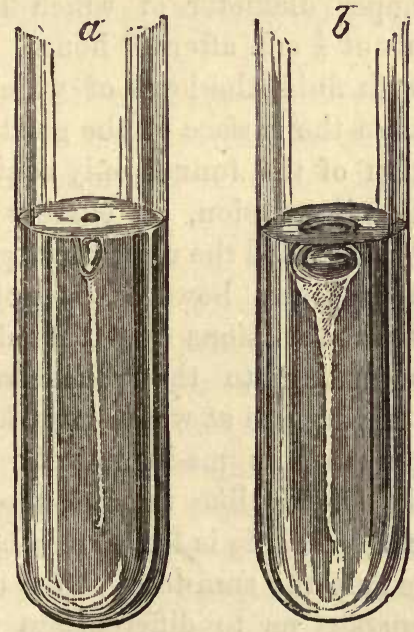

Fig. 123.-Puncture cultivation of Koch's comma bacillus.

$a$, two days old.

$b$, four days old.
Microscopical appearance of the colonies in nutrient jelly. is gradually formed at this place, the colony lying at the bottom of the funnel. The liquefaction only extends 
slowly. Where there is sufficient space between the individual colonies the funnels measure at their surface scarcely $1 \mathrm{~mm}$. in diameter after 48 hours growth at $22^{\circ}$ C., and even after 72 hour's their extent is not markedly greater.-Under the microscope the appearance is less characteristic after the commencement of the liquefaction. The margin of the area of liquefaction is circular, and has, for the most part, a sharp outline; further inwards a grey circular zone is formed which contains fluid and small fragments of the colony ; in the centre the latter appears as a yellowish-brown, dull, irregularly granular dise with indistinct outline.

Puncture cultivations.

Puncture cultivations in gelatine show, after 24 to 48 hours, a whitish turbidity along the track of the needle, and around this a slight amount of liquefaction. In this way a thin tube is formed, which contains at its peripheral part almost clear fluid, and at its central part the original whitish thread. Towards the surface of the gelatine this tube dilates in a funnel shape, tho upper diameter of which has attained the extent of about $\frac{1}{2} \mathrm{~cm}$. after 48 hours. This funnel is also filled with fluid, the level of which is often markedly lower than the surface of the gelatine, so that the upper portion of the funnel only contains air ; this gives rise to the impression, on cursory examination, as if an air bubble filled the uppermost portion of the funnel.-This appearance, however, is not observed in every tube; slight variations from the above description are found according to the concentration of the gelatine, the temperature at which it is lept, the mode in which the puncture is made, and the amount of material introduced. In like manner the one or the other culture characteristic is found in other species of bacteria, and it is only the sum total of the characters mentioned which enables us to differentiate with certainty the comma bacilli from other species.

After three or four days the puncture cultivation shows a moderate extension of the funnel and of the tube, and thus a slow increase of the liquefaction; it is not till after 4 to 6 days that the liquefaction has occurred 
to such an extent that it has reached, at the surface, the margin of the glass; after 8 to 14 days the upper two-thirds of the gelatine is liquefied throughout its whole extent.

On nutrient agar the comma bacilli form a superficial Growth on greyish-yellow, folded gelatinous layer, without any other nutriostrata. liquefaction of the substratum. These agar cultivations etain their vitality for a considerable length of time.On potatoes kept at the ordinary temperature no growth can be observed, but at from $30^{\circ}$ to $35^{\circ}$ C. a light brown, and later a more greyish-brown, mucous layer is formed.

The comma bacilli grow very luxuriantly in neutralised meat infusion, in blood serum, and in milk, the latter medium not undergoing any noticeable alteration. In none of these cultivations is there any development of putrefactive gases, nor any disagreeable odour; there is at most a peculiar aromatic and sweetish smell. (Buchner alone has observed a development of foul smell in his cultivations of comma bacilli in meat infusion.)

On the whole the comma bacilli are not very fastidious Behaviour in as regards the composition of the nutrient substrata. dilute soluIt is not till the nutrient solutions become very dilute water. that the growth ceases. As a rule no multiplication of comma bacilli takes place in infusions of the strength ordinarily employed for cultivations if diluted with 40 parts of water, while with somewhat greater concentration active growth occurs; in the former case there is a gradual diminution in the number of tho organisms introduced. In water, ${ }^{*}$ even when it contains a relatively large amount of organic and inorganic material in solution, there is never any multiplication of the comma bacilli. It is only where, at the margin of stagnant water, there is a local accumulation of nutrient materials from the presence of a variety of solid particles in suspension and of pieces of mud that development occurs, and this takes place especially on the floating solid pieces, and thus for example we have the explana-

* According to expcriments by Bolton, Zeitschr $f$. Hygiene, vol. iv. 
tion of the observation made by Koch, which will be referred to again, as to the multiplication of comma bacilli in a tank in India.--The comma bacilli are also sensitive as regards any acid reaction of the nutrient medium; the meat infusion, nutrient jelly, \&c., employed for cultivations must be accurately neutralised, or, better, slightly alkaline.

Relation to oxygen.

Influence of temperature.

The comma bacilli belong to the aerobes in so far as they only develop with great activity at the surface of fluid or solid nutrient substrata, where they are in contact with the oxygen of the air; it also appears as if they only moved actively in the presence of a certain amount of oxygen. Nevertheless their necessity for oxygen is by no means so great that they cease entirely to multiply where that gas is limited in amount or entirely absent; on the contrary, in that case the colonies only grow somewhat more slowly and to a less extent than those which have developed in the presence of air. Thus in gelatine plates which are covered with thin plates of mica, and in gelatine tubes from which the oxygen has been expelled by means of hydrogen, a delayed growth of the comma bacilli occurs, though ultimately one quite visible to the naked eye ${ }^{*}$ and it is this slight sensitiveness with regard to oxygen that enables the comma bacilli to multiply to a great degree under all circumstances, and even in the varying and often relatively slight amount of oxygen which they find in the intestinal canal.

The temperature has an important influence on the growth of the cultivations. According to Koch's experiments no growth occurs below $16^{\circ} \mathrm{C}$; ; at $16^{\circ}$ or $17^{\circ} \mathrm{C}$. growth is slight, and it does not begin to be active till about $17^{\circ}$ or $18^{\circ} \mathrm{C}$.; much better culture results are obtained, however, with temperatures between $22^{\circ}$ and $25^{\circ} \mathrm{C}$, and this is the temperature at which the gelatine cultivations should be kept if possible; the optimum of temperature is considerably higher, namely, between $30^{\circ}$ and $40^{\circ} \mathrm{C}$, a temperature at which the gelatine becomes completely fluid.

* Liborius, Zeitschr.f. Hygiene, vol. i. 
Koch has also made numerous observations with Conditions regard to the action of various inhibiting and destructive death. agents on the comma bacilli. As regards those hurtful factors, which most frequently cause the death of pathogenic bacteria in nature, namely, drying and overgrowth by saprophytes, it has already been mentioned, when discussing the question of spore formation, that the comma bacilli in all their stages of development die with extraordinary rapidity when dried. If a culti-Drying vation is spread out on a cover glass and exposed to the action of the air at the ordinary temperature the bacilli are found to be dead after 2 to 3 hours, so that no development occurs when such a glass is placed in nutrient jelly. If care is taken to have the culture fluid in a thicker layer it may be somewhat longer, but never more than 24 hours before all the comma bacilli are found to be dead. It follows from the fact of this great sensitiveness with regard to drying, which is present in all the stages of development of the comma bacilli, even in cultures which have been made under the most varying conditions, that no true resting spores are formed.Further, as the result of these experiments, we must draw the important conclusion that no living comma bacilli can be contained in any material which is in a dried or dust-like state; and as it is only from completely dry surfaces that particles of dust can be detached and carried to other localities by currents of air, it follows that a transport of living comma bacilli by the air, and the production of infection in this way, is impossible.Comma bacilli which are capable of development can Conclusionsas only be transported through the air for short distances to transport when infective fluids are agitated and bubbles are air. detached, as for instance when waves strike against a quay or on the wheels of a water-mill, or in washing cholera linen; in these cases small bubbles of the fluid containing bacteria may be brought by currents of air into contact with predisposed individuals.

The comma bacilli are also very easily injured by the Destruction of second factor, namely, the overgrowth by saprophytes. bacilli by When mixed with other bacteria they can, if they are saprophytes. 
present at first in considerable excess, and if the conditions as regards nutrition, temperature, reaction, and presence of oxygen, are especially farourable, gain the upper hand in the first instance, and thus form those pure cultivations which have been observed on the clothes of cholera patients, on moist soil impregnated with dejecta, and in the culture vessels prepared by Schottelius' method; but after two or three days a complete alteration in the character of the cultivation occurs in these cases; the comma bacilli die, and other bacteria gradually occupy the whole of the nutrient substrata. If the saprophytes are in excess in the first instance, or if the sum total of the conditions of life are not very favourable to the comma bacilli, the latter do not multiply at all, but the saprophytic bacteria lead rapidly to the death of the comma bacilli present, either by using up the nutrient material, or by producing poisonous products. According to Koch's experiments, comma bacilli when added to sewage could no longer be demonstrated after 24 hours; in the water in the Berlin Canal they died at the latest after 6 to 7 days. In impure water also they do not retain their vitality as a rule for a longer time, except when they are introduced in very large quantities.

Length of life

If the two hurtful influences above mentioned are of the comma bacilli in pure absent the vitality of the comma bacilli may be of cultivations. long duration. They can be kept alive for months in fluid, or, at any rate, moist, pure cultivations ; in gelatine cultivations they have been found living after 3 to 5 months, in agar cultivations after about 6 months (in one case mentioned by Hueppe after almost 10 months). It is evidently not impossible that an equally long preservation of living comma bacilli may at times occur in linen which is kept moist, on various parts of the soil, or on some object which is protected from drying and from the entrance of other bacteria. But under normal conditions cases of this kind must be of extreme rarity, for the comma bacilli are almost always destroyed either by drying or by the presence of such a large quantity of water that the substratum is overgrown by other bacteria. 
Among other noxious influences the following have Relation to been investigated by Koch, and by Nicati and Rietsch. influences. Low temperatures did not interfere with the vitality of the comma bacilli, (even- $10^{\circ} \mathrm{C}$., ) the cultivation having been completely frozen. On the other hand, high temperatures were very active; exposure for half an hour to a temperature of $60^{\circ} \mathrm{C}$. caused death with certainty, as did also boiling of the fluid for a short time. Their growth is also hindered when, for example, 10 per cent. of alcohol is added to the nutrient substratum; or 2 per cent. of sulphate of iron; or $\frac{1}{4}$ per cent. of carbolic acid; or $\frac{1}{20}$ per cent. of hydrochloric acid; or ${ }_{5}^{1} 0$ per cent. of quinine ; or $\frac{1}{2000}$ per cent. of bichloride of mercury ; the presence of 2 per cent. of common salt does not interfere with development. With the exception of bichloride of mercury, these organisms are most certainly killed by carbolic acid, which renders the comma bacilli incapable of development when employed in $\frac{1}{2}$ per cent. concentration for a few minutes.

In order to demonstrate with certainty the etiological Experiments significance of the comma bacilli it was desirable, if possible, to set up the choleraic process in animals by inoculation of pure cultivations. Nevertheless from the first there was but little expectation that this mode of direct experimentation could be employed with success. For it has been distinctly demonstrated that no animal of any species is ever naturally attacked with symptoms similar to those of human cholera, even although they live in intimate association with mankind and come in contact with the infective material of cholera in all sorts of ways and in places where the disease is endemic or epidemic.

Numerous experiments on animals made formerly and also in recent times with the dejecta and vomit of cholera patients, with the intestinal contents of cholera bodies, \&c., led to no noteworthy result. On some 
occasions it seemed as if a positive result had been obtained, but this was due to error in the experiments; thus in Thiersch's experiments white mice became ill after having been fed on filter paper impregnated with decomposing cholera dejecta, but they also became ill in the same manner if the cholera dejecta were omitted from the experiments; in like manner in the experiments made quite recently by Richards in which swine were fed with very large quantities of cholera dejecta and died in from $\frac{1}{4}$ to $2 \frac{1}{2}$ hours, we may assume with certainty, from the suddenness of the action, as well as from the circumstance that the resulting disease could not be transmitted in any way to other animals, that in these experiments he had to do with poisoning from poisonous products contained in the dejecta, and not with an infection.

Notwithstanding this slight prospect of success the experiments on animals have been again taken up by Nicati and Rietsch, Van Ermengem, Koch, \&c., since the discovery and cultivation of the comma bacilli; and, as a matter of fact, these authors have succeeded in finding a mode of infection by which a process at any rate similar to cholera can be set up in animals by means of pure cultivations of these organisms. According to the facts mentioned above as to the immunity of these animals to every sort of natural infection, it could hardly be expected that more than a similarity in the symptoms would be obtained, and even this result could only be looked for by the employment of an artificial mode of infection. In view of these unfavourable prospects of experiments on animals it is more correct to lay the greatest stress in the proof of the etiological rôle of comma bacilli on the demonstration of their constant and exclusive occurrence in cholera, and not on the experiments on animals; their constancy has been so completely shown that as a matter of fact the experiments on animals can be dispensed with.

Injection of cultivations into the duodenum.
Starting from the supposition that the seat of the action of the comma bacilli is the small intestine, but that infection by the mouth must be a difficult matter, 
because the acid in the gastric juice can kill the bacilli introduced, Nicati and Rietsch tried in the first instance to inject dejecta of cholera patients and pure cultivations of comma bacilli directly into the duodenum of guineapigs. In order to exclude the possible influence of the bile they also tied the bile duct; it was, however, soon evident that this was an unnecessary precaution, for the bile did not in any way interfere with the growth of the comma bacilli, even when the half of the nutrient substratum consisted of bile.

On the other hand it has been made out as the result of Koch's experiments that the result depends very much on the mode in which the operation is carried out, and on the greater or less irritation and maltreatment of the intestine. If the abdominal cavity of guinea-pigs is only opened to a small extent, and if the injections are made into the nearest part of the small intestine instead of into the deeply lying duodenum, so as to avoid disturbance of the intestine, the guinea-pigs die only very exceptionally (of six animals only one died). If, on the other hand, the duodenum is drawn forward and fixed for a considerable time with forceps; if in short the intestine is treated in such a manner that hyperæmia and alteration of the peristaltic action results, and if then $\frac{1}{2}$ to 1 drop of a pure cultivation of comma bacilli is injected into the intestinal canal, by far the greater number of the animals die after from 12 to 48 hours with symptoms resembling those of cholera. After death, which occurs with great depression of the body temperature, hyperæmic swelling of the mucous membrane of the intestine is found, and the intestinal contents are transformed into a very plentiful thin mucous fluid, which contains enormous numbers of comma bacilli almost in a pure cultivation.-Other Control kinds of bacteria injected in a similar manner into the experiments. intestine did not cause death in any case, even though numerous control experiments were made, with the exception of the organisms isolated by Finkler and Prior, which caused three fatal results among ten guineapigs treated in this way. The large number of negative 
Infection of the animals by the mouth.

control experiments shows at once that the operation per se, when properly carried out, does not place the animals in any serious danger.

Koch has however attempted to avoid this operation, which is by no means insignificant, and to obtain infection of guinea-pigs by the mouth, and he has succeeded by neutralising the gastric juice in the first instance by means of soda solution, and subsequently administering substances which cause slowing of the peristaltic action, and thus enable the comma bacilli to remain for a longer time in the small intestine. The following is the mode

Preparation of the animals in which an experiment of this kind is performed. In the first place 5 cc. of a 5 per cent. soda solution are introduced into the stomach of the guinea-pigs by means of a catheter passed downwards from the mouth (it has been shown that as a result the intestinal contents have an alkaline reaction for several hours), and some time afterwards $10 \mathrm{ccm}$. of fluid, to which one or several drops of a pure cultivation of comma bacilli have been added, are introduced; if only a very little of the cultivation, one-third of a drop or less, is employed the result is uncertain. After the injection a dose of opium is administered to the animals; if the opium is introduced into the stomach of guinea-pigs it scarcely produces any effect, and hence it is better to inject it directly into the abdominal cavity by means of a syringe, the dose being $1 \mathrm{ccm}$. of tincture of opium to every 200 grammes of the body weight ; the back of the animal is grasped with the left hand in such a manner that the abdomen is projected forwards, and then the syringe is rapidly pushed into the middle of the abdominal wall; when the operation is performed in this manner the intestines are pushed to one side so completely that they have almost never been injured, nor have any other bad consequences been observed.

Results.

After the administration of the opium narcosis occurs, lasting from $\frac{1}{2}$ to 1 hour, after which the animals seem quite well. On the evening of the same day, or on the following day, the animals lose their appetite and seem ill; a paralytic weakness of the hinder extremities 
gradually develops, the respirations become weak and slow, and death occurs with symptoms of severe collapse and with marked coldness, more especially of the head and extremities. On post-mortem examination the small intestine is seen to be much reddened, and filled with a watery colourless fluid containing flakes; the stomach and cæcum also contain a large quantity of fluid, and not, as is normally the case, solid masses. The contents of the small intestine are found in these cases, both by microscopic examination and by cultivation, to contain almost a pure cultivation of comma bacilli.-Infective experiments of this kind were made by Koch on about 100 guinea-pigs. He also succeeded in setting up the same fatal disease by employing, instead of cholera cultivations, the intestinal contents of an animal which had been infected and bad died.

The force of these experiments is somewhat diminished control by the observation made by Koch that some other species experiments. of bacteria, as, for example, the vibriones which morphologically resemble the comma bacilli, and were isolated by Finkler, Deneke, and Miller, when introduced into the small intestine in the same way at times set up a fatal disease; as a matter of fact, however, only 12 out of 51 animals infected with these bacteria died, while in the experiments with cholera bacteria the mortality was almost 90 per cent., and when the dose was larger all the animals were killed. Employed in the same manner the anthrax bacilli and the bacteria isolated by Brieger, as well as a number of other organisms, showed a distinct pathogenic action, while in the case of a large number of other species, for example the pyogenic cocci, the bacilli of rabbit septicæmia and of chicken cholera, \&c., no bad effect resulted.-The opium could be almost completely replaced by alcohol; other substances gave less satisfactory results.

In considering how far the attempts made in these experi- Differences ments to set up a disease similar to human cholera have been between he successful, it is necessary to bear in mind that in any case in pholera exguinea-pigs, which seem to be the most susceptible animals, produced and romiting and profuse diarrhœa are very seldom or never cholera. 
observed, while in these animals after infection with comma bacilli the enormous distension of the stomach and intestine with fluid material shows a great transudation into the intestine similar to that which occurs in man, and which leads to excessive diarrhoa and vomiting. It must further be expressly pointed out that the pathological anatomical alterations in the organs, and more especially in the intestines of the animals, correspond entirely with the appearances found in rapid and uncomplicated cases of cholera; extensive alterations, ulcerations, and losses of substance are, according to the best authors, not characteristic so much for pure acute cholera cases as for cases in which the course is protracted and complicated.- It is perhaps possible that in the course of further investigations means will be found to obtain a simpler and more natural mode of infection in these or in more susceptible animals. In any case it is right, bearing in mind the above facts as to the immunity of animals from cholera, not to place our expectations too high, but rather in the case of cholera to assign a subordinate importance in the etiological proof to the experiments on animals.

Toxic effects of cholera cultivations in large doses.

Where large quantities of cholera cultivations are employed toxic effects are produced in the animals. If pure cultivations of the comma bacilli are injected into the peritoneal cavity of rabbits or into the veins, or in very large doses into the subcutaneous tissue, paralytic weakness of the hinder extremities, slowing of the respiration, and gastro-enteritis set in, and as a rule death occurs after 1 to 3 hours; where the material is applied subcutaneously these results are inconstant; at times the animals recover after a few hours and then remain well; in the case of starving guinea-pigs a similar intoxication occurs when the material is introduced into the stomach, and in this case the toxic products seem to be absorbed with especial rapidity. Mice also die after the injection of large doses into the peritoneal cavity. Nicati and Rietsch* were able to demonstrate that cholera cultivations when at least 8 days old caused toxic effects even after filtration through a Pasteur's filter; in no case did fresh cultivations produce any effect. It must also be determined by further experiments whether, and to what degree, this production of poison is influenced by differences in the nutrient

* Compt. rend., vol. 99, p. 123. 
substrata, and by the other conditions of life, and also what is the nature of the toxic substance.

Some experiments have been made on man with Experiments cholera dejecta or cultivations, partly intentionally and partly unintentionally. Thus during the last cholera Experiments epidemic in Paris Bochefontaine swallowed pills con- by Bochefontaining cholera dejecta, and Klein in Bombay drank a Klein. fluid said to contain comma bacilli. In neither case did illness follow; but in neither was there any proof that living comma bacilli were present in the material taken. And besides, the negative, like the positive, result of these two experiments was of no value in reference to the etiology of the disease, as it is well known that by no means every man who swallows the infective material suffers from cholera, but only those who are predisposed to infection; and, on the other hand, had illness followed these infective experiments it might quite well have been objected that it was due to some other cause, for the experiments were made in a place where cholera was prevalent.

On the other hand, another experiment unintentionally Infection of made on man furnishes a further support for the etio- man by callogical significance of the comma bacilli. One of those comma bacilli. who took part in the courses on cholera, which were held in Berlin in November, 1884, under Koch's direction, became ill with somewhat severe symptoms of cholera. At this time there was no case of cholera either in Berlin or in Germany; the only possible source of the infection was the pure cultivations of comma bacilli with which the physician in question was working; and this physician was more predisposed to infection by these cultivations than any of the other students, because for some days he had suffered from gastric disturbances and slight diarrhœa. After the appearance of the symptoms of cholera the watery dejecta of the patient were examined, and were found to contain very large numbers of comma bacilli which coincided in all respects with those obtained by Koch from cholera dejecta in India.

There is, as yet, no definite proof tbat the virulent 
properties of these comma bacilli can be artificially attenuated, a thing which is by no means improbable, when we take into consideration the results obtained in the case of other pathogenic bacteria. According to a preliminary communication by Nicati and Rietsch, the virulence of cultivations of comma bacilli is diminished to a certain extent when the cultivation is carried on for a long time in meat infusion or nutrient jelly kept at $20^{\circ}$ to $25^{\circ} \mathrm{C}$. The protective inoculations which were made in Spain by Ferran with supposed attenuated cholera bacilli are so entirely wanting in the necessary experimental and statistical support (as is evident from the description given by Ferran himself, as well as from the reports of others,) that they require no serious discussion. As regards the bacilli found by Emmerich in the bodies of patients who died of cholera, see page 335 .

Mode in which the cholera infection occurs.

In accordance with the facts made out by Koch as to the biological characters of the infective agents of cholera, we may suppose that the infection takes place somewhat in the following manner :-

Distribution of the cholera bacilli in the patient.

The cholera process arises when living bacteria gain admission to the small intestine, remain there for a considerable time, and multiply actively. As the result of their growth toxic materials are formed, which in the first place cause the death of the epithelium, and ultimately of the superficial layers of the intestinal mucous membrane. If they multiply rapidly, and if large quantities of toxic materials are produced, the latter are absorbed in large amount and set up general symptoms, and ultimately paralysis of the organs of circulation. If in this way death occurs at an early period there are no deep alterations of the intestinal mucous membrane, and the appearances on post-mortem examination correspond to what has been described above in typical cases, viz., there is a pure cultivation of comma bacilli in the intestinal contents but no other 
noticeable morbid appearances. If, however, the formation and absorption of the toxic products of the comma bacilli do not take place so rapidly, and if the patient survives this stage, the results of the local poisoning, the necrosis of the mucous membrane, become more marked; bleeding occurs, there is enormous multiplication of putrefactive organisms which grow to the exclusion of any comma bacilli not yet expelled; the absorption of putrefactive poisons sets up typhoid symptoms which are not a necessary part of the cholera process itself, and post-mortem examinations made at this stage show those deep alterations of the mucous membrane which have been often erroneously looked upon as characteristic of cholera.-As can be readily demonstrated, the comma bacilli do not spread into the organs of the body, nor are they excreted in the secretions at any stage of the process. Further, direct experiments on animals show most distinctly that comma bacilli, when they enter the blood stream, unless when they are in enormous numbers, and unless toxic materials are injected at the same time, die very rapidly and do not pass from the blood in a living state into any organ, or into the intestinal canal or the urine.*

From these facts, as well as from what has been sources previously pointed out as to the vital properties of the infection. comma bacilli, we may draw some important conclusions as to the mode in which cholera is transmitted. In the first place the comma bacilli leave the body of the patient evidently only in the dejecta of the first few days of the disease (quite exceptionally in the material romited, see page 419), and hence it is only these dejecta, and the objects infected by them, as for example the bed and body linen, vessels, soil, water-closets, earth on which these dejecta are deposited, well-water into which the dejecta may pass, \&c., that can serve as sources of infection. The greater the number of things contaminated the more numerous will be the sources of infection, and the greater the danger of contagion.-These sources

* Wyssokowitsch, Zeitschr.f. Hyg., vol. i. See chapter on the production of disease. 
Duration of virulence.

Points of entrance into the body.

Modes of transport.

of infection are more especially limited by the fact that the comma bacilli so readily die, either as the result of drying or of overgrowth by saprophytes. As a consequence it is, as a rule, only fresh dejecta, and objects which have been recently soiled, that are dangerous; all materials which are completely dry, such as dry linen, rags, letters, various kinds of wares, \&c., may be excluded at once as possible carriers of infection. Where the materials are moist, and in the case of fluids, the duration of the vitality of the comma bacilli which have reached them depends upon their number, upon the number and kind of saprophytic bacteria present at the same time, and on various other external conditions ; but in any case it is only rarely that it lasts for more than a few days. But it is always possible that some materials, if kept moist and in which the comma bacilli are preserved in a state of almost pure cultivation, may act for some weeks as sources of infection; for example, this is conceivable in the case of moist cholera linen which is tightly packed, of moist earth, \&c., more especially when the temperature is low.

From the mode of distribution of the comma bacilli in the body, and from the experiments as to their fate when they are injected into the veins or subcutaneously, we must draw the inference that natural infection occurs as a rule only by the mouth.

In infection, therefore, we have to deal with two factors: on the one hand the sources of infection, which, as we have seen, vary greatly in number and are limited as regards resisting power; and on the other hand this one point of entrance. All the conceivable ways are evidently, however, not equally suitable for infection; on the contrary one or other mode of communication may be completely excluded, while other modes vary as regards their power under the influence of external conditions. Currents of air are entirely unsuitable for the transport of the infective agents, as by them only dry particles are detached and carried away, while the comma bacilli do not retain their vitality in the dry condition. We may ex- The only exceptions in this respect are bubbles of water, clude currents which may be carried through the air.- Hence a mode
of air and respiration. 
of infection which is evidently of great importance in other contagious diseases, namely, by the respired air, may be left out of account in cholera, and in this fact we have a further reason for limiting the point of entrance to the commencement of the alimentary canal.

As connecting links between the sources of infection and the point of entrance we have left therefore : in the infection by first place, contact between the dejecta or between objects soiled by dejecta, such as linen, soil, furniture, \&c., on the one hand, and the mouth on the other. This mode of infection is by no means so uncommon as would at first sight appear to be the case; where cholera patients are nursed by attendants who are inexperienced, and who are not very cleanly in their habits, it must very frequently happen in handling the soiled bed and bodylinen, \&c., that infective material adheres to the hands, under the finger nails, clothing, \&c., and that in the course of the next few hours, before it has become completely dry, it is brought into contact with the mouth by unintentional and often unconscious movements.

In the second place, the infective organisms may pass 2. Infection of from some of the sources of infection mentioned to articles of articles of food, and may then reach the point of entrance along with these. The transmission to articles of food By contact. happens by contact with soiled fingers or with other objects containing dejecta; further, it will not uncom-By insects. monly take place by the intervention of insects, more especially flies. The infective material will frequently multiply to a great extent on these nutrient substances, and thus the sources of infection may be increased to a dangerous extent.

A third mode of infection, which is especially worthy 3 . Infection of of notice, is by means of water employed for drinking drinking and purposes, for the preparation of food, for cleansing plates, \&c. This water may be contaminated by comma bacilli, either because dejecta are intentionally or unintentionally poured out in the courts of the house and reach the wells by gutters, which are not unfrequently present, or by the water employed for rinsing the cholera linen taking the same course. In contrast to the other articles of food 
we must, however, assume that in the case of the water ordinarily used for drinking and other purposes multiplication of the comma bacilli never occurs, and that therefore they can only be present in wells for a relatively short time. (Compare the investigations by Bolton in the Zeitschrift für Hygiene, vol. i.) In the case of stagnant water, however, in the bilge water of ships, in the water in harbours, which is often so extremely dirty, \&c., it is probable that the comma bacilli may retain their vitality for a much longer time, and in the case of a tank in India, where the small amount of stagnant water was not only employed for bathing, drinking, and cooking, but also for washing the linen and for the reception of the contents of the water-closets, Koch was able to demonstrate such a large number of comma bacilli that it seemed likely that they had multiplied to a great extent in the tank, and that their presence was in all probability the source of infection of a number of cases of cholera which occurred at a later period among those persons who lived in the neighbourhood.

Infinence of

But the factors which are concerned in infection by the individual cholera are not exhausted by the varying capabilities of the modes of transport. We are also compelled to assume that cholera does not by any means constantly occur on every occasion when the comma bacilli have passed the point of entrance and have reached the commencement of the alimentary canal; on the contrary, a further condition comes into play, namely, the so-called

Protective arrangements in the healthy body. individual predisposition. In a perfectly healthy person it is evident from what we have learned from experiments as to the destruction of the comma bacilli, and from experiments on animals, that the comma bacilli may be destroyed in the stomach, more especially by the hydrochloric acid present in the gastric juice; it is also conceivable that the food may pass too rapidly through the small intestine, and that also the digestive fluids or the products of digestion may interfere with the growth and development of the comma bacilli; and finally the energy of the cells and their resisting power towards the toxic products of the bacilli come into play. According 
to the greater or less perfection of the protecting and regulating arrangements of the body the same infective material will in one case cause no disturbance, in another only slight diarrhœa, which leads to rapid removal of the multiplying bacilli, and the rapid victory of the body, and in a third to serious illness.-We Acquired have also the experience that one attack of cholera proimmunity. duces immunity for a considerable period of time. The milder or severer course of the disease does not in this instance appear to make any difference; the cases also where the regulating arrangements of the body are in such good condition that the reaction to the infection is so slight as scarcely to be designated as disease, apparently acquire this immunity. It has not as yet been definitely ascertained how long this immunity lasts; it is probable that it may last on an average for 3 or 4 years, at any rate it usually lasts for several months, so that an individual is seldom attacked twice during the same epidemic.

On the other hand we must assume that the body is Predisposing more susceptible to infection when dyspeptic conditions and slight gastric disturbances or overloading of the stomach are present, also when the digestive process has arrived at the stage where the acid reaction of the intestinal contents is slight; and likewise when=large quantities of food can pass into the small intestine after a relatively short delay in the stomach, and when, on the other hand, the onward progress of the food in the small intestine is abnormally slow. The exact value of these and other assisting factors cannot as yet be accurately determined, but that as a rule factors of this kind come into play is clear from the fact that most cases of cholera occur on Mondays and Tuesdays, after there have been excesses in eating and drinking on the Sunday; and also from the observation made by Virchow that on post-mortem examination of very acute cases of cholera there are always signs that digestion has been going on actively.-Another predisposing factor seems to consist in the general weakening of the body, such as is occasioned by poverty, hunger, and 
disease, whether it be that in this case there is a want of resistance on the part of the whole body, or some weakening of the digestive organs. Dependence of Hence, on the whole, the occurrence of infection
contagion on external influences. depends to a great extent on external influences, which either favour its development or the reverse. The number of sources of infection is sometimes larger, sometimes smaller, the modes of transport are sometimes numerous, sometimes few, and may ultimately be entirely absent; and it is possible that if the infective material enters the body it may pass through it without setting up disease, thanks to the protective arrangements present.

Results of practical experience.

The question arises whether these views deduced from the chief facts which have been ascertained as to the biological characters of the comma bacillus coincide with the results which have been made out empyrically as to the mode of spread of cholera. Numerous facts have rendered it absolutely certain that cholera can be carried by contagion, the virus being transmitted from

Contagious cases of cholera. the sick to the healthy. Typical cases of contagion occur in almost every epidemic; they are most definite when the epidemic is only commencing and has not yet spread widely, while at the height of the epidemic, or in an endemic area, it is impossible to trace the origin of the individual cases. - As a classical example of undoubted transmission in this way we may mention the case observed by Virchow in the department of the Charité Hospital in Berlin, set apart for prisoners, where three individuals to whom the nursing of a cholera patient was entrusted became ill of cholera after a few days, while no case of cholera occurred among any of the other healthy or sick inhabitants of the hospital.* Many well-observed epidemics in ships and houses, in which the reproduction and the transmission of the disease may be distinctly followed through a number of patients one after the other, can also only be explained by contagion.-But for a long time the conclusion drawn

* Weissbach, Virchow's Arch., vol. 55, P. 249.-Virchow in th Verhandlungen der Choleraconferenz., 1885. 
from the facts as to the mode of spread of cholera has Differences in been that the mode of infection in this disease is the contagiessentially different from, and more dependens on, ex- cholera and ternal influences than in the case of other infectious diseases, for example in small-pox. And this experience is quite intelligible if we bear in mind that in small-pox there are none of those marked limitations in the mode of spread of the virus which are seen in cholera. In the case of small-pox we have a much greater multiplicity of the sources of infection on account of the fact that the virus is given off from the whole skin in the remains of the pustules, and that it is contained in the various secreta; we have also to do there with much more resistant infective agents, which evidently withstand drying, and can be carried by currents of air and dry objects; hence the facilities for the penetration of the contagium into the body are very great; apparently also the protective arrangements in the body which render the poison inactive even after its entrance have much less power. Hence the spread of small-pox by contagion is so very different from that of cholera, and the mode of spread of cholera acquires a special character from the fact that so many external influences render its diffusion difficult in certain cases.

In the dependence of cholera infection on external value of influences we have the explanation of the fact that in- $\begin{gathered}\text { prophylactic } \\ \text { measures }\end{gathered}$ dividuals can be so easily and completely protected against against this disease, much more easily than against scarlatina and small-pox. While in the latter cases all the numerous and permanent sources of infection can scarcely be attended to, and while the usual mode in which the virus enters, namely, by the respired air, cannot be controlled or influenced, it is by no means so difficult to exclude completely the possibility of the transmission of cholera. If the dejecta and the objects soiled by them are cleansed and disinfected all the sources of infection are got rid of ; if the hands, food, and drinking water are kept quite clean the most important contaminated sources are shut off; if all gastric disturbances are 
avoided the most dangerous cause of predisposition on the part of the patient is avoided. In correspondence with these facts we learn from experience that those individuals who are in a better position of life, who are the most cleanly and moderate in their habits, are attacked by cholera in much smaller numbers than those who pay no attention to cleanliness, moderation, or the digestibility of their nutriment. Hence the English who are resident in India, and who are able to bestow great attention on the selection and preparation of their food, are almost entirely protected against cholera even in the regions where it is endemic.

The immunity In harmony with this we have also the fact that of doctors and nurses. doctors and nurses are very seldom attacked by cholera; they are accustomed, by having to deal with other contagious diseases, to habits of precaution and cleanliness in handling the patients on the one hand, and in their mode of feeding on the other. Here and there, it is true, there are incautious or dirty nurses, or the arrangements of the hospital in question are such that the number of sources of infection is multiplied, and contagion rendered more easy; and as a result we have in some epidemics a greater number of cases of the disease among the attendants. Experience has also shown that it is on the whole a rare occurrence for other patients and convalescent persons to be attacked in the same hospital; and this is easily intelligible, because these individuals are usually kept clean, and their food is prepared with a care such as they do not usually employ in

Cholera on ships. their own homes. In like manner in the case of ships, where as a matter of experience it is relatively seldom that severe cholera epidemics occur, there is decidedly less opportunity for the transmission of the contagium than in private houses; on board ship the passengers between decks are compelled to be cleanly, at least to a certain extent, and as they do not take part in the preparation of the food there is never such a close relation between the sources of infection, the modes of contagion, and the predisposed individuals, as is seen in the houses of the poor. Nevertheless, there are naturally certain 
possible modes of transmission in large institutions and in ships.

Hence it is undoubtedly possible, by rigid and properly applied cleanliness, to exclude a very important portion of the modes of transmission of the cholera contagium. And I may refer to the marked influence-an influence which will be discussed more in detail afterwardswhich is exercised on the spread of the disease by the introduction of a good and plentiful supply of water, and by proper arrangements for the prompt removal of dejecta.

Having thus arrived at certain definite ideas as to the The epidemic mode of transmission of cholera to the individual, and cholera. as to the factors which come into play, ideas founded partly on the study of the biological characters of the comma bacilli and partly on the results of experience with regard to cholera, we may attempt by the aid of the same factors to explain also the mode of the peculiar epidemic distribution of cholera.

Cholera epidemics present a series of very striking Endemic phenomena, and phenomena very difficult to explain. We see that cholera is constantly present in an endemic manner only in Lower Bengal; in the rest of India, and more especially in Europe, it occurs only at intervals in the form of devastating epidemics, and then again completely disappears from these regions. The starting point of these epidemics must always be sought in J_ower Bengal; from thence the disease is evidently carried into other regions. From what has been said above, Transmission it is evident that this transmission seldom occurs by any of choler. other materials than the fresh dejecta of the patients, whether the disease be mild or severe. Hence the disease can only be carried over long distances when a patient passes over the whole distance very quickly, and at the end of his journey still furnishes dejecta containing bacilli, or when a continuous chain is formed, 
of which the individual patients who receive the infective material from one another, reproduce it, and pass it on, represent the links. The whole distance from India to Europe could not in former times be traversed by one and the same cholera patient; a chain of patients was always necessary, this chain stretching without interruption along the overland route; or the disease was carried by ships sailing from India to Europe, the chain being in that case shorter, corresponding to the shorter time required for the journey. These two chains were evidently not easily established; even the shorter one which suffices for the sea journey was difficult to obtain, because on ships the opportunities for the propagation of the disease are relatively unfavourable. It is, moreover, evident that any interruption of the chain, any failure in the transmission of the contagium to a new individual, must lead to failure of the spread of Present mode the disease. At the present time the spread of cholera cholera. is rendered very much easier, seeing that the network of railways in Lower Bengal communicates with the various ports of India, so that one and the same patient can be transported to any of the cities on the coast; and further, because a very small number of patients is sufficient to carry on the disease during the journey from Bombay to Egypt, and the active contagium may be carried from Egypt to the nearest European ports by one and the same patient.-In Europe also cholera can be distributed by travellers, and we must remember that even a slight attack of cholera which scarcely causes any noticeable disturbance of the general health, but in which nevertheless there is multiplication of the comma bacilli and their deposit in the dejecta, is quite sufficient to transmit the disease. Striking examples, showing to what distances the cholera contagium may be carried at the present time by means of the railway, are furnished by the case observed by Von Pettenkofer, where a child suffering from cholera carried the disease direct from Odessa to Altenburg, and the case published by Biermer, where the cholera contagium was brought directly from Rome to Zurich. 
Nevertheless we notice the very striking fact that Irregularity cholera does not necessarily develop in an epidemic form in the distriin the region to which it gains access; that all the regions cholera which lie along the main channels of trade, and to which, in the case of cholera spreading over Europe, there is no doubt that cholera patients and cholera dejecta frequently gain access, are not attacked by an epidemic ; but that, on the contrary, large tracts of territory and numbers of towns remain completely free, while neighbouring provinces and cities are violently attacked. Even within the same town similar local differences may be found. There are also a number of places where trade is great, Local prediswhich even during the repeated epidemics which have position. come into Europe have always remained immune, for example Lyons, Stuttgart, Hanover, \&c. These facts give rise to the impression that in addition to the introduction of the contagium there are some other local conditions necessary for the epidemic spread of the disease - in fact a local predisposition.

In like manner there is a peculiar seasonal distribu- Seasonal tion of the cholera epidemics. As the result of careful predisposition. statistical calculations it has been shown that the cholera epidemics which have attacked the northern part of Germany always attain their highest point in the latter part of summer and harvest, while during the spring months-from February to May - the number of cases is very few.* In other regions the maxima and minima as regards season are different: thus in Calcutta the constant minimum is from June to October, and the maximum in April ; in Bombay also the cases diminish in number from June to November, and rise again from November to June; in Lahore there is a marked rise from July to October, which attains its height in August, and an almost complete absence of cholera during the rest of the year. These numbers give rise to the im-

* Of the 167,000 fatal cases of cholera which occurred in Prussia between 1848 and 1859 , the following was the relation to the various months:-January, 1.4 per cent. ; February, March, April, and May together 1 per cent.; June, 2.6 per cent.; July, 5 per cent.; August, 20 per cent.; September, 34 per cent.; October, 21 per cent.; November, 10 per cent.; December, 5 per cent. 
pression that the epidemics are dependent on some factors which vary according to the season-on a seasonal predisposition.

Extinction of A third striking fact with regard to the mode of spread the epidemies.

of cholera is that in one place the epidemic is often extinguished, while in other and neighbouring situations it continues, and that this extinction is observed both after a short and moderate amount of disease, and after a long continued and violent outbreak of the plague.

The question arises whether these puzzling facts as regards the epidemic spread of the disease, which have excited the greatest interest during the last few years, may not possibly be solved by a more accurate analysis of the mode of infection on the same lines as that above given in explanation of the transmission of cholera from individual to individual.

What are the external factors which influence the distribution of cholera epidemics?
It is $\dot{a}$ priori probable that the peculiar local and seasonal distribution of cholera epidemics is brought about by the action of several factors varying according to local and seasonal conditions, and depending partly on the sources of infection available for the spread of the epidemic, partly on the paths of transport from these sources to the exposed individual, and partly on the susceptibility of the latter. In studying the infection of an individual we become acquainted with a number of influences by which the sources of infection could be multiplied or reduced in number, the paths of distribution enlarged or narrowed, and the individual susceptibility increased or diminished. These factors are also undoubtedly of equal importance in the epidemic distribution of the disease; for we must remember that an epidemic only originates and spreads when a chain of new cases follows the first in a continuous series, and that it disappears when this chain is broken. Just as the inoculation of the individual requires certain favourable chances, just as all those infections which serve for the continuance of the chains are influenced by chances of all kinds, so the epidemic will come to an end, chiefly because, owing to external circumstances, the sources of infection become less 
numerous or are entirely removed, or because the usual paths of transport have become too few, or because the exposed individuals are immune against the infection.

Accordingly those external factors which can act to a great extent on the sources of infection, on the paths of distribution, or on the exposed individuals, will probably furnish an explanation of the local and seasonal differences in the spread of cholera; and hence we must study more closely these external factors. We find these factors partly in meteorological conditions, partly in the soil, and partly in the habits and customs of different races. The most important are the following:-

1. Meteorological influences. High temperatures 1. Meteoroapproaching the optimum of the temperature of the influences. comma bacilli might favour the spread of the disease by enabling the comma bacilli to multiply as saprophytes, and by thus multiplying the sources of infection. And Temperature. the less energy of tissue change, and the less resisting power of the body by which excessively high temperatures are apt to be accompanied, appear to increase the individual predisposition to a certain degree.-On the other hand, epidemics are by no means absent in winter, because these favouring influences of temperature are not so important that they cannot be completely replaced by other predisposing factors. It must also be remembered that in winter we usually employ in our immediate surroundings artificial heating, and thus produce temperatures which are quite sufficient to enable the comma bacilli to multiply; and that on the other hand, in summer and in warm climates sources of infection which may be preserved for a long time at a low temperature are more readily rendered inert by drying, or by the quicker growth of saprophytic bacteria. On the whole, therefore, it is only rarely that temperature has a decisive influence on the spread of cholera.

Very great dryness of the air must render the trans- Moisture of mission of the disease more difficult, in that it occasions rapid death of the comma bacilli in the sources of infection. Cholera linen, soil contaminated with dejecta, \&c., are under these circumstances only infective for a very 
short time, and the chances of spread of the disease are correspondingly smaller. Further, the nutrient media are rendered unsuitable for the multiplication of the comma bacilli by drying of the surface, as well as for the derelopment of other bacteria which might possibly influence the individual predisposition. Finally, insects, which are of such assistance in transporting the infection, are absent. This result however will only occur where there is a very great deficiency in the saturation of the air with moisture, for example in a desert; moderate differences in the degree of moisture of the air can only with difficulty exert a noticeable action. Diminution of the moisture of the air, such as occurs, for example, in Calcutta during the so-called "dry season" of the year (November to April), can coincide very well even with an increase of cholera if the paths of transport and the individual predisposition are at the same time favourably influenced by other factors. On the other hand, it is conceivable that in a desert climate, such as is present in Multan and Lahore during the greater part of the year, and where everything dries up, as it were, under one's eyes, the conditions farourable for the spread of the cholera may only be present at most during the somewhat moister or so-called "rainy" season (July to October).

Rain. Very excessive and constant rains will, as a whole, cause a diminution in the number of the sources of infection and of the paths of distribution. Where, as in certain parts of India, and also in many villages and habitations of the poor in European cities, all sorts of filth and all infective dejecta are collected in the courts and in the immediate neighbourhood of the houses, and where attempts are never made to cleanse these surroundings, heary rainfalls, which are powerful cleansers of the surface of the earth, must lead to diminution and removal of the sources of infection. Where, on the other hand, the rainfall is slight and of short duration it can hardly exert any direct action, and will at all events occupy a secondary position as compared with other important factors. 
2. The nature of the soil is in the first place of im-2. Influence portance in so far as, according to the declivity and of the soil. porosity of the soil, the rain, the house, and the washingwater, the outflow from water-closets, \&c., can be readily carried off, or is retained in stagnant superficial collections, or in the uppermost layers of the soil. Where, as in the suburbs of Calcutta, we have the presence of tanks, and the artificial elevation of the foundations of the houses, the conditions are very fuvourable for the collection and preservation of infective material during the dry season of the year. A similar accumulation of filth and of sources of infection also occurs not uncommonly with us in narrow streets and courts.-The influence of the soil may also vary according to the season. The chances are evidently favourable for the spread of Dryness of cholera when a so-called "drying zone" exists in the the uppermost uppermost parts of the soil, so that all fluids and rain soil. which reach the soil remain in the uppermost dry layer (see Part VI.); where there is no drying zone the impurities and any infective agents present are as a rule carried to such a depth that they are no longer present at the surface, and thus many chances of transport to man and dwellings are removed; when however a drying zone is present all infective organisms, which usually reach the soil in considerable numbers with the dejecta, with the contents of the night-stools, with the water from washing clothes, \&c., remain for a considerable time in this upper layer. There the conditions are favourable for the preservation of the comma bacilli as well as other bacteria; and hence a source of infection is furnished from which the infective material may be carried either directly to man or to articles of food and other things in a great variety of ways, e.g. by man, animals and objects, and also by insects; and this source of infection is so much the more dangerous the longer it continues to exist.-The presence of a drying zone, which is best indicated in our neighbourhood by lowering of the level of the ground-water, is therefore under certain conditions an important seasonal predisposing factor for the spread of cholera, while under other circumstances, such as an 
unsuitable character of the soil, cleansing of the surface of the soil, \&c., it is much less important than many other factors.

3. Influence of drinking water.

Insects.

5. Habits of life.

Cleanliness.
3. The mode in which the population obtain their drinking and household water is at times of great importance. If the water has in the first instance become contaminated with comma bacilli it forms for a short time a dangerous source of infection, which leads in the simplest and most direct manner to the exposed individuals.--The establishment of this source of infection may be greatly favoured by the situation of the well, and its mode of formation; especially where water is carried to it from the surface of the soil, or where canals or gutters from cesspools, \&c., lead to the well. The more of these badly constructed wells there are in a town the more readily will cholera be spread by the water. Open and stagnant collections of water are naturally the most dangerous; in Lower Bengal such collections form the source of the water supply, and appear, as a matter of fact, to be one of the most frequent and dangerous sources of infection. Where the wells are deep and well constructed, so that they cannot be contaminated from the surface of the soil; or where the water is carried by well-constructed pipes, this mode of spread of the infective material is practically absent.

4. Insects deserve especial mention, as they vary extremely in numbers according to place and season, and form in all probability a by no means unimportant mode of conveyance of the poison, a mode which increases or diminishes according to the number and varieties of the insects. No quantitative estimate can be formed with regard to this factor.

5. Certain habits of life can in the case of one nation furnish greater opportunities for the spread of cholera than in that of another. The average cleanliness of the population has the greatest influence in this respect. The more cleanly the method of handling the sick and the infected clothes, the more carefully contamination of the soil, of the water, and of various other objects with the dejecta is avoided, the fewer will be the sources of 
infection. The more carefully the hands are cleansed and the articles of food prepared, the more will the paths of spread from existing sources of infection be diminished. It is evident that in this respect marked differences must exist between more or less civilised countries; between new and well-built, and old and narrow cities; between poor and wealthy neighbourhoods; between the portion of a city inhabited by the poor and that in which the better class dwell.

As a special example of the action of general clean- Arrangements liness we have the effect, often confirmed, of a good of water and supply of water and drainage. Formerly these arrange- removal of ments were supposed to produce their good hygienic results chiefly by keeping the soil and ground water free from all putrescible materials, and thus withdrawing the necessary nutrient substrata from any infective germs which may have reached them. This interpretation is no longer sufficient in accordance with our present knowledge as to the conditions of life of the pathogenic fungi, but the good effects of these arrangements for cleanliness still exist as they did formerly, for they lead to marked diminution of the sources of infection and to a limitation of the paths of spread. They act by remoring as quickly and completely as possible all the dejecta and the water employed for cleansing linen, utensils, \&c., without allowing them to come in contact with the surface of the soil, with wells, \&c. ; and further, by providing an ample and convenient supply of water, so that cleanliness in every form is faroured, and thus infection is limited to contact, nutrient materials, and so on. But even with these arrangements we must not under all circumstances expect a complete protection against the spread of cholera, for at certain places and at given times it is evident that other sources and paths of infection may develop, and thus the disease may spread quickly and over a wide area in spite of these sanitary arrangements.

The mode in which linen is cleansed may be especially cleansing of referred to as another of the habits of life which has an \&cothes, linen, important influence on the spread of this disease. Koch 
has pointed out that in Lyons, for example, the custom is not to wash the linen in the house, but on boats in the quickly-flowing water of the Rhone, or further down the stream, for example, in the village of Craponne. Clothes are soiled with dejecta in almost every case of cholera; the infective material retains its vitality under these circumstances for a relatively long period; the linen is a valuable material, which is treated with care and subjected to many manipulations; it is handled the more incautiously in that the cholera dejecta do not betray their presence by stink, or by any other disagreeable character. Hence linen is evidently one of the most dangerous sources of infection, and thus a very great part of the chances in favour of the distribution of cholera is removed when, as in Lyons, the linen is without exception cleansed outside the house; while on the other hand the greatest chance of infection is furnished when the linen is kept in the house, washed in leaky wells, or, as in India, in stagnant tanks.

6. Intlaence of individual predisposition.

Mode of nourishment.

6. An important factor which hinders or favours the local and seasonal spread of cholera is, finally, the individual predisposition of the population. Such a predisposition can in the first place be based on the habits of the population with regard to food, habits which show marked differences in different places and at different seasons. In one country the people live relatively sparingly, in other countries or towns, or in certain classes of the population, a very large amount of food, and more especially of fluid food, is swallowed. It is further worthy of notice that in our countries the food is almost always cooked during winter and spring, while in summer and harvest raw fruits and vegetables often form a considerable portion of the daily nourishment; these raw materials often set up mild gastric disturbances, and are also very suitable for the transport of bacteria. In other countries a much larger proportion of the food is constantly used without any preparation. It can casily be understood that by employing raw food the paths of infection are in the first place increased in number; that also as the result of the gastric disturbances, as well as of the 
habit of overloading the stomach; any comma bacilli which may have entered can the more readily obtain a footing and multiply in the alimentary canal.

The general nutritive condition, and the energy and resisting power of a whole population may also show marked differences, and may under certain circumstances influence the seasonal or local spread of cholera. Starvation as well as great assemblages of human beings, feasts, pilgrim festivals, \&c., favour an epidemic outbreak, partly on account of the slight amount of care employed in the selection and preparation of the food, partly by the frequent excesses, and partly by the weakening of the whole body.

A population is apparently in especial danger in Predisposing which at the time of the first cholera cases gastric dis- gastric turbances are prevalent. Such seasonal prevalence of mild or severe gastric disturbances, as shown by diarrhœas, dysenteric or even choleraic attacks, \&c., are observed in Germany almost exclusively during late summer and harvest. It is unfortunately as yet not possible to understand thoroughly the etiology of this great increase of gastric disturbances at particular seasons ; it is conceivable, for example, that the use of raw fruits or the low temperature so frequent during the night at this period of the year, and the consequent liability to cold, are of causal importance : or it may be due to some forms of micro-organisms for the preservation, distribution, and reception of which the circumstances during these months are particularly favourable; for example, these are the months during which in our country a dry zone is present in the upper layers of the soil, in which numerous bacteria may remain, and may be carried as dust by the winds, and further during these months bacteria are most frequently taken in by articles of food. Whatever may be the ultimate explanation, we may assume as certain that these autumnal gastric disturbances, in whatever way they have arisen, have a special favouring influence on the epidemic spread of cholera.

Lastly, the individual predisposition of a population Influence of epidemics. 
may be influenced by the fact that a larger or smaller proportion of the individuals have been rendered immune for a time by a previous attack of cholera. As has been previously stated, we must assume that even the mildest attack can produce this immunity, so that after a considerable epidemic a relatively high percentage of the population has been attacked. This circumstance must diminish to a great degree the chances in favour of the spread of a second epidemic ; and in India, where there are almost always insusceptible districts which have been recently attacked alongside of the susceptible ones, the mode of spread of the epidemics must consequently show peculiar interruptions and leaps. Koch has called attention to the fact that by this acquired immunity of certain tracts we can understand the remarkable distribution of cholera when it spreads from one of the large pilgrim resorts as a centre; the line which the disease takes does not correspond to all the radii, although all have undoubtedly been brought in contact with cholera patients; the cholera spreads only in those directions where this acquired immunity is wanting.

Increase of these influences as the result of continued infection. the cffect of

As the result of these numerous influences, varying according to place and season, variations in the epidemic spread of cholera are the more readily produced because the disease is not always carried from one individual to another, but often attacks a large number of individuals at the same time. Hence the differences in the effect in cases where the chances in favour of its spread are plentiful, and in those where they are few, are still Differences in more strikingly manifested. We have only to consider the effect of the first case of cholera. how completely different the mode of spread is according to the circumstances under which the first case of cholera is introduced into a town. In the one place the patient may be nursed in a well-to-do family, or in a suitably arranged hospital with trained nurses; in the other place the first case may occur in a narrow, poor 
quarter of the town where numerous individuals come in contact with the patient and with the dejecta, where the methods of cleanliness are by no means sufficient, where the food is prepared and eaten in the same room, where there are numbers of flies which aid in the transport of the germs, and where consequently it is only rarely that direct contamination does not take place. It is evident that in the latter case the chances of a sudden and great extension of the disease are present, and hence the effect is so very different from that of the former case, in which at most only an isolated further infection occurs.

If now the disease has attacked several individuals Differencedue these unequal chances continue to ast in an increasing ing cases. degree, because from every new case where the chances continue favourable there is a marked multiplication of the number of individuals affected, and along with this an enormous increase in the number of sources of infection. In the one town the primitive arrangements for the removal of fæees, badly constructed wells, small dwellings, poverty of the population, bad nutritive conditions, \&c., can readily so act that almost every new case forms a source of infection and a means of transport, and that susceptible individuals are constantly present in the neighbourhood of the sick. In other towns or at other seasons, on the contrary, a very much smaller number of cases may occur, on account of the presence of a drainage system, a good supply of water, well-built houses, well-to-do, cleanly population, or on account of the fact that the individuals in contact with the sick are in great part insusceptible or immune ; in this way the chances are against the further spread of the disease, and favour the interruption in the chain.

Circumstances which are apparently trivial and Influence of accidental, and which readily escape observation, may apparently often exert such an influence on the spread of a cholera accidents. epidemic that the presence of local and seasonal predisposing conditions may be of absolutely no importance. Thus to mention some examples of these 
accidental conditions we not uncommonly find in the smaller towns in Mid and North Germany that the relatively pure water flows through the streets of the town in open gutters, and that this water is not only employed for household purposes but also-per nefas, but nevertheless very frequently-for carrying away the refuse from houses. If a case of cholera occurs in the higher portion of such a town, and if dejecta or water employed for washing the linen gain entrance to this running water a sudden extensive spread, a sort of explosive epidemic, may be the result, whatever be the state of matters as regards the other factors which are of importance in the production of an epidemic. Koch observed another example in Marseilles; in that town the market women who offered vegetables for sale were wont to sprinkle their wares from time to time with water in order to keep them fresh, this water being taken by means of a broom from a gutter which ran past the market. The comma bacilli could very readily enter this gutter water; and hence, by means of the infected vegetables and fruit, the germs might be distributed to such an extent that a violent epidemic could result.-A similar occurrence can take piace when one of the first cholera cases occurs in a dairy, and when comma bacilli, though only in very small numbers, enter the milk by one of the modes described, for milk is a very excellent soil for the growth of the cholera bacilli.

Such accidents may now and then exert an important influence on the course of the epidemic, and as it maybe very difficult to trace them subsequently, we may have the occurrence of a number of so-called "inexplicable" cases.

If we review the whole series of factors which are here mentioned, and which can influence, both as regards place and season, the commencement and the course of a cholera epidemic, we must admit that a local and seasonal distribution of cholera, varying much at different places and times, undoubtedly exists. 
But even as regards the peculiar laws which seem to govern the local and seasonal spread of the disease, we may easily find, among the important factors mentioned above, some which completely explain the repeated or permanent insusceptibility of some places, or the constant preference for a definite season of the year.

Thus the occurrence of cholera in Germany in late Explanation summer and harvest can be explained by the presence of of the seasonal various predisposing factors during these months. It is in Germany. during this season, as Pettenkofer has pointed out, that the level of the ground-water is lowest, and that consequently the upper layers of the soil are driest; the existence of a definite drying zone has, as was pointed out above, a markedly favourable influence on the preservation and increase of the sources of infection. The cholera months are also those in which the largest numbers of insects are present, and these undoubtedly take part in the transport of the germs; they are also the months in which people eat the greatest quantity of raw food, which is also well suited for the transport; but above all in those months there is a marked individual predisposition on the part of a relatively large portion of the population on account of the frequent gastric disturbances, the causes of which have been previously referred to. It is easy to understand that where this dry zone is absent and with it a number of sources of infection, where the rarious means of transport referred to are wanting, and where there is no wide-spread individual predisposition, the chances for the spread of cholera are very unfavourable, and that therefore in our climate it does not usually spread at all during winter and spring, or at most only a few individuals are affected. At times, lowever, in spite of the unfavourable season of the year, some of the other predisposing factors may be so markedly developed that an exceptional epidemic may occur even in the middle of winter or in spring.

There are also a number of factors which explain the Explanation extinction of an epidemic after its longer or shorter dura- of the extinction. In this respect one important point is, that soon epidemics. 
after the first appearance of the epidemic the treatment of the individual cases is better carried out, that those who are in contact with the sick take greater care as regards cleanliness and other precautions, that the majority of the inhabitants take less raw food, that greater care is employed in providing pure water, that the individual predisposition is diminished as far as possible, partly by the aroidance of excesses, partly by early treatment of gastric disturbances, and partly, in the case of another portion of the population, by recovery from a previous mild or severe attack; and finally, that at times, with the change of the season of the year, one or other of the external influences are removed, and thus the sources of infection, and the ease with which the germs are transported, are diminished.-The more completely and quickly all those factors which tend to the extinction of the epidemic come into play the earlier will further infection cease; the longer the one or the other favouring condition continues the further will the epidemic spread. It is evident that in order that cholera should become permanent or endemic in the neighbourhood other very favourable conditions must be present, especially as regards the climate, and probably still more as regards the habits of life of the population.

It would lead us too far to explain the various striking phenomena which occur in the epidemic spread of cholera by the factors which come into play, and which have already been mentioned in detail. This much is evident, that the sum of the external factors furnishes a sufficient explanation of numerous epidemiological laws, and also of numerous exceptions; whether it be that in the one case several of these factors act together, and thus increase the effect, or whether it be that one or other are in opposition to, and thus neutralise each other, there are a number of possible explanations which may correspond to as many variations in the occurrence of cholera. For many persons the extraordinary multiplicity of the factors which furnish the explanation of the local and seasonal distribution of cholera is self-evident; this is more especially the case since Virchow drew attention so 
markedly to this point in the proceedings of the last cholera conference. But during the last decade the tendency to draw up a scheme of cholera epidemics, and the desire to find a single causal factor in explanation of the peculiarity of its course, has come to the front so exclusively that it seemed necessary to draw especial attention to the multiplicity of the factors which come into play, and to point out in detail what factors can produce regular local and seasonal variations in cholera epidemics, and what factors may lead to irregular and accidental rariations.

These deductions are chiefly based on the biological peculiarities of the comma bacilli as we have learned them from Koch's investigations, and on the assumption that cholera is contagious, and that the contagium is contained in the comma bacilli.

These views are, however, not as yet accepted by all views of the cholera investigators; on the contrary, the "localistic" localists. view brought forward by von Pettenkofer, Cuningham, and their followers, is opposed to this "contagionistic" standpoint. Cuningham assumes that in order to origi- Cuningham's nate a cholera epidemic it is not at all necessary that a view. patient suffering from cholera should enter the place where it begins, but on the contrary that cholera occurs everywhere sporadically, and that favourable local conditions are alone necessary to lead to the outbreak of an epidemic. This peculiar view is only a possible one on the arbitrary assumption that every case of violent diarrhœa is a case of true Asiatic cholera. This view was not easy to upset in any individual case so long as we had only symptomatic and pathological anatomical differences to enable us to distinguish between cholera asiatica and cholera nostras; it is, however, quite untenable, since we have found a marked difference between the two diseases, in that the characteristic cholera bacilli are always present in the one and never occur in the other. 
Von Pettenkofer's view.

Von Pettenkofer admits that in the case of cholera we have to do with a virus which is carried from place to place, but he lays chief stress on the facts as to the peculiar local and seasonal distribution of cholera, and he assumes that in addition to the virus introduced, other factors, dependent on the locality, must come into play in order that an epidemic should occur. If we call the virus which proceeds from the patients " $x$," and the something due to the locality " $y$," cholera only spreads when $x$ and $y$ occur together; $x$ alone can only quite exceptionally cause a single case of the disease, but never an epidemic. On the contrary, in a place where $y$ is alsent we may swallow cholera dejecta without any harm; while an infection would follow under these circumstances if $y$ was present in the same locality.

Pettenkofer has attempted to ascertain the nature of $y$ by an accurate investigation of the local and seasonal distribution of a large number of cholera epidemics, and he has come to the conclusion that the nature of $y$ is a certain character of the upper layers of the soil. A soil which predisposes to the disease must be porous and penetrable by air and water, it must be contaminated with dejecta, organic substances, \&c., and it must be to a certain extent moist. The moisture of the soil is the factor which chiefly varies with the season; too great moisture diminishes the predisposition in the same manner as too great drought. The degree of moisture of the soil is in the majority of cases most accurately shown by the variations in the level of the ground-water, in other cases it is better determined by the amount of rainfall.

Hence those localities are permanently immune where the ground is composed of rock or dense clay, also those where the soil is quite clean, and those where the surface of the soil is always either very dry or very moist. A temporary immunity is occasioned chiefly by too great or too little moisture of the soil.

According to Pettenkofer's view the relation between the virus $x$ and the factor $y$, which depends on the pres 
disposition of the soil, is either that $y$ so prepares man that he becomes susceptible for $x$, or that $x$ is altered under the influence of the $y$ properties of the soil, and is only then capable of producing infection in man. Pettenkofer looks on the latter alternative as the most probable, and he is also of opinion that $x$ is a species of bacterium, the development or distribution of which is much influenced by these $y$ properties of the soil.

Pettenkofer holds that Koch's comma bacillus is not Pettenkofer's the proper $x$, because its characters show that it cannot opposition to be favourably influenced by the $y$ properties of the soil ; bacillns. the comma bacillus dies as the result of drying, while a relatively dry soil furnishes the best seasonal predisposition for cholera. The comma bacillus further rapidly dies in putrefying substrata, while a soil contaminated with dejecta is one of the predisposing factors in favour of cholera.-Neither of these objections are, however, valid. Where the moisture of the soil diminishes the degree of dryness is almost never such that the comma bacilli which reach the soil must at once die. On the contrary, the conditions for the spread of the infection are, as was shown on $\mathrm{p} .457$, more favourable under these circumstances. In like manner the rapid destruction of comma bacilli in putrefying substrata has reference to their behaviour in fluids where there is active multiplication of saprophytes, but does not apply to the soil in which the multiplication and hurtful influence of the saprophytes are practically of no moment.-It is, therefore, evident that Pettenkofer's opposition to the comma bacillus is in reality not at all justified; while the fact of the constant and exclusive occurrence of the comma bacilli in cholera has led him to the assumption, which certainly does not seem by any means probable, that the virus of cholera is an organism as yet unknown, that this virus becomes altered in an as yet unknown manner under the influence of a porous, impure, and somewhat moist soil, and can then cause the infection, and that after the occurrence of infection the vibriones, which are present in small numbers in the intestine, 
become transformed into the enormously multiplying comma bacilli.

The peculiarities of the local and seasonal distribution of cholera are undoubtedly facts which we must all recognise. Pettenkofer's observation that the condition of the superficial layers of the soil frequently plays a causal part in these peculiarities is likewise undoubtedly correct; but it has been previously shown that this condition of the soil can exert an important influence, eren though we admit the etiological significance of the comma bacillus. But also to an unbiased mind it is evident that the nature of the soil, to which Pettenkofer gives such prominence, is by no means of itself sufficient to explain all the peculiarities in the spread of the epidemics. There is no doubt that Pettenkofer's explanation is not applicable in many cases; that, for example, cholera epidemics in the eastern part of Prussia have occurred on dense clayey soil, and in Bombay on non-porous rock, while, on the other hand, porous soils have been passed over. We must at all events regard Pettenkofer's views only as hypotheses, and must not ascribe to them the value of a firmly established theory, which must be used as a basis on which to test the results of present, and future investigations. We must, on the contrary, admit the possibility that numerous other causes come into play in the peculiar mode of spread of the epidemics, and we can only take the proper course if we also take into account the other possible explanations. If we base our investigations on the known biological characters of the comma bacillus, we are at all events on firmer ground, and are more likely to find out the truth than if we stubbornly hold to the view of an unknown $x$, and a still more unknown $y$.

Prophylactic regulations against cholera.
The practical propliylactic measures to be taken against cholera differ also in an important manner according as the localistic or the contagionistic view is 
the one held. The localists throw aside all quarantine regulations, all arrangements in order to afford protection against infection, and all disinfection; on the other hand they pay special attention to the diminution of the $y$ properties of the soil, of which the contamination of the soil is that which is most easily avoided and altered; drainage, or a proper method of removing the sewage, is supposed to lead to such a condition of the soil that it is no longer suitable for the epidemic spread of cholera.

From the standpoint of the contagionists all the measures discussed above which can protect the individual from infection are of the first importance. Hence the prevention of the introduction of the disease is the first protection against an epidemic of cholera. As cholera is generally brought to us over the sea from India by patients suffering from the disease a strict medical inspection of ships coming from India in the Suez Canal is of immense importance. It is only in sea-port towns that any good result can be hoped from quarantine. If cholera has once broken out on the Continent nothing more can be expected from quarantine regulations. In that case each town must take care above all that the first case of cholera is quickly brought to the notice of the authorities, and is diagnosed with certainty. The latter can be almost always done by means of plate cultivations, and the sanitary authorities must therefore know how to make them. A great deal also depends on proper treatment of the first case or cases. These should be nursed wherever possible in hospitals, or at any rate by trained nurses; the linen and clothes of the patient should be disinfected with steam in an institution for the purpose which should be present in every town; the dejecta should be rendered innocuous, and all other suspicious substances should be disinfected with carbolic acid, sublimate, or concentrated hydrochloric acid; the sick-rooms are most readily freed from infective germs by opening the window, and shutting up and heating the room for some days; in this way the comma bacilli will be 
killed by drying. The population should also be instructed as to the circumstances which favour or hinder infection, more especially as to the influence of careful cleanliness, as to care in preparation of the food and in the selection of drinking water, and as to the hurtful influence of excesses and of even the mildest gastric disturbances. Drainage, proper removal of waste materials, and a good water supply, are also, from the contagionistic point of view, excellent prophylactic measures for a town, the basis of these regulations being, however, somewhat different from that of the localists ; the chief advantage of these arrangements is not that they lead to cleansing of the soil from putrefying materials, or freeing of it from materials which could nourish the lower organisms, but it is the prompt removal of the infective agents, and the diminution of the opportunities for infection.

\section{Spirillum Finkler and Prior.}

(Vibrio proteus.)

Finkler and Prior's spirilla.
Morphological characters.
From the dejecta of patients suffering from cholera nostras which had been kept for some time, Finkler and Prior isolated a spirillum which resembles the comma bacillus of Asiatic cholera, but can nevertheless be very readily distinguished from it, more especially by neans of a number of differences in its mode of growth.

As a rule the individual curved bacilli, which when united together form the spirilla, are the chief forms present. The curved bacilli

Fig. 124.-Spirillum of Finkler and Prior $\times 700$.

are somewhat longer and thicker than Koch's comma bacilli; their thickness is not so regular as the latter, but on the contrary they appear oftener somewhat pointed at the ends, and thicker in the middle. Not uncommonly 
we find " $\mathrm{S}$ " forms similar to those of the cholera bacillus, and also longer screw-like threads, which, however, do not occur so frequently in gelatine cultivations, and do not show so many twists as in similar cultivations of the cholera bacilli. When examined in drop cultivations they show active movement.

According to Buchner, Finkler's bacilli have a great Involution tendency to alter their form when the state of the nutrient medium is unfavourable (Buchner has therefore proposed to give the bacillus the name Vibrio proteus). Under these circumstances they form sometimes spheres, sometimes spindles, and sometimes monad-like bodies; the latter may present an oval form as much as $4 \mu$. in breadth, or may appear as large spheres, or as very broad and fat portions of twisted threads, and they are obtained very easily by the addition of 5 per cent. of sugar, or 2 per cent. of glycerine, to the gelatine. These structures can only be looked on as pathological or involution forms.

On gelatine plates Finkler's bacilli form after 24 Cultivations hours white points, which under a low power present the appearance of circular yellow or yellowish-brown discs; in contrast to the young colonies of Koch's comma bacilli the outline of Finkler's colonies is very sharp, dark, and almost absolutely circular, while in the case of the cholera bacilli a wavy irregular outline is observed; the colour is also distinctly darker, and the surface does not present such a highly refracting, granular appearance as in the case of the true cholera colonies. Liquefaction of the gelatine begins very early; as soon as this occurs the outline of the colonies loses its sharp-

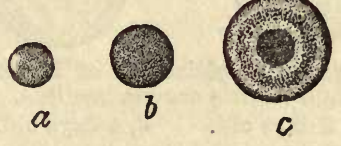

Fig. 125.-Colonies of Finkler and Prior's spirilla $\times 80$.

$$
\begin{aligned}
& a \text {, after } 16 \text { hours. } \\
& b, \quad, 24 \text {, } \\
& c,, 36 \text {, }
\end{aligned}
$$

ness, the periphery often appears dentate or as if eaten away, while, on the other hand, the external zone of liquefaction has a sharp border. One can often observe at this stage zones of different colour in the colony; a darker central zone, then a lighter, 
and then again a darker marginal zone. The young colonies can be distinguished from those of cholera bacilli without any difficulty by means of the above mentioned characters; at a later stage, more especially when the cholera colonies are older than Finkler's, the diagnosis is not so easy, but it can always be made when a considerable number of colonies are examined.-At a still later period Finkler's bacilli liquefy the gelatine very energetically; a funnel, $1 \mathrm{~cm}$. in diameter or more, is formed, and as a rule the whole plate very soon becomes entirely liquid.

Puncture cultivations.

In puncture cultivations in gelatine Finkler's bacilli are also characterised by the greater energy with which
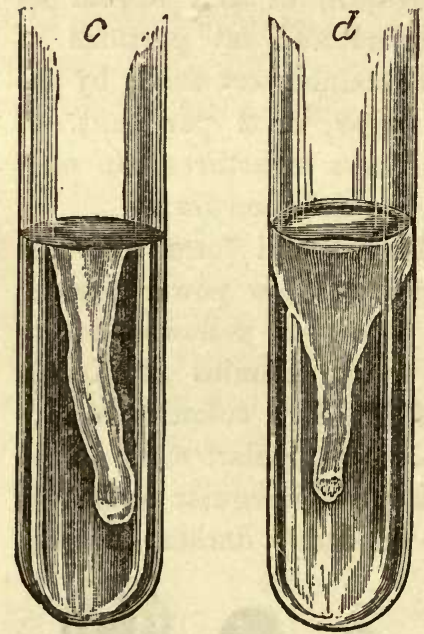

Fig. 126.-Cultivation of Finkler and Prior's comma bacillus.

$c, 2$ days old. $\quad d, 4$ days old. they liquefy the gelatine. When cultivated under the same conditions as Koch's bacilli they lead, even within 48 hours, to the formation of a comparatively wide sac-like tube which is filled with muddy fluid; after 24 hours more the liquefaction has usually reached the wall of the test-tube and has involved the uppermost portion of the gelatine, while the lower end of the sac has correspondingly increased in breadth.-When cultivated on nutrient agar the bacilli form yellowish-white deposits witlout liquefaction, and without any definite characters. Blood serum Growth on potatoes. is rapidly liquefied.- On potatoes kept at the temperature of the room they form within 48 hours a greyish-yellow gelatinous coating, which is marked off from the substance of the potato by a white border. This growth on potatoes forms the most striking contrast to the behariour of Koch's comma bacilli, which do not grow at all on potatoes at the ordinary tempera- 
ture, and at higher temperatures only give rise to a thin brown coating.

In all the cultivations of Finkler's spirilla a somewhat foul smell is developed. In nutrient substrata containing sugar, fermentation and the formation of acid take place, according to Buchner.-Finkler's bacilli seem, according to the experiments made by Finkler and Prior, to be much more resistant towards drying and overgrowth by other saprophytes than the cholera bacilli. A cultivation which had been dried and kept for two months over phosphoric acid free from water grew when planted on fresh nutrient substrata.

If a pure cultivation of Finkler's bacilli is injected Experiments directly into the duodenum of guinea-pigs a certain on animals. proportion (3 out of 10) die according to Finkler and Prior and numerous bacilli are found in the intestinal contents, having apparently multiplied there; Koch's control experiments also showed that about 30 per cent. of the guinea-pigs which had previously received soda solution and tincture of opium, as in the experiments with cholera cultivations mentioned above, died after the administration of cultivations of Finkler's bacilli by the mouth.-Injection of considerable quantities of cultivations, either subcutaneously, into the veins, or into the stomach, set up no disease in the animals experimented on. Pathogenic action seemed only to occur under such complex conditions, and then only so rarely that, as the result of the experiments on animals alone, Finkler's spirilla must be reckoned among the saprophytes.

It is still doubtful, however, whether these organisms Habitat of play a pathogenic rôle in man (this would be quite con- Finkler's ceivable when we bear in mind the similar though much more aggressive behaviour of Koch's bacilli on animals), and whether they stand in any etiological relation to cholera nostras. Finkler and Prior state that they found the same spirilla on microscopical examination in five cases of cholera nostras ; nevertheless these organisms could not be recognised with certainty by other observers, and more especially by Koch, in Finkler and Prior's preparations. Finkler and Prior have only isolated 
these organisms by cultivation (a plan that is necessary in order to render their identity certain) in the case of dejecta from cholera nostras which had been kept for a long time, and which had undergone putrefaction.-

Relation to cholera nostras.

Other authors have, however, sought in vain for Finkler's bacilli in a large number of cases of choler's nostras. Thus Koch examined a considerable number of cases, and among them several which ended fatally, with negative results; and investigations by Ermengem, Watson Cheyne, Biedert, and others, have in like manner yielded negative results.

On the other hand, Miller has found curved bacilli in a hollow tooth, and these must be looked on as identical with Finkler's, from their microscopic characters, and their behaviour on cultivation and on animals; and Kuisl* has obtained Finkler's spirilla in a nutrient solution containing peptone, meat infusion, and 2 per cent. of potash soap, from the contents of the cæcum of a patient who had committed suicide.

Hence from the mode of distribution of these bacilli we cannot find any evidence of pathogenic properties, nor any relation to cholera nostras, and they must therefore be reckoned among the saprophytes till better evidence of their pathogenic character has been furnished.

From Finkler and Prior's first publications, in which they held that their bacilli were identical with Koch's comma bacilli, it is evident that they made their experiments at that time in complete ignorance of the usual and necessary methods of cultivating and isolating bacteria; and in their paper they also speak of a mode of development of their bacilli in which "alternation of generation," "mother cells" which burst at a later period, "spore bearers," \&c., play a part, and which has no analogy in the developmental history of other bacteria. In their last communication, $\dagger$ it is true, these authors give a very detailed description of Koch's method of investigation, with which they have apparently become acquainted subsequently; but they attempt to bolster up their former standpoint with only slight modifications, and

* Münch. ärztl. Intelligenzbl., 1885, 36.

+ Centralbl.f. allg. Ges. Ergänzungshefte, vol. i., Parts 5 and 6. 
to defend, without any new and better reason, those original expressions which they have introduced into the science of bacteriology.

\section{Spirillum tyrogenum.}

\section{(Cheese spirilla.)}

These organisms were isolated by Deneke in the Cheese author's laboratory from cheese which had been kept for spirilla. a long time; morphologically and on cultivation they show a greater resemblance to Koch's comma bacilli than do Finkler's spirilla, but like the latter they can be definitely distinguished from the cholera bacilli by certain culture characteristics.

The individual bacilli are somewhat smaller than Morphologici Koch's bacilli, and often show very long spirillar threads with somewhat narrower twists and smaller screws. In drop cultivations they show active movements.

On gelatine plates the youngest colonies form small cultivations. white points after 24 hours, and under a low power they present the form of circular dises with sharp outlines,

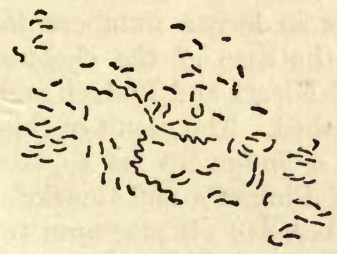

Fig. 127.-Cheese spirilla

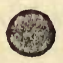

"

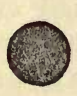

$b$

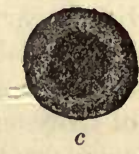

Fig. 128.-Colonies of cheese spirilla $\times 80$.

$a$, after 16 hours.

b, , 24,

and of a dark, greenish-brown colour. At a later period the margin appears somewhat lighter, the centre of a dark yellow colour; at the same time liquefaction of the gelatine commences, and the sharp outline of the colony not uncommonly disappears. The liquefaction of the gelatine is more energetic than in the case of the cholera bacilli, but does not occur so quickly as in Finkler's. This fact is seen also in puncture cultivations, where a sac-like liquefied tube is formed within 24 hours, and at a later period there is complete liquefaction of the 
gelatine. On agar the cheese spirilla form a yellowishwhite layer; they liquefy blood serum energetically. No growth takes place on potatoes, either at the ordinary temperature or at higher temperatures.

Experiments on animals.

By the ordinary modes of application no pathogenic action is exerted on animals. In two experiments in which the cheese spirilla were injected directly into the duodenum of guinea-pigs Deneke observed no morbid phenomena. Of fifteen guinea-pigs which were treated by Koch in the same manner as in his experiments with cholera bacilli, by previous introduction of soda solution and tincture of opium, and then of pure cultivations of these spirilla, three died.-From these results, as well as from the habitat of the spirilla, we must regard this species of bacterium as a pure saprophyte.

Deneke's experiments on animals were limited to one experiment on six guinea-pigs; into two of these cholera spirilla, into two Finkler's spirilla, and into two the cheese spirilla were injected into the duodenum. The two first animals died, the other four remained alive. It may be remarked here, in answer to an objection by Finkler, that these experiments on animals were not done on a larger scale because the author knew that the same experiments were being carried out at the same time in larger numbers in Koch's laboratory, and because in the case of the cholera bacilli more especially the results of Nicati and Rietsch and of Ermengem had already been published. The result of this comparative experiment permitted a judgment as to the pathogenic or saprophytic nature of Finkler's and Deneke's spirilla, so much the more readily because all attempts to injure animals by these bacteria by the ordinary modes of infection failed, and because in this case the habitat and mode of spread of the organisms did not, as in the case of the cholera organisms, point to a pathogenic rôle which required to be still further confirmed by experiments on animals.

\section{Spirillum sputigenum.}

Curved bacilli from the mouth.
In the deposit on the teeth and in the saliva of man curved bacilli not uncommonly occur which have a certain resemblance to the cholera bacilli, but are somewhat larger, thinner, and more pointed at the ends. Where the staining with aniline dyes is not too dark, it can also 
be seen that the colouring matter is irregularly distributed in the rod, being less plentiful at the ends. Lewis* has nevertheless held that these organisms are identical with cholera bacilli; but they differ very distinctly from these, in that the spirilla of the saliva cannot be cultivated by any of the ordinary methods of cultivation. Hence

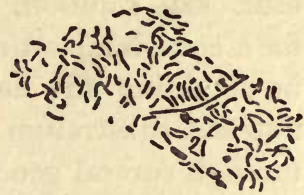

Fig. 129.-Spirillum sputigenum (after Ermengem $) \times 700$.
They grow on none of the ordinary nutrient substrata. the isolation of these bacteria and the study of their characters has not as yet been possible.

\section{Spirillum (Spirochete) Obermeicri.}

These organisms were first observed by Obermeier in Spirilla of the blood of patients suffering from relapsing fever. fever. They have the form of long, wavy, flexile threads, with 10 to 20 convolutions; their length varies between 16 and $40 \mu$., their breadth is from $\frac{1}{4}$ to $\frac{1}{2}$ that of the comma bacilli. In fresh preparations the spirilla are seen to be motile; they move quickly, and also show undulatory movements, which pass in a wavy manner through the whole length of the thread. Colouring matters, more especially fuchsine, alkaline methylene blue, and Bismarck brown, are comparatively readily taken up; nevertheless, on account of their fineness, it is only possible to dis-

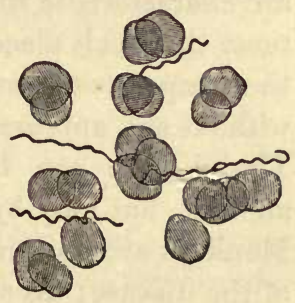

Fig. 130.-Spirilla of relapsing fever in blood $\times 500$.

cover these spirilla, when present in small numbers, with high powers, and good illumination. Larger numbers of the bacilli, which in many cases fill the blood, are on the other hand readily recognised, both in fresh and in stained preparations.

The spirilla are found exclusively in the blood of the Occurrence. patients, never in the secreta; further, they are only present during the febrile attack, but not in the interval between the attacks, or at most only for two days after 
the attack of fever. Their numbers vary very greatly. Outside the body, when liept in blood serum or in $\frac{1}{2}$ per cent. salt solution, the spirilla retain their movement. for a considerable time; but as yet we have not succeeded in obtaining any decided multiplication in any sort of nutrient substratum, nor can a cultivation be carried on through several generations.

Inoculation of On the other hand the disease, characterised by its the disease on attacks of fever and by the appearance of the spirilla, can
monkeys. be inoculated on monkeys, by means of human blood containing spirilla. Koch and Carter were able, in the case of long-tailed macaques, to set up a typical attack of fever by subcutaneous injection of a small quantity of defibrinated blood, containing spirilla, after an incubation period of several days; during the attack of fever the blood showed large numbers of spirilla, while the organisms were never found either before or after the appearance of the fever. Numerous spirilla could also be demonstrated in the organs of the animals killed at the height of the febrile attack. True relapses, such as are characteristic in man, did not occur in monkeys; the most that took place was that, a few days after the crisis, the temperature was again for a short time elevated, but without any appearance of the spirochrte in the blood.The disease can be inoculated from one monkey to another, but only by means of blood containing spirilla. Relapses. Monkeys are not protected from recurrence by one attack of the disease; Koch and Carter were able to set up the same typical attack of fever when the monkeys which had recovered from the first attack were inoculated again, after some days or weeks, with blood containing the spirilla.

From the constant and exclusive occurrence of these peculiarly-shaped bacteria in relapsing fever, and from the fact that the disease can only be set up in healthy monkeys by blood which contains these spirilla in the living condition, we may with certainty conclude that the spirilla are the causal agents of this disease, even although we have not as yet succeeded in cultivating the organisms, and in studying their characters more minutely. 
All the other spirilla are as yet very incompletely Incompletely known, and we do not possess methods of cultivating of spirilla. them in a state of purity, and of observing their mode of development. They appear to grow by preference on fluid substrata, and to accumulate more especially at the surface; a situation in which they are usually found in enormous numbers is in the ordinary cesspools (Mühlhäuser). Resting forms have not as yet been described with certainty in the majority of the species which have been observed, the only exception being spirillum rugula; but it is possible that at a future period spore-like structures will be found in other of the bacteria belonging to this almost unknown class.

Geddes and Ewart* state that they have observed the following facts as regards the mode of development and spore formation of spirilla; the spirilla have alternately a motile and a resting stage; they ultimately grow in the form of a small thread without any definite coils; this thread becomes longer and thicker, and spores appear in it. These spores divide rapidly and become glistening and brown, while the threads become again motile and break up sooner or later. The spores thus liberated become encysted, and divide into a number of capsules which become motile after a period of rest; the "sporulæ" contained in the capsules escape, sprout in a comma form, and soon grow to the ordinary spirillum.These observations have evidently not been made on pure cultivations, and are of no value.

The following are the spirilla which have as yet been distinguished from one another, but which require more accurate study:-

Spirochete plicatilis.-Threads thin with numerous narrow turns, 110 to $225 \mu$. in length. As a rule the threads form a double wavy line; the primary turns are of the same size in all the examples; the secondary turns are often unequal in size. $B$, Spirochæte from the teeth $\times 500$. The ends are blunt. The organism moves with extreme

* Proc. of the Roy. Soc., vol. 27, p. 481. 
rapidity.-It occurs frequently during the summer in marsh water in which algæ are putrefying, in gutters, sc.*

Spirochate denticola (Spirochrte of the saliva).These organisms are much shorter than the foregoing, as a rule 10 to $20 \mu$. in length; the threads have a simple wavy outline, and are pointed at both ends. It occurs very frequently in the deposit on the teeth, and along with Leptothrix buccalis in the contents of carious teeth. $\dagger$

Spirillum rugula (Vibrio rugula).-Cells 6 to $8 \mu$. in length, $\cdot 5$ to $2.5 \mu$. in thickness, with a single bend, or at most with flat spiral turns; at times united in longer chains, often matted together in considerable numbers (fig. 55A). They are motile, with active rotation around their long axis. Koch has observed distinct flagella. Before spore formation takes place
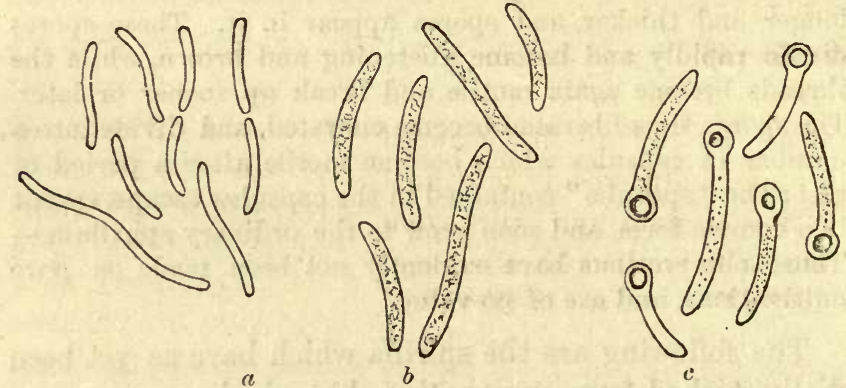

Fig. 132. - Vibrio rugula (after Prazmowski) $\times 1020$.

$a$, young rods. $\quad b$, thicker rods. $\quad c$, spore-bearing rods.

the threads become thickened throughout their whole length; a spherical swelling then occurs at one end, so that the rod has the appearance of a comma; this swelling ultimately becomes a spherical spore.-The organism occurs in marsh water, in the deposit on the teeth, in frces, \&c. It is often associated with bacillus butyricus, and is hence in all probability an anaerobe. According to Prazmowski + Vibrio rugula occasions energetic decomposition of cellulose. In decoctions

* Koch, Cohn's Beitr. z. Biol. d. Pflanzen, ii., p. 420.

+ Ibid., p. 432.

‡Untersuchungen, \&c., Leipzig, 1880, p. 44. 
made from regetable tissues (portions of potato, \&c.), Prazmowski was able to observe that the rods of Vibrio rugula collected around the cell walls of the tissue, and that they broke up in a short time ( 3 or 4 days) into swarms of Vibrio rugula. The intimate nature of the fermentative action has not as yet been ascertained.

Spirillum serpens (Vibrio serpens).-Threads thinner, 3 to 4 regular and permanent bends, 11 to $28 \mu$. in length, $\cdot 8$ to $1 \cdot 1 \mu$. in thickness; at times united in chains. Actively motile; often in dense masses.-Occurs frequently in various stagnant fluids.

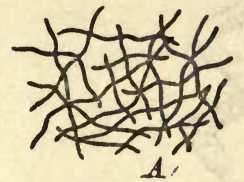

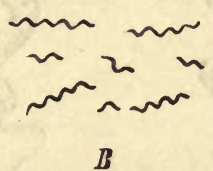

Fig. 133.

$A$, Spirillum (vibrio) serpens. $C$, Spirillum undula $\times 650$.

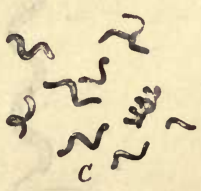

$B$, Spirillum tenue.

Spirillum tenue.-Threads very thin, at least $1 \frac{1}{2}$ turns of a screw, at most, however, 2 to 5 ; the space between the individual turns is from 2 to $3 \mu$., the length of the spirilla being therefore 4 to $15 \mu$.; they move with lightning rapidity. It often occurs in dense masses in decoctions of plants.

Spirillum undula.-Threads 1.1 to $1.4 \mu$. in thickness, 8 to $12 \mu$. in length, turns wider, 4 to $5 \mu$. in height. Each thread has $1 \frac{1}{2}$ to 3 turns. Rapid simultaneously turning and shooting movements; a flagellum can be distinctly seen at each end in the form of a long, slightly arched, and powerful thread, becoming thinner towards its end.- It occurs in the most various kinds of putrefying fluids.

Spirillum volutans.-Threads, 1.5 to $2 \mu$. in thickness, 25 to $30 \mu$. in length, somewhat thinner and rounded at the ends, with thick, dark, granular contents. Each thread has $2 \frac{1}{2}$ to $3 \frac{1}{2}$ turns, the interval being thus from 9 to $13 \mu$. Sometimes motile, sometimes nonmotile; a distinct flagellum at each end.-It occurs in marsh water, and it has been foun $\mathcal{l}$ in a decoction of dead fresh-water snails. 
Spirillnm sanguineum (Ophidomonas sanguinea) (according to Zopf belongs to the Beggiatoa, see page 488). - Threads $3 \mu$. or more in thickness, with 2 to $2 \frac{1}{2}$ turns, 9 to $12 \mu$. in width. A flagellum at each end. The spirals, which have a reddish shimmer, present a dark granular appearance, owing to the presence of numerous highly refracting reddish granules. Found by Warming and Cohn in putrefying brackish water. In such water, which occurs in harvest in
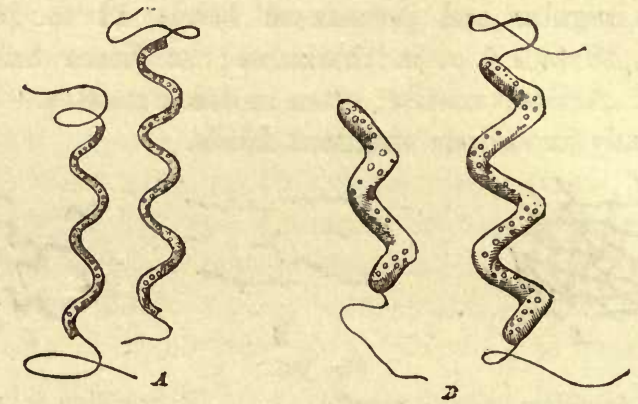

Fig. 134.-(After Cohn.)

$A$, Spirillum volutans $\times 650$.

$B$, Spirillum sanguineum (Ophidomonas sang.) $\times 600$.

many lakes on the Danish coast, and in which many algæ and salt water phanerogams decompose with the simultaneous appearance of red patches and masses, Warming found some other forms of spirilla, which as a rule contained granules of sulphur in their cell contents, and which he distinguished under the names Spirillum violaceum, Rosenbergii, attenuatum, \&c.*

Spirillum leucomelænum.-A form of rare occurrence (observed in water on the top of decomposing algæ), but which is noteworthy from the fact that alternate black and clear spaces occur in the spirillum, occasioned by the accumulation in the interior of the rod of dark granular substances at regular intervals. $\dagger$

\section{Fission Fungi with Variable Vegetative Forys.}

A considerable variation in form has been recently demonstrated by Zopf's investigations in the case of the

* Warming, Videnskabelige Meddedelser fra den naturhist. Forening $i$ Kjöbenhavn, 1875, p. 398.-Cohn, Beitrüge, vol. i., Part 3, S. 169.

+ Kooh, Mitth. a. d. Ges. Amt., i., p. 48. 


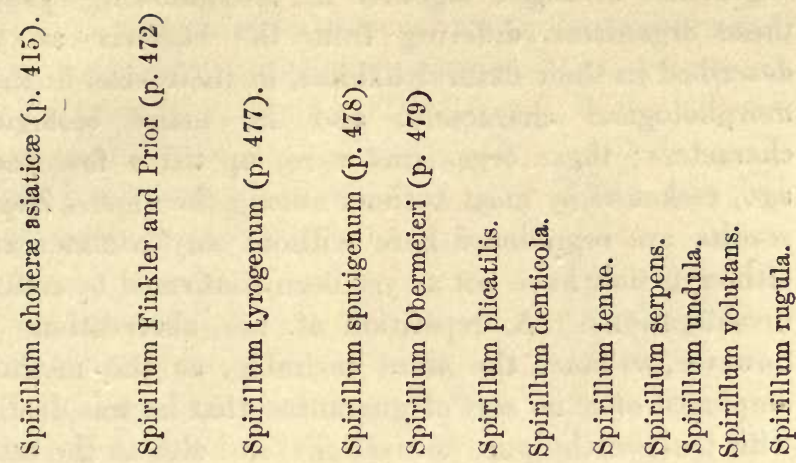

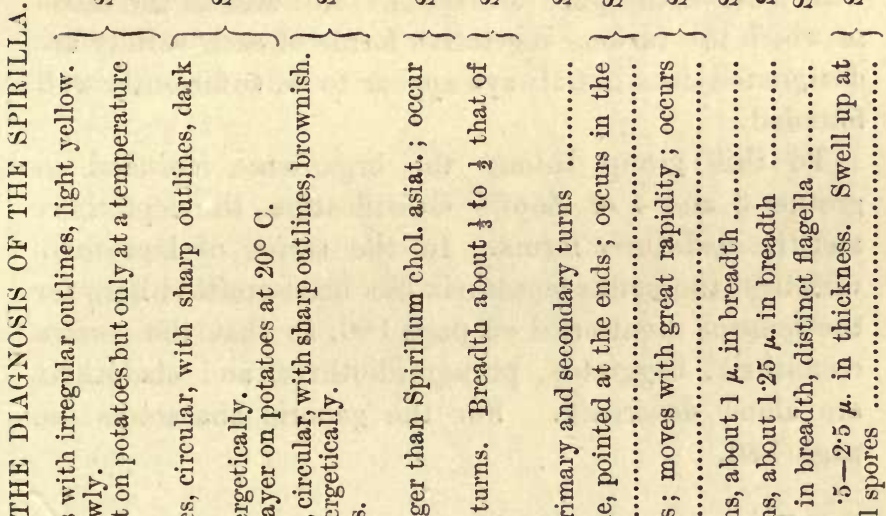

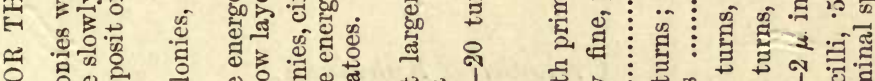
○ 과

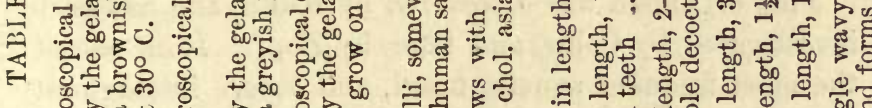

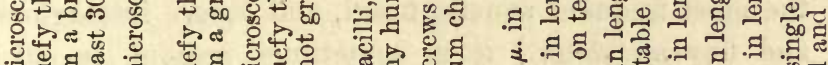

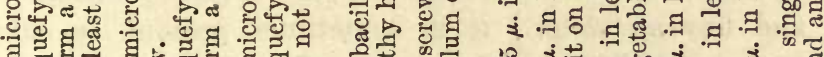

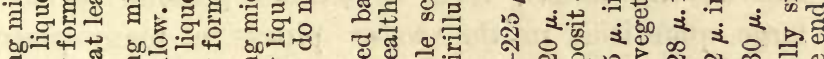

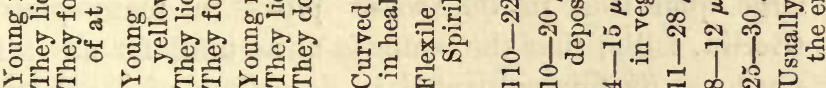

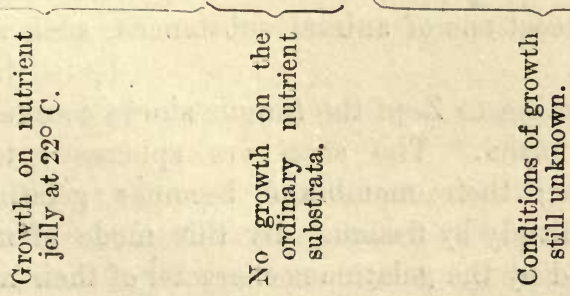


organisms arranged together in the following pages, these organisms differing from the bacteria as ret described in their natural habitat, in their size, in their morphological characters, and in many biological characters; these organisms were, up till a few years ago, reckoned by most authors among the algæ. Zopf's results are reproduced here without any commentary, although they have not as yet been confirmed by control investigations. A repetition of his observations is, however, so much the more desirable, as the methods employed offer no sort of guarantee that he was dealing with trustworthy pure cultivations, and also as the mode in which the various vegetative forms of each variety are designated does not always appear to be sufficiently well founded.

To this group belong the organisms included in groups 3 and 4 of Zopf's classification, the leptothrix and the cladothrix forms. In the series of leptothrix varieties, the genus leptothrix has been omitted here for the reasons mentioned on page 180 , so that the genera crenothrix, beggiatoa, phragmidiothrix, and cladothrix are alone described. For the generic characters see page 180 .

\section{Crenothrix Kühniana.}

Crenothrix. This organism was discovered by Kühn, and has been investigated by Cohn, and later by Zopf. It is one of the most frequent aquatic fungi, and occurs in stagnant and flowing water; it is sumetimes present in such large quantities in the water pipes in many places (Berlin, Lille) that the water is quite unfit for use. It can be artificially cultivated in decoctions of dead algæ, or in decoctions of animal substances, such as swine's bladder.

Morphological According to Zopf the fungus shows coccus, rod, and characters. thread forms. The cocci are spheres 1 to $6 \mu$. in diameter; their membrane becomes gelatinous, and they multiply by fission. By this mode of multiplication, and by the gelatinous character of their membrane, 
irregular masses of zooglæa of very various sizes are formed; these masses often form very large clumps, and may have a red, green, or brownish-black colour, from the deposit in them of oxide of iron. When cultivated in marsh water the cocci grow to form rods, which again form threads by continued fission, these threads projecting from the surface of the zooglæa mass in all directions. At a certain stage they show a distinct formation of sheaths, and the oxide of iron is often deposited in these sheaths. Within the sheaths the rods continue to divide transversely, and isodiametric pieces are formed which become rounded at the ends and then represent the cocci, which are, as a rule, fairly large (ma-

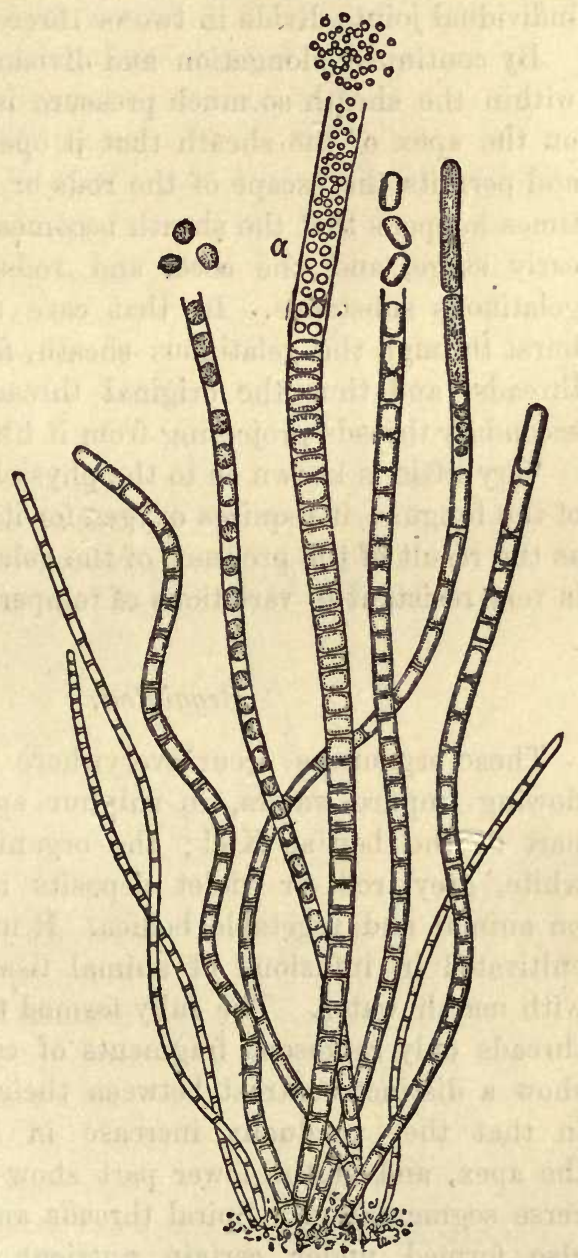

Fig. 135.-Crenothrix Kühniana $\times 600$.

Thread forms with eylindrical dises and (a) cocci. (After Zopf.) crococci). In the broad threads, however, the transverse division may go still further, so that the isodiametric portions are split up into quite small cylindrical 
plates. In the latter longitudinal divisions appear usually parallel to the axis of the thread, and thus each cylindrical plate becomes broken up into two or four small cocci. In these crenothrix threads, therefore, the individual joints divide in two or three planes.

By continued elongation and division of the segment within the sheath so much pressure is brought to bear on the apex of the sheath that it opens at that point and permits the escape of the rods or cocci. It sometimes happens that the sheath becomes gelatinous at an early stage, and the cocci and rods remain in this gelatinous substance. In that case they sprout and burst through the gelatinous sheath, forming rods and threads, and thus the original thread has numerous secondary threads projecting from it like a brush.

Biology.

Very little is known as to the physiological characters of the fungus ; it requires oxygen for its regetation, and, as the result of the presence of the gelatinous sheath, it is very resistant to variations of temperature.

\section{Beggiatoa.}

Boggiatoa.

These organisms occur everywhere in stagnant and flowing impure waters, in sulphur springs, and in a part of the bay at Kiel; the organism forms milkHabitat. white, grey, red, or violet deposits on the mud, or on animal and regetable bodies. It may be artificially cultivated in infusions of animal tissues, or of algæ, with marsh water. The fully formed threads (the free threads only represent fragments of complete threads) show a distinct contrast between their base and apex, in that they gradually increase in breadth towards the apex, and at the lower part show a distinct transverse segmentation. Spiral threads and fragments are also formed under certain nutrient conditions; the latter pass, under certain circumstances, into a swarm-

Presence of Sinlphur. ing stage. In the cells of beggiatoa sulphur is present in the form of highly refracting granules with dark outlines. The fungus is able to break up sulphur compounds, more especially sulphate of soda, and to cause 
the development of sulphuretted hydrogen; as a result, water in which these fungi are developing readily becomes uninhabitable by fish. The beggiatoa are but little sensitive to the influence of temperature, and they can develop luxuriantly even at $55^{\circ}$ C.Zopf distinguishes the following varieties:-

Beggiatoa alba.-This is the most widely distributed varicty. It occurs more especiallyin the waste water of sugar factories, of tanneries, and in sulphur wells (barégine or glairine). The threads grow on putrefying plants, dead insects, \&c.; they vary in thickness between 1 and $5 \mu$. Sulphur particles are not always present. On examining the threads, with or without the action of reagents, it can be seen that they are segmented into long or short rods or cocci. In the thicker threads a further subdivision of the cocei can be observed. Under certain conditions of nutrition the cocci pass into a swarming stage. After some time they again come to rest, and become attached to algæ, \&c., multiply by continued fission, and form irregular zooglæa. Under certain conclitions they grow and form rods which may likewise have a swarming stage; when these rods come to rest they grow to form threads. Further, the

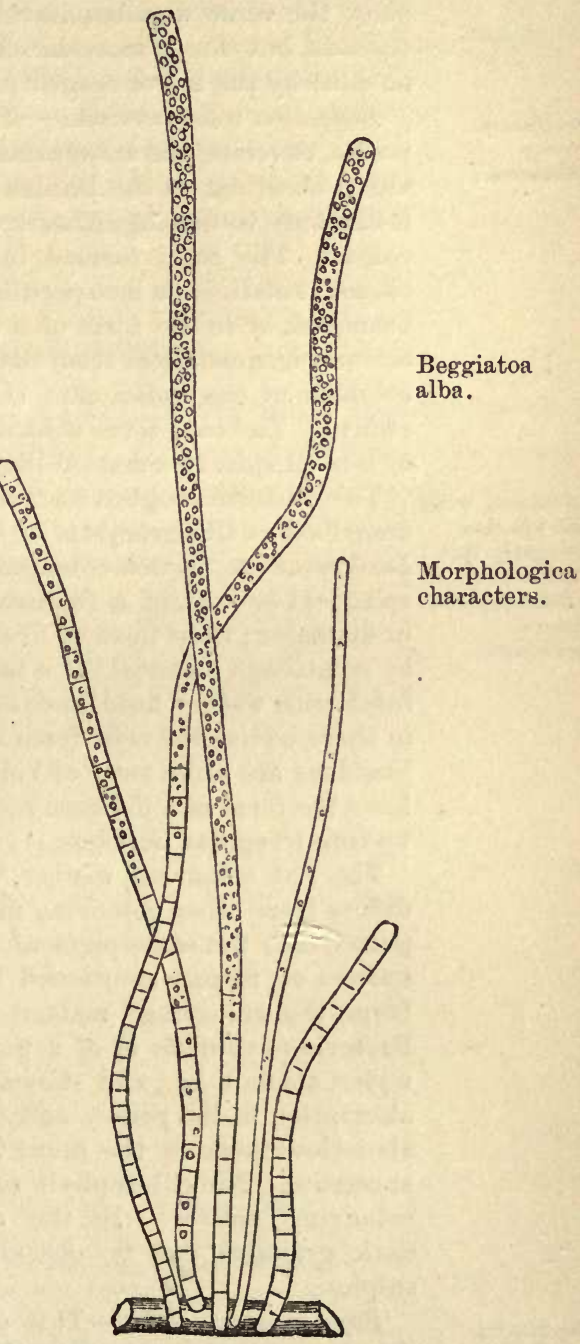

Fig. 136. - Beggiatoa alba $\times 540$.

Group of attached threads.

(After Zopf.)
Spiral th (Ophidomothreads may partially or wholly assume a spiral form, and the (Ophis). picces of the spiral which become free may, under certain conditions, swarm, their morement being caused by the presence 
of cilia at each end. These swarming spirals were formerly described as ophidomonas (see page 484). The spiral threads show the same division into rods and cocci as the straight threads, but this is more difficult to demonstrate, and can only be done by the aid of reagents.

Beggiatoa roseo-persicina.-Frequent in impure ditches and ponds, covering the substratum with a red or violet deposit. Often observed on the Danish sea-coast. In the thread stage it can only be distinguished from $\mathrm{B}$. alba by the reddish-violet colour. The cocci formed in the threads develop by continuous subdivision into peculiar zooglxa, which are lobulated, branched, or in the form of a network. Rods develop under certain circumstances from the cocci in these colonies, and after solution of the gelatinous sheath the rods and cocci can swarm. The rods form threads, and these may show a partial or a total spiral formation like B. alba.

Identical with the species formerly described as Clathrocystis roseopersicina.

Beggiatoa mirabilis.
The retiform zooglæa formation of B. persicina was formerly described as Clathrocystis or Cohnia roseo-persicina, and by Lankester as "peach-coloured bacterium."* The cells are spherical or oval, of a reddish colour, and as much as $2.5 \mu$. in diameter; they form at first solid families bound together by gelatinous material; at a later period hollow bodies appear, filled with watery fluid, and as much as $660 \mu$. in diameter; in these bodies the cells form a single peripheral layer. The bladders are often torn or riddled with holes, and then they have the form of a delicate network, which ultimately breaks up into irregular bunches.

The red colouring matter which is present in the cells differs from other colouring materials and is termed bacteriopurpurine; the same pigment is also contained in some of the species of monas mentioned below, but it is quite different from the colouring matter of micrococcus prodigiosus. Bacterio-purpurine is of a peach-red colour, is insoluble in water, alcohol, \&c., and shows under the spectroscope great absorption in the yellow and less in the green and blue, and also cloudiness in the more highly refracting half of the spectrum. No chlorophyll substratum is contained in the colouring matter. In the cells, especially in old cells, dark granules can be observed which consist of reguline sulphur.

Beggiatoa mirabilis.-This organism occurs in sea-water, forming whitish deposits on decomposing algæ, sea-weed, \&c. It is distinguished from the other beggiatoa by its large transverse diameter $-30 \mu$. The threads show segmentation, at first into almost isodiametric pieces, and then into short

* Rabenhorst-Winter, Lit., p. 1.-Cohn, Beiträge, i., Part 3, p. 157.Lankester, Quart. Journ. of Micr. Sc., 1873, vol. 13, p. 408. 
cylindrical plates. Its mode of derelopment is as yet other, wise unknown.

Phragmidiothrix multiseptata.

Found by Engler in the salt water of the bay at Kiel. 'The Phragmid threads are 3 to $6 \mu$. in thickness, and are subdivided by transverse divisions into very short cylinders; in these cylinders longitudinal division then occurs in two or more directions. From the minute coccus-like portions threads, at first very thin but constantly becoming broader, are formed.

\section{Cladothrix dichotoma.}

Very common in impure waters, in the waste waters Cladothri from manufacturing places, \&c. It may be artificially occurrenc cultivated in decoctions of decomposing algæ, mud,

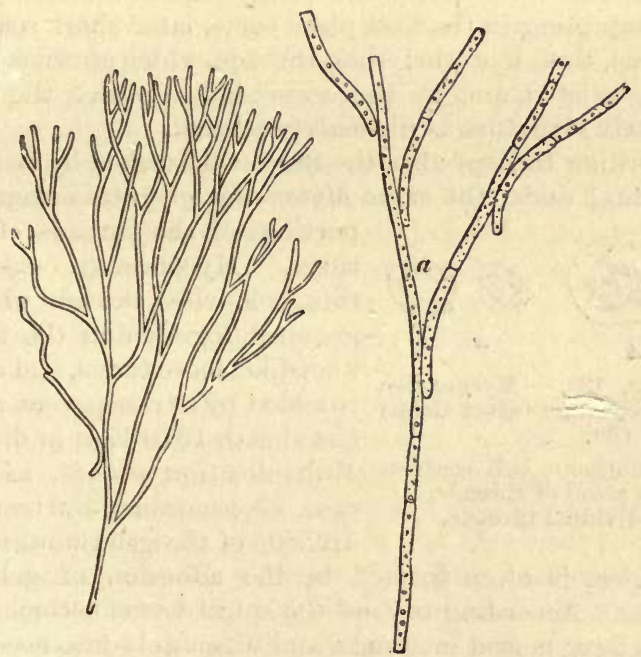

Fig. 137.-Cladothrix dichotoma. (After Cohn.)

Apparent dichotomons threads $\times 100$. At $a$ these are more highly magnified $(\times 600)$, and the false dichotomous divisions are distinctly seen.

flesh, \&c. It forms floating flakes and deposits on solid substrata 1 to $2 \mathrm{~mm}$. in height. The threads were ormerly described as a species of leptothrix; they form pseudo-branches, some of the rods bending to one side and elongating to form threads by continued subdivision. This system of branches often attains great ${ }_{\text {ing }}^{\text {False bran }}$ 
dimensions. The threads become segmented into long rods, later into short rods, and finally into cocci; but this structure is at times only visible after the employment of means which kill the organism. The segments of the threads as a rule pass out of the sheath; at times, however, the cocci grow to rods and threads in the interior of the sheath. Under certain conditions broken off portions of the branches are able to swarm, and show cilia. At times the fungus forms branches with regular spiral turns; from these also portions may be separated, and ultimately take on swarming movements. According to Billet,* spores are formed in the interior of the threads which compose the false branches.

oglæa migera.

yconostoc.

Zopf reckons the Zooglexa ramigerut to the cycle of development of the cladothrix; this is a zooglæa branched like a tree, containing in the first place cocci, later short rods, then long rods, then leptothrix-like threads, which at times become spirally twisted, and by the branching of which the typical cladothrix structure is ultimatcly formed.

According to Zopf also, the fungus described by Lankester and Cohn,+ under the name Myconostoc gregarium, represents

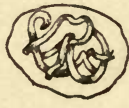

4.

Fig. 138. - Myconostoc gregarium (after Cohn) $\times 600$.

$A$, gelatinous ball containing a roll of threads.

$B$, individual threads. portions of the threads of cladothrix. Myconostoc consists of thin, colourless threads which are grouped together in the form of knot-like, loose turns, and are surrounded by a transparent gelatinous sheath 10 to $17 \mu$. in diameter. Multiplication occurs, as in the case of ascoccus, by transverse division of the gelatinous capsule. A zooglæa is often formed by the adhesion of gelatinous capsules. According to Zopf the spiral forms become broken up at a later period into rods, and ultimately into coccus-like fragments. As the result of the swelling of the jelly, the enclosed rods become more and more separated from each other, and ultimately escape from the jelly, and pass into a swarming condition.

ppendix oubtful arietics
In the case of the following lower organisms, which may be

* Billet, Compt. rend., vol. 100, p. 1251.

† Itzigsohn, Sitzungsber. der naturf. Ges., Berlin, 1867.-Koch, Cohn's Beilr., ii., Part 3, p. 414.

$\ddagger$ Cohn, Beitri.ge, i., Pa:t 3, p. 183. 
added here in the form of an appendix, their cycle of development is quite unknown, and it is doubtful whether they should be classed among the fission fungi.

Streptothrix Foersteri is the name given by Cohn to a thread- Streptoth like fungus which he found in the concretions in the tearducts of the human eye. This organism consists of fine colourless threads, usually straight, but also sometimes twisted, these threads showing at times, though seldom, distinct branching. The threads of leptothrix buccalis are thicker, straighter, stiffer, and unbranched, and thus differ from streptothrix. Nothing is as yet known as to the position and the mode of development of this organism.

Sphærotilus natans.-Cells 4 to $9 \mu$. in length, $3 \mu$. in thick- Sphærotil ness, roundish or elongated; they occur united in rows in large numbers in the interior of colourless gelatinous sheaths, forming long threads which appear as floating flakes, densely felted like a tress of hair. Multiplication occurs by isolated vegetative cells which develop new threads by continued subdivision. They reproduce themselves by means of spores which are formed endogenously in the vegetative cells. It occurs in stagnant and flowing water; the younger flakes are colourless, the older yellowish-brown; when spore formation is taking place they are sometimes milk-white in colour, and sometimes red.*

Spiromonas.-Cells flat like a leaf, twisted around an ideal Species of long axis. Multiplication by transverse division.

Spiromonas volubilis.-Colourless, transparent; rapid movements and rapid turning around the long axis ; length, 15 to $18 \mu$.

Spiromonas Colnnii.-Colourless cells very pointed at each end, with a flagellum, and with $1 \frac{1}{4}$ turns. Breadth of the cells $1 \cdot 2$ to $4 \mu$. It occurs in very putrid water. $\dagger$

In very foul watery fluids a number of minute organisms Red putr frequently develop in addition to the Clathrocystis roseopersicina described above, these organisms being also characterised by their reddish colour, and possibly belonging to the cycle of development of that fungus. They form red flakes on all sorts of detritus at the bottom of the water, but they swim at times on the surface; even in the most marked putrid condition of the water they do not die, but on the contrary apparently take part in the putrefactive process. They are grouped together under the general name of the "peachred putrefactive organisms." No chlorophyll substratum can be recognised in the colouring matter, and hence these organisms are more properly classed with the fission fungi

* After Rabenhorst-Winter, Lit., p. 1.

+ Beiträge z. Biol. d. Pfanzen, vol. i., Part 3. 
than with the lower monads, with which they have, however, certain morphological resemblances. Common to them are also the dark granules which are present in the pale red cell substance, and which probably consists of sulphur (compare Beggiatoa); and also their active movement caused by flagella. Cohn has distinguished the following varieties:*

Monas vinosa.-Spherical or oval cells about $2.5 \mu$. in diameter, often united in pairs. Cell substance pale red with dark granules. Active swarming movement; flagella not observed.

Monas Okenii.-Short cylindrical cells, $5 \mu$. in breadth, 8 to $15 \mu$. in length, rounded at the ends, slightly curved. Actively mobile; a flagellum at one end twice as long as the cell. Pale red cell substance with dark granules.

Rhabdomonas rosea. - Spindle-shaped cells 38 to $5 \mu$. in breadth, 20 to $30 \mu$. in length; slow trembling movement; a flagellum at one end. Very pale-coloured cell substance with dark granules.

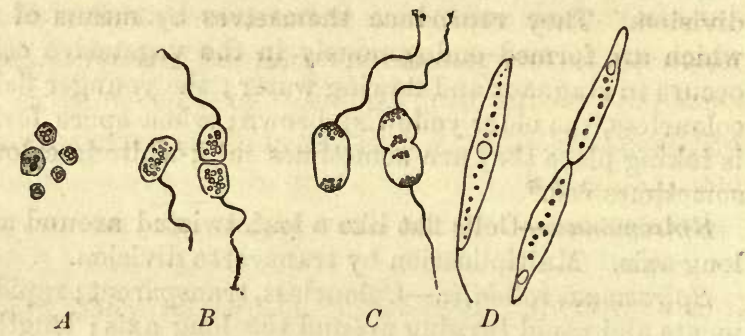

Fig. 139.-Monads. (After Cohn.)

$A$, Monas vinosa. $\quad B$, Monas Okenii.

$C$, Monas Warmingii. $\quad D$, Rhabdomonas rosea.

Monas Warmingii.-Similar to Monas Okenii, but nore robust; 15 to $10 \mu$. in length, $8 \mu$. in breadth; tumbling movements; a flagellum at one end. The pale red cell substance only contains dark red granules at each end; the ends are rounded.

* Beiträge z. Biol. d. Pflanzen, vol. i., Part 3. 


\section{PART III.}

\section{Biology of the Micro-organisms.}

Even at an early period, when elaborate experimental investigations on the subject of the vital peculiarities of the fungi were wanting, and when the attempt was made mainly by philosophical speculations to satisfy the already existing active interest in the significance and mode of life of the fermentative organisms, a definite and very important róle in the economy of nature was ascribed to the class of the fungi, and efforts were made to bring the vital phenomena of the fungi, in so far as they had been observed, into unison with this róle. These earlier views have latterly been confirmed in their essential points by recent investigations and experiments; but in certain details marked differences have been found.

The view as to the teleological function and signi- Former views ficance of the fungi rests chiefly on the absence of biological rechlorophyll; and this at once brings the fungi into lation between marked contrast with all other plants characterised by plants and the presence of chlorophyll. While the latter, including the algæ, which are so closely allied to the fungi, obtain the necessary carbon and nitrogen from the carbonic acid, ammonia, and nitric acid which surround them, and build up from these simple compounds with the aid of the chlorophyll, the complex nitrogenous and carbonaceous materials which they contain; and while these plants are consequently able to assimilate their nutrient materials from water, for example, which contains the necessary mineral substances, and from the air, which contains carbonic acid and ammonia; the fungi, on account of their want of chlorophyll, cannot live in the same manner, but require previously formed organic substances in order to replace the waste products, and 
to build up new tissue. Hence they cannot exist in pure water containing only mineral substances; they grow, on the contrary, only on dead organic matter, rich in carbon and nitrogen, especially on dead plants and animals; or they live as parasites, withdrawing from their vegetable or animal hosts the organic substances necessary for their life and growth.

Teleological rôle of the lower fungi.

From these facts we can at once understand the significance of the fungi in the economy of nature. In order to supply the necessary simple nutrient materials to the chlorophyllous plants, it is essential that the substance of dead plants should be continually broken up and reduced to these simple compounds.

The whole of the vegetation, which is yearly produced and again dies, must be so altered in a relatively short time that water, carbonic acid, and ammonia may be again formed from albumen, carbo-hydrates, cellulose, \&c.; and it is only under these circumstances that a constant and increasing renewal of vegetation is conceivable.

A portion of this destructive work is performed by the animal organism; the animal cells split up the vegetable materials which have been taken in, and prepares them for oxidation. The energy which had become stored up in the complex chemical compounds of the plant, from the conversion of the energy of the light rays into a chemical energy by the aid of the chlorophyll, is used up by the animal organism, and employed for the production of heat, and for the various functions of the body. This consumption of regetable materials by animals is, however, by no means sufficient to equalise the production of regetable substances and to keep the amount of the simple nutrient materials of plants at such a level as to suffice for the constant nutrition and growth of new regetation. It is evident that some other factor must come into play in the economy of nature by which a much more extensive destruction of dead regetable substances and a much greater formation of carbonic acid and ammonia is brought about than by the vital processes of animals; and this necessity has become 
more apparent since we have learned that a scarcely noticeable oxidation occurs when organic materials and the oxygen of the air are simply in contact with each other at the ordinary temperature, and that on the contrary it is the living cells which furnish the necessary conditions for a rapid destruction and oxidation of organic materials. Further, it must be pointed out that the substance of the dead animal body must also be exposed to destructive influences in the same manner as dead regetable materials; for we also see in the case of animal organic materials that the atmospheric oxygen alone is relatively powerless to convert these compounds into carbonic acid, ammonia, and water.

This dangerous gap in the constant process of re- The fungi generation in nature is made good by the action of the lower fungi. They form the necessary factor which renders a rapid destruction and oxidation of dead organic materials, whether of animal or vegetable origin, possible, for the hights.

and which reproduce the simple carbon and nitrogen compounds which are necessary for the nutrition of living and growing plants. The fungi are able to perform this rôle because they do not, like the chlorophyllous plants, utilise the energy of the sun, nor obtain their nutriment from carbonic acid and ammonia, but, like animals, feed on the complex chemical compounds, and utilise the energy so liberated for the performance of their functions. They are the better able to do this on account of the wide limits within which their external conditions of existence can vary without injury; also on account of their extraordinarily rapid multiplication, for which they use up a considerable amount of nutrient materials in a short time; and further, because under such circumstances they only utilise a relatively small proportion of the nutrient materials for their own growth, while a much larger proportion is decomposed by their peculiar fermentative actions, and thus prepared for further oxidation. Lastly, it is as it were only a slight alteration of their function when they at times settle as parasites on living plants and animals, and lead to their destruction by breaking up rery rapidly the organic con- 
Pasteur's investigations as to the nutritive requirements of the fangi.

stituents of their host and converting them into simple chemical compounds.

In correspondence with this view of the function and the significance of the fungi, we must look for their most important physiological peculiarities in the fact that they obtain their nutriment from complex organic substances, and are unable to assimilate the carbon and nitrogen from carbonic acid and ammonia. This characteristic therefore formed the basis of former investigations.

Pasteur was the first who made exact experimental investigations as to the biology of the fungi ; these experiments led to results which differed in many respects from the views which had been held up till that time. Pasteur showed more especially that yeast and mould fungi were in so far able to live in a similar manner to the higher plants in that they could assimilate the nitrogen from ammoniacal salts, and even from nitrates, and thus, like the chlorophyllous plants, could build up the complex albuminous materials of their body from simple substances. It was also found that different fungi showed great differences in their conditions of life ; that one required oxygen and led to rapid oxidation, that another could live without oxygen, and then often caused extensive though superficial decomposition of the nutrient material ; that only certain fungi could tolerate an acid reaction and great concentration of the nutrient medium ; that different organisms grew most luxuriantly at very different temperatures; that one preferred this, and the other that kind of nutrient material, and that they were not all equally capable of utilising the nitrogen of ammonia, or of nitric acid; that, lastly, even one and the same organism behaved very differently as regards their tissue change and energy under varying external conditions.

Fungi do not necessarily require complex organic nutritive materials.
It is true that the former views as to the significance of the fungi in nature were not completely upset by these results of experimental investigation. For it was still certain that all the lower fungi were able to live on complex chemical materials - that, in fact, these materials 
were preferred as nutrient substances, and that therefore the destruction of dead organic substances was chiefly caused by fungi; further, that carbonic acid could not in any way be utilised either for assimilation or for growth. But the physiological characters by means of which they were able to play their peculiar rôle no longer appeared to be so simple, and could no longer be defined in a few words, but were made up of a number of processes which required separate consideration, and which varied markedly according to the species of the fungus and the external conditions which surrounded it. Hence we can no longer content ourselves with a general formula if we would obtain an insight into the vital manifestations of the fungi; but we must proceed by the inductive method, and seek to understand the life of the lower organisms from a large number of individual observations and experiments. In this place we must therefore enter into a minute and detailed discussion as to the biology of the fungi, and we must do this the more thoroughly because this side of mycological investigation is of very great importance for hygiene.

The various biological phenomena which we observe in the fungi can be subjected to experimental study in the same manner as the vital phenomena of more complex living beings, e.g., of animals or of the higher plants. If we take the latter as our basis, we must proceed from the more complex to the simpler, but it is probable that many biological problems which have proved insoluble in the case of the more complex organisms, in spite of very numerous investigations, will be much more readily solved in these simple beings, and that thus at a later period the biology of the fungi will throw light on the biology of higher plants, more especially when we employ the methods of investigation which have been found good in the case of the former.

If we wish to study the tissue change of any of the more complex organisms we generally attempt in the first place, by a number of variations in our experiments 
on nutrition and tissue change, to determine the kind and quantity of material which is taken up by them, and to ascertain the normal relation of the other external conditions which are necessary for the regular progress of life; further, we investigate the fate of the materials taken up, and how they are used in the body, also the excretory products, and finally the functions of the organs; and we are thus in a position to form an approximate idea as to the alterations of the tissue and of the energy which form the basis of the life of that organism.

We must study the biology of the lower fungi in a similar manner. In the case of these also we must in the first place ascertain experimentally the necessary conditions of life; we must learn what solid nutrient materials must be supplied to the fungi, what rôle is played by oxygen, and whether temperature, atmospheric pressure, light, \&c., exercise any noticeable influence on the growth and the multiplication of the fungi. Where multiplication occurs by means of spores, we must ascertain what are the conditions necessary for this act, and also on what external circumstances the germination of these spores depends.

In the second place, it is necessary to study the results of the life of the lower fungi. Among these we learn, in the first place, the assimilation of the nutrient materials, the tissue change in the cells, and at the same time the various manifestations of energy - for example, growth, multiplication, and fructification; further, we find that the fungi excrete various products of tissue change which are of special interest; and finally, that they exert under certain circumstances two peculiar actions which require more minute study, viz., fermentative action and the production of disease.

The study of the conditions of life also implies a discussion of the influences which are hurtful and destructive to life. It is, however, advisable to consider the phenomena of involution and of the death of the lower fungi in a separate chapter, as well as the description of those means by which we can interfere with the growth or life 
of the fungi. These means are identical with the disinfecting agents which have recently become of so much importance.

Finally, the investigations as to the biology of the lower fungi must not be limited to the individual; the behaviour of a continued series of individuals must be taken into consideration. More especially we must direct our attention to the occurrence of modifications-to the formation of varieties, races, and species.

The discussions in the following pages are limited to those fungi which are of importance from a hygienic point of view (mould fungi, yeast fungi, and fission fungi); with regard to the other fungi and microorganisms which were mentioned in studying the morphological characters, we must refer to de Bary's excellent description of the morphology and biology of the fungi.

\section{Conditions of Life of the Lower Fungi.}

In order to understand the nutritive processes, it is in Conditions of the first place necessary to take a short survey of the chemical composition of the fungi. We must then ascertain the importance of the individual nutrient materials, in the first place of the nitrogen, and then of the carbon, hydrogen, and combined oxygen, of the mineral substances, of the water, and, finally, of the free oxygen. Special attention must also be paid to the concentration and reaction of the nutrient mixture. Of less importance is the influence of atmospheric pressure, light, electricity, and mechanical movement; while the action of various temperatures, the fermentative action, and the concurrent growth with other fungi are of very great importance in the development and growth of the individual micro-organisms.

In almost all these points the mould fungi, yeast fungi, and fission fungi show such differences that each must be separately studied. 
(a) Mould fungichemical constitution.

(a) Conditions of Life of the Mould Fungi.

1. Chemical Composition of the Mould Fungi.-Until recently wo had no complete analysis of the mould fungi; nevertheless it was assumed that their composition was similar to that of the higher fungi. In the case of the latter, the following numbers represent the average result of various analyses:-

88 per cent. water, 3 per cent. nitrogenous and 5 per cent. non-nitrogenous organic materials, 1 per cent. ashes; when dried in the air-17 per cent. water, 25 per cent. nitrogenous and 45 per cent. non-nitrogenous substances, 8 per cent. ashes.

Sieber* has recently made some analyses of the mould fungi, but, as it appears, without sufficient precautions as to the purity of the materials used. The following was the result-(1) of a cultivation of penicillium and mucor in a nutrient solution of gelatine and sugar:-

Soluble in Ether..... 18.7 per cent. of the dry substance.

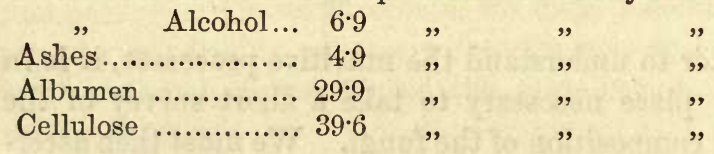

(2) Of a cultivation in a saccharine ammoniacal solution, consisting mainly of Aspergillus glaucus:-

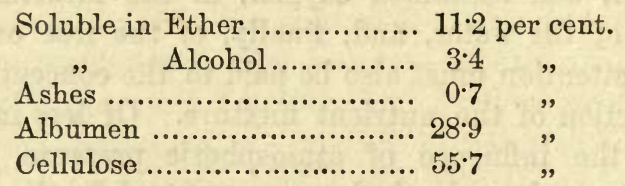

As compared with the analysis of the yeast and fission fungi (as given below), the marked excess of non-nitrogenous substances is specially noticeable; this in the main depends on the fact that in the case of the mould fungi a large amount of cellulose is present, and that it is only in the contents of the cells that albuminous substances exist; and also on the fact that soluble saccharine matters are present in recognisable quantity.

* Journ.f. prakt. Chemie (2), 23. 412. 
The mineral constituents in the case of the higher fungi have the following average composition:-

50 per cent. potash, 1.5 per cent. soda, 1 per cent. lime, 2 per cent. magnesia, 1 per cent. oxide of iron, 30 per cent. phosphoric acid, small quantities of silicic acid and hydrochloric acid, and very varying quantities of sulphuric acid.

According to this analysis, potash and phosphoric acid seem to be of most importance.

Stutzer* has found that mould fungi washed in water, and dried over sulphuric acid, showed a total of 3.776 per cent. of nitrogenous materials, consisting of 3.026 per cent. of proteids, and 1.539 per cent. of nuclein.

2. The Nutrient Materials of the Mould Fungi.-Cor- Nutrient responding to the chemical composition, a large amount of water is necessary for building up and maintaining the constituents of the mould fungi; also organic substances containing carbon and nitrogen, and of the mineral constituents, chiefly potash and phosphoric acid. The chemical compounds which these nutrient materials furnish, and the relative amount in which the latter must be present, can however only be ascertained by special experiments.

A series of experiments in this direction were formerly Raulin's made by Pasteur, and have been carried out in a very thorough experiments. manner by Raulin, $\uparrow$ who proceeded as follows :- He cultirated Aspergillus niger in a nutrient solution which, as the result of numerous experiments, he had reason to believe was particularly suitable for the nourishment of the fungus, and which may be regarded as the normal solution. It was composed of-

1500 grms. of water.

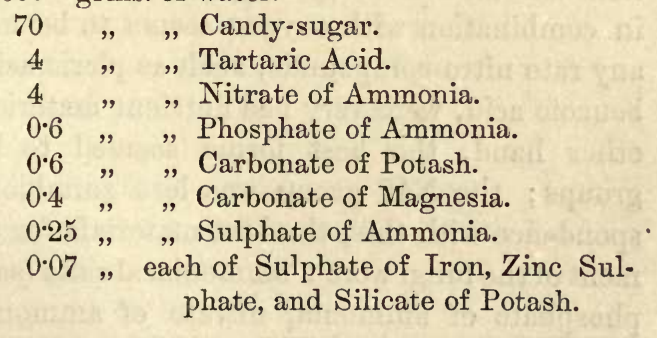


If Raulin sowed spores of Aspergillus niger in this fluid, which was kept at a temperature of about $35^{\circ} \mathrm{C}$. in shallow covered vessels in a layer 2 to $3 \mathrm{ctm}$. in depth, a fructifying mycelium was formed after three days; this was removed, and from the remaining fluid a new crop was obtained after three days more. After the removal of this second crop the nutrient materials of the fluid seemed to be almost entirely exhausted. The weight of the total growth when dry was determined, and was found to amount to about 25 grms. This result was compared with that obtained when one or other of the constituents of the normal nutrient solution was omitted. Raulin found that the absence of phosphoric acid had the greatest influence, the resulting growth being reduced to $\frac{1}{200}$ part of the normal ; that the absence of ammonia diminished the growth to $\frac{1}{150}$; and of potash to $\frac{1}{25}$. No constituent of Raulin's fluid could be omitted without harm; even the omission of the zinc had a marked influence on the result.

Nägeli's experiments.

Substances suitable for supplying the necessary nitrogen.
More complete experiments of a similar character have recently been made by Nägeli. He showed that there were certain sources of error in the former experiments; that, for example, sufficient care had not been taken to secure pure cultivations and to exclude all other organisms ; that, further, the access of air, the reaction, the most favourable concentration of each of the nutrient materials (the so-called "optimum of concentration"), and, finally, the alteration of the nutrient solution by the growth of the fungus itself, were not sufficiently taken into account. Nägeli's* numerous and exact experiments led to the following results :-

The necessary nitrogen cannot be obtained from free nitrogen, nor from the nitrogen which is in combination with carbon in cyanogen; in like manner nitrogen in combination with oxygen seems to be unsuitable, at any rate nitro-compounds, such as picric acid and nitrobenzoic acid, were very bad nutrient materials. On the other hand, the best forms seemed to be the $\mathrm{NH}_{2}$ groups; the $\mathrm{NH}$ group was less suitable. In correspondence with this, the best materials for the nourishment of the fungi were : ammoniacal salts (sal ammoniac, phosphate of ammonia, nitrate of ammonia; acetate, oxalate, succinate, and tartrate of ammonia, \&c.); also

* Nägeli, Untersuchungen üßer niedere Pilze, Munich, 1882. 
hydrochlorate of methylamine and æthylamine, trimethylamine; leucine, asparagine; acetamide, oxamide; and urea. The best nitrogenous nutrient materials were the soluble albuminates and peptone. Nitrogen can also be assimilated by the mould fungi from nitrates; probably in this case there is a gradual reduction of the nitric acid to nitrous acid, and ultimately to ammonia; but these reduction products have not yet been demonstrated. In comparative experiments no marked difference was found between the nutrient value of the nitrates and the salts of ammonia; urea was better than either, and peptone was better than urea.

The necessary carbon can be obtained from the For the supply groups $\mathrm{CH}_{3}$ or $\mathrm{CH}_{2}$, and in that case it is of advantage, and under certain circumstances necessary, that several carbon atoms should be united in one molecule. No carbon can be assimilated if in any given chemical combination there is only a union of carbon with nitrogen, oxygen, or carbon. Hence the following substances are not suitable for yielding carbon : carbonic acid, cyanogen, formic acid, urea, oxalic acid, and oxamide. Of course, also, those combinations which are not soluble in water are unsuitable as food, such as the higher fatty acids and the insoluble humine substances. Apart from the number of the carbon atoms, the ease with which the compounds can be decomposed seems to be of importance; the more readily the compound can be broken up by other agents, such as by oxidising substances, the more easily can it be assimilated. Nägeli has formed the following empirical table of the nutrient value of various organic compounds with regard to carbon: 1. Various kinds of sugar. 2. Mannite, glycerine; the carbon group in leucine. 3. Tartaric acid ; citric acid ; succinic acid; the carbon group in asparagine. 4. Acetic acid; æthylic alcohol; quinic acid. 5. Benzoic acid; salicylic acid; the carbon group in propylamine. 6 . The carbon group in methylamine; phenol. Pyrogallic acid and tannic acid were also fairly good sources of carbon; and finally we may mention the observa- 
Nutritive value of the combined carbon and nitrogen sources.
Supply of hydrogen, oxygen, and sulphur.

tion made by Pasteur in 1858, that racemic acid, which is a combination of two forms of tartaric acid, the one rotating to the right, and the other to the left, was able to nourish the mould fungi, in the form of racimate of ammonia, but that it was only the form which rotated to the right which is taken up by the fungi, while the other is left in the nutrient fluid.

It is very difficult to compare the nutrient value of the various sources of carbon, because they evidently vary in their action in accordance with variations in the sources of nitrogen; and again, if we take care that the nitrogenous materials are the same it becomes a question whether they may not be assimilated in another way when the carbon sources are different. Hence we would apparently obtain a more exact mode of comparison if we combined the sources of carbon and nitrogen, and then subjected some of these combinations to comparative experiments. In this way Nägeli has constructed the following scale, proceeding from the best to the worst nutritive materials: 1 . Albumen (peptone) and sugar. 2. Leucine and sugar. 3. Tartrate of ammonia, or sal ammoniac and sugar. 4. Albumen (peptone). 5. Leucine. 6. Tartrate of ammonia; succinate of ammonia ; asparagine. 7. Acetate of ammonia.

Thus albuminous materials, and those belonging to the group of carbo-hydrates, seem to be the normal nutritive sources of the mould fungi, and it is chiefly these materials on which they feed under normal circumstances. But, on the other hand, it is noteworthy how widely the nutrient materials may vary, the fungi subsisting with ease on very different chemical substances, and also how the mould fungi seem to be able to maintain their existence as the result of their ability to obtain nutriment from the most different sorts of chemical substances.

The supply of hydrogen and of combined oxygen is partly provided for by the above-mentioned carbon and nitrogen compounds, and partly by water and free oxygen.-Sulphur also takes part in the composition of the organic constituents of the mould fungi, and is 
probably contained in all true albuminous materials. According to Nägeli's experiments, it can be taken from the albuminates, and as well, or better, from sulphates, sulphites, or hyposulphites; sulpho-acids may also act as substitutes, but not sulpho-urea compounds or the sulpho-cyanides. Exact experiments, however, as to the supply of sulphur are very difficult to carry out, because the small quantities necessary for suitable nourishment commonly adhere as impurities to the other nutrient materials, as for example, to the sugar.

Water and mineral substances are of great importance Supply of for the nourishment of the mould fungi. A large quantity of water is necessary for the nutriment of the mould fungi; in part it enters into the complex substances which are built up by the fungi, in part it forms the chief constituent of the newly formed tissue of the fungus, and in part it acts as a dissolving and transporting medium, and thus enables the materials to move in the cell, just as in the case of the higher organisms. It is of special interest, as regards the necessity for water, to ascertain the smallest quantity necessary for the mould fungi to obtain sufficient nourishment. As regards this question we shall enter into further details when considering the subject of nutrient materials with reference to their concentration.-According to Nägeli's more recent researches, Need of a relatively small quantity of mineral substances are $\frac{\text { mineral }}{\text { substances. }}$ necessary. While the chlorophyllous plants require, besides phosphoric acid, sulphuric acid, and alkalies, also calcium and magnesium, and in addition iron, silicic acid, and chlorine, the mould fungi are satisfied with sulphuric acid, phosphoric acid, potash, and calcium or magnesia. The potash, however, cannot be replaced by sodium, although it may by cæsium and rubidium. In the place of calcium we may have, besides magnesium, also barium or strontium. One element from the group of the alkalies, and one from the alkaline earths, must, however, always be present; each of these representatives of the two groups appear to have different functions, which are probably the following: the earthy com- 
pounds in part in the form of earthy phosphates, only form deposits in plasma and in the cell membrane, while the alkaline salts are chiefly present in solution in the free fluid of the cell in the form of primary and secondary phosphates of potash $\left(\mathrm{KH}_{2} \mathrm{PO}_{4}\right.$ and $\mathrm{K}_{2} \mathrm{H} \mathrm{P} \mathrm{O}$, the first having an acid, and the second an alkaline reaction).

Free oxygen. In addition to the solid and fluid nutrient materials which have been already mentioned, the mould fungi require for their normal development and growth the presence of free, gaseous oxygen. Pasteur found that like the higher plants, the mould fungi (penicillium) take oxygen from the surrounding atmosphere. The need of the mould fungi for oxygen is also shown by the places in which they occur; they are limited to those situations which are in immediate contact with free oxygen. Hence they grow only on the surface of fluids (in like manner on the external surface of animal or human bodies, in the air-passages, \&c.), and then only in so far as they can obtain the oxygen dissolved in the fluids. The quantity of oxygen necessary is, however, small ; and, according to Brefeld, the mould fungi which do not cause fermentation will grow when placed in an atmosphere of carbonic acid, unless it contains less than 500 of its volume of air.

Behaviour when oxygen is absent.
If the mould fungi are immersed in fluids free from oxygen their normal growth ceases; and some fungi (such as mucor) can only form yeast-like buds, and in this way, according to Brefeld, provide for the maintenance of the species. Under these circumstances, however, the yeast-like cells set up fermentation, with plentiful development of carbonic acid and the stream of bubbles of carbonic acid again brings the elements of the fungi to the surface where they are able to grow and Growth in the fructify in a normal manner.-The growth of the mould animal body.

fungi in the animal body apparently forms an exception to the above rules. It has been recently proved, as a result of numerous experiments, that the spores of aspergillus and mucor can sprout in the lidneys and in the internal organs of the living body, and grow to form a mycelium. As yet however, only a limited formation of mycelium has been 
obtained under these circumstances, and the production of fruit-bearing mycelium and spores has never been observed; hence the relation of the fungi to oxygen may be stated by saying that normal growth with fructification can only occur in an atmosphere containing free oxygen, while on the other hand, only a formation of mycelium occurs where (as in many animal bodies) there is no free oxygen at their disposal. This view corresponds also on the whole with the facts as to the occurrence of the parasitic mould fungi in the lower animals; the pathogenic species of empusa, cordyceps, botrytis, and isaria form in the bodies of the caterpillars and insects which they attack well-developed mycelium, and ultimately the so-called cylindrical gonidia; true fructification, however, only takes place by means of fruit-bearing hyphæ, which have burst through the surface and come in contact with the air.

Thus far we have discussed the question of the quality Quantity of of the nutrient materials which are required by the mould the nutrien fungi. In addition to the quality we must now allude to their quantity. It is evident that either too small or too large a quantity of any of the nutrient materials will have an unfavourable effect, and that there must be an optimum of quantity as regards each individual component at which nutrition goes on best; this optimum, however, will depend on the general composition of the nutrient mixture, and will vary according to the amount of the other substances which are present at the same time. On this subject very little is as yet known, and only as regards two points are the experiments sufficiently numerous and precise to admit of their discussion at the present time-namely, in the first place, the amount of water which is necessary for a suitable nutritive mixture, or, in other words, the concentration of the mixture; and, in the second place, the quantity of free alkali or free acid, i.e., the reaction of the nutrient mixture.

As regards the concentration or the amount of water Limits within in the nutriment, it may vary very considerably without which the completely preventing the growth of the mould fungi; the water may mould fungi are in this respect much less sensitive than 
the yeast or the fission fungi. Some mould fungi can grow in extremely dilute nutrient mixtures which only contain traces of the necessary nutrient materials. (This has been especially observed with regard to penicillium.) While, however, in this respect the vital activity of the yeast and fission fungi is almost the same, the mould fungi, on the other hand, have the advantage when we come to deal with a small amount of water and marked concentration of the material. Under such circumstances they are by no means sensitive; nutrient mixtures from which a great part of the water has been removed by evaporation, or by the addition of salt or sugar, and which have therefore become unsuitable for the nutrition both of the budding and fission fungi, will still be available for the growth of various mould fungi. We have not yet gained exact information regarding the upper and lower limits of the amount of water, and such information is very difficult to obtain, because the quantity varies according to the other constituents of the nutrient medium, and according to the varying species of the mould fungi. In preserving articles of food, we have learnt by experience that salted or smolied meat, for example, which contains 50 per cent. of water, is no longer a suitable soil for fission fungi, but it may, nevertheless, become mouldy; in order to prevent the formation of mould, the amount of water must be reduced to only 10 to 12 per cent.; if, however, sugar is present at the same time in large quantities, mould formation is prevented, even with as much as 30 per cent. of water.-These numbers indicate the lowest limit as regards the amount of water; the optimum is much higher, perhaps 80 per cent., so far as the dependence of the optimum on the quantity of the other nutrient materials permits us to give definite numbers.-All the mould fungi, however, are not in like manner indifferent with regard to great concentration of the material on which they grow. Certain fungi appear to be much more sensitive, especially some which lead a parasitic life, and which only occur in moist seasons and in moist localities. 
The reaction of the nutrient mixture has a most im- Influence of portant influence on the growth of the mould fungi. the reaction They seem to be most sensitive to an excess of alkali, material. although some forms occur on substrata which have a marked alkaline reaction; an excess of acid is not nearly so hurtful. Free tartaric acid may be present in the nutrient mixture up to 5 per cent., and free phosphoric acid up to 1 per cent., or more, without preventing the development of mould fungi. This point is of great importance, because in this respect, also, there is a difference between the mould fungi and the majority of the fission fungi, which are very sensitive to excess of acid, and because by the reaction of the nutrient material alone the linds of fungi which obtain the mastery when growing together can be influenced.-But on this point also we can give no definite figures which take into account the differences in the nutrient solution, and the specific properties of the various forms of fungi.

As has been mentioned, there must be a most favourable proportion for all the other nutrient materials, and increase or diminution of the quantity will exercise an unfavourable action. Further, any admixture of foreign materials which are not nutritious must render the nutrient mixture to a certain extent unsuitable, even when such materials are not poisonous for the fungi, and do not hinder their growth even when present in great concentration. Finally, poisonous materials which have a specific noxious action on the growth of the mould fungi may be present in the nutrient substratum or in the surrounding air. The action of these substances will be discussed in the chapter on "Disinfection."

At times the mould fungi can convert insoluble mate- Fermentative rials into soluble, substances which can be absorbed, action of the and this is done by the formation of suitable ferments. For instance, in the case of penicillium and aspergillus niger, the production of a ferment which inverts cane-sugar and maltose* has been demonstrated, and Van Tieghem showed that penicillium and aspergillus niger were able to split up tannin into gallic acid and glucose; the

* Bourquelot, Compt. rend., vol. 97, p. 1322. 
Influence of external factors.

solution of cellulose, also, has been frequently noticed as a result of the penetration of mould fungi into the tissues of plants, and is only explicable by the agency of ferments.

The parasitic existence of the mould fungi, in which they take the necessary nutrient materials from the host on which they grow, will be considered at greater length further on.

3. Other Conditions of Life of the Mould Fungi.Increased and diminished atmospheric pressure, light and electricity, have not yet been exhaustively studied as regards their influence on the growth of the mould fungi; in so far as existing observations enable us to draw conclusions on this subject, they appear to have no marked effect. Nothing is known as regards either a disturbing or farourable influence of novement of the nutrient mixture; and with regard to a favourable or inhibitory action of fermentation on the growth of the mould fungi there can be no question whatever, for with the aborementioned exceptions they do not cause fermentation. There remain, however, some conditions of life which may influence the growth of the fungi, more especially temperature, and concurrent growth with other fungi.

Temperature. Temperature only requires consideration in so far as it varies within medium limits. The extremes of cold or heat will be considered among those conditions which may cause the death of the fungi. In the case of those temperatures which come into play under normal conditions, the same points are of importance as were mentioned with regard to the concentration of the nutrient materials. In the case of the mould fungi there exists an optimum of temperature at which they grow most quickly and flourish best; but this optimum differs according to the species of fungus, and also according to the other conditions of life and nutriment, in any given case. The optimum for penicillium is quite different from that for aspergillus, and they both differ from that of mucor. Penicillium glaucum appears to grow best at a temperature of about $20^{\circ} \mathrm{C}$.; it grows 
also, however, at relatively low temperatures (at $+2 \cdot 5^{\circ}$ C.), which are but little above the freezing point; as the temperature rises, so does the energy of their growth increase, till the optimum is reached; it then again diminishes and ceases entirely at about $43^{\circ} \mathrm{C}$.

In the case of Aspergillus glaucus the optimum of temperature lies between $10^{\circ}$ and $12^{\circ} \mathrm{C}$.; of Aspergillus flavus about $28^{\circ} \mathrm{C}$.; of Aspergillus niger from $34^{\circ}$ to $35^{\circ} \mathrm{C}$.; of Aspergillus fumigatus between $37^{\circ}$ and $40^{\circ}$ C. (Siebenmann); of Oidium lactis between $19^{\circ}$ and $30^{\circ}$ C., \&c.-From these figures we may draw the important conclusion, as regards the spread and the artificial cultivation of the mould fungi, that the temperature must often determine what species develops and obtains the mastery in any given nutrient material.

The simultaneous occurrence of other kinds of fungi Concurrence in the same colution exerts a with other in the same solution exerts a very important influence fungi. on the growth of a cultivation of mould fungi. While it is easy to obtain a luxuriant growth of the mould fungi in solutions in which they alone have been sown, and which are protected against the entrance of other organisms, there may be no growth of mould fungi in such a solution if bacteria have entered at the same time, and if the nutrient solution in question permits the latter organisms to multiply most rapidly. Under these circumstances, those conditions of life which differ in the case of the mould fungi, the budding fungi, and the fission fungi are of special importance; of these conditions the chief are the concentration and reaction of the nutrient material. In a mixture which contains only a small quantity of water, and which has a marked acid reaction, but few kinds of fission fungi can develop; where, therefore, these conditions are present, the soil belongs exclusively to the mould fungi and the yeast fungi. Thus, the mould fungi can obtain the mastery in a soil where, if it were less acid and contained more water, the fission fungi would certainly gain the upper hand, because they could assimilate the nutrient materials more energetically and take them away from the mould fungi. This concurrence between 
different classes of fungi is important, and must be noted under various other circumstances. A similar concurrence naturally occurs also among the species of one and the same class; in that case, however, other factors come into play, and lead to one or other species gaining the upper hand. Temperature has a very marked influence; if, for example, we employ a nutrient medium at $15^{\circ} \mathrm{C}$., in which the spores of Aspergillus fumigatus and of penicillium have been sown, only the latter fungi will develop well, and they will grow to such an extent that growth of the aspergilli cannot occur, although this would have taken place had there been no penicillium spores in the material in the first instance; and conversely, where both species are sown together in a medium kept at $35^{\circ} \mathrm{C}$. only the aspergilli ultimately develop. Other nutrient conditions also act in a similar manner, and hence the resulting cultivation and also the presence of any given mould fungus in nature does not rest alone on the various conditions of life which are present, but also depends in a very important manner on the other species of fungi which may have reached the nutrient soil at the same time and may be growing in concurrence with it.

Conditions of spore formation.

Conditions of spore forma. tion.
4. Conditions of Spore Formation and Spore Germination.- In the case of the mould fungi, the formation of spores is such an essential part of the life of the fungus that we cannot regard the formation of mycelium without fructification as a normal and complete development. The conditions of life described above hold good not only for the growth of the mycelium, but also for fructification and the formation of spores; it has already been pointed out how necessary the presence of oxygen is for the latter process, and in this place we need only mention the few facts that are known with special reference to the act of the germination of spores. For this process we do not as a rule absolutely require the presence of any particular nutrient material, with the exception of a large quantity of water. The formation of the germinating tube takes place at the expense of the nutrient materials which have been stored up in the spore, and it 
is not till development has reached a certain stage that the above-mentioned nutrient materials become necessary. Hence the sprouting of moistened spores can be observed even on glass plates. In the case of some fungi however, for example Mucor mucedo, it is true that the first sprouting can only occur on suitable soil.-Besides water the presence of oxygen and a suitable temperature are also necessary for the process of germination. Here also the minimum, optimum, and maximum of the temperature differ in the case of different species of fungi. In the case of penicillium spores the former is about $+0.5^{\circ} \mathrm{C}$., the latter about $+43^{\circ} \mathrm{C}$., and the optimum about $+22^{\circ} \mathrm{C}$; ; in the case of Aspergillus fumigatus, on the other hand, the minimum, according to Lichtheim, is $15^{\circ} \mathrm{C}$.- The presence of light is not necessary for the germination of the spores of the fungi.

Between the point when the conditions necessary for germination come into play and the formation of a germinating tube a certain period of time is necessary, the length of which is dependent on the species of spore, and probably, above all, on the thickness of the spore membrane, and varies from a few hours to several days. Similar variations also exist with regard to the duration of the vitality of the spores. In the case of the uredo and Duration of recidium spores of the rust fungi, as well as in the vitality of case of peronosporeæ, the duration of vitality is only a few weeks, while the spores of Penicillium glaucum are able to sprout after a year and a half, those of Aspergillus niger after more than a year, those of Mucor stolonifer after a year, of Aspergillus flavus after six years, of Aspergillus fumigatus after ten years, and of Tilletia caries and Ustilago carbo after about eight years.* There is a further peculiarity in connection with the spores, namely, that they are only able to sprout after a considerable period of rest. 


\section{b. Conditions of Life of the Budding Fungi.}

\section{Chemical Composition of the Budding Fungi.}

Budding

fungi, chemical composition.
As regards the budding fungi, very numerous experiments have been made, which enable us to obtain a fairly accurate idea of their chemical composition and of their tissue change. These experiments have almost entirely been limited to the ordinary yeast of beer, which on account of its value in the preparation of food has always excited special interest. It is seldom that other species of these fungi, such as Mycoderma vini (A. Schultze, in Mayer's Chemistry of Fermentation), have been chosen for investigation.

Complete analyses of yeast have been published by the following authors: Schlossberger, Mulder and Wagner, Mitscherlich, Payen, Liebig.* The following was the average result in washed and dried yeast, freed as much as possible from ashes:-

48 per cent. C, $9-12$ per cent. N, $6-7$ per cent. $\mathrm{H}, 0 \cdot 6$ per cent. $\mathrm{S}$.

More recent analyses by Niigelit have led to the following results in the case of yeast used for low fermentation :-

Cellulose and mucous material of cell wall 37 per cent.

$\begin{array}{lllllll}\text { Albuminous materials } & \ldots & \ldots & \ldots & 45 & \end{array}$

$\begin{array}{llllllll}\text { Peptone } & \ldots & \ldots & \ldots & \ldots & \ldots & 2 & \text {, }\end{array}$

$\begin{array}{lllllllll}\text { Fat } & \ldots & \ldots & \ldots & \ldots & \ldots & \ldots & 5 & ,\end{array}$

Extractives (glycerine, leucine, \&c.) $\quad$. $4 \quad 4 \quad$,

$\begin{array}{lllllllll}\text { Ashes } & \ldots & \ldots & \ldots & \ldots & \ldots & \ldots & 7 & \end{array}$

Yeast which has been carrying on fermentation for a considerable time contains, according to Pasteur and others, a markedly less amount of nitrogen (only $5 \cdot 0$ to 5.5 per cent.). - Schlossberger and Mulder have attempted to isolate the albuminoid materials, either by treatment with potash lye or with acetic acid; and they made out that the isolated materials had a composition closely

* See Mayer, Lehrbuch der Gührungschemie, 1879, p. 110.-S•hützenberger, Gährungserscheinungen, p. 58.

$\dagger$ Sitzungsber. d. bayr. Acad. d. Wiss. 1878, May. 
allied to that of the proteids. More recently an albuminoid material has been obtained from the yeast cells by boiling with dilute hydrochloric acid and precipitating with rock salt; this material is termed mycoprotein, and plays an important rôle in the composition of the fission fungi. The amount of myco-protein has not as yet, however, been ascertained in the case of yeast (Nencki*). If the material remaining after the action of potash lye is treated with acetic acid and water, a substance is obtained, which, on analysis, gives 44.9 per cent. C, 6.7 per cent. $\mathrm{H}, 0.5$ per cent. $\mathrm{N}$ (according to later analyses by Nägeli and Löw $41 \cdot 4$ per cent. $\mathrm{C}$, and $6 \cdot 6$ per cent. $\mathrm{H} \dagger$ ), and thus it seems to be fairly pure cellulose. These substances can be transformed, by boiling with sulphuric acid, into fermentescible sugar, and do not dissolve in ammoniacal oxide of copper, being therefore somewhat different from ordinary cellulose.-Stutzer + found in yeast which had been extracted with alcohol and then dried by means of sulphuric acid, 8.648 per cent. of total nitrogen, $5 \cdot 519$ per cent. of proteid nitrogen and $2 \cdot 257$ per cent. of nuclein nitrogen.

The amount of water in fresh yeast which is able to grow is 40 to 80 per cent. If there is a greater or less quantity of water the yeast is no longer intact or capable of multiplication.

The mode in which the relation between non-nitro- Relation begenous cellulose-like constituents and the proteid substances undergoes alteration, as compared with the mould fungi, is worthy of note; in yeast we find 37 per cent. of cellulose, and 47 per cent. of albuminous materials; in the mould fungi there is about $50 \mathrm{per}$ cent. of cellulose, and 29 per cent. of albuminous materials.-However, it is not quite correct to reckon the quantity of nitrogen found as belonging entirely to albumen; part of it belongs to other substances, such as leucine and tyrosine, which can be obtained in

* Nencki, Beitrage zur Biologie der Spaltpilze, 1880, S. 48.

† Journ. für prakt. Chem., No. 5, vol. 17.

‡ Stutzer, Zeitschr.f.physiol. Chemie, vol. vi., p. 572. 
certain quantities from yeast by extraction with icewater (with regard to this point see below). In like manner, besides cellulose, we find gum-like bodies, glycerine, succinic acid, \&c., which are also carbonaceous and non-nitrogenous materials; usually, however, these substances occur in too small quantities to exert any marked influence on the relation between proteid and cellulose.

Yeast ashes. Of the several analyses of the ashes of yeast, the following results seem the most trustworthy (Mitscherlich) :-

Ashes of Yeast.

High Fermentation.

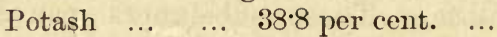

Phosphoric acid 53.9 ,

Calcium $\ldots . . . \quad 1 \cdot 0 \quad$,

Magnesia $\quad \ldots \quad 6.0 \quad$,

Silicic acid
Ashes of Yeast. Low Fermentation. ... $28 \cdot 3$ per cent.

$\begin{array}{ccccc}\ldots & \ldots & 59 \cdot 4 & \\ \ldots & \ldots & 4 \cdot 3 \quad,\end{array}$

$\begin{array}{llll}\cdots & \cdots & 4 & \\ \cdots & \cdots & 81 & \end{array}$

The ashes are therefore chiefly distinguished from those of the mould fungi by the much larger quantity of phosphoric acid present, this difference corresponding entirely to the larger amount of albumen.

\section{The Nutrient Materials of the Budding Fungi.}

Nutrient materials.

In investigating the mode of nutrition and the nutrient materials of the yeast fungi, it is necessary to note that these terms are not identical with fermentation and fermentescible materials. Fermentation runs its course to a certain extent independently of the nutrition of the yeast ; it is not a necessary part of the tissue change of the cells, but only forms an extension and complication of the same, which it is better to disregard for the present in attempting to ascertain the nature of the necessary nutrient materials, and the mode in which they are used up by the yeast cells. This separation of the two processes has only been properly carried out in the more recent experiments, while on the other hand former investigators always linked fermentation and the growth of yeast together. The more recent investigations made 
by Nïgeli, and more especially by Hansen, are also more free from objection because they have paid great attention to the purity of the cultivations of the yeast.*

As regards the nutrient materials required, the yeast Sources of fungi agree very closely with the mould fungi, so that what was mentioned with regard to the latter applies almost entirely to the former. A larger amount of nitrogen is requisite for the yeast fungi in correspondence with the larger quantity which they contain. The most farourable source of nitrogen is the soluble and easily diffusible albuminoid materials, and more especially peptone; but the place of the proteid substances may be taken by ammoniacal salts, substituted ammonia, and the other nitrogenous compounds mentioned in the case of the mould fungi; if, however, ammoniacal salts are the only source of nitrogen the yeast cells appear to undergo degeneration, their substance becoming richer in fat and poorer in nitrogen; and this degeneration occurs still more readily if other conditions of life, such as the presence of free oxygen, are also wanting (Nägeli). Under circumstances otherwise equal peptone is about four times better as a source of nitrogen than, for example, tartrate of ammonia. With regard to the nitrates there is an important difference between the mould fungi and the yeast cells; the nitrates are quite unsuitable for the nutrition of the yeast, and cannot serve as sources of nitrogen.

Carbon has the same relation to yeast fungi as to Necessity of mould fungi ; the best source is sugar, and then mannite, glycerine, tartaric acid, \&c. In the case of mycoderma vini, alcohol appears to be an almost necessary nutrient material, and can at most be replaced by malic acid (Schultz $\dagger$ ).-With regard to the hydrogen, combined oxygen, and sulphur there are no marked differences

* Compare Pasteur, Ann. de Chim. et de Phys., (3) vol. 58.-Duclaux, Thèses présent. à la fac. de sc. de Paris, 1865.-Dubrunfaut, Compt. rend., vol. 73. - Schützenberger, Compt. rend., vol. 78.-Mayer, Untersuchungen über die alkoholische Gahrung, \&c., 1869.-Landwirthsch. Versuchsstat., vol. 14.-Mach, Anal. de Oenologie, vol. 4.-Nägeli, Theorie der Gährung, 1879.-Untersuchungen über niedere Pilze, 1882.-Hansen, Meddedelser fira Carlsberg Laboratoriet : Kopenhagen, 1879-1884.

$\dagger$ Cit. in Mayer, Gührungschemie. 
between the yeast and mould fungi. Of mineral substances, potash, phosphoric acid, and calcium are indispensable; the presence of a considerable quantity of acid phosphate of potash (about 20 per cent.) has a markedly favourable influence on growth.

Necessity for free oxygen.

The mould fungi and yeast fungi behave very differently as regards oxygen. On the whole the presence of free oxygen exerts a very favourable influence on the growth and multiplication of the yeast-cells; when brought into contact with water containing oxygen or with oxy-hæmoglobin the yeast, as Schützenberger has shown, takes up the oxygen very greedily; and under otherwise similar circumstances the largest quantity of yeast is obtained when a continuous stream of air is passed through the nutrient fluid. Multiplication of the yeast can, however, occur without the access of oxygen, but only when the other nutrient materials are furnished in a suitable form, and when the yeast-cells are able at the same time to cause fermentation. Thus yeast grows actively without the presence of air in a solution of peptone, or in a decoction of yeast containing 1 to 10 per cent. of sugar, and $\cdot 5$ per cent. of phosphoric acid; its growth is less energetic when, instead of peptone, meat extract, urea, or ammoniacal salts are mixed with sugar; and growth does not occur, or only to a very slight extent, when no sugar is present, or when its place is taken by other bodies, such as glycerine or mannite, which do not so readily undergo fermentation. In all cases the multiplication of the yeast in the absence of oxygen goes hand in hand with fermentation of the sugar, and the fermentative activity seems to replace the action of the free oxygen. This possibility of living without oxygen naturally influences also the occurrence and the habitat of the yeast; thus it can vegetate in the interior of fruits, provided only that these contain fermentescible sugar, and that the other conditions necessary for a development of its fermentative activity are present.

Influence of the concentra tion of the material. 
and yeast fungi. The latter do not bear such marked concentration of the nutrient mixture as do the mould fungi ; the optimum of the amount of water is, however, equally dependent on the nature of the other nutrient materials. Nutrient materials which are not very suitable require as a rule a great dilution (salts of ammonia must not be present in more than 1 per cent.), while sugar, for example, may be present in the nutrient mixture up to 35 per cent. without leading to cessation of the growth.

With regard to the reaction, the yeast fungi resemble the mould fungi in that they can bear a fairly markedly mixture. acid reaction without harm; but the upper limit of the excess of acid is lower than in the case of the mould fungi, so that by increasing the acidity of the material (the addition of 5 per cent. of tartaric acid, or 1 per cent. of phosphoric acid) the growth of the mould fungi, as compared with that of the yeast fungi, is favoured. Yeast seems to be very sensitive to an excess of alkali, so that even traces of alkali can hinder growth. (Dumas, Mayer.)

\section{Other Conditions of Life of the Yeast Fungi.}

Some of the other factors which can influence the energy of growth of the fungi have also been investigated in the case of yeast. - Light and electricity are, so far as ex-Action of high periments have gone, without influence on the growth pressure. of the yeast: in like manner, according to experiments by Certes and Cochin,* a pressure of 300 to 400 atmospheres maintained for several days did not injure yeast; under these circumstances, in fact, it was still able to break up sugar into alcohol and carbonic acid. Hoppe- Action of Seyler has observed that mechanical movement of the mechanical nutrient solution acts in an unfavourable manner on yeast; but this investigation was limited to the question of the fermentative activity of yeast, and besides, the cultivations were much contaminated with bacteria. On the other hand, Hansen $\uparrow$ has demonstrated, in a series of

* Compt. rend. soc. biol., 1884.

+ Meddedelser fira Carlsberg Lab., vol. i., part 2. 
Influc nce of temperature.

Influence of fermentation

Concurrence with other fungi.

experiments which are much less open to objection, that the beer yeast multiplies more readily when constantly shaken than when kept at rest. The temperature has an important influence on the development of the yeast. The optimum appears to lie between $25^{\circ}$ and $30^{\circ} \mathrm{C}$.; but it depends to a certain extent on the composition of the nutrient solution. Above the optimum the rapidity of growth rapidly diminishes, and ultimately ceases at about $53^{\circ} \mathrm{C}$.; below the optimum the diminution of the growth occurs more slowly, and even slight vegetation may take place a little above the freezing point.

The fermentative activity of those yeast fungi which are able to excite fermentation forms a special factor of considerable importance. It is a matter of experience that the development of the yeast cells runs parallel with the energy of the fermentation; further, yeast appears to multiply much more rapidly when sugar is present in the nutrient solution than when materials, such as glycerine, which cannot be broken up by the yeast, are present. On the other hand, the latter substance is quite as good a nutrient material as sugar in the case of other species which cannot excite fermentation; and hence we may draw the conclusion that the fermentative activity itself is able to supply a certain amount of energy to the yeast cells which can be utilised for their vegetative life (Nägeli.)

The simultaneous presence of other fungi, and the concurrent growth with these, plays an important part in the cultivation of the yeast fungi. The bacteria more especially can, as the result of their more rapid multiplication, very readily limit the development of the yeast fungi; here, however, the result is also dependent on the sum total of the conditions of life which may be more favourable for the yeast fungi, and may thus form a substitute for the less energy of their growth. The concentration and reaction of the nutrient medium is here also of the greatest importance; at times also the temperature, higher degrees of which, for example, may protect the yeast against many mould fungi, such as penicillium. Fermentative activity also seems to exert 
a special influence on the concurrent growth of the yeast. For example, if a very minute quantity of yeast is introduced into a neutral saccharine nutrient solution, and if no care is taken to exclude bacteria, the latter generally multiply readily, and a very impure cultivation of yeast is obtained, or one in which the bacteria are in greatest numbers. If, however, we increase the wmount of yeast introduced up to a certain point-1.7 grammes of dry yeast, or $10 \mathrm{ccm}$. of thick yeast, for every litre of nutrient solution-the yeast alone multiplies, and the bacteria scarcely develop at all. It can be shown that this phenomenon does not depend on the excretion of materials hurtful to the bacteria by the yeast, and we must therefore suppose that it is the fermentative movement which hinders the multiplication of the bacteria. In accordance with this we have the observation that we are the more likely to obtain a relatively pure cultivation of yeast the quicker and more completely the fermentation occurs after the organisms are introduced, and that it is thus independent of the number of the fission fungi which have obtained admission at the same time. Thus we have the explanation why the ordinary beer yeast is usually fairly (but never quite) free from bacteria, and why, when the brewing process is properly carried out, we need not fear disturbance by the development of bacteria (Nägeli).*

4. Conditions of Spore Formation and Spore Germina- Conditions of tion- - In contrast to the higher plants, and also to the spore formmould fungi, the yeast and fission fungi are distinguished by the possession of a very great tendency to utilise the

- nutrient materials for the continuous production of purely vegetative cells without the formation of any true fructification. In suitable nutrient media the yeast fungi constantly form new cells by budding, and the bacteria divide continuously like an enormously developed tree without fruit. It is only when the nutrient conditions become markedly unfavourable, and when one of the most important nutrient substances begins to disappear, that there is an interruption in the ordinary mode of

* Nägeli, Theorie der Gährung, 1879, p. 77. 
multiplication; the fungus then converts the remains of the nutrient material at its disposal into a more durable cell, which can survive after the exhaustion of the nutrient material, and can grow again in new nutrient soil even after a long interval.

In the case of the yeast, the conditions necessary for the formation of spores are furnished when the nutrient substratum is very poor in nutritive materials, more especially in sugar, or is very dilute, while at the same time (as in the case of the mould fungi) free access of the oxygen of the air is permitted, and evaporation is limited. If yeast is spread out on thin slices of boiled carrot, or on moistened plaster, and then kept in a moist chamber, the formation of spores in the cells, as described on page 147, occurs in the course of a few days; the same result is obtained if a solution of sugar containing yeast is more and more diluted by the daily addition of water. According to Hansen, * spore formation is readily observed on microscopic slides covered with a layer of nutrient jelly, if the temperature is not too high; in like manner yeast water containing air is also a favourable nutrient medium. - The minimum of temperature at which spore formation has been observed is between $+2_{2}^{\circ}$ and $3^{\circ} \mathrm{C}$., the maximum at $37 \frac{1}{2}^{\circ} \mathrm{C}$. - The spores can be kept for a long time, and can be dried without losing their power of sprouting.

Germination of spores.
The conditions of the germination of these spores are similar to those mentioned in the case of the spores of the mould fungi. The presence of nutrient materials is not necessary for the commencement of germination; on the other hand, moisture and free oxygen are absolutely essential, so that in respect of the latter there is a marked difference between the vegetation and the fructification of yeast. Further, the temperature has an important influence, but this has not as yet been quantitatively determined. $\dagger$

* l. c., vol. ii., part 2.

† Russ. Annalen der Oenologie, vol. ii.-Botan. Zeit., 1873. 
(c) Conditions of Life of the Fission Fungi.

\section{Chemical Composition of the Fission Fungi.}

In order to isolate the fission fungi from the nutrient Chemical comfluid, it is well to follow Nencli's* method, by render-position of the ing the fluid acid by the addition of 2 to 3 per cent. of free hydrochloric acid, and then boiling it. The bacterial masses are thus coagulated, and may be easily obtained by filtration; we must, however, avoid nutrient solutions, from which albumen might be precipitated by this method. In a 2 per cent. solution of gelatine (and also in a solution of mucate of ammonia) Nencki found the following composition, in the case of the bacteria, corresponding to the different stages of their development, beginning with the formation of a very gelatinous zooglea :-

\begin{tabular}{|c|c|c|c|}
\hline Water. & $\begin{array}{c}\text { Pure zooglea } \\
\text { mass, } \\
\text { 84.81 per cent. }\end{array}$ & $\begin{array}{l}\text { Zooglea mass } \\
\text { with bacteria, } \\
84: 26 \text { per cent. }\end{array}$ & $\begin{array}{l}\text { Adult bacteria } \\
83.42 \text { per cent. }\end{array}$ \\
\hline & \multicolumn{2}{|c|}{ In the substance free from water. } & \\
\hline $\begin{array}{l}\text { Albumeh ...... } \\
\text { Fat ............. } \\
\text { Ashes ......... } \\
\text { Undetermined }\end{array}$ & $\begin{array}{c}85 \cdot 76 \text { per cent. } \\
7 \cdot 89 \quad \text { ", } \\
4 \cdot 20 \quad \text { ", } \\
2 \cdot 15 \quad \text {, }\end{array}$ & $\begin{array}{c}87 \cdot 46 \text { per cent. } \\
6 \cdot 41 \quad \text { ", } \\
3 \cdot 04 \quad \text { ", } \\
3 \cdot 09 \quad,\end{array}$ & $\begin{array}{c}84.20 \text { per cent. } \\
6.04 \quad, \\
4.72 \quad, \\
5.04 \quad,\end{array}$ \\
\hline
\end{tabular}

The albuminous material is to a great extent formed of a body which differs from other proteid substances in some of its reactions-for example, it is not precipitated by alcohol-and especially in its elementary composition; it has been called by Nencki myco-protein. This substance contains 52.32 per cent. C., 7.55 per Nencki's cent. H., $14 \cdot 75$ per cent. N.; no sulphur, and no phos- myco-protein. phorus. On heating it with caustic potash, the following substances were obtained: phenol, skatol, indol, large quantities of fatty acids especially valerianic acid, and leucine. $\uparrow$

* Nencki, Beiträge zur Biologie der Spaltpitze, 1880.

+ Nencki's Journ. für prakt. Chem., N.F., vol. 23. 
In the case of some pathogenic organisms, numbers have been obtained which differ considerably from the above. Spores of the anthrax bacilli cultivated in nutrient gelatine in large vessels, containing 1 to 2 litres, and collected after three weeks growth, showed, according to Nägeli, no myco-protein, but a peculiar albuminoid body, which he has called anthrax-protein, readily soluble in alkalies, but quite insoluble in water, acetic acid, and dilute mineral acids; it contains no sulphur.*

Brieger + has obtained the following results with regard to Friedlaender's pneumonia bacilli, which he cultivated on nutrient gelatine. He found 84.2 per cent. of water; 1.74 per cent. of fat in the dry substance; in the dry substance free from fat 30.13 per cent. of ashes; and in the dry substance free from fat and ashes 9.75 per cent. of nitrogen.-The organic substances gave on the whole the reactions characteristic of protein, but they were not identical with Nencki's myco-protein. -Vandevelde $\ddagger$ found on analysis of bacillus subtilis no cellulose, but nuclein.

Relation between nitrcgen and carbcn.

According to these results the relation between the albuminoid substances and the material resembling cellulose, which in the case of the yeast fungi was in favour of the former, is still more altered in the same direction in the case of the fission fungi, so that the non-nitrogenous materials pass completely into the background, and albuminoid substances form almost the whole substance of the fission fungi. There are, it is true, analyses of other fungi by Nägeli and Löw, which differ markedly Contradictory in part from the above results. A growth of micrococci analy: cultivated in tartrate of ammonia gave 10.65 per cent. of nitrogen and 6.94 per cent. of ashes; on the other hand, the vinegar plant, which consists of a tough jelly, in which short rods are embedded, yielded $98 \cdot 3$ per cent. water, and in the dry substance only $\mathbf{1 . 8 2}$ per cent. N. and 3.37 per cent. ashes, so that in this case also

* Chem. ber., vol. xvii., p. 2605.

+ Zeitschr. $f$.physiol. Chem., rcl. ix.

† Ibid., vol. viii. 
the chief body present must be the non-nitrogenous cellulose material.

Durin and Scheibler* also observed that the membrane of Leuconostoc mesenterioides chiefly consisted of a hydrocarbon closely allied to cellulose. Further analyses must show us in what way we are to explain these marked analytical differences, and what their value is.

The ashes of the fission fungi have not as yet been Ashes. accurately analysed. Brieger found in the ashes of the pneumonia bacilli phosphate of lime, phosphate of magnesia, sulphate of sodium, and chloride of sodium. As a whole, the ashes of the fission fungi have probably an analogous composition to those of the yeast.

In some species of fission fungi chemical substances are always, or at times, present which do not belong to the ordinary constituents of the bodies of these organisms. For example, substances resembling gran- Rarer ulose occur in bacillus butyricus and in Vibrio rugula constituents. before the formation of spores, also in bacillus Pasteurianus (Hansen) and in Leptothrix buccalis, and these may be demonstrated by their blue colouration by iodine. To this class of substances belongs the ruguline Sulphur. sulphur found in some species of beggiatoa; further, some specific dyes, the majority of which, however, do not appear to be deposited in the wall or cell contents of the organisms.

\section{The Nutrient Materials of the Fission Fungi.}

As a whole, the nutrient materials and conditions of Nutrient life of the fission fungi resemble those of the mould materials. fungi; the different species, however, differ in their requirements so much, that much more detailed investigations are necessary. We must therefore await further researches before wa can writs a complete account of this subject.

As a rule these fungi obtain nitrogen best from diffu- Sources of * Quoted from de Bary. 
sible albuminoid materials.* Ammoniacal salts are not so suitable, but are better borne than in the case of the yeast fungi. The remaining nitrogenous compounds appear to have the same relative value as in the case of the mould fungi ; according to Nägeli, the nitrogen can also be obtained from nitrates, and in the experiments in question it was possible to follow the gradual reduction of the nitric acid to nitrous acid, and finally to ammonia. Reduction of This reduction of nitrates by bacteria has been recently nitrates.

Sources of carbon. observed by Gayon and Dupetit, Déhérain, Maquenne, and Springer. Anaërobic organisms similar to or identical with bacillus butyricus when they set up a fermentation, combined with the development of hydrogen, seem to cause reduction of nitrates with formation of oxide of nitrogen. This was also the case with certain aërobes, and to a less extent with the bacilli of chicken cholera, anthrax, \&c. + In all these experiments, however, it is probable that the nitrates did not suffice to provide the necessary oxygen for the fission fungi, but that reduction was a secondary phenomenon, caused by other products of the tissue change or fermentation, and only accompanying the true tissue change of the bacteria.

The supply of carbon is obtained not only from sugar but also from bodies similar to it, from glycerine, and especially from the various salts of fatty acids, such as the allaline salts of tartaric acid, citric acid, malic acid, mucic acid, lactic acid, acetic acid, \&c.; even those compounds which act, when markedly concentrated, in a decidedly poisonous manner on the bacteria can be utilised in a very dilute state as sources of carbon supply, for example, carbolic acid, salicylic acid; further, aethylic alcohol, which forms the most favourable nutrient medium for the vinegar fungus, and which can be present in the nutrient solution up to 10 per cent. It is remarkable that, according to Pasteur's observations, it is only

* See more especially Nägeli, l.c.-Cohn, Beitrüge, vol. i., Heft 2.Bucholtz, Arch.f. Exper. Path., B. 7, S. 81.-Mayer u. Knierim, Landw. Versuchsstat., vol. 16 (Essigpilz).-v. Jacksch (Harnstoffpilz), Zeitschr. f. physiol. Chemie, vol. 5.

+ Gayon and Dupetit, Compt. Rend., vol. 95.-Deherain and Maquenne, ibid., and vol. 97.-Bull soc. chim, 2, 35.-Springer, Chem., Ber., vol. 16 . 
that form of tartaric acid which turns the polarisation to the right which can be taken up by bacteria.

In the case of some bacteria, the most favourable nutrient conditions have been more accurately determined; for example, by von Jacksch* for micrococcus urea, and by Hueppet for the lactic acid bacilli. Micro- Nutrient coccus ureæ can, for example, obtain the necessary materials nitrogen and carbon from nutrient solutions containing mierococeus succinate, lactate, malate, tartrate, or citrate of ammonia, from glycocoll, leucine, asparagine, salts of asparagine, creatine, benzoate of ammonia, hippurates, and peptone. On the other hand, the following were useless as sources of nitrogen and carbon: formate, acetate, butyrate, oxalate, and salicylate of ammonia, and acetamide.

In the case of bacterium lactis, carbon is best obtained For bacterium from milk sugar, cane sugar, mannite, and dextran; the best source of nitrogen was peptone, or among the salts, tartrate of ammonia. Nitrates were quite unsuitable as sources of nitrogen. The most favourable proportion of the nutrient salts was $0 \cdot 2-0.5$ per cent. of acid phosphate of potash, +0.05 to 0.1 per cent. of sulphate of magnesium $+0.015-0.025$ per cent. of chloride of calcium; this mixture could be replaced by 1 per cent. of extract of meat.

These numbers are, however, only applicable to these Difference as special cases. The more accurately the various species $\begin{aligned} & \text { regards the } \\ & \text { nutrient re- }\end{aligned}$ of bacteria have been studied during the last few years, quirements of the more have differences in the nutrient requirements species of of the different species been observed. Some require large quantities of certain albuminoid substances, and only permit a variation in the composition of the nutrient material within very narrow limits; others permit a greater variation in the nutrient materials, which, however, must be fairly concentrated and composed of complex molecules. Others, finally, prefer very dilute and simple solutions in which one can scarcely recognise anything of nutrient value. Among the bacteria contrast which are most sensitive in this respect are chiefly the between the pathogenic bacteria and

* Zeitschr.f.physiol. Chem., vol. 5.

$\dagger$ Mitth. a. d. Kais. Ges., vol. ii. those which multiply in water. 
Formation of ferments by bacteria.

Necessity for free oxygen.

Pasteur's division into aërobes and anaërobes. pathogenic forms, which can only grow on certain hosts, and which refuse to live on any other living or dead substratum (such as the spirilla of relapsing fever, or the bacilli of leprosy), or which, at any rate, require blood serum, or mixtures containing soluble albumen, peptone, and salts. The greatest contrast to these bacteria is formed by those which have been described by Bolton* (bacillus erythrosporus, micrococcus aquatilis, \&c.), which find sufficient nutrient material to enable them to grow in enormous numbers even in pure distilled water. As in all their other vital functions, so here, the bacteria present conditions which render it impossible to treat them in a schematic manner.

The number of suitable nutrient materials is increased in the case of many species of bacteria by the fact that they produce ferments which can transform insoluble substances into soluble and diffusible ones. Coagulated albumen, solidified gelatine, starch, and di-saccharates can be transformed by means of peptonising, diastatic, and inverting ferments into soluble and assimilable nutrient materials. As regards this production of ferment also the various species of bacteria show great differences both qualitatively and quantitatively.

The bacteria also behave very differently with regard to oxygen. Pasteur was the first to observe that there were bacteria which did not require free oxygen for their life and multiplication, but, on the contrary, could carry on their vital functions in the absence of oxygen, and, indeed, the presence of that gas might interfere with their multiplication and their vital phenomena. Pasteur gave effect to this distinction by his division of the bacteria into "aërobes" and "anaërobes." The surprising fact that life could occur without oxygen was also soon confirmed by other observers, such as Nencki, Prazmowski, Rosenbach, \&c., and though Gunning asserted that in none of these experiments was the oxygen sufficiently removed, and thus no complete anaërobiosis existed, nevertheless these objections cannot hold ground against the recent experiments by Nencki and Lachewicz;

* Gött. hyg. Institut. Mitgetheilt in Zeitschr.f. Hygiene, vol. i. 
Nencki convinced himself that in the cultivation apparatus ferrocyanide of iron and reduced hæmoglobin remained unaltered, and that thus we had to do with complete absence of oxygen so far as this can be confirmed by chemical means.

Nägeli has drawn especial attention to the great im- Replacement, portance of the fermentative activity in reference to the of the need for oxygen on the part of the fission fungi; if fermentative fermentative action is going on the access of oxygen becomes unnecessary; if the bacteria in question are unable to excite fermentation, or if it so happens that they live under conditions in which no active fermentation can occur, free oxygen becomes absolutely essential for their development.

Engelmann has further shown that the motility of Influence of the bacteria is influenced to a very great degree by the oxygen on tension of oxygen in the nutrient medium. Spirilla are in this respect much more sensitive than any other species of motile bacilli; the latter assemble at the margin of any air bubble which may be present within a drop of nutrient fluid; spirilla, on the other hand, remain at some distance from the margin of the air bubble, and only approach it when the amount of oxygen in the nutrient solution has become diminished. In this species of bacteria too great a quantity of oxygen has also a similar effect in causing the cessation of movement. The lower limit of necessary oxygen was very low in this species of spirilla; if they were placed, along with micro-organisms containing chlorophyll, in a medium which was free from oxygen but illuminated with white, red, or yellow light, the spirilla at once collected at those parts where traces of oxygen were developed by the chlorophyllous cells.

More recent investigations by Liborius* have added to our knowledge as regards the need for oxygen by the bacteria, and have more especially shown that the anaërobic organisms can live and multiply without exercising any simultaneous fermentative activity. According to Liborius' investigations we may divide the

* Gött. hyg. Inst. See Zeitschr.f. Hygiene, vol. i. 
Obligatory anaërobes.

Facultative anaërobes. bacteria into three groups, which differ in an important manner as regards their necessity for oxygen. In the first place, we have a group of what may be termed "obligatory anaërobes," which only grow when the oxygen is remored as completely as possible from the nutrient medium, at any rate when it can be no longer demonstrated by the ordinary chemical means. To this group belong, for example, the bacilli of malignant œdema, bacillus butyricus, bacillus muscoïdes, bacillus polypiformis, \&c. Some of these organisms have the property of exciting fermentation in certain fermentescible materials, and then they are able to multiply in large numbers in correspondence with the intensity of the fermentation. In the case of other species no fermentative activity has as yet been made out. The fermentations set up by these anaërobic organisms can be arrested by the admission of oxygen, just as is the case with the growth of the same organisms in non-fermentescible substrata.

A second group is formed by what we may term the "facultative anaërobes." These bacteria grow best and most quickly when the entrance of air is permitted, but they are also capable of developing slowly when air is excluded. The degree to which the growth is influenced by the exclusion of oxygen varies very much in the different species. On the whole an artificial increase in the tension of the oxygen is injurious to the bacteria belonging to this group; but here also the degree of sensitiveness varies in the different species. Among the very numerous organisms which belong to this group we may mention more especially the various pathogenic organisms, for example, staphylococcus, streptococcus, bacillus septicus cunic., bacillus sept. crassus, bacillus anthracis, bacillus typhi. abdom., bacillus pneumonix, spirillum choleræ asiaticæ. In this group also the majority of the bacteria do not require to exercise fermentative activity in order to live without oxygen. In many of them their behaviour, when fermentescible materials are absent, has not as yet been tested; nevertheless simultaneous fermentative activity favours the 
anaërobric growth of these bacteria to a marked degree. In the case of some organisms, for example, bacillus lactis aërogenes (Escherich), it has been demonstrated that they can only exist without air when fermentescible material is present, and fermentation is going on.The fermentations set up by these organisms are apparently not injuriously affected by the access of oxygen, but on the contrary are favoured.

In contrast to these groups we have a third, which is obligatory composed of "obligatory aërobes"; these organisms cannot grow when air is excluded, even though they could otherwise excite fermentation. Their growth is interfered with by any marked diminution in the amount of air, and under these circumstances one or other of their functions may cease (for example, the production of colouring materials, of ferments, \&c.) ; on the other hand, their life and growth is much favoured by artificial increase in the tension of the oxygen. To this group belong, for example, bacillus subtilis, bacillus aërophilus, \&c. Nevertheless, within this group there are marked differences as regards the quantity of oxygen necessary, so that we can only lay down a general law, viz., that each of these species of bacteria requires a definite amount of oxygen. The fermentative action of the bacteria belonging to the group of obligatory aërobes is without exception favoured by the access of air ; for example, the lactic, and more especially the acetic, fermentation. According to Hoppe-Seyler, * a continued and marked impregnation of the nutrient medium with air has a favourable action on the development of many putrefactive bacteria, as well as on the course of the putrefactive fermentations set up by them, and hence we may conclude that some of the bacteria which can excite fermentation belong to the group of aërobes, while, on the other hand, many obligatory aërobes also take part in this process.

We can say very little which is of general appli- Concentration cability as regards the most favourable proportions of of the nutrient the individual nutrient materials, on account of the 
very great differences in the requirements of the different species of bacteria. On the whole, the amount of water in the nutrient material must be very great, and the concentration slight. Fermentescible substances can be protected against the invasion of bacteria by the removal of a relatively small quantity of water, while they still remain a favourable soil for the growth of the yeast fungi, and more especially of the mould fungi. Very little has been ascertained as to the limits of concentration, for this must vary according to the nature of the nutrient materials; quite as little is known as regards the optimum of the amount of water. That the latter can as a rule vary within wide limits is evident from the fact that bacteria can be cultivated equally well on semi-solid nutrient soils containing about 80 per cent. of water, in concentrated fluids containing 5 to 10 per cent. of solid constituents, and in very dilute solutions containing scarcely more than traces of nutrient substances.

Reaction. Excess of acid or alkali may be either injurious or favourable to the development of the bacteria; the first, however, interferes most readily with the growth. In this respect there is an important difference between many of the bacteria and the mould and yeast fungi; and hence in the acid reaction of the nutrient medium we have an excellent means of protecting the cultivations of the latter organisms against the entrance of numerous species of bacteria. Many bacteria, for example, bacillus subtilis, anthrax bacilli, \&c., are very sensitive to slight excess of acid; but on the other hand there are bacteria, such as bacillus butyricus or the acetic bacterium, which can bear a very marked acid reaction without injury; indeed, many only grow when there is a certain excess of acid in the nutrient medium (for example the bacillus of blue milk, and the bacterium of acetic acid which only grows when at least 2 per cent. of acetic acid is present). Hence an excess of alkali is hurtful to these particular bacilli, while as a rule it has by no means such an injurious effect on bacteria as the free acids; indeed, some organisms, for example the 
micrococcus ureæ, can bear an extremely high degree of alkalinity. Some bacteria show such indifference with regard to the reaction of the nutrient medium that they may commence their development on a markedly acid soil, then convert the reaction by the products of their growth into an alkaline one, and continue to grow in the presence of a marked excess of alkali.

\section{Other Vital Conditions of the Bacteria.}

According to the experiments which have as yet Influence of been made light does not appear to be one of the general conditions of life of the bacteria; the observation made by Engelmann that in the case of one species of bacterium (bacterium photometricum) the swarming movements were dependent on the light does not with certainty refer to a bacterium but more probably to a fission alga.* With regard to the injurious action of sunlight, see Part 5. In like manner elec- Electricity. tricity, so far as it comes into play under normal conditions, is without any influence; strong currents, however, interfere with the development of the cultivations.t Alterations in the pressure are borne by Highpressure. many bacteria in a remarkable manner, as has been shown, for example, in the case of the bacillus butyricus ; Certes has also observed that putrefactive processes go on even under a pressure of 350 to 500 atmospheres, and that anthrax bacilli retain their virulence after exposure for 24 hours to 600 atmospheres.

To a certain extent rest and the absence of mechanical Mechanical movement appear to be of some importance for the fission fungi, although the experiments made in this respect have not given entirely uniform results. A continuous, gentle, flowing movement of the nutrient media does not appear to hinder the development of the fission fungit; on the other hand, it was observed that continuous and marked shaking of the fluid, such as is set

* Pflüger's Arch., vol. 26, p. 537.-Botan. Zeitg., 1882.

$\dagger$ Cohn and Mendelssohn, Cohn's Beiträge, vol. iii., part 1.

$\ddagger$ Hoppe-Seyler, Festschrift $u$. s. w. "Ueber die Einwirkung des Sauerstoffs auf Gährungen," 1881. 
Influence of temperature.

up by a special motor,* or by sounds of sufficient intensity conducted through the nutrient solution, $\uparrow$ have a distinct disturbing influence on development. More recently, however, somewhat different results have been obtained in a fresh series of experiments. $\neq$

Further, a certain medium temperature is a necessary condition for the development of the bacteria. Nevertheless, the optimum of temperature, as well as the upper and lower limits, are quite different in different species of bacteria, and are also dependent on the other conditions of life, more especially on the composition of the nutrient material. According to Eidam's experiments, with regard to the development of bacterium termo in Cohn's nutrient solution, growth begins at $+5 \frac{1}{2}^{\circ} \mathrm{C}$., increasing at first slowly as the temperature rises, and then quickly from $10^{\circ} \mathrm{C}$. upwards, attains the optimum between $30^{\circ}$ and $35^{\circ}$ C., and very rapidly diminishes, and ultimately entirely ceases at $40^{\circ}$ C. $\$$ In the case of the acetic bacterium the optimum lies between $20^{\circ}$ and $30^{\circ} \mathrm{C}$.; below $10^{\circ} \mathrm{C}$. growth goes on extremely slowly, and it diminishes rapidly above $35^{\circ} \mathrm{C}$., and ultimately ceases a few degrees higher.\| The tubercle bacillus grows, on the other hand, only between $30^{\circ}$ and $41^{\circ} \mathrm{C}$., best at $37^{\circ}$ to $38^{\circ} \mathrm{C}$. In the case of the bacillus subtilis Brefeld found that the growth was very slow at $6^{\circ} \mathrm{C}$; ; at $12.5^{\circ} \mathrm{C}$. 4 to 5 hours elapsed between each new sub-division of the rods; at $25^{\circ} \mathrm{C}$., $\frac{3}{4}$-hour; at $30^{\circ} \mathrm{C}$., $\frac{1}{2}$-hour. From these examples it is sufficiently evident that the various species of bacteria vary markedly with regard to their relation to temperature, and it can only be said with regard to the relation of temperature to the mould and yeast fungi, that as a rule the most favourable temperature is less than in the case of the bacteria, in which the optimum lies nearer the temperature of the human body.

* Horvath, Pflüger's Arch.f. Physiol., vol. 17.

+ Reinke, Ebenda, vol. 23.

† Tumas, Petersburger med. Woch., 1881.

$\S$ Eidam, Cohn's Beitrüge, i., 3, p. 209.

\|l Mayer, Gährungschemie, p. 178. 
The fermentative activity in all probability plays the Influence of same part with regard to the life of the bacteria as it the fermentadoes in the case of the yeast fungi. In the case of the bacteria which can set up fermentation, the fermentative activity appears to favour the growth of the organisms as soon as a certain intensity of the fermentative action has been attained, while the development of other bacteria which may be present at the same time is hindered. Hence a certain intensity of fermentative activity exerts a marked influence on the concurrent growth of various species of bacteria, and on the production of pure cultivations.

As a rule, in concurrent growth with mould and yeast concurrent fungi, the bacteria have an advantage in their ex-growth with tremely rapid multiplication, and in the very energetic manner in which they use up the nutrient materials. It is only when some of the conditions as regards the nutrient substratum are selected in such a manner that they exert an unfavourable influence on the development of the bacteria, while they at the same time permit the unhindered growth of the other classes of fungi, that it is possible for the latter to take possession of the nutrient medium and to exclude the bacteria. As has been mentioned, the concentration and reaction of the nutrient material are the chief means by which the growth of the yeast and mould fungi, as compared with that of the bacteria, may be favoured.-Among the bacteria themselves various factors, more especially reaction, temperature, relative amount of the individual nutrient materials, and more especially of the nitrogenous compounds, the tension of the oxygen, \&c., are the chief means by which one or other species may succeed in growing in excess, and ultimately in almost entirely gaining the upper hand.

\section{Conditions of Spore Formation and Spore Germination.}

To a still higher degree than the yeast fungi the Spore bacteria appear able to utilise suitable nutrient materials 
for the simple multiplication of cells. What the conditions are which must be present in order to set up the phenomena of spore formation, a process on the whole of rare occurrence, have not as yet been fully worked out. From analogy we may suppose that the exhaustion or vitiation of the nutrient medium forms the necessary condition for the commencement of this act; and as a matter of fact this seems to be the case in many species. Apparent exceptions have as yet been observed in bacillus butyricus, bacillus subtilis, anthrax bacilli, \&c. ; nevertheless, in the spore-bearing cultivations of these bacteria it is possible that one or other of the nutrient materials has become diminished to such an extent as to suffice for the introduction of the process of spore formation, or the nutrient substrata may have become sufficiently saturated with the noxious products of tissue change of the bacteria to render them imperfect as nutrient media. It is possible that further observations will enable us to formulate the conditions of spore formation in the bacteria in a similar manner to those of the jeast fungi; in that case, however, the marked differences between the individual species of bacteria must of course be taken into account. The oxygen exerts a peculiar effect on the spore formation of the bacteria. While in the case of the mould and yeast fungi oxygen must have free access, the bacteria are divided in this respect into two groups. The majority also appear to require oxygen for the formation of spores, and Prazmowski pointed out that it is characteristic of these forms that they are non-motile during the stage of fructification. The true anaërobes, however-this has been demonstrated with certainty as regards bacillus butyricus-can only fructify in the absence of oxygen, and continue to move during the stage of fructification.

The temperature exerts a marked influence on the process. Koch* has shown, in the case of anthrax bacilli, that a temperature of at least $16^{\circ} \mathrm{C}$. is necessary for the formation of spores; and under these circumstances limited formation of spores did not occur till alter seren

* Mittheilungen a. d. Kais. Ges. Antt., p. 65. 
days. At $21^{\circ} \mathrm{C}$. spores had formed after 72 hours, at $25^{\circ} \mathrm{C}$. after 35 to 40 hours, and between $30^{\circ}$ and $40^{\circ} \mathrm{C}$. after about 24 hours ; the best and strongest cultivations were obtained between $20^{\circ}$ and $25^{\circ} \mathrm{C}$. In the case of bacillus subtilis spore formation did not occur below $6^{\circ} \mathrm{C}$, at $18 \cdot 75^{\circ} \mathrm{C}$. it reguired two days, at $22 \cdot 5^{\circ} \mathrm{C}$. one day, and at $30^{\circ} \mathrm{C} .12$ hours.

As regards the germination of spores, and the neces- Germination sary conditions for that act, we have as yet no detailed of spores. observations. A certain amount of water and a fairly high temperature, differing, however, according to the species, must be reckoned as absolutely essential conditions. In the case of bacillus subtilis, the optimum of the temperature for germination lies between $30^{\circ}$ and $35^{\circ} \mathrm{C}$, and in the case of anthrax bacilli at about $35^{\circ} \mathrm{C}$.

As regards oxygen it has been made out in the case of the spores of some bacteria, for example of bacillus butyricus, that it may actually hinder the occurrence of germination; while, as a rule, the entrance of oxygen is just as necessary for the sprouting of the great majority of the spores of bacteria as it is for those of yeast and mould fungi, and as it is for the other functions of the same bacteria. 
PART IV.

VITAL ACTIONS OF THE LOWER FUNGI.

The vital actions.

Proposed plan of treating the subject.
Havivg discussed the conditions necessary for the life of the fungi with special reference to the nutrient materials which must always be present in their surroundings, it is the object of this part of the work to show how the nutrient materials are taken up, the trans. formations which they undergo in the body of the organisms, in what manner growth takes place, and how the energy, which is necessary in order to enable the fungi to carry out their other functions, is obtained from transformation of the material. It is evident that this subject, which has also to do with, and to explain as far as possible, the special activity of the fungi in exciting fermentation and disease, forms one of the most important chapters on the subject of the fungi.

The tissue change and development of energy of the mould, yeast, and fission fungi agree in their essential points to such an extent that it has not appeared necessary to treat of the three classes separately in this chapter. The behaviour of the fission fungi, as being the most important group from a hygienic point of view, is taken as a groundwork, and it is only at certain places that attention is specially directed to differences in the behaviour of the other chief groups.

In the first place, we shall make a short general review of the tissue change and development of energy of the lower fungi, closely following what is known as to the biology of the higher plants. We must then discuss the individual phases of the vital activity of the fungi, the assimilation of nutrient materials, and the changes which they undergo in the body, the development of 
energy, and the products of tissue change and the excreta. Among the latter the isolated ferments and the ptomaines require a more detailed consideration. Closely allied to these we have those two peculiar, and for hygienic purposes important, phases of the vital activity of the fungi, viz., the fermentative activity and the development of disease.

\section{Review of the Tissue Changc and Development of}

Energy in the Lower Fungi.

For the development of those movements and alterations of material particles, which make up the life of the vegetable cell, a certain amount of energy must in the first place be set free; without this these movements, and therewith the life of the plant, would cease. A small fraction of the necessary energy is obtained by osmosis; by far the greatest portion is, however, supplied to the plant by the splitting up of complex chemical compounds, and by regrouping of the atoms in more stable compounds, in other words by similar transformations to those which occur in the animal body, and which then give rise to the energy which is necessary for the various functions of the animal economy. The vital processes in vegetables Tissue change and animals differ only in the fact that the compounds and developto be broken up are taken up by the animal bodies in in the higher an unaltered condition, while in the case of vegetables plants. they must first be built up from more simple materials by means of the chlorophyll apparatus ; in the lowest forms of plants, viz., in the fungi, however, this preparative apparatus is absent, and the materials are taken up in the form of relatively complex molecules. What, however, is absolutely necessary, and common to the life of the cells of animals, vegetables, and fungi, is the decomposition of complex organic compounds accompanied with the liberation of energy.

These decompositions are carried out by means of the Decomposiliving protoplasm. The latter can apparently, like a tions in the 
ferment, gradually split up large quantities of suitable complex compounds. We do not yet know accurately the nature of the chemical bodies directly concerned in this action of the protoplasm, nor in what way decomposition takes place; it is probable that the compounds are nearly allied to the proteid materials, but are more complex. As products of decomposition we constantly observe carbonic acid, and also some other materials which will be mentioned below. We may, however, conclude from the amount of heat which becomes free at the same time, although it is trivial, that the transformation chiefly takes place in such a way that a more complete union of the atoms and greater saturation of the affinities, with consequent liberation of energy, results. Intra-molecu- This whole process, which is evidently the primary
lar respiraand true cause of life, is usually spoken of as "intramolecular respiration." For this process the access of oxygen is unnecessary, on the contrary it is characteristic of it that all vegetable cells can continue to live and breathe for a time without oxygen, and split up carbonic acid and produce heat. If substances capable of undergoing decomposition are still present in the living protoplasm, their decomposition is sufficient to furnish the necessary energy for the other processes which take place in the protoplasm, and it is only after a considerable time that there is such a deficiency of energy as to lead to the cessation of movement and life.

Decomposition when oxygen is admitted.
Although, therefore, the intra-molecular respiration is the chief and primary cause of development of energy in the plant, the energy so obtained does not suffice permanently to supply the whole amount required. This is usually only obtained when oxygen has free access, and when it takes part in the respiratory process. The compounds broken up in the protoplasm furnish, in addition to carbonic acid, a series of other products which readily enter into combination with oxygen. Thus extensive oxidations occur, and accordingly a more marked development of vital energy which completely 
and permanently suffices for the vital processes. The amount of energy is, however, regulated much less by the amount of oxygen present than by those processes of decomposition in the protoplasm by the intramolecular respiration, which sets up and governs the respiration by means of free oxygen.

The whole respiratory process, whether occurring Destructive with or without oxygen, is evidently of a destructive and assimil character, and it is absolutely necessary that a constant change. supply of new material should repair the deficiencies which occur as the result of the decomposing activity of the protoplasm and the oxidising action of the oxygen, processes which furnish for the most part gaseous and combustible products. As, however, those materials which can be broken up in the protoplasm never exist nor are taken up as nutrient materials, it is evident that there must be a special process of assimilation, which consists in the absorption of the nutrient materials present, and their transformation into compounds suitable for decomposition, and which thus stands in marked contrast to the destructive respiratory process. As a rule the part played by the assimilatory process is in excess of the destruction, and thus leads to the deposit of new protoplasm, and the growth and multiplication of the cells. This is the portion of the tissue change which usually alone strikes the eye, and leads us very readily to overlook the fact that, apart from the new formed material, large quantities of the nutrient substances taken up undergo decomposition in the protoplasm, and are burmed up by the oxygen.

The tissue change of the lower fungi must evidently go on in an exactly analogous manner to that of the higher plants. Here also we have a continuous destruction of organic materials, usually in the presence of oxygen, and in that case presenting the character of a complete combustion. Here also an assimilation of the new nutrient substances must provide the destructible material, and at the same time must supply the requirements as regards growth and multiplication, and it is a 
totally secondary matter that the assimilatory process in this case runs its course without the aid of a chlorophyll apparatus, and that thus certain simple materials, such as carbonic acid, cannot be utilised as nutrient Tissue change materials.-As in the case of the higher plants, so also in of the lower the lower fungi, a certain amount of energy is set free by
fungi. these tissue changes, and this energy is employed for the functions of these minute organisms, for their processes of growth and movement, for the changes in their tissue, and for the molecular processes.

It is true that by the recognition of these essential agreements between the tissue change and the development of energy in the higher and lower plants the whole of our insight into the biological processes of the lower fungi are pretty nearly exhausted. More especially we can scarcely at the present time form any quantitative idea as to the relation between the destructive and the assimilatory tissue change, how far the assimilation and the formation of new protoplasm is as a rule in excess, or what amount of the nutrient material is taken up to serve for the destructive tissue change. Hence in most matters provisional hypotheses as to the tissue change and development of energy in the lower fungi must take the place of facts and certain results.

Differences as compared with the higher plants in respect to the necessity for oxygen.
There is only one difference between the bacteria and the higher plants to which we need draw attention. While the activity of the protoplasm, the intra-molecular respiration, and the respiration by means of oxygen, with their development of energy and the assimilation of very various kinds of nutrient materials, are common not only to the higher plants but also to the fungi, there is a marked difference with regard to their relation to oxygen. As has been mentioned, the higher plants camnot be deprived of oxygen for lengthy periods without injury, because it is only by means of the process of oxidation that a sufficient amount of energy is produced; many of the lower plants, however, can live and multiply for a long time without the presence of oxygen. In this case the small amount of energy which is furnished by the intramolecular respiration either suffices for the whole of the 
vital functions, and this is the more intelligible the source of more correct are our conclusions as to the absolute easerg in the relations of weight and energy in these minute beings; anaërobes. or these organisms can take oxygen from certain nutrient materials and employ it for the oxidation of other complex substances. In the majority of cases the intramolecular respiration does not permanently suffice to supply the necessary amount of energy for the bacteria, on the contrary they can only bear the loss of oxygen if a suitable substitute is present in its place. This sub- Substitution stitute is furnished by the fermentative process, in which of oxygen br a large amount of material present in the nutrient medium tive process. is broken up superficially, but nevertheless in such a manner that a quantity of energy is set free which is about equal to that obtained by the process of oxidation. Thus fermentation may take the place of the oxygen, and the respiration by means of oxygen and the fermentative activity may be looked on as of equal significance as regards their relation to the vital processes in the fungi.

The little that is known as regards this peculiar mode of tissue change and development of energy in the lower fungi, may be put together in the following imperfect description, in which the outlines of the picture which will ultimately be constructed as the result of future investigations are probably scarcely recognisable.

\section{The Absorption and Assimilation of the Nutrient}

\section{Materials by the Lower Fungi.}

As the penetration of the nutrient materials must take Absorption of place in the case of the fungi, just as in that of every the nutrient vegetable cell, by means of diosmose through the cell wall and the plasma, it is evident that only those substances can be taken up which are diffusible and present in a watery solution; where the fungi apparently feed on solid materials, these substances are previously dissolved by the secretions of the organisms. In these preparatory processes the chemical ferments produced by the fungi take part; for example, those which peptonise solid 
albumen, or which hydrate the saccharine material and make them available for the use of the fungi, or which dissolve cellulose, and thus enable those organisms which live as parasites on vegetables to obtain an entrance.

The chemical nature of the materials taken up may, as has been above mentioned, be very various. That a transformation of these materials, a process of assimilation, must occur on their entrance into the cells of the fungi is probable, because it is not at all likely that these different compounds are of equal value as regards the different operations which occur within the cell. It is true that the assimilation of the carbon is not so marked as in the case of the chlorophyllous plants, anả morè especially that carbonic acid cannot be utilised. Nevertheless methylamine, acetic acid, alcohol, benzoic acid, tartaric acid, leucine, \&c., can without doubt be converted into more complex substances if they are offered as the only source of carbon; and this first product of assimilation must be built up with a certain expenditure of energy, which is, it is true, not so great as in the case of the assimilation of carbon from carbonic acid by green plants, but which is not replaced by energy obtained from the sun's rays, but by energy which must be set free as the result of other transformations occurring in the interior

Assimilation of carbon. of the cells. For the present we can only form hypotheses as to the nature of the first carbon assimilation product. In the case of the higher chlorophyllous plants starch is frequently one of the first products ; in the case of the lower fungi, however, this substance is apparently with few exceptions entirely absent (only in some species of bacilli and in leptothrix, see page 370). From the varying nutritive value of the carbon compounds we may perhaps come to the conclusion with Nägeli that the first product of assimilation consists of three carbon atoms, with which hydrogen and oxygen atoms are combined, and which can then unite with a similar complex of three carbon atoms to form a larger molecule of six carbon atoms; the more nearly the nutrient materials approach this hypotbetical body the less are the difficul- 
ties in their assimilation, and the more suitable are they for the nutrition of the plant.

Without doubt also the nitrogenous bodies are built Assimilation up to a very large extent in the cells; and not only of nitrogen. those which constitute the protoplasm, but also those which are broken up in the intra-molecular respiration are probably always of more complex structure than the nutrient materials. Even the peptones undergo a transformation during assimilation, and where ammoniacal salts and amides are the only sources of nitrogen a complex process must result, and more especially a union with assimilation products rich in carbon. The varying expenditure of energy which is necessary for building up the assimilation products according as the material offered as food is closely allied to these products in composition, or differs much from it and is much simpler, explains in part the varying nutritive value of these compounds. The more active the growth and the new formation of protoplasm, and the more heterogeneous the nutrient materials, the greater is the amount of energy which must be set free by the respiratory processes.

The salts, likewise, do not always appear to be taken Rôle of the up from the nutrient mixture in the same form in which mineral they are present within the cells. Here and there substances. transformation and decomposition must occur under the influence of the organic acids which are formed; further, sulphur, phosphorus, and magnesium, and possibly also calcium and potash, enter into combination with the complex molecules of the proteid materials of the protoplasm. For the production of the phosphorus, phosphoric acid seems to be alone suitable; the union of the phosphorus with proteid bodies must occur within the cell. These transformations of the inorganic materials, however, are much less extensive, and require much less energy, than those of the.organic substances.

In the case of the higher plants the composition of the salts may vary very greatly. Often excessive quantities of the necessary nutrient salts are taken up, so that the relation of the individual constituents 
to the ashes varies very greatly ; elements are also often absorbed which do not in reality possess the significance of necessary nutrient materials, and they can pass through the plant or be deposited in various parts of it without exercising any function (for example silicon, aluminium, manganese, \&c. ; silicic acid may at times form 50 per cent. of the ashes). It is still uncertain whether anything similar occurs in the case of the fungi ; the analyses which have been as yet made are not sufficiently elaborate to enable us to draw conclusions as regards this point.

As, according to Nägeli's experiments, potash cannot be replaced by calcium or magnesium, it is probable that the alkalies and the alkaline earths play very different parts ; the latter only appear to form deposits in plasma and in the cell wall, while the alkaline salts are in part dissolved in the free cell fluid. That the potash compounds cannot be replaced by sodium or lithium is probably not due to diosmotic differences, but to the less affinity of potash for water; we may perhaps assume that the salts of sodium and lithium when in a state of solution are surrounded by firmly united molecules of water, which render them unsuitable for contact (Nägeli).

Relation be. tween the plastic materials and the products of the destruc. tive tissue. change.
3. Alterations which the Nutrient Materials undergo, and the Functional Activity of the Lower Fungi.

The materials assimilated undergo within the cell a series of transformations, in that they are either employed in the manner described above for the formation of plastic material, and thus for building up new cell substance; or they undergo the destructive tissue change in which they are destroyed by the respiration, and in part converted into materials which can no longer serve as nutrient material, and which must be got rid of as excreta. Just as in the tissue change of animals, it is not by any means necessary to assume that all the assimilated materials form in the first place cell substance and afterwards undergo destruction; it is, on the contrary, probable that 
only a small fraction is employed to replace the cell substance which has been destroyed, and that the greater part remains in the juices of the cell, and is subjected to the decomposing action of the protoplasm while it is in contact with it in a soluble form; finally, a very varying portion is employed for the formation of new cell material, and thus meets the demand for growth and multiplication.

A more accurate insight into the quantitative division of these respective róles is however impossible at the present time. It is, indeed, frequently doubtful whether a body which is found by analysis to be a constituent part of the organism should be looked on as a plastic material suitable for its future functions, or only as an excretory product. It sometimes happens that substances which are split up from more complex compounds by intramolecular respiration and excreted by the cells, can still act as nutrient materials, and can be employed by otheror it may be the same-cells for the formation of plastic material; and in this case it is more or less a matter of choice whether these bodies are reckoned among the excreta or among the plastic materials. This difficulty, however, is present to a much less degree in the lower fungi than in the higher plants; for in the former we may look on the gaseous bodies, such as carbonic acid, with certainty as excreta, whilst the higher plants can assimilate them again.

As nitrogenous plastic materials, we have chiefly the Nitrogenous whole group of proteid bodies; these are present in plastic solution in the juices of the cell, and then either undergo decomposition in the protoplasm, forming for example new cell substance, or are deposited in an insoluble condition in the cell protoplasm. Nägeli was able to make out the surprising fact that yeast cells excrete albumen and peprone; the peptone being produced in non-fermenting neutral or acid nutrient media, and albumen in fermenting or non-fermenting fluids with an alkaline reaction. In addition to the proteid substances numerous amides and amido-acids, especially asparagine and glutamine, are found in the higher plants. These may be looked on partly as forerunners, and partly as the 
products of the decomposition of the proteid materials. In the same manner amides, such as leucine and tyrosin, also guanine, xanthine, and sarcine, are found in the yeast and fission fungi. More especially in the so-called selffermentation of the yeast numerous combinations of this kind occur, while asparagine and glutamine have not as yet been demonstrated in the lower fungi.

These amido bodies are for the most part good nutrient substances; there is no doubt that in the case of the lower fungi the necessary nitrogen can be obtained from them alone, and that they suffice for building up the proteid material of the protoplasm; while, on the other hand, where the nutriment is exclusively albuminous, or in the self-fermentation of the yeast, it has been shown that they arise from the splitting up of proteid-like bodies. These serve at the same time as plastic material and as excreta; and it is typical of the economical manner in which as regards nitrogen the functions of the fungi are performed, that in the decomposition of these substances portions as a rule remain, which can again be utilised.

Absence of nitrogenous excrementitious materials.
Those nitrogenous substances which readily appear in a gaseous form, such as trimethylamine and various compounds of ammonia-e.g., carbonate of ammonia, sulphate of ammonia, \&c.-cannot on that account be looked on as excreta. These also can, under conditions otherwise favourable, act as satisfactory nitrogenous nutrient materials, and it appears not improbable that they may be again employed as plastic substances. Accordingly, it is only free nitrogen, nitro bodies, and, in the case of some classes of fungi, the nitrates, which can be reckoned as under all circumstances excretory products; and as these apparently only occur under special circumstances, there is almost never a separation of undoubted excrementitious nitrogenous products. Hence it follows that a colony of fungi may exist and multiply for an extremely long time on a very small quantity of nitrogenous material, because the products of the decomposition of the proteid materials constantly recombine with non-nitrogenous compounds, and thus form new proteid substances which may again be utilised. 
It has, however, been shown, more especially in the case of yeast, by the investigations of Pasteur, Schützenberger, Mayer, and others, ${ }^{*}$ that the amount of nitrogen gradually diminishes when yeast is cultivated in a pure saccharine solution; and this is true not only as regards the percentage quantity of nitrogen, but also as regards its absolute amount; it therefore follows that nitrogenous materials are separated as excreta, and disappear in a gaseous form. Such a loss of nitrogen often occurs, when there is a relatively quick and copious formation of volatile nitrogenous substances which is not compensated for by the assimilation of nitrogen by the cells. Further, if those nutrient materials which can furnish carbon to the cells are absent, all those nitrogenous products of decomposition which do not at the same time contain utilisable carbon in their molecules (for example, ammonium salts, urea, oxamide), must remain as useless excreta; and in such a case, the diminution of the nitrogenous material is very readily noticeable, but in reality only because the carbon is not used up in such a sparing manner, and because the continuous loss of the carbonaceous gases leads to the exhaustion of this element. Finally, the amount of other nitrogenous substances in the nutrient material exerts an influence; if numerous highly nutritious nitrogenous bodies are present, nitrogenous molecules of an excrementitious character will appear much sooner, and, being less suitable as nutrient materials, will not be further used up. In cases of necessity, however, part of the nitrogenous decomposition products may probably again form nutrient material, and in this way there is a very parsimonious circulation of the material.

These facts enable us to some extent to under-Peculiarcirstand Bolton's experiments, referred to above, in which nitrogenous some forms of bacteria can live and multiply rapidly in material. pure distilled water, i.e., where an extremely minute quantity of nutrient material is present. These experi-

* Pasteur, Ann.Chim.phys., (3) 58, 507.-Schützenberger, Compt.rend., 1874, vol. 78.-Mayer, Unters. über die alkohol. Gälırung: Heidelberg, 1869. 
ments showed an equally marked multiplication of the organisms if the growth was allowed in the first place to attain its maximum, and if the water was then sterilised and again sown with individuals of the same species of bacteria; this occurred on several repetitions of the process. In this case it is evident that the products of tissue change must have been to a great extent excreted in a form which could again be utilised, and that the dead individuals could in like manner serve as nutrient material. It is only by some supposition of this kind that we can conceive the continuation of the life of these fungi with such a slight diminution of the organic materials, and the repeated development of new generations on the same substrata.

Non-nitrogen. Non-nitrogenous plastic materials secm to play a ous plastic materials. much less important part in the life of the fungi than in that of the higher plants. Starch is only found in exceptional cases, and of the other carbo-hydrates we find, in the case of mould fungi, trehalose and glucose, and in some cases also the alcohol mannite, which is usually reckoned among the carbo-hydrates. Of organic acids, tartaric acid, malic acid, and citric acid are usually reckoned as plastic materials, but as regards their destiny in the fungi nothing is as yet known; fatty oil seems, however, to be a frequent constituent of the cells of the fungi. Along with these mobile matters, corresponding in so far to soluble albumen, we have also cellulose, which is deposited in the cells and constitutes in the case of the mould and yeast fungi almost the whole of the cell membrane, but in the fission fungi only a small portion (see p. 526).-These materials are taken up from the nutrient substrata only to a slight extent in a prepared and utilisable form. As a rule, they arise in two ways, which very probably are often combined. We either find that they are built up of more simple compounds, as is, for example, certainly the case when relatively simple compounds (acetic acid, alcohol, leucine) are the sole source of carbon, or the non-nitrogenous plastic materials arise by the splitting up of more complex molecules, and more especially of 
the proteid substances, and this is, in fact, the only mode of origin when the fungi are fed, for example, only on peptone or albumen.

We must imagine, then, that the further fate of the non-nitrogenous substances is that they are in part employed for building up portions of the organisms (cellulose, fat); in part they combine with the nitrogenous molecules, and thus furnish the proteid-like materials; in part, lastly, they are split up in the protoplasm, chiefly in the form of carbo-hydrates, and further destroyed by the oxygen, thus furnishing true excretory products. Some of them can, like the nitro- Non-nitrogengenous materials, act on the one hand as plastic material, products. and on the other hand as excreta; for example, the organic acids (which are scarcely utilised when better carbonaceous nutrient materials are present at the same time) are made use of and given off if the nutrient material be poor in carbon, but otherwise suitable. Among the non-nitrogenous constituents of the fungi there are, however, some which must be looked on as true excreta, and which always act as such. Thus, oxalic acid, formic acid, \&c., cannot again play a part as nutritive compounds; and carbonic acid more especially cannot be utilised by the fungi, and hence must in all cases be looked on as excrementitious matter. As, however, carbonic acid is always produced by all the fungi, we have in its separation the chief reason for the gradual impoverishment of a nutrient mixture. Some aromatic products appear also to be formed to a slight extent in the tissue change of the fungi; for example, phenol, skatol, indol, \&c. As a rule, these bodies are bad nutrient materials, and indeed, at a certain degree of concentration, can act as poisons, and hinder the development of the fungi, even when other nutrient compounds are present; thus they for the most part behave as true excretory products.

Oxygen is the element which, in addition to the Tissue change materials mentioned, takes the most active part in the is present. changes which occur in the bodies of the fungi. As 
the result of its action there is at first a complete combustion, and therewith a production of active energy which suffices for the functional activity of the organism. The most various groups of atoms fall a prey to the oxidising action of the oxygen, nevertheless it is chiefly those which have been formed in the protoplasm as the result of the intra-molecular respiration, and which are more easily attacked by the oxygen than the materials which are taken up by the food and formed by the process of assimilation. The absorption of oxygen, and the respiration by means of oxygen, go hand in hand with the energy of the decomposition which takes place in the protoplasm, and therefore with the activity of assimilation and growth, and thus they render a large amount of energy available for the active tissue change.-External influences, especially the pressure of oxygen in the surrounding medium, appear relatively indifferent as compared with the powerful influence of the protoplasm; it is only the temperature of the nutrient materials which seems to exert a more marked influence on the amount of respiration, but it acts only by influencing the protoplasm and the decomposition occurring in it. In the case of the higher plants, it has been found that as the temperature rises, the extent of the respiratory process continually increases in such a manner that its curve rises from zero until the temperature at which death occurs is almost reached, and then it suddenly falls to zero. Whether a similar law holds good in the case of the micro-organisms is not yet known, but it is, à priori, probable.

Tissue change when oxygen is absent.
If oxygen is absent, decomposition in the protoplasm still continues for some time, as has been ascertained by investigations on higher plants, and more especially on fruits, but the tissue change differs both as regards its products and its energy. Atomic combinations which would otherwise at once enter into union with oxygen, either remain unaltered after they are once formed, or enter into combinations with other bodies, so that all sorts of products result, which are not observed when plenty of oxygen is present. Carbonic acid and 
water are chiefly formed when oxygen is present, and beyond this only slight quantities of compounds which are not so completely oxidised; where oxygen is excluded we still find a production of carbonic acid, which is by no means insignificant in amount, but, nevertheless, is much less than that produced by the respiratory process (282 grammes of pears furnished, for example, in 5 months $1762 \mathrm{ccm}$. of carbonic acid); in addition, alcohol, organic acids, and at times hydrogen, are formed.* Only a very minute quantity of energy is set free by the formation of these products from the more complex molecules; so that on the whole it is only for a short time, and under otherwise favourable circumstances, that the requirements of the living cells as regards energy can be supplied.

Although this intra-molecular respiration, as has been mentioned above, suffices for the complete supply of the energy required in the case of the anaërobic fission fungi, we have no facts with regard to the more intimate processes in these cases, nor with regard to the products formed. The tissue change of these organisms is more easily analysed when they can at the same time excite fermentation in the nutrient materials. In this case they are under particularly favourable circumstances as regards life, in that they have a substitute for the supply of the necessary energy in the absence of oxygen. Under these circumstances they are able to supplement the decompositions which take place in their protoplasm in such a way that a very large quantity of fermentescible substances-much more than the cells are usually able to decompose in their interior-is superficially broken up with the liberation of energy; and the latter is then utilised by the living and growing cells to supply the energy they require. At the same time, the substances which undergo this decomposition cannot be completely burned up; on the contrary, relatively complex products result, which differ much according to the fer-

* Lechartier and Bellamy, Compt. rend., 1869, T. 69 ; 1872, T. 75 ; 1874, T. 79.-Brefeld, Landwirthschaf. Jahrb., 1876.-Müntz, Ann. Chim. Phys., 1876. 
Quantitative estimation of the tissue change.

mentescible material, and are in part similar to those which usually arise when the respiration is exclusively intra-molecular.

If we attempt to estimate quantitatively tho tissue change of the fungi in the manner usually employed in the case of other organisms, viz., by placing on the one side the quantity of material taken in, and on the other side the amount which is destroyed, and also that employed for building up new tissue, we soon find that we are not as yet in a position to make any such estimation. If fungi settle in a nutrient medium the nutrient materials are consumed very quickly, the fungi multiply rapidly, and a large portion of the nutrient materials consumed is contained in the newly formed colonies of cells which are distinctly visible to the naked eye. Another portion has, however, been used up in the respiration and in the destructive tissue change, volatile products escaping and other excretory substances being dissolved in the nutrient medium. It often happens that the elementary constitution of the latter is completely altered, because the products of the tissue change have set up changes which destroy the nutrient qualities of the remainder of the nutrient solution (formation of excess of acid or of an alkaline reaction with precipitation of earthy phosphates, \&c.). Hence it is very difficult by analysis of the nutrient substratum to estimate the relative results of assimilation and of destruction, and we require more numerous investigations before we can obtain an insight into the quantitative relations of the tissue change of the fungi.

If we only pay attention to the process of assimilation, and if we take into account the enormously rapid multiplication of the fungi, we can understand as the result of this process alone the remarkably rapid consumption of a nutrient medium (especially where fission fungi are concerned). As above stated, we may assume that the complete growth and the division of a bacterium into two organisms occurs on an average within one hour; a single bacterium introduced into a nutrient solution furnishes 
after 48 hours (where there is no interference with growth) a colony consisting of two hundred and fiftysix billions of individuals ; and this colony will, according to Nägeli's estimation, represent a weight when Estimation of dry of about eight grammes, which consist chiefly of the amount of albuminoid substances. During the next hour sixteen required. grammes, and after a second hour thirty-two grammes of the nutrient solution will be transformed into fungus tissue; and in the course of the third day, more especially where we commence with a number instead of a single individual, we have truly colossal numbers which as a matter of fact are only not usually met with, because the close aggregation of the fungi and the production of noxious materials as the result of their growth hinders their free development.

Finally, as regards the interchange of energy, which Interchange accompanies the tissue change of the fungi, we do not as of energy in yet know anything directly, but can only draw conclusions fungi. from analogies with the higher plants. As regards the amount of energy taken in, the state of matters in the lower fungi differs somewhat in that it is practically only the chemical transformations of which we spoke above which furnish the necessary energy. In the case of the higher plants the rays of light supply the energy necessary for the assimilation of carbon; but the fungi which do not contain chlorophyll are unable to utilise this source of energy, and the whole assimilatory process takes place at the expense of the energy which has been liberated by chemical decomposition.

The energy which has been obtained by the respiratory process is used up partly in the process of assimilation and partly in the further combinations of the materials; also in the process of growth and germination; in locomotion; and finally in the production of heat and light.As regards the consumption of energy in the processes first referred to, we have no precise knowledge. In the process of growth, more especially in the case of the fission fungi, a large quantity of energy is often used up; rapid growth will therefore always go hand in hand with free respiration and the production of carbonic acid. A 
Influence of temperature on movement.

\section{Of oxygen.}

Of nutrient materials.

Of light.

Production of heat.

considerable expenditure of energy is also necessary for the process of the germination of spores, and this energy is only obtained in the case of most of the fission fungi by the respiration with oxygen, or by a vicarious intense fermentation. The movements of the fission fungi are swimming movements in fluid media, and are generally or always produced by cilia. The mode of movement varies much (see p. 159), and it is usually associated with simultaneous rotation around the long axis. The energy of the movement seems to be dependent especially on the temperature and on the supply of oxygen.

Too low a temperature, like too great heat, leads to a condition of arrest of movement, and the intermediate temperatures which favour movement most, vary very markedly in the different species of bacteria. According to Engelmann's experiments cited above the tension of the oxygen also influences the individual species in very varying degrees, and very slight alterations in it often interfere with locomotion.-Pfeffer* has further indicated the presence of suitable soluble nutrient materials as an exciting cause of movement; where the nutrient material is introduced into the fluid containing the bacteria at one side, the bacteria move towards this part; and if a capillary glass tube containing nutrient solution is placed in the fluid, the bacteria move towards the orifice of the tube and pass into its interior. If the nutrient materials are inadequate these movements do not occur.-Whether, finally, light exerts an influence on the mobility of the fission fungi, in a similar manner as it does in the case of certain swarming spores, must remain for the present undecided, because too few species have as yet been tested in this direction. $\dagger$

Another form of movement is presented by alterations of shape in the protoplasm without any true locomotion; the dancing movement of the micrococci may be ascribed to changes of this kind.

A distinctly noticeable production of heat, similar to

* Unters. des botan. Instituts zu Tütingen, i., 3 Heft.

† See Strasburger, Wirkung des Lichts und der Würme auf Schwärmsporen, 1878.-Engelmann, Botan. Zeitg., 1882. 
that seen in the higher plants, can also be observed in the lower fungi. This is minimal in amount if the intramolecular respiration alone is going on, and if there is neither access of oxygen nor the occurrence of fermentation; under these conditions an elevation of temperature of $\cdot 2^{\circ} \mathrm{C}$. over the surrounding temperature was found in yeast (growing in hydrogen); when air was admitted the elevation of temperature increased to $1 \cdot 2^{\circ} \mathrm{C}$., and when fermentation occurred, to $3.9^{\circ} \mathrm{C}$.* These numbers, of course, only apply to the particular circumstances under which they were obtained. Elevation of the temperature of the nutrient medium has also been observed in the case of the fission fungi, though chiefly during the fermentative action. $\dagger$

Lastly, a development of light sometimes accompanies Development the vital processes of the fungi. In the case of some of of light. the higher fungi, especially of species of Agaricus, this phenomenon has been known for a long time; quite recently the phosphorescence which putrefying fish or pieces of flesh at times show has been ascribed to lower fungi, especially to micrococci, which, however, only occasion this phenomenon when a free access of oxygen and a temperature not too low, permit an energetic respiration.

\section{The Products of the Tissue Change of the Lover Fungi.}

The number of the products of tissue change which Products of are from time to time observed in cultivations of fungi is extremely great; gases, such as carbonic acid, hydrogen, marsh gas, sulphuretted hydrogen, ammonia; nitrates; water; sulphur; also volatile bodies, such as trimethylamine, alcohol, formic acid, acetic acid, propionic acid, butyric acid; fixed acids, such as lactic acid, malic acid, succinic acid, oxalic acid, tartaric acid; sulpho-acids, such as taurin, amides of the fatty acids, especially leucine, alanine, \&c. ; bodies of the aromatic

* Eriksson, Unters. b. dem botan. Institut. in Tübingen, 1881, Heft 1.

† Popoff, Botan. Jahresb., 1875.-Wernich, Organisirte Krunkheitsgifte. 
series, such as tyrosine, phenol, cresol ; reduction products, such as indol, hydro-paracumaric acid; complex molecules, such as carbo-hydrates, peptone, hydrolytic ferments; finally, colouring materials and alkaloid-like poisonous substances. According to the species of the chief fungus present, and according to the external conditions of the nutrient medium, sometimes the one, sometimes the other of these products appear, and a particularly large number of them is observed when we have to do with fermenting or putrefying substrata.

Among these products of tissue change we can separate a group which generally occurs in the vital processes of all, or at any rate of numerous fungi; and we can place in opposition to this the group of the rarer and more specific products, the occurrence of which is limited to one or a few species. It is also of special interest to ascertain in how far the number and the quality of the products of each individual species of fungus undergo variations according to differences in the composition of the nutrient substratum, and whether, on the other hand, when the nutrient substratum is the same, the same products are always furnished by the same species of bacteria; in other words, whether the power of each species of breaking up a given nutrient substratum in a particular manner is constant and special. It is clear that the answer to these questions is of extreme significance for the diagnostic value of the products of the tissue change.

Carbonic acid. Carbonic acid alone is of constant occurrence; water and a nitrogenous body also undoubtedly always appear as products of decomposition, but they do not, like the carbonic acid, come under observation as excreta. The life of the lower fungi seems never to go on without separation of carbonic acid; hence it is always present, although in very varying quantities, whether it arises only as the result of intra-molecular respiration, or whether oxygen has been present, or fermentation has occurred.

Fatty acids and amide compounds.
A production of fatty acids and oxy-acids (acetic acid, propionic acid, butyric acid, lactic acid, succinic acid, 
\&e.), as well as of their amide compounds, occurs very often. We find one or other, or it may be a mixture of them, in most of the cultivations of fission fungi even when there has been no fermentation, but merely simple consumption of the nutrient material and the multiplication of the fungi; they are present, however, in much larger quantities when fermentation has occurred.

More seldom, but perhaps also equally widely distri- Aromatic buted, we find aromatic bodies (phenol, paracresol, \&c.) products. as products of the tissue change of the fission fungi; these have as yet been found chiefly or only in fermenting and putrefying mixtures.

Further, numerous fission fungi produce ferments, Ptomaines, others produce substances which act like poisons and ferments. resemble alkaloids, and are commonly grouped together under the term ptomaines. These two products of tissue change require, on account of their special importance in hygiene, a special discussion in the following pages.

Colouring materials are in some cases very common, Colouring in others they are among the rarer products of the tissue change. Red pigment is, for example, formed by the pink yeast, by micrococcus cinnabareus, by bacillus prodigiosus, by bacillus indicus ; green colouring matter by bacillus pyocyaneus, bacillus fluorescens putidus, bacillus erythrosporus, bacillus fluorescens liquefac., \&c.; blue colouring matter by bacillus cyanogenus, and in putrefying mixtures (Brieger, Rohmann); violet by bacillus janthinus; brown by bacillus fuscus; yellow by very numerous micrococci and bacilli.-These pigments are very rarely present in the cells or in the cell walls, (these are usually colourless), and it is only the substratum on which the fungi grow that is impregnated with the pigment. It has been further observed, and has recently been ascertained by Liborius in the case of a large number of pigment bacteria, that the colouring matters are only formed when free access of air is allowed, while if the access of air is even only moderately hindered (by covering with oil, \&c.), the substrata and the colonies remain completely colourless, 
Dependence of the formation of the colouring matters on the entrance of air.

Influence of the nutrient substratum on the forma. tion of pigment.

Chemical nature of the pigments.

Products of fermentation although otherwise the growth of the fungi is not affected. Hence the probability is that these pigments are not produced as such by the fungi, but that the latter form a chromogenic substance which becomes converted into the colouring matter only as the result of the action of oxygen. Not uncommonly we notice different shades of the pigment, and at times even marked differences in the colour when the organisms are grown on different nutrient substrata; this is evidently due to the influence of the different substrata, and of their reaction on the chromogenic substance. Such variations in the pigment are well seen in connection with the bacilli of blue milk. Very often a difference in the colour of a cultivation is due to contamination with other fungi; and this point must always be carefully tested before we refer the difference to the influence of the nutrient substratum.

But little has been ascertained as to the precise nature of these pigments ; with regard to most of them we only know a few reactions which have already been referred to in the systematic part of this work. The colouring matter, which has been most completely investigated, is that of greenish blue pus, pyocyanine; Gessard ascertained that chemically this substance was a base which was closely related to the ptomaines; the sulphate and chloride salts crystallise in the form of reddish needles, a crystalline precipitate is also deposited from their solutions by chloride of gold, chloride of platinum, iodide of potash, and mercury, further by tannin, chloride of mercury, and phosphoric molybdic acid. From a mixture of ferro-cyanide of potash and chluride of iron pyocyanine gradually throws down a precipitate of Berlin blue, but more slowly than morphine.

We have further to consider the specific products of fermentation which are limited to certain bacteria. Many of these, such as lactic acid, butyric acid, æthylic alcohol, \&c., occur, it is true, very frequently as products of tissue change and of fermentation, but nevertheless, when we take into account the quantity of these products and their relation to each other, we must look on them 
as specific products of the action of certain species of bacteria; they are only formed in large quantities under the influence of a few fungi, and they then go hand in hand with the best development and growth of these species. It is more seldom that we meet with other alcohols containing more carbon, such as mannite, viscose, \&c.; these appear almost entirely to be specific fermentative products of a few species of fission fungi.In like manner we have, as rare and limited products of the tissue change of the bacteria, the granulose of the fungi, which become blue on the addition of iodine, and the sulphur of the species of beggiatoa.

These various products of tissue change are not, how-Variations in ever, so limited to the species of fungi which produces the products them that each species only produce one of the products change as the belonging to the same group; on the contrary, we very alterations in frequently observe that the same species of bacteria can the nutrient at the same time produce carbonic acid, fatty acids, ferments, ptomaines, and colouring matters ; that they can also excite fermentation, and eventually can, as the result of their parasitic growth, set up disease in animals or vegetables attacked by them. We have already, on page 351 , referred to this matter in the case of many fission fungi.

As regards the answer to the questions as to the constancy and specific nature of the products of the tissue change, it becomes clear from numerous observations that the individual species of bacteria cannot on every nutrient soil furnish all the materials which it is capable of producing, but that, on the contrary, many products require the presence of special constituents in the substratum, these constituents not, however, being necessary for the life of the fungus.

The variation in the shades of the pigment according to the nutrient substratum points to some such infiuence of external conditions; and this influence is still more marked, for example, in the case of the bacilli of glanders and cholera, which only produce a brown colouring matter on potatoes and not on any of the other ordinary nutrient substrata; and it is also shown 
by the fact that the occurrence of definite products of fermentation is absolutely dependent on the presence of definite fermentescible substances, without which, howerer, the life of the bacteria in question can go on very well. We have also to bear in mind the marked influence exerted by the presence or absence of oxygen on the nature of the materials formed; further, that the composition of the nutrient medium and the excess of nitrogenous or non-nitrogenous substances determine the relative quantity in which the various products usually appear. Finally, in some cases abnormal alterations in or mere accidental admixtures with the nutrient medium lead to the transitory appearance of unusual products. In the same way we can observe in the higher plants the formation of large quantities of amides when there is no assimilation of carbon; further, the formation of benzoic acid when hippuric acid is given to the plants as the nitrogenous nutrient material. In like manner, the mould fungi, for example, are able to form gallic acid and glucose from tannic acid, and it is probable that the above-mentioned (p. 528) splitting up of the nitrates occurs in the same way. More elaborate researches will, without doubt, lead to the discovery of many of these more or less accidental products of tissue change occasioned only by deviations in the nutrient medium, and disappearing again with alteration in the nature of the soil.

Constancy of the products of the tissue change where the nutrient conditions remain the same.

These differences in the excreta do not in the least prevent us from utilising certain characteristic products of tissue change as a means of recognising the different species of bacteria. For so long as the external conditions remain the same, the same products of tissue change constantly accompany the specific form. We do not find that other fungi suddenly acquire the power of yielding products which are characteristic of a certain species of bacteria ; and where normal conditions are to some extent maintained, it happens just as seldom that this species of bacteria loses its characteristic properties, and furnishes other products of tissue change instead. Thus we find that the production of colouring matter, 
the formation of peptonising ferments, or the specific fermentations, so constantly accompany the same species of organism that we can employ these facts as diagnostic means for distinguishing and recognising the species. In the diagnostic key given above the possibility of peptonising gelatine and the production of pigment form a basis for the differentiation of bacteria otherwise very difficult to distinguish from each other.

Even when, under the influence of abnormal external conditions, these characteristic products, and along with them the most important means of recognising the species of bacterium, have disappeared, the property of the fungus in question can still be always regained as soon as it is cultivated under those conditions under which this property is usually observed. For even when Retention of the temporary unfavourable conditions were so abnormal this constancy that some of the individuals died, or were pathologi- action of hurtcally altered, it usually happens that if any individuals ful influences. retain their power of development, the same products of tissue change which are normally observed constantly reappear under the same normal conditions. The bacteria evidently behave in this respect as a whole like the higher plants, which do not acquire or lose the power of producing this or that specific product of tissue change; the hemlock, indeed, loses its power of producing conium, and the plants which furnish indigo cease to prepare indigo, when they lead a morbid existence under abnormal conditions, but both these functions are resumed when more favourable conditions permit the surviving examples or their offspring to exercise fully their vital functions, and thus under all circumstances this power remains as a specific property of each specific species.-It is only with regard to some with regard of the properties of the lower fungi, viz., the production to the producof fermentation or disease, that there is a peculiar tation and deviation from the behaviour of the higher plants; the fission fungi may permanently lose these properties under the action of abnormal external conditions, and this loss may then be transmitted to the offspring through a number of generations even when the con- 
ditions of existence have again become normal. This matter of attenuation is more fully entered into in the following chapter on the conditions affecting the death of the organisms.

Injury of the bacteria by the products of their own tissue change.

The products of the tissue change of many of the fission fungi appear to exercise a remarkable inhibitory action on the growth and multiplication of the same organisms. This has been definitely ascertained in the case of certain fermentations; thus, as is well known, in the alcoholic fermentation, alcohol when present in the nutrient substratum in the proportion of 14 per cent. interferes with the vital activity of the yeast cells; similarly, the ammoniacal fermentation of urine ceases when the amount of carbonate of ammonium In fermenting has risen to about 13 per cent.; in like manner the mixtures. lactic acid and the butyric acid, which are formed in the corresponding fermentations, must be neutralised by the addition of carbonate of lime or of oxide of zinc, because otherwise the constantly increasing amount of free acid is injurious to the life and the fermentative activity of the bacilli which are at work (lactic acid is inIn growths jurious even in the amount of 0.8 per cent.).- - Analogous
without without actions have also been often suspected with regard to the products of the tissue change of many bacteria where no fermentation is going on, but in these instances it has not been demonstrated with complete certainty. The relatively rapid death of these bacteria in nutrient substrata which still contain a large amount of good nutrient materials is usually explained by the hurtful action of the accumulated products of their own tissue change. Suppositions have also been frequently made as to the more precise nature of the materials which come into play in this action; attention has been chiefly paid to the aromatic products (phenol, paracresol, \&c.), which are found in numerous putrefactive processes, for these as a matter of fact exert an energetic inhibitory action Nature of the even in very small quantities. But even for these views injurious products. proof is still wanting, because from the occurrence of 
aromatic substances in certain fermentations we cannot without further evidence draw conclusions as to their general presence in the tissue change of other fungi, and because perhaps in this direction also the individual species of bacteria have a different and specific behaviour. -Buchner thinks that he has recently observed a totally different influence of the products of tissue change in the case of the cholera spirilla; these organisms are thought to develop particularly well, and better than other forms of fission fungi, in a nutrient solution which contains the products of the cholera spirilla obtained from a previous cholera cultivation.*

A further effect of the products of tissue change is Injurious their supposed action on the development of other influence of species of fission fungi. The observation that some of tissue the products species, more especially the sensitive pathogenic forms, otherbacteria. rapidly die, when, at the same time, saprophytic fungi have established themselves in the same nutrient medium-death occurring much too quickly for any hurtful action by the withdrawal of nutrient materialcan scarcely be explained otherwise than by supposing that the products of the tissue change of the saprophytic fungi have exerted a poisonous action on the other organisms. Here, however, we also require more precise facts, and more especially with regard to whether the group of aromatic products which is common to many saprophytic fungi is the important one, or whether in the case of different fungi different products take part in the action against the concurrent organisms.

\section{The Ptomaines.}

In investigating putrefying mixtures the discovery Ptomaines. was first made that, under the influence of bacteria, nitrogenous bases arise which are, in many respects, similar to the vegetable alkaloids; some of these bodies are innocuous to the higher organisms, others, however, like the alkaloids, exert a poisonous action. These basic bodies were found when putrefaction had gone on for some

* Münch. ärztl. Intell. Bl., 1885, Nr. 50. 
Extension of the term ptomaines to all the nitrogenous bases produced by bacteria.

First demon. stration of toxic putrefactive pro. ducts.

First demonstration of chemically pure ptomaines. time in human dead bodies, and the whole group of these materials was consequently included by Selmi under the designation "cadaveric alkaloids or ptomaines" (from the Greek word $\pi \tau \hat{\omega} \mu a$, a dead body). It is well to retain this term still, although recent investigations have shown that nitrogenous bases with specific action appear not only in the putrefactive process but also among the products of tissue change of pathogenie bacteria.

It would lead us too far to give here an accurate historical statement of the investigations which have been devoted during the last few years to the demonstration and analysis of the ptomaines.* The credit of having first drawn attention to the occurrence of poisonous putrefactive bases belongs to Panum; at a subse. quent period Bergmann and Schmiedeberg, Zuelzer and Sonnenschein, Hager, Otto, Selmi, \&c., obtained from putrefying substrata poisonous extracts, which usually resembled conium in their poisonous action or in their chemical reactions, but at times also atropine, curare, delphinine, or morphine. None of these investigations, however, led to the isolation of definite chemical substances from the toxic extracts.

Nencki + was the first to succeed in separating and in ascertaining the elementary composition and the constitution of a putrefactive alkaloid. He obtained from putrefying gelatine a crystallisable body which had the composition $\mathrm{C}_{8} \mathrm{H}_{11} \mathrm{~N}$, and perhaps the structure $\mathrm{C}_{6} \mathrm{H}_{4} \backslash \mathrm{CH}_{2}-\mathrm{NH}_{2}$. This base is isomeric with collidine, but differs from it by its behaviour on heating, \&c. Gautier and Etard, at a later period, isolated from putrefying fish two substances, of which the one appears to be identical with that obtained by Nencki, while the other had the composition $\mathrm{C}_{9} \mathrm{H}_{13} \mathrm{~N}$; further, Guareschi

* See Husemann's Reports in Arch. f. Pharmacie, 3 R., Bd. 16-22. Otto, Anleitung zur Ausmittlung der Gifle, 6 Aufl. Brannschweig, 1885.Brieger, Ueber Ptomaïne, Berlin, 1885, und Weitere Untersuchungen überPtomaine, Berlin, 1885. See the rest of the literature there, and in. Maly's Jahresber. $f$. Thierchimie.

+ Nencki, Ueber die Zersetzung der Gelatine und des Eirecisses, Bern, 1876 
and Mosso obtained, from putrefying fibrine, an oil of the composition $\mathrm{C}_{10} \mathrm{H}_{15} \mathrm{~N}$, which has a similar action to curare; and E. and H. Salkowski obtained by the putrefaction of flesh and fibrine a crystallisable base, which on analysis seemed to differ a little in its composition, $\mathrm{C}_{5} \mathrm{H}_{11} \mathrm{NO}_{2}$ or $\mathrm{C}_{7} \mathrm{H}_{15} \mathrm{NO}_{2}$, and hence probably was not quite pure.

Brieger has, during the last few years, taken up the Brieger's study of the ptomaines with great success; to his investigations we already owe a number of very important results.

Brieger isolated numerous nitrogenous bases, partly 1. Putrefacfrom putrefying fibrine, meat, fish, cheese, gelatine, and ptomaines. yeast ; partly from putrefying human bodies; and partly from pure cultivations of pathogenic fungi; some of these proved to be non-poisonous, others were distinctly poisonous.

To the non-poisonous, or, at any rate, to bases which only act in a poisonous manner in large doses, belong:

1. Neuridine, very widely distributed; obtained from Non-poisonthe putrefaction of meat, cheese, gelatine (in very large quantities), and from decomposing human organs from the third day onwards. Composition, $\mathrm{C}_{5} \mathrm{H}_{14} \mathrm{~N}_{2}$, a diamine which breaks up into dimethylamine and tri-methylamine. Characterised by the formation of a compound with picric acid, which is not readily soluble.

2. Gadinine, obtained from putrefying torsk, has the formula $\mathrm{C}_{7} \mathrm{H}_{17} \mathrm{NO}_{2}$; constitution still unknown.

3. Cadaverine, from decomposing bodies, found in traces from the fourth day upwards, plentifully from the tenth to the twelfth days. $\mathrm{C}_{5} \mathrm{H}_{16} \mathrm{~N}_{2}$; has a disagreeable odour, recalling that of conium.

4. Putrescine occurs along with the former, $\mathrm{C}_{4} \mathrm{H}_{12} \mathrm{~N}_{2}$.

5. Saprine, likewise a cadaveric alkaloid; it has the same percentage composition as cadaverine, but it is distinguished from it by the characters of its compound with hydrochloric acid, and of its gold salt.

6. Brieger also found cholin during the first few days of the putrefaction of dead bodies, and after the 
disappearance of the cholin, trimethylamine, also dimethylamine and triæthylamine.

The formula of cholin is, $\mathrm{C}_{5} \mathrm{H}_{15} \mathrm{NO}_{2}$, and it must be looked on as trimethyloxæthylammonium oxyhydrate $\left(\mathrm{CH}_{3}\right)_{3}, \mathrm{~N}, \mathrm{OH}, \mathrm{C}_{2} \mathrm{H}_{4}, \mathrm{PH}$. It occurs very widely distributed in the body, united in lecithin with distearylglycerinephosphoric acid, and appears at the commencement of the putrefaction of dead bodies, probably by the splitting up of lecithine. Cholin only acts in a poisonous manner in very large doses.

To the poisonous bases belong :

Poisonous

Peptotoxine.

1. Peptotoxine, the poisonous constituent of many peptones ; it is formed, for example, in the digestion of fibrine by artificial gastric juice. It can be in part extracted from peptone by æthyl- and amyl-alcohol ; composition as yet unknown. Frogs and rabbits are killed with symptoms of paralysis and insensibility.-This first poisonous product of the splitting up of albuminous bodies can probably be also obtained as the result of the peptonising action of bacteria, although this has not yet been directly proved.

Neurin. 2. Neurin, obtained from flesh which had putrefied for five or six days, was formerly frequently confused with cholin, but is distinguished from it by the absence of one molecule of water. It has the composition $\mathrm{C}_{5} \mathrm{H}_{13} \mathrm{NO}$, and must be looked upon as the oxihydrate of trimethylvinylammonium $\left(\mathrm{CH}_{3}\right)_{3}, \mathrm{C}_{2} \mathrm{H}_{3}, \mathrm{~N}, \mathrm{OH}$ (the vinyl group $\left.=\|_{\mathrm{CH}-}^{\mathrm{CH}_{2}}\right)-$ Neurin is poisonous in small doses to frogs and mammals; for cats five milligrams per kilo-weight is the poisonous dose. The symptoms observed are, salivation, dyspnœa, in the first place quickening, then lowering, of the heart's action; also violent peristalsis of the intestine, with diarrhœa; finally, convulsions and collapse. The group of symptoms most resembles those produced by muscarine; atropine appears to be the most active antidote.

Neurin is probably formed from the cholin of the lecithin by the withdrawal of water, and this separation 
of water seems to occur under the influence of many putrefactive bacteria. It is possible that it occurs also under many other circumstances, and especially as the result of the action of chemical agents.

3. A base similar to, and isomeric with, æthylendiamine, of the formula $\mathrm{C}_{2} \mathrm{H}_{4}\left(\mathrm{NH}_{2}\right)_{2}$. It has been recently shown to be distinct from xthylendiamine; obtained in the putrefaction of fish.

4. Muscarin, long known as the poison of the fungus of flies (muscardine), an oxidation product of cholin; $\mathrm{C}_{5} \mathrm{H}_{15} \mathrm{NO}_{3}$; was likewise found by Brieger in putrefying fish.

5 . In the putrefaction of human bodies Brieger obtained, after seven days, the first traces of toxic bases, and they were got more plentifully after two to three weeks. Two ptomaines could be recognised, of which, however, the quantities obtained did not suffice for more accurate analysis. One of them set up marlked diarrhœa in rabbits; the other, called mydalein, caused in the first place dilatation of the pupils, injection of the vessels of the ear, elevation of the temperature of the body, marked flow of saliva and diarrhœa, and finally death, with panting respiration and depression of temperature.

From pure cultivations of specific pathogenic bacteria 2. Ptomaines Brieger was able to isolate the following bases :-

The bacilli of typhoid fever, when grown in meat infusion, gave rise to no putrefaction, no development of sulphuretted hydrogen, indol, or phenol ; on repeated occasions, however, a new ptomaine was obtained from these cultivations, the gold salt of which was most easily purified; but a more exact analysis of this substance has not yet been published. This ptomaine caused, in guinea-pigs, flow of saliva, frequent respiration, dilatation of the pupils, and diarrhœa. On postmortem examination the heart was found in a state of systolic contraction.

Cultivations of Staphylococcus aureus in meat in- From fusion which was kept at a temperature of $30^{\circ}$ to $50^{\circ} \mathrm{C}$. ${ }^{\text {staphylococci. }}$ for about four weeks, gave a non-poisonous base which did not enter into combination with chloride of gold,

from pure cultivations of pathogenic fungi.

From typhoid bacilli. 
but formed, with chloride of platinum, a crystalline compound which could be analysed. More accurate details are still wanting with regard to this base.

Production of ptomaines by cholera spirilla.

By other bacilli.

Absence of ptomaines in anthrax cultivations.
The toxic action of pure cultivations has further been observed in various kinds of bacteria, without any attempt having been made to isolate the poisonous substances. For example, in the case of the spirilla of Asiatic cholera (see page 440); further, in a whole group of bacilli which cause a similar toxic effect with special involvement of the intestine, such as bacillus crassus sputigenus, bacillus oxytocus perniciosus, \&c. (see page 331). Other pathogenic bacteria have been investigated for similar products of tissue change, but as yet with negative results; thus, Nencki has in vain examined cultivations of anthrax bacilli for nitrogenous bases, and Marmé has arrived at the same result with cultivations of anthrax bacilli made in the author's laboratory.

The facts which have as yet been made out with regard to the occurrence of ptomaines are evidently of very great importance. In the first place, they are of importance in medical jurisprudence, for medical jurists must, in investigating cases of poisoning, proceed in a totally new direction, and with the most extreme care. Hygienic
importance of Hygiene also has an interest not less intense in the the ptomaines. accurate investigation of these peculiar products of the tissue change of bacteria. It appears that the wholesale poisoning of people so often observed, and which resembles severe epidemics of contagious diseases in its mode of appearance, is commonly caused by decomposing nutrient materials in the early stage Poisoning by of putrefaction. In cheese, sausages, meat, or fish, food contain. ing ptomaine (cheese, fish, mcat, \&c.). to which these cases of poisoning are usually referred, the bases described above, or others as yet unknown, have probably been formed under the action of bacteria from the albumen of the nutrient materials in question, and have occasioned these toxic symptoms. A circumstance which favours the occurrence of these accidents, 
the bases occur in the commencing stage of putrefaction, before any disagreeable smell is noticeable (only in the slow putrefaction of human tissues was Brieger unable to discover any poisonous ptomaines during the first few days), and that, on the other hand, a more advanced stage of putrefaction seems to destroy them ; at any rate, Brieger failed to find, on the eighth day of the putrefaction of meat, bases which were present at an earlier period.*

The ptomaines also play an important part in certain infective diseases of wounds. For a long time surgeons have held the view that "putrid intoxication" arises as The ptomaines as a cause of putrid the result of the growth of certain saprophytic fungi on the surfaces of wounds; these form ptomaines, which are absorbed and then set up their poisonous action in the body. Similar phenomena occur, in all probability, on the wounded surface of the puerperal uterus as the result of the growth of saprophytic fungi. Further, intoxication can also occur from the intestine, where it is not uncommon to find putrefaction of the intestinal contents and production of poisonous bases; here, however, absorption is on the whole slower, and occurs in smaller doses, so that the intoxication is not so intense. It is also of importance for the production of these ptomaine actions that the formation of the poisonous bases may begin in a very early stage of the decomposition of albumen by bacteria, even before true putrefaction.

Further, the discovery of specific ptomaines in the Specific cultivations of pathogenic fungi evidently gives us the the active key to the mode of action of these bacteria in the human agents of the body; we have every reason for believing that the most typhoid important morbid symptoms of typhoid fever, cholera, and many other infective diseases are due to the produc-

* In a case of poisoning with mussels, which recently occurred in Wilhelmshafen, Brieger's investigations have shown (Deutsche med. Woch., 1885, No. 53) that ptomaines, and, among them, a poisonous base which has been already analysed $\left(\mathrm{C}_{6} \mathrm{H}_{15} \mathrm{NO}_{2}\right)$ and called mytilotoxin, were the cause of the disease. The mussels were not in a putrid condition, but even in the fresh state exerted their poisonous action. In this case, therefore, there must have been either a production of ptomaines by the mussels themselves, or else they must have taken up from the surrounding water poisons produced by bacteria. 
tion of specific poisons by the bacteria which are the cause of the disease, and as the result of this knowledge, we may entertain the hope that important indications for a rational treatment of these diseases may result from the discovery of the specific ptomaines.

A number of important questions with regard to this matter still require solution. Thus it would evidently be of great importance to learn whether the putrefactive alkaloids are formed in the same quantity and with the same poisonous qualities by different bacteria in the same material, and conversely by the same bacteria but under varying composition of the putrefying material and

Influence of various materials on the formation of ptomaines. under varying external conditions. As regards the latter point, a larger amount of lecithin and cholin may, for example, favour the formation of the poisonous neurin; and as regards the various species of bacteria which set up putrefaction, researches, which are as yet incomplete, but which are being carried out in the author's laboratory by Henrigan, have already shown that certain anaërobes can, in the course of putrefaction without the presence of oxygen, furnish poisonous products much more quickly and energetically than any of the other putrefactive fungi which have been as yet tested.

Varying relation of the saprophytic bacteria to the production of ptomaines.

It seems in fact as if, as in the case of the higher fungi, the production of poisonous substances by different kinds of bacteria can show very marked qualitative and quantitative differences, so that an early and detailed knowledge of their vital actions is the more desirable in the case of the individual species of bacteria.

\section{Chemical Ferments.}

Ferments. Definition.
By "ferments" or "enzymes" we understand complex organic materials which readily undergo alteration, and have the power, within certain limits of temperature, of transforming relatively large quantities of other organic materials in such a way that bodies arise with, on the whole, less heat-producing power than the materials from which they were formed. 
Such ferments play an important rốle in physiological processes, especially in the nutrition of the body. Stated generally, they have the power of so transforming materials which, as such, cannot enter an organism, nor perform any function in it, that they become soluble, diffusible, and capable of being utilised as nutrient substances. Insoluble albumen is converted into peptone; Importance starch and cellulose into soluble dextrose; fat is broken for the proup; cane-sugar, which cannot be decomposed in proto- nutrition. plasm, is converted into glucose, which is readily acted on. The most highly organised animals require these ferments just as much as the most lowly organisms; the former prepare them in special glandular organs, but even in the lower fungi, in which no organs can be distinguished, ferments are nevertheless a very common product of tissue change, and one necessary for nutrition.

As regards the mode of action of these ferments, the most striking point is that a relatively small quantity suffices to transform a large quantity of the body which is being broken up; the whole chemical action, therefore, seems to run its course without the ferment itself playing an active part or becoming altered. This circumstance led to the use of the term "ferment," as applied to the chemical bodies of which we are speaking, and to the inclusion of the processes set up by them in the same class with the fermentative and putrefactive processes. Indeed, many investigators look on it as probable that all the fermentative processes may be referred to such chemical ferments, and believe that it is only by such a view that it is possible to understand aright the processes of fermentation.

Nevertheless the investigations which have been made as yet, compel us to take the view that the true fermentations, and the action of isolated chemical ferments, differ so much from each other that they must both be treated separately. As a rule, however, the chemical ferments play a part, and, in fact, set agoing many complex fermentative and putrefactive changes; and they play an important rofle in the nourishment of many 
Diastatic ferments.

As products of the tissue change of the bacteria. of the exciting agents of fermentation. For these reasons the chemical ferments require to be considered more in detail in this place.

We distinguish the following kinds of chemical ferments :-

1. Diastatic ferments. These convert starch into forms of glucose (maltose, dextrose, \&c.), and, as a rule, they only act where the reaction is neutral or slightly acid, but not where it is alkaline. They occur frequently in animals and plants. Of animal ferments we hare, belonging to this group, the ptyalin of the saliva; the ferment of the pancreatic juice, which, when the reaction is alkaline, converts starch into glucose; the ferment contained in the liver, which acts on glyocogen; two ferments present in the urine (Selmi,* Béchamp and Baltus $\uparrow$ ), \&c. We find the diastatic ferments very widely distributed in plants; they occur in specially large quantities in germinating wheat, in malt, and also in the most various organs of plants, in young seeds, leaves, \&c. (Brasseł).

Diastatic ferment has been frequently demonstrated during the last few years as a product of the tissue change of bacteria. Marcano $\S$ found a ferment of this lind in bacteria which frequently occur in the external sheath of maize; Hueppe\| demonstrated a diastatic action in connection with the bacterium lactis; Miller 9 isolated a species of bacteria from human intestinal contents which was able to dissolve starch. Wortmann** was also able to demonstrate energetic diastatic action in a mixture of bacteria which he obtained from decomposing beans or potatoes, and which he cultivated in a mixture of nutrient salts and wheat starch.-That the solution of the starch in these cases really depends on the production of a ferment can, however, only be re-

* Selmi, Atti dei Lincei, vol. v.

† Béchamp und Baltus, Compt. rend., vol. 92.

‡ Brasse, Ibid., vol. 99 .

$\S$ Marcano, Ibid., vol. 95.

II Hueppe, Mitth. a. d. Kais. Ges. A., vol. ii.

I Miller, Deutsch. med. Woch., 1885, Nr. 49.

** Wortmann, Z.f.physiol. Chem., vol. vi. 
garded as proved when we have succeeded in separating the active ferment from the bacteria. As a matter of Isolation of fact, the experiments which have been made in this direction by Marcano and by Wortmann, have led to an imperfect isolation of the ferment; the former found that the cultivating fluid filtered through porcelain, or treated with chloroform, still showed a diastatic action; and Wortmann was able to demonstrate an isolated ferment by extraction of the mixture of bacteria and precipitation with alcohol; this ferment was soluble in water, converted starch energetically into glucose, acted better in faintly acid solutions, and also exerted its diastatic action when oxygen was excluded. Wortmann found that this ferment was only produced by the bacteria in question when they had at their command neither albumen nor any other source of carbon; usually they furnished a peptonising ferment, but instead of this they produced a diastatic ferment when they were in a starving condition, and were unable to obtain the necessary nutriment in any other way than by solution of starch; further, the ferment was only formed when the bacteria had plenty of oxygen.-Wortmann's observations are, however, not completely convincing, because he worked with an unknown mixture of bacteria, and also because the possible action of the living bacteria, in addition to that of the supposed isolated ferment, is not entirely excluded in the researches, especially as the activity of the solution of the ferment only appeared after a longish incubation period. Nevertheless, taking into consideration all these experiments, it is very probable that renewed experiments free from these objections will lead to similar results as regards the diastatic ferments of bacteria.

2. Inverting ferments. These convert cane-sugar, Invertin. milk-sugar, and maltose into forms of glucose (dextrose, lævulose, galactose). They occur in the digestive track of animals, but they have not yet been demonstrated in the higher plants. A similar ferment has, however, been demonstrated by Gayon* in species of penicil-

* Gayon, Bull. soc. chim., 35, 58. 
lium and aspergillus (not in mucor); and Bourquelot * found in Aspergillus niger, a ferment which he was able to extract, and which inverted maltose and cane-sugar. The same ferment is also constantly, and in large quantities, produced by the ordinary yeast, which can only cause fermentation of cane-sugar by virtue of this ferment. According to Kjeldahl + the invertin of yeast extract does not act on maltose. The action on cane-sugar occurs best between $53^{\circ}$ and $56^{\circ} \mathrm{C}$, , and when the reaction of the fluid is slightly acid. All the species of yeast do not produce invertin; thus, Roux + found a small round torula, which caused intense fermentation in solutions of glucose, but which was without action on Occurrence in cane and milk sugar.-Bacteria also not uncommonly bacteria. appear to have the power of inverting these substances; this is asserted to be the case by Hueppe, for example, in the case of the bacillus of the lactic fermentation; this: organism causes fermentation of cane and milk sugar only after an alteration of the fluid-as regards the inverting property-has occurred, which alteration is probably caused by hydratisation. Bourquelot, on the other hand, concludes from his experiments that the bacteria of the lactic fermentation can cause the fermentation of maltose and cane-sugar directly and without preliminary inversion. This contradiction is perhaps explained by the circumstance that the two authors were not working with the same species of bacteria. In the case of the butyric acid bacilli, it is unanimously agreed that it does not possess any inverting power; on the other hand, in the case of some other species of bacteria Miller has made positive statements.

Cellulose $\quad 3$. A ferment which dissolves cellulose is prodaced ferment.

Peptonising ferments. presumably by the bacillus butyricus and by vibrio rugula, probably also by various other bacteria. Accurate investigations on this matter are wanting.

4. Peptonising ferments, which convert albuminous materials into soluble diffusible forms. In addition to

* Bourquelot, Compt. rend., vol. 97.

† Kjeldahl, Meddedelser fra Carlsberg Labor., vol.i., Parts 2 and 3.

‡ Roux, Bull. soc. chim., vol. xxxv. 
the ferments of the gastric juice and of the pancreatic secretions which belong to this group, bodies possessing a similar action also occur fairly widely distributed in plants. Thus, from Carica papaya we have papain, which acts like the pancreatic juice in alkaline solutions; then we have a ferment similar to pepsin, which acts when the reaction is acid, and occurs in those plants which feed on flesh, and in Fthalium septicum.-Ferments of this class are evidently extremely common in the lower fungi. The large number of species of bacteria now Occurrence in known which cause liquefaction of the nutrient gelatine, appear to cause this liquefaction only by the production of a ferment which dissolves albumen and gelatine. As the liquefaction usually occurs when the reaction is alkaline, these bacterial ferments approach the pancreatic ferment, trypsin and papain, rather than pepsin. Attempts at isolating these ferments, and accurate investigations as to the action of the peptonising bacterial ferments on various albuminous materials, are as yet wanting. The fact that many bacteria liquefy gelatine, but not solidified blood serum, seems to show that the various albuminous bodies are not all rendered fit for assimilation in the same manner, viz., by means of this production of ferment.-Many bacteria do not produce peptonising ferment under all circumstances; this production seems especially to cease when oxygen is excluded, just as was observed by Wortmann in the case of the diastatic ferment of the bacteria.*

5. Rennet ferment. This causes an alteration of Ferment the albuminoid materials of milk, which shows itself in the coagulation of the casein. A similar ferment is, as is well known, present in the stomachs of calves; and we may further assume that it is at times produced by the milk glands, for Meissner + found that the milk of goats, even when bacteria were completely excluded, became coagulated, evidently from a ferment which had

* For further details with regard to this subjeet see the Paper by Liborius (Zeitschrift $f$. Hygiene, i., Part 1 ) which has appeared while this book was passing through the press.

† Meissner, Deutsche Zeitschr.f. Chir., vol. 13, p. 334. 
already appeared in the milk glands. Then Duclaux, * and, later, Hueppe, $\uparrow$ have pointed out that numerous bacteria show a fermentative action by means of which they cause the coagulation of the casein of the milk, where the reaction is amphoteric, i.e., slightly acid, and slightly alkaline; afterwards they usually peptonise the precipitated casein by means of a ferment similar to trypsin, and ultimately break it up still further. To this group belong, for example, the butyric acid bacilli ; and also, according to Hueppe's observations, bacillus pyocyaneus, bacillus mesentericus vulgatus, sarcina aurantiaca, \&c.

Ferments of glucosides.

Decomposition of fat.

Urea ferment. 8. The ferment of urea, which breaks up certain amide combinations in urine with the absorption of water ; urea is converted into carbonate of ammonium, hippuric acid into glycocoll and benzoic acid. Formerly this action was exclusively ascribed to the micrococcus ureæ, and Musculus isolated, as he supposed, from these bacteria the active enzyme which was soluble in water. According to Ladureau, + this ferment is active in ressels

* Duclaux, Compt. rend., vol. 91.

† Hueppe, Deutsche med. Woch., 1884, Nr. 48 and 49.

† Ladureau, Compt. rend., vol. 99. 
from which the air has been exhausted, also under the pressure of three atmospheres, and also when oxygen, hydrogen, or nitrogen are present. According to the more recent investigations made by Leube, the property of splitting up urea belongs to various other bacteria ; and pure cultivations of the micrococcus ureæ proved to be inactive when they were freed from living micro-organisms by filtration through plaster. It is possible, therefore, that the ferment isolated by Musculus did not come from bacteria at all (see page 214).

All the ferments which have been mentioned here are Method of produced by the organs of higher animals, or by lowly separating the organisms, but are not so intimately connected with the life of the producer that it is impossible to isolate and separate the ferments from the living cells; when this is done the products so separated show the same activity. In the case of numerous ferments such a separation has been already successfully effected, and we may draw the conclusion from analogy that, as regards the separation of the ferments which have not yet been isolated, the difficulties are chiefly technical, and not insurmountable. They are usually obtained by precipitation from their solutions by such means as alcohol, or by carrying them down with precipitates, and then extracting them from the precipitate thus obtained by means of solvents (glycerine, water). The results of chemical analysis have given the following numbers :-

Carbon. Hydrogen. Nitrogen. Sulphur. Ashes. Chemical

$\begin{array}{lccccccccccc}\text { Diastase } & \ldots & 45 \cdot 7 & \ldots & 6 \cdot 9 & \ldots & 4 \cdot 6 & \ldots & - & \ldots & 6.1 & \text { composition. } \\ \text { Invertin } & \ldots & 40 \cdot 5 & \ldots & 6 \cdot 9 & \ldots & 9 \cdot 5 & \ldots & - & \ldots & - & \\ \text { Emulsin } & \ldots & 48 \cdot 8 & \ldots & 7 \cdot 1 & \ldots & 14 \cdot 2 & \ldots & 1 \cdot 3 & \ldots & - & \\ \text { Papain } & \ldots & 52 \cdot 2 & \ldots & 7 \cdot 1 & \ldots & 16 \cdot 4 & \ldots & - & \ldots & -\end{array}$

As regards the analyses as yet made, however, it is probable that the ferments were far from pure; by sleansing them as far as possible, more especially from dextrine and gum-like bodies, Loew* obtained ferments which approach albuminoid bodies in their composition much more than those which had been previously

* Loew, Pflüger's Arch., vol. 27. 
Analysis of purified ferments.

Mode of action The mode of action of these ferments may be generally of the ferments.

analysed. Thus Loew found in the case of the pancreatic ferment, which in a pure condition occurs as a snow-white powder, carbon $=52.75$ per cent.; hydrogen $=7 \cdot 51$ per cent. ; nitrogen $=16.55$ per cent.; oxygen + sulphur $=23 \cdot 19$ per cent. ; ashes $=1.77$ per cent.

Selmi* states that he has obtained from urine two crystalline diastatic ferments, the one crystallising in the form of microscopic dice, the other like a fern leaf. characterised, by saying that they produce hydrolytic decompositions; that is to say, every molecule of the substance which is being split up breaks up into two or more molecules by taking up one or several molecules of water. In correspondence with this, the decomposition in the case of some of the ferments mentioned above would occur in the following manner:-

(1) Diastase : $\mathrm{C}_{24} \mathrm{H}_{40} \mathrm{O}_{20}+3 \mathrm{H}_{2} \mathrm{O}=\mathrm{C}_{6} \mathrm{H}_{1}, \mathrm{O}_{5}+3 \mathrm{C}_{6} \mathrm{H}_{12} \mathrm{O}_{6}$.

$$
\text { Starch. Dextrine. Dextrose. }
$$

or, according to more recent views :

$$
\begin{aligned}
& \mathrm{C}_{36} \mathrm{H}_{62} \mathrm{O}_{31} \\
& \text { Starch. }
\end{aligned}
$$

(2) Invertin: $\mathrm{C}_{12} \mathrm{H}_{22} \mathrm{O}_{11}+\mathrm{H}_{2} \mathrm{O}=\mathrm{C}_{6} \mathrm{H}_{12} \mathrm{O}_{6}+\mathrm{C}_{6} \mathrm{H}_{12} \mathrm{O}_{6}$. Cane-sugar. Dextrose Lævulose.

(3) Emulsin: $\mathrm{C}_{20} \mathrm{H}_{27} \mathrm{NO}_{11}+2 \mathrm{H}_{2} \mathrm{O}=2 \mathrm{C}_{6} \mathrm{H}_{12} \mathrm{O}_{6}+\mathrm{C}_{6} \mathrm{H}_{5} \cdot \mathrm{COH}+\mathrm{CNH}$. Amygdalin. Dextrose. Oil of bitter Hydroalmonds. eyanic $\mathrm{C}_{13} \mathrm{H}_{18} \mathrm{O}_{7}+\mathrm{H}_{2} \mathrm{O}=\mathrm{C}_{6} \mathrm{H}_{12} \mathrm{O}_{6}+\mathrm{C}_{6} \mathrm{H}_{4} \mathrm{OH}, \mathrm{CH}_{2} \mathrm{OH}$.

$$
\begin{aligned}
& \text { Salicine. Dextrose. Saligenine. } \\
& \mathrm{C}_{16} \mathrm{H}_{22} \mathrm{O}_{8}+\mathrm{H}_{2} \mathrm{O}=\mathrm{C}_{6} \mathrm{H}_{12} \mathrm{O}_{6}+\mathrm{C}_{6} \mathrm{H}_{3}\left\{\begin{array}{l}
\mathrm{O} . \\
\mathrm{OH}
\end{array} \mathrm{CH}_{3}\right\} \mathrm{C}_{3} \mathrm{H}_{4}, \mathrm{OH} \text {. } \\
& \text { Coniferin. Dextrose. Coniferyl alcohol. }
\end{aligned}
$$

(4) Ferment of urea: $\mathrm{CO}, \mathrm{NH}_{2}, \mathrm{NH}_{2}+2 \mathrm{H}_{2} \mathrm{O}=\mathrm{CO}_{3}\left(\mathrm{NH}_{4}\right) 2$. Urea. Carbonate of ammonia.

In the case of some of the other ferments, for example, the peptonising one, we cannot make anything like an accurate formula for the transformation; but it is probable that in all, the decomposition takes place in a similar manner by the taking up of water.

Similar action Numerous other chemical agents are also capable of of chemical agents. playing the same part as we have observed in these ferments. When boiled with dilute sulphuric acid,

* Selmi, Atti dei Lincei, vol. 5. 
starch undergoes a similar transformation to that caused by the action of diastase; cane-sugar, the same transformation into dextrose and lævulose as by invertin; superheated steam splits up fat; continuous boiling with water peptonises albumen. As a difference between the action of these chemical agents and that of ferments, it has been suggested that the latter take such a slight part in the decomposition that they can split up unlimited quantities of the fermentescible bodies; but as a matter of fact such an unlimited action does not, by any means, appear to be the case. On the contrary, in the case of pepsin, ptyalin, diastase, \&c., there are distinct limits to the action; thus, diastase can, at most, act on two thousand times its quantity of starch. Under ordinary circumstances it is scarcely likely that all of this power will be employed, because the ferment becomes injured by the alteration of the substratum, or is partially precipitated in most fluids by the occurrence of precipitates.

The sensitiveness of the ferments towards external Dependence influences is comparatively great. As regards the tem- of the fermen. perature, in the first place every ferment has an optimum, on external which, however, is not constant in all cases, but depends on other circumstances simultaneously present. In the Temperature. case of diastase, the optimum is about $63^{\circ} \mathrm{C}$. (Kjeldahl, loc. cit.); in the case of emulsin about $50^{\circ} \mathrm{C}$.; in the case of ptyalin about $46^{\circ} \mathrm{C}$. Diastatic action has been observed even at $+5^{\circ} \mathrm{C}$.; from that point it increases with increasing temperature till it reaches the optimum. Between $65^{\circ}$ and $75^{\circ} \mathrm{C}$. we usually observe a complete cessation of the fermentative action, and a permanent loss of the fermentative power; the longer the heat is continued, so much the lower degrees of temperature suffice for this action. The addition of glycerine raises the degree of the hurtful temperature; the addition of alcohol acts in a converse manner. These numbers, however, are only valid as regards moist preparations; in the dry state the isolated ferments can be heated from $120^{\circ}$ to $160^{\circ} \mathrm{C}$. before they are injured.Among other circumstances which influence them may 
Action of acids.

be mentioned the reaction of the medium. Excess of alkali is injurious to most of the ferments. A slight degree of acidity is very well borne by some fermentsdiastase, invertin - and their action is, in fact, increased by a slightly acid reaction; the pepsin-like ferments absolutely require a certain excess of acid for the development of their action. Other ferments, such as emulsin, are hindered in their action even by 15 per thousand of hydrochloric acid (Falk*). Larger amounts of acid are always injurious. - The salts of the heavy metals, and other substances which precipitate albumen, act of course Carbolic acid. after the manner of poisons. Carbolic acid interferes with the fermentative action of emulsin and ptyalin; other ferments, and more especially diastase, are, on the contrary, scarcely affected; according to Kjeldahl (loc. cit.) the addition of $\cdot 2$ and $\cdot 4$ per cent. causes a scarcely noticeable diminution. On the contrary, on the addition of 03 per cent. of salicylic acid a marked diminution of the diastatic effect is observed, and on the adition of $\cdot 1$ per cent. the action entirely ceases. - Peroxide of hydrogen, which hinders all the fermentations dependent on the presence of living organisms (Bert and Regnard $\dagger$ ), and also hydrocyanic acid, chloroform, ether, benzole, and oil of turpentine, scarcely injure the isolated ferment at all ; and, for example, by the salts of ammonia (up to 10 per cent.) and by alkaloids, such as veratrin and curare, the inversion of cane-sugar is much favoured.

Most of the ferments act only on a certain class of chemical bodies; it is only combinations which are closely allied to each other which are, as a rule, broken up by the same ferments. Thus emulsin splits up several glucosides; but, on the other hand, invertin, for example, does not act on dextrine, maltose, or starch; nor does diastase act on cane-sugar, or on glucosides. If several chemical ferments are present in the same solution they may destroy each other; thus pepsin digests trypsin and ptyalin. This, however, does not hold good in the case of all ferments, for diastase

* Falk, Virchow's Arch., vol. 93.

† P. Bert und Regnard, Compt. rend., vol. 94. 
and rennet, for example, do not interfere with each other at all.

As to the mode in which the soluble ferments act, we Attempts to can make no definite hypothesis. We may perhaps axplain the suppose that the ferment acts as a carrier of the water ferments.

to be taken up; that it, in the first place, takes up the water itself, and then hands it on to the molecules which are breaking up. Or, according to Bunsen-Hüfner we may picture the contact and fermentative action by supposing that the ferment, like sulphuric acid in the formation of ether, has a greater affinity for certain atoms or groups of atoms of the molecule which is being broken up than the remainder has, and thus brings about a new grouping of the atoms, after the completion of which it is again regenerated. Both these hypotheses want the support of any actual demonstration that water is taken up, or that any such combinations of the ferment occur. A third view, put forward by Nägeli, is closely allied to that last mentioned, but also harmonises with the hypothesis put forward by Nägeli as to the process of fermentation, which will be referred to below; according to this view the ferments do not themselves enter into combinations, but only act on definite groups of atoms by the condition of movement of their molecules, and thus cause a transformation and new grouping of the elements.

In whatever way the action of ferments may bo Distinction ultimately explained, it is clear that we have here to between the do with another kind of process than that which occurs ferments and in the true fermentations. The ferments are soluble chemical bodies, not necessarily united with living organisms which are only able to set up hydrolytic decompositions, while in the true fermentation complex alterations of groups of atoms occur which require the constant presence and the immediate action of living organisms. The great difference in both these processes is most clearly evident from a comparison of the external conditions which favour or injure them; the soluble ferments act best at a 
temperature of about $60^{\circ} \mathrm{C}$, and when the reaction is acid and comparatively large quantities of peroxide of hydrogen, carbolic acid, oil of turpentine, \&c., hardly weaken their action, while under the same conditions we constantly observe a complete cessation of the life, or, at any rate, of the fermentative activity of all micro-organisms.

\section{Fermentation.}

Definition of fermentation.

Under certain circumstances we find a deviation in the biological behaviour of micro-organisms, which is accompanied by a very thorough decomposition and consumption of the nutrient material, and the formation of special products, characterised by their quality and quantity. Among these products, volatile gases usually take a prominent place; and in addition bodies are constantly formed of less heat-producing power than those materials from which they are derived, and thus in the process of decomposition there is constantly a liberation of vital energy. The sum total of these phenomena is usually designated by the term " fermentation."

Fermentation must also, at any rate ultimately, be referred to decompositions in the protoplasm, to the intramolecular respiration. We may suppose that the act of fermentation was evolved from this respiration, and that it originally only represented an act of self-preservation due to the continued absence of oxygen. Without active combustion by the aid of oxygen, the internal respiration alone is not able to furnish sufficient energy for the purposes of the organism. When oxygen is absent, the nutrient material is split up superficially, it is true, but so much the more extensively, and thus the energy which is requisite for the complete life of the micro-organisms is obtained. In the course of their further evolution the organisms become divided into two great groups : in the one, the fermentative action only occurs when there is necessity for it owing to the absence of oxygen; in the other, the fermentative action which corresponds to those special conditions has been gradually developed 
into a constant property, and these organisms excite fermentation even when the presence of a plentiful supply of oxygen does away with the necessity for the act, the fermentation occurring whenever they are provided with fermentescible materials.

A sine qua non for the occurrence of fermentative Classification action is the presence of fermentescible material. of the fermenOnly a limited number of chemical bodies form suit- cording to the able materials, and it is not every one of the substances ble material. which are capable of undergoing fermentation which can be broken up by all of the fermentative agents; on the contrary, each substance is only decomposed by one or a few organisms, and every species of bacteria is limited to a few suitable substances. In the case of many micro-organisms no body is as yet known which they are able to split up by fermentation. It is possible that the functions of these organisms are always limited to the ordinary respiratory tissue changes; but it is possible that, in the case of one or other of these bacteria, the necessary fermentescible substance will yet be found.

It is only by the consideration of individual cases that we can recognise and understand the nature and properties of the material suitable for fermentation, as well as the mode in which it is split up by the fermentative action. We differentiate a large number of specific fermentations, which receive their names either from one or a few characteristic products, or from the nature of the fermentescible material, or, finally, from the fermenting agent. In what follows we shall describe, in the first place, fermentation by the yeast fungi ; then the various fermentations caused by bacteria, which may be divided into five groups, viz., $a$. Fermentation of carbo-hydrates; $\beta$. Fermentation of the higher alcohols (glycerine, erythrite, mannite) ; $\gamma$. Fermentation of the fatty acids; $\delta$. Putrefaction; $\epsilon$. The formation of acetic acid from alcohol. 


\section{A. Alcoholic Fermentation of Sugar by Yeast.}

Fermentescible material.

The fermentescible material is furnished by the glucoses of the formula $\mathrm{C}_{6} \mathrm{H}_{12} \mathrm{O}_{6}$, namely, dextrose, lævulose, lactose, or galactose ; further, by maltose, to which the formula $\mathrm{C}_{18} \mathrm{H}_{34} \mathrm{O}_{17}$ is given, and which, therefore, only acquires the same composition as glucose by taking up water. Dextrose forms the most favourable material; if it is exposed to fermentative action in a mixture along with other forms of glucose, for example, lævulose, the dextrose is the first to undergo fermentation.-Cane-sugar and milk-sugar only undergo fermentation when they are converted into glucose; the former can be converted into dextrose and lævulose by means of invertin (therefore by yeast), the latter is transformed into galactose and dextrose by means of a ferment produced by some fungi ; further, they can both be converted into these glucoses by boiling with dilute mineral acids. - Other carbo-hydrates also, such as starch, gum, and cellulose, can be converted into glucose by ferments, or by treatment with acids; starch is transformed into dextrose by means of ptyalin and also by acids, and into maltose by diastase (malt). - All the carbo-hydrates last mentioned can therefore, in like manner, serve for fermentation, if only ferments which transform them into glucose are at the same time present in the fermenting mixture; and as these ferments are usually produced in large quantities by the same organisms which cause the fermentation (invertin by yeast, the ferment which transforms milk-sugar by bacteria), the incapacity of canesugar, starch, \&c., to undergo fermentation directly is practically of little account, and fermentation frequently occurs when these substances are present, and when the directly fermentescible glucoses are absent, being at most somewhat delayed in its commencement. By being provided with ferments which form glucose, the area of the vital and fermentative activity of the fermentative agents is markedly enlarged.

Forms of yeast capable of exciting fermentation.
The specific decomposition of glucose into alcohol and carbonic acid is limited to yeast, but all the species of saccharomyces are not able to set up an equally 
energetic fermentation. Two species, beer and wine yeast, act most powerfully. The former is constantly cultivated in beer wort; fresh fermentation is set up by the addition of the yeast from fermenting wort to fresh fermentescible fluid. According to the more or less violent progress of the fermentation, high or low yeast is obtained; in the former the budding takes place more rapidly, and we thus obtain groups of cells which are readily taken up by the stream of carbonic acid and carried to the surface. The wine yeast-S. ellipsoideus -is the form which is most widely distributed in nature; it establishes itself spontaneously in the most various saccharine solutions when exposed to the entrance of air, or it is introduced into these, for example, by the skins of the grapes, on which it is constantly found. The other forms of yeast, S. apiculatus, exiguus, \&c., appear to possess a less degree of vegetative energy and fermentative action. In the case of some, as, for example, pink yeast (rosa hefe), no fermentative action has, as yet, been noted; mycoderma only excites a temporary and trivial fermentation when it is artificially compelled to grow at the bottom of fluids.

The yeast-like growths of some of the mould fungi Fermentative have a more powerful fermentative action than the forms action of of yeast last mentioned, in that, when immersed in sugar fission fungi. solution, they set up a fairly energetic decomposition of the sugar, with the formation of alcohol and carbonic acid; at the same time they approach true yeast in their conditions as regards form and growth. These properties are most marked in Mucor racemosus, M. cercinelloides, M. spinosus ; they are less developed in Mucor mucedo, and hardly at all in Mucor stolonifer.Other mould fungi are also able to produce traces of alcohol and carbonic acid when they grow in saccharine solutions in the absence of oxygen; but the amount produced cannot be at all compared with that formed by the species of mucor and by the true yeasts, and only depends on the intramolecular respiration, by means of which also the cells of any of the higher plants can form alcohol and carbonic acid.-Further, in the fer- 
mentation of carbo-hydrates by bacteria, we have not uncommonly a plentiful formation of alcohol and carbonic acid (see below); but, in this case, numerous other products constantly arise, so that the amount of alcohol is relatively unimportant. Hence the production of alcohol and carbonic acid is not of itself characteristic for the fermentation by yeast. What is characteristic is the enormous and almost exclusive formation of these bodies from definite linds of sugar, and, in contrast to the organisms which only have a similar action when air is excluded, the circumstance that the presence of oxygen does not hinder the formation of these substances, but rather favours it.

Chemical processes in this fermentation.

The mode in which glucose is broken up in the fermentation by yeast was formerly represented by a rery simple chemical formula. It was believed that the glucose molecule was split up into two molecules of alcohol, and two molecules of carbonic acid: $\mathrm{C}_{6} \mathrm{H}_{12} \mathrm{O}_{6}$ (glucose) $=2 \mathrm{C}_{2} \mathrm{H}_{5}, \mathrm{OH}$ (xthyl-alcohol) $+2 \quad \mathrm{CO}_{2}$. Pasteur, however, showed that a number of other substances constantly appeared, even when the fermentescible materials and the yeast were, as far as possible, pure ; on an average 2.5 to $3 \cdot 6$ per cent. of the fermenting sugar appeared in the form of glycerine $\left(\mathrm{C}_{3} \mathrm{H}_{5}\right.$ $\left.(\mathrm{OH})_{3}\right)$, and $\cdot 4$ to $\cdot 7$ per cent. in the form of succinic acid $\left(\mathrm{C}_{2} \mathrm{H}_{4}(\mathrm{COOH})_{2}\right)$; and further, there were constantly traces of acetic acid, and often of other alcohols, such as amyl-alcohol. The attempt has been made to include these side products by the formula 49 $\left(\mathrm{C}_{6} \mathrm{H}_{12} \mathrm{O}_{6}\right)$ (glucose), +30 $\mathrm{H}_{2} \mathrm{O}=12 \quad \mathrm{C}_{4} \mathrm{H}_{6} \mathrm{O}_{4}$ (succinic acid), $+72 \mathrm{C}_{3} \mathrm{H}_{8} \mathrm{O}_{3}$ (glycerine), $+30 \mathrm{CO}_{2}$ (Pasteur), or by the formula $4 \mathrm{C}_{6} \mathrm{H}_{12} \mathrm{O}_{6}+3 \mathrm{H}_{2} \mathrm{O}=\mathrm{C}_{4} \mathrm{H}_{6} \mathrm{O}_{4}$ $+6 \mathrm{C}_{3} \mathrm{H}_{8} \mathrm{O}_{3}+2 \mathrm{CO}_{2}+\mathrm{O}$ (Monoyer); but this attempt has not been successful in giving a correct view of the quantitative conditions. - The same bye-products are also found in the fermentation by the yeast forms of mucor; at any rate Fitz was able, in this case, to demonstrate succinic acid with certainty. Further, Brefeld found that the bye-products were the more plentiful the more unfavourable were the nutrient con- 
ditions for the fermentative agents. Towards the end of the fermentation these materials seem to accumulate, and those fermentative agents which are only able to set up the fermentation with difficulty, and which in reality require other conditions of existence, furnish bye-products in especially large quantities ; for example, Mucor mucedo furnishes more than Mucor racemosus, and Mucor stolonifer more than Mucor mucedo.

We may, perhaps, suppose that in succinic acid, Significance glycerine, \&c., we have represented the special products of the byeof the tissue change of the yeast. As a matter of fact we must assume that, in addition to the splitting up of the sugar, there also occur decompositions, and, where oxygen is present, oxidations of the complex molecules of the protoplasm of the yeast, which are composed of nitrogenous and non-nitrogenous groups of atoms; as a consequence the ordinary products of the destructive tissue change appear in the nutrient mixture. It is, however, difficult to identify these products with those bye-products which appear in fermentation; the quantity of the latter is much too great, and their quality also is too peculiar. Further, in this case, the amount of the bye-products must be proportional to the amount of the active yeast cells which are present, and must also, in the first place, depend on the quantity which has been sown. But as yet nothing has been observed as regards any such relation. We must therefore either assume that the decomposition of the sugar in the fermentative action in reality occurs, at any rate as regards the largest amount, according to a more complicated formula, in which there is a constant formation of glycerine and succinic acid; or that the appearance of these bye-products is caused by impure fermentescible material, by the admixture of bacteria, and by their decomposition of the nutrient materials. The possibility of such impurities must be admitted in the case of the experiments which have been as yet made, in spite of the great precautions which have been taken by various author's since the time of Pasteur, because it was not possible, in the earlier methods, to isolate pure 
Employment species of yeast. It is only within the last few years of impure yeast in previous experiments. that Hansen has been able to obtain a completely pure material, by using Koch's solid nutrient media, and we must await the results obtained by chemical analysis, in the experiments made with this yeast.

Self ferment- Very special attention has been paid by many investigators ation of yeast. to the so-called "self-fermentation" of yeast. This occurs when large quantities of fresh, active yeast is left to itself in the presence of a plentiful supply of water, insufficient entrance of air, and a favourable temperature $\left(25^{\circ}\right.$ to $30^{\circ} \mathrm{C}$.). Under these circumstances a large amount of carbonic acid and alcohol are formed, the yeast becomes soft, and gives with warm water an extract containing numerous substances, which must be looked on as products of tissue change and of decay. According to the investigations of Béchamp and Schützenberger the water contains albuminoid substances, gum, a ferment rotating to the left, a substance called zymase, pseudo-leucin (with which a varying quantity of sulphur is mixed), tyrosin, butalanin, carnin, xanthin, guanin, sarkin.The substances last named are evidently derived from the decomposition of albuminoid materials; the production of carbonic acid and alcohol, however, can only be explained either by the presence of fermentescible sugar in the yeast, or by the ready conversion of some constituents of the yeast cell into sugar; in that case the substance from which the sugar is derived will belong either to the group of carbo-hydrates, such as cellulose or gum, or to the group of proteid substances. According to Pasteur, material resembling sugar is always present in yeast, this material being very difficult to extract as such, but becoming converted into sugar by mineral acids, for example; and it is this, along with the cellulose of the cell wall, which furnishes, according to Pasteur's view, the fermentative products which arise in the self-fermentation. Another important view was, however, advocated by Liebig; he found, in some experiments on the self-fermentation of yeast, such large quantities of alcohol and carbonic acid ( 8 to 13.5 per cent. of alcohol, of the total weight of the dry yeast), that the whole amount of cellulose and other carbohydrates contained in the yeast was not sufficient to furnish this amount of fermentative products; hence in order to explain the amount of these substances it was necessary to assume the occurrence, to a large extent, of a decomposition of albuminoid substances. Liebig laid the greatest stress on this decomposition of albuminoid substances because he saw in it the really essential and constant process which took place in fermentation; according to his view, the essence of the 
fermentative process is that a complex proteid substance, when in a state of decomposition, transmits its chemical movements to other molecules, such as sugar.

Nägeli's more recent researches, however, show most distinctly that, in the self-fermentation of yeast, the process which takes place is not limited to, and only dependent on, the yeast; but that, in the former experiments, without doubt bacteria also acted and took part in the decomposition of the substance of the yeast. In fact the very circumstances under which the self-fermentation was observed were such that of necessity an active development of bacteria must occur; these lived and multiplied at the expense of the dead yeast cells, and probably also set up fermentative processes in certain of the constituents of the yeast substance which had been rendered soluble by ferments given off by them. A portion of the nitrogenous derivatives found in the extract may result from the activity of these bacteria, which can probably also take part in the production of carbonic acid and alcohol. Nägeli so arranged the experiments that when, for example, by the addition of citric acid, the development of bacteria was rendered difficult, only minimal traces of alcohol were found, probably derived from the small quantities of saccharine substances which are contained in the yeast cells, and which underwent fermentation when no saccharine nutrient material was at the disposal of the yeast. This process would be quite analogous to the decompositions which occur in starving animals. But we have no grounds for believing that the proteid substance of the exhausted yeast cells can be utilised by other living yeast cells; because the ferments necessary for the solution of these substances are not found in yeast. Further experiments, in which attention is paid to the purity of the cultivation, are therefore required to give definite information as to the real extent of the self-fermentation of the yeast, and as to the products of tissue change.

Cochin* has attempted to ascertain the time required The time for fermentation, by continuous measurement of the required for amount of carbonic acid developed. He found that in the first instance ten to twenty minutes always elapsed before active fermentation commenced; and the time was still longer in dilute solutions. From that time onwards the course of the fermentation may be expressed by a steeply ascending line, which finally ends in the form of a parabola. This period of incubation does not mean that the saccharine solution must first penetrate

* Cochin, Cumpt. rend., vol. 96. 
into the interior of the yeast cells, and that for this a certain time is required; for the same phenomenon is observed when the yeast is implanted in a new solution directly from a solution in active fermentation.

Influence of various conditions on the quantitative result.

Amount of sugar.

Quantity of yeast.

The quantitative result of the fermentation undergoes marked variations according to the composition of the fermenting material, according to the quality of the yeast, according to the length of time, and according to various external influences.

The amount of sugar in the solution must not exceed 35 per cent., for otherwise the yeast cells suffer for want of the proper quantity of water; the best proportion of sugar seems to be 2 to 4 per cent., and then 20 to 25 per cent. (Wiesner), but this striking fact of two optirna requires confirmation. The quantity of yeast added is, within certain limits, irrelevant for the progress of the fermentations. Dumas found that one gramme of sugar was completely broken up at $24^{\circ} \mathrm{C}$. by 20 grammes of yeast within twenty-four minutes; the addition of 100 grammes of yeast did not alter this result in the slightest. Where a large amount of yeast is added intense fermentation occurs, even in pure solutions of sugar, which ultimately ceases, leaving behind a yeast which is exhausted and poor in nitrogen; if it is desired to keep up a permanent fermentation with relatively small quantities of yeast, the addition of other nutrient materials, more especially of nitrogenous Accumulation materials, is necessary.-Further, the continuation of of alcohol.

the fermentation is limited by the accumulation of the alcohol; the presence of 12 per cent. of alcohol hinders the growth of the yeast, and when more than 14 per cent. is present fermentation ceases entirely. In the case of the mucor yeast this limit is much lowerabout $3 \frac{1}{4}$ to 4 per cent. (in the case of Mucor stolonifer even 1.3 per cent.); this form of yeast is also much more sensitive to great concentration of the sugar solution, for a satisfactory fermentation only occurs in solutions containing less than 7 per cent. of sugar Temperature. (Fitz). - Of the external influences the temperature is of chief importance; as a rule $25^{\circ} \mathrm{C}$. seems to be 
the most favourable temperature, but this optimum varies under the influence of various factors. Further, the influence of the aerration of the fermenting mixture, its impregnation with oxygen, is of importance. Accord- Oxygen. ing to Nägeli, the access of oxygen favours fermentation in all cases; chiefly when, at the same time, materials which offer good nutriment for the yeast are present in the fermenting mixture, because in that case a much more active multiplication of the cells can occur. In investigations recently made by Hansen,* it was found that the same quantitative results require a longer time when air is absent, and that, at the same time, fewer yeast cells are formed and take part in the fermentation; on the other hand, by continued aeration the same result is reached in a shorter time, and there is a much more extensive multiplication of the cells. Therefore, under the influence of the presence of oxygen the formation of the cells and the occurrence of fermentation takes place more quickly, but the action of the individual cells is not, on an average, so great as when air is absent. - Of chemical agents which disturb or hinder fermentation may be mentioned free alkalies, also sulphurous acid, sublimate, chloroform; while sulphuretted hydrogen, arsenious acid, carbolic acid, salicylic acid, strychnine, hydrocyanic acid, only hinder the fermentation of yeast when markedly concentrated, or do not affect it at all.

As regards the fermentation of bread, kephyr, koumiss, see page 607 .

\section{B. Fermentation by Bacteria.}

(a). Fermentation of Carbo-hydrates.

The carbo-hydrates furnish, under the influence of Fermentation various bacteria, a lactic fermentation, a mucous or of carbomannite fermentation, a butyric fermentation, a dextran fermentation, and, finally, some fermentations in which æthylic alcohol and various other products are formed.

* Hansen, Meddelelser fra Carlsbcrg Lab., vol. i., Part 2. 


\section{Lactic Fermentation.}

Lactic

fermentation.

Fermentative agents.

Nature of the decomposition.
The materials necessary are grape-sugar, cane-sugar, milk-sugar, mannite, sorbite, inosite. Cane-sugar and milk-sugar are probably in the first place converted into glucose. Spontaneous fermentation is most frequently observed in milk; it probably also plays a part in the preparation of bread and leaven, and frequently occurs in the fabrication of starch, and in the saccharine juice of beet-root. We can artificially obtain a lactic fermentation either by leaving milk to stand at about $30^{\circ} \mathrm{C}$. for three or four days, or by mixing a weak sugar solution with somewhat old cheese and with purified chalk, and keeping the mixture for several days at $30^{\circ}$ to $35^{\circ} \mathrm{C}$.; in the latter case the lactate of lime which is formed can be easily obtained (see Schützenberger, page 172).

The bacillus acidi lactici is in most cases the exciting agent of the fermentation. But the lactic fermentation is by no means confined to this one species of bacterium, but, on the contrary, a large number of cocci and bacilli which have been mentioned above, share with it the fermentative power, and are only distinguished from it by the fact that the quantitative result of their action is much less, and that they are by no means so widely distributed as the ordinary lactic acid bacillus. Hence in all spontaneous fermentations we find that the lactic bacilli usually take part, and generally in much the largest numbers.

The nature of the chemical decomposition has not yet been completely explained. Formerly the attempt was made to explain the decomposition of sugar in the lactic fermentation by the simple formula, $\mathrm{C}_{6} \mathrm{H}_{12} \mathrm{O}_{6}$ (glucose) $=$ $2\left(\mathrm{C}_{2} \mathrm{H}_{4}, \mathrm{OH}, \mathrm{COOH}\right)$ (lactic acid), and Miller also states that he has observed in the case of some bacteria this simple decomposition of the molecules of sugar. Such a process, without any development of gas, and without any more marked alteration in the molecule, could not be regarded as fermentation according to the 
definition given both in this work and also by various other authors.

As a matter of fact, development of carbonic acid is always observed in the ordinary lactic fermentation; and Bontroux, as well as Hueppe, has observed the development of carbonic acid in fermentation set up by pure cultivations of lactic acid bacteria. Former observers Incompletehave also found, besides carbonic acid, other fermentative ness of the products (alcohol, butyric acid, mannite, gum). It is formula. probable that these substances often owe their origin only to the simultaneous presence of adventitious organisms which stand in no relation to the lactic fermentation; nevertheless, it is not by any means à priori impossible that the various bacteria which are capable of setting up lactic fermentation can occasion decompositions which are dissimilar, and combined with a larger number of bye-products. In any case, however, the above formula is incorrect for the lactic fermentation by the bacillus acidi lactici, because no account is taken in it of the carbonic acid which is constantly observed.

The course of the fermentation and its dependence on various external conditions has been already discussed on page 365 .

\section{Butyric Acid Fermentation.}

The materials for this fermentation are furnished by Butyric acid starch, dextrine, inuline, cane-sugar, and dextrose; and fermentation. also by milk-sugar, but only after hydration. The butyric acid fermentation occurs spontaneously, and is very widely distributed; thus it is found in milk which has stood for a long time, in "sauer-kraut," in cheese, in the ripening of which it probably plays a part, \&c. In order to obtain it artificially it is well, according to Fitz, to mix together 100 grammes of potato starch (or dextrine), one gramme of sal ammoniac and the ordinary nutrient salts, with two litres of water, and to add 50 grammes of carbonate of lime, in order to neutralise the butyric acid as it is formed. According 
to Déhérain* and Maquenne the exciting agents of the butyric acid fermentation are found in large numbers in the earth of fields and gardens; hence it is best to infect the fermentescible mixture with this, or with old cheese, or with cow dung. The vessels are then kept at $40^{\circ} \mathrm{C}$. Fermentative While formerly it was only supposed that one species agents.

of bacterium had the power of exciting the butyric fermentation, it has been recently demonstrated that several species of bacteria are capable of this act, and that the fermentation with one or with some forms of bacteria can occur in the presence of air, while for the activity of others the exclusion of air is a necessary condition. Besides the species mentioned on page 367 , it seems, according to Fitz, $\uparrow$ that a short cylindrical bacillus, described by him, is capable of setting up butyric fermentation, this bacillus possessing a moderate amount of spontaneous movement, not forming spores, and not becoming blue on the addition of iodine. It belongs to the class of aërobes, and causes fermentation of all carboNature of the hydrates except starch and cellulose.-The formula for decomposition.

the decomposition is probably different for the various different species; in any case, carbonic acid and hydrogen seem to be constantly formed in large quantities. Fitz has also found on analysis of the products obtained from a hundred grammes of starch, $34 \cdot 7$ grammes of butyric acid, $5 \cdot 1$ grammes of acetic acid, and 1 gramme of æthylic alcohol. As, however, it has, as yet, been scarcely possible to cultivate the butyric acid bacilli perfectly pure, no experiment with absolutely pure cultivations has been subjected to accurate analysis, and therefore we must not lay too great weight on these numbers. See page 369 .

\section{Viscous or Mannite Fermentation.}

Viscous fermentation of wine.
The materials which furnish this fermentation are dextrose and invert sugar ; as regards the ferment, the micrococcus viscosus, see p. 216. The fermentation

* Déhérain et Maquenne, Bull. soc. chem. (2) vol. 29-Compt. rend., vol. 97 -

+ Fitz, Chem. Ber., vol. xvii., P. 1188. 
often occurs in certain kinds of wine, more especially in white wine, also in the saccharine juices of turnips, carrots, onions, \&c.; the fluids attacked become viscous and can be drawn out in threads. The fermentation is best obtained artificially by using a decoction of beer yeast, which is filtered and mixed with sugar, or by employing starch, rice, or barley-water containing sugar; the optimum of temperature is about $30^{\circ} \mathrm{C}$. Among the products of fermentation is always a kind of gum, which is closely related to dextrine, and has been recently termed by Béchamp "viscose"; mannite and carbonic acid are also formed. Viscose is soluble in cold water, Viscose. is precipitated by alcohol, does not reduce Fehling's solution, shows the same composition as starch, and rotates in the same manner as soluble starch.-At times, and probably owing to the action of other ferments, lactic acid, butyric acid, acetic acid, and hydrogen are formed. Under the most favourable circumstances 100 parts of sugar yield $51 \cdot 1$ parts of mannite, $45 \cdot 5$ parts of gum, and 6.2 parts of carbonic acid; hence the fermentation can be expressed by the formula, $50\left(\mathrm{C}_{6} \mathrm{H}_{12} \mathrm{O}_{6}\right)$ (dextrose) $=12\left(\mathrm{C}_{12} \mathrm{H}_{20} \mathrm{O}_{10}\right)(\mathrm{gum})+24\left(\mathrm{C}_{6} \mathrm{H}_{14} \mathrm{O}_{6}\right)$ (mannite) $+12 \mathrm{CO}_{2}+12 \mathrm{H}_{2} \mathrm{O}$. Schmidt-Mülheim supposes that, in this fermentation of wine, there are, in fact, two fermentations taking place together; the one which produces mannite and carbonic acid, and the other as the result of which the gum-like substance arises. - SchmidtMülheim observed the formation of the latter substance alone without simultaneous production of carbonic acid and mannite in the so-called tenacious milk as the result of the growth of the micrococcus described on page 216. milk. This fermentation is not a fermentation of the albuminoid materials of milk, but is due to splitting up the milksugar, or it may be also cane-sugar, grape-sugar, or mannite. The viscous substance formed is precipitated by alcohol as a white sticky precipitate, which only swells up slightly in water, much more freely in potash lye, readily reduces Fehling's solution, and is stained brown by iodine and iodide of potash. - The optimum of temperature for this fermentation lies between $30^{\circ}$ and $40^{\circ} \mathrm{C}$. 


\section{Dextran Fermentation.}

Dextran

fermentation.

The only directly suitable material is grape-sugar; cane-sugar does not ferment directly, but, as the fermenting agents furnish large quantities of invertin, the decomposition of the cane-sugar is only slightly delayed. It not uncommonly occurs spontaneously in the juice of beet-root, and hence is much dreaded in sugar factories. The fungus which causes the fermentation is leuconostoc mesenterioides. The decomposition results mainly in the formation of large quantities of a jelly-like substance-the dextran. We have no accurate knowledge as to the process of the fermentation; as to the morphological characters of the fungus, see page 214 .

\section{Cellulose Fermentation (Marsh Gas Fermentation).}

Cellulose

fermentation.

Materials and fermenting agents.

Course.

First kind.
Cellulose, in the form of dead plants, straw, paper, or cotton-wool, frequently undergoes solution and fermentation by bacteria. Hoppe-Seyler* was able to set up this fermentation by all kinds of mud, and also by earth from fields, meadows, and woods; according to Déhérain $\dagger$ and Gayon $\ddagger$ it often occurs in dung; on the whole, it seems to be extremely widely distributed. Tappeiner has shown that cellulose is dissolved and broken up by the same fermentation in the intestinal canal of the ruminants.-The bacteria which set up this fermentation have not, as yet, been cultivated pure. As to the chemical processes, Tappeiner has made several investigations, and found that there are two kinds of fermentation of cellulose; the first occurs in neutral extract of meat solution containing 1 per cent. of extract of meat, in which purified cotton-wool or paper pulp is suspended; under these circumstances, carbonic acid and marsh gas escape (in the first few days the marsh gas is in much greater excess than at a later period); further, small

* Hoppe-Seyler, Chem. Ber., vol. xvi.

† Déhérain, Compt. rend., vol. 98 .

\pm Gayon, ibid. 
quantities of sulphuretted hydrogen, aldehyde, isobutyric acid, acetic acid. The second fermentation occurs when second kind. an alkaline extract of meat solution is employed; in that case only carbonic acid and hydrogen are formed, along with the same bye-products as in the former fermentation.-Tappeiner* has ventured to conclude from his researches that the solution and decomposition of cellulose in the intestine of ruminants only occurs as the result of this fermentation, and that therefore the cellulose is of no nutrient value for the organism. According to the experiments and calculations of Wilsing $t$ and Henneberg and Stohmann, + however, this view does not seem to be accurate, and only a part of the cellulose which disappears in the intestine is lost by fermentation.

\section{Other Fermentutions.}

In the case of various carbo-hydrates, Fitz observed a fer- Various other mentation in which æthylic alcohol was formed as the chief fermentations. product. From 500 grammes of starch he obtained 10 grammes of æthylic alcohol; from the same quantity of dextrine 22 grammes; milk-sugar also furnished chiefly the same alcohol.

Bontroux found a transformation of milk sugar into gluconic acid by a species of bacterium similar to the mycoderma aceti.

'To Brieger we owe the knowledge of a number of fermenta- Fermentations of carbo-hydrates caused by pathogenic bacteria. According to this author bacillus cavicida splits up solutions of grape-sugar in such a way that propionic acid is the chicf product. Bacillus pneumoniæ causes a marked development of gas in five per cent. sugar solutions to which a little nutrient gelatine has been added, and in the fluid there is acetic acid as the chief product of the fermentation, and, in addition, small quantities of formic acid and æthylic alcohol. Typhoid bacilli formed from grape sugar or starch æthylic alcohol, acetic acid, and lactic acid. A non-pathogenic coccus, obtained from fæces, which forms on gelatine flat pyramids of a glistening white colour, decomposes three per cent. grape-sugar or cane-sugar solution in such a way that wthylic alcohol along with traces of acetic acid is formed.

* Tappeiner, Chem. Ber., vol. 16.-Zeilschr.f. Biol., vol. 20.

+ Wilsing, ibid. $\quad \ddagger$ Henneberg und Stohmann, ibid., vol. 21. 
(3). Fermentation of the Higher Alcohols.

Fermentation of the higher alcohols.

In the case of glycerine, Fitz obserred four fermentations.
Under the influence of the bacillus Fitzianus-the morphology
and source of which we have discussed on page 388-glycerine
furnishes considerable quantities of athylic alcohol (for ex-
ample, 29 grammes from 100 grammes of glycerine), and, as
bye-products, capronic acid, butyric acid, and a little acetic
acid.

While no fermentations have been with certainty observed in the case of the diatomic glycol, various fermentations caused by bacteria have been demonstrated in the triatomic alcohol, glycerine, the tetratomic alcohol, erythrite, the pentatomic alcohol, quercite, and the hexatomic alcohols mannite and dulcite.

In order to set up the second fermentation, which chiefly furnishes butylic alcohol, solutions of hay-water and glycerine are mixed and kept at $40^{\circ} \mathrm{C}$. without being previously boiled. A bacillus is found in the fermenting mixture which is $2 \mu$. broad, and 5 to $6 \mu$. long, and which is actively motile while the fermentation is going on. In stronger solutions of glycerine (above 10 per cent.) the fermentation soon ceases, and the bacillus forms spores. If fresh cow-dung is sown in the glycerine nutrient solution, æthylic and butylic alcohols are formed in about equal quantities (also a little propylic alcohol), and, in correspondence with this, the nutrient solution is peopled by two forms of bacilli.

Thirdly, Fitz was able to set up a fermentation in glycerine by means of the bacillus pyocyaneus in which large quantities of butyric acid, along with æthylic alcohol and succinic acid, were obtained.

Fourthly, as the result of the growth of small thin rods, often united together in pairs, which are also able to set up fermentation in malate of lime, æthylic alcohol (21 grammes from 100 grammes of glycerine), and also formic acid and succinic acid were obtained.-A fermentation of glycerine was also caused by other bacteria; thus, as the result of the growth of microcooci, alcohol, butyric acid, formic acid, and acetic acid were found; Hoppe-Seyler found, on the addition of putrefying fibrine to a glycerine solution, chiefly butyric acid, acetic acid, and succinic acid as products of fermentation. Vigna* observed the formation of æthylic and butylic alcohol 
from glycerine, and was dealing therefore probably with the combination of the two fermentations first mentioned.-In all these decompositions of glycerine, with the exception, perhaps, of the fermentation by bacillus Fitzianus, which has been more accurately studied by Buchner, the methods employed do not furnish a sufficient guarantee for a thoroughly pure growth, and the morphological characteristics of the fermenting agents have not been sufficiently attended to, and thus the value of these careful chemical investigations is diminished.

In the case of erythrite Fitz also found a number of fer- Erythrite. mentations; one bacterium caused a decomposition in which two molecules of erythrite were split up into one molecule of butyric acid, and one molecule of succinic acid, with a loss of $2 \mathrm{H}_{2} \mathrm{O}$ and $1 \mathrm{H}$; another bacterium caused a fermentation with only slight traces of succinic acid.

Mannite, in the first place, gives rise to the lactic fermenta- Mannite. tion above mentioned. According to Fitz also, a bacterium causes in a three per cent. solution of mamnite the formation of normal butylic alcohol, æthylic alcohol, succinic acid, and lactic acid; and a club-shaped bacillus obtained from boiled hay infusion furnished æthylic alcohol (26 per cent.), formic acid (5*6 per cent.), and a little succinic acid.

Dulcite behaves very similarly to the carbo-hydrates as Dulcite. regards the lactic fermentation. According to Fitz, dulcite also gives rise to a fermentation with a little alcohol and much butyric acid. Quercite gives rise to a fermentation with the almost exclusive formation of normal butyric acid.

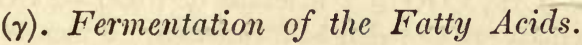

Numerous acids belonging to the group of fatty bodies Fermentation form a suitable fermentescible material when they are of the fatty given to bacteria in the form of neutral salts. The lime salt of these acids seems to be the most suitable, and with it almost all the experiments on fermentation have been made. The following are capable of undergoing fermentation: formic acid $(\mathrm{HCOOH})$, acetic acid $\left(\mathrm{CH}_{3}\right.$, $\mathrm{COOH})$; further, a number of oxy-acids, namely: lactic acid $\left(\mathrm{C}_{2} \mathrm{H}_{4}, \mathrm{OH}, \mathrm{COOH}\right)$, glycerinic acid $\left(\mathrm{C}_{2} \mathrm{H}_{3}\right.$, $\left.(\mathrm{OH})_{2}, \mathrm{COOH}\right)$, malic acid $\left(\mathrm{C}_{2} \mathrm{H}_{3}, \mathrm{OH},(\mathrm{COOH})_{2}\right)$, tartaric acid $\left(\mathrm{C}_{2} \mathrm{H}_{2},(\mathrm{OH})_{2},(\mathrm{COOH})_{2}\right)$, citric acid $\left(\mathrm{C}_{8} \mathrm{H}_{4}, \mathrm{OH}\right.$, $\left.(\mathrm{COOH})_{3}\right)$.

Formate of lime furnishes, according to Hoppe-Seyler, 
when mixed with sewer-mud, carbonate of lime, carbonic acid, and hydrogen; acetate of lime, treated in a similar manner, gives carbonate of lime, carbonic acid, and marsh gas.

Lactate of lime undergoes, according to Fitz, four different kinds of fermentation; in the first place, under the influence of a thin bacillus, which often forms long chains, it gives rise to the propionic acid fermentation, in which acetic acid, succinic acid, and alcohol appear as bye-products; the process may probably be expressed by the formula $3 \mathrm{C}_{2} \mathrm{H}_{4} \mathrm{OH} \mathrm{COOH}$ (lactic acid) $=2 \mathrm{C}_{2} \mathrm{H}_{5} \mathrm{COOH}$ (propionic acid) $+\mathrm{CH}_{3} \mathrm{COOH}$ (acetic acid) $+\mathrm{CO}_{2}+\mathrm{H}_{2} \mathrm{O}$. - In the second place, the acetate of lime under other conditions furnishes, along with propionic acid, large quantities of normal valerianic acid; from 3 kilogrammes, 126 grammes of propionic acid and 101 grammes of valerianic acid were obtained.-Thirdly, as the result of the action of the short aërobic butyric acid bacilli discovered by Fitz, butyric acid and propionic acid were chiefly formed.Fourthly, Pasteur (Comptes rendus, 1861) long ago observed the butyric acid fermentation of lactate of lime; Fitz obtained in this fermentation, from 500 grammes of lactate of lime, about 34 grammes of butyrate of lime, and also $3 * 6$ grammes of rethylic and butylic alcohol. This fermentation may be represented by the formula $2\left(\mathrm{C}_{2} \mathrm{H}_{4} \mathrm{OH} \mathrm{COO}\right)_{2} \mathrm{Ca}$ (lactate of lime) $=\mathrm{CO}_{3} \mathrm{Ca}$ (carbonate of lime) $+3 \mathrm{CO}_{2}+4 \mathrm{H}_{2}+\left(\mathrm{C}_{3} \mathrm{H}_{7}\right.$ $\mathrm{COO})_{2} \mathrm{Ca}$ (butyrate of lime).

Glycerinate of lime gives, when fermented by longish micrococci, chiefly acetate of lime, along with a little succinic acid and $x$ thylic alcohol; the pure fermentation probably occurs according to the formula $\left(\mathrm{C}_{2} \mathrm{H}_{3}(\mathrm{OH})_{2} \mathrm{COO}\right)_{2} \mathrm{Ca}$ (glycerinate of lime $)=\left(\mathrm{CH}_{3} \mathrm{COO}\right)_{2} \mathrm{Ca}$ (acetate of lime) $+2 \mathrm{CO}_{2}+2 \mathrm{H}_{2}$. The same material can also be fermented, by means of fairly large bacilli, to formic acid, with a little methylic alcohol and acetic acid as bye-products.

Malate of lime can likewise undergo several fermentations. Under the influence of thin bacilli-the same which caused the fermentation of glycerine-succinic acid (about 60 per cent. of the material) and a little acetic acid are formed ; with other shorter bacilli propionic acid is the chief product, along with a little acetic acid.- In the third place, there is, at times, a formation of butyric acid, with the development of hydrogen; and finally, according to Schützenberger, the malate of lime is split up with the formation of lactic acid and carbonic acid.

Tartrate of lime gives rise either to the propionic acid fermentation found by Pasteur, and also obtained by Fitz, which probably takes place according to the formula $3 \mathrm{C}_{4} \mathrm{H}_{6} \mathrm{O}_{6}$ (tartaric acid) $=\mathrm{C}_{2} \mathrm{H}_{5} \mathrm{COOH}$ (propionic acid) $+2 \mathrm{CH}_{3} \mathrm{COOH}$ (acetic acid) $+5 \mathrm{CO}_{2}+2 \mathrm{H}_{2} \mathrm{O}$; or butyric acid fermentation 
results; or, in the third place, a decomposition occurs, in which acetic acid is chiefly formed (from 100 grammes of tartrate of lime Fitz obtained 45 grammes of acetate of lime), and, in addition, æthylic alcohol, butyric acid, and succinic acid.

According to Koenig* there is obtained from a solution of tartrate of ammonia together with nutrient salts, on the addition of a drop of putrid fluid, a slight development of gas (carbonic acid and hydrogen), a large quantity of succinic acid, and a little formic acid and acetic acid. From tartrate of lime infected with the same material (which, however, forms an unknown mixture of bacteria) there results no succinic acid, but carbonic acid, acetic acid, formic acid, propionic acid, and a little butyric acid.

According to Fitz's experiments, citrate of lime furnishes large quantities of acetic acid, under the influence of small, thin bacilli (from hay-water), while as bye-products we have æthylic alcohol and succinic acid.-Mucic acid also is, according to Schützenberger, readily split up into acetic acid, carbonic acid, and hydrogen.

Finally, we may mention here the fermentation of quinate of lime, which has been observed by Loew, from which, when air is present, there results protocatechic acid; but when oxygen is absent, acetic acid and propionic acid.

Although the progress which has been made during Incompletethe last few years, as regards the method of performing experiments these experiments on fermentation, in that attention on fermentahas been paid to the purity of the organisms sown, is very marked, we must accept with a certain reserve all the decompositions which bave been referred to in the foregoing paragraphs, because in almost all the experiments the purity of the cultivations is not absolutely free from question. In order to obtain a really trustworthy result, it is evidently not only necessary to cultivate the fermentative agents pure, and to sterilise the fermentescible substratum carefully, but it is also well, after the termination of the fermentation, to examine the remaining fluid with the aid of the recent bacteriological methods in order to ascertain that no other bacteria than those that were sown are present, and have taken part in the decomposition observed. It is absolutely necessary to require these precautions on account of the danger, never completely avoidable, of the accidental entrance

* Koenig, Chem. Ber., vol. 14. 
Fermentations employed in the preparation of food.

Fermentation of bread.

of saprophytes. This test, however, has almost never been employed.

Thus on the whole we have very few certain facts as to the mode in which the decompositions are brought about by certain species of bacteria. Hence it is that we are, as yet, very imperfectly informed as to many of the most frequent fermentative processes which spontaneously occur, or are artificially set up in our surroundings, for example, in the preparation of food, in many manufactures, \&c. Even as regards the cause, the course, and the products of the fermentation of bread, we know very little that is trustworthy. It is very probable that the rising of the leaven is not caused by a pure yeast fermentation, for, especially in leaven, bacteria are present in preponderating numbers. According to the more recent investigations of Chicandard,* yeast does not play any part, or only a very secondary one, in the fermentation of bread, and the true agent seems to be rather a species of bacterium. Marcanot also sees in the mobile bacteria the true cause of the fermentation of bread, while Bontroux + is of opinion that in this process several kinds of organisms, varieties of yeast, and bacteria play an active part.-It would be very desirable to obtain information as to this daily fermentative phenomenon by means of accurate experiments made with the aid of the more recent bacteriological methods. $\S$

In some cases combinations of fermentations are employed in the preparation of nutrient materials, especially in order to obtain the formation of æthylic alcohol by means of yeast from materials which are not in reality fermentescible, for example, from starch, dextrine, milk-

* Chicandard, Compt. rend., vols. 96, 97.

‡ Bontroux, ibid., vol. 97.-Moussette, ibid., vol. 96.

$\S$ Duclaux has made minute investigations as to the bacteria which grow in milk and in cheese, and which take part in the decompositions which occur; he designates them under the generic name tyrothrix, and distinguishes T. scaber, T. tenuis, T. filiformis, \&c.-Unfortunately the papers in which these results are given in detail (Annals de l'Instit. agron., and Duclaux's Chimie biolngique) could not be obtained in the libraries in Göttingen and Berlin, and only became known to the author at too late a period to be utilised in this work. 
sugar. Such combined fermentations probably occur in the preparation of chicha from maize, as well as of the Japanese kösi from rice (Marcano*); further, in the two kinds of milk wine which have been already mentioned on page 372 -koumiss and kephyr.

Kephyr is, without doubt, the most important of these preparations as an article of diet. The method ordinarily employed in its preparation by the inhabitants of the Caucasus is very simple; the fresh cow or goat milk is collected in a flask, a small quantity of the kephyr bodies is introduced, the flask is closed and placed, in summer in a shady place and during the cooler part of the day in the sun, in winter in the dwelling rooms, and frequently thoroughly shaken. The drink is ready after one or two days; it is then poured off; over the remains of the kephyr bodies left in the flask new milk is poured.-Elsewhere, two methods are employed in its preparation. According to the first, the dry, Preparation brownish kephyr bodies, which are sold in this condition, are from dry placed for five or six hours in lukewarm water, till they swell Kephyr. Native mode of manufacture. up. They are then carefully washed, and introduced into fresh milk, which is changed once or twice daily till the kephyr bodies become of a pure white colour, and in fresh milk rapidly rise to the surface (after twenty to thirty minutes). On a table-spoonful of granules so prepared about a litre of milk is then poured, and the whole introduced into a flask which is allowed to stand open for five or six hours, then tightly closed and kept at about $18^{\circ} \mathrm{C}$., being shaken up abont every two hours. After eight to twenty-four hours the fluid is passed through a fine sieve into another flask (this must not be more than four-fifths full); it is then corked and shaken from time to time. After twenty-four hours the socalled one-day-old kephyr is obtained, which contains only little carbonic acid and alcohol; as a rule it is the two-day-old which is drunk, and which, after standing at rest for some time, divides into two layers-a lower, whey-like and transparent; and an upper, formed of extremely fine flakes of casein; when it is shaken up it has a cream-like consistence. Three-day-old kephyr is still thinner and very sour.-What remains after filtration through the sieve can be added to fresh milk after being thoroughly washed with water.

The second and more simple method can be employed where Preparation a good two or three-days-old kephyr is obtainable. Of this, from active

* Marcano, Compt. rend., vol. 95.

+ After Krannhalls.-Kephyr was introduced into Germany at the establishment of Dr. Stern in Kissingen. 
Chemical composition of kephyr.

one part is added to three or four parts of fresh cow milk, it is then introduced into flasks and allowed to stand for about forty-eight hours, being shaken from time to time. Of the drink so prepared, from one-fifth to one-third is left behind in the flask, as a ferment for new milk which is added to it.'The temperature must, as a rule, be about $18^{\circ} \mathrm{C}$.; it is only at the commencement that a higher temperature is desirable. -The kephyr granules which are being employed must be cleansed carefully from time to time, and broken down till they are about the size of a pea. The cleansed granules can then be dried on blotting paper in the sun or in the neighbourhood of an oven; in the dry state they retain their power of growth for a very long time-for several months, and even years.

The chemical investigations have as yet added as little knowledge as to the course of the kephyr fermentation as have the cultivation experiments. It is certain that the most important products of fermentation are æthylic alcohol, lactic acid, and carbonic acid; small quantities of glycerine, succinic acid, acetic acid, and butyric acid are also formed. The amount of lactic acid in prepared kephyr is usually about 1.5 per cent.; the amount of alcohol $1^{\circ} \mathrm{Tr}$.; both have been shown to arise only from the milk-sugar. During the first twenty-four hours the greater proportion of the milk-sugar is utilised for the formation of lactic acid, while during the following days the formation of alcohol is greater. When the temperature is high $\left(25^{\circ}\right.$ to $30^{\circ} \mathrm{C}$.) the lactic fermentation is too greatly favoured as compared with the alcoholic fermentation, and it is only at a definite low temperature that the two fermentations follow a normal course.-The amount of albumen in the milk is, according to the analyses as yet made, apparently not altered in the kephyr fermentation; but the casein undergoes an alteration in that it becomes suspended in the milk in extremely fine flakes, so that the whole fluid assumes an almost cream-like consistence. It is probable that the dietetic value of the preparation is largely due to this alteration in form of the casein. Peptone cannot be demonstrated.

\section{(8). Putrefaction.}

Putrefaction. Under the term putrefaction, or putrefuctive fermentation, we understand the rapid and intense decomposition of nitrogenous and chiefly albuminoid substances by certain bacteria in which gaseous, foul-smelling products are formed in large quantities. 
The material for this fermentation is, in the first Material. place, furnished by the albuminous substances themselves; these never seem to undergo the decomposition directly, but first become converted into peptone; as, however, a peptonising ferment is usually produced, by putrefactive and many other bacteria, there is practically only a difference as regards time between the putrefaction of soluble and insoluble albuminous materials; by the addition of peptonising pancreatic ferment the putrefactive process is, however, hastened. Further, gelatinous materials, and materials which give rise to gelatine, are liable to undergo putrefactive fermentation; then the peptones; finally, some nitrogenous bodies, which are, however, more removed from the proteid materials in their composition and in their characters, but which are closely allied to them in that they must be looked on as components of the albuminous molecule; more especially leucine, perhaps also tyrosin, indol, \&c.

In accordance with our present views as to the com- Nature of the position of the albuminoid bodies, and in accordance decomposiwith the analogies with the decomposition which these bodies undergo as the result of the action of acids and alkalies, we must, as a whole, assume that in the decomposition of the albuminoid molecule as the result of putrefaction, amido derivatives of the fatty acids (amido acids), nitrogenous bodies of the aromatic series, sulphoacids (taurin), and perhaps also peptone-like bodies are formed. As a rule, however, the products which first appear are rapidly broken up further, so that they scarcely attract attention; for example, the amido acids are broken up into ammonia and fatty acids, of which the latter are still further decomposed according to the formulæ given above, usually with the liberation of carbonic acid, hydrogen, and marsh gas. Thus, in the case of leucine a fermentation has been found which seems to take place according to the formula $\mathrm{C}_{5} \mathrm{H}_{10}$ $\mathrm{NH}_{2} \mathrm{COOH}$ (leucine) $+2 \mathrm{H}_{2} \mathrm{O}=\mathrm{C}_{4} \mathrm{H}_{9} \mathrm{COOH}$ (valerianic acid) $+\mathrm{NH}_{3}+\mathrm{CO}_{2}+2 \mathrm{H}_{2}$. Glycocol and other amido acids probably also undergo a similar decomposition. 
In the case of tyrosin also we must assume that further rapid decomposition takes place, because it is only found in considerable quantities at the commencement of putrefaction; according to Nencki this fermentation can occur according to the formula: $\mathrm{C}_{6} \mathrm{H}_{4} \mathrm{OH}$ $\mathrm{C}_{2} \mathrm{H}_{3} \mathrm{NH}_{2} \mathrm{COOH}$ (tyrosin) $=\mathrm{C}_{6} \mathrm{H}_{4} / \mathrm{CH}=\mathrm{CH}$ (indol) $+\mathrm{CO}_{2}+\mathrm{H}_{2} \mathrm{O}+\mathrm{H}_{2}$. According to Baumann, in the putrefaction of tyrosin, when the entrance of oxygen is not completely hindered, hydroparacumaric acid, paroxyphenylacetic acid, paracresol, and phenol are formed in that order; in this decomposition paraëthyl, phenol, and paroxybenzoic acid probably form intermediate stages, carbonic acid, water, and ammonia being set free. Other observers have demonstrated the formation of hydrocinnamic acid from tyrosine.-Among the transitory products we have also succinic acid, which breaks up into carbonic acid and propionic acid, likewise phenylamido-propionic acid, which furnishes phenylacetic acid, and phenylamidoacetic acid, which gives rise to small quantities of amygdalic acid, along with other products of decomposition.

Products. The following are the numerous bodies which arise in putrefactive processes: carbonic acid, hydrogen, freo nitrogen, sulphuretted hydrogen, phosphuretted hydrogen, methane; formic acid, acetic acid, butyric acid, valerianic acid, palmitic acid; acrylic acid, crotonic acid; glycollic acid, lactic acid, valerolactamic acid; oxalic acid, succinic acid ; leucin, glycocoll, glutaminic acid, aspartic acid, amidostearic acid; ammonia, carbonate of ammonia, sulphide of ammonia; numerous amine bases, propylamine, trimethylamine, \&c. ; indol, scatol-carbonic acid, scatol ; tyrosin, and the bodies belonging to the aromatic series which have been above mentioned as originating from it ; finally, the ptomaines referred to on p. 569.

The number and multiplicity of these products lead to the conclusion that their formation does not always occur to the same extent in every putrefactive fermentation. As a matter of fact we by no means always find all the products mentioned; on the contrary, the decom- 
position of the albuminous molecule runs its course in a varying manner, and leads to the production, sometimes of these, sometimes of those, products in largest amount. This varying course of putrefactive processes Varying can be in part occasioned by differences in the fermencourse of the putrefactive tescible material, in part, also, by differences in the processes. external conditions; but the cause of the greatest and most important variations is differences in the kinds of bacteria which set up putrefaction. According as one or other species of bacteria, or a varying mixture of them, gain the upper hand in the putrefying mixture we have a qualitative or quantitative difference in the nature of the products.

Since we have been able to employ the methods of Multiplicity pure cultivation for the organisms which excite putre- of the exciting faction, we have good grounds for believing that we shall putrefaction. be able to obtain definite proof of the fact that various kinds of bacteria are capable of splitting up albumen, and, at the same time, obtain an insight into the mode of action of each of these kinds. Even now we know a large number of species of bacteria which can, in pure cultivation, occasion a rapid decomposition of the albuminous molecule, with the formation of foul-smelling gases, but the action of these is very various, whether we look at the nature of the products, or at their quantity. In the case of the majority of these products we require a more accurate knowledge of their chemical nature; in the case of many it is only the development of foulsmelling gases, the chemical composition of which is not more accurately known, which leads us to assume that a putrefactive decompositicn of the albuminous molecule has occurred. The following are examples of these kinds of bacteria :-

Species of bacterium.

Bacillus putrificus coli

Bacillus saprogenes, I, II, III.
Putrefactive products as yet demonstrated.

peptone, ammonia, fatty acids, tyrosine, phenol, indol, scatol, \&c. (see p. 377).

foul-smelling gases. 


\begin{tabular}{|c|c|}
\hline Species of bacterium. & $\begin{array}{l}\text { Putrefactive products as yet } \\
\text { demonstrated. }\end{array}$ \\
\hline $\begin{array}{l}\text { Bacillus coprogenus fœetidus } \\
\text { Proteus vulgaris, mirabilis, } \\
\text { Zenkeri }\end{array}$ & $\begin{array}{l}\text { foul-smelling gases. } \\
\text { peptone, foul-smelling gases. }\end{array}$ \\
\hline $\begin{array}{l}\text { Bacillus pyogenes fœtidus ... } \\
\text { Micrococcus fotidus } \ldots . . . . . . \\
\text { Miller's Bacillus (p. } 375 \text { ) ...... }\end{array}$ & $\begin{array}{l}\text { foul-smelling gases. } \\
\text { foul-smelling gases. } \\
\text { sulphuretted hydrogon, am- } \\
\text { monia. }\end{array}$ \\
\hline $\begin{array}{l}\text { Bacillus fluorescens lique- } \\
\text { faciens (bacterium termo?) }\end{array}$ & $\begin{array}{l}\text { peptone, volatile fatty acids, } \\
\text { green colouring matter. }\end{array}$ \\
\hline Bacillus butyricus, Hueppe... & $\begin{array}{l}\text { peptone, leucin, tyrosine, am- } \\
\text { monia, substances with a } \\
\text { bitter taste. }\end{array}$ \\
\hline Bacillus ureæ & trimethylamine. \\
\hline Bacillus prodigiosus & trimethylamine. \\
\hline Bacillus pyocyaneus .... & peptone, ammonia. \\
\hline Bacillus fluorescens putidus & trimethylamine. \\
\hline Bacillus janthinus .............. & peptone, ammonia. \\
\hline Various anaërobes............... & foul-smelling gases. \\
\hline $\begin{array}{l}\text { Bacteria from mud or the in- } \\
\text { testinal contents of rumi- } \\
\text { nants (Tappeiner) }\end{array}$ & $\begin{array}{c}\text { carbonic acid, marsh gas, sul- } \\
\text { phuretted hydrogen, \&c. }\end{array}$ \\
\hline
\end{tabular}

It must be further mentioned that Salkowski has found very various quantities of indol and scatol in his analyses of putrefying mixtures, and that he refers these variations to differences in the prevailing kind of bacteria ; Tappeiner's observation must also probably be interpreted in the same manner. He has found that, in the paunch of cattle, scatol only occurs, and not indol, which is otherwise very widely distributed in the intestines of the herbivora.

Different results of the action of different putrefactive organisms.

Hence we must come to the conclusion that numerous kinds of bacteria are capable of splitting up albumen, but that they are not all able to furnish representatives of the various groups of putrefactive products in such a complete manner as Bienstock's bacillus putrificus coli, for example; but that many can only break up certain parts of the molecule, leaving considerable portions unaltered. Hence we cannot attempt to form general formulæ for the decomposition of albuminoid 
materials as the result of putrefaction. We can only employ definite chemical formulæ for each kind of putrefaction occasioned by a definite micro-organism.

The putrefaction which occurs spontaneously shows Spontaneous very great differences, according to the bacteria which putrefaction. are accidentally present, and according as the conditions of existence are at the time more favourable for one or other species. The kind of organisms which gain the upper hand at the commencement of the process depend on the concentration, the chemical composition, the reaction, and the temperature of the putrescible materials; in the course of time, and under the influence of gradually extending putrefaction, these external conditions alter completely; from neutral bodies others can arise which cause an acid reaction; by the decomposition chiefly of nitrogenous molecules and the formation of ammonia the alkalinity of the material may be increased; the relation of the individual chemical materials alters, because one kind is broken up to a greater extent than another. Thereby the most favourable conditions of existence are again provided for other kinds of bacteria; and thus the spontaneous putrefaction consists of a series of decompositions, not as a rule following any definite order, but dependent on individual conditions which cannot be controlled, these decompositions being caused by various different kinds of bacteria, and kinds which act in the most various ways. At the commencement of putrefaction we usually observe several kinds of micrococci and also large bacilli; in the later stages we find in addition masses of short bacteria; on the surface of the mixture forms seem to predominate which were formerly described under the name of bacterium termo, and of these it appears from plate cultivations that bacillus fluorescens liquefaciens forms the largest numbers. Nor must we forget that numerous forms of bacteria which have no fermentative action, or which do not find a suitable material for the development of their fermentative activity, establish themselves in putrefying mixtures, though it is true that at a later period, when energetic fermentation is present, the organisms which 
play an active part in it usually hinder the development of other forms. All these accompanying micro-organisms must complicate the putrefactive process, in that the specific products of their tissue change become mixed with the products of the fermentation.

Influence of oxygen on the course of the putrefactive process.

Pasteur's view.

The true putrefactive organisms are anaèrobes.
Oxygen exerts the greatest influence on the course of the putrefactive process. [t has been long known that true putrefaction, with foul-smelling gaseous products, occurs only when the amount of air is limited. When air is freely admitted these odours are absent, and a rapid and very complete oxidation of the putrescible materials takes place, this form of putrefaction being therefore designated under the special name decay. Pasteur was the first to indicate more clearly the difference between putrefaction in the presence of oxygen, and putrefaction without oxygen; according to Pasteur, when air is excluded, the oxygen contained in the fluid is, in the first place, used up completely by certain microorganisms (monas crepusculum and bacterium termo). As soon as the oxygen is removed these bacteria die, and fall to the bottom of the vessel in the form of a deposit. After this has occurred the true putrefactive bacteria appear; they can only exist where oxygen is absent ; they set up the putrefactive fermentation, and absolutely require the preparatory action of these aërobes. If, on the other hand, the fluid is freely exposed to air, the aërobic bacteria develop continuously at the surface and form a scum, which at times falls to the bottom in masses, but is constantly regenerated. This scum prevents the access of the oxygen to the fluid, and thus it is possible that vibriones, which can only live when oxygen is absent, but which cause the fermentations, can develop in the fluid, as it were under the protection of the bacterial cover. The somewhat complex fermentative products thus formed serve as nutriment to the aërobes at the surface, and the latter then break them up into the simplest compounds, water, carbonic acid, ammonia, and thus the products which are ordinarily characteristic of putrefaction are not found.

In this way Pasteur sought to explain the difference 
between putrefaction in the presence and in the absence Putrefaction of oxygen, in correspondence with his theory of fer- also occurs in mentation based on the absence of this gas. This view of oxygen. is, however, evidently not quite correct. As the result of more recent investigations, it has been shown beyond doubt that, as well in the presence as in the absence of oxygen, certain kinds of bacteria are able to split up the albuminoid molecule and furnish the products characteristic of putrefaction. Further also, we have in the chemical processes which occur in putrefaction a partial explanation of the influence of oxygen.

When oxygen is absent extensive reduction processes occur, which, for the most part, arise directly in the process of fermentation; fatty acids are formed from oxyacids; marsh gas, sulphuretted hydrogen, sulphur (for example in the beggiatoa) appear; above all, however, hydrogen is formed in the various fermentations. As is evident from the formulæ given above, hydrogen is processes liberated in the fermentation of formic acid, lactic acid according as (butyric acid fermentation), glycerinic acid, malic acid, present. tartaric acid, erythrite, leucin, \&c. ; this hydrogen must at times lead to further reduction effects. Nitrates must be converted by this hydrogen into nitrites, indigo bluo into indigo white, invert sugar into mannite; sulphates can also probably be reduced by it. On the whole, however, the alteration of the fermentescible material and of the products of fermentation, as the result of the action of the hydrogen, is only slight, and it is characteristic of the course of fermentation without oxygen that the true fermentative products appear in the main in an unaltered condition without having undergone further destruction and oxidation; and also we can understand that in this process of putrefaction only those bacteria can exist which are able to act without the presence of oxygen, so long as they have fermentescible material at their disposal.

The case is otherwise when there is free access of Role of the oxygen. In this case the same hydrogen which in the nascent former instance only performed a secondary function, probably now plays a much more important part. 
Hoppe-Seyler has tried to show that when oxygen is present the nascent hydrogen breaks up the molecule of oxygen and thus renders the latter active; the nature of the process being that, as the hydrogen is gradually formed, two atoms of it constantly take up one atom of the oxygen molecule and thus form water, while the other atom of oxygen is capable in the free state of causing the most powerful oxidations. Hoppe-Seyler* has recently shown that hydrogen arising in other ways also possesses this power of rendering oxygen active; thus it is possible to set up energetic oxidation processes by means of palladium hydrate by gradual dissociation of the hydrogen in the presence of oxygen; and the action of phosphorus on oxygen has a similar explanation.

On this view we can understand how it is that in the presence of oxygen putrefaction runs such a completely

Inodorons decas.
Spontancous occurrence of putrefaction and decay. different course than when oxygen is excluded. It is not only that the true reduction products, such as hydrogen, or sulphuretted hydrogen, do not appear, having undergone oxidation, but also that a number of other substances, which at the ordinary temperatures are quite resistant to the closed oxygen molecule, are attacked by the active oxygen and converted into the most simple compounds. Thus the destruction of the putrescible material occurs in as complete a manner as when it is broken up in the living animal body, or in that of bacteria which normally oxidise the nutrient materials when oxygen is present. Further, it is not uncommon that, both on and under the surface of the fluid, bacteriaor, when the circumstances are favourable, yeast, or mould fungi-obtain their nutriment from the products of the fermentation and burn these up to the most simple compounds; and we must regard it as at present undeter:mined whether the products of putrefaction can be more frequertly and in larger quantities destroyed in this way, or as the result of the nascent hydrogen, and its action on the oxygen.

In our nornial surroundings, both putrefaction and

* Zeitschr.f.physiol. Chemie, ii., 22.-See also Baumann, ibid., v. 244. 
decay constantly occur. Where fluids putrefy for a long time-in cesspools, canals, gutters, \&c.-fermentation and putrefaction ordinarily occur at first as the result of the action of aërobic bacteria; as the oxygen is gradually used up, and as carbonic acid, hydrogen, and other gases fill the fluid, a condition arises so favourable for anaërobic bacteria as can scarcely ever be procured by artificial means in pure cultivations. The anaërobes then continue the putrefactive process, and more especially occasion the formation of large quantities of stinking gases; and, in addition to these putrefactive anaërobes, other bacteria, which stand in no sort of relation to the putrefactive process itself, such as the bacilli of malignant œdema and of tetanus, utilise the favourable conditions of complete exclusion of oxygen, multiply, and form spores.

A true decay, that is to say a putrefaction without Decay in the the development of odorous gases and of reduction products, implies an extremely intimate contact of the putrescible material with the air. The most favourable conditions for this process seem to exist in soil which is very porous, and is moistened from time to time ; under such circumstances mineralisation of organic substances occurs in such a complete manner that in a short time neither ammonia nor sulphuretted hydrogen, nor more complex carbon compounds are present, but on the contrary only nitrates, sulphates, and carbonic acid. For further remarlis as to nitrification see the chapter on "Soil."-We very frequently meet with a mixture of putrefaction and decay in dead organic materials. In the upper layers of a fluid, or on the surface of a dead body, decay can occur, while in the deeper layers putrefactive processes of such extent and intensity take place that the products of true putrefaction appear side by side with the products of decay.

In the decomposition in the soil we frequently observe Mouldiness products which can not as yet be satisfactorily defined; (Vermoderthese are more especially seen in the destruction of portions of plants which chiefly consist of cellulose. In this case there is a formation of humin substances, and when oxygen 
is absent there is a plentiful formation of marsh gas in marshes. This decomposition of regetable substances, poor in nitrogen, is specially designated by the term mouldiness (Vermoderung); but the chemical meaning of this term is not yet quite clear. The term decay (Vervesung) is also at present employed for several different processes; thus Nägeli uses it for the destruction of organic substances by mould fungi. In this, however, we have no really marked fermentative action, but only a gradual consumption of the nutrient materials, and hence it is better to restrict the term to putrefaction in the presence of oxygen in which-when the concentration and reaction of the medium are favourable - the mould fungi naturally help in the complete decomposition of the material. Under special circumstances where suitable bacteria, or a fermentescible material, or other conditions for the fermentative processes are alsent, the consumption of the organic substances by mould, yeast, and fission fungi plays the chief part; the destruction must then, however, go on correspondingly slowly, and furnish the ordinary products of tissue change of the lower fungi. It would be incorrect to reckon such a process among the processes of fermentation or putrefaction.

(є). Acetic Fermentation.

Acetic

By acetic fermentation we mean the process by which fermentation. æthylic alcohol is converted into acetic acid, and which is expressed by the formula, $\mathrm{CH}_{3}, \mathrm{CH}_{2}, \mathrm{OH}$ (æthylic Material and alcohol) $+\mathrm{O}_{2}=\mathrm{CH}_{3} \mathrm{COOH}$ (acetic acid) $+\mathrm{H}_{2} \mathrm{O}$. Accourse. cording to Nägeli methylic alcohol is oxidised to formic acid in a similar manner. The oxygen is taken up to a very much less degree when alcohol is exposed to the air, and spread out over a large surface on filtered paper, wood shavings, \&c.; it occurs to a greater extent when spongy platinum, charcoal, and similar porous Fermentative bodies aid the conveyance of the oxygen. It is paragents. ticularly energetic, however, when the development of a definite fungus occurs in the alcoholic material, especially when it is spread over a large surface. As to the morphological characters of this fungus see $p$. 389. Along with it there are usually found other fungi; saccharomyces mycoderma often develops at the commencement in greatest numbers, so that this fungus 
was formerly looked on as the exciting agent of the acetic fermentation. According to Nägeli, however, this form of yeast only prepares the soil for the acetic fungus by using up the fruit acids when they are presont in large amount in the fermentescible material, and the presence of which would hinder the development of the bacteria; in this way it neutralises the medium. But this explanation of the peculiar concurrence of these two species of fungi, which is so often observed, is not completely satisfactory, because the acetic bacterium can bear the presence of acetic acid in the nutrient fluid in much larger amount than other bacteria.

The development of the acetic fungus only occurs Conditions of when the ordinary nutrient materials, nitrogenous sub-fermentation. stances, and salts, are present. The fermentescible material (the alcohol) must not be present in too great concentration (at most 10 per cent.). The development of the acetic fungus occurs best when a certain quantity of acetic acid ( 1 to 2 per cent.) is already present. The formation of acetic acid ceases below $10^{\circ} \mathrm{C}$. and above $35^{\circ} \mathrm{C}$.; the optimum lies between $20^{\circ}$ and $30^{\circ} \mathrm{C}$.; by heating the fermenting fluid to $60^{\circ} \mathrm{C}$. for twenty minutes, the fermentative action is permanently stopped unless new bacteria obtain access to it. As to the other products which appear in the fermenting mixture nothing is known; according to Nägeli, the acetic fungus forms extremely minute quantities of carbonic acid and water.

According to the few certain observations which have been Doubtful rôle made as to the acetic fermentation, this process seems to be of the organvery different from that of the other fermentations. Marked acetic ferdecomposition of the alcohol molecule and marked formation mentation. of carbonic acid does not occur; the formation of acetic acid runs its course much less violently than the other fermentative processes; the same effect is obtained by spongy platinum and by charcoal. All this has led Pasteur to the view that the formation of acetic acid is not really a physiological action of the fungus, but that the organisms only act in a similar manner as spongy platinum, as carriers of oxygen. Mayer has, however, pointed out, as against this view, that the optimum of the action of the acetic fungus is quite 
different to that where the acetic acid is formed by means of spongy platinum; the latter process is increased by an elevation of temperature which is destructive to the fungus. Nevertheless, it is evident that the action as oxygen-carriers must be bound up with a large number of intact fungus-cells, and that this action must, to a certain extent, run parallel with the active development of the fungus. And further, the fact that specific forms are found in association with the formation of acetic acid can not alter Pasteur's view; for the conditions of existence of the fungi which take part in the formation of acetic acid are so peculiar both as regards the amount of alcohol and the amount of acetic acid in the medium, that only few forms can enter into concurrence with them. Whether, however, as a matter of fact, only one or several forms are involved in the action must be determined by further pure cultivations.

If, on the other hand, the formation of acetic acid is a physiological act of certain fungi, we would expect that the multiplication of the fungi would be intimately connected with their function, that other products of tissue chango would also be formed, that, at all events, there must be in part a further oxidation of the acetic acid. And further, it is a question whether we ought in reality to look on the formation of acetic acid as a fermentative process, or whether we must not simply regard it in this way that the fungi, among other nutrient materials, also take up alcohol, when it is present in particularly large amount, and oxidise it only to acetic acid. In the latter case Pasteur's carrying of the oxygen takes place in the cells; the alcohol acts as nutrient material, which, when present in smaller quantity in the nutrient mixture, is destroyed and burned up by very various kinds of fungi; which, however, when in a more concentrated form only permits the growth of a few fungi, and is then no longer burned up to the usual end products. This oxidation of the alcohol can only be designated as fermentation in the ordinary acceptation of the term, when it has been demonstrated that relatively very large quantities of the material can be acted on in a short time, that almost the whole of the fermentescible material undergoes this incomplete oxidation, and that this metamorphosis of the material is sufficiently different from the ordinary physiological processes to be looked on as a special function, as compared with the assimilatory and destructive tissue change.-The solution of these questions must be given by further investigations. If, in reality, we have to do with a fermentation, then the whole process of the acetic fermentation can be best understood on Nägeli's theory, to be mentioned immediately. 
However different the chemical process is in each of General view the fermentations described, we can find some general of the ehemipoints of resemblance in all the true fermentations. fermentation. We everywhere observe a marked splitting up of the fermentescible molecule, and an extensive re-arrangement of the atoms. In all cases carbonic acid is formed, and for this it is evident that new combinations between carbon and oxygen are necessary, and these are rendered possible by the solution of combinations between oxygen and hydrogen, carbon and hydrogen, carbon and carbon.* In the fermentation of formic acid $\mathrm{H}-\mathrm{C}<\mathrm{O}-\mathrm{O}$ Wandering of the oxygen the union of the oxygen and hydrogen atoms in the hydroxyl group, and also that of the hydrogen and carbon atoms, is broken up. The liberated hand of the oxygen atom unites with the hand of the carbon atom liberated at the same time; the two hydrogen atoms which are freed unite with one another, and thus $\mathrm{CO}_{2}$ and $\mathrm{H}_{2}$ are formed. In a similar manner, in all fermentations there occurs a wandering of the oxygen atom from the hydrogen to the carbon; while, on the other hand, by the separation of the $\mathrm{C}-\mathrm{H}$ and $\mathrm{C}-\mathrm{C}$ union room is procured for the new attachment of the oxygen to the carbon. In short, the group carboxyl is formed while, on the other hand, reducing atomic groups, $\mathrm{H}-$ $\mathrm{H}$ or $\mathrm{C}-\mathrm{H}$ compounds, appear. In the whole movement stronger affinities are grouped together, and energy becomes free. Nevertheless, the wandering of the oxygen atom which leads to the breaking up of the molecule only occurs when the molecule is not too large in relation to the number of the displaceable oxygen atoms. If, as in the case of many benzole derivatives, and in the higher fatty acids, numerous carbon atoms are united with each other, while only one $\mathrm{C}-\mathrm{H}$ group is present which can form carboxyl, no such wandering occurs in a molecule; on the other hand, this wandering is possible when several $O$ atoms can enter into new $\mathrm{C}$ combinations, as in the fer-

* Hoppe-Seyler, Physiolog. Chem., p. 124.-Arch. f. d. ges. physiol., vol. xii. 1. 
mentation of the glucoses, where three carboxyl combinations are present in the six $\mathrm{C}$ atoms, and lead to the breaking up of the relatively large molecule. For the same reason fermentation of acetic acid is very difficult, and of propionic acid still more difficult; for here, as in the case of formic acid, there is only one $\mathrm{O}$ atom which can be utilised for the formation of carboxyl, while the molecule itself is much larger. On the other hand, fermentation can occur more readily in the oxy-acids (glycollic acid, lactic acid, \&c.), because in these there exists a second hydroxyl group, and thus a second displaceable $\mathrm{O}$ atom. Accordingly, the following substances are not at all capable of fermentation: carburetted hydrogen, amines which do not contain any oxygen; further, the large molecules of the higher fatty acids, and of the benzole derivatives which are poor in oxygen (the latter only in regard to the benzole portion, while, naturally, in the side groups, splitting up and wandering of oxygen can occur). On the other hand the following, among other substances, must be capable of fermentation: the higher alcohols, the lower uni-basic fatty acids, up to propionic acid, the oxy-acids, and the multi-basic acids of the fatty series, the carbo-hydrates, and the albuminoid materials.

The decomposition of the molecule in this case is different from the action of enzymes.
Hence without extensive displacement of the atoms, no fermentation is conceivable, and it is by this intense alteration of the fermentescible molecules that the true fermentations are chiefly distinguished from the hydrolytic decompositions caused by isolated ferments. All fermentations are direct results of the functional activity of micro-organisms, and it is not only absolutely certain, from the experiments previously described, that fermentation never occurs without living organisms, but we must also frec ourselves from the idea that the fermentative action results from the production of a ferment which cannot be separated from the micro-organism without interfering with its life. The intimate process of fermentation shows so much that is different from that of the action of enzymes, and shows, on the other hand, such an intimate connection 
with the other direct vital actions of the micro-organisms, The fermentathat we must of necessity look on the fermentation a that we must of necessity look on the fermentation as a physiological physiological function of the living cells.

We must further assume that the mode in which act of living organisms. fermentescible substances are split up differs very much according to the species of micro-organism which excites it. It is true that the former view, that one organism exclusively possesses the power of setting up a definite fermentation, is not confirmed by more recent investigations, but the functional action of the indiviaual fungi which set up fermentation is none the less a specific one, and the same fungus always splits up the same material in the same manner. This specific property Specific also remains constant for the same species, and is activity of the developed whenever the other conditions suitable for individual species of the fermentation in question, such as material, tempera- bacteria. ture, \&c., are present. It is only as the result of Constancy of certain noxious influences which will be discussed under this property. the conditions of death of the lower fungi that there can be a loss or a weakening of this property of exciting fermentation. (Facts of this kind have, at any rate, Weakening of been observed by Fitz in the case of two butyric acid of exciting fungi.) But these attenuated bacteria cannot occasion fermentation. some other fermentation; on the contrary, they retain their specific character, and they have only lost, as the result of noxious influences, that peculiar specific physiological function which is expressed in the excitation of fermentation.

Although it is thus clear that we must look on the fermentations as the physiological functional acts of certain micro-organisms, there still remains great uncertainty with regard to the mode in which we should define this function, and with regard to its relation to the other vital actions of the organisms.

In the organisms which are capable of setting up The tissue fermentation tissue change can run its course in various change of the ways; either the organisms are present in a nutrient, excite fermenbut not fermentescible, medium (such as yeast in a solution of milk-sugar), and in that case they do not behave like organisms which can cause fermentation; 
they assimilate their nutriment, grow and multiply, break up the nutriment in their protoplasm, and taking up oxygen form the products of tissue change formerly described. Or oxygen only may be wanting in the medium; in that case the intramolecular respiration, with its insignificant destructive tissue change, can for some time maintain the life of the organisms. Or, in the third place, a fermentescible material, suitable for the organism in question, is present; in that case extensive decomposition of the material occurs, along with active multiplication of the organisms; this takes place as regards the majority of organisms in every case where the other conditions of life are favourable, in the case of some (bacillus butyricus) it only occurs so long as oxygen is at the same time absent.

The fermenta. tive action.

The splitting up of the material, as the result of fermentation, differs in many respects from the ordinary tissue change. In the fermentation very much larger quantities of material are acted on than are otherwise necessary for the nourishment of the same number of organisms. Further, the decomposition is a relatively incomplete one; in the respiratory tissue change the nutrient substances are oxidised to simple compounds, but in the fermentation the materials of the nutrient medium remain, for the most part, in the form of complex molecules, and it is only some of the more simple groups that are broken up. Finally, in the fermentations the oxygen does not take an important part in the breaking up of the materials, and more especially in their conversion into the end products, as is the case in respiration, but the whole decomposition often takes place without any aid from oxygen, which only acts secondarily and then causes oxidation.

In correspondence with these differences between the ordinary tissue change and fermentation we have the fact that many chemical materials act as nutriment without being able to act as fermentescible materials, and vice versá; thus formic acid cannot serve as nutriment but is broken up by fermentation, while, on the other hand, the benzole derivatives and the higher fatty 
acids resist fermentation, but are to a certain extent good nutrient media.

The splitting up of the fermentescible substances never forms the only physiological act of the organisms which take part in it. It is evident that nutrition, growth, and multiplication of the cells must go on at the same time, and for this purpose the fermentescible materials do not, as a rule, suffice, but salts, nitrogenous substances, and at times also carbon substances, must also be at the disposition of the fungi; when oxygen is excluded, the presence of a particularly good nitrogenous nutrient material is an absolute necessity for continued growth. Further, the protoplasm, as the result of its action, must always be to a certain extent used up, and thus the products of the destructive tissue change must appear, only, in this case, the want of oxygen must bring about a conformity of these products with those of the intramolecular respiration. It is for the progress of this assimilating and destructive tissue change that the necessary energy is obtained as the result of the fermentation, although the sum of the material which is directly utilised for this tissue change appears to be very small in relation to the amount of fermentescible substance which is broken up; according to Pasteur, the amount of the sugar employed for nourishment, for example in an energetic fermentation of sugar by means of yeast, amounts only to 1 per cent. of the fermented mass.

As, in this way, the fermentative processes, up to a Is the fercertain point, go on alongside of the ordinary tissue change, the further question arises whether it is necessary for the occurrence of the fermentations that the fermentescible material, like the nutrient material, must not only come in immediate contact, but also enter in a loose combination with the protoplasm, and must pass into the interior of the cells, or whether the decomposition can take place outside the cells, and whether less intimate contact of the protoplasm with the fermentescible materials is sufficient for their decomposition? According to experiments made by Cochin* it can be

\footnotetext{
* Cochin, Compt. rend, vol. 96.
} 
demonstrated that a part of the sugar from a saccharine solution in which yeast lept without oxygen is sown, passes into the yeast cells and is there rapidly broken up; but this only takes place with regard to a small fraction of the sugar, and it does not occur in every yeast capable of setting up fermentation. Hence the question as regards the seat of the decomposition cannot as yet be decided with certainty; the great quantity of the material broken up in a short space of time leads at any rate to the presumption that in fermentation a chemical combination between the protoplasm and fermentescible materials does not occur, but that that process is limited to the ordinary nutritive and respiratory processes of the cells.

Nägeli's theory of

Nägeli has in fact put forward some very definite reasons for believing that fermentescible molecules lying outside the cells (but it is true in their immediate neighbourhood) can be broken up by the movements in the protoplasm. This is shown, for example, in the formation of acetic ether, which frequently accompanies the alcoholic fermentation; acetic ether is not formed when acetic acid is present in the fermenting mixture; acetic acid and alcohol must, on the contrary, meet in the nascent state; if both were produced by the same organisms it would be conceivable that they arose and combined within the cells; but the alcohol is formed by yeast cells, the acetic acid by bacteria, and thus their combination is only possible. if both the components arise outside the cells. Nägeli also observed that bacteria were able to reduce and decolourise litmus colouring-matter, although it could be shown that the colouring material could not penetrate into the living plasma of the cells. Further, numerous observations indicate that the alcoholic fermentation which occurs in the interior of uninjured fruits is brought about by yeast cells, which have their seat on the skin; lastly, Nägeli explains the fact that in a sugar solution containing large numbers of yeast cells bacteria which may have been present gradually die, by supposing that the movements which are communicated from the plasma of the yeast cells to the sugar molecule ultimately pass on to the bacteria and thus weaken these 
organisms, which require another kind of movement. This fact can be utilised for obtaining, to some extent, pure cultivations of yeast and of other fermentative organisms.

Nevertheless, the observations made by Nägeli do not lead us to any certain conclusion as to the occurrence of the fermentative action. With regard to the formation of acetic ether, it is always conceivable that the same bacteria produce both components, because we know that the formation of alcohol is not limited to the yeast fungi, and that glycerine, for example-a body always present in fermentation by yeast-is split up, according to Fitz's experiments, by bacteria with the formation of alcohol and acetic acid. Objections may also be made to the other facts brought forward by Nägeli, but, on the whole, Nägeli's view appears, at any rate for the present, to be the best grounded, and hence the most probable, hypothesis as to the act of fermentation. According to him the fermentative act occurs in this way, that as the result of the intramolecular activity in the protoplasm intense conditions of movement are brought about, and that, on the other hand, chemical molecules are present outside the cells, which are set into active movement as the result of these motions, so that the breaking up of the molecule results. Those organisms are not capable of setting up fermentation, in the plasma of which unsuitable and insufficient movements arise; only those chemical substances can be broken up by the fermentation to which the movements can be readily communicated.

\section{The Parasitic Existence of the Lower Fungi.}

The extension of the vital activity of the lower fungi Parasitismús which is of the greatest importance to us, is that they can under certain circumstances grow as parasites on $\mathrm{or}^{\circ}$ in the higher living organisms. It does not of necessity follow that injury to the host is the consequence of such 
a parasitismus; on the contrary, there are certain parasites which can live in a plant or an animal for a long time without in any way influencing its normal existence, and indeed in many cases the parasitismus can form an advantageous symbiosis for the host, as, for example, in the lichens, which consist of a combination of algæe and fungi, in which the chlorophyl-bearing algæ provide carbon compounds which can be utilised by the fungus, while the latter takes up mineral nutrient materials from the substratum, and thus supplies them for the common nourishment.

As a rule, however, the advent of parasites, and more especially of the parasitic fungi, is accompanied by more or less severe injury to the organisms which they attack. A number of the most devastating diseases of plants, animals, and man, have been proved with complete certainty to be due to parasitic fungi, and our chief motive and real aim in studying the morphology and biology of the lower fungi is the fact that they can excite disease.

Classification of the parasitic fungi.

Among the large number of the fungi which are capable of leading a parasitic life, we notice, when we study them accurately, differences as regards the mode of the parasitismus which render it easier to understand this peculiar phenomenon. Many of the parasitic fungi are only able to lead this kind of existence, and these can carry on their vital functions, either not at all, or only in a very limited manner, on dead substrata; other fungi, on the contrary, also flourish as saprophytes, and their parasitic existence is in fact only a continuous extension of the wide limits within which they can carry on their life and action.

De Bary has sharply defined these differences, and has based on them the following classification of the parasitic fungi :-

Obligatory parasites.
1. Obligatory parasites. These require a parasitic life in order to attain their full development. They may be divided into two classes, namely, (a) Strictly obligatory purasites, which only occur in nature as parasites, and can be cultivated on dead substrata only under conditions artificially produced in the laboratory; and $(b)$ 
Facultative saprophytes, which as a rule complete their cycle of development as parasites, but which can exist, under certain circumstances as saprophytes, and can pass through some portion of their developmental cycle as such.

2. Facultative parasites. These are species, which Facultative usually grow as saprophytes, but which, however, at ${ }^{\text {parasites. }}$ times find the conditions necessary for their existence in living organisms, and can then multiply there.

3. Obligatory saprophytes, which cannot obtain any foothold in the living vegetable or animal organism, but can only grow on dead substrata.

The mould, yeast, and fission fungi behave so differently in their rôles as exciting agents of disease that they must be discussed separately. It is not the purpose of the present work to give an accurate description of the parasitic diseases caused by the mould fungi; they will only be noticed in so far as they furnish facts for some general conclusions. For a more detailed description of the diseases of plants we must refer to the works of de Bary, Hartig, and Frank.*

The natural mode of origin and spread of the diseases caused by the bacteria will be discussed in detail in the sixth and seventh chapters, while in this place we shall only speak of the action and fate of bacteria which have already penetrated into the body.

\section{A. 'The Mould Fungi as Exciting Agents of Disease.}

(a) Parasitic mould fungi.

The mould fungi are dangerous chiefly to the higher Mould fungi plants. They are alble to attack plants. They are able to spread in the tissue of the plants.

plant, their germinating tubes and mycelial threads penetrating into natural openings or through accidental injuries of the epidermis, and then running between the cells ; they frequently also bore through the walls of the cells, and in that case have probably the power of secreting a ferment which dissolves the cellulose.

The mode of action of the parasitic moulds is very Mode of penetration

* De Bary, Vgl. Morph. u. Biol. der Pilze, Leipzig, 1884, P. 384, ff.-- and action. Hartig, Lehrb. d. Baumkrankheiten-Vortrüge im ärztl. ver. zu Wünchen, 1881.-Frank, Die Pfankenkrankheiten, Schenk's Handb. d. Botanik. Breslan. 
various. At times they gradually destroy the whole of the surrounding tissue, so that a mass of fungi, consisting of mycelium and spores, occupies the place of the original regetable substances (ustilagineæ, exoascus); or alterations of a more local character arise, for example, marked growth of the parenchyma, which leads to all sorts of swellings and alterations in form (chytridiaceæ, cystopus, \&c.); or, finally, local alterations are less noticeable, but instead a gradual degeneration of the surrounding tissue occurs, which shows itself in discolouration and browning of the cells attacked. In by far the greatest number of cases the infection leads to death of the plant, or to death and degeneration of the fruit.

Individual Among the large number of mould fungi there are relapredisposition tively few species which possess this pathogenic power,
of the plant. and we must assume that these species are provided with particularly powerful means of penetrating the cell membrane. Further, each of the pathogenic forms can only attack one or a few species of plants, and among plants which are apparently similar there are often only a few individuals which are specially predisposed to the action of the parasitic fungus. Minute differences in the structure of the epidermis and of the cell walls, slight variations in the chemical composition of the cell juice, greater or less energy of growth and of tissue change, are the conditions to which must be referred the connection between certain parasitic fungi and certain plants, the immunity of other plants, and, in short, the individual predisposition to the infective diseases. The epidermis of the plants seems to oppose an especially great resistance against the fungi, and hence infection can often only occur while the parts attacked are in a young condition and still possess a delicate skin. Thus the ustilagineæ and peronospora inf. only attack young plants or young seed; hypoderma macrosporon only penetrates into young pine cones. An injury of the epidermis is often requisite to enable the mycelium threads to penetrate it; species of fumago only develop on parts which are attacked by aphis; in the case of 
a species of nectria, which occasions the so-called cancer of the pine bark, the necessary condition for the penetration of the germinating tube is only furnished where the bark has been eroded by moths; the spores of trametes pini sprout only on freshly broken surfaces of branches, and from that point send their mycelial threads into the wood. Frequently also it is only certain parts of the plants which are suitable for the attack and development of the fungi. Thus claviceps attacks the flowers, exoascus the fruit, and byssothecium the roots of the plants which are infected by these fungi. De Bary gives an interesting example in the parasite of the white rust of cresses, cystopus candidus, the germinating tube of which can only develop in the cotyledons, and can hence only infect those plants which have just formed cotyledons at the time at which the spores are being distributed and are germinating.

While these peculiarities in the spread of the parasitic seasonal and diseases of plants may be satisfactorily explained by local differdifferences in individual predisposition, we often observe distribution another series of phenomena which cannot be referred of plants. to the same cause. For instance, we often see in particular localities an epidemic spread of a parasitic disease, while in other places plants of the same species are only attacked in a sporadic manner; and in like manner there are years in which the disease only spreads to a slight degree, while at other times severe epidemics occur in the same places.

These differences have their explanation in part in certain external-influences which vary with locality and season, and which form the so-called local and seasonal predisposition. A factor belonging to this class which favours most of the infections caused by mould fungi is, for example, a continuous and marked degree of moisture in the air and in the soil, which of itself permits the sprouting of the fungus spores. The ustilagineæ, claviceps, and many others, require such a continuous moisture ; peziza willk., which occasions the cancer of larches, only forms fruit-bearing hyphæ when the air is 
Factors which moist. The duration of the period of moisture is often influence the spread.

the important point; thus epidemics of rosellinia quercina develop only when there is continuous rain ; the fruit carriers of hypoderma macrosp. swell up and burst only when rain has lasted for several days. At times also the temperature must be specially farourable for the sprouting of the spores, and they can only cause infection when suitable temperature and suitable moisture happen to be present together.-The conditions for a successful infection are still further complicated, in that the above-mentioned factors which predispose to the penetration of the fungus mycelium into the plant must coincide with a certain stage of development of the fungus, and with external conditions which are favourable to this development. A moist warm season is often a predisposing factor which favours the growth of the parasite when young plants are present, or when, at the same time, insects have caused injuries of the epidermis, or when, as the result of storm, \&c., fresh fractures of the branches have been produced. If these predisposing factors are absent during the moist period, or if the latter occurs when the plants in question are older and provided with firmer epidermis, no infection occurs.-Here and there other more remote factors, which often seem to be a matter of chance, play a part in the development, and more especially in the epidemic spread of the parasitic diseases of plants. Thus the development of the urediner depends upon the condition of their second host, which they require as the result of their alternation of generation, and if the barberry bushes are accidentally or intentionally removed the rust of grain ceases; in many species of fungi suitable means of transport must aid the spread of the spores, as in the case of phytophtora fagi, where men and animals in passing transport the spores. Lastly, in some cases where infection can only occur in the immediate neighbourhood from the further spread of the mycelium, everything depends on the grouping of the plants which can be attacked ; it is only when these occur in close contact with each other that an epidemic 
spread can take place, while the latter is impossible as soon as other species of plants, which are not liable to the infection, are mixed with the individuals of the kind that are threatened.- It is evident that by taking into consideration all these numerous factors which exercise an influence on the occurrence of epidemics, the rise and fall of the parasitic diseases of plants can be explained, and thut at the same time these observations, which can be made on plants with great certainty, must be of great advantage in enabling us to understand the epidemics of animals and man with which they offer numerous analogies.

Among animals it is chiefly the invertebrata, and, Mould fungi among these, the insects, which are attacked by para- as parasites sitic mould fungi. The infection always occurs by the penetration of the mycelial threads into the external uninjured skin; in the case of empusa radicans it has been demonstrated, as the result of experiments, that infection never occurs from the intestine. In some In insects. cases the fungus may enter almost anywhere; for example, laboulbenia can penetrate through the back, head, legs, or wings of flies. In other cases the place of entrance is limited; empusa muscæ, for example, can only enter at the abdomen of the fly, and in the case of isariæ the infection of the caterpillars occurs through the stigmata of the tracheæ.-In some cases the parasitic fungi cause very little inconvenience to their host; thus laboulbenia muscæ may exert no injurious action, but the insects attacked usually die. The mycelium threads, when they have penetrated into the body, grow through the muscle and fatty tissue, and usually give off conidia in the blood, which grow to form an extensive mycelium; during this process there is an almost entire consumption of the structures of the animal attacked. Such an energetic growth is only conceivable when the nutrient conditions which the animal body offers are particularly favourable to the fungus, when the animal cells assimilate with very little energy, and when there is a more or less complete absence of reaction. These conditions appear to be present in the insects which are 
attacked. Here, however, we can also recognise certain predisposing factors; thus it has been observed that botrytis bassiana does not attack all silk-worms equally, but chiefly young individuals, and more especially those which are in a weak state as the result of imperfect nourishment, \&c. It is only by careful selection in the culture of the silk-worms that this disease can be combated.

In fish and birds.

In man.

An infection by saprolegnia has been observed in fish ; the fungus occasions, in the first place and very gradually, a disturbance of the function of the skin, and an affection of the gills, and, according to de Bary, the disease develops only in fish which are already ill from other causes. In the case of birds, mould fungi occur comparatively frequently in the respiratory organs; Bollinger* and Schütz (see p. 124) have shown that these fungi do not occur secondarily in organs previously diseased, but that they are the primary causes of the disease ; they develop partly in the trachea and in the bronchi, partly also in the tissue of the lungs and in the cavities of the lung, and they cause severe disturbance of the respiration, and ultimately lead to the death of the animal. The forms which have as yet been found are species of aspergillus and mucor; possibly the same which grow also in mammals and in man.

In man epiphytic development of pathogenic mould fungi is frequently met with on the external surface of the skin, where they set up diseases of the skin (favus, tinea tonsurans, \&c.). Certain species of aspergillus and mucor also frequently develop on collections of dead portions of tissue, for example, on the coating of the tongue, in the contents of a dilated stomach, in cavities of the lungs, \&c.; also in the external auditory canal and on the cornea, where they set up inflammation.-If spores of saprophytic mould fungi (penicillium) are injected into the circulation of dogs or rabbits, they stick on the walls of the capillaries, or in the endothelial cells, especially in the liver, spleen, and medulla of bone, and they may remain there for a long time without

* Vorträge im ärztl. Verein zu München, 1881. 
sprouting, and without causing any disturbance. Wyssokowitsch* was able to demonstrate their presence in these organs in large numbers even after seven days. If, on the other hand, the spores of certain species of aspergillus and mucor were injected into the veins, the sprouting of the spores occurred at various parts of the body, and masses of mycelium were formed, which were visible to the naked eye. If very numerous spores were injected, and if very large numbers of these mycelium masses developed, the animals died. As has been above described (see p. 123), the largest number of the deposits after injection of aspergillus and mucor occurred in certain organs. This apparent choice of certain parts of the body does not depend only on variation in the distribution of the spores and on greater deposit of the spores in certain organs differing according to the species of fungus injected; but the sprouting of the spores and the development of the mycelium in the organs is also more or less favoured by certain other conditions, so that, for example, spores of aspergillus glaucus form the most luxuriant mycelium in the kidneys and in the liver, and the spores of mucor the most distinct and numerous deposits in the kidneys, mesenteric glands, and Peyer's patches, while in other parts the spores either do not sprout at all or only to a very imperfect degree.

That only a few species of mould fungi occur in the Limited bodies of warm-blooded animals seems to be chiefly, but not exclusively, due to the fact that only these forms can, at the high temperature of warm-blooded animals, development of the mould fungi in the animal body develop a sufficient amount of energy to enable them to live in concurrence with the cells of the animal body (see p. 136). The limitation of their fructification to the surfaces of the animal body is explained by the necessity for contact with free air.

On the whole, among the infective agents of higher animals the mould fungi play only an insignificant part, the nutrient conditions which they find there are unsuitable, the temperature being high, the juices of the body being highly albuminous and weakly alkaline, and

* Zeitschr.f. Hygiene, vol. i., Part 1. 
further they are completely surrounded by fluid media, so that an extensive formation of mycelium or fructification can never occur. On the other hand, the chemical composition as well as the temperature of the juices of plants furnish better conditions of existence for the mould fungi, and here, as in the case of insects, they find an opportunity of quickly penetrating through the whole mass of the body attacked, and of thus bringing the mycelial threads into contact with the free air.

\section{B. The Budding Fungi as Infective Agents.}

Parasitic yeast fungi.

Parasitic budding fungi have never as yet been observed in plants, and in animals they occur extremely rarely, and then only as epiphytic parasites. The only known case of the latter kind is that of the fungus of thrush, which for a time was looked on as a species of mycoderma. Large numbers of yeast cells also at times occur in the stomach and intestines of man, and probably on account of the plentiful supply of saccharine nutriment, can keep up fermentation for some time, and can thus occasion certain disturbances.

\section{Fission Fungi as Causes of Discase.}

Parasitic bacteria.

In plants.
In contrast to the mould fungi, the bacteria almost never attack higher plants, while warm-blooded animals very frequently serve as their hosts. In the affection known as the yellow disease of hyacinths in Holland, we have however, according to Wakker,* an exception to this rule in that an accumulation of yellow gelatinous bacterial masses occasions the disease of these plants. The low temperature and the chemical composition of the vegetable juices is evidently very unfavourable for the development of bacteria, more especially as the cell juices are almost always distinctly acid, and thus protect the plants against the bacteria, which are so sensitive in this respect. Further, the cellulose which surrounds each individual 
cell cannot be dissolved or penetrated by the majority of bacteria; some forms, it is true, can convert the dead cellulose into sugar, or can cause it to ferment, but even these organisms appear to be unable, under the otherwise unfavourable conditions, to live in concurrence with the living vegetable cells. On the other hand, in the warm-blooded animals the bacteria find a substratum, rich in albumen, faintly alkaline, and at a temperature of about $37^{\circ} \mathrm{C}$., and thus they have the most favourable conditions for their development and multiplication; hence the bacteria threaten the living animal with much more serious dangers.

Nevertheless, it is by no means all bacteria which are In animals. able to live in the living animal; on the contrary, we can here also employ the classification given by de Bary, of obligatory parasites, facultative parasites, and true saprophytes. The species belonging to the group of the saprophytes are much more numerous than the others; bacteria, such as bacillus subtilis, micrococcus flavus, bacillus erythrosporus, micrococcus aquatilis, and innumerable other forms, can be introduced in enormous quantities into the veins, subcutaneously by the mouth, or by inhalation into living warm-blooded animals without causing any injury to the body.

Among the facultative and obligatory parasites, the Various different species show the most various degrees of patho- pathogenic genic action.--In considering this question it must be action. remembered that the parasitic bacteria are often limited to definite species or races of animals as their hosts, and that not uncommonly the same species of bacterium which in one class of animals excites a severe disease, behaves in regard to another class as a pure saprophyte. We shall enter more minutely into these important differences in the chapter on "Predisposition" ; we need only point out here that we are accustomed to reckon a species of bacterium among the group of parasites if it exerts pathogenic action on any one species of animal.

The least amount of parasitic energy is shown by those Bacteria bacteria which almost never multiply in the interior of which cause the living body, but vegetate only on the surface, on the means of their 
ptomaines when they grow over a large extent of surface.

Bacteria which act as poisons in smaller numbers, and which ultimately penetrate into the body.

Bacteria which readily penetrate into the body, and multiply in its interior.

skin, on the mucous membranes, on wounds, in the intestine, \&c., and cause injury to the body by producing ptomaines which, being soluble, penetrate from the surface into the body and there act as poisons. Many of the bacteria belonging to this class live as a rule as saprophytes. Some of them excite fermentation and putrefaction; they do not injure the living animal at all so long as they occur in small numbers on the surface, and it is only when they can develop in large numbers, and when they are not removed from time to time, as occurs under normal conditions, that the production of ptomaines is so marked that injury to the host ensues.

Some bacteria have a more marked pathogenic character, in that they produce very poisonous ptomaines, to which the bodies of warm-blooded animals have not become gradually adapted. Hence these injure the organism, even when they are growing only over a slight extent of surface. It not uncommonly happens in this case that the ptomaine action is only the precursor of the invasion of the bacteria into the interior of the body; the latter is so weakened by the poisoning that the bacteria find less resistance, and can develop in the blood and in the organs, which previously could easily have resisted their invasion.

A further stage in the development of parasitismus is represented by those bacteria which, without further assistance, and in relatively small numbers, can establish themselves in the interior of the living body and multiply there. These either lead to lccal morbid processes (tuberculosis, pneumonia) at the place of entrance, or they spread through the whole body with the circulation, and grow in the whole of the capillary vascular system. The bacteria then occasion either morbid growth of tissue or necrotic destruction of tissue, or the mechanical disturbances of the tissue change and of the cell life which results from the distribution and multiplication of the bacteria leads to grave injury to the animal by means again of specific ptomaines.

Growth in the 'The gradual spreading necrosis of the tissue, and the pany accomnecrosis of the spread of the bacterial growth into new territory killed tissue 
by the action of the products, is very characteristically seen in the progressive necrosis of tissue observed by Koch in the case of mice (see p. 209), also in connection with the bacilli of pigeon diphtheria, \&c. (see p. 326). It is probable that such bacteria do not always lead to a progressive destruction of the tissue; at times it is evident that such a violent reaction and such a great new formation of cells occurs that the development of the bacteria and the production of the injurious materials cannot keep pace with it; in that case the inflammation indicates the limit and the end of the bacterial development.

Another mode of development within the living body Development is ill œdema, and of symptomatic anthrax. These bacilli, belonging to the class of anaërobes, are not able to multiply in the living blood, nor in open wounds, nor can they grow when introduced in minute quantities; on the contrary, they require the previous occurrence of an injury which must furnish at least a certain amount of dead tissue, and further they must be present in large numbers from the beginning; or if a wound is present oxygen must to a certrin extent be excluded from it; further, the bacilli do not penetrate in all directions in the various tissues of the body, they only grow where the smallest amount of interchange of gases renders their existence easier, for example in the subcutaneous cellular tissue, or in the serous coverings of the organs; and it is only when the whole body has become extremely poor in oxygen-as a rule only after death-that they are able to develop in the blood and in the various internal organs.

Another mode of spread and penetration is shown by Penetration the micrococci of erysipelas. These also do not multiply into the in the blood-ressels, nor, when injected into the reins, vessels. do they cause any disease of internal organs; on the contrary, they only grow in the lymph channels of the skin, exciting here a locally limited inflammation, and furnishing also, in all probability, toxic materials, by the absorption of which the marked general symptoms 
Penctration into, and within, the blood-vessels.

are produced. They do not show any very great parasitic energy, because, as a rule, they are only found in a living state at the margin of the erysipelas, and apparently very readily succumb to the influence of the living tissue cells which accumulate there.

Lastly, those species of bacteria which cause the numerous forms of septicæmia and pyæmia which have been closely studied in animals, live and act chiefly in the blood-vessels. They multiply most readily and rapidly in the free blood current; they are found especially in the smaller vessels and in the capillaries in such numbers that the vessels are here and there completely filled with them, or the blood corpuscles appear embedded in a large mass of bacteria. They form a thick layer on the walls of the ressels, and their distribution is so extensive that, on making sections from any internal organ, almost all the capillaries in every preparation are found completely lined by them. Many bacteria also attack the colourless blood corpuscles; in preparations of such blood large plasma cells are found, which are quite filled with bacteria, others are met with in the stage of decay, which has evidently been caused by the entrance of the bacteria (as in the so-called mouse septicæmia, p. 310). As the result of this extensive distribution of the bacteria serious alterations must occur in the tissue change of all the tissues involved; the energy of the nutrient stream which passes into the tissues from the capillaries, the remoral of the waste products formed in the tissue cells, and the exchange of gases in the tissue, must all undergo a marked alteration; in correspondence with the altered nutrition of the cells there is an alteration in their functional activity, in the first place, in that more extensive decomposition of the material which is present occurs, for which, on the other hand, there is no corresponding substitute; in like manner the new formation of cells, in place of those which are exhausted or clead, does not occur in a normal manner. Finally, in addition, we have perhaps also the production of specific noxious materials on the part of the growing bacteria, and thus there results a complete 
disturbance of the tissue change and of the arrangements which regulate the functions of the body, and this disturbance goes on till severe general morbid symptoms occur, which usually lead to death.-Some of the micro- Embolism. organisms which belong to this class may very readily lead to blocking of the smaller blood-vessels, either by their accumulation in large numbers, or by the heaping up of materials which have arisen from the breaking up of the plasma cells; in such cases there very readily occurs, in parts, necrosis of the surrounding tissue, and subsequent development of the bacteria in this tissue, which still further degenerates under the direct action of the organisms. At times the most active multiplication of the bacteria in the capillary system only occurs in one or some organs which are particularly predisposed, and thus the emboli often show a predilection for certain organs. Thus it happens that the local symptoms are often the most striking, and that the type of the disease varies markedly, according as in the one case the general phenomena, in the other, these or those local symptoms are prominent.

The power possessed by a limited number of bacteria Biological of leading a parasitic existence in the body of warm- peculiarities blooded animals raises the question to what biological genic bacteria. peculiarities of these bacteria this power is due; what differences exist between their properties and those of the saprophytic bacteria ; what are the protective arrangements of the living body which render the multiplication and development of the latter impossible, but which, on the other hand, are powerless against these pathogenic bacteria?

The attempt was formerly made to explain this rela- Resistance tion by the aid of some one active factor in the living against the organism. Thus, it has been pointed out that it is the fuids of possible that some bacteria can only grow in a quiescent the body? medium and not in the fluids of the body which are in active movement, and it has been supposed that 
Horvath's experiments give some support to this view. But these experiments, and the control experiments which have been since made, do not, as has been mentioned above (p. 535), yield any satisfactory results applicable to the continuous flowing movement of the fluids of the body.

Resistance against oxygen?
Resistance against excre. tion from the body?
The supposition has also been frequently expressed that the bacteria which are able to live in the living body are only those which find there a sufficient supply of oxygen, and as Szpilmann had shown that anthrax bacilli are not destroyed by the action of ozone, while putrefactive bacilli are rapidly killed, there seemed to be some ground for this view.-But more accurate experiments which have been made by Liborius,* as to the requirement of oxygen by the pathogenic bacteria, have shown that these are obligatory or facultative anaërobes, and require much less oxygen than a large number of saprophytes. On the contrary, a certain indifference with regard to oxygen seems to be a necessary condition for the parasitic existence of the bacteria; it is only thus that they are able to develop a large amount of vegetative energy in parts of the body in which the tension of the oxygen is very low.

Further, the view has been frequently expressed that the living body tries to prevent the development of bacteria by continually eliminating any organisms which get into the blood stream by the kidneys, and ultimately by other secretory organs, from which it would follow that only those bacteria are capable of growing in the body which can multiply in the material present in it and at that temperature with such an amount of energy that the continued elimination of a large number of the bacteria is provided for.-But by the researches of Wyssokowitsch* it has been definitely shown that the normal living body does not excrete saprophytic and pathogenic bacteria. This only takes place when pathogenic bacteria have become deposited and have grown in a secretory organ, and when, in consequence of this growth, injury to the tissue of the

* Zeitschr.f. Hygiene, vol. i., Part 1. 
organ has occurred.-Besides, it may be easily seen that Preference the nutrient material present in the body of warm- nor the blooded animals, and the temperature of the body, are ditions in the not specially favourable for the pathogenic organisms, and do not enable them to multiply more rapidly than the saprophytes; for in a dead body, kept at $37^{\circ} \mathrm{C}$., the saprophytes obtain the mastery in a short time, even when they have been introduced in smaller numbers than the pathogenic bacteria.

This want of influence of the movements of the Resistance to fluid, of the tension of the oxygen, of the secretory the living functions, of the temperature, and of the chemical composition of the body on the one hand, and on the other hand the fundamental alteration of the conditions of existence of bacteria when death of the body occurs, shows us that it is in the protoplasm of the living cells that the most important factor, and that which regulates the differences in the behaviour of saprophytes and parasites, lies. Only those bacteria can be reckoned in the latter class which are able to obtain the mastery, and to multiply in concurrence with the living cells, while the saprophytes are not able to grow when subjected to the influence of the living cells, but on the contrary die. Thus the living cells would form the seat where the body carries on the battle with the invading bacteria, where the saprophytes are destroyed, and where the parasitic bacteria gain the victory.

This view of a battle between the cells and bacteria, for a time only obtained by deduction, seems to have gained a definite support from the experiments of Metschnikoff. He was able in experiments with a Metschnikoff's yeast parasite of daphnis, as well as in experiments with phagocytes. anthrax bacilli, which he introduced under the skin of frogs, to observe that bacteria are taken up by leucocytes; the bacteria were gradually destroyed in the substance of the leucocytes, being as it were, digested. Metschnikoff at a later period made similar observations in rabbits and guinea-pigs which he had inoculated with attenuated anthrax bacilli. Nevertheless, Metschnikoff's experiments are by no means free from 
objection, and a large number of control investigations which were made in the author's laboratory by Wyssokowitsch led to a totally different result, and showed that after introduction of large quantities of saprophytic and pathogenic bacteria into the blood stream of warmblooded animals the leucocytes did not take them up.

They play no part in warmblooded animals.

Wyssokowitsch's investigations.

Fixation of the bacteria on the walls of the capillaries. Death of non- cells, which results either in death of the bacteria or in pathogenic bacteria in the endothelial cells.

It is only some specific forms of bacteria which are found constantly in large numbers within the colourless blood corpuscles, such as the bacilli of Koch's mouse septicæmia, or of swine erysipelas. In these cases, however, the leucocytes which occur in all stages of degeneration give much more the impression as if they were the attacked and decaying part, and the bacteria, on the other hand, of which large numbers are found in the dying cells, as if they were the victorious agents.

Certain other cellular elements of the body seem, however, as a matter of fact, to play an important part in the battle with the invading bacteria. According to the more recent investigations by Wyssokowitsch, bacteria, both saprophytic and pathogenic, when introduced into the blood of warm-blooded animals are in the first place very rapidly eliminated from the circulating blood, in a similar manner as has formerly been shown in the case of particles of colouring matter. This disappearance from the blood stream is not occasioned by excretion of the bacteria in any of the secretions, nor by their destruction in the circulating blood; but the bacteria are fixed in the capillaries of various organs, chiefly of those where the current of blood is slow; they adhere to the walls of the capillaries, or are taken up into the interior of the endothelial cells. These bacteria are found in largest numbers in the liver, spleen, and medulla of bone. The fight with the parasites seems to occur at the seat of deposit chiefly in the endothelial the destruction of the cells which are immediately concerned, and the multiplication of the bacteria. It can be observed that typical saprophytes die at the seat of deposit in a relatively short time - within a few hoursand bacteria which are pathogenic for other species of 
animals, within twenty-four to forty-eight hours. It is only the spores of saprophytes, for example of bacillus subtilis, which evidently play the part of completely indifferent foreign elements, that were found alive and capable of development after about three months in the endothelial cells of the capillaries of the spleen and liver.

When the bacteria do not enter in large numbers nor directly into the blood, but in small numbers through slight injuries of the skin or of the mucous membrane, a similar battle between the bacteria and the tissue and endothelial cells of the immediate neighbourhood, probably also occurs in the first instance, and thus all those bacteria are pathogenic for a definite species of animal which, after their contact with these cells, are able to grow and multiply, while the cells, on the contrary, undergo pathological alterations or die.

We obtain, also, a further insight into the causes of the pathogenic action of bacteria by some experiments, which will shortly be published by Wyssokowitsch, in which he succeeded, by artificially lowering the energy of the cells of the body, in enabling bacteria which, under ordinary circumstances, are not pathogenic for the animals employed, to multiply rapidly and occupy the whole of the living body. Such a weakening of the Non-pathobody resulted, for example, by the employment of high genic bacteria temperatures approaching closely the body temperature genic when by which the tissue change was as much as possible artificially reduced ; further, by certain mineral poisons, such as weakened. chromate of ammonia; by far the most completely and rapidly, however, by some of the ptomaines furnished by bacteria. The products furnished by bacillus crassus Influence of sputigenus, by bacillus Neapolitanus, \&c., act apparently ptomaines. on the walls of the capillary vessels, and alter the endothelial cells in such a manner that small quantities of micrococcus tetragenus, Finkler's spirillum, bacillus pneumoniæ, and other species of bacteria, not at all injurious to normal rabbits, can multiply in enormous numbers after the injection of these products, are not completely removed from the blood stream, and do not die in the endothelial cells. 
It is probable that we must explain in an analogous manner the former experiments by Salomonsen as to the action of jequirity on frogs (p. 348); further, the influence of papayotin on the number of bacteria in the blood, as observed by Rossbach. The investigations in this direction must be still more extended and varied before we can draw general conclusions from them; we may, however, expect that they will ultimately enable us to obtain definite views as to the more intimate details of the battle which occurs between cells and bacteria. 
PART V.

CONDITIONS AFFECTING THE DEATH OF THE LOWER

FUNGI.

Various external influences cause injury to the lower Disinfection. fungi, and affect their vital activity more or less profoundly. All these injurious factors are evidently of great interest, because we must search among them for the means to enable us to oppose the grave dangers which threaten us on the part of the fungi, namely, the infective diseases; and the whole of the influences which alter the normal life of the lower fungi are usually considered together under the heading "Modes of Disinfection."

Very numerous experiments have been already made Difference in with regard to the mode and the degree of action of the action of disinfecting means; these must, nevertheless, be still cording to the greatly expanded. For just as in the study of the fungus.

biological characters of the fungi, so in this case it has been found that the various species do not behave in the same manner, but that the one is most markedly affected by this influence, the other by that; and that, further, the sum total of the other conditions of life which are present influences the action of the individual disinfecting means. High temperatures injure the fungi According to more readily when bad nutrient materials are present at ditions of life. the same time; the active dose of specific poisons varies according as the external conditions represent the optimum or vary from the optimum. The stage of development of the bacteria has also a marked influence on their resisting power; young individuals as a rule are more resisting, while older individuals which are approaching the stage of involution can be destroyed 
According to the stage of development.

by trivial and transient injuries. The effect of the formation of spores is of very special importance. If we have to deal with organisms which form these extremely resisting bodies, means which would greatly injure, or even destroy, other fungi may be entirely without effect. Hence in disinfection experiments spore-bearing and non-spore-bearing organisms must not be mixed together, each must be tested separately.

Among the means of disinfection we reckon not only those which kill and destroy the organisms, but also those influences which only cause a permanent loss or a diminution in activity of some of their vital phenomena, and even those which only occasion a temporary delay in their growth and multiplication. These different degrees of degeneration and death require a separate discussion.

\section{I.-Inhibitory Means.}

Inhibition of development.

Inhibition of individual vital phenomena.
The smallest degree of injury which micro-organisms can experience, as the result of external influences, consists in a disturbance of their complete development, which only lasts so long as the injurious factors are present, while afterwards under normal conditions the ordinary vital phenomena can again go on undisturbed.

Minute departures from the normal conditions of existence often lead to cessation of some one biological function. Thus by alterations in the nutrient substrata, by diminution in the amount of oxygen, by a temperature somewhat too low or too high, we may have cessation of the swarming power, of the secretion of peptonising ferments, of the fermentative action, of the production of colouring matter, or of the spore formation; while otherwise growth, multiplication, and all other vital phenomena remain unaltered. Their power in producing disease also may be influenced by similar trivial alterations in the conditions of life, and may even be temporarily removed; and it would be a matter of great interest to learn more accurately the various means-for example, small doses of specific poisons, alterations in 
temperature, \&c.-by the employment of which we might be able for a certain time to neutralise the superiority of the pathogenic bacteria over the cells of the animal body.

The cessation of all vital phenomena, and also of Complete growth and multiplication, is only brought about by development. marked abnormalities in the external conditions. A partial interference with growth is produced by all those alterations in the conditions of existence which lead to a departure from the optimum. These most favourable conditions of existence have been referred to already in detail, and it has also been pointed out in what way every variation of temperature, concentration, \&c., beyond a certain limit results in interference with the vital energy of the fungi.

Complete cessation of growth frequently occurs as the Withdrawal result of grion of necessary In every nutrient medium it ultimately happens, as the materials. result of continued multiplication of the fungi, that some or all of the colonies no longer find the nutrient materials necessary for their further development. In fluids the yeast or fission fungi which have already formed are deposited in the form of a powdery precipitate on the bottom of the vessel. It depends chiefly on the species of the fungus in question how long they can retain their vitality under such conditions without a fresh supply of nutriment. Some only exist in a latent condition for a short time, they soon degenerate and break up; others are much more resisting. To the first group belong the majority of the micrococci, to the latter the spore-forming bacilli, the spores of which can retain their vitality for years; but many micrococci also-for example, Staphylococcus aureus - show a similar resisting power. It is not necessary that all the nutrient materials should be exhausted; on the contrary, the loss of a single necessary material is sufficient to lead to a period of rest.

A very frequent cause of cessation of the growth of withdrawal bacteria is the diminution of the necessary amount of of water. water in the nutrient medium. Growth ceases on the most various nutrient media on the surface of the soil, 
\&c., whenever the amount of water has fallen below 60 to 70 per cent.; more accurate determination of these limits is, however, wanting.

Light, electricity, and pressure.

Among other influences light and pressure seem scarcely to exert any noticeable effect on the development of the lower fungi. Certes and Cochin found that yeast could break up sugar under a pressure of 300 to 400 atmospheres; in like manner putrefactive phenomena occurred in fluids which were kept under a pressure of 350 to 500 atmospheres.Electricity, in the form of the constant galvanic current, causes cessation of the multiplication of the bacteria; this effect is due to the electrolytic action of the current, which leads to the production at the positive pole of a distinctly acid reaction, and at the negative pole of a distinctly alkaline one. No influence is noticeable when the current is weak; the effect is not produced till at least two powerful elements are employed.

Temperature. Of much greater practical importance is the temperature of the nutrient medium. At a low temperature as well as at a high temperature multiplication of bacteria (and also of mould fungi) ceases; but in almost all species the limit of the low and high temperature appears to be different. In the case of many organisms these limits have not yet been accurately determined. In the case of many saprophytes (the water bacteria, the organisms formerly grouped under the term "bacterium termo," \&c.) slight growth may occur at a temperature of $+6^{\circ}$ C., and development only ceases at a temperature of from $4^{\circ}$ to $5^{\circ} \mathrm{C}$. On the other hand, the lowest limit of growth for the spirillum of Asiatic cholera is from $15^{\circ}$ to $16^{\circ} \mathrm{C}$.; for the bacilli of glanders, about $22^{\circ} \mathrm{C}$.; and for the tubercle bacilli, $33^{\circ} \mathrm{C}$. Cessation of multiplication as the result of higher temperatures occurs: in the case of the lactic acid bacillus, above $45 \cdot 3^{\circ} \mathrm{C}$.; in the case of bacterium termo, from $40^{\circ}$ to $43^{\circ} \mathrm{C}$; in the case of bacillus subtilis, at $50^{\circ}$ to $55^{\circ} \mathrm{C}$. The higher limit is difficult to ascertain, because the temperature which only leads to temporary cessation of vital activity, and that which-more especially when it acts for a considerable time-causes permanent loss of certain properties, usually lie very close to each other. 
Of great practical importance also is the cessation of Chemical development as the result of the addition of small quan- poisons tities of active chemical and specifically poisonous materials to the nutrient substrata. Here also it is not easy to ascertain precisely the value of these means, because they behave very differently according to the composition of the nutrient substrata. This difference chiefly depends on Difference in the fact that when these chemical materials ore added the action the fact that when these chemical materials are added according to to the nutrient substrata, chemical decompositions fre- the nature of quently occur, as the result of which a portion of the substratum. disinfecting substance is destroyed or rendered inactive. Hence it is clear that definite values of the inhibitory means can only be laid down in the case of one and the same nutrient solution, while the values will differ where the composition of the nutrient substratum varies. For example, Boillat* ascertained that in albuminous substrata chloride of zinc and other metallic salts only produced a disinfecting action after all the albumen was precipitated by them, and when a sufficient excess remained in the solution for purposes of disinfection. Further, as mentioned above, various species of fungi behave differently towards noxious agencies, and in the same species the degree of the action always depends on the other conditions of life which may be present at the same time. Hence a generally applicable scale of the value of disinfecting substances cannot be given; and in like manner trustworthy results are only obtained from those experiments which have been made with known and well-characterised species of bacteria.

Of the figures which have been as yet published we Experiments may mention here only a few, some of which, however, by De la Croix have not been obtained by the employment of all the in meat inabove-mentioned precautions. De la Croix tested the bacteria of meat infusion (that is to say, not a pure cultivation of a single species), and found that their development in meat infusion ceased when the following substances were present in the degree of concentration mentioned below :- 


\begin{tabular}{|c|c|}
\hline & \\
\hline alorine ........ & $1: 25,25$ \\
\hline of lime & $1: 11,1$ \\
\hline us acid & 1 \\
\hline & $1: 6$ \\
\hline Sul & $1: 5$, \\
\hline & $1: 5$ \\
\hline Oil & $1: 3$, \\
\hline Sali & $1: 1,00$ \\
\hline ate of potash.. & $1: 1,001$ \\
\hline acid. & 1: \\
\hline & \\
\hline & \\
\hline
\end{tabular}

By Ratimoff

According to Ratimoff, in order to render meat infusion aseptic, the following concentrations were necessary:-

Sublimate ......................... $1: 13,300$

Nitrate of silver ................. $1: 10,000$

Iodine ............................. 1: 8,000

Carbolic acid....................... 1: 400

In order to prevent the development of bacteria on meat, about 30 times the amount given above was necessary.

By Miguel.

According to Miguel's experiments, development of bacteria in meat infusion is prevented by-

Mercuric oxide $1: 40,000$

Peroxide of hydrogen ............. $1: 20,000$

Mercuric chloride.................. $1: 14,300$

Nitrate of silver ................. $1: 12,500$

Iodine ............................... 1: 4,000

Chlorine ............................ 1: 1,000

Bromine ............................ 1: 1,667

Sulphate of copper ............... 1: 1,100

Salicylic acid........................ 1: 1,000

Mineral acids .......... 1 : 500 to 1 : 333

Carbolic acid ........................ 1: 313

Permanganate of potash ........ $1: \quad 286$

Arsenious acid ...................... 1: 170

Boracic acid ........................ 1: 130

Sulphate of iron .................. 1: 90

Borax ............................... 1: 14

Athylic alcohol ................... 1: 10.5

Iodide of potash .................. 1: 7 
Koch has tested the inhibitory action of various poisons Experiments on non-spore-bearing anthrax bacilli. The results were with anthrax obtained by filling small vessels with $10 \mathrm{ccm}$. of blood serum or of peptonised meat infusion ( 1 per cent. peptone, $\frac{1}{2}$ per cent. meat extract and water), and then adding the disinfecting substances. A number of these vessels, and among them some without any disinfecting substances, were placed side by side under a bell-jar in the presence of moisture. A silk thread, impregnated with anthrax spores, was then placed in each vessel; in the control vessels growths of long anthrax threads were always present after twenty-four hours, and presented a very characteristic appearance, and one not easily mistaken. In a similar manner the other vessels were examined under the microscope in the course of the next few days, and thus absence of growth or the appearance of threads indicated the activity or inactivity of the disinfecting means. (In the case of other species of bacteria nutrient gelatine is often preferable for these experiments, the chemical substance to be tested, and also a small quantity of the bacteria, being added to it, and then the liquefied jelly poured out on glass plates.) The following are the most important figures obtained by Koch :-

Distinct hindering of Complete cessagrowth tion of growth

Occurred when the concentration reached

\begin{tabular}{|c|c|c|}
\hline Bichloride o & $1: 1,600,000$ & $: 300,000$ \\
\hline Oil of mustard & $1: 330,000$ & ...... 1: 33,000 \\
\hline Allyl-alcohol & $1: 167,000$ & $\ldots$ \\
\hline Arseniate of potash. & $1: \quad 100,000$ & ..... 1: 10,000 \\
\hline Thymol ...................... & 80,000 & - \\
\hline urpentine & 75,000 & \\
\hline Hydrocy & 40,000 & \\
\hline Oil of $p$ & 33,000 & \\
\hline $\mathrm{clc}$ & 5,000 & $\ldots . .$. \\
\hline Potash soap & 5,000 & ..... 1: 1,000 \\
\hline Iodine ................... & 5,000 & ....... \\
\hline Hydrochloric acid ... & 2,500 & ..... 1: 1,700 \\
\hline Boracic acid ............. & 1,250 & ..... 1: \\
\hline Bromine | & 1,500 & - \\
\hline Permanganate of potas & 1,400 & ...... \\
\hline
\end{tabular}


Action of various metallic salts
Distinct hindering of Complete cessagrowth tion of growth

Occurred when the concentration reached

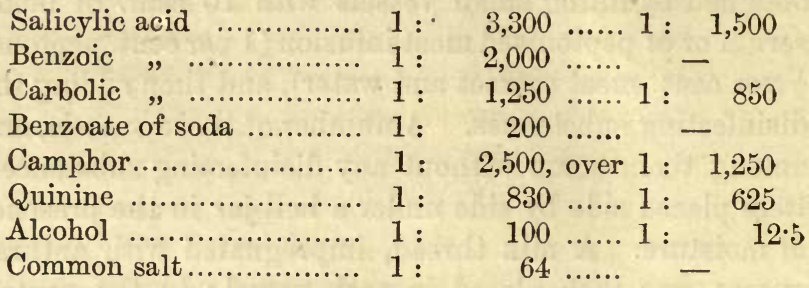

A series of experiments by Richet* may also be mentioned where the fluid employed was a mixture of 900 grammes of sea-water, 100 grammes of neutralised urine, and 1 gramme of peptone, the attempt being made to ascertain how much of the various metallic salts it was necessary to add to this solution to prevent the development of bacteria. In the following table the amount of the pure metal has been calculated from the amount of the metallic salt which it was necessary to add to each litre of fluid, and also for comparison those figures are given which correspond to the quantity of metal per litre which was necessary to kill salt water fish. From this comparison we see at once the much greater resisting power of the bacteria, and also the unequal behaviour of certain metallic poisons in reference to the animal and vegetable cell.

\section{Amount of metal per litre of fluid}

To hinder the development To kill fish. of bacteria.

\begin{tabular}{|c|c|c|c|c|c|}
\hline Mercury ............. & 0.005 & mme & $\ldots$ & 0.00028 & \\
\hline Zinc ................... & 0.026 & ", & $\ldots$ & 0.0084 & " \\
\hline Copper................ & $0 \cdot 062$ & , & •. & $0 \cdot 0033$ & ", \\
\hline Iron ........ & $0 \cdot 24$ & , & ... & 0.014 & ", \\
\hline Barium ....... & $3 \cdot 35$ & , & ... & 0.78 & , \\
\hline Manganese ......... & $7 \cdot 7$ & , & $\ldots$ & $0 \cdot 3$ & , \\
\hline Ammonium......... & $18 \cdot 7$ & , & $\ldots$ & 0.064 & , \\
\hline Calcium ............. & $30^{\circ} 0$ & , & & $2 \cdot 4$ & , \\
\hline Sodium & $43 \cdot 0$ & , & ... & $24 \cdot 0$ & \\
\hline Potassium ......... & $58 \cdot 0$ & , & ... & $0 \cdot 1$ & , \\
\hline
\end{tabular}

Of the inhibitory substances not included in the foregoing tables, but which have been tested and recommended, we may mention the following :-

According to the experiments of Wassileff $†$ calomel has an 
energetic action in preventing putrefaction, whilst it does not interfere with the activity of the digestive ferments.According to Schulz and Hoffmann organic acids of the fatty series, citric acid, formic acid, \&c., are powerful antiputrefactive substances; formic acid in the amount of 25 per cent. is able to preserve Bucholtz's nutrient fluid for months. According to Donath* chinolin is antiputrefactive in the percentage of $\cdot 2$, and according to Vigier $†$ orthophenolsulphoacid is active in a percentage of $\cdot 5$ to 1 .-Bert and Regnard $\ddagger$ have made experiments as to the antiseptic and disinfecting properties of peroxide of hydrogen, and Chappuis $\S$ on ozone, but without paying sufficient attention to the dose of the substance and the species of the bacterium.-Kolbe $\|$ has drawn attention to the fact that when kept in vessels filled with carbonic acid fresh ox flesh can be preserved against putrefaction for four to five weeks; mutton cannot, however, be similarly preserved. More accurate examination of the antiseptic properties of carbonic acid is desirable.

According to experiments by Kuisl 9 potash soap is not such a good inhibitory substance for other bacteria as for anthrax bacilli. Even when present in a concentration of 10 per cent. it was not able to prevent putrefaction in meat.

\section{II.-Attenuation of Pathogenic and Fermentative Organisms.}

By noxious influences of definite but closely limited At:enuation intensity we may so alter many bacteria that they lose of organisms certain of their vital functions, this loss lasting for a long time and even when the cultivation is continued under completely normal conditions. The noxious factors which are suitable for this action are less energetic than those which cause complete death of the bacteria; on the other hand, the effects are more marked than in the case of the inhibitory means, which only exert their action so long as they are present in the nutrient substratum. At times, however, the greater effect necessary for attenuation can also be produced by sufficiently long-continued action of the milder means. When properly regulated, high temperatures and various

* Chem. Ber., vol. 14.

‡ Compt. rend., vol. 94.

II Journ.f.prakt. Chem., (2) vol. 26.

T Münch. ärztl. Intelligenzbl., 1885.
† Mém. soc. biolog., 1884.

$\S$ Bull. soc. Chim., vol. 35. 
chemical poisons are able to produce a permanent attenuation.

The vital phenomena which are in this way lost are, as far as has yet been ascertained, only the power of producing fermentation and that of exciting disease. A similar occurrence has not been observed in the case of the other functions and products of the tissue change (pigment, ferments, \&c.). The loss of the fermentatire or pathogenic properties is usually designated shortly

The more intimate nature of attenuation.

Attenuation of the agents of fermentation.

Attenuation of pathogenic bacteria.

Anthrax bacilli. Attenuation by high tem. peratures. under the term "attenuation of the bacteria." Whether at the same time there is diminished energy of growth and of the whole phenomena of tissue change in the pathogenic bacteria, thus explaining the victory of the cells of the body, or whether it is only one of the vital phenomena which is of importance in the warfare with the cells of the body, namely, the production of a poison, \&c., which is acted on by the noxious agent and destroyed for a considerable time, can only be decided as the result of further investigations.

Attenuation of the pathogenic mould fungi has not as yet been observed; see the above-mentioned experiments by Fränkel, p 126.

As regards the attenuation of the fermentative bacteria we have observations by Fitz. The anaërobic bacillus butyricus could be so altered by heating it for five hours at a temperature of $90^{\circ} \mathrm{C}$, or for seven hours at $84^{\circ} \mathrm{C}$, that it no longer furnished the characteristic fermentative products in suitable materials although it multiplied actively. In like manner the agent of butyric fermentation isolated by Fitz at a later period (p. 388), as well as the bacillus Fitzianus, lost readily the power of producing fermentation, but also readily regained it.

The attenuation of pathogenic bacteria has as yet been successful in the case of bacillus anthracis, the bacillus of symptomatic anthrax, the bacillus of fowl cholera, the bacillus of swine erysipelas, and the as yet unknown exciting agent of hydrophobia.

The phenomenon of attenuation has been most accurately studied in the case of the anthrax bacilli. The employment of high degrees of temperature has proved 
to be a very suitable means; the temperature may vary between $42^{\circ}$ and $55^{\circ} \mathrm{C}$, and the organisms must be exposed to it for a longer time the lower the temperature employed. Thus according to Toussaint a temperature of $55^{\circ} \mathrm{C}$. was able to attenuate the bacilli of an anthrax cultivation in ten minutes; according to Chauveau a temperature of $52^{\circ} \mathrm{C}$. must be employed for fifteen minutes, of $50^{\circ} \mathrm{C}$. for twenty minutes, of $47^{\circ} \mathrm{C}$. for one to four hours after previous exposure to $42^{\circ}$ to $43^{\circ} \mathrm{C}$. for twenty hours ; according to Pasteur and Koch a temperature of $43^{\circ} \mathrm{C}$. must be employed for six days, a temperature of $42^{\circ} \mathrm{C}$. for about twenty-eight to thirty days, in order to obtain a complete loss of the pathogenic action; where the action is continued above thirty days death of the bacilli occurs.

According to Pasteur's recommendations, which have Most suitable been more precisely worked out by Koch, the following is the method best suited for obtaining attenuated anthrax bacilli: the cultivations are made in neutralised chicken broth, which is placed in a moderately deep layer in Erlenmeyer's flasks. These flasks are then placed in a D'Arsonval's thermostat kept at $42^{\circ} \mathrm{C}$. In spite of careful regulation the temperature varies somewhat in the interior; and hence the individual vessels frequently show a somewhat varying degree of attenuation. At times, also, spore formation may take place, though as a rule this does not occur at $42^{\circ} \mathrm{C}$; if it does take place the attempt at attenuation fails. Hence it must always be borne in mind that some of the cultivations may not have succeeded. From eight days onwards the vessels must be tested daily; and the degree of attenuation of each specimen is ascertained either by sowing the material in a vessel containing chicken-broth and kept at $37^{\circ} \mathrm{C}$., so that spores are soon formed; or by inoculating a mouse with the specimen, and after its death making cultivations from the spleen, and thus obtaining spores. The cultivations or spores so obtained preserve for a long time that degree of virulence at which the material had arrived.

After exposure to a temperature of $42^{\circ} \mathrm{C}$. for ten days Various the anthrax bacilli are so attenuated that rabbits and degrees of 
guinea-pigs show almost no reaction when inoculated; at a somewhat earlier period, guinea-pigs, but not rabbits, are killed. From the tenth to the twenty-fourth day we obtain the so-called "mouse anthrax," that is to say, a cultivation of bacilli which is only able to kill mice. These attenuated bacilli behave, according to Koch, somewhat differently in the body of the mouse than the virulent bacilli, the capillaries of the lung becoming filled with extremely long pseudo-threads in a manner which is not observed in the case of ordinary anthrax.

The first and second vaccines prepared by Pasteur for the protective inoculation of sheep are treated for twelve and twenty-four days respectively in the manner above described.

According to Pasteur's view the oxygen of the air is the chief active agent in this process of attenuation; while Koch regards the temperature as the most important factor, its effect being perhaps also aided by certain products of tissue change of the bacilli. The results of attenuation experiments at varying high temperatures show most distinctly that the effect depends almost exclusively on the temperature, and is in fact the result of the action of a certain temperature, as well as of the length of time to which the material is exposed to it.

Return of attenuated bacilli to virulent bacilli.
In the case of anthrax bacilli attenuated in this manner, researches have been made as to whether they regain their former virulence when cultivated under normal conditions, or whether they permanently retain the attenuated virulence when once it is acquired. On the whole the experiments have not given an uniform result, and are as yet too few in number to enable us to deduce any law which accounts for the return of the virulence in some cases, and the absence of such return in others. The virulence appears to be regained most readily and most regularly where the attenuation has been brought about, according to Toussaint's method, by the short action of high temperatures; the bacilli which have been attenuated by ten minutes' exposure to $55^{\circ}$ C. regain 
their virulence, according to Chauveau, in the first normal cultivation, and this is also the case where a temperature of $47^{\circ} \mathrm{C}$. has been employed; on the other hand, where, in Pasteur's method, a temperature of only $42^{\circ}$ to $43^{\circ} \mathrm{C}$. is employed, there is as a rule no return of virulence. Thus Koch cultivated completely attenuated anthrax bacilli which had been kept for twenty-nine days at $42^{\circ} \mathrm{C}$. for two years under the most favourable conditions without the last cultivations being able even to infect mice; at the same time, however, the morphological characters of the bacilli and the appearance of the colonies did not show any difference from those of the virulent bacilli.-According to Pasteur the virulence can be regained if anthrax bacilli attenuated according to his method are in the first place inoculated on a newly-born guinea-pig; this animal succumbs to the infection, and then an animal one day old is inoculated from the first, then an animal two days old from the second, and so on; and thus ultimately a gradual increase of virulence is obtained, till even adult animals are killed. Koch, however, on repeating this experiment was unable to confirm these results.

Among other means of attenuating anthrax bacilli we Attenuation may mention the action of chemical substances which of anthrax are poisonous to bacteria, a method first employed by carbolic acid Toussaint, and later by Chamberland and Roux. According to the latter authors carbolic acid of the strength of 1 to 600 causes complete attenuation of a cultivation kept for twenty-four days at $35^{\circ} \mathrm{C}$.; if examined after twelve days the cultivation still possesses its full virulence. Solutions of bichromate of potash of the strength of 1 to 1700 kill anthrax bacilli ; where the dilution is greater ( 1 to 2,000 to 1 to 5,000 ), it only causes such an attenuation that sheep are no longer affected by inoculation, while guinea-pigs and rabbits still die. If a 2 per cent. Bysulphurous solution of sulphurous acid acts for eight to ten days on anthrax spores at a temperature of $35^{\circ} \mathrm{C}$., and if the spores are then cultivated on normal nutrient jelly, a growth is obtained which is still able to kill guineapigs, but does not kill rabbits. 
By cultivation in an apparatus kept constantly in motion.

By long. continued cultivation.

By light and pressure.

Attenuation of the bacilli of fowl cholera.

Of symptomatic anthrax.

Of swine erysipelas.

Attenuation of the virus of rabies.
Buchner obtained loss of virulence in the anthrax bacilli if he cultivated them outside the body for a number of generations in certain nutrient substrata, such as in extract of meat solution, with or without peptone, to which a very plentiful supply of air was added by the employment of an apparatus which kept the solution in constant motion. There were many objections to this method as first described by Buchner (p. 240); but protective inoculations which have been made by Frank with Buchner's attenuated anthrax bacilli show that, as a matter of fact, a gradual loss of virulence can be obtained by this method.

A diminution of virulence also appears to occur when the anthrax bacilli are kept for a long time in the same culture fluid (Koch).

Lastly, according to Arloing, * exposure for three hours to sunlight, and, according to Chauveau and Wossnessenski, $\uparrow$ increased atmospheric pressure, cause an attenuation of the anthrax bacilli.

Among other pathogenic bacteria the bacilli of fowl cholera, of symptomatic anthrax, and of swine erysipelas show a similar behaviour. In the case of the firstmentioned bacillus the mode of the attenuation has not as yet been accurately ascertained (p. 317); in the case of symptomatic anthrax the attenuation is best obtained by the employment of high temperatures (p. 301). A special and new principle has been followed by Pasteur in the case of the bacilli of swine erysipelas; he found that their virulence was increased by repeated transmission of the infective agents through pigeons, while, on the other hand, it was diminished by their acclimatisation in the bodies of rabbits (p. 307).

Another plan, and one not as yet completely explained, has been recently employed by Pasteur+ for the attenuation of the virulence of the poison of rabies. Pasteur's method is shortly as follows:-As the infective agents of rabies are as yet completely unknown, and have not been cultivated artificially, a pure rabic poison, and

* Compt. rend., vol. 99. + Ibid., vcl. 98.

$\ddagger$ Compt. rend., 1885, 26th October. 
one which is practically uniform in its virulence, must be procured for the attenuation experiments. This is obtained by continued inoculation of the poison on rabbits. If one starts from a rabid dog, and inoculates from this animal a rabbit under the dura mater into the brain substance, rabies appears in the latter animal after an incubation period of about fourteen days; if the inoculations are carried on from rabbit to rabbit the period of incubation becomes gradually shorter; after 40 to 50 inoculations it has fallen to seven days, and up till the ninetieth transmission there is scarcely any further alteration to be observed; hence the poison has become acclimatised in the body of the rabbit, and has attained an almost constant degree of virulence.-It has been further proved that the spinal cord of these rabbits contains the rabic poison throughout its whole extent.

If now the cord is cut up into fragments a few ctm. in length, and if these are hung up in dry air, the virulence gradually disappears; the length of time which elapses before complete disappearance of the virulence varies with the thickness of the fragments, and above all with the external temperature; the lower the temperature, the longer is the virulence retained. If the pieces are preserved in a vessel from which air is excluded, or in carbonic acid gas, or in a moist condition, the virulence is retained for months, always provided that the access of saprophytic bacteria is prevented.-In order to obtain rabic poison of varying virulence suitable for protective inoculations a number of pieces of cord are placed at the same time in a corresponding number of vessels, the air of which is kept dry by pieces of potash. The portions of cord which are kept in this manner for one to two days set up, like the fresh material, rabies in rabbits after seven days' incubation; when the pieces are preserved for six days the length of the incubation period is increased to fourteen days; when the pieces are kept for seven days in the dry air rabbits inoculated no longer become ill.

Definite facts as to the active agents are as yet wanting, nor do we yet possess a sufficient explanation of the 
mode of action. Pasteur has only been able to give a series of hypotheses, which at the most show how, with the help of vague speculations, this ingenious inrestigator is able to obtain great experimental results.

\section{III.-Means for Killing Bacteria.}

Means for killing bacteria.

Continued withdrawal of nutriment.

Withdrawal of water.
The means which are suitable for the destruction of the lower fungi have a special interest, because in the practical work of disinfection the problem is usually how to injure the infective agents so that they can no longer grow and multiply even under the most favourable conditions of existence.

Death of the bacteria occurs in the first place when the exhaustion of the nutrient materials, or the withdrawal of some material important for life and the conseguent state of latent life, are continued for too long a time. The death of the individuals ultimately follows the prevention of their development, but the period of time at which this effect is produced varies greatly according to the resisting power of the individual species of bacteria. The spores of bacilli are the most resistant, and may probably survive in a latent state for hundreds of years; non-spore-bearing bacilli and micrococci, and more especially numerous parasitic fungi, are the most sensitive in this respect.

The withdrawal of water plays a particularly important part. This mode of destruction occurs very widely in nature, and all those bacteria which do not form resting spores die in a relatively short period of time. The marked difference in the length of time during which non-spore-bearing bacteria, and those provided with spores, can resist the action of drying is a very useful criterion as to whether any doubtful morphological structure is, or is not, a spore (pp. 428 and 406). Spirilla and some species of cocci (streptococci) appear to be the most sensitive to drying. Differences also exist between the resting forms of various species, but these differences have not as yet been accurately made out. 
The other conditions of life of the bacteria do not produce any such marked effect. Pressure and electricity only appear to destroy bacteria when carried to extremes (p. 535); intense sunlight is said to have a comparatively energetic action, but these experiments must be repeated with more careful attention to the possibility of other hurtful factors coming into play.

A very active agent for the destruction of the lower High temperafungi is high temperature, while, on the other hand, low temperatures, even carried to an extreme degree, only prevent development, but never cause the death of the organism. The effect of heat depends on the degree of temperature, and on its duration; continued action of relatively low temperatures produces the same result as a short action of high temperatures. The temperature necessary to cause the death of the Varying organisms varies also very greatly according to the other ${ }_{\text {power of }}^{\text {resisting non- }}$ couditions of life, and more especially according to the spore-bearing resisting power of the species in question. The chief of spores. difference is found between bacteria which do not form spores and those which are spore-bearing. - The former are, as a rule, killed when in a moist state or in fluids by exposure for one to two hours to a temperature of $48^{\circ}$ to $60^{\circ} \mathrm{C}$.; where they are dry the temperature must as a rule be continued for a longer time. Even spore-forming bacteria may be killed by these relatively low degrees of temperature if the heat is applied on repeated occasions, and if in the intervals between its application the organisms are placed under the most favourable conditions of existence, so that any spores that are present may sprout and form bacilli.-If the latter are killed by the subsequent application of heat before new spores are formed, we may be certain that after the heat has been applied five or six times no living spores exist, and all the adult organisms are destroyed. For example, blood serum may be freed from all organisms, although the heat employed has not been sufficient to cause coagulation of the albumen; the material is placed for an hour daily for five or six days in succession at a temperature of about $56^{\circ} \mathrm{C}$., and is in this way com- 
pletely freed from all living organisms.- It is much more difficult to kill quickly the spores of the mould fungi. Hot air at a temperature of $120^{\circ} \mathrm{C}$. does not completely destroy them after half an hour's exposure; they are not certainly killed unless they are exposed to a temperature of $110^{\circ}$ to $115^{\circ} \mathrm{C}$. for an hour and a half. The spores of penicillium appear to be less resistant than the spores of Aspergillus niger.-The most difficult to kill are the spores of bacilli, although among these great differences exist. Thus anthrax spores are less resistant than the spores of tubercle bacilli, and these again are less resistant than those of bacillus subtilis, and more especially of the bacilli contained in garden earth.

Influence of moisture.

In the process of disinfection it is very important to remember that dry spores always require much longer exposure to heat than spores in a moist state. It appears as if that total alteration of the protoplasm which leads to death occurs much more readily when there is a certain amount of water in it than when it is completely dry. Hence it is very difficult to destroy the spores of bacilli by hot air ; even when a considerable amount of watery vapour is added to air kept at a temperature of $100^{\circ}$ to $140^{\circ} \mathrm{C}$. it acts to a large extent as a drying medium, and objects exposed to it rapidly pass into such a state of dryness that it is only with great difficulty that alterations of the protoplasm occur. Thus the dry spores of bacilli are only killed by exposure for three hours to a temperature of $140^{\circ} \mathrm{C}$. If it is desired to disinfect the interior of large masses which are bad conductors of heat, a much longer duration of the heat is necessary in order to obtain the desired effect. But even an exposure for three hours to $140^{\circ} \mathrm{C}$. irreparably spoils all sorts of clothing.

Action of heat It is much more easy to destroy the spores of bacilli
in fluids. in fluids. Anthrax spores are destroyed in boiling water "ithin two minutes; the spores of the hay bacillus resist this temperature for about ten or fifteen minutes (according to Buchner for sixty minutes); after. fifteen minutes the majority of spores are destroyed. It is, however, often difficult to raise the temperature 
of the whole mass of fluid to be disinfected to $100^{\circ} \mathrm{C}$. ; on the other hand it is easy, as Koch has shown, by means of a current of steam to obtain the necessary temperature of $100^{\circ} \mathrm{C}$. in all sorts of materials. At the Action of a bottom of the apparturent of bottom of the apparatus necessary for this purpose ste m. there is a large vessel, on the top of which a tube of sheet zinc, 1 to 2 metres in height, is fixed; this tube is gradually narrowed at the top, and finally runs out in the form of a short tube, only $1 \mathrm{~cm}$. in diameter. The zinc tube is fixed tightly on the top of the boiler, and its outer surface is enveloped in some substance which conducts heat badly. If the water in the boiler is boiled, the steam passes out of the narrow upper opening in a strong current, and from that opening downwards the steam has a temperature of $100^{\circ} \mathrm{C}$. If now the objects to be disinfected are placed inside the vertical tube they are rapidly penetrated by the steam and raised to a temperature of $100^{\circ}$, and even in a few minutes the majority of the spores of bacilli are destroyed. The duration of the heat must of course be somewhat varied according to the nature of the materials. Fresh tubercular sputum is disinfected with certainty in about fifteen minutes, dried sputum in thirty to sixty minutes. A duration of sixty minutes is sufficient to kill the most resistant spores as yet known, even when surrounded by a relatively dense mass of material.-The rapidity of the effect is increased by employing a salt solution, and thus obtaining steam at a higher temperature than $100^{\circ} \mathrm{C}$.

A number of chemical poisons are also suitable for the Chemical destruction of bacteria. With regard to these, we have to note the concentration of the poison, the duration of its action, the nature of the nutrient substrata and the other conditions of life, and the specific resisting power of the species, more especially the presence of resting forms. -Bacteria free from spores are on the whole destroyed by very small proportions; thus carbolic acid kills anthrax bacilli when in a concentration of $\cdot 25$ to $\cdot 5$ per cent.; 1 per cent. sulphurous acid kills them within five to fifteen minutes.-In the practical work of disinfection 
Trustworthy disinfecting means must destroy spores.
Experiments with anthrax spores.

a knowledge of the proportions necessary for destroying bacteria free from spores is of comparatively little importance ; in many cases we have to do with infective agents which undoubtedly form spores, in other cases the infective agents are not accurately known, and the possibility of the formation of resting forms is doubtful. Complete trust can therefore only be placed in those methods which can destroy any spores which may possibly be present. It is therefore of chief practical importance to test the disinfecting media with regard to their action on spores.

In this respect a series of experiments made by Koch is worthy of note, these experiments having been made by the comparison of various chemical poisons as regards their action on the same object-for example, on anthrax spores. The following are the most important results of these experiments :-

1. The following substances had no action on anthrax spores, even after acting for several months :-

Distilled water

Absolute alcohol

Chloroform

Glycerine

Benzole

Benzoic acid (concentrated watery solution)

Salicylic acid (5 per cent. in alcohol, 2 per cent. in oil) Thymol (5 per cent. in alcohol)

Ammonia

Salt solution (concentrated)

Chloride of calcium solution (concentrated)

Chlorate of potash (5 per cent. in water)

Alum (4 per cent. in water)

Borax (5 per cent. in water)

Potash soap (2 per cent. in water).

2. The following showed incomplete or slow action on anthrax spores:-

Ether (incomplete action after eight days, complete action after thirty days)

Acetone (incomplete after five days)

Iodine, 1 per cent. in alcohol (incomplete after one day) 
Sulphuric acid, 1 per cent. in water (incomplete after ten days)

Sulphate of copper, 5 per cent. in water (incomplete after five days)

Boracic acid, saturated watery solution (incomplete after six days)

Hydrochloric acid, 2 per cent. in water (complete after ten days)

Arsenious acid, 1 per thousand in water (complete after ten days)

Sulphuretted hydrogen in water (incomplete after five days)

Ammonium sulphide (complete after five days)

Formic acid, 1.12 specific gravity (complete on the fourth day)

Quinine, 2 per cent. in water $\left(\begin{array}{l}2 \\ 5\end{array}\right)$ and alcohol ( $\left.\begin{array}{c}3 \\ 5\end{array}\right)$ (incomplete on the first day)

Quinine, 1 per cent. in water with hydrochloric acid (complete on the tenth day)

Oil of turpentine (incomplete on the first day, complete after five days)

Chloride of lime, 5 per cent. in water (incomplete on the first and second day, complete after five days)

Chloride of iron, 5 per cent. in water (incomplete on the second day, complete after six days)

3. The following showed rapid and complete action, all of them destroying the organisms on the first day :-

Chlorine water freshly prepared

Bromine, 2 per cent. in water

Iodine water

Osmic acid, 1 per cent. in water.

Permanganate of potash, 5 per cent. in water

Bichloride of mercury, 1 to 20,000 in water

A 5 per cent. watery solution of carbolic acid caused complete destruction of spores between the first and second day; a 5 per cent. solution in oil or alcohol had no action on anthrax spores.

We may also mention a series of experiments by Effect of a Gärtner and Plagge* which are more especially of short action of

* Verhandl. der Deutschen Gesellsch.f. Chirurgie, 1885. 
practical interest to the surgeon.' Gärtner and Plagge employed carbolic acid in the strength of 1 per cent., 2 per cent., and 3 per cent., and also 1 to 1,000 sublimate solution. The materials used for the research were pure cultivations in meat infusion of the following organisms: 1. Non-spore-bearing anthrax bacilli; 2 . Glanders bacilli; 3 . Streptococci from a case of puerperal fever; 4. Pyogenic streptococci; 5. Erysipelas cocei ; 6. Micrococcus tetragenus; 7. The bacilli of diphtheria ; 8. Staphylococcus albus ; 9 . Staphylococcus aureus; 10. The cocci of osteomyelitis; 11. Bacillus prodigiosus; 12. Bacillus of typhoid fever free from spores; 13. Micro-organisms from a case of spontaneous meningitis. The cultivations were mixed with the disinfecting fluids for only a very short time-as a rule eight to sixty seconds-and a small quantity was then introduced into nutrient jelly or blood serum.-It was found that the sublimate solution killed all these organisms even in eight seconds, with the single exception of the meningitis organisms, which were still living after sixty seconds. The 3 per cent. carbolic acid killed all the organisms without exception in eight seconds. In the case of the 2 per cent. carbolic acid the osteomyelitis and the meningitis bacteria required thirty to fortyfive seconds; with the 1 per cent. carbolic acid rapid disinfection was only obtained in the case of the anthrax and glanders bacilli.

As regards the disinfecting action of certain chemical poisons a large number of experiments have been made which we need not here refer to in detail, but the following materials which are much employed may be mentioned :-

Action of sulphurous acid.
Sulphurous acid was formerly recommended as a good and cheap means of disinfection for dwelling-rooms. 20 grammes of roll sulphur were burned per cubic centimetre of space; in order to render the burning of the sulphur easier $100 \mathrm{ctm}$. of sulphur matches and $40 \mathrm{ctm}$. of spirit were added to every kilo of sulphur. In this way an amount of sulphurous acid was obtained representing 1.4 per cent. in volume. The duration of 
the action was at least eight hours.-More recent investigations by Koch and Wolffhügel have however shown that sulphurous acid, even when as concentrated as possible - a degree of concentration which cannot be attained in practice-only kills spores imperfectly ; even with regard to non-spore-bearing bacteria the action is uncertain when present in 10 per cent. by volume if the layers to be disinfected are at all thick.-Further, sulphurous acid penetrates with considerable difficulty into the deeper layers of masses of clothing, \&c., and only has a certain amount of disinfecting action when the objects have been previously moistened, while at the same time it causes considerable injury to them.Dujardin-Beaumetz has recently again recommended sulphurous acid, and asserts, as the result of practical experience and of experiments with cultivations of bacteria in infusions, that the burning of 20 grammes of sulphur per cubic metre is sufficient for complete disinfection. The experimental proofs brought forward by Dujardin are, however, quite insufficient.

Chlorine and bromine have, on the whole, a very Action of marked action, more especially when the objects have chlorine a been moistened, or when the air is saturated with moisture. In dry air, and where the material is dry, even several parts per 100 of these vapours in the air do not cause complete disinfection. Where, however, the materials have been previously artificially moistened the presence of 3 per cent. by volume of chlorine and - 21 per cent. of bromine when acting for three hours is sufficient to kill all spores ; $\cdot 03$ to $\cdot 04$ per cent. by volume also suffices when it acts for twenty-four hours. This favourable effect has, however, only been obtained in experiments in laboratories, and not where the experiments were carried on on a larger scale, e.g., in dwellingrooms. In the latter case it is very difficult to keep up the necessary concentration, and to have the vapour equally divided through the whole room.

In disinfection with chlorine it is best to employ for every cubic metre of space 25 kilo of chloride of lime $+\cdot 35$ kilo of crude hydrochloric acid. The material is 
divided into portions of at most half a kilo in each vessel, and these vessels are placed at as great a height as possible, and at regular intervals. In order to protect the individual engaged in the experiment care must be taken that the chief mass of the hydrochloric acid does not gain access to the chloride of lime till the room has been closed. In this way 1 per cent. per volume of chlorine is obtained at first, but the proportion very rapidly diminishes. Spores which are exposed on free surfaces are killed pretty certainly, but if they are surrounded by various layers of material the result is doubtful. By this method, however, all sorts of materials are irreparably damaged.

Bromine is best employed in the form of masses of silex, impregnated with definite quantities of bromine, as recommended by Frank. These masses are placed at the highest points of the room to be disinfected. According to Frank, 4 grammes of bromine per cubic metre are sufficient for complete disinfection, if the temperature is kept uniformly at at least $18^{\circ} \mathrm{C}$. According to Fischer and Proskauer, the distribution of the bromine in the room is still more unequal than that of chlorine, and hence the disinfection is correspondingly more uncertain. These experiments were, however, made at a low temperature, and this probably favoured an unequal distribution. Sufficient proof is still wanting that at higher temperatures a really trustworthy disinfection is obtained at all parts of the room. The injury to the materials by bromine is at least as great as by chlorine.

Action of corrosive sublimate.

Corrosive sublimate is, as is evident from the preceding figures, the most active bacterial poison. A solution of 1 to 5,000 kills all spores in the course of some hours; a solution of 1 to 1,000 has the same effect in a few minutes. As such a solution can be scarcely called poisonous to man, it is the best means for the lisinfection of the hands and of numerous articles in common use. It must be noted, however, that in the case of many substrata, for" example albuminous fluids, the action may not occur, because the sublimate is precipitated, and a sufficient quantity does not remain in solu- 
tion; for example, the addition of sublimate to tubercular sputum has proved to be quite insufficient for disinfection. Sublimate has been recommended by König* for the disinfection of dwelling-rooms in the form of vapour, obtained by heating about 60 grammes of sublimate for a room of about 60 cubic metre space. It has, however, been shown by Lübbert, + Heraeus, + and Kreibohm $\$$ that it is only the bacteria which are superficially placed that are reached and killed by the sublimate, while on the other hand the very slightest covering of the objects hinders disinfection.

Carbolic acid is likewise a certain means of disinfec- Action of tion when in strong solution, and when allowed to act carbolic acid. for a considerable time; 5 per cent. watery solutions destroy resistant spores in a few days. Non-sporebearing bacteria are killed by 3 per cent. solutions in a very short time (see the experiments by Gärtner and Schotte, mentioned above). Carbolic acid often acts better than sublimate for the disinfection of albuminous fluids, more especially of fresh tubercular sputum which is disinfected with certainty in twenty-four hours by the addition of an equal quantity of 5 per cent. carbolic acid.

As regards the methods of disinfection which should be employed in practice, see Part VII.

* Centralbl.f. Chirurg., 1855, Nr. 12.

† München ärztl. Intelligenzbl., 1885, Nr. 49.

$\ddagger$ Zeitschr. f. Hyg., vol. i., Part 2.

$\S 1 b i d$. 


\section{APPENDIX.}

CONSTANCY AND MUTABILITY OF THE SPECIES OF FUNGI.

Are there constant morphological and physiocharacters for the various species of bacteria?

Behaviour of higher organisms.

Special importance has recently been attached to the question whether the species and varieties of the lower fungi, which have as yet been looked on as distinct, are really of constantly distinct form and possess constant physiological characters, or whether the morphological and biological characteristics which are employed for distinguishing the species are varying and inconstant attributes, which readily undergo permanent alteration under the influence of the external conditions of existence.

For the solution of this question we may possibly obtain information from comparison with the higher plants, which form useful analogies as regards the constancy or variability of species and their characteristics. We cannot, however, come to a true decision by such comparison : this can only be arrived at by direct investigation.

As a matter of fact, it has long been known that a number of morphological and biological alterations can be observed in all plants. In the first place, certain alterations are constantly seen in all normal plants of the same species; these belong to the characteristics of the species, and only complete its special characters. To this class of alterations belong those which the plants show at various stages of their growth and development; further, the alternation of generation of the fungi, with its enormous differences in form and physiological chaDifferences in racters. Where the developmental cycle of a species the phases of development.

has not yet been completely ascertained, it may readily happen that various developmental forms of the same species may for a time be looked on as independent 
species, till more accurate knowledge of the relations between them has been obtained.

Further, some plants show differences in their behaviour at times, which may be designated as modifications, and usually as abnormalities of lesser or greater degree. These changes are set up by some unusual external influence; injuries and mechanical insults, abnormal nutriment, unfavourable situation, and many other causes act in this way, either singly or together. The conse- Nonquences are degenerative and involution changes of the hereditary most various kinds visible to the eye, and abnormalities in their physiological behaviour. The variations in the percentage of ash in the plants, the ofttimes enormous accumulation of silicic acid, the pallor of plants when the nutriment is free from iron, the accumulation of amides in starving flowering plants, the paler colours of many flowers, and so on, are alterations of this kind set up by external conditions. But it is characteristic with regard to these alterations that they are inconstant and non-hereditary attributes of the plants; they only last so long as the external conditions which produce them are in action, and they disappear after a few generations if completely normal conditions have been present. These modifications are thus so variable that they cannot serve for the formation of new species, for which, ou the contrary, constant characters, which are transmissible through a long series of generations, are necessary.

In the third place, however, it must be admitted that the characters of the species which appear to us as constant may undergo a change after the lapse of a considerable period of time. Among many similar plants exposed to the same external conditions some individuals at times show slight differences; the subsequent generations of these plants retain these differences; after a considerable time fresh differences may be observed among some of the descendants, and in this way we have a gradual formation of new varieties and species. This ultimate result is attained either when the varia- Mode of origin tions are of such a kind that the plants affected by them of hereditaiy grow more strongly and more quickly under the ordinary 
external conditions than the other more normal examples, or when the cultivator intentionally selects the individuals which show a certain kind of abnormality, and only employs these for further cultivation.

In this way, Darwin's hypothesis seeks to explain the origin of varieties, species, and genera. But it is important and necessary for the definition of a well-marked species that the new properties should be relatively constant, and not undergo alteration, under the influence of

The varieties are not produced by external con. ditions.
Conclusions from analogy applied to th? lower fungi. varying external conditions. As a matter of fact it seems to be impossible, by selecting the external conditions, to produce other species at will; in experiments performed with this aim the plants always remain the same, they at most undergo modifications and degenerate, but they do not acquire any constant and hereditary abnormalities, provided that there is no tendency to abnormal growth in the plants themselves. The origin of all varieties may be referred to a tendency in the plants towards variation which is peculiar to them and cannot as yet be explained. This tendency is of very varying intensity according to the species of plant; some form varieties extremely readily, others extremely seldom, and the variations occur quite as well when the plants are all kept under conditions which are as much as possible the same as when they are subjected to different influences. It is only the vital power and the power of development of the varying plants that depends on the sum total of the external conditions.-Of the most marked influence on the tendency to variation is the sexual union of different individuals; where such a union occurs rariations are usually formed very plentifully. But even without sexual processes the tendency of many plants to form new varieties is very great.

If now we attempt, from these views as to the origin and characteristics of the species of the higher plants, which have been put forward more especially by Nägeli, to obtain a standpoint to explain corresponding variations in the lower fungi, we must assume that in these the formation of modifications, varieties, and species must as a whole occur in a similar manner. Certain altera- 
tions in form can only be looked on as stages in the development of the same species, and belong within the boundaries of the species ; further, temporary modifications will arise under the action of definite external influences; finally, varieties and new species with constant hereditary characteristics may be formed from existing species. To what extent the formation of varieties occurs will probably depend on the tendency of the lower fungi to undergo variation; whether this is great or small can only be decided by direct observations. As in the case of the lower fungi, and more especially in the bacteria, sexual processes are absent, and thus one of the most important factors in the formation of varieties is wanting, we must a priori expect a greater constancy in the species, and a slower variation. On the other hand, the rapid growth and the quick succession of new generations can lead to more rapid occurrence of variations than in the higher plants, and to their formation within measurable periods of time, and, as it were, before our eyes. Nevertheless, it is a question how we should define the individual generations of the fungi. Is every bacteric cell to be regarded as an individual, and does each individual colony represent an innumerable number of generations, or are the cells of such a colony analogous to those of higher plants, and is it only when fructification and spore formation occurs that a new generation is formed?

We thus obtain only a number of open questions, and Results of arrive at the conviction that from the analogy with the direct obserhigher plants we cannot gain any definite conclusions as to the behaviour of the lower fungi ; hence it is only by actual observations and experiments that we can hope for a definite result.

In so far as observations have gone, we have in the 1. Morphofirst place observed all sorts of morphological differences $\underset{\text { ences. }}{\text { logical differ- }}$ in the lower fungi. Some of these differences undoubtedly belong to those which only help to characterise the species. In this sense the processes of growth and development occasion certain alterations in form which are always the same in the same species. We observe 
that from the most simple spore-cells rods and threads proceed, and that spores again form in these threads;

Stages of development. we observe, further, in the mould fungi, such as aspergillus or penicillium, a transition into a completely different form of fructification -we see the ordinary yeast pass into spore-bearing cells of a totally different form. External influences often lead to the formation of the one or the other form of development; but under these circumstances there always arise only the definite forms which are characteristic of the species, and not all sorts of variations differing according to the external conditions which have been at work. According to Zopf's views there is in the case of many bacteria a particularly wide cycle of regetative forms ; but in spite of all these differences in form definite species can nevertheless be made. We have only, in this respect, to learn all the stages of development, and to arrange them among the characteristics of the species.

Degenerative conditions and modifications according to nutriment.
In the second place, in the lower fungi modifications of form also occur under the influence of external agencies. To a certain degree the nutrient conditions, for example, can influence the form in a similar manner as in the case of higher beings. Slight increase or diminution in length and thickness, a more marked swelling of the cells and threads, is not uncommonly observed (Buchner); and according to the external conditions of existence, now the one, now the other stage of development may be most prominent, and may be observed in a particularly complete form. But on more careful examination we can ascertain that these variations scarcely erer go far enough to alter the types of form which are looked on as characteristic of the individual species. The relation of the length of the rod-shaped bacteria to the breadth, the form of the ends of the rods, the character of the thread form, the mode in which the individuals are grouped together, remain, as a whole, untouched by such variations. Under the practically abnormal external conditions more marked alterations in form, and the production of pathological and involution forms, often occur. These variations in form render it difficult to 
differentiate the bacteria on the basis of their morphological characters, more especially as in the case of the bacteria we have to deal with extremely slight and delicate differences in form; and hence we must give up the former classifications based essentially on such differences. But as a matter of fact these various alterations in form do not lead to the disappearance of the species, but only serve, by the use of more complete means of observation, for a more accurate differentiation of the individual species.

After the lapse of long periods of time it is probable True varieties that a third kind of morphological alteration may occur in the lower fungi, and lead to the formation of varieties and new species; these alterations, however, appear as a rule to occur in a similarly slow and inappreciable manner as in the higher plants. Very distinct evidence has recently been produced which shows that the form of certain bacteria has undergone extraordinarily little variation even in the course of hundreds and thousands of years. In thin sections of the petrified roots of conifers from the coal period, van Tieghem* was able to demonstrate the characteristic butyric acid bacillus; and Zopf and Miller + found in the tartar on the teeth of Egyptian mummies the same forms of bacteria which can at the present time be demonstrated as the ordinary inhabitants of the mouth. These examples, however, are only of value for the species in question, and we cannot without further information draw the conclusion that all fungi have a similarly slight tendency to undergo variation.

Nägeli, Buchner, Wernich, and others have formerly Differenees in asserted that under the influence of external conditions a the views as very marked variation in form occurs, and that one species ability of can be converted by variations in the conditions of its form. existence into another species, characterised by other morphological characters and other modes of growth (thus the anthrax bacilli were converted into a so-called transition form, and then into true hay bacilli, see p. 241).-The 
more, however, the methods of pure cultivation have been perfected, the more has the conviction gained ground that such variations in their characters probably occurs to as slight an extent in the case of the bacteria as in that of higher organisms, and that the former observations on which these statements were founded were not made by methods which were free from objection. Buchner himself has in his more recent investigations pointed out numerous specific morphological characters. It is no doubt not impossible that many of the species which have as yet been looked on as definite forms from examination by incomplete means, and at an early period of our knowledge, may, when the modes of investigation have become more perfect, be recognised as related to each other, and that thus from two species which have as yet been looked on as morphologically distinct we may have to form a single species with a somewhat great variability in vegetative form. But as yet no facts of this kind have been demonstrated, and if they should be demonstrated in any individual case they would not afford any ground for doubting the value of the morphological characters in distinguishing the species of other bacteria.*

2. Physiological differences.

In view of the difficulty of the morphological distinction of species, we must, as has already been mentioned above, in many cases employ marked and specific physiological characters as means of diagnosis and of classification. The characters so employed must naturally be constant and hereditary; it is only then

* Buchner has recently (Arch. f. Hyg., vol. iii., p. 380) implied that I confound variability in vegetative form with that of species, and that I fight against the former, while in reality I mean the latter. But from various portions of my criticisms of Zopf's hypothesis, as well as in the first edition of this book, it is very evident that I am by no means guilty of any such mistake. As a proof I cite the following passage from p. 276 of the first edition of this work:-

"In spite of the view that cocci, bacteria, bacilli, spirilla, only represent developmental forms which readily pass into each other, it might nevertheless be still possible to form distinct morphologically characterised species. We observe in the cocci, bacilli, and spirilla, many other peculiarities of form which might serve to characterise a species, and if the chief weight were laid on these peculiarities we would obtain a classification founded on morphological characters, and could ultimately attempt to make a diagnosis of the species according to the external form, even though the same fungus occurred in a coccal, bacteric, or spirillar form."

According to the view which Buchner and Wernich support, such a differentiation of constant forms would not, however, be trustworthy ; these morphological characters would, as a rule, only be the product of the external conditions of life. 
that they can be of use for the formation of distinct varieties. Characters which readily undergo alteration under the influence of all sorts of external conditions, which are readily lost and acquired, are as little suitable for characterising varieties as varying differences in form.

As a matter of fact we have, in the production of ferments, in the formation of pigment, in the setting up of fermentation and disease, and in the whole mode in which the rutrient substrata are assimilated and broken up by the bacteria, such hereditary and characteristic physiological attributes of the species of bacteria.

It has been already mentioned above (p. 563) that Variability the sum total of the external conditions of existence exerts a very marked influence on the quality of the products of tissue change, and that by abnormal external of varying external conditions. conditions every individual phase of the characteristic vital phenomena may be abolished; but, nevertheless, these variations in physiological characters follow definite lines and do not go beyond the characters of the species in question. In correspondence with this fact those vital phenomena which are constant under certain nutrient conditions can be very readily employed as means of distinction; and the loss of the individual characters as the result of definite external conditions only serves as a means of increasing the number of characteristics of the species.

Further, as in the case of other organisms, so also Alteration by probably in the case of bacteria, they may become accli- acclimatisamatised to abnormal conditions of existence; for example, to an excess of salts, to a different reaction of the nutrient medium, to temperature, \&c. It is conceivable that the same abnormal conditions when suddenly employed cause cessation of development, while when gradually introduced they still permit the exercise of the vital functions. More accurate facts, however, are still wanting as to the behaviour of bacteria under such conditions, but it is a priori probable, from what we know of the behaviour of the higher organisms, that even under 
suitable acclimatisation of bacteria the result will be not a loss or diminution, but a multiplication of their specific characters, and that the properties thus acquired will again be lost after a few generations when the abnormal external conditions are replaced by normal ones.

Nägeli's views as to the mutability of the bacteria.
Nägeli, Buchner, Wernich, and others have formerly assumed the existence of a very rapid and limitless alteration of the characters of species of bacteria which had up to that time been distinguished from each other. "According to my view each of the species of bacteria could occasion the formation of lactic acid, putrefaction, and various forms of disease. Each species has the power of accommodating itself to unequal external conditions, and consequently of appearing in various forms morphologically and physiologically peculiar. The adaptation or acclimatisation may be more or less complete and more or less permanent, according to the time and the other factors which are at work. . . . Thus forms of an unequal degree of development and of unequal constancy would be produced in accordance with the various external conditions. The same bacterium would at one time live in milk and form lactic acid; at another on meat and cause putrefaction; again in wine, and lead to the formation of a gummy substance; subsequently in the earth without setting up any fermentation; and finally in the human body, and take part in some form of disease. . . . It would on a soil which was equally disposed for various fermentations occasion those changes which most correspond to the physiological stage at which it has arrived by its previous mode of life. Bacteria which frequently change their habitat would of course retain an indefinite character, and be equally well disposed to assume different forms and to excite different fermentations" (Nägeli*).

Nägeli and Buchner found an experimental support for these views in the observation that baeteria which caused milk to become sour lost this property in a saccharine solution of meat extract, and caused there an ammoniacal fermentation, and it was only after a hundred or more generations in milk that the property of forming acid slowly recurred.

Hueppe, however, tested this question accurately, and was unable to make out any such variability in the behaviour of the lactic acid bacilli, but he showed that an ammoniacal fermentation could be caused in the milk by butyric acid bacilli, which, in the form of resistant spores, could readily

* Nügeli die niederen Pilze, München, 1877, p. 22. 
remain unnoticed in a living condition in milk which had been insufficiently sterilised; and thus he showed that it was probable that in these experiments we did not have to do with variation in the characters of the same species, but with the effect of different species of bacteria.

The more the methods of pure cultivation of bacteria have been improved, and the more complete our knowledge as to the biology of the bacteria has become, so much the more certainly do all other experiments lead us to the conviction that the specific vital characters of the lower fungi can be retained in a similar manner as in the higher organisms, and are not subject to any extensive variation.-Even Buchner in his more recent investigations recognises the physiological attributes of the bacteria as sufficiently constant to enable him to base on them a distinction between the individual species.

It is true that during a long period of time, just Formation of as in the case of the higher plants, a real formation of varieties may occur in the lower fungi, the physiological characters being chiefly affected. This variation does not, however, arise as the direct result of definite external conditions, but is due originally to a certain tendency to variation which often only leads to an ephemeral existence of the somewhat abnormal examples, and thus to no important consequences; at times, however, when by chance the external conditions are such that these abnormal examples are, as the result of the abnormality in their physiological characters, especially able to grow concurrently with other organisms, and are not weaker than individuals which have not these properties, we may have a continuation of these abnormalities through a series of generations, and thus the formation of a new variety. In many of the lower fungi, however, the tendency to this form of variation is extremely slight; more especially we must accept it as undoubted with regard to most of the exciting agents of fermentation that they have retained the same physiological characters and the same mode of breaking up the fermenting materials for thousands of years.

In one respect, it is true, a character of the bacteria has been observed which does not apparently follow the 
The loss of the power of bacteria to excite disease and fermentation.

It would be necessary to regard attenuation as a degenerative process if it were not hereditary. laws which have been made out with regard to the higher organisms. The power possessed by many bacteria of multiplying in the body of living warm-blooded animals, as well as the property of others of exciting fermentation in suitable substrata, have, as has been above mentioned (p. 656), proved extremely labile in many species of bacteria, and can be destroyed by numerous influences, such as high temperatures, chemical poisons, \&c., which cause degeneration of the organisms. Indeed, the repeated passage of certain parasitic bacteria through more or less suitable hosts appears, according to Pasteur's experiments, to lead to increase or diminution in their virulence, ${ }^{*}$ and in the case of glanders, for example, a cultivation for a certain length of time on potatoes, which is otherwise the most suitable dead nutrient material for their growth, suffices to lead to complete disappearance of their virulence (Loeffler).

This "attenuation" of the lower fungi would not be of much importance if we had only to do with a degenerative process which had arisen under the influence of the abnormal conditions of life employed, and which was only retained so long as these conditions acted, and was not hereditary through a long series of generations under normal conditions, but was rapidly lost.

* A similar alteration of pathogenic properties of the lower organisms was formerly stated to occur by Davaine as the result of his experi. ments on progressive virulence. Davaine thought that he had observed that the virulence of septicæmia bacilli constantly increases the oftener they are inoculated from one animal to another; thus, while of an infective fluid found accidentally several drops are necessary to insure infection in the first instance, yet, when it has been inoculated from animal to animal for a considerable time it is ultimately found that the minutest fraction of a drop is sufficient to cause the fatal disease. Koch and Gaffky (Mittheil. a. d. Kais. Ges. Amt., vol i.) were able to demonstrate that in the case of several bacteria which occasioned septicæmia no such progressive increase in virulence existed; that it was only necessary to employ larger doses at first, when the material used for inoculation was very impuro and only contained a few of the pathogenic organisms; that, on the other hand, when the material was pure the same dilution was as active at the commencement of the series of experiments as at the end. More recent experiments of Pasteur as regards swine erysipelas, hydrophobia, \&c., point, however, to the fact that some species of bacteria undergo marked alterations in virulence as the result of their passage through the bodies of certain warmblooded animals. 
In this case the attenuation would be analogous to the numerous degenerative processes which have been observed in higher organisms; the diminution in the amount of quinine in the species of cinchona, the loss of the production of conium in hemlock when the plants are cultivated in unsuitable soil, the diminution in the amount of chlorophyll, or the imperfect and slower growth of the various organisms under unfavourable external conditions, would then furnish analogous examples.

But it is remarkable that the attenuated condition of An attenuated pathogenic and fermentative bacteria cannot as a matter condition is, of fact be removed, as in the case of these degenerated transmissible plants, by subsequent cultivation under normal condi- generations. tions. On the contrary, undoubted facts have been made out which show that this attenuated condition can last for a long time, and through a long series of generations, more especially when it was set up by milder means, employed for a long time.

Thus in the case of many bacteria a character has been made out which must be regarded as a biological curiosity, and which does not in any way harmonise with the other biological characters of the bacteria. For Thus a on the whole we undoubtedly observe, as has been stated above, a constancy in the hereditary properties of the bacteria similar to that of the higher plants, and even the virulence of the parasitic bacteria appears to correspond in its laws with those of the other characters, in that of the that in spite of numerous variations in the cultivation, no isms. alteration occurs, or only appears under certain abnormal conditions, and then affects the one generation alone.

There can, however, be no longer any doubt as to the remarkable fact of the artificial development of a hereditary attenuated condition in some bacteria, and as the result of this most recent development of our knowledge, we must come to the conclusion that we ought to be extremely cautious in our judgment when we attempt to apply laws which concern other organisms to bacteria, or when we would draw general conclusions with regard to bacteria from single observations. 
More than in any other scientific department is it necessary to limit our judgment in the case of the lower fungi to the particular species in question, and we are just as little justified in declaring that a hereditary attenuated condition of the bacteria is impossible, as the result of theoretical considerations, as we would be in deducing from a few instances in which such attenuation has been proved that there is an extensive alteration of virulence as the result of other influences, and in the case of other species of bacteria, which have not been tested, or that there is a similar variable condition of all the other properties of the bacteria. 


\section{PART VI.}

\section{DISTRIBUTION AND HABITAT OF THE BACTERIA.}

NuMERous forms of bacteria grow in the most various General surroundings of mankind, whenever they meet with of the sufficient moisture, nutritive material, and a temperature bacteria. of at least $6^{\circ}$ to $10^{\circ} \mathrm{C}$, and they multiply the more quickly the nearer the temperature approaches the arerage optimum of $20^{\circ}$ to $30^{\circ} \mathrm{C}$., and the better and more plentiful the nutritive material. Wherever dead organic materials, excreta of man and animals, dead bodies, dead plants, household refuse, \&c., accumulate on the surface of the ground, in stagnant or running water, or within dwelling-houses, in the presence of sufficient moisture and temperature, bacterial growth occurs, and ultimately occasions the complete destruction of these materials, the place of which is taken by an enormous number of newly-formed individuals.

In view of the distribution, the enormous capacity for multiplication, and the relatively great resisting power of the bacteria, one involuntarily inquires as to the means which come into play in nature in order to destroy the masses of bacteria which are being constantly formed, and to provide against their accumulation in too great numbers. The cold of winter is not the active agent, for, as is well known, it only occasions an arrest of development, and appears to preserve all the bacteria in a living state. The natural means of disinfection is in The natural the first place drying of the bacteria; then exhaustion of means of the nutritive substrata; at times also high temperatures, more especially on the surface of the soil from the solar heat. These various agents in truth only kill the less resistant vegetative forms, while the majority of the permanent forms retain their vitality in a dry state, and 
also in solutions in which the nutriment is exhausted, and at the highest temperature reached by insolation at the surface of the soil.

Nevertheless, the effect of these means may be great, and indeed sufficient for the purpose, because opportunities for the sprouting of the spores often present themselves in nature, and they thus assume a vulnerable form; and hence it is chiefly by a constant variation between good nutritive conditions on the one hand, and the absence of water and nutritive materials on the other, that destruction of the various kinds of bacteria and regulation of the bacterial life are brought about.

Fate of parasitic bacteria.

In the case of those forms of bacteria which excite our special interest by the fact that they can at times develop in the bodies of the higher living animals, their continued existence in our natural surroundings is rendered more especially difficult, because they are for the most part very particular as to the quality of their nutriment, reguire a farourable temperature, and are often extremely sensitive to alterations in the nutritive substrata, and to the amount of water present. Further, all the facultative parasites are very readily overgrown by saprophytes, which grow much more quickly under the conditions of life present in our surroundings; the latter therefore withdraw from the former the necessary nutritive materials and also injure them by the products of their tissue change. If, therefore, it is necessary for infective agents to grow for a considerable time under the ordinary conditions, they must evidently have the opportunity of growing in a sort of pure cultivation; and such an exclusive occupation of the substratum by pathogenic bacteria sometimes occurs on semi-solid nutritive materials, on floating portions of vegetable or animal tissue, \&c.-In fact the preservation of facultative and obligatory parasites which have grown in this way outside the human body, or which have grown in the human body, and passed from it into the surrounding world, is a matter of considerable difficulty. They are most easily preserved when spore forms are present, which can persist unaltered for a long time in a dry condition, or in 
exhausted nutrient material. Where spore forms are absent, preservation can possibly still occur if the existing conditions are such that the sensitive parasitic bacteria are not destroyed or overgrown by saprophytes. Conditions of this kind are furnished, for example, where the temperature is under $+5^{\circ} \mathrm{C}$.; and also (as will be described more fully afterwards) in porous and moderately moist soil.

For the distribution of bacterial life on the surface of T'ransport of the soil, it is also of importance that they should not be restricted to the original place where they developed, but should be transported over greater or less distances. Currents of air and flowing water are the most important means of transport; to a less extent, but in a great variety of ways, they may also be carried by animals and by the trade and intercommunication of mankind.

When we examine our various surroundings as to the Occurrence presence of bacteria, we find them, in the first place, in and behaviour the air in very varying numbers. By the methods as the air. yet employed for these investigations, from 100 to 500 living bacteria have been found in every cubic metre of the layers of the air which lie immediately above the ground; in the air of dwelling-rooms they have been found in very small numbers when all movement of the air has been as much avoided as possible for some time, while they are present in large numbers when the dust has been raised by movements and other disturbances. Direct microscopical examination of the collected air germs, as well as the experiments on filtration of the air (Hesse), have shown that the micro-organisms floating in the air do not occur as isolated individuals, but that numerous individuals of the same kind are as a rule united together in chains and groups, or adhere to coarse particles and visible pieces of dust.

The origin of the air germs must almost always be Origin of air sought in the bacterial colonies on the surface of the ${ }^{\text {germs. }}$ earth, for there is not sufficient moisture to permit 
Only

thoroughly dry bacteria pass into the air.

Difference in weight of air germs. multiplication during their transport through the air. Further, bacteria as a rule only pass into the air from bacterial colonies which are thoroughly dry and are broken into fragments by external force. Nägeli has shown that even strong currents of air are unable to detach bacteria from moist surfaces; it is only when there is at the same time a spurting up of the fluid by waves, or by violent agitation (mill wheels, washing, \&c.), or by the formation of bubbles, that particles of water, and with them bacteria, can be carried by currents of air over short distances. Even when a colony of bacteria dries up it cannot at once become loose, so that portions could pass into the air ; on the contrary, the dried bacteria generally adhere very firmly to the substance beneath, and it is only by breakage due to external violence, or to the effect of temperature, that small light particles are loosened and can be carried away by currents of air.

Former observers had, it is true, at times obtained evidence of detachment of bacteria by feeble currents of air, and even from moist surfaces, but those experiments were not made with pure cultivations of bacteria, nor by the help of solid nutrient substrata, and hence bacteria entering through insufficient joints might easily cause deception and lead to the idea that they had become detached from the surfaces of the fluids investigated. At the present time the experiments can be readily repeated with completely uniform results if we work with pure cultivations of the rarer forms of bacteria and are thus able to distinguish organisms which have come accidentally from without, from those which were present on the surface of the nutrient substrata.

The bacteria, once they have passed into the air, float or are carried about by currents of air for a varying time. In addition to differences in the strength of the currents, the size and weight of the floating particles is of especial influence in this respect. Gross particles of dust, such as one sees with the naked eye by any mode of illumination, soon fall in quiescent air along with the bacteria adhering to them; the smaller or so-called solar specks float more easily, and are carried about by slight currents. Finally, the minute collections of bacteria or individual bacteria which are never visible to the naked 
eye, and of which the weight represents the billionth of a gramme or less, do not become deposited to any great extent even in quiescent air. We must also suppose that these minute bodies are surrounded by a condensed coating of air consisting chiefly of the vapour of water, and forming as it were a parachute and mantle which renders floating easier (Nïgeli).

From these observations and considerations we at Local differonce arrive at some laws as to the local and seasonal ences in the distribution of bacteria in the air. Everywhere where germs. there is a plentiful development of bacteria on the surface of the soil, and where complete dessication of superficial colonies takes place, there will be a considerable number of bacteria in the air. Where there is no opportunity for the growth of bacteria (in deserts, on high mountains, \&o.), or where the surface is always moist (over the sea), the air will be almost or entirely free from bacteria. Nothing certain is known as to the distances to which dry but living bacteria can be carried by the wind; from the extraordinary distances over which other particles of dust can be carried, we may conclude that when opportunity offers the bacteria may be carried over very considerable areas. This circumstance naturally tends to destroy to a considerable extent local differences in the amount of bacteria in the air; nevertheless, by far the greater number of the air germs will always originate from local sources.

It cannot be decided, and it is also of subordinate importance, whether the few bacteria which have been found on high mountains have their origin in winds or in the body, the clothes and utensils of the observers, or in insignificant local sources; and of equally slight importance is the hunt for bacteria in the air of the highest mountains and on the most distant seas, which has been carried on for the last few years, has been entirely wanting in proper aim and has more reference to the sensational public than to scientific interest.

Variations at different times in the number of air variations at germs are, apart from the varying quantity of available different timcs bacterial colonies, dependent in the first place upon the germs. conditions which favour the passage of new bacteria 
Influence of dry winds.

Effect of the distribution of the germs over a great extent of air.

Deposit of air germs by the condensation of water vapour.

into the air; and in the securd place upon the factors which influence the deposit of floating germs from the air. Dry winds more especially lead to an increase in the number of bacteria in the air. Even when the deficiency of moisture in the air is not great, and when the air is moist, drying of the most superficial layers may occur at the exposed parts of the surface of the earth, and dust may be carried into the air along with a certain number of bacteria; great drought lasting for some time (as in the case of the east winds in our neighbourhood) leads, however, to a much greater degree of drying ; every corner of the streets, courts, and houses, the deeper layers of the soil, \&c., gradually become dry, and many more, and also greater varieties of, bacteria,-ultimately also pathogenic bacteria,- pass into the air in these places.

In spite of this markedly favourable influence of dry winds in increasing the number and kinds of air germs, it is nevertheless possible that a cubic metre of the air in our neighbourhood may scarcely show more germs than in still, damp weather. For the dry winds will possibly distribute the germs which are taken up over a much greater area, and more especially carry them to a considerable altitude. A greater amount of water in the atmosphere, on the contrary, more especially, however, the occurrence of descending currents of moist air, and in particular a great condensation of water vapour, must lead to sinking of the particles of dust, and thus occasion, in the first place, an increase in the number of germs in the layers of air close to the surface of the earth, until continued condensation and rains have eventually brought back the greater number of the bacteria to the soil.- In the investigations made up to the present time, but little attention has been paid to these conditions affecting the distribution of the germs in the air, and especially to the possibility of their deposition by condensation of water vapour, although it is probable that a more intimate knowledge of the mode of distribution of the air germs will give us enlightenment as to the mode in which many infections (e.g., malaria) occur.

Over estima. On the whole too great a rôle was formerly ascribed to
tion of the 
the air in the spread of saprophytic and infective germs. danger of air By the experience obtained in bacteriological work and in surgical practice, it has become evident that bacteria but seldom enter nutrient substrata from quiescent air, that even a simple cover which keeps off the vertically falling particles of dust forms even in impure air an extremely efficient protection, and that the entrance of bacteria occurs far more frequently from unclean objects, unintentional contaminations, \&c., than from air germs. On the other hand, dusty air in active movement offers an excellent opportunity for the spread of bacteria; and it is remarkable in what numbers they may be deposited on a cool object-on nutrient materials, \&c., placed in ice-along with the water vapour condensed at the same time. But even then the pathogenic bacteria form only a minute fraction as compared with the saprophytes. In fact in the open air the dilution of the pathogenic germs soon becomes so very great that a direct infection is a rare occurrence; it is only from the air within dwellings and in the neighbourhood of the sick that infection occurs at all frequently.

Neither the points of view nor the methods for the in-Defects in the vestigation of the air are at the present time so precise that investigations it is possible to make definite statements as to the local on air germs. and seasonal differences in the number of the air germs, or that well-founded conclusions can be drawn as to the part played by the air in the spread of one or other of the infective diseases. Miquel's attempts to draw a parallel between the results which he has obtained in his air investigations, and the mortality from the various infective diseases, are at least premature, and only show how long-suffering the statistical method is, and how easily it can be misused in order to prove a deceptive causal connection.

The distribution and behaviour of bacteria in the soil Occurrence is of very special hygienic interest, because for a long of bacteria in time, and especially since Pettenkofer's convincing de- the soil. ductions, the soil has been regarded as a very important 
factor in the occurrence of epidemic diseases. The connection proved by statistics to exist between the variations in the mortality from typhoid fever in Munich and the variations in the level of the ground water furnished the chief argument for the view that something took place in the soil which exercised an important influence on Pettenkofer's the spread of a number of infective diseases. The views as to the relation between the soil and infec. tive bacteria. interesting results of that statistical observation leave it however, in the first place, doubtful whether the alteration in the soil, as shown by variations in the ground water, exercise any influence on the development of the infective germs; or whether it is only of special importance for the transport of the germs present in soil to man; or whether, in the third place, there is a direct connection between the conditions of the soil and the infective germs, or an indirect one in this way, that the apparently predisposing condition of the soil and the spread of the epidemics must be referred to a third causal factor common to both.-Further, the question arises, supposing that the soil exerts some direct influence on one or several of the infective agents, whether this influence must be regarded as absolutely necessary for the epidemic spread of the diseases in question, so that a necessary and specific rôle must be assigned to the soil; or whether the spread of the same disease may not frequently occur in other ways without any connection with the soil?

The decision of these questions is evidently only possible when we obtain a more accurate knowledge of the pathogenic agents, of their vital characters, and of their mode of spread; before we possessed any knowledge of this kind we could only form hypotheses as to the more intimate connection between the soil and infective diseases.

View as to a specific influence of the soil on the development and spread of the infective grerms.
Pettenkofer and his followers formerly sought to show that it was probable that the soil exercised a peculiar and definite influence on the development of the infective germs as well as on their transport to man; a porous soil infiltrated with waste organic materials and moistened from time to time was supposed to be indispensable for the development, and, so to speak, ripening of the 
infective agents; and the same soil was supposed, perhaps at a definite stage of dryness, to enable the infective germs to be transported by currents of air.

This view was undoubtedly completely justified by the state of our knowledge at that time as to the nature of the pathogenic agents. But since we are now able to set on foot direct observation and experimental investigations as to the mode of development and the conditions of existence of the infective agents, we must subject our former views as to the occurrence of infective diseases, and more especially as to the influence of the soil on the pathogenic bacteria, to revision and criticism. In fact as to the behaviour of bacteria in the various media in our surroundings many thorough investigations are necessary, and we are far from seeing clearly the relations between the soil and the pathogenic bacteria. But in many directions the more recent bacteriological investigations have given us valuable facts which compel us to alter our former views.

If we shortly summarise what we have learned during Results of the last few years by direct observation and experiment as to the general behaviour of the most various kinds of bacteria in the soil, we obtain in the first place the unanimous result that, as a matter of fact, the bacterial life in the soil is extremely active, that the soil is evidently the chief reservoir for bacteria, into which the greatest part of all fluids containing bacteria, almost all refuse water, excreta, \&c., pass, and on the surface of which the germs which have passed into the air are again in great part deposited. Enormous numbers of bacteria have always been found in the soil by the most various observers. Infusions made from manured field and garden earth, even though Richness of the earth in various kinddiluted 100 times, still contain thousands of bacteria in every drop, and the ordinary soil of streets and courts also shows the presence of large numbers. Bacilli are present in much the largest numbers; but in the most superficial layers and in moist ground there are also numerous forms of micrococci. Some species are markedly prominent, and are found in the most varied places and at the most various times in the soil, while they occur in other 
Pathogenic bacteria in the soil.

substrata much less commonly; such are, for example, the bac. mycoïdes (p. 403), and some other forms which have not as yet been more minutely described. Various kinds of bacilli must also be very often present in the soil in the form of resting spores, as can be concluded with certainty from disinfection experiments:

Pathogenic forms are also not uncommonly found. Well-known inhabitants of the soil are the bacilli of malignant cdema, of infective tetanus, the bac. septicus agrigenus, \&c., which are commonly and almost exclusively found in garden or field earth. Pathogenic bacteria occur with such frequency in the soil that no material found in nature so easily produces infection as earth. If mice, guinea-pigs, or rabbits are inoculated with a quantity (not too small) of earth from the surface of the ground a much higher percentage of cases of disease is obtained than when the inoculation is made with some fluid containing bacteria. If large quantities of the latter are injected a large number, or it may be all of the animals die of ptomaine poisoning; but an Frequency of infective disease only results in rare cases. We have an infective action of the soil. also reason to assume that the infective diseases caused by the soil would be more numerous, and would lead to the isolation of other species of pathogenic fungi, were it not that these œdema and tetanus bacilli are so widely distributed that they obscure the other infective agents and cause the death of the animal before other more slowly growing bacteria have had time to multiply.This marked infective property of the soil must evidently make us a priori inclined to accept the view that the soil is of special importance in the occurrence of human infective diseases.

Vital powers of the bacteria of the soil.
We have also obtained some information as to certain effects produced by the bacteria on the soil. Thus Schlösing and Müntz, and at a later period Warington, showed that the formation of nitric acid from the ammonia of organic substances is chiefly caused by lowly organisms ; when soil has been heated or treated with disinfecting means it loses almost entirely this power, which is otherwise constantly observed. In like manner Wollny and Fodor 
were able to show that the formation of carbonic acid in the soil was entirely the result of the life of lower organ- nitric acid and isms. Further, Gayon and Dupetit, as well as Déhérain and Maquenne, have furnished proof that when oxygen is deficient a reduction of the nitrates to nitrites, ammonia and nitrogen can be brought about by the bacteria of the soil. According to investigations made by Reducing Heraeus (Zeitschrift f. Hyg., vol. i.), many forms of bacprocesses. teria (such as bac. prodigiosus, cheese spirilla, Finkler's spirilla, typhoid bacilli, anthrax bacilli, staphylococci) are able to oxidise ammonia to nitric acid; while other species (for example, two kinds of bacilli cultivated from water) cause the reduction of the nitrates in a marked manner. Schlösing and Müntz held that nitrification was Nitrification caused exclusively by one species of bacteria which was is not caused isolated by them from the soil; but their description of the the bacteria of bacteria does not at all indicate that they worked with a really pure cultivation, and the investigations of Heraeus compel us to adopt the view that a large number of bacteria are capable of causing nitrification either by simple assimilation and oxidation, or by a sort of fermentation. In soil the conditions are especially favour- But the most able for some of these bacteria which act by oxidation conditions for because concentrated solutions and large quantities of are presented organic material further the multiplication of the re- by the soil. ducing bacteria, while in more dilute nutrient substrata, which is usually the condition even of unclean soil, the oxidising bacteria gain the upper hand. Hence in by far the greatest number of cases we observe oxidation processes in the soil, which on account of the marked subdivision of the material in thin layers, the intimate contact of air, and the simultaneous surface attraction of the soil, lead to an extremely rapid and complete destruction of organic material.-As to the individual phases of the decomposition of the soil, and as to the various influences which act on it, we must await the results of continued investigation with pure cultivations of bacteria from the soil under various conditions.

We also possess some observations, although on the Transport of whole unsatisfactory ones, as to the distribution and bacteria within the soil. 
transport of bacteria in the soil. The bacteria in the first place generally reach the most superficial layers with refuse fluids, from the air, \&c. ; and hence in these layers we find by far the greatest number of bacteria. Many bacteria also pass at once from cesspools, \&c., into somewhat deeper layers of the ground, 1-3 metres under the surface, and impregnate these especially strongly in the immediate neighbourhood of the cesspool. The question is whether bacteria can spread from these points over considerable distances of the soil in a horizontal and vertical direction. Currents of water or air suggest themselves as the chief means of transport. The former, when they soak through the soil from the surface as far as the ground water, ultimately carry the bacteria into the deeper layers and into the ground water; or again, where there is great evaporation from the surface, the water rising by capillary action carries bacteria which have collected beneath By downward into the upper layers. But on experimental investigaeurrents of water. tion neither mode of transport has prored to be practicable. Numerous filtration experiments on a large and small scale have shown most distinctly that a layer of earth $\frac{1}{2}$ to 1 metre in thickness is an excellent filter for bacteria, and hence the purification of fluids from bacteria must be still more complete in cultivated and especially in clay soil, and where the fluid moves with extreme slowness. In harmony with this we have the fact, first ascertained by Koch and later on repeated occasions in the author's laboratory, that the deeper layers of soil contain very much fewer or indeed no bacteria in contrast to the superficial layers which are almost always rich in them (apart naturally from soil which has been artificially disturbed). Further, it has been repeatedly observed that wells which are well protected against contamination with bacteria from the surface and from the sides of the well furnish a water almost entirely free from bacteria; that, further, wells of water containing bacteria become the purer the more water is pumped up, and the more ground water comes in from the deeper layers of the soil.-Hence we can only assume 
that bacteria penetrate to a very limited degree into the deeper layers of the soil, more especially as it has been shown from Hofmann's investigations that the passage even of fluids and of substances in solution only takes place with extreme slowness, and usually months and years elapse before the layers in the neighbourhood of the ground water are reached.

That a current of fluid passing upwards by capillary By upward attraction can carry bacteria from the deeper layers of the capillary soil to the more superficial has been recently asserted water. by Soyka* as the result of a series of experiments. Similar experiments, however, when repeated by Pfeiffer + and also in Koch's laboratory, have led to entirely contrary results. However, even if such a transport of bacteria by capillary currents were possible to a slight degree, we could hardly regard this mode of transport for bacteria as of any value under normal conditions, for we have evidence that the deeper layers of the soil are the poorest in bacteria, while the most superficial layers have the largest numbers ; and, further, with regard to man, the capillary current as a means of transport for germs from the soil is scarcely of any importance, because, as we shall see, it is only the composition of the actual surface of the ground which has to be taken into consideration.

Whether currents of air passing through the soil can By currents of carry bacteria along with them was first experimentally air. tested by Nägeli, and then by Renk, Soyka, Pfeiffer, and others; all these observers obtained the uniform result that even strong currents of air were unable to carry a single bacterial germ through a layer of earth a few centimetres in thickness; the layer of earth even in the completely dry state acts perfectly as a filter, and in ordinary soil, which is always slightly moist, and in which the movement of the ground air is very slight, there is so much less possibility of detachment and transport of bacteria.-Lastly, we might also think that By continued bacteria might spread by continued growth. The growth.

* Prager med. Wochenschr., 1885, No. 28.

$\dagger$ Repert. d. anal. Ch., 1886, No. 1.-Zeitschrift f. Hygiene, vol. 1, Part 3. 
Behaviour of the pathogenic bacteria in the soil.

1. Do the pathogenic bacteria mul. tiply in the soil?

encrgetic processes of oxidation in the soil show us that active life, and in correspondence with that, marked multiplication of bacteria, occurs in it; but even were the growth very active, the regetation could only spread extremely slowly over the enormously large surfaces which a porous soil offers, and this mode of spread would not come at all into consideration in the case of pathogenic bacteria.-Finally, transport of bacteria can occur in many instances by all sorts of animals which live and move in the soil, for example, by worms, but this can only take place to a very limited extent. On the whole, then, we must regard the bacteria in the soil as more or less fixed in a particular place, and only altering their position slowly and over short distances.

The results of the recent investigations as to the behaviour of pathogenic bacteria in the soil are thus of great importance. We have to ascertain whether the soil can in reality exert a specific influence on pathogenic bacteria, whether such an influence is shown in favouring the growth and the multiplication of the pathogenic bacteria, or whether it affects their preservation and spore formation, or whether, in the third place, it is only the spread of the infective agents from the soil to man which depends on definite conditions of the soil.

From our present knowledge as to the conditions of life of the pathogenic bacteria, it seems very improbable that they are able to multiply in the soil. The low temperature in the deeper layers is of itself sufficient to prevent entirely the multiplication of this class of bacteria. In those upper layers, which always or at times show a temperature of at least $16^{\circ} \mathrm{C}$., growth of pathogenic bacteria could occur if suitable nutritive substances were present, if there were nothing to hinder the development, and if none of the more rapidly growing saprophytes were present. These conditions, however, are almost never fulfilled under ordinary circum-

Unfarourable stances. Numerous experiments by Bolton, Heraeus, nutritive con-
ditions in the and others, have shown most distinctly that even the soil.

typhoid bacilli, which are the least fastidious of all 
the pathogenic organisms, absolutely require a small quantity of the best nutritive materials for their growth and multiplication. In this respect the pathogenic bacteria show a marked contrast to some of the saprophytic forms, which can maintain life with nutritive materials of almost any quality, and can, therefore, grow actively in the soil. Better nutritive materials may, however, be occasionally found in certain localities in the most superficial layers of the soil, but at the most only temporarily, because rapid destruction and decomposition is always being brought about by saprophytic bacteria, and by the surface action of the elements of the soil. Various pathogenic bacteria can, it is true, be cultivated in pure diluted urine, and Schrakamp has also observed a development of anthrax bacilli in soil which was previously sterilised, and to which urine, blood serum, nutritive jelly, \&c., were added. From this, however, we cannot draw any conclusions as to the conditions of the normal soil. The excreta, \&c., reach it usually in a markedly altered condition, and containing numeDirect experiments with rous saprophytic bacteria. As a rule they become very much diluted in the soil by rain, and the layers in which they are in the first place retained are likewise full of saprophytes and fermentative agents, and in a suitable state for rapid decomposition of the material. Hence manured soil presents very different nutritive conditions to those of pure fluids, and conclusions as to the behaviour of the natural soil can only be drawn from experiments with real manured field and garden earth. Experiments of this kind have already been made by Koch. He attempted to grow anthrax bacilli in garden earth, in very rich mould from the banks of rivers, in the mud of the same rivers, and also in the mud of streets, a little water being added to these substances. Nevertheless no growth occurred.-Praussnitz has also made investigations in this direction in the author's laboratory, but has not as yet obtained any marked or permanent multiplication of pathogenic bacteria in any kind of soil, or by any mode of manuring. These experiments are being continued, and it is rery possible 
that here and there degrees of uncleanness of the soil may be found which permit a short-lived and local multiplication; but on the whole such a property of the soil is exceptional, even under the conditions employed in laboratory work. And these conditions are in so far very much more favourable for the multiplication of the pathogenic bacteria than are the natural ones, because in them earth which has been previously sterilised at $100^{\circ}$ C., and freed from other bacteria, and air not containing carbonic acid, are always employed. In reality the concurrence of the saprophytes which find their most favourable conditions for existence in the soil, and also the accumulation of carbonic acid, are in a very marked degree unfavourable for multiplication of the pathogenic bacteria.

Multiplication Hence it appears to be of relatively little importance only occurs very exceptionally even in impure soil. for the question of the multiplication of pathogenic bacteria in the soil, whether the latter is more or less contaminated, that is to say, impregnated with excreta. Possibly greater or less contamination may lead to a certain fluctuation in the prevalent species of bacteria, but all of these belong to the category of the obligatory saprophytes, and leave no room for the facultative parasites which are much more particular as to the conditions of their life. Without doubt it will at times happen that a pure cultivation of pathogenic bacteria (for example blood from animals suffering from anthrax) reaches the upper layers of the soil along with good nutritive material, and then multiplication of the anthrax bacilli will occur in the soil so impregnated. But this is evidently no special action of the soil, for the same thing might happen on any other substratum. In a similar manner typhoid and cholera bacilli, which pass along with the fresh dejecta into a soil containing bad nutritive materials and numbers of saprophytes, may multiply to a certain extent for a short time at the expense of the nutritive materials contained in the dejecta, in the same manner as would happen under other very different conditions without contact with the soil. Here there is no sort of favouring and specific 
influence of the soil, and of the impurities of the soil, but on the contrary rather an unfavourable action.

If, however, we ask whether the soil favours the pre- 2. Are pathoservation of pathogenic bacteria, our answer must perhaps $\begin{gathered}\text { genic bacteria } \\ \text { preserved in }\end{gathered}$ be somewhat different. This might occur if circum- the soil? stances were present which faroured spore formation or long preservation of preformed spores, or of those formed in the soil, or retention of vitality by non-sporebearing bacteria. Soyka* has recently obserred, in a series of experiments with anthrax bacilli, that spores are formed more quickly when the fluid containing them is mixed with soil than when they are kept in the original fluid under conditions otherwise similar (at the same temperature, \&c.). Now spore formation in the No important case of anthrax bacilli occurs chiefly at the surface of furtherance of fluids, and hence spores are the more numerous, and formation. the earlier formed in a fluid the thinner the layer in which it is spread out. In soil which is not saturated with moisture, any fluids poured on it are quickly distributed in very thin layers, and thus offer the best conditions for spore formation. But these conditions are also furnished on any substratum when the fluids are spread out in thin layers on the surface.

According to Soyka, acceleration of the spore formation is most marked when the soil contains such an amount of moisture that from 25 to 75 per cent. of the pores are filled with fluid. This gives a very large margin, which besides was never sharply defined in his series of experiments, for numerous spores were found, and the delay in their formation was only trivial when a hundred per cent. of the pores were filled, while where the proportion was under 25 per cent. the spores were so widely distributed that comparison was impossible.

Soyka was unable to observe spore formation in the anthrax bacilli when the temperature of the soil was below $18^{\circ} \mathrm{C}$., or under conditions which would hinder spore formation in fluids.

From these results it is evident that the soil exercises no marked or specific influence on the formation of * Fortschrilte d. med., 1886, Nr. 9. 
spores in the case of anthrax bacilli; on the contrary, the bacilli form spores in the superficial and somewhat dry layers of the soil in the same manner-perhaps here and there somewhat quicker, but certainly not to any marked degree-as in portions of the bodies of animals which have died of anthrax and which are lying on the surface, in the dejecta of anthracic animals, on nutrient vegetable materials, in marshy flats, \&c.

It is conceivable that in the case of some other pathogenic bacilli, which are less disposed to the formation of spores than the anthrax bacilli, spore formation may occur in a more exclusive manner and much more favourably under the conditions peculiar to the soil; as yet, however, we have no evidence in favour of such a view.

On the other hand spores once formed are well preserved.
Preservation of non-sporebearing bacteria.
On the other hand, pre-existing spores, or those formed in the soil, are perhaps better preserved there than in any other superficial substrata. In the latter, as the result of rains, or of currents of water and air, which may bring new nutrient materials, may again moisten the dried masses, or may carry the spores to other parts rich in nutriment, the spores may very readily sprout and form bacilli, which then succumb to the saprophytes present. In the soil, on the other hand, the unfavourable nutrient conditions, and the unfavourable conditions of temperature, can almost always prevent the sprouting of the spores, and thus we have an explanation of the fact that existing spores can remain there for a long time, and that we so often find in the soil large numbers of resisting spores.

But even without previous spore formation the soil may possibly preserve various kinds of bacteria, including pathogenic ones. We saw previously that the chief reason why non-spore-bearing bacteria so readily died under natural conditions, was either because they were present in fluid media, and were then exposed to the danger of being overgrown by other bacteria, or because the loss of water and the drying of the nutrient substratum led to their death.

We can readily conceive that such complete drying of 
bacteria as to lead to their destruction does not readily occur in the soil, not even in the so-called dry soil, because the air in it is saturated with moisture, and a layer of vapour surrounds the elements of the soil; but that, on the contrary, as Soyka has suggested, the arrangement of the fluid in the soil in thin capillary layers surrounding the particles produces a sort of fixation of the bacteria, and hinders such free circulation of the organisms as occurs in thicker layers of fluid, and thus both their overgrowth by other bacteria and their destruction by drying are avoided; and these two factors, which are present in the soil in a very exceptional manner, lead to preservation of non-spore-bearing pathogenic bacteria to an extent which occurs much more rarely in other substrata.

The result that the soil may possibly be a particularly good Explanation preserving medium for bacteria, but does not permit their multiplication, seems opposed to the experience mentioned of the marked infectivity of above that a soil impregnated with putrid fluids sets up infective diseases in animals much more readily than the putrid fluids themselves. But this fact is easily explained without assuming a multiplication of these bacteria. In putrid fluids parasitic bacteria are present in very much smaller numbers than the saprophytic forms, among which some are always present which furmish very poisonous ptomaines. On account of these ptomaines we cannot employ large doses of the putrid fluid if we wish to obtain an infection; after the injection of large quantities the animals only die of intoxication, and when on the other hand small doses are injected the chances of an infection are very slight on account of the relatively small number of the pathogenic bacteria.-If now the putrid fluids reach a porous soil the individual bacteria are fixed and preserved, while there is rapid destruction of the ptomaines. Numerous experiments formerly performed, and also those earried on of late by Falk and Soyka, have shown that the soil by its capillary attraction splits up poisonous organic bases, and also ptomaines, in a very short time. Hence we can introduce subcutaneously into animals large quantities of an impure soil without in any case causing intoxication, and hence with such a soil infective diseases are much more easily produced than with the fluids themselves. Very small quantities of the soil are usually without any effect.

The question now arises whether this supposed, but 
Local and seasonal differences in the power of the soil to preserve bacteria.

as yet by no means proved, power of the soil of preserving pathogenic bacteria is subject to local and seasonal variations; and whether these variations might suffice to explain the local and seasonal differences in the distribution of epidemic diseases as understood by Pettenkofer?

Although we have as yet no experimental proof of such a view, it is probable that certain local and seasonal differences in the preserving power of the soil do in fact exist. Thus compact rock, which does not permit the entrance of fluids and bacteria, would be out of the question as a means of preservation. Further, the various forms of porous soil would show quantitative differences according to the size of the particles and the degree of porosity. Possibly also the greater or less contamination of the soil is of influence, but only in so far that if the soil contains a large quantity of saprophytes and of nutritive materials, it will be less suitable for the preservation of pathogenic bacteria.

As regards time also, certain variations may occur; more especially it is conceivable that a very moist soil presents more the conditions of a fluid, and prevents the rapid distribution and fixation of the bacterial masses which are necessary for their preservation, while the action of the air which is present in the pores of a soil only partially moistened does not occur, and thus preservation is prevented. As excessive moistening of the upper layers of the soil is generally accompanied by a high level of the ground water, the sinking of the ground water may frequently indicate increased suitability of the soil for the preservation of pathogenic bacteria.

The preserva- But in spite of the possible existence of these local tion of bacteria in the soil is, however, not necessary for the spread of disease. and seasonal variations, the preserving power of the soil would not be in the slightest degree sufficient to exert an exclusive influence on the spread of epidemic diseases. For we cannot assume with regard to any species of bacterium that the condition of preservation in which it is present in the soil is at all necessary to fit it for being transmitted to other individuals; on the contrary, all infective agents are without doubt capable of causing 
further infection without and before coming in contact with the soil. And further, the preservation of the pathogenic bacteria is certainly not an exclusive property of soil ; on the contrary, sufficient preservation can occur in very various substrata, especially when the bacteria in question can readily form spores, as in the case of the anthrax bacilli, or are already spore-bearing when they leave the body, as in the case of the typhoid bacilli. Many kinds of soil may perhaps in this respect be of more than average value, and the preservation of the spores in them may be remarkably long and complete. But there are always so many other possible modes of distribution of the pathogenic bacteria that the action or want of action of the soil in their preservation cannot in very many cases exercise any marked influence on the spread of the epidemic.

A third question arises, in what way bacteria preserved 3. How do the in the soil can spread to man, and whether a definite preserved condition of the soil, varying according to time and place, spread from has much influence on this spread? The following man? modes of transport may come into play in the case of the bacteria of the soil :-

1. Winds, which carry up the dust, and with it the winds. bacteria, from the most superficial layers of the soil, and transport them through the air. From what has been said above as to the organisms of the air and as to the movement of bacteria within the soil, it is evident that such a detachment of bacteria is only possible in completely dry soil, and only from the superficial layers, which are converted into dust. A thoroughly moist soil does not permit the detachment of bacteria, nor does a soil which possesses a superficial dry layer, but the outermost surface of which is moistened from time to time by slight rains.

2. The ground water, and the water taken from it for Ground water. drinking and other purposes. Where there is a thick layer of cultivated soil above the ground water this mode of transport cannot come into play; but where the ground water is only separated by thin layers of loose soil from the surface, and where it can ultimately reach the sur- 
Food. 3. Articles of food which grow in the soil (potatoes,

face if it increases in amount, and also when fissures and cracks open a communication between the contents of cesspools and the ground water used in houses, it will occasionally happen that the bacteria poured into the soil again return to man and to dwellings. turnips, roots, \&c.) carry particles of earth adhering to them, and large numbers of bacteria from the upper layers of the soil, into dwellings, kitchens, kitchen utensils, towels, \&c., and thus ultimately to other kinds of food.

By animals. 4. Men and animals who come in any way in contact with the soil, implements which are employed in cultivation, \&c., can in a similar manner aid in the transport of the bacteria from the soil to the domestic economy.

Digging. $\quad 5$. By digging the soil and laying bare the deeper layers which may contain bacteria, while at the same time dry winds prevail, numbers of pathogenic bacteria may be detached which have reached the soil from defective cesspools, or at a former time from the surface, but which have been withdrawn from contact with the outer air by being covered with new layers of soil. It is possible that we may in this way explain the frequently suggested connection between typhoid epidemics and digging up the soil of streets.

As a matter of fact it is evident that these various modes of transport of the pathogenic bacteria of the soil do not come equally into action in every soil and at every season, but that local and seasonal causes of variation exist, and favour or hinder one or other mode of transport.

Seasonal influences on their spread due to the moisture of the ground.

Behaviour of the water in the soil.
The seasonal influences are most distinctly seen in the first and most widespread mode of transport, viz., the spread through the air; and this is due to the varying degrees of moisture of the upper layers of the soil.

As to the important conditions of the moisture of the soil in relation to this point we have obtained clearer information by Hofmann's investigations.* In porous soil we have to 
distinguish, in the first place, a superficial zone of evaporation in which the degree of moisture of the soil is very variable, and oscillates between complete saturation and marked dryness; in this zone, when of great breadth as the result of the summer heat, the whole of the rain in late summer and harvest often finds a place, and the filling of the capillary pores does not reach to its lower border; in this case there is therefore always a dry layer between the most external part which is temporarily wetted by the rains, and the deeper layers of the soil in which the water lies. And under these conditions all the impurities which reach the soil remain in the upper dry zone.

Under this layer lies a zone which never dries, but in which the capillary pores are always full of water. If this zone receives water from above (when the upper dry layer has been completely filled with rain water) the amount of water in it remains the same, for the excess runs downwards into the third zone, that of the ground water.

It is evident that, when a drying zone exists, the con- Favouring ditions are the most favourable for the detachment and action of a carrying away of the bacteria of the soil by currents of air. It is only in that case that this most important mode of transport comes into play. During the whole of the winter and a great part of the spring there is usually no dry zone in our climate, and hence no possibility for such a passage of germs into the air. In the latter end of summer and in autumn, on the other hand, this possibility is present, and is only absent from time to time when the occurrence of rain renders the outer surface moist.

As the existence of a dry zone always results in the The variations cessation of addition to the ground water from above, and in the ground thus leads to sinking of the level of the ground water, index of we have in the variations in the level of the ground water of the soil, a fairly useful index of the possibility of a transport of the bacteria of the soil by the wind. This index is not, however, quite correct, because the temporary moisture of the surface of the soil (sometimes lasting even for weeks and months) and the cessation in the transport thus occasioned find no expression in the variations of the level of the ground water.

The existence of a dry zone has a further favourable 
Furtheraction effect on the number and variety of the bacteria transof the drying zone.

ported by the wind, because all impure fluids, dejecta, \&c., and with them all bacteria, remain in the most superficial dry zones. In this way the accumulation of the most various kinds of saprophytes, and also of pathogenic bacteria, takes place to a much greater extent than in the case of a thoroughly moist soil where there is no drying zone, because the continuous stream of water in the latter case carries the bacteria to a certain though moderate depth and removes them from the action of the wind.

The other modes of transport are only to a slight degree subject to influences varying according to season. Formerly a variation in infective power was ascribed to the ground water according as its level was high or low, usually, however, the number of bacteria present in it is but little influenced by alterations of the level.

The spread by food, man, and various materials can perhaps be faroured by the presence of a drying zone, in that when such a zone exists a large accumulation of bacteria occurs in the most superficial layers of the soil from which the transport takes place; nevertheless a constant difference of this kind can only be made out in the case of those soils which are exposed to continual contamination, as in the soil of streets, courts, \&c.; while the soil of fields, for example, which are only impregnated at considerable intervals with fluid containing bacteria, can only show seasonal variations in the action of the mode of transport as the result of a conjunction of accidents.

On the whole, therefore, it is practically only the drying of the surface of the soil which increases the danger of distribution of pathogenic germs from the soil.

Influence of the local c snstitution of the soil on the spread of the bacter:a.

The existence of any influence on the transport of the bacteria of the soil as the result of the character of the soil in any given locality is not so evident. Here again it is only a porous soil, and one which can take uplarge numbers of bacteria, which could exert an influence on their distribution. Further, we may suppose that where the pores are large the bacteria do not on the whole accumulate in such numbers, but are more readily distributed over con- 
siderable distances than in finely porous soil; and this must be the result, more especially when copious rains thoroughly soak the soil, and when there is no drying zone. In such a grossly porous soil the drying zone assumes a special importance; for it is only while it exists that there is any chance of the bacteria being transported by winds, or by men or things. Finely porous soil, on the other hand, keeps back the bacteria in the superficial layer to a much greater extent, and even possibly when the dry zone is absent; in this case the bacteria may be distributed, not indeed by winds, but in other ways, for example, by contact with man, \&c., even when the surface is moist, and hence the difference between the dry and the moist stage is not so sharply marked in finely porous soil.

We must, however, for the present leave it to experimental investigations made with bacteria to confirm or to correct these ideas, and to give us definite information as to the special disposition of the individual kinds of soil for the spread of infective germs.

From what has gone before we can at all events come Résumé. to the definite conclusion that the soil does not lead to any special ripening, or even to active multiplication of the pathogenic bacteria, but on the other hand, that it possibly aids in their preservation, and in the distribution of the bacteria so preserved. Both preservation and distribution are probably subject to local and seasonal variations; for it is only a porous soil, and only at a time when a superficial dry zone exists, and where the ground water is as a rule sinking, that a preservation and more especially a distribution of the infective germs can take place.

By this property of preserving the pathogenic agents Influence of in an unaltered condition, and allowing their return of the soil on again under certain conditions in large numbers to the the spread of surroundings of man, the soil probably takes part in the disenses. spread of many infective diseases; and the dependence of these properties of the soil on local and seasonal influences will ultimately find its expression in the local and seasonal variations of many epidemics. The most 
Frequent distribution of the typhoid bacilli from the soil.

Their distribution, however, does not occur only by means of the soil.

The pathogenic agents do not acquire infective properties as the result of the influence of the soil.

important mode of spread, more especially of such pathogenic bacteria as reach the soil directly or in a roundabout way along with the dejecta of the sick (e.g., typhoid bacilli), and which either contain resistant spore forms in the dejecta as passed, or form these in the soil, is that in one or other of the ways mentioned they are again carried into the household from the uppermost layers of the soil. And this distribution only occurs from a porous soil, and at a time when a dry zone exists (in other words when the level of the ground water is low), that is to say, it depends markedly on local and seasonal predisposition.

But even the typhoid bacilli are not always restricted to this mode of spread. We must assume that they can cause infection in other ways, and this assumption is still more necessary in the case of those pathogenic bacteria which do not reach the soil to the same extent, or which (like the cholera bacilli) cannot be distributed from the soil in the most common manner, viz., by currents of air, for the reason that they cannot with- stand the necessary degree of drying. In the case of the majority of the facultative parasites, therefore, their preservation in and distribution from the soil forms in reality a rare exception.

The important difference between our views and those of Pettenkofer is, therefore, that we (basing our opinions on our present knowledge of the biology of the pathogenic bacteria and their behaviour in the soil) can find nothing in the soil which must of necessity act on the pathogenic bacteria in order to make them capable of producing infection. The idea formerly held as to a sort of ripening of the infective agents under the influence of certain mysterious properties of the soil cannot be brought into accord with the recently ascertained facts as to the biological properties of the bacteria, and must now be definitely abandoned. Nor can we assume that the multiplication of pathogenic bacteria takes place exclusively in the soil (perhaps with the exception of the as yet completely unknown cause of malaria), because other superficial substrata are as a whole 
much more suitable for such a multiplication; what the soil really effects in a marked manner, viz., the preservation and the distribution of the preserved pathogenic agents, is, however, not an exclusive privilege of the soil ; on the contrary, the distribution of these infective agents can also take place by other means and in other ways, which are for the most part more available than the roundabout way through the soil.

Further, the occurrence of local and seasonal varia- The local and tions in the distribution of the infective diseases, which, according to Pettenkofer, are only explicable on the assumption that the soil exerts an influence, does not by any means necessitate the idea of a constant connection between soil and epidemics. We see, on the contrary, that the other modes of spread in which the soil does not come into question, e.g., the spread by the food, by contact, \&c., are subject to local and seasonal variations which are quite sufficient to explain the corresponding oscillations of the epidemics (see the following part).

Bacteria are almost. always present in very varying Occurrence of numbers in water. The varieties observed are almost bacteria in without exception saprophytes. Among these there are some which are of special interest, because they are able to multiply markedly in the presence of imponderable quantities of the most simple nutritive materials, and at a temperature of $8^{\circ}$ to $10^{\circ} \mathrm{C}$., and hence they are present in large numbers in the most various kinds of water. These "water bacteria" of which Bolton" has isolated six Bacteria varieties, which are very widely distributed, influence the total number of bacteria in any particular water; for which multiply in where they are present they multiply with such extreme rapidity, that very soon the number of all the other bacteria becomes insignificant compared with them. The quality of the water is quite indifferent for these typical inhabitants of the water; they multiply quite as markedly

* Bolton, Zeitschr. f. Hygiene, vol. i., Part 1.-See Cramer, Die Wasserversorgung von Zürich. Zürich, 1885.-Wolffhügel, Arb. a.d. Kais. Ges. Amt., 1885, vol. i.-Wolffhügel and Riedel, ibid., 1886, vol. 2.Lisone, Atti della R. Acad. dei Lincei, Ser. 4, vol. i. 
in distilled water which is as pure as possible, as in the so-called bad well water which is contaminated with sewage.-Besides these special bacteria we have as inhabitants of the water those forms which are characterised by their more advanced morphological development, and by the variability of their vegetative forms insisted upon by Zopf, riz., crenothrix, cladothrix, beggiatoa. We require more accurate investigations as to the character of the water which is necessary for the development of these fungi.

Many of the other saprophytic forms apparently either do not multiply at all in water, or only to a very limited

Behaviour of pathogenic bacteria in water. extent. Nor can any of the pathogenic bacteria multiply in water even where the temperature is favourable, because they absolutely require a certain even though a small quantity of the best nutritive materials. Typhoid bacilli require, according to Bolton's experiments, at least 67 milligrammes of organic nutritive materials per litre of water, cholera bacilli require 400 milligrammes per litre. Such an amount of organic materials only occurs extremely rarely in water which is employed for household and drinking purposes; and besides, in the case of the pathogenic bacteria very much depends on the quality of the nutritive materials, and even the presence of a considerable quantity of the less nutritious organic materials which are usually present in water is unable to replace the necessary but small amount of peptone and albumen.

On the other hand, the pathogenic bacteria retain their vitality for a comparatively long time in water. Nonspore-bearing anthrax bacilli and micrococcus tetragenus live for about six days, typhoid bacilli free from spores for fourteen to twenty days, spore-bearing bacilli from thirty to ninety days or longer. In the case of cholera bacilli Wolffhügel and Riedel have made out a duration of vitality of about eighty days, and frequently also a multiplication; however, in some of their experiments, the results of which are not completely in unison, they have probably sown too many organisms, and have carried over a small amount of nutritive material from 
the cultivation, which has been able to exert a decided influence on their multiplication and preservation. In numerous experiments which have been made in the author's laboratory multiplication of cholera bacilli has never been observed in any water when only small numbers of the organisms were sown; on the contrary, they have always died within eight to fourteen days.

In these laboratory experiments the conditions are particularly favourable for the development and preservation of the pathogenic bacteria, because sterilised water has always been employed for the cultivation experiments. Under ordinary circumstances the saprophytes, which are always present in large numbers in water, must render the conditions much more unfavourable for the existence of the pathogenic bacteria. This has in fact been directly proved by experiments made by Wolffhügel and Riedel, who have found that cholera bacilli disappear in unsterilised water even after two days, although large quantities are introduced.

The entrance of the bacteria into the water does not Mode of occur to any great extent through layers of intact soil, or through the ground water. The unanimous results of the experiments made by Roth, ${ }^{*}$ Bolton, + Heraeus, + and others show that in the majority of wells the number of bacteria constantly decreases the more fresh ground water is drawn into them by continuous pumping. Further, after the pumping has been continued for some time there are unusually few bacteria in the wells if they are well covered on the surface and protected, as far as possible, from fresh contamination from the well wall and from the pumping tube; e.g., where we have tubular iron wells and conducting pipes. Hence we must conclude that the bacteria reach the drinking and household water chiefly by currents from the surface, and also by cracks and passages which run through the soil from cesspools, \&c., towards the wall of the well. It is evident that pathogenic bacteria can also reach wells in

* Viertelj.f.ger. med., N. F., Bd. 43, Heft 2.

$\dagger$ Zeitschrift f. Hygiene, Bd. 1, Heft 1.

† Ibid., Heft 2. 
the same manner. Hence we have the best opportunity for the infection of drinking water where an imperfectly covered well stands in the middle of the ordinary dirty court; as a rule all dejecta and waste water are poured out on the soil of these courts, and further, the arraugements are frequently such that the superfluous water employed for washing clothes, for example, flows back again into the well.-At times, also, the ground water which supplies the well contains numerous bacteria; this is the case, for example, when the distance from the surface is slight, or when cesspools in the neighbourhoods of the wells reach as deep as the ground water, or when the soil is exceptionally porous.

Factors which influence the number of bacteria in water.

The number of bacteria in a water chiefly depends on whether varieties are present which are able to multiply in the water, and whether the conditions are favourable for their multiplication. These conditions are the more favourable the higher the temperature and the longer the water is stagnant and able to maintain the newly formed bacteria. Hence we find the greatest numbers of bacteria in stagnant water and during the summer months, and the smallest numbers in wells which are much used and during the cold season of the year. The other conditions of the water, the amount of organic material and salts present in it, are not of importance for the multiplication of these special kinds of bacteria, nor for the number of bacteria in any given water. It is only when the true water bacteria are absent, and saprophytes are present, which require a large quantity of nutritive materials, that the differences in the chemical constitution find an expression also in the number of the bacteria.-We cannot, therefore, draw any conclusion from the number of living bacteria in a given specimen of water as to its infective power, or even as to the degree of contamination; such conclusions can only be come to when we ascertain at the same time whether aquatic bacteria are present, and whether the conditions, such as the season of the year or the frequency with which the well is used, are favourable for their multiplication before the specimen was taken. 
It is always very difficult to pick out the pathogenic DemonstraIt is al the bacteria from among the large number of saprophytes. presence of And in attempting to ascertain their presence we have pathogenic also to remember that they do not as a rule live long in well water; that as they never multiply in the water, every withdrawal of water, and every addition of pure ground water diminishes their numbers; and it is only in those cases where there is repeated contamination by pathogenic bacteria that the chances of demonstrating them by cultivation are at all farourable.-It is probably owing to these difficulties that pathogenic bacteria have never as yet been demonstrated with absolute certainty in any water.

In addition to the ground water which is chiefly Running employed for drinking and household purposes, the means of water which flows on the surface of the ground often ${ }_{\text {bacteria. }}^{\text {transport of }}$ serves as a means of transport of saprophytic, and at times of pathogenic bacteria. In fact the water in gutters, streams, and rivers is particularly dangerous, because it not unfrequently serves the double purpose of taking up and removing waste water of the most various kinds, and at the same time of supplying water for household purposes.

Further, stagnant and superficial collections of water, Banks of the muddy banks of rivers, and fields which are at times rivers, ponds, submerged, are probably of special importance for the regions as etiology of many infective diseases. These act not only bacteria. as means of transport for all sorts of disease germs, but they also in all probability facilitate the growth and multiplication of the fucultative parasites. It has been shown that anthrax, typhoid, and cholera bacilli can grow well on moist, dead portions of plants, such as often occur in enormous quantities on the banks of rivers, in regions which are flooded, \&c. In these places the bacteria mentioned find a favourable temperature, as well as the necessary moisture and nourishment, during a great part of the year, and if a saprophytic existence of parasites is possible anywhere in the natural surroundings of man, it must be here. Such a saprophytic growth is most likely to occur in tropical climates; it 
was there that Koch succeeded in demonstrating the presence of cholera bacilli in one of the Indian tanks, and proving that a marked saprophytic multiplication of the bacilli had occurred on the banks of the tank.

Bacteria in articles of food.

We daily take into our bodies very large numbers of living bacteria, not only with water, but also with our food. To some articles of food-for example, beer, cheese, \&c.-numerous bacteria are intentionally added in their preparation. In the case of other articles of food, of which the edible portions are formed beneath the surface of the soil, large numbers of bacteria adhere to the particles of earth surrounding them. Others again, such as fruits, are covered with numerous bacteria from the air, which are either fixed on their sticky surface, or are deposited there by the condensation of watery vapour. Further, it very frequently happens that articles of food which were originally free from bacteria, or which were sterilised in their preparation (milk, meat, various kinds of cooked food), are infected either by contact or from the air, and according to their nutrient conditions and the prevailing temperature, smaller or larger colonies of bacteria develop on them.

In all these cases the colonies may consist of completely harmless saprophytes; or, on the other hand, bacteria may be present which are able to set up fermentation, and which are not altogether indifferent, for if taken into the body in very large numbers they may exert their energies in too marked a manner in the human digestive tract; or, again, the bacteria may belong to a class which usually grow as saprophytes, but which produce very active ptomaines, some of which may cause morbid changes in the intestinal mucous membrane; or, finally, pathogenic bacteria may be at times present in the food.

Development of facultative parasites on articles of food.
Those bacteria which develop on food kept in the house seem to be especially worthy of attention. Under these circumstances the temperature is often very 
favourable for a multiplication of facultative parasites; further, the nutrient substrata could scarcely be better even if they were prepared for the artificial cultivations of the pathogenic bacteria; again, many articles of food are solid, and thus it is not so easy for the saprophytes to overgrow these bacteria. Milk, broth, and meat are excellent nutrient substrata for typhoid and cholera bacilli, and we cannot but suppose that these and similar pathogenic agents, when they once reach the food, the vessels, or washing-cloths, \&c., either through the air, or from the earth, or by contact, very readily multiply to such a marked extent that the greatest dangers may result from the use of such food.

Not only the facultative parasites, which find here obligatory conditions particularly favourable for their development, parasites. but also the obligatory parasites can be carried to man by the food, and especially those which (like the tubercle bacilli) are infective for animals as well as for man, and are at times introduced by the use of meat.

The dangers on the side of articles of food can be almost completely avoided by the mode of preparationby sufficient boiling and roasting - and by avoiding the use of food which has been kept for a considerable time after being cooked. But as we know, in all nations and in all classes of the people part of the food is eaten in a raw state, or after it has been kept for a long time, and thus it contains numerous bacteria. The proportion of Local differthe whole food which is employed in such a dangerous ences in the condition is very variable, and differs according to the bacteria in customs and manners of each people. Thus while in Southern lands there is the greatest carelessness as regards the food, even the larger portion of it being used in a raw or half decayed condition, in other regions there is such great care in the selection, treatment, and preparation of articles of food that the danger of this mode of infection is reduced to a minimum.

Hence the number of bacteria in articles of food, and the danger of infection resulting therefrom, is evidently subject to marked local differences, and seasonal variations can also occur with equal frequency. Thus, in 
Seasonal differences.

our country the summer is naturally the time of the year during which those parasites which require a high temperature can most readily establish themselves on articles of food; further, on account of the presence of raw decaying fruits autumn is a particularly favourable time for contamination with numerous and different kinds of bacteria, and it so happens that, at the same time of the year, the various articles of food are exposed to greater danger of contamination by the bacteria preserved in the soil, because the latter are at that time readily distributed owing to the formation of dust on the surface of the ground. This dust formation is in our climate almost exclusively limited to the end of summer and to autumn, because it is only then that a superficial dry zone is constantly and for a considerable time present.-Hence we have various reasons for believing that at a particular time of the year exceptionally large numbers of bacteria are taken into the intestine with the food, some of which perhaps produce ptomaines, and thus possibly prepare the intestine for more severe diseases, while others may penetrate as infective agents into the predisposed intestinal tract.

From what has been said, it is evident that articles of food probably form such a marked factor in the spread of the infective diseases that we must in future attempt to gain a more accurate knowledge of this mode of infection.

Bacteria in clothing.
Numerous bacteria of all kinds are also frequently present in the artificial surroundings of civilised man; thus the clothing is for the most part very rich in living micro-organisms, which have reached it partly from the surface of the body and the excreta, and partly from without by the dust and rain. Washing clothing is not uncommonly the means of transport of facultative and obligatory parasites; such a rôle on the part of elothes is well known in the case of those infective diseases which are localised in the skin (e.g., small-pox), 
also in the case of cholera, where, owing to the fact that Infection by the linen becomes soaked with the nutrient substances clothing. contained in the dejecta, multiplication of the pathogenic agents may occur on it, so long as drying does not take place. Infective diseases of wounds, diphtheria, puerperal fever, tuberculosis, \&c., are also without doubt frequently carried by linen and dressings. Unfortunately we do not as yet know, and must still ascertain by exact researches, how far the usual methods of cleansing linen destroys the infective agents, or how long they may retain their vitality in linen which has been washed and put away.

The dwelling offers many opportunities for the pre- Occurrence of servation and distribution of bacteria, and especially of bacteria in the facultative and obligatory parasites; a multiplication within the materials, which in a narrow sense belong to the dwelling, does not seem to occur. The soil under the In the soil floors forms, according to Emmerich's investigations, a under floors. particularly favourable reservoir, and often contains enormous numbers of saprophytic, and not uncommonly also of pathogenic bacteria. These are present partly in the original and for the most part very impure material, and in part they reach it through the medium of the water used for scouring, which carries with it sputa, remains of dejecta, \&c., and passes through the numerous joints and seams of the floor into the porous material beneath. In this way the bacteria of pneumonia, spores of tubercle bacilli, \&c., can readily reach the soil. It is probably quite exceptionally that a multiplication of bacteria occurs here, because as a rule the material contains very little water. But it is probable that various forms of bacteria can be preserved in the porous mass in a manner similar to that which occurs in the natural soil. The bacteria can be extremely readily detached and distributed from this reservoir by the mechanical disturbances to which the floor of a dwelling-room is exposed; the large masses of dust which rise from the seams at every step can be readily seen in a beam of sunlight.-Where the flooring is close and covered with oil colours, more especially, 
however, where it is waxed and polished, this reservoir of bacteria with its danger of infection need not be taken into consideration.

Further, the furniture, curtains, and corners of the rooms, which are usually insufficiently cleaned, form places on which bacteria may be deposited and preserved for a considerable time.

Bacteria in refuse.

Not a good nutritive sub stratum for pathogenic bacteria.

The refuse of houses and of cattle stalls forms also a favourable place for the accumulation of bacteria. The intestinal excreta contain at times infective agents mixed with the large numbers of saprophytes; for example, typhoid bacilli, cholera bacilli, tubercle bacilli, anthrax bacilli, the bacilli of swine fever, of chicken cholera, \&c.; further, probably the infective agents of dysentery and of the epidemic diarrhœa of children. Fresh urine seldom contains micro-organisms, but it is a suitable nutritive substratum for the most various kinds of bacteria; we must further bear in mind the kitchen refuse, kitchen water and washing water, which are for the most part laden from the first with numerous bacteria, and can also serve as a settling place for others when it stands for a long time. All these waste materials have up to the present been looked on as the chief nutritive materials for pathogenic bacteria, and in this respect have as a rule been much over-estimated; on the contrary, they usually offer such excellent nutrient conditions for the saprophytes that they are totally unsuitable for the growth of infective agents. We see in all waste waters, in putrid fluids, \&c., that the facultative parasites, even when they are sown in them in enormous quantities, die in a few hours, or at most days; and it is only in the spore form that they can be preserved (without multiplication) for a longer time.

Dangerous on Hence these waste materials are only of importance account of the for the spread of the infective diseases in so far as they
presence of dejecta which may at times contain obligatory or facultative parasites contain patho- which come from the bodies of diseased individuals; and hence the most important hygienic point with regard to the removal of the waste materials is that the whole mass, with the infective agents which may be present in 
it, should be removed as quickly and completely as possible from the dwellings and from the neighbourhood of susceptible individuals. This aim will be best fulfilled Their prompt by a system of drainage which is at the same time com- removal by bined with a constant and sufficient supply of pure water, thus rendering the carrying out of cleanliness easier. The system of removal of refuse by means of pails seems less satisfactory, especially when by this means the excrement and the infective agents in it are thrown on gardens or fields in the neighbourhood of dwellings, thus leading to the preservation of the germs, and therefore probably to their re-introduction into the dwellings. The system of cesspools, by storing up the masses for a longer time, affords a better guarantee than the pail system for the death of the infective bacteria before they reach the ground. A decided disadvantage of the two last-mentioned methods as compared with the drainage tages of the system is, that there is always a danger of infective germs methods. spreading in some way or other to the surroundings of man, from dried masses in the exit-tube; while in the former system the water-closets and pipes leading therefrom can be readily kept in a clean and moist condition. And further, stagnant gutters, dirty courts, \&c., with their multifarious dangers of infection, can only be effectively dealt with by flushing with water and by drainage.The question as to the hygienic value of the methods of cleansing towns must therefore be reconsidered from the points of view shortly indicated above; we must also trace out more accurately the fate of the pathogenic agents in each of the systems employed, and of course we must also carefully weigh other interests before coming to a final conclusion as to the value of any given system. At all events the most important hygienic Necessity for points of view from which these matters have up to the fresh conpresent been considered are incorrect, because the view has been acted on that especially good nutrient materials for pathogenic bacteria are present in the refuse materials, and that it is necessary to keep the soil free from these substances, and to remove them from human dwellings, in order to prevent a development of disease germs in 
Significance of contamination of the soil.

Infection as the result of profession and occupation.

Infection by doctors, mid. wives, \&c.

Opportunities for infection in children.

them or in the contaminated soil. We must undoubtedly give up this view, since we have become better acquaintel with the conditions of life of the pathogenic bacteria; and we cannot now see in a contamination of the soil such a great and immediate danger of infection as formerly, especially when the water required for household purposes is not taken from this soil, but is conducted from a distance by a system of pipes. Of course, however, it is very desirable for other reasons to keep the soil pure, and this is attained at the same time and in the most complete manner by those methods which keep prominently in view as rapid a removal of all pathogenic agents as possible from the dwelling-house. The necessity for and the sanitary effect of drainage thus remain the same, and it is only the basis on which the precautions are taken which is altered in accordance with the more recent views.

The profession and business of the individuals also in many ways aid the spread or the reception of pathogenic bacteria. In former times, for example, the infective diseases of wounds were undoubtedly often carried by physicians who did not at that time hesitate to examine the infected wounds of one patient and the fresh wounds of another with the same imperfectly cleansed finger. Even now infection is frequently carried by the clothes and hands of those medical men who do not rightly estimate the dangers of infection. In like manner midwives, to whom is almost entirely to be ascribed the transmission of puerperal fever, nurses, washerwomen, old clothes men, rag-collectors, \&c., very often lead to the further spread of infective agents.-We only require to speciaily mention further the manifold possibilities of infection to which children are wont to expose themselves; how they cover their hands now with the soil of dirty courts, now with the water of gutters, and the most various objects rich in bacteria, and then the next moment place them in their mouths, or eat their food with their dirty hands. It is difficult to understand how when a child becomes ill from typhoid fever, diphtheria, \&c., the majority of doctors, in spite of these dangers of 
infection which are constantly present and very evident, always search for the ominous glass of "impure " water which has in their opinion caused the disease.

Large numbers of bacteria are also present on the Bacteria on surfoce of the human body. The most various forms of the surface of bacteria have already been demonstrated on the skin, in the sweat from the feet and axilla, \&c. It is evident on the skin. from the researches of Forster, ${ }^{*}$ that in spite of apparently careful washing, bacteria still adhere to and retain their vitality in the folds of the skin of the finger and under the finger nails; he found that, even after

- cleaning the hands with brushes, water, and soap, if the fingers were pushed into nutrient jelly a varying number of bacterial colonies constantly developed.

On the internal surfaces of the body still greater In the mouth. numbers of bacteria are found. For a long time saprophytes have been known to exist in the mouth, which excite fermentations, and bear a distinct relation to caries of the teeth (p.391); various forms of pathogenic bacteria have also been observed there. Thus Kreibohm in a relatively small number of cultivations from the secretions of the mouth has isolated four different forms which cause septicæmia in animals (see p. 319); and also the bacillus crassus sputigenus, which occurs comparatively frequently in man, which likewise causes septic infection in some animals, and which produces in its cultivations a violent poison, killing those animals which are not susceptible to infection by intoxication if introduced in large doses. This state of matters is readily intelligible when one considers that in the cavity of the mouth there exists a very suitable temperature, and in the dead epithelium, \&c., a good nutritive material for the development of pathogenic bacteria. Hence it is readily conceivable that parasitic bacteria, which require a special point for their invasion of the body, can live for a time as epiphytes, till they find an opportunity of entering the body, and thus the occurrence of an infec-

* Centralb. f. klin. méd., 1885, Nr. 18. 
tion need not be immediately preceded by the reception of the infective agent. Possibly this is the meaning of the observation made by Loeffler on the presence of the diphtheritic bacilli in the secretions of the mouth of a healthy child (see p. 287).

On the respi- Various bacteria (e.g., Micrococcus tetragenus) are ratory mucous
membrane. also found in the laryngeal mucus, and in that of the trachea and bronchi; these have been carried in by the respired air, and have in part multiplied to a considerable extent in the mucus.

In the stomach.

Feeble action of the gastric juice

In the intestine.

Some prevailing varieties.

Enormous numbers of bacteria are also met with in the intestinal tract. Numerous forms are found even in the contents of the stomach. It has been erroneously assumed that the acid contents of the stomach kill most forms of bacteria; this is, however, not the case. Experiments which have been made by Mac Fadyan in the author's laboratory have shown that even the strongly acid gastric juice of the dog can kill only cholera and anthrax bacilli with anything like constancy, that, however, most other bacteria are not so susceptible to the action of the gastric juice, and can pass in a living state through the stomach even when conditions are as favourable as possible for an energetic action of the gastric juice; among bacteria which behave in this way may be mentioned micrococcus tetragenus, staphylococcus aureus, bacillus cuniculicida, \&c.

\section{Hence there is for the most part only a temporary} hindrance to development in the stomach, and vegetative forms such as spores reach the small intestine in a living condition in large numbers. There they find a good opportunity for development so long as the reaction of the chyme remains neutral or faintly alkaline; it is true that this multiplication appears to be limited chiefly to certain definite forms of bacteria, so that in spite of the multiplicity of forms and varieties which strikes one at first, there are some which evidently find in the intestinal contents a particularly favourable soil for multiplication, and occur there almost constantly. These prevailing varieties seem to vary according to the 
composition of the food as well as the course and stage of digestion.-The occurrence of an acid reaction in the intestinal contents must cause marked alteration in the bacterial life in the intestine. More especially do organic acids, such as occur in the later decompositions of the chyme, exert a particularly marked inhibitory action on many bacteria; it is only some forms which are exceptionally insensitive, such as lactic acid and butyric acid bacilli, which still remain capable of development, and thus gain the mastery the sooner.-Anaërobes are also Anaïrobes. constantly found in the intestines, and often in such large numbers that there can be no doubt that they have multiplied there. This is easily intelligible, because in certain sections of the intestine, and in certain layers of the intestinal contents, there is always a deficiency of oxygen sufficient to permit the development of anaërobes.

Among the large numbers of intestinal bacteria the Pathogenic saprophytes are most numerous, nevertheless those bacteria in the bacteria which do not grow so quickly as thes saprophytes, and are hence as a rule hardly adapted for concurrent growth with them, not uncommonly multiply to a marked extent, and possibly grow in the folds of the intestinal wall which are more removed from the action of the saprophytes of the chyme. In this way bacteria may develop in the intestine which are dangerous to the body, partly by means of their ptomaines, and partly by penetrating into the intestinal wall and causing infection.

We must await future investigations for a more accurate knowledge of the intestinal bacteria, for an isolation of the varieties which occur most frequently or regularly, and also of those which only occur now and then, and for facts as to their functions and their effects.*-This study is to some extent rendered difficult by the fact, that in microscopical preparations made

* While these sheets were passing through the press, an extensive research, which has just been published by Escherich (Die Darmbakterien des Säuglings, Stuttgart, 1886), forms an important beginning to the investigations in this department. 
Some of the intestinal baeteria do not grow in the ordinary eultures.
Absence of bacteria in the interior of the healthy body.

from the contents of some part or other of the intestinal canal, or from the secretions of the mouth, we see a much greater number of varieties of bacteria than when the bacteria contained in the same specimens are isolated by our ordinary methods of cultivation. It is evident that only a small fraction of the bacteria which are present develop. It is by no means clear what is the cause of this result of cultivation. Some of the bacteria which do not appear in the ordinary cultivations are evidently anaërobes, and a markedly better development of bacteria is often obtained when the material is cultivated in the absence of air. Others of the bacteria which are seen and stained in the microscopical preparations have probably been so affected by the action of the gastric juice, or of the organic acids of the intestinal contents, that they grow very slowly, and only in specially favourable fluid nutritive media; hence Buchner was able to cultivate a greater number of varieties from the intestinal contents by the employment of isolated cultivation in fluid media, and by carrying on the cultivation for a longer time than when he limited himself to jelly plates. It is also possible that the mucous membrane may exert some inhibitory influence on the bacteria, and that this may continue even after their inoculation into cultures.

While the external and internal surfaces of the body are thus richly supplied with bacteria we find none in the interior of the body under normal conditions (see p. 83). It is only when parasitic organisms have penetrated into the body, and have set up disease there, that we have the presence of specific bacteria either in Excepticns. the blood or in various organs. Further, Wyssokowitsch has shown that bacteria may be temporarily present in an apparently quite normal body when bacteria, either saprophytes or at any rate species not infective for the animal in question, have penetrated into the blood through a wound. Such bacteria are deposited chiefly in the liver, spleen, and medulla of bone, and remain there in a living condition for a length of time varying from a few hours to days, while 
spores, e.g., those of bacillus subtilis, may live for several months (compare p. 644).

The secretions of the body also, more especially the Absence of urine, are according to the investigations of Wyssoko- of pathogenic witsch * free from bacteria, even when infective bacteria ones, in the are present in the body and circulate in the blood. It is only in the cases where there is plugging of the ressels of the kidneys by masses of bacteria, and in consequence necrotic patches with marked lesion of the tissue, that we have an excretion of bacteria in the urine. Such a state of matters is almost always seen after the injection of staph. aureus into the blood, but these bacteria do not appear in the urine soon after the injection even when large numbers were introduced, but only after deposits have been formed in the kidney and have opened up artificial passages.

Gunning + has examined the air expired by man for Absence of bacteria. He found that when the air was expired bacteria in the through a nutrient solution there was no infection of the latter if only the entrance of saliva, \&c., was prevented. As a matter of fact we must, from what we have learnt as to the detachment of bacteria from moist surfaces (see p. 688), regard it as very improbable that bacteria would be detached from the constantly moist mucous membranes and carried with the current of expired air which is constantly saturated with moisture. -Hence the only way in which we can conceive that organisms present on the mucous surface of the respiratory tract can spread through the air, is that in speaking and coughing small particles of fluids are detached, expelled, and remain mixed for short distances with the expired current of air, or that sputa dry up after their expulsion, and are converted into dust.

* Zeitschr.f. Irygiene, Bd. 1, Heft 1.

+ Klin. Monatbl.f. Angenheilk., Jahrg. 20, 1882. 


\section{PART VII.}

THE MODE OF SPREAD OF THE INFECTIVE DISEASES.

The principal Is the following paragraphs we shall sketch shortly features in the mode of spread of the infective diseases. the mode of spread of the human infective diseases, but only in so far as it bears an intimate relation to the biological facts mentioned in the preceding pages, to the distribution of the pathogenic bacteria, and to the conclusions already drawn. And even within these limits we shall by no means attempt to give a complete description in view of the large number of these diseases which never completely coincide in their mode of spread, of the number of the problems to be solved, of the numerous isolated facts obtained by investigation and observation, and of the manifold hypotheses and theories which have been promulgated. This limitation will be the more permissible, because in a former chapter on "Cholera" a detailed description of the mode of spread of at least one kind of infective agent has been given, and to this we must refer the reader as an example which may be extended on the fundamental lines to be mentioned below.

In considering the mode of spread of the infective diseases we have in the first place to take into consideration the sources of infection, the modes of transport to man, and the points of invasion at which the penetration of the infective agents into the healthy body occurs. Then we have to pay special attention to the individual predisposition and immunity, for these points influence the mode of spread of many infective diseases in a high degree. Finally, we must shortly consider the meaning and the causes of the local and seasonal variations in the epidemic distribution of the infective diseases. 


\section{The Sources of Infection.}

At the present time we only reckon as infective All infective diseases those affections which are caused by the diseases are penetration of a pathogenic agent from without into agents which the body of the patient, and its multiplication there. the body of the Hence a relatively insignificant quantity of the virus is patient. always sufficient for the infection, but a certain time usually elapses before the development of the action, this time being necessary for the multiplication of the virus.

If a noxious agent must be employed in a certain and large dose, if it does not multiply in the body of the patient, and if the action sets in relatively quickly, the process is comprehended under the term "intoxication." And in like manner when disease is produced by a so-called miasma, that term implying a gaseous chemical substance or a mixture of unorganised substances not capable of reproduction in the body, we regard it not as infection but as intoxication.

From the fact that reproduction is necessary, it follows Hence the that the infective agents are all organised beings. It pathogenic has been further ascertained by the researches of the ing organisms. last ten years that these organisms-quite apart from the animal parasites-chiefly belong to the class of bacteria; it is possible, however, that the exciting agents of certain human infective diseases belong also to other as yet imperfectly known classes of micro-organisms, e.g., the mycetozoa.

It follows also, from the reproduction of the infective All infectire agents in the body of the patient, that all true infective diseases can diseases can be transmitted continuously from sick to from the sick healthy individuals, although it is possible that for to the healthy. reasons to be discussed later this transmission is at times accomplished only under marked difficulties, and at certain stages of the disease, and in one particular way. Quite recently the malarial virus has been transmitted to healthy individuals by inoculation of the blood of sick people, and hence the infective character of this disease has been demonstrated with certainty.

Although this power of multiplication and trans- 
mission is common to all infective agents, we have still to ascertain their natural mode of spread in each individual case, and especially whether and to what extent the infective agents are transmitted from the sick to the healthy under the ordinary conditions met with in practice.

With reference to the natural mode of spread, the question is whether agents capable of producing infection are given off by the sick.

Contagious non-contagious infective diseases.

The natural mode of transmission evidently depends on whether the infective agents can leave the body of the sick in a state capable of producing infection. If they are given off from some diseased surface of the body in sufficient quantity, in a living state and sufficiently resistant, then the disease may be transmitted directly from the sick to the healthy, and spreads under certain circumstances by contagion.

If, on the other hand, the infective agents which are reproduced in the body of the sick do not leave it at all, or only in a state incapable of causing infection, the infective disease in question is non-contagious. The infective agents which cause these diseases must be located somewhere in the surroundings of man, from whence they can penetrate into healthy individuals, and where they can also probably continue to multiply. Hence all the non-contagious infective agents are capable of a saprophytic existence, and belong to the group of facultative parasites (see p. 629). The most important representatives of this group are the infective agents of malaria.

In the group of the contagious infective agents we are at once struck by a remarkable variety in the degree of contagiousness. This undoubtedly depends in part on the unequal resisting power of the healthy body against the various pathogenic agents, an influence which will be dwelt on presently; in part also, however, on the quantity and the resisting power of the infective agents which are given off from the diseased body. Contagion by Some of these are very vulnerable and quickly die after directcontact. they leave the body, and therefore can only pass from the sick to the healthy by direct contact. Others retain their vitality in the surroundings of the sick for some time after they are given off from the body; they 
can therefore be transmitted not only by direct contact Contagion by but also by all sorts of objects which play the rôle of surrounding but also by all sorts of objects which play the role of objects. transporting agents; some are characterised by a particularly lengthened resisting power, and in the case of these, the number of modes of transport is markedly greater. In effecting the transport, and in preserving the infective agents, surrounding objects are not all of equal value, some act better, others worse. Porous substances, soil, articles of clothing, \&c., appear to be particularly well fitted for these purposes.

In the preceding paragraph we have only referred to the case where the objects in human surroundings act merely as indifferent means of transport for the contagious infective agents, and where the latter do not grow or multiply on them; these infective agents are only able to multiply in the human body, and therefore belong to the obligatory parasites.

But there are also contagious infective agents which can lead a saprophytic existence on the dead materials in our surroundings, and must therefore be classified as facultative parasites. In this case there is a multiplication of the sources of infection outside the body of the patient, and this may go on to such an extent in our surroundings, that there are in fact more chances of infection by the infective agents produced outside the body than by direct or indirect transmission by indifferent objects of the infective agents given off from the patient. On the whole, however, the simple transport of resistant infective agents by various objects is in many respects of as great importance for the spread of a disease as when a certain degree of multiplication is possible outside the body; where the obligatory parasites are preserved for a long time, and are very resisting, the important influence of the surroundings is often as marked as when multiplication of the possibly less resistant facultative parasites has here and there taken place. In recent times special slight importstress has been laid on the distinction between theinfective agents according as they belong to the facultative or to the obligatory parasites, or according as they multiply in the surroundings, or pass through them unchanged;

Multiplication of the infective agents on surrounding objects. ance of saprophytic growth for the spread of diseases. 
but this distinction is not of great importance from the point of view of the mode of spread of human infective diseases. 1. Contagious To mention some examples, we have in the group parasites with of the contagious obligatory parasites infective agents slight resist- which are distinguished by slight resisting power and
ing power.

With greater resisting power. require direct inoculation; for example, the agents of syphilis, gonorrhœa, and hydrophobia. To those diseases which can also be carried by various objects on account of the greater resisting power of their causal agents belong small-pox, measles, scarlatina, tuberculosis, glanders, diphtheria, and the majority of the infective diseases of wounds. Differences in the contagiousness of these diseases are either due to the degree of resisting power of the infective agents, or to the fact that the situation of the points of invasion and the special protective arrangements of the healthy body only permit their entrance in rare cases.

2. Contagious To the group of the contagious facultative parasites
facultative parasites. belong the exciting agents of typhoid ferer, cholera, and anthrax. Here also the chief mode of spread is by means of surrounding objects, which only act as transporting agents, viz., clothing, water, soil, \&c. ; at times, however, multiplication or fructification also occurs on articles of food, in regions which are marshy, or where vegetable remains are plentiful, \&c. This occurrence may exert a special influence on the mode of spread of the disease, because the maintenance of the species is thereby rendered certain for a considerable time, and also because, as in the case of anthrax, the formation of resisting spores occurs at times only outside the body.

Spread of anthrax.

Anthrax behaves very differently according as it pursues the course of a septicæmia as a result of a cutaneous inoculation, or of an intestinal anthrax from swallowing food containing spores. In the first case, bacilli are not usually given off from the affected body; the surface of the wound is occupied by other bacteria, and it is only at times that anthrax bacilli are excreted in the urine; after death the cadaver may become a prey to putrefactive bacteria without the passage of virulent anthrax bacilli into the surroundings. In such cases-for example, in animals artificially inoculated 
with anthrax - it is evident that healthy animals do not easily become affected, even when they live in close contact with the diseased ones. On the other hand, in intestinal anthrax quantities of dejecta containing anthrax spores are poured out on the meadows from which healthy animals obtain their food, and thus it is easy to understand how the disease spreads by the spores which are preserved in the grass. In like manner in burying the bodies of animals which have died of anthrax, and which have been opened, blood, \&c., may be left on the surface of the soil, and spores subsequently form there and ultimately get into the fodder.-While, however, in this mode of spread the pathogenic agents are as a rule ultimately killed or interfered with by some meteorological influence, it is probable that there are some natural abodes of the anthrax bacilli where they multiply outside the body and constantly form new spores, these abodes being therefore dangerous and permanent reservoirs; situations of this kind are present in the neighbourhood of rivers and marshes, where sufficient moisture, favourable temperature, and a plentiful supply of dead vegetable substances are present, and thus in exceptional cases a saprophytic growth of anthrax bacilli can take place. From these situations the spores may be transported to meadows by means of floods, and there give rise for a series of years to outbreaks of disease, although the multiplication of the infective agents may be limited to the body of the diseased animal.-In the case of man, as is well known, infection with anthrax occurs almost exclusively by means of the bacilli and spores developed in the diseased animal, and adbering to the skin, hairs, \&c., and the fact that the formation of the spores occur for the most part after the death of the animal does not in any way detract from the contagious character of this mode of spread.

Various other infective agents may show a certain Parasites amount of saprophytic growth, which, however, is of less which have importance as regards their spread than in the case of saprophytic typhoid fever, cholera, and anthrax. The staphylococci growth. are very widely distributed; but it is relatively unimportant whether their number increases only as the result of constant reproduction in pus, or also as the result of saprophytic growth. The streptococci, erysipelas cocci, \&c., are able to multiply on dead nutrient substrata under favourable conditions; but the usual mode of spread to healthy individuals is nevertheless either in the fresh state by contact, instruments, \&c., or in the 
preserved state by clothes, dressings, furniture, or from the surface of the body.

Unequal re. sisting power of the faculta. tive parasites.

Also among the so-called facultative parasites we find very varying degrees of resisting power, and this influences the mode of spread to a much greater degree than the temporary saprophytic multiplication. Anthrax spores show, for example, a very marked resisting power, and hence can be carried by the most various objects, and can act after a very long interval of time; the spores of the typhoid bacilli which are possibly present in large numbers in the dejecta of the sick do not, it is true, possess such great resisting power, but they can nevertheless retain their vitality for several months in various substances, in fluids, and in the dry state; the cholera bacilli, on the other hand, as mentioned above (p. 444), die in a few days under the conditions normally present in our surroundings.

Non-contagious facul tative parasites.
In the third group of the non-contagious facultative parasites we must include the exciting agents of malaria, which, however, are as yet completely unknown; these organisms possibly belong to the mycetozoa, and probably multiply in water which is rich in vegetable materials, and especially on marshy ground, and are carried when drying occurs into the air immediately over the surface.

For a long time it has been the fashion to employ the term non-contagious for all those infective diseases in the spread of which our surroundings play a distinct rôle, and in these cases-for example, in malaria-it has been assumed that the infective agents are transmitted, Pettenkofer's not by the sick, but by the surroundings. This incorview that typhoid fever and cholera belong to the last group.

Undoubted contagiousness of typhoid fever and cholera. rect view as to the sources of infection has even been applied to the obligatory parasites ; but it is the facultative parasites, more especially such as the exciting agents of typhoid fever and cholera, that have been designated by a large number of epidemiologists as non-contagious, and placed in the same category as malaria.

Apart, however, from undoubted practical experience that cholera and typhoid fever are contagious, the view just referred to, and which is now held chiefly by Petten- 
kofer, is irreconcilable with the results of the more recent experimental investigations with regard to the specific exciting agents of typhoid fever and cholera. We see that both in typhoid fever and cholera the living infective agents of these diseases are given off in large numbers in the dejecta of the sick, and there is absolutely no reason why they should not transmit the disease to a healthy predisposed individual, either by immediate contact, or through the intervention of some object. Pettenkofer assumes that these agents as they Excretion of come from the sick are not ripe, and are not able to cause infection; and he holds that they must first acquire their infective properties in a suitable soil outside the body. This idea of a specific transformation of the infective agents in the soil could, however, only be held so long as we were completely in the dark as to the nature of the infective agents; it is no longer admissible in the present state of our knowledge as to the biology of the infective agents of typhoid fever and cholera. And besides, we have definitely ascertained from experiments on animals, as well as from involuntary experiments on man, that there is no necessity for a transformation of the infective agents after they are given off by the sick in order to enable them to cause infection.

The possibility of the spread of these diseases by Role of the contagion, and its occasional occurrence, must there- surroundings contagion, and its occasional occurrence, must there- in the spread fore be looked upon as undoubted facts. It is true that the surroundings play a very marked part in the natural of both distribution of these diseases, but they do so chiefly by preserving unaltered the infective agents given off by the sick, and bringing them in contact with predisposed individuals. Among the numerous substrata and objects in our surroundings, the soil appears particularly well adapted for such a preservation, and therefore in many cases it plays a prominent part as a means of transport. To a less degree the spread of these diseases is also influenced by a multiplication of the infective agents outside the body-on nutritive materials, on the surface of the soil, \&c.; but in our climate this ectogenous development and multiplication of the typhoid 
Local and seasonal predisposition may be explained withont assuming any specific influence of the soil. and cholera bacilli is of little importance, and has but little influence on the mode of spread of the disease, while on the other hand it plays a more important róle in tropical countries.

The chief fact which Pettenkofer has brought forward in support of his views is the peculiar local and seasomal distribution of cholera and typhoid fever, which according to him can only be explained as a result of some influence of the soil. It has been already shown in the chapter on cholera, and will be further discussed below, that such local and seasonal variations in the distribution of these diseases can be very well explained, even though we hold to the opinion of the contagiousness of both diseases, and only ascribe to the soil the rôle of a part of our surroundings, in that like other substrata it harbour's the infective agents given off by the sick for a considerable time, and then again brings them into contact with man.

In accordance with the fore. going views we have to consider the following sources of infection.

Haring thus arrived at definite views as to the various modes of spread of the infective diseases, it is easy to group together and characterise the sources of infection in the case of each individual disease. The following is the result in the case of the more important infective diseases, omitting those whose mode of transmission is as yet too imperfectly known (viz., leprosy, recurrent fever, dysentery, yellow fever, \&c.) :-

\section{a. Contagious Obligatory Parasites.}

(a) With slight resisting power.

Syphilis and gonorrhoa: sources of infection, the fresh secretions.

Rabies : fresh saliva, blood, spinal cord, and brain. 
( $\beta$ ) With greater resisting power (also transmissible by various objects).

The acute exanthemata (small-pox, scarlatina, measles, sc.) : typhus fever. Sources of infection, the morbid products of the skin and mucous membranes. The exciting agents are probably cast off in large quantities ; they can withstand drying, they adhere to rags, wash linen, beds, furniture, \&c.

Diphtheria: the sputa, membranes expelled by coughing, secretions of the mouth, secretions from other mucous membranes attacked by the disease. The pathogenic agents can probably retain their vitality in the dry state for a certain time, for how long is as yet unknown; they can adhere to the linen, bedding, floors, soil, \&c. We do not as yet possess more accurate knowledge as to the nature of the sources of infection.

Tuberculosis: chiefly the sputa. The spores cast off in the sputum retain their vitality in the dry state for about six months. They can adhere to the linen, clothes, furniture, \&c.; they are also present in the soil under the flooring in a living condition, in the dust of the streets, \&c. In consequence of the large number of phthisical patients, the number of the infective agents in the sputa, and their resisting power, the sources of infection are almost everywhere present.

Glanders: the secretions of the diseased mucous membranes, and of the ulcers of the skin, furnish the infective agents in large quantities. According to Loeffler's recent investigations spores are probably not formed, for the dry cultivations usually die after some days or weeks (it was only exceptionally that they were found alive after three months), and a temperature of $55^{\circ} \mathrm{C}$. kills the infective agents in five minutes. The most important sources of infection are therefore the fresh secretions and, for some days or weeks, the various objects to which they adhere.-According to Loeffler a saprophytic growth of the bacilli does not occur in the nutrient materials present in the stalls. 
Erysipelas and other human infective diseases of wounds (puerperal fever, \&c.): secretions of wounds either in the fresh state or dried on linen, dressings, bedding, ultimately beneath the floors. In the majority of cases we do not as yet know how long the infective agents retain their vitality in the dry state. The ordinary pyogenic organisms are present in dust, on clothing, on the surface of the human body, \&c.

\section{b. Contagious Facultative Parasites.}

Anthrax: 1. The fresh secretions of wounds or of the diseased mucous membranes, also dressings, clothes, \&c. 2. Fæces of animals suffering from intestinal anthrax, soil and grass impregnated with such dejecta. 3. Preserved portions of anthrax cadavers (skin, hair), earth (or portions of the dwelling, clothing, \&c.) which has come in contact with the blood, organs, \&c., during the post-mortem examination. - In all cases the duration of the infective power depends on whether or not spores are formed. There are plenty of opportunities for their formation outside the living body in a great variety of substrata, provided the temperature is sufficient. 4. Saprophytic colonies of bacilli growing on the banks of rivers, \&c.

Typhoid ferer: dejecta of patients. For the most part the infective agents are present in the spore form ; they retain their vitality for a considerable time in a dry state, at all events up to three months (Gaffky); they also live for sereral months in watery fluids, and in drinking water. Hence various objects (linen, bedding) which come in contact with the dejecta may retain infective properties for a long time. It is probable also that the spores may be preserred for a long time in the soil (in garden and field earth on which dejecta has been deposited).-Multiplication can ultimately occur in nutrient materials, especially in milk, in broth, on meat, \&c.

C:holera: dejecta of the sick. They only retain their 
vitality for a few days under ordinary conditions; they die as the result of drying or from over-growth by saprophytes. Hence the most frequent sources of infection are the fresh dejecta, and the objects contaminated with them : linen, bedding, water, food, superficial layers of the soil.-Multiplication can occur on various nutrient materials, as in the case of typhoid bacilli.

\section{c. Non-contagious Facultative Parasites.}

Malaria: probably in marsh water, on the banks of rivers, on the surface of marshy soil.' Nothing more precise is known.

\section{The Modes of Transport.}

According to the description given in the preceding Modes of chapter, the sources of infection are as a rule repre- transport sented by the fresh or dry secretions of wounds, of the sources of diseased mucous membranes, or of the skin; further, healthy by objects and materials in our surroundings contaminated by them, especially dressings, linen, clothing, bedding, the soil under the flooring, drinking water and articles of food, the most superficial layers of the soil.

From these sources the infective agents may be carried to individuals capable of taking the infection.

1. By contact between the healthy and sick. The 1. Contact surface of the body of healthy individuals is brought between into direct contact with the morbid secretions or the sick indiobjects harbouring them, by handling the infected persons, or even through a third person. Almost all the infective diseases can be transported in this way. This mode of transport is on the whole extremely frequent, and in the case of many diseases it is the only, or at least the most important, mode of infection (syphilis, gonorrhœa, infective diseases of wounds, \&c.).

2. By contact with infective animals. The transmis- 2 . Contact sion of the most important zoonotic diseases occurs by between 
diseased animals and man.

3. Transport by insects.

4. Transport by water and food.

5. Transport by currents of air.

Influence of the transport by air on the contagious. ness contact with the fresh or dried morbid excreta, or with objects contaminated therewith, the contact being brought about by intentionally handling these materials, by bites, \&c.

3. By insects which transport fresh or dried excreta, or objects contaminated with them, to individuals capable of taking the infection.

4. By swallowing food or water which contain infective germs. This is the most important mode of transport for those infective diseases in which the invasion only begins from the intestine (typhoid fever, cholera). Water and food may be directly contaminated by the infected excreta, or the contamination in the case of the food may be occasioned by contact, insects, adhering portions of soil, or infective air germs, in the case of water by the wash linen, \&c.

5. By aërial germs. As has been pointed out above, the transport by currents of air only occurs in the case of those infective agents which can withstand drying. Accordingly it does not come into play in cholera; it is, further, almost excluded or occurs very rarely in glanders and some infective diseases of wounds; on the other hand it plays an important róle in the acute exanthemata, typhus, typhoid fever, tuberculosis.

It is apparent that the last-mentioned mode of transport has an important influence on the mode of contagion. In cases where it cannot occur the other modes of transpurt are much more easy of recognition and avoidance. We can comparatively readily protect ourselves against infection by contact by means of careful cleanliness, and against the introduction of the infective agents by food and water, by careful selection and preparation of the nutriment, and direct transport by infected animals or insects occurs on the whole very seldom. On the other hand, transmission by currents of air occurs in an unnoticeable manner and one against which no protection exists, and it may extend over considerable distances; the infective agents which are transportable in this way may also infect individuals who do not come into immediate contact with the sick 
or with infectious objects. The number of infections caused by them is under certain circumstances much greater and more widely distributed. That all the diseases belonging to this group do not in practice show an equally high degree of contagiousness, - that, for example, the acute exanthemata and typhus fever are extremely contagious, while in typhoid fever and tuberculosis the danger of contagion is much less,-is explained by the other conditions necessary for infection; for example, by the situation of the seats of invasion and by the individual predisposition. These two conditions are referred to more in detail in the following pages.

The detachment of the infective agents from their Conditions for substrata and their passage into the air occurs from the transport by dried excreta and the various objects to which they adhere-from clothing, from the flooring, from the surface of the soil. In all cases complete dryness of the surface is a necessary condition for the detachment of the infective germs; hence in the soil this only occurs when a drying zone is present, and when the most superficial layer is in a state of dust.

It frequently happens that the same mode of transport Indirect transdoes not carry the infective agents directly from the source of infection to the point of invasion, but that it carries them in the first place to another means of transport. Thus, for example, the detached infective agents may be carried by currents of air to articles of food, and from thence reach the exposed individual.

\section{The Seats of Invasion.}

Before we can arrive at definite ideas as to the im- Do the skin portance of the seats of invasion for the spread of the and mucous infective diseases, we must decide the question whether the healthy the bacteria can penetrate the various surfaces of the the entrance body, the skin, and especially the mucous membranes, of bacteria ? when these are in a normal condition? 
'This question was formerly answered in the affirmative in the case of the intestine and lungs.

'The saprophytes are supposed to die in the blood.

This assump. tion is in. correct.
This question has or the most part been answered in the affirmative. The passage of oil globules through the walls of the intestine, and the enormous surface and delicate epithelial corering of the lung, has been prominently pointed out; and the constant entrance of saprophytic bacteria, and the occasional passage of infective agents into the interior of the body, especially into the circulating blood, has been assumed. Pettenkofer has indicated the lungs as the chief organ through which the pathogenic bacteria pass into the blood; according to the view generally held, they are then carried from the lungs to those parts of the body in which the local affections characteristic of the disease in question usually appear. Thus the infective agents of cholera and typhoid fever, when they are inhaled, are supposed to pass through the lungs into the blood, and from thence into the mucous membrane of the intestine, where they multiply and set up the specific alterations.

The fact that no bacteria have been found in the interior of the healthy body in various careful investigations is opposed to the riew that saprophytic bacteria are constantly penetrating into the normal body from the lungs and intestine. Von Fodor and others have, however, sought to explain this contradiction by the assumption that the saprophytic organisms which pass into the body are rapidly destroyed in the blood.

Such an explanation is, however, no longer admissible after the researches of Wyssolzowitsch, to which we have previously alluded. These investigations have shown that a great variety of bacteria are not destroyed in the circulating blood, but retain their vitality in the interior of certain organs for several hours, days, or even months. If, therefore, there were a constant passage of bacteria from the lungs and intestines into the blood, we must undoubtedly frequently find them in considerable numhers in the interior of the body, and the resistant subtilis spores which are always present on the surface of the body would gradually accumulate in the body.

As the result of these experiments it is rery improbable that bacteria ean pass through the mucous mem- 
branes and lymphatic glands, and ultimately reach the blood. It is probable also that pathogenic bacteria behave in this respect in the same manner as the ordinary intants of the surface of the body; for the excreting membranes of the animal body (kidneys) are just as impassable for the numerous kinds of pathogenic bacteria as for the saprophytic organisms.

Nevertheless it was desirable to make direct experi- Direct experiments as to the passability of the walls of the lungs and of the intestine by bacteria; and experiments of this kind have been carried out in large numbers by Wyssoments as to the passability of the lungs and the intes. lowitsch during the course of last year in the author's tine by laboratory. From these experiments, which will be shortly published in the Zeitschrift für Hygiene, it follows with complete certainty that neither the surface of the lung nor of the intestine permits the direct passage of bacteria into the blood, so long as the mucous membrane is intact; even if small lesions of the mucous membrane are present, the bacteria do not as a rule reach the blood, but remain in the neighbouring lymphatic glands.-In the Intestine. experiments on the intestine, staphylococcus aureus, bacillus indicus, and spores of subtilis were employed; the cultivations were given in large quantities as food, and it was found that the bacteria did not suffer any injury from the gastric juice; but in order to be more certain as to this point, they were in some cases injected into loops of intestine isolated by ligatures. In no case, however, were the bacteria found in the organs which, as had been previously ascertained, always preserved any germs which had really reached the blood; while, on the other hand, they were always found when even only very small quantities of the same bacteria were introduced into the blood or into the peritoneal cavity. In the experiments with loops of intestine, small injuries of the intestinal membrane were unavoidable; and then the bacteria in question could be found in limited numbers in the corresponding mesenteric glands, but did not pass beyond them.*

* Ribbert (Deutsch Med.Woch., 1885, Nr. 13) and Bizzozero (Centralbl. f. l. med.Woch., 1885, Nr. 45) found various kinds of bacteria in healthy 
Experiments as to the passability of the surfaces of the lungs were made by causing the animals to inhale either the dried cultivation in the form of dust, or a fluid cultivation in the form of spray; or the material was injected into the trachea in small and repeated quantities. Here also no passage of the bacteria into the blood was observed, even when the lung tissue had undergone pathological changes as the result of the injections.These results harmonise entirely with those obtained by Arnold, who found by very numerous and careful investigations that minute bodies (soot, ultramarine, \&c.), when inhaled do not pass into the blood or organs of the body, but at most only reach the neighbouring bronchial glands. Arnold has ascertained by accurate microscopical investigations that the human lung does not behave differently to that of animals as regards its passability to minute elements; soot does not pass into the internal human organs by normal preformed paths, but only by abnormal ways.

There is no passage of bacteria through the lunge and in. testine.

Invasion of the body either by direct introduction of bacteria into the blood.
Hence we have given up the former view that bacteria can pass readily into the blood, and from thence into the organs of the body through the intact lungs or the normal intestine; on the contrary, the bocly of warm. blooded animals nowhere offers a surfuce permeable by infective agents, so far as is as yet known, unless important alterations of the normal tissue have previously occurred.

One mode in which an infective agent can enter the blood and the internal organs of the body is when a large opening is present which permits its direct passage into the blood; for example, a wound of the skin or mucous membrane communicating with a blood vessel.

animals in the follicles of the processus vermiformis and of the sacculus rot. at the entrance to the cæcum, which had evidently penetrated from the lumen of the intestine; they did not appear to be alive in the deeper layers of the follicles, and could not be traced beyond the follicles. This occurrence of bacteria at one special part of the intestinal mucous membrane, together with the constantly negative results obtained in other parts of the intestine, and with the evident death of these bacteria in the deeper layers, quite corresponds with the results of Wyesokowitseh's experiments. 
This is a mode of infection which we frequently produce artificially in our experiments on animals, but which seldom occur's under natural conditions. 'The experiments Even then inon animals, however, teach us further that in many infec- fection does tive diseases the penetration of the infective agents into occur. the blood is not sufficient for the production of infection; we see that the bacilli of pneumonia, of malignant œdema, of cholera, the micrococci of erysipelas, \&c., do not cause disease when injected into the blood, with suitable precautious against the entrance of other bacteria, such as disinfection of the wound in the skin, while they are virulent in the same animals when introduced into other parts, such as into a wound of the lung, into a wound of the skin, into an altered intestine, \&c. This is explained in part by the fact demonstrated by Wyssokowitsch that bacteria circulating in the blood are not excreted through certain surfaces of the body, such as the wall of the intestine, and cannot pass into the lumen of the intestine, for example, except when hæmorrhages occur in the mucous membrane; and that therefore cholera and typhoid bacilli, even when they have penetrated into the blood, do not always reach their proper seat of action. Wyssokowitsch's experiments also give a partial explanation, these experiments showing that the endothelial cells of the capillaries have the power of fixing and destroying bacteria circulating in the blood; hence only those bacteria which are able to overcome this protective arrangement can set up disease from the blood. In the case of those resistant infective agents which can penetrate with the blood into various organs, and multiply there or in the blood itself, injection into the blood is a very active mode of infection, e.g., in the case of the exciting agents of septicæmia, anthrax, and tuberculosis.

Besides this infection through the blood, which occurs Or the infeccomparatively seldom, infection evidently occurs in many tive agents dieases by the primary establishment and development special point of the infective agents at those parts of the body in wards become which the specific process occurs or begins; so that the future disense. seat of the alterations characteristic of the infective 
disease in question coincides with the specific seat of invasion. Erysipelas develops in the lymphatic channels of the skin; wounds of the skin which open an entrance to these channels form the points of invasion of the erysipelas cocci: gonorrhœa establishes itself only on the uretbral and conjunctival mucous membrane, and these are likewise the seats of invasion of the gonococci : pneumonia is limited to the lungs, and there the invasion of the infective agents must begin: typhoid and cholera localise themselves in the first place in the intestine (leaving out of account the secondary deposits of the typhoid bacilli), and here we must look for the seats of invasion of the infective agents. If typhoid bacilli are introduced into the lungs, pneumoria bacteria into wounds in the skin, gonococci on the intestinal mucous membrane, there is no result eren when small wounds and injuries are present.

Some infective agents can set up a primary specific disease in several different organs of the body; for example, anthrax in wounds of the skin, in the intestine, in the lungs; tuberculosis likewise in the lungs, intestine, genito-urinary system, \&c.; diphtheria on various mucous membranes. In the case of these diseases the points at which the infective agents can enter are therefore correspondingly more numerous.

In the case of the acute exanthemata it is probable that the skin or the surface of the mucous membranes are the parts which are specially predisposed for the derelopment of the infective agents, and it is also probable that these parts are the seats of invasion of other as yet unknown infective agents.

These points of invasion permit the entrance of bacteria either when in a normal condition;

We must next inquire whether these points of invasion peculiar to the various kinds of infective agents permit the establishment and development of these agents when the tissues are in the normal condition, or whether solutions of continuity of the skin or mucous membranes must be present to enable the infective agents to penetrate. It is conceivable that some infective agents do not require any preparation of the seat of invasion, but only that they should be protected while 
developing in folds and recesses of the mucous membrane, and not be readily removed with the mucus or overgrown by saprophytes. In such situations the parasites might be able to multiply to a certain extent, and then lead to a production of toxic materials which would be sufficient to destroy the neighbouring cells, and thus allow them to penetrate more deeply into the tissue. Such penetration through normal skin and mucous membrane must be assumed, more especially in the case of the infective agents of the acute exanthemata, which often attack very numerous individuals.

Other infective agents, on the contrary, probably require or the infecminute lesions or solutions of continuity of the mucous membrane in order to obtain a firm footing in the tissue, tive agents require small lesions at the and multiply at first at the cost of the dead cell material, sion. and spreading from that point carry on the struggle against the living cells. In all cases, however, the presence of such minute injuries farours the entrance of all infective agents and increases the individual predisposition (see below).

The fact that a specific and exclusive seat of invasion Importance of is necessary for each infective agent evidently is of great the specific importance as regards the mode of spread of the infective diseases. For the transmission of this group of diseases of the diserse. it is evidently not sufficient that the means of transport should carry the infective agents from the source of infection to some part or other of the body, but it is also necessary that they should be brought to a particular situation. In the case of cholera and typhoid the disease must therefore occur chiefly as the result of swallowing infected water and infected food; it is possible that the germs may also reach the mouth by contact or by the inspired air, but it is only in relatively few cases that a sufficient number of the infective agents will pass in this way in a living state through the stomach into the intestine.

It is further evident that the position and other con- Influence of ditions of the specific points of invasion must have a the position of great influence on the danger of infection. Although invasion. the spores of the typhoid bacilli are probably more 
resistant than the infective agents of the acute exanthemata, and although both are produced in large quantities and distributed in the surrounding world by the patient, the latter are, nevertheless, incomparably more contagious, because the unprotected surfaces of the body can be readily invared by them, and these surfaces are very easily infected by contact or by currents of air ; on the other hand, in the case of typhoid fever we usually have to do with a limited mode of transport by means of imperfectly prepared food and of impure water, and the seats of invasion are difficult of attack and provided with a protective arrangement; in this case also currents of air can only exercise an influence as a means of transport in so far as they curry the specific infective agents, in the first place to the food, and under favourable conditions by means of the food to the intestine.

In the case of some infective agents which are as yet but little known (malaria, relapsing fever, \&c.), we can scarcely put forward any hypotheses as to whether specific points of invasion are present at all, or where they should be looked for.

\section{Individual Predisposition.}

Unequal predisposition of different species and of different in
dividuals.
Experience has long ago taught us that the different infective agents are not equally dangerous to all kinds of warm-blooded animals, but that the one can affect only this, the other only that species. Closely allied species and races of animals often show in this respect the most striking differences; thus the bacillus murisepticus kills without exception every house-mouse inoculated even with the most minute quantity, while field-mice are not at all affected even by large doses; and the micrococcus tetragenus is only infective for the white variety of house-mice, while it is not infective for the grey variety.-But even among the individuals of one and the same species similar differences exist; and the infective organisms which are peculiar to man attack for the most part only a certain number of predisposed in- 
dividuals, while others equally exposed to the attack of the infective agents are not affected, in other words are immune.

As to the causes and the meaning of this individual predisposition and immunity we know as yet very little, but the results of a large number of experiments on animals give us some insight into the behaviour of the infective agents in the body. Further investigations must, however, be made on these points before we can come to any very definite conclusions. The factors Factors which which influence the predisposition of the body lie partly are of inin the body itself, in the constitution of its cells, secretions, \&c., and come partly from without, these external factors aiding the infective agents in that they render the body abnormally susceptible to attack.

In the first place it may happen that the access of Protective certain infective agents to their specific points of invasion is rendered difficult by the natural protective arrangements of the body; thus the gastric juice can, according to its degree of acidity, and according to its quantity, injure those infective agents which must develop in the intestine; and this injurious action may be present to a greater degree in one species of animal, or in one individual than in other individuals, where the infective agents more easily pass this protective arrangement.Further, as regards those infective agents which have their seat in the lungs, the more or less narrow and convoluted entrance to the respiratory tract, the ciliated epithelium, and the sensitive mucous membrane form a protective arrangement of varying efficacy, and according to the development of these arrangements the one species or the one individual will have an advantage over the other as regards the ease with which parasitic bacteria can enter the lungs.

Further differences in the constitution of the points Differences in of invasion even of an apparently trivial character must the characters exercise a very important influence. Thus according to of invasion species and race, according to the age and state of nutrition of the individual, \&c., there are probably differences in the skin, in the mucous membrane, and 
especially in the epithelium, which, although scarcely noticeable, have nevertheless a marked effect, and permit or prevent the growth of the infective agents. Loefler, in his investigations on diphtheria, has brought forward a very beautiful experimental proof of the importance of the character of the epithelium; he showed that young guinea-pigs could be infected in the vagina by cultivations of the bacilli of diphtheria, evidently because the epithelium of the mucous membrane is extremely delicate and easily injured; older animals, whose vagina is protected by tough epithelium, were, on the contrary, quite insusceptible to this mode of inoculation.-The variation in predisposition in accordance with age which is seen in various human infective diseases, must probably be in part referred to a similar influence of the epithelium at the point of invasion. Further, many facts point to the view that even the very slightest pathological alterations or loosening of the epithelium, such as usually occurs in catarrhs for example, also render infection easier.

Influence of the other cells.

Further, the condition of the other more deeply placed cells of the affected organ is also of importance for the occurrence of the disease. The endothelial cells of the capillaries, and to a very marked extent in some organs the cells of the lymphoid tissue, appear to play an important part in the battle with the attacking bacteria, and on the vital energy of these cells the result of the battle-its rapid termination before general infection occurs, or its continuation in ever-increasing dimensions-will depend to a very marked degree. In the case of the endothelial cells of the blood vessels it can be experimentally shown how a general depression of the cell energy by poisons, and especially by ptomaines, leads to a totally different ending to the battle in which in the normal condition these cells are, in the case of certain species of bacteria, always victorious; it can be shown that, under the influence of ptomaine poisoning, the same bacteria which formerly quickly died in the endothelial cells, and never caused disease in the animals, are now able to multiply extremely rapidly in 
the blood and cause the death of the animals which were previously immune (Wyssokowitsch).

Not uncommonly small injuries due to the most External in. various causes seem to prepare the points of invasion funceses; in for the reception of the infective agents, and to pave the $\begin{gathered}\text { points of inra- } \\ \text { sion. }\end{gathered}$ way for their growth. Experimental proof of this mode of predisposition has been recently brought forward by Orth and Wyssokowitsch; these investigators were able to set up typical endocarditis in rabbits by first causing trivial lesions of the cardiac valves, and then injecting cultivations of staphylococci; on the other hand, the infection did not succeed when the cultivation was injected without simultaneous injury of a valve.

In the intestinal mucous membrane predisposing injuries of this kind may at times be caused by animal parasites, by sharp and pointed constituents of the food, \&c. It is possible also that other, though not truly infective, bacteria, which, however, when they multiply to a marked extent in the intestine produce considerable quantities of ptomaines, and by means of these cause irritation of the intestinal mucous membrane with loosening of the epithelium, may be able to prepare the soil for the true infective agents, and thus give rise to predisposition.

It is evident that the various fuctors just mentioned Importance of present such manifold though slight differences that the different behaviour of individuals and species is rery diseases. easily intelligible. It is true that these-and especially the individual differences-do not play an equally prominent part in the case of all the infective agents; the more exposed the points of invasion, the more extensive and numerous they are, and the more energetically the infective agents in question are able to orercome the resisting power of the cells, so much the less will individual predisposition come into play. These con- Slighter insiderations seem to be especially applicable in the case $\frac{\text { fluence of the }}{\text { predisposition }}$ of the acute exanthemata of man, and hence the danger in the acute of infection in these diseases is much more general than the mode of in other cases where the exciting agents, although they possess the same or even a greater degree of resisting 
power, and can be distributed by the most various modes of transport, establish themselves, however, chiefly in the lungs or in the intestine,-in other words, in places which are protected by special arrangements against the entrance of infective agents in a manner varying in individual cases; and the danger of contagion is still less when the energy of the infective agents is so slight as compared with that of the cells of the body that they can only reach the place of their development when the epithelium has been specially prepared and weakened.

Influence of the predisposition in the spread of tuberculosis.

The influence of individual predisposition is most strikingly seen in the case of tuberculosis; in this disease we learn from experience that the greater or less accumulation of resistant infective agents in human surroundings plays a relatively subordinate part in the spread of the disease; on the other hand, the state of the protective arrangements at the points of entrance, and especially the state of nutrition of the mucous membrane, has such a definite and important influence that it has become the rule to pay the greatest attention to the removal of the individual predisposing factors (by good nourishment, increased respiratory movements, \&c.), and not to attempt the careful removal of the infective agents, as is done in the case of other infective diseases.

\section{Acquired Immunity and Protective Inoculation.}

Of special importance is the immunity acquired as the result of recovery from the same disease, or from one caused by similar or attenuated exciting agents.

Relapsing diseases.
Such immunity is not acquired in the case of all infective diseases. Erysipelas, pyæmia, gonorrhœa, relapsing fever, pneumonia, and malaria, frequently show relapses even within a short time after recovery from the first attack. Other diseases are followed by immunity for some time, but never without exception, nor to a similar degree, in the different species of animals; for example, anthrax may occur repeatedly in 
man and horses, while sheep and cattle seem to be protected by one attack of the disease. Cholera, as a rule, gives protection for some years against a second attack; nevertheless even in this case exceptions not uncommonly occur. A marked immunity, lasting for a Varying long time, follows a single attack of the acute exanthe- degrees o mata, and of typhoid fever. immunity.

In the case of those diseases which produce immunity, even though for a short time, it almost always happens that the second attack runs a milder course, and often occasions only a very trivial disturbance of the general condition. Nevertheless the length of time between the two attacks may, according to the nature of the infective agent, completely neutralise this effect.

Further, it is important to note that in the case of many diseases the severity of the attack seems to be almost of no importance for the production of immunity. In the case of the acute exanthemata, typhoid fever, cholera, \&c., we often observe remarkably mild cases, in which there is only a trivial local development of the infective agents at the seat of invasion, and yet recovery from such affections, which can scarcely be called diseases, may lead to immunity against the infective agent in question.-Nevertheless, in other diseases we are able not unfrequently to trace a relation between the degree of the immunity and the severity of the disease.

An explanation of the peculiar phenomenon of acquired Former immunity cannot at present be given on the basis of experi- attempts to ments. Numerous attempts have been made to furnish an explain the explanation. Thus Klebs and Pasteur assume that in the immunity. first attack of the disease some material that is necessary for the life of the pathogenic fungi has been removed from the body, and that the body thus acted on no longer offers a suitable soil for the development of the organism at a subsequent period. But the results of our cultivation experiments and all our biological experience contradict, on the one hand, the idea of such a sensitiveness of pathogenic bacteria towards minute quantities of an unknown nutrient material, and on the other the probability that such a state of matters should be kept up for years in the living body.-Chauveau, Wernich, and others have assumed that those products of the life of the bacteria which are noxious to the organisms them- 
selves may remain for a long time in the body, and thus afford a protection against subsequent invasions. But this disinfecting power of the products of the bacteria, which has been often insisted upon, appears, according to the accurate experiments of Sirotinin, to be in most cases a fable, or at any rate to be much exaggerated; and, on the other hand, such a stubborn retention of minute quantities of this bacterial poison in the living body does not at all correspond to our ordinary physiological ideas.-Grawitz sought to explain immunity by supposing that as the result of the battle between the cells of the body and the pathogenic organisms, the vital energy and the assimilating power of the animal cells is increased as compared with that of the parasites; and that the duration of the immunity is occasioned by the transmission of this increased physiological energy from one cell generation to another. But in this case it would be very difficult to understand why it is always only the same or similar infective agents which occasion a sufficient increase of the cell energy.

Assumption of a reactionary alteration at the seat of invasion.
A better view, and one more in correspondence with the views developed in the preceding pages, as to the mode of entrance of the infective agents, is that put forward by Buchner, viz., that that organ which is associated with the development of the specific infective:agents undergoes a reactionary alteration of its tissue under the influence of the bacteric development, and that this lasts for a long time, and does not permit a second development. Wolff berg has put forward a similar hypothesis with regard to the origin of the immunity against smallpox after vaccination. Wolff berg asserts that the alterations which lead to the immunity must occur in the skin, as being that organ which forms the first and most important point of attack for the infective agents; and he tries to point out the probability that the causes of the immunity are chiefly the destruction of the weak cells of the rete, and the retention and development of the more resistant elements.

On the assumption of a reactionary alteration of the specific seats of invasion, we can understand that it is only the infective agents of the same disease, or of one similar to it (or only wealiened agents), which are able to give immunity against a later attack by the same 
organisms. Only those parasites which have exactly the same seats of invasion can come into play in causing a reactionary alteration of these seats. - It further becomes intelligible that complete immunity against later invasions is at times obtained by locally limited affections which have caused an almost unnoticeable disturbance of the whole body, for it is only a certain local affection of the seats of invasion which seems to be of importance for the production of the immunity. - It is to be hoped that experimental investigations will soon afford a more sure basis for the attempt to explain immunity; as yet the explanations are quite hypothetical, and do not meet all cases, but only apply to that group of infective diseases which have specific points of invasion.

The experience as to the action of pestilences, and Protective inmore especially the knowledge of the protective effect of vaccinia against small-pox, which has been gained by experiments on millions of men for almost 100 years, have demonstrated that the acquired immunity is in many respects the most important factor in preventing the devastating action of the infective diseases. In vaccination we artificially transmit organisms which are remarkably like the infective agents of small-pox, but which excite in man only a mild and local disease. By this In variola. inoculation we can prevent the invasion of virulent infective agents of the same kind; and such a vaccination is of great value, especially for variola, because, as we know, one attack of this disease gives a very long continued and certain immunity; because, further, the attenuated vaccine material preserves its slight degree of virulence with great constancy; and because as a result we need neither fear injury from the inoculation, nor uncertainty in the result.

During recent years only few, and at the same time crude and uncertain attempts have been made to extend protective inoculation to other infective diseases, especially in the case of domestic animals, but since the year 
In chicken cholera.

1880 there has been a very active movement in this direction with the aim of providing an extensive application of protective inoculation.*

The starting point of this movement was Pasteur's discovery that the microbes of chicken cholera could be artificially attenuated, and that the inoculation of these attenuated bacteria caused a local affection in fowls, after recovery from which they were found to be immune against inoculation with the virulent infective agents of fowl cholera. On page 317 a more minute description of Pasteur's experiments is given; we need only add here that two vaccines have been employed in practice, of which the first is more, and the second less attenuated; the first vaccine is injected by means of a Pravaz syringe at the tip of the wing of fowls, and the second raccine is employed twelve to fifteen days later. As a result the animals are said to be protected against the virulent bacteria. Kitt was, however, unable to confirm Pasteur's results as regards the protective action of these inoculations. And eren if the action of the vaccine were prompt, it is very seldom that it could be of practical value in view of the usually very rapid spread of the disease in the hen-houses which are attacked, and of the length of time which must elapse till the protective inoculation is completed. The value of the inoculation is also correspondingly less, because by proper disinfection of the hen-houses a much more reliable prophylaxis can be obtained.

In symptumatic anthrax.

The method of protective inoculation with the artificially attenuated infective agents was then attempted in the case of anthrax, symptomatic anthrax, and swine In swine ferer. fever. The methods employed in the two last diseases have been already described on pages 300 and 307 ; it was there shown that the practical ralue of the inoculations against swine fever is as yet extremely doubtful, while the results in symptomatic anthrax are more

* While these pages were passing through the press a very valuable paper has been published by Kitt under the title Wert und Unwert der Schutzimpfungen gegen Thierseuchen, Berlin, 1886, to which we must refer the reader for all the details with regard to protective inoculations. 
favourable; but here also we cannot yet come to a final judgment on account of our ignorance of the length of duration of the protection, the absence of a calculation as to the cost, and the neglect up to the present time of other prophylactic measures in the infected districts.

The inoculations for anthrax have excited special In anthrax. interest. They were carried out in the first place with bacilli attenuated by Toussaint's method (p. 657); a practically useful vaccine was later produced by Pasteur and Chauveau, each by a different method. Pasteur Pasteur's employed as his first vaccine a cultivation in meat method. infusion which had been kept at a temperature of $42^{\circ}$ to $43^{\circ} \mathrm{C}$. till it no longer killeả guinea-pigs and rabbits, but was still fatal to mice (see page 657). One division of a Pravaz syringe of this vaccine is injected on the inner side of the hind thigh of sheep ; in the case of cattle two divisions are injected behind the shoulder. After the lapse of twelve to fourteen days a similar injection is made with the second vaccine, which has been kept at $42^{\circ}$ to $43^{\circ} \mathrm{C}$. till rabbits are not killed by it, while mice and guinea-pigs still die. It was not till Koch introduced the method of testing the cultivations on these three kinds of animals that it was possible to know exactly the degree of virulence of the organisms. Chauveau makes his vaccine by heating the organisms Chaureau's for a shorter time at higher temperatures; he emmethod. ploys fresh anthracic blood and not cultivations, and in order that it may be warmed as quickly as possible, he collects it in very small glass tubes. More recently Chauveau, in conjunction with Wosnessenksi, has also utilised for the purpose of attenuation the simultaneous action of high pressure (page 660). The virulence of his vaccine lies somewhat between that of the two vaccine materials employed by Pasteur; it is chiefly intended for cattle, and they are inoculated in the ear by means of a syringe. - The other methods of attenuation and protective inoculation for anthrax have not as yet been introduced into practice.

In judging of the results obtained we must, in the first place, note that the effect of the protective inocu- 
Value of the protective inoculation for anthrax.

lation differs in different species of animals; for example, guinea-pigs and rabbits cannot be made immune by the attenuated anthrax bacilli; rats often resist inoculation with the virulent material, but do not thereby acquire immunity. . In like manner the effect is different in sheep and cattle, the two species of animals chiefly inoculated in practice. In the case of sheep the protective inoculation appears to be particularly uncertain in its results ; too weak vaccines do not give the necessary guarantee for immunity; too strong materials, on the other hand, readily cause the death of the animal; further, the duration of the protection is very short, probably not lasting more than a year; and it has also been shown by Koch that sheep inoculated with strong vaccines are not able to resist natural infection produced by feeding them with anthrax spores.-In the case of cattle the result is probably more favourable, because stronger vaccines can be borne, the losses by the inoculations themselves are less, and the chances of immunity are better. Nevertheless even here we cannot make any definite statements as to the duration of the protection, nor as to its potency against the natural modes of infection. In any case the strong vaccines present a certain amount of danger for the people who have to attend on the animals, and without doubt these protective inoculations can only be looked on as a temporary means to be employed till rational means of prophylaxis, proper modes of disinfection, change in the pasture, care in burying the dead bodies, \&c., have been generally introduced.

Protective inoculation for rabies. Method.
The protective inoculation which has most recently attracted attention is that employed by Pasteur against rabies. When the method of attenuating the rabic virus described on page 660 had been ascertained, Pasteur attempted to rencer dogs immune by first inoculating them with virus which had been dried for the longest time, and which was the weakest; then two days later less virulent material was used, and so on till finally the virulent virus was employed.--When these experiments had led to uniform results. Pasteur made pro- 
tective inoculations on persons who had been bitten by dogs which were stated to be rabid. His method consisted in injecting into the patient on the first day a Pravaz syringeful of an emulsion prepared by the aid of sterilised infusion from a portion of the spinal cord of a rabbit which had died of rabies, the cord having been dried for fourteen days; on the following day a mixture from a piece of spinal cord dried for twelve days was injected; on the third day a cord eleven days old was used, and so on, till on the twelfth day a virulent material which had been preserved for only one day was employed.

By this method hundreds of people have been treated Results of the in Pasteur's laboratory, and the number is still increas- protective ining. However, of these some have died of rabies shortly after the treatment, and others at a later period. It is difficult to decide with certainty whether the percentage of those who have died after inoculation is smaller than of those who die when no protective inoculation is used, as among those who have been treated by Pasteur there is a large number who were, it is true, bitten by dogs, but in which there was no certainty that the dogs were mad. It is nevertheless probable that a much smaller percentage of those persons who have been inoculated have died as the result of the bite than of those not inoculated, and, therefore, that the protective inoculation has had the desired effect in a large number of cases. But this result is far from being a certain and constant one, and in addition to the uncertainty of the effect, we have on the other hand the danger that persons who were not infected by the bite, and who would not therefore have died of rabies, may have been infected by the inoculation itself. In some of the fatal cases which have followed the preventive treatment, the suspicion of such an unintentional production of the disease cannot be entirely put aside.

On the whole an unbiased person will receive the Differences impression that Pasteur's discovery, which is of un- petweent the doubted scientific value, has been introduced into prac- oculation for tice too hurriedly. As contrasted with the preparation other modes of of other vaccines, the metbod of attenuation is difficult protective i 
to control, and does not sufficiently guarantee the degree of virulence. Further, the whole process of protective inoculation against rabies completely differs from former protective inoculations for small-pox, anthrax, symptomatic anthrax, and swine fever, and also from the experiments made on dogs with the rabic virus, and which served as a proof of the utility of the method, for the people which were inoculated by Pasteur were already infected by the virulent disease. In all the former protective inoculations which might be thought to be analogous, the preventive means were employed before the infection, and experience has tanght us that inoculation with vaccine lymph, for example, has no effect if infection with variola has occurred before the vaccination was performed. In like manner the dogs experimented on by Pasteur, with regard to which accurate numbers have been published, were not infected before the protective inoculation. Pasteur mentions, however, that he has attempted subsequent protective inoculation on dogs which had been previously bitten or infected with virulent material; but accurate numerical details of these most important experiments have not been given, and hence the suspicion arises that in these experiments the result obtained has been as little constant and certain as those which have followed the inoculations on infected individuals.

A more thorough scientific study of the matter in various directions would, therefore, have been at all events desirable before the method was introduced into practice. It is very possible that the method in its present form, being so difficult of control, may, if employed extensively and by less experienced hands than those $\mathrm{cf}$ Pasteur and his assistants, lead to many serious mishaps.

General value of protective inoculations.
In conclusion, neither the inoculation for rabies, nor the other modern protective vaccinations, represent the ideal of a satisfactory prophylaxis against the infective diseases. Even the valuable vaccination for small-pox has not been generally introduced without difficulties, and yet in the case of rariola we have to do with a disease which, on account of the number and resisting 
power of the sources of infection, on account of the easy transportation of the infective agents, and on account of the readiness with which the body is attacked, can be influenced with extreme difficulty by other prophylactic means. It is further a disease which is very specially suitable for a protective inoculation on account of the peculiar certainty and persistence of the immunity. On Advantages of the other hand, in the case of the majority of other in- rational prnfective diseases, it is decidedly more rational to aim at means. the destruction of the infective agents, and the prevention of their spread or invasion, than to rely on an uncertain protective inoculation. That in the case of rabies suitable prophylactic rules deserve by far the greatest confidence is shown most distinctly by the condition of those countries in which a high tax on dogs, stringent rules against stray or possibly rabic animals, and under certain circumstances compulsory muzzling, have been already introduced; statistics show that in these countries (Prussia, Bavaria, \&c.) the deaths from rabies in dogs have diminished to a marked degree, and in man have practically disappeared.

\section{The Local and Seasonal Predisposition to Infective Diseases.}

From the foregoing considerations as to the mode of Irregular disspread of the infective diseases, we may draw the con- tribution of clusion that this distribution cannot occur either equaily diseases. over a large area or in an unbroken course as regards time, but that seasonal and local variations must appear and exert an influence on the occurrence of these diseases.

In none of the infective diseases is the spread of the infective agents like that of a gas which diffuses itself equally in all directions, and over great distances; on the contrary, the effective agents, even in the most favourable cases, only spread equally from one centre over a small distance. Even the mosi typical contagia, viz., the exciting agents of the acute exanthe- 
Multiplicity of the local and seasonal variations. mata, are not distributed over a wide area by means of currents of air; on the contrary, with the distance from the patient and the progressive dilution by pure air there is evidently such a rapid diminution of the chances of infection that they are no longer sufficient for a natural spread of the disease; on the other hand, where the transport is by the air the chances of infection only exist in the immediate neighbourhood of the sources of infection, and when the infective agents pass over greater distances they are usually carried by means of man or by surrounding objects.

The patient may therefore form the centre of a small infectious area; from this new centres may then be established in all possible directions, these centres having their origin in infected patients, or in any other suitable source of infection. The immediate neighbourhood of such a centre is always specially dangerous; whether, howerer, a number of infections will occur in the same house, or whether the danger will disappear there without the occurrence of any new infection while infective agents may possibly hare been carried to other streets or places, and give rise to fresh areas of infection, depends in every individual case on a great variety of circumstances - on the number and resisting power of the sources of infection, on the number of modes of transport, on the individual susceptibility - and may vary to a great extent. We must, therefore, after what has been said in the foregoing chapters as to the multiplicity of all the factors which come into play in infection, look on the whole essence of distribution as something so diverse and varying, and we must realise that the paths are so tortuous and the results so unexpected, that we need not be surprised either by a persistent localisation, or by an apparently causeless leap of the disease over a considerable distance.

It is only where a community is overtaken by a new and very contagious disease, where total ignorance of the danger of infection renders every mode of transmission easier, and where every individual presents a predisposed body not yet protected by recovery from similar 
affections, that there can be a general distribution of the disease without distinction of person. In every other case we meet with a great number of variations.

In the great majority of these variations it is unaroid- Laws as able that we here and there come across apparent natural locards the laws; one locality will be more frequently attacked than seasonal another, one season of the year will cause an increase in the number of cases of the disease, another will cause a diminution, and so on. Such recurring local and seasonal variations are in their essence only a further result of the numerous concomitant accidents, and one cannot from small numbers deduce laws which justify the assumption of a special local or seasonal influence.

Here and there, however, the variations apparently follow more distinct laws, and these point to external influences, varying with place and season. This is $a$ priori intelligible if we consider in how marked a degree the number and resisting power of the sources of infection, the facility of transport, and the state of the seats of invasion are dependent on causes varying with place and time. Even in those diseases, which are ex-In obligatory tremely easily transmitted, e.g., the acute exanthemata, we can at times, though by no means always, recognise regularly recurring seasonal or marked local variations. Thus the statistics of small-pox epidemics show that the disease usually increases markedly in the cold months and diminishes in summer; and that, further, in warm parasites. climates there is a marked increase in the dry season, and an almost complete disappearance in the wet months.* One can scarcely go wrong in attributing the regular increase of small-pox in winter to the greater amount of time spent at home, to the more intimate association of individuals, to the wearing of the same clothing for some time, and to the diminished cleansing of the skin, thus rendering the transport of the infective agents and their preservation at the seats of invasion much easier than in summer when all these favouring factors are absent. These differences are of course more or less marked in different countries, according to the climate and the

* Hirsch, Handbuch der histor. geogr. Path., 2 Aufl., i., p. 105. 
mode of life. In tropical climates the remarkable diminution of small-pox in the rainy season may be due to the easier cleansing of the body and to the increased difficulty in the transport of the infective agents by currents of air, perhaps also to certain habits of life which cannot be thoroughly appreciated.

Local varia. tions in scar. latinal epidemics.

The mode of spread of scarlet fever forms a very striking example of the effect of locality. While epidemics of scarlet fever have constantly occurred in Europe during the present century, and many of them have spread from place to place, some towns have remained entirely free from the disease for years, although they have been in communication with the infected places. Thus Münster has been free from scarlatina for 50 years, Tuttlingen for 35 years, and Ulm for 17 years, while long intervals have occurred between the epidemics in Lyons and also in the whole department of Indre-etLoire.* Experiences of this kind might very readily mislead us into supposing that there was some special influence, proceeding from the nature of the soil or from some other part in the surroundings of man, which favoured the development of scarlatinal epidemics in the one case and hindered it in the other; and yet we have overwhelming proof that scarlet fever only spreads by contagion. Nevertheless, in spite of the purely contagious character of the disease, differences in its local distribution may quite well occur. Thus it may happen that all sorts of accidents, which can scarcely be gauged, may prevent the infective agent, although repeatedly introduced, from causing infection; for example, these agents may only come in contact with individuals which have been previously attacked, and are therefore immune; or again, the infective agents may find a difficulty in obtaining a foothold in these individuals, owing to their cleanly habits, and so on. In a similar manner it is possible that a particular city may present better opportunities for a long continued immunity than another, in that the population may have been largely attacked during a former epidemic, or in that the spread of the

\footnotetext{
* Hirsch, l. c., p. 128.
} 
disease from the first case may be rendered difficult on account of certain habits of the population, such as the mode of treatment of the sick (inunction of fat), special attention to cleanliness, \&c.-It is, however, evident that even when a place has remained free from the disease for several years, although repeated epidemics have occurred in its neighbourhood, we are not justified in asserting that this place possesses a permanent immunity, due to a direct influence of the nature of the place on the infective agents ; on the contrary, all these places have ultimately been found to be susceptible as soon as the effect of the previous epidemic has disappeared, and the chances against the attack of the infective agents have become less favourabie.

A priori we may, however, expect that these local and Greater local seasonal variations will be more marked in the case of and seasonal those infective diseases which ore not so extremely con the less conthose infective diseases which are not so extremely con- the lesious tagious as the acute exanthemata, but in which the diseases. distribution is much more dependent on external accidents. This will evidently be the case where the sources of infection, the modes of transport, and the seats of invasion are limited, and where a marked spread of the infection can only resuit when there is a certain concurrence of these circumstances. The chief of these diseases In cholera. are those which are occasioned by the contagious facultative parasites, in which the number of the sources of infection increases or diminishes under the influence of external conditions, the modes of transport vary in their value, and the seats of invasion become accessible or inaccessible. The numerous influences which come into play in these cases have been subjected to a more accurate analysis in the chapter on cholera (page 443), and from the description which has been given there we may readily understand the manifold character of these influences and the applicability of the facts to other diseases which show a similar mode of distribution.

In many towns a regularly recurring seasonal varia- In typhoid tion is still more marked in the case of typhoid fever fever. than in cholera; thus during the dry harvest months, and when the level of the ground water is low, tho 
number of cases of typhoid fever increases, while it Influence of a diminishes as the ground water rises. In explanation drying zone of the soil on the of this phenomenon the same factors must be taken typhoid fever. into account as afforded to some extent an explanation of the corresponding variation in the cholera epidemics, but in the case of typhoid fever the drying of the superficial layers of the soil at the time when the frequency of typhoid fever increases comes more markedly into play than in the case of cholera. As the typhoid bacilli undoubtedly often reach the soil with the dejecta, either when fresh or after being retained for some time in cesspools, and as they are present partly in the spore form, and can thus be preserved for a long time and carried by currents of air, the drying of the surface of the soil or the sinking of the ground water must exert a much greater influence on the spread of this disease than in the case of cholera. The typhoid spores can, when a dry zone is present, be very readily carried by currents of air from the surface of the soil along with the dust to dwellings and to various materials on which they can develop, and thus the chances of infection are much increased at these times.

It is true that there is no absolute necessity for assuming an exclusive influence of the soil as an explanation of the coincidence between the frequency of typhoid fever and the dryness of the soil at the end of Other factors.summer and during harvest. It is quite possible that, as in the case of cholera, other factors which come more markedly into play at these periods-such as the character of the food, the large numbers of insects, factors which influence the individual predisposition, \&c.have an influence on the seasonal distribution of typhoid epidemics. In those cities where there is a constant and immediate connection between the dryness of the soil and typhoid fever we can scarcely go wrong in ascribing the sudden increase of cases chiefly to the Their multi. drying of the surface of the soil. Where, howerer, the
plipity. seasonal relation is less marked, and where we have also to explain a local distribution, we must not without rery streng reason refer the explanation only to alterations 
in the soil ; on the contrary, the whole series of factors which influence the local and seasonal occurrence, and which have been referred to above, must be taken into consideration just as much as in the case of those affections which are only contagious and which are in no wise influenced by the soil, but which nevertheless also show local and scasonal variations (scarlet fever, smallpox). Among these factors the chief are certain habits of life, selection and preparation of food, water supply, cleanliness of the person and of the dwelling, and the previous occurrence of epidemics with the consequent immunity.

There are a number of factors which we can with Drinking more or less certainty refer to as affording a certain water as an amount of explanation of the smaller epidemics of local outtyphoid fever which often show a marked local and typhoid fever. seasonal occurrence. At present there is a tendency among physicians to find something remarkable and only explicable by the assumption of a special and specific mode of spread in almost all cases of typhoid fever, whether they are limited to a single house, or occur in neighbouring houses, or pass over streets; the usual explanation has been the presence of wells containing so-called impure water.

It is no doubt quite true that the typhoid bacilli are carried by the water in many large and in numerous small epidemics, but it is equally certain that in a large number of cases this mode of transport has been assumed without sufficient justification. The view is also generally held that it is only by means of the drinking water that we can explain those cases whcre a small circle of people become affected around the small central epidemic, some of the persons in this circle being passed over (these usually not having partaken of the water), and where in addition a ferw individuals outside this immediate circle become affected, these being slown to have also consumed this water. On examining such cases, however, we very often find that the statistical facts were insufficient and incorrect, because they only take into account a small portion of the population 
Influence of various accidents on the distribution of the bacteria. surrounding the wells, and that the observer has paid but little attention to this defect, on the assumption that in no other way could such a peculiar distribution of the disease have occurred.

To obtain an idea of the innumerable small accidents which may influence the spread of the infective agents in one or other direction, and that without the intervention of drinking water, we only require to follow the fate of a cultivation of some readily recognisable form of bacterium, e.g., bacillus prodigiosus, when placed anywhere in a bouse. We can often observe how small red colonies appear on various nutrient substrata and articles of food, with regard to which it is evident, from the place where they have developed or from the grouping of the colonies, that they have been carried by the fingers, sleeves, table, or flies without intentional or even conscious contact with the exposed cultivation. It may further be observed that at one time the epidemic is limited to the room in which the culture is; at another it suddenly appears in another and distant room; again it rapidly spreads over the whole house; or again it appear's in neighbouring houses without any affection of the immediate neighbourhood; and lastly, although the conditions are apparently the same, no epidemic may occur. The result is so dependent in each individual case on the most trivial accidents, that in laboratories where much work is done with bacteria one soon ceases to wonder at the peculiar and varying mode of spread of this or that readily recognisable impurity.

It is often impossible to discover the cause of the local distribu. tion of epidemics.
Exactly analogous are the sources of infection of typhoid epidemics, whether originating from a patient suffering from the disease, or from infected earth, or from spores which have been carried to suitable nutrient substrata, or from any materials which have been contaminated with typhoid dejecta. The mode, the direction, and the extent of the spread of the epidemic from these sources depends on a great variety of accidents. As in the case of the prodigiosus cultivation, the transport by man and various objects will play a very important rôle; the result in each case will, howerer, 
depend on whether the germs can live in the place to which they are transported, whether they find sufficient nutrient materials to permit their growth, \&c.

Thus it is only seldom that we are able to pick out the true mode of transport from the many possible ones. This want of knowledge, and our open acknowledgment of it, does not, however, render it more difficult to take prophylactic measures against a typhoid epidemic. In whatever way the spores have been transported they are in all probability introduced into the body by water and food; and they only leave the body by the dejecta. If the latter are thoroughly disinfected or removed by a good system of drainage, if the water is taken from proper wells, and if the selection and preparation of food is attended to, a typhoid epidemic can be satisfactorily coped with even though the exact mode of transport in each individual case remains unknown. The closure of suspected wells is also a perfectly proper procedure, though the reason for doing so is not now the same as formerly; the former practice led to insufficient and probably erroneous views as to the etiological importance of the water, and to too great onesidedness in the prophylactic measures.

It is evident that the great multiplicity of the factors which play a part in the local and seasonal distribution of all infective diseases makes it extremely difficult tô draw conclusions as to the nature and the infective properties of the causal agents from these local and seasonal variations and from the laws which appear to govern them. At the present time, when we can study Difficulties in the behaviour of the infective agents themselves, and estimating the can solve the question of their mode of distribution local and experimentally, it would help us but little to employ the seasonal preformer circuitous method by which we drew conclusions as to the characters of the infective agents from the phenomena of their local and seasonal distribution; it is much better to attempt to gain a solid basis from experiments with the isolated infective agents themselves, and thus to obtain an explanation of the results of epidemiological statistics. 
7. The most Important Prophylactic Measures against the Spread of the Infective Diseases.

We can very easily deduce the prophylactic measures against infective diseases from the facts as to the mode of spread of these diseases which have been referred to in the foregoing paragraphs.

Prophylaxis by influencing the individual predisposition.

In some cases it seems best to direct our precautionary methods rather towards the individual predisposition of the body than towards the infective agents, and in fact to neglect the latter more or less completely. The most marked example of this is tuberculosis (see p. 752). It is possible also that other infective diseases will be best held in check by such a method of prophylaxis, and probably there is a great field for investigation and for practical work in this direction.

Among the means of lessening the individual predisposition we have also protective vaccination, the practical value of which-with the single exception of vaccination for small-pox-must, however, for the reasons given above (p. 760), be judged on the whole unfavourably.

In the great majority of cases, however, our prophylactic measures deal with the infective agents themselves, and seek to destroy them, or to hinder their development or spread.

Prophylaxis

by destruction or removal of the infective agents.

General prophylactic measures.
The reporting of cases, quarantine, and the isolation of the sick are precautions which do not require any special discussion, nor do the points which would have to be discussed in connection with them specially concern the matter of this work, and we may therefore pass them over. We have here to do with the measures for the destruction and removal of the sources of infection mentioned on p. 736, and for interfering with the modes of transport (see p. 739). The following are the most important precautions in this direction :-

a. Measures which are generally applicable.-In cases of disease it is of the first importance to destroy or disinfect all the excreta of the sick which may contain the effective agents, and all the objects contaminated with them, 
more especially linen, beds, \&c.; it is further necessary to keep all these sources of infection in a moist state till they can be disinfected, so that the infective agents may not become detached and carried away by currents of air. (This is unnecessary in cholera.) All surrounding objects which might retain the infective agents, and which are difficult to cleanse, should be removed as far as possible, and protected from contamination (for example, soil, \&c., the doors and walls of sick-rooms should be closely covered with some impermeable material). Those who come in contact with the sick should be particularly cleanly, and should also wash with sublimate or carbolic lotions; similar cleanliness is also necessary with regard to the clothing, the dwelling, the kitchen, \&c. It is also desirable that those who are particularly predisposed to one or other disease on account of the presence of abnormal points of invasion (as in the case of wounds, catarrhs, gastric disturbances, \&c.) should avoid the danger of infection, and should observe the necessary precautions even when no evident sources of infection are present.

b. Special precautions in individual diseases.-In Special prethe case of the acute exanthemata we must attempt by cautions in rubbing oil over the skin of the patient to prevent, or at diseases. any rate to limit, the detachment of the infective agents from the surface of the body, and their transport through the air. Thorough ventilation of the sick-room, which is much recommended for prophylactic purposes, can, it is true, lead to a dilution of the germs, but it is difficult even by the best methods of ventilation to diminish the chances of infection to such an extent as occurs in the open air, and as is requisite if we are to place ventilation on the same footing as the other prophylactic measures.

In those diseases in which the seat of invasion and the seat of the disease lie in the intestinal tract, such as cholera and typhoid fever, we must, when there is a great danger of infection, pay the greatest attention to the preparation of the food, and we must also see that the drinking water comes from pipes or from good wells, 
and this is done by insisting that all food must be cooked, and that all water must be filtered through a proper apparatus. Where sources of infection are present we must also employ the general precautions referred to above. An extremely important measure consists in making arrangements to remove dejecta and waste water rapidly and to get rid of gutters, and thus to render it impossible for the surface of the surrounding soil, the wells, and the watercourses to become contaminated with dejecta.

Disinfection. The prevention of fresh sources of infection by means of a rational method of disinfection, forms the most important part of the prophylactic measures in the majority of the infective diseases. This method applies to the following materials, and is carried out by the following means :-

Disinfection 1. The infective excreta of the patient (sputa, dejecta, of excreta. pus, \&c.) should be mixed with 5 per cent. carbolic acid (or if necessary with commercial fuming hydrochloric acid), and allowed to stand for twenty-four hours, each motion being disinfected at once. The receptacles must be repeatedly washed with similar solutions. Infective material on the body of the patient must also be removed by means of carbolic acid, or sublimate solutions.

Disinfection 2. The linen and bed linen of the patient, dressings, of linen, beds, feather beds, woollen blankets, mattresses, straw beds,*
\&c. handkerchiefs, curtains, carpets, \&c., should be disinfected by a current of steam at $100^{\circ}$ C. Various apparatuses have been constructed in recent years for carrying out this method of disinfection, and of these Apparatus for three have been tested and found satisfactory. These disinfecting by means of a are the apparatus made by Schimmel \& Co. in Chemeurrent of steam. nitz, the stationary and portable apparatuses made by $\mathrm{J}$. I. Bacon in Berlin, and lastly that by Rietschel \& Henneberg. - So far as possible these various machines

* It is usually best to burn straw beds and other worthless materials. In practice, however, this cannot always be done without risk of infection, and in that case it is simplest to disinfect these materials also in the steam apparatus. 
should be round, or nearly round, in order to avoid the presence of corners in which the disinfection may very readily be imperfect. It must also be borne in mind that hot air containing a certain amount of steam does not by any means have the same effect as a good current of steam without any air (see p. 665); those forms of apparatus are untrustworthy in which steam is present even under high pressure, but not in such quantity that after filling the apparatus a good current of steam escapes from it. It does not seem to be necessary to raise the temperature of the steam by employing saline solutions; it has been definitely proved by numerous experiments in Koch's laboratory, and by comparative tests by Wolff which were made on a number of machines and in a trustworthy manner, that even very large objects (balls composed of 22 woollen blankets) are completely disinfected by exposure for one to two hours to a current of steam at $100^{\circ} \mathrm{C}$. One hour suffices for smaller objects, and half an hour for linen and clothing, the time being reckoned from the moment when the steam which escapes shows a temperature of $100^{\circ} \mathrm{C}$.

By this plan the injury done to the materials is very slight. Linen, feather beds, mattresses, clothing, printed matter, \&c., are quite unlurt, but sensitive colours are somewhat altered. Disinfection by heat cannot be employed for objects made of leather (boots), gum, or caoutchouc, and bound books.

No definite statement can be made as to the special advantages of one or other of the disinfecting apparatuses mentioned above; at all events, they are all trustworthy and useful. They are prepared in various sizes and at various prices, and one ought to be in use in every town.

In Göttingen a very simple and cheap apparatus has been Special introduced provisionally, and acts extremely well. It is con- description of structed on the same principles as the sterilising apparatus ratus for discommonly used in laboratories and described on page 665 , infection. being merely correspondingly larger. It is desirable to have two of these machines of different sizes, the one being $\cdot 7$ metres in height and $50 \mathrm{~cm}$. in diameter, the other 1.4 metres 
Construction high and $80 \mathrm{~cm}$. wide. The smaller, which costs with accesof the machines.

Method of heating. sory apparatus about $£ 710$ s., is employed when portions of clothing or linen are to be disinfected (as in tuberculosis); the larger, which costs about $£ 13$, serves for the disinfection of beds, mattresses, \&c.-The apparatus is made of tin, with the exception of the bottom, which is copper, and has a conical shape, enlarging at the lower part so as to increase the heating surface. The receptacle for the water is provided with a tube projecting outwards, through which it is filled, with a pressure gauge tube, and with a stop cock to empty it. To provide air-tight fittings for the lid, and also at the attachment of the body of the machine to the boiler, these parts fit into grooves which are filled with water. To prevent cooling, the body and the lid are protected by a thick layer of clay, which is fixed on by means of gauge bandages, and an external arrangement of wire netting. In the lid there is a tube for a thermometer, and another for the steam, with which a long leaden tube is connected so as to conduct the steam out of the house.

The apparatus is heated by gas. In the case of the larger apparatus twelve large Bunsen burners are necessary to raise the temperature of the thermometer in the lid to $100^{\circ} \mathrm{C}$. within half an hour; for the smaller apparatus five burners are sufficient. This method of heating has the advantage that it can be very cheaply fitted up, that the temperature remains constant, that the heat is very completely utilised, and that the disinfection is completed in a very short time (within two hours). The cost of the gas for the larger apparatus is about sixpence per hour, that for the smaller about $2 \frac{1}{2} d$. Where larger machines are employed boilers and fires are of course indispensable.

Attempts have been made to add arrangements to warm the clothing, \&c., previously, and to pass a current of dry hot air through them subsequently to the disinfection in order to dry them as quickly as possible. These arrangements have not, however, acted well, and they lengthen the Prevention of process too much; they are besides quite superfluous if care wetting of the is taken to prevent the materials from coming in contact materials. with the water. If the materials are only moistened by the current of steam they dry in a very short time, within half an hour; and it is only at those places where the water has soaked in that the moisture remains longer and that the colours are more readily destroyed. Hence in the apparatus described above special care has been taken that the water condensing on the walls or top of the apparatus shall not run on to the materials which are being disinfected. Beds and similar bodies are placed in a cylindrical basket of strong 
wire, the sides of which are at least $1 \mathrm{~cm}$. from the wall of the vessel, and are lined with wire netting and inside that with waxed cloth, which is the only material impermeable to water which stands heating well. Further, to protect the articles from water dropping from above without preventing the passage of the steam they are covered with several layers of cloth. By means of these simple arrangements the articles can be dried in half an hour if they are laid out on a dry frame arranged around an ordinary iron stove, and thus only two to three hours elapse from the beginning to the end of disinfection.-Above the apparatus an arrangement is fixed by means of which the cover can be raised and turned aside, the basket introduced or removed, and the cover replaced in it very few minutes.

Spring mattresses can be sufficiently disinfected by scrubbing them with sublimate solution $(1: 2000)$; it is most convenient to combine this procedure with the disinfection of the dwelling. Boots, indiarubber materials, \&c., should also be washed with sublimate solution.

3. In the house, the bedstead (and the other furni-Disinfection ture if necessary) and the floor should be scrubbed with of thelling. sublimate solution, and afterwards washed with soap and water. In the water-closets, the seat, the pan, and the drain should be scrubbed or sluiced with 5 per cent. carbolic lotion. The contents of cesspools, \&c., should be mixed with commercial hydrochloride acid till the reaction of the contents after being well stirred is markedly acid. Where the cesspools are very large we cannot attempt disinfection.-As to the defects and the methods of disinfection of the air see p. 669. In most cases no attempt is made to disinfect the air, but reliance is placed in thorough ventilation. We may, however, before disinfecting the floor, furniture, \&c., attempt to cause deposition and fixation of the air germs by loading the air with moisture by means of steam or spray.

To carry out thorough disinfection it is essential that Necessity for there should be a staff of educated persons, indeed this an ed is quite as necessary as the possession of a proper apparatus. In a small town three trustworthy persons are sufficient; these should be thoroughly instructed and examined by the medical officer; in larger cities the staff must be correspondingly more numerous. 
Regulations for disinfection in Gottingen.
In Göttingen the following regulations have been drawn ur by Dr. Schütte.-Families in which a case of infective disease has occurred, and who desire disinfection, must send an intimation to the court-house, stating also the nature of the disease. In this way the staff can judge as to the extent of the disinfection and the method to be employed; the following are their instructions according to the nature of the case:-

Small-pox, scarlet fever, typhus fever, diphtheria, \&c.; linen, beds, curtains, \&c., are to be disinfected with a current of steam; bedsteads and floors to be scrubbed with sublimate solution; upholstery, \&c., to be moistened with sponges dipped in sublimate solution, and at once dried.

Cholera, typhoid fever, dysentery: disinfection of linen, \&c., by steam. Water-closets disinfected with 5 per cent. carbolic acid; cesspools, \&c. with commercial hydrochloric acid. In cholera warm and ventilate the room, in typhoid fever and dysentery cleanse the bedsteads, floor, \&c., with sublimate solution.

Tuberculosis : disinfection of the linen and beds.

The persons who are to carry out the disinfection take with them all the solutions, vessels, brushes, \&c., also some indiarubber garments, and a number of moistened clotlis of various sizes; also the wire basket from the sterilising apparatus. These are transported in a suitable hand barrow. When they reach the house they put on the indiarubber garments, and take the utensils and cloths into the room, wrap the beds, mattrasses, clothes, \&c., in the moist cloths, cleanse their hands and mackintoshes with sublimate solution, and place the parcels in the wire cage. One of the disinfectors takes these back to the apparatus, which has been in the meantime heated by the third, while the first remains behind and disinfects the room. After two to three hours the beds, \&c., are brought back, and in the meantime the room has been disinfected.

The detailed instructions may be obtained from the magistrate of Göttingen, or from Dr. Schütte, the medical officer of health.

It is a fact which cannot be overlooked that it is as a result of the recent bacteriological investigations that we are in a position to employ trustworthy prophylactic measures against the infective diseases, and more especially to carry out the disinfection so thoroughly that it has become one of the most potent means of opposing the spread of these affections. 


\section{PART VIII.}

\section{METHODS OF INVESTIGATING BACTERIA.}

I do not propose in the present work to give at all a complete description of the various methods of bacteriological investigation; such an attempt would very much increase its size, and is so much the less necessary as very thorough descriptions of bacteriological methods have been given by Hueppe, and also in a recent work by Huber and Becker (Leipzig, Vogel, 1886).

In the following pages I shall only put together the most important methods for the microscopical examination of bacteria, for their cultivation, and for their demonstration in air, water, and soil.

\section{Microscopical Examination of the Lower Fungi.}

We can examine microscopically a great variety of Methods of materials, such as fluid and solid substances, nutritive microscopical materials, dust, earth, animal and vegetable organs and of bacteria. juices, fungus colonies, \&c. In doing this we must always remember that these lowly organisms are constantly present in all our surroundings, and that in order to demonstrate the presence of the fungi in any one of these materials care must be taken to prevent the accidental introduction of fungi into the preparation from the surroundings. All instruments, glasses, re- Apparatus. agents, \&c., must therefore be free from organisms, and this is best attained in the case of the instruments and glasses by exposing them for a short time to a temperature of at least $150^{\circ} \mathrm{C}$., or, still better in many cases, by placing them in a solution of corrosive sublimate 1 to 2,000 . 
If we are investigating pathogenic organisms we must remember that numerous fungi are constantly growing on the surface of healthy living animals, on the skin, in

Mode of obtaining the specimens.
Staining of bacteria.

Cover glass preparations. the cavity of the mouth, \&c. After death these organisms rapidly spread, in the first place, into all the superficial parts of the body; specimens taken with the view of investigating the presence of pathogenic organisms must therefore never be taken from the impure surface, even in the case of living animals ; and after death we must always try, if possible, to obtain the specimens from the interior of the organs by making a series of fresh cuts with a heated knife.

The direct microscopical observation (sometimes after the addition of a half per cent. soda solution, a mixture of glycerine and water, or a solution of acetate of potash 1 to 10) without further aids only gives results at all satisfactory in the case of the larger fungi, or of cultivations of bacteria ; if other objects, such as cells, nuclei, or fragments of nuclei, crystals, and amorphous inorganic materials, are present in the preparation we may not be able to recognise the bacteria, even under very high powers of the microscope. Hence in almost all cases where it is important to examine the preparation accurately it becomes necessary to stain the microorganisms. The bacteria take up certain colouring materials with extraordinary energy, and we can usually so manage the staining that the micro-organisms alone are coloured, or at least these alone are markedly stained, while all the other objects in the preparation are but faintly, or not at all, tinged. And where we wish to demonstrate the absence of micro-organisms from some material it is only possible to do so with any degree of certainty by the aid of methods of staining.The treatment of the preparations with the view of staining them differs according as we have to do with fluids or with animal organs.

Fluids are in the first place dried on a cover glass in a very thin layer, a small drop being placed on the glass by means of a recently heated platinum wire, and spread out over it by a few circular movements, or still 
better by laying a second corer glass on the top of the first, so that the drop is spread out, and the layer of fluid extends to the border of the cover glass; these glasses are then slid asunder, and thus we obtain two thinly-spread layers; these layers dry in a few minutes. If now the cover glass is at once brought into contact with the staining solution the layer again becomes detached, and is washed away; hence the organisms must first be fixed on the glass as far as possible. This can be done either by prolonged immersion of the glasses in absolute alcohol, or by exposing them for a short time to a temperature of from $110^{\circ}$ to $130^{\circ} \mathrm{C}$. (for two to ten minutes), but the exact degree of heat differ's somewhat in the case of different objects, and must be ascertained by experiment. This heating can be conveniently and sufficiently done by passing the cover glass two or three times slowly ("about as quickly as we cut bread") through the flame of a Bunsen burner or a spirit lamp. After this treatment the organisms adhere so firmly to the glasses that these can be kept for a long time in watery fluids without any bad result.

The cover glass being prepared in this way a drop of one of the staining solutions mentioned below is placed on it; it nsually suffices to allow the solution to act for from fifteen to twenty minutes; if we wish to prolong the action it is advisable to float the cover glasses on the staining material contained in a flat vessel. The cover glass is then seized with forceps, freed from the stain by filter paper, washed in distilled water, or at times in very dilute acetic acid (5 to 10 drops to $100 \mathrm{ccm}$. of water), and then placed on the slide with a drop of water, or else dried and mounted in oil of cloves or Canada balsam.

Organs must in the first instance be hardened in Treatment of absolute alcohol for some time (several days); in doing this plenty of alcohol must be used, and it is well to cut the organs into small pieces. A number of fine sections are then made, if possible by means of a microtome, and are placed in the first instance in absolute alcohol, and from thence transferred to the staining solution. The 
sections remain in this solution for from a half to five hours, in some cases even for twenty-four hours. By warming the solution to $30^{\circ}$ to $40^{\circ} \mathrm{C}$. the duration of the staining can be considerably shortened. When the sections are taken out of the stain the whole tissue is strongly coloured, and hence we must attempt to produce a differentiation between the organisms and the tissue by placing the sections in alcohol, or in dilute acetic acid, which has the effect of withdrawing the colouring matter from the cells, and leaving only the organisms and at most the nuclei of the cells stained (in addition also certain forms of mucine, horny tissue, at times fat, and the axis cylinder of nerves retain the stain). In most cases the best method of decolourising tissue is to leave the sections in alcohol for fifteen to thirty minutes, then to transfer them to oil of cloves, from this again to pure alcohol, and then again to oil of cloves. It is well at times to employ dilute acetic acid before the alcohol. The sections can be at once examined in the oil of cloves; or they can be transferred to slides, the oil removed carefully by blotting paper, and the sections then mounted in balsam. Some colouring matters are dissolved out by the oil of cloves, and in these cases the sections are transferred from alcohol to oil of bergamot or xylol, in some cases after a previous short immersion in oil of cloves. - If we have a freezing microtome at hand the fresh organ can be at once frozen and cut. The sections are then in the first instance placed in salt solution, from which they are carefully removed to absolute alcohol, and then treated as above described.

Staining materials.

Carmine or hæmatoxylin are only rarely employed as staining materials, the chief dyes used being the aniline colours, to which the lower fungi show a great affinity.

According to Ehrlich* we have to distinguish two great groups of aniline dyes which are sharply defined from each other by their chemical and histological peculiarities; these are the acid and the basic colouring materials.

\footnotetext{
* Westphal, Schwarze, Spilling (Lit.), Weigert.-See also Virchow's Arch., vol. 84 .
} 
Among the acid dyes we reckon all those colouring matters in which the staining substance is an acid; the dye is not necessarily, however, a free acid, nor need it even have an acid reaction, it may be in combination with bases forming salts, such as picrate of ammonia. There are four classes of acid colouring materials, viz.: 1 . Fluorescine; to this group belong fluorescin, pyrosin, eosin (tetrabromfluorescin), and several others. 2. Nitro bodies - for example, Martin's yellow (a salt of binitronaphthol), picric acid, aurantia (the ammonia salt of hexanitrodiphenylamine). 3. Sulpho acids-for example, tropæolin, bordeaux, ponceau ; derivatives of the form of aniline blue which is soluble in spirit; aniline black, \&c. 4. Primary acid dyes-for example, rosolic acid, alizarine, nitroalizarine, purpurine, cœruleine, possibly hæmatoxyline, \&c.

To the basic dyes belong fuchsine (rosaniline), methyl violet, methyl green (both of them methyl derivatives of rosaniline, the latter being usually contaminated with methyl violet), triphenylrosaniline (impure aniline blue) and its derivatives, cyanine, safranine, magdala; further, the stains which are more especially employed for colouring bacteria, viz., Bismarck brown, dahlia, and gentian violet.

The basic colouring matters are not usually sold as free bases, but as salts; thus fuchsine is sold as hydrochlorate or acetate of rosaniline.

The basic aniline dyes are almost alone suitable for staining bacteria; they, however, also stain the nuclei. In order to prevent the occurrence of a diffuse stain of the whole tissue we must treat the stained preparations with solutions which have a greater affinity with the staining material than the tissue, but less affinity than the micro-organisms (and nuclei of cells); such solutions are alcohol and dilute acetic acid.

Many bacteria only take up ferw stains well; and hence in searching for unknown micro-organisms all the various staining materials must be employed with or without the addition of acetic acid, or in faintly alkaline solution; the spores of bacilli do not take up the colouring matter unless when they are specially treated. In the case of most forms of micrococci all the nuclear stains (carmine, hæmatoxyline, basic aniline dyes) are suitable. These organisms can be stained red with the various forms of carmine which stain the nuclei, and also with purpurine, 
fuchsine, magdala, and magenta; brown, with Bismarck brown, or vesurine; green, with methyl green; blue or violet, with hæmatoxyline, methylene blue, iodine violet, methyl violet, dahlia, and gentian violet. Many of the bacilli, however, can only be stained by those aniline dyes which stain nuclei. The following are the materials which are most used.

Most useful staining solutions.

Methylene blue, more especially in faintly alkaline solution (Loeffler's universal staining fluid). This fluid is prepared by mixing $1 \mathrm{ccm}$. of concentrated alcoholic solution of methylene blue, which can be kept for a long time, with $200 \mathrm{ccm}$. of distilled water, and then adding two to four drops of a 10 per cent. solution of caustic potash. The mixture must be refiltered every day, and must be freshly prepared about every eight days.

Gentian violet (B.R. in the catalogue of the Berlin company for the manufacture of aniline dyes) in about 1 per cent. watery solution.

Fuchsine is kept at hand in the form of a concentrated alcoholic solution, and is diluted with about five times the amount of water when required.

Methyl violet, gentian violet, and dahlia show in a special degree the property of metachromatic staining, i.e., they stain various elements of a shade somewhat different from the primary colour, reddish to red, \&c. Methyl green, which is usually contaminated with methyl violet, often gives blue, and at times rose tints.

Double stain. In order to differentiate better between nuclei and ing. bacteria double staining is at times very suitable; we may mention, for example, double staining with picrocarmine and gentian violet, which depends on the fact that the carmine can drive out the violet from the nuclei, but not from the bacilli. The sections are placed in the first instance in a solution of gentian violet, then in alcohol, then for a moment in water in order to remove the alcohol, and then in Weigert's picro-carmine solution. After remaining in this solution for a half to one hour they are passed through water, alcohol, oil of cloves, and Canada balsam. The result is that the nuclei of the cells have a red colour, while the bacilli 
are stained blue. The clubs of actinomyces can be stained reddish-blue by treatment first with Wedl's orseille (Virchow's Archiv, vol. 74), and then with gentian violet.

Tubercle bacilli are best stained by the following To stain method (see p. 261): aniline oil and water are well tubercle shaken up together, and then filtered through moistened thick filter paper; concentrated alcoholic fuchsine or gentian violet solutions are then cautiously dropped into the filtered aniline water till a slight cloudiness is noted, which later again disappears (about 10 to 20 drops of the stain to $10 \mathrm{ccm}$. of aniline water). The cover glasses, prepared with sputum in the manner above-mentioned, are then floated on this colouring material for from twelve to twenty-four hours, or, if the solution is kept at a temperature of $30^{\circ}$ to $35^{\circ} \mathrm{C}$., for one to two hours ; in the case of sections, it is best to stain them for twenty-four hours, and then to warm the solution for one to two hours. The cover glasses and sections are then washed in the first instance in acidulated alcohol $(100 \mathrm{ccm}$. alcohol, $20 \mathrm{ccm}$. water, and 20 drops of concentrated hydrochloric acid); after a short time (a half to two minutes) the red or violet colour is removed from all the thinner parts of the preparations, which are now carefully washed in water, the cover glasses dried, and then stained in dilute watery solution of methylene blue if fuchsine has been employed in the first instance, or with a solution of vesuvine if gentian violet has been used. After five to fifteen minutes they are washed in water, dried, and mounted in Canada balsam. Sections are placed for half an hour in the methylene blue or vesuvine solution, and then treated in the usual manner; if the preparations are to be preserved we must employ oil of bergamot instead of oil of cloves. In this way we obtain preparations in which the tubercle bacilli are stained red or violet, and the cells and cell nuclei blue or brown. The only other organisms which show the same staining reactions as tubercle bacilli are, so far as we know at present, the leprosy bacilli. Some other materials also retain the stain in this method, such as the epidemic structures, the spores of the mould fungi, 
the spores of bacilli under certain conditions, and also at times fat crystals, which are sometimes present in sputum; the fat crystals are, however, readily soluble in ether and chloroform (Celli and Guarneri).- The pure solutions of the dyes, and also the mixture of aniline and water, can be kept for a long time, but the latter must always be freshly filtered before use, and the mixture with the colouring material must always be freshly prepared. - The following solution will, however, keep for from ten to twelve days: $100 \mathrm{ccm}$. saturated aniline water, $+11 \mathrm{ccm}$. concentrated alcoholic solution of methyl violet or fuchsine, $+10 \mathrm{ccm}$. absolute alcohol.-With regard to the numerous other methods of staining bacteria, see the papers by Plaut* and Kaatzer. $\dagger$

As regards the staining of the bacilli of syphilis and smegma, see p. 289.

Gram's method.

Gram's method is admirably adapted for the differential staining of bacteria in the tissue, and also as a means for the diagnostic separation of many species of bacteria. It consists of, 1, aniline gentian violet solution, Ehrlich's formula (as for staining tubercle bacilli); 2 , solution of iodine and iodide of potassium, composed of 2 grammes of iodide of potassium, 300 grammes of water, and 1 gramme of iodine. The sections are transferred from absolute alcohol to the staining solution, and remain there for from one to three minutes (in the case of tubercle bacilli for twelve to twenty-four hours), then after a short immersion in alcohol they are placed in theiodine solution. After one to three minutes the sections are again placed in alcohol till they are completely decolourised, then in oil of cloves, \&c. As a result the tissue and nuclei have a faint yellow colour; the bacteria, on the other hand, are intensely blue or black. Cover glass preparations are treated in a similar manner.-The following organisms retain the stain in this method: the bacteria of pneumonia, the cocci of pyæmia and erysipelas, staphylococci, tubercle bacilli, anthrax bacilli, and various saprophytes;

* Plaut, Färbungsmethoden u. s. w., 2 Aufl., 1885.

+ Kaatzer, Die technik der Sputumuntersuchung auf Tuberkelbacillen 2 Anfl., 1885. 
on the other hand, typhoid bacilli and cholera spirilla are decolourised by the iodine solution.

Buchner,* and subseguently Hueppe, was the first Staining of who was successful in staining the spores of various the spores of bacilli. In order to stain the spores the cover glass preparations are raised to a higher temperature than in staining the bacteria, thus they are not passed three times but from six to ten times through the flame, or they are kept for a quarter to half an hour in a dry chamber at a temperature of $180^{\circ}$ to $200^{\circ} \mathrm{C}$. After this treatment the spores take up the ordinary aniline dyes. - Neisser, however, succeeded in staining spores by the use of the solutions employed to stain tubercle bacilli when they were at the same time warmed. Cover glass preparations, prepared in the ordinary manner, are floated on the aniline fuchsine solution at a temperature of $80^{\circ}$ to $90^{\circ} \mathrm{C}$. for ten, twenty, or even forty minutes, and are subsequently treated like preparations of tubercle bacilli. By this method the spores are stained red and the bacilli blue.

In order to preserve the preparations we can employ Preservation Canada balsam, dammar, a concentrated solution of paration. acetate of potash or glycerine; the latter, however, is only suitable for preparations stained with solutions of aniline brown which contain glycerine. - The best mounting material for mould and yeast fungi is glycerine gelatine (one part of gelatine, six parts of water, seven parts of glycerine, and one part of carbolic acid, warmed and filtered).

For the examination of the preparations only the best Microscopical microscopes are suitable. In the case of the larger forms of bacteria-for example, anthrax bacilli-dry lenses are sufficient, in the case of all the smaller forms it is necessary to use the best oil immersion lenses. $\dagger$ In order to be able to recognise the stained bacteria in the tissue a special mode of illumination is necessary.

* Münchener ürztl. Intelligenzbl., 1884, p. 370.

$\dagger$ Excellent oil immersion lenses and apparatus for illumination are furnished by Zeiss of Jena, Seibert and Kraft, Leitz and R. Winkel in Göttingen. Winkel's lenses are excellent, and, according to the author's experience, are most worth the money.-Colouring materials and other apparatus can be obtained from Dr. Grübler in Leipzig. 
It would of course be best if we could obtain a pure colour picture, i.e., if the Canada balsam and the tissue had an identical refractive index, and as a consequence the tissue were not at all visible, and only the bacteria could be seen by virtue of the stain that is in them. But usually the various portions of the tissue have a different refractive index to the Canada balsam, and give rise by diffraction of the transmitted rays of light to the structure picture, which consists of lines and shadows, and which obscures the colour picture. We must therefore try, as far as possible, to obliterate these diffraction appearances and the structure picture, and this can be done by the employment of a suitable illumination apparatus.

Abbé's substage condenser.
If we examine a microscopical preparation illuminated at first with a narrow, and then with a constantly but slowly increasing cone of light, we find that the diffraction appearances and the structure picture, which were most intense with the narrow diaphragm, gradually disappear; and to the same degree as the structure picture diminishes, so the colour picture becomes more intense and sharper. Hence where possible a condenser must be employed with so large an angle that the diffraction appearances are completely obliterated. An instrument which attains this object completely is the condenser devised by Abbé, and prepared by Zeiss. This consists of a combination of lenses, the focal point of which is only a few millimetres distant from the front lens. When this lens is placed in the opening of the stage of the microscope at a somewhat lower level than that of the stage the focal point falls on the object under examination, and the latter is consequently best illuminated in this position. The angle of aperture of the rays is so great that the most external of them are bent in a layer of water almost $16^{\circ}$ towards the axis, and hence the total active cone has an aperture of $120^{\circ}$, a broader aperture than that of any other condenser. The rays of light are sent into the system of lenses by means of a mirror which can only rotate around a fixed point in the axis of the microscope. Between the mirror and the lens, and near the focal point of the former, we have the arrangement for diaphragms which can be moved laterally and circularly, so that the cone of rays may be altered in any manner desired. By means of a greater or less diaphragm the aperture of the lens is modified from the smallest to the lurgest. 
The appearances observed under the microscope are Photography best reproduced by means of photography. The cover glass preparations prepared in the manner above described permit the employment of high power immersion lenses. It is best to stain the organisms brown. Photography also possesses a special advantage in that the photographic plate reproduces the microscopic picture better, or rather with greater accuracy, than does the retina of the eye.

The sensitive plate is to a certain extent an eye which is not blinded by bright light, and which does not become tired by the attempt to distinguish between minute differences in light, \&c. We often find on the negative, when the picture has been sharply focussed, fine objects, for example, minute flagella, which can only be seen with the greatest difficulty, and under the most favourable conditions of illumination.

As regards the methods of photography see the works mentioned below.*

Bacteria, more especially micrococci, may be con-Differential founded with detritus, but the latter shows granules of diagnosis of irregular size and grouping; we also at times find small drops or little spheres, which become stained with the dyes, and the nature of which is as yet doubtful. Confusion is most likely to occur with the cells described by Ehrlich under the name of "Mastzellen" (plasma cells, granular cells), which are very widely distributed, and increase in number in various pathological processes. The uniform round granules of these cells are usually stained in a similar manner, and with a similar shade, to the bacteria; and the two forms can often be only distinguished by the position which they occupy, and more especially by the fact that the granules in the plasma cells are always grouped in the form of cell-like structures. If it is necessary to make certain that we are studying bacteria the following method may be employed: after staining with aniline the sections are

* Gerlach, Die Photographie als IÏ̈lfsmittel mikroskopischer Forschung Leipzig, 1863.-Beneke, Die Photographie als Hülfsmittel $u$. s. w., Brannchweig, 1868.-Reichardt u. Stürenburg, Lehrbuch der mikroskopischen Photographie, Leipzig, 1868.-Vogel, Lehrbuch der Photographie, Berlin, 1874. See also the excellent photographs by R. Koch in Cohn's Beitr., vol. 2, and in the IIttheilungen a.d. Kais. Gesundheits-Amt., vol. 1. 
treated, not with acetic acid or alcohol, but with a weak solution of carbonate of potash, and under these circumstances the nuclei and plasma cells, and in fact all animal tissues, lose the stain, and the bacteria alone retain it (Koch).

II. The Artificial Cultivation of the Lower Organisms.

Methods of cultivation.

Vessels.

Artificial cultivation is absolutely essential for the minute study of the properties of the various microorganisms.

The vessels most commonly employed for this purpose are thick-walled test tubes; or vessels $5 \mathrm{~cm}$. in diameter with narrow necks ; or flasks of various sizes, the best of which are the so-called Erlenmeyer's flasks with flat

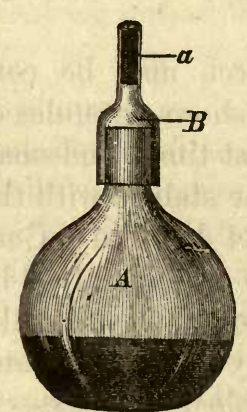

Fig. 140.-Pasteur's culture vessels. bottoms. In order to exclude the organisms plugs of cotton wool are employed, which extend for about $3 \mathrm{~cm}$. into the neck of the ressels, and project about $1 \mathrm{~cm}$. above it; this must not press too closely on the walls lest channels be left on the surface of the compact mass. Pasteur employs small flasks (matras), on the neck of which a small helmet fits $(B)$, which contains the plug of wool $(a)$. These vessels are more especially suitable for culture fluids where one wishes to re-inoculate frequently; in this case it is not necessary to take out the cotton wool plug with the particles of dust adhering to it-the helmet itself is lifted. Fol* employs a complicated plan consisting of an external cotton wool plug which remains untouched, in the interior of which is a glass tube which becomes narrower at the lower part. This tube contains at the lower part an asbestos, and at the upper part a cotton wool plug, and when a specimen is required only the latter is removed, while the asbestos plug is perforated by a heated canula.-As a rule, how* Arch. des sc. phys. et natur., Génève, 1884, t. 11. 
ever, these precautions are quite unnecessary; when the vessels are opened it is sufficient to burn the outer part of the cotton wool, which contains the dust, in the flame of the Bunsen burner in order to remove almost entirely the danger of the introduction of germs.

In many cases where we wish to have a larger surface of nutrient material we may employ, besides Erlenmeyer's flasks, small flat glass capsules with vertical walls 1 to $2 \mathrm{~cm}$. in height, and with a diameter of 4 to $6 \mathrm{~cm}$. - the so-called crystallisation capsules. These are preserved in a wider cylindrical vessel, 15 to $20 \mathrm{~cm}$. in height, in which the capsule can be readily raised and lowered by means of a bent strip of metal; the cylinder is plugged with cotton wool in the usual manner. If microscopic slides or glass plates are employed for cultivation it is sufficient to preserve them in glass dishes which are well closed, and it is best for the cover to overlap the lower part* of the dish.

The nutrient substrata. These must, in correspcidence The nutrient with what has been said above with regard to the conditions of life of the lower fungi and of the necessary nutrient materials, consist of carbonaceous, nitrogenous, and mineral substances; the excellence of the nutrient solution depends on the nutritive value of the materials employed, and also on whether the quantities present approach as nearly as possible the optimum of concentration, on whether the reaction is that which is best for the organism in question, on whether, and in what quantity, oxygen is present, \&c.

If we wish to cultivate mould fungi, and to aroid as far as Formould and we can the entrance of bacteria, we must employ a substratum yeast fungi. which is solid, which contains a small amount of water, and of which the reaction is markedly acid; in the case of the yeast fungi the best conditions are obtained by the employment of fluids which are not so markedly acid, but are still distinctly so, and which contain a considerable amount of

* A more precise description of the apparatus and the utensils necessary for the cultivation of bacteria will be found in the special catalogues of the firms from which all these articles can be obtained. The following may be recommended : R. Muencke, Berlin, N.W.; H. Rohrbeck, Berlin, N.W. 
sugar; for bacteria the most suitable substrata are those which contain a large amount of water, and of which the reaction is neutral or alkaline.

As nutrient soil for mould fungi we employ decoctions of dried plums and other fruits; decoctions of the fresh dung of herbivorous animals; decoctions of yeast containing a large amount of sugar; spread out dung of herbivorous animals; pieces of bread which may be impregnated with various decoctions; a paste made of bread, \&c. If the substrata are not sufficiently acid they may be made so by means of tartaric acid ( 2 to 5 per cent., according to the concentration of the nutrient solution) or phosphoric acid ( $\frac{1}{2}$ to 1 per cent.). - In the case of yeast fungi we select a decoction of malt, wort, or one of the above-mentioned decoctions, to which grape sugar is added; in the case of bacteria, urine; hay infusion, meat infusion, \&c., to which may be added the ashes of yeast, cigars, \&c., and of which the reaction should be as far as possible neutral, or at the most very slightly acid or alkaline.

For saprophy- Pasteur formerly recommended the following as a pure tic bacteria. artificial nutrient solution : 100 parts of water, 10 parts of candy sugar, 1 part of tartrate of ammonia, and the ashes from 1 part of yeast, the weight of the latter being about 075 of that of the whole mixture. Bucholtz replaced the yeast ashes in this solution by $\cdot 5$ grm. of phosphate of potash. Cohn selected the following mixture: $\cdot 1 \mathrm{grm}$. of phosphate of potash, $\cdot 1 \mathrm{grm}$. of crystallised sulphate of magnesia, $\cdot 01$ grm. of tribasic phosphate of lime, $20 \mathrm{grm}$. of distilled water, and 2 grm. of tartrate of ammonia.-These and similar nutrient solutions were, however, imperfect in various ways, as has recently been discovered by Nägeli. As the result of numerous experiments as to the nutriment of the lower fungi, Nägeli recommends the following solutions as normal fluids for bacteria (from these, solutions suitable for mould and yeast fungi can be readily prepared by the addition of sugar and acid) :-

1. Water $100 \mathrm{ccm} .$, tartrate of ammonia $1 \mathrm{grm}$. , biphosphate of potash $\left(\mathrm{K}_{2} \mathrm{HPO}_{4}\right) \cdot 1$ grm., sulphate of magnesia $02 \mathrm{grm}$., and chloride of calcium 01 grm.

Instead of the tartrate of ammonia we may employ acetate or lactate of ammonia, \&c., or even asparagine or leucine.

2. Water $100 \mathrm{ccm}$., peptone or soluble albumen $1 \mathrm{grm}$., biphosphate of potash $\left(\mathrm{K}_{2} \mathrm{HPO}_{4}\right) \cdot 2$ grm., sulphate of magnesia 04 grm., chloride of calcium $\cdot 02 \mathrm{grm}$.

3. Water $100 \mathrm{ccm}$., cane sugar $3 \mathrm{grm}$., tartrate of ammonia $1 \mathrm{grm}$. , and mineral salts as in No. 2. 
These various nutrient substrata are more or less un- For pathosuitable for the cultivation of the pathogenic bacteria. genic bacteria. These organisms evidently require a certain quantity of albumen and peptone, and sometimes also sugar, and are very sensitive to variations in the composition of the nutrient substratum. In the case of the majority of the pathogenic bacteria, the most favourable medium must be specially ascertained by experiment.

The following nutrient solutions are the best: meat infusion (prepared in the same manner as in the preparation of the nutrient jelly); meat infusion, with 1 per cent. peptone and 2 per cent. dextrose; solution of meat extract (Liebig's meat extract, 1 per thousand), with peptone and dextrose; milk; blood serum. We have also a series of soft but solid nutrient substrata, more especially boiled potatoes ; mixtures of the nutrient solutions with solidifying agents, such as gelatine or agar; solidified blood serum. All these nutrient substrata must be neutralised till the reaction becomes faintly alkaline; where the reaction is at first markedly acid, this is done by the addition of concentrated soda solution, where the excess of acid is slight it is best to employ a solution of the acid phosphate of soda.

All the vessels and nutrient substrata must be Sterilisation thoroughly sterilised before their employment, i.e., of the vessels they must be deprived of all living germs. This is done substratz. by heating the ressels (test tubes, with their cotton wool plug, \&c.) in copper or iron cases kept at a temperature of $150^{\circ}$ to $180^{\circ} \mathrm{C}$. for an hour ; at this temperature the wool is slightly burned; as a rule the temperature differs at various parts of the oven, and we must therefore ascertain in what part the proper temperature is present.-Larger dishes are washed out with a solution of corrosive sublimate ( 1 to 2000 ), and then they are repeatedly rinsed with distilled water which has been sterilised by boiling, or with absolute alcohol.-The nutrient substrata as soon as they have been introduced into the sterilised vessels are freed from their germs by boiling them in a steaming apparatus ; according to the amount of material they remain for fifteen to 
sixty minutes in the current of steam. The mixtures containing gelatine often lose their power of solidification if the heat has been continued for too long a time; hence for these mixtures we employ discontinuous heating, i.e., the gelatine mixture is placed on the first day in the steam for only five minutes; it is then kept till next day at a temperature of $20^{\circ}$ to $30^{\circ} \mathrm{C}$., so that any living spores which have remained behind may germinate; it is then exposed to the steam for five minutes on the second day, and this is repeated on the third day. -In the case of blood serum, which must be obtained clear and transparent, temperatures of only $55^{\circ}$ to $60^{\circ} \mathrm{C}$. are employed, and for five or six days in succession the material is exposed to this temperature for several hours (see p. 663).

Special Nutrient substrata.

Potatoes.

\section{Methods of Preparing some of the Nutrient Substrata.} -Potatoes are immersed for half-an-hour in a solution of corrosive sublimate in order to kill the resisting spores present in the particles of earth which adhere to the outside of the potato; they are then washed with sterilised water, ind cooked for thirty to forty minutes in the steaming apparatus. They are then placed to cool in a sterilised and covered vessel, and when they are cold they are cut by means of a knife which has been previously heated, and is still warm; the cultivation is then spread over the freshly cut surface.

Meatinfusion. Meat infusion and nutrient jelly. One kilo of good beef, free from fat, is minced and placed in two litres of water; after it has been kept for twenty-four hours at $15^{\circ}$ to $20^{\circ} \mathrm{C}$., the fluid is drained off, and the solid material is well squeezed; the infusion is then placed in flasks and boiled for one hour in the steaming apparntus, and then filtered. One per cent. of peptone and half per cent. of common salt is then added to the filtrate, which is neutralised with soda solution; the mixture is again boiled and filtered, and then introduced into the cultivation vessels; these vessels are again sterilised in

Nutrient jelly. the steaming apparatus for twenty to thirty minutes. - If a solid substratum is required we add, in addition to the peptone and common salt, 5 to 10 per cent. of gelatine, 
or 1 per cent. of agar-agar. The gelatine is dissolved by heat; the mixture is then neutralised, boiled for ten minutes in the steaming apparatus, and filtered through a warm filter. If the filtrate is not clear it must be again boiled, either with or without the addition of white of egg. The clear filtrate is introduced into the test tubes or flasks, and sterilised in the steaming apparatus for five minutes on three successive days.-The agar Nutrientagar. mixture must be kept for a long time (ten to twelve hours) in a state of constant simmering over a small flame, the water being replaced as it evaporates; it is then filtered through a warm funnel, or it is poured into a tall cylinder which is kept in warm water till the muddy portion is deposited; it is then allowed to solidify, the upper clear portion is cut off, dissolved by boiling, and placed in the various vessels; these are then again sterilised by exposure for half hour to the steam.

If possible sheep's blood should be received with anti- Blood serum. septic precautions in a sterilised vessel and covered with a sterilised glass plate; after forty-eight hours the clear serum is removed by a pipette, transferred directly to the vessels to be employed for cultivation, and kept at a temperature of $68^{\circ}$ to $70^{\circ} \mathrm{C}$. till the serum is solidified. The vessels are then placed in an incubator, and it is generally found that the great majority are sterile.-If it is found impossible to obtain the blood with antiseptic precautions, it must in the first place be sterilised as above described at $55^{\circ} \mathrm{C}$. on several successive days. - Instead of killing the germs we may sometimes try to get rid of them by filtering the nutrient material through plaster or porcelain (Chamberland's filter).

All the nutrient substrata which are to be employed for cultivation must be tested before use to see whether they are sterile; for this purpose they are kept for some time, and generally at a high temperature $\left(30^{\circ}\right.$ to $35^{\circ} \mathrm{C}$.); where the nutrient material is completely sterile no alterations ought to occur. The substrata are protected against drying by means of a caoutchouc cap placed over the wool plug. - Nutrient materials prepared with gelatine must not be placed at a higher temperature than $20^{\circ}$ to 
Re-inocula. tion.

$25^{\circ} \mathrm{C}$., otherwise they will become liquid; on the other hand, agar mixtures and solidified blood serum may be kept at a temperature of $35^{\circ}$ to $39^{\circ} \mathrm{C}$.

The inoculation of these sterilised media must be performed with great care; a small quantity of material containing the organisms is taken by means of a heated platinum wire, or of a fine glass tube, and the cotton wool plug being removed for the moment the wire is introduced into the nutrient material. In this method the entrance of organisms from the air is never quite excluded, but as the danger of contamination from the air is much less than from the instruments employed, this source of error is not of any great importance in practice. However, it is advisable in all cases where we wish to be certain as to the purity of the cultivations, to aroid draughts in the room, shaking of the room, \&c., and if necessary to moisten the floor and the walls.-It is well for the experimenter to wash his hands in sublimate solution before proceeding to the inoculation.

\section{Special Methods of Cultivation.}

Some special methods of cultivation.
Small cultivations, such as those on hollow microscopic slides, or in the so-called "glass chambers," are

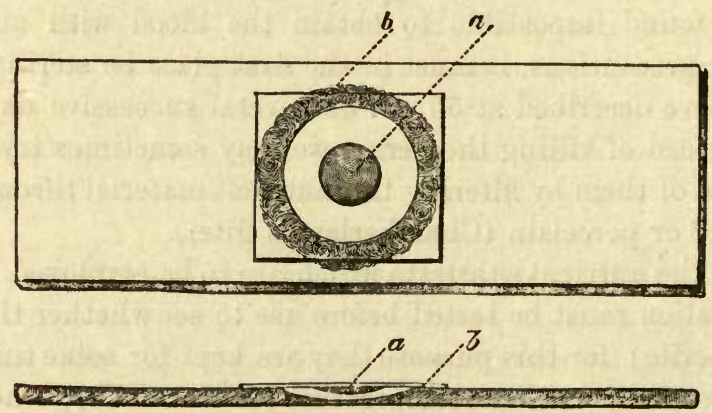

Fig. 141.-Drcp cultivations. $a$, the hanging drop.

$b$, the layer of vaseline.

of use for studying the stages of development of a species Drop cultiva- of bacteria which has already been cultivated pure. The tions. most simple mode of carrying on these cultivations is by 
placing a small drop of the nutrient solution on the centre of a sterilised cover glass; the latter is then seized with heated forceps, turned over, and placed orer the hollow in a sterilised excavated slide. Before doing this it is well to place a layer of vaseline around the cavity in the slide, and the cover glass is pressed on this layer, and thus air is excluded (see fig. 141; $a$, the hanging drop; $b$, the vaseline layer, which must not touch the border of the drop). The development of the bacteria in the drop can then be watched with high powers of the microscope, either by the use of a warm slide, or by Watson Cheyne's method (see p. 344).

Access of air is necessary for the development of many fungi, and the arrangement just described does not permit it. In these cases Prazmowski has devised an arrangement by which a small channel leads from the moist chamber to the outer air, and is not closed by the vaseline. These moist chambers do not permit a long observation, because the closure is imperfect, and impurities, more especially mould fungi, are generally found after a few days.

The glass cells employed by von Recklinghausen and Glass cells. Brefeld are more perfect arrangements. Brefeld's apparatus, which has been specially constructed for the cultivation of mould fungi and for their observation with high powers, consists of a narrow glass tube which dilates in the middle and forms a flattened sphere. The walls of the chamber are only of the thickness of cover glasses, and are so flat that an uniformly thin layer of fluid may be readily obtained in their interior. These vessels are thoroughly cleaned and freed from fat by immersion in ether and subsequently in boiling water, and then the fluid containing the fungus to be examined is sucked in, so that the inner wall of the chamber is only covered by a thin layer, and thus an individual spore can be watched for days with a high power.

Where larger cultivations are required we employ Adrantages of either fluid or solid nutrient substrata. The latter are solid nutrient most suitable for obtaining and maintaining a pure cultivation, and they also form the best means for isolating 
individual species of bacteria from a mixture of organisms. Solid nutrient media had been formerly frequently employed, but Koch was the first to use them with the definite view of obtaining thereby pure cultivations. - While in the case of fluids the organisms which are introduced, and any which may have accidentally entered, become mixed with each other, so that those that are few in number are scarcely recognisable among the larger number of rapidly growing organisms, in the case of solid substrata the individual species are much more easily isolated. If we inoculate a species of bacterium at various parts of the solid nutrient substratum, small colonies, soon distinctly visible to the naked eye, derelop at each of the points of inoculation; if extraneous organisms accidentally fall on the same nutrient soil, they on their part form isolated colonies which do not usually mix with those inoculated, and which are readily distinguishable from them by their colour, form, and consistence; should, however, the extraneous germ fall on one of the colonies inoculated, and multiply at the same part, they usually cause an alteration in the external appearance of this colony; and we can ascertain by simple microscopical observation whether at any part which we wish to choose for the inoculation of fresh soil impurities are present. For the second inoculation we only employ those parts which are found to be quite pure, and it is in the certainty with which we can find the material for each further inoculation that we have one of the greatest advantages of solid as compared with fluid nutrient substrata. If in the latter extraneous organisms once enter they spread through the whole medium, and it is pure chance if we succeed in avoiding one of these extraneous organisms when we inoculate fresh soil; the previous examination of a drop under the microscope is not sufficient; for if we find on examination that other organisms are present it is very difficult to obtain a pure cultivation. In the case of the solid nutrient substrata, on the other hand, it is not necessary to avoid altogether the entrance of other organisms, for in this case, as we can constantly control the selection of the part for re-inocu- 
lation, we have a guarantee for the purity of the second cultivation.

Among these solid nutrient substrata potatoes are Transparent more especially convenient. Nevertheless, it is better suld nutratrient if we can obtain a transparent soil, as, for example, by the admixture of gelatine or agar with the fluid; on these transparent soils the majority of the bacteria grow in a very characteristic manner, and we can distinguish the colonies very easily, not only with the naked eye, but also by the aid of the microscope. I have already, on p. 167, pointed out the most important differences of the stroke and puncture cultivations on these nutrient substrata.

It is, however, difficult to isolate the individual species Isolation of bacteria from a mixture by means of stroke and bacteria. puncture cultivations on solid nutrient substrata. 'If after the gelatine has been allowed to solidify on a glass slide we draw several long strokes over the surface with the infected needle we observe that discrete colonies appear at various parts of the track, and we can then reinoculate from these before they have coalesced with the other colonies. The more we dilute the material to be investigated, the more readily do we succeed in obtaining these discrete colonies. But where numerous species are present it may very readily happen that the organisms are carried along the stroke, and that several species develop at the same place.

On the other hand, the organisms can be very readily Plate cultiraisolated by means of plate cultivations. In this method the material to be investigated is in the first place mixed with the fluid jelly in various degrees of dilution, and this jelly, containing the subdivided germs, is then poured out on a cold glass plate, on which it rapidly solidifies. It is evident that in this method each of the suspended germs will be fixed at a particular spot, and if they are not too numerous, isolated colonies will develop from each organism, and these can be recognised by their characteristic appearance under the microscope, and may be inoculated into test tubes.

For this purpose we employ square, or, better, oblong 
plates of about 8 to $12 \mathrm{~cm}$. in length, and 6 to $8 \mathrm{~cm}$. in breadth. A number of these are sterilised at $180^{\circ} \mathrm{C}$., and kept in a covered vessel; the uppermost plate is always taken, and the gelatine is placed on its lower surface. We usually employ three plates, of which each is laid on a large sheet of glass, which is kept level. If the room is warm it is well to place a ressel containing cold water or ice beneath this glass plate. A mixture of nutrient jelly and bacteria is then poured out on its surface. This mixture is prepared in the following manner: we take three test tubes each containing 8 to 10 ccm. of nutrient jelly, and the gelatine in each is liquefied by dipping them in water at $40^{\circ} \mathrm{C}$. A small quantity of the material to be investigated is then introduced into the first glass and slowly but carefully mixed with the jelly; from this mixture three to five loopfuls are introduced into the second glass; this is again thoroughly shaken up, and from this glass three to five loopfuls are introduced into the third. The contents of these three glasses are then poured out on separate glass plates, the gelatine being equally divided over the plate by means of a previously heated glass rod. A strip about $1 \frac{1}{2} \mathrm{~cm}$. in breadth is left free all round the margin; on these free places sterilised glass supports are placed and fixed with a few drops of gelatine, and thus several plates may be piled one above the other. The plates are lept covered with a bell-jar till the gelatine is quite firm; after ten to fifteen minutes they can be placed in a glass vessel and set on one side. The ressel and its cover are lined with moistened filter paper, and sterilised in the steaming apparatus. These vessels may be placed in incubators kept at a temperature of about $22^{\circ} \mathrm{C}$, and are examined every twelve or twentyfour hours, at first without removing the cover, and later by examining the plates under the microscope at a magnification of 80 to 100 diameters.

By employing three degrees of dilution as above described, we almost always find that one of the plates is good, i.e., it contains a few isolated colonies which can be counted, and on the other hand not too fow 
colonies to make it doubtful whether or not they have arisen from accidental impurities, air germs, \&c. If at least 10 , or at most 500 colonies grow on a plate, it is in most cases a useful plate; if we only wish to count the colonies, and not to investigate them further, the number on the plate may be as great as 5,000. If in all three plates the numbers are greater or less than those given it is well to repeat the experiment.

In investigating various questions it is of great im- Enumeration portance that we should be able, by counting the colonies of the which have grown on the plate, to estimate the number of bacteria which are present in a mixture of organisms. In order to do this we must add a measured quantity of the material to the jelly, and afterwards count the number of colonies accurately. This is most easily done, when the colonies are numerous, by means of a glass plate divided into squares. In such a case we only count a few of the squares, strike an average from the figures so obtained, and calculate the number in the whole plate.

Similar plates can also be made with nutrient agar. Agar plates. This material is first liquefied in the tubes by boiling, and then cooled to $40^{\circ} \mathrm{C}$. in a water bath; the material is then added to the liquid agar, and the mixture poured out on the plates. We must employ agar, which becomes fluid at $40^{\circ} \mathrm{C}$., but solid at $38^{\circ}$ or $39^{\circ} \mathrm{C}$. The agar afterwards often expresses water, and as a result the whole mass may subsequently glide over the glass plate. It is therefore of importance to line the vessels in which the agar plates are to be kept only with dry filter paper; and thus the water as it is expelled from the agar evaporates so quickly that it cannot collect between the material and the glass plate.

A modification of the plate cultivations which has Esmarch's been made by Esmarch* is very useful for many practical purposes. Instead of flat glass plates he employs wide test tubes, and the surface of the glass plate is replaced by the equally large internal wall of the test tube; while the gelatine is still fluid, and after it has been mixed with the material under investigation, the

* Zeitschr.f. IIygiene, rol. i., Part 2. 
tube is continually rotated in a horizontal position, and thus as the material cools it solidifies in the form of an equally thin layer over the whole wall of the tube. The best way of doing this is to close the tube by means of a caoutchouc cap, let it swim on cold water, and give it a slight rotatory motion with the right hand, holding the orifice of the tube loosely in the left, and keeping it in the horizontal position.-In order to count the colonies the outer surface of the tube may be divided into larger or smaller portions by ink lines. One great advantage of this method is, that in the case of bacteria which grow very slowly an opportunity is afforded for their growth in these tubes, in which contamination cannot occur. It is more difficult to examine accurately the individual colonies, and to inoculate from them, than in the case of the plate cultivations, and it is only in special cases that this method would be employed when further cultivations were required.

Where it is important to obtain as complete knowledge as possible of all the species of bacteria which are present, we must vary the nutrient conditions as far as we can, more especially we must vary the amount of sugar, the degree of alkalinity, the temperature, and the amount of oxygen; in the case of numerous bacteria the conditions necessary for their artificial cultivation are not as yet known, and hence it is desirable to vary the Cultivation of conditions as much as possible.-For cultivating the anaërobic bacteria.

anaërobic bacteria Liborius recommends deep layers of nutrient agar containing 2 per cent. of dextrose. For this purpose test tubes are filled to a height of about 10 $\mathrm{cm}$. with the nutrient material, and the bacteria to be investigated are mixed with this material while still fluid and at a temperature of $40^{\circ} \mathrm{C}$.; the result is that isolated colonies of the anaërobes grow in the deeper layers. Instead of this method we may employ ressels containing nutrient substrata from which all the air has been expelled by means of hydrogen. Vessels of the form shown in fig. 142 are best suited for this purpose, and these are filled with the nutrient agar up to the level of the lateral tube; the material to be tested is then introduced 
through the upper opening, while a continuous stream of hydrogen is sent through the lateral tube, and when it has passed for a sufficient length of time the tubes are sealed at $a$ and $b$. In vessels of this kind we obtain luxuriant growth of the most typical anaërobes. If we wish to obtain the colonies of the anaërobes in such a way that they may be examined under the microscope, we employ little vessels containing a layer of the nutrient material at least $1.5 \mathrm{~cm}$. in depth, and these vessels are placed in an iron case with a tight fitting cover and provided with stopcocks, by means of which hydrogen can be passed through the vessel and all the air driven out. For further details, see Liborius, Zeitschr.f. Hygiene, vol.i., part 1.

If we have to do with bacteria which will not grow on solid nutrient substrata but only in fluids, the difficulty of isolating them is much greater. This was formerly done by Klebs' method-the so-called method of fractional cultivation; in this method a vessel is in the first place inoculated

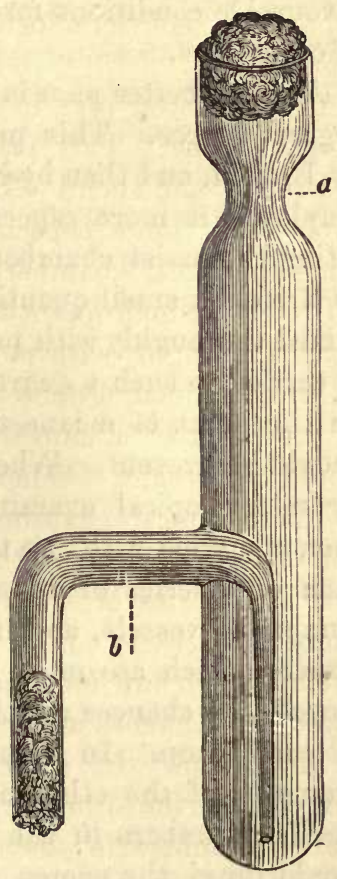

Fig. 142.-Apparatus for the cultivation of anaërobes.

and the bacteria are allowed to grow; a small quantity is then taken from the first vessel and introduced into a new nutrient material; this is again allowed to develop, and the process repeated through a series of cultivations. In this method the cultivations gradually become purer and contain only those organisms which grow most quickly under the conditions present, while the chances of the presence of the more slowly growing organisms become constantly less. This method is, however, not as a rule of much use, because it is not 
always the most quickly growing organisms which interest us; it is true that by varying the external conditions, more especially the temperature, we may vary the species of organism which grows most quickly in the mixture; but the method is always uncertain and tedious, more especially as we know very little as regards the most favourable conditions for the growth of the various linds of organisms.

Dilution method.

A much better plan is that of diluting the material to a great degree. This principle was first recommended by Brefeld, and then by Nägeli and Buchner, and Brefeld employed it more especially for the purpose of inoculating the moist chambers described above. According to Brefeld a small quantity of the material is taken and mixed thoroughly with pure sterilised water; the dilution is carried to such a degree that in the quantity contained on the point of a lancet-shaped needle only one germ should be present. When we have convinced ourselves by microscopical examination that this condition has been complied with, we then introduce this amount into each of a series of vessels, and if we employ a large number of vessels, and if in these the same organisms develop which are most numerous in the material employed, the chances are that only one germ was present in each drop. In some of the vessels we will find examples of the other organisms which are present in smaller numbers in the material. If we are isolating mould fungi, the spores of which are difficult to see, it is well to employ a nutrient solution instead of water, in order that the spores may sprout, and thus become larger and more easily visible, and then to dilute the material in the manner above described.

In the case of the bacteria the microscopical examination is, as a rule, of but little value, because the spores, and even the fully grown organisms, are so small that it is practically impossible to ascertain the presence of a single germ in one drop. In this case we can only get an approximate idea as to the amount of dilution from the microscopical appearances. The whole process rests on the assumption that the organisms in which we are interested 
were present in relatively large numbers in the material employed, and in many cases, even where we have to do with pathogenic organisms, this condition is probably fulfilled; where, however, saprophytes of various kinds are present in great excess, it is hardly feasible to hope for complete separation by this method.

In some cases it is well to combine the plate method and the dilution method in order to obtain good results.

The whole method of pure cultivation must of course be practised in the first instance with some typical examples. As good specimens for this purpose I would recommend the cultivation of bacillus prodigiosus on potatoes, gelatine, \&c., at various temperatures; the cultivation of anthrax bacilli on potatoes, nutrient jelly, blood serum, and in fluid substrata, likewise at various temperatures; the cultivation of Aspergillus flavescens on slices of potato at a low temperature $\left(15^{\circ}\right.$ to $20^{\circ} \mathrm{C}$., \&c.). If every one who attempts the cultivation of fungi, and especially the isolation of pathogenic organisms, would first test their knowledge with these typical examples, a great many imperfect papers would remain unpublished.

Having succeeded in obtaining a pure cultivation of A further an organism, we have next to determine its morpho- tifferentialogical and biological characters. We have to ascertain species what are the nutrient materials, and what the temperature which most favour its growth, and whether, and in what degree, it requires the presence of oxygen; we have to test whether it is able to excite fermentation, and for this purpose we have to add the most important of the fermentescible substances (carbo-hydrates, the higher alcohols, fatty acids, albuminous materials, de.) to the ordinary nutrient materials, and under the other conditions necessary for the growth of the organisms. We have further to ascertain whether the organism isolated has any pathogenic action; inoculation experiments must be made on a variety of animals, more especially on mice, which are so very susceptible to infective diseases, and also on guinea-pigs, rabbits, monkeys, \&c. These experiments must be carried out 
with smaller and larger doses, and the organisms must be introduced either by superficial inoculation, or by injection into the subcutaneous tissue, or by direct injection into the blood stream. If the animals become ill or die similar attempts at cultivation and inoculation must be made with their blood or organs, and the identity of the organisms inoculated with those found must be ascertained. All these experiments must be frequently repeated.-Lastly, we must make experiments as to the conditions of death of the organisms, and more especially as to the loss of their pathogenic properties, and we must ascertain what external conditions and what disinfecting means can most readily cause their destruction (see p. 653).

3. Bacteriological Investigation of Air, Water, and Soil.

Examination of air.

Miquel's method.

a. Air.-Attempts were formerly made to ascertain the number, species, and vitality of the organisms pre-

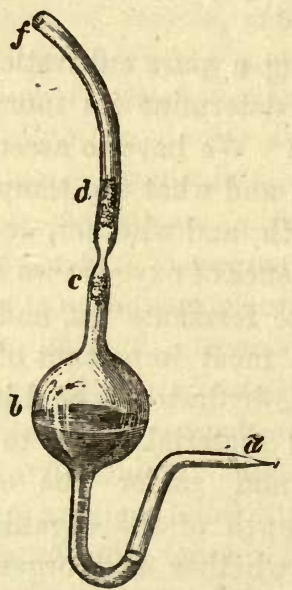

Fig. 143.-Miquel's ap. paratus for the investigation of air. sent in the air by fixing the germs on sticky surfaces, and by subsequent microscopical examination. These attempts were, however, failures, but in recent times fresh methods have been devised, the essential aim of which is to obtain a development of the individual germs, and then to count the colonies. Miquel employed for this purpose a fluid nutrient substratum, a broth prepared somewhat after the method described on p. 792 ; this material was introduced into a large number of small glass vessels of the form shown in fig. 143. These sterilised ressels were fixed in a stand, the end $f$ was connected with an aspirator, and the 
point $a$ was heated and then broken off. A small quantity, 1 to 3 litres, of air was drawn through the fluid and the point $a$ was sealed, the plug $c$, composed of spun glass, and which might have taken up some of the germs, was blown back into the fluid, and the apparatus was placed in an incubator. In each of these experiments 20 to 50 vessels were employed; after some time it was ascertained in how many of these muddiness had occurred as the result of the development of bacteria, and if this did not occur in all the ressels, but only in a small proportion of them, it was assumed that in each of the muddy vessels only one germ had entered. Hence the number of the vessels in which development occurred gave also the number of the germs which were present in the quantity of air aspirated through all the ressels. If none of the tubes became muddy, or if, on the contrary, they all became turbid, the experiment was repeated with larger or smaller quantities of air; if all the tubes had become turbid it was only possible to obtain the approximate minimal number of the organisms present, for in each case the muddiness might have been due not only to one but even to two, or ten, or more germs.

As is quite evident, the utility of this method rests on Sources of the assumption that the germs are very equally dis- error in this tributed in the air, and that they do not exist in masses. All other observations, however, show that this assumption is incorrect. Direct microscopical observations demonstrate that there are numerous collections of bacteria among the germs present in the air, and that they are by no means equally distributed throughout the air.-Besides, the whole method is extremely troublesome, and does not permit any sufficient variation of the nutrient media.

Hesse has attempted to utilise the solid nutrient sub- Hesse's strata for the investigation of air. A glass tube, $70 \mathrm{~cm}$. in length and $3.5 \mathrm{ccm}$. in width, is filled with $50 \mathrm{ccm}$. of nutrient jelly in such a way that the inner wall is lined with the material, and that a thicker layer of it is present at the lower part of the tube. One end of the tube is closed 
with an india-rubber cork, the centre of which is perforated, and contains a glass tube plugged with cotton wool; this glass tube is connected with the aspirator, the other end is covered with a caoutchouc cap, in which there is a central hole through which the air enters. The whole tube is placed on a stand in a horizontal position.

The germs present in the air fall-usually shortly after the entrance of the air into the tube-on the gelatine, and develop there to form isolated colonies. By this method we often obtain very instructive appearances, but even this method does not give accurate comparative results. For one thing, it is difficult to ascertain the proper rapidity of the current of air, so that no germs shall pass through the tube, and yet that they shall not be too numerous near the entrance of the tube; again, the dry surface of the gelatine is not a suitable place for the commencement of development; and, lastly, a mass of organisms gives rise to colonies which are equally well isolated as those which develop from a single individual.

Other Other attempts to determine quantitatively the germs methods. of the air have also as yet failed in giving entirely satisfactory results. Von Sehlen's attempts to employ agar nutrient solutions are open to the error that rapidly growing saprophytes may enter these nutrient materials while the air is being slowly drawn through them; and further, that it is difficult to retain the germs in the fluid, and Faults of also to vary the composition of the nutrient substratum. the methods as and suggestions for their - It seems best to employ indifferent substrata for the reception of the germs of the air. This can be best done by the use of cotton wool, glass wool, and similar substances. The material employed for the filtration of the air, and laden with the air germs, is then put into nutrient jelly, and after this has been shaken up for about half an hour (in order to break up any colonies that may be present) it is poured out on plates. If we wish to employ a variety of nutrient substrata the material used for the filtration is in the first place shaken up with salt solution, and equal known quantities of this solution are 
added to the various nutrient substrata.-Attempts carried out on those principles seem to promise useful results, but as yet this method has not been sufficiently tested.

b. Water.-The specimens to be investigated must be Investigation taken in sterilised vessels with glass stoppers, or, in order of water. How to avoid contamination which is very apt to occur during specimens. the transport, in small glass bulbs devoid of air and subsequently sealed. These glass bulbs have a diameter of about $1 \frac{1}{2} \mathrm{~cm}$., and are provided at one side with a glass tube almost of capillary thickness, and 10 to $15 \mathrm{~cm}$. in length.* By warming the bulb, and subsequently immersing it in distilled water it is about half filled with water; it is then placed on a stand, the glass tube being directed obliquely upwards, and surrounded with filter paper; the water in the bulb is then brought to the boil, the steam streams out of the capillary tube, and any drops of fluid which may be carried with it are soaked up by the filter paper. When all the water, with the exception of half a drop, has been volatilised the capillary tube is sealed while the stream of steam is still passing.

These tubes are carried in this state,

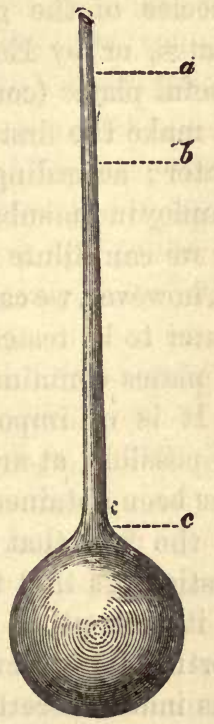

Fig. 144.-Apparatus for collecting water. and can be readily sent over considerable distances in tin vessels with a wooden bottom in which two hollows are present. - In taking the specimen to be tested a solution of sublimate (1 to 2,000) is poured over the bulb and the hands of the experimenter, and then the sublimate is removed by a portion of the water to be tested. When it has been quite removed, the capillary tube is broken near the point (at $a$ ) under water, which then rushes into and fills the bulb. The tube is then sealed (at $b$ ) in the flame

* These glass bulbs are readily prepared by means of a blow-pipe, or they can be obtained from any glass manufactory at a price of from $3 d$. to $7 d$. per dozen. 
of a spirit lamp.-When these bulbs are brought back to the laboratory they are again disinfected and washed with sterilised water. A mark is made with a file close to the junction of the tube with the bulb (at $c$ ), and the tube broken off at this point. The resulting opening is sufficient to enable one to remove the desired amount of water-a drop to a cubic centimetre or more-by means of a sterilised pipette.

Investigation. The best method of ascertaining the number and species of the germs present is by means of gelatine plates, or by Esmarch's method. In order to obtain useful plates (containing 10 to 5,000 colonies), it is well to make the first experiment with from 1 to 10 drops of water; according to the result of this experiment we can employin the subsequent attempts either larger quantities, or we can dilute the water with sterilised distilled water. If, however, we cannot again obtain a fresh specimen of the water to be tested we must at first make a large number of plates containing varying amounts of the water.

Error as the result of keeping a specimen of water.
It is of importance to examine the water as soon as possible, at any rate within one to three hours after it has been obtained. This precaution is essential, in view cf the fact that has now been confirmed by many investigators that the bacteria in the water multiply rapidly if it is kept in a warm place (see p. 711). In transporting the water it should be packed in ice; Wolffhügel has indeed ascertained that when water is preserved in ice the number of living germs present gradually diminishes; but the diminution is not so marked during the first twenty-four or forty-eight hours as to make any essential difference in the result. The great point is to avoid as far as possible any delay in the investigation.

Fol and Dunant have described a method of analysing water which is closely similar to Miguel's method of examining air, but it also possesses all the errors of this method, and is not of any practic $x$ l use.*

In judging the results of the investigation we have to bear in mind the points which hare been referred to on p. 714 .

* See Boito 1, Zeitschr. f. Hy, iene, vol. 1, Part 1. 
c. Soil.-As yet no accurate methods of investigating Investigation the bacteria of the soil have been published. The ${ }^{\text {of soil. }}$ author has found that the best method is to take a small known quantity of the soil and mix it with a known quantity of sterilised distilled water; the mixture is thoroughly shaken up for a half to one hour ; and then various quantities of the fluid are taken and employed, as in the case of the examination of water, for a number of plate cultivations. - In the case of the soil, also, it is of importance to examine the specimen as soon as possible after it has been taken, because the saprophytes multiply rapidly in the laboratory as the result of the higher temperature. No trustworthy method has been published with regard to taking specimens of the soil at various depths in such a way that all contamination from without and from the adjacent layers of soil is avoided.

It is of extreme importance in the interest of hygienic investigation that the methods of the bacteriological investigation of air, water, and soil should be improved. 
LONDON :

Printed by JAs. Truscott \& Sox, Suffolk Lant, E.C. 


\section{N D E X.}

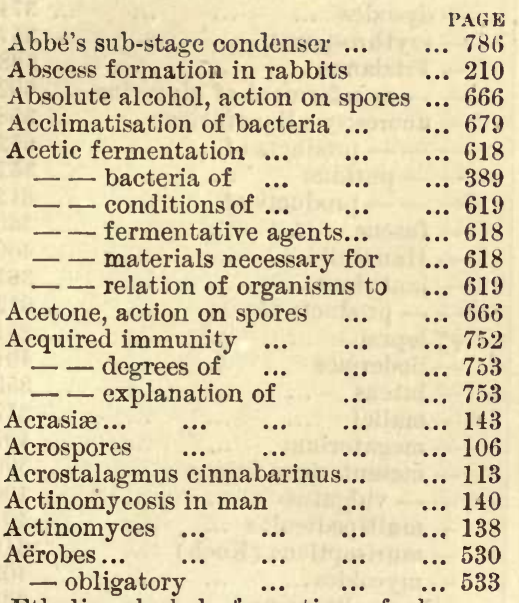

Ethylic alcohol, formation of, by fermentation $\quad . . \quad \ldots \quad \quad \ldots 601$

Agar plate cultivations $\quad \ldots \quad \ldots 799$

- preparation of, for cultivations 793

Air, bacteriological investigation of 804

- occurrence and behaviour of bacteria in $\quad . .6 \quad \ldots \quad$... 687

- transport by currents of _.. 740

Air germs, deposit of, by condensation of water vapour ... $\quad . . \quad 690$

- - errors in the recent investigations on $\quad \ldots \quad$... $\quad \ldots 691$

$\begin{array}{lllll}\text { - } \text { origin of } & \ldots & \ldots & \ldots & \ldots 87\end{array}$

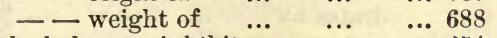

Alcohol as an inhibitory agent $\ldots 6654$

- influence of amount of, on fermentation $\quad \ldots \quad \ldots \quad \ldots 594$ Alcoholic fermentation of sugar by $\begin{array}{lllllll}\text { yeast } \quad \ldots & \ldots & \ldots & \ldots & 588\end{array}$ Alcohols, fermentation of the higher 602 Allyl-alcohol as an inhibitory agent ... 653 Alum, action on spores $\quad . .6 \quad \ldots 666^{\circ}$ Alvarez and Tavel on smegma bacilli 291 A mido bodies as nutriment for bacteria 550 Ammonia, action on spores ... $\quad \ldots 666$ A mmonium sulphide, action on spores 667
Anaërobes PAGE

— cultivation of $\quad \ldots \quad$... $\quad \ldots \quad \ldots 8800$

$\begin{array}{lllll}\text { - facultative } & \ldots & \ldots & \ldots & 532\end{array}$

- in relation to putrefaction $\quad \ldots 6614$

—obligatory $\quad$... $\quad$... $\quad \ldots 532$

- source of energy in $\quad \ldots . \quad \ldots .545$

- which excite putrefaction $\quad . . .38$ 3

$\begin{array}{lllll}\text { Anaërobic parasites } & \ldots & \ldots & \ldots & 639\end{array}$

Analysis of anthrax bacilli $\ldots . . \quad \ldots .526$

$\begin{array}{lllll}\text { - of bacteria } & \ldots & \ldots & \ldots & 252\end{array}$

- of Friedlaender's pneumonia

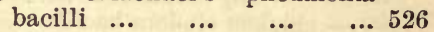

—of micrococci $\quad \ldots . \quad \ldots . \quad \ldots 526$

- of the ashes of the fission fungi 527

- of the budding fungi $\quad$... $\quad \ldots .516$

— of the mould fungi $\quad$.. $\quad$... 502

—of the vinegar plant $\quad \ldots \quad$... 526

Aniline dyes, Ehrlich on $\quad$... $\quad \ldots 780$

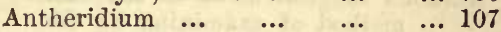

Anthrax bacilli, analysis of ... $\quad . . .526$

- - attenuation of $\quad \ldots \quad \ldots 657$

- - degrees of attenuation $\quad \ldots 657$

- Koch on spore furmation in 538

- -- Pasteur's views on the attenuation of $\ldots . \quad \ldots \quad \ldots 658$

$\begin{array}{lllll}- \text { products of } & \ldots & \ldots & \ldots & 658\end{array}$

Anthrax, protective inoculation $\begin{array}{lllll}\text { against } \quad \ldots & \ldots & \ldots & 757\end{array}$

- source of infection of $\ldots . \quad \ldots 738$

$\begin{array}{lllll}- \text { spread of ... } & \ldots & \ldots & \ldots & 732\end{array}$

Anthrax-protein $\quad \ldots \quad \ldots \quad \ldots 526$

Apparatus for disinfection by steam 772

Aquatic bacteria $\quad \ldots \quad \ldots . \quad \ldots$ ill

Area Celsi, micrococci in ... ...203

Arloing, Cornevin, and Thomas, on the bacillus of Rauschbrand ... 299

Aromatic bodies, production of, by the lower fungi $\quad . . \quad \ldots \quad \ldots 561$

Arseniate of potash as an inhibitory agent $\quad . . \quad \ldots \quad \ldots \quad \ldots \quad \ldots 653$

Arsenious acid, action on spores $\quad \ldots 6667$

$\begin{array}{lllllll}\text { Asci } & \ldots & \ldots & \ldots & \ldots & \ldots & 106\end{array}$

Ascococcus Billrothii ... $\quad \ldots . \quad \ldots 2231$

Ascomycetes ... $\quad \ldots \quad$... $\quad \ldots 108$

Ascospures $\quad \ldots \quad \ldots \quad \ldots . \quad \ldots 106$

Ashes of fission fungi, analysis of ... 527

Ashes of yeast, analysis of $\ldots . \quad \ldots 518$ 

$\begin{array}{llllll}\text { Aspergillus } & \text {... } & \text {... } & \text {... } & \ldots & 119\end{array}$ $\begin{array}{llllll}- \text { albus } & \ldots & \ldots & \ldots & \ldots & 122\end{array}$

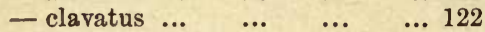
— distribution of $\ldots \quad$... $\quad \ldots \quad 126$ $\begin{array}{llllll}\text { - flavus } & \ldots & \ldots & \ldots & \ldots & 121\end{array}$ - fumigatus $\quad \ldots \quad$... ... 121

— infective, temperature optimum $\begin{array}{llllll}\text { of } & \ldots & \ldots & \ldots & \ldots & 125\end{array}$

$\begin{array}{llllll}- \text { niger } & \ldots & \ldots & \ldots & \ldots & 121\end{array}$

- ochraceus $\quad \ldots \quad$... $\quad \ldots 122$

- parasitic, occurrence of, in birds 124

— - - in mammals ... $\quad . .125$

- - - in $\operatorname{man} . . . \quad \ldots . \quad \ldots \quad 125$

Assimilation by the bacteria... 543, 545 Atmospheric pressure, influence of, on bacteria... $\quad . . \quad \quad \ldots \quad \ldots 535$

- - in relation to yeast ... $\quad \ldots .521$ Attenuated anthrax bacilli, return of virulence of $\quad \ldots \quad \ldots \quad \ldots 658$ Attenuation of anthrax bacilli $\quad \ldots 2239$ - _ - by carbolic acid $\quad \ldots 659$ — - - by chromic acid ...659 - - - by heat $\quad . .6 \quad \ldots 656$ — — - by sulphurous acid $\quad \ldots 659$ - chicken cholera bacilli $\quad \ldots 317$ - pathogenic and fermentative $\begin{array}{lllll}\text { organisms } \quad \ldots & \ldots & \ldots & 655\end{array}$

- - Rauschbrand bacilli... ... 300

- - the bacilli of chicken cholera 660

- - the virus of rabies ... ... 660

Author's suggestions as to the best method of examining air for bacteria 806

B.

Babes on red sweat ... ... ... 225 Bacillary necrosis of the liver Bacilli, characters of the $\quad$... $\quad \ldots l 172$

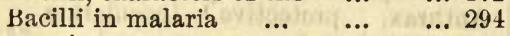
— in smegma $\quad$.. $\quad \ldots . \quad \ldots 291$

- key for the diagnosis of $\quad \ldots 411$

- of saliva ... $\quad \ldots \quad \ldots \quad \ldots \quad \ldots 319$

- pathogenic in animals ... ... 299

- pathogenic in man $\quad . . \quad \ldots 2234$

- with no known pathogenic pro-

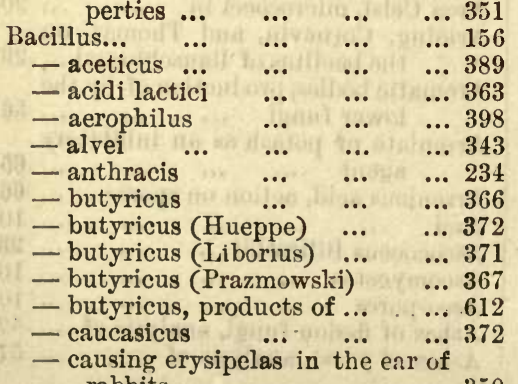
rabbits ...
PAGE

- fermentation of carbo-hy drates by drates by $\quad$... $\quad$... $\quad$... 601

- choleræ gallinarum $\quad$... $\quad$... 314

- coprogenes fotidus $\quad$... $\quad$... 379

— - products of $\quad \ldots . \quad \ldots 612$

- - parvus... $\quad . . \quad \quad \ldots \quad \ldots 333$

- crassus sputigenus (Kreibohm) 322

— cuniculicida (Koch) ... ... 312

- cyanogenus $\quad \ldots \quad \ldots . \quad \ldots 361$

- diphtheriæ (Loeffler) ... $\quad \ldots 280$

- - columbarum (Loeffler) ... 326

- vitulorum (Loeffler)... ... 328

- dysodes ... $\quad \ldots \quad$... $\quad \ldots .374$

\begin{tabular}{lllll} 
- erythrosporus & $\ldots$ & $\ldots$ & $\ldots$ & $\ldots$ \\
\hline
\end{tabular}

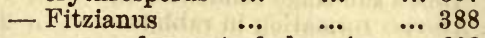

$\begin{array}{lllll} & \text { - as a ferment of glycerine } & \ldots & 602\end{array}$

— fluorescens liquefaciens _.. 358

$\begin{array}{llll}- & - \text { products of } \quad \ldots & \ldots & 612\end{array}$

$\begin{array}{lllll} & \text { - putidus } \quad \ldots & \ldots & \ldots & 357\end{array}$

- - products of $\quad \ldots . \quad \ldots 612$

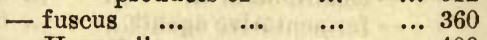

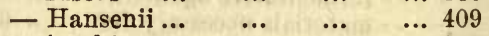

\begin{tabular}{lllll} 
- janthinus... & $\ldots$ & $\ldots$ & $\ldots$ & $\ldots$ \\
\hline
\end{tabular}

- $\begin{array}{lllll}\text { - products of } & \ldots & \ldots & \ldots & 612\end{array}$

$\begin{array}{lllll}\text { - lepræ } \quad \ldots & \ldots & \ldots & \ldots & 274\end{array}$

$\begin{array}{lllll}\text { - liodermos } & \ldots & \ldots & \ldots & 401\end{array}$

\begin{tabular}{llllll} 
- luteus & $\ldots$ & $\ldots$ & $\ldots$ & $\ldots$ & $\ldots$ \\
\hline
\end{tabular}

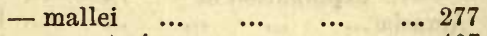

- megaterium $\quad \ldots \quad \ldots . \quad \ldots 407$

— mesentericus fuscus $\quad \ldots . \quad \ldots 399$

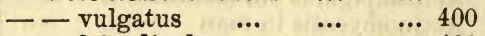

$\begin{array}{llll}\text { - multipediculus } \ldots & \ldots & \ldots & 401\end{array}$

- murisepticus (Koch) ... ... 310

$\begin{array}{lllll}- \text { mycoides ... } & \ldots & \ldots & \ldots & 403\end{array}$

$\begin{array}{lllll}\text { - neapolitanus } & \ldots & \ldots & \ldots & \ldots 35\end{array}$

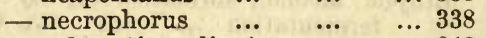

— œdematis maligni $\quad$... $\quad \ldots 242$

— of jequirity ophthalmia $\quad$... 346

— of Rauschbrand... ... ... 299

— of rhinoscleroma $\quad \ldots . \quad \ldots 291$

— of swine erysipelas $\quad$... $\quad$... 302

$\begin{array}{lllll}\text { - of syphilis } & \ldots & \ldots & \ldots & 288\end{array}$

— oxytocus perniciosus $\quad . . \quad \ldots \quad \ldots 332$

$\begin{array}{lllll}\text { - parvus ovatus } & \ldots & \ldots & \ldots & \ldots 399\end{array}$

- Pasteurianus ...

- pneumoniæ (Friedländer) ... 255

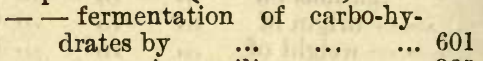

- pneumonicus agilis $\quad \ldots . \quad \ldots 325$

$\begin{array}{lllll}\text { - polymyxa } & \ldots & \ldots & \ldots & 374\end{array}$

\begin{tabular}{llll} 
- prodigiosus & $\ldots$ & $\ldots$ & $\ldots$ \\
\hline
\end{tabular}

—- products of $\ldots . \quad \ldots . \quad \ldots 612$

- pseudopneumonicus $\quad$... $\quad$... 324

$\begin{array}{lllll}\text { - putrificus coli } & \ldots & \ldots & \ldots & 376\end{array}$

- - - products of $\quad \ldots . \quad \ldots 611$

- pyocyaneus, as a ferment of $\begin{array}{lllll}\text { glycerine } & \ldots & \ldots & \ldots & 602\end{array}$

— - products of $\ldots . \quad \ldots . \quad \ldots 612$

- pyogenes fotidus $\quad$.. $\quad \ldots 375$

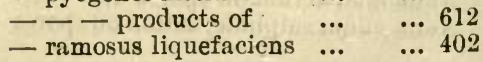


PAGE

Bacillus saprogenes $\quad \ldots \quad \quad \ldots \quad \ldots 377$

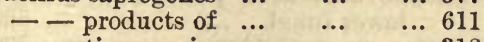

- septicus agrigenus $\quad \ldots \quad \ldots \quad$... 318

— - sputigenus (Fraenkel) $\quad \ldots 325$

$\begin{array}{llllll}\text { - subtilis } & \ldots & \ldots & \ldots & \ldots & 394\end{array}$

\begin{tabular}{lllll} 
& - analysis of $\quad \ldots$ & $\ldots$ & $\ldots$ & \\
\hline
\end{tabular}

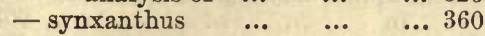

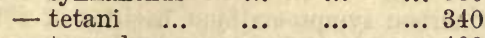

$\begin{array}{ccccc}- \text { tremulus } \ldots & \ldots & \ldots & \ldots & \\ - & \ldots & \ldots & \ldots & 409\end{array}$

— tuberculosis $\quad \ldots \quad \ldots \quad \ldots 260$

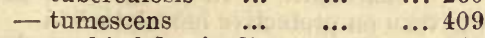

- typhi abdominalis $\quad \ldots . \quad \ldots 248$

$\begin{array}{lllll}\text { - ulna } \quad \ldots & \ldots & \ldots & \ldots & 409\end{array}$

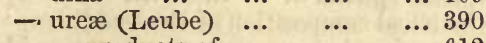

- $\begin{array}{llll}\text { products of } \ldots & \ldots & \ldots & \ldots 12\end{array}$

Bacteria, analysis of $\ldots . . \quad \ldots . \quad \ldots .5525$

- arthrospores in ... $\quad \ldots \quad 161,163$

- assimilation by ... ... 543,545

- characters of the cultivation of 164

- classification of ... $\quad \ldots \quad \ldots 169$

- Cohn's classification of... $\quad \ldots 177$

- conditions of spore formation and spore germination of $\quad \ldots 537$

— de Bary's classification of $\quad \ldots 179$

- destruction of, in the borly ... 643

- diagnosis of, from tissue elements $\ldots \quad \ldots \quad \ldots \quad \ldots 787$

- distribution of $\ldots . \quad \ldots \quad \ldots 685$

- endospores in $\ldots . \quad \ldots \quad \ldots 161$

- fermentation by $\quad$.. $\quad$... 59 5

— fermentation of sugar by $\quad \ldots .590$

- from mud, or the intestinal contents of ruminants, products of $\quad \ldots \quad \ldots \quad$... 612

- germination of spores of $\quad \ldots .163$

- growth in meat jelly ... ... 165

- habitat of $\quad \ldots \quad \quad \ldots \quad \ldots 685$

— in articles of food $\quad \ldots . \quad \ldots 716$

— in dwelling houses $\quad \ldots . \quad \ldots 7719$

— in clothing $\quad \ldots \quad \ldots . \quad \ldots \quad \ldots 718$

- influence of atmospheric pressure on ... $\quad \ldots \quad$... $\quad \ldots 535$

-influence of concurrent growth on 537

— influence of electricity on ... 535

- influence of fermentative activity on the life of ... $\quad . .5536$

- influence of light on ... $\quad$... 535

- influence of mechanical movement on

— influence of temperature on $\ldots \begin{array}{ccc}\ldots 36 & \end{array}$

$\begin{array}{lllll}\text { - in refuse ... } & \ldots & \ldots & \ldots & 720\end{array}$

— in the intestine ... $\quad \ldots . \quad \ldots 724$

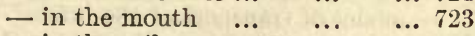

$\begin{array}{lllll}\text { - in the soil } & \ldots & \ldots & \ldots & 693\end{array}$

— in the soil under floors... $\quad \ldots 719$

— in the stomach ... $\quad \ldots \quad \ldots . \quad \ldots 724$

— involution forms of $\quad \ldots . \quad \ldots .6156$

- means for the destruction of ... 662

— method of diagnosing ... $\quad \ldots \quad 176$

- methods of investigating $\quad \ldots 777$

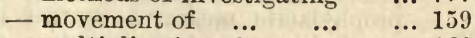

$\begin{array}{llll}- \text { multiplication of } & \ldots & \ldots & 160\end{array}$
.. 375

- on the respiratory mucous mem-

brane ... $\quad \ldots \quad$... $\quad \ldots 724$

- on the skin $\quad \ldots \quad \ldots . \quad \ldots 723$

— on the surface of the body $\quad \ldots 723$

- parasitic, in plants $\quad . . \quad \quad \ldots 636$

- propagation of, by spores _... 161

- reaction of the nutrient medium in relation to ... $\quad . . \quad \ldots 534$

- relation of concentration of the nutrient medium to ... ... 533

- relation of, to oxygen ... $\quad$... 530

$\begin{array}{llll}\text { - spores of } \ldots & \ldots & \ldots & 156,162\end{array}$

— staining of $\quad \ldots \quad$... $\quad \ldots 778$

- structure of cells of $\quad \ldots . \quad \ldots \quad 158$

- transport of $\quad \ldots \quad \ldots . \quad \ldots 687$

- vegetative forms of $\quad \ldots . \quad \ldots \quad 155$

- with variable vegetative forms 175 ,

7op's 484

Tacteriof's classification of ... 180

Bacteriological investigation of air, water, and soil... $\quad \ldots \quad \quad \ldots 804$

Bacterio-purpurine ... $\quad \ldots . \quad \ldots 490$

$\begin{array}{llllll}\text { Bacterium } & \ldots & \ldots & \ldots & \ldots & 156\end{array}$

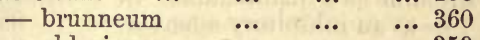

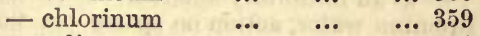

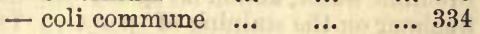

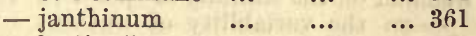

- lactis aërogenes ... ... ... 335

- lactis, nutrient materials neces$\begin{array}{lllll}\text { sary for... } & \ldots & \ldots & \ldots & 529\end{array}$

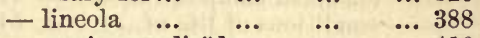

- merismopedioïdes $\quad$... $\quad . .410$

- syncyanum $\quad$... $\quad \ldots . \quad \ldots 361$

$\begin{array}{lllll}\text { - synxanthum } & \ldots & \ldots & \ldots & 360\end{array}$

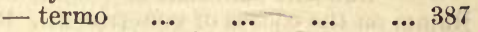

— - relation of temperaiure to ... 536

$\begin{array}{llllll}- \text { Zopfii } & \ldots & \ldots & \ldots & \ldots & 405\end{array}$

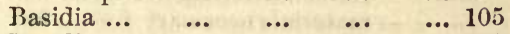

$\begin{array}{lllll}\text { Basidiosporeæ } & \ldots & \ldots & \ldots & 108\end{array}$

Basidiospores ... $\quad \ldots \quad$... $\quad \ldots 106$

Bassi on muscardine ... $\quad \ldots \quad \ldots .94$

$\begin{array}{llllll}\text { Beer yeast } & \ldots & \ldots & \ldots & \ldots & 589\end{array}$

Bees, bacillus of foul brood of $\quad \ldots 343$

$\begin{array}{lllll}\text { Beggiatoa } & \ldots & \ldots & \ldots & 174,488\end{array}$

$\begin{array}{llllll}- \text { alba } & \ldots & \ldots & \ldots & \ldots & 489\end{array}$

- mirabilis ... $\quad \ldots \quad \ldots . \quad \ldots 490$

— roseo-persicina $\ldots . \quad \ldots . \quad \ldots 490$

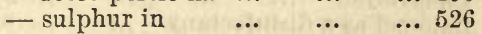

Behaviour of bacteria in the air $\quad \ldots 687$

— of bacteria in the soil ... $\quad$... 691

Benzoate of soda as an inhibitory agent 654

Benzoic acid, action on spores ‥ 666

- - as an inhibitory agent ...653

Benzole, action on spores $\quad \ldots . \quad \ldots 666$

Bichloride of mercury, action on spores

$\begin{array}{lllll}\text {... } & \ldots & \ldots & \ldots & 667\end{array}$

- - as an inhibitory agent ...653

Bienstock's bacilli from fæces 333,404

- putrefactive bacillus from fæces 376

Billroth's objections to the parasitic

theory ... 
Biological relations between the higher plants and the fungi, former views as to ... ... 495

Biology of the micro-organisms $\quad . .449$.

Birds, mould fungi as parasites in ... 634

$\begin{array}{llllll}\text { Black yeast } & \ldots & \ldots & \ldots & \ldots & 154\end{array}$

Blight fungi $\quad \ldots . \quad \ldots \quad \ldots . \quad \ldots \quad 109$

Blood serum, preparation of, for cultivations $\quad$... $\quad$... $\quad$... 793

Blue milk, bacillus of $\quad$... $\quad$... 361

Boracic acid, action on spores $\quad \ldots 667$

- - as an inhibitory agent $\quad \ldots 653$

Borax, action on spores $\quad . . \quad \ldots 666$

Bostroem on cultivation of actino-

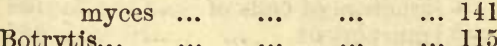

$\begin{array}{lllll}\text { Botrytis... } & \ldots & \ldots & \ldots & 115 \\ \text { Bread, fermentation of } & \ldots & \ldots & 606\end{array}$

Brefeld's glass cells ... $\quad \ldots \quad \ldots 795$

Brefeld on temperature in relation

to bacillus subtilis ... $\quad \ldots \quad 536$

Brieger's analysis of Friedlaender's pneumonia bacilli $\quad$... $\quad . .5526$

Brieger on ptomaines... $\quad$... $\quad$.. 569

Bromine as a disinfectant $\quad . .6 \quad$... 669

— as an inhibitory agent ... ... 653

Bromine water, action on spores $\quad . .6667$

Buchner on the staining of spores ... 785

- on the variability of anthrax bacilli... $\quad . . \quad \ldots \quad \ldots 240$

Budding fungi as infective agents ... 636

- - chemical composition of $\ldots \quad 516$

$\begin{array}{llll}- & - \text { conditions of life of... } \quad \ldots & 516\end{array}$

- - conditions of spore formation and spore germination of $\quad \ldots \quad 523$

- - nutrient materials of $\quad \ldots 518$

Bumm on the coccus of gonorrhœea... 199

Butyric acid fermentation $\quad . . \quad \ldots \quad \ldots 597$

_- - fermentative agents of the 598

_ - materials necessary for ... 597

- - nature of the decomposi-

tion of ...

Bye products in the alcoholic fermentation of sugar ... ... 590

\section{C.}

Cadaverine

Calomel as a disinfectant $\quad$... $\quad$... 6504

Camphor as an inhibitory agent $\quad . .654$

Carbo-hydrates, bacilli causing fermentation of ... ... $\quad \ldots 363$

— fermentation of, by bacteria $\ldots . .595$

Carbolic acid, action on bacteria $\quad \ldots 667$

— - action on spores $\quad$... $\quad \ldots 667$

— - as a disinfectant $\quad \ldots . \quad \ldots 671$

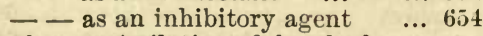

Carbon, assimilation of, by the lo ver fungi $\ldots \quad \ldots . \quad \ldots \quad \ldots 546$

- sources of, for the fission fungi... 528

— - of, for the mould fungi ... 504

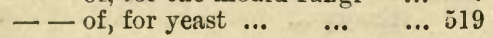

Carbonic acid as a product of the lower fungi $\quad . . \quad$... $\quad . .560$ Cellulose fermentation $\quad \ldots . \quad \ldots 660$ - solution of, by the butyric acid bacillus... $\quad . . \quad \ldots \quad \ldots$

Cerebrospinal meningitis, micrococci in $\quad \ldots \quad \ldots . \quad \ldots \quad \ldots 203$

Charbon symptomatique, bacillus of 299

Charrin's septicémie consécutive au charbon... $\quad \ldots \quad \ldots \quad \ldots 207$

Chaveau on protective inoculation in anthrax... $\quad \ldots \quad \ldots \quad \ldots 757$

$\begin{array}{lllll}\text { Cheese spirilla } . . . & \ldots & \ldots & \ldots & 477\end{array}$

Chemical composition of the budding fungi $\quad \ldots \quad \ldots \quad \ldots \quad \ldots \quad \ldots 516$ - - of the fission fungi ... $\quad \ldots \quad 525$

- - of the mould fungi ... $\quad$... 502

Chemical ferments $\quad \ldots \quad \ldots \quad \ldots \quad \ldots 574$

- - rôle of ... $\quad \ldots \quad \ldots . \quad \ldots \quad 575$

- poisons as inhibitory agents of bacterial growth $\quad . . \quad \ldots 651$

Cheyne's method of studying spore formation and the sprouting $\begin{array}{lllll}\text { of spores } \quad \ldots & \ldots & \ldots & 795\end{array}$

Chicken cholera, attenuation of the bacilli of $\quad \ldots \quad \quad \ldots \quad \quad \ldots 660$

- - bacillus of $\quad \ldots . \quad \ldots . \quad \ldots \quad$... 314

- - protective inoculation against 756

Chinolin as an antiputrefactive agent 655

Chlorate of potash, action on spores 666 Chloride of calcium, action on spores 666 Chloride of iron, action on spores ... 667 Chloride of lime, action on spores ... 6667 Chlorine as a disinfectant $\quad$... $\quad$... 66 6 9

— as an inhibitory agent ... $\quad . . .65 \%$

- water, action on spores... $\quad \ldots 667$

Chloroform, action on spores $\quad$... 666 Cholera, acquired immunity ... $\quad \ldots 447$

- artificial production in animals 438

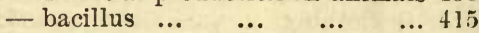

- contagiousness of $\quad \ldots . \quad \ldots 734$

— Emmerich's bacillus of... $\quad$... 33.

— endemic occurrence $\quad \ldots . \quad \ldots \quad 451$

— factors predisposing to $\ldots . \quad \ldots .447$

- influence of individual predisposition on $\quad . . \quad \ldots \quad 446,460$

— influence of the soil on $\ldots \quad \ldots 457$

- local and seasonal variations $\begin{array}{llllll}\text { in } & \ldots & \ldots & \ldots & \ldots & 765\end{array}$

- localistic view $\ldots . \quad \ldots . \quad \ldots 467$

- local predisposition _.. …453

- meteorological influences ... 45.5

- modes of transport of the infective agents of ... $\quad \ldots \quad \quad \ldots \quad 444$

— natural mode of infection $\quad \ldots 4422$

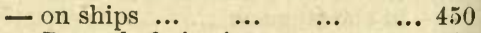

- Pettenkofer's views on ... ... 468

- points of entrance of the infective agents into the body $\quad . .444$

— present mode of spread of $\quad . .452$

- prophylactic measures against 449

- prophylactic regulations against 470 
Cholera, protective arrangements PAGE the healthy body ... $\quad \ldots 446$ - seasonal predisposition ... ... 453 - sources of infection ... 443,738 - transmission by the sick

Cholera nostras, relation of Finkler and Prior's spirillum to ... 476

Choline... $\quad$... $\quad \ldots \quad$... $\quad \ldots .569$

Citrate of lime, fermentation of $\quad \ldots .605$

$\begin{array}{lllll}\text { Cladothrix } \quad \ldots & \ldots & \ldots & \ldots & 174\end{array}$

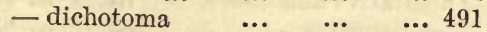

Clathrocystis roseo-persicina $\quad \ldots 490$

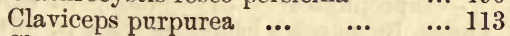

$\begin{array}{llllll}\text { Cleospora } & \ldots & \ldots & \ldots & \ldots & 115 \\ & & \ldots & \ldots & 115\end{array}$

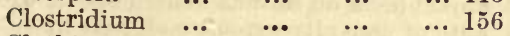

Clothing, bacteria in ... $\quad \ldots . \quad \ldots 718$

Clou de Biskra... $\quad \ldots . . \quad \ldots . \quad \ldots \quad 188$

Cochin on the time required for fermentation $\quad \ldots . \quad \ldots \quad$... 593

Cohn's nutrient solution $\quad \ldots . \quad \ldots 790$

Comma bacillus $\quad \ldots \quad \ldots . \quad \ldots 415$

Common salt as an inhibitory agent 654

Concentration of the nutrient medium

in relation to the bacteria $\ldots 533$

Concurrent growth of bacteria $\quad \ldots .537$

- - of mould fungi with other organisms $\quad \ldots \quad \ldots \quad \quad \ldots \quad 513$

$\begin{array}{llll}\text { - } & \text { of yeast with other fungi } & \ldots & 522\end{array}$

Conditions of life of the budding fungi 516 - - of the fission fungi $\quad . .5525$

- - of the lower fungi $\quad . .501$

- - of the mould fungi $\quad$... 502

$\begin{array}{llllll}\text { Conidia ... } & \ldots & \ldots & \ldots & \ldots & 106\end{array}$

Constancy of the character's of the fungi $\quad . . \quad \ldots \quad \ldots \quad \ldots 672$

- of the products of tissue change 564

Contact, transport by $\quad$... $\quad$... 739

Contagion by direct contact $\quad$... $\quad$... 730

- by surrounding objects... ... 731

Contagious facultative parasites $\quad \ldots 732$

$\begin{array}{lllll}- & - \text { sources of ... } & \ldots & \ldots & 738\end{array}$

$\begin{array}{llll}\text { — infective diseases } & \ldots & \ldots & \ldots 730\end{array}$

— obligatory parasites $\ldots . \quad \ldots 732$

— - - sources of infection by ... 736

Contamination of the soil $\quad \ldots \quad \ldots . .722$

Cordua on zoonotic finger erysipeloid 201

$\begin{array}{lllll}\text { Cordiceps isaria } \quad \ldots & \ldots & \ldots & 115\end{array}$

Corrosive sublimate as a disinfectant 670

Cover glass preparations $\quad \ldots \quad \ldots 778$

$\begin{array}{llllll}\text { Crenothrix } & \ldots & \ldots & \ldots & \ldots & 174\end{array}$

- Kühniana $\quad$.. $\quad \ldots . \quad \ldots 486$

Cryptococcus xanthogenicus $\quad$... 203

Cultiration of anaërobic bacteria $\ldots .800$

- of micro-organisms $\quad$... $\quad$... 788

- special methods of $\quad \ldots \quad \ldots 794$

D.

Dahlia... $\quad \ldots \quad \ldots \quad \ldots . \quad \ldots 782$

Davaine on progressive virulence $\quad \ldots 6862$

Death of the lower fungi, conditions affecting the
De Bary on bacillus megaterium

- - classification of the parasitic

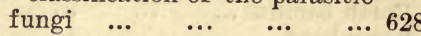

$\begin{array}{llllll}\text { Decay } \ldots & \ldots & \ldots & \ldots & \ldots & 628 \\ \text { Degenerative } & \text { changes } & \ldots & \ldots & \ldots & 616\end{array}$ variations as the result of $\quad \ldots 676$

De la Croix on the action of chemical agents on bacteria $\quad . . \quad \ldots 651$

Dencke on cheese spirilla $\quad \ldots \quad$... 477

Dental caries, bacilli in $\quad \ldots . \quad \ldots 298$

- - bacteria in ... $\ldots . \quad \ldots 391$

Destruction of bacteria by chemical poisons ... $\quad \ldots . \quad \ldots \quad \quad \ldots 665$

- - by steam ... $\quad \ldots \quad \ldots 665$

- - in the blood $\quad \ldots . \quad \ldots 742$

- - means for $\quad \ldots \quad \ldots 662$

Dextran fermentation $\quad \ldots . \quad \ldots 6600$

Dextran fermentation of sugar $\quad \ldots 215$

Diagnosis of bacteria from tissue elements $\quad \ldots \quad \ldots . \quad \ldots 787$

- of the bacilli, key for .... $\quad$.... 411

—of the micrococci, key for $\quad \ldots 232$

- of the spirilli, key for ... ... 485

Diastase, chemical composition of ... 581

Diastatic ferments ... $\quad . . \quad \ldots .576$

Dilution, separation of bacteria by... 802

Diphtheria in calves, bacillus of $\quad$... 328

— in pigeons, bacillus of ... $\quad \ldots 326$

- Loeffler's bacillus of ... ... 280

- micrococci in ... $\quad \ldots \quad$... 202

- sources of infection of ... $\quad \ldots . .737$

Diplococcus albicans tardissimus $\quad \ldots 230$

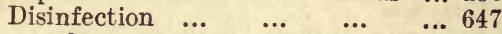

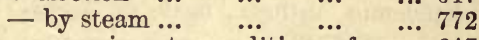

- experiments, conditions of $\quad \ldots 647$

- natural means of $\quad$... $\quad \ldots 685$

— of dwelling-houses $\quad \ldots . \quad \ldots \cdot 775$

$\begin{array}{lllll}\text { - of excreta } & \text {.. } & \text {... } & \ldots & \text {... } 772\end{array}$

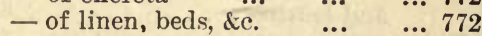

— Schiitte's regulations for $\quad \ldots 776$

$\begin{array}{lllll}\text { Dispora caucasica } & \ldots & \ldots & \ldots & 372\end{array}$

Distilled water, action on spores $\quad \ldots 666$

Distribution of bacteria $\quad$... $\quad \ldots 685$

$\begin{array}{lllll}\text { Double staining } \quad \ldots & \ldots & \ldots & 782\end{array}$

Drainage, advantages of $\quad \ldots . \quad \ldots 787$

Drinking water in relation to $\begin{array}{lllll}\text { typhoid fever } & \ldots & \ldots & \ldots & 767\end{array}$

Drop cultivations $\quad \ldots \quad \ldots \quad \ldots \quad \ldots 794$

Drying, influence of on cholera bacilli 433

Dry zone in relation to the spread of bacteria from the soil

Duclaux, on the coagulation of caseine by bacteria ... ... ... 580

Dujardin-Beaumetz on sulphurous acid as a disinfectant... $\quad$.. 669

Dulcite, fermentation of $\quad \ldots \quad \ldots 603$

Duodenum, injection of cholera bacilli into $\quad . . \quad \ldots \quad \quad \ldots 436$

Durin and Schebler on the analysis of bacteria... $\quad . . \quad \ldots \quad \ldots 527$

Dwelling-houses, disinfection of $\quad \ldots .775$ 
E.

Earth bacillus...

PAGE

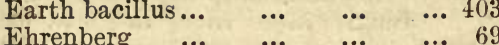

$\begin{array}{lllr}\text { Ehrlich on Mastzellen } & \cdots & \ldots & 69\end{array}$

— on the aniline dyes $\quad \ldots . \quad \ldots 780$

Eidam on temperature in relation

to bacterium termo ... ... 536

Electricity, influence of, on bacteria 535

Embolism by bacteria $\quad \ldots \quad \ldots 641$

Emmerich's bacillus of cholera $\quad . .335$

Emmerich on bacteria in diphtheria 287

- on cholera bacilli ... ... 420

- on pneumonia bacteria outside the body ... $\quad . . \quad \ldots \quad 259$

$\begin{array}{lllll}\text { Empusa muscæ } & \ldots & \ldots & \ldots & 111\end{array}$

- radicans ... $\quad \ldots . \quad \ldots . \quad \ldots 112$

Emulsine, chemical composition of... 581

Endocarditis ulcerosa $\quad \ldots . \quad \ldots 197$

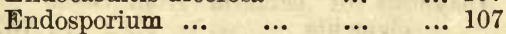

Endothelial cells, relation to bacteria 644

Endothelium, importance of, in regard to infection $\quad . . \quad \ldots \quad \ldots 750$

Energy, development of, by the lower fungi $\quad . . \quad \quad \ldots \quad \quad \ldots \quad \ldots 544$

- interchange of, in the lower fungi 557

- source of, in the case of the anaërobes $\quad \ldots \quad \ldots \quad \ldots 545$

Engelmann on the influence of oxygen on the movement of the bacteria $\quad . . \quad$... $\quad . .5531$

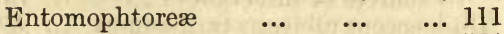

$\begin{array}{llllll}\text { Enzymes } & \ldots & \ldots & \ldots & \ldots & 574\end{array}$

Epidemic anthrax, mode of occurrence of... $\quad$... $\quad$... $\quad \ldots 239$

Epidemic diseases of plants, factors which influence their spread... 632

- of plants, relation to season and locality $\quad . . . \quad \ldots \quad \ldots$

$\begin{array}{llllll}\text { Episporium } & \ldots & \ldots & \ldots & \ldots & \ldots \\ & & \ldots & \end{array}$

Epithelium, importance of, in regard to infection $\quad \ldots \quad \ldots . \quad \ldots \quad 750$

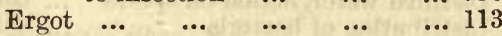

Erlenmeyer's flasks $\ldots . . \quad \ldots . \quad \ldots .788$

Erysipelas, sources of infection of ... 738

$\begin{array}{lllll}\text { Erysiphæ oïdium } \quad \ldots & \ldots & \ldots & 126\end{array}$

Erythrite, fermentation of ... $\quad \ldots 603$

Escherich on bacilli in the fæces of infants... $\quad . . . \quad \ldots \quad \quad \ldots 334$

Esmarch's method of separating bac$\begin{array}{llllll}\text { teria } & \ldots & \ldots & \ldots & \ldots & \\ & & \end{array}$

Ether, action on spores $\quad \ldots . \quad \ldots 666$

Etiology of cholera ... $\quad$... $\quad \ldots .421$

\begin{tabular}{llllll} 
Eurotium & $\ldots$ & $\ldots$ & $\ldots$ & $\ldots$ & $\ldots$ \\
\hline
\end{tabular}

— aspergillus glaucus $\quad \ldots . \quad \ldots .6123$

$\begin{array}{llllll}\text { - repens } & \ldots & \ldots & \ldots & \ldots & 123\end{array}$

Exanthemata, sources of infection of 737

Excrementitious nitrogenous products of the lower fungi ... 550

Excreta, disinfection of $\quad \ldots . \quad \ldots .772$

Excretion of infective agents by the

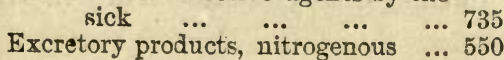

PAGE

Excretory products, non-nitrogenous 553

Exoascus taphrina $\quad . . \quad$... $\quad . .146$

Expired air, absence of bacteria in the 727

External conditions, variations in, as influencing the products of time change

\section{E.}

Facultative anaërobes

... $\quad$... 532

$\begin{array}{lllll}- \text { parasites ... } & \ldots & \ldots & \ldots & 629\end{array}$

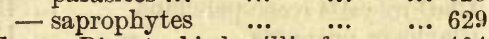

Fæces, Bienstock's bacilli of $\quad$... 404

Falkenheim on sarcina ventriculi ... 326

Fate of non-nitrogenous materials in the lower fungi

- of the parasitic bacteria outside the body

Fatty acids as anti-putrefactive substances... $\quad \ldots \quad \quad \ldots \quad \quad \ldots 655$

- - fermentation of $\quad \ldots \quad \ldots 603$

- production of, by the lower $\begin{array}{llllll}\text { fungi } \quad \ldots & \ldots & \ldots & \ldots & 560\end{array}$

$\begin{array}{lllll}\text { Favus, fungus of } & \ldots & \ldots & \ldots & 127\end{array}$

- of mice, fungus of $\quad$... $\quad \ldots .130$

Fermentation ... $\quad$... $\quad \ldots \quad \ldots 586$

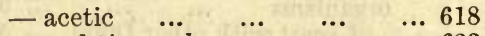

- and tissue change $\quad \ldots \quad \ldots 623$

- a physiological act of living $\begin{array}{lllll}\text { organisms } \quad \ldots & \ldots & \ldots & 623\end{array}$

- as a substitute for oxygen in supplying energy $\quad \ldots \quad \ldots 545$

— by bacteria $\quad \ldots . \quad \ldots . \quad \ldots 595$

- butyric acid $\quad \ldots . \quad \ldots . \quad \ldots 595$

- of cellulose $\quad$... $\quad \ldots . \quad \ldots 600$

- chemical changes in ... ...6 621

- classification of ... $\quad \ldots . \quad \ldots .587$

- definition of $\quad \ldots . \quad \ldots . \quad \ldots 586$

- dextran ... $\quad . . \quad \ldots . \quad \ldots 600$

— influence of oxygen on... ... 595

- influence of the quantity of $\begin{array}{lllll}\text { yeast on } \quad \ldots & \ldots & \ldots & 594\end{array}$

— influence of temperature on $\ldots 5.594$

- influence of the amount of alcohol on $\quad . . \quad$... $\quad . .594$

- influence of the amount of I sugar on $\quad$... $\quad . . . \quad \ldots .594$

- lactic acid $\quad \ldots . \quad \ldots . \quad \ldots 596$

—of bread ... $\quad \ldots \quad \ldots 6 \quad \ldots 606$

— of carbo-hydrates by bacteria ... 595

- of glucose, chemical process of 590

— of the fatty acids $\quad$... $\quad \ldots 603$

— of the higher alcohols ... $\quad$... 602

— products of $\quad \ldots \quad$... $\quad \ldots \quad 562$

— time required for $\quad \ldots \quad$... 593

- viscous ... ... ... ... 598

Fermentative action of the mould fungi $\quad . . \quad \ldots \quad \ldots \quad \ldots \quad \ldots 511$

- - relation to acids $\quad \ldots . \quad \ldots .584$

- - relation to temperature $\ldots .583$

Fermentative activity as a substitute

for oxygen $\quad . . \quad \ldots \quad \ldots 531$ 
Fermentative activity, influence of, on

the life of the bacteria $\quad . .536$

- $\begin{array}{lllll}\text { of yeast } \quad \ldots & \ldots & \ldots & 522\end{array}$

Fermentative organisms, attenuation

of $\quad \ldots \quad \ldots \quad \ldots \quad \quad \ldots 656$

Fermented fluids, scums on .... ... 151

Ferments and true fermentations, distinction between ... $\quad . .585$

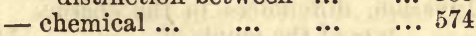

- chemical composition of $\quad$... 581

- formation of, by bacteria $\quad . .530$

- method of separating ... $\quad . .5851$

- mode of action of $\quad \ldots \quad 582,585$

- relations to carbolic acid ...584

- relations to salicylic acid ... 584

— which break up glucosides ... 580

- which decompose fat ... ... 580

Finkler and Prior's spirillum $\quad \ldots 472$

Fission fungi as causes of disease ... 636

- - chemical conditions of $\quad$... 525

- - conditions of life of... $\quad . . .525$

- - granulose in ... $\quad . . \quad \ldots . . .527$

— nutrient materials of $\quad \ldots 527$

- - sources of carbon of $\quad$... 528

- - sources of nitrogen of $\quad \ldots 527$

Fish, mould fungi as parasites in ... 634

Fitz on the fermentation of dulcite... 603

- on the fermentation of erythrite 603

- on the fermentations of glycerine 602

- on the fermentation of mannite 603

Flacherie, micro-organisms in $\quad$... 207

Flies, parasitic mould fungi in $\quad \ldots 633$

Fol's method of cultivation ... $\quad . .788$

Food, bacteria in $\quad$.. $\quad$.. $\quad \ldots 776$

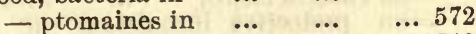

— transport by $\quad \ldots . \quad \ldots . \quad \ldots . .740$

Form of the fungi, variations in, as the result of degenerative changes 676

Form of the lower fungi, variations in, during development ...6 675

Formate of lime, fermentation of ... 603

Formic acid, action on spores $\quad \ldots 667$

Foul brood, bacillus of $\quad \ldots \quad \ldots 343$

Fowl scab, fungus of ... $\quad \ldots . . \quad \ldots .129$

Fractional cultivation $\quad$... $\quad \ldots 801$

Frank on disinfection with bromine 670

A. Fraenkel's bacillus of pneumonia 325

E. Fraenkel on a diplococcus from vaginal secretion

Freire on micro-organisms in yellow fever ... ... ... ... 203

Friedländer's pneumonia bacteria ... 255

$\begin{array}{llllll}\text { Fuchsine } & \ldots & \ldots & \ldots & \ldots & 782\end{array}$

$\begin{array}{llllll}\text { Fumago } & \ldots & \ldots & \ldots & \ldots & \ldots \\ & & \ldots & \ldots & \ldots & \end{array}$

Function of the lower fungi in nature 497

Functional activity of the lower fungi 548

Fungi, absorption and assimilation of nutriment by ... ... ...

- alterations which the nutrient materials undergo $\ldots \quad \ldots 548$

— assimilation of carbon $\begin{array}{lll}\ldots y & \ldots & 546 \\ \end{array}$
Fungi, conditions affecting the death $\begin{array}{llllll}\text { of } \quad \ldots & \ldots & \ldots & \ldots & 647\end{array}$

— functional activity of $\ldots \ldots . \quad \ldots 548$

- morphology of ... $\quad \ldots \quad \ldots 103$

- place of, in the vegetable kingdom $\quad . . \quad \ldots \quad \ldots \quad \ldots 101$

— products of tissue change of ... 559

- spore formation in $\ldots . \quad \ldots \quad 105$

- tissue change and development of energy in $\ldots \quad$... $\quad . .5451$

— vital actions of ... $\quad \ldots . \quad \ldots 540$

Fusisporium solani $\ldots . . . .6113$

\section{G.}

$\begin{array}{llllll}\text { Gadinine } & \ldots & \ldots & \ldots & \ldots & 569\end{array}$

Gaffky on micrococcus tetragenus ... 205

- on typhoid bacilli ... ... 248

Gärtner and Plagge on the action of carbolic acid on bacteria ... 668

Gastric juice, action of, on bacteria... 724

Gastro-enteritis, bacteria of ... ... 330

$\begin{array}{lllllll}\text { Gemmæ } & \ldots & \ldots & \ldots & \ldots & 105\end{array}$

General prophylactic measures $\quad \ldots 770$

Gentian violet... $\quad \ldots \quad \ldots \quad \ldots 782$

Germ theory, development of $\quad \ldots \quad 70$

—- objections to... ... ... 81

Germination of spores of bacteria $\ldots .163$

— - - of yeast ... ... ... 524

Giant cells and tubercle bacilli $\quad \ldots 263$

Glanders, bacillus of ... $\quad \ldots \quad \ldots .277$

- sources of infection of ... $\quad \ldots 737$

Glucose, forms of, suitable for alcoholic fermentation $\quad . . \quad \quad \ldots \quad 588$

Glucosides, ferments of $\quad \ldots \quad \ldots . \quad 580$

Glycerinate of lime, fermentation of 604

Glycerine, action on spores ... $\quad \ldots 666$

Glycerine, fermentations of ... $\quad \ldots 602$

Gonorrhœa, micrococcus of ... $\quad . .198$

— sources of infection of ... $\quad \ldots 736$

Goodsir on sarcina ventriculi $\quad \ldots 226$

Göttingen, regulation for disinfec-

tion in ... $\quad \ldots \quad \ldots . \quad \ldots \quad 776$

Gram's method of staining ... $\ldots 784$

Granuloma fungoides, streptococci in 204

Granulose in the fission fungi ... 527

Grawitz on the development of pathogenic properties in mould $\begin{array}{lllll}\text { fungi } \ldots & \ldots & \ldots & \ldots & 138\end{array}$

Ground water as an index of the moisture of the soil ... $\quad . .707$

H.

Habitat of bacteria $\quad . . \quad \ldots \quad \ldots \quad \ldots 685$

Habitats for bacteria in water $\ldots 715$

Hæmophilia neonatorum, micrococci in... $\quad . . \quad \ldots \quad \quad \ldots 203$

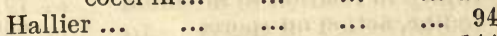

Haplococcus reticulatus $\quad \ldots \quad \ldots .144$

Hauser's putrefactive bacilli $\quad$... 380

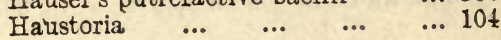


Healthy body, absence of bacteria in the

Heat, production of, by thelowerfungi 558

Henle's views on contagia ... $\quad . .691$

Hereditary variations in the loxer fungi, mode of origin of $\quad \ldots 673$

Hesse's method of examining air for bacteria

Hoppe-Seyler on the influence of oxygen on putrefaction ... 533

Hueppe on spores in comma bacilli... 428 - on the production of invertine ferment by the bacillus lactis 578

- on the staining of spores ... 78.5

- on variability in the lactic acid bacilli $\ldots \quad$... $\quad \ldots \quad$... 680 Hyacinths, yellow disease of... $\quad \ldots \quad 636$ Hydrochloric acid, action on spores 667 - - as an inhibitory agent $\quad \ldots 653$ Hydrocyanic acid as an inhibitory $\begin{array}{llllll} & \text { agent } \ldots & \ldots & \ldots & \ldots & 653\end{array}$ Hydrogen, rôle of nascent, in putre-

$\begin{array}{cccccc}\text { faction } & \ldots & \ldots & \ldots & \ldots & 615 \\ \text { Hyphæ ... } & \ldots & \ldots & \ldots & \ldots & 104\end{array}$

I.

Illumination of specimens, method of 786 $\begin{array}{lllll}\text { Immunity } \quad \ldots & \ldots & \ldots & \ldots & 752\end{array}$ Indirect transport of infective agents 741 Individual predisposition ... ... 748 Infants, bacilli in fæces of ... $\quad . .334$ Infection as the result of profession and occupation

... $\quad \ldots 722$

— by doctors, \&c. ... $\quad \ldots . . \quad \ldots 772$

\begin{tabular}{lllll} 
— in children & $\ldots$ & $\ldots$ & $\ldots$ & $\ldots$ \\
\hline
\end{tabular}

— in cholera $\quad \ldots . \quad \ldots . \quad \ldots 4442$

- sources of $\quad \ldots \quad$... $\quad \ldots 729$

Infective agents, accidents influencing the spread of $\quad \ldots \quad \ldots 768$

- - mode of transport of $\quad$... 739

- - multiplication of, on surrounding objects $\quad \ldots \quad \ldots 731$

- - seats of invasion of ... $\quad \ldots 741$

- - slight importance of saprophytic growth of, for the spread of disease $\quad \ldots$... $\quad .$.

Infective diseases, local and seasonal predisposition to $\quad . . \quad \ldots 761$

$\begin{array}{llll}- & \text { mode of spread of } \quad \ldots & \ldots & 728\end{array}$

- prophylactic measures against 770

$\begin{array}{llll}\text { Infective nature of soil } \quad \ldots & \ldots & 694\end{array}$

Influenza, micrococci in $\quad \ldots . \quad \ldots 203$

Inhibition of growth of bacteria $\quad \ldots .648$

Inhibitory action of the produsts of tissue change ... $\quad . . \quad \ldots 566$

Injury in relation to infection $\quad \ldots .751$

Iodine, action on spores $\quad . .6 \quad \ldots .666$

- as an inhibitory agent...

Iodine water, action on spores $\ldots 60$
$\ldots .653$

... 667
PAl:E

Insects, parasitic mould fungi in $\quad \ldots 633$

— transport by $\quad \ldots \quad$... $\quad \ldots 7740$

Intestine, bacteria in the $\ldots 4 \quad 417,724$

Intestinal mucous membrane, passage of bacteria through $\ldots 7 \pm 2$

Intramolecular respiration in the lower fungi $\quad . . \quad \quad \ldots \quad \ldots 542$

- - relation of oxygen to $\quad \ldots .542$

Invasion, differences in the characters of the points of ... $\quad . .749$

Invasion of infective agents, seats of 741 Invertine $\quad \ldots \quad \ldots . \quad \ldots \quad \ldots 577$ — chemical composition of $\quad \ldots .581$ - production of, by bacillus lactis 578 Involution forms of cholera bacilli... 426

\section{J.}

Jequirity ophthalmia, bacilli of $\quad \ldots 346$

K.

Kepbyr, chemical composition of ... 608

$\begin{array}{llllll}\text { - ferment of } & \ldots & \ldots & \ldots & 372\end{array}$

- preparation of $\ldots \quad \ldots \quad \ldots 607$

Key for the diagnosis of the bacilli... 411

- for the diagnosis of micrococci 232

- for the diagnosis of the spirilla 485

Kitt on protective inoculation $\quad$.. 756

Klebs on fractional cultivation $\quad \ldots 801$

Klebs and Tommasi-Crudeli on bacilli in malaria $\quad . . \quad \ldots . \quad \ldots 294$

Koch, experiments on the inhibitory action of various poisons $\quad . .653$

- on cholera bacilli f.. ... 415

- on protective inoculation in anthrax... $\quad . . \quad \ldots \quad \ldots 758$

- on spore formation in anthrax bacilli ... $\quad$... $\quad$... $\quad \ldots 538$

— on the advantages of solid nutrient substrata $\quad \ldots \quad$... 796

- on tubercle bacilli $\quad \ldots \quad \ldots 260$

Koch and Wolffhügel on sulphurous acid as a disinfectant... $\quad \ldots \quad 669$

König on disinfection with sublimate 671

Kreibohm's bacilli of saliva ... $\quad . .319$

Kurth on bacterium Zopfii ... $\quad . . .405$

\section{L.}

$\begin{array}{llllll}\text { Laboulbenia } & \ldots & \ldots & \ldots & \ldots & 115\end{array}$

Lactate of lime, fermentation of $\quad$... 604

Lactic acid bacteria ... $\quad$... $\quad \ldots 363$

Lactic fermentation ... $\quad \ldots \quad \ldots . \quad \ldots 596$

- - fermentative agents of $\quad \ldots 596$

- - materials necessary for $\quad . . .596$

- nature of the decomposition 596

Lankester on a peach-colouied bac-

terium $\ldots \quad \ldots \quad \ldots \quad \ldots 490$

Laveran on organisms in malaria $\ldots 2.295$

Leprosy, bacillus of ... $\quad . . \quad \ldots .2 \%$

$\begin{array}{llllll}\text { Leptothrix } & \ldots & \ldots & \ldots & \ldots & \text {... }\end{array}$

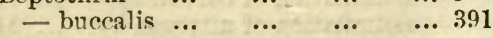




\section{PAGE}

Leptothrix gigantea

Leube's bacillus ureæ

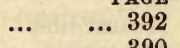

- micrococcus ureæ

$\ldots \quad \ldots 390$

... $\quad \ldots 212$

Leuconostoc mesenterioides ... $\quad$... 214

Liborius on bacteria in relation to oxygen ... ... ... ... 531

Lichen ruber, organisms in ... $\quad \ldots 297$

Liebig's views on fermentation $\quad$... 86

Light, development of, by the fungi $\mathbf{5 5 9}$

- influence of, on bacteria $\quad . .535$

- influence of, on the motility of bacteria... $\quad . . \quad$... $\quad$... 558

Linen, disinfection of $\quad \ldots \quad$... $\quad \ldots 7772$

Liver, acute yellow atrophy of micrococci in ... ... ... ... 203

Local differences in the number of air germs $\quad \ldots \quad \ldots$....

- - in the number of bacteria in food $\ldots$... ... ...

Local predisposition to infective diseases... ... ... ... 761

Localistic view of cholera $\quad . . \quad \ldots 467$

I,ochia, cocci in $\quad \ldots . \quad \ldots \quad \ldots 200$

Loeffler on diphtheria in calves ... 328 — on streptococci in diphtheria ... 283 —on streptococcus articulorum ... 194

Loeffler's bacillus of diphtheria ... 280 — bacillus of pigeon diphtheria ... 326

— universal staining fluid ... 782

Loeffler and Schütz on glanders bacilli 277 Loss of fermentative and pathogenic properties

.. 565

Lower fungi, conditions of life of ... 501

Lungs, passage of bacteria through... 742

Lustgarten on the bacilli of syphilis 289

M.

Malaria, bacteria in ... $\quad . . \quad \quad \ldots 292$ — sources of infection of ... $\quad \ldots 739$

Malate of lime, fermentation of $\quad . .604$

Malignant vedema, bacillus of $\quad$... 242

- - in $\operatorname{man} \quad \ldots . \quad \ldots \quad \ldots 247$

Mannite fermentation-see viscous.

- fermentation of ... ... ... 603

Marchiafava on bacilli in malaria ... 294

Marchiafava and Celli cn organisms in malaria ... ... ...

Marsh gas fermentation-see cellulose.

Mastzellen $\quad . . \quad \ldots . \quad \ldots \quad \ldots 787$

Measles, micrococci in $\quad \ldots .6202$

Meat infusion, preparation of, for cultivations ... ... $\quad$... 792

Mechanical movement, influence of,

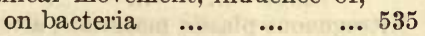

Merismopedia ... $\quad \ldots .6 \quad \ldots . \quad \ldots .160$

Meteorological influences in cholera 455

Methol of isolating bacteria $\quad . .797$ — of staining spores $\quad . . \quad \ldots 78 \tilde{5}$

Methods of investigating bacteria ... 777

Methods of the microscopical examination of the lower fungi 777
Methylene blue PAGE

$\begin{array}{lllll} & & & & \\ \text { Methylene blue } & \text {... } & \text {.. } & \text {... } 782\end{array}$

Methyl green ... $\quad \ldots . \quad \ldots . \quad \ldots 782$

- violet $\ldots . \quad \ldots . \quad \ldots . \quad \ldots 782$

Metschnikoff on phago-cytosis _.. 643

Mice, progressive necrosis of tissue in 209

Micrococci, characters of $\quad . . \quad \quad \ldots 171$

- analysis of $\quad \ldots \quad$... $\quad \ldots \quad 526$

- key for the diagnosis of $\quad$... 232

- of putrefaction ... $\quad . . \quad \quad \ldots 217$

- pathogenic in man $\quad \ldots \quad \ldots 183$

Micrococcus ... $\quad . . \quad \ldots \quad \ldots \quad \ldots 155$

— albicans amplus $\quad \ldots . \quad \ldots 229$

\begin{tabular}{lllll} 
- aurantiacus & $\ldots$ & $\ldots$ & $\ldots$ & 229 \\
\hline
\end{tabular}

- candicans $\quad \ldots . \quad \ldots \quad \ldots 218$

- cereus albus $\quad \ldots . \quad \ldots \quad \ldots 228$

- - flavus $\quad \ldots \quad$... $\quad \ldots 228$

- chlorinus... $\quad \ldots . \quad \ldots . \quad \ldots 228$

- cinnabareus $\quad . . \quad \ldots \quad \ldots \quad \ldots 218$

- citreus conglomeratus ... $\quad \ldots 228$

- coronatus $\quad \ldots \quad$... $\quad \ldots 220$

- cyaneus ... $\quad \ldots . \quad \ldots . \quad \ldots 224$

— flavus desidens ... $\quad \ldots . \quad \ldots 222$

- - liquefaciens ... $\quad \ldots \quad \ldots 219$

- $\begin{array}{llll}\text { tardigradus } \quad \ldots & \ldots & \ldots & \ldots 19\end{array}$

— fœetidus ... $\quad \ldots \quad \ldots . \quad \ldots 216$

- - products of $\ldots . \quad \ldots .612$

— fulvus $\quad \ldots \quad \quad \ldots \quad \quad \ldots \quad \ldots 225$

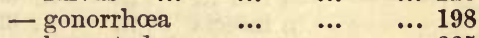

- $\begin{array}{llll}\text { hæmatodes } \quad \ldots & \ldots & \ldots & \ldots 25\end{array}$

- lacteus faviformis $\quad \ldots . . \quad \ldots 229$

- luteus $\quad . . . \quad \ldots . \quad \ldots . \quad \ldots 224$

- Pflügeri $\ldots . \quad \ldots . \quad \ldots . \quad \ldots 216$

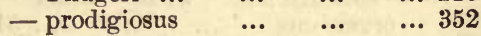

- pyogenes tenuis... $\quad \ldots . . \quad \ldots 189$

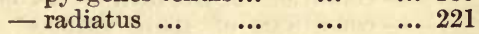

$\begin{array}{lllll}\text { roseus } \quad \ldots & \ldots & \ldots & \ldots 229\end{array}$

- subflavus ... $\quad \ldots . \quad \ldots . \quad \ldots 200$

- tetragenus $\quad \ldots, \ldots . \quad \ldots 205$

$\begin{array}{llllll}\text { ureæ } & \ldots & \ldots & \ldots & \ldots 212\end{array}$

- - liquefaciens ... $\quad \ldots \quad \ldots 213$

- nutrient materials necessary

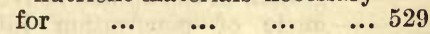

— versicolor $\quad \ldots . \quad \ldots \quad \ldots 22$

- violaceus... $\quad \ldots \quad \ldots . \quad \ldots \quad 224$

- viscosus ... $\quad \ldots . \quad \ldots . \quad \ldots 216$

- viticulosus $\quad \ldots . \quad \ldots . \quad \ldots 223$

Micro-organisms as parasitic exciting agents of disease $\quad \ldots . \quad \ldots \quad 90$

- classification of ... $\quad \ldots . . .101$

Microscopical examination, mode of obtaining the specimens $\quad . .778$

Microscopical examination of specimens $\quad . . \quad \ldots \quad \ldots . \quad \ldots 785$

Microscopical examination of the lower fungi, methods of $\quad . .777$

Milk, viscous fermentation of $\quad \ldots 599$

Miller on curved bacilli in carious teeth $\quad . . \quad \ldots \quad \ldots \quad \ldots \quad \ldots 476$

Miller's bacillus, products of $\quad \ldots 612$

- bacteria from the reposit on teeth $\quad . . \quad \ldots \quad \ldots \quad \ldots \quad \ldots 393$

- coccus from carious teeth $\quad$... 230 
Mineral substances, assimilation of, by the lower fungi ... ... 547 Miquel's experiments on disinfection $\mathbf{6 5 2}$ - method of examining air for bacteria... $\quad . . \quad \ldots \quad \ldots 804$ Mitscherlich's analysis of the ashes of yeast... $\quad \ldots \quad \ldots \quad \ldots 518$

Mode of spread of the infective diseases... $\quad \ldots \quad$... $\quad \ldots 728$ Mode of entrance of bacteria into wells 713

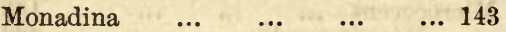
Monas Okenii ... $\quad \ldots \quad \ldots \quad \ldots \quad \ldots 494$ $\begin{array}{llllll}-\operatorname{vinosa} & \ldots & \ldots & \ldots & \ldots & 494\end{array}$

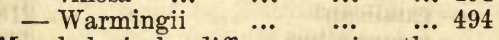
Morphological differences in the $\begin{array}{lllll}\text { lower fungi } \quad \ldots & \ldots & \ldots & 675\end{array}$ Morphology of micro-organisms ... 101 Motility of bacteria, influence of

light on... $\quad \cdots$ of $\quad$ nutrient materials on ... $\quad . . \quad \ldots 558$ _ _ - influence of oxygen on $\mathbf{5 3 1}, \mathbf{5 5 8}$ _ _ _ influence of temperature on 558 Mould fungi as exciting agents of disease ...

—— as parasites in birds $\ldots \quad \ldots 6634$

- - - in fish ... $\quad . . \quad \ldots 6634$

- - - in insects $\quad \ldots .6633$

- - - in man... $\quad \ldots . \quad \ldots 634$

_ - - on animals $\quad \ldots .6 \quad \ldots 633$

- - chemical composition of ... 502

- concurrence with other organisms $\quad . . \quad \ldots . \quad \ldots 513$

- - conditions of $\dddot{0}$ life of... $\quad \ldots .502$

- conditions of spore formation and spore germination ... 514

- - duration of the vitality of the spores $\quad . . \quad \ldots . \quad \ldots 515$

— - fermentation of sugar by $\ldots 589$

- - fermentative action of ... 511

- - growth in the animal body... 508

- - mode of penetration into plants ... $\quad . . . \quad \ldots \quad$...

- - nutrient materials of $\quad \ldots .503$

- - relation of, to oxygen $\quad$... 508

- relation to concentration of nutrient material ... $\quad . .509$

- - relation to temperature ... 512

- - relation to the reaction of the nutrient material ... ... 511

$\begin{array}{llllll}\text { Mouldiness } & \ldots & \ldots & \ldots & \ldots & 617\end{array}$

Mouse septicæmia, bacillus of $\quad \ldots 310$

Mouth, bacteria in ... $\quad$... $\quad \ldots 727$

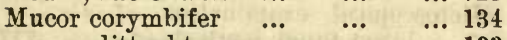

— melittophtorus ... $\quad \ldots \quad \ldots 133$

$\begin{array}{llllll}\text { - macedo } & . . & \ldots & \ldots & \ldots & 131\end{array}$

$\begin{array}{lllll}\text { - racemosus } & \ldots & \ldots & \ldots & 133\end{array}$

— rhizopodiformis ... $\quad \ldots \quad \ldots \quad 133$

$\begin{array}{lllll}\text { - stolonifer } & \ldots & \ldots & \ldots & 133\end{array}$

$\begin{array}{llllll}\text { Mucoriner } & \ldots & \ldots & \ldots & \ldots & 131\end{array}$

Iultiplication of pathogenic bacteria in the soil
PAGE

$\begin{array}{llllll}\text { Muscarine } & \ldots & \ldots & \ldots & \ldots & 115\end{array}$

Musculus's ferment of urine $21 \%, 580$

Mussels, poisoning by $\quad$... $\quad \ldots 573$

Mutability of bacteria, Nägeli's views

on $\quad \ldots \quad \ldots . \quad \ldots \quad \ldots 680$

- of the characters of the fungi... 672

$\begin{array}{llllll}\text { Mycelium } & \ldots & \ldots & \ldots & \ldots & 104\end{array}$

$\begin{array}{llllll}\text { Mycetozoa } & \ldots & \ldots & \ldots & \ldots & 142\end{array}$

$\begin{array}{lllll}- \text { parasitic ... } & \ldots & \ldots & \ldots & 144\end{array}$

$\begin{array}{lllll}\text { Mycoderma aceti } & \ldots & \ldots & \ldots & \\ & \ldots & \ldots & & \end{array}$

Myconostoc gregarium $\quad \ldots \quad \ldots 492$

Mycosis fungoides, streptococci in ... 204

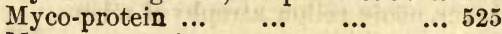

Myco-protein in yeast $\quad \ldots . \quad \ldots 517$

$\begin{array}{llllll}\text { Mydaleï } & \ldots & \ldots & \ldots & \ldots & 571\end{array}$

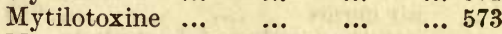

$\begin{array}{lllll}\text { Myxomycetes ... } & \ldots & \ldots & \ldots & 142\end{array}$

\section{N.}

Nägeli on mineral substances in relation to the lower fungi ... 548

- on the assimilation of carbon by the lower fungi ... ... 546

— on the self-fermentation of yeast 593

Nägeli's analysis of anthrax bacilli... 526

- analysis of yeast... ... ... 516

- experiments on the nutrient materials of the mould fungi 504

— normal nutrient solutions ...790

— theory of fermentation... $\quad \ldots 626$

- views as to the mutability of bacteria... $\quad \ldots \quad \ldots . \quad \ldots 680$

Natural means of disinfection $\quad \ldots 68 \tilde{5}$

Neisser on the coccus of gonorrhœa 198

Nencki on ptomaines $\quad \ldots \quad \quad \ldots 568$

Nencki's analysis of bacteria $\quad \ldots 525$

$\begin{array}{lllll}\text { - myco-protein } \quad . . & \ldots & \ldots & 525\end{array}$

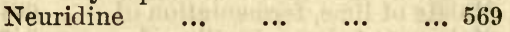

$\begin{array}{llllll}\text { Neurine... } & \ldots & \ldots & \ldots & \ldots & 559\end{array}$

Nicati \& Rietsch on the artificial

production of cholera in

animals ... $\quad \ldots \quad$... $\quad \ldots \quad 436$

Nicolaier on the tetanus bacillus $\ldots 340$

Nitrates, reduction of, by bacteria ... 528

Nitrification ... ... $\quad \ldots \quad \ldots 695$

Nitrogen, assimilation of, by the lower fungi $\quad . . \quad \ldots \quad \ldots \quad \ldots 547$

- sources of, for the fission fungi 527

- sources of, for yeast ... ... 519

- source of supply for the mould fungi ... $\quad . . \quad \ldots \quad \quad \ldots 504$

Nitrogenous plastic materials, alterations in by the lower fungi ... 549

Non-contagious facultative parasites 734

- infective diseases $\quad . . \quad \ldots 730$

Non-hereditary variations in the lower fungi $\quad \ldots \quad \quad \ldots \quad \ldots 673$

Non-nitrogenous plastic materials $\ldots .552$

Nosema bombycis ... $\quad \ldots \quad$... 208 
Number of air germs, local differences in the $\quad . . \quad \ldots \quad \ldots 689$

Nutrient jelly, preparation of, for cultivations $\quad . . \quad \ldots \quad \ldots 792$ - materials of the budding fungi 518 - - of the fission fungi ... ... 527 - - of the lower fungi, alterations which they undergo $\ldots 548$ - - of the mould fungi ... ... 503 $\begin{array}{lllll}- \text { substrata ... } & \ldots & \ldots & \ldots & 789\end{array}$

Nutriment of the lower fungi, amount required $\quad \ldots . \quad \ldots \quad \ldots 557$

Nutritive requirements of the fungi, Pasteur on ... 498

\section{O.}

$\begin{array}{lllll}\text { Obermeier's spirillum } & \ldots & \ldots & 479 \\ \text { Obligatory aërobes } \quad \ldots & \ldots & \ldots & 533\end{array}$

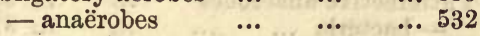

\begin{tabular}{llll} 
- parasites ... & $\ldots$ & $\ldots$ & $\ldots$ \\
\hline
\end{tabular}

- saprophytes $\ldots \ldots \ldots, \ldots, \ldots 629$

Occurrence of bacteria in the air ...6 687

- - in the soil... $\quad \ldots \quad \ldots 691$

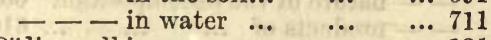

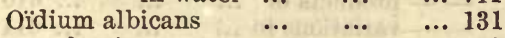

$\begin{array}{llllll}- \text { lactis } & \ldots & \ldots & \ldots & \ldots & 127\end{array}$

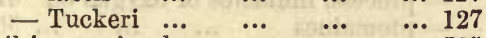

Oil immersion lenses ... $\quad . . \quad \ldots \quad$... 78 ö

— of cloves as an inhibitory agent 653

- of mustard as an inhibitory agent $\quad \ldots \quad \ldots . \quad \ldots \quad \ldots 653$

- of peppermint as an inhibitory agent $\quad . . \quad \ldots \quad \quad . . \quad \ldots 653$

- of turpentine as an inhibitory

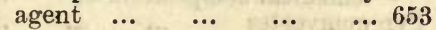

$\begin{array}{llllll}\text { Oogonium } & \ldots & \ldots & \ldots & \ldots & 107\end{array}$

$\begin{array}{llllll}\text { Oospores } & \ldots & \ldots & \ldots & \ldots & 107\end{array}$

Ophidomonas sanguinea $\quad \ldots \quad \ldots 484$

Origin of air germs $\quad \ldots \quad \ldots \quad \ldots 687$

Osmic acid, action on spores $\quad \ldots 667$

Oxygen, influence of, on fermentation 595

- influence of, on the motility of

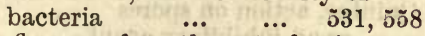

- influence of, on the putrefactive $\begin{array}{lllll}\text { process ... } & \ldots & \ldots & \ldots & 614\end{array}$

— influence of, on yeast cells $\quad \ldots .520$

- in relation to intramolecular respiration $\quad \ldots \quad \ldots \quad \quad \ldots \quad 542$

— in relation to the mould fungi... 508

- in relation to the tissue change of the lower fungi $\ldots \quad \ldots .553$

- relation of, to bacteria ... $\quad \ldots .530$

Ozæna, micrococci in ... $\quad \ldots . . \quad \ldots 203$

\section{P.}

Pancreatic ferment, chemical composition of . $\quad$.. $\quad \ldots \quad$... 582

\begin{tabular}{lllll} 
Parasitic bacteria & $\ldots$ & $\ldots$ & $\ldots$ & 682 \\
\hline
\end{tabular}

- - degrees of pathogenic action 637

- - fate of... $\quad . . \quad \ldots \quad \quad \ldots 686$

—- modes of action of $\ldots . .638$
Parasitic bacteria, modes of development in the body ... ...638

$\begin{array}{llllll}\text { - fungi } & \ldots & \ldots & \ldots & \ldots & 109\end{array}$

—- classification of $\quad \ldots . \quad \ldots 6628$

- mould fungi $\quad \ldots \quad \ldots . \quad \ldots \quad \ldots 629$

- rôle of micro-organisms, proof of 98

- yeast fungi $\quad \ldots \quad \ldots \quad \quad \ldots 636$

Parasitismus of the lower fungi $\quad \ldots 6627$

Parrots, disease of $\quad$... $\quad \ldots \quad$... 207

Passet's pseudopneumonia bacteria... 324

Pasteur on acetic fermentation ... 619

- on aërobes and anaërobes ... 530

- on attenuation of chicken cholera bacilli ... $\quad \ldots \quad \ldots 317$

- on fermentation by yeast $\quad \ldots .77$

- on protective inoculation against $\begin{array}{lllll}\text { anthrax } & \ldots & \ldots & \ldots & 7 \text { ๖ั6 }\end{array}$

- on protective inoculation for

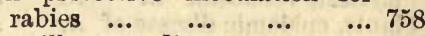

— on silk-worm disease $\ldots . . \quad \ldots 209$

- on the attenuation of the virus of rabies $\quad \ldots \quad \ldots \quad \ldots 660$

— on the fermentation of glucose 590

- on the nutritive requirements of the fungi $\quad \ldots \quad$... $\quad \ldots 498$

Pasteur's bacillus of saliva ... ... 321

— flasks for cultivations ... $\quad \ldots 788$

— nutrient solution $\quad \ldots . \quad \ldots 790$

- views on putrefaction ... $\quad \ldots 614$

- views on the attenuation of anthrax bacilli $\quad \ldots \quad \ldots 658$

Pathogenic bacteria, behaviour of, $\ldots$ water ... $\quad . .6 \quad \ldots \quad$... 712

— - biological peculiarities of ...6 641

— - in the soil, behaviour of ... 698

- - resistance against excretion 642

- - resistance against oxygen ... 642

- - resistance to the living cells. 643

Pathogenic organisms, attenuation of 656

- - fermentation of carbo-hy-

drates by $\quad \ldots \quad \ldots \quad \ldots$

Peach-coloured bacterium, Lankester

on $\quad . . . \quad \ldots \quad$... $\quad . .4490$

Pebrine, micro-organisms in... ... 208

\begin{tabular}{llllll} 
Penicillium & $\ldots$ & $\ldots$ & $\ldots$ & $\ldots$ & \\
\hline
\end{tabular}

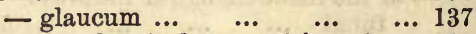

Pepsine, chemical composition of ... 581

Peptone, production of, by yeast ,... 549

Peptonising ferments... $\quad . . \quad \ldots 578$

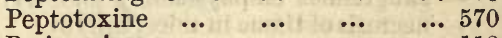

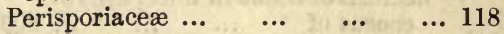

$\begin{array}{llllll}\text { Perithecia } & \ldots & \ldots & \ldots & \ldots & 106\end{array}$

Permanganate of potash, action on spores $\ldots \quad \ldots . \quad \ldots \quad \ldots 667$

_ _ as an inhibitory agent ...653

$\begin{array}{llll}\text { Peronospora infestans } & \ldots & \ldots & 112\end{array}$

Peronosporeæ $\ldots \quad \ldots \quad \ldots \quad \ldots \quad \ldots 112$

Pettenkofer on the relation between the soil and infective bacteria 692

Pfeffer on certain nutrient materials in relation to the movement of bacteria... $\quad . . \quad \ldots . \quad \ldots 558$

Phago-cytosis ... $\quad$... $\quad$... $\quad \ldots 643$ 
PAGE

Phosphorus, source of, in the fungi... 547

Photography of bacteria $\quad$... . .. 787

Phragmidiothrix multiseptata $\ldots 491$

Phthisical sputa, distribution of the

bacilli by means of ... $\quad . .2271$

Phycomycetes ... $\quad$.. $\quad \ldots . \quad \ldots .109$

Physiological differences between the

lower fungi $\quad \ldots \quad \quad \ldots \quad \quad \ldots 678$

Pig typhoid, bacillus of $\quad \ldots . \quad \ldots 302$

Pigeon diphtheria, bacillus of $\quad$... 326

Pigment, chemical nature of $\quad$... 562

- formation, relation of oxygen to 562

- - relation of the nutrient substratum to

562

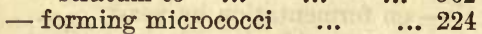

- production of, by the lower fungi $56 \mathbf{i}$

$\begin{array}{llllll}\text { Pink yeast } \quad \ldots & \ldots & \ldots & \ldots & 154\end{array}$

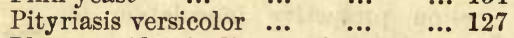

Plants, epidemic disease of $\ldots . \quad \ldots 6631$

- parasitic bacteria in ... $\quad \ldots 636$

$\begin{array}{llllll}\text { Plasma cells } & \ldots & \ldots & \ldots & \ldots & \\ \end{array}$

Plasmiodophora Brassicæ $\quad$... $\quad$... 144

$\begin{array}{llllll}\text { Plasmodia } & \ldots & \ldots & \ldots & \ldots & 142\end{array}$

$\begin{array}{lllll}\text { Plate cultivations } & \ldots & \ldots & \ldots & 797\end{array}$

Pleuropneumonia in cattle, microorganisms in ... ... ... 204

Pneumonia, bacillus of (Friedländer) 255

- bacilli (Friedlaender) analysis of 526

- bacteria, bacilli resembling ... 322

- Fraenkel's bacillus of ... $\quad . .325$

Potash soap, action on spores $\quad \ldots 666$

_ - as an inhibitory agent $\quad \ldots 653$

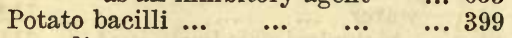

\begin{tabular}{llllll} 
- disease & $\ldots$ & $\ldots$ & $\ldots$ & $\ldots$ & \\
\hline
\end{tabular}

Potatoes,preparationof,forcultivations 792

Predisposition, rôle of, in tuberculosis 273

- to infection in different species and individuals

748

Preservation of pathogenic bacteria in the soil

_ _ - in the soil not necessary for the spread of disease ... 704

Products of the putrefactive fermentation ... $\quad . . \quad \ldots \quad \ldots$

- of the tissue change of the lower fungi $\quad . . \quad \ldots \quad \ldots \quad \ldots \quad$... 559

Progressive abscess formation in rabbits, micrococcus of ... $\quad \ldots 210$

- gangrenous emphysema in man 247

- necrosis of tissue in mice, micrococcus of

Promycelium $\quad \ldots \quad$... $\quad$... 209

Prophylactic measures against the spread of infective diseases ... 770

- regulations against cholera ... 470

Protective inoculation $\quad$... $\quad \ldots 752$

- - general value of $\quad \ldots . \quad \ldots 760$

- - in anthrax $\quad . . \quad \ldots . \quad \ldots 240$

- in Rauschbrand $\quad \ldots . \quad \ldots 300$

- - in swine erysipelas ... $\quad \ldots 306$

$\begin{array}{lllll} & \text { Proteus mirabilis } \quad \ldots & \ldots & \ldots & 382\end{array}$

- vulgaris ...
Proteus vulgaris and mirabilis, products of $\quad$... $\quad \ldots \quad \quad \ldots 612$

$\begin{array}{lllll}\text { - Zenkeri } \ldots & \ldots & \ldots & \ldots & \mathbf{3 8 5}\end{array}$

\begin{tabular}{llllll} 
Protospores & $\ldots$ & $\ldots$ & $\ldots$ & $\ldots$ & $\ldots$ \\
\hline
\end{tabular}

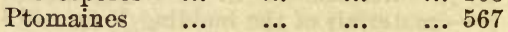

- action of $\ldots . . \quad \ldots . \quad \ldots . \quad \ldots 638$

- hygienic importance of $\quad \ldots .572$

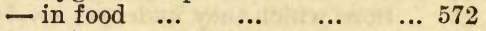

- influence of nutriment on the formation of ... ... $\quad . .574$

— influence of, on parasitismus ... 645

- of putrefaction ... . ... ... 569

— of typhoid bacilli _.. _.. 571

- production of, by the lower fungi 561

Puccinia graminis $\quad . . \quad \quad \ldots \quad \ldots 116$

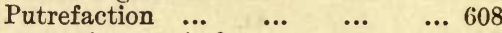

— micrococci of $\quad \ldots \quad \quad \ldots \quad \quad \ldots 217$

- spontaneous $\quad \ldots \quad$... $\quad \ldots 613$

Putrefactive anaërobes $\quad$... $\quad . .385$

- bacteria ... $\quad . . \quad \ldots \quad \ldots 375$

- fermentation, materials for ... 609

- - multiplicity of the exciting agents of $\quad \ldots \quad \ldots \quad \quad \ldots 611$

- nature of the decomposition 609

- - products of ... $\quad$... $\quad \ldots 610$

— - variations in ... $\quad \ldots . \quad \ldots 611$

- process, influence of oxygen on 614

- ptomaines $\quad$... $\quad \ldots . \quad \ldots .569$

$\begin{array}{llllll}\text { Putrescine } & \ldots & \ldots & \ldots & \ldots & 569\end{array}$

Putrid intoxication, ptomaines as the cause of... $\quad \ldots \quad \ldots \quad \ldots \quad 573$

Pyæmia in rabbits, micrococcus of ... 210

$\begin{array}{llllll}\text { Pycnida } & \ldots & \ldots & \ldots & \ldots & 106\end{array}$

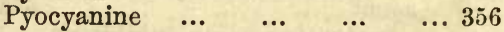

— chemical composition of $\quad \ldots 562$

$\begin{array}{lllll}\text { Pyrenomycetes } & \ldots & \ldots & \ldots & 113\end{array}$

Q.

Quantitative estimation of the tissue change ... $\quad . . \quad \ldots \quad \ldots \quad \ldots 556$

Quercite, fermentation of $\quad \ldots \quad \ldots 603$

Quinate of lime, fermentation of $\ldots 605$

Quinine, action on spores $\quad \ldots \quad \ldots 667$

- as an inhibitory agent... ... 654

R.

Rabbits, progressive abscess formation in ... $\quad \ldots \quad \ldots \quad \ldots 210$

$\begin{array}{lllll}- \text { pyæmia in } & \ldots & \ldots & \ldots & 210\end{array}$

- septicæmia in $\ldots . \quad \ldots . \quad \ldots 211$

- septicæmia, bacillus of... ... 312

Rabies, attenuation of the virus of... 660

— protective inoculation for ... 758

- sources of infection of ... ... 736

Rasmussen's species of leptothrix $\quad$... 392

Ratimoff on disinfection $\quad . . \quad \ldots 652$

Raulin's experiments on the nutrient materials of the mould fungi 503

Rauschbrand, bacillus of $\quad \ldots \quad \ldots 299$

Reaction of the nutrient material in relation to the yeast fungi ... 521 
Reaction of the nutrient material in

relation to bacteria $\quad . . \quad \quad \ldots .534$

Relapsing diseases $\quad . . \quad \ldots \quad \ldots \quad \ldots 752$

Relapsing fever, spirillum of $\quad \ldots 479$

Rennet, ferment of $\quad . . \quad \ldots \quad \ldots \quad \ldots \quad 79$

Respiratory mucous membrane, bacteria on... $\quad$.. $\quad$... $\quad \ldots 724$

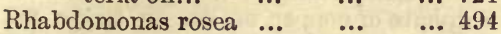

Rhinoscleroma, bacillus of ... $\ldots 291$

Ribbert on bacteria in healthy intestinal mucous membrane ... 743

Richet's experiments on disinfection 654 Rinderpest, micro-organisms in $\quad$... 204 Rindfleisch on streptococci in mycosis fungoides $\quad$... $\quad$.. $\quad$... 209 Rouget du porc, bacillus of ... $\quad \ldots .302$ $\begin{array}{llllll}\text { Rust } \quad \ldots & \ldots & \ldots & \ldots & \ldots & 116\end{array}$

\section{S.}

\section{Saccharomyces albicans}

- apiculatus

- cerevisiæ ..

- conglomeratus

- ellipsoideus

\section{...}

...

$\ldots 152$

- - as the ferme

$$
\text { .... }
$$

$\cdots$

... 150

- exiguus ...

$$
\text { ment of wine }
$$$$
150
$$

- glutinis ...

- mycoderma

- Pastorianus

$$
\because .
$$

Salicylic acid, action on spores

- - as an inhibitory agent

Saliva, spirochæte of ... ...

Salt solution, action on spores

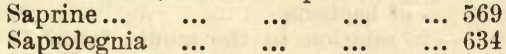

$\begin{array}{lllll}\text { Saprophytic bacilli } & \ldots & \ldots & \ldots & 351\end{array}$

$\begin{array}{lllll}- \text { micrococci } & \ldots & \ldots & \ldots & \ldots\end{array}$

- mould fungi, results of injection in animals

Sarcina ...

$\begin{array}{lllll}\text { - aurantiaca } & \ldots & \ldots & \ldots & 160 \\ & \ldots & \ldots & \ldots & 226\end{array}$

$\begin{array}{lllll}\text { - intestinalis } & \ldots & \ldots & \ldots & 226 \\ & & \ldots & \ldots & 227\end{array}$

- litoralis Reitenbachii hvalina... 228

$\begin{array}{llllll}\text { - lutea } \quad . . & \ldots & \ldots & \ldots & 22 \text {. }\end{array}$

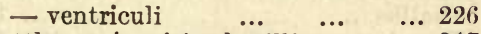

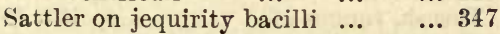

— on micro-organisms in trachoma 203

Scarlatina, micrococci in $\quad \ldots \quad$... 202

- epidemics, local variations in ... 764

$\begin{array}{lllll}\text { Schizomycetes ... } & \ldots & \ldots & \ldots & 15 .\end{array}$

Schou's bacillus pneumonicus agilis... 32 \%

Schroeder and Dusch... $\quad \ldots \quad \ldots .72$

$\begin{array}{llllll}\text { Schulze... } & \ldots & \ldots & \ldots & \ldots & 71\end{array}$

Schütte, regulations for disinfection in Göttingen ... $\quad . . \quad \ldots \quad 776$

$\begin{array}{llllll}\text { Schwann } & \ldots & \ldots & \ldots & \ldots & \ldots \\ \end{array}$

$\begin{array}{llllll}\text { Sclerotium } & \ldots & \ldots & \ldots & \ldots & \ldots \\ \end{array}$

Season and locality in relation to the epidemic diseases of plants ...631

Season, influence of, in cholera $\quad . .4453$
Seasonal differences in the number

of bacteria in food ... ... 718

Seasonal predisposition to infective diseases... $\quad \ldots \quad \ldots . \quad \ldots 76$

Seats of invasion of infective agents 741

Sections, method of preparation and staining of $\quad \ldots . \quad \ldots \quad \ldots 779$

Separation of bacteria by dilution ... 802

- - - in fluid substrata $\quad$... 801

Septicæmia in mice, bacillus of $\quad$... 310

— in rabbits, bacillus of ... $\quad$... 312

- - micrococcus of $\quad \ldots . \quad \ldots 211$

Ships, cholera on $\quad \ldots \quad \ldots . \quad \ldots \quad 450$

Sieber's analyois of the mould rungi 502

Significance of micro-organisms $\quad \ldots \quad 66$

Silk-worms, lethargy of $\quad \ldots \quad \quad \ldots 207$

Skin, bacteria on $\quad \ldots \quad \ldots . \quad \ldots 723$

Small-pox epidemics, seasonal variations in ... $\quad \ldots \quad \ldots \quad \ldots 763$

$\begin{array}{lllllll}\text { Smut } & \ldots & \ldots & \ldots & \ldots & \ldots & 110\end{array}$ Soil, bacteriological investigation of

— influence of, in cholera... ... 457

- occurrence and behaviour of bacteria in ... ... ... 691

- preservation of pathogenic bacteria in ... $\quad \ldots \quad$... $\quad . .701$

— relation to infective bacteria ... 692

- transport of bacteria within the 695

Solid nutrient substrata, advantages

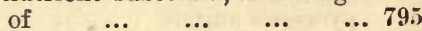

Sources of infection $\ldots . . \quad \ldots . \quad \ldots \quad 729$

Special methods of cultivation _.. 794

Special prophylactic measures in individual diseases... $\quad \ldots \quad \ldots 771$

Specific points of invasion, importance of, for the mode of spreal of the disease ...

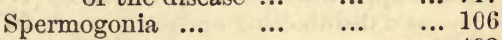

Sphærntilus natans $\quad \ldots \quad$... $\quad \ldots .493$

$\begin{array}{llllll}\text { Spiril'a ... } & \ldots & \ldots & \ldots & \ldots & 415\end{array}$

— characters of $\quad \ldots \quad \ldots \quad \quad \ldots \quad 174$

— key for the diagnosis of $\quad \ldots 485$

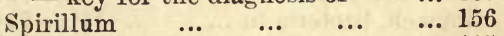

— choleræ Asiaticæ $\quad$... $\quad$... 41 \%

- Finkler and Prior $\quad \ldots \quad \ldots 472$

- leucomelænum ... ... ... 484

— Obermeieri $\quad \ldots \quad \ldots . \quad \ldots 479$

$\begin{array}{llllll}\text { - rugula } & \ldots & \ldots & \ldots & \ldots & 482\end{array}$

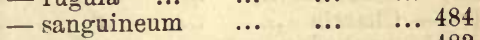

$\begin{array}{llllll}\text { - } \operatorname{serpens} & \ldots & \ldots & \ldots & \ldots & 483\end{array}$

- sputigenum $\quad \ldots \quad \ldots . \quad \ldots 478$

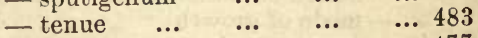

— tyrogenum $\quad \ldots \quad \ldots . \quad \ldots 477$

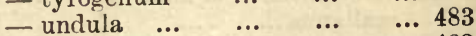

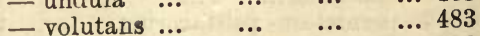

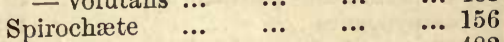

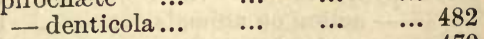

\begin{tabular}{llll} 
- Obermeieri & $\ldots$ & $\ldots$ & $\ldots 4$ \\
\hline
\end{tabular}

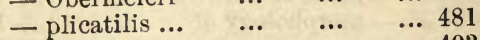

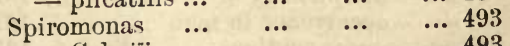

$\begin{array}{lllll}- \text { Cohniï } & \ldots & \ldots & \ldots & \ldots \\ \end{array}$ 
Spiromonas volubilis $\quad$ PAGE

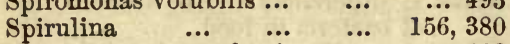
Spontaneous putrefaction $\quad \ldots \quad$... $\begin{array}{llllll}\text { Sporangium } & \ldots & \ldots & \ldots & \ldots & 106\end{array}$ Spore formation in bacteria, conditions of ... $\quad . . . \quad \ldots . \quad \ldots 537$ — - in the mould fungi ... $\quad \ldots .514$ —— in yeast $\quad \ldots \quad \ldots . \quad \ldots 524$ Spore germination in bacteria, conditions of ... ... $\quad$... ... 539

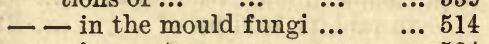

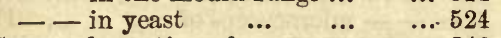
Spores, formation of $\ldots . \quad \ldots \quad \ldots . .342$ - method of staining $\quad \ldots . \quad \ldots 785$ - of bacteria, destruction of ... 663 - of fungi, acrogenous segmentation of ... $\quad \ldots \quad \ldots \quad \ldots 105$ _ - endogenous, formation of 106 - - intercalary, formation of 105 _- sexual fructification of ... 106 Spores of mould fungi, duration of the vitality of ... 515 Spores, resistance of, to high tem$\begin{array}{lllll}\text { peratures } & \ldots & \ldots & \ldots & 663\end{array}$ Staining materials for bacteria $\quad \ldots 780$ — of bacteria $\quad$... $\quad \ldots . \quad \ldots 778$

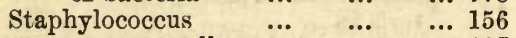

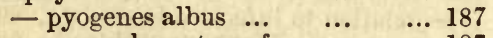
—- characters of $\quad \ldots . \quad \ldots 187$ - - - effect on animals... $\quad \ldots .188$ — pyogenes aureus _ ... $\quad . .183$ - - - action on animals $\quad \ldots 185$ - - mode of growth ... $\quad \ldots .184$ - - morphology of $\ldots . \quad \ldots . .183$ - - occurrence in man $\quad \ldots 186$ - - products of growth 130.571 - - citreus $\quad . . . \quad \ldots . \quad \ldots 188$ Steam, apparatus for disinfection by $_{772}$ — as a disinfecting agent... $\quad . .665$ $\begin{array}{llllll}\text { Sterigmata } & \ldots & \ldots & \ldots & \ldots & 105\end{array}$ $\begin{array}{lllll}\text { Sterigmatocystis } & \ldots & \ldots & \ldots & 121\end{array}$ Sterilisation of vessels and nutrient $\begin{array}{lllll}\text { substrata } \quad \ldots & \ldots & \ldots & 791\end{array}$ Stomach, bacteria in ... $\quad \ldots . \quad \ldots \quad$... 724 Streptococci in diphtheria, Loeffler on $\mathbf{2 8 3}$ - distinction between the _.. 196

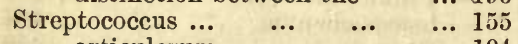
\begin{tabular}{lllll}
- articulorum & $\ldots$ & $\ldots$ & $\ldots$ & 194 \\
\hline
\end{tabular} - bombycis... $\quad \ldots \quad \ldots . \quad \ldots 207$

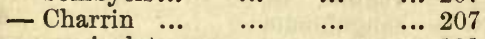
- erysipelatosus ... $\quad \ldots . \quad \ldots .191$ — - action on animals $\quad \ldots . . \quad \ldots .192$ - - mode of growth $\quad \ldots . \quad \ldots .191$ - - occurrence in man ... ... 192 - malignus ... $\quad . . \quad \quad \ldots \quad \quad \ldots 193$ - perniciosus psittacorum $\quad \ldots 207$ — pyogenes ... $\quad . . \quad \quad \ldots \quad \ldots 189$ —- action on animals $\quad . . \quad \ldots 190$ — - mode of growth $\quad \ldots . \quad \ldots 189$ —- morphology of $\quad \ldots . \ldots 189$ - occurrence in man ... $\quad \ldots 191$ Streptococcus septicus $\quad \ldots \quad \ldots 195$
PAGR

Streptothrix Foersteri $\quad$... $\quad$.. 493

Stutzer's analysis of yeast ... $\quad \ldots 517$

— analysis of the mould fungi $\quad . .50503$

Sugar, alcoholic fermentation of, by $\begin{array}{llllllll}\text { yeast } & \ldots & \ldots & \ldots & \ldots & 588\end{array}$

- influence of the amount of, on fermentation ... ... ... 594

Sulphate of copper, action on spores 667 Sulphur in the beggiatoa $\quad \ldots \quad \ldots 527$ Sulphuretted hydrogen, action on spores ... $\quad . .6 \quad \ldots \quad \ldots 667$

Sulphuric acid, action on spores $\quad \ldots .667$

Sulphurous acid as a disinfectant ... 668

Sweat, red $\quad \ldots \quad \ldots \quad \ldots \quad \ldots 225$

Swine erysipelas, attenuation of the bacilli of $\quad . .6 \quad \ldots . \quad \ldots 660$

- - bacillus of $\quad \ldots . \quad \ldots . \quad \ldots 302$

- - micrococci in... $\quad \ldots . \quad \ldots 205$

Swine fever, protective inoculation against... $\quad . . \quad \ldots \quad \ldots 756$

Symptomatic anthrax, attenuation of the bacilli of ... ... ... 660

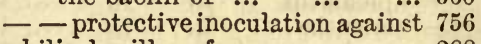

Syphilis, bacillus of ... $\quad \ldots \quad \ldots 288$ - sources of infection of ... $\quad \ldots .736$

\section{T.}

Tappeiner on cellulose fermentation 600 Tartrate of lime, fermentation of ... 604 Teeth, caries of, bacilli in ... ... 298

- Miller's curved bacilli in $\quad \ldots 476$ Teleological rôle of the lower fungi 496 Temperature in relation to the growth of bacteria ... ... ... 650

- in relation to the mould fungi 512

— influence of, on fermentation ... 594

- influence of, on the motility of $\begin{array}{llllll}\text { bacteria } & \text {... } & \text {... } & \text {... } & 558\end{array}$

— relation of, to bacteria ... $\quad . .5536$

- relation to yeast _.. ... 522

- resistance of bacteria to $\quad \ldots 663$

Test for trustworthy disinfecting $\begin{array}{llllll}\text { media } & \ldots & \ldots & \ldots & \ldots & 666\end{array}$

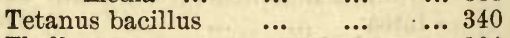

$\begin{array}{llllll}\text { Thallus ... } & \ldots & \ldots & \ldots & \ldots & 104\end{array}$

$\begin{array}{llll}\text { Thrush, fungus of } \quad \ldots & \ldots & \ldots & 131,152\end{array}$

Thymol, action on spores $\quad$... $\quad . .666$

- as an inhibitory agent ... $\quad . .6653$

$\begin{array}{lllll}\text { Tilletia caries ... } & \ldots & \ldots & \ldots & 110\end{array}$

Tinea tonsurans, fungus of $\ldots . \quad \ldots \quad 127$

Tissue change in presence of oxygen 553 - - in the lower fungi ... ... 541

- - of the lower fungi, products of 559

- - when oxygen is absent ... 554

Toxic effects of cholera cultivations 440

Trachoma, micrococci in $\quad . . \quad \ldots 203$

Transmission of infective diseases

from the sick to the healthy... 729

Transport by air, conditions for $\quad . .7471$ 
Transport of bacteria... $\quad \ldots \quad \ldots 687$ - - in the soil by downward currents of water

- - within the soil $\ldots . \quad \ldots 695$

- of infective agents to individuals, mode of. $\quad$... ... 739

- of preserved bacteria from the soil to the man ... ... 705

True fungi, classification of ... $\quad \ldots \quad 108$ Tubercle bacillus $\quad \ldots \quad \quad \ldots \quad \quad \ldots 260$ - method of staining of $\ldots 783$

- mode of entrance into the body $\quad \ldots \quad \ldots . \quad \ldots \quad \ldots 272$

Tuberculosis, mode of spread of $\quad$... 271

+ sources of infection of ... $\quad \ldots 737$ Turpentine, oil of, action on spores ... $\quad \ldots \quad \ldots \quad \ldots 667$

Typhoid bacilli, distribution from the soil ... $\quad \ldots \quad \ldots \quad \ldots 710$

- - fermentation of carbo-hydrates by $\quad . . \quad \ldots \quad \ldots 601$

- - modes of distribution of $\quad \ldots 253$

- - points of entrance of $\quad$... 253

Typhoid fever, bacillus of ... ...248

- - contagiousness of $\quad \ldots \quad \ldots 734$

- - local and seasonal variations

in $\quad \ldots \quad$... $\quad \ldots \quad \ldots 765$

- - sources of infection of $\quad \ldots 738$

$\begin{array}{llllll}\text { Tyrothrix } & \ldots & \ldots & \ldots & \ldots & 606\end{array}$

U.

Unboiled tissues, preservation of $\quad \ldots \quad 74$

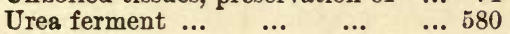

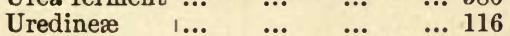

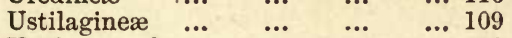

Ustilago carbo... $\quad \ldots \quad \ldots \quad \ldots 110$

$$
\text { V. }
$$

Vaccination $\quad \ldots \quad \ldots . \quad \ldots \quad \ldots 755$

Vaccinia, micrococci in $\quad \ldots . \quad \ldots 202$

Vandevelde's analysis of bacillus $\begin{array}{lllll}\text { subtilis ... } & \ldots & \ldots & \ldots & 526\end{array}$

Variations in the lower fungi $\ldots 681$

- in the form of the fungi as the result of degenerative changes 676

- in the form of the lower fungi during development ... $\quad \ldots 675$

- in the lower fungi, relation to external conditions ... ... 674

- in the products of tissue change as the result of varying external conditions $\quad$... $\quad \ldots 679$

Variola, micrococci in $\quad \ldots \quad \ldots 202$

Various anaërobes, products of $\quad \ldots 612$

Vessels for the cultivation of organisms $\quad \ldots \quad \ldots \quad \ldots \quad \ldots \quad \ldots 788$

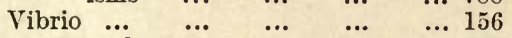

$\begin{array}{llllll}- \text { rugula } & \ldots & \ldots & \ldots & \ldots & 482\end{array}$

Vibrion septique $\quad \ldots \quad \ldots . \quad \ldots 242$

Villemin on the inoculation of tubercle
Vinegar plant, analysis of

PAGE

Violet bacillus ... $\quad$... $\quad$... $\quad \ldots 361$

$\begin{array}{lllll}\text { Viscose } \ldots & \ldots & \ldots & \ldots & 216,599\end{array}$

Viscous fermentation... $\quad$... $\quad \ldots .598$

- - of milk $\quad$.. $\quad$... $\quad$... 599

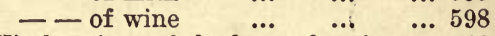

Vital actions of the lower fungi $\quad . .540$

Von Pettenkofer's views on cholera... 468

Von Sehlen on organisms in malaria 295

\section{W.}

Water, bacteriological investigation of 807

- influence of, in cholera... $\quad$... 458

- occurrence of bacteria in ...711

- transport by $\quad$... $\quad$.. $\quad$... 740

Weight of air germs ... $\quad \ldots \quad$... 688

Whooping-cough, organisms in ... 297

Winds, influence of dry winds on the number of air germs ... $\quad . .696$

Wine, viscous fermentation of $\quad$.. 598

Wortmann on diastatic ferment $\quad \ldots .577$

Wyssokowitsch on the destruction of bacteria in the body ... $\quad . .644$

- on the passability of the walls of the lungs and intestine by bacteria...

X.

Xerosis conjunctivæ, organisms in ... 297

Y.

Yeast, alcoholic fermentation of sugar by $\quad \ldots \quad \ldots \quad \ldots \quad \ldots 588$

- concurrent growth with other fungi $\quad . . \quad \ldots \quad \ldots \quad \ldots 522$

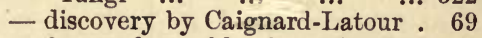

- forms of, capable of exciting fermentation

- influence of fermentative activity on the growth of ... 522

- influence of quantity of, on fermentation $\quad$... $\quad$... $\quad . .5594$

- myco-protein in ... $\quad \ldots \quad \ldots .517$

— necessity for oxygen $\quad$... $\quad$... 520

Yeast of beer ... $\quad \ldots \quad \quad \ldots \quad \ldots 149$

- relation of temperature to ... 522

- relation of, to the fermentative

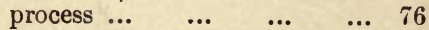

- relation to atmospheric pressure 521

— self-fermentation of $\quad$... $\quad$... 592

- spore germination $\quad \ldots . \quad \ldots 524$

- $\begin{array}{lllll}\text { spores of ... } \quad \ldots & \ldots & \ldots & 524\end{array}$

- the only cause of alcoholic fermentation $\quad$... $\quad \ldots \quad$... 71

Yeast fungi, characters of $\ldots . \quad \ldots \quad \ldots 146$

- - formation of mycelium by ... 147

- - formation of spores in $\quad \ldots .147$

- - multiplication of $\quad \ldots . \quad \ldots .147$

- - relation to concentration of nutriment 
Yeast fungi, relation to the reaction of the nutriment Yellow fever, micrococci in ... ... 521

... 203 ... 297

Z.

Zooglæa
Zooglæa ramigera

PAC:E ... $\quad$... $\quad \ldots 492$ Zoonotic finger erysipeloid, micrococci in $\quad$... $\quad . .2 \quad \ldots 201$ Zopf on crenothrix Kühniana $\quad \ldots 486$ Zopf's classification of bacteria, objections to ... $\quad \ldots \quad$... 181

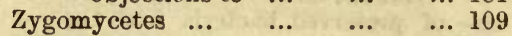
$\begin{array}{llllll}\text { Zygomycetes } & \ldots & \ldots & \ldots & \ldots & 109 \\ \text { Zygospores } & \ldots & \ldots & \ldots & \ldots & 107\end{array}$ 



\section{DAY USE \\ RETURN TO DESK FROM WHICH BORROWED BIOLOGY LIBRARY}

TEL. NO. 642-2532

This book is due on the last date stamped below, or on the date to which renewed.

Renewed books are subject to immediate recall.

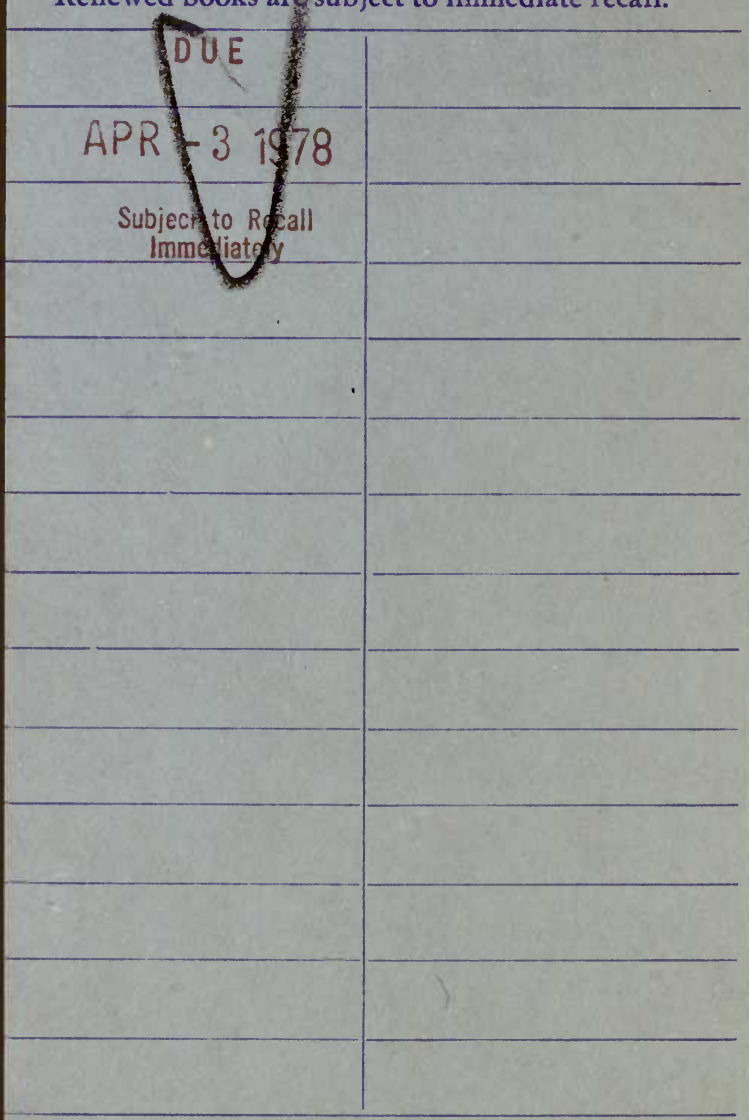




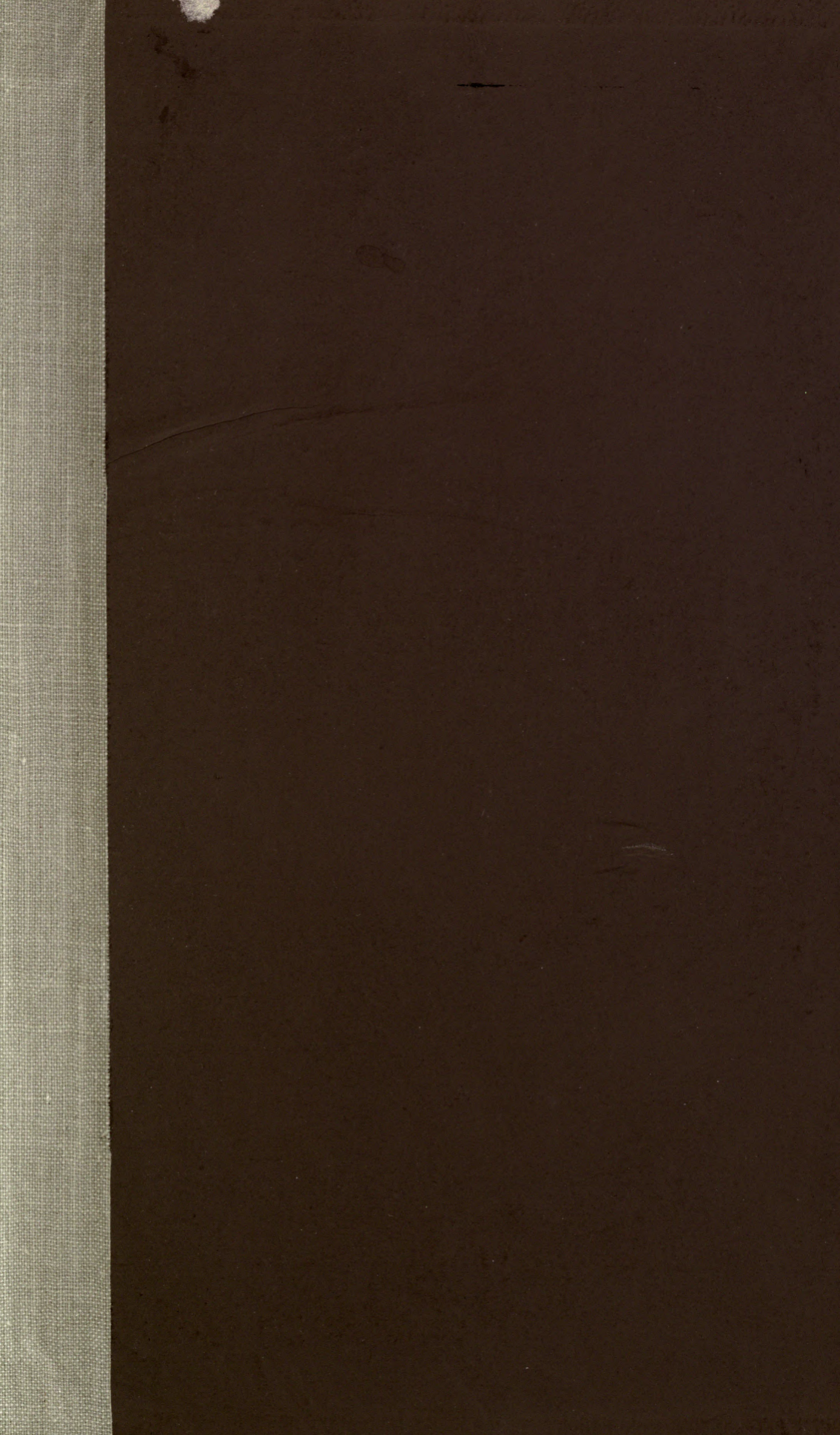


